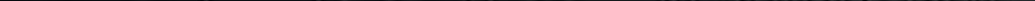




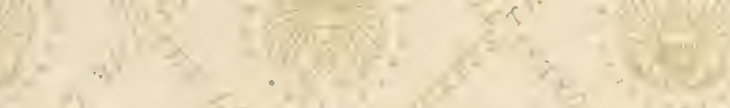

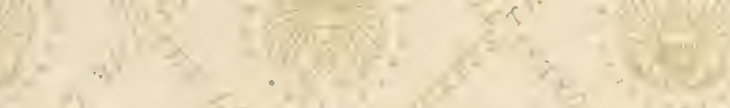

$(4)^{3}=$

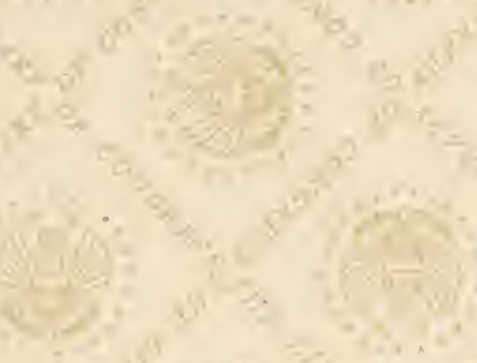

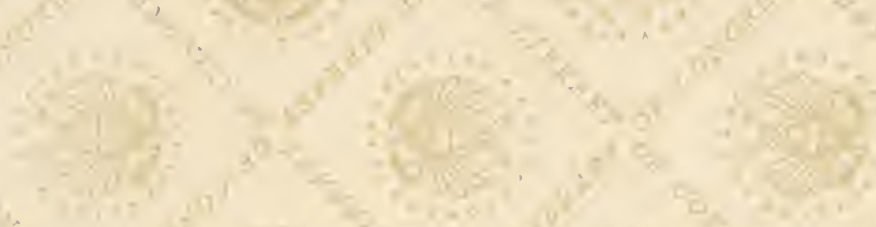

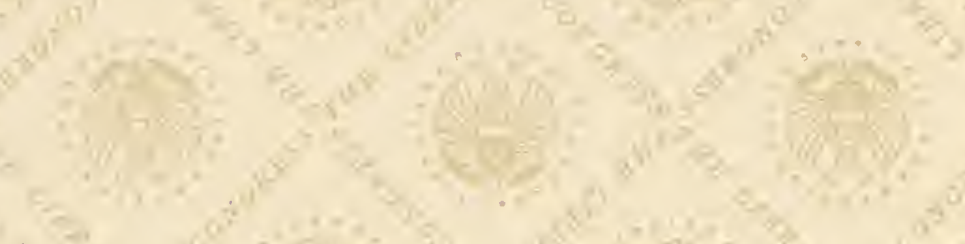

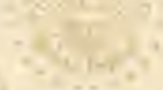

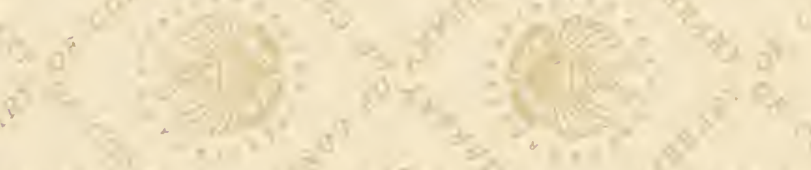

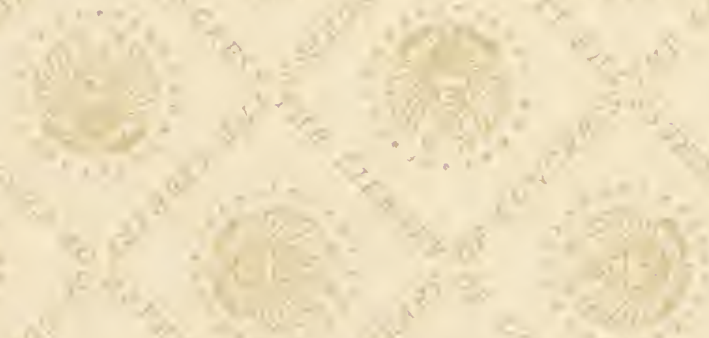

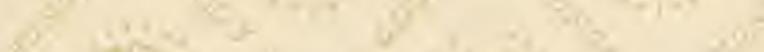<smiles>C1C2CC3CC1C23</smiles>

$(5)$

(2) $18=$

$-x^{\prime}$

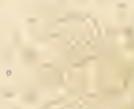

$+80^{8}=$

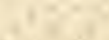

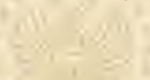
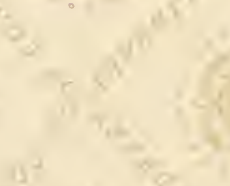

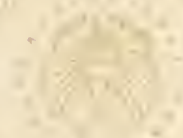






$$
5 x^{2} y^{6}
$$




\section{OLEOMARGARINE AND O'THER IMITATION DAIRY PRODUCTS, ETC. \\ LIRAARY OF CONGRESS, HECEIVED}

\section{FEB 1 \& 1901}

JANCARY 26, 1901.-Ordered to be pringhyISION OF DOCUMENTS,

Mr. Procror, from the C'ommittee on Agriculture and Forestry submitted the following

\section{REPOR'T, WITH THE VIEWS OF THE MINORITY.}

[To aecompany H. R. 3717.]

The Committee on Agriculture and Forestry, to whom was referred House bill 3717, known as the Grout bill, and entitled "An act to make oleomargarine and other imitation dairy products subject to the law: of the State or Territory into which they are transported, and to ehange the tax on olcomargarine," begs leave to submit the following" report and reeommend the passage of the bill:

This bill proposes to increase the tax on olcomargarine eolored in semblance of butter and reduce that not colored in imitation of butter to the mere nominal sum of a quarter of a cent a pound, the purpose being to encourage the sale of the genuine article, and to disconrage the sale of the imitation article and to protect the honest producer. dealer, and eonsumer of both butter and oleomargarine.

So far as the identifieation of the eommodity to the wholesaler is concerned, the law of 1886 has been successful. So far as the identitication of the commodity to the consumer is concerned, the law of 1886 is of little value, the evidence being that a very large proportion of the oleomargarine manufactured goes to the consuner finally as butter, either as a purchaser of the retailer or as a guest at a hotel, restaurant, or boarding house.

Your committee, realizing the importance of the questions incolved in the bill, has inquired very carefully and exhaustively into the existing conditions, as shown by the report of the testimony before the committee. which oecupies 5 50 pages, the taking of which was begun December 19 last and oceupied the attention of your committee much of the time from that date to and including Jannarv 16. Your conmit- 
tee can eonceive of no interest which would be afferted that was not represented at the hearings and does not see how any thing new could have been presented had the hearings been continned indefinitely.

It apears from the testimony that through the legislatures of 3. States, with fons-fifth of the population of the United States, the people have expressed their cisapprovilof oleomargarine colored in semblance of butter: that those who have been charged with the duty of enforeing the State laws regarding this product are positive in the opinion that so long as it is colored in imitation of hutter fraud upon the consininer. if not upon the dealer, 'an not be prevented. Your committee is of the opinion that such frand is actually sanctioned and defended by some of the largest manufacturers, who guarantee their retailers protection in case of proserution for the sale of oleomargarine in contravention of State laws.

It also appeared, and it was not denied by the mamufacturers themselves, that they do not feel in any way bound to respect the laws of the States against selling oleomargatrine colored in imitation of butter. claiming that they are unconstitutional: and the testimony revealed methods by which such laws are evaded or their enforement defeated, despite the fact that such laws have been sustained by the courts of last resolt in the states and also by the Supreme Court of the L'nited States.

So far as the "ommittee has been able to ascertain, this measmre has the approval of all state officials and food conmissioners whose duties are the enforcement of the laws regulating the mamufacture and sale of oleomargarine.

It appears to be unamimousty desired hy the farmers of the country who are engaged in dairying. and has the armest approval of the Secretary of Agrienlture, who appeared before the committee at its request and who has made an exhanstive study of the question from a broad, economic point of view.

Your' 'ommittee bas listened with interest to the representations of the live-stock interests and the cotton-seed oil manufacturer's. and is mable to see in this measure anything that can greatly injure either. The Secretary of Agriculture expressed the opinion before the committee that the dairy cow was a necessity to the restoration of the rxhansted cotton lands of the Srouth.

Tre have heard some objections to this measure from organized labor", and while it is true that some laboring men may, as represented. prefer, as a matter of pride, to consume oleomargarine that is yollow instead of white, yet your committee helieves that while the pride of some may suffer under this measure, which will raise the tax on the colored and rednce it on the uncolored, a far greater number are now being deceived througu the sale of oleomargarine as hutter' and at butter prices.

Yonr committee is of the opinion that if oleomaryarine is the wholesome and nutritions product that those interested in its manufacture and sale claim it to be, it will meet with a ready demand in its natural rolor, and especially as the tax on the meolored product is by this bill reduced from 2 cents to one-quarter' of a cent per pound.

We submit herewith the report on this measure by the committer of the House and the views of a minority of that body. 
[Honse Report No. 18.H, Fifty-sixth (ongress, first sexsion.]

The Committee on Agriculture, to whom was referucd H. R.3717, known as the Grout bill, "To make olenmargarine and ofl er imitatir n dairy I rr cinets subject to the laws of the st: te or Tertitory into wh ich they are transported and to change the tax on olcomargarine," leg leave to submit the fillow ing report and recommend the pass age of the lill:

We are of the opinion that the people have anple anse for alarm at the tremendous illegal grow th of the oleomargarine traftic in this countsy dumitgr the past few rears, which now appeass to have reacherl proportions beyond the power of the States to successfully regulate or control, and the puesent Ferleral aw are apparently altogether inarlerpate for the emr rgency.

After earefully we ighing the evidence and suggestions offered for rmedics for the regulation of this traffic: we ale constrained to loold that the provisions of 11 . R.3717 offer the best practical solution of the difficulty.

We helieve that the States should be protected in their rights to regulate their internal affairs to the fullest extent in relation to articles of food which have been adlusclged adulterated or of a deceitful character, and we do not think that the interstate-commerce law of the ciovermment shonld protect a deceitful imitation from the jurisctiction of the State's laws, even if the article in question is in the original package and is shipped from an untsider into the state in such prackage.

We fiml that the rery foundation and canse of the enormous amount of framd and illegal selling of oleomargarine is in the great profits which are deriverl from the sale of the initation because of its absolute comterfeit of butter, which enables uncerupulous dealers to impose upon unsuspecting customers. These profits are sufficiently large to cause the retailer to run the chances of detertion and proverution; and they are further emboldened and encouraged through the guaranties of the manufacturers of protection against prosecutions miler the State laws.

Thirty-two States, having four-fifths of the entire population of the Initerl States, ahsolntely forbid the manufacture and sale of uleonargarine colored to resemble butter. These laws have been upheld in the higher courts without a single exception, and the question has twice been pasied upon favorably by the Supreme court of the Uniterl States. Therefore, the policy of a very large majority of our people is plainly against the existence of the article in such counterfeit form.

The tax of 10 cents per pound upon oleomargarine colored to recemble butter will not deprive the manufacturers ami dealers or consumers of any great amount of legal right they now possess. Four-fifths of the colored article made is sold illegally nuw, as indieated by the reports of the Treasury Department, and the only effect of this tax, even were it prohibitive upon this class of oleomargarine, wouli be to prevent the manufacture of an article the sale of which is eontrary to the laws of $3: 2$ states if the Enion. This tax will bring the cont of the colored article up to a figure that will take from it the possibility for the large profits which have been the incentives to violate the laws of the State and Government and leframd innocent purchasers, while the reduction of the tax on oleomargarine in its natural color from 2 cents to one-fourth cent per pound will make it possible for the man who really desires to consume oleo:rargarine to procure it at a much lower cost than heretofure, the only difference being that it will not contain coloring matter, which not even the opprinents of this measure claim contributes anything to its palatableness or nutritive value.

We believe the manufacture and sale of oleomargarine will continne muer this measure, and that those who lesile a cheap substitute for butter will purchave the uncolored article. The only difference is that the romterfeit article, coloren in imitation of butter, will no longer be accessible to hotel keepers, restanrant keepers, and boarding-house proprietors at such prices as will be an inducement for them to deceive their guests, as is now, we believe, absolntely universal where it is served, and thus another class of eonsmmers, who have been subject to imposition for more than went years, will be able to know whether they are eating butter fat or hog fat when they spread their bread. If colored oleomargarine is served it will he becanse it is better and not because it is eheaper than butter.

Serious conditions require drastic measures, and it certainly appears from the testimony of those representing the producers of butter, as well as from the admisions of the witnesses for the other sirle, that those who are engaged in this oleomargarine traftic have absolutely no regard for State laws, and regard the public as their legitimate vietim, in whose behalf ther resent the interierence of the cieneral Government. The continued existence of such a condition we can not but believe furnishes a demoralizing example to our penple in tralle, who are bejng tutored by this oleomargarine interest in the art of evasion am definces of the legally constitutul authorities. 


\section{APPENDIX.}

The population of the States which have passed laws forbidding the sale of oleomargarine colorel in semblance of butter, as shown by the census of 1890 , is as follow:

\begin{tabular}{|c|c|c|c|}
\hline Кеш York & Population. & Soutb Carolin & Population. \\
\hline Pennsylyania ............. & $5,228,014$ & $\begin{array}{l}\text { Sotitn Carolma } \\
\text { Nebraska ..... }\end{array}$ & $\begin{array}{l}1,151,1+9 \\
1,058,910\end{array}$ \\
\hline Illinois $\ldots \ldots \ldots \ldots \ldots \ldots \ldots$ & $3,826,351$ & Marylanel .... . & $1,042,390$ \\
\hline Ohio $\ldots \ldots \ldots \ldots$. & $3,672,316$ & West Virginia.. & 762,794 \\
\hline Missouri ................ & $2,679,184$ & Connecticut.... & $7+6,25: 3$ \\
\hline Massachusetts ............ . & $2,238,943$ & Daine ........ & 661,086 \\
\hline Michigan .............. & $2,093,889$ & Colorado............. & 412,198 \\
\hline Iowa & $1,911,896$ & New Hampshire.......... & 376,530 \\
\hline Kíntucky................ & $1,858,635$ & Washington ............. & 349,390 \\
\hline eorgia................... & $1,837,353$ & Oregon ........... & 313,767 \\
\hline Tennessee................ & $1,766,518$ & Vermont.. & $332,+42$ \\
\hline Wisconsin . . . . . . . . . & $1,686,880$ & South Dakota ........... . & 328,808 \\
\hline Virginia............ & $1,655,980$ & Utah $\ldots \ldots \ldots \ldots$ & 207,905 \\
\hline Alabaina............ & $1,513,017$ & North Dakota ............ & 182,711 \\
\hline New Jersey . . . . . . . . . . . . & $1,444,933$ & Delaware ............... & $168,+98$ \\
\hline $\begin{array}{l}\text { Minnesota } \\
\text { California } \ldots \ldots \ldots\end{array}$ & $\begin{array}{l}1,301,826 \\
1,208,130\end{array}$ & \multicolumn{2}{|c|}{ Total ........... 50,117, 440} \\
\hline \multicolumn{4}{|c|}{$\begin{array}{l}\text { The States and Territories which have not passed laws forbidding the sale of oleo- } \\
\text { margarine colored in semblance of butter are: }\end{array}$} \\
\hline Texa: & $\begin{array}{l}\text { Population. } \\
2,235,523\end{array}$ & New Mexico & Population. \\
\hline Indi & $\approx, 192,+04$ & Montana... & 132,156 \\
\hline North Carolina.... & $1,617,947$ & Idaho ...... & 84,385 \\
\hline Kànsas .......... & $1,+27,096$ & Oklahoma .. & 61,834 \\
\hline Mississippi $\ldots \ldots \ldots \ldots \ldots$ & $1,289,700$ & Wyoming. . . . . . & $60,70.7$ \\
\hline Arkansas .............. & $1,128,179$ & Arizona ...... & 59,620 \\
\hline Lonisiana . . . . . . . . . . . . . . . & $1,118,587$ & \multirow{3}{*}{ Total } & 45,761 \\
\hline e Island ..... & $321,+22$ & & \\
\hline District of Columbia....... . & 230,392 & & \\
\hline
\end{tabular}

\section{VIEWS OF THE MINORITY.}

The minority of the Committee on Agriculture of the House of Representatives beg leave to submit the accompanying bill, which we offer as a substitute for $\mathbf{H}$. R. 3717 , known as the Grout bill.

We first wish to bring to the attention of the House proof positive that oleomargarine is a wholesome and nutritious article of food, and is therefore entitled to a legitimate place in the conmerce of our country. In substantiation of this statement we beg to submit the following testimony taken before the committee:

\section{OPINIONS OF LEADING SCIENTISTS.}

Prof. C. F. Chandler, professor of chemistry at Columbia College, New York, says: "I have studied the question of its use as food, in comparison witl the ordinary butter made from cream, and have satisfied myself that it is quite as valuable as the butter from the cow: The product is palatable and wholesone, and I regard it as a most valuable article of food."

Prof. George F. Barker, of the University of Pennsylrania, says: "IButterine is, in my opinion, quite as valuable as a nutritive agent as butter itself. It is perfectly wholesome, and is desirable as an article of food. I can see no reason why butterine should not be an entirely satisfactory equivalent for ordinary butter, whether considered from the physiological or commercial stand point."

Prof. Ienry Morton, of the Stevens Institute of Technology, New Jersey, says: "I am able to say with confidence that it contains nothing whatever which is injurious as an article of diet, but, on the contrary, is essentially irlentical with the best fresh butter, and is superior to much of the butter made from cream alone which is found in the market. The conditions of its manufacture involve a degree of cleanliness and consequent purity in the product such as are by no means necessarily or generally attained in the ordinary making of butter from cream."

Prof. S. WT. Johnson, director of the Connecticut Agricultural Experiment Station, 
and professor of agricultural chemistry in Yale College, New IIaven, says: "It is a product that is entirely attraetive and wholesome as food, ant one that is for all ordinary and culinary purposes the full equivalent of good butter made from cream. I regard the manufacture of oleomargarine as a legitimate and beneficent industry."

Prof. S. C. Caldwell, of Comell University, Ithaca, N. Y., says: "While not equal to fine butter in respect to flavor, it nevertheless contains all the essential ingredients of butter, and since it contains a smaller proportion of volatile fats than is found in genuine butter, it is, in my opinion, less liable to become rancisl. It can not enter into competition with fine butter, but so far as it may serve to drive poor butter out of the market, its manufacture will he a publie benefit."

Prof. C. A. Goessmann, of Amherst Agricultural College, says: "Oleomargarine lutter compares in general appearance and in taste very favorably with the average quality of the better kinds of dairy butter in our markets. In its composition it resembles that of ordinary dairy butter, and in its keeping quality, under corresponding (arcumstances, I believe it will surpass the former, for it contains a smaller percentage of those constituents which, in the main, cause the well-known rancid taste and odor of a stored butter."

Prof. Charles P. Willians, professor in the Missouri State University, says: "It is a pure and wholesome article of food, and in this respect, as well as in respect to its chenical composition, fully the equivalent of the best quality of dairy butter."

Prof. J. W.S. Amold, profeswor of physiology in the Univerity of New York, says: "I consider that each and every article employed in the manufaeture of oleomargarine hntter is perfeetly pure and wholesome; that oleomargarine butter differs in no essential manner from butter made from cream. In fact oleomargarine lutter possesses the advantage over natural butter of not decomposing so readily, as it contains fewer volatile fats. In my opinion oleonargarine is to be considered a great discovery, a blessing for the poor, and in every way a perfectly pure, wholesome, and palatable article of food.

Prof. W. O. Atwater, director of the Uniter States Govermment Agricultural Experiment Station at Washington, says: "It contains essentially the same ingredients as natural butter from cow's milk. It is perfectly wholesome and healthy and has a ligh nutritious value."

Prof. Henry E. Alvord, formerly of the Massachusetts Agricultural College, and presilent of the Maryland College of Agriculture, and now chief of the Dairy Division of the United States Department of Agrieulture, and one of the best butter makers in the country, says: "The great bulk of butterine and its kindred products is as wholesome, cleaner, and in many respects better, than the low grades of butter of which so much reaches the market."

Prof. Paul Schweitzer, Ph. D., LL. D., professor of chemistry, Missouri State Lniversity, says: "Av a result of my examination, made both with the microscope and the delicate chemical tests applicable to such cases, I pronounce butterine to be wholly and unequivocally free from any deleterious or in the least objectionable substances. Carefully made physiological experiments reveal no difference whatever in the palatability and digestibility lietween butterine and butter."

Professor Wiley, chief of the Division of Chemistry of the Uniter States Department of Agriculture, also appeared before the cominittee and testified to the nutritive and wholesome qualities of oleomargarine.

The Committee on Manufactures of the United States Senate, in a report daterl Fehruary 28, 1900, finds, from the evidence before it, "that the product known commercially as oleomargarine is healthful and nutritions."

Julge Inghes, of the Ferleral court of Virginia, in a decision, says:

"It is a fact of common knowledge that oleomargarine has been suljected to the severest scientific scrutiny, and has been adopted by every leading govermment in Europe as well as America for use by their armies and navies. Though not originally invented by us, it is a gift of American enterprise and progressive invention to the world. It has beeome one of the conspicuous articles of interstate commerce and furnishes a large income to the General (iovernment annually."

Believing that this testimony establishes beyond controversy that oleomargarine is a nutritious and wholesome article of food, the main question to be consillerer is: the complaint that frand is practicerl in its sale.

The only just eomplaint (indeer the only complaint) against the existing oleomargarine law consists in the facility with which the retail (lealer, in selling from the original or wholesale package and sulstituting a new and ummarked wrapper, may violate the law. There is nothing in H. R. 3717 (known as the Grout will) which would slecrease the temptation or increase the difficulty of such violations. On the contrary, the increased taxation wonld either be fraudulently evarled or else would force the honest manufacturer out of business. H. R. 3717 merely increases taxation without providing any new or additional penalties or any new methorls to prevent the sale of oleomargarine as butter, either in its colored or uncolored state. In fact, 
the radical arlyocates of the (irout bill do not seek this encl, as they have declared in their testimony before the committee and in dectarations elsewhere that their sole intention is to absolutely "rush out the mannfacture of oleomargarine and eliminate it as a food prorlurt.

In substantiation of this assertion we quote the following:

Mr. Adams, pure food rommissioner of the state of Wisconsin, in his testinomy before the committee on March 7,1900 , sairl:

"There is no use beating about the bush in this matter. We want t" pass this law and drive the nleomargarine manufacturers nut of the business."

Charles Y. Knight, secretary of the National Dairy [nion, in a letter to the Virginia rlairymen, dated May 18, 1900, writes:

"Now is the time for you to elip the fangs of the mighty octopus of the oleomargarine manufacturers, who are ruining the dairy interests of this conntry by mantefacturing and selling in defiance of law a spurions article in initation of pure butter. We have a remedy almost in gras] which will eliminate the manufacture of this. article from the food-product list. The Grout bill, now pending' in the Agricultural Committee of the Honse of Representatives in ('ongress, meets the ilemand."

IV. D. Hoard, ex-governor of Wisconsin and presillent of the National Dairy Union, stated in his testimony before the committee on Marels $\overline{7}, 1900$, as follows:

"To give added force to the first section of the bill, it is provirled in the second sertion that a tax of 10 cents a pound shall be imporect on all oleomargarine in the color or semblance of butter. In plain work, this is repressive taxation."

In view of this testimony the minnity believe they are justified in claming that the Grout bill, if enacted into law, wonld destroy the business of the legitimate oleomargarine manufacturers. In other words, Congress is being asked to ruin one industry to benefit another; and this, in the opinion of the minority, is a thing Congress ought not to slo. The minority believe it to be elass legislation of the most pronomncerl kind and would establish a precerlent which, if allowed, wonld create monopolies, destroy competition, and militate against the jublic good.

The substitnte bill offered ly the minority would, in onr opinion, eliminate all possibility of fraul, and would eomine] the nanufacturers of and dealers in oleomargarine to sell it for what it really is ans not for butter. The substitute offeresl is practically an amendment to section 3 and 6 of the existing oleomargarine law. The licenses for manufacture and sale of this article are not wangerl, and are as follows: Manufacturers, $\$ 600$ per annmm; wholesale dealers, $\$ 400$ per anmm; retails ers, $\$+8$ per annum, while the penalties imposed for violations of the law are materially increased. We gnote in full section 2 of the sulstitute bill, and ask for it the eareful and thoughtful consideration of the Honse, lelieving that it is just and fair to all the interests involved:

"Sec. ". That all oleomargarine shall he put up hy tho manufacturer for sale in packages of one and two pounds, respertively, and in no other or larger or smaller package; and npon every print, brick, roll, or lump of oleomargarine, lefore being so put up for sale or removal from the factory, there shall be impressed by the manufacturer the word 'olemmargarine' in sunken letters, the size of which shall be prescribed by regulations made ly the Commiswioner of Internal Revenue and approved by the Secretary of the Treasury; that every such print, lirick, roll, or lump of oleomargarine shall first be wrapped with pajer wrajper with the worc] 'oleomargarine' printed thereon in distinct letters, and saicl wrapper shall also hear the name of the manufarturer, and thenshall be put by the manufacturer thereof in such wooden or paper paekages or in such wrappers, with the word "olenmargarine" printed thereon in distinet letters, and marked, stamperl, and branted in such manner as the Commissioner of Internal Revenue, with the approval of the serretary of the Treasury, shall preseribe, and the internal-revenue stanp shall be aftixert so as to surround the onter wrapper of each one and two [ound latckage: Promided, That any number of snch original stamped packages may be put up by the manufacturer in crates or boxes, on the outside of which shall be marked the word 'oleomargarine,' with such other marks and branls as the Commissioner of Internal Reronue shall, by regulations approved by the Secretary of the Treasury, prescrilse.

"Retail s]ealers in oleoniargarine shall sell only the original package to which the tax-paid stamp is affixerl.

"Every person who knowingly sells or offers for sale, or clelivers or offers to deliver, any oleonargarine otherwise than as provided by this act or contrary to the regulations of the Commissioner of Internal Revenue marle in pursuance hereof, or who packs in any package any oleomargarine in any manner contrary to law, or who shall sell or offer for sale as butter any oleomargarine, colored or uncolored, or who falsely brands any package, or affixes a stamp on any package denoting a less amount of tax than that reguired by law, shall be fined for the first offense not less than one hundred nor more than five hmolred dollars and be imprisoned not less than thirty days nor more than six montlis; and for the second and every sulsequent offense 
shall be fined not less than two bundred nor more than one thousand dollars and be imprisoned not less than sixty lays nor more than two years."

One of the claims marle by the iriends of the Grout bill is that it will protect the interests of the farmer. We call attention to the fact that every ingredient that enters into the manufacture of oleomargarine is as much a prouluet of the farm as is butter, and that such ingredients are made more valuable on account of their use in the manufacture of oleomargarine.

Your committee has bad before it representatives of both the cattle and hog raiser: of the country, and also representatives of the cotton industry, and they are unanimous in their opinion that their business will be materially injured and the price if their product lowered by the passage of the Grout bill and the destruction of the oleomargarine industry.

The manufacture anil sale of oleomargarine does not interfere with the growth and prosperity of the butter industry. Statistics show a nuch greater percentage in the increase of the production of butter than in the production of oleomargarine. Thougl similar in ingredients, they are not strictly competing, as the oleonargarine is prastically all bought ly the poorer class of our people.

In justification of this statement we have received a large number of petitions from the labor organizations of our comntry protesting against the pawsage of this bill for the above-given reasons.

It being possible to keep oleomargarine in a sweet and sound condition much longer than butter, it is also used extensively in the mining and lumber camps, on exploring and hunting experlitions, on ships at sea, and by armies in the fiehl.

The claim made by the friends of the (irout bill that the manufacture and sale of oleomargarine has greatly clepreciated the price of butter will not obtain when it is known that there is now manufactured in the Uniter States nearly $2,000,000,000$ pounds of butter annually, and it is positively known that there only were $83,000,000$ pounds of oleomargarine manufactured last year, which shows that the anount of oleomargarine producerl is alsout + per cent of the amount of butter proulnced. Therefore, the argmment that oleomargarine in any material sense controls the price of butter is not justified by the facts.

The manufacture and sale of oleomargarine have in no way clepreciated the price of butter, as more lutter is being soltl at a higher price in this country than ever before, as shown hy testimony.

It is a suggestive fact that those sections of our comntry which are most exelusively devoted to the dairy interests are blessed with the greatest prosperity, as brought out in the testimony of ex-(rovernor Hoarl, of Wisconsin, before our committee, who said that a few years ago land was worth only $\$ 15$ an acre in that state, but as the State began to be devoted more exclusively to the dairy interests land had rapilly appreciated in price, and that farmers had gotten out of lebt, harl paid their mortgages, and the lant is now worth the sum of $\$ 80$ per acre, this price averaging much higher than agricultural lands in other parts of the country.

In concluwion, the members of the Committee on Agriculture who have joined in this minority report beg to assure the House and the country in the most solemm manner possible that it has been their earnest intention, and is now their dotermination, to do everything possible to be rlone to enforce the sale of oleomargarine as oleomargarine and to prevent its sale as butter. To prevent frand and not to stamp out an inclustry has been and is our purpose. We helieve that it ought to he the sole purpose of all legislation and the sole motive of all just men.

J. W. WAMsWoRTH.

WM. IORIMER.

W. J. BAILEY.

G. H. White.

Jolix S. WiLLIAM.

J. WM. N'TOKES.

H. D. AlLEX.

\section{[Fubstitute for H. R. 3717.]}

A BILI, To amend sections three and six of an aet entitled "An aft defining butter, also imponing :! tux upon and regulating the manufacture, sale, inuortation, and exportation of oleomargurine," approved August second, eighteen hundred and eighty-six, and also to define manufueturers unil dealers and to provide for the parment of special taxes by them.

Be it enacted by the Senate and ITouse of Representatiors of the Lnited states af aturerire in Congress assembled, That sections three and six of an act entitlerl "An act defining butter, also imposing a tax upon and regulating the manufacture, sale, importation, and exportation of oleomargarine," approved Angust second, eighteen humbred and eight y-six, he amended so as to read as follows:

"SEC. 1. That special tax on the manufacture and sale of oleomargarine shall he 
inposed as follows: Manufacturers of oleomargarine shall pay six hundred dollars per ammun. Exery person who manufactures oleomargarine for sale shall be deemed a manufacturer thereof.

"Wholesale dealers in oleomargarine shall pay four hundred and eighty dollars per annum. Every person who sells or offers for sale oleomargarine in quantities greater than ten pounds at a time shall be deemed a wholesale dealer therein; but a manufacturer of oleomargarine who has given the required bond and paid the required special tax, and who sells oleomargarine of his own production only at the place of its manufacture in the original packages to which the tax-paid stamps are affixed, shall not be required to pay the special tax of a wholesale dealer on account of such sales.

"Retail rlealers in oleomargarine shall pay forty-eight dollars per annum. Every person who sells or offers for sale oleomargarine in quantities not greater than ten pounds at a time shall be regarded as a retail dealer therein.

"SEc. 2. That all oleomargarine shall be put up by the manufacturer for sale in packages of one and two pounds, respectively, and in no other or larger or smaller package; and upon every print, brick, roll, or lump of oleomargarine, before being so put up for sale or removal from the factory, there shall be impressed by the manufacturer the word 'oleomargarine' in sunken letters, the size of which shall be prescribed by regulations made by the Commissioner of Internal Revenue and approved by the Secretary of the Treasury; that every such print, brick, roll, or lump of oleomargarine shall first be wrapped with paper wrapper with the word 'oleomargarine' printed thereon in distinct letters, and said wrapper shall also bear the name of the manufacturer, and shall then be put by the manufacturer thereof in such woorlen or paper packages or in such wrappers and marked, stamped, and branded with the word 'oleomargarine' printed thereon in distinct letters, and in such manner as the Commissioner of Internal Revenue, with the approval of the Secretary of the Treasury, shall prescribe, and the internal-revenue stamp shall be affixed so as to surround the outer wrapper of each one and two pound package: Prorided, That any number of such original stamped packages may be put up by the manufacturer in crates or boxes, on the outside of which shall be marked the word 'oleomargarine,' with such other marks and brands as the Commissioner of Internal Revenue shall, by regulations approved by the Seeretary of the Treasury, prescribe.

"Retail dealers in oleomargarine shall sell only the original package to which the tax-paid stamp is affixed.

"Every person who knowingly sells or offers for sale, or delivers or offers to deliver, any oleomargarine otherwise than as provided by this act or contrary to the regulations of the Commissioner of Internal Revenue made in pursuance hereof, or who packs in any package any oleomargarine in any manner contrary to law, or who shall sell or offer for sale, as butter, any oleomargarine, colored or uncolorerl, or who falsely brands any package, or aftixes a stamp on any package denoting a less amount of tax than that required by law, shall be fined for the first offense not less than one hundred nor more than five hundred dollars and be imprisoned not less than thirty days nor more than six months; and for the second and every subsequent offense shall be fined not less than two hundred nor more than one thonsand dollars and be imprisoned not less than sixty days nor n110re than two years." 


\section{VIEWS OF' THE MINORITY.}

The minority of the Committee on Agriculture and Forestry beg leare to submit to the Senate a substitute for the bill H. R. $3717^{\circ}$, with farorable recommendation. The substitute is as follows:

[Substitute for H. R. 3717.]

A BILL to amend sections three and six of an act entitled "An act defining butter, also imposing a tax upon and regulating the manufactnre, sale, importation, and exportation of oleomargarine." approved August second, eighteen hundred and eighty-six, and also to define mannfacturers and dealers and to provide for the payment of special taxes by them.

Be it enacted by the Senate and House of Remresentatives of the Inited states of America in Congress assembled, That sections three and six of an act entitled "An act defining butter, also imposing a tax upon and regulating the manufacture, sale, importation, and exportation of oleonargarine," approved August seconi, eighteen hundred and eighty-six, be amended so as to read as follows:

"SEc. 1. That special tax on the manufacture and sale of oleomargarine shall be imposed as follows: Manufacturers of olemmargarine shall pay six hundred dollars per annum. Every person who manufactures oleomargarine for sale shall be deemed a manufacturer thereof.

"Wholesale dealers in oleomargarine shall pay four hundred and eighty lollars per annum. Every person who sells or offers for sale oleomargarine in quantities greater than ten pounds at a time shall be lleemed a wholesale dealer therein; lut a manufacturer of oleomargarine who has given the required bond and paid the required special tax, and who sells oleonargarine of his own production only at the place of its manufacture in the original packages to which the tax-pair stamps are affixed, shall not be required to pay the special tax of a wholesale dealer on account of such sales.

"Retail dealers in oleomargarine shall pay forty-eight dollars per annum. Every person who sells or offers for sale oleomargarine in quantities not greater than ten pounds at a time shall be regarded as a retail dealer therein.

"SEc. 2. That all oleomargarine shall be put up by the manufacturer for sale in packages of one and two pounds, respectively, and in no other or larger or smaller package; and mpon every print, brick, roll, or lump of oleomargarine, befole being so put up for sale or removal from the factory, there shall be impressed by the manufacturer the word 'olermargarine' in sunken letters, the size of which shall be prescribed by regulations made by the Commissioner of Internal Revenue and approved by the Secretary of the Treasury; that every such print, brick, roll, or lump' of oleomargarine shall first be wrapped with paper wrapper with the word 'oleomargarine' printerl thereon in cistinct letters, and said wrapper shall also bear the name of the manufacturer, anıl shall then be put by the manufacturer thereof in such wooden or paper packages or in such wrapperw and marked, stamped, and branded with the word 'oleomargarine' printed thereon in listinct letters, and in such manner as the Comminsioner of Internal Revenue, with the approval of the Secretary of the Treasury, shall prescribe, and the internal-revenue stamp shall be affixed so as to surround the outer wrapper of each one and two pound package: Provided, That any number of such original stamperl packages may be put up by the manufacturer in crates or boxes, on the outside of which shall be inarker the word 'oleomargarine,' with such other marks and brands as the Commisioner of Internal Revenue shall, by regulations aplored by the Secretary of the Treasury, prescribe.

"Retail realers in oleomargarine shall sell only the original package to which the tax-paid stamp is affixed.

"Every person who knowingly sells or offers for sale, or delivers or offers to deliver, any oleomargarine otherwise than as provicled by this act or contrary to the regulations of the Commissioner of Internal Revenue maite in pursuance hereof, or who packs in any package any oleomargarine in any manner (ontrary to law, ol wh" shall sell or offer for sale, as butter, any oleomargarine, colored or uncolored, or who 
fakely brauds any package, or aftixes a stamp on any package denoting a less amount of tax than that requireil by law. Shall be fined for the first offense not less than one hmulred nor more than five humbred dollars and be imprisoned not less than thirty days nor more than six months; and for the second and every subseguent offense shall be fined not less than two hundred nor more than one thousant dollars and be imprisoned not less than sixty days nor more than two yeals."

Oleomargarine is a legrtimate article of commerer.

This has been distinctively held by the Supreme Count of the Lnited states. In the ase of Schollenberger r. Pemmsylvania (171 U. S., $30)$, which was decided May 26,1898 , the Supreme Cont held as tollows:

In the examination of this subject the tirst question to be considered is whether oleomargarine is an artide of commere. No aftirmative evitence from witnesses alled to the stand and speaking directly to that subject is found in the record. Ire must detemine the guestion with reference to those facts which are so well and miversally known that courts will take notioe of them withont particular proofs. being adkluced in regard to them, and also by reference to those dealings of the commercial world which are of like noturiety. Any legislation of Congress upon this mbject must, of coursen, be recognized by this court as of first importance. If Comgress has attirmatively promonneed it a proper subject of commerce, we should rightly be influenced by that reclaration.

After referring to the aret of ('ongress of Algust 2. 1856 , being the law now in forere inmosing a tax of 2 rents a pound on oleomatrgarine, the court further stated as follows:

This shows that congress at the time of its passage in $18 s 6$ recognizerl the article as a proper subject of tixation, and as one which was the subject of traftic and of exportation to foreign comitries and of importation from such comntries. Its mamfacture was reognized as a lawful pursuit, and taxation was levied mon the matnfacturer of the article, mon the wholesale and retail dealers therein, and also upon the article itself.

Conchuding mpon this hranch of the "ase, the court stated as follows:

The article is a snbject of expont and is largely nsed in forejgn onntries. Upon all these facts we think it aplarent that oleomargarine has become a proper subject of eommere among the states and the foreign nations.

coloring matter is rsed both in the making of butter and in the manufacture of oleomargarine for the purpose of ateling to the tastes of consumers who hate fren aledestomed to a generally yellow tint in looth food products.

Neither the makers of butter nor the manufacturers of oleomalean-e rine can claim rightfully any exchusive right to the use of coloring matter in their respective products. Both admit that coloring matter is used for the reason that their customers prefor an article of a rollowish tint. If consumers pleferred the atticle white, or fres from any tint whaterer, the makers of butter and the manufaturers of oleomargarine could just as easily and ren more asily, respond to that taste. 'The question for the lawnaking power to consider is this: should the law interfere in a case of this kind and aid the makel's of one product and injure the manufartner's of the other'!

The second section of the proposed hill imposes a tax of 10 cen's a pound upon colored oleomargarine, or" in the language of the act, "colored in the imitation of hutter." The adrorates of this proposed legislation admit that their object is to place the tax on oleomaldarine so high that it can not he placed upon the markets of the country if colored.

It is the mniversal opinion of those engaged in the manufacture of oleomargarine that a tax of 10 eents a pound upon the product colored a yellow tint will destroy that industry, for the reason, which expe- 
rience has shown, there would not be any considerable demand for oleomargarine in an uncolored condition. "This opinion is based upon efforts which have already been made to introduce and sell the uncolored product in States where anticolor laws now prevail. The ohject. therefore. of imposing this excessive tax of 10 cents a pound upon colored oleomargarine is not for the purpose of raising revenue, but for the purpose of prohibiting its manufacture, and of thus destroying the industry. It is of no importance that the proposed legislation reduces the tax on uncolored oleomargarine from 2 cents a pound to one-fourth of a cent a pound. Unless there is reason to believe there would be a sulstantial production of that kind of article, the increase of the tax of 10 cents a pound would, in all probability, prevent any substantial revenue being derived from its manufacture.

The allegerl frauds committed in the sale of oleomargarine are not attributed to the manufacturers. but to the retail dealer's in the article.

This brings us to the consideration of the question whether frand in the sale of oleomargarine as butter can better be prevented by the proposed legislation. which imposes a tax of 10 cents a pound upon its manufacture, or by the enactment of more stringent regulations governing the retail dealer.

Under the present law the retail dealer is required to break the original package in which he receives oleomargarine from the manufacturer. The smallest package which the law permits the manufacturer to place upon the market contains 10 pounds. The retail dealer is only permitted to sell from the manufacturer's original packages. If he desired to sell in 10-pound packages or over, he would be required to take out a wholesale dealer"s license. which is fixed at $\$ 480$ a rear. This makes it necessary for the retailer to break the original package. and it is conceded that whatever frauds may be committed occur hy reason of this fact.

If the retail dealer desires to commit a fraud upon his customer, the opportunity for so doing is thus afforded. If legislation can be enacted which will require the retail dealer to sell oleonnargarine in the original package put up by the mantifucturer without breaking the wrapper or the internal-revenue stamp of the Government, and if such wrappers and stamps were clearly and distinctly marked and branded. under regulations of the Commissioner of Internal Revenue, the opportunity, to commit fraud upon the customer would be wholly eliminated or reduced to a minimum. This opinion is entertained by those most intimately connected with the manufacture and selling of oleomargarine: and it is also the opinion of the Secretary of the Treasury, given in his statement before the Senate Committee on Agrieulture: and also the opinion of ex-('ommissioner of Internal Revenue. Mr. Wilson, given in his statement before the House ('onmittee on Agriculture.

Under the proposed bill the temptation to fraud on the part of the retail dealer would be largely increased from the fact that he will be enabled to buy the uncolored oleomargarine, on which one-fourth of a cent per pound tax is imposed, and by coloring the same himselt increase the value of his product ! $\frac{3}{4}$ cents per pound, for the reason that he could sell the same at this latrely increased protit for either butter or oleomargarine.

We assume that the lawmaking power of the Government desires to prevent the possibility of frand in the sale of oleomargarine as but- 
ter and not to destroy the industry itself. We therefore recommend legislation upon the subject which will make fraudulent sales as near impossible as laws can provide.

We have omitted reference heretofore to the first section of the pending bill. This section has for its object the placing of oleomargarine under the police laws of the sereral States, notwithstanding its introduction into a State in the original package. This provision is for the purpose of aroiding the effect of the ruling of the Supreme Court of the United States in the ease of Schollenberger 2 . Pennsylvania, reported in $171 \mathrm{U}$. S., 1-30. The opinion of the Supreme Court in that case was to the effect that a lawful article of commerce can not be wholly excluded from importion into a State from another State where it was manufactured. It was conceded in that opinion that a State has power to regulate the introduction of any article, including a food product, so as to insure purity of the article imported. but that such police power does not include the total exclusion even of an article of food.

The States may provide for a reasonable inspection of all food products imported into them, but the object of this legislation must be inspection and not prohibition of the traffic. It is true that Congress, in 1890 , passed an act which placed intoxicating liquor's under the police power of the States; but oleomargarine, which is a wholesome and nutritious food, ought not to be treated in the same manner that the law regards intoxicating liquors. The States should not be permitted by Congress to interfere in its sale, and especially should Cong'ress refuse to place the article subject to the laws of the States, which might exclude its manufacture or sale entirely. The States my inspect oleomargarine for the purpose of ascertaining whether it was free from adulterants or unwholesome ingredients: but Congress should not recognize the right of a State to exclude it from importation and sale therein, so long as it is conceded to be mutritious as an article of food.

The proposed bill is not a revenue measure. It is not for the pur. pose of raising revente or reducing surplus revenue. In fact, in no sense is it a measure resting for its authority upon the taxing power of the Gorernment. Its object is to prevent competition between two home industries by building up the one and destroying the other. Such use of the taxing power of the Government is an abuse which should not be encouraged or even tolerated for a moment. The precedent will open wide the door for all manner of vexatious schemes and instigate selfish greed to demand legislation involving every conceivable interference of Government with private interests. It is an effort to so frame our internal-revenue laws that one class of home producers will be protected from competition with another class of home producers. While our Government has adopted the policy of protecting home producers against foreign producers of the same kinds of articles, there can be no excuse or justitication for interfering among our own citizens by aiding one industry at the expense and to the injury or destruction of another. 'This policy would tend to destroy all benefits which consumers receive from improved processes of production, from labor-saving machinery, and from the results of invention. By such means all progress could be arrested and mankind could be deprived of the blessing's which modern science and genius are securing to the world.

The taxing power of the Gorermment can not be used for any object 
other than the public needs. As was said by the Supreme Court of the United States, in Loan Association x. 'Topeka (20) Wallace, 66t). "To lay with one hand the power of the Gorernment on the property of the citizen and with the other to bestow it upon favored individuals to aid private enterprises and build up private fortunes is none the less a robbery hecause it is done under the forms of law and is called taxation." While under the proposed bill the object is not to donate the taxes which may be raised to aid a particular industry, yet the imposition of the tax is for the purpose of enabling one industry to sell its products free from competition with another, and thus to exact from the public an increased price for the product, not for the benefit of the public Treasury but for private purposes solely. The effect upon the people is the same in both cases. As was stated in the opinion of the Suplene Court in the 'Topeka case, "there can be no lawful tax which is not laid for a public purpose." "This doctrine is so well recognized that it is umecessary to produce further anthorities upon the subject. There is no conflict of juclicial opinions: all are in harmony with the opinion in the Topeka case.

'The proposed bill is class legislation of the most dangerous character. It is not demanded by any existing economic conditions in this country, and its passage would be a perversion of the taxing power of the Government, and a violation of the Constitution, hoth in its letter and spirit.

'The Hon. Lyman J. Gage, Secretary of the Treasury, was invited to come before the committee and give his view from a revenue standpoint. 'The following is a part of his testimony:

Secretary Gace. Of conrse I only feel at liberty to state my views as the Secretary of the Treasury, and only upon that part of the bill which in rolves the question of revenue. I might have personal views which go far beyond those; but you would probably not care much about them.

'There is, in my opinion, an objection to the bill on either theory. If it is a revenue proaucer, it is superfluous; we do not need it. If it is not a revenue producer, then the title of the bill is a misnomer, and it is inoperative in the name of revenue. It seems to me that on either theory there are serious objections to it.

I think that covers all I care to say directly on the subject.

* * * * * * *

The Actixg Chairuav. Mr. Secretary, can you tell us what has been the experience, in a general way, of your Department in the collection of the revenue on oleomargarine? You know, of course, that there is now a 2-cent tax on it.

Secretary Gage. Yes, sir; I think the revenue is well collected. There has been considerable discussion of that subject between the Commissioner of Internal Revenue (especially Commissioner Wilson) and myself, at different times; and we think we are cheated to some extent, as we are in all revenue matters.

Senator BAte. Then I suppose the losses in oleomargarine internal-revenue collections are about on a par with the losses in all other revenue collections?

Secretary GAge. Well, they are on a par with the losses in most of the revenue collections. There is not any great disparity.

* * * * * * * * * * * * * * * * *

Senator Allex. Of course the liquor can not go ont without the consent of the Govermment?

Secretary GAge. No, sir; but the tax on liquor is $\$ 1.10$ a gallon, while that on butterine is 2 cents per pound, so that the temptation is very much greater in the one case than in the other.

Senator Alusx. The only thing with which you are concerned is the tax?

Secretary GAgE. That is the main thing, of course.

Senator Monex. The remark you have just made, Mr. Secretary, suggests this question: You say the greater the tax the greater the incentive to fraill. The same rule would apply here, would it not?

Secretary GAGe. Undoubtedly. 
Conflicting interests have appeared before the eommittee, one to demand the exereise of the taxing power in order to crush a rival in the business, and the other to ask that it be permitted to continue the manufacture of a product. wholesome and nutritious, for the benefit of the thousands who are unable, by their porerty, to buy butter. "The makers of oleomargarine of dairy butter, of creamery butter, of the process or renovated or resurrected hutter, have all appeared, personally or hy representatives, to insist upon their interests being more or less protected or not to be interfered with. 'The producers of cottonseed oil and the live-stock growers have also heen represented. asking that there be no further interference with the profits of their sereral industries for the benefit of the dairy men.

In the consideration of this subject the quarrels of the respective manufacturer's and parties at interest as to the profits to be lost or made from this legislation ale not so important as the rights of the consmmers of the several products. 'There are millions of working' people who are not producers of any articles of food, but who must consume these rarious products. They can not all of them buy butter. and. as the ohject of this bill is evidently-from the expressions of the leading adrocates of the bill-to exterminate the oleomargarine industry. these great numbers of people are interested that such nefarious legislation should he defented. They have rights as well as the manufacturer's of hutter and oleomargarine. as well as the cotton-seed-oil and the live-stock men, and it is the cry of the consumer, the cry of the poor. that should have the first attenition of the Senate.

Below is appended statements by acredited representatives of the various labor organizations of the comntry, and it cau not be doubted that they speak not only for those who have formally acoredited them to us. bit also for the vist number of nurepresented poor people whose interests and whose wants are the same.

Mr. Patrick Dolan. president of the Lnited Mine Workers' Assoviation, testified as follows:

Our people, Mr. Chaiman, are against the passage of the measure. I represent over 40,000 miners and their families, and I know from the sentiment in other sections of the comtry to which I go, from talking to people who are interested in our organization, that they do not want to be deprived of the ability to purchave this wholesome article of food. If it is not made in a wholesome way, then they do not want it; but if it is just as good to them to spread their bread with as 35-cent butter, they do want it. And if this measure passes the chances are that butter will go up) to 50 cents, and poor people will not be able to pulchase it at all.

Mr. John Pierce, representing the Analganated Association of Iron and Steel Workers, said:

Colored oleonargarine is at present retailed at from $12 \frac{1}{2}$ to 20 cents per pound. On investigation I am satistied that nowt of our people are paying about 15 cents per pound for it, and I can not admit that those who buy it can afford to pay more. I therefore arrive at the conclusion that they must either find 10 cents per pound more to pay this proposerl roblery (for I can not dignify it by the name of tax) or buy and eat white wleonargarine. Ant this to satisfy the creed of the manufacturers of butter, who think that white oleomargarine is good enough for those who can not afforil to pary 10 cents arditional for yellow, or the 20 cents or more arditional for creamely butter, or use the off grades of butter now musalable as foot.

Shall those thus defranded of what should be their inalienable constitutional right be compelled either to wear in their homes, on their very tables, flamnting before the eyes of their children and of those who may share their board, a badge of their poverty, and an emblem of their inability to pay a legalized rolbery; or, on the other hand, to contribute from their meager hoard to the hellish greed of the butter interests, of 
whom it has been doubtless truly said that they seek to follow the fanthiom and form a trust, but are deterred by the existence of oleomargarine?
*
*
*
*
*

Now, Mr. Chaiman, there are a good many of mo people who make pretty croor wages, and of comrse they (an buy butter; but the nuajority of then make small wages now, esprecially since we got into this trust business. I know there are lots of men who do not like to buy this white oleomargarine, because it looks more like laril than anything else. It does not look like butter at all. Why should they be nrarke to pay 10 cents a pound more becanse they get butter that resembles comntry lutter and looks a little better on the table? That is why I am here to oppose the passage of this bill. It is for our people alone, for of courive $I$ do not know much alout the hutter business my'self.

Mr. John F. MeNamee, vice-president and chairman legislative con1mittee Columbus Trades and Labor Assemhly, Columbus, Ohio, said:

I bear from the (entral Labor Union of the eity of Columbus, Olio, officially known as the Colmmbus Trades and Lahor Assembly, eredentials which, with your permission, I will,read to yon:

\section{To whom it mey concerm:}

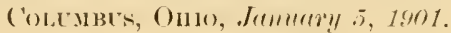

This is to certify that the bearer, Mr. John F. Mr.Namee, vice-president of the ('olumbus Trades and Labor Assembly, is authorized and empowered by sair hody to exert every effort and use all honorable means in ac'omplishing the defeat of a measure now pending in the United States Senate, and known as the Gront bill, the object of which is to destroy a legitimate industry in the interest of its eompetitors, said Grout bill being regarderl by saif Trades and Lahor Assembly and all it represents as a gross injustice, class legislation, an invasion of citizenship rights, and a serious menace to the best interents of all eitizens, particularly those in moderate (iremonstances.

Any courtesies extended to our representative, Mr. McNamee, will be fully appreciated and remembered hy the Colunilus Trarles and Labor Assembly.
[SEAL.]
Frank B. Chuenos, President.

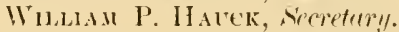

This letter of introduction which I have uresented represents but faintly the bitter antagonism which prevails in the ranks of organized labor to sainl measure.

The members of organized labor are thoronghly familiar with all of the phases of this bill. They speak about the ehemical analyses which have been made of oleomargarine by official chemists, and they disenss all of the varions components and ingreclients of the product with ahmost as much familiarity as the manufacturers themselves are capable of doing. So I say that they are wide awake to the necessity, in the protection of their own interests, of having the bill defeaterl. Not only that; but as patriotic American citizens they feel deeply the indignity to which our legislative hodies have heen subjected by this attempt to utilize them for the promotion of the interests of certain individuals and corporations in violation of every sense of right and justice and at the expense of the constitutional prerogatives of other citizens. They feel that the legislative bodies of some of our States and the Congress of the United States have been insulterl by this attempt to utilize them as touk for the protection of eertain interests which can not sustain themselves against competitors.

Gentlemen, there are hundreds of thousands of our eitizens in molerate circumstances who are now looking to the United States Senate for protection against the perpetration of such a gross injustice. They are depending absolutely upon that sense of justice, that sense of honor, fair play, and conservatism which has always characterized this body to protect them from this, one of the most enlpable violations of their rights which any individual or combination of indivituals has ever attempted to perpetrate upon the American publie. They are looking to this body with the firm hope that its traditional love of justice will prevail and predominate in this crisis. Should this measure become a law, arising from the mists of the near future there will come a monster into whose insatiahle maw the eontributions of our citizens shall continually flow, and whose appetite shall he increased by all attempt at its gratification. This monster we have all, in our apprehensive conviction of the certainty of its existence, learned to regard as the creamery trust of the future-the combination of ereamery interests into one great organization, which shall monopolize the mann- 
facture, not only of the food product known as butter, but of everything of that nature. That octopus is now being conceived. If the United States Senate should consent to the passage of a bill so outrageously unjust as this one is, then its birth will have been accomplished.

*

*

$\therefore$

Now, we can not see that there is any justice whatever in placing any tax upon oleomargarine. Heaven knows that its manufacture is already sufficiently restricted and that it is an utter impossibility, uncler the stringent laws which exist in almost all of our States regulating its sale, for any deception to be practiced therein. And I want to assure you, gentlemen, that if any deception in this connection shonld be attempted in our part of the country it would be, and often is, in undertaking to palm off inferior butter for the product known as oleomargarine. I am myself a constant consumer of the article, and I propose that it shall be continually used by my family, becanse I know, and so do all of the nembers of organized labor who have listened to the discussions relative to this product in their varions unions, that it is absolutely free from all disease germs; that the process of its manufacture is such as to destroy all the bacilli of tuberculosis and various other disease germs that exist in the cow and through the medium of butter consmmption are conveyed to the human system, and that butter is not subjected to any process which will eliminate that element of danger.

$*$

Here is an expression from one of the largest representative labor bodies in the United States-the Chicago Federation of Labor-and here is what they say relative to the tax:

"We believe the efforts to place a tax of 10 cents per pound on colored butterine is inspired by selfish motives, so that the manufacturers of butter may charge an unreasonable price for their commodity and enable the large creameries to establish surely and securely a butter trust which may raive prices as their cuyidity may dictate."

Here is another expression:

"Justice demands equal rights for both manufacturers of butter and butterine both products having equal merit. Any adverse legislation against either must be condemned.'

* * * * *

This is from the Journerman Horseshoers' Union:

"We feel that all people having arrived at the age of discretion should be left to exercise their own whoice as to whether they shall use butter or nleomargarine: Therefore, be it

"Resolved by Journeyman Horspshoers' Urion No. 40, of Columhus, Ohio, That as long as butterine is colored with a healthful ingredient sais coloring should be encouraged, as it improves the appearance of the product; that we do most emphatically contemn the persecution being waged against the butterine industry; that we protest against the attempt to increase the tax thereon, and that copies of this resolution be forwarded to every Congressman, with the request that they each and every one exert the most strenuous efforts to crushingly defeat once and for all any and all measures provilling for the further taxing of butterine."

* * * * * * *

Here is something from the Painters and Decorators of Cleveland, Ohio. It speaks in very plain language. This is in the form of a letter signed by Mr. Peter Hasrenpflie, 442 Erie street, Cleveland, president of said union.

"I have been instructed by our union, containing over 400 members, to write and inform you that we are manimously and bitterly opposed to the bills now pending in Congress provirling for the persecution of the butterine industry. As you doubtless know, there are laws now that are being carefully enforcerl anil lived up to that make it impossible for butterine to be manufacturesl and sold for anything else but butterine, and it is the unanimous opinion of our members that butterine made according to these laws is hetter for all wises than three-fourths of the butter that can be bonght. It won't get strong, and it don't come from fererish cows that are full of disease germs, and butter frequently does.

"We feel this way-that if butterine is wrong. or poison, or liable to injure public health, then clo away with it altogether; but if it is not (and years of experience in using it have taught us it is not) then why pervecute the industry and keep passing laws against it? Our belief is that this is kept up just for political reasons, and that some people in Congress that are sworn to protect the rights and interests of alt the people are willing to increase our already too ligh cost of living and add to our taxes just to catch the farmer vote and increase the business of the butter trust 
or trusts (and if butterine is killed they will soon be in one), and make them a present of the butter market, so they can either rob the people or make them go without butter. It is the rankest kind of injustice to kill one industry that is right and legitimate in order to accommodate another. We want butterine; we know what it is; we would rather have it than butter, and it is an outrage, in order to gratify the people who make butter, that we should have to go without it and pay two prices for butter which we are compelled by law to eat, and which, nine cases out of ten, is not fit for human use. It is getting to be pretty serious when the Congress of the United States is asked to go into the business of booming certain interests, and for their accommorlation driving their competitors out of existence simply becanse they are competitors, and for no other reason on earth. A great deal is being said about butterine being a certain color. Now, the only reason that a kick is made on that color is because it helps to sell that commodity. If the butterine makers were to use red or black or blue, these patriotic statesmen, and others so solicitous for the people's protection, would raise no objection, because that would make the same point that they want to make by law, and that is to hurt its sale and thereby tickle the farmers and advance the interests of the creamery trusts. The ingredient userl in butterine which gives it its color has been proven by official chemical analysis to be a natural and healthful product. As there is no reason to kill butterine but because it hurts another business, then why not do away with these hose painting machines beeause they hurt our business?

"We know it would be unreasonable to ask this, but it would be no more so thae for butter makers to try, as they are doing, to drive butterine out of existence becausn it hurts their business.

"I will close by saying that we consider any further legislation by Congress tampering with the butterine business as a prostitution of that dignified body to the greed and avarice of certain corporations and individuals, at our sacrifice and that of the people in general who don't own farms or creamery factories; and in the name of my union, under its seal, and by its unanimous instruction, I earnestly request you do everything you can to defeat all measures that provide for the increase in the tax of or further interference with the mannfacture or sale of butterine."

From the Chicago Federation of Labor:

\section{Hon. Willi.ji MicAleer.}

Chicago, Maich $21,1900$.

DeAr Sir: The following resolutions were unanimously adopted by the Chicago Federation of Labor at regular meeting, Sunday, February 4 , and I was instructed to forward a copy of same to you:

"Whereas the Chieago Federation of Labor is deeply interested in and desires to encourage every legitimate industry which furmishes employment to the laboring classes; anrl

"Whereas efforts are being attempted by contemplated legislation at Washington to destroy the manufacture and sale of butterine, thereby displacing large numbers of the industrial element and preventing them from gaining a livelihood as well as the use of an article of food which has received the lighest testimonials of every chemist in this country and the indorsement of every standarl work that treats on the subject of liygiene; and

"Whereas we believe the efforts to place a tax of 10 cents per pound on colored butterine is inspired by selfish motives, so that the manufacturers of butter may charge an unreasonable price for their commodity and enable the large creameries to establish surely and securely a butter trust which may raise prices as their cupidity mav dictate; and

"Whereas justice demands equal rights for both manufacturers of butter and butterine, both products having equal merit, any alverse legislation against either must be condenmerl; and

"Whereas the late published reports furnished to Congress by the Secretary of the Treasury proves the legitimate and growing demand for butterine and discloses the large amount of revenue deriverl therefrom; and

"Whereas we believe that the present Federal law taxing butterine 2 cents per pound and the atditional regulations imposed by the Commissioner of Internal Revenue aresufticient to properly regulate the manufacture and sale of butterine: Therefore, be it

"Pesolved, That we, the representatives of the industrial classes in Chicago, and voicing, as we know we do, the sentiments of the mechanic and the laborer throughout the country, protest against the passage of the Tawney, (irout, or any other bills that have for their object the further increase of tax or the relegating to the different States the right to enact laws that are opposed to the interests of the people and in

$$
\text { S. Rep. } 2043-\mathrm{II}
$$


no way in harmony with the inventive and progressive spirit of the age; and be it further

"Resolved, That we instruct our secretary to have sufficient copies of these resolutions printed that one be mailed to every Senator and Congressman in Washington and one to each of the labor organizations affiliated with the Federation of Labor, requesting them to indorse same or pass others of a similar character, so that a full expression of our condemnation of such legislation may be made known."

Respectfully sulomitted.

$$
\begin{aligned}
& \text { Walter Cariody, } \\
& \text { Secretary Chicago Federation of Labor. } \\
& \text { * * * } \\
& \text { * } \quad * \\
& \text { * } \\
& \text { * } \\
& \text { * }
\end{aligned}
$$

Dear Sir: The Building Trades Council of Cleveland, Ohio, and vicinity, representing over 5,000 mechanics, has by unanimons vote indorsed the action of the Chicago Federation of Labor and all the other labor organizations who are so doing in opposing the persecution of the lutterine industry.

We can not see any justification in placing a larger or, in fact, any tax on butterine or oleomargarine. The article is sold on its merits, and it would rather hurt than help its sale to attempt to sell it for butter, as it is more popular and generally regarderl as more healthy than butter. Any of our people that may not want butterine can, while it is on the market, louy butter at a reasonable price, but if the attempt to kill it by legislation is snccessful, the butter manufacturers will have no competitors, and the result will be that the present butter trust will absorb the butter industry and control the purchase of milk by having little creameries in every farming locality on the plan of the Standard Oil Company, and we will have the pleasure of paying 50 or 60 cents per pound for butter or going without it altogether, the chances being in favor of the latter.

We feel that as butterine is demanded and sold for what it is, and as the laws regulating its manufacture ancl sale are operating successfully in preventing its adulteration, that the legislative borlies of our country have gone as far as they have any right to go, and that further interference on their part is persecution and intended to adrance private interests at the expense of the rights of the people.

There is, undoubtedly, political motive behind all this.

There are a hundred different eases in which legislative vigilance could protect the people from adulterater foorls where such vigilance is not exercived, or if in any remote way ever applied it is not being taken advantage of by the officials supposed to enforce it; and why? Simply because the manufacturers of allulterated foods or the beneficiaries of their existence hare no influential competitors to be servel by their suppression.

Butterine has been the victim of legislative attaks for a number of years, and we feel it is now time to let up on it and devote the effort wasted in the persecution of this legitimate industry to some more worthy cause in the protection of the real interests of the people.

There is an old saying that "He who is bent on an evil rleerl is nerer lacking for an excuse," and it is certainly applicable in this case, the excuse being that it is wrong to color butterine becanse it is likely to be sold as butter, whereas, in fact, owing to the extreme popularity of the former, there is more liability of an attempt being made by some butter manufacturer to imitate it, and the only reason why an attempt is made to prevent the use of the material in butterine imparting color to it is to hurt its sale, as it has been proven this material is perfectly healthy. And where is the justice of prohibiting its use simply because it helps the sale of an honest product?

As long as the people want butterine and it is good to use, as the Goverment chemist have proven, why should it be abolished? We can not see that there is need to say more. You can not but see the rank injustice of this whole business, and we woull, therefore, earnestly request, in the name of common American justice, - that you would strenuonsly oppose and exert every means in your power to defeat all such legislation.

This letter has the hearty indorsement of our body, and as a testinony of which it bears our seal.

$$
\begin{aligned}
& \text { W. C. Davis, } \\
& \text { President. } \\
& \text { Grant Morgan, } \\
& \text { Secretary }
\end{aligned}
$$


The minority insert here, as a part of their report, the views of the minority of the Committee on Agriculture of the House of Representatives, which is as follows:

\section{Views of the MinoRity.}

The minority of the Committee on Agriculture of the House of Representatives beg leave to submit the accompanying bill, which we offer as a substitute for $I$. $R$. 3717 , known as the Grout bill.

We first wish to bring to the attention of the House proof positive that oleomargarine is a wholesome and nutritions article of food and is therefore entitled to a legitimate place in the commerce of our country. In substantiation of this statement we beg to submit the following testimony taken before the committee:

\section{OPINIONS OF LEADING SCIENTISTS.}

Prof. C. F. Chandler, professor of chemistry at Columbia College, New York, says: "I have studied the question of its use as food, in comparison with the ordinary butter made from cream, and have satisfied myself that it is quite as valuable as the butter from the cow. The product is palatable and wholesome, and I regard it as a most valuable article of food."

Prof. George F. Barker, of the University of Pennsylvania, says: "Butterine is, in my opinion, quite as valuable as a nutritive agent as butter itself. It is perfectly wholesome, and is desirable as an article of food. I can see no reason why butterine should not be an entirely satisfactory equivalent for ordinary butter, whether considered from the physiological or commercial standpoint."

Prof. Henry Morton, of the Stevens Institute of Technology, New Jersey, says: "I am able to say with confilence that it contains nothing whatever which is injurious as an article of diet, but, on the contrary, is essentially identical with the best fresh butter, and is superior to much of the butter made from cream alone which is found in the market. The conditions of its manufacture involve a degree of cleanliness and consequent purity in the prorluct such as are by no means necessarily or generally attained in the ordinary making of butter from cream."

Prof. S. W. Johnson, director of the Comnecticut Agricultural Experiment Station and professor of agricultural chemistry in Yale College, New Haven, says: "It is a product that is entirely attractive and wholesome as foorl, and one that is for all ordinary and culinary purposes the full equivalent of good butter made from cream. I regard the manufacture of oleomargarine as a legitimate and beneficent industry.",

Prof. S. C. Caldwell, of Cormell University, Ithaca, N. Y., says: "While not equal to fine butter in respect to flavor, it nevertheless contains all the essential ingredients of butter, and since it contains a smaller proportion of volatile fats than is found in gennine butter, it is, in my opinion, less liable to become rancid. It can not enter into competition with fine butter, but so far as it may serve to drive poor butter out of the market, its manufacture will be a public benefit."

Prof. C. A. Goessman, of Amherst Agricultural College, says: "Oleomargarine butter compares in general appearance and in taste very favorably with the average quality of the better kinds of dairy butter in our markets. In its composition it resembles that of ordinary lairy butter, and in its keeping quality, under corresponding circumstances, I believe it will surpass the former, for it contains a smaller percentage of those constituents which, in the main, cause the well-known rancid taste and odor of a stored butter."

Prof. Charles P. Williams, professor in the Missouri State University, says: "It is a pure and wholesome article of food, and in this respect, as well as in respect to its chemical composition, fully the equivalent of the best quality of dairy butter."

Prof. J. W. S. Amold, professor of physiology in the University of New York, says: "I consider that each and every article employed in the manufacture of oleomargarine butter is perfectly pure and wholesome, that oleomargarine butter differs in no essential manner from butter made from cream. In tact, oleomargarine butter possesses the arlvantage over natural butter of not decomposing so readily, as it contains fewer volatile tats. In my opinion oleomargarine is to be considered a great discovery, a blessing for the poor, and in every way a perfectly pure, wholesome, and palatable article of food."

Prof. W. O. Atwater, director of the United States Government Agricultural Experiment Station at Washington, says: "It contains essentially the same ingredients as natural butter from cow's milk. It is perfectly wholesome and healthy and has a high nutritious value." 
Prof. Henry E. Alvord, formerly of the Massachusetts Agricultural College, and president of the Iaryland College of Agriculture, and now chief of the Dairy Division of the United States Department of Agriculture, and one of the best butter makers in the country, says: "The great bulk of butterine and its kindred products is as wholesome, cleaner, and in many respects better, than the low grades of butter of which so much reaches the market."

Prof. Paul Schweitzer, Ph. D., LL. D., professor of chemistry, Missouri State University, says: "As a result of my examination, made both with the microscope and the delicate chemical tests applicable to such cases, I pronounce butterine to be wholly and unequivocally free from any deleterious or in the least objectionable substances. Carefully made physiological experiments reveal no difference whatever in the palatability and digestibility between butterine and butter."

Professor Wiley, Chief of the Division of Chemistry of the United States Department of Agriculture, also appeared before the committee and testified to the nutritive and wholesome qualities of oleomargarine.

The Committee on Manufactures of the United States Senate, in a report dated February 28, 1900, finds, from the evidence before it, "that the product known commercially as oleomargarine is healthful and nutritious."

Judge Hughes, of the Federal court of Virginia, in a lecision, says:

"It is a fact of common knowlerlge that oleomargarine has been subjected to the severest scientific scrutiny and has been adopted by every leading government in Europe as well as America for use by their armies and navies. Though not originally invented by us, it is a gift of American enterprise and progressive invention to the world. It has become one of the conspicuous articles of interstate commerce and furnishes a large income to the General Government annually."

Believing that this testimony establishes beyond controversy that oleomargarine is a nutritions and wholesome article of food, the main question to be considered is the complaint that fraud is practicer in its sale.

The only just complaint (indeed, the only complaint) against the existing oleomargarine law consists in the facility with which the retail dealer, in selling from the original or wholesale package and substituting a new and unmarked wrapper, may violate the law: There is nothing in II. R.3717 (known as the Gront bill) which would decrease the temptation or increase the difficulty of such violations. On the contrary, the increasel taxation would either be fraudnlently evaded or else would force the honest manufacturer out of business. H. R. 3717 merely increases taxation without providing any new or additional penalties or any new methorls to prevent the sile of oleomargarme as butter, either in its colored or uncolored state. In fact, the radical advocates of the Grout bill do not seek this end, as they have declared in their testimony before the committee and in declarations elsewhere that their sole intention is to absolutely erush out the manufacture of oleomargarine and eliminate it as a food product.

In substantiation of this assertion we quote the following:

Mr. Arlames, pure-foor commiscioner of the State of Wisconsin, in his testimony before the committee on Marrh 7, 1900, said:

"There is no use beating about the bush in this matter. We want to pass this law and drive the oleomargarine manufacturers out of the business."

Charles Y. Knight, weretary of the National I airy Union, in a letter to the Virginia Dairmen, dated May 18,1900 , writes:

"Now is the time for you to rlip the fangs of the mighty octopus of the oleomargarine manufacturers who are ruining the dairy interests of this country by manufacturing and selling in defiance of law a spurious article in imitation of pure butter. We have a remedy almost in erasi, which will eliminate the manufacture of this article from the foorl-product list. The (ront bill, now pending in the Agricultural Committee of the House of Representatives in Congress, meets the demand."

IV. D. Hoard, ex-governor of Wisconsin and president of the National Dairy Lnion, stated in his testimony before the committee on Wareh 7, 1900, as follows:

"To give added force to the first section of the bill, it is provided in the second section that a tax of 10 cents a pound shall be imposed on all oleomargarine in the color or semblance of butter. In plain words, this is repressive taxation."

In view of this testimony the minority believe they are justified in elaiming that the Grout bill, if enacted into law, wonld destroy the business of the legitimate oleomargarine manufacturers. In other worls, congress is being asked to ruin one industry to benefit another; and this, in the opinion of the minority, is a thing Congress ought not to do. The minority believe it to be class legislation of the most pronounced kind and would establish a precerlent which, if followed, wonld create monopoliew, destroy competition, and militate against the public good.

The sulstitute bill offered by the minority would, in our opinion, eliminate all possibility of fraud and would compel the manufacturers of and dealers in oleomar- 
garine to sell it for what it really is and not for butter. The substitute offeren is practically an amendment to sections 3 and 6 of the existing oleomargarine law. The licenses for manufacture and sale of this article are not changed, and are as follows: IIanufacturers, $\$ 600$ per annum; wholesale dealers, $\$ 4 \$ 0$ per annum; retailers, $\$+\$$ per annum, while the penalties imposed for violation of the law are materially increased. Wequote in full section 2 of the substitute bill, and ask for it the careful and thoughtful consideration of the House, believing that it is just and fair to all the interests involved:

"SEC. 2. That all oleomargarine shall be put up by the manufacturer for sale in packages of one and two pounds, respectively, and in no other or larger or smaller package; and upon every print, brick, roll, or lump of oleonargarine, before being su put up for sale or removal from the factory, there shall be impressed by the manufacturer the word "oleomargarine" in sunken letters, the size of which shall be prescribed by regulations made by the Commissioner of Internal Revenue and approved by the Secretary of the Treasury; and every such print, brick, roll, or lump of oleomargarine shall first be wrapped with paper wrapper with the word "oleomargarine" printed thereon in distinct letters, and said wrapper shall also bear the name of the manufacturer, and then shall be put by the manufacturer thereof in such wooden or paper packages or in such wrappers, with the word "oleomargarine" printed thereou in distinct letters, and marked, stamped, and branded in such manner as the Commissioner of Internal Revenue, with the approval of the Secretary of the Treasury, shall prescribe, and the internal-revenue stamp shall be affixed so as to surromind the outer wrapper of each one and two pound package: Provided, That any number of such original stamped packages may be put up by the manufacturer in crates or boxes, on the outside of which shall be marked the word "oleomargarine," with such other marks and brancls as the Commissioner of Internal Revenue shall, by regulations approved by the Secretary of the Treasury, prescribe.

"Retail dealers in oleomargarine shall sell only the original package to which the tax-paid stamp is affixed.

"Every person who knowingly sells or offers for sale, or delivers or offers to deliver, any oleomargarine otherwise than as provided by this act or contrary to the regulations of the Commissioner of Internal Revenne made in pursuance hereof or who packs in any package any oleomargarine in any nanner contrary to law, or who shall sell or offer for sale as butter any oleomargarine, colored or uncolored, or who falsely brands any package, or afixes a stamp on any package denoting a less amount of tax than that required by law, shall be fined for the first offense not less than one hundred nor more than five hundred dollars and be imprisoned not less than thirty days nor more than six months; and for the second and every subsequent offense shall be fined not less than two hundred nor more than one thousand dollars and be imprisoned not less than sixty days nor more than two vears.'

One of the claims marle by the friends of the Gront bill is that it will protect the interests of the farmer. We call attention to the fact that every ingredient that enters into the manufacture of oleomargarine is as much a product of the farm as the butter, and that such ingrerlients are nrade more valuable on account of their use in the manufacture of oleomargarine.

Your comnittee has had before it representatives of both the cattle and hog raisers of the country, and also representatives of the cotton industry, and they are unanimous in their opinion that their business will be materially injured and the price of their product lowered by the passage of the Grout bill and the destruction of the oleomargarine industry.

The mannfacture and sale of oleomargarine does not interfere with the grow th and prosperity of the butter industry. Statistics show a much greater percentage in the increase of the profluction of butter than in the production of oleomargarine. Thongh similar in ingredients, they are not strictly competing, as the oleomargarine is practically all bought by the poorer class of our people.

In justification of this statement we have received a large number of petitions from the labor organizations of our country protesting against the passage of this bill for the above-given reasons.

It being possible to keep oleomargarine in a sweet and souncl condition much longer than butter, it is also used extensively in the mining and lumber camps, on exploring and hunting experlitions, on ships at sea, and by armies in the field.

The claim made by the friends of the Grout bill that the manufacture and sale of oleomargarine Ias greatly depreciated the price of butter will not obtain when it is known that there is now mannfactured in the United States nearly 2,000,000,000 pounds of butter annually, and it is positively known that there only were $83,000,000$ pounds of oleomargarine manufactured last year, which shows that the amomnt of oleomargarine produced is about 4 per cent of the amount of butter produced. There- 
fore, the argument that oleomargarine in any material sense controls the price of butter is not justified by the facts.

The manufacture and sale of oleomargarine have in no way depreciated the price of butter, as more butter is being sold at higher price in this country than erer before, as shown by testimony.

It is a suggestive fact that those sections of our country which are most exclusively devoted to the dairy interests are blessed with the greatest prosperity, as brought out in the testimony of ex-Governor Iloard, of Wisconsin, before our committee, who sairl that a few years ago land was worth only $\$ 15$ an acre in that State, but as the State began to be deroted more exclusively to the dairy interests land had rapidly appreciated in price, and that farmers had gotten out of debt, had paid their mortgages, and the land is now worth the sum of $\$ 80$ per acre, this price averaging much higher than agricultural lands in other parts of the country.

In conclusion the members of the Committee on Agriculture who have joined in this minority report beg to assure the House and the country in the most solemn manner possible that it has been their earnest intention, and is now their determination, to do everything possible to be done to enforce the sale of oleomargarine as oleomargarine and to prevent its sale as butter. To prevent fraud and not to stamp out an industry has been and is our purpose. We believe that it ought to be the sole purpose of all legislation and the sole motive of all just men.

J. IV. WADSWORTH.

WM. LORIMER.

W. J. BAILEY.

G. H. WHITE.

JоHN S. WILLIAMS.

J. WM. STOKES.

Mr. W. E. Miller said:

H. D. AlLEN.

At this juncture we would like to introrluce as evidence an article from Experiment Station Record, United States Department of Agriculture, on the mutritive value of oleomargarine:

"THE NitRITIYE VALUE OF MARGARIN COMPARED WITH BUTter. E. Bertarelli (Rix. Ig. e.San. Pubb., 9 (1898), Nos. 14, pp. 53S-545; 15, pp. 570-579).- Three experiments with healthy men are reported in which the value of margarin and butter was tested when consumed as part of a simple mixed diet. In one experiment the value of a mixture of olive oil and colza oil, which is commonly used in Italy in the neighborhood of Turin, was also tested. The author himself was the subject of one of the tests. He was 24 years old. The subjects of the other tests were two laboratory servants, one 27 years old, the other 32 years old. The coefticients of digestibility and the Jalance of income and outgo of nitrogen in the different experiments were as follows:

Digestion experiments with margarin, butter, and oil.

Laboratory servant, P. G.: $500 \mathrm{gm}$. white bread, $270 \mathrm{gm}$. veal, $70 \mathrm{gm}$. butter, $250-300$ ce. wine.........

Laboratory servant, P. G.: $500 \mathrm{gm}$. white bread, $250 \mathrm{gm}$.veal, $70 \mathrm{gm}$. margarin, 250-300 ce. wine

Author: $450 \mathrm{gm}$. White bread, 250 $\mathrm{gm}$. meat, $70 \mathrm{gm}$. butter........ Author: $450 \mathrm{gm}$. white bread, 250 rm. meat, $70 \mathrm{gm}$. margarin....

Laboratory servant, F. D.: $\$ 24 \mathrm{gm}$. white bread, $250 \mathrm{gm}$. meat, 61.6

Laboratory servant, F. . . . 859 gm. white bread, $250 \mathrm{gm}$. meat, 61.6 gm. margarin..

Laboratory servant, F. D.: $910 \mathrm{gm}$. white bread, $250 \mathrm{gm}$. meat, 61.6 $\mathrm{gm}$. olive and colza oils........

\begin{tabular}{|c|c|c|c|c|c|c|c|}
\hline \multirow[b]{2}{*}{ Time. } & \multicolumn{3}{|c|}{ Coefficients of digestibility. } & \multicolumn{4}{|c|}{ Nitrogen. } \\
\hline & Protein. & Fat. & $\begin{array}{c}\text { Carbo- } \\
\text { hydrates. }\end{array}$ & $\underset{\text { food. }}{\text { In }}$ & $\begin{array}{c}\text { In } \\
\text { urine. }\end{array}$ & $\begin{array}{c}\text { In } \\
\text { feces. }\end{array}$ & Gain. \\
\hline Days. & Per cent. & Per cent. & Per cent. & Gms. & Gms. & Gms. & $G m s$. \\
\hline 5 & 81.75 & 92.67 & 97.25 & 15. 7 & 9.6 & 2.6 & 3.5 \\
\hline 5 & 79.50 & 93.90 & 97.07 & 15.7 & 10.3 & 3.2 & 2.2 \\
\hline 6 & 81.85 & 94.25 & 97.35 & 13.5 & 10.1 & 2.5 & .9 \\
\hline 6 & 77.80 & 93.73 & 96.70 & 13.5 & 9.6 & 3.1 & .8 \\
\hline 5 & 85.32 & 95.80 & 97.38 & 16.5 & 13.2 & 2.9 & .4 \\
\hline 5 & 82.92 & 95.33 & 97.24 & 16.9 & 12.5 & 3.4 & 1.0 \\
\hline 5 & 83.27 & 95.82 & 97.56 & 17.5 & 13.4 & 3.5 & .6 \\
\hline
\end{tabular}


"The principal conclusions follow: When properly prepared, margarin differs but little from natural butter in chemical and physical properties. On an arerage 93.5 to 96 per cent of fat was assimilaterl when margarin was consumed and 94 to 96 per cent when butter formed part of the diet. The moderate use of margarin did not canse any disturbance of the digestive tract."

*

$$
\text { * }
$$

* *

$$
\text { * }
$$$$
*
$$

This is a resolution passed by the Sioux City Live Stock Exchange:

"Whereas a bill has been introrluced in the House of Repreventatives known as Honse bill 6, proviling for an amendment of 'An act defining butter, also imposing a tax upon and regulating the manufacture, sale, importation, and exportation of oleomargarine;' and.

"Whereas snch a bill, if enacted, is calculated to build up and restore one industry at the expense of another by means of uncalled-for and unjust taxation; and

"Whereas the destruction of the oleomargarine industry would greatly impair the market value of beef cattle, and would thereby deprive the prodncer of a large amount of revenne: Therefore, be it

"Resolved, That the Sionx City Live Stock Exchange of Sionx City, Iowa, emphatically protests against the enactment of the law proposed in House bill No. 6 .

"Vitness the signatures of the president and secretary of saill exchange and the official seal thereof affixed at Sioux City, Iowa, December 28, 1899.

\section{"J. H. Nason, President.}

"W si. Magivis, Secretary."

$*$

$*$

*

*

These are resolutions passed by the Texas Cotton-Seed Crushers' Association:

"DEAR SIR: At a meeting of the Cotton-Seed Crushers' Association, held in Dallas on Tuestay, November 14, 1899, T. P. Sullivan, of Jefferson; R. K. Erwin, of Waxahachie; IV. R. Moore, of Ardmore, Ind. T., and Robert Gibson, secretary, of Dallas, were appointed a committee to draft resolutions expressive of the sense of the meeting on the matters discussed. The resolutions as submitted were unanimously adopted, and are as follows:

"MAR1ON SANsoM, Chairman:

"The undersigned committee appointed by you beg leave to submit the following preamble and resolutions:

"Whereas the line of industrial business represented by this association is coextensive with the entire area of the cotton-eultivated zone of our Southern States and, in conjunction with cotton in its varions uses, represents the wealth of the south; and

"Whereas Texas represents over 30 per cent of the cotton and cotton seed ammally producerl in the United States, any embargo placed by legislation on the growth and derelopment of our industry is detrimental to the vast interests committed to our care. It is therefore of most vital necessity that all arennes leading to the sale and consumption of our cotton-oil prorlucts should be free and unrestricted, and inasmuch as cotton oil is used to a large extent in the manufacture of butterine, which is a most wholesome and healthful substitute for butter; and

"Whereas a tax at present exists of 2 cents per pound on the manufacture of this most healthful article of food, and that it is contemplated to introduce at the next session of Congress an increased tax of 10 ecuts per found on same: It is, therefore,

"Resolved, That this association enter its protest against the existing tax of 2 cents per pound on butterine and ask for its alorogation and repeal, and against the introduction or adoption of any future tax on same as an article of fond, as it directly affects our great industry both at home and on the continent of Enrope, where a cheap and wholesome article of food, such as butterine, is appreciated.

"Resolied, That we helieve the imposition of a special tax of this nature is class legislation and should be combatted by all the means at our command, and that our Senators and Representatives in Congress are hereby requested to give us all the necessary aid in this behalf; and it is further

"Resolved, That thesecretary of this association transmit a copy of these resolutions to each cotton-oil mill in the South, with the request that they interest their Senators and Representatives therein, and also to our Senators and Representatives in Congress from Texas.

"T. P. Sullivan, chairman, Jefferson, Tex.

"R. K. Erwin, Harahachie, Tex.

"W. R. Moore, Ardmore, Ind. T.

"Robert Gibson, Secretary, Dullas, Tex." 
Resolutions against oleomargarine tax offered at meeting of cotton-oil mill superintendents:

"Cinarleston, S. C., July 6 .

"Cotton-oil superintendents from South Carolina and North Carolina met yesterday at the Calhoun Hotel for the purpose of organizing the cotton-oil mill superintendents' anvociation;

"After the constitution and by-laws were read and alopted, the following resolutions were offered by $\mathrm{A}$. A. Haynes:

" "Resolved, That this association, representing millions of dollars of investerl capital in the Sonth, strongly protest against national class legislation which aims directly at the destruction of competition in the mannfacture and sale of wholesome anul healthful articles of food.

"Resolved, That we protest strennously against the passage by Congress of the Grout oleomargarine bill, which proposes to tax oleomargarine 10 cents per pound, and thus to drive it from the market.

"Resolved, That this association implores Congress not to ilestroy an industry which now unes nearly $10,000,000$ pommls of the best grate of cotton-seed oil amnally, and thus kill that quantity of our most profitable output.

"Resolved, That we urge the legislatures of south Carolina and of other sonthern States to remove from their statute books the antioleomargame legislation thereon, becanse such acts are only in the interest of the renovated and process butter factories of the North and Northwest, and against the hog fats, leef fats, and cotton-seedoil products grown on our southern tarms.

"Resolverl, That a copy of these resolutions be sent to the National Provisioner, of New York and Chieago, the indomitable champion of the cotton-oil interests, for publication, and that the members of this association proceed to secure, if possible, the repeal of the olmoxious State laws alove referred to.

"Resolverl, That this association will dlo what it can to cause the dofeat of the Grout antioleomargarine bill in Congress during the coming session."

Mr. Ioln C. Mac'oy presented the following resolutions:

The Kaxsan City Live Stock Exchange, Kansas City, Mo., February $8,1900$.

The following preamble and resolutions were unanimonsly adopted by the board of directors of the Kansas City Live Stock Exchange at a regular meeting held February 5, 1900:

"Vithereas certain billw have been introducer in the Inose of Representatives of the United States looking for the endetment of a law, by way of taxation, whereby the mantuarture, sale, importation, and exportation of oleomargarine will be ruined; and

"Whereas such bills, if passed and allowed to become laws, will build up one industry at the expense of tearing down ani ruming another, the logical effect of which will be the granting of a monopoly to the inclustry sought to be benefiterl; and

"Whereas the destrnction of the oleomargarine industry will reduce the value of cattle and hogs to the farmer's and raisers thereof, as well as work a hardship upon millions of poor people who are mable to pay the fancy prices asked for butter: Thereiore, be it

Resoled, That the Kansas City Live Stoek Exchange, of Kansas City, Mo., earnestly protest against the enactment of the law proposerl relating to oleomargarine; and be it further

Resolved, That the boarl of directors of this exwange be requested to memorialize the Congress of the United States against the passage of a law or laws inimical to the live-stock industry, and that a copy of these resolutions be sent to the honorable the Senate and the House of Representatives of the United States."

Respectully, yours,

IV. S. Havxah, President.

Mr. William H. Thompson, president National Live Stock Exchange, Chicago, Ill., said:

In round numbers there are $75,000,000$ people in this country. I believe a reasonable estimate of the number of Indians and children uniler a jutter-eating age to be $25,000,000$, which would leave a population of $50,000,000$ outside of these classes who are consumers of butter.

Of this $50,000,000$ peolle at least one-half are able to buy the best butter manufactured, irrespective of price, while the other $25,000,000$ are a class of people whom the butterine manufacturers aim to reach and benefit, and are a class of our citizens 
known as laborers, not in the common acceptance of the term, but as a class of people following a variety of pursuits at small salaries, and in most cases, owing to their dependencies and meager earnings, compelled to go without the luxuries of life.

It is this class of people whose interests need careful consideration, whose claims upon you as their representatives are invariably backed by justice, who are always the greatest sufferers by and the most sensitive to inimical legislation, who always are the first to respond to ancl cheerfully comply with all just and reasonal,le laws.

As the representative of the National Live Stock Exchange, I also plead for a consideration of the rights of this class of our citizens, who, from the nature of their surroundings and conditions, are unable to appear before you in their own lehalf.

They, who are the principal consumers of butterine, are not asking for any legislation. The producers and raisers of fat eattle are not asking you for any legislation in this respect.

Why should it be any more unlawful to put into butterine, the product of the beef steer, the same coloring matter as is put into lutter, the similar product of his sister, the dairy cow?

Is there any equity or ju-tice in such clenial? Is it made necessary by the conditions? Is it warranted upon any grounds? If it is, I am at a loss to comprehend it.

This hind of legislation is most assuredly the worst and most vicions lind of class legislation, because it is inangurated solely for the purpose of destroying a competitive industry equally as important and equally as deserving of legislative support and protection.

The Grout bill represents an attempt on the part of Congress to tax me legitimate industry out of existence for the benefit of another industry. The ostensible purpose is protection to the consumers against "imitation butter;" but the public has never asked for such protection. It does not even object to the coloring of butterine the same as butter, so long as the butterine is properly labeled and sold on it merits. As a matter of fact, the consumers of bntterine prefer to have it colored, so long as the coloring material nsed is harmless. They like butterine because of its cheapness and because they are satisfied with its purity and wholesomeness.

The enactment of this bill will not only deprive the consumer of a healthy and nutritious article of food, but immediately it becomes a law will depreciate the value of the beef cattle and take from the producers of this conntry upward of forty-five millions of dollars.

The following is not part of the hearing before the committee, but is rouched for as the true resolution passed by the convention.

At the Fourth Annual Comvention of the National Live Stock Association, held at Salt I ake ('ity, Utah, January 15, 16, 1T. and 1S. 1901, at which 1,412 delegates were represented and 5.000 visitors were present, from nearly every State and Territory in the Union, the following memorial to the Senate of the Lnited States was adopted:

\section{To the homorable the Senate of the Lnited States:}

Your orator, the National Live Stock Association, respectfully represent uuto your honorable body that it is an association composed of 126 live-stock and kindred organizations, all directly interested in the production, marketing, and disposing of live stock, and whose holdings thereof represent an investment of over $\$ 600,000,000$.

Fonr orator, in amnual session assembled at Salt Lake City, Utah, desires to enter its emplatic protest against the enactment of what is commonly know as the Grout bill (Honse bill 3717), and in behalf of its protest desires to record a few of the many reasons in support of its contention.

This measure is a species of class legislation of the most iniquitous and dangerons kind, calculated to buils up one industry at the expense of another equally as important.

It seeks to impose an unjust, uncalled-for, and unwarranted burien upon one of the principal commercial industries of the country for the purpose of prohibiting its manufacture, thereby destroying competition, as the manufacturers can not assume the additional burdens sought to be imposed by this measure and sell their product in competition with butter.

"The passage of this law would destroy the demand, except for export, for that product of the beef of animals, oil of oleo, of which $24,000,000$ pounds was used in the year 1899 in the manufacture of oleomargarine, and also would serionsly injure the liog industry by a similar destruction of the demand, except for export, of neutral lard, 31,000,000 pounds of which was used in the year 1899 in the niannfacture of this food product, and by thus eliminating the demand for these legitimate articles 
of eommerce force dealers to seek other chameds for their disposition, at greatly reduced prices, thereby entailing a loss to the producers of live stock of the United States of millions of dollars ammally.

"The measure seeks to throttle competition, and, if enaeted, will render useless immense establshments, erected at great expense, for the manufacture of oleomargarine, deprive thousands of employees of the opportmity to gain a livelihood, and deny the people-and especially the workingmen and their dependencies - of a wholesome article of diet.

"In olenmargarine a very lange proportion of the consumers of this combry, and especially the working classes, have a wholesome, nutritions, and satisfactory article of diet, whieh, before its advent, they were obliged-owing to the high price of butter and their linited means-to go withont.

"Your crator contends that it is manifestly unjust, mmeasonable, and unfair to deny manufacturers of the product of the beef animal and the hog the same privileges in regari to the use of coloring matter that are accorded to the manuactures of the product of the dairy, and that the rights and privileges of the producers of eattle and hogs should be as well respecterl as those of others, and, as they are the benefieiaries in the manufarture of this wholesome article of food, they should not he borrlened with mnecessary and opluessive special taxes or needloss restrictions in the manufacture of this prochet, other than is alsolutely necessary for the support of the Government and the proper govermmental regulations surrounding the handling of the same.

Your orator respectfully contends that these prodncts shomb receive at the hamds of Congress no greater exactions than those injowed upon competing food products; and that the manufarture and sale of olecomargarine is aheady surromded by numerous safeguards which Congress, in its wisklem, has seen tit to provide, stipulating a severe punisment for selling same under misepresentation as to its composition: and that this produce has, by experience, proven to be just what a lawe majority of the people of this comntry want, and that none but the dairy and allied interests are asking for or reeking any further legislation in this matter, and their indorsement of the proposed lexislation is purely and simply selfish.

In conchion, your orator, in belalf of the prodneers and consmmers of this great comntry, solemnly protests against the enaetment of the (irout bill or any other legislation calculated to sutail an cnormons loss on the live-stock prodncers of this comntry, to ruin a great industry, and to deprive not only the working classes, but many others of a (beap, wholesome, mutritions, and acceptable artiche of fool.

The National Live Stock Astociation.

Jolix Wr. Springer, President,

By C. F. M.дntis, Secretary.

The bill recommended by the majority is. in the opinion of the minority, an meonstitutional measure in that it is class legislation. If it is designed als a revenue measure. then it would be meonstitutional. because it taxes one man for the benefit of another, which, according to the language of the Suprene Court, " is robbery under" the form of law."

\section{H. D. Moner. Hexry HeITFELd.}

I concur generally in the riews expressed in this minority report, without indorsing all the expressions therein used. especially in the testimony of witnesses and extracts made a part of it. I conciur fully, howerer. in the conclusion of the minority that the bill ought not to pass.

Wy. B. BATE. 


\title{
THE OLEOMARGARINE BILL.
}

\section{HEARINGS}

BEFORE THE

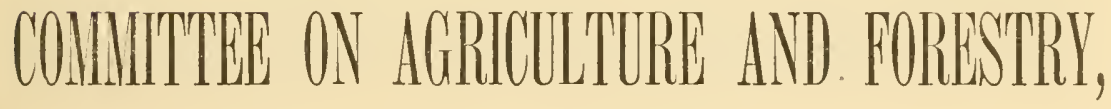

\section{UNITED STATES SENATE,}

\author{
ON THE
}

BILL (H. R. 3717) TO MAKE OLEOIARGARINE AND OTHER IMITATION DAIRY PRODUCTS SUBJECT TO THE LAWS OF THE STATE OR TERRITORY INTO WHICH THEY ARE TRANSPORTED, AND

TO CHANGE THE TAX ON OLEOMARGARINE.

S. Rep. 2043 



\title{
HEARINGS ON THE OLEOMARGARINE BILL.
}

\author{
WAshington, D. C., \\ Tednesday, December 19, 1900.
}

The committee met at 10.30 a. $\mathrm{m}$.

Present: Senators Proctor (chairman), Hansbrough, Warren, Foster, Bate, Money, Heitfeld, and Allen.

Also, Hon. William WV. Grout, a Representative from the State of Vermont; Hon. W. D. Hoard, ex-governor of Wisconsin and president of the National Dairy Union; C. Y. Knight, secretary of the National Dairy Union; Hon. William M. Springer, of Springtield, Ill., representing the National Live Stock Association; Frank M. Mathewson, president of the Oakdale Manufacturing Company, of Providence, R. I.; Rathbone Gardner, representing the Oakdale Manufacturing Company, of Providence, R. I.; Frank IV. Tillinghast, representing the Vermont Manufacturing Company, of Providence, R. I.; Charles E. Schell, representing the Ohio Butterine Company, of Cincinnati, Ohio; and others.

\section{STATEMENT OF HON. W. W. GROUT.}

The Champuns. General Grout, whose name has been given to the bill, is here, and we shall be glad to have him make any statement in regard to the bill which he sees fit.

Mr. Grout. Mr. Chairman and gentlemen of the committee, I shall detain you only a moment.

It $v \mathrm{~s}_{\mathrm{s}}$ thought best that the friends of the bill should open with a very brief statement, and we do so by submitting the hearings before the House Committee on Agriculture, which were quite full, and the report of that committee of the bill to the House, together with the minority views.

It has also been thought well that some one should explain somewhat to you, as the subject I presume is new to most of the committee, the general scope of the bill.

The first section puts all imitation dairy products under the control of State laws the moment they come from the State of manufacture, or from one State into another, to state it more exactly. This principle has already been established by the decision of the Supreme Court in the case of Plumley $v$. The State of Massachusetts, which came up to the Supreme Court on a writ of error from the supreme court of that State. Plumley was indicted for a violation of the State law in the sale of oleomargarine and was convicted and imprisoned. He brought a writ of habeas corpus before the State court. The State court held the proceeding regular. It was brought here on a writ of error, and the Supreme Court decided that the State of Massachusetts 
had the right to pass a law taking control of this article so soon as it came into the State, the interstate clause of the Constitution to the contrary notwithstanding; and that the State had the right to enforce that law on the ground that this article was calculated to deceive, it being made in imitation of butter. It was upon that ground that the case went off in the State court, and it was upon that ground that it was affirmed by the Supreme Court.

You may ask, then, why do we need any statute law on the subject, the Supreme Court having settled it? Here is the reason why: That decision was made by a divided court, Chief Justice Fuller and two associate justices dissenting from the view taken by the majority of the court, the opinion having been given by Mr. Justice Harlan. It has been thought for these many years--this was a decision some eight or nine years ago; I have forgotten the cxact date of it - it has been thought by the dairy interests that they wanted this written in the statutes of the country as well as in a Supreme Court decision, for the question is very likely to arise there again, and it might result in a different decision by the court.

Mr. Knigir. Allow me to make a suggestion. In the Schollenberger case, in Pennsylvania, the cireuit judges-some of them, at leastoverruled or reversed the Plumley ease, and it was so held in the State of Minnesota by Judge Lochren.

Mr. Grout. That has been done by one or two cireuit or distriet judges certainly, and in some of the State courts, but I thought it well to refer only to the court of last resort, the Supreme Court, not wishing to take time to go into the details. It is true this decision has already been bronght in question by some decisions of subordinate conrts.

Senator Aluwn. Let me ask a question. Did the case to which you refer go off on the ground that the property, having gone into Massachusetts and become mingled with the property there, at the end of transit is subject to the police regulation of the State?

Mr. Grout. Precisely. It is the police power of the State which gives this right to take charge of the article.

Senator Aluex. Do you know that there is a decision which holds that Congress may abdicate its power to control interstate commerce to the State?

Mr. Grout. Yes, sir; there is snch a decision, under what is known as the Wilson law. The Wilson law was passed to overcome what was known as the original package decision, and there is a decision by the Supreme Court in a case coming up from the State of South Carolina under the constabulary act of that State, or whatever name it went by, in which it is held that that power could be passed to the States. I am not able now to name the case, but I hare examined it.

Senator Alden. Inder the Iowa liquor law originally the court held that liquors which went in original packages were not subject to State regulation.

Mr. Grout. Certainly; that was the original package decision. The Wilson law conferred power on the States to take charge of it.

Senator Altex. Mr. Wilson introdnced a bill, which became a law, remitting that power to the States. Has that act itself been passed upon?

Mr. Grout. Yes, sir; it was passed upon by the Supreme Court in the case from South Carolina, already referred to, the opinion having 
been delivered by $\mathrm{Mr}$. Justice White, as I remember, in which the authority of State law is recognized. So there can be no question on that score, I think.

This feature of the bill has been pending in the two Houses for several years. I introduced the first section of the bill in the House six or eight years ago, certainly, and four years ago this very winter, I think, the first section of the bill passed the House. I am speaking now of the first section of the present bill. It passed the House and came to the Senate, but was not acted upon by this body.

In addition to that, there is the second section of the bill, which puts a tax of 10 cents a pound on all oleomargarine made in imitation of butter, and reduces the present tax of 2 cents per pound to one-fourth of 1 cent a pound on all that is left in its natural, uncolored state. 'The great objection thus far to this bill has been to the second section. Very few complain of the first section, but it is to the second section that objection is principally leveled.

I am not going into any long statement here. Read the testimony which we have submitted, and you will see that the testimony is abundant on all sides that olcomargarine is sold constantly for butter. You will learn from that testimony that the manufacturers arrange with the retailers to sell it - they do not say as butter in their circulars, but to sell it. They know very well that the retailer will sell it for butter-that is a part of the programme-but he is to sell it, and they will stand between him and all State laws for payment of fines, costs, and damages, this being substantially the language used in their circulars. You will find that in the printed hearings before the House committee. There is no question about this. They in fact make no reply to it, or hare thus far made no reply, and I presume they will not undertake to do so.

Only a small portion of oleomargarine relatirely, however, as I believe, is really sold through the retailers. There are no statistics on the subject, because it is a matter wholly within the knowledge of the manufacturers. The great body of it is worked off through hotel keeper's and restaurant and boarding-house keeper's, who buy directly of the manufacturers; if not, perhaps they buy of some intermediary wholesale dealer this stuff, and palm it off upon their guests as butter. The great share, I believe, of the article is marketed in that way.

Now, the oleomargarine men claim, or have claimed, that they are not parties to this fraud, that persons buying it know just what it is. This is undoubtedly true of the hotel man and the restaurant and boarding-house keeper. They know what they are buying, but the manufacturer knows that they intend to palm it off on their guests as butter. There is no question about this, and it makes them, morally at least, parties to the fraud.

Senator Allen. How are you going to sustain the constitutionality of the second section?

Mr. Grovt. In what respect, if you please, sir?

Senator Allev. In respect to its being a tax to destroy an industry.

Mr. Grout. The decisions are all one way, as undoubtedly the Senator knows. You may go back to an early decision by Chief Justice Niarshall, in which the Supreme Court denied itself the power to inquire into, "to review," to use the language of that authority, the discretionary power of the legislature to tax. The tax must be laid alike, of course, upon the same class of articles. The legislative power 
may, in its discretion, single out one thing and tax it and leave another untaxed; but wherever you lery a tax it must be levied uniformly on the same class of articles. The courts insist upon uniformity, but they never question the discretionary power lodged with the legislative body to impose the tax.

Senator Allen. I know of but one precedent for this proposed legislation, and that is the taxation of State bank issues.

Mr. Grout. Exactly. 'That is a notable instance, the rankest instance probably, our opponents would say, that has ever been furnished of the exercise of the power to tax out of existence.

Mr. Hoard. In addition to the State bank tax, there is the tax on filled cheese and adulterated flour.

Mr. Grout. Yes, to be sure, and along the same line of this proceeding. The power to tax and tax out of existence is unquestioned, as I believe, gentlemen. The only question which the court ever inquires into is whether the tax is laid evenly, uniformly, upon the class of articles which it proposes to deal with. It may select a single thing and tax it and leare another thing untaxed. That is according to the discretion of the legislative power. 'The cure for any wrong in this respect is with the constitueney. If an unjust tax be imposed, the people will send men here who will exercise better discretion.

Senator Allen. The conrt can not inquire into the motive of the legislative department; but if that motive is apparent upon the face of the act, then it does enter into the litigation and become a part of the construction of the act.

Mr. Grour. Tes; but they do not, then, even give it effect to the extent of setting aside the power of the legislature to tax. How could it have been otherwise than that the intent was apparent in the law taxing State banks?

Senator Allew. Suppose it is apparent on the face of this bill that the motive for imposing the tax is to destroy the thing taxed?

Mr. Grout. We deny this. We say that is not the motive.

Senator Aluev. What would be the rule, then?

Mr. Grout. I do not think it would change it a particle. Judge Collamer, up in our State, who was a Senator with you gentlemen, and held a high place when in this body - the very first in his time, as tradition will tell you, and as discussions will disclose if yon turn to themJudge Collamier, on the bench up in Vermont, said you conk not inquire into the motive by which one cid a legal act; and that I understand to be good law everywhere.

Senator Allen. That is true; but suppose the motive is apparent upon the act itself?

Mr. Grout. Very well; the motire makes no difference, providing the act be legal, and here inquestionably the act is legal.

Senutor Allen. Then you must take into consideration the motive, because it is a part of the act?

Mr. Grout. Well, I hare expressed to the committee my views on this subject, but let me say it is not the purpose here to tax ont of existence. The object of this second section is to prevent the sale of oleomargarine as butter. to prevent a fraud. And we say that is the only rational construction which ean be given, because if the purpose of the section was to destroy the article it wonld not proride as it does in the closing clause for a small tax, the least possible tax, on the 
uncolored article. It might he made still less, if the legislative power thought best to do so, although I do not think it ought to be less, for it ought to be large enough to cover the cost of policing the business. Now, when it reduces the tax to the lowest possible limit, so that oleo undisguised can go to the consumer at the cheapest possible price, who can fairly say that this second section is intended to destroy the manufacture of oleomargarine? No, instead of destroying, it encourages the manufacture of the honest article. All that it seeks to destroy is the fraud that is perpetrated when it is colored like butter.

It may stop its sale as butter and yet not go to the extent of preventing its manufacture, as $I$ will show you a little later. The profit on the sale of $104,000,000$ pounds of oleomargarine and a little more, last year, fairly estimated, must have been anywhere from $\$ 13,000,000$ to $\$ 15,000,000$ - thirteen to fifteen million dollar's between the cost of the article and the price paid hy the consumer.

Some oleomargarine friend present smiles-I hear a smile-but such is the case, disguise the matter the best they can. But we will, to accommodate the gentleman's state of mind, call the profit $\$ 12,000,000$, or any large sum you please along there; it can not be less than that amount, as it costs but 9 cents per pound, tax paid, and the consumer pays anywhere from 18 to 30 cents per pound for it. Call it 22 cents, and for $104,000,000$ pounds it would amount to $\$ 22, \$ 80,000$. Take from this $\$ 9,360,000$, cost of production, and you have left $\$ 13,520,000$ profit. But call it $\$ 12,000,000$ for safety, if you please. Remember this stuff is sold as butter almost exclusively to the consumer; that is, the consumer takes it supposing it is butter. The guest at table eats it and pays his $\$ 5$ a day to the hotel. It passes with him as butter and he pays the price of butter. The same is true at the restaurant and the boarding house. And the retailer everywhere sells it as butter and for the price of butter.

Senator Allex. Is not that a subject of police regulation in the State?

Mr. Grout. Yes; but we have got a regulation here in this second section which transcends police regulations, and, if the Senator will allow me a moment, I will make it plain to him.

Senator Allen. Can you do that?

Mr. Grout. Oh, yes, sir, in the way we propose to do it here, as I believe.

Here are the large profits of which I have spoken. I might go more into details, but I feel that I must not detain the committee. I intended to be very brief when I began, and I will now be as brief as possible. The profits are what I have indicated, twelve or thirteen million dollars annutuly. If you put a 10-cent tax on $104,000,000$ pounds of oleomargarine, that will make $\$ 10,400,000$ the manufacturer would have to pay before he could put the stuff afloat. And this would so reduce the profits that it would take away the inducement to enter into the fraudulent practices now resorted to to work it off as butter. It would reduce the profits $\$ 10,400,000$.

If it be true, however, as the oleomargarine crowd claim, that people really prefer oleomargarine to butter and they desire to hare it colored, that large numbers of the middle class of people prefer it to butter-that is the war one cireular puts it-if that be true, it can be colored and sold to those people for oleomargarine at just about the price it is fraudulently sold now for butter'; so they can have it at 
a price not exceeding the present cost. But this is not true, and I believe this 10-cent tax on the colored article will stop the sale of oleomargarine for butter by making the business unprofitable.

Senator Warren. Would it disturb you if I should ask you a question?

Mr. Grout. Not at all, if the committee wish to delay the hearing for this talk by me.

Senator Warren. The bill proposes to tax oleomargarine 10 cents a pound when it is colored in imitation of butter. Is there any established color that butter has?

Mr. Grout. Yes, sir; it is yellow.

Senator Warren. And always the same?

Mr. Grout. The world over and through all time it has been yellow-rarying shades of yellow.

Senator WArren. Is it always the same?

Mr. Grout. No; not always the same shade, but always yellow-the cow color's it yellow.

Senator WARren. Is it the same color at different seasons of the year?

Mr. Grout. Oh, no, it varies; but it is yellow, different shades of yellow at different seasons of the year.

Senator Allen. Depending on the condition of the cow?

Mr. Grout. Yes, sir; but there is no cow so poor nor fed so poorly in all the world, I believe, but that the butter made from the crean of her milk would be yellow in some degree; I do not say highly yellow, but I say yellow.

Senator Warren. If that were the case there would not then be any necessity of coloring butter?

Mr. Grout. Yes, there is, because many people want it a little yellower than the cow at some seasons of the year nukes it. Many people think it tastes better. There is a demand in certain localities to have it colored a little, and in some places more than a little. and butter makers have to eater to the taste of their customers. I did not intend to enter upon a discussion of this color question, but I am perfeetly willing to do so if the committee wish to hear me. There is much that can be said abont it.

Senator WArren. One question more. When in New England, say in Vermont, at this time of the year and from now until, say, April 1, a farmer has one or two or three cows and is making butter, what is the color of that butter if it is not colored with anything except the wilk which comes from the cow?

Mr. Grout. It is yellow, but not as yellow as when the cow is fed on grass in June. Then, too, it would be yellower if the cow were were well fed during the winter-fed on corn meal, shorts, and earlycut hay, and the like-and kept in a healthy condition.

Senator WARrex. I ask for information whether oleomargarine is colored different shades at different seasons of the year to follow the different shades of butter?

Mr. Grout. Yes, sir; these very circular's to which I have alluded diselose that fact. You will find them in this printed report here. They do that very thing, sir, to meet the varying shades of butter. That is one of the tricks of the trade. They are up to it, Senator, clear up to it, you may be sure; and they are up to every other possible scheme that ingenuity can devise to work this stuff off for but- 
ter. But if you will put this 10 -cent tax on it and stop coloring it like butter the game will then be up.

Senator Foster. They put on a June color or a December color?

Mr. Grout. Yes, sir; that is it exactly. They advertise to do it and they do it with neatness and dispatch. They say in these eircular's, which you will find in the printed testimony, that they will give it just such color as may be wanted.

Senator WARRen. As a matter of faet, butter made naturally from the milk of cows will vary at different times of the year almost as much as the difference between the color of that desk and the color of this sheet of paper. If that is so, where is your guard against coloring oleomargarine?

Mr. Grout. Safety consists in the fact that oleo is white. But the Senator will not seriously claim that the color of butter varies as much as indicated by him

Senator W ARren. But in imitation butter, as to what degree?

Mr. Grout. They are not to color it at all.

Senator Wances. It must be purely white?

Mr. Grout. Yes, sir; it must be white or some other color than butter. The bill, if law, will prevent its assuming the color of butterthat is the only object-so that it can not go forth and practice these frauds. The closing clause in the section puts the tax so low that it enables pure oleo, without disguise, to go at the eheapest possible price to the consumer, and he can get it for 10 or 11 cents a pound with great profit to the manufacturer and a fair profit to the retailer, who will then do an honest business.

Senator Allew. Suppose a man says from choice that he wants to use oleomargarine, but he wants it colored, has he not that right?

MIr. Grour. Yes, he has the right, and let him color it himself if he wants to be to that trouble. But the legislative power, to prevent fraud, has a right to intervene and say that it shall not take a color which is ealculated to produce fraud, and then put it on the market, eren though it contrarenes the taste of some gentlemen.

Senator Alten. Do you think it is within the legislative power to compel all butter to be colored, December butter, for instance?

Mr. Grour. I do not think Congress will ever enter that field. If it does, and I am here, I will then enter on the discussion of that question.

Senator Allew. Suppose Congress should pass a law that no December butter should be sold unless it were colored as June butter. Do you think that would be within the porrer of Congress?

Mr. Grout. I do not quite see how Congress would get jurisdiction of the question. We would not, certainly, unless it could be made clear that some fraud was to be perpetrated, and took jurisdiction by the taxing power' in some way. We might do it then, but otherwise we could not take jurisdiction of it.

Senator Alten. Suppose the article is stamped as oleomargarine. Do you then contend that it is within the power of Congress to condemin the article or to give it a particular color?

Mr. Grout. No; we are not asking you to give it any particular color. We are only asking that you make so expensive the colormg of this stuff like butter as to leave no temptation to so color it and fraudulently sell it as butter.

Senator Alles. You want to prerent fraud? 
Mr. Grout. That is it exactly. Pass this bill and I believe you will stop this great fraud-the greatest the world has ever known in the manufacture and sale of a food product. Do this and you will have the thanks of the millions of hard-working men and women who make honest butter, and the thanks also of the millions on millions more who want to eat honest butter.

Mr. Chairman and gentlemen of the committee, I thank you for your kind attention.

\section{ORDER OF PROCEDURE.}

The Chairman. I am obliged to attend a meeting of the Committee on Military Affairs, and I will ask Senator Hansbrough to preside while I am away. I may say before going that I am sure it is the desire of the committee to give all interests a fair hearing, but we wish you to bear in mind that we are very busy-busy without precedent, almost, at this time-with the measures before Congress, and we hope you will make your statements as concise and brief as possible and, so far as possible, not repeat what is already before us. The testimony given in the House is before us, and it will be received on both sides. That is all I need to say.

Mr. Gardner. May I say a word before the chairman retires?

The Chamman. 'The committee will remain, and the hearing will continue.

Mr. Gardner. Owing to the lack of opportunity we have had to prepare for this hearing, I desire to express the hope that we may be allowed to present our case at a somewhat later date. The parties whom I represent have never had an opportunity to appear before any committee with reference to this subjeet. They were informed of this meeting very recently for the first time. They feel that they come here to-day utterly unprepared, and they are most anxious that they shall have an opportunity to present their view to the committee after a reasonable preparation may have been made.

The Crairuan. The committee will try to be reasonable and fair. I can not speak about that definitely. You represent the oleomargarine interest?

Mr. Gardner. I represent simply one, the Oakdale Manufacturing Company, of Providence, R. I.

The Chamman. I wired you Wednesday morning, did I not?

Mr. Gardner. Yes; some time during the week.

The Chamban. I think I wired you Wednesday morning. That gave you just a week's notice. We hope that we may get through with the hearing speedily, because after the holidays we shall be extremely busy. It is for your advantage to have the hearing as early as possible, hecause after the holidays it will probably be a very small subcommittee that we could get together. So. in order to have the hearing by the entire committee, the earlier the better, and we shall determine as we go along when we must close. But I merely want to urge you to be as expeditious as possible.

Mr. Springer. May I ask, Senator, whether you intend to continue this investigation from day to day during the holiday recess?

The Chambuan. Certainly, if necessary. I expect to be here most of the time and some nembers of the committee will be here all the time. I think probably we could have fuller meetings during the recess than afterwards. 
Senator Haxsbrough. Mr. Chairman, I wish to ask if there has been any arrangement whereby a limit is placed on the hearing?

The Chamman. There has not been any, and in the notice I sent out I said that we would hear gentlemen to-day, and to-morrow, and the next day.

Mr. Grout. I simply want to say, gentlemen, that with this testimony the friends of the bill submit their case, and give the field to those who are opposed to the measure.

The Acting Chairuax (Senator Hansbrough). It is understood that Governor Hoard is present and clesires to be heard.

\section{STATEMENT OF HON. W. D. HOARD.}

Mr. Hoard. Mr. Chairman, I have nothing to submit at the present time. I think it only fair that the men who are opposed to this legislation should have the time. The proponents of the bill have had their say before the House. I am astonished to hear one gentleman say that he has had no chance to appear before any committee, because this bill occupied trro months last winter before the House Committee on Agriculture.

I will only add that the bill is for the purpose of preventing the comnterfeiting of food, so far as the constitutional power of the Federal Government can go. The Federal Government is limited in its constitutional power. It has no right to enact prohibition. It has no police power. Those things you are as well aware of as $I$ am. But it has taken ground upon certain lines, like the taxation of State banks. in the interest of a sound currency.

WTe believe this is a taxation of a counterfeit and a fraud in the interest of fair dealing, in the interest of the consumer, and in the interest of the producer. Here is a great army, between fire and six million men, in this nation who are engaged in one of the most important branches of agriculture. Here is another great army of consumers who are being defrauded and imposed upon. The one is being swindled out of his rightful market and the other out of his property, and they are both imposed upon by a fraud and a counterfeit.

The question was raised whether it is not just as lawful to color oleomargarine as it is to color butter. No. In one case the question of color is a matter of taste. In the other it is a matter of fraud, a vehicle of deception. In no instance is the coloring of butter a vehicle of deception.

I had a distinguished member of the other House ask me if butter was not colored in winter to make the consumer beliere that it was made last June. That gentleman was a student of maxims, not of markets. The cheapest and poorest butter in winter is that made last June. The highest-priced butter is that which is not orer ten days old and faultless in character and flavor. In the butter scores at all dairy fairs and conventions you will find in a scale of 100 that flaror takes 50, color, 5. It is a question of taste with the consumer. Senator Allen appears here with a woolen suit of clothes colored black. It is a question of taste with him. He would not wear that suit in its original color for any reason except that of taste. It was not colored black to make him believe it was silk, or that it was linen or cotton. It was simply colored to suit his taste; that is all. So it is with the 
coloring of butter. There is a market demand, a demand of the consumer, which compels the producer to adapt himself and eater in that particular, as the maker of fabrics has to do.

So, as I said, in one case the matter of color is a question simply of taste, withont any change whaterer in the mind of the consumer or in the character of the product.

Senator Allen. Governor, will you permit me to ask you a question?

Mr. Hoard. Certainly.

Senator Allex. Why does the prudent farmer, ordinarily in June, endeavor to put down enough butter to carry him through the winter for his own use?

Mr. Hodrd. Senator, that is not done at the present time to any appreciable extent.

Senator Allen. It has been done ever since I was a boy.

Mr. Hoard. It may have been done when you were a boy and when I was a boy. As to that, you are right, but at the present time the whole system of butter making is changed. Not one man puts down butter in June for the next winter, where 10,000 did it forty years ago. This wonderful change has come through the organization of creameries, where now a very large proportion of the best butter is made.

'That is the only thing I have to submit at the present time. I do not think it is fair to take the time of these gentlemen who are desirous of being heard, and what I may have to say I hope to have an opportunity, if granted, to submit at a subsequent meeting of the committee. I thank you, gentlemen, for your kind attention.

OPPONENTS OF TIIE BILL.

The Acting Chairuax. I should like to ascertain, if possible, the number of gentlemen here who desire to be heard on the other side, and about the length of time they would want to consume.

Mr. Schell. Mrr. Chairman, I represent the Ohio Butterine Factory, of Cincinnati.

The Acting Cunarman. Are you the only one here in the interest of that institution!

Mr. Scheld. I am the only one here in the interest of that institution, and that institution eame into existence the same day that the Grout hill passed the House. We certainly have not had any chance to be heard. But I do not want to take the time of this committee at all myself if some one representing identical interests can cover the ground better than I can. However, I want time to unite our forces, to get together and select one man to present our side of the question.

The Acting Champian. I (lo not believe that it is the desire of the committee to traverse the ground that has been covered by the hearings in the House.

Mr. Schell. I understand that.

The Acting Cimamman. If possible it is desired to aroid doing that, and I simply desire to ascertain how many gentlemen are here now who wish to be heard in opposition to the bill and how much time they desire to take. We have heard from one gentleman who wishes to be heard on the other side.

Mr. Gardner. I represent the Oakdale Manufacturing Company, of 
Providence, R. I., which desires to be heard. I shall endeavor to be as brief as I possibly can, but owing to lack of time for preparation I can not be as brief to-day as I could be after the holidays.

The Acting Chamman. Are there any other gentlemen here who wish to be heard?

Mr. Tillinghast. I wish to be heard, representing the Vermont Manufacturing Company, of Providence, R. I., and I assure you if I do speak I will not go over the ground, or at least while I may go over the ground I will not present the same facts or perhaps the same arguments that were used in the House. I did not appear before the House committee. I did not have any opportunity to do so.

The Acting C'hairman. Are you ready to go on now?

Mr. Tillingriast. I am not ready to go on this morning, but Mr. Gardner is, I understand, ready to speak this morning if it is the desire that he shall proceed at this time, though he has not had that opportunity for preparation that he wished.

The Acting Champian. We have heard from three gentlemen who are present and who desire to be heard. Are there others?

Senator Allen. Does not the gentleman sitting by you, Mr. Gardner, desire to be heard?

Mr. Mathewson. No, sir; Mr. Gardner will represent me.

Mr. Schell. I wish to add that I have not had a chance to go orer what was presented to the House, and I do not know what is before the committee. I will put in every minute of my time in preparation.

Senator Bate. You are the only one representing your interest?

Mr. Schell. I am the only one representing it on this side.

Senator Bate. We ean probably hear you now.

$\mathrm{Mr}$. Scheld. If the same arguments that I would advance appear in the hearing in the House I would have nothing to say. All I want is time to prepare.

Senator Allew. I think we ought to have the hearing and be prepared to report the bill promptly upon the meeting of Congress after the holidays.

Senator Bate. I do not think we can do that. Telegrams are coning here from gentlemen who want to be heard after the holidays.

The Acting C'mairman. We shall have to decline to sit here and listen to arguments the balance of the session. Mr. Springer will be heard now.

Mr. SPRinger. I yesterday received a telegram from the president of the National Live Stock Association of the United States, asking me to appear before this committee in behalf of the live-stock interests of the whole country to oppose the passage of the bill. I received this notice only yesterday afternoon and it was receired by telegram, and I will receive a written communication probably by to-morrow morning, giving some of the views and interests that that association desires to have presented to this committee.

I will state that I am not aware that that association appeared in any capacity before the House conmittee. I have not had a chance to examine all its hearings yet, but I will do so at once and, if I find that they have presented their riews there in any way I will not desire to go over that ground again. I do not think they have been heard.

The Acting Chamman. You represent a live-stock association?

Mr. Springer. All the live-stock associations.

Senator Foster. The National Live Stock Association? 
Mr. Springer. All the live-stock associations of the whole country. I represent every live-stock interest in the country.

Senator Heitfeld. Who is the president of the lire-stock association?

Mr. Springer. John W. Springer, of Dallas, Tex.

Mr. Hoard. You say that you represent all the live-stock associations?

Mr. Springer. All who are embodied in the live-stock association.

Mr. HoArd. You do not represent the Holstein and Friesian Association?

Mr. Springer. No; I do not. Howerer, the association that I represent embodies the large majority of the live-stock interests in the United States.

Mr. HOARD. I knew that the Holstein and Friesian Association were here in support of the bill.

Mr. Springer. Yes; they are dairymen. These are people who raise eattle for the purpose of supplying the markets of the country with live stock, and it is that association which I desire to appear for before this committee.

The Acting Chatrian. Are you ready to go on now?

Mr. Springer. As I stated before, Mr. Chairman, I had this notice yesterday afternoon, and I have not had a chance yet to read all the testimony. I am going to go over it as rapidly as I ean. I do not desire to ask for more than a reasonable delay. I think an association representing such large interests as this ought to be permitted to present their views, and that there onght to be at least a reasonable time given for that purpose. While I can do so some time during the holidays I could not promise to do it this week, becanse this is now Wednesday, and I understand Senator's are very busy with matters, expecting to adjourn on Friday, but during the holday recess I hope to be able to present to the committce or a subcommittee that you may appoint the riews of the association.

The Acting Chambian. We have three-quarters of an hour this morning if some gentleman is ready to go on now.

Senator Foster. Mr. Gardner is ready, I believe.

\section{STATEMENT OF RATHBONE GARDNER.}

Mr. Gardner. Mr. Chairman, I am as ready perhaps as a gentleman can be with forty-eight hour's' preparation, and possibly I am as ready as anyone else who desires to be heard.

As I said, I appear here representing the Oakdale Manufacturing Company, which is a corporation engaged in the city of Providence, R. I., in the manufacture of oleomargariue. I also represent a large number of wholesale and retail dealers in the city of Providence, who sell oleomargarine, and who I think are, perhaps, a class which has not heretofore been represented in any hearing upon this bill. They are men who claim that they sell the product honestly and absolntely in aecordance with the requirements of the laws of the United States and of the State of Rhode Islaud, where they do business.

The Oakdale Manufacturing Company, as also my other clients, feel that an attack upon their existence eompels them to protest as strongly as possible against the passage of this bill. They believe that the passage of the bill would absolutely destroy their industry, and they 
believe that the proposed law is an unwarrantable interference by the Congress of the United States with their conduct of a legitimate business.

We protest against the bill, in the first place, upon the broad ground that we consider it a dishonest act-dishonest in purpose, pretending to be that which it is not.

The Acting Champman. Of course you do not desire to reflect on the gentlemen at the other end of the Capitol who have passed the bill?

Mr. Gardner. Not at all, because one of the representatives of the gentlemen at the other end of the Capitol has this morning expressed exactly what we claim makes the bill dishonest. He has expressed his view and his opinion that it is a bill to prevent the competition of colored oleo with butter, and I think that that purpose in a bill avowedly a revenue bill stamps it as legally a dishonest bill. I have, of course, not the slightest intention to reflect upon the motives of any person who advocates the bill, but it is a bill which seeks to accomplish by indirection that which Congress can not accomplish directly.

It is avowedly a revenue measure, and in explanation of my meaning. I say that it is only as a revenue measure that the second section of this act can be considered and passed upon by the Congress of the United States. It is only upon the theory that it is a revenue measure that the constitutionality of the act can be upheld by the courts of the United States.

I do not go into the question of the constitutionality of the proposed act. I have felt that the act would be pronounced constitutional on the same ground that other acts which imposed a tax the purpose of which was really not the collection of revenue have been pronounced by the courts of the United States to be constitutional. Upon the same ground upon which I think that the oleomargarine act of 1856 has been by the circuit court pronounced constitutional, upon the ground that the courts of the United States can not impugn the purposes, motives or intentions of the legislative body.

Upon the face of this act it is a revenue measure. The courts wi'l not say that, notwithstanding the fact that this is avowedly a revenue measure, they know from any source that the purpose of the act was not the collection of revenue; that it was not the intention of the legislative branch of the Government in passing the act to collect revenue; that there is another motive lying underneath and behind it. The court does not feel that it is at liberty to do that; and so it seems to me that the court probably would hold to be constitutional any measure which was avowedly a revenue measure.

But, gentlemen, I say that this proposed act is not honest, in that sense. The promoters of the bill are not acting sincerely, because, while they claim the constitutionality of the act upon the ground that it is a revenue measure, and while every one of us understands that it can only be upheld upon that ground, they come here and tell you with perfect frankness that that is not the purpose of the act; that the act has another purpose. The author of the bill tells you this morning that the purpose is not to destroy this industry, but that the purpose is to prevent a fraud by enabling the States to exercise their police powers, or by exercising, as in effect the bill does exercise, as I think I can show in a moment, the police powers of the State for them; that the purpose and intention of the act is to prevent a fraud.

I maintain that the Congress of the United States has no more right, 
under the guise of a revenue act, to pass an act the purpose of which is to prevent a fraud than it has to pass an act the purpose of which is to destroy an industry. It is in either case stepping outside of its province. The author of the act has this morning stated its purpose. An advocate of the act in the House stated its purpose in these words:

"It proposes to require the oleomargarine manufacturer to pay a tax on oleomargarine, colored as butter, large enough to raise the expense to the producer equal to the expense of producing pure butter.'

That is to say, so far from the purpose of this act being the production of revenue, although that is arowedly its purpose, the purpose of the act as declared by its adrocates is to regulate competition between different businesses. The advocates of the act come before this committee to-day and say that colored oleomargarine enters into unfair competition with colored butter; therefore they propose through this act to make the production of colored oleomargarine as expensive as the production of colored butter, and to destroy the advantage which they claim colored oleomargarine has to-day in the markets of the country.

Now, that is a purpose which is absolutely contradictory of the claim that must be made before Congress in asking them to take action upon this bill. It is absolutely contradictory of the claim which must be made before the courts if this bill ever comes before the courts. The adrocates of this measure frankly state that they are seeking by this act to do something other than what the act purports to do.

The adrocates of the measure before the House argued that this act was harmless because the legislatures of a large number of the States had already adopted laws which prohibited the sale of colored oleomargarine within those States; that they had found themselves unable to enforce those laws; that this law would simply operate to make the laws of the different States in that respect effective; and that while it was, as a matter of fact, the exercise by Congress of the police power which is reserved to the States, yet it was a hirmless exercise, because in so many of the States similar laws had heen adopted. It seems to me that Congress has no more right to pass a law to enable States to enforce their own laws governing the exercise of the police power, under the guise of a revenue bill, than it has itself to try to exercise that police power.

I wish to call your attention to the fact that in many of the States there are no laws which forbid the sale of colored olcomargarine as such. In the State of Rhode Island, in which my client is doing business, colored oleomargarine is allowed to be sold as colored oleomarga rine. The regulation of that power of sale is something which erery member of this committee will admit belongs absolutely and solely to the police power of the State. This proposed act of Congress comes and says that colored oleomargarine shall not be sold within the State. It imposes a condition upon the sale of colored oleomargarine which absolutely prohibits that sale. Upon the theory of the adrocates of the bill that the passage of the bill is to enforce the police laws of the States which have enacted prohibitory legislation, it must enact in effect laws for those States which have not enacted any such prohibitory legislation.

To-day the State of Rhode Island, as a dozen other of the United States which permit, in the wisdom of their legislatures, the sale of this product, when this bill is passed will be disabled from haring the product sold within the State, and the Congress of the United States 
is directly exereising the police power of the State. That is true if it is true that the effect of the bill is to prohibit the sale of artificially colored oleomargarine, and the advocates of the measure claim that that is its effect, because they claim that only by the passage of the bill ean the State laws now existing which forbid the sale of colored oleomargarine be enforced.

Therefore I say that this act is, it seems to me, properly characterized as legally a dishonest act, a pretense, an act which seeks to do by indirection what Congress can not do directly; and while it is upon its face a revenue act, it is arowed by its friends and adrocates to be an act not for the purpose of raising revenue, but for the purpose of regulating competition; an act which enables Congress to exercise the police power which is reserved to the State.

If that is true, that, it seems to me, is sufficient to condemn the act. It is utterly in violation of principle, and if it is in violation of principle, then no considerations of expedieney are strong enough to justify the patsage of the act. 'That is the broad ground which we take.

But we do claim much further than that - that even though this act were justified on principle, if it were not what we claim it to be, a subterfuge, it is not just or expedient in its provisions. As the author of. the bill has said this molning, the chief opposition to the proposed act has not come upon the first section of the bill, but the first rection of the bill is nevertheless for certain reasons rerr objectionable, and for certain other reasons it may in the future be rery dangerous. It may, I believe, accomplish what eren the advocates of the measure do not desire should be accomplished.

Of course every honest manufacturer of oleomargarine protests against the first section of the act because it places oleomargarine in the category of those dangerous articles of food the use of which the State by the exercise of its police power ought to regulate and does regulate. We claim that we make an absolutely healthful food product, a food product which more than any other is certified to be healthful and wholesome - the one food product. perhaps, which the Gorernment of the United States makes it its business to see that it is absolutely wholesome; and we object and protest against having that product of ours placed in the category of articles which justify the cxercise of the police regulations of the different States.

But I desire to call the attention of every member of the committee, if I mar, to the wording of the last part of the first section of the act, which jeads as follows:

" Provided. That nothing in this act shall be construed to permit any State to forbid the manufacture or' sale of oleomargarine in a separate and distinct form, and in such manner as will adrise the consumer of its real character, free from coloration or ingredient that causes it to look like butter."

Every ingredient of oleomaromine causes it to look like butter. Without the use of any artificial coloring matter whaterer' oleomarowrine as it comes from the factory looks like butter. It is in its natural state nearly white, and ordinary hutter produced at most seasons of tho year is in its natural state almost white.

It nay be very well claimed under the language of this section that this section does permit any State to make a law forbidding the manufacture and sale of oleomargarine which contains any ingredient which makes it look like butter: and upon the section as it stands wo know 
not how we could meet a prosecution based upon a law which forbade the making of oleomargarine to resemble butter, even thongh it had no coloring matter whatever.

Further than that, there are certain absolutely essential ingredients of oleomargarine which do give it color. Oleomargarine can not be manufactured without the use of oleo oil, but oleo oil gives to the product a certain tint which takes it off of white, as I understand. Therefore oleo oil is an ingredient which to some extent, at least, makes oleomargarine look like butter. If a State, under this anthority of Congress, passes a law which forbids the manufacture of oleomargarine that contains any ingredient which makes it look like butter, I do not see why they can not institute prosecutions and convict us for manufacturing oleomargarine which contains oleo oil, and such may be the result, if it is not the purpose, of the bill.

'Then there is cotton seed oil. There are other ingredients, as I am informed, all of which have some slight tendency to give a shade of color to the substance. So if this bill is acted upon it should be drawn in such a manner as simply to forbid, or to enable the States to forbid, the artificial coloring of oleomargarine, and these very dangerous provisions with reference to the ingredients of the sulsstance should be omitted.

It is to the second section of the bill, or to the bill ats a whole, that we chiefly object, and we object upon different grounds. I do not desire to cover, and will not, so far as I am able, cover any of the ground which has been covered in the hearings before the House committee, although this matter has been brought to my attention within a time which has rendered it utterly impossible for me to know exactly what has been presented in the Honse. But we claim that there are absolutely no conditions existing to-day which render the passage of such legislation necessary or desirable, and that the reasons urged for the passage of this act are not valid.

It then becomes necessary to consider what the reasons are that are urged for the passage of this act. The reason that has heretofore been urged for the passage of similar acts is that the product was unwholesome. That argument is presented still. I do not think there is any testimony, which is worthy of being considered as testimony, to that effect. As I have said, I believe it is the one substance which is, as no other substance possibly can be under existing laws, certified by the Gorennment of the United States to be absolutely pure. We have, in addition to that, the testimony of chemists of the very highest standing and repute who have examined the substance and who have certified over and over again to its absolute purity.

But notwithstanding all that, the strongest opposition to-day to oleo. margarine, the strongest popular support brought to this act, is based upon the opprobrions epithets which are hurled at the product and which have been used by the advocates of this bill in the Honse. While in the face of the testimony which is introduced it is impossible to claim that there is anything deleterious in this product, it is nevertheless claimed by innuendo and indirection that there are in the product those things which render it harmful to certain persons or on certain occasions, and there is something which perhaps is called evidence with reference to its effect in almshouses somewhere in England.

It seems unnecessary to argue this point. I presume the members of this committee know the conditions under which oleomargarine is 
produced-that there has to be a regular formula; that there is a chemist maintained at the expense of the Government, who examines samples; that representatives of the Internal-Revenue Department stand in the doorway of every oleo manufactory; that they know exactly what comes into the building and what goes ont of the building. But at the same time there is lingering to-day in the public mind an impression that there is something unclean or unwholesome in the product itself.

The Acting Chairinan. That question is not raised here, I think, Mr. Gardner.

Mr. Gardner. I do not think that it is raised here. It was, however, strongly urged by the advocates of the bill in the House, and it is for that reason that I refer to it. There is testimony here also with reference to its effect upon inmates of poorhouses and asylums in England. Whether the question is raised before the committee, or will be raised before the committee, I have no way of knowing. It was raised by immuendo certainly before the House committee.

Then the second reason that is alleged for the necessity of this act is that oleomargarine is fraudulently sold as butter. 'To a certain extent this is true. There is no doubt but that retailers, unscrupulous retailers, do occasionally sell oleomargarine, pretending that it is butter. just as they sell the imitation of everything else which they carry in stock, pretending that it is the article that it purports to be. But we do claim here that there is less fraud in the sale of oleomargarine as butter than there is in the sale of most imitations, and that that elimination of fraud has been procured by the rigid Government supervision, and can be extended by an even more rigid Government supervision, which every honest manufacturer of oleomargarine is anxious to submit to, and, so far as it lies in his power, to secure.

But the statements which are made with reference to the amount of the fraudulent sales of oleomargarine in imitation of butter are absolutely groundless. The author of the bill, in advocating its passage in the House, said that not one pound in a thousand of this substance was sold as oleomargarine, but that nine hundred and ninety-nine pounds out of every thousand were sold as butter. Another advocate of the bill said that 90 per cent of the product was sold as butter. Another advocate of the bill said that it was never put npon the market except as butter. All those statements were made in the advocacy of the bill in the House of Representatives, and all those statements doubtless had their effect upon those who had not investigated the testimony.

After looking through the testimony which was taken before the House committee very thoroughly, the only evidence which I find in support of those assertions is that out of twenty-five hundred dealer's in Illinois two were found who had made a fraudulent sale of this product and the affidavits of a certain party, or perhaps parties, in Philadelphia that on several occasions they had purchased in one market or at one place oleomargarine for butter.

I belicve that that was absolutely the only evidence which was submitted in substantiation of these wild charges. What was the evidence to the contrary? 'The late Commissioner of Internal Revenue has stated that, in his judgment (and there is no man who had such opportunities to form any judgment, he being charged with the regulation of this business), not 10 per cent of this product was sold anywhere for anything else except what it actually is, oleomargarine. 
Who sells this oleomargarine as butter? I say, and I say without fear of contradiction, that no manufacturer of oleomargarine sells one pound of oleomargarine for anything else except oleomargarine. It is utterly impossible for him to do it. It is against his own interests to do it. Possibly member's of the committee know the kind of supervision which is exercised over the manufacture of this substance; that inspectors of the Internal-Revenue Department take account of every pound of material which goes into a factory and see that erery pound of oleomargarine which can be produced from that material goes out of the factory. There is absolutely no opportunity for' any manufacturer, if he wished, to send out oleomargarine as butter.

Then, nobody has any occasion to go to that factory for anything except oleomargarine, hecause nothing except oleomargatine can be sold at that factory or manufactured at that factory for sale. 'The inspection is rigid. "The penalties, involving the forfeiture of the manufacturer's entire plant, are so extreme as to render absolutely untenable the supposition that any manufacturer, however dishonest he might desire to be, should sell this product for any thing but oleomargarine.

I do not know how it may be with the great packing houses with whom my clients hare no comnection, but we say that three-quarters of our entire product is sold by the manufacturer directly to the consumer. I think I am right.

Mr. Mathewson. You are correct.

Mr. Gardner. Approximating three-quarters of the entire product is sold directly by the manufacturer to the consumer in the original package, usually a 10-pound package. Now, if the Congress of the Inited States are to legislate to prevent the keeper of a boarding house from giving his guests some imitatation food product they have undertaken a contract. What the head of a family does, whether a husband deceives his wife and his children. or a wife deceives her hushand as to the nature of the product which he puts upon the table, we do not know. Whether the keeper of a boarding house deceives his guests as to what they are eating, we do not know. That is not a matter of purchase and sale. It is not anything which by this bill ean be controlled. We make the assertion that by the manufacturer there is no violation of the law whatever; that every pound of oleomargarine produced at the factory is sold as oleomargarine; that he desires that it should be sold as oleomargarine; that he is making a reputation for his factory, and that the necessities of his business and his own selfinterest require that he should do it. And as a matter of fact, with the people whom I represent, the great proportion of the product is sold by them directy to the consumer.

I shall have to take up this question regularly, and I will go over it as quickly as possible. I do not know whether the committee deem it essential that I should finish what I have to say absolutely this morning. I hare, I think, less than twenty minutes left.

Senator BATE. It is about 10 minutes to 12.

The Acting Chairman. We shall have to adjourn at 12.

Senator Warren. I suggest that we fill in what time there is left, and then if Mr. Gardner wishes to present further facts to the committee the opportunity will be given to him to do so.

Mr. GARDNER. I do not think I shall want to occupy a great deal more time. 
The Acting Chairman. If agreeable to the committee, we will continue the hearing to-morrow.

Senator Foster. Certainly.

Senator Allun. Let us meet at 9 o'clock in the morning.

The Acting Chamrinan. You have only about ten minutes left, and I will ask you a question. Can you inform the committee as to the arerage price of the manufacture of oleomargarine-the cost of production?

Mr. Gardner. I should say about 12 cents-from 12 to 13 centsbut my client can answer that question better than I.

Mr. Mathewson. The selling price of our goods runs from $12 \frac{1}{2}$ to $13 \frac{1}{2}$ packed in tub, and the average profit will average less than a cent a pound-barely half a cent a pound from the day we commenced manufacturing' up to the present time. 'To substantiate that statement our' books are open for the inspection of any member of this committee, or the members of a subcommittee of this committee.

Mr. Gardner. That is what I understood.

Senator Foster. Is there any residuum? Have you anything else except oleo left?

Mr. Mathewson. The only residuum you can speak of are some byproducts which come from the rerendering of the scrap of leaf lard and the refining of a certain amount of grease which goes out on the floor, which passes off into soap grease.

Senator BATE. What ingredients are put into oleomargarine before you sell it?

Mr. Mathewson. The ingredients that go to make up oleomargarine are oleo oil, neutral lard, lard made from the leaf, and nothing but the leaf.

Mr. Gardner. You buy the leaf?

Mr. Matinewson. We buy the leaf and make the lard ourselves. It is made from absolntely pure leaf.

Senator Bate. What are the proportions?

Mr. Mathewson. Cotton-seed oil, cream, milk, salt, and coloring.

The Acting Charrman. What is the proportion of cream and milk?

Senator Foster. Is there a secret in your formula?

Mr. Mathewson. Oh, no; there is no secret about it. There is absolutely no secret as far as the making of oleomargarine is concerned. The three ingredients of oleo-oil, lard, and cotton-seed oil-make from 75 to 80 per cent of the whole.

Senator Bate. Of equal proportions?

Mr. Mathewson. The proportions vary according to the seasons of the year and according to the climate.

Senator Bate. Of those three articles?

Mr. Mathewson. Of those three articles. The other 20 per cent is made up of cream, milk, salt, coloring, and the natural gain which comes from the churning of the article, the same as in butter.

The Acting Chamman. There is not enough milk and cream in it, however, to give it a butter color'?

Mr. Mathewson. Under this bill we shonld be absolutely unable to use any butter, because all butter is colored, and we would be indicted for using butter.

The Acting Chairman. I understood Mr. Gardner to say that butter was universally white when first manufactured.

Senator Bate. In winter. 
Mr. Gardner. I stated that it was ordinarily so. I do not think I said that was universally the case; but in point of fact butter at most seasons of the year is practically white. It is slightly colored.

The Acting Champun. And you said there was some slight color to oleomargarine when first manufactnred.

Mr. Gardner. There is some slight color to it. It would be very difficult to distinguish the ordinary butter of commerce at this time of the year from uncolored oleomargarine. One bears as much resemblance to the other as can possibly be.

The Acting Cinamuan. The two articles would be on all fours until properly treated with coloring matter?

Mr. Gardner. Absolutely on all fours; and, as I said, the danger of the first section is that the manufacturer would manufacture a product that would look like butter.

Senator WARren. That is to say, if a creamery was getting milk from a dairy where the cows were fed through the winter on grain, the butter might take a high color, but if butter was made by a farmer who had three or four cows who were eating hay alone it would be nearly the color of your oleomargarine?

Mr. Gardner. That is what my elients have told me.

Mr. Mathewson. That is the fact.

Senator BATE. What kind of food is it that gives butter a yellow color?

Mr. Mathewson. Grain, ensilage, grass, and carrots. The color depends on the food.

The Acting Chamman. Why do you color oleomargarine?

Mr. Gardner. I was going to speak of that, later, but I am willing to answer the question. We color it to meet the public taste-for exactly the same reason that the manufacturer color's butter. We can not sell it unless we color it.

Senator Foster. Butter is colored through the cow, and oleomargaline is colored after it is made.

Mr. Gardner. Butter is colored after it is made.

The Acting Chairman. So when a gentleman sits down at a table with butter before him he does not know whether it is oleo or butter.

Mr. Gardner. If he is living at a boarding house he trusts, perhaps, to the honesty of the person with whom he is living.

Senator Foster. What is the difference in value between butter and oleo?

Mr. Gardner. Cheap butter, renovated butter, resurrection butter, as we call it, made up of old rancid butter which has been melted and made over and then colored, can be produced cheaper than oleomargarine can be produced. Then butter runs up to any cost which taste and luxury call for:

Senator WARIEN. For creamery butter they would charge a price twice as much?

Mr. Gardner. Yes; and oleomargarine never under any circumstances comes in competition with it. It has not the taste and has not the flavor.

Senator BATE. You did not answer my question. I want to know what kind of food produces white and what kind yellow butter?

Mr. Tillinghast. As I am something of a farmer perhaps I can answer that question better.

Senator Bate. What kind of food affects the color' of butter? 
Mr. Mathewson. One of the members of rour committee has already explained that. I am not a practical farmer, and I do not pretend to know so much abont it probably as some of the other gentlemen, but in a general way when a herd of cows is kept on an ordinary farm, ordinary country stock, not Jerseys, or Alderneys, or Guernseys, not high grade, but kept in an ordinary barn during the winter and fed on hay and fodder, the butter will come out very nearly white. Now, if rou go from that to a herd of high-grade Jerseys, or Guernseys, or Alderneys, any of the high-grade cattle, and they are fed on grass or on grain, or carrots, or ensilage, or anything of that kind, they will produce a butter more bighly colored. but it will not be eren then of the shade of that which is ordinarily served on the tables. Every section of the country has a different color, and that color is obtained in butter the same as it is obtained in oleo, and it could not he gotten any other way.

Senator Bate. Cows that are fed in winter upon hay, etc., produce white butter?

Senator Heitfeld. On dry food.

Senator Bate. On dry food?

Mr. Mathewson. Yes, sir.

Senator Bate. Suppose those same cows are grazed in summer on grass, how does that affect the color of the butter?

Mr. Mathewson. That would give it a different color-more of a yellow shade.

Senator WARren. It generally makes a difference whether the row is fresh or not. 'The butter is more highly colored soon after calving. Senator Foster. Mr. Mathewson, do you use oleomargarine on your table?

Mr. Mathewson. I use both. My family is not large.

The Acting Cirairman. You know the difference when both are on the table?

Mr. Mathewson. I think I do. I use the best creamery butter which I can buy, and we never hare elaimed that oleomargarine was in competition with that grade of butter; that is, on the table. For all other purposes in my family I use oleomargarine.

Senator Warren. For cooking.

Mr. Mathewson. For cooking and for the dressing of meats, fish. pastry, and every other purpose. Many a time have I sent from my table butter that cost 35 and 38 cents a pound and asked them to bring oleo in place of it.

The Acting Chairman. It is not necessary that it should be colored for cooking purposes?

Mr. Mathewson. That is not necessary for cooking purposes.

'The Acting Chairuan. I think it is the aim of Congress to undertake in some manner to inform the hundreds of thousands of people who are boarding at boarding houses and hotels as to exactly what they are eating, whether it is butter or oleomargarine. They have no way of ascertaining that fact.

Mr. Mathewson. Tou can not inform them by this bill.

On motion of Senator BATE (at 12 o'clock meridian), the committee adjourned to meet to-morrow at half past 10 o'clock a. m. 
Thunsiar, December $20,1900$.

The committee met at 10.30 a. m.

Present: Senators Proctor (chairman), Hansbrough, Warren, Foster, Bate, Moner, Heitfeld, and Allen.

Also, Hon. Willian W. Grout, a Representative from the State of Vermont; Hon. Wr. D. Hoard, president of the National Dairy Union; C. Y. Knight, secretary of the National Dairy Union: Hon. William M. Springer, representing the National Live Stock Association; Frank M. Mathewson, president of the Oakdale Manufacturing Company; Rathhone Gardner, representing the Oakclale Manufacturing Company; Frank W. Tillinghast, representing the Vermont Manufacturing Company; Charles E. Schell, representing the Ohio Butterine Company; John F. Jelke, representing the firm of Braun \& Fitts, of Chicago, IIl., and others.

\section{PERSONAL FXI'LANATION.}

Senator Aluen. Mr. Chairman, before the hearing progresses further I desire to make a hrief statement, to be entered on the record as a part of the proceedings of the committee.

During the last three days I have been in receipt of numerous telegrams from different gentlemen in my state to the effect that it is reported in Nebraska that I am opposed to this so-called Gront bill and strongly urging me to support it. I have never, either publicly or privately, given utterance to anything from which any man conld infer that I was either for or against the bill; but resterday I had occasion to ask General Grout some questions, from which it was inferred, I suppose, by the lobbyist, present in favor of the measure, that I was opposed to it; and during the night and this morning I have received numerons telegrams to that effect.

There is but one conclusion to be drawn from the situation, and that is that telegrams were sent out resterday to the State of Nebraska, after the conclusion of the hearing hefore the committee, to the eflect that I was opposed to this hill and urging persons there to flood me with telegrams to support it.

I want to enter my protest against this cheap-john peanut political method. It is an old and threadbare scheme to undertake indirectly to bring pressure upon a Senator to support a measure regardless of its merits by the implied threat of a withdrawal of support at home if he fails to do so. I have no words to express my utter contempt for this method and for those who would engage in it.

The lobbyists who are supporting this hill are doing it more injury than its open and avowed opponents. This method can have no effect upon my action. If after the hearings are concluded I become convinced that the bill ought to be supported and become a law, I will support it, regardless of public sentiment in my State or elsewhere: and if, on the other hand, I become satisfied that it ought not become a law, I will oppose it and rote against it, regardless of any pressure that may be brought to bear in its support.

1 desire to add, in conclusion, that if any more reports are sent out to the effect that I am opposing the measure or supporting it, and if I am the recipient of any more letters or telegrams which I may have reason to believe emanate from the lobbyists in faror of or against this measure, I shall ask that these hearing's be private and that no one but 
the particular individual who is giving testimony shall be present at any time. I want again to denomnce, in the sererest language I am capable of using, the sneaking and cowardly method that has been pursued in respect to this measure.

The Chairuan. Mr. Gardner, you may proceed.

\section{STATEMENT OF RATHBONE GARDNER - Continued.}

Mr. Gardner. Mr. Chairman, at the time of the adjournment resterday I had partly completed my argument, and with the permision of the members of the committee I will resume it. I was engaged at the time of the adjourument in the endearor to support the proposition that there were no existing conditions to-day which demanded the passage of legislation of this character in the interest of any legitimate industry. I was considering somewhat in detail the reasons which have been advanced by the advocates of this measure for its passage. I had referred to the claim heretofore made, and now I think practically abandoned, that oleomargarine is an unwholesome substance which it is proper, in the interest of the public health, to legislate against. In this connection I desire to refer to one piece of evidence which I did not mention yesterday.

The Chammax. May I ask yori a question right there? I do not know anything about this business, I will state in advance, and I want to learn about it what I can. Presuming what you say to be true, and I have no reason to question it, that oleomargarine is, as now made, wholesome, I want to ask if it is not possible, it being a combination of various materials, I suppose, to introduce ingredients that are in themselves unwholesome--whether, in other words, an unserupulous dealer might not put in unwholesome ingredients and so conceal them that the final consumel would not be able to know it?

Mr. Gardner. I will answer that question as well as I can, Mr. Chairman, not being thoroughly familiar personally with the methods of manufacturing oleomargarine.

The Chaminav. You appear as counsel!

Mr. Gardner. I appear as counsel. In answer to your question I would say that while I presume it is possible in the manufacture of any compound to introduce elements which are deleterious to the public health, I believe that there is no product in which it is so difficult, so well-nigh impossible to do it as here. The manufacture of this produet is under the control of the Gorernment. The Department of Internal Rerenue have provided the most stringent regulations. They keep in every factory, I think, an inspector whose duty it is to know what comes into that factory and what goes out of the factory. Nothing can go out of that factory except oleomargarine, and ererrthing that goes into that factory is to be used for the manufacture of oleomargarine. If any substance of that kind is taken into the factory it must he known. 'Moreorer, the Gorernment of the United States maintains an expert chemist to whom the articles of this manufacture can be submitted without eost for analysis and for constant inspection as to their component parts. So I believe if it ean be said of any commodity that it is imposibible to introduce deleterious substances into it that can be said of this commodity.

The Chammax. That answer's my question. 
Mr. Gardner. And I think that to-day there is no question made by any person whose judgment is worth anything, there is no question by anvone else than those who hurl epithets, who eall it grease produet and that sort of thing, that the product is in any degree unwholesome.

In this comnection I desire to ask the careful attention of the committee to the report with reference to oleomargarine which is contained in the findings of the committee of the Senate which was appointed to consider the question of the adulteration of food products. Such a consideration will show to the member's of this committee that that committee has certified, as every competent authority has certified, that oleomargarine is probably the one purest compound which is manufuctured for human consumption.

Semator Haxsibodgh. Let me ask a question. Do I understand you to say that the Government keeps an inspector, or agent, or expert, in each of the oleomargarine factories in the country?

Mr. Gardner. I think so. If not constantly in each of the oleomargarine factories, eertainly in each district where there is an oleomargarine factory, whose duty it is to visit the factory.

Senator Hansbrough. Can you tell us how many oleomargarine factories there are?

Mr. GARDNER. I am informed that the manufacturers make every month a sworn return of every item of material which goes into the manufacture of oleomargarine, and that there are in each distriet inspectors of the internal revenue department who investigate the facts from time to time to ascertain whether these returns are correct.

Senator Hansirougu. Can you inform the committee how many oleomargarine factories there are in the United States, approximately?

Senator Bate. And where located?

Mr. Gardski. I shall perhaps refer that question to some gentleman engaged in the business.

Mr. JELKE. The Internal Rerenue Department in the last report state that there were twenty-seren oleomargarine factories in the United States on the 1 st of last July. Since then there have been some new establishments opened.

Senator Hansbrough. So there are several of them in an internalrevenue district?

Mr. JELKE. In several of the internal-revenue districts there are a number.

Senator Hansbrodgh. Do I understand that the inspector in each district depends upon the man at the factory for the report to his Department, and that he has no personal supervision?

IIr. JELKE. Our factory is risited almost daily by some internalrevenue deputy, and I hare personally taken the new deputies who have come to visit us over the factories and let them see every nook and comer.

The Chamminn. What is your factory?

Mr. JeLk s. I represent Bruun \& Fitts, of Chicago.

Senator BATE. Cin you tell us where the factories are located, or will you submit it in writing, so that we may know in what States they are located?

Mr. JELKE. I can do so.

Senator BATE. I do not ask you to stop to do it now.

Mr. JELke. The Internal-Revenue Commissioner's report gives each one in detail. I will furnish that if it is desired. 
Senator Hansbrodgh. There is but one Government chemist, however, who is authorized to inspect the ingredients?

Mr. JELKE. I understand there is one head chemist.

Senator Foster. He has several deputies?

Mr. Jelke. He has sereral deputies.

Senator Heitfeld. Are you compelled to submit this product to the ('hemist!

Mr. JELKe. Whenever he ealls for it we submit to him anything:

Senator Hansbrougir. He has no personal supervision orer the constituent parts that go into oleomargarine?

Mr. JELkE. If he desires it he ean have. It is his privilege to investigate every part of the manufacture, and our factory is as open to him as it is to any employee of the establishment.

The Champlax. You will resume, Mr. Gardner.

Mr. Gardner. I had then taken up the claim of the advocates of the bill that oleomargarine is to a great extent fraudulently sold, not as oleomargarine, but as butter. I had endeavored to show that while undoubtedly there is a certain element of fraud in the sale of this article, as there is in the sale, it seems to me, of every food product, the element of fraud is much less than has been claimed, and that it consists entirely in the transactions between the retailer and the consumer. I had considered at length, and I hope established to the satisfaction of the members of the committee, that there is and can be no fraudulent sale of this product by the manufacturer; that the manufacturer sells nothing else at his establishment; that be is not allowed by law to keep for sale in his establishment anything else, and that anyone who comes to purchase any substance there comes to purchase oleo margarine and nothing else, and that there is no fraud on his part.

That is the point at which I left my argument yesterday, namely, the assertion that whatever frand there is in the sale of this article for something other than what it is is confined entirely to the transaction between the retailer and the consumer.

The manufacturer, gentlemen, is just as anxious to prerent fraud as anyone possibly can be, and he must be so in the nature of things. He is a manufacturer of olemargarine. He himself is obliged, as I have shown you, and as Mr. Grout admitted yesterday, I think, to sell it as oleomargarine, and nothing else. It is for his interest that oleomargarine should have a legal and a respectable standing as a food produet, and every fraud that is practiced with reference to it through the retailer, every prosecution that is instituted upon the ground of a fraudulent sale, is an injury to the article which the manufacturer has to sell. Anything which this eommittee can possibly derise, which shall make it more difficult, if that may be possible, for the retailers to practice fraud in this respect upon his customer will be welcomed by the manufacturer.

I make another assertion, gentlemen. I make the assertion, without fear of successful contradiction, that all the fraud which exists in the sale of this product is due to the passage in the different States of laws forbidding the sale of the produet for what it is-for oleomargarine. As was suggested here yesterday, in some 32 States laws have been adopted which forbid the sale of colored oleomargarine. Therefore, in those States oleomargarine can not be sold as oleomargarine; and I make the statement here and now that in those States which permit the sale of oleomargarine as oleomargarine it is practically never sold for anything else but oleomargarine. 
As I have said, I appear here simply as an attorney, simply as an advocate, without a special knowledge of this business. Upon this point, however, I can appear as a witness, for I know the condition of affairs which exists in my own city of Providence. The State of Rhode Island has a law which prorides that oleomargarine when it is sold shall be branded as such. That is all the law upon the subject in the State of Rhode Island. The result is that in the State of Rhode Island the sale of oleomargarine is a legitimate business. It is sold as oleomargarine, and it is sold as nothing else. Our wholesale and our retail dealers advertise in the paper's that they have this, that, or the other brand of oleomargarine for sale, and as you walk up and down our streets you will see upon the placards in front of our grocery stores this or that brand of oleomargarine at such a price. The business is advertised as widely as it can be advertised. When you enter thestores you will see the same signs. You will see the Oakdale oleomargarine or the Vermont oleomargarine or Swift's oleomargarine for sale side by side with process butter, and side by side with creamery butter, and it is sold for what it is.

It is undoubtedly the fact that at the inception of this industry unserupulous dealers saw an opportunity for large protits, and that they sold this substance for butter. As district attorney of the United States for the district of Rhode Island. I had occasion, twelve years ago or so, to prosecute many such persons, and prosecutions were instituted and most vigorously carried on by the Internal-Revenue Department of the United States.

Under the stimulus of the possibility of a legitimate business with a fair profit into which high-minded business men can enter, that condition of affairs has absolutely disappeared. I state, gentlemen, that to-day in the one eity with which I am familiar, as a result of the fair treatment of this business, the business is conducted fairly and honestly. This article is sold simply for what it is, as honestly as any other article of food is sold for what it is.

I assert as a colollary to this proposition that almost every item of fraud of which the adrocates of this bill complain is due to the enactment in very many States of unjust and unwholesome laws forbidding its sale for what it is-laws which have no backing in public opinion, and which interfere with what otherwise would be a legitimate business.

Let me refer to what is the condition of things in Massachusetts, a neighboring State which does forlbid absolutely the sale of colored oleomargarine eren as oleomargarine. The condition there follows perfectly naturally, it seems to me, from what we must all understand to be the cireumstances. We all know that there is no more universal demand than the demand for butter or something to take the place of butter. Butter is not a luxury. Butter is a necessity of life to-day, and there is a demand on the part of all classes in the community for a pure butter at a reasonable price, or a pure butter substitute at a reasonable price. Creamery butter is undoubtedly the best which can be used or which ean be purchased, but, as we all know, the great mass of the community can not pay the price which is charged for creamery butter. 'They go to the person from whom they buy their butter in Massachusetti. Where the sale of oleomargarine colored is forbidden, and they tell him that they want a pure butter, a good butter, at a reasonable price. 
This dealer has upon his shelres the process butter, or the renovated butter, to which I shall refer in a few moments. That he is allowed to sell by the laws of Massachusetts without let or hindrance. He offers it to his customer, and perhaps his customer buys it. He goes home and tastes it and finds that when he uses it it takes the skin off the roof of his mouth. He comes back the next time he requires butter, and he says to the dealer, "We can not use that stuff you sold me." There is a demand which this dealer is tempted in some way to supply. He has oleomargarine. He knows that if he sells oleonargarine to this man at the same price or a little higher price than he paid for his process butter this man will be a satisfied customer. He does sell it to him. He sells it to him as butter; and why does he sell it to him as butter? Not because the man is not perfectly willing to take it as oleomargarine, but because if he sells it as oleomargarine he violates the law of the State of Massachusetts. He does not dare to trust the customer, who may appear as a witness against him, and for that simple reason, instead of selling this substance for what it is, oleomargarine, he sells it for butter, which it is not, and to that extent he perpetrates a fraud upon his customer. It is the most innocent of all frauds so far as the customer is concerned, for the customer gets what he wants, a pure article of good flavor, which satisfies his needs. But he does buy it upon the statement, perhaps under the impression, that it is something else than what he asks for, and that is a fraud.

Senator AlLen. What do you call process butter?

Mr. Gardner. Process butter, as I understand it, is a butter which is produced in this way: Butter which has become unmarketable-rancid butter, butter which is old and left over, which for any reason can not be used in the trade--is purchased, and it is melted over. It is treated; it is rechurned; it is colored, and it is put upon the market as butter.

Senator AlLEN. What ingredients enter into process butter?

Mr. Gardner. I do not think that any ingredients enter into it. It is the original butter spoiled and made over again.

Senator Foster. Flavored over?

Mr. Gardner. Flavored over and washed with acids, as my clients inform me.

Senator Allen. How do you remove the tainted taste?

Mr. Gardner. I will ask some of my friends here to answer the question.

Senator Foster. It is sterilized?

Mr. JeLke. It is removed by aeration and washing in acid.

Senator Allen. What acid?

Mr. JeLKe. Sulphurie acid.

Senator Allen. Something injurious to the digestion?

Mr. HoARD. I should like to ask a question. Do you know that renorated butter is washed with sulphuric acid?

Mr. JeLke. I have known it.

Mr. Hoard. How do you know it?

Mr. JELKE. Because I have been in the butter business years ago. Mr. HoArd. When was the renovated butter process instituted?

Mr. JELKE. The recent improvements in process butter have been adopted within the last five or six years.

Mr. HoARD. Do you know of any establishment making renorated butter that uses sulphuric acid? 
Mr. JeLKe. In water; yes, sir.

Mr. HOARD. Where?

Mr. JnLKe. They have used it in Chicago.

Mr. Hoakd. In what establishment?

Mr. JELKE. I do not think it would be proper for me to say.

Mr. HoA RD. All right.

The Cliamman. I did not understand your question, Governor Hoard.

Mr. Hoard. I was speaking of the manufacture of process butter, so called. The gentleman says that it is treated with sulphuric acid. There is no occasion whatever to treat it with sulphuric acid or any acid.

Senator Alcen. How ean you remore the taint?

Mr. HoArn. The taint is in the easein content of butter, not in the butter fat. The whole process of albuminous fermentation is in the casein content, and the aeid does not take ont the casein. The simple method of making process butter is that it is melted, boiled, clarified, skimmed, and the elements taken out of it. It is then reincorporated into milk and separated by centrifugal separation, the same as butter fat is separated from ordinary milk. It is then taken and put into creamery vats and subjected to the same process of ripening that the process of creamery butter is subjected to. I know of no introduction of acids in its treatment, and I was asking the gentleman what he knew, that is all.

The Cirammax. I did not quite eateh the question that the gentleman declined to answer.

Mr. HoArn. I asked him what establishments he knew were treating it with sulphurie acid. So far as that is concerned, the testimony before this body in 1886 was abundant as to the use of sulphuric acid in oleomilgarine.

Senator Allen. I do not think the question is yet answered as to how you climinate the rancid taste or the deeayed taste of the butter fat from process butter.

Mr. Hoard. By boiling and clarifying, and in that mamner taking the easein content out of it.

Senator Almex. But the fat itself is decayed, is it not?

Mr. Hoard. No, sir; not at all.

Senator Allex. It is in process of decay?

Mr. HoAlid. You can not decay butter fat chemically. The only process by which it can be decayed is through what is kuown as albuminous firmentation, and albuminous fermentation is imparted to it by the casein content, which is almost pure albumen or protein. Any person who is a student of these things will readily know that this process butter is not a fram or comterfeit in any sense. It is an imposition if sold for other than it is. Therein eonstitutes the wrongdoing.

Senator Allex. You say that the butter fat itself is not affected or tainted by the process?

Mr. Hoard. No, sir. The whole process of rancidity and distaste which you have in rancid butter is not the butter fat itself but is in the casein content which may be left in the butter.

Senator Allen. Is that the case with any other decalying animal substance?

Mr. Hoard. I do not know. 
Mr. Matunwson. May I have the privilege of asking the gentleman an question?

The Cramman. Yes, sir.

Mr. Mathewson. He says the only fraud in the question of process butter on the market is that it is not marked or brandecl.

Mr. Hoard. No; I did not say so.

Mr. Mathewson. That it is sold for what it is not.

Mr. Hoard. I say in case it is sold for what it is not is a fraud.

Mr. Mathewson. Is it ever sold for anything else? Cin you tell the committee of a case where it is sold for renovated or process butter?

Mr. Hodro. I do not know any thing about the sale of process hutter at all, because I have had nothing to do with it. I am simply reasoning abstractly on the proposition as to wherein the process lies to the extent that the butter fat in process butter is original butter fat and not another kind of animal fat.

Mr. Matuewson. I understand you to state to the committee that the butter fat from which process butter is made is not tainted and is perfectly sweet.

Mr. Hoard. I did not say that the butter was sweet.

Mr. Matiewson. The butter fat?

Mr. HoARD. The butter fat, when boiled and clarified.

Mr. Mathewson. How is it clarified?

Mr. Hoard. By boiling. It is steamed.

Mr. Matunwson. Are you familiar with the process?

Mr. Honrd. I am, somewhat.

Mr. Mathewson. And you know that this boiling and steaning absolutely clarifies that fat?

Mr. Hoard. Certainly; I know that.

Mr. Mathewson. I shall have to differ with you, because I have seen the process time and time again, and I know that that is not the (ase.

Mr. Hoand. Very well; I ask for information. What do you know, please!

Mr. Mathewson. I know that the fat extracted from old butterbutter that has becone putrid, or strong, or l'ancid-is thoroughly scented with that same odor. No amount of boiling-you can boil it from now until doomsday-will ever remore that rancid smell.

Mr. Hodrd. What is done to remove it?

Mr. Matiewson. It has to be treated in other ways.

Mr. Hoskd. In what way?

Mr. Mathewson. There are several ways. I am not a manufacturer of process butter myself, so I do not know, and in such factories as I have been in they have tried, I think, not to let me see the whole process.

Mr. Knight. 'If you want information, I am thoroughly familiar with the matter. I have been through the largest factories in the United States, and I know the manufacture of process butter very thoroughly. If the committee want the information. I can give it at any time.

Senator Allen. I would like to have it.

The Cilalrmax. I presume that Mr. Gardner may be in some haste to conclude. I suggest that we allow him to proceed.

Senator Heitreid. We will be glad to hear Mr. Knight later on.

Mr. Gardner. I will enciearor to elose my argument as quickly as 
I possibly can, and in anything I may state which may require investigation or answer the answer, perhaps. can be reserved.

The point which I was trring to make was that absolutely the only occasion for the fraud which the androcates of this bill complain of is the passage in so many States of laws which make it impossible for a dealer to be honest, howerer much he may desire to be so, if he is to sell this product at all, which actually supplies a denand. I say that if the advocates of the bill are consistent and desire that oleomargarine should stand in the market solely upon its own merits and should not come into competition with butter, they can accomplish this purpose by procuring the repeal of those laws. They would do so if they knew where their own interests lay. It is simply by making it illegal to carry on this business as it ought to he carried on that there is a temptation offered to carry on the business as it ought not to be carried on.

But what does this bill do! The bill proposes that upon the States which under the influence of wiser counsels have not enacted such lawslaws which have occasioned frand-there shall be imposed the same conditions which exist in the States where those laws have been enacted, and in those States where it is desired to do an honest business to make it possible only to do a fraudulent business.

Let me point out, further, that the bill does not seek to stop such fraud. The bill only seeks to make the carrying on of that business more expensive. The bill allows oleomargarine to be manufactured and to be artificially colored so as to resemble butter. It simply provides that when it is so colored as to resemble butter it shall pay a tax of 10 cents per pound instead of paying a tax of 2 cents per pound.

Now, let us suppose it to be true-I assert that it is not true, but it is the basis of the whole argument of the adrocates of the bill-let us suppose it to be true that this substance when artificially colored does cone into competition with the best. or with good ereamery. butter. 'That is what they assert. 'They say that it can be sold for 28 or 30 , and in some instances for 35 cents a pound. Let ussuppose that to be true. Then oleomargarine which sells to-day at 15 cents a pound at retail, after the tax of 2 cents a pound has been paid, would sell, after the passage of this bill, to secure the same profit to its manufacturer and its retailer, at 8 cents a pound more, or at 23 cents a pound. If it does come into competition with creamery butter at 25 and 30 and 35 cents a pound it will come into competition still. and if the dealer wants to make his profit he will simply have to press the sale of it harder. 'There is to be a profit of 7 or 12 cents a pound in the perpetration of this fraud, even after the passage of the bill, if the statement of the advocates of the bill is even approximately correct that it can be sold as pure creamery butter of the highest type. Therefore it appears that the adrocates of the bill do not offer any remedy for the frand of which they complain, but that upon their own hypothesis they are only making the fraud more expensive to the man who carries it on; and the bill is utterly inadequate for the purpose for which it purports to be drawn.

Senator Hansbrough. How would it do to make the tax 20 cents a pound?

Mr. Gardner. That would be more effective. A tax of a dollar a pound would be more effective still. But you come right back to the proposition which I laid down at the start, that this is legislation which seeks to prohibit the sale of oleomargarine, and if you want to prohibit 
it, you should adopt the suggestion which has been made and put the tax so high that it can not be sold at all to anybody.

Senator Hansbirougr. If there were no State or national law on the subject, would the manufacturers of oleomargarine seek to color their product?

Mr, Gardner. If thele were no State law?

Senator Hansbrough. Yes. You complain of the existence of State lavis.

Mr. (rardner. I do complain of the existence of State laws, not of the existence of national laws.

Senator Hansbrough. You say that is the way to get rid of the frand?

Mir. Gardner. Yes; to repeal the State laws which say that colored oleomargarine shall not be sold as oleomargarine.

Senator Hansbrough. And to have no laws whaterer?

Mr. Gardner. I beg your pardon; I do not wish to have no laws whatever. I say, have the most stringent possible laws to provide that it shall be sold simply as oleomargarine and as nothing else. Have the most stringent laws possible, but no laws forbidding the sale of colored oleomargarine. 'The United States law to-day is stringent. Every manufacturer is glad that it is stringent. Erery manufacturer wonld like to have it made more stringent in the direction of sccuring the sale of this article simply for what it is.

Senator Hansbrodgr. If denied the privilege of coloring the product, would the rolume of the product diminish?

Mr. Gardner. It would diminish, absolutely. 'There would not be any sold at all, in my judgment.

Senator Hansirougr. Would that be the case with butter, if there should be a law enacted that butter must not be colored!

Mr. Gardner. If people could not get any yellow substance to eat on their bread they would take white, undoubtedly; but as long as there is a rellow substance on the market, as I will argue to the committee in a few minutes. people will not take white.

Now, the next reason advanced why this legislation ought to be cnacted is that yellow is what is called the butter trade-mark. 'That phlase was used by the adrocates of this bill in the House. It was said that butter has some sort of a trade-mark or copyright upon the color yellow. 'That matter has been hashed out at great length, and it is not necessary for me to go into it in detail very much; but I do want to call the attention of the committee to these considerations.

It has already, I think, sufficiently appeared by the admissions of the author of the bill made here yesterday that the re is mo such thing as a uniform butter color. The color of natural butter, the color of butter before coloring matter is artificially applied to 1 , raries with every change of circumstance. It raries at different seasons of the year. It raries in different places. It varies at different times. It varies in accordance with the way in which the animal from which the base of the product comes is fed and cared for. There is no such thing; no tint can be pointed at or referred to as the tint of butter.

Ordinary butter-butter the year round, butter under the usual circumstances of its manufacture-is nearly white. It is slightly off the color of white, with a slight yellow tinge. Even before the invention of the great creameries, and before the use of the substance which has now boen adopted for coloring it, butter has always been artificially 
colored. It has been colored for the reason which has been referred to, happily, I think, in this argument by the advocates of the bill, in the phrase that "the eye might aid the palate." It is colored to meet the demand - the taste of those who use it. It is colored in different tints for the different localities in which it is to be sold. It has always been colored. The honsewife has colored it in her churn with carrots, and the manufacturer has colored it as he deemed proper to meet the demands of those to whom he was to offer it.

I call the attention of the committee to the fact that there was no one substance used for the coloring of butter-there was no standird coloring matter-until after the manufacture of oleomargarine had been commenced. 'The manufacturer's of oleomargarine colored their substance also. The manufucturers of oleomargarine were inventors. The manufacturer's of oleomargarine, or those who advised them, were scientists looking for the best substances which could be used for each and every purpose which they desired to accomplish; and they discovered, or found, or invented-I do not know which - a substance which is called annotto, and they used it for the coloring of their product as the article best adapted to that purpose.

Senator Allen. Do the ereameries use the same coloring matter?

Mr. Gardner. That is what I am informed; absolutely the same substance.

Mr. Hoard. May I ask the gentleman a question? Is he certain that he is historically correct when he states that the oleomargarine men invented amnotto?

Mr. Garbner. I do not say that they invented it. I do not know whether they invented it or not. 'They discorered and adopted it as the article bost fitted for the purpose, it not having been used before for that purpose.

Mr. HoARD. I beg your pardon. I was a cheese manufacturer fortyfive years ago in New York, and I used annotto. Has oleomargarine been in use that long?

Mr. Gardner. I am arguing from the evidence before this committee. I understand the evidence taken by the House committee is here, and I am arguing upon that evidence. 'The truthfulness or the untruthfulness of the persons who gave the evidence I can not rouch for, but as an attorney $I$ take the evidence as here and argue from it. There certainly is evidence, and the strongest evidence, to the effect that after' the manufacturers of oleomargarine had shown the desirability of this substance for this purpose the manufacturers of butter adopted it, and that the manufacturer of butter to-day, who previous to 1886 used all sorts of different substances in attenipting to color his butter as he desired to have it colored, is using annotto and nothing else. Yet, it appearing by the evidence that the manufacturer of oleomargarine first called this possibility to the attention of the manufacturer of butter, the manufacturer of butter to-day claims the tints which are produced by this coloring matter as his trade-mark. 'That is a fair argument, at least from the evidence, and the truth or falsity of the evidence-

Senator Allen. Do you claim to have used this coloring matter before the creameries used it?

Mr. Gardner. That claim is made, as I understand. That is in evidence.

Senator WrarRen. I think it will develop that the substance called annotto was used many years ago in a crude way for coloring butter. 
I think it will also develop that by an admixture of ingredients a new and better coloring has been adopted by the oleomargarine manufacturers and that that coloring has been purchased and used in ereameries.

Mr. Gardner. 'That is probably the case; but annotto is too broad a term, perhaps.

Senator WARlien. As Governor Hoard has said, annotto, or a substance under that name, was used many years ago in coloring both butter and cheese.

Mr. GARDNER. My statement is that the substance which is used now by the manufacturers both of oleomargarine and of butter to color their products was first used by the manufacturers of oleomargarine and afterwards adopted by the manufacturer's of butter.

Now, how is it with reference to the coloring of oleomargarine? The natural color of oleomargarine is nearly white, very near the natural color of ordinary butter. For precisely the same reason that the manufacturer of butter color's his product, in order that the eve may aid the palate, in order that it may be attractive to his customers, for the very same reason that he colors it sometimes a very light yellow, sometimes a very deep yellow, because in order to carry on his business successfully he finds it necessary to meet the demand-for precisely those reasons the manufacturer of oleomargarine colors his product, and he colors it all sorts of shades to meet all sorts of demands. For a certain trade he gives it but a slight tint; for other trade he gives it a deeper tint.

For some of his trade, his export trade, he colors it a deep rich red or brown, because the people of the country where that oleo is sent demand that the article which they put upon their food shall be of that color. He colors it a color which would make it absolutely impossible to sell one ounce of it in any part of the United States of America, and from which you or I would turn away with loathing, simply because there is somewhere a demand for a butter substance of that color. It is for simply that reason that he color' it for sale in the United States the same color that the manufacturer of butter colors his product; and, as I have previously said, the color which in the vast majority of instances is used is a color the desirability of which was first found out and was first applied by the manufacturer of oleomargarine.

The next reason given for the passage of this proposed act is that the sale of oleomargarine will destroy the dairy industry of the United States. I say that that is absurd. I say, in the first place, that oleomargarine, no matter how it may be colored, can never compete with high-grade, high-priced creamery butter. We need something besides color to enable us to do that. The author of this bill here yesterday dropped a statement which it seems to me is of the very greatest value. He said that in judging of the grade, or quality, or value of butter color pointed for 5, while taste pointed for 50. Now, coloring may make oleomargarine look like butter, coloring may make people think that oleomargarine is butter, but neither coloring nor anything else (an make oleomargarine taste like the high-grade creamery butter. A man may be deceived once into purchasing it; he is not deceived twice into purchasing it, and the man who deceires him does not receive his custom. It is absurd to say that this substance, which can not under any conditions have the flavor which is the item of value in high-grade 
creamery butter, competes with high-grade creamery butter. Therefore it seems to me that that is out of the question. I will show in a moment that, as it seems to me, there is no reason why it should not compete with low-grade bntter for what it is.

Further than that, it appears from the testimony taken before this committee that the total sales of oleomargarine during the period covered by the last report of the Commissioner of Internal Revenue amounted to 4 per cent of the total sales of butter of all kinds. If we take the statement of the Commissioner of Internal Revenue, who, as I argued yesterday, is best fitted to judge, not more at any rate than one-tenth, 10 per cent of the oleonnargarine which was sold, was sold as butter. Therefore not more than 10 per cent of the total sales of oleomargarine came into competition with the sales of butter: and from that it is mathematieally evident that the total sales of oleomargarine as butter amount to only four-tenths of 1 per cent of the total sales of butter in the United States.

Mr. KNight. What do you call the total sale of butter, please?

Mr. Gardoner. It is given in the report as 2,000,000,000 pounds.

Mr. KNight. Upon what anthority?

Mr. Gardner. Upon, I think, the estimate of the Commissioner.

Senator WARren. The estimate of the Agricultural Department is $1,500,000,000$ pounds.

Mr. Knight. The estimate of the Agricultural Department is $1,500,000,000$ pounds as the production, not the amount put on the market. Only abont 50 or 60 per cent of that goes on the market.

Mr. Gardner. By some possibility, taking the gentleman's own figures, it might make the sales of oleomargarine at the outside 1 per cent of the sales of butter. It could not bring it above that.

Another fact, which I think is established by the evidence and which I think I can truthfully assert without successful contradiction, is that in spite of and in the face of the use and sale of oleomargarine the price of butter is higher to-day than it has been in twelve years, and that in spite of the use and sale of oleomargarine the percentage of increase in the sale of butter to-day is greater than the percentage of increase in the sale of oleomargarine. Therefore the assertion that whatever unsatisfactory condition may exist in the butter industry is or can be due in any large extent to the sale of oleomargarine is an assertion which has no foundation in fact.

Mr. KNight. May I ask upon what you base your claim that the sale ef butter has increased orer the sale of oleomargarine? Where do you get your statistices?

Mr. Gardner. As I stated to the committee yesterday, I have taken this matter up since last Monday and I have not read through this report. I can not tell in what item of the report that is fonnd, but that statement is made to me, and if necessary (I hope $11 y$ friend will make some memorandum of these questions) it ean be substantiated.

Those are all the reasons which I have heard urged for the passage of this bill. Not one of them is valid. It is said that oleomargarine is nuwholesome. There is no substance sold to the consumer in the United States of America to-day which is so absolutely certain of being wholesome or the healthfulness of which is certified to by such high authority.

Mr. Honrd. May I ask the gentleman one question? I understood you to say, sir, that an inspector is at the oleomargarine factory to see that no unwholesome ingredient is introduced into oleomargarine? 
Mr. Gardner. To see what ingredients go into oleomargarine. The manufaeturer is required to make a monthly statement, under oath. of every pound of ingredient he uses in the manufacture. It is the duty of the inspector or the deputy inspeetor, as I under'stand it, to verify that report and under oath to say that the manufacturer's statement is correct or ineorrect.

Mr. IOARD. Do you believe that the manufacturer always states the truth concerning the ingredients of oleomargarine?

Mr. Gardner. Yes, sir; the manufacturers of which I know anything. That is my belief; it is not worth much one way or the other.

Mr. Hoard. The department of agriculture of New York has found by chemical analysis 11 per cent of paraffin in oleomargarine. That is a substance which no known acids have any effect upon. Do you believe that the manufacturer made a return to the Government that his product contained paraffin?

Mr. Gardner. What I believe in that particular is of very little importance.

'The Ciramarax. I suggest that Mr. Gardner be allowed to conclude, and then we will hear from some of the men who are actually engaged in the business.

Mr. Hoard. All right.

Mr. Gardner. As I said, that, it seems to me, is not a valid reason. The other reasons which I referred to are no more valid, the reason of the small amount of fraud. which can be prevented if the mannfacturers of butter see fit to prevent it, the reason which is claimed, that yellow is the trade-mark of butter, the reason that the sale of oleomargarine will destroy the butter industry. That is negative. I have met, so far as I was able, all the claims of the adrocates of this bill.

Now, affirmatively, I do elaim these as reasons why the bill should not be passed. I assert, in the first place, that the passage of the bill would absolutely destroy the oleo industry, which during the past sixteen years under the sanetion of the Government of the United States has been built up at a vast expenditure of money.

I assert that the advocates of this bill intend that that shall be the result of this legislation; that it is not intended by this legislation merely to prohibit the sale of colored oleo and to make that impossible, but it is intended by this legislation to make the sale of any oleomargarine impossible. And I submit that if the member's of this committee will read carefully the argument of my friend on my left and the argument of the gentleman on my right and the argument of the anthor of this bill, they will see that determination stamped upon every sentiment which those gentlemen have nttered. My friend upon the left was obliged, I believe, to present a letter or an affidavit, which was read during the diseussion of this matter in the House, saying that he had not expressed the sentiments which were attributed to him by the report.

Mr. Hoard. No, sir.

Mr. Gardner. Then some one.

Mr. HoARD. I never made any affidarit that I know of.

Mr. Gardner. Then I think a letter from Gorernor Hoard was read.

Mr. Hoard. No, sir; no communication of the kind was ever made by me.

Mr. Gardner. 'Then I withdraw that. 
Mr. Knigur. Somebody forged my name to a letter, and I denounced it.

Mr. Gardner. I do not know, but, according to the report in the Congressional Record, a letter was read, I thought, from Governor Hoard. Of course I accept his statement. The letter stated that he was incorrectly reported in what he said before the committec.

Mr. Hoard. I submitted my argument in writing, so that whatever I said was correctly printed.

Mr. Gardner. Besides the allegations made by the adrocates of this bill, what they have done in the States where they had the power to eary their theories into effect shows that they intend to destroy this industry. In the State of Vermont there is a law which requires that no oleomargarine shall be sold unless it is colored pink.

Mr. Hoard. No; that was the law in the State of New Hampshire.

Mr. Gardner. That is said to be the law in the State of Vermont and in the State of West Virginia.

Mr. Knight. The New Hampshire law has been repealed.

Mr. Galidner. The New Hampshire law has been repealed, and it is the law of the State of Vermont to-day.

Senator Hansirovgri. It is in the report here.

Mr. Galidner. It is in the report.

Mr. KNight. I guess that is tiue. Two States hare that law.

Mr. Gakdnek. Oecasionally I do make a statement which is accepted to be true by my friends on the other side.

Mr. Hoakd. It is news to me.

Mr. Gandner. There is a good deal that is news to you, no doubt, but it is true, notwithstanding, that in the State of Vermont, the State which is represented in Congress by the author of this bill, there is a law which requires that all of this substance which is sold shall be colored pink. Now, this substance can not be colored pink without introducing an element into it which makes it a menace to human health, which makes it a deleterious substance. The State of Vermont has, therefore, legislated not to regulate this industry, but to destroy it. It is absolutely certain that no man would spread upon his bread any pink substance.

Senator Warren. Those laws have been repealed in some of the States.

Mr. Gardner. I do not care whether the law is in force or not; I do not care whether the law is operative or inoperative; it shows the purpose which is entertained by the people who are here advocating this bill; a purpose not to regulate this industry, but to destroy it; a purpose not to have oleomargarine sold as bitter, but not to have oleomargarine sold at all. That is the purpose which is evidenced by the words; it is the purpose that is evideneed by the action which, is londer than words, and whether it is the purpose or not it is the inevitable result.

It is the inevitable result for this reason: Oleomargarine can not be colorecl and pay a tax of 10 cents a pound and be sold in competition with cheap butter. I have previously argued to you, and I will not repeat myself, the reasons why it seems to me that it can not be sold in competition with high-grade butter. It can not be sold in competition with butter which costs over 22 or 23 cents a pound. It can not be sold in competition with cheap butter.

Oleomargarine, which to-day pays a tax of 2 cents a pound, retails at from 13 to 15 cents, with a profit, I assert, of much less than 1 cent 
per pound to the manufacturer, and with a profit to the retailer at the lowest rate at which he is willing to handle it, because where he sells his oleomargarine it sells in the strictest competition with other oleomargarine. Remade butter', renovated butter', process butter', resurrection butter, as it has been called, the method of manufacture of which I understand the committee is to inquire into, it is shown, I I think, by the evidence, can be produced for 13 or 14 cents a pound. It pays no tax, and oleomargarine, which ean only be retailed, as it evidently can be retailed, after the payment of a 10-cent tax, at not less than 21 or 22 cents a pound, has got to come into eompetition, if it is sold colored, with this made-over, acid-treated butter, which can be sold at a profit at 15 cents per pound. 'Therefore, colored oleomargarine is absolutely driven out of the market.

Mr. Knight. I beg your pardon, but where do you get the figures which show the price of renovated butter?

Mr. Gardner. I get those from statements whieh will be made here, if they have not already been made. My elients say that renovated butter is sold to-day in the eity of Providence for 15, 16, and 18 cents per pound, and colored oleomargarine can not possibly be sold at less than 21 or 23 cents a pound if taxed ten cents a pound.

But gentlemen will say to me that oleomargarine can still be sold uncolored. Gentlemen, it can not. We come back to the old question of the eye aiding the palate. The attempt to sell oleomargarine uncolored runs counter to a law which is more universal in its operation and stronger in its action than any law of Congress-a law of human nature-the law of conformity to custom. The people of the United States have been aceustomed to spreading upon their bread a yellow compound. The manufacturers of butter realize it. The anthor of this bill said here yesterday that he considered it was silly and foolish and unwise for people to demand an artificially colored butter; but he admitted that people did demand an artificially colored butter, and that a butter which is not artificially colored, no matter how excellent it may be in any other respeet, can not be sold in market to-day in competition with a butter which is artificially eolored.

It is exactly the same with oleomargarine. No matter though the purehaser may be convinced that oleomargarine is absolutely pure, no matter though his taste may inform him that it is palatable, if an attempt is made to make him use it when it bears a color absolutely distinct and different from that which belonged to the article which he and his fathers have used for the same purpose he refuses to use it. The illustration was used here yesterday with reference to the coat of a gentleman. When the author of this bill was asked why the manufacturers of butter colored their product, he said they did it to meet the denand; that they did it to comply with a law of conformity to custom, and he illustrated it by saying that a member of this committee was wearing to-day a black coat. He did it because black suited his taste.

If it were proposed to-day to a member of this committee that he should purchase either a black eoat of poor quality and high price or a bright pink coat of the very best quality at a low price, the poor black coat at a high price would be purchased and the excellent pink coat at a low price thrown aside. It is silly; yes, it is silly; but it is a law of custon which exists more vividly and with greater effect in that which we eat than it exists anywhere else. We may violate it in the 
matter of dress; we can not violate it, our eye will not allow us to violate it, our edueation will not allow us to violate it, in regard to what we eat. It is absolutely impossible to force upon the market at any price a white substance to be used as butter, and therefore if it is proposed to insist that this substance shall be sold in its natural condition and without any coloring matter you force it absolutely out of sale entirely.

Now, gentlemen, the manufacturer of oleomargarine does not color his product in order that it may resemble butter. He wants to sell it as oleomargarine. He can not sell it as anything else. When a sale for it as oleomargarine is established his business increases and his business becomes reputable, but it is ahsolutely impossible for him to carry on that business if he is eompelled to put up his product in a form in which the publie will not take it. We color our oleomargarine for exactly the same reason that the manufacturer of butter color's his hutter. As the author of the bill said yesterday, the manufacturer of butter must color his butter in order that the people who are aceustomed to spread that yellow substance upon their bread may spread it. When we send oleomargarine to South America we color it, as I have said, a deep blood red or dark brown, because the people of that comntry like to spread that kind of substance upon their bread.

Senator Hansizough. Is that the color of their butter down there?

Mr. Galidner. I do not know whether it is the color of their butter or not; it is what they demand. It is the color of taste. It is a substitute for something else that they use as butter.

Senator Bate. 'The color and not the taste governs the sale altogether, then?

Mr. Gardner. No, sir; I think not. The color is a necessary element, but the taste is eren more important. We ean not sell yellow butter which is raneid because it is yellow, neither can we sell good butter which is white because it is good. Both elements must concur if we are to make a sale of the product.

Now, I want to say to you, gentlemen, on behalf eertainly of one manufacturer whom I represent, and I believe on behalf of every other mannfacturer, that the manufacturer's of oleomargarine. weleome any legislation which will render it more difficult and which will make it absolutely impossible to sell this substance for anything except what it is. We welcome the suggestion that oleomargarine shall be placed within the provisions of the pure-food bill which it is proposed to adopt. But we do protest against the destruetion of our industry.

There is, I think, now before this committee a bill (it was here at the last session) entitled "A bill to define renovated butter, also imposing a tax upon and regulating the manufacture, sale, importation, and exportation thereof." That bill is upon the files of this committee. If that bill is left to slumber upon the tiles of the committee, if this substance is not included within the provisions of the bill which is now before this committee, then the result of the legislation is to drive absolutely away and out of conmerce an article which is acknowledged to be pure and wholesome and for which there is acknowledged to be at demand, and to force upon the whole community as a substitute for it an article which is acknowledged, I think, to be deleterious. The manufacturers of oleomargarine can manufacture process butter if they are driven to do it; but process butter is an article which should not under any regulations be permitted to be used as food. 
Mr. Kingur. If you will give me just a second, let me ask a question. You represent the Oakdale Manufacturing Company?

Mr. Gardener. I do.

Mr. Knignt. Are they satisfied with the present law on oleomargarine?

Mr. Gardner. Yes; they are satisfied with it.

Mr. KNight. Do they comply with the provisions of it?

Mr. Garnner. Ther do.

Mir. Knight. That is all.

Mr. Gardner. In concluding, gentlemen, it seems to me that I ought to apologize for all the time that $I$ have taken up this morning. I have argued this morning largely upon the question of expediency. I have not endeavored to meet, as perhaps I ought. and as perhaps I must meet, the matter which has been referred to this morning by a momber of the committee - a matter which is so familiar to us allthat this legislation is urged upon this committee and urged upon Congress because it is stated that 5,000,000 people engaged in agriculture in the United States desire it. It ought not to be a balancing of the numbers who desire it or who do not desire it. It ought to be a matter of principle. But it is perhaps necessary to meet arguments of that character, and if it is necessary to meet them I ought perhaps to take the time to show that not only the interests of a few manufacturer's and dealers in oleomargarine are here concerned, but that the interests of very many other producers in this country are indirectly concerned.

Oleomargarine is not produced by magic. Into oleomargarine have to enter various substances which are the product of the agricultural industries and interests of this country. The raiser of hogs, the raiser of cattle, and the producer of cotton-seed oil are all interested in the growth of the oleomargarine business. The neutral lard which is used in the manufacture of oleomargarine, and which comes from the hog, is a product which sells at $2 \frac{1}{2}$ cents per pound higher than the only other alternative product which could be made-lard itself-and 8 pounds of this substance are produced from the hog. That shows that for all the hogs that can be utilized for this purpose there is an added value of 20 cents to each hog. The report of the Commissioner of Internal Revenue for the year ending June 30, 1899, when the production of oleomargarine was considerably less than it is to-day, shows that $31,297,251$ pounds of neutral lard were used in the manufacture of this product.

Senator Moner. What is neutral lard?

Senator Heitfeld. Leaf lard.

Senator Foster. How many pounds do you state were used?

Mr. Gardner. Thirty-one million two hundred and ninety-seren thousand two hundred and fifty-one pounds in that year. So there is a vital interest on the part of the farmers who are engaged in the raising of hogs that this industry shall not be wiped ont of existence.

Senator Foster. What part of beef enters into it?

Mr. Gardner. Oleo oil is a product of the beef, and it sells at a much larger price than any other product.

Senator Allex. What would become of these elements if ther were not used in the manufacture of oleomargarine?

Mr. Gardner. They would have to be sold at lower prices for other purposes-tallow in the case of beef. 
Senator Moner. Will you allow me to ask you a question?

Mr. Gardner. Certainly.

Senator Moner. As I came in I heard you speaking about the rights of the producers of butter, oleomargarine, renorated butter, and so on. Have you said anything to the committee about the rights of the people who use these things-the consumers?

Mr. Gardner. I did at considerable length yesterday.

Senator Moner. Excuse me, I will get it in your printed remarks. Senator BATE. The hearing will be printed.

Mr. Gardner. There were also during that same year about four and a half million pounds of cotton-seed oil used, forming a very large outlet for that industry. I wish to call once more the attention of the committee-_

Senator Foster. How much oleomargarine was made that year?

Mr. Gardner. Ninety-one million pounds.

Mr. KNight. Eighty-three million pounds, I guess it was.

Mr. Gardner. It is given as 91,000,000 pounds. I do not know. If you dispute the report of the Commissioner I can not help it.

Mr. Knigit. You have not got the right report.

Mr. Gabdner. I have the report for the year ending June 30, 1899, and I have read the figures correctly.

Mr. Knight. Yon have read the ingredients and not the product.

Mr. Gardner. In this connection I wish to call the attention of the committee once more to the precise wording of the proposed act which is before the committee. It authorizes any State to forbid by law not merely the manufacture of any oleomargarine containing coloring matter, but any oleomargarine containing an ingredient which makes it resemble butter, or look like butter, in the language of the act. I an informed that there is a slight tinge to cotton-seed oil which makes oleomargarine manufactured from cotton-seed oil a little off the white, and which to that extent makes it look like butter. Therefore, if this act is left as it is, it is going to have the effect, or it may have the effect, if States see fit to comply with the terms giren them in the act, to forbid the manufacture of any oleomargarine containing cottonseed oil. I do not know whether any substitute for cotton-seed oil which is absolntely colorless can be found or not. The bill would make it perfectly possible for the legislature of the State of Vermont, or the legislature of any State of this Union, to say, "Mannfacture your oleomargarine if you can, but do not put any cotton-seed oil into it."

Mr. Grout. Do you refer to the proviso to the first section?

Mr. Gardner. Ýes, sir.

Mr. Grovt. That, allow me to state, is the language of the Supreme Court in deciding the Plumley ease, and it was incorporated in to this bill. That first section went through the House four years ago. It was incorporated in the bill on the motion of Mr. Williams, of Mississippi, who then said it made that section of the bill satisfactory to him, and that language was taken from the decision of the Supreme Court. It is Mr. Justice Harlan's language.

Mr. Garnner. I ask the lawyers on the committee to read that section and tell me if the inference which $I$ have drawn from it is not correct.

Senator Warren. I understood you yesterday to say that butter and milk also tend to color oleomargarine. 
Mr. Gardner. Butter and milk do tinge oleomargarine. Cottonseed oil does tinge oleomargarine. Therefore, if cotton-seed oil is allowed to enter into it the State ean pass a law which forbids the manufacture and sale of oleomargarine at all.

Gentlemen, I ought to have concluded long ago. I should have done so if it had not been for these interruptions, which I have been rerv glad to answer as far as I ean. In concluding, I should like to ask you to forget all these questions of expediency. I should like to ask you to forget that there are 5,000,000 people who are mistakenly calling for the passage of this legislation, 5,000,000 people who, during the pendency of these different bills, have been told for the last six years that everything that is unsatisfactory in their condition is due to oleomargarine, people whose condition can not be benefited at all by the passage of this act, but people who believe that it can.

I should like to ask yon to forget that those people are demanding it. I shonld like to ask you to forget also that the people whose circumstances are to be injuriously affected by the passage of the act are protesting against it, and I should like to ask you to go back and simply and absolutely consider nothing else but the principle upon which this act is based, which we considered yesterday, that it is an act which pretends to be a revenue act; that as a revenue act under the Constitution of the United States you have a right to pass it; that as a revenue act, unless the real purpose of it appear's too grossly upon the face of the act itself, the Supreme Court of the United States would perhaps uphold it; but that it is not a revenue aet; that every gentleman who appear's here in advocacy of it says that the revenue which it is calculated to produce is not entitled to any consideration, but that it is an act simply and solely to affect competition between two legitimate articles of manufacture and trade. 'That is avowed by evervone. As such an act, as an act with that purpose, it is an act which those who regard the Constitution of the United States as sacred would not be induced to pass by any considerations of expediency or by any demands of selfish private interests.

The Supreme Court may say, as they have said before, that they can not impugn the motives, purposes, or intentions of the legislative branch of the Gorernment. But no less than the members of the Supreme Court have the members of Congress taken an oath to uphold the Constitution of the United States, and the member's of Congress to-day who are authorized by the Constitution of the United States to levy taxes for the purpose of paying the debts of the United States and providing for the maintenance of the General Gorernment know in their own consciences that they have no right to levy a tax for the purpose of regulating competition between different industries. Gentlemen, it does seem to me (I can not throw it away or get it out of my mind) that the Congress of the United States is asked absolutely to disregard the highest obligation which they have assumed.

I appear here to-day as an adrocate. I appear as an attorney. I ask no more belief in my statements, no more consideration for my argument, than is due to the statements and the argument of a paid attorney. But to-day, as I contemplate the possible results of this art, as I see the possibility of any class of our citizens or persons engaged in any kind of trade who believe that their interests in that trade may be injurionsly affeeted by some new rival coming time and time again to the Congress of the United States and asking that that 
new industry may be taxed out of existence, as I see what legislation of this lind is likely to lead to, it seems to me that I nust throw off for the time being the character of advocate and appear before this committee merely as a citizen, and that I must ask them not to make a precedent by which the Congress of the United States, under the guise of internal-revenue taxation, is legislating in order to destroy one industry for the benefit of another, or to affect competition between two industries which have loth legitimate rights.

I thank you, gentlemen, rery kindly and heartily for your attention.

The Charrman. I may say that the committee join me in thanking you for the very clear and lawyer-like statement of your views. I wish to ask you one question. As I understood you, you made the claim, or admitted, that if this article were to be sold in its natural color it conld not possibly be sold; that as to the ingredients, it might be known what they are; that they are all healthful and good, but that if left in its natural color it could not be used; that such a restriction would destroy the manufacture. Is that the ground?

Mr. Gardneli. That is my belief.

Senator Moner. You said something about the necessity of coloring butter in order that it may be sold.

Mr. GARDNER. I say that as long as there is in the market something which people want and which they have been accustomed to use you can not sell them something which they do not want and which they are not aceustomed to use. Do not misunderstand me, please. If all butter was left uncolored and if all oleomargarine was left uncolored, of course both oleomargarine and butter would sell, and they would sell upon the same plane. People would still have something to put on their bread, although they could not get what they wanted. But butter is not left uncolored. Butter is artificially colored vellow. The author of this bill insisted yesterday that that was absolutely necessary in order to meet the demand. I say as long as there is in the market, even at a higher price, or as long as there is in the market even a lower grade of the kind which the consumer wants, that will sell as against what he does not want.

'The Chamman. Your clients take the ground that not the material, but the color, sells the produet?

Mr. Gardener. No, sir. I beg your pardon; my elients take the ground that both material and color sell it. They can not sell it without good material; they can not sell it without color. Neither one will sell it: it must be both.

Senator Moner. You take the same position as to white butter, too?

Mr: Gardner. Precisely. I do not mean to say that people would go absolutely withont white butter if the butter manufacturer would not gire them what they wanted. But the butter manufacturer will gire them what they want. I simply say that when the manufacturer of any article attempts to run counter to demand, to taste, to custom, he gets left. I think there is a small demand for very light colored butter.

The Chamman. In some countries I have seen very light butter.

Mr. Gardner. Precisely.

The Chamman. It was the fashion, and it was good.

Mr. Gardner. In some countries perhaps uncolored oleo could be sold. We know that in some countries practically black oleo can be sold and the people want it; but where the demand is for yellow, neither white nor black can be sold. 
ORDER OF PROCEDURE.

Senator Allen. Mr. Chairman, I move that the sessions of the committee be continuous during the holidays, to the end that the committee may be fully prepared to report promptly on the bill upon the reconvening of Congress after the holiday recess.

The Chamman. I will state that I have told parties who wish to be heard, and I have told those representing some of the Southern interests, that they might be heard as late as the $3 \mathrm{~d}$ of Junuary.

Senator Alres. I make the motion beeause if the report rnns over to the middle or the latter part of January there is no possibility of the bill being considered at the present session of Congress.

Senator Moner. In the first place, there will be no one here during the holidays to hear these gentlemen except the chairman.

'The Chamman. I was going to say that I thought there would be a subcommittee here, and any members of the committee who will be here I will name as a subcommittee.

Senator Money. There will not be any members of the committee here but yourself.

Senator Bate. I hold in my hand some telegrams in regard to the matter, and other Senators I know have received similar telegrams, and the parties ask that they may be heard here at some time by the committee as late as the 15 th of January. These parties are from Texas, Temnessee, and other States. 'They did not expect any hearing' during the holidays. Then let us fix the very latest date. They want to come here as a committee or a delegation on this question. 'I may differ' with them, but, notwithstanding, I think they are entitled to be heard.

The Chairuax. Quite a number of dispatches have been received, and, curiously, they all seem to name the same time, as though there was a little concert. 'They name the 15th of January. But that is no matter. I have replied to them that it would be impossible to postpone the hearing is long as that date. Several Senators spoke to me yesterday on the subject, and I told them that I eould not make any promise to extend the hearing after the $3 d$ of January.

Senator Altex. I will modify my motion and move that the hearing be concluded by the 10th of January.

The Chalryan. That gives almost three weeks' notice, and it strikes me that it is reasonable.

Senator Bate. But the holidays intervene.

The Chairman. But the parties can be preparing their statements. We have had a rery good one this morning. After that time we shall have the appropriation bills, the army bill, and all the other measures pressing upon us. We do not know exactly what will be the state of the public business. Of course we want to treat everybody fairly, but it seems to me that that is the latest time. When the time comes, if there is good reason for it, the committee can ehange their view, but I think it would be unwise now to name a later time.

Senator Money. In the first place, I think it is unwise to fix a day at all. There ought not to be a termination to information. I do not think the committee is likely to be too well informed upon this subject. It is very much more important than merely the regulation of a competitive struggle between the manufacturers of hutter and oleomargarine. There are some millions of people in the United States 
who can not buy butter and who can buy oleomargarine. I think we onght to hear all who want to be heard, if they have anything to state.

Of course we are not to be expected to protract needlessly the sessions of the committee, but I lo not think we ought to fix a time for reporting the bill or to terminate the hearing. The session goes off on the thi of March. If the Senate consider's this measure to be of the importance it is supposed to have by some members of the committee, it will give us a hearing, and it is very much better that it should be argued out right here than on the floor of the Senate, as far as the speedy passige of the bill is concerned.

Therefore I would prefer, if the Senator from Nebraska will be patient, that he withdraw his proposition and let us determine about a day later on when we have heard further and can see what else there is to be heard. It is not necessary that we shonld agree thus far in advance to stop the hearing on the $3 d$ or on the 10th of January.

Senator AlLes. If we should undertake to hear all who wish to be heard on this question we would not get through in three months. Why not have four or five or half a dozen men selected on either side to address the committee?

Senator Moxer. When we have heard them we can then judge whether we want to hear any more. We ought not to shut our'selves out from the opportunity of being enlightened on the subject.

Senator Alues. If we extend the hearings beyond the 10th day of January there is not the shadow of a possibility of acting upon the bill at this Congress.

Senator Mover. As far as that argument goes, it is not worth anything to me, for I would kill it to-day if I could. I am only talking for fair play for both sides.

Senator Alles. I am talking for fitir play, too.

Senator. Warren. I presume we will be able to get through entirely by the 10th of January. I would say, howerer, if we should get along to the 9th of January, and there should be a considerable number of the committee who winted further light or information, we could extend the time. I do not want to tie my hands in the matter.

Senator Foster. I second Senator Allen's motion.

The Ciramman. The question is upon the motion of Senator Aller that the hearings be concluded by the 10th day of Jamuary.

The motion was not agreed to; there being on a division-ayes 4 . noes 4 .

Senator Allins. Let us have a yea-and-nay vote.

Senator Hansbrodgh. I move that we close the hearings on the $3 c$ of January.

Senator Allex. I wish it to appear of record that I made a motior to close the hearings on the 10th.

The Cilaimian. Shall I put the motion again?

Senator W' WRren. I move that the committee adjourn.

Senator Haxsbrough. I am not inclined to be factions.

The Cinaminan. Will you change your vote?

Senator Hansbrougr. I am opposed to extending the hearing: beyond a reasonable length of time, because we can get all the infor mation we may require out of the hearings before the House committee

The CHaminas. It is moved that the committee adjourn until hall past 10 o'clock to-morrow.

Mr. TIllinghast. Do I understand that after to-morrow the hear: ings will adjourn until the $3 \mathrm{~d}$ of January? 
The Cirairman. No; that is not decicled.

The motion was agreed to; and (at 12 o'clock and 5 minutes p. 111.) the committee adjourned until to-morrow, Friday, December 21, 1900, at 10.30 a. 11 .

The committee met at 10.30 a. $\mathrm{m}$.

\section{Friday, December 21, 1900.}

Present: Senator's Proctor (chairman), Hansbrough, Warren, Bate, Money, and Heitfeld. Also Hon. William M. Springer, of Springfield, Ill., representing the National Live Stock Association; Frank IV. Tiliinghast, representing the Vermont Manufacturing Company, of Providence, R. I.; Charles E. Schell, representing the Ohio Butterine Company, of Cincinnati, Ohio; W. E. Miller, representing the Armour Packing Company, of Kansas City, Mo.; John C. McCoy, of Kansas City, Mo.; G. M. Walden, President of the Kansas City Live Stock Exchange; Philip E. Mullen, of Kansas City, Mo., representing the Armour Packing Company; R. H. Armstrong, of Washington, D. C., representing the Armour Packing Company, and other's.

The Ciraminan. Who wants to be heard this morning?

Mr. Miller. Mr. Chairman, I represent the Armour Packing Com pany, of Kansas City.

-Senator Hansbrougil. As a manufacturer?

Mr. Mrller. Yes, sir.

The Chairman. You may proceed, Mr. Miller.

\section{STATEMENT OF W. E. MILLER.}

Mr. Milder. Mr. Chairman and gentlemen of the committee: Our object in asking for a hearing before this honorable committee to-day is to make a final appeal to you and member's of the Senate not to kill the butterine industry by passing the Grout bill. We shall endeavor not to reiterate anything given in our testimony before the Agrieultural Committee of the House, which we ask you to consider seriously, together with what we present to-day.

The butterine business is one of the valuable branches of our packing house, in which we have thousands of dollars invested, and have spent years of valuable time in placing it where it is to-day. We desire to impress upon this eommittee that manufacturers can not exist under the Grout bill. In the first place, uncolored butterine is practically unsalable. It is unsightly and does not appeal to the eye of even the poor man.

This product has a creamy appearance, and although the laws in many States legalize its sale, yet when we endeavored to sell it in two States, viz, Iowa and California, we had to defend our dealers in suits brought by the dairy commissioner and prove that it was not artificially colored, the slight color coming from the materials. After haring won these cases in the lower courts, we were assured that such persecution would continue as long as we offered uncolored butterine. Therefore we gave up these States altogether. In our opinion, a large number of States under the Grout bill would take similar action. The intention of the dairyman is not to regulate the sale of this product, but to kill the industry, both on colored and uncolored butterine.

It is unreasonable to suppose that we could pay $\delta$ cents additional tax and sell this produet. The main object which prompts a man to 
buy butterine is because it is just as good and a great deal cheaper than butter. One grade of butterine we make in our factory eosts 14 cents a pound: add to this $S$ cents additional tax, and you bring it to within 3 cents of the cost of Elgin creamery. Butterine is nsed almost exclusively by the poorer class of people. It retails all over the West at from $12 \frac{1}{2}$ to 15 cents a pound for low grade, and 18 to 20 cents a pound for high gride. We speak of the West because we are nore familiar with that section.

The Cimminas. What makes the difference in the grades?

Mr. Miller. There is a difference in the materials used. In some grades we put more ereamery butter than we do in others.

The Cinaminas. That is the main difference, is it-the quantity of butter that is put in?

Mr. Miller. Yes, sir.

Instead of killing our industry, we are perfectly willing that you should enact any law whatsoever which will prevent fraud, providing the tax is not increased or the privilege denied us of making it attractive in appearance. We favor the Wadsworth or the substitute bill, which we considered in the House, or any other bill regulating the marking or branding of our product, so that it can not be sold for butter, and we will assist the Internal-Revenue Department in enforcing same to the letter.

At this juncture we would like to introduce as evidence an article from Experiment Station Record, United States Department of Agriculture, on the nutritive value of oleomargarine:

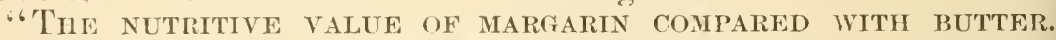
E. Bertarelli (Riv. Ig. e Sen. Pubb., 9 (1898), Nos. 14, 1'1). 5.38-545; $15, \mathrm{p}$. 5\% $0-5 \% 9)$. - Three experiments with healthy men are reported in which the value of margarin and butter was tested when consumed as part of a simple mixed diet. In one experiment the value of a mixture of olive oil and colza oil, which is commonly used in Italy in the neighborhood of Turin, was also tested. 'The author himself was the subject of one of the tests. He was 24 yeurs old. 'The subjects of the other tests were 2 laboratory servants, one 27 year's old, the other 32 years old. The coefticients of digestibility and the balance of income and ontgo of nitrogen in the different experiments were as follows:

Inigestim. ceperiments with margarin, butter, and vil.

\begin{tabular}{|c|c|c|c|c|c|c|c|c|}
\hline & \multirow[b]{2}{*}{ Time. } & \multicolumn{3}{|c|}{ Coeffieients of digestibility. } & \multicolumn{4}{|c|}{ Nitrogen. } \\
\hline & & Protein. & Fat. & $\begin{array}{l}\text { Carbo- } \\
\text { hydrates. }\end{array}$ & $\begin{array}{l}\text { In } \\
\text { food. }\end{array}$ & $\underset{\text { In }}{\text { urine. }}$ & $\begin{array}{l}\ln \\
\text { feces. }\end{array}$ & Gain. \\
\hline Laboratory servant, P. G.: $500 \mathrm{gm}$. & Days. & Per cent. & Per cent. & Per eent. & $G m s$. & Gims. & Gms. & Gms. \\
\hline $\begin{array}{l}\text { white brear, } 270 \text { gm. veal, } 70 \mathrm{gm} \text {. } \\
\text { butter, } 250-300 \text { ec. wine.......... }\end{array}$ & \multirow[t]{2}{*}{5} & \multirow{2}{*}{81.75} & \multirow{2}{*}{92.67} & \multirow{2}{*}{97.25} & \multirow{2}{*}{15.7} & \multirow{2}{*}{9.6} & \multirow{2}{*}{2.6} & \multirow[t]{2}{*}{3.5} \\
\hline & & & & & & & & \\
\hline $\begin{array}{l}\text { gm. margarin, } 250-300 \text { ec. wine. } \\
\text { Author: } 150 \mathrm{gm} \text {. White bread, } 250\end{array}$ & \multirow{3}{*}{6} & 79.50 & 93.90 & 97.07 & 15. 7 & 10.3 & 3.2 & 2.2 \\
\hline gm. meat, 70 gm. butter ........ & & 81.85 & 94.25 & 97.35 & 13.5 & 10.1 & 2.5 & .9 \\
\hline $\begin{array}{l}\text { Author: } 400 \mathrm{gm} \text {. white bread, } 250 \\
\text { gm. meat, } 70 \mathrm{gm} \text {. margarin ..... }\end{array}$ & & \multirow{2}{*}{77.80} & \multirow{2}{*}{93.73} & \multirow{2}{*}{96.70} & \multirow{2}{*}{13.5} & \multirow{2}{*}{9.6} & \multirow{2}{*}{3.1} & \multirow{2}{*}{.8} \\
\hline $\begin{array}{l}\text { Laboratory servant, } \mathrm{F} . \mathrm{D} .: 824 \mathrm{gm} \text {. } \\
\text { white bread, } 250 \mathrm{gm} \text {. meat, } 61.6\end{array}$ & 6 & & & & & & & \\
\hline 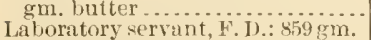 & 5 & 85.32 & \multirow[t]{2}{*}{95.80} & 97.38 & \multirow[t]{2}{*}{16.5} & \multirow[t]{2}{*}{18.2} & \multirow[t]{2}{*}{2.9} & \multirow[t]{2}{*}{.4} \\
\hline 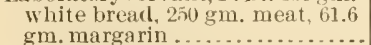 & \multirow{2}{*}{5} & \multirow{2}{*}{82.92} & & & & & & \\
\hline Laboratory servant, $\mathrm{F}$ i.: $910 \mathrm{gm}$. & & & 95.33 & 97.24 & 10.9 & 12.5 & 3.4 & 1.0 \\
\hline gm. olive atui cotza oils.......... & 5 & 83.27 & 95.82 & 97.56 & 17.5 & 13.4 & 3.5 & .6 \\
\hline
\end{tabular}


"The principal conclusions follow: When properly prepared, margarin differs but little from natural butter in chemical and physical properties. On an average $\$ 3.5$ to 96 per cent of fat was assimilated when margarin was consumed and 94 to 96 per cent when butter formed part of the diet. The moderate use of margarin did not eause any disturbance of the digestive tract."

I also submit the report of the Illinois live-stock commission investigation regarding tubereulosis. It is as follows:

"We have before us the fourteenth annual report of the State board of live-stock commissioner's for the year ending October 31, 1899, and in addition there is a bulletin devoted to the question of tuberculosis and the tubereulin test, eontaining a full statement of every tubereulin test eonducted by the board during the year. In conneetion therewith also excerpts from the writings of scientific investigators with relation to the nature of tuberculosis, its contagion and methods of transmission. It also contains the report of the College of Physieians and Surgeons of Chieago upon the milk taken from 41 eows that had reacted under the tuberculin test, with a view of ascertaining what percentage of the milks under investigation eontained or transmitted tubereule baeilli. The report shows that tuberculo bacillio were found to exist in the milk of 16 different animals out of the 41 , or over 39 per cent. The conclusions of the scientifie investigators in charge of this experiment were as follows:

"First. Prolonged searching of the concentrated milk from cows showing tubereulosis, but with sound udders, will reveal bacilli in about 35 per cent of the cases.

"Second. Bacilli are found with about equal frequeney in the sediment and in the cream.

"Third. This milk, when eoneentrated, will produce tuberculosis in the guinea pig in about 25 per cent of the cases.

"Fourth. Not much dependence can be put on the physical appearance of the milk in eases where the udder is not demonstrably involved.

"Fifth. While the large number of cases in which pus cells were found in the milk would indicate that there was beginning involrement of the udder, there is no question but what the search for lesions in these udders was far more eareful than will ever be possible on the living cow, and therefore the udder appearances ean not be aceepted as a safe guide.

"The report also shows that during the period from May 17 to Norember 1, 1899, the board tested with tuberculin 3,651 dairy and breeding cattle of all ages, of which number 500 , or 15.32 per cent, were condemned or destroyed and 41 were isolated or held for retest.

"In several eases which the board investigated there was positive proof of the transmission of the disease through the milk to the ealves. The board also gives an account of the official investigation and test of the herd of Mr: H. B. Gurler, of De Kalb, Ill.

"He began testing for tuberculosis in 1895 , and all the eattle that reacted were destroyed and the premises were thoroughly dism fected. Since that date the dairy has been conducted on strietly sanitary regulations; and, also, animals for the dairy are tested by the tuberevilin test and all that suecessfully pasied the test were admitted to his herd. Tests were also carried on during the years $1896,1897,1898$, and 1899. None of them were found to be affeeted, excepting during the 1899 test some calres were found to be affected. As there were no other ani- 
mals that responded to the test the question was how those calves had been affected, and it was found that they had been fed on milk procured from a near-by creamery, and the inference was that the creamery milk was the canse of the indication.

"The same cause apparently was found in the case of calves at the Kane County almshouse farm, where none of them responded to the test, neither of the older cows or the young, excepting six yearlings and one yearing bull, and upon the post-mortem examination after the test they were found to be diseased. It was prored by a letter from the superintendent, Mr. Keyes, that these ealves had been fed on milk that had been bonght at a butter factory."

I also submit resolutions against further legislation on butterine, which are not in the records of the proceedings before the House.

NEW YORK BU'TTER MARKET.

Receipts of butter and cheese for six days ending Necember 11, 1900.

\begin{tabular}{|c|c|c|}
\hline & Butter. & Cheese. \\
\hline $\begin{array}{l}\text { Wednesday } \\
\text { Thursday } \\
\text { Friday } \\
\text { Saturday } \\
\text { Monday } \\
\text { Tuenda. }\end{array}$ & $\begin{array}{r}\text { Packages. } \\
4,120 \\
3,206 \\
5,357 \\
3,463 \\
7,297 \\
10,083\end{array}$ & $\begin{array}{r}\text { Boxes. } \\
3,066 \\
7,015 \\
5,112 \\
5,258 \\
3,005 \\
12,483\end{array}$ \\
\hline 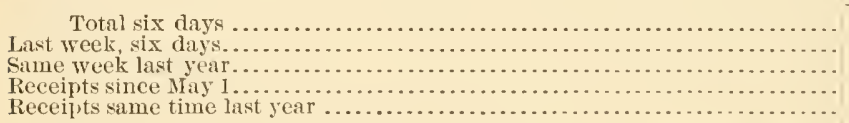 & $\begin{array}{r}33,526 \\
29,363 \\
25,949 \\
1,376,1 \times 9 \\
1,307,365\end{array}$ & $\begin{array}{r}35,939 \\
30,173 \\
18,553 \\
1,14,985 \\
968,5606\end{array}$ \\
\hline
\end{tabular}

Senator Bats. How many pounds are there in a package?

Mr. Miller. It is supposed to be 60 pounds. The creameries always estimate that a package is a tub of 60 pounds.

We contend that the manufacturers of butter do not need protection. Wre regret that it is impossible to get the complete figures on the amonnt of butter produced in the United States. From reports which are made public the business is prosperous and increasing. Reports from both Missouri and Kansas show a good increase over last year. The following, from the New York Produce Review and American Creamery of Decomber 12, show the healthy condition of that market:

"Conditions affecting' the general market have not changed materially since our last review, except that we bave had an increase of fully 4,000 packiges in the week's receipts. 'The good prices ruling here have attracted a larger part of enrrent productions, and several carloads of storage hutter have come forward from Western refrigeritors. On the whole, trade has been quieter. Consumption has been lessened by the full prices asked by retailers, and the distribution to out-of-town bingers has been quite imoderate. 'This has brought the supply and demand closer together and convinced operators that the safety of the market lies in very conservative action until after the holidars. Of course much depends on the available supply. We have probalily reached the lowest point of production, and in some sections of the country the make is on the increase. Beside this, the home demand is lighter, farmers' rolls being more plenty and of better quality, and these are going to a good deal of the trade in the local towns and to the 
patrons of the ereameries; this results in larger shipments of the fresh product. 'Then, too, there is still a large stock of refrigerator Jutter not only here but at other storage centers, and holder's feel that the time has come for disposing of as many of these goods as possible. Naturally, the freezer butter fills a large place becanse of the difference in price, and this is urged as a reason why no further advance should be attempted. In view of the conditions prevailing, we regard our market as quite high enough for safety."

I will also read the following from the Elgin Dairy Report, D. IV. Willson, editor. under date of November 15, 1900, indicating increased business in Chicago, New York, PLiladelphia, and Boston, which are the four largest butter markets in the United States. The Elgin Dairy Report is supposed to be the organ of the ereanery people in Illinois. This is an article on the increased consumption of butter. It says:

"Inquiry in Chieago, New York, Philadelphia, and Boston indicates an increased consumption of butter by the people who depend upon those sources of supply. The reason given for this increased consumption varies according to the opinion of parties giving the same.

"The New York people claim that the increase in population and the better elass of goods arriving on the market and the better conditions prevailing among mechanics and working people has increased the consumption of butter in their eity.

"Boston people say about the sane thing. However, whatever the cause may be, it is a gratifying result to all interested in the developing and uphuilding of the dairy industry. We have contended for many year's that improvement in the quality of butter placed upon the market will induce greater eonsumption. We all know that if on our own tables or on the tables of hotels or boarding houses the butter is grood we will use more than if the butter is pool.

. We call attention to the readers of the Report to this increased consumption as reported by parties who are handling the goods, that it may be an inducement to the maker's to put more skill and more care into the manufacture of their goods. While the proportion of good butter has increased during the past ten years, it is not yet what it should be. The reason of this large proportion of mediun to poor butter placed upon the market is a problem that the edncation and enlightenment that has been promulgated through the dairy press and the dairy associations has not solved."

Mr. Chairman, good butter needs no legislation to give it a price. Good oleomargarine asks no legislation against chenically mixed and chemically purified butter. The maker's of butter and the maker's of oleomargarine ought to be equal before the law. Each industry should thrive or decay because of its own merit or demerit. Those who wish to buy oleomargarine because it is as wholesome and cheaper than butter should be free to do so. The dairymen have ohtained protection against oleomargarine interests beanise they are more numerous. They are protected at the expense of the people, not because they are more deserving, but because they are stronger. It is a system of might against right, which, if extended, will soon deprive honest American eitizens of their liberty or hope for constitutional redress.

The prejuclice of the masses comes from the jealousy of the farmer. Beeause of the fear that he might be injured by the production of oleomargarine, the press of this country have given columns to the contentions of the agrieultural interests whenerer its representatives went to 
State capitals for the purpose of wiping out the oleo side and fostering its own, and on few occasions has it waid a friendly word for oleomargarine. Public opinion, biased by this ex-parte work of the press, falls into line, and casting upon it eyes of scorn, pins its faith upon butter. No unprejudiced person can view our establishment and fail to notice one absolute characteristic, deanliness-such cleanliness that the far-famed Holland housewife is put to shame. No one can visit the so-called dairies that dot the mural districts and fail to note that cleanliness is not a characteristic. Were the oleomargarine manufacturers, the packers, the cattlemen, and the cotton-seed oil producers animated by the same strong feeling of self-interest which seems to permeate the rely being of our farmer friends, and did we use our influence with the press of the country, the masses would gain an entirely different riew.

Warner Miller, of New York, who was the champion of the butter interests when the tax of 2 cents a pound was put on butterine, some time afterwards visited Chicago and was incidentally taken through our butterine factory, which was then in operation. He had never seen butterine made, but the New York dairymen had told him what filthy, vile stuff it was. We took special pains to show him every detail of its manufacture, and when he had comprehended it all, especially its purity and cleanliness of manufacture, he was introduced to Mr. P. D. Armour. Senator Miller understood the general ronspiracy of which he was the deluded vietim, and he confessed to Mr. Armour that if he had known as much about butterine the year hefore he would have fought such a measure instead of being its champion.

Our product has been so maliciously misrepresented that many who are opposed to it now might also change their views upon close investigation, as did Senator Miller. Butterine is pure, wholesome, and economical: therefore we appeal to you in the name of justice, equity, and right that you allow us to exist under the present law or under one similar to the Wadsworth or substitute measure discussed in the House.

Just here I would like to eall the attention of the committee to the methods pursued by the so-called National Dairy Association. They found it impossible to win by fair, honest competition. Therefore they formed a political organization with Boss Knight, who dictated the policy, and also dietated who should come to Congress. Anyone who would not agree to rote for the Grout bill was borcotted, maligned, and abused. All sorts of vile literature was sent out from Chicago by Boss Knight into the district in which the candidate was located. Ask Congressinan Wadsworth, of New York, or Long, of Kansas, or Cowherd, of Kansas City, something about this.

I will say just here that Congressman Cowherd, from our distriet, was the nominee on the Democratic side, and Brown on the Republican side.

About two weeks before the election a committee from the Produce Exchange visited Mr. Cowherd and asked him how he stood on the Grout bill. Hesaid he was against it and would rote against it. They also visited Mr. Brown, and Mr. Brown tacitly gave them to understand that he would rote for the bill. Of course the friends of Mr. Cowherd in Kansas City did not think it would be poliey for him to faror this bill, as there are six or eight packing houses located there, sereral of them manufacturing butterine. 'Therefore he did not think it was in 
his interest to support the bill. These dairy people sent ont committees in all the precincts and all this territory, and did all sorts of things to try to defeat him.

The sime thing is true of Congressman Long. Any one not believing my statement can consult these three men and find that this was the truth.

All sorts of vile literature was sent out through the district, and I ann told that it all emanated from Boss Knight, of Chicago. In fact, most of the literature which Congressmen and Senators have been flooded with emanated from one source. They are printed and the language of each is the same. I understand that some postal ards have been sent here which were originally sent out by Knight asking for the signatures of four or five men in the neighborhood. That one party would sign for four or five men, and these cards would be sent here to Congressmen and Senators.

We feel just this way: Whenever we have got to organize a political association to defend our product, the Armour Packing Company, for one, will go out of business. We ean use our factory for some other part of our business.

I should like to read these resolutions

The Champinan. Before doing so let me ask you a question: Can this difference in the two grades of butterine be detected by the taste?

Mr. Miller. Yes, sir.

The Chairman. Readily?

Mr. Miller. Yes, sir. The better grades have, of course, more butter flavor than the cheaper grades.

Senator Bate. Because you put in more butter?

Mr. Miller. Yes, sir; butter and cream.

The Chambian. I thought it was claimed that it could not be detected from the best dairy butter anyway.

Mr. Mrluer. The best grades you can not tell from the best grades of butter.

The Chamman. Yon could?

Mr. Mrller. I could. But it would be very hard for anyone to detect the difference between the lower grades and the good grades of dairy butter.

Senator Haxsbrough. It requires a cultivated taste, does it not?

Mr. Mrluer. Yes, sir; for an inexperienced person it would be very hard to distinguish the difference.

Senator Haxsbrough. So a low grade could be palmed off on an inexperienced or tasteless person as a high grade?

Mr. Mrrmer. Yes; it is very hard to distinguish between the two.

The Chamman. What do you say is the clifference in price between these two grades of butterine?

Mr. Mrller. I simply mentioned one grade. I said we manufactured one grade that costs us about 14 cents.

The Chamrian. That is the wholesale price?

Mr. Mirlek. Yes, sir.

Senator BATE. That is the lowest grade?

The Cramman. It is a higher grade.

Mr. Minler. That is one of the highest grades we make.

We have

a lower grade that costs a little less than that.

The Chamrian. How much less?

Mr. Miller. Well, a cent and a half to two cents. 
Senator BATE. But to increase the tax on it to 8 cents would take it practically out of the market?

Mr. Miller. It would make it practically unsalable.

Mr. Springer. What percentage of pure butter do you put in oleomargarine?

Mr. Mrluer. That varies-25 to 30 per cent.

Mr. Springer. What are the other ingredients?

Mr. Mrllek. Oleo oil, neutral lard, coloring.

Senator Bate. What coloring do you use?

Mr. MiLler. We use coloring that is manufactured by the TellsRichardson Company, of Burlington, Vt. That is coloring that is sold quite universally over the United States.

Senator BATE. What is the technical name of it?

Mr. Mulen. I do not know the composition of it. We simply buy it as improved butter coloring. 'Their process, I think, is secret. I do not think they give to the public the formula for making it.

Senator Hansbrougur. That is purchased also by dairymen?

Mr. Miller. Yes, sir.

Senator Haxsbrough. It is the same coloring matter that is used by dairymen?

Mir. Miller. Yes, sir. I wonld say just here that the Creamery Package Company have offices in all the large cities in the United States, and-

Senator Bate. Where is the head of that establishment?

Mr. Millel. In Chieago. They have offices all over the United States, and of course they supply the ereamery men as well as the butterine manufacturers. I asked their manager in Kansas City one day what coloring he handled, and he said that he handled several grades, but he had no call for any but the Wells-Richardson improved butter coloring, and that was used exclusively by the butter makers as well as by the butterine manufacturers.

Mr. Springen. Let me ask a question. Do you know whether the manufacturers of creamery butter use oleo or neutral lard in their manufacture of butter?

Mr. Miller. I could not say as to that. I know that we would refuse to sell a ereamery any materials that they would try to mix with creamery butter. We would not care to be a party to a fraud of that kind.

The Chamman. What grade of butter would be used in the best quality of butterine?

Mr. Miller. The very best ereamery butter that we ean buy.

The Chamrax. Because a less quantity of it will answer?

Mr. Miller. Of course it is to gire it a fine flaror. I would say just here that it has been a fact that the manufacturers for years have endearored to put the very best materials in their butterine; not the cheapest, but the rery best they eould get. We ean not use any of the baser fats of the steer in the manufacture of oleo oil, because it would give it a rank, tallowy taste. We use the very choicest fats of the beef.

Senator Proctor. Can not the cheaper lower grades of fats be purified so as to conceal the grade?

Mr. Mrluen. They are perfeetly pure, but of course they have a very tallowy taste.

The Ciraminan. And that taste can not be corrected? 
Mr. Mrller. No; not without injuring the quality of the oil.

Mr. Tillinghast. Do you know anything about the use of paraftin in the making of oleo?

Mr. Miller. As I stated before the House, that is unreasonable. I can not see how any sane man could believe that fol a minute if he ever investigated the question. I investigated this faet last winter. Good paraffin costs 14 cents a pound, and I can not see any object in putting it in butterine. It would not give it any flavor; it would not add to the texture; and we can get materials that do not cost us 14 cents a pound to put in the product. Therefore I ran not see any olject whatever in using it. I have never heard but one test made, and that was made in New York-the one that the dairy people have made so much stock of -and I expect that that sample was prepared by some dairyman. If there was any object to be accomplished, if we could decrease the cost of our butterine, if we could improve the flavor in any way by using paraftin, some unserupulous manufacturer might do it, but there is no reason for it. There is nothing that would he gained by using it.

Mr. Tilminghast. 'Then, as a matter' of fact, in your establishment at least you know positively that it is not used?

Mr. Mirller. We have never had a pound of paraffin in our factory.

Senator WARren. Are there any other factories that you either know or suspect of using it?

Mr. Muluer. None whatever. Last winter, when that question came up, I got a sample of butterine from every manufacturer in the United States, and I had our chemist examine the samples for parattin, and he said he found no trace of it.

Senator Haxsbroug11. You do not know of any creameries which use butterine or oleomargarine in connection with their product?

Mr. Miller. Well, it has been currently reported that they did, but I do not know of any instance.

Senator Hansbiough. Current report, of course, is not very good testimony.

Mr.' Milller. No.

Senator Bate. Tell us what are the proportions of the elements, the ingredients with which you make your material, butterine.

Mr. Miller. Of course those are trade secrets, more or less.

Senator Bate. I do not want you to state the secrets, but I wish to know how much butter and how much cream you use in manufacturing your product.

The Chaipman. Are you not required under the internal-revenue laws to state the ingredients?

Mr. MrLler. Of course, but it is given collectively.

Senator WARREN. It is giren in the report of the Commissioner of Internal Rerenue, and is in the eridence taken before the House as it came from the Internal-Rerenue Department.

Senator Haxsmiougir. The specific ingredients?

Mr. Milleer. Yes, sir.

Senator Bate. Then what objection is there to giving them?

Senator Warren. He may not be authorized to give it, but it is important that some one should file it.

Mr. Miller. Such a paper was filed, giving all the materials used in all the factories. That would be the average for all the factories. Senator Bate. You speak of that which was given in the House? 
Mr. Milleri. Yes, sir.

Senator Bate. Do you know in whose testimony it will be found?

Senator Warren. You will find it more quickly by looking for the table. It is tabulated matter.

Mr. Mrluer. There was a resolution passed by the House calling on the Secretary of the Treasury to give the materials used for the past year in butterine. You will find that given by the Secretary of the 'ireasury. It was not in the testimony given by the manufacturers.

Senator BATE. But when you are silent upon the subject, it may create the impression that you have a different formula from what is given there.

Mr. Millwer. None whatever. I will say that it ranges about this way: We use about 35 per cent, or say 30 per cent, of oleo oil and 30 per cent of nentral. The balance would be cream, butter, and salt.

Mr. 'Tilinnghast. Cotton-seed oil?

Mr. Miclar. Cotton-seed oil in the cheaper grades.

Senator BATs. What about beef fat?

Mr. Miller. That is oleo oil. Oleo oil comes from beef.

Senator Bate. Do you mix the fat from lard and the fat from beef?

Mr. Mrluer. Those are all churned together.

The Crrarrman. Those are the later products of the lard and tallow?

Mr. Millek. Yes, sir.

Senator Bate. Do you use steam in pressing them, or how do you press them?

Mr. Mrtr.er. The materials?

Senator Bate. Yes, sir.

Mr. Mrller. They are all heated to a temperature of about 155 to 160 degrees.

Senator Bate. Fahrenheit?

Mr. Mrruer. Yes, sir. Professor Wiley, the Chief Chemist of the Agricultural Department, made a statement before the House committee to the effect that this temperature is sufficient to kill any germs whaterer that might be in these materials.

The Cramruns. What do you use to harden them, to make them solid?

Mr. Miller. The oil is heated to a temperature of about 155 or 160 degrees. Then it is placed in presses, and we get two products from it, oleo oil and stearin. Stearin is used in the manufacture of candles We do not use stearin at all in the manufacture of butterine.

The Craminian. The latter oils are tallow and lard? I would not suppose that they wonld have the consistency, that is, they would not be solid enough to stand for hard butter, and I understand that oleo keeps well in a hot climate. Is there not something used to harden it?

Mr. Murcer. All these materials are churned together, and when taken from the churn they are in a liquid form. It is run into vats filled with either ice-cold water or cracked ice, and after it has been stirred for some time it congeals.

The Chamman. And remains solid?

Mr. Mrllaer. Yes, sir.

Senator Bate. And then it is put in a mold?

Mr. Mrleter. Yes, sir; it is then placed in tubs and made in prints and rolls.

This is a petition from the South St. Paul Live Stock Exchange:

"To the honorable the Senate and the House of Representatives of the United States: 
"Your petitioner, the South St. Paul Live Stock Exchange, respectfully represents to your honorable body that it is an association of livestock dealers engaged in buying and selling, feeding and shipping, and slanghtering live stock, and was organized, among other things, for the purpose of promoting the best interests of the live-stock industry of the Northwest, jealously guarding the interests of the producer and consumer alike.

"Your petitioner, in behalf of its constituency, desires to enter its emphatic protest against the enactment of House bill No. 6, introduced by Mr. 'Tawney, providing for a tax on the manufacture and sale of oleomargarine. In support of this protest, a few of the many reasons that might be mentioned are hereinafter set forth."

I will say just here that this petition was drawn when the former bill, the Tawney bill, was before the House more prominently than the Grout bill. That bill was practically the same as the Grout bill, and the petition would of course apply to any further legislation on butterine.

The Ciramman. 'That we will print with the rest.

Mr. Millerr. Yes, sir.

The Chimirman. There is no need to read it unless you care to do so.

Mr. Miluer. Very well, if the committee would not like to hear it. Senator BATE. I think that you had better read it.

Mr. Mrluer. All right. The petition proceeds:

"The measure is a species of class legislation of the most dangerous kind, calculated to build up one industry at the expense of another equally as important. It seeks to impose an unjust, uncalled-for, and unwarranted burden upon one of the principal commercial industries of the country. Manufacturers can not assume this added burden and continue to sell their product in competition with butter. The passage of this measure wonld throttle competition, render useless the immense establishments erected at a great expense for the manufacture of oleomargarine, deprive thousands of employees of the opportunity to gain a livelihood, and deny the people, and especially the working people, a wholesome article of diet.

"The butter fat of an average beef animal for the purpose of manufacturing oleomargarine is worth from $\$ 3$ to $\$ 4$ per head more than before the advent of oleomargarine. This has increased the value of the beef steer and consequently to the profit of the producer.

"To legislate this article of commerce out of existence, as the passage of this law would surely do, would compel slaughterers to use this fat for tallow, and depreciate the market value of beef cattle of this country $\$ 3$ to $\$ t$ per head, which would entail a loss on the producer of this country of millions and millions of dollar's.

"The use of this fat for the purpose set forth is an encouragement to the producer to improve his herd and raise a class of thoroughbred cattle capable of carrying the fat, and thus resulting in a benefit to all.

"The rights and privileges of the producers of beef cattle should be as well respected as those of other's, and as they are the beneficiaries in the manufacture of this wholesome article of food they should not be burdened with umnecessary special taxes levied avoredly for the purpose of prohibiting its production.

"The product of the beef steer should receive at the hands of Congress no greater exactions than are imposed on competing food products. The manufacture and sale of oleomargarine is already surrounded 
with numerous safeguards which Congress in its wisdom has seen fit to provide.

"Experience has taught us that it is just what a large majority of the people in this country want, and in behalf of the producer's and consumer's of the great Northwest we do solemnly protest against the cnactment of legislation calculated to ruin a great industry.

"Charles L. Haas,

"President South st. Paul Live Stock Exchunge.

"H. B. Carrolit,

"Secretary South St. P'unl. Live Stock Exchange."

These are resolutions passed by the 'T'exas Cotton-Seed Crusher's' Association:

"Deal Sn: At a meeting of the Cotton-Seed Crusher's' Association, held in Dallas on Tuesday, Norember 14, 1899, T. P. Sullivan, of Jefferson; R. K. Erwin, of Waxahachie; W. R. Moore, of Ardmore, Ind. T., and Robert Gibson, secretary, of Dallas, were appointed a committee to draft resolutions expressive of the sense of the meeting on the matter's discussed. The resolutions as submitted were manimously adopted, and are as follows:

\section{"Marion Sanson, Chaimun:}

"The undersigned committee appointed by you beg leave to submit the following preamble and resolutions:

"TVhereas the line of industrial business represented by this association is coextensive with the entire area of the cotton eultivated zone of our Southern States, and in conjunction with cotton in its various uses, represents the wealth of the South; and

"Whereas Texas represents over 30 per cent of the cotton and eotton seed annually produced in the United States, any embargo placed by legislation on the growth and development of our industry is detrimental to the vast interests committed to our care. It is therefore of most vital necessity that all arenues leading to the sale and consumption of our cotton-oil products should be free and unrestricted, and inasmuch as cotton oil is used to a large extent in the manufacture of butterine, which is a most wholesome and healthful substitute for butter"; and

Whereas a tax at present exists of 2 cents per pound on the manufacture of this most healthful article of food, and that it is contemplated to introduce at the next session of Congress an increased tax of 10 cents per pound on sanre: It is, therefore,

"Resolved, That this association enter" its protest against the existing tax of 2 cents per pound on butterine and ask for its abrogation and repeal, and against the introduction or adoption of any future tax on same as an article of food, as it directly affects our great industry both at home and on the continent of Europe, where a cheap and wholesome article of food, such as butterine, is appreciated.

"Resolved, That we believe the imposition of a special tax of this nature is class legislation and should be combated by all the means at our command, and that our Senators and Representatives in Congress are hereby requested to give us all the necessary aid in this behalf; and it is further

"Resolved, That the secretary of this association transmit a copy of these resolutions to each cotton-oil mill in the South, with the request 
that ther interest their Senators and Representatives therein, and also to our Senators and Representatives in Congress from Texas.

$$
\begin{aligned}
& \text { "T. P. Suldran, Chaiman, Defferson, Tex. } \\
& \text { "R. K. Enwr, Waxalachie, Tex. } \\
& \text { "W. R. Moore, Ardmore, Ind. T. } \\
& \text { "Robert Grbson, Secretary, Dallas, Tex." }
\end{aligned}
$$

Senator Warren. May I ask a question at that point? You are exporting oleomargarine to some extent?

Mr. Mirlekr. Yes, sir.

Senator. Warren. Can you give us some idea of the percentage of the total amount manufactured that is exported?

Mr. Miller. About 3,000,010 pounds were exported last year.

Senator Proctor. Out of what quantity?

Mr. Miller. Out of 107,000,000 pounds.

Senator Bats. Where does it go?

Mr. Mrumer. Most of it to southern tropical elimates. It is sold in countries where the climate is too warm to permit butter to keep. We can pack butterine in hermetically sealed tins, and it will keep for two or three year's perfectly sweet.

Senator Warrex. Have you been exporting it right along?

Mr. Miller. The have been doing some export business for the last few years.

Senator Warrex. Is that business growing or is it not growing?

Mr. Mrluer. It is not growing very rapidly. The territory, of course, is limited.

Mr. SPRINGER. Do you get a rebate of the tax when you export it? Mr. Mrliter. Yes, sir.

Senator Warrex. I wish to ask another question which is not in connection with that point.

Mr. Miluer. All right.

Senator Warren. Have you erer given the matter any attention as to the sensibility of the product which you manufacture and that of butter in taking in the odor's of impurities that are surrounding it: for instance, in some close mining eamp or outpost. Butter, as we all know, takes on any odor that may be existing and becomes rancid very quickly from exposure. Do you claim that oleomargarine is more hardy or less so?

Mr. Mrllek. It is much more so. It will, perhaps, take up foreign odors. For instance, if you ship a tub of butterine in a car of oranges, of course, by the time the butterine reaches its destination it will taste like oranges instead of butterine; but it will keep much longer than butter. You can put a package of butterine in a room and let it stay there for three or four months, and it will be perfectly sweet. It never gets rancid. It may have lost the butter flaror. but it is still sireet.

'The Chammax. How about kerosene? Does not that taint it!

Mr. Millter. Oh, yes, sir.

The Cramman. And rery quickly, I suppose. It will taint either butter or butterine.

Senator BATE. What do you mean by the rebate you were asked about!

Mr. Mrluer. We pay 2 cents a pound tax, you understand, on domestic goods. Of course, in case we ship out of the country we get the 2 cents a pound back. 
Senator BATE. On what principle-the reeiprocity treaty?

Mr. Thiminghast. It is a provision in the original oleomargarine act.

$\mathrm{Mr}$. Milier. It is in the original oleomargaine act of 1886 .

Senator Bate. You get a rebate under that act?

Mr. Mlluer. Yes, sir: it is simply a drawback of 2 cents a pound.

Senator BATE. Then, in point of faet, you pay no tax on it? You get the tax back?

Mr. Miller. No, sir; we pay no tax on the export.

Senator Bate. And you pay a tax of 2 cents a pound on what you sell here?

Mr. Mruter. On all that is sold for domestie use.

Senator Bate. But you do not have to do that on exports?

Mr. Millekr. No, sir.

Senator WARREN. It is the reverse of the ordinary tariff.

Mr. Miliser. As a matter of fact, it is a fine of 2 cents imposed by the dairy interests on the article sold here, while when exported it does not interfere with the dairy interests and we get a rebate.

Senator BATE. The law is more lenient to the man who lives abroad than at home.

Mr. SPRINGEr. It is the same as the internal-rerenue tax on whisky. That tax is taken off of whisky when it is exported.

Mr. Mnlmer. This is a resolution passed by the Sioux City Live Stock Exchange:

"Whereas a bill has been introduced in the House of Representatives known as House bill 6, providing' for' an amendment of 'An act defining butter, also imposing a tax upon and regulating the manufacture, sale, importation, and exportation of oleomargarine;' and

"Whereas such a bill, if enacted, is calculated to build up and restore one industry at the expense of another by means of unealledfor and unjust taxation; and

"Whereas the destruetion of the oleomargarine industry would greatly impair the market value of beef cattle, and would thereby deprive the producer of a large amount of revenue: Therefore, be it

"Resolved, That the Sioux City Live Stock Exchange of Sioux City, Iowa, emphatically protests against the enactment of the law proposed in House bill No. 6 .

"Witness the signatures of the president and secretary of said exchange and the official seal thereof affixed at Sioux City. Iowa, December 28, 1899.

"J. H. Nason, President.

"Wir. Magivny, Secretary."

The Cinamian. If you have other resolutions, will it not answer your purpose to have them inserted in the record and printed without reading them?

Mr. Miller. That will be satisfactory. These are resolutions passed by the superintendents of the oil mills of North and South Carolina:

SUPERINTENDENTS OF OIL MILLS IN NORTH AND SOUTH CAROIINA.

Resolutions against oleomargarine tax offered at meeting of cottonoil mill superintendents.

"Charleston, S. C., July 6.

"Cotton oil superintendents from South Carolina and North Carolina met yesterday at the Calhoun Hotel for the purpose of organizing the cotton-oil mill superintendents' association. 
"After the constitution and by-laws were read and adopted, the following resolutions were offered by $\mathrm{A}$. A. Haynes:

.. Resolved, That this assoriation, representing millions of dollars of invested capital in the Sonth, strongly protest against national class legislation which aims directly at the destruction of competition in the manufacture and sale of wholesome and healthful articles of food.

"Resolved, That we protest strenuously against the passage by Congress of the Grout oleomargarine bill, which proposes to tax oleomargarine 10 cents per pound, and thus to drive it from the market.

".Resolved, That this association implores Congress not to destroy an industry which now uses nearly 10,000,000 pounds of the best grade of cotton-seed oil annually, and thus kill that quantity of our most profitable output.

.. Resolved, That we urge the legislatures of South Carolina and of other Southern States to remove from their statute books the antiolcomargarine legislation thereon, because such acts are only in the interest of the renorated and process butter factories of the North and Northwest, and against the hog fats, beef fats, and cotton-sced-oil products grown on our Southern farms.

-. Resolied, That a copy of these reselutions be sent to the National Provisioner, of New York and Chicago, the indomitable champion of the cotton-oil interests, for publication, and that the members of this association proceed to secure, if possible, the repeal of the obnoxious State laws above referred to.

"Resolved, That this association will do what it can to cause the defeat of the Grout antioleomargarine bill in Congress during the coming session."'

This is a resolution passed by the Mereantile Club of Kansas City, Mo.

Senator Bate. They are all to the same purport?

Mr. Miller. Yes, sir.

KANSAS CITY, KANS., MEICANTILE CLUB.

The Mercantile Club, Lansas City, Lans., March 14, 1900.

At a recent meeting of the Mercantile Club the following resolution was adopted:

"Whereas bills have been introduced in the Senate and House of Representatives as follows: H. R. No. 6, by Mr. Tawney, of Minnesota; H. R. No. 43, by Mr. Davidson, of W'isconsin; H. R. No. 3717, by Mr. Grout, of Vermont; H. R. No. 64t5, by Mr. Glynn, of New York; H. R. No. 2049, by Mr. Allen, of Nebraska, increasing the present tax of 2 cents a pound on butterine to 10 cents per pound; and

"Whereas such legislation, if enacted, is calculated to build up one industry at the expense of tearing down and ruining another, and will in effect amount to the giving of a monopoly to the industry sought to be benefited by such legislation at the expense of another by means of uncalled-for taxation; and

"Whereas the destruction of the oleomargarine or butterine industry would greatly impair the market value of beef cattle, doing great injustice to eattlemen of Kansas, and would be a serere blow to the manufacturing interests of Kansas City, United Stites of America: Therefore, be it 
"Resolved. That the Mercantile Club of Kansas City, Kans., protest against the enactment of the law proposed in said bills, to the end that just competition in the manufacture and sale of food products be maintained."

We ask rour "areful consideration of the same, believing, as we do, that the subject is one of great importance. The sale of butterine is already regulated by the aret of 1886 , and an increase in the tax would simply kill a great industry, in which millions of dollars are inrested and many thousands of mein employed. Therefore, we feel confident that on examination you will find inany more people benefited by the furnishing to them of a wholesome and attractive substitute for liutter than conld possibly he benefited by the giving of a monopoly to the dairy interests.

$$
\text { Tours, very truly, IV. E. Griffith, Secretary. }
$$

Here are resolutions passed by the Commercial Chub of Kansas City:

KANSAS CITY, MO., COMMELCIAL CLUB.

"To the lemorable the semats and the House of Representatives of the Thied Stutes:

"The Commereial Club of Kansas City respectfully represents that it is an organization composed of over 700 business men of Kansas City, Mo.; that the business interests represented by its members comprehend the principal jobbing and manufacturing plants of Kansas City. The population of Kansas City and its adjacent territory, comprising one commereial eity, is nearly or quite 300,000 , and within a radius of 100 miles there is a population of $3,000,000$. Kamsas ('ity occupies the tentl place in the amount of bank clearings in this country. We have nine states and Territories that regard Kansas City as their banking center. The commercial oreanization is constantly watchful in adrancing the commercial interests of Kansas City, and seeks to protect these interests when threatened by adverse legislation. As an association it desires to enter its emphatic protest against the enactment of H. R. bill No. 6, which was introdued in the House of Representatires December t, 189!:. Wy Mr. Tawney, of Minnesota, providing for an enactment of 'An act defining butter, also imposing a tax upon and regulating the manufiseture, sale, importation, and exportation of oleomargairine; that this measure, if passed, will build up one industry at the expense of tearing down and ruining another industry, and will in effect amomit to the giving of a monopoly to the industry sought to be benefited hy such legislation: that the bill above referred to, if it becomes a law, will reduce the value to the farmers and raisers of cattle an arelage of $\$ 2$ per head and a corresponding decrease in the value of hogs.

"The use of the fat of beef, as well as the use of thousands of gallons of milk daily, and the other fats used in making oleomargarine, not only increases the value of every beef animal, but every milch cow and every hog, and acts as an encouragement to the owner and raiser of eattle and hogs to improve his herd and raise the grade of his live stock so that they will carry more of this animal fat and will in the end raise the standard and the grade of cattle and hogs throughout the entire United States. The farmers and cattle raisers of the United States are directly interested in such legislation as depreciates the value 
of every animal that they now own and every animal that should be raised licreafter.

"It is but just that the rights and privileges of the produccrs of cattle and hogs should be duly considered and respected as well as shonld the desire of a certain class whose only object and purpose in lecgislation of this kind is to decrease the supply of butter substitutes, thereby increasing the demand for butter and the price thereof.

"Oleomargarine, as now manufactured, is just as wholesome as butter, and many chemists have declared it to be even more so. It is surrounded by the numerous safeguards which Congress has seen tit to provide, and it is a cheap, pure, and wholesome substitute for butter. Its cheapness in price allows it to become a substitute for expensive butter, and it is used by millions of poor people in the United States who are unable to pay the price demanded for creamery product.

"Oleomargarine has by experience proven to be just what a great majority of the people in this country want, and in the name of the producers of eattle and of hogs we do solemnly protest against the enactment of legislation calculated to cheapen the price of eattle and hogs, ruin the manufacture of oleomargarine, and deprive countless thousands of poor people from the use of a cheap but wholesome, nutritions, and acceptable article of food.

"Marieli 8, 1900."

- E. M. Clendening, Secretary.

Are there any further questions that any Senator would like to ask me?

Mr. Schell. You spoke a monent ago of a resolution in favor of the dairy interests emanating from the same source.

Mr. Milleer. Yes, sir.

Mr. Schell. Is that true of these resolutions which you ale offering?

Mr. Miller. No, sir; they were spontaneons.

Senator Hansbrodgr. Nompolitical?

Senator Bate. How is that? I did not get your question.

Mr. Scriell. I asked whether the same rule applied to these resolutions that Mr. Miller had said applied to the resolutions emanating in favor of dairy interests, all from one source. He said no, that they are from different sourees and are voluntary.

Senator Hansbrough. Congressman Tawney, in a speech in the House, said very positively that the most strenuous efforts were made in his district to defeat him on account of the fact that he was a friend of the Grout bill.

Mr. Miller. I will say that I am thoroughly familiar with all that has gone on among butterine manufacturers, and there never was an effort of any description exerted in Mr. Tawney's district to defeat him.

Senator Haxsbrough. It is simply a question of veraeity between Mr. Tawney and yourself.

Mr. Milier. I do not think we have a friend located in Mr. Tawner's district. 'There never was a letter written that I know of, or any influence brought to bear upon a man in opposing him.

Senator Bate. There was in other districts, I suppose?

Mr. Miller. None whatever. We have no political organization to try to elect member's to Congress who are in faror of our interestsnone whatever. 
Senator Haxsbrough. What would have happened to Mr. Cowherd in Kansas City had he proclaimed himself in faror of the Grout hill?

Mr. Miller. I do not know what would have happened. I know if the packer's had not come to his rescue he would have been hopelessly snowed under. He was the only Democrat elected in the county. We were taking no part in electing any candidate on either side, but as Mr. Cowberd had expressed himself as favoring our interests we felt it our duty to come to his rescue.

The Chambuan. You roted, I hope, for some one, did you not?

Mr. Miller. Yes, sir; I did; but we made no attempt whatever in the last year to elect any one to Congress who farored our interest.

Senator Bate. 'Then you voted for' your interest, not on principle, in that case?

Mr. Miller. Yes, sir; in that particular case we did.

\section{STATEMENT OF JOHN C. M'COY.}

Mr. McCor. Mr. Chairman and gentlemen of the committee-

Senator Haxsbiougir. Do you represent a mannfacturing industry, or do you appear as attorney for a manufacturing industry?

Mr. NcCor. No, sir; I am not an attorney. I am simply an individual - a private citizen-and I am here, as I will state to you directly, in two capacities. I will say that I have been handicapped all my life by the misfortme of not being able to express my feelings in public the way I should like to do. I am not a public speaker, and I therefore ask the privilege of reading what I have prepared on this subject.

The Chamman. Certainly.

Mr. McCor. I will say also that I hare been rery badly handicapped since I left Kansas City a few days ago, as I have been quite sick ever since, and I have had rery little time to make any preparation whaterer.

I wish to say, gentlemen, that I appreciate the honor of being permitted to appear before your committee, and regret my inexperience and lack of ability will prevent me from presenting my views on this important subject as I feel them. I am here before you in a dual capacity - as an individual, a Western farmer, stock raiser, a commission merchant for the sale of cattle, hogs, and sheep, and as a representative of the Kansas City Live Stock Exchange, the member's of which handled during this year of 1900 over $6,000,000$ head of live stock, valued at over $\$ 125,000,000$. I feel that the importance of the industry with which I am connected and the most important bearing the bill under discnssion will have on it should be sufficient apology for my trespassing upon your time.

I am at a loss, however, gentlemen, to know what to say to you. Since the first introduction of the Grout bill in the House up to the present time the matter has been so thoroughly discnssed in the public press, before committees, by a flood of literature of all kinds, that it does not seem possible that a new argument could be presented, though I know there are many, like myself, desirous of doing all possible to prevent what seems to us so unjust a measure.

Because I have taken such a deep interest in the matter the field seems to have been thoronghly corered. A large number of the most celebrated chemists of this country, including Prof. H. W. Wiley, Chief Chemist of the United States Department of Agriculture, have 
testified that the ingredients of oleomargarine are healthful and nutr.itious and that the product contains nothing deleterious to health. The same gentlemen have also testified that the coloring matter used in its manufacture is the same that is used by the maker's of butter all orer this country, and it is used by both for the same purpose. The manufacturers of the article have testified under oath time and again as to what ingredients go to make up the product until it has become known to almost every intelligent man in this country. Its purity and cleanliness are, I believe, unquestioned, even by its opponents, the creamery butter manufacturers, and a committee of your own body, the United States Senate Committee on Mamufactures, of which the Hon. W. E. Mason was chairman, after a most thorough investigation of the subject, reported "that the ploduct known as oleomar"garine is bealthful and nutritions, and no further legislation is necessary," and the great mass of testimony taken by that committee is arailable to this committee.

All of this being well known to your honorable body, or at least matters of public record, what can I add to the argument why this bill shourd not become a law? Possibly nothing hut to add my rigorous protest in the name of the stock raiser's of the great IVest against the passage of such selfish, unjust, and ultra class legislation.

I admit that we of the IVest are hardly up with the times and are slow to take hold of and adopt all the new-fangled notions that are so rapidly brought forth in this age of progress, but having been taught from our infancy to lore our country and honor the Constitution, God forbid that we should ever cast aside the clause that "gives equal rights to all and special privileges to none" and take up with the spirit of class legislation such as is attempted and exemplified in this bill.

I do not think there is any sane man who has giren this bill any serious consideration whatever but believes that this bill is aimed at the life of the oleomargarine industry, to legislate it out of existence, so as to gire the butter makers (and hy the hutter maker's I do not mean to say the great mass of farmer's and farmer's wives who make butter, for they cut little figure in this matter) exclusire right to produce an article of diet to be spread upon hread to make it more palatable, to gain a monopoly on one of the most ralued necessities of life. It has been asserted by those that have inrestigated the subject that in the average household butter comes second in the expense list for provisions.

It is larger than the outlay for bread or coffee or sugar, and is exceeded only by the meat bills. One of the most serious problems before the American people to-day is the one of trusts and monopolies.

Howerer much political economists and intelligent men may differ. on that great subject, most serious consideration should be given before a way is prepared whereby such an important article, one that comes into the daily life of the rich and poor alike, whether it he upon the dainty rolls of the millionaire or the coarse but wholesome corn bread of the laborer, can be made the subject of absolute control in the hands of mercenary men.

Legislate out of existence practically their only competitor, oleomargarine, and would not the cremmery interests be able to control the supply of butter in this country as it is now claimed they are able to control the price of creamel'y hutter?

A more thorough organization nor a more extensive one does not S. Rep. $2043-5$ 
exist to-day than that of the creamery associations, as we have discovered by their work in favor of this bill out West.

The gentleman who just preceded me has told you of the methods that have been used by the ereamery interests in furthering their own interests by mixing into politics. I know it to be a fact that almost every little creamery on the prairies of Kansas and Nebraska has been flooded for a year with all sorts of literature and postal cards urging them to write to their Congressmen and Senator's to support this Grout bill, and if the members of this committee are flooded with requests of that character from their constituents they may know exactly where they have emanated.

Senator Hansbrough. Where have they emanated?

Mr. McCor. From the National Dairy Association headquarters at Chicago.

Conscious of their power and organization I think the gentlemen deserve eredit for not framing their bill as follows:

"Be it enacted by the Senate and House of Representatives of the United States of America in Congress assembled, That all articles known as oleomargarine, gravy, goose grease, or any substance to be spread upon bread to make it palatable, as good as butter or eheese, not the usual product of the dairy and not made exclusively of pure and unadulterated milk and crean shall be absolutely prohibited," etc.

Although this bill is aimed at the life of the oleomargarine industry, we believe that it will if enacted into a law seriously cripple one, with which by comparison both oleomargarine and its opponent butter pale into insignificance, that of the live-stock industry. Neither myself or the people I represent are direetly interested in the manufacture of oleomagarine or of butter, and interested only so far as our interests are affeeted and our inherent love of personal liberty and freedom, but we ask you gentlemen not to allow one great industry to be ground between the warring factions of these two opposing industries. It has beeome a matter of general information, and is also in evidence before this eommittee, that the two principal ingredients of oleomargarine are the caul fat of the beef steer and the leaf fat from the hog.

Senator Bate. What do you mean by caul fat?

Senator Waliren. It is kidney fat, the best quality.

Mr. McCor. It is kidney fat, and, as Mr. Miller, who just preceded me, explained, it is purer fat, a higher grade of fat.

Senator BAtE. That is what he said, but he did not give it the name of caul fat.

Mr. MIcCor. The arerage beef steer contains about 50 pounds of caul fat, and the average hog about $S$ pounds of leaf fat. The market price to-day for eaul fat for oleomargarine purposes is about 10 cents per pound, while tallow is worth about 6 cents: and the leaf fat for oleomargarine purposes $S \frac{1}{2}$ cents per pound, and for lard only 6 cents. 'Those are very elose approximate values.

There has been slaughtered in Kansas City since January 1, 1900, to date over $1,000,000$ cattle, producing, approximately, $50,000,000$ pounds of oleo oil, worth to-day for oleomargarine purposes 10 cents per pound, or $\$ 5,000,000$. W Were it not for the demand the manufacture of oleomargarine has created for oleo oil, this product would have been sold for tallow at 6 cents per pound, netting $\$ 3,000,000$, a difference of $\$ 2,000,000$, or $\$ 2$ per head for each animal slaughtered.

During the period just mentioned there were slaughtered at Kansas 
City approximately $3,000,000$ hogs, producing about $24,000,000$ pounds of leaf fat, worth for oleomargarine purposes, at $8 \frac{1}{2}$ cents per pound, $\$ 2,040,000$. The demand for this product as an olcomargarine ingredient remored, it would have been sold for lard at 6 cents per pound, or $\$ 1.440,000$, a difference of $\$ 600,000$, or 20 cents per head for each hog slaughtered.

Had it not been possible to use these two products for oleomargarine purposes instead of tallow and lard, it would have cost the farmers mirketing their stock at Kansas City this year \$2,600,000. The same is true at all the principal live-stock markets in proportion to their receipts. The five large Western markets-Chicago, Kansas City, St. Louis, Omaha, and St. Joseph-have handled sinee January 1,1900 , to date, $6,500,000$ eattle and $16,300,000$ hogs. Of that number at least $75 \mathrm{per}$ cent of the cattle, or $4,875,000$, were slaughtered, and practically all of the hogs. A difference of $\$ 2$ per head on the cattle and 20 cents per head on the hogs would mean a loss to the Western farmers on their marketing of eattle and hogs for the year 1900 of $\$ 13,000,000$. But, gentlemen, carry the reasoning still further. The Government report shows that on January 1,1900 , there were in the United States $27,610,000$ cattle other than milch cows, or cattle available sooner or later for beef. A depreciation of $\$ 2$ per head on them would mean $\$ 55,220,000$. The same authority gives the number of hogs in the United States on January 1, 1899, approximately, 38,650,000.

The Chalruan. Would it reduce the value of the milch cow to have the manufacture of oleomargarine stopped? I thought you included all the cattle.

Mr. McCor. No, sir; I included only the eattle other than milch cows. The Government makes a distinction. It would reduce the ralue of the milch cow, because the ultimate destination of all cattle is the block. Milch cows are used for a long time for milk purposes, but unless they should happen to die of old age, which the farmer generally sees is not the case, the ultimate destination of the milch cow is the block.

Senator Walrenen. You have entered into a calculation as to the price of cattle other than cows. We assume, without your stating it, that when a cow comes to the block she brings relatirely that much more, whether $\$ 2$ or $\$ 1$. Now, on the other side of the question, I want to get your opinion as to what the effect is liable to be upon the price of cows if the manufacture of oleomargarine is continued or if it is discontinued. Would the discontinuance of the manufacture of oleomargarine raise the price of eows; and if so, how unth? Would the continuance of the present amount manufactured, or double the amount, we will say, reduce the price of cows, and how much, in rour opinion?

Mr. McCor. In my opinion it would reduce the ralue of the milch cow at the same time that it reduced the ralue of the beef steer.

Senator Warizen. No; you misunderstand me. I want to know whether the manufacture of oleomargarine reduces the price of the cow.

Mr. McCor. No, sir.

Senator WArRex. In other words, do you consider that through the manufacture of oleomargarine you are reducing the price of butter on the market to a point that will reduce the price of the cows that produce the butter?

Mr. McCor. I think I ean answer that question, if the Senator will allow me, by a statement on that line that I made before the House committee. 
Senator IVARREN. In the concrete, I want to know if the sale of oleomargarine is lowering the price of butter, or displacing the sale of butter, or reducing the price of cows.

Mr. McCor. You mean the price of cows instead of the price of butter?

Senator WARrex. Yes; a reduction in the price of butter through the manufacture of oleomargarine would, of course, reduce the price of cows naturally.

Mr. MoCor. I think this will answer the question:

The Orange Judd Farmer, published in the State of New York, an agricultural jomrnal of exceptionally high standing, and one that has enjoyed the confidence of the agricultural community for a decade, in a recent issue says:

"Cows are worth 50 per cent mole now than during the ten years preceding 1897 , and are fully as high as during the boom of 188t-85."

Is that along the point?

Senator WARren. That is along the point, but it does not touch it exactly yet.

Mr. MIcCor. The article proceeds:

"Last summer cheese got back to old-time prices. Butter has of late sold much above the quotations of four or five years ago. Even milk sold in market is stiffening in prices and may go up to those of the early eighties, and will go there with organized persistency by producers and reasonable cooperation from the trade."

Senator WArris. 'That, I understand, is with reference to the condition of the business, but not with reference to the effect of the manufacture of oleomargarine. That is from some report?

Mr. McCor. No. "But during the period when we had a boom and increased the value of milk and butter and cows"

Senator WARren. What are you reading from, please?

Mr. McCor. I am reading an extract from the Orange Judd Farmer, and that same paragraph or article is in the report of the House committee.

Senator WarRex. What is the pamphlet from which you are reading?

Mr. McCoy. It is a statement of evidence before the House committee.

A reduction of 20 cents per head on the hogs of the United States would mean a loss of $\$ 7,730,000$. 'Thus it will be seen that if this bill becomes a law the stock raisers of this country will suffer a depreciation in the value of their property of $\$ 62,750,000$. By what course of reasoning ean the creamery interests ask us to suffer a depreciation of almost $\$ 63,000,000$ in our property that they may gain an advantage over a fair and honorable competitor? Why should my State, the State of Missouri, sutfer a depreciation of $\$ 2,7-5,230$ on its beef cattle when it has only 659.731 milch cows all told! And so, gentlemen, each member on this committee. I care not from what State he comes, catn take the number of cattle in his State and in two minutes figure what the loss to his cattle-growing constituents would be.

I ask you, gentlemen, in all candor and faimess, is it right that this Govermment should come in by its lawmaking power and legislate in favor of one section as against the other? For the cattle-growing States and the dairy States are almost as elearly defined as if the one was red and the other blue on the map. Or should they legislate in favor of one agricultural industry as against the other! "For' every ingredient 
that enters into the manufacture of oleomaragarine is as much a product of the American farm as is the milk from which cow butter is made. If a precedent is set by the enactment of this bill into a law, will not our friends from the South introduce a bill at the eoming session of Congress as follows?

"Be it enacted by the Senate and ITouse of Representatives, etc., That all sugar known as bect sugar, or any substance in the semblance of sugar not the usual product of the old, time-honored sugar cane, be taxed 2 cents per pound unclarified and 10 cents per pound when clarified a beautiful white in imitation of genuine cane sugar, as it is now clarified to meet the tastes of the consumer."

Or' will not the r'ubber manufacturer's ask that the manufacturers of celluloid goods be prohibited from making any article in imitation of rubber? And so, gentlemen, where will such legislation end? These gentlemen ask you to prohibit us from using three or four of the pure, healthful, and nutritious products of our farms and ranges, blending them into a palatable article of diet to be used, when a man wants to do so, in the place of cow butter. And yet the same gentlemen, or rather the principal dairy States, will take the cotton and wool that we raise and, by dipping in certain solutions, so change its texture that it can be woven into most beautiful fabrics that they send to us unsophisticuted people out West to be used in the place of silk. The gentlemen object very strenuously to the use of the word "butterine" as tending to deceive, and yet they call this beautiful slick and shiny goods "silkaline."

The advocates of this bill object to taking the same ingredients that enter into the composition of cow butter (though in a different form) and componnding them into an article of food in erery way as good, but the same gentlemen will take a small portion of the wool from our Western sheep, mix it with a very large proportion of Sonthern cotton, and send it back to us gullible Westerners as being all wool and a yard wide.

Much has been said on both sides of this question in regard to the color in oleomargarine and in cow butter; and I believe it has been conceded that both interests use the same material for that purpose, and both use it to accomplish the same ends-that of giving to the consumer something that he wants, something that the Constitution gives him as a free-born American eitizen the right to use, so long as it does not injure him nor trample upon the rights of others, and something that will make his bread go down with that pleasing sense of satisfied taste so essential to good digestion and preservation of health and life. To assert that food taken to nourish does not have to be pleasing to the eye as well as to the taste seems ridiculous and reflecting upon the common sense and intelligence of this committee. If it were not so I will ask the gentlemen on the other side why they do do not use the good old-fashioned brown sugar, usually a good, rich. dark brown-the color of mahogany-that possesses strength and flavor far beyond the clarified pure-white sugars of the present day. I will guarantee our friends here, the adrocates of this bill, have used none other than the pure white sugar for years. You all know why they use it, and so do they. They prefer it of that color as being more pleasing to their taste and better satisfying their pride. People want oleomargarine and butter colored yellow for the same reason. 
There is one subject on which I may be able to give the committee some information, and that pertains to the purity and healthfulness of the two principal ingredients of oleomargarine--that of the cone fat and the leaf fat. Under the most excellent system of governmental inspection inangurated a few year's ago by the Bureau of Animal Industry, the liability of diseased cattle and hogs being used for food has been reduced to a minimum. On our market, and the same is true at all other large abattoirs (exeept in Chicago a little different but I believe a more stringent method is used), Government inspectors who are under a chicf, who has to be a graduate of a veterinary college and stand an examination, go throngh the stock yards and take from the eattle received all such as show signs of any disease or as in any manner unfit for human food. As cattle are sold and go to the seales two of these inspectors examine them as they pass between them and cut out and eondemn all that in their judgment should be. After the cattle go to the slaughtering establishment they are again given an ante-mortem inspection. After they are killed they are again given a post-mortem inspection, and if found healthy and free from any disease that would be injurions or a menace to the public health, a certificate of inspection is placed on each carcass. The same is true of hogs, except the certificate is not placed on the carcass.

So I am here to-day, gentlemen, to assert with all the force that I am able to command that when either our cow-butter friends or the agrarian party in Germany, both of whom seem inclined to strike a blow at the eattle products of this country, claim an inferiority or unhealthfulness of those two principal ingredients of oleomargarine or the meat products of this comntry, they perpetrate a base slander and not warranted by the faets. Your own Department of Agriculture in its Yearbook published January 1, 18:99, said the health of animals and of men is rery largely dependent upon the use of sanitary precautions and the enforcement of sanitary regulations. As a certain disease (therein named) in animals is reduced, so will that disease in man be proportionately deereased. Along that line we are ready to meet our butter and creamery friends at any time. I understand that the present tax of 2 cents per pound on oleomargarine brings in a revenue to the Gorernment of about $\$ 2,000,000$ per annmm. Oleomargarine destroyed, the factories closed, it having become so generally known that the eool fat from every steer and the leaf fat from every hog can he so used by any ordinary intelligent man, would not our creamery operator's, if not a large number of farmers, take advantage of the situation, oleomargarine be still extensively made, and the Govermment be deprived of the revenue? What means will be taken to see that it is not done?

The cattle growers of this conntry have never but once, so far as I know, had to appeal to the Congresis for protection of their industry, and that was a few year's since when we appeared before the agricultural committees of both Houses to ask for relief against foreign embargoes on American meats. I am glad to say that I see here to-day several member's of this committee that were present at that hearing. But I say, gentlemen, that the cattle-growing States of this country, which are largely of the West and Sonth, are watching with anxious eyes the onteome of this measure. They would keenly feel the effect of such legislation, and I do not believe our creamery friends, or, to put it more plainly, the dairy States, are in a position to thus injure us. 
Germany and several other Enropean countries have already shut out our canned meats and serionsly hampered the free importation of our cattle and dressed meats. They have a measure now before the Reichstag to exclude American wheat, which would seriously tonch the hearts and purses of farmers of Minnesota, Wisconsin, Illinois, Nebraska, Kansas, Idaho, the Dakotas, and California. And as they are gradually shutting ont one of our great industries after the other, can our butter-producing people expect to escape for very long? Fights between competing industries are not desirable at this time, but rather a united people, for in union there is strength, and it will take, within the next few years, the united efforts of the producing portion of this most wonderfully productive country to combat the jealous and selfish interests of the less favored nations on the globe. Let us be fair and just to one another, and be the better prepared to combat a common enemy.

Mr. Chairman, I just wish to file the resolutions and the memorial of the Kansas City Live-Stock Exchange, of which I am a representative.

\section{The Kansas City Live-Stock Exchange, Kansas City, Mo., February 8, 1900.}

The following preamble and resolutions were unanimously adopted by the board of directors of the Kansas City Live-Stock Exchange at a regular meeting held February 5, 1900:

"Whereas certain bills have been introduced in the House of Representatives of the United States looking for the enactment of a law, by way of taxation, whereby the manufacture, sale, importation, and exportation of oleomargarine will be ruined; and

"Whereas such bills, if passed and allowed to become laws, will build up one industry at the expense of tearing down and ruining: another, the logical effect of which will be the granting of a monopoly to the industry sought to be benefited; and

" Whereas the destruction of the oleomargarine industry will reduce the value of cattle and hogs to the farmers and raisers thereof, as well as work a hardship upon millions of poor people who are unable to pay the fancr prices asked for butter: Therefore, be it

Resolved, That the Kansas City Live-Stock Exehange, of Kansas City, Mo., earnestly protest against the enaetment of the law proposed relating to olcomargarine; and be it further

Resolved, That the board of directors of this exchange be requested to memorialize the Congress of the United States against the passage of a law or laws inimical to the live-stock industry, and that a copy of these resolutions be sent to the honorable the Senate and the House of Representatives of the United States."

Respectfully, yours,

\section{W. S. Haxnah, President.}

We have addressed the following to the honorable the Senate and House of Representatives of the United States:

"The Kansas City Live-Stock Exchange, located at Kansas City, Mo., respectfully represents that it is an association composed of raisers, owners, and buyer's and sellers of live stock, whose interests extend to and cover a great portion of the West and Southwest of the United States, and whose business, as represented by the individual members 
of the association, deals almost exclusively in the live-stock industry. As an association it desires to enter its emphatic protest against the enactment of House bill No. 6, which was introdnced in the House of Representatives December 4 , 1899, hy Mr. Tawney, of Minnesota, providing for an amendment of 'An act defining butter, also imposing a tax upon and regulating the manufacture, sale, importation, and exportation of oleomargarine.' That this measure, if passed, will build up one intustry at the expense of tearing down and ruining another industry and will in effect amount to the giving of a monopoly to the industry songht to be benefited by such legislation. That the bill above referred to, if it become a law, will reduce the value, to the farmer's and raisers of cattle, an average of $\$ t$ per head and a corresponding decrease in the value of hogs.

"The use of the fat of 'beef,' as well as the use of thousands of gallons of milk daily, and the other fats used in making oleomargarine, not only increases the ralue of every beef animal, but every mileh cow and every hog, and acts as an enconragement to the owner and raiser of cattle and hogs to improve his herd and raise the grade of his live stock so that they will earry more of this animal fat, and will in the end raise the standard and the grade of eattle and hogs throughont the entire United States. The farmer's and eattle raisers of the United States are directly interested in such legislation as depreciates the value of every animal that they now own and every animal that should be raised hereafter.

"It is but just that the rights and privileges of the producers of cattle and hogs should be duly considered and respected as well as should the desire of a certain class whose only object and purpose in legislation of this kind is to decrease the supply of butter substitutes, thereby increasing the demand for butter and the price thereof.

"Oleomargarine, as now manufactured, is just as wholesome as butter, and many chemists have deelared it to be even more so. It is surrounded by the numerous safeguards which Congress has seen fit to provide, and it is a chcap, pure, and wholesome substitute for butter. Its cheapness in price allows it to become a substitute for expensive butter, and it is used by millions of poor people in the United States who are unable to pay the price demanded for creamery product.

"Oleomargarine has, by experience, proven to be just what a great majority of the people of this country want, and in the name of the producers of uattle and of hogs we do solemnly protest against the enactment of legislation calculated to cheapen the price of cattle and hogs, ruin the manufacture of oleomargarine, and deprive countless thousands of poor people of the use of a cheap but wholesome, nutritious, and acceptable article of food.

\section{"Board of Directors of the}

Kansas CitT Live Stock Excirange,

"By W. S. Hannah, President.

-Attest:

\section{"R. P. Woodiulix, Secretary."}

\section{ORDER OF PROCEDURE.}

The Champuan. Who is ready to proceed to-morrow morning?

Mr. WALDEN. Mr. Chairman, if you will allow me just a moment, I will not take any of your time. I desire to be heard extensively on this subject. I came quite a long distance for that purpose, and as 
the time for adjournment is just at hand I should like to be heard after the holidays on this subject. I represent such a rast interest-the Kansas City Live Stock Exchange, of which I am the present presi dent. with perhaps some 400 member's, that loan millions of dollars annually to the cattle growers, feeders, ete. - I say the interest is so large that the few moments allowed now before adjourmment will not give me time to present the evidence.

The Chamman. Allow me to interrupt you. As you have come such a long distance, would it not be better that you should be heard now! We shall be still more busy after the holidays. We can give you a hearing this afternoon or to-morrow morning. The Senate will probably adjourn quite early to-day.

Mr. IV ALDEN. Unfortunately, I am here on another mission that will require all my time during to-morrow.

Senator Hansbrougir. What length of time would you like to have?

Mr. Walden. Possibly an hour or more.

The Cinarman. I have just learned of the death of the wife of the President pro tempore of the Senate, and it is quite likely that the Senate will adjourn immediately, and we can come right back here.

Mr. Siringer. II that is so, it adjourns you over the holidays?

The Chairian. Certainly.

Senator Money. But it does not adjourn this committee.

The Chamman. The committee may remain in session. I will appoint a subeommittee. We shall probably meet this afternoon. I suggest to Mr. Walden that he appear at 2 o'elock this afternoon.

Mr. Schell. May I ask whether the committee will sit during the holidays!

The Chammian. Certainly; it will be obliged to do so.

Mr. Sches... I leave for Cincimnati this afternoon. I want to be heard, and I should like to be heard some time between January 3 and 10 .

The Charrinas. We shall have a hearing on the 3d of January, but the state of business is such that oul hearings then will have to be hurried. It will not be possible to give the time then that we are ready to give now and during the holidays, so that matters will have to be put in writing and go into the record without reading to a considerable extent. The army bill is of pressing importance, and that measure will come up immediately after the holiday recess. Three members of this committee are upon the Committee on Military Affairs. So you can see the urgency which compels us to close this hearing as soon as possible after the $3 d$ of January.

Mr. Schell. Your honor, I see all that, and I appreciate it. However, there is one thing that is apparent to me and apparent to every. member of the committee. It is that there is no organized opposition to this bill. Everybody comes in and talks at random. That condition will continue unless we are allowed some time to organize and get together. We will not be before this committee properly unless we are allowed some time to get together and agree on the objections that should be urged and agree on somebody to present those objections.

The Chamrman. Well, we shall have a hearing the $3 \mathrm{~d}$ day of January. We want to give you all the time we possibly can, you know, and to be just as liberal in that respect as possible. It was for that purpose that I thought we had better have the committee open during the holidays. But still we shall have a hearing on the $3 d$ of January. 
Senator BATE. Mr. Chairman, will you not agree to have hearings later than that date? The proposition yesterday was to keep the hearings open until the 10th of January, and we differed about it. I wanted to have the time extended to the 15 th. I have telegrams waiting to be answered, and the parties desire to be heard the 15th of January.

The Chamman. I do not think it would be right to give that time; that is only six weeks before final adjournment.

Senator BATE. Then what time shall I indicate to them?

'The Cirampun. I think they should appear here on the $3 \mathrm{~d}$ of Jantary; probably we shall not finish the hearing on that date, but we will continue it. I think everybody should be here the $3 d$ of .Jumary.

Senator Bats. Between the $3 d$ and the 10th?

Senator Monex. I have answered the dispatches I have received to the effect that the parties should come at once; that nobody knew when the hearings would close. I received dispatches of the same tenor.

Senator BATE. I expect that I had better state to them that they must be here between the $3 d$ and the 10 th, beeanse the proposition of Senator Allen yesterday was to close the hearing on the 10 th.

Mr. Walden. Am I to understand that the hearing will be continned between the 3d and 10th of Jannary?

The Champman. It will be open on the $3 d$ and continue as long as we think we can give rou time-not later than the 10th, but I think it will be concluded that week. The $3 d$ is on Thursday, and I hope to conclude it that week-in three days.

Semator BATE. But let us understand that, Mr. Chairman, and see what gentlemen desire. I want to know it myself. No one will be shut out or exchuded up to the 10 th of the month, and if we can get through before the 10th we will do it. Let us have that understood.

The Chamman. I am not prepared tosay that. There will be nobody excluded up to some date, say the 6th, corering the $3 \mathrm{~d}$, 4th, and 5th. We shall have to be able to close it in that time, because the hearings have been rery full before the House, and anyone can appear during the holidars and have all the time he wants.

Senator Hansbrovgh. Do I understand that it is the intention of the Chair to appoint a subcommittee to sit during the holidays?

The Chairuan. I will appoint a subeommittee now, consisting of yourself, Senator Dolliver, and Senator Heitfeld, or any number of you, and any other members of the committee may come in and take an equal part. I expect to be here myself most of the time.

Senator Haxsbrodgh. I wish to ask, for information, if it intended to postpone the hearing to suit the individual convenience of all the gentlemen who I see would like to have all the month of January in which to be heard? I clo not see the neeessity of appointing a subcommittee at all. It would be well for the whole committee to adjourn until those gentlemen get together and decide when they would like to have us consider this measure.

Mr. ScherL. That would save the time of the committee.

Senator Hansbrougr. I say that from the standpoint of the gentlemen who desire to be heard.

The Chalrian. 'This committee is in the nature of a court, and these gentlemen are here as witnesses and advocates.

Senator Haxsibougr. We have not summoned them, however.

The ('marminan. They must come at our' convenience.

Senator Hansbrougir. I thought so. That is right. 
The Ciramman. Still, we wish to give them all the fair time we possibly can.

Mr. Tilmangmast. Perhaps I misunderstood the matter yesterday when it was before the committee; but I know it was my understanding, and it was the understanding of most of those who were here, that the hearings would be continued from the $3 d$ until the 10 th. It was, therefore, thought by most of those opposed to the bill that there would be no hearings during the holidars. Those who are here, like myself, are men who hare a great deal to do at the end of the year, and we feel as if we must be home at that time. Of course the business of the committee is of more importance to us than our business at home, but at the same time we can not help urging that our business at home demands immediate and vigorous attention at this closing season of the year.

For that reason I had anticipated that after to-day we might go home and appear on the $3 d$ of January, when we will so consolidate our forces as to take as little time as possible before the committee. I can say for one that if I had the time from now until the $3 \mathrm{~d}$ or 4 th or 5th-along there somewhere-I would speak before the committee on some day, and I assure you now my only purpose in speaking before the committee is to be of some ascistance to it.

In addition to everything that has been said. I should like to bave the privilege of giving my own digest of what the evidence up to date has shown, and I should also like to give, in a mathematical calculation. exactly the result indicated by one question of the gentleman to-day, which is the result to the farmer.

Senator Hansbrough. When will you be ready to do that?

Mr. Tillinghast. At any time on the $3 \mathrm{~d}$ or any day thereafter. I will take one hour.

The Cirairinan. Of course the dairy interest is entitled to a hearing to make any rebutting statements they may wish to present after your hearing.

Mr. Thluingmast. I understand.

The Cirarruan. I think we will settle it in this way: We will give you three days-Thursday, Friday, and Saturday, the $3 d, 4$ th, and 5 th of January. I think that is a reasonable time. I will come here at night, if you wish, and hold sessions all night; I do not care. Do you not think that that is a sufficient and reasonable time?

Mr. Trlminginast. I have no objection to that. I think it is reasonable, and I think with that time sessions during the holidays would be entirely unnecessary. Howerer, I speak only for myself.

'The Chatrman. I will ask another question. Is there anyone here who would like to be heard during the holidays or this afternoon?

Senator Heitferd. Mr. Chairman, I should like to say a word as one of the members of the subcommittee. I have not been asked whether I could be here. I will be in the eity, but I conld not give an hour to-morrow or Monday. Thereafter $I$ am willing to sit as long as may be clesired.

The Charranan. Perhaps the subcommittee might hear anyone who is ready.

Mr. Schell. Allow me to suggest that as far as I am personally concerned, and I think it will be the case with most of the people who are here, this matter came on us so suddenly that if I were to attempt to talk on the subject now and do my side of it justice it would take 
several hours, and I think, from what I have seen of the subject, if I were given time I could reduce all I want to say in about a twentyfive minutes' talk.

The Chamman. Is there anyone here who wishes to be heard now or during the holidays?

Mr. Springer. Mr. Chaiman, let me say a word. I have been informed by the president of the National Live Stock Association, which represents all these varied associations in the West, that letters have been addressed to the chairman and other members of this committee requesting the privilege of that association to be heard through a committee to be appointed by them at their coming national convention at Salt Lake City, and that they could not get their committee here before the 1st of February.

The Charrian. That is entirely ont of the question, Judge. Congress can not wait for the live-stock association. I think these gentlemen will admit that we are trying to be fair and to give them all the time we can.

Mr. Springer. I should like to explain the reason of their requesting that time. They are now engaged in assembling and preparing for assembling at a national convention at Salt Lake City on the 15th, 16th, 17 th, and 18th of January. It will be a conrention containing lepresentatives of all the eattle-growing interests and live-stock interests of every kind of the West and of the whole country, really. New York State is represented, as well as other's. In that convention they expect to take some definite action and appoint a committee.

In the meantime I have been requested to represent the association here and ask that all the time be given to them that is possible for the purpose of presenting their views. They have never been heard an an association. They have never gone into politics nor into any business of this kind. They have stood still and watched the operations of the gentlemen who are engaged in the mannfacture of oleomargarine until they see that their interests would be vitally affected, stricken down in many respects, by this proposed legislation, and for the first time they desire to appear before the legislative department of the Government and present their protest against this proposed legislation, and they wish to do it in a way that will at least set forth the varied interests which this great association represents.

Senator HAnsbrough. When will they be ready to go on?

Mr. Springer. As I stated, they meet in convention on the 15 th of January.

Senator Money. While dividing out time here I must claim some time for the cotton-seed oil men. Everybody knows that cotton-seed oil is much better than butter, oleomargarine, beef, or anything else. You all use it on your tables as olive oil, and you ought to use more of it. While they do not want to compel the use of cotton-sced oil, at any rate they want to be heard, and they want you to give them a chance, I know.

The Cilarrmax. Certainly. Already several Southern Senators have spoken to me about that interest and I have told them that its representatives might be heard on the 3d of January.

Senator Mionex. I will telegraph them to come on at once, and some of them will be here during the holidays.

The Chaminan. Some of them have expressed themselves as satisfied with that date. Judge Springer, I should like very much to accom- 
modate you on old scores between us, but I think we do all we can consistently with proper attention to the public business by postponing the hearing to the $3 d$ of Jannary. I have communicated with the live-stock association at Denver and told them that that was the best we could possibly do. No one has given any notice to appear, and if there is no one here who wishes to be heard to-day we will adjourn the full committee until the $3 d$ of January, but the subcommittee will be here subject to call. If anyone notifies the clerk of the committee that he would like to be heard during the holidays, the clerk will summon the subcommittee.

The eommittee (at 12 o'clock meridian) adjourned until Thur:st:3. January 3, 1901, at 10.30 a. m.

\section{Thutsdar, January 3, 1901.}

The committee met at 10.30 a. m.

Present: Senators Hansbrongh (acting chairman), Warren, Foster, Bate, and Heitfeld.

Also, Hon. W. D. Hoard, president of the National Dairy Union; C. Y. Knight, secretary of the National Dairy Union; H. C. Adams, dairy and food commissioner of Wisconsin; George L. Flander's, assistant commissioner of agrieulture of New York; James Hewes, president of the Produce Exchange, Baltimore, and vice-president of the National Dairy Union, of Maryland; IV. A. Roger's, representing the Agricultural Society of Northern New York; F. B. Richardson, assistant eommissioner of agrieulture, fifth agrieultural dirision, of New York; S. B. Medairy, of Baltimore, representing dairy interests; E. B. Norris, master of the State Grange of New Iork; Hon. Wm. M. Springer, of Illinois, representing the National Livestock Association; Frank M. Mathewson, president of the Oakdale Mamufacturing Company, of Providence, R. I.; Charles E. Schell, representing the Ohio Butterine Company, of Cincinnati, Ohio; W. E. Miller, representing the Armour Packing Company, of Kansas City, Mo.; John F. Gelke, representing Bram \& Fitts, of Chicago, IIl., and others.

'The Acting Ciraminan. Iudge Springer' will now be heard.

\section{STATEMENT OF HON. WILLIAM M. SPRINGER.}

Mr. SrRinger. Mr. Chairman and gentlemen of the committee, I appear before you in behalf of the National Live Stoek Association. A list of the associations that compose the National Association is printed in the hearings before the Honse Committee on Agriculture, which reported the pending bill, on pages 75 and 76 . They number 126 associations in all, and comprise a majority of all the live stock organizations now existing in this country, and they represent a capital of over $\$ 600,000,000$. The association held a national convention at Fort Worth, 'Tex., in January a year' ago. Here is a book containing the proceedings of the convention at Fort Worth.

Another national convention of the association will be held in Salt Lake City, Utah, on the 15th, 16th, 17th, and 18th of the present month (Jantary, 1901).

The Fort Worth convention adopted a memorial to the Congress of the United States, which is as follows: 
"Memortal No. 1.-Olemomargarine Legislation.

\section{"To the honorable the Senate and Ilouse of Representatives of the} United States:

"Your orator, the National Live Stock Association, respectfully represents unto your honorable body that it is an organization composed of over one hundred and twenty-five of the principal stock raiser's, feeder's, and breeder's' organizations and those of allied interests located thronghout the United States, and was organized, among other things, for the purpose of promoting the best interests of the live-stock industry as a whole.

"Tour orator, in behalf of its constituency, desires to enter its emphatic protest against the enactment of House bill 6 , introduced in the House of Representatives Deember 4, 1899, by Mr. Tawney, providing for an amendment to 'an act defining butter, also imposing a tax upon and regulating the manufacture, sale, importation, and exportation of oleomargarine, and in support of its protest desires to record a few of the many reasons in support of its contention.

"This measure is a species of class legislation of the most dangerous kind, calculated to build up and restore one industry at the expense of another, equally as important. It seeks to impose an unjust, uncalled-for, and unwarranted burden upon one of the principal commereial industries of the country for the purpose of prohibiting its manufacture, thereby destroying competition, as the manufacturers can not assume the additional burdens sought to be imposed by this measure and sell their product in competition with butter. The enactment of this measure would throttle competition, render useless the immense establishments erected at great expense for the manufacture of oleomargarine, deprive thousinds of employees of the opportunity to gain a livelihood, and deny the people, and especially the workingmen and their dependencies, of a wholesome article of diet.

"In oleomargarine a very large proportion of the consumer's of this country, especially the working classes, have a wholesome, nutritious, and satisfactory article of diet, which before its advent they were obliged, owing to the high price of butter and their limited means, to go without.

"The 'butter fat' of an arerage beef animal, for the purpose of making oleomargarine, is worth from $\$ 3$ to $\$ t$ per heald more than it was before the adrent of oleomargarine, when the same had to be used for tallow; which increased value of the beef steer has been added to the market value of the animal, and consequently to the profit of the producer.

"To legislate this article of commerce ont of existence, as the passage of this law would surely do, would compel slanghterers to use this fat for tallow, and depreciate the market value of the beef cattle of this country $\$ 3$ to $\$ t$ per head, which would entail a loss on the producers of this country of millions of dollars.

"The use of this fat for the purpose set forth is an encouragement to the producer to improve his herd and raise a class of grade or thoroughbred cattle capable of making and carrying this fat rather than the common or scrub animal which is so hard and unprofitable to fatten, and the cattle raiser or producer las come to know the valne of this product, and that the amount of the increase in the market value 
of his matured animal depends somewhat on the value of the 'butter' fat' carried by the animal.

"The rights and pririleges of the producers of beef cattle should be as well respected as those of others, and as they are the beneficiaries in the manufacture of this wholesome article of food, they should not be burdened with unnecessary special taxes or needless restrictions in the manufacture of this product other than is absolutely necessary for the support of the Government and the proper governmental regulations surrounding the handling of the same.

"This product of the "beef steer" should receive at the hands of Congress no greater exactions than that imposed upon competing food products. It is already surrounded by numerous safeguards, which Congress in its wisdom has seen fit to provide, stipulating severe punishment for selling same under misrepresentation. It has, by experience, proven to be just what a large majority of the people of this country want, and in behalf of the producers and consumers of this great country we do solemnly protest against the enactment of legisla tion calculated to ruin a great industry and to deprive not only the working classes but many others of a cheap, wholesome, nutritious, and acceptable article of food."

This memorial was discussed in open convention and adopted by a rising rote.

In order to show the spirit of the conrention and the great interest manifested in the subject, I will read, with permission of the committee. extracts from some of the speeches on the adoption of the memorial. Colonel Hobbs, who is the editor of the National Provisioner, a paper published in Chicago and New York in the interest of stock raiser's, said:

"Mr. President. I would like to make a few remarks. I do not want to be personal or talk sharp, but our chief chemist is a practical packing-house chemist. He has been in packing houses of the West for the last fifteen years. We have had him analyze a large number of samples of butterine. These samples were from every Government inspected butterine or oleomargarine manufactory in the United States. We hare done this to test the melting point. It has been said that 102 is its melting point, while the temperature of the stomach is only 98. Therefore it could not be melted in the stomach. There were many other objections raised that we wanted to investigate. I want to state that we have analyzed samples taken from trade and from factories, and that the melting point of butterine is just under 91 degrees and up to 97 degrees, the latter the highest melting point of the crudest butterine made in any Government inspected factory in the United States-and mind you, nobody else has a legal right to make it. It does not need paraffin to hold it up.

"The melting point of a pound of choice dairy butter' was $91^{\circ}$ and a shade over. The melting point of the best butterine is $91^{\circ}$ and just under $91^{\circ}$.

" In butterine is used beef and hog products and cotton-seed oilall of the highest and best products - so that there is not an unhealthy element in it. 'The hog product that goes into it, the beef product that goes into it, and the cotton-seed oil are the highest and purest products. It is the same as butter-chemically the same.

"If Congress passes this 10 pel' cent bill. it will simply kill the butterine industry; it will hit the cotton-seed industry; it will hit every 
hog and every cow in this country. There is 27 per cent of milk in it. It will hit every steer in this comintry, and I want to ask this convention to pass this memorial with a rising rote and send it to Washington to defeat this iniquitous bill.

"Butter is higher than ever before. It is now 27 cents per pound. Butter never was shorter in this conntry than now. Let the butter people go and stop that condition before they ask to kill an existing industry that is helping the farmers of this country. I thank you."

This was followed by applause, and one delegate said "Amen," which may indicate the feeling which was manifested.

Mr. Sotham, of the American Hereford Breeders' Association, of Chillicothe, Mo., said:

"We have no objections, as beef raisers, to the contention of the dairymen if butterine or oleomargarine is sold for just what it is, but I think, and you all seem to, that it is wrong to put a tax on a product which is exactly the same as butter, pronounced exactly the same by the best chemical process; and while we would be willing to establish the product on the best footing if sold for just what it is, as butterine, we also want to see the dairymen hold in mind a matter in which we are interested with them. Every time you get a miserable and inferior butter, of farm butter, these fellows straightway call it oleomargarine, while the fact is the product of these packing houses to-day is better than two-thirds of the butter that is produced in this country. Any of us would rather have it on our tables." [Applause].

This fact I do not know and will not vouch for.

The motion was then carried hy a rising vote, there being but 3 votes in opposition to the adoption of the memorial. So that may be considered as being before this committee as the unanimous expression of those who have been engaged in cattle raising, which embraces also the hog industry and the other live-stock interests.

The book containing the proceedings of the convention furnishes some valuable statistics in reference to the cattle industry of the United States. On page 82 will be found statisties of the number and value of milch cows and other cattle in the United States January 1, 1900.

Nilch cows, 16,292,000; average value, $\$ 31.60$, and total value, $\$ 514,812,106$. Other cattle, $27,610,054$; average value, $\$ 24.97$, and total value, $\$ 689,486,260$. The number of other cattle exceeded the number of milch cows $11,308,800$, and their value exceeded the value of milch cows $\$ 174,674,154$.

The National Live-Stock Association has not heretofore appeared before any committee of Congress, through its own representatives, to oppose the legislation contained in the pending bill.

Several of the members of the National Association appeared before the House Committee on Agriculture, and their remarks will be found in the hearings of that committee which are before you.

This is the volume which was laid before you by Representative Grout, and I call the attention of the committee to some of the remarks in this book, beginning on page 70 .

I also call your attention to the remarks of John S. Hobbs, editor of the National Provisioner, of New York and Chicago, on pages 130 to 141. It contains much valuable information on the subject now before this committee.

Also to the statement of Mr. J. A. Hake, president of the LiveStock Fxchange of South Omaha, Nebr.. printed on pages 157 to 166 of the Honse hearings, which contains valuable statistics. 
As I do not desire to repeat any of the statements which have been made before the House committee, as this committee has the printed hearings before it, I will only call attention to some of the remarks before the House committee.

There is one point, however, to whieh I desire to call the attention of the committee, and that is the unanimity with which all those who oppose the passage of the pending bill deelare that its passage will destroy the oleomargarine industry in the United States. The testimony on this point is so clear and emphatic that there ean scarcely be any doubt of the fact. The persons who have testified upon this point are engaged in the business or have thoroughly investigated it. They know whereof they speak, and Congress ought to give their testimony the most serious consideration.

But the friends of the bill declare their purpose to destroy the industry. They have framed the bill with that end in view, and haring the framing of it with that end in view, they ought to have been able to so express themselves as to earry out their purpose.

I eall attention to a portion of the minority report of thc Committee on Agrieulture of the House, which is before you, in which $\mathrm{Mr}$. Adams, the pure-food commissioner of the State of Wisconsin, in his testimony before the committee, Mareh 7, 1900, said:

"There is no use beating about the bush in this matter. We want to pass this law and drive the oleomargarine manufacturers out of the business."

Mr. AdAus. Mr. Chairman

Mr. Springer. Mr. Adams is here and ean state for himself.

Mr. Adaus. Will the gentleman allow me?

Mr. Springer. Certainly.

Mr. Adams. I think it is proper at this time to state that the statement in the report of the minority as quoted, and properly read by the gentleman, is absolutely and unqualifiedly false. I made no such statement. There was no stenographer present at that hearing. I have never had any such idea. I simply stated that our purpose was to stop the fraud in the sale of colored oleomargarine and nothing more; that we had no purpose to stop the manufacture and sale of oleomargarine, but simply of the colored imitation-counterfeit product.

Mr. Springer. I so understood the gentleman. There is no other kind of oleomargarine made except colored oleomargarine.

Senator Heitfeld. Judge, did you quote from the report of the minority?

Mr. Springer. Yes, sir; it is a part of their proceedings I was quoting, and that has been put before the eommittee by Mr. Grout. I assumed it was eorreet or I should not hare refer'red to it. But I have in my hand a newspaper entitled "Hoard's Dairyman," a recent publication, in which there is an extract from an address of Mr. Adams, who has just spoken to the eommittee, before the Wisconsiu Dairymen's Association, in which I find this statement:

"Now, why do we want this tax? I will tell you why. Because oleomargarine, which is colored in imitation of yellow butter, is a counterfeit, which the arerage purchaser can not detect, and it is placed upon the tables of the people and eonsumed by men and women who ask for butter and think ther are getting it, and we want to put a tax upon the article so high that they ean not place it upon the markets of this country in imitation of butter." 
That I presume is correct.

MIr. Adans. 'That is absolutely correct.

Mr. Springer. 'That is eorrect. In this connection, therefore, I desire to say that I believe it will be the testimony of all those gentlemen 'ngaged in the manufacture of oleomargarine that all the product made in this country is colored practically in imitation of butter. There may be some that is not colored, but the manufacturers generally regard it as necessary to color it in order to make it salable.

Other statements were made before the Committee on Agriculture of the House, and of similar purport to that which I have read.

Mr. Knight. Mr. Chairman. if I may be pardoned, there is a statement credited to me which appears there that not only was never made before any committee, but it purports to be a letter written by me to a Virginia dairyman, and which was never written by me. I never heard of it and never thought of anything of the kind. If it has ever appeared it is a forgery. I denounced it so before the House comnittee and it appeared as such in the Congressional Reeord.

The Acting Chairman. It has appeared in the Congressional Record?

Mr. KNIGHT. As soon as I saw the minority report I telegraphed to Congressman Grout to lay the matter before the House, that that purported letter, if there was ever any ground for it, was a forgery. I was not prepared to say that someone in the oftice might not have sent it out in my absence while I was here. But at the time it purports to have been written I was in Washington and not in Chicago, and I was sending out no literature from here. When I went home I questioned my clerks and assistants there and could find no leeord of such a letter having erer been written to anybody, or of anyone who ever had any idea of sending it out.

Mr. SPRINGER. I, of course, assume that nutters which appear in an official document are there with some responsible authority, and I usually quote them without apology; but the gentleman's statement is to be considered as controlling in this matter.

Mr. Knight. The point was raised and never has been met.

Ml. Springer. I do not desire to hold the gentleman or anyone else responsible for any statements which he has not made. It is a rery commendable course on the part of these gentlemen that they should desile that the committee would understand exactly what they have stated, and that they should not be misrepresented.

Before entering upon the discussion of the pending bill, I desire to enter $m y$ plotest against the course pursued by some of the gentlemen who favor the passage of the bill.

I read from the aroument of ex-Gorernor Hoard, of Wisconsin, printed on the first page of the hearings. If this is not correctly printed, the Gorernor is present and he can correct it. I will take it back if it is not stated correctly. 'This report states, as coming from Governor Hoard, the following:

"The oleomargarine combine consists of less than twenty manufacturers, who have entered into a conspiracy to break down these State laws. and, by bribing merchants, by deception of all kinds, by subsidizing city newspaper's, by employing leading politicians, to so neutralize the effect and administration of those laws that they may force their counterfeit upon the public. These manufacturers are assuming to override all law. They stand behind all infractions of State and national laws, and furnish money for the defense of their agents when arrested. 
"On one side stands one of the greatest of our agricultural interests, together with the millions of consumer's who are tired of being swindled.

"On the other side stands the oleomargarine trust, engaged in manufacturing a counterfeit, depending on lawbreaking, falsehood, and deception for its success, backed up with millions of eapital."

I do not lepresent the manufacturers of oleomargarine, but I do insist that neither the manufacturers of oleomargarine nor the representatives of the live-stock interest or the cotton-oil industry of the United States should be arraigned before this committee as, in the language which I have read, guilty of such disreputable practices as are alleoed.

Mr. Hoard. May I interrupt the gentleman!

Mr. Springer. Certainly.

Mr. Hoard. I will say, Judge Springer, that the statement there made is based on the testimony of the dairy and food commissioners of the United States, who have met those very propositions and facts in their work-the absolute bribery of merchants-offering to place certified checks in my own State on deposit, to defend merchants against the infraction of our State laws if they would take up the sale of oleomargarine.

Mr. SPRINGer. I assume that I hare correctly quoted you?

Mr. Hoard. You have, entirely.

Mr. Springer. The gentleman has not disclaimed it, as was done in the other case. But other methods have been adopted by the friends of this bill against which I desire to enter my solemn protest, and that is the system of bringing undue influence to bear upon the constituents of those who have had the courage to act in Congress so as to carry out their convictions upon this great question. Then the chairman of the Committee on Agriculture of the House of Representatives was a candidate for reelection at the last election, circular's were sent into his district bearing the signature of the gentleman who is here, Mr. Knight. I will not ask the committee to consider those circular's, mless the gentleman here states that this paper emanated from him [handing paper to Mr. Knight].

Mr. Kright [examining paper]. That was a letter written to Mr. P. P. Hubbard, of Perry, N. Y.

Mr. Sirringer. By you?

Mr. Knight. Yes, sir; a letter, and not a circular.

Mr. Springer. A letter?

Mr. Knight. A personal letter written to Mír. Hubbard.

Mr. Springer. Mr. Hubbard was a constituent of Mr. Wadsworth?

Mr. Kinignt. Yes, sir. He wrote to me and asked me about Mr. Wadsworth's position, and I answered it. I ou have got the letter.

Mr. Springer. This, then, is the answel that was given so as to represent the course of $\mathrm{Mr}$. Wadsworth. The letter is as follows:

\section{"The National Dairy Union,}

"Office of tile Secietary, $18 S$ Southi Mater Street.

"Mr. P. P. Hubibard, Perry, 1 . I.

"Chicago, Ill., October 18, 1900.

"Dear Sir: You ask me to what extent Congressman Wadsworth opposed the Grout bill. Well. if you have nrer been in court and observed a lawyer defending a criminal you can understand how he fought for the oleomargarine maker's. He was the most active oppo- 
nent we had in Congress. He spent more time lobbying against our bill than even the acknowledged agent of the oleomargarine makersLorimer, of Chicago-to whose tender mercies Wadsworth consigned the Gront bill when it was referred to his committee, that it might be smothered.

"As to Wadsworth's bill, offered as a substitute for the Grout bill, it is nothing more nor less than a deep-laid plan to break down completely all anticolor laws, including New York. His bill makes 1-pound packages original packages so they can be sold under protection of the interstate-commerce laws by the retailer with a $\$ 48$ license. Only wholesalers paying $\$ 480$ can sell an original package now, and they can't sell less than 10 pounds. While no oleomargarine is made in his State, he has conceired a great affection for the kind of oleomargarine that is an exact counterfeit of butter, forbidden by New York, and which defrands the public ererywhere, and the only kind we are seeking to suppress.

"Wadsworth's friends in Congress were amazed at his attitude in this matter. His conduct was unprecedented. No Congressman representing a Northern agricultural district has ever been known to take such an aggressive stand against the farmer's of his district in face of such floods of petitions, and no support whatever from his own people in his position.

"Wadsworth, with his bill, is the most dangerous enemy the dairymen have in the world. As chairman of the Agricultural Committee he has certain prestige. If he is returned to Congress by the rotes of the farmers of his district, thereby wimning their approval of his course, it will be bad for us. His reclection, unless with a greatly reduced majority, will be a rictory for the stock yards and oleomargarine fraud of Chicago, and a death knell to the farmer's influence in Congress.

"The National Dairy Union, howerer, is not in polities, and its officers happen to be of the same political faith as Wadsworth. Our organization is merely for the purpose of urging measures in protection of the farmer who keeps cows, and furnishing information to them regarding the records of Congressmen upon such measures. "Respectfully, your's,

$$
\text { "Secretary Mational Dairy Union." }
$$

The result of that election is a very emphatic protest against the methods used to defeat him. He succeeded in being reelected at this time by an increased majority of over 3,000 above the rote he received two years ago, and had $\$ .000$ majority in his district to return him to the next Congress.

Mr. Knight. Judge Springer, do you know how far he ran behind his ticket?

Mr. Springer. I do not.

Mr. Kinight. I do.

Mr. Springer. He got votes enough, however, to gire him a majority of about 9,000 in his district.

Mr. Flanders. The official returns of the State of New York hare not been printed, but the returns in the agricultural papers in the State of New York show that he ran 2,000 behind. I will not state this as a positive fact, becanse the official returns are not in, but that is the statement made and the general understanding among the people.

Mr. Springer. There were various circular's sent abroad in his 
district having as their object his defeat for the reason that he cxercised his judgment upon this measure and nsed his influence to secure the passage of another bifl, to which I call the attention of this committee, and which I believe will meet every objection that has really any foundation in it.

I desire to discuss this bill on its merits. I concede to every Senator and Representative in Congress the right to an honest difference of opinion with other Senator's and Members. The constituents of Senators and Members of the House will recognize the right of their representatives to express their honest convictions, and all efforts to threaten Senator's and Members of the House with popular condemnation should be reprobated.

The Committee on Manufactures of the Senate has recently investigated the subject of the adulteration of food products. It has submitted an able report on the subject, accompanied with all the testimony. The report is known as Senate Report No. 516, first session Fifty-sixth Congress, and was submitted to the Senate on February 28, 1900.

I call the attention of the committee to the conclusions reached by the Committee on Manufactures of the Senate at this very Congress. That part of the report on this subject will be found printed on pages 7 to 9 , and is as follows:

"In regard to butterine or" oleomargarine it is not claimed by any of the witnesses before your committee that it is in any way deleterious to public health. On the contrary all expert evidence upon this point strongly confirms the testimony of the manufacturers of this article, to the effect that it is a healthful food product. The testimony shows that this product is the result of a combination of beef and pork fats, butter, cream, and milk with coloring matter, which is similar to that universally used by farmers and dairies engaged in the manufacture of butter for the coloring of that product. As under the resolution under which this committee is operating it is made one of its duties to investigate food products and to ascertain what is sold that is deleterious to the public health, your committee made every effort to obtain information upon this bianch of the subject, and in addition to oral testimony there were submitted authorities of an expert character, as follows:

"Henry Morton, Sterens Institute 'Technology, New Jersey:

" 'It contains nothing whatever which is injurious as an article of diet; but, on the contrary, is essentially identical with the best fresh butter.'

"S. C. Caldwell, chemical laboratory, Cornell University: 'Possesses no qualities whaterer that can make it the least degree unwholesome."

"Charles P. Williams, analytical chemist, Philadelphia: 'It is a pure and wholesome article of food, and in this respect, as in respect to its chemical composition, is fully the equivalent of the best dair'y butter.'

"Henry A. Mott, analytic:tl chemist, New York: 'Essentially identical with butter made from eream, and perfectly pure and wholesome article.'

"J. S. W. Arnold, medical department, University New York: 'A blessing for the public, and in every way a perfectly pure, wholesome. and palatable article of food.'

"W. O. Atwater, Wesleyan University, Connecticut: 'It is perfectly wholesome and healthy, and has a high and nutritions value."

"Scientific American: O Oleomargarine is as much a farm product as beef or butter, and is as wholesome as either.' 
"Prof. Charles F. Chandler, New York City: 'The product is palatable and wholesome, and I regard it as a most valuable article of food.' "Prof. George F. Barker, University of Pennsylrania: 'It is perfectly wholesome, and is desirable as an article of food.'

"It has been claimed by some that the coloring matter alluded to is a by-product of coal tar, and that if taken into the human stomach it might be dangerous to health; but, upon the evidence taken before your committee, there appear's to he no foundation for prohibiting its use in the manufacture either of butter or oleomargarine.

"As to the right of manufacturers to color their oleomargarine, it would appear from the tenor of late decisions in United States and States courts that the legislative branch would exceed its power by prohibiting the use of such coloring matter in the manufacture of either butter or oleomargarine, and in the opinion of your committee such legislation would be roid, for lack of uniformity were permission granted to use coloring matter in one of these products to the exclusion of its use in the other.

"There have been several recent decisions by the Supreme Court of the United States, the most prominent being the case of Schollenberger 2 . The Commonwealth of Pennsylrania, in which it is held that oleomargarine has been recognized for nearly a quarter of a century in Europe and the United States as an article of food and commerce, and has been so recognized by acts of Congress. The court refer's to the itet of August 2, 1856 ( +4 Stat., 209), An act defining butter, also imposing a tax upon and regulating the manufacture, sale, importation, and exportation of oleomargarine.' One description of oleomargarine contained in this act includes, "all mixtures and compounds of tallow, beef fat, suet, lard, lard oil, regetable oil, annatto and other coloring matter, intestinal fat, and offal fat made in imitation of butter.' The decision in the Schollenberger "ase holds, "that the manufacture of oleomargarine by the compounding of the ingredients named in this quotation from the act of August 2, 1886, is recognized by Congress as being a lawful business and that the oleomargarine so produced is a lawful article of commerce.

"It was claimed by some of the witnesses hefore your committee that the present laws are inadequate to carry out the original intention of legislatures, and that under the operation of the varions laws regulating the manufacture and sale of oleomargarine it is sometimes sold to consumer's as butter. Some of the witnesses who testified before your' committee stated 'that having' asked for' butter, there were occasions when oleomargarine had been given them instead of the former article.' 'The examination of the retailer's of oleomargarine and butter who came before your committee tends to show that consumers of these articles know which of these products they are purchasing, but in many instances do not wish it known that they are using oleomargarine, and it is the testimony of manufacturer's of oleomargarine before your committee that there is no instance of any consumer having ever brought action to prosecute dealer's for having sold them oleonurgarine instead of butter. This testimony has not been contradicted, nor has any proof of its accuracy been offered.

"There has been much eridence and argument before your committee as to whether the manufacture of oleomargarine is detrimental to the interests of the farmers of the country. The evidence shows, howerer, that all of the ingredients entering into the composition of both butter and oleomargarine are the products of our farms, with the 
possible exception of the coloring matter, the use of which is infinitesimal in both cases.

"The resolution under which this committee was appointed does not authorize investigation except:

"First. What food is sold that is deleterious to the public health; and.

"Second. What food is sold in fraud to the consumer.

"The committee finds from the evidence before it that the product known commercially as oleomargarine is healthful and nutritious, and that no additional legislation is necessary."

There is no minority report of the Committee on Manufactures upon the pure-food bill, so called.

Mr. Knight. Judge Springer, may I interrupt you for a moment?

Mr. Springer. Yes, sir.

Mr. Knight. Senator Hansbrough will probably recall the fact that Senator Mason made a statement on the floor of the Senate toward the latter part of the last session that subsequent developments have conrinced him that he was mistaken in the premises. That is now a matter of record in the Congressional Record. He said it had dereloped that there was a great deal of frand in oleomargarine that he did not know about, and he had changed his conclusions as to that matter. That you will find in the Congressional Record, and I will attempt to look it up.

Mr. Springer. Senator Mason is a Senator, and when this matter comes before the Senate he will have an opportunity of stating whether he retracts any part of the official report he has made, and it will lest on his statement.

Mr. KNight. I simply desire to eall attention to that fact.

Mr. Springer. I have collected some statistics in reference to oleomargarine, which will be of interest to the committee and to all others who desire to be thoroughly imformed on the subject.

PRODUCTION OF OLEOMARGARINE.

The report of the Commissioner of Internal Revenue for the fiscal year ending June 30, 1900, shows that the production of oleomargarine for that year was $107,045,028$ pounds, and that the tax of 2 cents a pound paid to the Government thereon amounted to $\$ 2.543 .785 .18$.

The following table of production and total receipts from all oleomargarine sources for each fiscal year since November 1,1886 , the date the oleomargarine law took eflect, is interesting as showing the extent of operations in the country:

During the fiscal year ended June 30 -

1887 (from November 1,1886 )

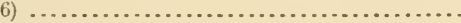

1889

1890

1891

1892

1893

1894.

1895

$1896^{\circ}$

1897

1898

1899

1900.

Total produe- Amount retion. ceived.

Pounds. 181,090

$21,513,537$ $31,325,527$ $35,661,026$ $32,324,032$ $44,392,409$ $48,364,155$ $67,224,294$ $69,622,246$ $56,958,105$ $50,853,23 !$ $45,531,207$ $57,516,136$ $83,130,474$ $107,045,028$
$\$ 723,918,04$ $864,139.88$ $894,217.91$ $7 \times 6,291.72$ 1, 077, 924. 14 $1,266,326.00$ $1,670,643.50$ $1,723,479.90$ $1,409,211.18$ $1,219,432.46$ 1, $034,129.60$ $1,315,70 \times .51$ $1,956,618.56$ 2, $543,7 \leftarrow 5.18$ 
THF INGREDIENTS OF OLEOMARGARINE.

The House of Representatives at its last session called upon the Secretary of the Treasury for information as to the kind of material used in the manufacture of oleomargarine in the United States, the amount of each ingredient, and the per cent that each bears to the total amount of olcomargarine produced in the comntry for the period named. In response to this resolution the Seeretary, through the Commissioner of Internal Revemue, on May 14, 1900, furnished the following statement:

Quantities and kinds of ingredients used in the production of oleomargarine in the United States for the fiscal year ending June 30, 1899; also the percentage each ingredient bears to the whole quantity.

\begin{tabular}{|c|c|c|}
\hline Material. & Pounds. & $\begin{array}{l}\text { Percent- } \\
\text { age each } \\
\text { ingredient } \\
\text { bears to } \\
\text { the whole. }\end{array}$ \\
\hline 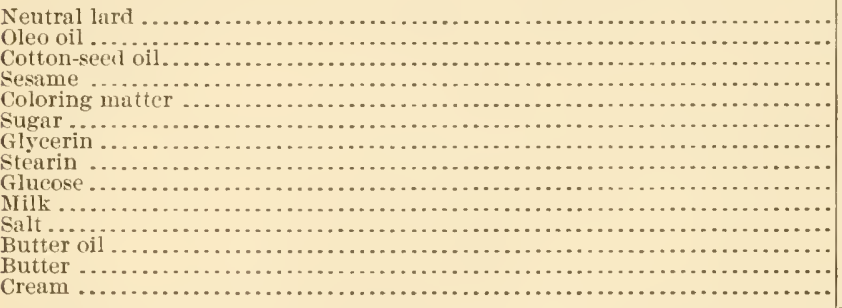 & $\begin{array}{r}31,297,251 \\
24,491,769 \\
4,357,514 \\
486,310 \\
148,970 \\
110,164 \\
8,963 \\
5,890 \\
2,550 \\
14,200,576 \\
6,773,670 \\
4,342,904 \\
1,568,319 \\
3,527,410\end{array}$ & $\begin{array}{c}34.27 \\
26.82 \\
4.77 \\
.53 \\
.16 \\
.12 \\
.01 \\
.007 \\
.003 \\
15.55 \\
7.42 \\
4.76 \\
1.72 \\
3.86\end{array}$ \\
\hline 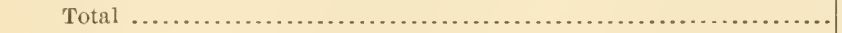 & $91,322,260$ & 100 \\
\hline
\end{tabular}

Or, more definitely stated. the quantity, character. and value of ingredients used in the production of oleomargarine for the time specified above are as follows:

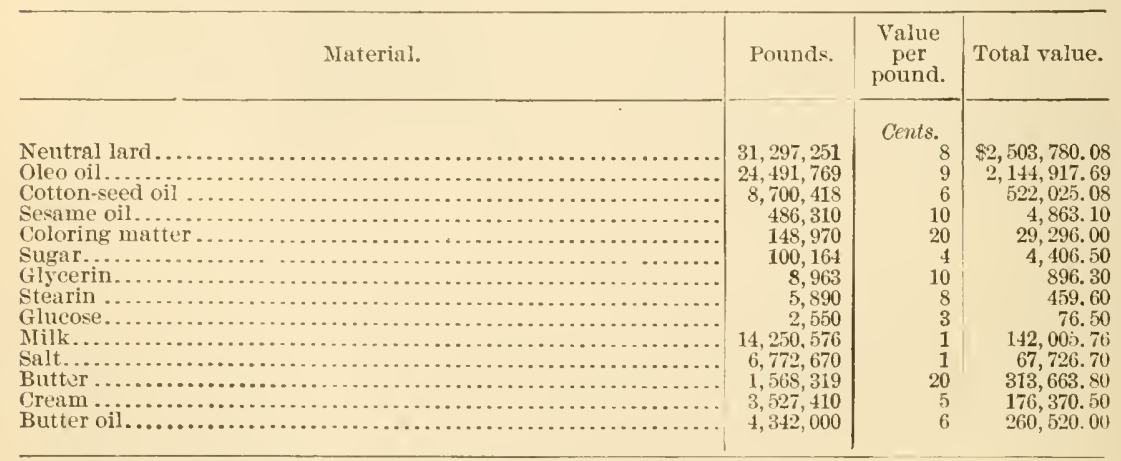

Average value per pound of materials, 7.09 cents.

Arerage cost of packages (extreme), one-half cent per nound.

Highest possible cost all expenses connected with manufacturing, 1 cent per pound.

Internal-revenue tax, per pound, 2 cents.

Total cost to manufacturer of finished product, arerage, 10.59 cents.

Finished product quoted at from $11 \frac{1}{2}$ cents for lowest grade to 18 cents for highest quality, averaging, probably, 14 cents per pound. 
STATES WHICH HAVE PROHIBITED OLEOMARGARINE AND THEIR POPULATION, 1890 AND 1900.

I have obtained from the Director of the Census a statement of the population of the United States for the census years 1890 and 1900. The statement is as follows:

[States marked with a dash (thus, -Alabama) are those in which laws have been passed forbidding the sale of oleomargarine colored in semblance of butter.]

Population of the United States by States and Territories, 1890 and 1900.

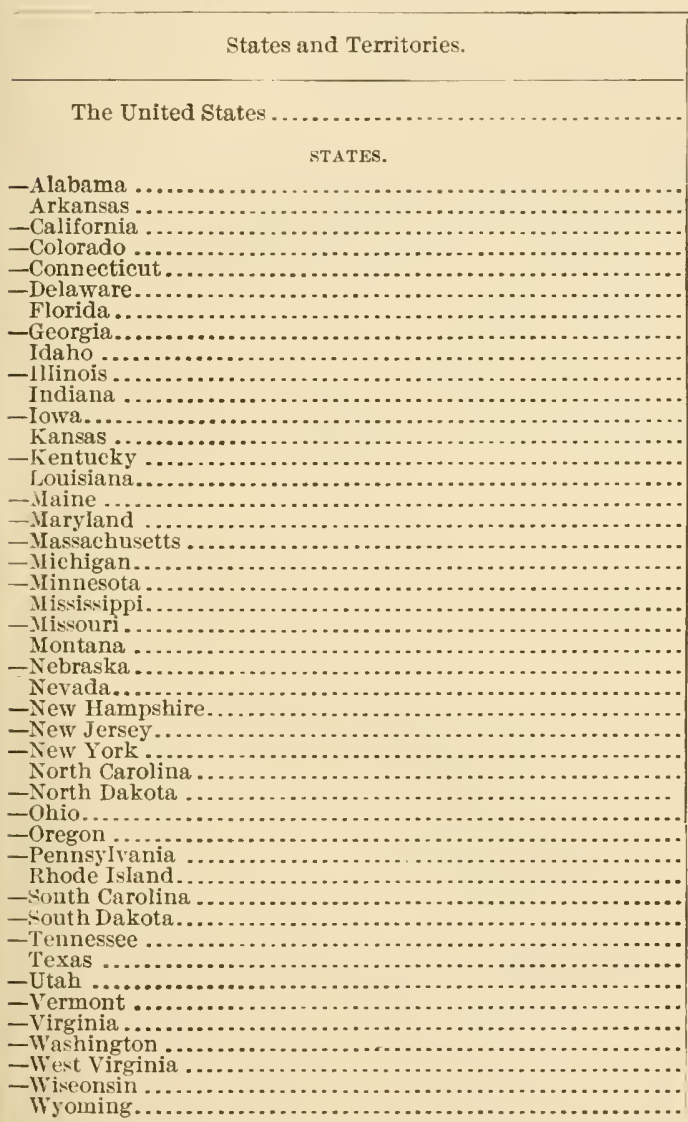

Total for 45 States.

TERRITORIES.

Alaska.

Arizona

District of Columbia

Hawaii

Indin Territory.

New Mexico.

Oklahoma.

Total for 7 Territories

Persons in the service of the United States stationed abroad. Indians, ete., on Indian reservations, exeept Indian Territory.

\begin{tabular}{c|c}
1900. & 1890. \\
\hline$a 76,304,799$ & $63,069,756$ \\
\hline
\end{tabular}

Indians not taxed, 1900 .

$1,828,697$

$1,311,564$

$1,485,053$

539,700

908,355

181, 735

528,542

$2,216,331$

161,772

4. 821,550

$2,516,462$

$2,231,853$

$1,470,495$

$2,147,174$

$1,381,625$

694,466

$1,190,050$

$2,805,346$

$2,420,982$

$1,751,394$

$1,551,270$

$3,106,665$

243,329

$1,068,539$

42,335

411, 588

$1,883,669$

7, 268, 012

$1,893,810$

319,146

$4,157,545$

413,536

$6,302,115$

428,556

1, 340,316

401,570

$2,020,616$

$3,048,710$

276,749

343,641

$1,851,184$

518,103

958,800

$2,069,012$

92,531

$74,610,523$

$1,513,017$

1, 128,179

$1,208,130$

412,198

746,258

168, 493

391,422

$1,837,353$

84,385

$3,826,351$

$2,192,404$

$1,911,896$

$1,427,096$

1, 858,635

1, 118,587

661, 086

1, 042,390

$2,238,943$

$2,093,889$

$1,301,826$

$1,289,600$

2, 679, 184

132,159

$1,058,910$

45,761

376,530

$1,441,933$

$5,997,853$

$1,617,947$

182,719

$3,672,316$

313,767

$5,258,014$

345,506

$1,151,149$

328,808

$1,767,518$

$2,235,523$

207,905

332,422

$1,655,980$

349,390

762,794

$1,686,880$

60,705

$62,116,811$

134,158
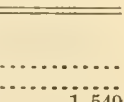

1,549
597

...........

2,297

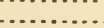

.............

.............

.............

............

1,768

10,746

1,665

$4,7 i 1$

4,692

.

10,932

1,472

2,531

1,657

44,617

\begin{tabular}{r|r|r}
\hline \hline & & \\
63,441 & 32,052 & $\ldots \ldots \ldots \ldots \ldots$ \\
122,931 & 59,620 & 24,644 \\
278,718 & 230,392 & $\ldots \ldots \ldots \ldots \ldots$ \\
154,001 & 89,990 & $\ldots \ldots \ldots \ldots \ldots$ \\
391,960 & 180,182 & 56,033 \\
195,310 & 153,593 & 2,937 \\
398,245 & 61,834 & 5,927 \\
\hline $1,604,606$ & 807,663 & 89,541 \\
189,670 & $\ldots \ldots \ldots \ldots$ \\
$\ldots \ldots \ldots \ldots \ldots$ & 145,282 & $\ldots \ldots \ldots \ldots$ \\
\hline $76,304,799$ & & \\
\hline
\end{tabular}

$76,304,799$

1 Including an estimated popnlation of 14,400 for certain military organizations and navaI vessels stationed abroad, prineipally in the Philippines for which the returns have not yet been received. 
According to the population of 1890 the States which have prohibited the sale of colored oleomargarine contained a population of $50,117,440$, while the States and Territories whose laws permit such sale, merely requiring that the oleomargarine be branded, marked, or labeled so as to distinguish it, contained a population of only 12,604,790. The District of Columbia, with 230,392 population in 1890 , is embraced in the latter list.

According to the population of 1900 the States which have prohibited the sale of colored oleomargarine contained a popnlation of about $60,000,000$, while the thirteen other States contained a population of $14,671,001$.

\section{QUANTITY CONSUMED IN EACII STATE.}

The Secretary of the Treasury has furnished a statement of the quantity of oleomargarine shipped into the several States and Territories, and probably consumed therein, during the fiscal year ending .June 30 , 1599. A table showing similar information for the year ending. June 30,1900 , could not be prepared in time to be of use to this committee during the consideration of the pending bill.

I have marked a dash before the States in which laws have been passed prohibiting the sale of oleomargarine colored in imitation of butter. 'The number' of the dealers in each State is giren, and the perrentage of the whole product consumed in each State. The table is as follows:

Quantity of oleomargarine shipped into each State for fiscal year ended June 30, 1899.

\begin{tabular}{|c|c|c|c|c|c|c|c|}
\hline State or Territory. & $\begin{array}{l}\text { No. of } \\
\text { deal- } \\
\text { ers. }\end{array}$ & Pounds. & $\begin{array}{l}\text { Per cent } \\
\text { of total. }\end{array}$ & State or Territory. & $\begin{array}{l}\text { No. of } \\
\text { deal- } \\
\text { ers. }\end{array}$ & Pounds. & $\begin{array}{l}\text { Per eent } \\
\text { of total. }\end{array}$ \\
\hline 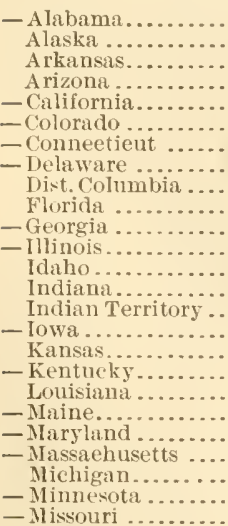 & $\begin{array}{r}21 \\
5 \\
35 \\
5 \\
\cdots \\
55 \\
5 \\
45 \\
61 \\
82 \\
61 \\
2,020 \\
3 \\
306 \\
21 \\
3 \\
186 \\
217 \\
140 \\
17 \\
58 \\
105 \\
109 \\
30 \\
231\end{array}$ & $\begin{array}{r}226,053 \\
18,050 \\
380,389 \\
78,767 \\
74,923 \\
1,123,537 \\
134,255 \\
40,475 \\
816,848 \\
590,225 \\
495,004 \\
18,638,921 \\
58,224 \\
3,923,228 \\
152,278 \\
79,922 \\
1,658,544 \\
1,490,577 \\
1,043,502 \\
102,274 \\
1,791,950 \\
2,083,889 \\
2,092,521 \\
1,343,865 \\
3,133,313\end{array}$ & $\begin{array}{r}0.28+ \\
.02+ \\
.48- \\
.10- \\
.09+ \\
1.41- \\
.17- \\
.05+ \\
102+ \\
.74+ \\
.62+ \\
23.39- \\
.07+ \\
4.92+ \\
.19+ \\
.10+ \\
2.08+ \\
1.87+ \\
1.31- \\
.13- \\
2.25- \\
2.61+ \\
2.63- \\
1.69- \\
3.93+\end{array}$ & 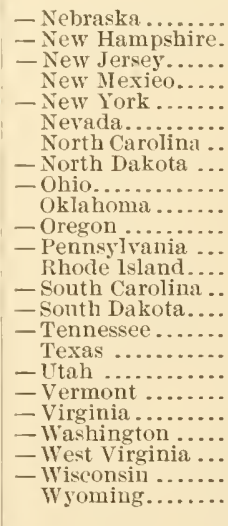 & \begin{tabular}{|r}
73 \\
19 \\
296 \\
12 \\
14 \\
\hdashline.- \\
9 \\
18 \\
1,005 \\
10 \\
3 \\
717 \\
333 \\
24 \\
4 \\
83 \\
162 \\
$\cdots$ \\
1 \\
121 \\
5 \\
172 \\
23 \\
5
\end{tabular} & $\begin{array}{r}1,024,985 \\
455,583 \\
5,875,975 \\
115,850 \\
222,788 \\
625 \\
110,244 \\
7,710 \\
8,830,969 \\
117,398 \\
41,250 \\
11,433,341 \\
3,594,984 \\
258,159 \\
55,432 \\
714,640 \\
1,518,264 \\
8,450 \\
2,990 \\
1,159,400 \\
63,345 \\
1,706,865 \\
714,7.12 \\
39,547\end{array}$ & $\begin{array}{r}1.29- \\
.57+ \\
7.37+ \\
.15- \\
.28- \\
.00+ \\
.14- \\
.01- \\
11.08+ \\
.15- \\
.05+ \\
14.35- \\
4.51+ \\
.32+ \\
.07- \\
.90- \\
1.91- \\
.01+ \\
.00+ \\
1.45+ \\
.08- \\
1.51+ \\
.90- \\
.05-\end{array}$ \\
\hline $\begin{array}{l}\text { Mississippi ......... } \\
\text { Montana......... }\end{array}$ & 17 & $\begin{array}{l}104,622 \\
446,022\end{array}$ & $\begin{array}{l}.13+ \\
.56-\end{array}$ & Total & & $79,695,744$ & 100.00 \\
\hline
\end{tabular}

The information contained in this statement is valuable and instructive. It shows the effect upon the consumption of oleomargarine which is prodnced by State legislation. In Rhode Island, having a population of 428,556 by the census of 1900 , the consumption of oleomargarine for the rear ending June $30,18 ! 9$. was $3,594,984$ pounds. This amounted to over 8 pounds per eapiti. 
The Acting Chamman. Have they a State law in Rhode Island prohibiting it!

Mr. Springer. No, sir; in that State it is allowed to be sold, designated as oleomargarine, with proper marks and brands. A gentleman who addressed the committee the other day explained how it wasthat there was a sign up in the windows of every store stating that oleomargarine was sold there, and that its sale as such was understood.

In Vermont, having a population of $3+3,6+1$, the consumption was only 2,990 pounds, or practically notling. The principal reason for this difference in consumption is that in Rhode Island the sale of oleomargine, colored in imitation of butter, is permitted if marked and branded as such. In Vermont oleomargarine, colored in imitation of yellow butter, is prohibited, and when sold at all it must be colored pink.

In Illinois, where there is hostile legislation, yet there were consumed in the State during the year 1899 over $18,000,000$ pounds. But the courts were generally opposed to the enforcenent of the law, and it was practically ignored. The production in that state for that year amounted to over $38,000,000$ pounds. But in New York, where there is strongly repressive legislation, and where we may assume from the result produced the law was fairly well executed, the consumption amounted to only 222,758 pounds. The population of the State is over 7,000,000. The consumption is well-nigh completely suppressed. If the laws of New York had been the same as those of Rhode Island, the consumption might have reached 8 pounds per capita, or $56,000,000$ pounds.

The total production of oleomargarine in the United States for the year ending .June 30,1900 , was $107,045,028$ pounds. 'This was a consumption of only $1 . t$ pounds per eapita. Without repressive laws in any of the States the consumption might have been as great per capita as in Rhode Island. This would have increased the demand for olcomargarine for consumption in the United States per annum to orer $600,000,000$ pounds. It is not surprising, in view of these facts, that the friends of the pending bill desire the enactment of the first section, which will place oleomargarine under the repressive laws of 32 States in the Union, with a fair prospect of securing equally oppressive legislation in the remaining 13 States.

The apprehension of the dairymen of the United States that their industry will be seriously injured by the production and consumption of oleomargarine is not well founded. It is stated in the minority report of the Honse Conmittee on Agriculture on the pending bill that the production of butter in the United States at this time amounts to abont 2,000,000,000 pounds per annum, and that the production of oleomargarine is but little over $t$ per cent of that of butter. 'This does not threaten serious competition. A possible consumption in the United States of 8 pounds per capita, as in Rhode Island, would not serionsly injure the butter industry, for the reason that the consumption of oleomargarine would be confined in the main, under proper regulations, to those who do not use butter, by reason of its high price. Greater comforts would be possible with no perceptible injury to any class of our people.

But even if butter should be brought into sharp competition with oleomargarine sold under proper regulations, the producers of milk and of dairy and creamery butter hare no right to complain. Every ingre- 
dient of oleomargarine is the product of our farms and ranches. Those who produce the ingredients of oleomargarine are just as much entitled to a fair field and open competition as are those who produce milk and butter. 'The consumers of the country are entitled to the best that the country affords and at the most reasonable prices that home competition in production can afford. The opposition to oleomargarine is as unreasonable as is that to improved processes of production and to labor-saving machinery. The time has long since passed when the machine must be destroyed because it saves labor and cheapens production. If American genius can invent some means of producing butter or any other article of consumption which will add to human comfort and happiness, such article is entitled to equal rights before the law with all other articles of like character, even if the old is driven out of the market and the new material entirely supplants it.

The Acting Chairman. Judge, is not that what would happen to the American cow? If she became more valuable for oleomargarine than for butter, would she not be driven out?

Mr. Springer. Yes, that is possible; but she would go to the slaughterhouse, where she would be utilized to very great bencfit in feeding the hungry people of the world. A gentleman who addressed the committee a few days ago stated that all cows were sent to the block sooner or later.

The Acting Chairiax. Then would not the oleomargarine people be required to discover some new method of producing calves?

Senator Heitferdo. An incubator might be used.

Mr. Siringer. An incubator process might be invented, as suggested by the Senator from Idaho. But if the honorable chairman will consult those gentlemen whom I have the honor to represent here, on their ranches upon the vast prairies of the West, he will find that most of the calres which mature into beef cattle are produced by the cows on the ranches which are not used for dairy purposes.

Senator Heitfeld. Judge, are you not surprised that a farmer from North Dakota does not know that dairy cows are not those that produce the calves-that it is the range cows?

Mr. Springer. The range cows are those that produce most of them. All calves from dairy cows as a rule are sent to slaughter as soon as they are old enough to be of value as veal.

T'he Acting Chamman. I supposed it was necessary for a cow to become a calf producer before producing milk.

Senator Heitfeld. That is true, but most of the dairy calves, perhaps three-fourths of them, go right to the slaughterhouse.

Mr. Springer. Those that we rely on to produce beeres are raised on ranches, and the cows are not used as milch cows. But, however this may be, I reassert what I stated before, that the law-making power can not interfere with the industries of the country so as to strike one down and build up another merely by reason of the fact that one of them is getting the advantage of the other by adopting improved processes of production so as to cheapen the price of the product to the consumer. That doctrine has long since been exploded, and it never will reappear again, I hope, in this country. If you want to see the fulfillment of the doctrine of repressive legislation to prevent improved processes go to China, and you will find a country that regards the machine as the enemy of labor. 
TIIE LAW OF THE CASE.

I desire to call the attention of the committee to the law of this case, and I trust that I shall not weary your patience on a subject so important as that.

I have been engaged during the past five years in interpreting the laws of my country and in enforeing them, and having occupied the position of a judge I realize more fully that it is the duty of all per'sons to look to the law, and, when the law points out the course, to follow it. So I shall ask this committee to follow the law as announced by the Supreme Court of the United States.

Two recent opinions of the Supreme Court of the United States in reference to oleomargarine are of the highest importance in considering the pending bill. To these opinions I will ask the committee to give special consideration.

The first opinion was handed down in the case of Plumley $v$. Massaehusetts, in 1894. The second opinion was handed down in 1898, and was in the case of Schollenberger $v$. Pennsylvania. The opinions were given upon the oleomargarine laws of the States of Massachusetts and Pennsylyania. The sections of those laws which were construed by the Supreme Court are as follows:

\section{TIIE MASSACIIUSETTS AND PENNSYLVANIA STATUTES COMPARED.}

Massachusetts oleomargarine statute of March 10, 1891, which the Supreme Court of the United States held to be valid, in Plumley $v$. Massachusetts, 155 U. S., 461-182. Decided December $10,1894$.

SEc. 1. "No person, by himself or his agents or servants, shall render or manufacture, sell, offer for sale, expose for sale, or have in his possession with intent to sell, any article, product, or compound made wholly or partly out of any fat, oil, or oleaginous substance, or eompound thereof, not produced from unadulterated milk or eream from the same, which shall be in imitation of yellow butter produced from pure unadulterated milk or eream from the same: Provided, That nothing in this act shall be construed to prohibit the manufacture or sale of oleomargarine in a separate and distinct form, and in such manner as will advise the consumer of its real character, free from coloration or ingredient that causes it to look like butter."
Pennsylvania oleomargarine statute of May 21, 1885, which the Supreme Court of the United States held to be in valıd, to the extent that it prohibits the introduction of oleomargarine from another State and its sale in the original package, in Schollenberger $v$. Pennsylvania, 171 U. S., 1-30. Decided May 26, 1878.

"No person, firm, or corporate body shall manufacture out of any oleaginous substance, or any compound of the same, other than that produced from unadulterated milk or cream from the same, any article designed to take the place of butter or cheese produced from pure unadulterated milk or cream from the same, or of any imitation or adulterated butter or cheese, nor shall sell or offer for sale, or have in his, her, or their possession with intent to sell, the same as an article of food." 
The difference between these two seetions was that in the Massachusetts law the phrase was, "shall be in imitation of yellow butter" produced from pure unadulterated milk or cream from the same," etc., while in the Pennsylvania law, which was declared unconstitutional, the language was, "Designed to take the place of butter or cheese."

An examination of the pleadings in these cases reveals the fact that the oleomargarine sold in each case was in the original package in which it was imported into the State, and that all the prorisions of the act of Congress of August 2, 1886, had been complied with in each case.

In the Massachusetts case it was admitted in the pleadings that the article sold was that forbidden by the statute: it was therefore made in imitation of yellow butter; but that it was marked and distinguished by all the marks, words, and stamps required of oleonargarine by the laws of Congress and those of the Commonwealth of Massachusetts.

In the Pennsylvania case it was conceded that the oleomargarine sold was manufactured out of an oleaginous substance, not produced from unadulterated milk or cream, and was designed to take the place of butter as an article of food; "but the fact that the article was oleomargarine and not butter was made known by the defendant to the purchaser, and there was no attempt or purpose on the part of the defendant to sell the article as butter, or any understanding on the part of the purehaser that he was buying anything but oleomargarine."

The Supreme Court, in its opinion in the Schollenberger case, referring to the decision and opinion in the Plumley case, said:

-This court held that a conviction under that (Massachusetts) statute for having sold an article known as oleomargarine, not produced from unadulterated milk or cream, but manufactured in imitation of yellow butter produced from pure unadulterated milk or cream, was valid. Attention was called in the opinion to the fact that the statute did not prohibit the manufacture or sale of all oleomargarine, but only such as was colored in initation of yellow butter produced from unadulterated milk or cream of such milk. If free from coloration or ingredient that caused it to look like butter, the right to sell it in separate and distinct form and in such manner as would advise the consumer of its real character was neither restricted nor prohibited. The court held that under the statute the party was only forbidden to practice in such matters a fraud upon the general public, that the statute seeks to suppress false pretenses and to promote fair dealing in the sale of an article of food, and that it compels the sale of oleomargarine for what it really is by preventing its sale for what it is not."

The court further beld-that is, the court in the Schollenberger case-in reference to the Plumley case:

"It will thus be seen that the case was based entirely upon the theory of the right of a State to prerent deception and fraud in the sale of any article, and that it was the fraud and deception contained in selling the article for what it was not, and selling it so that it should appear to be another and a different article that this right of the State was upheld. 'The question of the right to totally prohibit the introduction from another State of the pure article did not arise, and, of course, was not passed upon."

The only difference in the texts of the two statutes in question is found in these phrases: In the Massachusetts statute these words are used: "Any article *** which shall be in imitation of yellow 
butter produced from pure unadulterated milk or "ream from the same." In the Pennsylvania statute these words were used: "Any article designed to take the place of butter or chcese produced from pure unadulterated milk or cream from the same." Or, to narrow the distinetion still further, in one case the words used were: "In imitation of yellow butter:" in the other, "dlesigned to take the place of butter."

Notwithstanding this finely drawn distinction in the meaning of the two statutes in question. the entire opinion of the Supreme Court in the schollenburger case does substantially overiule the Plumley case. Attention is called to the following quotations from the opinion of the court in the Schollenburger case. I read from volume 171, of United States Supreme Court Reports. Mr. Justice Peckham delivered the opinion of the court. At the bottom of page 7 and at the top of page S. the court stated as follows:

- In the examination of this subject the first question to be considered is whether oleomargarine is an article of commerce. No affirmative evidence from witnesses called to the stand and speaking directly to that subject is found in the record. We must determine the question with reference to those facts which are so well and universally known that courts will take notice of them without particular proof being adduced in regard to them, and also by reference to those dealings of the commercial world which are of like notoriety.

"Any legislation of Congress upon the subject must of course be regarded by this court as a fact of the first importance. If Congress has affirmatively pronounced the article to be a proper subject of commerce, we should rightly be influenced by that declaration."

The court then proceeded to show that Congress had recognized it as a legitimate article of commerce. The court then pointed out the various provisions of the act of Congress of August 2,1886 ( 26 Stat., 209), imposing a tax of 2 cents a pound upon oleomargarine, and concluded its synopsis of the act with the following statement, on page 9:

"This act shows that Congress at the time of its pastage in 1886 recognized the article as a proper subject of taxation and as one which was the subject of traffic and of exportation to foreign countries and of importation from such countries. Its manufacture was recognized as a lawful pursuit, and taxation was levied upon the manufacturer of the article, upon the wholesale and retail dealers therein, and also upon the article itself."

The court then referred to the fact that oleomargarine was well known as an article of food and is dealt in as such to a large extent throughont this country and in Europe. The court quoted, with approval, the following case and opinion thereon:

"In Ex parte Scott and others the circuit court for the eastern district of Virginia ( 66 Fed. Rep., 45), speaking by Hughes, district judge, said: "It is a fact of common knowledge that oleomargarine has been subjected to the severest scientific serutiny and has been adopted by every leading gorernment in Europe. as well as America. for use by their armies and navies. Though not originally invented by us, it is a gift of American enterprise and progressive invention to the world. It has become one of the conspicuous articles of interstate commerce and furnishes a large ineome to the General Gorernment annually. * * * It is entering rapidly into domestio use, and the trade in oleomargarine has become large and important. The attention of the National Government has heen attracted to it ats at source 
of revenue. * * * Provincial prejudice against this now staple of commerce is natural, but a city of the size and prospects of Norfolk as a world's entrepôt ought not to be foremost in manifesting such a prejudice.'

Summing up on this branch of the case the court said, on page 12:

"The article is a subject of export, and is largely used in foreign countries. Upon all these facts we think it apparent that olcomargarine has become a proper subject of commerce among the States and with foreign nations.

"The general rule to be deduced from the decisions of this court is that a lawful article of commerce can not be wholly excluded from importation into a State from another State where it was manufactured or grown. A State has power to regulate the introduction of any article, including a food product, so as to insure purity of the article imported, but such police power does not include the total exclusion even of an article of food.'

The court then reviewed the previous decisions of the Supreme Court bearing on this subject. Referring to the opinion of the court in Railroad Company $v$. Husen (95 U. S., 465, 469), the following principle was asserted:

"The court said that a State could not, under the cover of exerting its police powers, substantially prohibit or burden either foreign or interstate commerce. Reasonable and appropriate laws for the inspection of articles, including food products, were admitted to be valid; but absolute prohibition of an unadulterated, healthy, and pure article has never been permitted as a remedy against the importation of that which was adulterated and therefore unhealthy or impure.

* * * * * * * * * *

"Conceding the fact, we yet deny the right of a State to absolutely prohibit the introduction within its borders of an article of commerce which is not adulterated and which in its pure state is healthful, simply because such an article in the course of its manufacture may be adulterated by dishonest manufacturer's for purposes of frand or illegal gains. The bad article may be prohibited, but not the pure and healthy one.

-In the execution of its police powers we admit the right of the State to enact such legislation as it may deem proper, even in regard to articles of interstate commerce, for the purpose of preventing fraud or deception in the sale of any commodity, and to the extent that it may be fairly necessary to prevent the introduction or sale of an adulterated article within the limits of the State. But in carrying ont its purposes the State can not absolutely prohibit the introduction within the State of an article of commerce like pure oleomargarine. It has ceased to be what counsel for the Commonwealth has termed it-a newly discovered food product. An article that has been openly manufactured for nearly a quarter of a century, where the ingredients of the pure article are perfectly well known and have been known for a number of years, and where the general process of mannfacture has been known for an equal period, can not truthfully be said to be a newly discovered product within the proper meaning of the term as here used.

"If properly and honestly manufactured it is conceded to be a healthful and nutritious article of food. The fact that it may be 
adulterated does not afford a foundation to absolutely prohibit its introduction into the State. Although the adulterated article may possibly, in some cases, be injurious to the health of the public, ret that does not furnish a justification for an absolute prohibition. A law which does thus pronibit the introduction of an article like oleomargarine within the State is not a law which regulates or restricts the sale of articles deened injurious to the health of the community, but is one which prevents the introduction of a perfectly healthful commodity merely for the purpose of in that way more easily preventing an adulterated and possibly injurious artiele from being introduced. We do not think this is a fair exercise of legislative discretion when applied to the article in question."

At this point, the hour of 12 having arrived, the committee took a recess until half past 20 'olock, at which time it reassembled.

The Acting Clialrian. Judge, you may proceed.

$\mathrm{Mr}$. Springer. Mr. Chairman and gentlemen, when the committee took a recess I was reviewing the decision of the Supreme Court in what is known as the Schollenberger Case. I had quoted some of the passages in that opinion and there are one or two others to which I ask your attention. On pages 22 and 23 of the rolume from which I was quoting $(171 \mathrm{C}$. S.) is this reference to the rery celebrated case decided by the Supreme Court a few years ago, known as the Original Package Case. That case is reported in $135 \mathrm{U}$. S., page 100 , and is the ease of Leisy $v$. Hardin. The Suprene Court of the United States, referring to that case, in the Schollenberger opinion, says:

"The case of Leisy $"$ Hardin (135 U. S., 100, 124) went a step further than the Bowman Case and held that the importer had the right to sell in a State into which he brought the article from another State in the original packages or kegs, unbroken and unopened, notwithstanding a statute of the State prohibiting the sale of such articles except for the parposes therein named and under a license from the State. Such a statute was held to be unconstitutional as repugnant to the clause of the Constitution granting power to Congress to regulate commerce with foreign nations and among the several States. Mr. Chief Justice Fuller, in speaking for the court, said: "Under' our decision in Bowman $v$. Chicago and Northwestern Railway, they had the right to import this beer into that State; and in the view which we have expressed, they had the right to sell it, by which act alone it would become mingled in the common mass of property within the State. Up to that point of time. we hold that in the absence of Congressional permission to do so the State had no power to interfere, by seizure or any other action, in prohibition of importation and sale by the foreign or nomresident importer.' The right of the State to prohibit the sale in the original package was denied in the absence of any law of Congress upon the subject permitting the State to prohibit such sale. There is no such law of Congress relating to articles like oleomargarine. Such articles are therefore in like condition as were the liquors in the cases alore cited.

"Subsequent to the decision in the Leisy case and on the Sth of August. 1890, chapter 7ะ8, 26 Stat. L., 313, Congress passed an act, conmonly known as the Wilson Act, which provided that upon the arrival in any State or 'Territory of the intoxicating liquors transported therein they should be subject to the operation and effect of the laws of the State or 'Territory enacted in the exercise of its police power to the same extent and in the same mauner as though such 
liquors had been produced in such State or Territory, and that they should not be exempt therefrom by reason of being introduced therein in original packages or otherwise. This was held to be a valid and constitutional exercise of the power conferred upon Congress."

Senator BATE. If I understand, they did not have the right to tax it until after the original package was broken, or there was a sale by the importer or agent, and it became mingled with the common property of that State.

Mr. Springer. When it became mingled with the common property of the State it was subject to the State law then. The court continues:

"In re Rahrer, petitioner, 140 U. S., 545 . In the absence of a Congressional legislation, therefore, the right to import a lawful article of commerce from one State to another continues until a sale in the original package in which the article was introduced into the State."

This opinion will account for the effort being made by the friends of this bill to secure the passage of what is known as the first section of the pending bill. It is an effort to place oleomargarine within the police powers of the State, the same as was done with intoxicating liquors by the Wilson Act of 1890. The Supreme Court in concluding its opinion upon this subject in the Schollenberger case held as follows:

"How small may be an original package it is not necessary to here determine. We do say that a sale of a 10-pound package of oleomargarine, manufactured, packed, marked, imported, and sold under the circumstances set forth in detail in the special verdict was a valid sale, although to a person who was himself a consumer. We do not say or intimate that this right of sale extended beyond the first sale by the importer after its arrival within the State.

And, further:

"The right of the intporter to sell can not depend upon whether the original package is suitable for retail trade or not. His right to sell is the same, whether to consumers or to wholesale dealers in the article, provided he sells them in original packages. This does not interfere with the acknowledged right of the State to use such means as may be necessary to prevent the introduction of an adulterated article, and for that purpose to inspect and test the article introduced, provided the State law does really inspect and does not substantially prohibit the introduction of the pure article, and thereby interfere with interstate commerce. It can not, for the purpose of preventing the introduction of an impure or adulterated article, absolutely prohibit the introduction of that which is pure and wholesome. The act of the legislature of Pennsylvania under consideration, to the extent that it prohibits the introduction of oleomargarine from another State and its sale in the original package, as described in the special verdict, is invalid."

Mr. Justice Gray and Mr. Justice Harlan dissented fron this opinion.

There is another case, following this immediately, known as the case of Collins $v$. New Hampshire. It is reported on page 30 of the same volume $(171 \mathrm{U}$. S.). To that opinion I desire to call your attention, for it raises and disposes of another point involved in this legislation. 'The Supreme Court in its opinion in the Collins Case, page 34, says:

"If this provision for coloring the article"-

I will state, by the way, that the New Hampshire law at that time required oleomargarine to be colored pink. That was held invalid"If this provision for coloring the article were a legal condition, a legislature could not be limited to pink in its choice of colors. The 
legislative fancy or taste would be boundless. It might equally as well provide that it should be colored blue or red or black. Nor do we see that it would be limited to the use of coloring matter. It might, instead of that, provide that the article should only be sold if mixed with some other article which, while not deleterious to health, would nerertheless gire out a most offensive smell. If the legislature have the power to direct that the article shall be colored pink, which can only be accomplished by the use of some foreign substance that will have that effect, we do not know upon what principle it should be confined to discoloration, or why a provision for an offensive odor would not be just as ralid as one preseribing the particular color. The truth is, however, as we have abore stated, the statute in its necessary effect is prohibitory, and therefore, upon the principle recognized in the Pennsylvania cases, it is invalid."

The same justices dissented in this as in the other case.

I now invite the attention of the committee to the provisions of the pending bill. The first section of the bill is, in my opinion, the most objectionable of any of its provisions. It is as follows:

"Be it enacted, etc., That all articles known as oleomargarine, butterine, imitation butter, or imitation cheese, or any substance in the semblance of butter or cheese not the nsual product of the dairy and not made exclusively of pure and unadulterated milk or cream, transported into any State or Territory, and remaining therein for use, consumption, sale, or storage therein, shall, upon the arrival within the limits of such State or Territory, be subject to the operation and effect of the laws of such State or 'Territory enacted into the exercise of its police powers to the same extent and in the same manner as though such articles or substances had been produced in such State or Territory, and shall not be exempt therefrom by reason of being introduced therein in original packages or otherwise: Provided, That nothing in this act shall be construed to permit any State to forbid the manufactmre or sale of oleomargarine in a separate and distinct form and in such manner as will advise the consumer of its real character, free from coloration or ingredient that causes it to look like butter."

This is for the purpose of getting around the decisions of the Supreme Court in the Leisy Case and in the Schollenberger Case, which held distinctly that you could not prevent an original package from going into a State and being sold in the original package to a consumer. If this provision should become a law, it would breathe the breath of life into the statutes of 32 States of the Union, which are now practically void by reason of the recent opinion of the Supreme Court of the United States in the Scholleuberger Case. A synopsis of these laws is given in the hearings before the House Committee on Agriculture on the Grout bill, pages 11 to 17 .

The attention of this committee is called to some of these State enactments.

The law of California prohibits the manufacture or sale of oleomargarine colored to imitate butter. Patrons of eating places shall be notified if substitutes for butter or cheese are nsed; and its use in State charitable institutions is prohibited.

In Connecticut the law prohibits the sale of oleomargarine unless free from coloring matter which causes it to look like butter. 'The use of imitation butter in public eating places, bakeries, etc., must be made known by signs. 
In Iowa the law is practically the same as in Connecticut. The use of colored oleomargarine in hotels, bakeries, etc., nuust be made known by signs.

In Maryland the manufacture, sale, and use in public eating places of any article in imitation of butter is prohibited. Mixtures of any animal fats or animal or vegetable oils with milk, cream, or butter shall be uncolored and marked with the names and percentages of adulterants, and this information shall be given to purehasers.

In New Jersey oleomargarine in imitation of pure, yellow butter is prohibited. But if it is free from artificial color and in original package, encircled by a wide black band bearing the name of the maker, and baving the name of the contents plainly branded on them with a hot iron, its sale is permitted. Retail sales must be accompanied with a printed card containing ingredients and naming maker, and the purchaser must also be orally informed of the character of the article at the time of sale.

In New York the manufacture of oleomargarine in imitation of but.. ter is prohibited, and no article intended as an imitation of butter shall be colored yellow.

In Vermont the manufacture or sale of oleomargarine in imitation of bntter is prohibited. Innitation butter for nse in publie eating places or for sale shall be colored pink.

In West Virginia there is a pink-color law.

In $\mathrm{W}$ isconsin the manufacture and sale of oleomargarine in imitation of yellow butter is prohibited; but free from any color its sale is permitted, but it shall not be sold as butter. Signs must be displayed in selling places and on wagons, and hotels, etc., using it must notify guests. Its use is not permitted in charitable or penal institutions.

In Pennsylvanià the statute of May 21, 1885, which was pronounced unconstitutional by the Supreme Court of the United States in the Sehollenberger case, has been supplemented by the act of May 5, 1899, which prohibits the manufacture and sale of oleomargarine made in semblance of butter. The act of 1885 used the words, “ designed to take the place of butter." The legislature has evidently endeavored to bring its statute within the ruling in the Schollenberger case, but I am inclined to the opinion that the decision of the Supreme Court in the case of Plumley $\because$. Massachusetts (155 U. S.. 462) was due to defective pleadings in the case. If Plumley had in his petition alleged that, at the time and place charged, he offered for sale and sold one package eontaining 10 pounds of oleomargarine manufactured in the State of Illinois and shipped to him as the agent of the manufacturers, packed, sealed, marked, stamped, and branded in accordance with the requirements of the act of congress of Angust 2, 1886; that said package was an original package, as required by said aet, and was of such form, size, and weight as is used by producer's or shipper's for the purpose of sccuring convenience in handling of merchandise between dealers in the ordinary course of commerce; and that said form, size, and weight were adopted in good faith, and not for the purpose of evading the statutes of Massachusetts; that at the time alleged the oleomargarine sold by defendant remained in the original packagebeing the same package - with seals, marks, stamps, and brands unbroken in which it was packed by the manufacturers in Illinois and thence transported to the city of Boston; and that said package was not broken nor opened on the premises of defendant, and that as soon 
as it was sold it was remored from the premises, as was alleged and proven in the Schollenberger Case. The decision of the Supreme Court would undoubtedly have been the same as in the latter case. The right to import from foreign comntries and from other States any legitimate articles of commerce and sell the same in the State into which they are imported in the original packages has been recognized and sustained by the Supreme Court of the Lnited States for seventy-fire year's by an unbroken line of decisions. In the leading cases of Gibbons $\%$. Ogden (: Wheaton, 1), and Brown $v$. Maryland (12 Wheaton, 419), the opinions were written by Chief Justice John Marshall, the most illustrious jurist our country has produced. In those cases the great Chief Justice delivered opinions which have become classics in our jurispr'tudence, and no jurists who value their reputations as such will ever have the temerity to assail their soundness.

I desire to call the attention of the committee to one of the opinions of Chief Justice Mar'shall on this subject, in 12 Wheaton, in the case of Brown against Maryland. This case was decided in 1527:

"It may be doubted whether" any of the evils proceeding from the feebleness of the Federal Govermment contributed more to that great revolution which introduced the present system than the deep and general conviction that comnerce onght to be regulated by Congress. It is not, therefore, matter of surprise that the grant should be as extensive as the mischief, and shonld comprehend all foreign commerce and all commerce among the States. To construe the porrer so as to impair its efficacy would tend to defeat an object in the attainment of which the American public took, and justly took, that strong interest which arose from a full conviction of its necessity.

"What, then, is the just extent of a power to regulate commerce with foreign nations and among the several States? 'This question was considered in the case of Gibbons $v$. Ogden (9 Wheat., 1), in which it was declared to be complete in itself, and to acknowledge no limitations other than are prescribed by the Constitution. The power is coextensive with the subject on which it acts, and can not be stopped at the external boundary of a State hut must enter its interior. We deem it unnecessary now to reason in support of these propositions. Their truth is proved by facts continually before our eyes, and was, we think, demonstrated. if they could require demonstration, in the case already mentioned.

"If this power" reaches the interior" of a State, and may be there exercised, it must be capable of authorizing the sale of those articles which it introduces. Commerce is interconrse; one of its most ordinary ingredients is traffic. It is inconceivable that the power to authorize this traffic, when given in the most comprehensive terms with the intent that its efficacy should be complete, should cease at the point when its continuance is indispensable to its value. To what purpose $s^{2}$ ould the power to allow importation be gireu, unaccompanied with the power to authorize a sale of the thing imported! Sale is the object of importation, and is an essential ingredient of that intercour'se of which importation constitutes a part. It is as essential an ingredient, as indispensable to the existence of the entire thing, then, ats importation itself. It must be considered as a component part of the power to regulate commerce. Congress has a right, not only to authorize importation, but to authorize the importer to sell." 
In the case of Leisy ". Hardin (135 U. S., 100-124) the right to import into and sell beer in original packages in the State of Iowa, in the face of the local prohibitory law, was recognized and upheld. After the decision in that case Congress was appealed to by the Senators and Representatires in Congress from States which prohibited the importation and sale of intoxicating liquors, and they secured the passage of an act on the Sth of August, 1890, known as the Wilson Act (26 Stat.. 313), which provided that upon the arrival in any State or Territory of intoxicating liquor's transported therein they should be subject to the operation and effect of the laws of the State or Territory cnacted in the exercise of its police power to the same extent and in the same manner as though such liquor's had been produced in such State or Territory, and that they shonld not be exempt therefrom by reason of being introduced therein in original packages or otherwise.

In the case In re Rahrer ( $140 \mathrm{U} . \mathrm{S} ., 545)$ this act in reference to intoxicating liquors was held to be a ralid and constitutional exercise of the power conferred upon Congress.

But in the absence of Congressional legislation the right to import a lawful article of commerce from one State to another continnes until a sale in the original package in which the article was introduced into the State. (Schollenberger 2 . Pennsylvania. 171 U. S., 23.)

The friends of the pending bill now seck to place oleomargarine upon the same plane upon which Congress placed intoxicating liquors. The articles are entirely different. The one is recognized everywhere as a proper subject of police regulation, and euch State should be left free to legislate upon the subject as it may see fit.

The Acting Chairmax. Will you permit me right here?

Mr. Splinger. Yes, sir.

The Acting Chamrman. A very large number of States have passed laws which practically make oleomargarine a contraband article?

Mr. SirRINGER. Yes.

The Acting Chairman. Only a few States have passed laws making liquor a contraband article.

Mr. Springeli. That is true.

The Acting (hamman. I simply wanted to call your attention to that fact as you went along.

Mr. Siringer. It was for the purpose of permitting the States which hare passed prohibitory liquor laws to have the benefit of those laws that Congress passed the act of 1890 and took intoxicating liquors out of the list of legitimate articles of commerce and permitted them to be subject to the police powers of the States. This legislation in reference to intoxicating liquors is not of a kind that is applicable to oleomargarine. Oleomargarine is universally conceded to be a wholesome article of food and a legitimate article of commerce. In this connection I desire to state that that statement does not depend upon my affirmance or upon the affirmance of any committee of this body. It has been so held by the Supreme Court of the United States, and that is the law of the land until it has been reverwed. Congress, therefore, has no more right to place oleomargarine under the police power of the State than it has to place the manufacture and sale of woolen goods, iron, or tin plate under the police power of the States, enabling them thus to suppress, if they please, the manufacture of such articles.

This brings ns to the consideration of two of the provisions of the Constitution which are applicable to the pending bill. The first is 
paragraph 2 of section 10 of Article VIII, and the other is paragraph 3 of section $S$ of Article I. I call the attention of the committee and of every lawyer in the Senate and the House and the country to these provisions. They are as follows:

"No State shall, without the consent of the Congress, lay any imposts or duties on imports or exports except what may be absolutely necessary for executing its inspection laws; and the net produce of all duties and imposts laid by any State on imports or exports shall be for use of the Treasury of the United States; and all such laws shall be subject to the revision and control of the Congress." Art. VIII, sec. 10, par. 2.

Now bear in mind that this is the clause of the Constitution which is inroked in justification of the first section of the bill. It must rest there, or it can not rest any place in the Constitution of the United States. The next provision is, "Congress shall have power" * * * to regulate commerce with foreign nations and among the several States, and with the Indian tribes." (Art. I, sec. 8, par. 3.)

The confusion which has arisen in the minds of many jurists and statesmen in construing these constitutional provisions is due to a misconception of the police powers of the States.

The police power's of the States are inherent in the States themselves, and can not be exercised or controlled by Congress. Neither of the constitutional provisions just read can be construed as granting to Congress the power to interfere with or regulate matters in a State which are the proper subject of police regulation or power, nor can either of them be construed as implying that there are certain police powers which the States may not exercise without the consent of Congress.

In this connection I desire to call the attention of the committee to a decision of the Supreme Court in 125 U. S., page 489. This is the case of Bowman $v$. The Chicago and Northwestern Railway Company In that case the court, referring to a previous decision of the court on the subject, said:

"Upon this point the observations of Mr. Justice Catron in the License Cases (5 How., 504, 599) are very much to the point. Speaking of the police power, as reserved to the States, and its relation to the power granted to Congress over commerce, he said: 'The assumption is that the police power was not touched by the Constitution, but left to the States, as the Constitution found it. This is admitted; and whenever a thing, from character or condition, is of a description to be regulated by that power in the State, then the regulation may be made by the State, and Congress can not interfere. But this must always depend on facts subject to legal ascertaimment, so that the injured may have redress; and the fact must find its support in this, whether the prohibited article belongs to, and is subject to be regulated as part of, foreign commerce or of commerce among the States. If, from its nature, it does not belong to commerce, or if its condition, from putrescence or other cause, is such when it is about to enter the State that it no longer belongs to coinmerce, or, in other words, is rot a commercial article, then the State power may cxclude its introduction, and as an incident to this power a State inay use means to ascertain the fact; and here is the limit between the sovereign power of the State and the Federal power-that is to say, that which does not belong to commerce is within the jurisdiction of the police power of the State 
and that which does belong to commerce is within the jurisdiction of the United States; and to this limit must all the general views come, as I suppose, that were suggested in the reasoning of this court in the eases of Gibbons $v$. Ogden, Brown $v$. The State of Maryland, and New York $x$. Miln."

And further, the Supreme Court, in the ease of Railroad Company v. Husen (95 U. S., 465), used this language:

"While we unhesitatingly admit that a State may pass sanitary laws and laws for the protection of life, liberty, health. or property within its borders; while it may prevent persons and animals suffering under contagions or infections diseases, or convicts, ete., from entering the State; while, for the purpose of self-protection, it may establish quarantine and reasonable inspeetion laws, it may not interfere with transportation into or through the State beyond what is absolutely necessary for its self-protection. It may not, under the cover of exerting its police power's, substantially prohibit or burden either foreign or interstate commerce."

Again, in the Bowman case the eourt said:

"If so, it has left to each State, aecording to its own caprice and arbitrary will, to diseriminate for or against every article grown. produced, manufactured or sold in any State and sought to be introduced as an article of eommerce into any other."

Just as this bill proposes to do.

"If the State of Iowa may prohibit the importation of intoxicating liquors from all other States it may also include tobaceo or any other article, the nse or abnse of which it may deem deleterions. It may not choose even to be governed by considerations growing ont of the health, comfort, or peace of the community. Its policy may be directed to other ends. It may chose to establish a system directed to the promotion and benefit of its own agriculture, mannfactures, or arts of any description, and prevent the introduction and sale within its limits of any or of all articles that it may seleet as coming into competition with those which it seeks to protect."

Just as is done in this case. The conrt holds that that ean not be done.

In view of these opinions of the Supleme Court, what is the proper construction to be given to the eonstitutional provisions I have yuoted?

What is the meaning of the words "imposts or duties on imports or exports?" Chief Justice Marshall, in his opinion in the case of Brown $v$. Maryland (12 Wheaton, 436), answers this question. He said: "An impost or duty on imports is a custom or tax levied on articles brought into a country, and is most usually secured before the importer is allowed to exereise his right of ownership orer them." The constitutional provision, then, which says "no State shall, withont the consent of Congress, lay any duties on imports" means that the States can not impose enstoms duties or taxes on imports without the consent of Congress. That is all that is meant. And it is further provided that the net produce of all such duties shall be for " Treasury of the United States."

Is there any semblance between that anthority as defined by Chief Justice Marshall and the authority undertaken to be conferred by the first section of the bill, which simply says that the article of oleomargarine shall be placed under the supervision of the State laws passed in the excreise of their police power, which State laws, as has been 
pointed out, are generally of a nature to prohibit entirely the introduction and sale in the State of oleomargarine colored in semblance of butter.

Mr. Hoard. Is there any such issue before this committee?

Mr. Springer. No, sir; but $I$ am calling attention to the fact that you are seeking to exert the power which relates to duties on imports as authority for enacting a law placing the manufacture and sale of oleomargarine in the States under this provision of the Constitution, so that it can interfere with the introduction of these articles into the State.

No duties were to be laid on imports by a State "except what may be absolutely necessary for executing its inspection laws." These are the duties that the States may lery upon articles coming into the State which are legitimate articles of commerce. The States may pass laws for the inspection of all products which may come into them from other States or from foreign countries. Such laws are a proper exercise of the police power of the States. But, as was said by the Supreme Court in the case of Railroad Company $v$. Husen (95 U.S., 465), " the police power of a State can not obstruct foreign or interstate commerce beyond the necessity for its exercise; and under color of it objects not within its scope can not be secured at the expense of the protection afforded by the Federal Constitution." The States can provide for reasonable inspection, but can not obstruct interstate or foreign commerce or burden it beyond the requirements of the inspection.

The power of Congress to pass the first section of the pending bill can not be invoked or justified under this provision of the Constitution. Congress is not giving its consent to the States to lay duties on imports, which duties, if laid, should be paid into the Treasury of the United States.

The consent of Congress is not given for the purposes contemplated in the provision to which attention has been called.

Mr. Hoard. Have any of the States asked the right to lay imposts on oleomargarine?

Mr. Springer. No, sir; none of them.

Mr. HoARD. Is there any mention of such fact in the proceedings?

Mr. Springer. None whatever; but that is the only power you can ask for- the right to do that under this provision in the Constitution.

Mr. Hoard. Is that included in the Wilson Act?

Mr. Springer. It is included in the Wilson Act so far as intoxicating liquors are concerned, which were to be subject to the police power by reason of the very nature of the subject itself.

The Acting Chamriax. This is a revenue measure.

Mr. Springer. I will come to that point in a moment and discuss it further on. Therefore I ask gentlemen of the committee and Congress to consider the scope of the prorision of the Constitution, and unless section 1 can be brought within the provisions of that section it has no place in the Constitution upon which it can rest.

Now, can it rest upon any other provision? The other constitutional provision inrolved is the power of Congress to regulate commerce with foreign nations and among the several States. 'This power is given to Congress alone. There is no exception or qualification to this grant of power. Congress alone can exercise it. 'The power can not be delegated by Congress to the States. If it had been intended to permit the States to exercise this power under any circumstances 
the Constitution would have so provided. But it did not so provide. As was said by the Supreme Court in the case of Robbins $\because$. Shelby Taxing District (120 U. S., 489), "that, in the matter" of interstate commeree, the United States are but one country and are and must be subject to one system of regulation and not to a multitude of srstems. The doctrine of the freedom of that commerce, except as regulated by Congress. is so firmly established that it is mnecessary to enlarge further upon this subject."

That is the decision of the Supreme Court - that under the commerce clause Congress alone can pass the laws that are to regulate the interstate and foreign commerce, and it can not delegate that power to the States. Is there a delegation of such power in section 1 of this bill?

The right to pass the first section of the pending bill can not be derived from the commerce clause of the Constitution. In fact, there is no power given in the Constitution, either directly or by implication, for the passage of this first section. Its passage will be, in my opinion, a plain and flagrant violation of the Constitution of the United States. There is no warlant in the Constitution for such legislation, and if enacted into law the courts must hold it mull and roid.

So much for the first section of the bill.

The second and only other section of the bill is as follows:

"That after the passage of this act the tax upon oleomargarine, as prescribed in rection 8 of the act approved August 2, 1886, and entitled 'An act defining' butter, also imposing' a tax upon and regulating the manufuture, sale, importation, and exportation of oleomargarine, shall be one-fourth of 1 cent per pound when the same is not colored in imitation of butter; but when colored in imitation of butter the tax to be paid by the manufacturer shall be 10 cents per pound, to be levied and collected in accordance with the provisions of said act."

This section inrokes the taxing power of the Constitution not for the purpose of raising revenue, but for the purpose of suppressing the manufacture of oleomargarine colored to resemble butter.

I want it distinetly understood that I have not contended, and I do not know that anyone else contends, that the object of this bill is to suppress the manufacture of uncolored oleomargarine, but all of the gentlemen opposing the bill and favoring it concede that it will work to the destruetion of the manufacture of oleomargarine eolored in the semblance of butter, and that is the object of the bill.

The eighth section of Article I of the Constitution is as follows:

"The Congress shall have power to lay and eollect taxes. duties, imports, and excises to pay the debts and provide for the common defense and general welfare of the United States."

The "general welfare" to which reference is made is that welfare which is provided for and set forth in the text of the Constitution itself, and not that welfare which is left to the discretion of the lawmaking power. 'This is universally conceded. To hold otherwise would destroy all the limitations and restrictions of the Constitution. The power, then, to lay and collect taxes, duties, and imposts is given in order to provide the means "to pay the debts and provide for the common defense and general welfare of the United States," as anthorized in the Constitution. Will any Senator or Representative in Congress say, upon his oath, that this section of the pending bill is being enacted "to pay the debts and provide for the common defense and general welfare of the United States?" Is this proposed taxation for 
a constitutional purpose? Has it any warrant or foundation in the Constitution?

There is already pending in the Senate a House bill to reduce the revenue, for the reason that the existing revenue laws are bringing into the Treasury a large surplus - a surplus of many millions of dollars. Revenue is not the object. What, then, is the object? There can be but one answer to this question, namely, the placing upon yellow oleomargarine a tax so burdensome that it can not be paid, and thereby the loss of the revenue now being collected and the destruction of the industry which is taxed.

But it may be said that the Supreme Court has held similar legislation to be solely within the discretion of the lawmaking power. So it has. It has held that the courts will not inquire into the motives of legislators when exereising the discretion which the Constitution has given them. But, gentlemen of this committee, the courts have not held that the lawmaker's are not bound to obey the Constitution. You have each taken an oath to support it. That oath is a moral obligation only, but it is binding upon the consciences of legislators, and they can not violate the Constitution without moral turpitude. If you are convinced-and I trust you are-that there is no warrant in the Constitution for the passage of this legislation you can not give it your sanction. I appeal to your judgments in the one case, and to your consciences in the other.

This concludes what I desire to state in regard to the legal aspects of the case. There are, as you know, but two sections to the bill. The first section has for its object the placing of oleomargarine within the police powers of the States. Thirty-two States have already, under the exercise of what they call their police powers, passed laws which prohibit the sale of colored oleomagarine in those States. In my judgment those laws are now, by reason of the decision of the Supreme Court, virtually nullities and can not be enforced, when an importation is made from one State into another in the original package, as pointed out in the Schollenberger case, and sold in such package. But the effort is made to take the article of oleomargarine from under the opinion of the Schollenberger case, and to place it upon the plane of intoxicating liquors-articles which from time immemorial have been regarded as proper subjects of the police powers of the several States. Hence, it was competent for Congress simply to recognize the fact that intoxicating liquors are subjects of State control.

In my judgment Congress did not give any power to the States by the passage of the Wilson Act. They had that power already, and Congress could not take it away from them. Liquor is a proper subject of the police power of the States, but all these opinions hold that that which is a legitimate article of commerce, a nutritious article of food, can not be interfered with in its importation into another State or from a foreign country and in its sale in the original package to -any person in that State. That is the purport of these decisions.

Under the first section of the bill, even if the article pays the tax of 10 cents a pound provided in the second section, not a pound of it that has paid this burdensome tax can be put into these States and sold. In other words, Congress will say to the manufacturer's, "Pay a tax of 10 cents a pound, and you can manufacture and sell it;" and at the same time say, "But you must not take it into 32 States of this Union. If you do, it will be confiscated under the police laws of the State. You can not sell a pound of it in those States, after the Government 
has taken the tax for it." To say nothing of constitutional provisions, is that justice? Can you defend it upon any ground of doing justice to any class of our people? I do not think you can.

The second section of the bill, imposing a tax of 10 cents a pound upon the articles manufactured in semblance of butter, will only permit the article having paid the tax to be sold in 13 States of the Union, and then under the laws regulating its sale by marking it and indicating what it is.

I wish to call the attention of the committee to the fact that if you pass the first section of the bill you provide as to every law in those States that that law may have its full force and effect. "You must say that of the law which requires the keeper of a hotel to notify all his guests that oleomargarine is used in his hotel; that he must put up signs here and there over his hotel notifying them that oleomargarine is used. In some States it must be colored an offensive color, bearing which no one will purchase it, and in other States even the wagons carrying it along streets must have labels upon them that these wagons are carrying oleomargarine. The inventive genius of legislators, it seems to me, has been exhausted in throwing around oleomargarine in the States those offensive provisions which will drive it out of existence, if possible.

In this country we have for many years, in fact from the foundation of the Govermment, recognized the right of the United States, in imposing taxes upon foreign goods coming into this country, so to discrminate in the laying of those taxes that our manufacturers would be protected from ruinous competition with the manufacturers of like goods in other countries. That policy has almost become a part of our fixed system. But never until this legislation has been invoked has it been contended that Congress should interfere between home producers, and by the use of the taxing power build up one industry and destroy another. This is the firstattempt; and, gentlemen of the committee and of Congress, let me call your attention to the fact that if you start on this road there is no end to it. You will be vexed with applications for interfering in almost erery kind of business in this country.

An effort was made, and has been renewed several times, to get Congress to put a tax on what is called compound lard. In two or three Congresses committees of the House have investigated the subject of compound lard, and once they passed a bill in the House upon that subject for the purpose of having compound lard subject to a tax. I do not know that that would make it any different from what oleomargarine is subject to.

There has been a suggestion that what is known as process butter should also be subjected to taxation, but that suggestion has been very much opposed by those engaged in the manufacture of process butter. I will ask permission to print in the record a letter that I have on the subject, which I will not take up your time to read, showing that the dealers in process butter are very much concerned in regard to this proposed legislation for fear that the next bill proposed will be a tax upon process butter.

The following letter was recently received by a member of the House of Representatives:

\section{"Danville, Ilu., March 1\%, 1900.}

"Dear Sir: I see by a circular mailed to me that a member of Congress from Mississippi by the name of Williams introduced a bill on 
February 20 last taxing process butter as follows: Nanufacturers, $\$ 600$ per year; wholesalers, $\$+80$ per year'; retailers, $\$+8$ per year'; and the butter 2 cents per pound. This would virtually prohibit the sale of that kind of butter. I get on hand a lot of butter same as other merchants, and it will get stale; it is then bought up by parties who thoroughly work it over, taking out all the milk, resalting it, and place it in cold storage till butter gets scarce, then it finds a market. There are times of the year when butter is very plenty, and if we could not dispose of it we could not pay the farmers anything for it. As it is, these parties pay us from 10 to 14 cents a pound for rancid butter. I suppose I sell during the year as much as 5.000 pounds of that kind of butter, and when this bill is called up you would favor this district by voting against it, not only for the benefit of the merchants, but the farmers also, who would not have a market for their surplus butter.

"Respectfully, your's,

\section{"John F. Depke."}

Mr. Springer. What is process butter? It is butter that has been shipped out to dealers and by being kept long on hand has become rancid and unfit for sale. The dealer's then send it back to the manufacturing centers, where it is collected in immense quantities and put through chemical processes and worked orer again and made into a butter that goes out and takes the place of dairy butter and creamery butter. I think here is a place for Congress if Congress wants to look after a fraud-to look after a real one-because I can not understand how process butter, which is made out of butter which has become rancid and unfit for use, can become a wholesome and healthful article of food. It ought to be subject at least to the police powers of the State. Why not put it in this bill?

Mr. Hoard. One thing at a time.

Mr. Springer. I desire to call the attention of the committee to another direction in which articles coming into general use in this country have been adulterated, and Congress has never undertaken to do away with the evil or to abate it.

The total production of wool in the United States in the census year 1890 amounted to $276,000,000$ pounds in the grease, which was equal to only $92,000,000$ pounds when scoured ready for weaving into eloth. The shoddy used during that year in manufacturing' woolen goods amounted to $61,626,261$ pounds. Thus the shodky had a cloth-producing power equal to 67 per cent of all the wool produced in the United States. 'The whole number' of sheep in the United States for' the census year 1890 was $4,336,072$; the fleeces produced scoured wool to the amount of $61,000,000$ pounds. Thus the shoddy used during that year produced woolen goods equal to the fleeces of $29,605,168$ sheep.

Mr. Hoard. A great fraud.

Mr. Sirringer. Ýes; equal to the fleeces of $29,000,000$ sheep.

Mr. Hoard. You will not find any of the dairy interests upholding it.

Mr. Flanders. It is not a proper subject of the police power. We are invoking the police power.

Mr. Springer. The prevention of this kind of adulteration

Mr. Flanders. That is not adulteration; it is a substitution. It is not within the police power. 
Mr. Springer. But it is within the taxing power. In the manufacture of woolen goods during the census year 1890 the shoddy, cotton, and other adulterants used exceeded the amount of pure wool, the ratio used being 45 parts of pure wool and 55 parts of shoddy, cotton, and other adulterants, not including camel's hair and mohair. Yet, notwithstanding this fact, there has been no effort made in this country or in any other, so far as I am advised, to place a special tax upon woolen goods manufactured in part of shoddy, cotton, and other adulterants for the purpose of protecting the sheep industry from a ruinous competition with cheap substitutes for wool. The adulterants, when woven into woolen cloths, look so like pure woolen goods that only an expert can distinguish the pure article from the imitations, and it is well known that most of the adulterated fabries are sold to consumer's as "all wool and a yard wide." Pass the pending bill and the sheep raiser's will come forward and demand a tax that will protect wool from ruinous competition with shoddy and other adulterated goods.

There is no place where this will end. It does seem to me that if our woolen goods are so adulterated, hy putting shoddy and cotton into them, that the ratio of pure wool to adulterants is as that of 45 to 55 , Congress might be called upon, in the exercise of its taxing power, to place a duty upon the home-manufactured goods that are not composed of pure wool exclusively. That would protect the growers of pure wool-the sheep raisers-from competition with shoddy. I do not know whether the gentlemen of the committee understand what shoddy is. Old woolen clothes are put into some kind of a machine, ground up, and then spun and put into a yarn, which is woven into new cloths. The nap is not more than a sixteenth of an inch long, but it is wool all the same, and when mixed with long nap of natural wool it forms a product which deceires experts themselves.

The sheep men have just as much right to come before this committee and ask that woolen goods which do not consist entirely of that article shall be taxed so much a pound-

The Acting Cirairuax. Have any of the States passed laws against shoddy?

Mr. Springer. No, sir; not that I know of. I never heard of it. It is conceded that shoddy is a legitimate article of commerce, and that its manufacture has proved a great benefaction to mankind.

Mr. Grout. I suppose the shoddy betrays its character largely to the feeling?

$\mathrm{Mr}$. SPRInger. When there is as little as 20 per cent you can not tell it from the original long wool. It does not last so long; it is not so good; but it is used all the same, and as I have indicated by these statistics, it is being used more from year to year. The object of calling attention to these things is to show that you are now entering upon the matter of interfering between two home producers of articles necessary for our consumption, and endearoring by the taxing power of the Government to build up one industry and destroy another. In this case it is the building up of one by the total destruction of the other. In the other case there might be laws which would allow both of them to exist, but this does not allow the manufacture of oleomargarine in the semblance of butter to exist at all as a manufacture in this country. 
Gentlemen of the committee, I desire to call your attention to the fact that the discussion upon this subject when the bill was before the House of Representatives in 1886 was misleading to the Representatives. At that time I had the honor to be a member of the House, and I was chairman of the Committee of the Whole House during the entire discussion of the oleomargarine bill in the House in that Congress. At that time the House of Representatives was a deliberative body, as the Senate now is. The discussion lasted some time, and every gentleman who desired to speak had the opportunity to do so. They now have rules by which they can bring them to a vote in a very short time. At that time the discussion upon this subject was such that the majority of the members of the House were led to belicre, and did believe, that oleomargarine was a dangerous, unwholesome, and filthy production.

Let me call your attention to several statements made by gentlemen at that time. You will hardly believe that such things could have been. There were several bills pending, and the Hatch bill was finally passed. It provides for placing a tax of two cents a pound upon oleomargarine, and for a general inspection, through the Departments of the Government, of every part of the article manufactured, so that when you see oleomargarine manufactured in this country you see an article that the officer's of the Government have inspected from its inception to the time it passes away from the factory in the original packages. They certify to its condition.

Mr. Hoard. You mean that the law provides for the inspection?

Mr. Sprivger. Yes, I do.

Mr. Flanders. That it may be done.

Mr. Springer. It provides for it.

Mr. Hoard. It may be done.

Mr. Springer. It provides for it.

Mr. Hoard. You do not assert that it is done:

Mr. Springer. No, sir; I do not assert as to whether or not anybody performs his duty, but the law presumes that every officer of the Government does his duty, and until the contrary is shown I assume that they have done their duty. The law assumes that everybody is honest, and especially does the law assume that the officer's of the Government and of the States do their duty. I hope ther do. If they do not, they ought to be taught to do it.

During the discussion of this act in the House, it was charged by its friends that oleomargarine was deleterious to health.

Mr. William L. Scott, of Pennsylvania, said in the House May 2t, 1886:

"The genius which succeeded, by the application of chemical fluids and compounds, in transforming a mass of loathsome and unwholesome ingredients into an article of food at a trifling cost, does not hesitate to impose the product upon the public, and receive in the way of excessive profit the difference between the cost of the imitation or connterfeit article and that of pure butter."

Mr. A. J. Hopkins, a member of Congress from the dairy district of Illinois, said (May 24, 1S86):

"During the Franco-Prussian war an inventive genius, by the name of MI. Mége, discovered that the fats of such animals as cattle, horses, and dogs could be made into a substitute for butter. The war measure 
of the inventive Frenchman was seized and improved upon by the everinventive Yankee. Our Patent Office has been besieged with app!ications for patents."

After pointing out the various articles said to be used in the manufacture of oleomargarine, comprising $60 \mathrm{in} \mathrm{all,} \mathrm{Mr}$. Hopkins proceeded ats follows:

"If these imitations of, and substitutes for, pure butter" were marked or labeled what they really are, and the dealer's and consumers advised of what they are purchasing and eating, no eomplaints would be made by the dairymen."

I am sorry that they have now departed from the doctrine Mr. Hopkins announced.

Mr. Flanders. I announce that we have not. I will take that up and show that we have not.

Mr. Springer. If you get up a bill providing in the most stringent manner that the consumer shall be advised of what he is purchasing I do not think any of the opponents of the bill will object to it. Mr. Hopkins continued:

"The great wrong is the frand and deception practiced in selling such loathsome compounds for genuine butter." * * * "It is asserted by the friends of these bogus substitutes for butter that they are healthy. They are not. All kinds of filthy fats are used in their manufacture. Animals dying from all kinds of diseases are utilized, and after going through their bleaching and deodorizing' processes are manufactured into oleomargarine and sold for pure butter." *** "Gentlemen of rare scholarship and seientific attainments have given this whole subject years of careful thought and study, and are unqualified in their statements of its unwholesome and loathsome character. Its eonsumption in their judgment leads to insanity, Bright's disease, and many of the ailments that undermine the strongest and most robust constitutions.'

He did not diselose the names of those "gentlemen of rare scholarship and seientific attainments" who thus exposed oleomargarine. They probably existed only in the minds of the butter manufacturers. Before Mr. Hopkins closed he made it clear that his chief object in faroring the antioleomargarine bill was to protect the workingman. He said:

"Has it come to this in Ameriea that the laboring man must live upon adulterated food? Must his wife and family use for pure butter of our dairies an artificial butter, the compounds of diseased hogs and dead dogs?"

Mr. Hatch, of Missouri, now deceased, was the author of the bill and the champion of the cause of pure butter. He was very pronounced in his views. He denounced oleomatrgarine as "the monumental fraud of the nineteenth century, " a sentiment which was received in the House with "applause." He was willing to admit that the Chicago packers made the very best and purest oleomargarine that is used in the United States. He added:

"But that is not the danger. The danger" is in the hundred and one little dead-animal factories on the lines of the railroads, where they buy broken-down, diseased, and dead animals from the railroads; these little rendering establishments in out of the way towns and villages that simply operate by purchasing the refuse and scrapings of the butcher shops and making this oleo oil to be used in the manufacture 
of oleomargarine and butterine, spreading disease and destruction throughout the country."

He quoted with approval from a prominent newspaper, which stated, among other things, the following:

"The gang of adulterator's and counterfeiters who manufacture bogus butter from soap grease protest that the Hatch bill makes martyr's of them and violates their constitutional rights. They have their headquarters in Chicago."

Such were the arguments, or some of them, used fifteen years ago to secure this legislation, and they were effective at that time; and arguments of a similar purport in many respects have been used since that time to secure repressive legislation in the several States of this Union. But notwithstanding all this detraction, oleomargarine has survived the assaults of its enemies and now has thes anction of the Supreme Conrt of the United States, in an opinion, which does that court great honor, that it is a pure and a healthful article of food and a legitimate article of interstate commerce. Such is the judgment of the court, and that is the law of the land.

Now, if gentlemen desired that this useful and nutritions article of diet shall be hedged about with such inspection laws in the States as will simply provide, as the Constitution recognizes, that what is sold shall be the pure article, there will be no objection from the manufacturers of oleomargarine. They are willing to go into the open field of fair competition, with the name of their product inseribed upon their banners, and stand or fall in the field of competition of products useful to mankind. Have not those who can not afford to pay 27, 28, 29 , now 35 , cents a pound for creamery butter the right to purchase an article at half that price if it ean be produced in a manner which will be satisfactory to them? But gentlemen say, "If you will not color it yellow, we will not object." We might just as well answer them by saying, "If you will not color butter yellow, as you always do, except in a few months in the summer time, there will be no objection to that." But the question of color in an article of food is a matter of taste, solely a matter of taste, and all manufacturers of food products must pander to the tastes of their customer's.

As was said in one of the Latin maxims, "de gustibus non est disputandum." When it comes to a question of taste, there is no discussion permitted. You can not reason a man out of the belief that butter tastes better when it is yellow than when it is white-there is no use to reason with him on the subject-or that oleomargarine tastes better when it is yellow. He has a right to his taste, and those who manufacture oleomargarine have a right to manufacture it in such a way that it will be most attractive to their customers and that the retail dealer can best dispose of it to those who consume it. When the manufacturer has done that he has met all the requirements that the lawmaking power of the Government should throw about him. He is willing to go into the market with his article branded, even its name pressed into the article itself, as the Wadsworth bill provided, which was farored by the minority of the House committee. Mark it in any way you see fit; but let it stand, after it has been marked, upon the color which the manufacturers desire it shall have and which the consumer's desire it shall have.

A gentleman.who addressed the committee since these hearings began stated that in the little State of Rhode Island, where the sale of colored 
oleomargarine is permitted under restrictions requiring it to be labeled and signs to be put up in the stores that oleomargarine is sold, the manufacturers did not offer to sell this article in any other way or as any other thing than as oleomargarine, and that on every counter where it was for sale was a card asserting that oleomargarine was sold, and in the windows were the cards of Swift and other firms announeing the sale of their particular product. In that State there was a sale in the last year amounting to $\&$ pounds per capita of the whole population. Do you believe that the sale of butter was interfered with by this competition? I do not. There is no means of telling how much butter was sold, but I believe those who desired creamery and dairy butter bought it and paid the excessire price for it, as they had the right to do.

As was said by one of the gentlemen who discussed this question, there is no real competition in the market between creamery butter and colored oleomargarine when the customer knows what he is buying, and the opponents of this bill, therefore, will not object to any reasonable regulation that Congress may see fit to throw around the manufacture of oleomargarine for the purpose of having it known by the consumer, when it is sold to him, just exactly what he is buying. When you have done that you have exhausted your power as legislators to interfere with the tastes, the peculiarities, and the wishes of the consumers of the country, who constitute the great body of our people.

Gentlemen of the committee, I desire to thank you for your attention, and before closing I wish to present to the committee a statement addressed to the committee from Mr. Walden, president of the Kansas City Live Stock Exchange, who was here the other day and desired to address the committee, but was compelled to return. He has reduced his riews to writing. I have them here in this form, and I will ask the committee to insert them in the record.

The Acting Chamrian. The statement will appear in the record.

Mr. Sprixger. If any gentleman desires to ask questions, I will be very glad to answer as I may be able.

Mr. KNIGHT. You have not stated what the objectious of the livestock growers are to the bill.

Mr. Springer. Those were stated-

Mr. Knight. In the resolution?

Mr. Springer. In the memorial which will be printed.

The Acting Chamman. It will be printed.

Mr. SPRINGER. I read a portion of it. I have asked the committee to embody it at length, but I will briefly state the objections. They object to it because it deprives them of a market for one of their products. In other words, the product of beef known as eaul fat, which amounts in the arerage beef to about 58 pounds per steer, is now or may be manufactured into oleo oil, and if the whole product were so manufactured there would be a large amount-in fact, nearly all of it-used for that purpose, thus increasing the value of the caul fat in the steer to the amount of the difference between oleo oil and tallow.

Mr. Hoard. Does that include kidney fat?

Mr. Springer. It includes all that is known as caul fat. $\mathrm{I}$ am not an expert as to the various fats.

Mr. Knight. Your objection, then, is not so much to what it will do to the live-stock industry as to what it will deprive the live-stock industry of some time in the future? 
Mr. Springer. What they are now securing. In the first place, they are now securing a market for a portion-

Mr. Grout. What portion of the grand aggregate of caul fat produced from the steers which are slaughtered throughout the country is thus used?

Mr. Springer. I think it was stated that about 5 per cent or 10 per cent of the caul fat is now utilized in the manufacture.

Mr. Grout. You said in your statement that if it was all so used it would make a very large difference.

Mr. Springer. 'Yes; a very large difference.

Mr. Grout. Enough to float an empire?

Mr. Springeri. I made this estimate, but I have not the details of it - that the oleo oil actually used now in the manufacture of oleomargarine increased that product to the amount of $\$ 1,430,000$ annually, or on the production of the year 1899

Mr. Flanders. How much a steer?

Mr. Springer. I did not estimate it in that way.

Mr. Grout. He says the amount now used-

Mr. Springer. In 1899.

Mr. Grout. Amounted to $\$ 1,000,000$.

Mr. Springer. $\$ 1,434,000$. That is my estimate.

Senator Heitfeld. Did you say 5 per cent of the product is now so used?

Mr. Springer. I will not state what the percentage is, but I have it in my notes somewhere. I will look it up.

Senator Heitfeld. It bears the same relation to the total product that the manufacture of oleomargarine now bears to the total production of butter?

Mr. Springer. Yes, sir. I have put into my remarks a statement showing the ingredients of oleomargarine as reported by the Treasury Department. You will find it in my printed remarks. It shows the number of pounds of oleo oil and the number of pounds of neutral lard that were nsed during the year 1899 .

Mr. Grout. Are you able to state the number of pounds of oleo oil that was used in the production of oleomargarine last year?

Mr. Springer. Yes, sir.

Mr. Grout. Will you give it?

M. Franders. He will publish that statement.

Mr. Knight. It is $24,400,000$ pounds.

Mr. Springer. The table gives the "quantities and kinds of ingredients used in the production of oleomargarine in the United States for the fiscal year ending June 30, 1899; also the percentage each different ingredient bear's to the whole quantity." Neutral lard, $31,000,000$ pounds; oleo oil, 24,000,000 pounds; cotton-seed oil, $4,357,000$ pounds.

Mr. Grout. What is the amount we exported?

Mr. Sprixger. We exported $142,000,000$ pounds of oleo oil, I think. That is not taken into consideration in the amount that was used in this comtry.

Mr. Knight. But in the resolution of the lire-stock association is it not stated that the passage of the Grout bill would mean a damage or loss in ralue of $\$ 3$ or $\$ t$ a head per cattle?

Mr. Springer. Yes, sir; it is so stated I think. 
Mr. Knigut. How do you figure that, please?

Senator Heitreld. Was it not $\$ 2$ in the statement made here?

Mr. KNight. From $\$ 2$ to $\$ 4$ in some statements.

Mr. Springer. They say in their memorial:

"In oleomargarine a very large proportion of the consumers of this country, especially the working classes, have a wholesome, nutritious, and satisfactory article of diet, which before its advent they were obliged, owing to the high price of butter and their limited means, to go without.

"The 'butter fat' of an average beef animal, for the purpose of making oleomargarine, is worth from $\$ 3$ to $\$+$ rel head more than it was before the advent of oleomargarine, when the same had to be used for tallow, which increased value of the beef steer has been added to the market valiw of the animal, and consequently to the profit of the producer.

"To legislate this article of commerce out of existence, as the passage of this law would surely do, would compel slaughterers to use this fat for tallow, and depreciate the market value of the beef cattle of this country $\$ 3$ to $\$ 1$ per head, which would entail a loss on the producers of this country of millions of dollars."

Mr. Knight. The amount of oleo oil used was $24,000,000$ pounds?

Mr. Springer. Y'es, sir.

Mr. Knight. Valued last year at about $\$ 2,000,000$ ?

Mr. Springer. Yes, sir.

Mr. KNight. 'There were 5,000,000 head of cattle slaughtered in this country last year.

Senator Heitreld. If you took that amount out of the use to which it was formerly put, would not that make a difference?

Mr. Hoard. The Treasury Department shows that there was used of oleo oil produced in this country $24,000,000$ pounds. That is a fraction less than 5 pounds of fat from each animal.

Senator Heitfeld. It takes that 5 out of the gross product.

$\mathrm{Mr}$. Hodrd. It is $\$ .99$ to each animal. At their figures it would be worth about $\$ 1$ a pound.

Mr. Grou't. What is the price of it?

Mr. Hoard. Nine cents.

Senator Heitfeld. In what way would it?

Mr. HoARD. Because there are 5,000,000 animals slaughtered and $24.000,000$ pounds of oleo oil used. Divide one by the other, and it makes 4.99 pounds to each animal; 45 cents a pound.

Senator Heitfezd. I do not think that is a fair estimate.

Mr. Springer. I will make this explanation.

Mr. Hoard. I am taking the amount that would be used in cleomargarine.

Senator Heitfexd. But you are figuring the $24,000,000$ pounds as the entire output from the beef, and the only output that is bringing any money, throwing away the other 95 per cent.

Mr. HoArd. I am figuring as to relationship and the worth of the oleo oil, and it does not square with that live stock statement.

Mr. SPRiNGEl. I will answer that.

Mr. Hoard. It is overestimated.

Mr. Sprixger. Mr. Knight, in his statement before the committee of the House (pages 26 and 27 of the House hearing), endeavored to expose the figures used by Swift \& Co. in regard to this subject. I 
did not prepare those figures, and I do not know who did, but it appears to me from an examination of both of those statements that the gentlemen and those who prepared these estimates are both out of the way in their estimates upon this subject. In other words, they have, by a loose manner of expression, failed to state exactly what the truth is and what the difference would be. It seems to me that the proper statement is this: We must gro for the amount of oleo oil that was consumed in the manufacture of oleomargarine to the Treasury statisties in order to ascertuin the exact truth. That does not embrace the amount of oleo oil exported, and a great deal more is used for export than is used in this country.

Mr. Knight. What has this to do with the oleo oil that is exported?

Mr. Springer. Nothing, except that the use of oleo throughout the world has created a demand for it, and a portion of that demand is in this country. Now, if all of the caul fat in the beeves that were slaughtered during the year had been used in the manufacture of oleomargarine in this country, it would have amounted to the figures stated by Mr. Swift in his circular, which are practically the ones stated in the resolution and memorial of the cattlemen.

Mr. Knignt. Is there anything in the Swift letter to Congress indicating that it was not?

Mr. Splinger. I say that I think he was mistaken in placing it upon that basis, but I wish to call the attention of the committee to the fact that it is beyond the power of man to tell what would be the loss to the cattlemen of this country by reason of the destruction of oleomargarine as an article of commeree.

Mr. Hoard. It is beyond the power of man to tell what the destruction to the butter industry is by this business.

Mr. Springer. You can guess at it.

Mr. Knight. Now, Judge-

Mr. Springer. Let me finish. You can not tell. Why? There was already created, by the amount of oleo oil used in the actual production of oleomargarine in this country, a demand for $24,000,000$ pounds of their product which would not have existed if oleomargarine had not been manufactured in this country. To that much we will all agree.

Mr. Hoard. Yes.

Mr. Springer. There is that much increased demand for their stock.

Mr. HoArD. With a corresponding destruction on the other side?

Mr. Springer. Excuse me for one moment. There is that large increase. Now, gentlemen, how can you tell what effect that increased demand for the $24,000,000$ pounds had upon the price of all the other products of animal fats? Who can tell that? Nobody can tell. But it is my opinion that the pending bill and the restrictive laws in 32 States in this Union will injure the cattle and hog industry to the extent of many millions of dollar's annually, and that injury will reach the extent stated in the memorial of the National Live Stock Association.

Let me call attention to the fact that the prices of agricultural products in this country are determined by a number of causes, and the man who operates on the board of trade is looking even to a cold smap or a little drought to see whether corn and wheat and other such products will go up or down. Why? Because if the weather is good and the farmers have good crops, there will be low prices; and if there 
is bad weather and short crops, there will be high prices. By the demand for $24,000,000$ pounds of oleo oil in the manufacture of oleomargarine you have taken that much of the product and raised it in price from 6 cents to about 10 cents a pound. You have increased at least the demand for this kind of product, and by increasing the demand for that much of the product you have raised the price of the whole product to some extent. To just what extent it would take a board of trade man to tell, and he might make a mistake and get caught in the deal. But it does have some effect.

Now, suppose you stop the manufacture of oleomargarine in this country and throw the $24,000,000$ pounds of oleo oil back into the condition of tallow, to what extent will you depress the price of the whole product of tallow in the United States? Nobody ean tell. But you will depress it: you will depress it something, depress it even to the amount of several points at least, as they say upon the board of trade, by reason of throwing $24,000,000$ pounds upon the market and putting itin to tallow, increasing the product that much and depressing the price.

So when you come to estimate the loss or gain to those engaged in agriculture by reason of this legislation, it is in a great measure speculative. What is known is-and that is the fact to which I call attention-that there was, under all the restrictive legislation of the several States of this Union, amounting to prohibition in 32 States, a demand for $24,000,000$ pounds of oleo oil and $31,000,000$ pounds of leat lard, the product of the hog, and this large demand, if taken away, would depress these virious articles in the market, and nobody can tell exactly where it wonld land.

The Acting Chammax. Let me ask you a question. Is oleo oil used for any purpose other than the manufacture of oleomargarine?

Mr. Springer. Some of the gentlemen engaged in that manufacture can tell.

Mr. Mrluer. I will say that it is not. I am with Armour \& Co. I should like to bring ont a point here in regard to oleo oil. If you destroy the olcomargarine industry you naturally place a ban on our oleo oil which will necessarily have a very injurious effect on the foreign market. It will perhaps also place a ban on our oil, and we would lose the use of $24,000,000$ pounds in the United States and perhaps the sale of $1+2,000.000$ pounds in foreign countries.

Mr. Hoard. 'That is speculative.

Mr. Miller. Everyone here is familiar with the agrarian spirit which predominates in Europe at present. They have not only tried to restrict the importation of cotton-seed oil, but of meats and many other agricultural products.

Mr. Splinger. While I can not say, and no other man can say, just how much the price of cattle would be depreciated by destroying this industry, or how much it would be appreciated by repealing the restrictive State laws and letting oleomargarine go free, as other food prodnets do, yet I know it would depreciate animal fats in the one case, and it would appreciate in the other very largely if this article should be left in the same condition that other food products are left.

I called your attention this morning to the possibility, under the amount consumed in Rhode Island, for a demand for oleomargarine in this country of $500,000,000$ pounds a year. Suppose that existed instead of the demand for $100.000,000$ pounds that existed last year, how much that would appreciate the price of all the products of the 
cattle of the country it is impossible to state. Yet you are not only asked to pass laws here to take away the demand for the 24.000.000 pounds, but you want to perpetuate the laws in 32 States which destroy the prospect which the manufacturers of oleomargarine and which the growers of hogs and cattle have of an increased demand in this country in the near future of $500,000,000$ pounds a year. The people of this country who eonsume food products have a right to indulge their tastes, if they want to, in that direction, and it is depriving the people of the comforts and necessaries of life to say they shall not have oleomargarine in a colored state, if they want to buy it in that state and know what they are buying at the time.

Gentlemen, I have not taken up your time in regard to the coloring matter, or a great many other subjects that have been before you heretofore. I am not an expert in the manufacture of oleomargarine. I have no connection with any manufacturing establishment. What I objected to in regard to the remarks of Governor Hoard was that he placed all the opponents of this bill in what is ealled the oleomargarine trust. I do not know any thing about any trust. I am not in any trust. I am here to speak for those who raise cattle and hogs, and who ask the Congress that their product shall not be legislated against and discriminated against by Congressional legislation. They represent a vast population in the United States. Their property represents a capital of $\$ 600,000,000$.

They have never before asked to be heard as a national association before this committee or before any other committee of Congress. They now ask to be heard, and they ask that their memorial which I have presented here to-day shall be considered fairly and that they may be placed, by the legislation of Congress, upon an equal footing with the other farmers of the country, for they are farmers and have the right to sell their pioducts in the markets where they can get the most for them, and not be hampered by restrictive legislation, either by Congress or by the States, that will destroy in a measure a portion of the value of the products which they are engaged in laising.

I thank you, gentlemen.

\section{STATEMENT OF G. M. WALDEN, PRESIDENT OF THE KANSAS CITY LIVE STOCK EXCHANGE.}

Mr. Chairman and Gentlumen of the Committee: Business engagements of great importance prevent my appearing before your honorable body in person to present the protest of the Kansas City Live Stock Exchange against the passage of the Grout bill, the provisions of which you are familiar with. Arguments have been presented before you from the allied interests for and against, with the exception of the live-stock commission merchant.

The Kansas City Live Stock Exchange is composed of 300 member's, 90 per cent of whom are engaged in buying and selling live stock, and by their zeal and enterprise have succeeded in building the second lirgest live-stock market of the world. During the year just closed there were received 1,970,000 head of cattle, 69 per cent of which were killing grades; 50 per eent of these killing grades furnish the butter fats used in the manufaeture of oleomargarine, 19 per cent representing the more common beef and "canner" grades, which furnish an insignificant per cent of butter fat. 'The remaining 31 per cent are 
shipped and driven back to the grazing lands, feed lots, or are used for breeding purposes, with the exception of a slight fraction known as milch stock. Ultimately, however, all find their way to the bleck, which would lead us to the proper basis to figure from, viz, 100 per cent.

While statisties are dry and uninteresting reading, if correct they silence all argmment. We propose to show to this honorable committee the tremendous loss which will accrue to the live-stock industry of this country, especially the cattle-growing States of the great West, North, and Sonthwest, if this Grout bill becomes a law and how such loss affects the live-stock commission merehant.

Through the members of this exchange nearly $\$ 60,000,000$ are loaned to the men engaged in this great industry in the territory tributary to this market. The greater proportion of this enormous sum of money does not belong to the men engaged in the commission business, but to the financial institutions in every section of the country. True, the commission merehant makes the loans and sells the paper, which is negotiable, from the Atlantic to the Pacific coast, with his, the commission merchant's, indorsement, atecompanied with the usual safeguard of mortgages on cattle. Any depreciation of values from any cause may result in loss to the holders of the paper. 'This enormons sum of $\$ 60,000,000$ controls abont 2,000,000 cattle, whose ultimate destination is the market. Competition has, from many causes, grown so sharp in the live-stock commission business that great risks are taken. Only a few years ago freight and pasturage money was all that was required to control a good share of what we term "range" business, but lately the cattle raisers and speculators from the cattleproducing States of Colorado, New Mexico, Arizona, and Texas, who move their herds to the grazing lands of the Territories and Kansas, demand a very large percentage of the purchase price of cattle, and in many instances the full cost.

We now come to the point where we, the live-stock commission merchants, suffer. In the event of the Grout bill becoming a law our security would be depreciated just $\$ 2$ per head, whereas, nnder the strain of competition, we have loaned up to the full raluc of cattle already. We should also mention that cattle deals are not closed up cach year they are made. Renewals are granted, loans extended by reason of unfavorable conditions for fattening cattle, such as crop failures, drought in the grazing districts, or unusual severity of the winters. During the winter of 189820 per eent of all cattle in winter range districts were frozen to death. So you can readily see we have enough of the element of loss to contend against without the Government permitting legislation that will make an additional burden of $\$ 2$ per head loss.

While this market is the "open door," the very threshold, of the great cattle-producing States and 'Territories, the same conditions governing the details of our business is proportionately true of every market of the United States: and not alone does this bill propose to kill an industry that benefits the producer and the packing industries, but every butcher who slaughters his own cattle in the United States; for he ships his butter fat to the nearest manufacturers of oleomargarine, which, if legislated out of business, goes into candles and boot grease, and he must charge the consumer a higher price for his beef in order to offset the loss on butter fat. 
During the year just closing there were received at this market $3,100,000$ hogs, 90 per cent of which were slaughtered here and the remainder shipped to other markets. The loss to this industry if the Grout bill become a law, figured by the same experts on cattle, is 20 cents per head. A very large percentage of this trade is controlled by commission money, and the same depreeiation of security relatively obtains as in loans on eattle. Summing up the actual loss to the livestock industry of the United States if the Grout bill pass, it means $\$ 2$ per head on 50 per cent of the killing grades of cattle and 20 cents per head on 85 per cent of the hogs slaughtered. It would take too much of the valuable time of your honorable body to make a detailed statement of the immense loss, but it is appalling.

In closing, we desire to voice the sentiment that we regard this bill hurtful, vicions, and intended to kill one great and beneficial industry to build up and fatten another whose business during the year just closed has eclipsed all former years in prosperity. We further believe that if this un-American measure is forced upon the people a panic will ensue in the live-stock industry of the United States most disastrous; declines will immediately follow, tending to disrupt the whole system of trade as it relates to the live-stock industry. But we have faith that this honorable body will report unfavorably. If to the contrary, the great court of justice of the whole people, the United States Senate, will not consent to deprive the vast army of the poor, the great majority of the American people, the substantial middle class, even the wealthy, of purchasing a pure, wholesome food product.

I thank you, gentlemen.
G. M. WALDEN, President Kansas City Live Stock Exchange.

Kansas City, December 31, 1900.

\section{STATEMENT OF GEORGE L. FLANDERS.}

Mr. George L. Flanders, assistant commissioner of agriculture of the State of New York, appeared before the committee.

Mr. Franders. Mr. Chairman and gentlemen of the committee, I am a little surprised at the length of the argument of the eminent gentleman on the other side. He dwells entirely upon the proposition that there is nothing involved here but a financial question. I come here representing the department of agriculture of the State of New York, and there we feel that we are protecting the consuming public, and we believe that they are a great element in this country. We believe that this business thrives upon fraud, and that the great consuming public are the ones that are defiauded.

In 1878 it appeared in the State of New York that oleomargarine was being sold, and sold as butter. It was thought then that the State would try to regulate the matter. It passed a statute that the goods might be sold, but should be branded as such. That law proved ineffectire, and in 1880 the State passed another act providing that when sold it should be branded as oleomargarine. That act, althongh more restrictive, proved ineffective; and in 1882 the State passed another law more restrictive, and that failed to produce a result, and, finally, in $188+$ it passed an act providing oleomargarine should not be sold as a substitute for butter. That act was declared unconstitutional by our 
State courts. In 1885 the State passed a law providing it should not be sold in imitation or semblance of butter. So much for the proposition that they would like to stand out before the world and sell these goods for what they are. There is not one solitary word of truth in it from the standpoint of our experience in the State of New York.

For nearly seventeen year's I have seen this work go on. From the city of Chicago last year several hundred tubs came into the State of New York without the national stamp; not a thing on them would indicate that the five tacks had ever been in the tub as required by law, and it was sold as renovated butter and branded as such. It was traced back to Chicago by our detectives and traced to one house there whose representative, I am told, is here to-day.

Let me modify that statement by saying this: Our detective went back there and traced the goods as best he could. It was reported to the National Government. They seized the goods and sold them in Detroit, and my informant told me it was traced to dangerously close proximity to a certain oleomargarine manufactory. Our detective reported that a person, said to represent Braun \& Fitts, appeared and gave bail for the defendants and otherwise interested himself in their behalf. The indications pointed to that manufactory. But, be that as it may, whichever one of the concerns it came from, it came in carload lots, in semblance of butter, with not the iota of an intention on the face of it to comply with the State or national law, and a violation of both of them.

Now, sir, an argument was made as many as fifteen years ago before the governor of the State of New York, wherein these people said, "Let us sell oleomargarine for what it is, and we will do it." We replied, "For" six years we have tried to let you sell it for" what it is, and you would not do it. Now you must be made to be honest with the people." That was the experience in Ohio, Iowa, Pennsylvania, Massachusetts, Connecticut, New Hampshire, Vermont, and all the States of the 32 which have passed such laws, as I understand it. New York and the other States passed these laws because foreed to do it to protect the consuming public.

After that we had our litigation, and the law under question went to the court of appeals of our State, and in the case known as the People $v$. Arenburg the law was declared to be constitutional. The Massachusetts law was declared constitutional. The Pennsylvania law was declared unconstitutional. Finally a case was made up which went from Massachusetts, which was discussed here to-day, and I was astonished at the discussion and conclusion coming from the gentleman it did. The conclusion he drew is, in my judgment, absolutely wrong. What did the Plumley case involve? He said had the pleadings been right he thought the decision would have been different. He said it did not appear in the pleadings, as I understand it, that that was an original imported package of oleomargarine on which had been paid the duties as required by the national law.

Mr. Springer. I said it did.

Mr. Flanders. Vely well. I did not so understand you; and now I do not understand what could have been your thought when you agreed that the decision would have been different under certain conditions which you seemed to think should have prevailed. In my judgment, the case contained all the necessary and proper questions of fact, and was well presented and considered by the court. As to the particular 
question which $\Upsilon$ understood you to say was not in the case, and should have been, viz, "that the goods were sent into the State in the original importer's package, and that the manufacturer and importer and petitioner had complied with all the requirements of the law of Con. gress relative to oleomargarine," permit me to call your attention to the fact that in the ease as reported in 155 United States supreme Court Report, that among the statement of facts as agreed to in the case appears the following statement:

That the article sold was sent by the manufacturers thereof in the State of Illinois to the petitioner, their agent in Massachusetts, and was sold by him in the original package, and that in respect to the article sold the importers and the petitioners had complied with all the requirements of the act of Congress regulating the sale of oleomargarine, and it was marked and distinguished by all the marks, words, and stamps required of oleomargarine by the laws of this Commonwealth.

That being so, it was an original importer's package, transported from one State to another, sold there in defiance of State law; and the only question was, Could the law be maintained on any principle whatsoever?

Now, prior to this time the decisions of United States courts had been to the effect that articles of commerce in original packages could be sold in the State irrespective of the State law except in the ease of In re Rahrea. The question was presented in Leisy $v$. Hardin as to whether or not an importer's original package could be sold in a State in violation of the laws passed under the police power. That case was tried. It went to the Supreme Court of the United States, and that court said that the power to regulate commerce was one of the power's granted by the Constitution to the National Government and could not be exercised by a State; and the State law was declared unconstitutional as to the package in question.

Inmmediately Mr. Wilson introdneed in the House of Representatives a bill providing that whenever such goods were transported from one State into another they should immediately upon entering a State become subject to the State laws, irrespective of the fact that they were in the original package, in the same manner and to the same effect as if produced in the State. The liquor men said, "We will test that; that law is unconstitutional; it is a regulation of commerce between the States by a State; that is a power which is given to Congress, and Congress can not delegate it back to the State." That was the question involved in In re Rahrer (1 10 U. S.). The Supreme Court of the United States, in its opinion in that case, said that the enactment of the so-called Wilson law was a proper exercise of the power granted in the Constitution, and that the law was constitutional.

Now, sir, any' man that should question the right of the National Government to exercise the power given in the first section of this bill, in riew of that decision, passes my comprehension. In that decision (In re Rahrer') the court practically said that the Government might, by virtue of that clause in the Constitution, say to a State, "When you pass a law relating to goods produced in the State, it shall apply to all goods coming into the State, whether they come in original packages or not."

I want to go back to the proposition as to why that clause was put into the Constitution of the United States. A careful reading of the discussion at the time it was adopted will show you that it was thought at that time by the framers of the Constitution that it would not be 
well to let Minnesota (not in those words, but in principle) say to Vermont, "Because you exclude our' wheat we will exclude your dairy products," because the States of the Union might then build fences around themselves, to the detriment of the general welfare. "We will put the power in the National Gorernment;" in other words, fix it so that a State can not say that a citizen outside of the State shall not have the same commercial lights her citizens do inside. But I do not believe it was ever contemplated for one moment that that power, granted in that way, should work out this result - that people in outside States should have rights in the markets of a State that the citizens inside do not have.

'These States have done what they have done by virtue of the police power. What is that? It is the power left in the State to legislate along lines to protect the health, the morals, and the lives of the people. Now, by virtue of the police power, and under no other pretext whatever, have these 33 States passed such laws. They now say to the Congress of the United States, in one instance where those police laws have been outraged, "You have remedied the difficulty by saying that the original package shall be subject to the same laws as goods made within the States. We eome to you by virtue of the decision in In re Rahrer and by virtue of the action of the Wilson bill, and say, do likewise relative to oleomargarine. We are not asking you to aid us to do something to a person outside of our State that we do not do to our own citizens. We simply say to you, we do not allow our citizens to be imposed upon by oul own citizens; help us so that people outside ean not impose upon our citizens."

Now, if the argument which I propose to present to you later, relative to the healthfulness of these goods, is sound, for I propose to give you instances showing that this business thrives upon fraud, then it seems to me that the argument is almost conclusive that you should help us as asked in this bill. The Plumley decision was simply a majority decision, and we were afraid that the conditions might erentually be such that it would be reversed. We had our eyes upon the compass in all directions to see what would come next, and out of Pennsylrania came a case known as the Sehollenberger case. It went to the Supreme Court of the United States, and the oleo people secured a farorable decision in that case. What was the difference between the two cases? I know it was heralded all over the country that it was a reversal of the Plumley ease, but I say to you it was not, in my judgment, notwithstanding the fact that certain judges in certain localities have so said to the contrary. It was an original package of oleomargarine, but it did not appear to the court that it was colored in imitation or semblance of butter. That element was in the Plumley case, but not in the Schollenberger ease, making it plainly a different case. My friend seems to think that the Schollenberger case reversed the other case, but I read from Mr. Justice Peckham's opinion:

"Nor is the question determined adversely to this view in the case of Plumley $x$. Massachusetts, 155 U. S., 462 . The statute in that ease prevented the sale of this substance in imitation of yellow butter produeed from pure, unadulterated milk or cream of the same, and the statute contained a proviso that nothing therein should be 'construed to prohibit the manufacture or sale of oleomargarine in a separate or distinct form and in such manner as will advise the consumer of its 
real character, free from coloration or ingredients that eause it to look like butter.' This court held that a conviction under that statute for having sold an article known as oleomargarine, not prodnced from unadulterated milk or cream, but manufactured in imitation of yellow butter produced from pure, unadulterated milk or cream, was valid."

The judge said that that decision was not adverse to the decision in the Schollenberger case. We know it did not appear in the case that it was a semblance of butter, but it did in the other case, and therein lies the distinction; and if those two decisions mean anything at all, they mean that the Supreme Court has put its brand upon oleomargarine, colored in imitation or semblance of butter, as an imitation and a fraud and a counterfeit. They did so hold, and so did two of the State courts of last resort, and if they have virtually placed the brand of counterfeit upon it, then we come to you and ask you to assist us, to the end that the fraud in this business may be wiped out.

We will take the question of competition for a moment. I do not care to discuss the other eases discussed by my friend, for they are discussed by the court in arriving at the conclusions in these last two cases and disposed of. They are immaterial here. The shoddy matter, given by Judge Springer, would not come within the police power of a State, as it involves simply a commercial question. A prophet or a philosopher can be a prophet or a philosopher' still with shoddy on his back, but he can not be either without nourishment in his stomach or with something in his stomach furnishing only half the nourishment that he ought to have. You must feed nutritiously or you can not produce good men and women. Somebody has said, "Show me what a people eat and I will tell you what they are." Another has said, "Think of the chemical work whereby food is put in the human stomach and produces the divine tragedy of Hamlet." You must look after the nourishment and health of your people if you would have a strong nation.

Now, how about the question of competition? In the first place, let us go back to the color of butter. 'The natural color of butter, when the cow is living upon nature's food, is a rich rellow. Butter has been that color so long that the memory of man rumneth not to the contrary. When these people back in the seventies started to make oleomargarine, what did they do? They undertook to make it look like our commodity. Is that all? No. In taste and smell they attempted to make it like our commodity, so that crery feature would deceive erery sense that man could possibly apply to the commodity. Were they content with that? No, sir. They came into the market and sold it for butter.

Now, I am not guessing or talking at random, for in 1854 and 1885 , when we commeneed to enforce these laws, you were selling, or those who were in the same business that you are in to-day were selling, in the State of New York 15,000,000 pounds, and they told the same story then as ylibly as you tell it now, that they wauted to sell it for what it was. Our men went into the city of New York, and if they went into a store where they were known and called for butter ther got butter; but just as soon as they put on the garments of longshoremen, which they did in a great many instances, to see what the facts were, and took a basket upon their arms and bought a quarter of a pound of tea and a loaf of bread, they got oleomargarine. 'This is no faneiful dream. It is a fact. 
Take that into consideration, and then take into consideration the fact that these people send out all over the country-I will modify that a little; I will say that they send into the State of New York, and I know whereof I talk-agents who try to induce our people to enter into the business of selling those goods; and we are told that they promise to indemnify them against the State law. Mind you how I put itthat we are told by parties who have been approached that they offered to indemnify them. When you think of that state of facts as I have given it, can you listen with equanimity to the statements made here that there is a demand for those goods? There is no demand in the State of New York for oleomargarine by any consumer.

They talk about it as the poor man's goods, and ret not long since, when the great strike was on in Pennsylvania, which we knew of all over the country by the results it produeed, the papers, looking into the facts and trying to show how the poor man had to work practically for nothing- $\$ 200$ or $\$ 300$ a year-gave us a schedule of the goods the laborer's purchased and the prices paid, and the price for oleomargarine on that list was 30 cents a pound; and there is not a farmer in the United States who would not hare been glad to furnish butter all the year round for 25 cents. And yet they call it the poor man's butter. The poor man in our State does not want it. If he does, he wants it for what it is and at its true value.

The great difficulty is they are imitating our goods. We have used, or the butter people have used, that color so long that it has become a trade-mark. If you are familiar at all with the fundamental prineiples of the laws of trade-marks, you know, sirs, that when a man or a firm has used for a given length of time, under certain conditions, a trademark, others are estopped by the laws from trespassing upon it. Why do they come and take our color and take our smell and take our taste and put it in their goods and then come forward and sell them as our goods, and yet come here and talk about healthful competition? In the way the oleomargarine business is carried on there is no competition at all. If I go into the open market to compete, I have to put my goods up against yours and let the consumer know what he is buying. When I put my goods in with yours and declare they are yours, you can not call that competition.

Let us see. I will go outside of the State of New York. Not long ago I started from New York and I went to Fort Worth, Tex. In St. Louis we stopped to get something to eat. We went to as good a restaurant as we could find. Mr. Kracke was with me. He is an expert and can tell oleomargarine every time. I can not always do it. He said to me, "That is oleomargarine." I said, "I want butter; not oleomargarine." The waiter said, "That is butter." I said, "It is not butter." After a good deal of confal) he came baek and said it was butter. I insisted that it was not; and by and by he came back and said. "That is the only kind we hare here; that is oleo." The same thing happened to us on Pennsylrania arenue, in this eity, with Mr. Adams present. The same thing happened at the W'orth House, the best hotel, I understand, in the city of Fort Worth, Tex. These people do not sell it for oleomargarine. Ninety-nine times out of a hundred they sell it for butter. I do not mean the manufacturers. I mean when it gets down to the last parties-from the last man to the consumer. I know when you turn it ont at your factories you turn it out as a rule, though not always, as oleomargarine. You comply with the letter of the law, but you make your goods in the best possible 
shape, so that as it filters down through the arenues of commeree it may ultimately be sold as butter. While living up to the letter of the law evade its spirit.

Mr. Mathewson. How would the proposed 10-cent tax do away with that difficulty?

Mr. Flanders. I am not a prophet or the son of a prophet. I can not tell what would happen, but I will tell you what I wish to see happen. I speak individually, and I do not speak for anybody but myself. I hope it would tax the fraud out of the oleomargarine. That is all I want.

Mr. Mathewson. If oleomargarine sold at a price high enough so that the manufacturers could pay the 10 cents, would not the fraud exist the same?

Mr. Flanders. No, sir. I will stake my reputation now as a prophet-I would not a moment ago-on the proposition that when you put butter at 30 cents or above cows enough will come forward to produce butter enough to hold it down. That never will happen in this country under ordinary conditions.

Mr. Mathewson. I merely asked how the 10 cents tax would remore the fraud.

Mr. Flanders. We hope it will. We want the fraud stopped, and then we want your people, if your goods are as good as you say they are, to step out into the open market and sell them for what they are, so that they can deceive no one. That is fair.

Mr. Mathewson. Would it be a fair proposition to ask the manufacturers of ereamery butter to leave the color out of their butter?

Mr. Flanders. No, sir; and I will tell you why. In the first place, that is the natural color of the butter, if they color it as they ought to color it. Butter is yellow when the eows feed upon nature's succulent food. Color in butter is for the purpose of uniformity.

Mr. Mathewson. It brings a little more on the market.

Mr. Flanders. Not at all. I ate butter in New York City the other day with all the flavor you could ask, and not one bit of coloring and not a bit of salt in it. I ate to-day down at the hotel cheese with not one bit of coloring matter in it, and I liked it just as well. The truth is that the people, if your commodity is good, ean be educated to eat it without its coloring matter, and you will not deceire them as to the commodity.

Mr. Mathewson. If the butter is so good when it is white, why not leave out the coloring matter?

Mr. Hoard. That is not the proposition.

Mr. Flanders. I am willing to discuss that point at length at the proper time and place, but you are aware that your speaker oceupied an hour and three-quarters, and my time is limited and vanishing with ordinary rapidity.

Mr. Mathewson. The Judge answered very courteously any question put to him.

Mr. Fuanders. If you will give me time, I will gladly answer your questions.

Mr. Mathewson. We will give you all the time the committee will.

Mr. Flanders. Talk about the healthfulness of the commodity. We say that the commodity that is sold upon the market is not healthful. The Judge in speaking said that it was universally acknowledged to be healthful. That is not true. I think the Judge made the statement from a lack of knowledge of the facts. 
Mr. Springer. 'The Supreme Court so stated.

Mr. Flanders. 'The Supreme Court did not say that. I should like to hear the statement. It said when the goods are properly made; but I submit the proposition that the Supreme Court is not to pass upon the question of the healthfulness of a commodity. They are to construe the laws and the Constitution. If a law contravenes the Constitution, they say so; if it is within the powers, they say so; but whether legislation is wise or unwise, good or bad, the court has said time and again is no concern of theirs. I do not think that the court determined or tried to determine that question.

Here, gentlemen [exhibiting], is one of many samples of paraffin wax taken from oleomargarine sold in the open market in the city of New York, gathered by our agents, and here is a pamphlet prepared by Chemist Joseph F. Geisler, of New York City relative to the matter. I will not read it to you, but will leave it with yout.

Mr. Militer. Where did he purchase that oleomargarine?

Mr.Flanders. Mr. Kracke, where was that oleomargarine purchased?

Mr. Kracke. It was found on Third avenue in New York City.

Mr. Mrlier. How many samples did he examine?

Mr. Flanders. Here is the statement of the chemist showing number of samples. If we find any adulteration in the course of our work in enforeing the law we make a note of it. Here are eight cases.

Senator HEITFELD. When was this analysis made?

Mr. Flanders. In 1899; some of them. I will read the opening clause of this pamphlet, if the Senators will permit me:

"One often hears of adulterated food, but rarely are such sophistications of a nature that they may be deemed injurious to health. The recent finding of paraffin as an adulterant in a number of samples of commercial oleomargarine may therefore prove of interest.

"Though paraffin has been mentioned as an adulterant of chocolates and eandies, the use of such an indigestible substance as an adulterant of oleomargarine seemed so improbable that the actual separation of the paraflin was required to convince some skeptical minds.

"Its use in oleomargarine is by no means new, for" I first observed it in a commereial sample in September, 1893, and reported the fact to the New York State department of agriculture. The general properties of the fat of the sample, its behavior during saponification, and

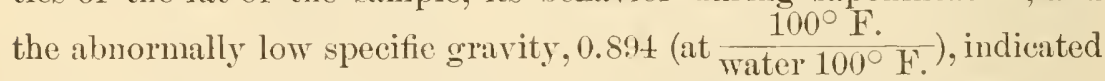
an irregularity and the probable presence of paraffin. Although the sample under" examination amounted to only a few grams, sufficient of the unsaponifiable matter was obtained from the same to show that it was paraffin. It was impossible at the time to get more of this particular sample or duplieates of several others in which paraffin was found between that date and March, 1894, when I was enabled to prepare an exhibit of the paraftin extracted from one of the samples. About this time experts of the department of agriculture, in the course of their inspeetions in New York and Brooklyn, found quite a number of samples of oleomargarine which, upon analysis, were found to contain paraftin. Some of these were analyzed by Drs. Love, Waller, Stillwell, and myself, and the amounts of paraftin in the various samples were found to range from 9.72 per cent to 11.25 per cent."

Now, gentlemen, those are facts. This pamphlet was issued by Dr. Geisler, of New Iork. 
Mr. Milcels. Why would any manufacturer use that? We have been engaged in the manufacture of butterine from fifteen to sixteen years. I can not understand why any manufacturer wonkd use it.

Mr. Flanders. I do not understand why men commit murder. I understand that they do. I do not want to stop to discuss that point, because I am limited for time.

Mr. Matiewson. I suppose you have examined a great many samples of butter?

Mr. Flanders. Our chemists have.

Mr. Mathewson. Did you ever in all your examinations find anything in straight butter, stuff sold as straight butter or supposed to be straight butter?

Mr. Flanders. We have never found dairy butter adulterated.

Mr. Matuewson. You never have?

Mr. Flanders. No, sir. I should like to say that we pay attention to every communication, anonymous or otherwise. It does not make any difference who the man is who sends in the communication, we take cognizance of it and hunt it down to the roots.

I now turn to the report made by Dr. R. D. Clark upon the healthfulness of oleomargarine. He is a chemist and medical man of twenty year's' standing, and I want to say here and now that our opinion in the State of New York, after having given this subject a great deal of study and thought and after having obtained the very best advice we could get, is that a chemist is not, by virtue of his chemical knowledge, a competent man to tell about the healthfulness of food products. A chemist's province is to take a commodity, and take it apart, and tell what is in it. It is no part of his work to tell what effect that article produces upon the human system. That is a physiological question. Dr. Clark, a physician, says, relative to the healthfulness of oleomargarine:

"We now come to the all-important aspect of the subject, Is artificial butter a wholesome article of food? We answer it in the negative, on the following grounds:

"First. On account of its indigestibility. fats.

"Second. On account of its insolubility when made from animal

"Third. On account of its liability to carry germs of disease into the human system.

"Fourth. On account of the probability of its containing, when made under certain patents, unhealthy ingredients."

I should like to read the patents - I have here 40 or 50-showing not necessarily what goes into oleomargarine, but what they say goes into it. What they do we do not know. Our chemist has been to Chicago under the expressed promise that he might go into the works, but he never got through.

Mr. Mrller. Are these patents for the manufacture of oleomargarine or butter?

Mr. Flanders. Oleomargarine, as filed hele in Washington.

Mr. Miller. They are substitute: for butter in a great many cases.

Mr. Flanders. 'They are not substitutes for butter, but patents for oleomargarine. I am quite familiar with the subject, and I tell you they are for oleomargarine. Dr. Clark says:

"Before entering upon the argument we wish to state that we have investigated the claim made by the 'oleo' makers that the 'weight of the testimony of the medical profession was in favor of its being

$$
\text { S. Rep. } 2043-9
$$


healthy.' 'This, no doubt, was true a few years ago; but we have made it a point of inquiry for nearly two rears past and find that this opinion of the physicians was based not, as a general thing, upon investigation, but upon the sanction given to the stuff by such eminent chemists as Profs. C. F. Chandler, R. Ogden Doremus, ete. The opinion was also based upon Mege's product, which must be admitted to be less deleterious to health than most, if not all, the others. Then, too, these spurious articles were sold so surreptitionsly, until those whose personal interests were incidentally affected stirred up the legislature to investigate, that but little or no attention was given to the subjert. and consequently but little known about it; but now, since attention has been so forcibly called to it by the agitation of the dairy commissioner in his endearor to execute the laws prohibiting its manufacture and sale, no difliculty will attend the finding of plenty of eminent physicians who will declare it may be a rery unhealthy article of food. We wish also to state here that the physiology, like the ehemistry, of fats until recently has been studied as a whole, and consequently but little was known of their individual properties.

"We read in Wanklyn's Milk Analysis, published in 1874, that "with regard to the question of admixture of foreign fats with milk fat we are unable, in the present condition of our knowledge, to deal with that part of the problem.' We have no less than four reliable chemical methods for distinguishing butter fat from other fats. Experimental physiologists are now entering this unexplored field, and important dincoveries may be confidently expected."

Again he says: "The large proportion of butyrin in butter and its nonoccurrence in any of the other animal fats, together with the volatility of its acids, has long impressed us with the belief that it had some important oflice to perform in the digestive process. Under this belief we began a series of experiments upon the artificial digestion of different fats. Our digestive Huid was composed of 5 grains of Fairchild Brothers' and Foster's 'Extractum pancreatis' and 5 grains of bicarbonate of soda dissolved in 10 c. c. of distilled water. After the solution was complete we added half a dram of melted fat.

"The whole was well agitated in a test tube and placed in an oven at a temperature of from 100 to $101^{\circ} \mathrm{F}$. The fats experimented on were cod-liver oil, butter, oleomargarine butter, the commercial oleomargarine oil, lard oil, benne oil, cotton-seed oil, lard, and mutton and heef suet. The cod-liver oil was bought from a reliable drug store.

"Both fresh and stale butter was used and was such as we had made ourselves, seeing the milk from which it was made drawn from the cow, or such as we had analyzed ourselves and found to be pure cows' butter. Fresh and stale 'oleo' Was used, and was also either' made by ourselves under the 'Nathan' patent, which 'oleo' contained some free acid, or was that which we had analyzed. The oils were all obtained from 'oleo' maker's or dealer's in New York City. Both the pure washed dry fats of the butters and 'oleos' and the natural products were compared, as will be described directly. The contents of the test tubes were examined under a microscope at intervals of one, two, three, four, six, twelve, sixteen, and twenty hours.

"'The cod-liver oil nearly always showed the finest emulsion.

"Next, and the difference was often just perceptihle, came genuine butter. 'Oleo' and lard oil came next, there being frequently no 
appreciable difference between them, but between the butter and the 'oleo' there was a marked difference at the end of each period.

"Fig. 4, Plate I, and fig. 1, Plate II, shows the difference between 'oleo' and genuine butter after being acted upon by the digestive fluid for one hour. It will be noticed that there is no emulsion at all of the 'oleo' while the butter is well adranced.

"Fig. 5, Plate I, and fig. 2, Plate II, shows the same at the end of four hours. It is seen that the 'oleo' is not nearly as much emulsified as the butter was at the end of one hour.

"Fig. 6, Plate I, and fig. 3, Plate II, presents the same at the end of twelve hours, which shows that the 'oleo' is but a trifle, if at all, further emulsionized than the butter was at the end of the four hours."

And again:

"It is important to know that the approval given to Mege's oleomargarine as an article of food by the council of health of Paris, in 1872 , on the strength of the favorable report made by M. Felix Baudet (an abstract of which is given on page 30 of this report) was morally, at least, withdrawn in consequence of a report of an investigation made by a commission of the academy of medicine for the prefect of the Seine, disapproving of the article for use except to a limited extent in cooking, on the ground of its comparatve indigestibily. It was never allowed to be sold in the public markets of Paris except under its own name. Its sale is now prohibited in the public markets.

"The insolubility of those artificial butters made from animal fats is another potent quality for rendering them indigestible. In man the digestive process is carried on with greater rapidity than in any of the lower animals; and the gastric juice acts upon iood from the outside toward the center; that is, it does not soak the material and exert its solvent action upon the whole of it at the same time. Consequently the greater amount of surface of food directly exposed the more rapid its digestion. It is for this reason that it is so necessary for man to carry out the process of mastication thoroughly. It is for this reason also that some people experience distress after eating eggs boiled just hard, but none after eating them soft boiled, or after being boiled for some time, when they become 'mealy.' The difference in the digestion of an egg is again felt when eaten raw without beating and when it is beaten. The beating mixes the albumen with the air, rendering it porous.

" The artificial butters made from animal fats, although the olein and palmitin are separated as much as possible by pressure, will not liquefy at the stomach temperature, as is demonstrated by the following experiments: We placed in an oven kept at a temperature of from 100 to $104^{\circ}$ F. four beakers containing, respectively, pure butter, oleomargarine butter, oleomargarine oil (commercial). and lard oil, about 20 drams of each, and which were all of the temperature of about $60^{\circ} \mathrm{F}$. when taken. At the expiration of thirty-five minutes, and the temperature at 100 F., the butter presented a clear limpid appearance, but the other's remained solid, being but very little affected, and at the end of fire hours, the temperature being from 101 to $10 t^{\circ} \mathrm{F}$., they were in a semisolid condition, the oleomargarine oil being most softened, the olco butter next, and the lard the least softened.

"These insoluble fats, then, must interfere with digestion in two ways: First, by not being acted upon themselves by the gastric juice, 
and second, by being thoroughly mixed with the other foods in the mouth they form an impervious covering to them, thereby preventing the gastric juice from coming into direct contact with them.

"Randolph says that 'a further' reason that the fats, especially when cooked with other foods, are frequently found to be unwholesome is that in the process of cooking they so surround and saturate the tissues of the substance with which they are combined that it is rendered nearly inaccessible to the action of the salira and gastric juice, and at times digestion is in so far delayed that the fried substance does not become entirely freed from this more or less impervious coating of fat until subjected to the action of the pancreatic juice.'

"This retards digestion and prevents that increased flow of gastrie juice which follows the absorption in the stomach of the first portion of food digested, as is shown to be the case by Heidenhan's experiment, and also deprives the proteids of that aid in their digestion which fats are declared to render."

That is the same proposition laid down but a moment since.

The Acting Chamman. If there is anything you desire to insert, if you will mark it and hand it to the reporter, it will be inserted.

Mr. Franders. I am sorry to have to rush over this so fast, because it embodies facts that ought to be presented to the committee. It is not fancy. It is not quoted npon hearsay.

Here [exhibiting] is a book that is just out. I telegraphed last Saturday to New York for it, and they had to telegraph to Chieago for it, and it came down, perhaps, with our Chicago friends. It is just out on the market. The author is J. Milner Fothergill, M. D., member of the Royal College of Physicians of London; senior assistant physician to the city of London Hospital for Diseases of the Chest (Victoria Park); late assistant physician to the West London Hospital; associate fellow of the College of Physicians of Philadelphia. I want to read what he says. He is a physiologist, and not a chemist.

He says:

"And now to the consideration of the third division of the subject, the digestion of fats.

" We do not know as ret any change exereised upon fat by heat, by the act of cooking, except that of rendering it fluid. Certainly cooking renders fat more toothome, and in the case of fat exposed directly to great heat, as in the case of the fat of a heefsteak or a mutton chop, the action of the heat upon the albuminous capsule of the adipose tissue is to make it decidedly tasty; but heat does liquefy fat, and separates (we believe) olein from stearin and margarin. The liquid portion of fried bacon is digested by many who can not digest the solid portion of bacon fat. This is a well-known fact. The fluid is the olein. Fats vary in their digestibility. The late Dr. John Hughes Bennett said: "The main causes of tuberculosis were the dearness of butter and the abundance of pastry cooks, the poor not getting sufficient fat and the upper classes disorctering their digestion by pull taste.' Now, butter consists of the fat globules of milk removed from their envelopes of casein by the act of churning, thus getting rid of the albuminous envelope, which is one of the difficulties in the digestion of animal fat."

I believe you can not find any evidence in nature anywhere to show that nature ever intended any globule of fat to go into the human stomach raw except that one globule of butter fat which is found in 
the secretion of the manmary glands. Nature provides fat for the offepring of mammals by producing a fat in fluid found in the mammary gland, and that will always melt at less than the temperature of the stomach, is easily digested, and aids in the digestion of other foods. When you put these other fats, containing stearin, which is the most objectionable, into the stomach, they can not be readily digested.

There are cases on record where jackknives have gone into the stomach and the bone handle digested, but that is extruordinary, and we are here in the interest of the ordinary. Animal fats other than those found in the secretion of the mammary gland will not as a rule melt at the temperature of the stomach, and instead of aiding digestion they hinder it. It may be said by our opponents that the difference is one of degree only. For the sake of the argument let us admit it, and then say it cau be illustrated by the difference in energy exerted by a man rowing a boat down a stream and up a stream, and then the difference is in the faror of butter, and the extent of the difference may vary in different samples of oleomargurine as the swiftness of streams vary.

We come here and say that 32 States of the Union, containing 75 per cent or at least $60,000,000$ out of the $77,000,000$ of population, have declared in their State laws that the people should not be deceired into buying this commodity, as it is harder to digest than the other. Suppose that everything about its manufucture everywhere is as clean as it onght to be-and I will admit that in the great manufactories of Chicago that is probably true, but unfortunately they are not the only manufactories. But let us suppose that ererywhere it is so. Then we say to you that 32 States have said that the people shall not be deceived, and that the only thing that arises now to prevent the full enforeement of those laws. which they believe to have been enacted within the police power properly, is the fact that the power to regulate commerce between the States is given to the National Government, and then ask such action at your hands as will complete State power to the end that our people shail not be imposed upon into buying or consuming a commodity which really is detrimental as compared with the other commodity. Is not this request within bounds and warranted by the facts!

On what ground do our friends assert that oleo is healthful? My understanding is that they have none whatever. To illustrate: They quote a chemist as saying, "There is nothing in oleomargarine that is not in butter, and nothing in butter that is not in oleomargarine." Now, to my mind, this is a fair sample of their reasons; it has just enough truth in it to answer the purpose. Now, what are the facts, or some of them? Both oleomargarine and butter contain stearin, a fat that melts only at quite too high a temperature for the human stomach, and, therefore, very hard to digest, and oleomargarine contains from four to five times as much of it as butter. Take one more illustration: "Butyrin" is in both substances, melts at a low temperature, digests easily, and aids digestion of other foods. Butyrin is found in butter to the extent of about 8 per cent, while there is rery little-only a trace-in oleomargarine. This being true, it is not, in my judgment, a full, fair statement of the fact to say "there is nothing in butter that is not in oleo, and nothing in oleo that is not in bitter," but is an illustration of some of the methods adopted in the oleo tiaflic. 
These people talk about an ideal oleomargarine. They do not talk about the kind referred to by Dr. Bartlett, of Brooklyn, in a letter to Dr. R. D. Clark, of Albany, N. Y., which I wish to read:

\section{"Brooklyn, N. Y., .Jamumy 18, 1886.}

"Dear Doctor: In reply to yours of the 12th instant, I would say that all I can say of the oil I showed in New York was that it was manufactured on Newtown Creek by Mr. Henry Beran. Mr. Beran has the eontract for the dead animals and offal of the city of Brooklyn. The oil in question was made from the comb fat (so ealled) of horsesthat is, from the top part of the necks of the horses which were obtained from this eity and tried out by the contractor. The horses were such as die in every city from both aceident and disease. There were a large number of horses killed in Brooklyn last year that were suffering with glanders. Whether any of these horses helped to make up this oil I do not know; nor does Mr. Beran. The specimen I had in New York was a very fine oil, and it shows that an oil ean be made from dead horses which in taste and naked-eye appearance is as palatable as the best 'oleo' oil.

"Mr. Beran has told me that he is satisfied that some of his" oil has been used for' the manufacture of 'oleo' butter. He has always been very careful about telling me to whom he sells it and he evidently thinks it is used for that purpose; in fact, he says he knows it has been. I give this as his own statement, and for what it is worth. I could not prove it. From the odor, taste, etc., of this oil I am of the opinion that it can be used to make 'oleomargarine' and that its use for that purpose ought to be strongly condemned. I also hold that the use of lard tried out at a temperature below $130^{\circ}$ Fahrenheit should be prohibited. Hoping this will answer your questions, I am.

"Very sincerely yours,

\section{"E. H. Bartley, M. D."}

He says he feels satisfied that that oil was made into oleomargarine; that there was entirely too much for any other purpose. Now, the smile is so audible that I must pay attention to it. Then we commenced to investigate those questions these frands were practiced. They are not practiced now. Our law has hedged you about, and more capital has gone into the business. You have put the business on a higher scale than it ever was before, and you are making as good a commodity as you can out of the stuff you have to make it out of. We only ask you in fairness to step one noteh higher and do not make it resemble butter.

Do you know that in the great State of New York there are 1,600.000 cows? Do you know we have 250,000 persons engaged in farm work? And yet you seek to come into our market and drive us out and ruin that industry. Is there anything fair about that? We ask you to stand up like men and sell your commodity for what it is. Then if you can compete with us we will stand it like men. Not many years ago we were in the meat market. We raised cattle in New York and sold them for meat. We sold cereals. The Genesce and Rochester valleys were great wheat fields. Then the wheat fields of the Mississippi Valley were opened up, cultivated by machinery. Then South Ameriea opened up her wheat fields and produced grain at 37 cents a bushel on shipboard, Australia opened up her wheat fields, and now Russia is opening up Siberia to the production of the cereals. We 
are driven entirely out of the cereals market. We have been driven out of the meat market, and there has not been one word of complaint. It was done among men in open competition, but we do complain when you take all that is left and seek to do it by fraud. I can not conceive how any man who has had any experience anywhere that gives him a knowledge of ethics can sustain the man who has placed upon the market a commodity looking, smelling, and tasting like another, as that other, and then say when we ask him to stop it that we are trying to down a healthy competition. It is not competition. It is downright robbery.

We have with us the president of the State Dairymen's Association, representing 250,000 persons. They want this measure. We have the master of the New York State Grange, representing 60,000 grangers. They want this bill. He is anthorized by the master of the National Grange to say that the National Grange wants it. It has passed a resolution farorable to it. The National Farmers' Congress at Fort IVorth passed a resolution in faror of it. So did the congress at St. Paul. It passed a resolution favoring the first part of the bill. At that time the 10-cent tax was not in. The national congress at Boston favored the first section, and last summer, at Colorado Springs, they passed a resolution faroring this bill. The National Association of Dairy and Food Commissioners in Detroit passed a resolution faroring it, at Harrisburg, at Chicago, and this year at Milwaukee. The National Dairy Union is for it. All these people are farorable to it. I only quote them to offset the proposition relative to the one organization which has been quoted as against the measure.

Now, learing out the question of how many people are for it or how many people are against it, in my judgment if it is an unjust measure it should not pass; but it seems to me that the only thing which it seeks to do is to suppress a fraud that exists, and I tell you it does exist, and every dairy and food commissioner here can bear testimony to it. It is not giren to you as hearsay. For sixteen years I have been watching this work, seeing it go on. There is a gentlemen here representing a large firm in Chicago. They came down into our State two or three years ago and attempted to put in oleomargarine. I myself went into the city of Cohoes with two other men. We watched for two weeks. We finally found that it came in over the railroad in barrels of 10-pound tubs, with canvas over the heads of the barrels. We had it watched day and night. I went myself with men from house to house inhabited by French families who could not speak a word of English. I asked an old woman if she bought it for butter. She could not speak any English. I got a little girl there to ask the old lady what she bought it for, and she said, "For butter." "For pure butter?" I asked. She said, "Yes." I said, "What did you pay?" She told me 22 cents, and that was the price of butter. It was sold to those people for butter. It has been our experience for sixteen year's in the State of New York that that is what is done. This business thrives down at the last end, when it reaches the consumer, upon fraud. And when I say that I do not accuse any manufacturer when he puts out oleomargarine of committing a fraud; I simply say that if he is guilty at all he is particeps criminis.

Now, all we want of you is to stop that. Is there anything unfair about it? We do not ask an unjust thing. We will stand in fair competition with anybody in this country or abroad if we can have 
competition, but we do not want to be robbed, and we think it is just that this measure may be passed, giving us the right to enforce our State laws, and then put on the tax and, if possible, tax out the fraud that is in it. I will not try to discuss the decision relative to State banks. My friend did not discuss that phase of the question. I am sorry to have had to cut this matter so close.

In closing I wish to submit what Dr. Clark says:

"In order to give an appreciable understanding of the indigestibility of artificial butter we must briefly deseribe the digestive processes. The great variety of foods taken by man is derived from the mineral and organic kingdoms. From the mineral comes water, salts, etc., with which we bare no concern at present. The organic foods are the products of living organized bodies, and divided into two great classes, viz: First, protein principles, also called albuminoid and nitrogenized principles. These are chemically composed of oxygen, hydrogen, carbon, and nitrogen. The latter element chemically distinguishes them from the second class, the hydrocarbons, which are composed of oxygen, hydrogen, and carbon. In sugar, starch, and some other substances belonging to this class, the oxygen and hydrogen exist in proper proportions to form water, which has given rise to a subdivision of the hydrocarbons into hydrocarbons and carbohydrates. Fats and oils belong to the hydrocarbons.

"When food is taken into the mouth its presence stimulates, through the nerrous arrangement, the salivary glands to produce a copious flow of saliva, which, during mastication, is (or ought to be) thoroughly mixed with the food. Aside from a slight conversion of starch into sugar the act of matication is purely mechanical-the food is broken up, lubricated, and gathered into proper form to be swallowed. The temperature in the mouth is $100^{\circ} \mathbf{F}$., and, of course, any free fat whose melting point is at or below this temperature will liquefy. The chemial reaction of saliva is alkaline.

"When the food reaches the stomach its presence, as in the mouth, acts as a stimulus and causes an increased secretion, which has already hegun when the food was taken into the mouth, of the acid tluid called gastric juice.

"The muscular construction of the stomach keeps the food in constant motion so that it is thoroughly mixed with the gastric juice. When the bolus of food mixed with saliva comes in contact with the acid gastric juice the conversion of starch into sugar ceases, the proteids are broken up and dissolved, the proteid cell walls of the adipose tissue are dissolved, which sets the fat-drops free, and the free fats which liquefy at or below 100 degrees, or perhaps $101^{\circ} \mathrm{F}$., which is the highest temperature in the stomach, are melted and to some extent emulsified and split up into fatty acid and glyceryl. The acidity of the gastric juice is essential to its activity.

"As the food is dissolved or digested (it is now called chyme), it is mostly carried into the intestines by the muscular action of the stomach where it is met by three other digestire tluids-the bile, pancreatic juice, and intestinal juice, which are all alkaline in reaction. When the chyme leares the stomach it is, under normal conditions, acid; but as it is mixed with these alkaline fluids its acidity is neutralized and its reaction becomes alkaline.

"In the intestine the conversion of starch into sugar takes place with great rapidity and the proteids or peptones, as they are called, 
after being acted upon by the pepsine of the gastric juice, are still further broken up. The pancreatic juice, so far as is known, is the chief agent in bringing about these changes. The bile does nothing more than to aid in neutralizing the acidity and thus prepare them for the action of the pancreatic juice. But with fat it becomes an important factor. Its salts unite with any free fatty acid and form soaps. It also dissolves soaps which, as we shall see hereafter, materially aid the pancreatic fluid in its action upon fats. Bile also has some emulsifying power on fats. A soap is a fat acid united with a base, as soda, potash, etc.

"The pancreatic juice has a powerful emulsifying effect upon fats; that is, divides then in to very minute particles. "It also has the power, to some extent, of breaking them up into their fatty acid and glycerin; and if an alkali is present the fatty acid unites with it to form soap.

"As we have alleady stated, bile has a slight emulsionizing and solvent effect upon fat, but the fact which is known to be the most important in its relation to the digestion of fat is that it unites with the free fatty acids which are present in the chyme and forms soaps. It also dissolves soaps that may have been formed before reaching it; and the presence of soluble soaps are known to aid the emulsion of fats.

"Foster" says in reference to this: "Thus a rancid fat-i. e., a fat containing a certain amount of free fatty acid forms an emulsion with an alkaline finid more readily than does a neutral fat. A drop of rancid oil let fall on the surface of an alkaline fluid, such as a solution of sodium carbonate of suituble strength, rapidly forms a broad ring of emulsion and that even without the least agitation. As saponification takes place at the junction of the oil and alkaline fluid currents are set up by which globules of oil are detached from the main drop and driven out in a centrifugal direction. The intensity of the currents and the consequent amount of emulsion depend on the concentration of the alkaline medium and on the solubility of the soaps which are formed; hence some fats, such as cod-liver oil, are much more easily emulsionized in this way than others. Now, the bile and pancreatic juice supply just such conditions as the above for emulsionizing fats; they both together afford an alkaline medium. The pancreatic juice gives rise to an adequate amount of free fatty acid, and the bile in addition brings into solution the soaps as they are formed. So that we may speak of the emulsion of fats in the small intestine as being carried on by the bile and pancreatic juice acting in conjunction, and, as a matter of fact, the bile and pancreatic juice do largely emulsify the contents of the small intestine, so that the grayish turbid chyme is changed into a creamy-looking fluid, which has been sometimes called chyle.'

"Now, we believe that butter fat is especially fitted to supply these conditions. Butter, as is well known, readily becomes rancid, and, no doubt, butter contains some free acid very shortly after being made; hut we will consider a perfectly fresh specimen. According to Lang, the first step in the decomposition of butter is a conversion of lactic acid into butyric. The second is the breaking up of butyrin into butyric acid and glycerin, the butyrin furnishing by far the most free acid-abont 7 per cent. Thus we see that the first fit in the mixture of butter to break up outside of the body is butyrin, and doubtless this is the catie inside.

"J. Bell asserts that when a solution of aleohol and an alkali is used 
in sufficient quantity to saponify all the butter fat treated, the alkaline base unites with the soluble fatty acids, and what is left undecomposed are the fats containing the insoluble fatty acids. He also illustrates this by relating an actual experiment. 'This strongly corroborates the supposition trat it is the butyrin that is first broken up in the stomach and intestines.

"We have seen in the process of stomach digestion that some fat was emulsionized and broken up into its acid and glycerin constituents. So we have butyric acid set free in the stomach to unite with a base from some of the weaker salts, as the carbonates, for instance, to form a very soluble soap which is dissolved by the bile as soon as it comes in contact with it, and thus furnishing, even a fresh butter, the most favorable conditions for starting the action of the pancreatic juice upon fats. Indeed Roberts claims that a small admixture of a free fatty acid in the chyme, together with the agitation produced by the movements of the intestines, is sufficient to emulsify fats withont the aid of pancreatic juice.

"Routh also declares the same. None of the other animal fats contain butrrin.

"The large proportion of butyrin in butter and its nonoceurrence in any of the other animal fats, together with the volatility of its acid, has long impressed us with the belief that it had some important office to perform in the digestive process. Under this belief we began a series of experiments upon the artificial digestion of different fats. Our digestive fluid was composed of 5 grains of Fairchild Bros. and Foster's 'Extractum pancreatis,' 5 grains of bicarbonate of soda dissolved in $10 \mathrm{c}$. c. of distilled water. After the solution was complete we added half a dram of melted fat.

"The whole wits well agitated in a test tube and placed in an oven at a temperature of from 100 to $101^{\circ} \mathrm{F}$. The fats experimented on were cod-liver oil, butter, oleomargarine butter, the commercial oleomargarine oil, lard oil, benne oil, cotton-seed oil, lard, and mutton and beef suet. The cod-lirer oil was bought from a reliable drug store.

"Both fresh and stale butter" was used, and was such as we had made ourselves, seeing the milk from which it was made drawn from the cow, or such as we had analyzed ourselves and found to be pure cow's butter. Fresh and stale 'oleo' was used, and was also either made by ourselves under the 'Nathan' patent, which 'oleo' contained some free acid, or was that which we had analyzed. The oils were all obtained from 'oleo' maker's or dealers in New York City. Both the pure, washed, dry fats of the butter's and 'oleos' and the natural products were compared, as will be deseribed directly. The contents of the test tubes were examined under a microscope at intervals of one, two, three, four, six, twelve, sixteen, and twenty hour's.

"The cod-liver oil nearly always showed the finest emulsion.

"Next, and the difference was often just perceptible, came genuine butter. 'Oleo' and lard oil came next, there being' frequently no appreciable difference between them, but between the butter and the 'oleo' there was a marked difference at the end of each period.

"Fig. 4, Pl. I, and fig. 1, Pl. II, shows the difference between 'oleo' and genuine butter' after' being' acted upon by the digestive fluid for' one hour. It will be noticed that there is no emulsion at all of the 'oleo', while the butter' is well advanced.

"Fig. 5, Pl. I, and fig. 2, Pl. II, shows the same at the end of four 
hours. It is seen that the 'oleo' is not nearly as much emulsified as the butter was at the end of one hour.

"Fig. 6, Pl. I, and fig. 3, Pl. II, presents the same at the end of twelve hours, which shows that the "oleo' is but a trifle, if at all, further emulsionized than the butter was at the end of the four hours.

"It will be further noticed that the globules of butter are finer, more uniform, containing very few large globules, and what is particularly conspicuous is the clearness and distinetness of the butter globules. They are well defined. sleek looking, and have a clean-ent outline which strongly intimates that they would go through an animal membrane-which they are required to do, as will be seen later on-quicker than 'oleo, which has a rough, coar'se, ill-defined appearance. This holds true until the whole is saponified. The best results were obtained after exposing the fats to the digestive fluids for five or six hours at a temperature of $100^{\circ} \mathrm{F}$., then allowing the whole to stand over night at a temperature of about $60^{\circ} \mathrm{F}$., and in the morning adding an equal bulk of warm water. 'The butter then presents under' the mieroscope a most perfect emulsion. The globules are all very minute, grading off into almost impereeptible granules.

"By examining the corresponding figures on the different plates the comparative digestibility of the various fats and oils used in making artificial butter may be seen.

"That butyric acid does have some important rôle to play in the alimentary canal is evident from the faet that sugar undergoes butyric fermentation in the small intestines. Yeo says, in reference to this, -Some of the sugar in the intestines, moreover, undergoes fermentation, by which it is eonverted into lactic and buty ric acids. How much of the sugar is absorbed as lactic and butyrie aeids has not been determined, but the amount of sugar found in the portal vessels or lacteals does not at all correspond with the amount that disappear's from the cavity of the intestines.'

"Foster" says, "This suggests the possibility of the sugar of the intestinal contents undergoing the butyric acid fermentation (during which, as is well known, carbonic anhydride and hydrogen are evolved), and thus, so to speak, put on its way to beeome fat. * * * Moreover, it is probable that by other fermentative changes a considerable quantity of sugar is converted into lactic acid, since this acid is found in increasing quantities as the food descends the intestines.'

- No doubt the lactic acid is converted into butyrie acid, which, in turn, is converted into soluble soaps, and which may perform, and we believe do perfor'm, important offices. As will be seen further on, fat is often covered with soap, when absorbed, and soaps are found in the chyle, as well as some fatty acids. Furthermore, it is shown that fats undergo still further emulsion after being absorbed while passing through the lacteals to enter the general cireulation. Now, these soaps may be, and rery likely are, the chief agents in accomplishing this. One of the arguments always advanced by the advocates of artificial butter is that it possesses better keeping qualities and does not become rancid, and is, therefore, more wholesome than rancid butter. Now, it is true that it does not set free butyric acid (as it contains no butrrine), which gires the raneidity to butter, but, as it eontains some cellular tissue (in our specimens considerable), it undergoes a different decomposition, which is liable to develop the septie material peculiar to dead animal matter, and which is often very poisonous to human beings. On the other 
hand, rancid butter is probably more readily digested than fresh and is not poisonous, the repugnance to it being simply one of taste, as will be seen from the following, taken from Roberts by Fothergill:

"'The different beharior of two specimens of the same oil, one perfectly neutral and the other containing a little free fatty acid, is exceedingly striking. I have here before me two specimens of cod-liver oil; one of them is a fine and pure pale oil, such as is usually dispensed by the better elass of chemists, the other is the brown oil sent out under the name of De Jongh. I put a few drops of each of those into two beakers, and pour on them some of this solution, which contains 2 per cent of bicarbonate of soda. The pale oil, you see, is not in the least emulsified; it rises to the top of the water in large, clear globules; the brown oil, on the contrary, yields at once a milky emulsion. The pale oil is a neutral oil, and yields no acid to water when agitated with it - in other words, it is quite free from rancidity-but the brown oil when treated in the same way causes the water with which it is shaken to redden litmus paper. ( " W When the inhabitant of Aretic regions prefer's his fat rancid, probably he is only following ont what experience has tanght him is good in his liberal consumption of fat.") The bearing of these ohservations on the digestion of fat is plain. When the contents of the stomach pass the pylorus, they encounter the bile and pancreatic juice, which are alkaline, from the presence in them of carbonate of soda, so that the fatty ingredients of the chyme, if they only contain a small admixture of free fatty acids, are at once placed under farorable cireumstances for the prodnction of an emulsion without the help of any soluble ferment, the mere agitation of the contents of the bowels by the peristaltic action being sufficient for the purpose.' (Roberts.)

"Possibly some fats containing a large proportion of oleine emulsionize more readily than other's. But the whole subject is in its infancy so far as our acquaintance with it is concerned.

"Cod-liver oil contains about $1 \frac{4}{10}$ per cent of volatile fatty acid, some of which is butyric acid. This, together with its fluidity, accounts for its easy digestion and absorption.

The following is what some of the standard authors say about the digestibility of butter and other fats:

". Like other fats and oils it (lard) is difficnlt of digestion, and, therefore, is sometimes used as a laxative for ehildren, and for its protective power in diarrhea, dysentery, ete. *** It has been proposecl as a substitute for cod-liver oil in the treatment of phthisis (consmmption), but its indigestible nature unfits it for this purpose.'

".Apart, howerer, from the deficieney in flavor, it is doubtful whether "butterine" (artificial butter) can be said to fully supply the place of butter as an article of diet. When the highly complex and peculiar character of the constitution of butter is considered, and that it is the fat derired from or natural to milk, which for a time at least is the principal food of the young, it is probable that butter performs some more specific office in the system than ordinary fats.'

"As before stated, fats consist of a fatty acid and oxide of lipyl. In the adult it is the pancreas which effects this separation into these approximate constituents. We all know that if this change does not occur the fat passes off unchanged by the bowels; and, as Bernard has shown, the expulsion of fat is one of the surest indications of diseased pancreas. In the infant, judging from the want of development 
of the salivary glands, the pancreas probably does not suffice to the complete performance of this function.

- It is here that we remark one of those wonderful adaptations of nature. First, in butter we hare excess of a free fatty acid; therefore rendering the assimilation of it possible without the assistance of the pancreas.

- Another way in which this emulsion of fat can be accomplished is by giving the patient, not fats, properly so called, but the fatty acids of which they are composed, and which are very readily absorbed into the system. The good effects of cod-liver oil are probably in some measure due to the excess of fatty acids present. So, also, those of butter; it is indeed a matter of popular observation that many children grow fat upon bread and butter. They appear to thrive on it when other means fail. This good effect can not be due simply to bread, for reasons before stated, but to the free acid, which is also in excess in butter.

" "It (butter) is the best known of all this class of substances (fats), but it is eaten in very different quantities, from the large cupful before breakfast, as drank by the Bedouins, near the Red Sea and the Persian Gulf, to the scarcely perceptible layer on the bread eaten by the needlewomen of London, and the supply is limited by pecuniary means rather than desire. It is also the form of separated fat which is less frequently disliked by consumptive people and invalids generally, as was shown by me in an inquiry into the state of 1,000 patients at the Hospital for Consumption, Brompton.'

"In answer to a letter of ours, Professor' Stelle, of Philadelphia, says:

"If you care for my personal opinion, it is that fresh butter and fresh olive oil are the most digestible of fatty bodies; next to them comes lard, and, finally, tallow.'

"Finally, it is a matter of common observation among physicians that natural butter is taken by invalids, especially consumptives, when other fats, even cod-liver oil, can not be tolerated.

"It is important to know that the approval given to Mege's oleomargarine as an article of food by the council of health of Paris in 1872 , on the strength of the favorable report made by M. Felix Baudet (an abstract of which is given on page 30 of this report), was morally, at least, withdrawn in consequenee of a report of an investigation made by a commission of the Academy of Medicine for the prefect of the "Seine disapproving of the artiele for use except to a limited extent in cooking, on the ground of its comparative indigestibility. It was never allowed to be sold in the public markets of Paris except under its own name. Its sale is now prohibited in the public markets.

"The insolubility of those artificial butters made from animal fats is another potent quality for rendering them indigestible. In man the digestive process is carried on with greater rapidity than in any of the lower animals, and the gastric juice acts upon food from the outside towards the center-that is, it does not soak the material and exert its solvent action upon the whole of it at the same time; consequently the greater amount of surface of food directly exposed, the more rapid its digestion. It is for this reason that it is so necessary for man to earry out the process of mastication thoroughly. It is for this reason also 
that some people experience distress after eating eggs boiled just hard, but none after eating them soft boiled, or after being boiled for some time, when they become 'mealy.' The difference in the digestion of an egg is again felt when eaten raw without beating, and when it is beaten. The beating mixes the albumen with the air, rendering it porous.

"The ar'tificial butter made from animal fats, although the olein and palmitin are separated as much as possible by pressure, will not liquefy at the stomach temperature, as is demonstrated by the following experiments: We placed in an oren kept at a temperature of from 100 to $104^{\circ} \mathrm{F}^{\mathrm{S}}$. four beakers containing, respectively, pure butter, oleomargarine butter, oleomargarine oil (commereial), and lard oil, about 20 drams of each, and which were all of the temperature of about $60^{\circ}$ F. when taken. At the expiration of thirty-five minutes, and the temperature at $100^{\circ}$, the butter presented a elear, limpid appearance, but the others remained solid, being but very little affected; and at the end of five hours, the temperature being from 101 to $104^{\circ} \mathrm{F}$., they were in a semisolid condition, the oleomargarine oil being most softened, the oleo butter next, and the lard the least softened.

"These insoluble fats, then, must interfere with digestion in two ways - first, by not being acted upon themselves by the gastric juice, and, second, by being thoroughly mixed with the other foods in the mouth, they form an impervious covering to them, thereby preventing the gastrie juice from coming in direct contact with them.

"Randolph says that 'a further' r'eason that the fats, especially when cooked with other foods, are frequently found to be unwholesome, is that in the process of cooking they so surround and saturate the tissues of the substance with which they are combined that it is rendered nearly inacessible to the action of the saliva and gastric juice, and at times digestion is in so far delayed that the fried substance does not beeome entirely freed from this more or less impervious coating of fat until subjected to the action of the pancreatic juice.'

"This retards digestion and prevents that increased flow of gastrie juice which follows the absorption in the stomach of the first portion of food digested, as is shown to be the ease by Heidenhains experiment, and also deprires the proteids of that aid in their digestion which fats are declared to render.

"In experimenting with gastrie festula on different dogs, for example, we have found in one instance, like Dr. Beaumont, that the gastric juice was always entirely absent in the intervals of digestion; the mucous membrane then presenting invariably either a neutral or slightly alkaline reaction. In this animal, which was a perfectly healthy one, the secretion could not be excited by any artificial means, such as glass rods, metallic catheters, and the like, but only by the natural stimulus of digested food. Tough and indigestible pieces of tendon introduced through the fistula, were expelled again in a few minutes, one after the other, without exciting the flow of a single drop of acid fluid, while pieces of fresh meat introduced in the same way produced at once an abundant supply.

"After food has been changed by the act of digestion it is required to enter the current of blood before it can fulfill its office of nourishing the body. In order to do this it must pass through the walls of the alimentary eanal, which passage constitutes the process of 'alsorption.'

"While absorption may take place through any part of the body containing blood and lymph ressels and not covered with a hard, 
thickened cuticle like the palnus of the hand and the soles of the feet, yet the locality especially adapted to it is the upper part of the small intestine. Here the lining membrane is thrown into numerous folds in order to increase the amount of surface, and covered with myriads of minute projections resembling the pile of relvet which are technically called villi. Each little villus constitutes an absorbent gland. Its surface is corered with columnar epithelial cells containing protoplasm, and also little rod-like projections extending from their free extremities.

"These cells rest upon a basement membrane which contains muscular tissue so arranged as to aid in carrying along the solid particles of food on their passage to the lacteals and blood ressels.

"This membrane incloses a framework of connective tissue, in which are contained the blood vessels and lacteals. The blood vessels are arranged in the form of latticework around the lacteals. which latter contain no perceptible openings. Now, fat is the only element of food that is absorbed in the form of solid particles, at least to any extent, and therefore would seem to be the most difficult of absorption. This absorption of solid particles of fat has indeed always been a puzzle to physiologists. The peptones and sugar are almost wholly liquefied and can not be recognized by the microscope after entering the lacteals, but fat is seen after reaching the lacteals in a very minute state of division. On the principle of osmosis, it is easy to understand how liquid foods are absorbed. Some physiologists believe that the epithelium covering the villus is prolongated, so to speak, into the central lacteal vesicle and that the fat granules pass not through but between the epithelial cells along this prolongation of protoplasm, and so reach the lacteal. Others believe that they pass through the cell by being taken up by the protoplasm in the manner in which an amoba takes its food, and passed on to the lacteals by this protoplasmic agent, being aided by contraction of the muscular element in the villus. 'The latter theory is the most satisfactory, and probably the most modern. It is also believed that the layer of rods or pores projecting from the free surface of the epithelium has to do with the absorption of fats. Whichever theory is correct, it seems pluin to us that the finer the particles of fat the more readily will they be absorbed. Moreorer, it is well known that an animal membrane moistened with water will not allow the passage of emulsionized fat, but when moistened with bile fat passes through it. From this fact it is quite probable that the soaps formed, as previously described, perform important work in connection with the alssorption of fat.

"Yeo says in reference to this: "It has therefore been suggested that the epithelial cells of the mucous membrane are more or less moistened with bile, and the particles of fat in the emulsion are also coated with a film of bile or soap. Thus they are enabled to pass into the epithelial cells, in which they can be detected during digestion. The bile or soapy coating of the fat particles may no doubt aid in their. transit through the various obstacles on their way to the lacteal radicles.'

"I know of but few actual experiments upon human beings as to the comparative absorptivity of butter and other fats, but it is fair to assume from the foregoing circumstances that butter is much more readily absorbed than its sham congeners. Rubner ascertained that butter was much more readily ahsorbed than ham fat. Randolph says that cod-liver oil is absorbed with the greatest ease and to a greater 
degree than any of the other fats, and that, on the other hand. the vegetable oils are the least readily absorbed.

"A. Mayer experimented to determine whether" natural or' artificial butter was the easiest absorbed by the system. He took a man and a boy and fed them for three days on various mixtures of bread, milk, eggs, and vegetables, together with natural butter. Then followed two days' rest, they being fed on ordinary diet; after which for three days they were given precisely the same food as on the first three days, except artificial was substituted for natural butter. Each successive day of the experiment the solid evacuations were collected and analyzed, commencing twenty-four hours after the beginning of the experiment. The amount of fat in the excrements was estimated, which determined the amount of fat that had been absorbed. The following is the percentage of the amount absorbed:

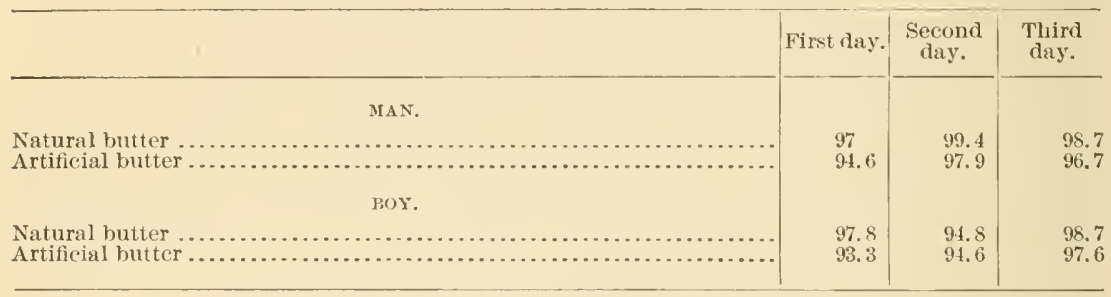

"It will be seen, therefore, that the average was about 1.6 per cent less of the artificial absorbed than of the natural. 'The greatest diflerence was 2.5 per cent less of the artificial. The experimenter concludes that except in sickness this trifling difference may be overlooked with safety.

"Of course, these experiments were not carried on long enough to be of much value, but as far as they go they harmonize exactly with our idea of the difference in the absorption of these two articles. If this difference was manifest in three days, we would expect a very mueh greater difference in three months.

"Magendie's experiments on dogs for the purpose of testing the effeet of feeding nothing but fat incidentally shows a striking difference in the life-sustaining power between butter and lard. He used two dogs for the experiment. One he fed butter and the other lard. The first lived sixty-eight, the second fifty-six days; that is, the dog fed on butter lived twelve days longer than the other, or one-fourth of the whole time which the other dog lived.

"The liability of conveying disease germs into the human system through artificial butter is, in our opinion, greater than is supposed by those not familiar with the subject. In the first place, investigations are showing that many more diseases than was formerly supposed are communicable from animal to man. The following are some of those known to be such: Consumption, anthrax, trichinosis, tapeworm, glanders, foot-and-month disease, corpox, hydrophobia, ete. Many more, as epidemic pleuro-pneumonia, smallpox of sheep, splenic apoplexy, braxy of sheep, typhus, ete, have, when the Hlesh of animals suffering from them was eaten, produced serious sickness in human beings.

"We wonld like to give the history of these diseases and also of the cases of the sickness resulting from consumption of the flesh of these 
diseased animals, for we think the effect would be to startle the populace and to induce it to lend a heartier support to those public officers to whom has been assigned the duty of preventing unwholesome food being sold to it; but the want of time prevents. TTe must content ourselves with a bricf reference to some points bearing directly upon the subject in hand. The manner in whieh trichina can get into artificial butter ean easily be seen from the following: When the animal takes a erst containing a trichina into its stomach the cyst is dissolved by the gastric juice, which sets the trichina free, when it passes out of the stomach into the intestine, where it develops in from a week to ten day's, and the female deposits her embryos-from 60 to 2,000 for each female trichina. The young trichine then make their way through the connective tissue to the muscles. Trichina are found in hogs, eattle, and sheep. Now, if those animals are killed during the migratory stage, the caul fat would doubtless contain the parasite. Dr. Billings says he has frequently found eneysted trichinæ in the adipose tissue between museular tissue of very fat hogs, but not in the fat lying upon the muscles. He states, however, that Professor Taylor, of the Department of Agrieulture at Washington, has seen in the journal of the Miscroscopical Association that they hare been found in fat. Everyone is aware of the dangerons eharacter of this clisease.

"A tapeworm is developed from a kind of germ ealled a eysticereus. These are of different varieties, and are found in the solid parts of hogs, eattle, and sheep. Animals infested with these germs are said to have the measles. A cysticereus is dereloped from the ego of a tapeworm. The fully matured tapeworm is dereloped in two separate stages, as follows: The eggs of the worm pass out of the body and are eaten by a man or another animal. They then find their way into the solid tissues of this animal, when they develop into cysticerci, and so remain until the eysticerci are again taken into the intestines of another animal or man, where they reach their full development as a tapeworm. Now, the heat applied to the fats emplored in making artificial butter is not sufficient to destroy these germs, as most of them are treated at a temperature below $140^{\circ} \mathrm{F}$., as is seen from the abstracts. One patent for making a compound to substitute butter for cooking purposes requires a temperature of $190^{\circ}$ to $200^{\circ} \mathrm{F}$. One other for "improrement in shortening for culinary uses' uses a heat of $400^{\circ} \mathrm{F}$. Six for purifying and bleaching tallow, lard, etc., heats to $140^{\circ}, 150^{\circ}, 200^{\circ}$, $200^{\circ}, 200^{\circ}$, and $347^{\circ} \mathrm{F}$, respectively.

"Much interest is manifested at the present time in regard to germs and their destruction, and as is always the case with new subjects there is some difference of opinion in regard to the effieacr of different disinfecting agents. The following will give some idea of the amount of heat required to kill disease germs:

"Toussaint showed by experiment that the tubereulons element was not confined to the diseased loealities, but were diffused through all the tissues, and that the juice of the flesh of a eonsumptive animal had prodneed a disease in other's after having been heated to $50^{\circ}$ or $60^{\circ} \mathrm{C}$. $\left(122^{\circ}\right.$ to $140^{\circ} \mathrm{F}$.), the temperature of roasting beef, and that when giren in rery small doses.

"Referring to these experiments. Bartley says: "Considering the faets in this light, we ought to establish no degrees in tubereulosis; when it exists it renders the consumption of flesh dangerous.'

"In reference to trichina, some observer's, as Vallin, state that a 
temperature of 129 to $133^{\circ} \mathrm{F}$. kills most of them, and that $140^{\circ} \mathrm{F}$. is safe; but Collin found living trichinæ in half a pound of steak that had been boiled for ten minutes, presenting a white appearance when cut, having no red points, and discorered trichine in the intestines of a bird after having been fed upon it.

"Pasteur asserts that an exposure for ten minutes to a temperature of $129.2^{\circ} \mathrm{F}$. will kill anthrax rods, but spores resist prolonged boiling. The spores develop in the rods rapidly after the death of the animal, under proper conditions, and will remain active for years. They are not destroyed by drying or putrefaction when exposed to oxygen (Maguire).

"Klein also affirms that the anthrax spores will resist prolonged boiling.

"Vantieghem is quoted by Magnin as saying that a temperature of $121^{\circ} \mathrm{F}$. is fatal to most bacteria; but he has studied the bacillus that is able to multiply and form spores in a culture fluid at $165.2^{\circ} \mathrm{F}$, but which cease to multiply at $171.5^{\circ} \mathrm{F}$. Magnin also states as coming from Lebedeff that septic blood does not lose its virulence at the end of forty days, or by being heated to the boiling point $\left(212^{\circ} \mathrm{F}\right.$.) for from three to twenty-fom hour's, and that the bacteria in it are capable of multiplying after such exposure.

"Arloing and Chaureau have found what they consider to be the bacillus causing gangrenous septicamia. When fresh it is destroyed by a temperature of from 194 to $212^{\circ} \mathrm{F}$., but when dried it required $248^{\circ} \mathrm{F}$.

"The heat to be trusted for destroying pathogenic germs in practice will be seen from the following:

"Dr. Van Bush, of Berlin, used a temperature of $149^{\circ}$ to $167^{\circ} \mathrm{F}$. for the destruction of puerperal-ferer contagion. The late Dr. Elisha Harris, in 1859 , employed a temperature at and above $212^{\circ} \mathrm{F}$. to disinfect clothes of yellow-ferer subjects. He quotes Dr. William Henry as saying' that 'the infectious matter' of cowpox is rendered inert by a temperature not below $140^{\circ} \mathrm{F}$., from whence it is inferred that more active contagion is probably destructible at temperatures not exceeding $212^{\circ} \mathrm{F}$.'

-Dr. Henry could not communicate trphus after exposing flannel shirts to $204^{\circ} \mathrm{F}$; ; same with scarlet ferer. He salys: "The experiments which we have related appear to be sufficiently nimerous to prove that by exposure to a temperature not below $200^{\circ} \mathrm{F}$. during at least one hour the contagious matter of scarlatina is rather dissipated or destroyed.'

"'The following circular, issued to the enstoms officers December 22, 18st, shows what temperature is considered safe by the Government: 'All circulars of the Department concerning the importation of old rags are modified as follows: No old rags, except afloat on or before Januar'y 1, 1885, on vessels bound directly to the United States, shall be landed in the United States from any ressel, nor come into the United States by land, from any foreign country, except upon disinfeetion at the expense of the importers, as provided in this circular or may hereafter be provided.

" 'Either of the following' processes will be considered a satisfactory method of disinfection of old rags, and will entitle them to entry and to be landed in the United States upon the usual permit of the local health oflicer, viz: 
$" 1$. Boiling in water for two hours under a pressure of 50 pounds per square inch.

" "2. Boiling in water for four hours with pressure.

" 3 . Subjection to the action of confined sulphurous-acid gas for six hours, burning $1 \frac{1}{2}$ or 2 pounds roll brimstone in each 1,000 cubic feet of space, with the rags well scattered npon racks.

"4. Disinfection in the bale by means of perforated screws or tubes through which sulphur dioxide ol superheated steam at a temperature of not less than 330 degrees shall be forced under a pressure of four atmospheres for a period sufficient to insure thorough disinfection,' etc.

"James A. Russell, in Quain's Dictionary of Medicine, says: 'It is extremely improbable that any contagium cin withstand a temperature of $220^{\circ} \mathrm{F}$. (104.5 C.), maintained during two hours. When contagium is shielded by thick material into which heat penetrates slowly, the time necessary to reach the disinfection temperature may be long, and hence the necessity for spreading elothing and opening out bedding in special hot-air chambers, where the heat ought not to be less than $220^{\circ} \mathrm{F}$. (104.5 C.) nor more than $250^{\circ}$ F. (112.1 C.).'

"The following is an abstract from the report of the committee on disinfectants of the American Public Health Association: 'The experimental evidence recorded in these reports seems to justify the following conclusions: The most useful agents for destruction of spore-containing infectious matèrials are:

" 1. Fire, complete destruction by burning.

‘2. Steam under pressure, $230^{\circ} \mathrm{F}$., for ten minutes.

"' '3. Boiling in water for' one hour.'

"For" the destruction of infectious material which owes its infecting power to micro-organisms not containing spores, the committee recommended:

$\because 1$. Fire, complete destruction by burning.

"2. Boiling in water half an hour.

"' '3. Dry heat, $230^{\circ} \mathrm{F}$., for two hours,' ete.

"It is alleged by the makers of artificial butter that the fats from animals dying from disease conld not be used in making these articles, as they would 'stink' and taint the product, and the deodorization would not remove said stink, etc. This is false, for we have tasted and smelled of oil made from horses and dogs pickerl up in the streets of New York and Brooklyn, dead of disease, and it had no unpleasant taste or apperance; in fact, tastes as sweet as pure dried butter fat. And, too, the suspicion is growing stronger and stronger among those who are cognizant of the facts that those oils go into the artificial butters. Why should so much pains be taken to render a sweet, cleur oil from deat horses and dogs! This would be adding unnecessary expense if it was intended for lubricating purposes, and we do not hear of its being commonly used in soap making.

"The following letter, in answer to one from us, will tell its own story:

\section{"Brooklyn, N. Y., January 18, 1886.}

- Dear Doctor: In reply to your's of the 12th instant I would say that all I can say of the oil I showed in New York was that it was manufactured on Newtown Creek, by Mr. Henry Beran. Mr. Beran has the contract for the dead animals and offal of the city of Brooklyn. The oil in question was made from the comb fat (so called) of horsesthat is, from the top part of the neck of horses-which were obtained 
from this city and tried out by the contractor. The horses were such as die in every eity from both accident and disease. There were a large number of horses killed in Brooklyn last year that were snffering with glanders. Whether any of these horses helped to make up this oil I do not know; nor does $\mathrm{Mr}$. Beran. The specimen I had in New York was a rery fine oil, and it shows that an oil can be made from dead horses which in taste and naked-eye appearances is as palatable as the best 'oleo' oil.

"Mr. Beran has told me that he is satisfied that some of his oil has been used for the manufacture of 'oleo' butter'. He has always been verr careful about telling me to whom he sells it, and he evidently thinks it is used for that purpose; in fact, he says he knows it has. I give this as his own statement, and for what it is worth. I could not prove it. From the odor, taste, etc., of this oil I am of the opinion that it can be used to make 'oleomargarine' and that its use for that purpose ought to he strongly condemned. I also hold that the use of lard tried ont at a temperature below $130^{\circ} \mathrm{F}$., should be prohibited. Hoping this will answer your questions, I am.

Very sincerely, your's,

- E. H. Bartley, M. D.

"It might be asked if natural butter was not exposed to the same contamimation. We answer that it is not; for, in the first place, the fat of milk is doubtless manufactured in the gland by the metabolic action of the protoplasmic cells, and consequently worild not be apt to contain disease germs even if they were in the cow's system, unless the udder itself was diseased. Then, too, it is difficult to make good butter from a diseased cow; and but few farmers would risk their reputation by selling butter made from sick eattle. Furthermore, I am unable to find a single authentic instance where milk butter has produced any serious sickness, which, in consideration of the length of time it has been known, is significant.

- Dr. Alfred Hill, on account of assertions being made that the milk quickly became rancid and produced typhoid fever, and that the butter was very offensive which came from cows that had been partly fed on sewage grass, made a thorongh examination of the milk and its butter which came from the Birmingham Sewage Farm, and found that the keeping and other qualities of the milk were not in the least inferior to ordinary milk. In regard to the butter, he says: 'In order to test the quality of the buttre made from it, I requested the wife of the farm manager, who thoroughly understands butter making (although no butter is ordinarily made on the sewage farm), to make a churning for me, which she was kind enough to do. The resulting butter was excellent in quality and retained its sweetness and other properties as well as other fresh butter, although the weather at the time was excessively hot; so that the conditions of the experiment were as unfavorable as possible.'

"When we look orer the ingredients used in making artificial butter or preparing the fats and oils for the same, and find such powerful acids as sulphuric, nitric, benzoic, salicylic, etc., and such alkalies as caustic soda, bicarbonate of soda, carbonate of ammonia, saleratus, sal soda, ete., and such drugs as sugar of lead, alum, carbonate of potash, nitrate of soda. sulphate of soda. borax, niter, etc., and such easily decomposed material as slippery-elm bark, rennet, yolk of eggs, cow's udder, fresh vegetable pulps, etc., mixed with it, and after having 
prepared this stuff according to the specifications of certain patents, we can not repel the conviction that the greatest care must be exercised or they will contaminate the product. By referring to patent No. 263199 , it will be seen that about 150 pounds of melted lard is thoroughly 'washed'-that is, mixed-with 60 gallons of ice water holding in solution 3 ounces of nitric acid (strong) and borax. The lard solidifies in this solution, and while solid is washed in 60 gallons of ice water. Every time this quantity of fat is washed in the acid water 1 ounce more of nitric acid is added, which shows that this amount of nitric acid is considered to be taken up by the lard. In the manufacture of 'oleo' under this patent from 5 to 50 per cent of this deodorized lard is added to commercial oleomargarine oil.

"The whole is then subjected to a heat of $95^{\circ} \mathrm{F}$. (which is not sufficient to melt it) and churned with milk or cream, sugar, and coloring matter. It is then treated with ice water, which causes it to rapidly and completely solidify. After mixing thoroughly and salting it is ready for market.

"It will be seen by this process that the fat, after being treated with nitric acid, is never again subjected to a thorough washing, and in view of the fact that fats possess the property of retaining free acids with remarkable tenacity, it is difficult to believe that the marketed product does not contain nitric acid.

"The following is the conclusion of Nothnagel and Rossbach concerning the effect of small, greatly diluted doses of acids:

" "When acids are used for" too long a time the appetite and digestion are finally injured and a series of pathological conditions result.

6"It is readily supposable that the long-continued administration of diluted mineral acids to the living organism leads to the decomposition of the alkaline combinations with the weaker acids, e. g., carbonic acid, or with the albuminoids, the stronger acids uniting with these alkalis and being exereted with the urine as mineral salts, so that not only the bloor, but the whole body, would become poorer in alkalis and salts.

"Salkowski and Lasar proved directly that the alkalescence of the blood is diminished by the internal administration of dilute mineral acids.'

"We now return to the question, is artificial butter a wholesome article of food? It seems to us, from the facts set forth in the foregoing pages, that there can be but one answer to this question.

"TVe do not mean to say that every individual who eats artificial butter will sicken and die any more than every man who uses ardent spirits, tobacco, or narcotics to excess would do so, but what we do mean to say is that it, like them, possesses physiological properties 'unfavorable to health' and are very liable to possess ingredients very dangerous to health. Dyspepsia is a prevalent disease in this country and is not acquired in a day, for a strong stomach will stand much abuse before it will permanently rebel.

"Several instances are on record where pennies and other" metallic substances have been swallowed and digested; even jackknires have been swallowed and their bone handles completely digested, but no person would consider these healthy articles of diet.

"Strong, vigorous men and those whose habits are invigorating to the digestive powers might substitute a food hard of digestion for an easy one for a long time with apparent impunity, but weaker men 
and those whose habits are sedentary and whose labors are mental, which tend to debilitate digestion, would soon be injured.

"Fats as a whole are considered by medical men to be difficult of digestion: and to substitute those haird of digestion for one that is easy, and, too, for one which we believe is endowed by nature with properties that not only render it, per se, easily digested and assimilated, but which also render important aid in these processes to other fats. must eventually produce sickness. The little genuine butter added to these spurious articles helps as far as it goes, but the amount in most of them is very small indeed.

"It is true we eat fats which, when raw, are more difficult of digestion than some of the artificial butters, but it must be borne in mind that they are eaten in conjunction with natural butter, and the cooking process to which they are subjected no doulst render's them much more easily digested. As is well known, 'drippings' are much easier' digested than the fats from which they come.

"That cooking renders fats much more easily emulsionized by artificial means is demonstrated by the following experiments:

-We subjected a portion of oleomargarine butter placed in a frying pan to the heat of a cook store, the same as would be employed to fry a piece of meat. for about five minutes. (Our thermometer registered 200 C., and the heat went above this somewhat.)

"The fat was then poured off, and equal quantities of it and the same specimen of 'oleo' uncooked were exposed to the action of artificial digestive fluid, the two specimens being placed under exactly the same conditions.

"At the end of four hours the microscope showed that the cooked 'oleo' was decidedly the best emulsion-approaching in appearance natural butter uncooked under the same circumstances. It was intended to have artotypes to show this, but the experiments were not completed in time, and we would add here that we are carrving on various experiments with a view to demonstrating the differences between natural and artificial butters, which we hope to publish in our next ammual report.

"As the fusing point of the cooked and uneooked 'oleos' remained identical, the difference in the emulsions must have been due to chemical changes produced by the heat, as the separation of the fatty acids and glycerin, which again gives us a free fatty acid.

"After pouring off the cooked fat there remained in the frring pan a considerable quantity of scrap.

"Fothergill says: 'But heat doesliquefy fat, and separates (we believe) olein from stearin and margarin. The liquid portions of fried bacon is digested by many who can not digest the solid portion of bacon fat. 'This is a well-known fact.'

"Furthermore, the great heat to which fats are subjected in frying is probably suflicient to set free considerable quantities of fatty acids, and also to eause partial breaking up of the whole fat.

"The friends of the bogus butter ask us in a spirit of defiance to show any eases of siekness produced by it. This is, in fact, a demand for a complete demonstration, and may be answered by stating that we have seen a great many cases of sickness, and much of it dyspepsia, during the period in which the bogus butter has been sold, for which we have been unable to assign a cause. This may have been artificial butter, but the deceptive manner in which it has been handled has 
prevented physicians from ascertaining its effects. Consequently we must judge by its qualities.

"No person would gainsay that these articles, if they contained germs of disease or such materials as cnumerated above, were numbolesome. We have pointed out the liability and great probability of their containing them, and many things have been publicly condemned on less liability to produce sickness; for instance, the water of Albany has been used by nearly 100,000 people for several years and no serious results ean be shown, yet the conditions are present which render it liable to produce disease, and this eircumstance has agitated the public mind to such an extent that some of the best medical and other men of the city have deroted themselves to finding a better supply, and they have finally decided that it is expedient to obtain it from another source than the present, which will necessitate the expenditnre of $\$ 450,000$.

". 'Bob real' produces sickness in comparatively few cases, yet on account of its liability to produce disease its sale is prohibited.

"Dr. Fox says, in connection with anthracic diseases, that large quantities of this meat have been eaten with apparently no injurious effects, but so many disastrous oceurrences have followed its employment as to warrant the medical oflicer of health in condemning such meat."

At 5 o'clock and 15 minutes p. m. the committee adjourned until to-morrow, Friday, January 4, 1901, at 10.30 o'clock a. m.

Committee on Agriculture and Forestry,

United States Senate, Friday, January 4, 1901.

The committee met at 10.30 a. m.

Present: Senators Proctor (chairman), Hansbrough, Foster, Money, and Heitfeld; also Hon. W. D. Hoard, ex-governor of Wisconsin and president of the National Dairy Union; C. Y. Knight, secretary of the Nation Dairy Union; Hon. William M. Springer, of Springtield, Ill., representing the National Live Stock Association; Frank IT. Tillinghast, representing the Vermont Manufacturing Company, of Proridence, R. I.; Charles E. Schell, representing the Ohio Butterine Company, of Cincinmati, Ohio; Frank M. Matthewson, president of the Oakdale Manufacturing Company, of Providenee, R. I.; H. C. Adams, and other's.

The Cirairmax. The committee will come to order. I am informed that there are present two representatires of the dairy interests who are anxions to get away, and who desire to make brief statements to the committee before leaving.

Mr. Matthewson. Mr. Chairman, I do not think there is any objection on the part of the oleo people to the dairymen going ahead, if they are anxious to do so.

The Criarrian. There are two of them, and they have said to me that they will not take more than fifteen minutes each. You may proceed, Mr. Hamilton. 


\section{STATEMENT OF JOHN HAMILTON, SECRETARY OF AGRICULTURE OF PENNSYLVANIA.}

Mr. Hanilton. Mr. Chairman and gentlemen of the committee, I come here as the representative of the department of agriculture of the State of Pennsylvania, as well as a representative of the dairy union of our State. I want to say at the outset that Penusylvania is in favor of this bill. The State Grange of our State, at its meeting in Loekhaven recently, passed resolutions favoring the Grout bill. The dairy union, at its meeting in Corry just a few weeks ago, passed strong resolutions indorsing the Grout bill. The people of the State generally endorsed the Grout bill. The oleomargarine question was made a campaign issue in Pennsylvania; and if there ean be an expression of opinion of the people, I think that Pennsylvania's vote shows that Pennsylvania, in all of her cituzenship, is very much in favor of some law that will repress the sale of eolored oleonargarine in our State.

The governor, in his message which was given to the legislature only a day or so ago, makes use of the following language in discussing the oleomargarine question. It took about a column in the newspaper, and closes with this sentence:

"I am mueh gratified at the prospects of the early passage in Congress of the Grout bill. If this bill becomes a law, it will greatly aid in the suppression of the oleomargarine traffic."

In my preliminary report to the governor as secretary of agriculture only a week or so ago, I say:

"The passage of the Grout bill by the Congress of the United States, whereby a 10-cent tax is imposed on all eolored oleomargarine manufactured and the operations of the interstate-commerce law so suspended as to oleomargarine trade, will greatly aid the State dairy and fruit authorities in suppressing the oleo traffic."

The State Alliance at its meeting also passed resolutions indorsing the Grout bill. 'The Republican platform of the State of Pemnsylvania indorsed the suppression of the oleomargarine traflic or its regulation in our State. So we have pratically the unanimons indorsement of the people of our State, irrespective of party, in faror of the passage of this bill.

Perhaps I could just as well stop what I have to say here now, and not take the time of the eommittee, because this is as explicit a piece of expression as any that can be presented: and yet there are one or two other matters that I think the committee ought to have their attention ealled to, inasmuch as, so far as I know, the points that I desire to diseuss have not been fully presented.

Before taking up the items that I wish particularly to diseuss. I would like to refer to the argmment of Judge Springer yesterday for the purpose of getting rid of some things that seem to cloud a little the bill itself. The Judge referred to the many State laws and the difficulties that were encountered by the sereral States in their efforts to suppress the oleomargarine traffic, or at least to regulate it within their borders; and those gentlemen of the committee who were here yesterday recall that most of the Judge's presentation was taken up in the discussion of these laws. Now, if I had been going to make an argument in favor of the passage of the Gront bill, instead of against it, I think I would have taken the very same document. If that argu- 
ment showed anything at all in the presentation of these various laws by the many States that hare enacted them it shows this, that there is necessity for national legislation in order to simplify this work and make it effective thronghout the United States. I think that is the only conclusion that can be drawn from the argunent as it was presented.

There was also the constitutional question raised as to the power of Congress in certain respects. Of course, so far as the conflict with the Constitution is concerned by the passage of the Grout bill, this, I think, ean be said: 'That there is nothing given back to the States that they did not surrender when the interstate-commerce law was enacted: and if Congress had the right to pass the interstate-commeree law, and it was ratified. it surely has the right to reseind the law wholly or any portion of it that Congress may see fit. I think that part of the argument does not hold good.

As to the authority to tax, that is unquestioned. Congress does it now in this oleomargarine matter, and it did it in a number of instances, and of course that has no force.

So far as concerns the States taking advantage of this and levying a tax, that was one of the points that the judge seemed to be serious about and to which he asked the committee to give serious consideration-as to the States taking advantage of this law, in ease it shonld pass, to enact revenue laws, the amount receired from the tax on oleomargarine to go for the general purposes of the expenses of the State. We all know that such a thing would be unconstitutional. There has been no instance of it in any of the States so far, and there is no State that I know of that expects to levy any tax or license upon oleomargarine, the proceeds of which will be greater than simply enough to enforce the law. 'There was a case in North Carolina, I believe, on a somewhat different question, the taxing of fertilizer's in that State, in which a sum was first used for the purpose of enforeing the law, and then later the surplus was nsed for other State purposes. 'The Supreme Court declared that that was unconstitutional and was in conflict with these sections that the judge quoted yesterday; but no one contemplates doing this thing, and if anyone did do it it would be elearly unconstitutional, and that would be the end of it. No harm could come from it.

I may say, further, that if they suppose that the act is unconstitutional, then it seems to me that the judge's argument was upon the wrong side. If I had been holding that position and believed that it was unconstitutional, I certainly would not stand here and adrocate its passage; and I can not quite see how the gentleman on the other side, believing it to be unconstitutional, conld stand and resist its passage, because the passage of the act--knowing that it would be unconstitutional-would make it inoperative, and they would have secured the exact thing that they seem to desire. So I think the judge's argument went a little too far.

There is another thing that was referred to, if yon will permit me, and it scems to me that this was the most forcible presentation of our side of the question and in favor of the passage of this bill that has yet been presented. That is this fact, that 32 States of this great Union have passed laws regulating this traffic within their horders, and to say that these States do not understand what they are ahout; that the legislatures of all these States, acting independently and rep- 
resenting their citizens and representing about two-thirds to threefourths of the citizens of the United States, do not understand what they want, is so ridiculous that I can scarcely believe that anybody can present such an argmment. The voice of the people in this country, if it is properly expressed. is the ruling power; and there is no stronger argument in favor of the passage of this bill than that rery fact, that 32 States have for years been passing laws and amending laws with a view to regulating this traffic within their borders.

Mr. Springer. Exeuse me a moment. Will you explain why it is, then, that in the State of Illinois, where they hive a law prohibiting the sale of colored olcomargarine, $18,000,000$ pounds were sold within that State and $35,000,000$ pounds were manufactured?

Mr. Hamuton. I will answer you, if you will exeuse me just a moment.

Mr. Springer. Does it not show that the people are not in favor of these laws and will not enforce them?

Mr. Hamilox. My time is very limited, and if the gentleman will make a note of things as I go along, when I get through I will be very glad to answer any questions that I may be able to answer.

I will say in reply to the Judge that in some of these States the laws are defective. They are not sufficiently rigorous, and the legislatures have not been able in those particular States to pass laws that will restrict. The effort is to do it, but in many cases it has been so resisted by the interests in the State that they have not yet succeeded in passing laws that the people desire. I reiterate that the effort of 32 States of this Union, representing, I believe yoll said, sir, about $60,000,000$ people-

Mr. Springer. Sixty millions of people; yes.

Mr. Hanilton. Sixty millions of people ont of $76,000,000$-that the representatives of those $60,000,000$ people do not know what they are abont is inconceivable.

Now, with regard to this bill. It is constitutional. That is elear to the committee. I will not argue that to the committee, because they know it already just as well as it is possible to know it. The bill is constitutional, and the discnssion of the bill should be upon its merits. Is it a wise measure! Is it a proper measure? That is the point.

Now, the real argument that is presented-and about the only argument that is presented on the other side --so far as I know, is that the article is a healthful and proper article of food, and that it is equally nutritive and harmless with butter, and that therefore it should be permitted to go into the market and be sold colored as butter. I believe that is the argument that is presented, so far as I am able to understand, that they claim that it is equally nutritions with butter; that it is a substance that the public desires, and that it is equally digestible with butter, and that therefore it is a wrong to undertake to do any thing that would limit its sale in this country.

That is at least one proposition. Now, in reply to that they give the testimony of some of the most eminent chemists in the country. The testimony is guarded, it is true, but they put it in a somewhat unequivocal form. What does the analysis of oleomargarine and butter show as compared with each other? The first thing that can be said is that they are not identical. The analysis shows that while the amount of fat in the two is practically the same, yet the composition of these fats that go to make up what is called fat in a chemical sense 
is entirely different in oleomargarine and in butter; that the amount, for instance, of butyric acid in the one is very much greater than in the other. The amount of butyric acid that they get is the amount that is secured from the milk that is churned with their product. The amount that is naturally in butter is a larger percentage, and just what effect this condiment has-and doubtless it acts as a condiment in some way; at all events, it gires a special flaror and aids in the digestion, it is believed-just what effect this condiment has we do not know, and physiologists do not know. It think it is agreed that it bears an important relation to the digestibility of this substance and of other substances in the human stomach, but just what its operation is is not known. 'The other thing which the chemical analysis discloses is that the amount of stearin in oleomargarine is much greater. Dr. Wiley says it is about five times as much as is found in butter.

Senator Hertfend. The amonnt of what?

Mr. Hamilton. Stearine.

Senator Heitfeld. Is that added?

Mr. Hamlton. Some of it is added and some is found in the oils out of which oleomargarine is produced. So that in those respectsand they are very important respects-these substances differ from each otber in a ehemical view.

Now, so far as heat muits are concerned-that is, the amount of energy-producing power that the two substances contain-that, our physiologists say, is about equal, so far as they can determine.

Senator Heitfel.d. Does any user of butter consume enough to give any particular energy to the body?

Mr. Hamiltos. The energy is transmitted into heat and is measured in heat units. One unit, or calory, as they call it, which is a unit of energy, is regarded by these physiologists as equivalent to heat sufficient to raise water $t^{2} \mathrm{~F}$; so for every unit of energy there is heat enough to do that thing.

Mr. Matirewson. How much water?

Mr. Hamilon. A poind of water-4 $4^{\circ} \mathrm{F}$.

Mr. Matilewson. How much butter does it take to make a unit?

Mr. Hamimon. The exact amount is given here. One gram of the ordinary butter fat is equal to about nine ealories, which would be about $36^{\circ}$ of heat; a little more than that. It would be pretty nearly 40 of heat. So that there is a great deal of energy-producing power in butter. But that was only incidental. The thing I started to say, gentlemen of the committee, was this, that in that respeet these two substances seem to be on about the same basis. The analysis shows that they contain about the same amount of butter fat, and so their energy-producing power is equal.

The fallacy of their argment comes in right there. They say that because these substances are equal, therefore they are equally inutritious and beneficial. 'That does not follow at all, and it is to that point that I want to call your attention just for a little to show that that is a mistake or at least that the unqualified assertion that these two are equally noninjurious to health is simply an assumption, and is not based upon any reliable ascertained data that has been continued for any length of time.

We have very familiar examples of how things that are identical produce entirely different effeets. I know a lady who for the last seven or eight year's could not eat fresh bread or biead that had been 
baked for a day or so. It produces violent illness, and it is simply out of the question, although it has been tried numerous times. She can not do that, but she can eat that very same bread taken and sliced into thin slices and put in an oven at a low temperature of heat; that is, a temperature too low to permit the change of starchy dextrine, which, of course would promote digestion, but a simple drying out. That she can eat in any quantity to satisfy her hunger and with perfect conifort.

A chemist will say that there is no difference between those two substances, in an analytical point of view, except the loss of water. There has been no chemical change, because the amount of heat supplied was not sufficient to bring about a chemical change. He will say that they are identical, and yet the effects that are produced upon the same system are altogether opposite. To assert that substances that are analyzed and shown in an analytical sense to be of similar composition in fact, but which vary in other minor matter's that to us scem to be infinitesimal almost, yet which have a very important effect upon the physiological organs and upon digestion, is to assert, as I say, something that is not based upon reliable information. So that it does not follow that because the things have the same amount of heat-producing power and nourishment-producing power therefore they are equally beneficial to health.

I want to call attention to Professor Atwater's statement with regard to that, if you will permit me.

'The Chamman. 'These hearings, I may say, are sandwiched in ahead of the oleo people, and it was promised that they should be very short, about fifteen minutes each. You have occupied nearly twenty-five minutes, but you have been interrupted somewhat and I do not want to eut you offi.

Mr. Hamilton. I will not refer, then, to these matters. I did want to refer to them in substantiation of the position I have taken.

Senator Hassbrough. I suggest that you put the statements you desire in the record.

Mr. Hamilton. I will do so. I desire to refer to the article on the "Digestibility of food," a statement by Prof. R. H. Chittenden, in Bulletin No. 21 of the Department of Agrieulture, page 72, and also to a statement by Dr. W. O. Atwater in the same bulletin, on page 53.

The statement of Professor Chittenden is as follows:

"As to the reasons for the differences of digestibility but comparatively little is detinitely known. There are, however, certain a priori considerations which help toward explaining them. For eximple, the digestibility of the proteids is discussed by Prof. R. H. Chittenden ats follows:

"If of two foods possessing a like composition one be more easily digestible, that one, though containing no more arailable nutriment than the other, is in virtue of its easier digestibility more valuable as a food stuff, and in one sense more nutritious, as well as more economical for the system.'"

Dr. Atwater's's statement is as follows:

"The value of food for mutriment depends not only upon how much of nutrients it contains, but also upon how much of these the body can digest and use for its support.

"The question of the digestibility of foods is rery complex, and it is noticeable that the men who know most about the subject are generally 
the least ready to make definite and sweeping statements concerning it. One of the nost celebrated physiologists of the time, an investigator in whose laboratory this particular subject has been studied more than in almost any other, says in his lectures that, aside from the chemistry of the process and the quantities of nutrients that may be digested from different foods, he is unable to affirm much about it. The contrast between this and the positiveness with which many persons diccourse about the digestibility of this or that kind of food is marked and has its moral.

"One source of confusion is the fact that what people commonly call the digestibility of food includes sereral very different things, some of which, as the ease with which a given food naterial is digested, the time required for the process, the influence of different substances and conditions upon digestion, and the effects upon confort and health, are so dependent upon individual peculiarities of different persons and so difficult of measurement as to make the laying down of hard and fast rules impossible. Why it is, for instance, that some persons are made seriously ill by so wholesome a material as milk, and others find that certain kinds of meat, of vegetables, or of sweetmeats 'do not agree with them,' neither chemists nor physiologists can exactly tell.

Mr. Adans. May I ask you a question, Mr. Hamilton, before you close?

Mr. Hammton. I am not closing yet. I want to make another statement, if the gentlemen will permit me. I feel, gentlemen, that this is an exceedingly important question.

The Champran. Go on, but be as brief as you can.

Mr. Hanilton. With regard, therefore, to the question whether butter and oleomargarine are equally beneficial to health or noninjurious to health, the fact is that we do not know about it; and when they say unequivocally that it is not injurious to health, or that it is equally beneficial with butter, they are talking in a rather loose way and are not supported by the best authorities in the country.

Now, with regard to another matter, the question of public policy. Is it a proper measure? If you will permit me to use for my illustration the State of Pennsylvania, with which I am familiar, and the conditions there, I think it will illustrate what I desire to present, and the application of it is wide enough to extend to, I think, almost all of the States of the Union. I have here a little statement that I made in my report. It is a discussion of this question, and I wonld like to read it:

"Careful examination should be made into the effect which this will have upon the dairy industry of the Commonwealth, which has now become one of the leading and most profitable branches of our agriculture. If, upon examination, it is found that oleomargarine will to any considerable degree drive ont the dairy interests from the markets of the Commonwealth. it would seem to be only wise public policy to first make sure that the industry that is to replace this branch of our agriculture shall do more for the Commonwealth in the way of substantial and permanent support than the important occupation that it proposes to supplant.

"The admitting of oleomargarine in competition with the dairy produets of the State endangers a great industry that is now a part of our system of agriculture more widely distributed than any other. We have now about $1,100,000$ cows in Pennsylvania. Their product is 
about $90,000,000$ to $100,000,000$ pounds of butter per year, and according to the census of 1890 the milk product was $437,525,349$ gallons. These cows are distributed among 211,412 farmer's families, consisting of over 1,000,000 persons, or about one-fifth of our entire population. The income of the farming people of Pennsylvania last year from butter alone amounted to between eighteen and twenty millions of dollars; and the milk product, at 8 cents per gallon. amounted to $\$ 35,000.000$ more. This vast sum is a new product each year, adding this much to the actual wealth of the State, and is distributed all through the Commonwealth, going to the support of orer $1,000,000$ people, enabling them to maintain themselves in comparative comfort. The loss of such a sum as this by the agricultural people of the State would be a calamity, particularly because much of the material that is used in the feeding of these dairy cows would, if the industry were destroyed, be left on the farmers' hands valueless.

"If the product of these animals were seriously threatened there would also be an immediate depreciation in the value of milch cows throughout the Commonwealth amounting to many millions of dollars, and would involve the partial or total loss of the stabling, ereamery buildings, and machinery that are now in use in the prosecution of this industry. A large number of our people, also, would be thrown out of employment. Instead of men, women, and children on the farms having at all seasons occupations suited to their strength and attainments, there would be, in the cutting off of this line of work, comparative idleness during a considerable portion of the year.

"The people of this State require about $200,000,000$ pounds of butter amnually to supply their needs. The business, therefore, is one that has room for growth, and the doubling of the products of milk and butter will double the income of the farming people-an increase of from fifty to sixty millions of dollars annually.

"If oleomargarine were wholly substituted for butter in this State it would mean a direct loss on that article alone of from $\$ 30,000,000$ to $\$ 40,000,000$ per year, and the profits of the new industry, instead of being distributed among 1,000,000 of people, would be retained in the hands of a very few, rendering them inordinately rich at the expense of those whose industry they had destroyed.

-It is true that in no erent can oleomargarme entirely supplant butter production, but enough is known to make sure that this produet, which can be made for about 7 cents per pound, will serionsly injure the butter industry and effectually prevent its derelopment. It would be extremely bad business poliey to drive out a source of revenue and means of livelihood as important as the dairy industry for the sake of benetiting a few individuals belonging to the oleomargarine trade; to take from 1,000,000 agricultural people the profits of their chief industry and give these profits to a select syndicate of eapitalists, that they may become enormously rich.

"If this new industry required for its prosecution the employment of 2,000,000 people instead of the $1,000,000$ at present needed by the dairies, one could see how it might be to the advantage of the State to substitute the new industry for the old, because of the increased number of laborers that it would employ; but when it proposes to do away with 1,000,000 laborers and substitute therefor' a factory system employing only a few workmen, the danger that will ensue becomes apparent to every thoughtful citizen. We need employment for more labor 
instead of turning men idle who are now employed. We need additional markets for the rough products of our farms instead of closing up the ones we now have. Under modern conditions it is necessary to change farm articles of bulk into a more valuable and compact shape in order to ship them to distant markets. The butter industry does this, and has the additional adrantage over every other product in that it at the same time removes almost no fertility from the farm."

It is claimed that it is unjust to exelude from the Commonwealth an article of food that is not injurious to the public health, taking for granted that oleomargarine, as now manufactured, is not unwholesome as an article of food.

The sale of oleomargarine as butter and in imitation of butter is a fraud, and it is also a menace to a great industry which comprises a large portion of our agricultural wealth.

The Chamman. Mr. Wadsworth is here from the House and desires to address the committee.

\section{STATEMENT OF HON. J. W. WADSWORTH, OF NEW YORK.}

Mr. WAdswortir. Mr. Chairman, I saw a statement in the paper yesterday which puts the report of the minority of the Committee on Agriculture of the House in a rather dubious odor. That is, the contradiction of $\mathrm{Mr}$. Adams that he ever stated to that committee that there was no need of beating around the bush; that the object of this second section of the bill was to drive the oleomargarine manufacturers out of business. Mr. Adams is right in the statement that there was no stenographer present at that time, owing to an oversight. The remark was taken down, however, by a member of that committee at the time, because its very boldness attracted the attention of the whole committee to it.

Another contradietion made yesterday was by Mr. Knight, secretary of the National Dairymen's Union, that he never wrote that letter to the Virginia farmers. 'That letter, or a copy of it, is in the hands of a member of the committee, who has not returned from the West as yet. If it is considered of enough importance, the copy of the letter or the original will be produced. I say this simply to place the minority report of the committee in the proper light.

Another matter, which is per'sonal to myself-and I only call attention to it because this man Knight has used it simply for purposes of intimidation. He says that my majority in my district was cut down over 2,000. 'That is a falsehood. My majority is the largest I have ever had there, except in 1896.

Senator Heitfeld. I believe, Mr. Wadsworth, that was a mistake. He admitted that your majority was larger; he simply stated that you ran behind the ticket.

Mr. WADsworerir. I did not; that is false also. I only desired to call attention to that because I believe it was stated for a political purpose.

Mr. Adays. Mr. Chairman, this is a personal matter, and I hope Mr. Wadsworth will remain while I make another statement with reference to the statement which I made before the Committee on Agrieulture. I did not make the statement which was reported in the report of the minority of that committee. I simply said there was no use in 
beating about the bush; that it was the purpose of the friends of the Grout bill to enact that measure into law and stop the manufacture and sale of oleomargarine colored in imitation of yellow butter-neither more nor less. It may be that the gentlemen understood that I made a stronger statement than I did make; but it is an unfair thing to the representatives of the dairy interests of this country to put them in the false position of making an idiotic attack upon oleomargarine pure and simple under its own color and in its own form; and at no place will I permit any gentleman to quote me as having said something which I did not say and which is an injustice to myself and to the interests which I represent.

Mr. WADSwortir. Mr. Chairman, that report was published last May. This is the first time it has been contradicted. We will drop it now, so far as I am concerned, except that I will simply say to Mr. Adams that it is a question of memory between the committee and him as to the words he used.

Mr. Adans. Permit me to say further that, at the request of a member of Congress, when my attention was first called to the statement of the minority, I submitted a written statement of the facts, which he incorporated in his speech, and that was published in the Congressional Record.

The Chairman. This committee is not trying the proceedings of the other Honse.

Mr. WADsworTh. I wished it molerstood that I appear here simply to correct that matter, on the part of the minority of the committee.

\section{STATEMENT OF JOHN HAMILTON RESUMED.}

Mr. Hanilton. Mr. Chairman, I will finish in a moment, if you can indulge me. This article, oleomargarine, is a fraud on the public. I think that statement is corroborated by every dairy and food commissioner that has to do with it in every State where laws exist regulating its sale. We have had a great deal of experience in Pennsylvania with this article, and a large amount of it is not branded, although it may be sold for butter. TTe have examined more than a thousand samples of it this year, and a large percentage of it is not.branded so as to distinguish it from butter, and is sold as butter.

Now, with regard to the Grout bill. My riew, and the views of those whom I represent, is that the Grout bill will orercome our difficulties; that it will enable the dairy and food commissioners of the sereral States to enforce their laws better than they do at present; that this Grout bill is not a prohibitive law; that it is simply one that protects the dairy industry. It costs the farmers from 16 to 20 cents to make butter, according to the season of the year, and if this article can he sold down as low as 15 cents or 12 cents it makes it impossible for the dairymen of the State to compete with such an article. The purpose of the Grout bill, as I understand it, is simply to raise the price of oleomargarine up somewhere near the cost of producing butter, so that they may start in the market at equal prices. Then it is sold colored, and the butter is sold colored, and they will have a fair chance in the market, started equal; but if the one starts down at 10 cents or 9 cents and the other ean not start until it reaches 16 or 18 cents, it does not take much of a prophet to know what the conclusion of the whole matter will be in the very near future-the destruction of the 
dairy industry of this country. That can not be avoided. The price at which it must be sold is not excessive. It is not an excessive price. It simply brings it up to the necessary cost of good butter, so that the bill can not be attacked on the gromnd that it is an excessive tax and that it puts them at a disadvantage with the farming interests of the State. They start upon the same footing, and they are entitled then to the same privilege.

I am very much obliged to the committee for their indulgence, and I am sorry to have transgressed upon the time of the gentleman who is to follow me.

Mr. 'Tillinghast. Will the gentleman answer' one question!

Mr. Hanilton. Yes, sir.

Mr. Tillinginast. How much oleomargarine do you estimate was sold in the State of Pennsylvania last year?

Mr. Hanilton. I do not know anything about it.

Mr. Adans. What percentage do you think is sold as and for butter?

Mr. Hanilton. I should say 50 per cent, at least.

Mr. Mathewson. If you do not know about one thing how do you know about the other?

Mr. Hamilton. I am talking about the percentage we collect.

Mr. Adans. I would like to say, Mr. Chairman, that Mr. Blackburn, who will now address the committee, only asks for ten minutes.

The Chairulan. Very well.

\section{STATEMENT OF JOSEPH H. BLACKBURN, DAIRY AND FOOD COMMISSIONER OF OHIO.}

Mr. Blackburn. Mr. Chairman, I will endeavor to set an example to those who follow me by finishing my remarks within the allotted time. I have heard this question discussed so much technically, scientifically, therapentically, and physiologically that I do not intend to give any consideration whatever to those phases of this question. I have been asked perhaps a dozen times since I have been in W ashington, "Why don't you enforce your State laws?" I have been asked that perhaps a dozen times in my own State. We have a State law against the manufacture and sale of artificially colored oleonargarine. It is not limited to the coloring or semblance of butter, but any coloring matter whatever is forbidden.

I desire to say that I have been dairy and food commissioner of the State of Ohio for ahout four years. In that time I have spent nearly $\$ 200.000$ of the State money, and of that amount I presume 60 per cent has been spent in oleomargarine prosecutions. The difficulties to contend with in the State of Ohio may be very briefly stated. The principal sales of oleomargarine, as everybody knows, are in the large cities, where butter, in the winter time especially, is scarce and hard to get. It has been sold so long in the larger cities of Ohio-and I refer to the cities of Cleveland, Columbus, Cincinnati, Dayton, and Toledo as the larger cities in the State - that there is a certain clientele built up, many of whom want oleomargarine, many of whom are deceived into believing that they are buying and using butter; but when a prosecution is brought there is so much sentiment there. or mamufactured for the occasion through the manipulation of the public press and the carefully worded 
reading notices and advertisements and through the personal solicitation and interference with the jurymen or those who are to be summoned as jurymen to try a case, that it is almost impossible to secure convictions in these large towns, or many of them.

I will refer to one case that happened a short time ago in a smaller town in Ohio, the city of Portsmouth. The case was tried by a jury, as all our cases have been until this week. The law makes the sale of colored oleomargarine a misdemeanor, and we have always gone on the theory that these cases must be tried by a jury. We are working now under a new plan, and trying to do away with the jury because it increases the difficulties of securing conviction. In the case of a jury trial the State must have twelve men who are convinced that there has been a violation of the law, while the defendant only needs one to hang the jury; and, under a peeuliarity of our jury law, a member of the jury is not paid unless the defendant is either aequitted or convicted, so that hung juries do not get their fees until the case is finally decided. In this ease that I have reference to, in Portsmonth, the case was not tried very hard-sometimes our cases are fought very bitterly and a great deal of feeling derelops-but the rery next day after that jury hung, or disagreed, two members of the jury went to work for grocers in that town. We have no proof that this was prearranged, but we hope to get some proof on that subject in the near future, and everything indicates, and everybody who has paid any attention to the subject believes, that that jury was corrupted. That is simply one instance. I could relate dozens of such cases.

I will state that it has become a common practice in the larger citiesand I refer to Cincinnati and Dayton, where instances have lately oceurred of the jury haring acquitted the defendant for having sold colored oleomargarine as oleomargarine; not as butter, but colored oleomargarine - for the jury to be taken out and banqueted by the defendant and the defendant's attorneys. I will state further that I have been informed by one of the most prominent representatives of grocery interests in the State of Ohio that they are encouraged to sell oleomargarine for butter. I asked him why and by whom. He said, "Well, there is not much in the grocery business any more, and if we sell oleomargarine as oleomargarine we make about a cent or 2 cents a pound on it. If we sell it for butter, we make 8 or 10 cents a pound or more." I asked him who encouraged this. He said, "Well, when the manufacturers' agents come around and give us a guarantee to protect us against all prosecution it is a pretty big temptation for a fellow to take chances." I said, "Are they in the habit of doing this?" He said, "They are." I understand it is a very common practice for manufacturers, as an inducement to handle oleomargarine contrary to the laws of Ohio, not only to pay part or all of their license fees, their national license, but also to give them assurances and guarantees that under no circumstances will they permit them to be involved in any trouble on account of the activity of the dairy and food department; that they guarantee them against any loss whatever; that they will protect them and do protect them.

Perhaps the largest oleo manufacturing concern in our State, the Capital City Dairy Company, of Columbus, provides a lawyer nearly all of whose time is taken up in defending retail dealer's. They not only furnish a lawyer, but they furnish a stenographer to make and 
keep a record of every case. They furnjsh two or three agents, who usually appear on the ground when a trial is about to be had, a day or two in advance, and secure all the information they can. I presume they usually have a list or copy of the venire-the jurymen whom we propose to call upon. And in one instance recently, that is the Portsmouth case, of which I spoke a while ago, which was tried the second time last week, the attorney for this Capital City Dairy Company in Portsmouth pulled a list out of his pocket that had the renire on itall the member's whom we expected to serve on that jury-and he had a chart made showing each gentleman's politic's, his religion, his predilections on these various questions, and especially with reference to the pure-food law, and so on-six or seven very important points. Now, that case was not half tried by the defendants, not half; yet the jury stood nine to three for aequittal.

Senator Foster. Have they ever had any convictions in the State of Ohio?

Mr. Blackburn. Yes; a few. I should say that when cases are tried by a jury we secure about 25 or 30 per cent of convictions, and those are nsually in the smaller towns or some place where the sentiment is in favor of butter and opposed to oleomargarine.

Mr. Tillinghast. Were those indictments you speak of indictments for the sale of oleomargarine as oleomargarine or for the sale of oleomargarine as butter?

Mr. Blackburn. Our law is a little different firom most of the State laws. We do not have indictments.

Mr. Tillinghast. The complaint, or whatever it was.

Mr. Blackburs. It is a charge made in the justice of the peace court. These cases that I have mentioned have been for the sale of oleomargarine as oleomargarine artificially colored contrary to law.

Senator Foster. Do these same people defend the cases where they are tried for selling oleomargarine for butter?

Mr. Blackburn. My impression is that they defend every case, but I can not recall now one particular instance of that kind.

Mr. Tillinghast. Do you remember making any prosecutions where the complaint was that oleomargarine was sold for butter under your State law?

Mr. BLackburn. I remember of having made a number of such prosecutions, and according to my recollection-I will not be positive on that point-they were all defended by the manufacturer's or their agents.

Mr. Tilinghast. What was the result of those prosecutions, so far as you remember?

IIr. Buackburn. The majority of them resulted in convictions-the large majority.

IIr. ADAms. I would like to ask you what percentage of oleomargarine, in your judgment, in the State of Ohio is sold for butter at retail stores, or finally sold upon the tables of hotels, restaurants, and boarding houses, as well as to the ordinary consumer?

Mr. BLackburs. I would have to guess at that, Mr. Adams. My judgment would be 75 per cent of it. I might state that the three leading hotels in the city of Columbus - the Chittendon, the Neale House, and the Southern Hotel-are now and have been for months back using oleomargarine on their tables in defiance of law. 
Mr. Tiluinghast. They know what they are using?

Mr. Blackburn. Certainly; the manager knows, but does the guest who pays $\$ 5$ a day for entertainment know?

Mr. Springer. They must have good oleomargarine when they deceive the guests of a \$5 a day hotel.

Mr. BlackBurn. It is good oleomargarine. I have no feeling against their goods at all. That only illustrates the necessity for this kind of legislation.

I have studied this matter for four years. I went into it absolutely without bias or prejudice. I do not now, and never did, own a nickel's worth of interest in any dairy farm nor in any cow, nor am I interested the other way in any thing that goes into oleomargarine, directly or indirectly. I have studied the matter for four years, and it is my carnest conviction that it will require national legislation of a very radical character to stamp the fraud ont of the manufacture and sale of oleomargarine, and I refer especially to the sale of oleomargarine, becanse the manufacturer produces olcomargarine as oleomargarine, and usually sells it to the jobber and agent and deales for precisely what it is. There is very little deception practiced at that stage of the game.

\section{STATEMENT OF FRANCIS W. LESTRADE, OF NEW YORK CITY.}

Mr. Lestrade. Mr. Chairman and gentlemen of the committee, I wish to state on the outstart that it is seldom I am called upon to speak in public.

The Chamman. You are interested in the manufacture, are you, or are you acting as counsel?

Mr. Lestrade. No; I was about to say that I am nothing more than a practical everyday butter man. I have been in business for twenty years, and what I say before you is entirely from a practical standpoint, not a theoretical standpoint, and not from any scientific point of view, but from what has come under my observation as a butter man ever since I was a boy.

I am a member of the firm of Lestrade Brothers. New York City. I am an owner of and interested in dairy farms, both in the West and in the Eist. I am also interested in cows. I am also interested in three different creameries. I am also, and this is our chief business in the city, an exporter, a packer of butter and cheese to the hot countries as well as to the Continent, but mostly to the hot countries. Our business extends over all the hot countries - that is, the tropical climates, consisting of the West Indies, the East Indies, South Africa, China, South America, and even now into the Philippine Islands.

So what I have to say is entirely in my own interest, and more particularly as an exporter of the genume butter that goes out of this country to foreign climates.

In the few opening l'emarks that I have to make I may go over some ground with which you are all more or less acquainted. I desire to state to you-maybe some of you do not know the fact-that in this country of ours there are, we will say, four classes of butter. The first is the packing stock, or the original dairy butter. That is the commonest butter that comes before us, as butter men. It is made by the innumerable farms throughout the great West. We get rery little 
of it from the Eastern States; they make little chunks of butter in their barnyards, in their barns, on the side stoops of their honses. I mean the farmers who have one, two, three, four, five, a dozen, or fifty cows. They bring these little chunks to the country store where they trade, and this butter is put before the grocer or the provision man, and in return he gives them ealicoes and groceries of different kinds. I have a man stationed in the West-yes, two of them in different parts of the West, and they buy up this class of buttel. Originally, up to within four or five year's, the price ran from 6 to 10 cents a pound. Ten cents was the highest price. My men will go around and gather in all this roll butter in little pats of all colors and descriptions, wrapped in swaddling clothes and old towels and sheets and everything else, and they are packed down into tierces holding 300 to 400 pounds. They are brought to a central point and then shipped by the carload to me at New York City, or else I store the goods in Chieago or in the West until I need them for my manipulation in coloring the butter and resalting it and sending it -imost of it - to the hot countries.

'The second class of butter that is made in this country is ladles. Ladles is made from this same class of butter I spoke of a moment ago. The ladlers send ont, as I do, their men from Chicago and from other large places in the West, and they gather in this same butter as I do and take it to their creameries-so-called creameries. That is, they make ladles out of this butter, but they do not use eream if they manipulate it. It is done with milk, but as a rule it is merely manipulated with a little salt and a little water and recolored and put up into 60-pound tubs, and there you have what is ealled the ladle butter.

By a little further process and a little more working you have what is commonly termed imitation creamery. That is a little higher order' of ladle butter, and that is brought on to this market and sold.

The next that comes is the creamery butter. That is, as we all know, made out of the very best eream, as a rule, or we try to make it ont of the best cream; and it is put before those who can pay the price in the East and in the West.

There is a new butter that has come on the stage-what is called renovated or process butter. I may later on refer to that again.

Right here I wonld like to say that up to within ten or possibly twelve years ago I was preaching and talking and threatening my different men throughout the country, telling them that their butter was poor, that we had to contend with the foreign butter, and that the foreigners were making better butter than we were in this country; that it was hard work for us to compete in the hot countries and throughout the foreign countries with the Danish butter, with the French butter, with the Italian butter, with the Irish butter; that our butter was poor; that it would not keep, and that we must do something; that they must bring things up to a higher level; that they must take more pains with their butter. I sent them samples of the Danish butter. I sent them samples of the French butter. We experimented. I went at that time, at considerable cost, among the different creameries and put in my own money to endeavor to raise the standard of our butter; but, gentlemen, let me tell you as a butter man, as a man whose bread and butter-I mean that earnestly-is entirely in the product of butter, I tell you honestly that when the new product oleomargarine came on this market some ten or twelve years ago, I saw it and examined it, and I 
said, "Thank God for oleomargarine." Why? Said J, "That is going to bring up butter to a higher grade." Why, in the old days of twelve or fifteen years ago, when the ladle butter came into our markets, we ealled it bull butter. Invariably it was mushy, invariably it was soft, invariably almost it was in lumps, in different eolors, in globules, swaying and straying like a fluid; and I bonght samples of oleomargarine and sent it to our' men and said: "Gentlemen, unless you can make your" butter similar to olcomargarine, butter in this country is dead." Why, it opened their eyes; and then, by George, when I sent them butterine, I believe they called it, with ereamery butter generally put into it, that smelt like a summer rose compared to our creameries, and said: "Unless you ean make your ereameries similar' to that you might as well go out of business, and give it up to this new product that has come in," it was the means, which every butter man knows, of revolutionizing butter.

Mr. Adays. Oh, no; we do not know that.

Mr. Lestrade. I know it from a practical standpoint. You may be a practical man-but I know it. I have been there all my life. This is a matter of bread and butter to me.

The Chairman. Speak to the committee, please, Mr. Lestrade.

Mr. Lestrade. I am partienlarly interested in butter, Mr. Chairman. From that time gradually everything changed. We began to bring in a better grade of ladles. We began to bring in a hetter grade of imitation ereamery. We began to bring in a better grade of creameries, until to-day we have arrived at almost a stage of perfeetion as far as creameries are concerned.

Senator Heitferd. What do they do now with that butter that you used to gather up in Kansas and Nebraska? How do they handle it or pack it now?

Mr. Lestrade. I will answer that now immediately, For some time it was a question, of course, in our minds as to whether oleomargarine was not going to knock things sideways as far as the butter interests of this country were concerned. We watehed it very closely; and of c $c$ me, naturally, being a praetical man in the business I watched it, and I found that our dairy interests were growing very rapidly and that we were increasing in the quality of our goods year by year. I found, and I still find to-day, that, as the gentleman who first spoke here very wisely remarked, the butter industries of Pennsylvania are growing and widening and more creameries are going up throngh that great State. That is true. Instead of oleomargarine being a detriment to butter, it has, as an absolute fact, been a great benefit to all butter men. It has not, as a matter of fact, lowered the price of butter. It has not taken away the profit, as, from a theoretical standpoint, a great many of these gentlemen will tell you. I know differently, and I ean prove it and show it to you.

Ten or' twelve year's ago this packing stock that I spoke of we could buy at from 7 to 10 cents a pound during the spring months. New butter comes in May, and we get this butter in the months of May, June, July, and August; very little, however, in August. The lowest price of hutter cluring the year is in the latter part of May, in June, and sometimes in July. Year by yoar I found, as a large eonsumer of this cheap article, that I was obliged to pay more money for it. This was due merely to the natural laws governing a country like ours and the growth of it. But the demand for butter outgrew the industry, 
and I will merely state that for the last two real's the price has gradually gone up froin sor or lo conts a pound until a year ago I put that same butter away at 13 to 14 cents a pound. This spring I put it awar at from 14 to 16 cents a pound. We are obliged to put large quantiticis of it away for our fall and winter' use, for it does not come in quantitics at that time of the vear, so we are obliged to buy it in the flood in the spring.

Mr. Tuldinghast. Will rou permit a question!

Mr. Lestrade. Yes, sir:

Mr. Tillinghast. How does the quality of that article compare now with what it was ten or twelve year's ago!

Mr. Lestrade. It is all made of dairy butter. I'nderstand, it is not ladle hutter. It is not manufactured by machinery or anything like that. It is made by the wives and danghters of the farmer's. Consequently it is a hard. solid A i piece of cheap butter, made with all the hacteria and all the parasites and everything else all shored in and brought to us, and we manipulate it and wash it and put it on the market.

Mr. Flanders. How long have they been making this ladle buttergathering this Western butter and making it!

Mr. Lestrade. Since I have been in the busines.:

Mr. Flanders. When they first began there was a great quantity of it, was there not! It was a drug on the market!

Mr. Lestrade. A what?

Mr. Flanders. A drug on the market.

Mr. Lestrade. Not necessarily, unless it was utterly unfit for use.

Mr. Flanders. This butter that is brought in by the IV estern farmers and gathered up by the stores is sent to central stations just as fast as it is prodtued, is it not?

Mr. Lestrade. Well. the rolls are.

Mr. Franders. Would not that account for the increase in price? When you tirst began to gather up this butter there was no market for it, was there! It was an experiment, was it not!

Mr. Lestrade. No; it was no experiment. It was an everyday business.

Mr. Flanders. The reason I asked this question was that your testimony, so far as it goes, is contrary to all I have ever heard on the subject, and I have given it a great deal of study. I know of your firm. Are you not an exporter?

Mr. Lestikade. Yes.

Mr. Flanders. Do jou agree with Bardon Brothers on this proposition?

Mr. Lestrade. I believe I do.

Mr. Flanders. Do you sell to the home trade?

Mr. Lestrade. No.

Mr. Flanders. It is simply a question of money in the foreign market, is it not?

Mr. Lastrade. Entirely as an exporter I am now talking.

Mr. Flanders. Do you ohserve the laws of your state on this sulject?

Mr. Lestrade. How do you mean do l observe them!

Mr. Flanders. Do youl ohey them?

The Crammax. 'That is hardly al fair question.

Mr. Lestrade. I do not know what you meatn.

Mr. Fuandens. The point I would like to make. if the committee 
will permit me, is that this hutter originally, when they conceived the idea of gathering it up from the farmers or the stores, had never been used. When they found they could use it, they began to gather it up, and there came a demand for it, and they gathered it as fast as it was brought, and that raised the price.

Mr. Lestrade. This gentleman may possibly be correct about that, Mr. Chairman, thirty year's ago, but I am not going as far back as that-thirty or forty years ago, when there were pioneers in the West-but it is not correct since twenty-five years ago; and a quarter of a century is pretty far back to go.

I will say also that I do sell the home trade in creameries. I am interested in two or three creameries, and I was about to go on to the creamery question. The same thing applies in regard to the cheapness of creameries. The poor creameries that were coming East up to the time that oleomargarine dawned upon the United States were something abominable. There was hardly such a thing as knowing what your next shipment would be. You would get a fine piece of butter in to-day, and from the same creamery next week you would get a poor piece of butter.

I state as a fact that oleomargarine did for butter all I have stated. The time came when my export trade and the demand for ereameries was so great from this country, on account of our being able to start a little bit of a process of our own, an imitation of the Danish process, that I found I had to make some arrangement with some ereamery in this country to make my butter. I went to two or three of the best creameries in New York State and they were unable or unwilling to make the high grade of butter that I wished for. I went West and the same thing happened. I was then obliged to go in and put myself in a position to make this butter, and the consequence is that to-day - and there is no egotism on my part, because the proof of the pudding is in the eating of it - we are sending now butter in competition with the well-known world-renowned Dänish butter. We are sending it all over South America, all over the West Indies, down in China, and down in South Africa, but we could not do it until we put up and became interested in our own creameries. Even to-day the creameries of this country are not making the butter they should make.

Now, another thing right here in regard to the creamery question, and I am endearoring to lead up to a point here, gentlemen of the committee, which I trust I will be able to make clear to you. Another thing that is detrimental is that the wonderful mechanism and discoveries that we have made in regard to centrifugal force and the different machinery used in making butter is really a detriment to butter for this reason: That to-day the dairyman, the creamery man, wants to turn his butter ont in fifteen minutes, and from the cow he wants to give you a piece of butter on your plate twelve or fifteen or twenty minutes after you have seen the milk taken from the cow. That is all they are aiming at. I heard one of my neighbors say that he thought he would soon be able, with the discoveries that were being made and the new processes that were being used, to milk his cow and put butter into the market the next day. I do not believe it needs a very brilliant mind to know that butter of that character will not stand up.

The Charrman. What is the Danish process you have been speaking of? 
Mr. Lestrade. The Danish process, without going into too much detail-there may be otber butter men here and they might catch on is a slow process. It is an old-fashioned process of making butter, really.

The Chatrunan. Do they make the butter with the hands or machine?

Mr. Lestrade. With crude machiner"r, in almost the same way you would make it by churning with your hand.

The Chamman. That is, they let the milk turn?

Mr. Lestrade. Yes.

The Charrman. Is there nothing about it except more care?

Mr. Lestrade. More care and knowing how to work it, really. What we aimed at was to get the consistency of body so that it would keep, so that we can guarantee to the United States Government when making purchases, which we are obliged to do, that the butter will keep a year without going into liquid form, without going into oil or without getting strong. I do not dare to take the butter from any creamery into this country and put it into my stock with the idea that it will keep like that. So the old-fashioned way, after all, is best. You and you and you used to buy your butter and keep it all winter, and it kept all winter; but to-day you take one of our fresh creameries and you keep it a week and it will go strong. However, that we consider is in the long line of progress and promotion, and getting toward the perfection of butter. In one sense it is and in another sense it is not.

Senator Haxsbrough. You were obliged to compete with this Danish process, were you not?

Mr. Lestrade. Yes, sir.

Senator Hansbrovgr. You were obliged to make butter in the same fashion, on the same plan, in order to compete with them?

Mr. Lestrade. Yes, sir.

Senator Hansbrougir. That brought your butter up to a higher standard?

Mr. Lestrade. Up to a higher standard.

Senator Hansbrough. That it was not altogether oleomargarine that brought the standard up?

Mr. Lestrade. The point with oleomargarine was that for years I was bothered to get these men interested to make better butter. They would not do it. I would show them this butter. I would show them the necessity for making better butter, but their butter sold for a figure, and consequently they were satisfied; but when oleomargarine came in-I do not know whether some of these gentlemen representing these different States were interested in butter then; I do not know that they are interested in butter now-but it created a tremendous furore in the West, and every butter man knows positively beyond question that oleomargarine had more to do with raising butter and bringing up to a better condition and a better quality than all the lectures and all the talks and appeals that we could give them by letter or otherwise. That is known.

Mr. ADAus. If the gentleman will permit me-I do not want to bother him with interruptions-he makes his statement too sweeping. We have no objection to the statement of your belief, but some of us who have been interested for many years in the butter interest do not agree with you; so you should not say all.

Mr. Lestrade. I am perfectly willing to answer every question put 
to me, and if I am not able to back it up by facts and figures, I am willing to apologize and withdraw my remarks. Up to the present time I am not.

The Cirampun. I was in the Isle of Jersey and in Denmark a few years ago, and I noticed that the Iersey cattle have mostly gone to Denmark.

Mr. Lestrade. That is very true in one sense.

The Cuamman. The Jersey farms seem to have sold all of their best eattle to Denmark.

Senator Money. Mr. Chairman, it seem to me we ought to have some rule about the time these gentlemen are to be allowed to speak. If their time is to be limited, I think interruptions are unfair.

Senator Hnitferd. It will perhaps take Mr. Lestrade some time to rearrange his notes. It is now 5 minutes to 12 , and we might as well take at recess at this time.

The Chamrinan. Can you tell us anything about how much more time you want for the oleomargarine people!

Mr: PotTer. There are a number of gentlemen who want to be heard to-morrow, and several cotton-seed oil representatives will be here Sunday. 'They would also like to be heard.

'The Chaimun. Yes; I promised to hear them Monday. You will want all the time to-day and to-morrow, will you?

Mr. Potter. Yes, sir; and perhaps Monday and Tuesday.

The Chamman. Leaving out the cotton-seed oil people, I have promised Senator Penrose that some butter friends of his night be heard to-morrow for a little time, but I will try and not let it interfere with you very much.

Mr. PotTer. Wíe have some gentlemen here who are anxious to be heard on lines that have not been"taken up before.

Senator Haxsbrougir. Who, in behalf of the Grout bill, desire ret to be heard! Mr. Kinight, rou ean tell us.

Mr. KNignt. Mr. Adams. I think, an give you the information. He and Governor Hoard, I think, arranged that this morning.

The Craminan. That had better be postponed just as far as possible, without too great inconvenience, until the oleomargarine people have finished.

Senator Haxsbrodgh. I am trying, Mr. Chairman, to get at the length of time we are to be employed here, heeause there are members of this committee who have other thing's to do.

Mr. A Dams. I ean state, Mr. Chairman, with your permiswion, that so far as the friends of the Grout bill are concerned, I think if all our representatives were here we conld close our part of this testimony in three hours. Governor Hoard and myself will remain here during this week,

The Chammax. We will take a recess now until half past 2 o'clock.

The committee, at 11.45 a. m., took al reeess until 2.30 o'clock p. m.

At the expiration of the recess the committee resumed its session. feld.

Present: Senators Hanshrough (acting (hatrman). Foster, and Heit-

The Acting Chamman. You may proceed, Mr. Lestrade. How much further time do you desire?

Mr. Lestiane. About half an hour, I should think. 


\section{STATEMENT OF FRANCIS W. LESTRADE-Resumed.}

Mr. Lestrade. The question may arise in your minds, gentlemen, why am I opposed to this bill. as all my interests - my money, what little I have, or the greater part of it - are in butter. It is merely this: That, as I hare stated, oleomargarine has been a friend to butterhas made us dairymen, farmers, creamery men, make better butter. The second reason is that the dairymen throughout the United States are getting a good profit on their butter. We are making money. Ny creameries are making money. I do not know of any creameries that are not making money. We are making from 10 to 50 per cent. Legitimately we are making from 10 to 20 per cent; speculatively we are making a great deal more.

Mr. Hoard. Will you allow me to ask you a question?

Mr. Lestrade. Yés, sir.

Mr. Hoard. Are you a creamery man!

Mr. Lestrade. Yes, sir; that is. I am interested in creameries; I am interested in three of them.

Mr. Hoard. You say you are making from 10 to 50 per cent?

Mr. Lestrade. I said from 10 to 20 per cent legitimately and we do make as high as 50 per cent at times.

Mr. Hoard. Do you mean as the owner of a creamery?

Mr. Lestrade. No, sir; in selling our butter. I will give you an illustration in a very few minutes. As I stated this morning, the prices of butter are gradually adrancing in this country. The output is larger every year, as I prestime you know from statistics, yet the price is gradually going up each spring when new butter comes in. A few years ago, as I stated, we could buy this packing stock, this original stock which I described, at all the way from 6 to 9 and 10 cents. At times it would rmo as low as 3 cents a pound. I bought thonsands and thousands of pounds of it within ten or twelve years at 3 to 4 cents a pound. The markets were flooded with it. Latterly. on account of the general prosperity of the country and the increase of inhabitants, it has maintained its position, until in the year 18:s. I think it was-a year ago last spring-prices went to $13,13 \frac{1}{2}$, and 14 cents. This year it went as high as 15 to 16 cents-that is, when the new butter came in. That is supposed to be the lowest price of the year. and there has been an adrance of $t$ to 6 cents a pound over previous years. This is in the face of increase of oleomargarine also throughout the country and in the face of the howl that is set up by those who really do not study the true condition of the dairy interests. If I remember rightly, in the year 1898 or 1899 the output of oleo was from $80,1000,000$ to $100,000,000$ pounds.

Mr. CLaRK. It was 107.010,000 pounds last year.

Mr. Lestrane. It was about $91,000,000$ pounds in 1898 . Notwithstanding that, the cheapest kind of hutter. that we used to buy at 9 to 10 cents a pound started in this year on a basis of 13 and 14 cents a pound, and I put away thousands of pounds at 15 cents.

Mr. Hoalio. What do you mean by saying you put it away?

Mr. Lestrane. We are obliged to put it away for use in the winter, for we can not get it in the fill and in the winter. It is not made throughout the Ti'est.

Mr. Hoalid. How do you put it away? 


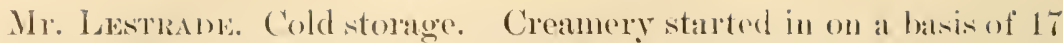
and 18 eents. I am spoaking of 1895 , a year ago bast spuring. 'That is when the new areamery buter bergins. They begin to come in the last of May, and during ol une and July. The market started at $16 \frac{1}{2}$ to 16 cents. Even that leaves a profit to us creamery men. The market gradually rose from $166^{1}$ and erept up. It kept quiet during the month of July and then the export men started in again. Then we gradually raised the price of our held ereameries-I mean our . June goods that were put in cold storage-and some of us sold out as high as $2 S$ and 30 cents. That is where the illegitimate protits come in.

Mr. Hoard. You are not a patron to creameries?

Mr. ILATRADE. I am at part owner of three creameries.

Mr. Hoxkn. You are not a man who supplies milk to the crmameries?

Mr. Lastrade. No.

Mr. Hoard. You are not speaking of the cost of buter to the farmer, are you?

Mìr. Lestrads. No: the cost of butter to the creamery man, to the patrons, to the famers who own the creameries.

Mr. Hoarid. Not to the patrons! The patrons are the farmers who supply the milk?

Mlr. Lastrads. Yes: and they are also interested in ereameries, as I am.

Mr. Honlid, No: only very few of them.

Mr. Leatrane. They onght to be, then. They are not looking after their own interests if they are not. Every farmer onght to be interested in a creamery.

Mr. Hoans. We have 80 patrons in 10 creameries and not a matn of them owns a dollar in them.

Mr. Lestiade. Then it is a monopoly.

Mr. Hoand. You may all it what you please. They control the proposition.

Mr. Lestrade. They should own them. That is what I am adrocating, gentlemen, now, as a butter man. I say to the farmers: "Put up your own ereameries. There is money in it." I am now adrocating buying farm land in Massachusetts that has been lying idle, and farm land in New Hampshire. I rent up to see some most elegant land. where the springs are eonstantly cold in midsummer, and I said to those gentlenen: "Why, men, fellow-dairymen. fellow-farmers, there is money in hutter. Why don't you put your money in it? Instead of growling that you can not get anything ont of milk, put rour moner into "reameries instead of selling" vour milk." The gentheman who preceded me, the food commissioner of one of the Western States, male this remark, at which I cond not help smiling, that in the winter. when butter is hard to get and high in price, then the oleo man gets in his licks. He did not use that term. but that is what he meant. You have no business to have butter so high in winter and hard to get if you manage your milk right, if you feed your cows right, if rou look after them and take an interest in them. "In other words. I do not blame the farmers so much. They are being educated every day. We are all trying to educate them-we who have other industries, we who are distributing this butter right and left throughout the United Stater and throughout the world. We are endearoring to educate the farmer to that extent. hut he works slowly. It is hard for him to make a change. It is hard even to induce him to use new imple- 
ments-these new ideas of making butter fa:t hy machinery and by centrifugal force, and all that sort of thing. They will gradually get there, but the great dairy industry of this country has not begun to show itself. There is a tremendons field for it.

Now to go back. Butter started in 1898-notwithstanding this $80,000,000$ to $100,000,000$ pounds of oleo-started in at the beginning of the season, with now butter. when prices are supposed to be the lowest of the rear, on a basis of from $16 \frac{1}{2}$ to 17 cents.

Mr. Hoakd. That was creamery butter?

Mr. Lastrade. I am speaking now of creamery. The demand was so great throughout the United States and abroad that the price gradually arose to $21,22,24,26$. and some of it sold at as high as 27 and 28 cents. That butter cost all the way from 17 to 20 cents. The export that year was about $14,000,000$ pounds, if I remember lightly. In the spring of this your, to our dismay-for we have not felt the effects of it yet; I fear we will-this packing stock I spoke of this morning - this ladle stock, this original butter out of which we make ladles-started in on the high basis of from 14 to 15 cents; and a great deal of it was bought during the low prices, what we call low prices, the spring prices. at 15 to 16 cents. This is a most phenomenal price. It can hardly be conceived of.

'This spring creameries started in at 19 cents. Very few of them were sold below 19 cents. These were put away in cold storage. for that is the business of the country generally to-day. It is an understood thing. It is hardly called speculative to-day. although it is speculation: but there is hardly erer a time that a creamery man or a dairy man or a commission man or a speculator can not buy his creameries in the spring and put them in cold storage during the months of .Jnne and July, and keep them until summer or fall and sell them at a handsome profit. Creameries started in at a very high figmle, 19 cents, one of the highest figures that they ever reached for the spring of the year. The price gradually rose from 19 to 21,22 , and $2: 3$ cents. and they have been selling as high as 24 conts. I, myself, on account of the demand that I have had from abroad, bonght within a month over a thousand tubs of creamery that cost the creamery from $16 \frac{1}{2}$ to 17 cents, not over 17 cents. I bought them at $23 \frac{1}{2}$ cents in St. Lawrence County, yut down in New York. If the farmers are patrons of thowe creameries they should also be part owners and have derived the benefit of that advance of from $t$ to 5 cents a pound.

Now, you see the position of the butter industry in this country. It is a money-making industry and always will be, if properly conducted. You ask, What has oleo to do with this, and why is it that there is such an earnest attempt on the part of somehody to crowd out that produet? Speaking from the standpoint of an expert. on aecount of the legitimate rise in value of cheap goods and of creameries. we exporter's are having a hard time of it. Fearing the oleo out. We find that we can ship this cheap roll butter, this packing stock that I spoke of, at 16, 17, and 18 cents in tins to the hot countries or throughout the world and get back a reasonable protit, but we find that through legitimate sources and the call for these cheap goods throughout the country. as I say, they have put the price of original stock up to 15 or 16 cents. We ale crowded pretty hard to see where our profit is coming in. for the reason that the foreign market - the Danish market, the Italian market, the French market, the Irish market, and the Australian market-are able 
then to compete with us. They can put their butter in South America, in South Africa, and thronghout the West Indies on a basis of 17 to 18 cents. That is, their cheap butter. When we come to creameries, when we are obliged to pay 24,25, and 26 cents for creaneries, we find that we are being again clowded close, hecanse the foreigners can put their foreign butter throughout the world at that price, and a little less.

It may surprise you, gentlemen, hut within ten years we were selling and sending to the hot countries about 10 per cent of the butter that they use. Ninety per cent has been placed by the foreign markets in those countries. "We have increased that, I am happy to say, about 4 per cent, mostly through our creanery butter. We have had a hard time of it to get our ereamer" butter into these foreign markets on account of the fact, as I remarked this morning, that we did not make creamery butter as it should be made. With our usual way of doing things here, the high nervous temperament in which we all live, our great ambition is to turn out butter quick - turn it out with a magnifieent flavor, and let it take its chance to keep. Consequently we could not ship that hutter. The process I am using now, that I am adroeating right and left among the best creameries I can get hold of, is to change that all and make a better butter, costing a little more; but the demand for butter is so great that they an well afford to do it.

If you put this tax on oleomargarine, which. I think we all agree, means a prohibitory tax, means the wiping out of the $80,000,000$ pounds or the $107,000,000$ pounds per year, what is going to take its place? What am I going to do to take the place of oleomargarine? In my study as a practical man, and having cone in contact with it in my butter industry and seeing the effect it had on butter twelve or fifteen years ago, I noticed and recognized fully it is, as it were, a counterbalance to a small extent on butter. It keeps the price of butter down to a certain extent. It prevents, to a larger extent, manipulation and speculation in butter. You gentlemen from Illinois well know, and I know also, that you would love to corner butter if you could, but you have not been able to do it. You have tried it over and over again and met your fate. I have heen asked to go into it many a time; but fortunately having my interests in the East more, although I buy largely from you, I have refused: but every time you have tried to corner butter you have failed. for up to this time there has been sufficient butter to prevent it, although you, gentlemen, readily see by the remarks that have gone before me on the part of the dairy interests that we do not begin to have sufficient butter to supply this country.

Butter goes higher and higher every winter. It starts in higher and higher every spring. Consequently I say from my observation that if you wipe out oleo and place $107,000,000$ pounds of that stuff, you open a dangerous channel, and butter is bound to be hurt by it. "We dairymen are bound to be hurt by it. It will give an opportunity to men like Swift or Armonr or any other man who has large sums of money to invest to go in and speculate. Do the farmers want that? My friend says the farmer's are not interested as a rule in the creameries themselies. Then, consequently, in the end they will be hurt by it. Butter at times will go up high, it is true, on account of speculation, by taking away that which up to now has regulated it. After all, I ask you again, what hurt does oleo do! If it were not for a few agitator's who really are theorists, who really do not have the best 
interests of the dairy industry at heart, you would not know any thing about oleo in the dairy interest. I have proven that by my figures. You would never think of it. Erery year our butter "interests are growing, and we are making more money, and it is a better profit cn our speculation or on our investment. Consequently I say let weli alone. Do not wipe it out.

Mr. Hoard. Do you say that the average wholesale prices of butter hare been increasing for a number of years?

Mr. I. Sastrade. I say that the lowest prices in the spring have been gradually working up on a higher level for the last five year's.

$\mathrm{Mr}$. Mloakd. Have the average prices of butter for the whole year been increasing for, say, five or six years?

Mr. Lestrade. Yes; they have been increasing.

Mr. Hoard. Have they?

Mr. Lestrade. Yes. If you will allow me, Mr. Chairman, I will read from a report that I happened to pick up yesterday in my oftice just before starting. 'This is a report from Mr. Kracke, of New York, the associate of the gentleman who spoke this morning. Mr. Kracke is yolir associate, is he not?

Mr. Flanders. Yes, sir.

Mr. Lestrade. This report is as follows:

"BUTTER TRADE OF 1900 -RECEIPTS SHOW A GAIN OF NEALLY 48,000 PACKAGES FOR THE YEAR-LARGE FALLING OFF IN EXPORTSIIOME CONSUMPTIVE DEMAND VERY LARGE, WHCH GIVES A HIGHER AVERAGE PRICE FOR NEARLY ALL DESCRIPTIONS.

"Not for" many years, if ever, has the butter trade of the country seen just such conditions as we have had during the year 1900, and while many of the dealers and speculative operators will have no regret that the year has closed, because of the small margins they have had, the producers of butter will find much of encouragement and satisfaction in the larger consumptive demand and better average prices realized.

"The product of the country has been larger; how much it is impossible to say. New York's receipts show an increase of $2 \frac{1}{2}$ per cent, the total arrivals being 1,999,874 packages, as compared with 1,951,957 packages the preceding year, 1,974,071 packages in 1898, and 2,109,503 packages in 1897. This is the first time for more than three year's that there has been an increase rather than a decrease. What is true of New York is to some extent true of other large distributing center's, and with the known fact that the consumption in the producing sections has been expanding steadily, we are inclined to think that the total output of butter for the country has been fully 2 per cent greater than in 1899. This increase is encouraging, as it indicates a disposi. tion to give the dairy a better place on the farm.

"The first three nonths showed a considerable falling off in receipts, due to only fair conditions for making butter and the fact that the storage stocks of the country were entirely exhausted."

Some of these men endeavored to get me interested in this dairy association. I an opposed to them merely on the ground that I consider that they are working against my interests as a dairyman, against my interests is a crotimery man, and against my interests as a famer. They said to me, "Look at the surplus of butter we have constantly 
over." I said to them, "My dear sir, go and study the statistics for last year and you will find there was no surplus. 'The year before you made no surplus. The year before that you made no surplus; and the year before that I think there was a surplus on account of the depression in this country, which all of us have been through. I will proceed with this report:

"Not until June did the arrivals begin to run ahead, and the gain was less than $10 \mathrm{per}$ cent during the summer months. From septenber on, howerer, the increase was marked, and during December the gain was a little over 30 per' cent. 'This was due in large measure to the rapid unloading of western refrigerat's's, the butter coming this way beeause of the strength of our market.

$\therefore$ There has been a marked falling off in exports of butter from all the ports of this country. New York shipped 9,728,397 pounds, only a little more than one-tialf the amount that was cleared through this port during 1899. Of these shipments 81,is6 parkages, or, say, $4,089,300$ pounds, went to the markets of Great Britain, Germany, Denmark, and Scandinavia, and about $5,633.097$ pounds were sent to the tropical countries, mainly south Ameriea and the West Indies. This shows a falling off in the latter business of nearly 1,000,000 pounds, which was lost to us during the early part of the year when packing stock was so scarce and high. We have found it implacticahle to attempt to compete much with other comntries for the English trade, except in certain grades of which we had a sufficient surplus here to undersell other points. Most of the year the table grades of butter have been relatively higher on this side of the ocean than in Great Britain.

"After the little flurry just at the opening" of the year" when prices momentarily touched so dizzy a height-30 cents."

That was for old goods. held goods, goods bought in .June and put away and sold in the fall at 30 cents a pound and costing from 16 to 17 cents.

Mr. Hoand. Sold where?

Mr. Lestrade. That is in the creamery.

Mr. Hoalis. Sold at 30 cents a pound; "old-storage butter?

Mr. Lestrane. 'That is, aceording to Mr. Kracke.

Mr. Hoard. Sold in the United States!

Mr. Lestrade. Sold in New York City.

Mr. Hoand. Do you know of any cold-storage hutter selling last year at 30 cents?

Mr. Lestrade. Yes; I sold them at 30 cents. I sold June goods a year ago in September at 30 cents - a year ago this fall.

Mr. KNint?. What was the market for fancy ereameries at that time in New York!

Mr. Llestrade. For fresh goods?

Mr. Knigirt. Yes.

Mr. Lestrade. Very elose. They ran right along together, becanse the fresh goods were very searec. and that is the reason old goods went up. We could not get the fresh goods, because they were not being: made.

"The market got down to a fairly conservative basis until the storage season opened, when the competition set in keen because of the large profits realized on the 189 (rop, and speculative operations largely controlled values during the summer. The average price of 
fancy creamery during June was $19 \frac{2}{5}$ cents and for July $19 \frac{1}{2}$ cents, which was more than 1 cent per pound higher than in the previous year. Relatively full rates were maintained later, and when we got well into the fall business was so good that prices steadily hardened, reaching the high figure of 27 cents about the middle of November, which held for a week and then settled back gradually."

Mr. Hoard. That is, New York?

Mr. Lestrade. Yes; New York, and there was only about a cent's difference in Chicago.

Senator Heitreld. That is the wholesale price?

Mr. Lestrade. Yes, sir; wholesale prices.

"The average for the yoar was $22 \frac{2}{5}$ cents for creamery as compared with $21 \frac{1}{8}$ cents in 1899 and $19 \frac{1}{2}$ cents in both 1898 and 1897 . The lowest point of the season-18 cents-was late in April, before we reached grass butter."

I wish to call your attention, gentlemen, to the fact that in 1898 and 1897 , when the output of oleomargarine was in the neighborhood of $60,000,000$ pounds, or possibly 70,000,000 pounds, the price of butter was only 19 cents.

Senator Heitfeld. What year was that?

Mr. Lestrade. In 1898 and in 1897. The average, I mean, for the year was only about $19 \frac{1}{2}$ cents when the output of oleo was, I should imagine, from $60,000,000$ to $70,000,000$ pounds, and butter went up to from $19 \frac{1}{2}$ to $22 \frac{1}{2}$ cents average price on an output of $108,000,000$ pounds oleomargarine.

Senator Heitfecd. Does the price of oleomargarine fluctuate?

Mr. Lestrade. No; I do not believe it ever does. Does it, gentlemen?

Mr. 'Tilumingast. Oh, yes; it changes some.

Mr. Lestrade. I suppose it does. We send a good deal of oil to Rotterdam, and I suppose that is what makes the fluctuation of it.

Mr. Tillinghast. Yes.

Mr. Lestrade. In the report of Mr. Kracke, the assistant in the agricultural department of New York State-

$\mathrm{Mr}$. Schelc. He is the principal, is he not?

Mr. Franders. Mr. Kracke is in charge of the work in the central division.

Mr. Knight. May I ask you, Mr. Lestrade, the market price of butter in New York to-day?

Mr. Lestrade. About 25 or 26 cents is the average price.

Mir. Knight. Is that the quoted price-the official price?

Mr. Lestiade. Yes.

Mr. Knight. And what was it a year ago at this time; do you renrember?

Mr. Lestrade. I think 27 or 28 cents; possibly higher. I do not remember, exactly. It may have been 30 cents.

Mr. KNIGHT. It is about 5 cents cheaper than it was a year ago?

Mr. Lestrade. Yes. I do not want the sale of oleomargarine prohibited. I want it for a balance, so to speak, to keep wild speculation down. I can not afford as a creamery man, a man interested in butter, to put myself in the position. if I can help it, of allowing speculator's to come in and manipulate butter. It is bad enough now as it is: but wipe out oleo, which you will if you put this 10 -cent prohibitory tax on, and there is not a man in the country could do anything in regard

S. Rep. $2043-12$ 
to steady prices. They (an no more sell oleomargarine white than you conld sell butter white. I have made white butter up in small quantities, and the only people who take white butter are our friends, the Israelites, and they only take it in small quantities.

Mr. Hoard. One firm in Milwaukee sells 30,000 pounds of white oleomargarine a year-one retail firm.

Mr. Flanders. Did you read the first column of this paper you had in your hand?

Mr. Lestrade. I read all that article.

Mr. Flandelis. That is not hy Mr. Kracke.

Mr. Hoard. You sar oleomargarine would not be sold at all in its natural state?

Mr. Lestrade. I say it would not.

Mr. 'Tillinguast. What clasis of people use this 30,000 pounds yon spoke about, Governor?

Mr. Hoand. The Polaks and Bohemians.

Mr. Tildinginast. I venture to say there alre not $30,00(0)$ pounds of uncolored oleomargarine in the L'nited states.

Mr. Hoarb. Youmay venture to say so, but the statement was made by the firm in Milwalke who sold it.

Mr. LESTrade. In regard to this report from which I read, which I picked up yesterday in my office, I wish to say that it is in the New York Produce Review and American ('remery. I inquired who wrote this article, or who gave the figures, and they told me Mr. Kracke. You say he did not write this article!

Mr. Flanders. The last colmm is an excerpt from his report to us at the Albany office. 'The first two colmmns are not his, and you read from them.

Mr. Lestrade. 'These were not compiled by him, then!

Mr. Fuanders. No. I was a little antonished, because his report comes to me personally, and I did not recognize what you read ats part of his report.

Senator Heitfend. Whose report is it?

Mr. Lestrane. It is the New York P'rodnce Reriew and American Creamery, a dairymen's paper from the city of New York.

Senator Foster. What you read was probably written by some editor?

Mr. Lestrade. Yes. I asked one of the assistants yesterday where they got their figures, and I understood hin to say they got them from Mr. Kracke. The record of eases he has tried, etc., is on the same page.

Now, if you will allow me one minute longer, sir, I will try to finish what I have to say in my crude manner. If I had the eloquence of you three gentlemen as public men, I do not question that I could convince you of the fallacy of attempting to put what I consider a dangerons precedent upon the dairy interests of this country. I know conclusively that it will wipe out the export trade. I know eonclusively that it will open the door for gigantic speculation, for cornering. It will be possible to do that. Wîe can almost do it now at times. I am free to confess that I have been in where we have made some money cornering certain butter in certain parts of the comntry; and why is not the question pertinent to you ats well as to me and to all of our dairymen and men interested in butter! Them what is the trouble! Merely that we are not making butter enongh. If we want to tight oleomar. 
garine, let us fight then with their own weapons. Let us make more butter. Let us make betteı hutter. Let us make more creamer'y butter and fight them that way. We have got a wide margin yet. We have got a good profit yet in butter. There is no danger of oleomargarine, as one gentleman said this morning, wiping out the butter industry. It has not wiped ont the butter industry. Oleonargarine has been advancing year after year in quantity, and butter has been advancing year after year in quantity and going up in price, and there has been a better profit year after year. Consequently there is no danger in that way. So, if you want to do anything, if you want to go to an extreme, why not propose to you gentlemen down here in Washington to take the 2-cent tax on oleomargarine-there is a good deal of talk about subsidies just now-and give that 2 -cent tax as a subsidy to the farmers to make better butter and fight oleomargarine in that way, the same as England did with Australia. The dairymen down in Australlia made nothing but the same kind of truck which we were making before oleomargarine cume into the country. It was so bad that it was dumped in the sen when it arrived in England; and England offered a subsidy.

Mrr. HoArd. Did England offer the subsidy or did Australia offer it?

Mr. Lestrade. England. Australia is a colony of England.

Mr. Hoard. I know that, but did England offer the subsidy?

Mr. Lestrade. What difference does it make?

Mr. Hoard. It makes a great deal of difference. One is a colonial subsidy and the other is a general subsidy. This was a colonial subsidy.

Mr. Lestrade. I do not think it is a matter of argument. It makes no difference whether the colonial government offered it or whether England offered it. 'There was a subsidy offered to Australia for a better grade of butter. If it came up to a certain test they were to receive a certain percentage. I do not recall it now, but possibly. we will say, a shilling on so many pounds. To-day the quantity of butter has advanced from 250,000 pounds a year to two or three or four million pounds a year, and they are putting as fine a piece of creamery butter into England as you want to see. That was done by subsidy. I say to the farmer and I say to Congress, if you want to do something for the farmer's, give them 2 cents as a subsidy and fight the oleomargarine, so that we will make a better creamery.

In talking to some of the gentlemen connected with the dairy assocation I have said to them, "As a matter" of fact, you and I know that oleo is not hurting butter in this country." They said, "Well, we are going to wipe it out. It has got to be wiped out." Then I used the arguments that I have used to you. I told them my position personally - that cheap butter was getting to that price that very soon if it kept on I could not ship it; that all our export would stop. They had no answer to that except to say, " Well, we are going to wipe out oleo if we can." I said, "All right; it will give a chance to you fellow: who have a lot of money to go ahead and speculate." "They said. "That nay be. We won't make money on the other side of the grave." I said, "That will be benefiting the few at the expense of the dairy interests again, and they will he the losers." I am trying now to interest a certain number of farmer's up in Massachusetts to buy certain lands that I know of where there is good cold water and endearor to make a cooperative soriety there for the making of fancy creameries by the Danish process. 
The butter that I am making to-day will bring from 1 to 2 and $2 \frac{1}{2}$ cents more a pound than the best faney extra butter that you can send out of Chicago, and there is butter which is selling to-day, as you dairymen know, if there are any of you here, as high as 40 and 50 cents a pound. Do you think that it is merely heing sold on the brand? It is not. It is being sold on the exquisite flaror and the perfection of being made as it should be made. That is not to say that we are all going to get 40 and 50 cents a pound, but I do mean to say that for a long time to come, if you make good butter, you are going to get a good price. I said to these gentlemen from ('hicago representing this association: "You remind me a great deal of the walking delegates of the Knights of Labor. You are looking around for something to do and to earn your salaries, and consequently you are taking up this oleomargarine question, which in the past has been, and, I think, even to-day is, a good friend of butter, and you are agitating it and all that sort of thing to endeavor to show the dairy interests that you are performing functions and doing your work as it should be done; whereas, if you would let the thing alone and spend your time in edurating the farmers how to make good creamery butter, rou would be doing a noble work and a grand work, and a work that every farmer and every dairyman through this country wonld bless you for in the end."

Mr. Flanders. Mr. Chairman, may I ask the gentleman a question?

The Acting Chambian. Yes, sir.

Mr. Flanders. Do you not know, you being from New York, that it is a part of the work of the departinent of agriculture of the State of New York to do just exactly what you have suggested, and do you not know that hey keep five or six men continually employed in this division work?

Mr. Lestrade. Yes.

Mr. Flanders. And that department spends $\$ 20,000$ at year in firmers' institutions throughout the State in that work?

Mr. Lestrade. Yes, sir; but the work is not being done fast enough. It is going too slow.

Mr. Hoard. Do you know that the men representing the dairy interests here are on a salary?

Mr. Lestrade. No. I know some of them are.

Mr. Hoard. Who among them are on a salary?

Mr. Lestrade. I do not suppose every one of them is doing it without compensation.

Mr. HoARD. I want to say to you, as president of the National Dairy Union, that I never have drawn a penny even for my expenses, and I have paid out over $\$ 1,100$ in the prosecution of this fight.

Mr. Lestrade. Well, my renarks were made to two or three of these gentlemen, and I said if they would only spend their time in the noble work of educating the farmer, and spend on that the money that is being spent in fighting oleonargarine, they would be doing a fal nobler and grander work.

Mr. HuRd. I have been engaged in dairy educational work for thirty year's and I have never heard of you before.

Mr. Lestrade. I am glad to make your acquaintance.

Mr. KNight. I would like to ask a question, if the gentleman will allow me.

Mr. Lestrade. (Certainly.

The Actrng Chamman. The gentleman las been plied with a good 
many questions and his time has ahout expired. I hope the puestions will he limited.

$\mathrm{Mr}$. Knigut. As another ofticer of that organization he has referred to in connection with a salary, I want to go on record here as stating that I, as secretary of the National Dairy Union, never have in the four' year's I have been connected with the association had one cent of salary, nor has there ever been a salary attached to the office.

Mr. Lestrade. I did not mean that as a slur in the slightest degree. There was no slur in my remark at all.

Mr. KNight. I do not like to be referred to as a walking delegate.

Mr. Lestrade. I was not referring to you personally.

Mr. Srhell. Just one question: You say the farmers who supply your milk are interested in your creameries?

Mr. Lestrade. Some of them are; and that is what I am edncating them to do.

Mr. Schell. You really buy just the cream, as I understand?

Mr. Lestrade. No; we buy both milk and cream. At some of our creameries we buy the rrean alone and at others we buy the whole thing.

Mr. Schell. How do you estimate what you pay the farmers for this milk and cream? How do you get at the value of the milk and eream?

Mr. Lestrade. How do you mean?

Mr. Sehell. How do you fix the price you pay them for it: by contract, or how?

Mr. Lestrade. In both ways; sometimes by contract and sometimes otherwise. That part I am not familiar with, for I do not attend to it.

\section{STATEMENT OF WILLIAM H. THOMPSON, PRESIDENT NATIONAL LIVE STOCK EXCHANGE, CHICAGO.}

The Acting Champur. Whom do you represent, Mr. Thompson?

Mr. Thompson. The National Live Stock Exchange.

The Acting Chlampan. How much time do you want?

Mr. Thompson. I just want the time that you think I ought to have. It is simply a business proposition, or a business talk, rather, that I propose to present.

The Acting Chiarman. It would be agreeable to the committee to have you cover as little time as possible in making your statement. five.

Mr. Thompson. I should hate to say ten minutes and only occupy

The Acting Chammax. We will give you fifteen minntes.

Mr. 'Thompson. 'Thank you.

I am pleased to come before you gentlemen to place the people whom I represent on the side of right and justice and against this Grout bill.

To explain who I represent I may be permitted to briefly enlighten you gentlemen regarding the nature, make-up, object.. and purposes of the National Live Stork Exchange, which I. as its president, have the honor to represent.

The National I ive Stock Exrhange is a commercial organization without capital stock, organized, not for the transiction of business, 
but to foster. promote, and protect the interestis of the live-stock trade in all of its many branches. It is composed of local live-stock exchanges located at the principal live-stock market centers of the Lnited States. and counts anong its members in the great corn belt and beef-producing sections the local exchanges located at Sioux City, lowa; St. Paul, Minn.; Omaha, Nelm.: St. Louis, Mo.; East St. Louis, Ill.; St. Joseph, Mo.; Fort Worth, Tex.; Chieago, Ill.: Indianapolis, Ind.: P'ittshurg, Pa.; Lonisville, Ky. and Milwankee, Wis.

Each of these local exchanges are composed of lire-stock breeders, raiser's, feeder's, shippers. seller's, slaughterer's, buyer's, banker's, and commission merchants, and some of their employees, and have a representation in the deliberations of the national exchange based on the local membership roster, such representation being fixed at 1 representative for every 25 member's. It is the official mouthpiece of the live-stock trade, and while it aims to protect, foster, and promote the interests of the prodncer of lir 2 stock on the one hand, it is equally as zealous in its protection of the interests of the consumers of livestock products on the other.

It is to this organization, The National Live Stock Exchange, that all these interests look for advice, assistance, and relief or protection on any general live-stock question of an interstate or international character.

The Yearbook of the United States Department of Agriculture for the rear 1899, page S1S, gives the number of cattle in the United States other than milch cows on January 1, 1900, as 27,610,054. From this number I would deduct 1,610,05t head, which 1 believe to be a fair estimate of that number which are bulls, which yield little or no butter fat. This would leave $26,000,000$ steer cattle, from which I wonld deduct 12.000,000 head of young eattle, called in the parlance of the trade" "storkers and feeder." which would leare 14,000,000 head of fat cattle immerliately atfected and depreciated by this proposed legislation. At the rate of $\$ 3.42$ per head, prorided the manufacture of butterine is prohibited by legislation, this would entail a loss on the producer's of this comtry of $\$ 47,880,000$.

We adopt those figures from the manufacturer, because we simply consider him as a manufacturer or as a creature of circumstances, as it might be termed. He goes onto the market and buys what we term the raw material the bullock - and if he is enabled to manufacture out of that bullock the different artickes that we know to be in the bullock, and make a healthiful food for the people, he certainly should have a right to do so, and if in doing so he ean pay this $\$ 3.42$ a head, the producer recoives the benefit. If he is not allowed to do it, he simply goes onto the market and buys those eattle at about $\$ 3.4 \%$ a head lesis, which is most assuredly a total loss to the producer.

The National Live Stock Exchange has repeatedly and publicly solicited Congress and other legislative bodies to cause a critical exanination to be made through a committee of its own selection into the methods employed and ingredients used in the manufacture of this wholesome article of diet, with the request that, if after such information is satistactorily and ofticially obtained it shall appear to any such committee that butterine is a legitimate article of commerce and a wholesome article of diet, they shall in their report recommend that no coloring restrictions or taxes be imposed, except such as shall apply also to the manufacture and wale of its only competitor, hutter, 
therehy permitting the manufacture and sale of hutterine under such safeguards as the Federal Govermment may see fit to impose to insure its being sold on its merits.

In round numbers there are $75,000,000$ people in this country. I believe a reasonable estimate of the number of Indians and children under a butter-eating age to be $25,000,000$, which would leare a population of $50,000,000$ outside of these classes who are consumers of butter.

Of this $50,000,000$ people at least one-half are able to buy the best butter manufactured, irrespective of price, while the other $25,000,000$ are a class of people whom the butterine manufincturers aim to reach and benefit, and are a class of our eitizens known as laborers, not in the common acceptance of the term, but as a class of people following a variety of pursuits at small salaries, and in most cases, owing to their dependencies and meager earnings, compelled to go without the luxuries of life.

It is this class of people whose interests need careful consideration, whose claims upon you as their representatives are invariably backed by justice, who are always the greatest sufferers by and the most sensitive to inimical legislation, who always are the first to respond to and cheerfully comply with all just and reasonable laws.

As the representative of the National Live Stock Exchange, I also plead for a consideration of the rights of this class of our citizens, who, from the nature of their surroundings and conditions, are unable to appear before you in their own behalf.

'They, who are the principal consumers of butterine, are not asking for any legislation. The producers and raisers of fat cattle are not asking you for any legislation in this respect.

Why should it be any more unlawful to put into butterine, the product of the beef steer, the same coloring matter as is put into butter, the similar product of his sister, the dairy cow?

Is there any equity or justice in such denial! Is it made necessary by the conditions? Is it warranted upon any grounds? If it is, I am at a loss to comprehend it.

This kind of legislation is most assuredly the worst and most ricious kind of class legislation, because it is inaugurated solely for the purpose of destroying a competitive industry equally as important and equally as deserving of legislative support and protection.

The Grout bill represents an attempt on the part of Congress to tax one legitimate industry out of existence for the benctit of another industry. The ostensible purpose is protection to the consumers against "imitation butter;" but the public has never" asked for such protection. It does not even object to the coloring of butterine the same as lintter, so long as the butterine is properly labeled and sold on its merits. As a matter of fact, the consumers of butterine prefer to hive it colored, so long as the coloring material used is barmlen.s. They like butterine because of its cheapness and because they are satisfied with its purity and wholesomeness.

The enactment of this bill will not only deprive the consumer of a healthy and nutritions article of food, but immediately it becomes a law will depreciate the value of the beef cattle and take from the producers of this country upwards of forty-five millions of dollars.

In conclusion, I desire to thank you for granting me the privilege of recording our organization on the side of riglit and justice and in furor 
of the many, believing that you will act in this matter for the best interests of the people as a whole.

This kind of class legislation, if enacted, would establish a very bad precedent, one of the worst kind, as it is against a healthful article of food.

A remark was made by a gentleman before you this morning that this article could be produced for 7 cents a pound. That shows to me most conclusively that it comes within reach of the laborer, just the man we should protect.

Now, in regard to taxes. Suppose there was a tax of 10 cents put upon this butterine, and it should still remain upon the market, who pays the tax? The laboring man, of course. The man of wealth buys butter. The burden of the whole thing rests upon the consumer, who is the laboring man. If it is legislated out of existence, then the burden or the loss goes back to the producer.

Mr. Flanders. May I ask one question?

The Chairman. Yes.

Mr. Flanders. Have you any knowledge what the consumer pays for these goods?

Mr. Thompson. I can answer for a consumer. I pay 15 cents a pound for it.

Mr. Flanders. In our State it never has been sold, taking it generally-there may be isolated eases - cheaper than butter. For the last fifteen years, as far as I know, and I have been looking after it, I myself bought it for butter in the city of Troy and paid 22 cents a pound, and the butter right opposite it was 22 cents a pound. It is sold to consumers for butter and at butter prices. There is no exception to it in the State of New York.

Mr. 'Thompson. If you will allow me to answer for one consumer', I will say that I pay $15^{\circ}$ cents a pound for it for use on my table. I do it for this reason, that to get the best butter, which at times seems almost impossible, I would have to pay 30 cents a pound, to go to our grocer and get the butter, as they term it. It does not seem to me as though it was near as good as the butterine, and I would have to pay from 20 to 25 and 26 cents for it.

Mr. Flanders. In our State that is just what has been done right along. It is sold for butter at butter prices.

Mr. Thompson. I am speaking of Chicago.

Mr. KNight. Do you buy the best grade of butterine at 15 cents?

Mr. 'Thompson. I do not know, sir, what they call the best grade. I buy as good a grade as I can get and pay 15 cents for it.

Senator Foster. Do you call for butterine when you go to the store? Mr. Thonpson. I do not buy it at the store. I'buy it at the manufacturer's.

Senator Foster. Do you call for butterine?

Mr. Thompson. I call for butterine.

The Acting Chairuan. Have you finished, Mr. Thompson?

Mr. Thompson. Yes; unless there are some other questions. I have a memorial here which is rather lengthy, and I would like to attach it to my remarks.

The Acting Chamman. Yon can file it, and it will be printed with your remarks.

The memorial referred to is as follows: 
The National Live Stock Excilange,

Office of the Secretary,

Union Stock Yards, Chicago, Ill., December 21, 1900.

\section{The Honorable the Senate of the United States:}

Your orator, The National Live Stock Exchange, respectfully represents unto your honorable body that it is an association composed of local live-stock exchanges located at all the principal live-stock centers throughout the country, having a roster of over two thousand members actively engaged in breeding, raising, feeding, shipping, buying, selling, and slanghtering all kinds of live stock; was organized, among other things, for the purpose of promoting the best interests of the live-stock industry as a whole, jealonsly guarding the interests of the producer and consumer alike, and is the recognized and official mouthpiece of the live-stock industry on all questions of an interstate or international character, especially when the interests of the producer or consumer are in any way affected.

Your orator in behalf of its constituency desires to enter its emphatic protest against the enactment of what is commonly known as the Grout bill, and in support of its protest desires to record a few of the many reasons in support of its contention.

This measure is a species of class legislation of the most dangerous kind, calculated to build up one industry at the expense of another equally as important. It seeks to impose an unjust, uncalled for, and unwarranted burden upon one of the principal commercial industries of the country for the purpose of prohibiting its manufacture, thereby destroying competition, as the manufacturers can not assume the additional burden sought to be imposed by this measure and sell their product in competition with butter. The enactment of this measure would throttle competition, render useless the immense establishments erected at great expense for the manufacture of butterine, deprive thousands of employees of the opportunity to gain a livelihood, and deny the people, and especially the workingmen and their dependents of a wholesome article of diet.

In butterine a very large proportion of the consuners of this country, especially the working classes, have a wholesome, nutritious, and satisfactory article of diet, which before its advent they were obliged, owing to the high price of butter and their limited means, to go without.

The "butter fat" of an average beef animal for the purpose of making butterine is worth $\$ 3$ per head more than it was before the advent of butterine, when the same had to be used for tallow, which increased value of the heef steer has been added to the market value of the animal, and consequently to the profit of the producer.

To legislate this article of conmerce ont of existence, as the passage of this law would surely do, would compel slaughterer's to use this fat for tallow, and depreciate the market value of the beef cattle $\$ 3$ per head, which would entail a loss on the producer's of this country of millions of dollars.

Your orator submits that it is manifestly unjust, unreasonable, and unwarranted to deny the manufacturers of the product of the beef steer the same privileges in regard to the use of coloring matter that are accorded the manufacturers of the product of the dairy.

The rights and privileges of the producers of beef cattle should be 
as well respected as those of other's, and as they are the henficiaries in the manufacture of this wholesome article of food, they should not be burdened with unnecessary special taxes or needless restrictions in the manufacture of this product, other than is absolutely necessary for the support of the Government and the proper governmental regulations surrounding the handling of same.

This product of the "beef steer" should receive at the hands of Congress no greater exactions than those imposed upon competing food products. It is already surrounded by numerous safeguards, which Congress in its wisdom has seen fit to provide, stipulating severe punishment for selling same under misrepresentation as to its composition. It has by experience proven to he just what a large majority of the people of this country want, and in behalf of the producer's and consumer's of this great country we do solemnly protest against the enactment of legislation calculated to ruin a great industry, and to deprive not only the working classes, but many others, of a cheap, wholesome, nutritious, and acceptable article of food.

The Executive Committee of tile

$$
\text { National Live Stock Exchange, }
$$

By W. H. Thompson, President.

Attest:

C. W. BAKER, Secretary.

\section{STATEMENT OF HENRY C. PIRRUNG, GENERAL MANAGER OF THE CAPITAL CITY DAIRY COMPANY, COLUMBUS, OHIO.}

\section{The Acting Chairhas. Where are you from?}

Mr. Prreverg. From Columbus, Ohio. I am the general manager of the Capital City Dairy Company and the general manager of the Columbus Cream and Milk Company, producers of creamery butter and dealers in milk and cream.

The Acting Champman. Tou may proceed.

Mr. Pirruxg. Mr. Chairman and members of the eommittee, I am present to-day to defend the butterine interests in the capacity of a manufacturer, being general manager of the Capital City Iairy Company, of Columbus, Ohio, makers of high-grade butterine.

It has bern suggested to me to be as brief as possible in my statement, and I will endeavor, therefore, to present the matter in as concise a form :s possible, and yet as terse as I hope will meet the convenience of you gentlemen.

First of ail. I desire to take up the subject of so-called "natural" butter. In my humble opinion, the term "natural " is an idiosyncrasy, fostered and fathered hy the ereamery and dairy butter churners and by the proprietor's and editors of dairy papers. for the purpose of alluring, perhaps, more particularly the illiterate into the belief that butter is absolutely a product given to us in its entirety and finished shape by nature. 'I, howevrr, have never heen able to find a cow, no matter of what hreed, color, or size, that gives to us this much-talkedof product, "natural" butter. Nor have I been able to find any tree, shrub, or plant upon which grows this much-talked-of "natural" butter. We, howerer, do know that hutter is churned from matural products, ehiefly the milk of the cow, which milk undergoes: a prosersis of manufacture conducted through a system of mechanical hand o1" stean- 


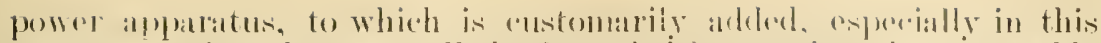

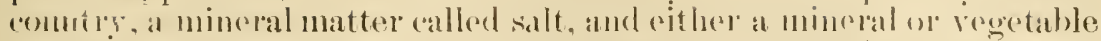

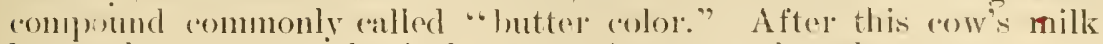
has motregone a mechanical process for separating the eream of fat out of it, and which cream is then set aside for ripening, to a suitable condition of acidity, it is now leady to be put into a merhanical rontrivance, either of a round or square pattern, commonly called a chun, in which receptacle it undergoes a process of congelation, after which it is put upon another mechanical device, operated either by hand or stran power, for the purpose of introducing the salt, and which is commonly known as a butter-salter. 'The color is sometimes added on this salter, but more generally is the color added in the churn. After these varions processes we find that we have a nice golden yellow product, resembling, perhaps, more a mass of deep yellow gold than anything else, but surely have a product that does not look one particle like the milk it was made from, either in texture, form, or color, and we certainly dare not class this article under any other head than a manufactured product. In my opinion we would have just as much right to call apple, peach, or quince butter" "natural" butter, althongh I think we will all agree that they are not entitled to be so named, because they are artificially made and compounded or manufactured from "natural" products only.

From what and how is butterine made? It has been stated before the committee of the House of Representatives of this Congress and no doubt hefore this committee, of what it is composed; so I will not dwoll upon that, but simply state that the ingredients of butterine are mixed or churned by hand or steam power in a manner similar yet decidedly distinet from the process used for making butter. 'There is also introduced into hutterine salt and a harmbescoloring matter. We have therofore two food products mannfactured, or churned, as it is more commonly ealled, and what do we tind! In the language of Professor Burner, formuly dean of the department of chemistry in the Ohio Medical Lniversity, and chemist for the Ohio food and dairy department - we can best quote the finding in his own language, as follows: "After extracting from butter" all mineral matter, water, cte, there remains a residue of 100 per cent fat. After treating butterine in the same mamner I arrived at the same result of having a residue of 100 pereent fat. An examination with the mirroseope of the different fats shows them to be very nearly identical, so much so that ne arenrate determination could be depended upon by this instrument. After a chemical analysis I find that they are still very nearly identical. ('xcept that the butterine contained less of the volatile alcid."

Prof. Honry A. Wrber, of the department of chemistry of the Ohio State University, also chemist for the Ohio food and dairy department, testified under oath that there was no fat present in the simple of but. terine he amalyzed which would not be present or might not he present in butfre, noj was there any fat absent in Jutterine which you wond find in hutter: also testified that in ucither ease is there a chemical combination, but that in both cases it is a mixture, and that the on! y difference lutwonn butter and butterine lies in the small clifference of but yiju.

I (a)ule wo on and give you innumerable quotations from leanod men, unhiased and unprejudiend. from varions palts of the Lunted states, fully in alceord, and perhaps eren stronger in faror of butterine than 
the two previously quoted, from which opinions we aun only derive that butter and butterine are identical, save in the difforence of the percentage of luntyric acid and the difference in the process of manufacture. The rancidity which makes butter so objectionable to taste and smell comes from the liberation of butyric acid, and therehy is explained the reason why butterine never get's rancid, because it contains only a small percentage of this butyrin, wholly insufticient to cause any objectionable odor. Having thoroughly explained that both butter and hutterine are artificially made food products, and that the ingredients of both compounds are extracts from the animal provided by nature, and that they are nearly identical in every particular, we come to the all-important subject of " coloring."

We need not go bark fifteen or twenty-five years to remember that dairy butter was mostly white, or of a very light yellow, and very rarely, if ever, seen in that golden-yellow color so prominent and characteristic of butter to-day. Let us take up the subjec $t$ of the color of dairy butter to-day - with all the advanced ideas of dairying, of making, and with ail the advanced ideas of keeping, caring, and feeding the cow-and what is the result? We find that the color of dairy butter is as varied to-day, and perhaps more so, on account of the interbreeding of eattle, uncommon and perhaps not known twenty-five years ago. WVe also find that there is a difference in color of butter from nearly each different herd of dairy cattle, conditioned upon the care and the feeding of the cattle, and these different colors are anain multiplied hy the different seasons' changes affecting the color of butter which is churned free from artificial coloration. This proves undeniably and indisputahly that "nature" has made no changess in the milk-giving properties of her cow, and therefore we must in all reason firmly believe that the universal golden color of hutter is due solely and alone to the introduction of an artificial ingredient cailed " coloring." I heg to "all your attention to the fact that not all butter is colored artificially, because there are a number of conditions from artificial feeding and caring for the cattle and certain seasons of the year during which different shades of yellow butter ean be produced.

In my opinion good fresh butter is better suited as an article of food when it is colored with a harmless coloring matter, yet one is very apt to be deceired in the purchase of colored butter, because the introduction of coloring matter, which is allowed to be introduced and is most frequently used in inferior makes of butter, is calculated to deceive even the imost wary. In this lies the greatest danger, not only in the deception of the quality, but also in the price of butter, because I do not believe that any person using only the sense of sight ean distinguish rancid from fresh butter which is colored alike. I will not attempt to state that the introduction of coloring in butter should be prohibited. On the contrary, in my humble opinion the coloring of butter should be allowed, because even the school child who has passed the primary grade will define the color of butter as "yellow," and every adult expects at this advanced age to have the product served to him "yellow." Now, why should not all of the foregoing be applicable to this new food product legislatively called "oleomargarine," and why should not every argument in favor of colored butter be applied to butterine? Butterine is as decidedly a farm product as butter, because there is absolutely no ingredient in its composition that does not come from 
the farm, and being identical in their nature and composition they should enjoy the same relative privileges for their appearance.

There must be a reason for manufacturers of butter coloring their product, and as I am a manufacturer of butter also, owning four large ereameries in Ohio, I think that I am entitled to give my opinion for the using of such coloring matter, and which, in my vast experience, has not been disputed, and that is that coloring is added to the butter made in our creameries at all seasons of the year to give it, first, a uniform color; second, to make it more marketable, and third, to enhance its value as a food product. Does not this same reasoning hold good for the coloring of butterine, and should not the manufacturers of butterine enjoy the same privileges as those enjoyed by their competitors. I an assuming in my argument that there has been nothing said before the House committee hearing this testimony, nor have I heard that anything has been said before this committee against the healthfulness of either butter or butterine, and desire it to be understood that when making comparisons between butter and butterine I am describing the fresh products of both. The subject of coloring butterine is not a new one, nor have our butter competitors confined themselves to "yellow" color, for they have gone so far" as to usurp and coerce political influence to the extent of having several State laws passed aetually prescribing a " pink" coloring for butterine. This, however, has been a significant failure, precipitating upon their heads the severest condemnation, not only from the consumers of butterine, but from the butter-maker's' liberal-minded 'onstitnency. It is an accepted theory that there must be a reason for everything, but following the old adage that "it takes an exception to prove a rule," there has been no reason given by the advocates of these "pink" laws for the enactment of such a measure. We therefore are privileged to draw our own conclusions.

First and foremost, it appear's that they decided that by prescribing a "pink" color the product would be so disguised that not even the most suspicious would ever entertain the idea it was butterine, and hence its sale would be stopped from lack of identification, or, even if identified, a refusal to eat such a discolored product as prescribed by these "pink" laws would follow. I may state, to the credit of the attempting destructor's of this new food product, that they introduced these "discoloring" laws in only a very few States, becoming quickly and painfully aware that the general public would not countenanee such a glaring destruction of an industry and a desirable food produet in such an insincere and unpardonably outrageous mamer. Failing in their attempt to compel manufacturers of butterine to discolor their product with a "pink" coloring matter" they are now attempting' (and somewhat successfully, too) the "forbidding" the use of a "yellow" coloring matter, and the same coloring matter that they testify is used in their product, called butter. You will therefore readily perceive the reason for their astounding acrobatic performance in the guise of legislation, turning from the outrageous enactment of actually prescribing a "pink" discoloration to the enactment of laws prohibiting the use of any eoloring matter. 'They have played their part splendidly and somersaulting was well suited, because of the very important fact that by stopping the introduction of yellow coloring matter in butterine it would leave this product in its natural color of nearly 
white, and which color would be quite as repugnant and as offensive to sight in this twentieth century of eulture and science as the preseribed introduction of a "pink" color", and would result in a positive and absolute refusal of the consumer to purchase butterine in a "white" color at any price. In order to prove that my reasoning comes from the most learned source, I would beg the privilege of quoting from Justice Peckham, of the United States Supreme Court, in his decision in the case of Collins $x$. The State of New Hampshire, which State had enacted one of the now invalid "pink" color laws:

He says: "Although under the wording of this statute the importer" is permitted to sell oleomargarine freely and to any extent, provided he eolors it 'pink,' yet the permission to sell, when accompanied by the imposition of a condition, which. if complied with. will effectually prevent any sale. anomts in law to a prohibition.

"If this provision for coloring the article were a legal condition, a legislature could not be limited to "pink" in its choice of color's. The legislative fancy or taste would be boundless. It might equally as well provide that it should be colored blue, or red, or black. Nor do we see that it would be limited to the use of coloring matter. It might, instead of that, provide that the article should only be wold if mixed with some other article, which, while not deleterious to health, would nevertheless give out a most offensive smell. If the legislature has the power to direct that the article shall be colored "pink, which can only be accomplished by the use of some foreign substance that will have that effect, we do not know upon what prineiple it should be confined to discoloration, or why a provision for an effensive odor would not be just as valid as one prescribing the particular color. The truth is, however, as we have above stated, the statute in its necessary effect is prohibitory and, therefore. upon the principle recognized in the Pennsylvania eases, it is invalid."

Now, gentlemen, you will note from the above abstract of Iustice Peckham's decision that he says a legislature ("an not be limited to "pink" in its ehoice of colors, and that the legislative fancy would be boundless. He further states the legislature might equally as well provide that it should be colored blue or red or black, and he might have gone on and said " white," for it is the very commonest knowledge that "white" is one of the most distinctive eolors known in this age, and has been from time immemorial. Justien Peekham confined himself to the mention of only three color's, because we all know that to have recited the entire list of colors would have filled a book nearly the size of an encyclopedia. We must, therefore, presume that hy his recitation of only three color's he meant to conrey, and in fact doessar, that the legislative fancy or taste for colors would be boundless, and it is only reasonable to presume that he meant to include a "white "olor" as being equally as repugnant to the taste of the consumer as "pink," "blue," "red," or "black." You can readily sce, therefore, why the astounding acrobatic performance of the dairy interests is necessary, and I can plainly see eoncealed in all of this midue "rollow" color agitation that a no plainer exposé of their legerdemain conld be given than in the words of Justice Peckham, and I do not think that anyone will attempt to say that they have been a particle overdrawn. It is as plain as daylight that the attempted legislation forbidding the nse of yellow coloring is only a subterfuge to overeome the invalid law preseribing a "pink" discolol"ation. Since we are on the subject of opin- 
ions from learned men of the Supreme Bench of the United States, it might not be irrelevant herewith to quote an opinion from Chief Justice Fuller in the case of Plumley $r$. Commonwealth of Massachusetts, in which, among other things, he says:

"Upon this reeord oleomargarine is conceded to be a wholsisome, palatable, and nutritious article of food. in no way deleterious to the public health or welfare. It is of the natural color of butter, and looks like butter, and is often eolored, as butter is, by harmless ingredientsa deeper yellow- to render it more attractive to consumers. The assumption that it is thus colored to make it appear a different article generically than it is has no legal basis to rest on."

It is noteworthy that in the first case appearing hefore the supreme Court of the United States the court was nearly a unit against hutterine, because this article at that time was not so well known as at present, hut quite as steadily as this product ingratiated itself ('ommercially the cont in its opinions more equally dirided itself, until only recently it gave its opinion almost manimonsly in faror of hutterine; and this further proves, through these learned men, that the product is not such a menace to public health or commeree as the dairy or creamery interests would have us believe. I desire to take up a few of the charges by the creamerymen against this product, the most prominent one being that when butterine is colored it is done so to imitate "yellow butter." I do not believe that any one person in the world to-day possesses the exact knowledge of the number of "yellow" colors that could be given to butter by any one coloring matter, and therefore say, without fear of contradietion, that there is no one eapable of giving the number of shades of yellow colors that can he produced in butter with the numerous makes of mineral and regetable colors on the markets to-day.

We all know that there are very light yellows, canary yellows, straw yellows, light yellows, medium yellows, light and dark golden yellows, sunflower yellows, orange yellows, deep yellows and, in faet, yellows indescribable from the almost indistinguishable faint yellow to the most intense pumpkin yellow. They say we color our product to resemble butter. I, for one. would like to have either' the adherents of this Grout bill or Congress to decide what yellow we are imitating. It just occurs to me that if these dairy exhorter's were really sincere in their motives to have hutter and butterine distinct in color, and in connection the rewith desire to extend the equity due their fellow man, they would ask Congress to regulate and speeify a deep, rich, golden yellow for dairy and creamery hutter, and specify for the butterine maker a liwht straw rellow for his product, which, in my judgment, wonk thoroughly inform the consumer of what he is purchasing. Or, in order' not to be a bit choice in the matter, let the regulation of color's be reversed if it should please the butter makers. Other adherents of this Grout bili have said that we make and color our butterine in "semblance of butter"." which in my opinion is still more indefiuable. because it not only takes in all of the "yellow" colors of butter but the white and various other hues of butter which I will not eren begin to define. but all of which illustruter how ridiculous these charges appear to the most ordinary observer.

'To those who ale interested in this controversy there can be but one "onelusion, that eithere the adherents of this bill do not know what they want, or want a spread-engle law that amounts to actual prohibition. 
To prove that there is less gained by coloring butterine than butter we will take some average prices of the different products for the summer and winter months, admitting, for the sake of argument, that both butter and butterine are colored during all seasons of the year. During the grass or summer months of the year butter retails at from 15 to 20 eents per pound, and butterine at from 15 to $17 \frac{1}{2}$ eents per pound. During the winter months butterine retails at about 20 cents per pound, while we all know that butter brings an average price of about $27 \frac{1}{2}$ cents per pound. By this comparison you will note that butterine advanees about $2 \frac{1}{2}$ cents per pound during the winter season, and butter about $7 \frac{1}{2}$ eents per pound, and that both products are admitted to be colored. Now, then, I would ask, What price butter would bring in the winter time if it was sold in its natural color of white? I will answer this myself by stating that the average price would be something like 10 to 15 cents per pound, and could then only be sold for eooking or baking purposes. You will therefore note by the above illustration, and I think that the prices are fairly given, that there is not such a fearful fraud committed in eoloring butterine as some of the dairy papers would have their readers believe, and indeed the shoe could be put on the other foot if the Elgin butter prices of last winter are taken into account.

Creamery butter makers will remember very distinetly that the Elgin Board of 'Trade last winter steadily advanced the price of butter to 29 cents per pound wholesale, and we all know that these prices are made each Monday on the Elgin board and are supposed to hold good for the remainder of the week. A great many people predicted that this high price of ereamery butter was fictitions. and their predietion was verified when the next meeting of the board reduced the price from 29 cents to 24 rents per pound, and which, as far as we know, is the greatest drop that ever oceurred in the Elgin Board of Trade in one week's time. We can only eonjecture what would have been the price of butter' on the Elgin Board of 'Trade last year if there had been a law forbidding the use of yellow coloring, liut we can be reasonably positive that the price would not have been 29 cents per pound. Another absurd charge made through the dairy journals is that butterine is sold for butter and that if the consumers really knew that they were eating butterine that the manufacture and sale of butterine would almost amount to nothing. To this charge we can only refer our competitors to the statement of the honorable Commissioner of Internal Revemue, in which he says that less than 3 per cent of butterine was sold contrary to law. Now, then, who eats the other 97 per cent? Close observation on this point has divided the consumers of butterine into two distinct dasses, the first being those who consume it from ehoice and who are familiar with its composition, manufacture, ete., and the other class are those who consume it from necessity, on account of the reduced price at which it ean be purchased, and close observation further proves that a great part of the former elass is made up from the latter, becanse of the cultivation of the taste for the product which is encouraged by continuous consumption.

Friends of the Grout bill say that the sale of butterine is growing to an alarming extent. That, in my opinion, is the best indorsement that the product is meeting farorably not only with the poeketbook but with the taste of the consumer. Of course, the sale of butterine is growing every year, and it will ever continue to do so. Because of its 
very composition and manufacture, it is an article that commends itself to the most fastidious person and especially to the literate, who positively know that its manufacture is condueted under the rigid supervision of the most punctilious revenue officials and, in most States, under the prejudiced and biased supervision of food and dairy departments. The best indorsement for the purity of butterine is the fact that Govermment and State analytical experts have never found a flaw in its ingredients or its manufacture; otherwise they would hare been compelled, and in State cases would have been glad, to wipe the manufacture and sale of butterine out of existence under the now oppressive and unreasonable laws.

The adherents of the Grout bill make the bold and astounding announcement that there is nothing in this bill to prevent the sale of uncolored butterine, and even refer with great pride to their magnanimity in the reduction of the present tax of 2 cents per pound to onefourth cent per pound on butterine free from eoloring matter. This astounding declaration either precedes or succeeds a statement that butterine is unfit for human food. I therefore would ask if it is their. acknowledgment that this Congress should be asked to encourage the sale of uncolored butterine by a reduction of the present tax, and should by an exorbitant tax prohibit its sale simply because it is colored with a harmless coloring matter, and such a coloring matter as the butter makers admit using in their product. It is certainly the height of inconsistency to ask Congress to encourage the sale of a product which they claim unfit for human consumption. Everyone knows that color in butter and butterine is a nutritive ingredient, adding neither flavor, texture, nor weight, but is used in very minute quantities, and therefore ean not possibly make colored butterine any more unhealthy than colored butter. I can not, therefore, understand the logic of such attempted legislation, which presumably intends to increase the sale of uncolored butterine at a lower rate of taxation and intends to prohibit the sale of colored butterine through an exorbitant tax.

It has also been eommon phraseology in the dairy journals to refer to colored butterine as being adulterated, which, in my judgment, is a two-edged sword, provided the term is used correctly. Upon reference to Webster's Dictionary, howerer, we find the definition of the word "adulterated" to be as follows: "To corrupt, debase, or make impure by an admixture of baser materials." It is readily perceived, therefore, that the term "adulter'ated" as applied to the coloring of butterine is inconsistent, unless the makers of butter or the editors of the dairy journals desire to establish a new definition for the word "adulterated," or that they will admit that they have debased their product or made it impure by the admixture or addition of baser materials, such as coloring matter.

Another one of their prize cries in the dairy journals is that they want protection. Who asks for it? 'The manufacturer? The merchant? The retailer! The mechanic! The artisan? The laborer! No; $11 \mathrm{y}$ dear sirs, not these. It is the publishers of the creamery and dairy journals and a few would-be promoters for a creamery butter trust. Nor is it, as they publish in their palpers, the farmer that asks for protection, because. in the first place, the farmer does not have to eat butterine, and consequently needs no proteetion on this point, and. besides, butter making on the farm never was an important factor, and during 
the present advanced age of creamery butter making is almost a lost art, on account of creameries springing up at every crossroad and to which farmer's deliver milk, because it pays them better than to make butter in small quantities, taking up a great deal of their time for delivery and sale in the cities, etc. In onr opinion if anyone needs protection it is the consumer that should ask for it, and let this cry of protection die out until it emanates from the proper source-the consumer. I could go on at length pointing out arguments entirely inconsistent to the charges made against the butterine manufacturers of the United States, but will content myself with the few eases already submitted, and will conclude by submitting. my humble opinion of what ought to be done with this biannually rexations problem of coloring.

First of all, I, as a manufacturer, stand upon the broad base and high pinnacle of fair-mindedness, and openly state, without retraction, that if butterine is not wholesome, pure, and nutritious, and if its manufacture is not conducted in a scrupulously cleanly manner, and if it is not in every way a food product fit for the consumption of our citizens of the United States, it is a plain and reeognized duty to forbid its manufacture entirely; but, on the other hand, if its ingredients are pure and its manufacture conducted in a proper manner, and if it is in every way proportionately as wholesome and satisfactory as butter, it should be allowed to be manufactured containing that very insignificant but all-important ingredient of yellow color, which is so liberally prescribed for butter. I also broadly assert that Congressional and State legislation should tend solely for the betterment of food products, and particularly in the case of butter and butterine should actually prescribe that both products should be colored with a harmless coloring matter, and while in a certain sense it would be equitable to forbid the coloring of butter if the coloring of butterine be disallowed, yet I, for one, would condemn any such action, because I think, as stated before, that legislation should encourage the coloring of both produets in order to enhance their value and improve the sightliness of both, which would please the eye, and through the eye, which is in direct communication with the stomach, inerease the palatability of the products, naturally aiding the digestive organs, which is the creator of "better health," and which should be the sole object of all food legislation.

Mr. Knigirt. May I ask a question, Mr. Chairman!

The Acting Cimalnuan. Yes, sir.

Mr. Kxigirt. Are you sure, Mr. Pirrung, that the Commissioner of Internal Revenue said that it was 3 per eent of oleomargarine that was sold as butter!

Mr. Pirruxg. That is common knowledge all orer the United States.

Mr. KNinit. But I am speaking of his statement. He made a statement before the Anricultural Committee of the House, and you have made the statement here. I say are you sure of that?

Mr. Prinung. That was my information; yes. I did not read his report.

Mr. Knight. Another thing. In speaking of the inspeetion of the Government in the oleo factories, do you mean to infer that the Government does inspeet the oleo factories!

Mr. Piriung. Most decidedly.

Mr. Knigirt. Do they make chemical analyses of the oleomargarine right along? 
Mr. Prraunc. Yes, sir; the Bureau of Chemistry of the Agricultural Department does that for them.

Mr. Knight. How many factories are there in the United States?

Mr. Pirrung. I think about twenty-fire or thirty.

Mr. Knight. And about how many inspections do they make of the products you turn out?

Mr. Pirrung. I can not state for other manufacturers, but perhaps they come to us five or six times a year. They do not only require samples from the factories for the inspection. They go all over the United States, or States where our prodnct or any other manufactured product is sold, and take up samples unknown to us.

Mr. Knignt. Do they analyze them?

Mr. Pirisung. Yes.

Mr. KNight. That is done among the retailers?

Mr. Pirrung. Yes; I presume so, and among wholesalers as well.

Mr. Knight. There are about 10,000 retailers in the country, according to the last report.

Mr. Prrnung. I do not know. You are better posted on that than I am.

Mr. KnIght. What is the penalty if anything is found in your product that is not wholesome?

Mr. Pirruxg. I have always understood the Government would be compelled to close up our factory.

Mr. Knight. You are not acquainted with the law very well, then, are you?

Mir. Prreung. I thought I was.

Mr. Clark. They would not only close it up, but would confiscate it.

Mr. Kvight. They would confiscate the goods that they find?

Mr. Pinrung. They will close up our factory. If you will read the law, you will post yourself.

Senator Heiterld. What are the restrictions on the sale of oleomargarine in the District of Columbia?

Mr. Knight. I can not answer as to the District of Columbia, Mr. Heitfeld.

Senator Heitreled. When you have time, I wish you would look that up.

Mr.'KNight. They are not the same as they are in the States.

Senator Hertfeld, I find that at the Center Market here ther sell a good deal of it. I also found, after carefully looking orer the ground, that they were selling butter at one side of the stand and butterine at the other" side, and there was a sign above the stand saying "Butterine." I could not see anything on the product itself that showed that it was butterine, except that it was piled in each ease on boxes, and the boxes had the revenue stamp on them, and there was paper lying on the counter which had the stamp "Oleomargarine" across it. I was very much interested in the matter, and I found that they had butterine on one side of the stand and butter on the other side. I did not know whether there was any law that compelled them to keep it separate from the butter product, but I did not see any case of butterine being sold on the butter side of the stand. J asked one of the salesmen there whether this was the common way of doing this, and he said it was. I said to him, "Now, there is not a thing that tells me" this is butterine except the fact that I see it above there, and I might not look up there. Do you tell anybody you are selling butterine 
here?" He said, "No, we do not; but then," he said, "you can see it when we wrap it in paper," which is true. I said, "Are you afraid to state that this is butterine?" He said, "No; but we get called down pretty often if we do call it that, because it seems to be objectionable to the people to have their attention called to it."

Mr. Springer. I will state, Senator, that on page 12 of the House hearings the synopsis of the District of Columbia law is given. It is the act of Congress approved March 2, 1895:

"Substances in semblance of butter or cheese, not made exelusively of milk or cream, but with the addition of melted butter or any oil, shall be plainly branded on each package 'Oleomargarine,' and a label similarly printed must accompany each retail sale.'

Mr. KNIGHT. In answer to your question, Senator, I will give you a little information on that. You said you saw no marks on the brieks?

Senator Heitfeld. I saw no mark.

Mr. KNight. In the House hearing the oleomargarine people, Swift \& Co., came before the committee and exhibited some bricks of oleomargarine with those wrappers on. That was in accordance with a certain ruling.

Senator HeITFELD. I think that mark was on the brown paper they wrapped it in down here; but I did not see any marks on the product itself.

Mr. Knight. I will tell you why those marks were absent. A few years ago they used to put the words "Jersey," "Holstein," and all kinds of ereamery names on butterine. Just about a year ago the Internal-Revenue Department made a ruling to the effect that if they put any printed matter whatever on the parehment wrappers that went around butterine, they must also put the word "Oleomargarine" in letter's of a certain size. Immediately in this market every vestige of printed matter disappeared from every package of oleomargarine, and I do not believe you ean find in the city of Washington to-day a pound of oleomargarine on sale that has a printed wrapper on it; beeause, if they put the printed wrapper on, or any kind of printing, it must have the word "Oleomargarine" on it.

Senator Heitfeco. They wrap it up in a wrapper that has the word "Oleomargarine" on it.

Mr. Knight. But it does not have that word on the brick.

Senator Heitfeld. No, not on the brick. The brick is wrapped in tissue paper.

Mr. KNight. Formerly they had the words "Swift's Jersey" and such words as that; but when the ruling was made that they should put the word "Oleomargarine" on if they had any printing, immediately everything dropped off. I made a seareh of this town, in company with Representative Neville, of Nebraska, Representative Haugen, of Iowa, and Representative Dable, of Wisconsin, and we searched every place to find a package of oleomargarine in parchment paper that had any printing on it at all, and we failed to find one in the city.

Senator Heitfecd. Of course, if anyone were looking out for it, he could find it very nicely in this sign above the stand.

Mr. Knight. That may be, in the Center Market.

Senator Heitrecd. If anybody desired to avoid buying it, he could see that sign; or if anybody wanted it very bad he could see it.

Mr. KNight. It is just as likely to be butterine on the butter side, 
though. I want to tell you an experience I had in the house of this man who is promoting this National or Standard Butterine Company here. We ealled in there, and asked him if he had any of Swift's Jersey Butterine. He said he had. Mr. Neville and Mr. Haugen and Mr. Dahle were with me. I said, "Let me see a package, please." He brought out a package which was absolutely plain. I said, "Is this Swift's Jersey Butterine?" He said, "It is." I said, "But I am accustomed to seeing it. I am quite familiar with the brand." $\mathrm{He}$ took me for a dealer, from the knowledge I displayed of the different brands of oleomargarine, and he said, "Well, I will tell you. According to a new rule that has been issued by the Internal-Revenue Department, if they put anything on they must put on the word 'oleomargarine,' don't you see; so you would have to have the word 'oleomargarine' on it if there was anything printed on it at all." Congressman Neville and Congressman Haugen and Congressman Dahle heard him tell me that thing at that time: and he is now promoting a million-dollar plant for manufacturing butterine in the District of Columbia.

Mr. Pirrung. Mr. Knight, the United States internal-revenue laws preseribe, under penalty, that each retail lot of oleomargarine shall have on the wrapper, on the wooden dish, plainly stamped, the name of the seller, his address, and the word "oleomargarine?"

Mr. Knight. Yes.

Mr. Pirrung. Tell me what injustice there would be to have on the product itself "Swift's Jersey," "Holstein," "Elgin," or" any other name, with that wrapper on the outside, as prescribed under penalty by the United States interal-revenue laws?

Mr. KNight. What injustice there would be?

Mr. Pirrung. Yes; what injustice?

Mr. KNIgHt. It would be just about like printing it on ice. You could print it on ice with about the same effeet.

Mr. Pirrung. What does the consumer first see?

Mr. Knight. He does not see anything, as a rule.

Mr. Prrrung. He sees the outside of the wrapper.

Mr. KNignt. And what is the outside of the wrapper? I have a few of them to exhibit to the committee.

The Acting Champran. We must proceed in order here. Who is the next gentleman who desires to be heard?

Senator Heitreld. Is it not time for the committee to adjourn? If we adjourn so late in the afternoon, it does not give me time to look over my mail in the evening, and it makes it rather burdensome in the morning.

The Actrra Charrmax. I understood there were four gentlemen here to speak for the oleomargarine side.

Mr. Clark. The samples of one of the gentlemen hare not arrived ret.

The Acting Ciramrinan. How many of you will be prepared to go on to-morrow? How long a time do you want, Mr. Tillinghast? less.

Mr. Tillinghast. I shall be through in a hour, at least; perhaps

The Actrng Chairuan. Another gentleman said he would desire to speak for an hour.

Mr. Schell. Yes; but I can say what I have to say at any time.

The Acting Chammax. You are both ready to go on to-morrow! 
Mr. Schell. If there is no one here who wants to get through and get away I will be ready; yes.

Senator Heitfeld. Did not Senator Proctor say that he had promised some time to some of Mr. Penrose's constituents to-morrow?

The Acting Chaimian. Yes; they will be here to-morrow.

Senator Heitfeld. Of course we will have to be guided by what the chairman arranged for in the matter. The gentlemen who are ready to proceed had better be here to-morrow morning.

'The Acting Chamian. I assume that these two gentlemen ean be heard to-morrow as well as the Pennsylrania people.

Mr. Scheld. Mr. Chairman, just one suggestion there. It seems to me it wonld be fairer if the friends of this bill should get their ease in, and then we can reply. As it is, they put it in piecemeal. They have the right to elose, and we are talking in the air. The burden of proof is on them, and they should make their case and then give us a chance at it.

Senator Heitfeld. Some of your men are dilatory also, so we will have to do the best we can. We find that some of those who desire to appear before the committee can not be here until next week, and if we do not have these dairymen to fill in, we will probably be without work.

'The Acting Champuax. The Chairman understands that Governor Hoard and Mr. Knight desire to close their case, but in the meantime you are asking each other questions back and forth, and taking up time in that way; and it is not quite the fair thing.

The committee stands adjourned now until half past ten to-morrow morning.

The committee, at 4.30 o'clock p.m., adjourned until Saturday, January 5, 1901, at 10.30 a. m.

\section{Wasingatox, D. C., Saturday, January 5, 1901.}

The committee met at 10.30 a. m.

Present: Senators Hansbrough (acting chairman), Foster, Moner, Heitfeld, and Dolliver. Also, Hon. W. D. Hoard, ex-governor of Wisconsin, president of the National Dairy Union; C. Y. Knight, secretary of the National Dairy Union; Hon. William M. Springer, Frank M. Matthewsou, Frank W'. Tillinghast, Charles E. Schell, Francis W. Lestrade, and others.

The Acting Chamman. You may proceed, Mr. Tillinghast.

\section{STATEMENT OF FRANK W. TILLINGHAST.}

Mr. Tillinghast. Before I begin my remarks, Mr. Chairman, I am requested to read a short letter written to the committee by the Holland Butterine Company, manufacturers of high-grade butterine, of Pittsburg, Pa., whose representative could not be present. It is very short, and I will read it.

The Acting Charruan. You may have it printed without reading it, if you so desire.

(The letter above referred to is as follows:) 
Hon. Redfinld Proctor,

Pittsburg, Pa., January 1, 1901.

Chairman Committee on Agriculture,

United States Senate, Washington, D. C.

Dear Sir: Being the only manufacturers of oleomargarine in Pennsylvania, operating under a charter granted by our State, and situated in Pittsburg, one of the largest markets for oleomargarine in the country, we are in such close touch with the trade that we can speak cor'rectly on the situation here.

We know and ean furnish indisputable proofs that scarcely any of our product is sold to consumers as butter. Our goods cost the consumer 17 to 20 cents per pound, while creamery butter costs 30 to 33 cents. We maintain that 90 per cent of the purchasers of oleomargarine in the Pittsburg district know exactly what they buy.

The great difference in prices of the oleomargarine and butter has been the best possible source of enlightenment, especially to the laboring classes, and it is on these that such a tax as proposed by this bill will be the greatest burden; being deprived of oleomargarine as an article of diet to which they have become accustomed, they will be compelled to pay a much higher price for the same or a similar article. Custom, habit, and the involuntary influence of the eye on the palate demands that all butter and substitutes for it shall he golden in color, and seeing that natural butter is artificially colored in order to be more palatable, why should oleomargarine not be also?

If necessary to tax oleomargarine to prohibition because artificially colored, why not also tax all compounds which are vile sulstitutes for molasses, jellies, rinegars, preserves, liquor's, etc., in the same manner. This exorbitant and unjust tax will not prevent, but rather encourage fraud, because the increased cost will bring retail prices so much nearer that of butter, thereby taking away the best possible proofs to the consumer whether he buys oleomargarine or butter. For example, in our market where the prevailing price is 3 pounds for 50 cents it will be 3 pounds for 75 cents, and consequently much more easily represented as pure butter at 2 or 3 cents higher.

If the sole object of this bill is to prevent frand and not to deprive the laboring classes of a cheap and wholesome article of food there are many ways of fully advising the purchaser what he buys without changing its present constituent parts or color.

It is plainly erident that the object of this bill is to increase profits for one class, butter makers, and to do so at the expense of three others, stock raisers, oleomargarine manufacturers, and the class of millions who consumed about $100,000,000$ pounds of oleomargarine in 1900. This last class mentioned must pay for all in the end-millions of dollars in unnecessary taxes to the United States 'Treasury or else corresponding millions to the "innocents" who furnish them pure butter at advanced prices.

Is it possible that such legislation can be enacted by our great United States Senate! We hope not.

Very respectfully submitted.

Holland Butterine Company, W. W. Prince, Manager.

Mr. Tillinghast. In the discussion of this measure I shall make no reference to the legal status of the bill only in so far as it is necessary 
to characterize the spirit of the advoeates of the measure. This bill, if it rests upon good legal foundation, must of necessity base its strength upon the taxing power of Congress, an all-powerful weapon; and it is confessedly, by its adrocates and by its opponents, a bill which will not raise a revenue, but which will destroy the revenue which is now collected by the present tax on oleomargarine. Therefore, we must say at once that the bill is not honest in raising revenue, but really is an attempt under the guise of a revenue measure to do that which it could not do direetly. In other words, Congress could not pass an act prohibiting the sale of eolored oleomargarine. Its police power would not extend to the States in that matter. The police power of the States, and they have almost sovereign power within the limits of the State constitution and the Constitution of the United States, is supposed to extend itself to those matters affecting the public health, public morals, and public safety; and within those limits the States have the right to legislate and do legislate, so that if any State requires to pass a law against colored oleomargarine, it has been decided, as you well know, that they have that power; and, indeed, I am told that some thirty-two States have already passed laws against the sale and manufacture, or against the sale, at least, if not the manufacture. of colored oleomargarine, or oleomargarine made in semblance of butter.

So that the States having full power to pass those laws and having the entire machinery of the States to enforce them may do so as they please. They have no excuse whatever to come to Congress and ask Congress to pass police regulations for the several States. The only excuse that can possibly be offered in coming to Congress and asking it through the guise of taxation to extend itself and pass police regulations in the sereral States, is the eowardly confession that the laws of those States are not enforced; that the laws against colored oleomargarine are violated in those States while those laws obtain; and they would have just as good an exeuse to come here to Congress and ask Congress to pass some sort of legislation under some guise or other, taxation or whaterer you please, to enforce the laws against larceny or adultery, or any one of the criminal code.

Therefore, gentlemen, the proposition for you to extend the police regulations of the United States to the several States is something which you have not the constitutional or moral or historical right to do, if it came in exactly that form. It must be done under the deception of a revenue measure, and that is the way it is attempted to be done here. What possible right, what possible reason can be suggested that you shall impose upon the State of Rhode Island a police regulation which it does not desire. The State of Rhode Island is quite well satisfied with the enactments of its own legislature. It legislates eoncerning this oleomargarine question just as it pleases, and it is quite satisfied with that legislation. It looks with alarm, as every jurist and thoughtful person must look, at the attempt on the part of Congress to extend a police regulation into a State that is supposed to have had heretofore the right to make its own police regulations.

I am not attempting a constitutional argument. 'That can better be made by those who are more qualified to make it than myself; but I am enforeing that point, that Rhode Island, with other States, claims the right to exercise its own police power's, and that this is nothing more than a police law. 
I said that the only excuse they could have for coming here was the confession that those laws are not enforced concerning colored oleomargarine in those States where those laws obtain; and I said that that was no excuse for coming to Congress, and it is not, even if it were admitted, for the purposes of argument, that there was a large amount of colored oleomargarine sold in those States contrary to law, and sold in fraud of butter-a proposition which I am not ready to admit. But I am ready to confess and state what I believe to be true with reference to that matter, that there is more colored oleomargarine sold contrary to law in those States which have laws against it than there is in those States where oleomargarine is permitted to be sold for exactly what it is; and concerning that question I can speak with some personal experience and some knowledge. This committee has sat most patiently, and they have the gratitude, I am sure, of all the oleomargarine people as well as the dairymen, because they have been most fair and lenient; and if we have been, perhaps, rery anxious to present our claims, it must be pardoned because of the fact that the consideration of this bill is of the greatest importance to us, of far greater importance to us than it is to the dairy interests. There should be no argument left unmade, and no fact, disguised or unknown, that should not be put in the possession of this committee.

I was about to say that I had some knowledge of how oleomargarine is sold in one State, at least, where the only regulation concerning oleomargarine is that it must be sold for what it is and can not be sold for what it is not; and that does not appertain to the color. In Rhode Island oleomargarine has been sold ever since it was invented, and the sales of oleomargarine have constantly increased in that State. While those sales have constantly increased, I will say that with reference to the city of Providence there is not a better butter market in the world in comparison to the population. There is not a place where butter brings a higher price, or where better butter is found upon the market. Within less than one week I have myself tasted butter in the city of Providence that is better than I have seen in the city of Washington or in the city of New York.

Further, oleomargarine is not sold in Providence or in the State of Rhode Island for butter, and I would be willing to state that I would pay a forfeitnre of $\$ 500$ for every violation of the oleomargarine law of the State of Rhode Island. There is no temptation whatever in that State to sell oleomargarine for what it is not, because it comes in competition with butter. It is advertised on the streets for what it is. Everybody knows that they can buy oleomargarine for 15 cents a pound in wholesale quantities in 10-pound packages, or 17 cents at retail; and it is in the stores side by side with butter. Tou hare free course to buy whatever you please, and there is no attempt on the part of the retail dealer or the wholesale dealer to induce you to buy it. It is so generally known as a food produet in the stores and throughout the States, that there is no temptation whatever to deceive anybody, and try to sell it for butter.

It is true in the State of Massachusetts, as I suppose it is true in all other States that have the anticolor law, that a percentage, perhaps a considerable percentage (I can give you my guess, as other people can give you theirs) is sold for butter. I want to be honest ahout thisI want to treat this question fairly; and I say the reason that any of it, or any considerable amount of it, is sold for butter is due to the 
State laws that prohibit its being sold for what it is; and it is simply rumning up against the experience of all mankind - that if people want an article they will give it. They will obtain it; and you can no more cuforce prohibition of oleomargarine in Massachusetts than you can enforce prohibition of liquor in the State of Maine. You can enforce them approximately, but there will be constant violations of the law, and people will obtain the article if they really want it- if it is an article which they desire.

But I am not ready to admit, sir, that any large amonnt of oleomargarine is sold in Massachusetts-for I am quite familiar with the sales of oleomargarine in that State for butter-or that many people in the State of Massachusetts are deceived who get oleonargarine when they buy butter. As a matter of faet, three-fourths of all the oleomargarine sold in Massachusetts is sold in the original package, and it is, I think, a fact-it is so far as I have examined the matter, and I have been very familiar with the prosecutions in Massachusetts-that during the entire time that they have had the anticolor law in the State of Massachusetts there has not been a prosecution for selling oleo for butter. The prosecutions have invariably been for selling oleo for oleo; and in courts where I have been many times the testimony is this: "I went to a store and asked for oleomargarine and I obtained oleomargarine;" and the court has only to say, "Yon are guilty."

I should say that it is possible that 25 per cent of the oleo in those States that have such laws-laws to the effect that it can not be sold for what it is - in those 32 States it is possible, perhaps, that 25 per eent of the amount sold is sold for butter. Now, gentlemen, suppose that were true. It has been estimated here by the gentleman who spoke yesterday that in Pennsylvania he thought 50 per cent of the oleo sold in Pennsylvania was sold for butter. Another man, I think, said he thought what was sold in Ohio would be equivalent to 50 or 75 per cent of the whole. But neither of those gentlemen could give you any information whatever as to the amount of oleo that was sold in Pennsylvania or the amount of oleo that was sold in Ohio; and if they could not give you any estimate as to the entire amount I should doubt very much the accuracy of their judgment as to what proportion was sold for butter.

Suppose it were true that 25 per cent of the oleo of the countryand certainly the percentage could not be more than that, for as I said a little while ago it is only in those States that have these severe laws where oleo is sold for hutter-suppose that thonghout this entire comntry last year "25 per cent of all the oleo of the country was sold for butter; what effect would that have upon the farmer? One hundred and seren million pounds of oleo were sold year before last. We have not the remins for last year.

Mr. Springer. 'That was for the year ending last. June.

Mr. Tillinghast. Yes, sir. 'Twenty-five per cent of that in round numbers would be 25.000,000 pounds. Every ingredient that went into that oleo came ofl the farm. The farmer did not lose it all, because it was sold for oleo instead of butter. Every dollar that the raw material cost came from the farm. I have estimated it, and estimated it fairly, I think, at 6 cents per pound, so that the farmer did reeeive, even for that oleo which was sold for butter, $\$ 1,500,000$. Now, the only thing you can say he lost was the difference between what he would have had if that same amount had been sold for butter and what 
he did get; in other words, if they had bought the farmer"s product instead of oleo, figuring that as 16 cents a pound, the farmer would have received $\$ 1,000,000$-or the farmers would have reeeived it as a class, as a whole $\$ 2,500,000$ more than they did receive when they bought oleo instead of butter. What percentage of profit would that figure to the farmer? The profit is there, because the farmer only lost his profit. He could not receive the $\$ 2,500,000$ for his butter without giving up something for it. He would have to give up labor"; he would have to give up cows; he would have to give up everything that went into the cost of the butter; and I am told here by farmer's that with butter at 16 cents a pound the profit is not anything; but assuming the profit to be at least a cent a pound, or 5 per cent, which the wholesale dealer tries to make, then the profit which the farmer lost would be exactly $\$ 500,000$ - the farmer's as a class.

If we speak of the farmers as a class, that is what they would have lost, $\$ 500,000$; and if the estimare is correct, that there are $5.000,000$ farmers in the United States, the loss to each farmer would be exactly 10 cents, and no more. But it is not right to speak of farmers as a class and say that they lost it, because we are only a part of this great community of $75,000,000$ people, and instead of the farmers getting it it went elsewhere, perhaps into channels as meritorious as the farmers themselves. It is sometimes wrong, it seems to me, to speak of farmers as a class. The farmer of to-day becomes, perhaps, the mechanic of to-morrow, or becomes the teacher or the legislator. His daughter's and his sons become teachers and professors and lawyers, so that it is not quite correct to single out a certain class and say that class is entitled to so much money. It is simply a part of one growing unit.

So that the loss to the farmer was not mole than 10 cents apiece throughout the United States, what possible reason is there, gentlemen, for their coming here to Congress to make the howl about this bill that they are making? What possible benefit would it be to the farmer over and above that small amount to hare this amount of oleo which is sold for butter-admitting that there was so much sold for butter-taken out of the market and butter supplied in its place? You understand, gentlemen, that if these people are honest in their contentions they mean simply this: They say they have no objection to the sale of oleo so long as it is sold for what it is; that they have no objection to selling oleo, whether colored or uncolored, if it can be sold for what it is. They simply tell you, gentlemen, that it can not and nerer will be sold for what it is unless it is so made that it can not be sold for butter, so that nobody can be deceired.

Now, gentlemen, it seems to me that the ingenuity of a legislature, it seems to me that anrbody with ordinary capacity, could so frame a law and enforce it that oleo must be sold for what it is, wheiher it is colored or uncolored. It strikes me that if we had a law providing that the packages themselves must be so done up in certain paper, so marked, so branded, as to make it distinguishable, and then if we had a regulation that it should only be sold in those original packages from the factory, nobody could ever be deceived as to what they were buying.

Now, if you tell me that even then the deception would be continued, becalse a man would buy it and take it home to his wife and deceive his wife and his children in putting it on the table and telling his wife he was buying butter. I submit to you, gentlemen, that if you attempt 
to regulate the table of the home you are attempting something which is absolutely impossible, and there is no use in attempting it. It would be an absurd thing to attempt. You might as well say that I shall put upon my table a synopsis, a digest, of what the hash is made of, or that I shail brand my coffee, and say that it cost only 20 cents a pound, or that I shall expose my poverty to my guest by saying that this is oleomargarine. I will not discuss this further, beeause I am sure, gentlemen, that that is too absurd to talk about, and it is not necessary to consider in any sense that it is proper or legitimate to go into the secrets of the home and try to regulate the home table.

Senator Dolurver. Have you discussed the reason why the product is colored? Why do they not put it on the market in its natural condition?

Mr. Tilunngmast. That has been discussed by others who preceded me, and very thoroughly, too.

Senator Doldiver. If it is in the record, that is all that is necessary.

Mr. Tillinghast. I will say that it is simply confolmable to the law of eustom and taste, one of the strongest laws to run up against.

Senator Dolunver. Do you think anybody would buy it if it was light or" white colored?

Mr. 'Trlunghast. Yes, sir; I think it would be sold in very limited quantities.

Senator Dolliver. I understood from some of your people that they thought if they were compelled to color it white it would destroy the market. They have written to me to that effect.

Mr. Tilminghast. Yes, sir; there is no doubt abont that. It would entirely destroy the industry as an industry. An industry putting out $107,000,000$ pounds a year would be practically totally destroyed, because nobody would buy white oleomargarine to put upon their table.

Senator Dolurver. Is that mere prejudice and custom?

Mr. 'Tillingrast. Solely that and nothing more, sir'.

Seuator Dolliver. It seems to me you might overcome that prejudice.

Mr. Thllinghast. You could not orercome it so long as butter is colored. So long as butter is put upon the table yellow, in my judgment, it would be impossible to sell white oleo as against colored butter. You can sell white oleo against white butter.

The Acting Chatruan. Would it destroy the butter business if butter were not colored?

Senator DoLlrver. The great hotels, I notice, are serving white butter. Have you noticed that?

Mr. Tillinghast. Yes, sir.

Senator Dolliver. Without even salt in it?

Mr. Trllinghast. Yes, sir. I know that is true in some cases.

Senator Dolliver. I noticed that in a hotel in New York the other day.

Mr. Tillinghast. Yes; that is true, I think, at the Waldorf.

Senator Doluiver. They do that, perhaps, in order to guarantee their good faith.

Mr. Tillingriast. In response to your question, Mr. Chairman, I am of the opinion that people would eat butter, that they could not get along without the use of butter, and that if all butter was white there would be the same quantity of butter used as is used to-day. 
Seuator Heitfeld. Then you think if all butter was uncolored, you could let your oleo go uncolored?

Mr. Tillinghast. Why, certainly.

Senator Heitfern. I would suggest a compromise with the dairyman-throw away all the color.

Mr. Trulinghast. Yes, sir; if they will do that. I noticed the gentlemen on the other side laugh when I said that if all butter was white, we could sell oleomargarine white.

Senator Heitfeld. Oh, well, you had your laugh resterday.

Mr. Tillinginast. I am going to have it again. I said that if all butter was white we could sell oleo white: and that is true. I will tell you why it is true. I am here to confess and to state that oleomargarine, notwithstanding it is a distinet product known to seience, is a product that is used by people who use it for butter knowing that it is oleomargarine, and using the substitute instead of the real article. They use it because it is a substitute. You mar use the word "imitation" if you please, and I will agree with you. "It is an imitation of butter; and being an imitation it is sold as the imitation, and people buy it becanse it is an imitation, and they would not want it if it was not an imitation. It is an imitation, precisely the same as cotton may imitate worsted. People buy it because it is an imitation, and they know what they are buying and they know what they are using. Would you pass a law here that would destroy the use of all imitations? Why, it is one of $\mathrm{my}$ delightful recollections to think that for 25 cents I can buy a painting that will imitate the finest paintings in the world by the finest masters, and I buy it because it is an imitation. It is gratifying to me to know that for 25 cents I can buy a volume of Shakespeare that will contain just as good reading matter as the most expensire edition that could possibly be put out. Imitations are not to be legislated against. They are proper; they are legitimate; they are right; and people will have them just as long as people live.

So that if oleomargarine imitates butter, as it does, and people buy it becanse it imitates butter, and would not buy it if it did not imitate butter, then unless there is some reason other than has been giren here, there should be no legislation against it. The only reason suggested is that in some instances it is sold for butter. I have already stated that that is of too small consequence to be considered by the Congress of the United States, because it amounts to so very, very little.

There is one feature of this discussion that I had supposed mould be entirely umnecessary to enter upon. That is the wholesomeness and healthfulness of the article. I had supposed before coming here that if there was one question that had been settled to the knowledge of all men it was the question of the healthfulness of this article. Indeed, it was so generally understood that I was not at all surprised at one member of this eommittee, when that question was spoken of, saying that he did not understand that that question was raised here. But, gentlemen, it has been raised here. It has been raised here incidentally by almost every speaker who has spoken in adrocacy of this bill. and notwithstanding the mass of testimony, the number of chemists, doctors, and scientific men throughont the United States and elsewhere thronghout the world hare testified to the entire healthfulness of this article; yet, notwithstanding this, in this temple distinguished for learn- 
ing and research, you will find that it is suggested even at this late day that the article which they are asking you to tax at the rate of 10 cents a pound may not be a wholesome and healthful article. Look at the flimsy argument that they submit as tending to show that that is true. Why, they say, gentlemen, that it does not digest as quickly as butter, that its melting point is higher, and therefore it is more difficult to digest, as they say; and they read from Professor Wiley to that effectthat its melting point was higher. As a matter of fact, gentlemen, the melting point of butter and butterine of the best grades is precisely the same. But they did not read all of Professor Wiley's statement about its being slower to digest. If they had they would have been fairer to the committee. I therefore all the attention of the committee to this again.

Dr. Wiley. My impression in regard to the digestibility of butter as compared to oleoniargarine is formed from a purely theoretical standpoint, without having tried experiments on human beings and noted the time of digestion, because I do not know that that has been accomplished, and more than that the actual time of digestion is a matter of very little consequence, provided the food is digested. In fact it is a very good thing that we do not digest all our food instantaneously, because otherwise we would be hungry after one meal before we would get the next. The fact that a food is slow of digestion, like fruit, for instance, is no reason that it is unwholesome. No one would say that meat is necessarily more wholesome than fruit because it is more easily digested. You can digest meat in much less time than you can digest fruit, and yet nobody claims that fruits are unwholesome.

Mr. Flanders. Will the gentleman permit me to ask a question for information?

Mr. Tillinghast. Yes, sir.

Mr. Flanders. You said that the melting point of the better grades of oleomargarine is the same as that at which butter melts?

Mr. Tillinghast. Yes, sir; aceording to Professor Wiley's experiments.

Mr. Franders. I would like to make a double question of this. What constitutes the better grades of oleomargarine? What is the difference between the poorer grades and the better grades as to ingredients?

Mr. Timinghast. There is very little difference between the better grades and the ordinary grades of oleomargarine, with the exception, as I understand, of the use of butter. A larger amount of butter is used in the more expensive grades of oleomargarine; but the percentage is small.

If you will notice on page 200 of the report of the House committee, you will find given there the melting point of the different grades of butterine which were submitted to Professor Wiley. You will find that the best butter melts at 96.80 and the best butterine at $96.80-$ precisely the same.

Senator Heitfeld. Are those Mr. Wiley's experiments?

Mr. Tillinghast. Yes, sir.

Mr. Edson. I beg your pardon; that was not made by Professor Wiley, but by Professor Schweitzer, professor of agricultural chemistry and chemist to experiment station.

Mr. Tillinghast. The fact is, gentlemen, that oleomargarine is a 
purely healthful food product, desired by the people of this country. It is desired by the citizens of Rhode Island, that I have a right to represent; it is desired by the people who live in Rhode Island and work in the mills; it is desired by the poor people of that State, who can not afford to pay the high prices for butter, and you have no moral or constitutional right, in my judgment, to deprive them of the privilege of huying it as they are now buying it.

Senator HertFeld. You speak of the large consumption of oleo in Rhode Island. One of the gentlemen who appeared here said that it was about 8 pounds per eapita for last year.

Mr. Springer. That was my statement, Senator.

Senator Heitreld. Can you tell me what the consumption of butter per eapita was in that State?

Mr. Tillinghast. I can not tell you the consumption of butter in any locality in the United States.

Mr. Flanders. Are you about to leave the health question, Mr. Tillinghast? I would like to ask a question before you leave that.

Mr. Tillinghast. Yes, sir.

Mr. Flanders. Have you any evidence as to any physiological tests as to digestion of oleomargarine and butter?

Mr. Tillinghast. I have the tests of the whole State of Rhode Island.

Mr. Flanders. I do not mean that. I mean a scientific experiment as to the digestibility of butter as compared with the digestibility of oleomargarine. The testimony you have given there is simply as to the melting point of two samples by the particular chemists.

Mr. Tillinginast. All I have to say about that matter is that if that fact has not been established, that oleomargarine is a perfectly healthy food product, withont a single thing in it that is deleterious, it seems to me that before this discussion goes any further this committee should resolve itself at least into a committee of one or two and find out whether that is so or not: but the evidence throughout the world is orerwhelming on that question.

Mr. Flanders. I do not want to press this too hard, Mr. Chairman, but the evidence so far is in dispute. We brought from the State of New York and left here with this committee evidences of scientific experiments in digestion. We have raised the question here as to the right of a chemist to determine a physiological question. The gentleman is making a very nice argument from his point of riew, and I like it. It would like him to tell me if he knows anything on that subject. He has submitted here the melting point of oleomargarine and of butter, as found by a chemist, of some particular samples. The eridence we submitted here was of oleomargarine bought on the open market and known to be oleomargarine, and it went through digestive experiments. I say that is evidence on the comparative digestibility of the two, and I ask him, so long as he is trying to make so fair an argument, if he has any eridence from his State or anywhere relative to the comparative digestibility of the two, because if a sample of oleomargarine of the hest kind were submitted to a chemist it is hardly a fair illustration of the oleomargarine found in the open market. and particularly when he submits it only as to the one proposition of its melting point, not to the proposition of digestibility. I wonld like the gentleman to discuss that if he has anything on the subject.

Mr. Tillinghast. If $I$ hare not taken too much time, I would like 
to refer the committee to page 209 of the report before the House Committee on Agriculture. I will read a few lines:

[Extracts from pages 659, 660, and 661 of No. 7, Vol. XI, of United States Experiment Station Record, edited by E. W. Allen, Ph. D.]

"The relative digestibility of several sonts of fat by man. I, Margarin and natural butter, II. Lührig (Ztschr. Untersuch. Nahr. u. Genussmtl., 2 (1899), No. 6, pp. 484-506). - The author reviews the literature of the subject and reports results of 4 experiments on the digestibility of margarin and butter, made with a healthy man, 29 years old, weighing $74 \mathrm{~kg}$. Holstein butter and 3 sorts of margarin were used, called, according to their quality, No.1,2, and 3. The tests were quite similar, the fat in each case forming part of a mixed diet of meat, bread, vegetables, etc. The composition of the margarin and butter was determined and the fat content of all the articles of diet.

"The average results of the tests follow:

Average digestibility of margurin and butter.

Margarin No. 1, consumed with mixed diet 6 days

Margarin No. 2, consumed with mixed diet 4 days

Margarin No.3, con

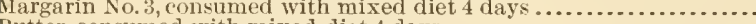

Butter, consumed with mixed diet 4 days..............................

\begin{tabular}{|c|r|r}
\multicolumn{3}{|c|}{ Fat. } \\
\hline $\begin{array}{c}\text { In daily } \\
\text { food. }\end{array}$ & $\begin{array}{r}\text { In daily } \\
\text { feces. }\end{array}$ & Digested. \\
\hline Grams. & Grams. & Per cent. \\
138.35 & 4.62 & 96.68 \\
118.64 & 3.91 & 96.70 \\
112.89 & 3.46 & 96.93 \\
111.79 & 4.82 & 95.69 \\
& & \\
\hline
\end{tabular}

"If corrections are made for the fat in the food supplied by other materials than margarin or butter, the average coefficients of digestibility in the 4 tests are $97.35,97.39,97.90$, and 96.53 per cent, respectively. The author studied the undigested fat in the 4 experiments and determined the amount of true fat in the undigested ether extract. Taking account of these values, the corrected digestibility of the margarin and butter fat in the tests reported above is $98.31,98.25,98.46$, and 97.77 per cent, respectively. In the author's opinion the true undigested fat was not butter or margarin fat, and accordingly he believes that it is safe to conclude that butter and margarin are completely digested. ('The fat recorered in the feces is believed to be derived from the digestive juices and metabolic products produced in the body during the experiment.) If it is insisted upon that the two kinds of fat are not completely digested, it must still be granted that as regards digestibility they are practically alike, since the difference is rery small.

"From a study of the chemical characteristies of the undigested fat the author introduces certain corrections in the above values and concludes that 97.86 per cent of the butter was actually digested and 97.55 per cent of the margarin. From a physiologieal standpoint the 2 fats are thought to be completely digestible and of equal value."

Mr. Miller. I would like to inform the committee that that article was a contribution by a scientist to the Agricultural Department, and that report is from the experiment station records of the Agricultural Department. Here is a similar article that was given in the testimony before this committee before Christmas. It also came from the experi- 
ment station of the Agricultural Department, and I would like to ask Mr. 'Tillinghast to read the eonclusion in this same test.

Mr. 'Tillingrast. The prineipal eonclusions follow: When properly prepared, margarin differs but little from natural butter in chemieal and physieal rroperties. On an average 93.5 to 96 per cent of fat was assimilated when margarin was consumed, and 94 to 96 per cent when butter formed part of the diet. The moderate use of margarin did not cause any disturbance of the digestive tract.

Mr. Flanders. Mr. Chairman, I do not want to interrupt the gentleman too much, but I would like to ask another question.

The Chambinas. Do you object to being interrupted?

Mr. Tullinghast. Not in the least. I want to get at the truth.

Mr. Flanders. That simply bears out the contention we made here yesterday

Mr. Tilungarast. If the gentleman is going to make a speech I object to his interrupting me.

Mr. Flanders. No; I want to put it so that we can understand eaeh other. That experiment, as I understand it, simply determined how mueh fat was taken ont of the system, out of the material put through the animal, does it not? Does it determine the physiological effect on the animal, or the length of time or exertion of the animal to handle it? That is the bone of the contention.

Mr. Tilingarast. I take it that the statement of that scientist, saying there is very little difference between the digestibility of butter and butterine, goes for the opinion, at least, of the scientist who made that statement.

Mr. Flanders. If we are going to leare it that way, then I would like to say this: IVe admit all he says. We make that assertion ourselves, that the amount taken out did not determine the question of the effect upon the animal nor the length of time that it took. Those are the only two essential questions that we contend for-as to the effect upon the system and the time it takes to take it ont.

Mr. 'Tillingiast. Let me state one thing more. I have talked with a good many physieians in my State and elsewhere who have observed the use of oleonargarine carefully, and who know some of its chemical properties, and who know some of its effects upon patients and upon well people; and the universal testimony without a single exception is that it is just as valuable a product as butter, and just as easily digested by both sick and well persons. Of eourse that statement is secondhand, hearsay; but it is a statement which I expeet to be believed.

As I remarked, if it is possible that that question has not been settled within the last quarter of a eentury, since oleomargarine has been upon the market, if it is possible that that question has not been settled when people who have been interested in dealing in oleomargarine and putting it upon the market, it is time it was settled: and I tell you that inasmuch as it has had an upward movement. onward and upward constantly since it was first put upon the market, until last year we had a production of $107,000,000$ pounds, that itself is an argument that it must be a healthful product, or it would not be used. It has not been put upon the market surreptitiously. It has not been put upon the market in deception of the rights of people who were to use it to any large extent. Why, gentlemen, the oleomargarine dealer's and manufacturers of this country have endeavored to exhibit their goods wherever they had the opportunity-at all food exhibits. at county fairs, where they could gret the opportunity. They have pre- 
sented their goods, put them before the people, and they have said to the people, "Here, try these goods; take them home. Take them to your wife. Don't tell her it is butter, but tell her it is butterine. Make an honest, fair test of it." That is the way the oleomargarine dealer's have tried to introduce their product. It is the way they have introduced it, and it is because they have introduced it in that open, straightforward manner that it has grown in faror throughout the United States. And I say because it has grown in favor it must be an article which the people desire, and one which scientists, doctors, and chemists have indorsed and will indorse, whatever may be said to the contrary by anyone who has not made that investigation which it is necessary to make to find out whether it is an article that is really deleterious to health.

Why, gentlemen, while I am on this point I want to call your attention to an advertisement that $I$ have seen I think a thousand times. It is very short, and I will read it:

"Have you ever seen any butterine? Did you ever try it on your table or for cooking? If not, we ask you to do so. Try it. Take home a pound. Don't tell your family it is butter. Tell them it is butterine. Show it to your family physician. Ask his opinion about it. All we ask is a fair show, and the truth."

That is all, so far as the oleomargarine industry is carried on in Rhode Island, at least, and in the East, that the oleo dealer's have done. 'They have tried to put their product on the market honestly and fairly. 'They want people to use it for' what it is, and for nothing more than what it is; and I tell you when people come here and say they must have a law which will tax that product at 10 cents a pound because it is sold for butter, and because no law can be framed, as they say, that will prevent its being sold-they asked this law to be passed beeause they say no law can be f'amed whereby it will be sold for what it is except this taxation law-you know, as intelligent men, that that can not be the fact, and that that ean not be true. Frame a law, if you please, and no one will take any exception, no matter how strenuous you make it, no matter how many safeguards you may put around it. You may say that every pound of it shall be put in a piece of paper of a certain color; that it shall have all the printing on it that is necessiry to inform everyone as to its contents; and that it shall only be sold in that original jackage. Now, if they are honest, if they mean what they say, what objection would there be to such a law as that? They tell you, gentlemen, and they have told me, that they only care to stop the sale of oleomargarine as butter. If so, gentlemen, it can be arranged so that it can not be sold for anything except oleo, by the proper law.

Senator Dolurver. I have often wondered where the swindle comes in. There have heen prosecutions in this city of grocers for selling oleomargarine for butter, and some of the grocers claimed that they were swindled in buying it. The public has claimed that they were swindled in buying it; and you seem to have laid it off on the man who takes it home and swindles his wife with it.

Mr. Tiluinghast. I would say that that undoubtedly has happened, that men have taken it home to their wives and have not told them anything about it. I have heard of many such eases, and I have no doubt you have. As a matter of fact, I' can not see how tho retail dealer can be deceived, because he buys necessarily in the original 
package. This has stamps on it, and everything to apprise him of what he is buying, so that it is not possible that the butter dealer in Washington or: elsewhere conld ever be deceived as to what he is buying. 'The retail dealer buys a 10 -pound package or' a 60 -pound package, or whaterer it may be, of oleomargarine in the tub. The retail dealer under the present system can cut out of that tub anything that his customer desires. Well, here is this tub standing up here, we will say, on the shelf. 'The cover' is off, and you look at it, and it looks like butter; and the only thing to apprise the customer of the fact that it is oleo would be the stamp on the tub, which may be laid down or on the side or may not be called to his attention. He comes in and calls for, say, two pounds of butter, and if the retail dealer is a dishonest man, and desires to palm oleo off on him, why of conrse he would cut it out of that tub and sell it to the customer.

Senator Dolliver. Then how could your scheme of wrapping a delieately colored paper around it have that effect?

Mr. Tillinghast. I wonld not permit it to be sold in the original package in tubs. I would have the original package a small package of, say, five pounds, and not permit it to be sold in the manner in which it is now sold.

Senator Dolliver. It seems to me if it was only identified by a paper, the man would take the paper off and put another paper on.

Mr. Tillinghast. No ; because it could be stamped, and it could be provided that it should only be made in prints, and it could also be provided that the word "Oleomargarine" should be printed into the substance itself.

Senator Dolliver. Even that is not a ver'y permanent record.

Mr. Tillinghast. Well, that with the cover itself would be suffieient, it seems to me.

Senator Dolciver. If the dealer was trying to swindle, he could take the imprint out of the butter.

Mr. Tillinghast. It strikes me that if the laws were enforced as they should be, and as they possibly would be, there would be very little difliculty and very little fraud practiced, if you had the most stringent regulations.

Senator Douniver. I have not heard lately any charges of fraud against those manufacturing the article.

Mr. 'Tillinghast. No; there is undoubtedly very little fraud on the part of the manufacturer. I have not heard of any for a good many yeurs, and I can conceive of no temptation on the part of the manufacturer to sell his article for anything except for what it is, for he is not allowed to keep anything else in his factory, and his factory is subject to the inspection of the United States revenue officers daily. If he should attempt to put goods out of his establishment as butter, the penalties are so severe that he would be deterred from doing so.

Mr. Knight. I would like to ask one question about the present law. Does not the present law require the retailer to stamp the article?

Mr. 'Trminghastr. I am not familiar' with the retail trade.

Mr. Schell. Yes; it does.

Mr. J ELKE. If you will permit me to explain. The retailer is permitted to sell in quantities not exceeding 10 pounds. If must take up his own package, and stamp the package with his name, his address, and the word "oleomargarine," and the quantity contained therein. That is the present law. The retail dealer sells his goods in that 
Mr. Springer. Will you allow me, Mr. Chairman, to make an explanation here?

The Acting Chamman. Yes, sir.

Mr. Springer. The present law, as it will be seen, permits the retail dealer to make a large original package, say 60 pounds a tub, and from that he can retail it out in small quantities by breaking the original package. The Wadsworth bill, which was favored by the minority of the Committee on Agriculture in the House, provided that all oleomargarine should be put up in 1 and 2 pound packages; that each package should contain on the material itself, imprinted in it, the word "Oleomargarine;" and that each package should be wrapped separately, and should be sold separately to the purchaser; that on each package there should be the stamp of the Government and a paper also wrapped around that with the word "Oleomargarine" printed on it in large letters, to be regulated by the Commissioner of Internal Revenue. So that while now the merehant may fix up a package and sell it so as to deceive, if you want to compel him to sell it for what it is, take the provision of the Wadsworth bill and require each package to have a stamp engraved in it and wrapped together, and do not allow the merchant to break that package at all, but let it go into the hands of the consumer with the stamp on it just as it comes from the manufacturing establishment. Then if the consumer wants to take it home and deceive his wife with it, he will have to cut off the word "Oleomargarine."

Mr. Flanders. May I ask Judge Springer one question in regard to that?

The Acting Chairman. Yes.

Mr. Flanders. Does not that same bill make that 1-pound package the original importer's package?

Mr. Springer. It provides that 1 and 2 pound packages must comprise all of the output of the factory, and that they must be put in that shape, and can only be sold in those packages by the retail merehant.

Mr. Flanders. My question is, Did not that bill provide distinetly that they should be considered an original importer's package?

Mr. SPrInger. Certainly. That was to be considered as an importer's package, and the sale was confined to those packages so as to prevent the retail merchant from imposing on his customer; so that it went into the hands of the consumer he was obliged to know and could not help knowing that it was oleomargarine. After that the law leaves it with the head of the family or the wife or whoever purchases it - the hotel proprietor, if you please.

Mr. Flanders. How about the guest of the hotel?

Mr. Springer. If the guest of the hotel can not discover the difference he is not robbed.

The Acting Champman. The Chair hopes the gentleman will be allowed to finish.

Mr. Tiluinghast. I will say that in the State of Massachusetts, and I do not know but in many other States, the law provides that if hotels, restaurants, and boarding houses do use oleomargarine on. the table, they must apprise the guests of the fact that they do use it. With that regulation it seems to me there can be very little fraud practiced.

Senator Moner. Can an ordinary guest tell what he is eating? Can you tell whether you are eating oleomargarine or butter?

Mr. Tillinghast. Yes, sil. 
Senator Monex. I can not.

Mr. Triminginst. In response to your question, Mr. Money, I should say that the ordinary person would not distinguish between a nice specimen of oleomargarine and the ordinary butter.

Senator Moner. If they can not tell the differenee, and they are both healthful, what are the odds?

Senator Foster. And a nice specimen of oleomargarine has more butter in it.

Mr. Tillinghast. Yes, sir.

Senator Foster. So that, the more butter you get in it, the better the oleo.

Mr. Tiluingmast. This matter has been before Congress several times, and a committee of the Senate, the Committee on Manufactures, I think it was, investigated this very question under the pure-food law. Without going into their report to any extent, but as substantiating what erery committee, it seems to me, must find if they investigate it carefully, what every man must find if he investigates it carefully, with the desire or intention of getting at the truth of the matter, I will read what they find:

"The committee finds from the evidence before it that the product known commercially as oleomargarine is healthful and nutritions, and that no additional legislation is necessary."

I do not mean to say that this is res adjudicata for this committee, but it is some evidence, at least, that a committee of this Senate, after an investigation of this whole question, did find that it was a healthful and nutritious article; and it seems to me, gentlemen, that if one question could be proven by such a preponderance of evidence as to permit of no shadow of doubt in the mind of anyone that it has been shown and established, it is that oleomargarine is healthful and nutritious and that it is folly to attempt to raise any question on that score.

I take it, gentlemen, that you will find that as proven and that the only question that will disturb your minds at all will be whether there is any legislation needed-whether, under the guise of a revenue measure, the circumstances are such and the expedients are such as to warrant your extending the arm of this Gorernment to assist the laws of the States in preventing oleo being sold as butter. I have shown to you that it can make but very little difference, if any, to the farmer whether that is done or not; but it makes a vast difference to the capital employed and the men employed whether you in effect confiscate my property and destroy an established industry. It makes a difference of a great many millions of dollars, and besides it is going so far as to destroy an industry which came into existence legitimately and fairly, and which desires to remain in the same manner.

Now, gentlemen, I do not anticipate that such an act of injustice will be done by the United States Senate. I do not anticipate that this bill will ever become a law, but I have found many times to my sorrow that what appeared very clear to me was not always so clear to others; and so, gentlemen, there is one thing that I want to call your attention to, if by any possiblity a bill of this character should become a law, and that is the language of the proviso, on the serenth line of the second page:

"That nothing in this act shall be construed to permit any State to forbid the manufacture or sale of oleomargarine in a separate and distinct form, and in such manner as will advise the consumer of its real 
character, free from coloration or ingredient that causes it to look like butter."

The words I complain of are the words following the word "coloration." If it stopped there, then there would be no opportunity to put any coloration into the oleomargarine. It would have to be made white if it were made at all, but there are added there these words: "or ingredient that causes it to look like butter." With those words in there, they may be a disturbing element. We claim that every ingredient that goes into oleomargarine and that makes oleomargarine, whether color is used or not, is an ingredient that makes it look like butter. We claim that oleo oil looks like butter, some shades of butter. It was explained to you yesterday by a gentleman who knew all about the business, that butter is of many shades, and of course that is common knowledge. I have seen butter that is just as white as white oleomargarine, and Senator Dolliver this morning said that not very long ago he had seen in New York within a day or two some white butter. Now of course if we make white oleonargarine, we use ingredients that look like the butter the Senator saw. The dairy interests do not desire a prohibitory law if they are honest, and I concede honesty to them. I think they are misguided. They are willing, they say, as I understand, that we should make all the white oleomargarine that we can sell. Is not that so?

Mr. Flanders. Yes, sir.

Mr. Tilminghast. Very good. If that is so there is no need, if you please, of the words following the word "coloration" in that section. And, gentlemen, if you forget everything else that I have said-and I do not flatter myself that you will remember very much of it-please remember this, that I suggest to you that if by any possibility you should consider any part of this bill favorably, you will strike out that part of that section, because otherwise we shall be right up against this same proposition and have the same prosecutions whether we make white oleomargarine or whether we make colored oleomargarine, because every ingredient will make it look like butter, and perhaps make it look more like what is generally spoken of as natural butter than it would if we colored it. I presume there is more butter made in the twelve months of the year that would be white if no eoloring matter were used, or if not white a very light shade of yellow, than there is made of colored butter. You must remember that oleomargarine has considerable of a yellowish tint by the use of cotton-seed oil, and the only thing white that goes into the oleo is the leaf lard and the milk, and of course the milk has a slight color. Then we use a quantity of butter. That has a slight color. So that there would be many of the ingredients that would cause it to look like some butter.

So, gentlemen, take care of that question. Be honest with us and fair with us, and do not put us to the difficulty of any question before the courts that we are using ingredients that cause oleomargarine to look like butter, because it is not needed in this case; and it seems to me that the gentlemen representing the dairy interests themselves, in fairness, should say they have no objection to those words being stricken out.

Gentlemen, I thank you for your attention. If I have said anything that I ought not to have said, I beg you will overlook it, and if I have left unsaid some things which I should have said, I beg you to supply them. 
The Acting Chamrinan. It is now ten minutes of 12 o clock. I think the committee will have to take its recess.

Mr. Lestrade. Mr. Chairman, will you allow me to make a short statement before yon retire?

The Acting Chairman. Yes, sir.

\section{ADDITIONAL STATEMENT OF FRANCIS W. LESTRADE.}

Mr. Lestrade. Mr. Chairman, after the session yesterday afternoon I was approached by a member of the dairy association who seemed to have a misunderstanding-I do not mean so far as the committee was concelned - of the remarks I made in relation to the prices of butter; and perhaps the committee might also have had an erroneous impression or a wrong impression, or did not understand it exactly. It will take me but a few minutes to repeat what I said, and if any of the dairy gentlemen here can show me where I am in the wrong, I shall be very glad to have them do so. If they are silent we will take it that they agree with me perfectly in my statement.

I said y esterday that the cheapest butter in this country, the packing stock, which I endeavored to make plain to you what it was, is put away in large quantities in cold storage during the last part of May and in the months of June and July, as the lowest price for fresh butter is reached at that time of the year. That is gathered in from the Western farmers as I explained. During these early months in 1899 it was put in cold storage at a price as low as $11 \frac{1}{2}, 12,12 \frac{1}{2}$, and 13 cents.

Senator Heitfeld. Let me understand. Is that the price at the storage point, or what the packer got?

Mr. Lestrade. I am now quoting prices in New York, freight all paid. It is gathered up by these different men, put into car's, packed into barrels, tierces, and tubs, and brought into New York. I am quoting prices from the New York standpoint. There is a difference of about three-quarter's of a cent to a cent in Chicago. This is put in New York at a cost of 12 to $12 \frac{1}{2}$ cents to the butter men, and as high as 13 . Gentlemen, it was sold out by the butter men generally throughout the country at a profit of from 3 to 6 cents a pound in the fall and winter. It was sold as high as 18 cents-this cheap, common, roll butter that is made in the commonest manner possible. Those were the figures it was sold at-at a very handsome protit by the clairymen, and by the butter men interested in the butter, particularly in this bill.

What we call fancy extra creamery butter was put into cold storage in New York city and other points at from $16 \frac{1}{2}$ to $18 \frac{1}{2}$ cents. The butter men kept this butter to a greater or less extent, and it sold out as high as 30 cents. A gentleman from Chicago, who, I beliere, represents the dairy interests here, was surprised at that statement. and asked me the question, you remember, "Was it sold at 30 cents ?" I said, "Yes, sir" it was sold at 30 cents." He, apparently, did not know that, and yet he should have known it. There was a profit of nearly 50 per cent for the butter men.

Senator Foster. That is between the highest and the lowest?

Mr. Lestiade. From the highest to the lowest.

Senator Foster. During the year?

Mr. Lestrade. In six months" time.

So that you can see, gentlemen, 
we are not poverty stricken. We are not going to the poorhouse, as the gentleman from Pennsylvania said yesterday. Oleomargarine is not wiping us out, but, on the contrary, we are making better profits ever'y year, according to my statements, which can not be contradicted.

I will say that as far as this year is concerned, this last May on account of the high prices butter started in from $18 \frac{1}{2}$ to 19 cents, these fancy extra creameries. They were put in cold storage during the months of June and July, and they have been sold out during this September and October and up to within two or three weeks as high as 24 cents, making a handsome profit of 3 to 4 cents a pound. 'To-day, althongh the market is depressed, although the butter market is declining, as it usually does in January, you can sell your best fancy extra creamery butter, if you have it-I am speaking now of old June butter-at 23 cents. These gentlemen will probably say you can not do that. The butter you can not sell at 23 cents is butter that has been bought by speculators, not knowing what they are buying, and put in cold storage, and now when they turn it out they find it is poor and old and has no flavor; but if the butter is made properly, although it is an old butter, it still has an elegant flavor and taste and smell.

Senator Heitfeld. Is that old butter all sent to Washington?

Mr. Lestrade. I do not know much about that.

Senator Hertekco, I judge it is from my difficulty in getting good butter.

Mr. Lestrade. I desire to ask the dairymen here whether they have been approached in regard to a butter trust. I have, and the moment that this bill is passed there will be the biggest butter trust that ever was organized in these United States. If this bill does go through, I shall be one of them to go in if I can.

All I ask of you, gentlemen, is, if I have shown you in any way that these facts are as I state, you will give them consideration; that you will explain upon the floor of the Senate and let the people of the United States know what we are doing in the dairy interests; that we are not porerty stricken; and let the people be the judge whether the dairy interest of the United States is in such a poor, forlorn condition.

The committee (at 12 o'clock meridian) took a recess until $2.30 \mathrm{p.} \mathrm{m}$.

At the expiration of the recess ine committee resumed its session.

Present: Senator Hansbrough (acting chairman); also, Hon. William W. Grout, a Representative from the State of Vermont; Hon. W. D. Hoard, ex-governor of Wisconsin and president of the National Dairy Union; C. Y. Knight, secretary of the National Dairy Union; Hon. William M. Springer, of Springfield, Ill., representing the National Livestock Association; Frank IV. Tillinghast, representing the Vermont Manufacturing Company, of Providence, R. I.; Charles E. Schell, representing the Ohio Butterine Company, of Cincinnati, Ohio; W. E. Miller, representing the Armour Packing Company, of Kansas City, Mo., and John F. Jelke, lepresenting Braun \& Fitts, Chicago, Ill., and others.

The Acting Champuan. I understand, gentlemen, that an arrangement was made for the hearing, this afternoon, of the gentlemen who represent the dairy interests of Pennsylvania. Is that correct?

Several Gentremen. Correct.

The Acting Cirampinan. And how many of you are here?

Mr. Rauffinan. Mr. Chairman, I am the attorney for the Pure Butter Protective Association of Pennsylvania, and we have four dif- 
ferent interests from Philadelphia and Pennsylvania represented here. Those interests are the creamery men, the wholesale dealer's in butter, the farmers, and the retail dealers. If your committee will permit, I would like to suggest that you allow us a certain time, and let each of these gentlemen, in five or ten minutes, give the facts from the point of view of his own specialty. Then I, as attorney, will round up the matter in such time as you will permit me to occupy.

The Acting Chairian. And how much time will you wantaltogether?

Mr. KaufFuan. I think we ought to have at least an hour and a half, Mr. Chairman.

The Acting Chairman. That will be agreeable.

Mr. Kauffuan. Mr. Chairman, if you will permit me I will say, as I stated before, that we have four different interests from Pennsylvania here represented. Each one of these interests will be represented by a speaker, who will occupy, say, about ten minutes of time, and who will show how this bill affects his special interest, and why that special interest desires the passage and enactment of the bill.

The first speaker will be Mr. Habecker, of Philadelphia, a wholesale butter merchant.

\section{STATEMENT OF JOHN J. HABECKER, BUTTER MERCHANT, PHILA- DELPHIA, PA.}

Mr. Habecker. I have not much to say, gentlemen. I am not an orator, nor am I a paid attorney. I have been in the butter business about twenty-one years, and have gone through this whole controversy from the beginning to the end, and I understand that this Gront bill is for the purpose of compelling the manufacturers of oleomargarine to sell it for what it is.

That is all we desire. We are not afraid of honest competition in oleomargarine or anything else that may come on the market. But our experience has been, from the beginning, that these men who manufacture oleomargarine, and the men who sell it, do it in a way to deceive the public into buying it. In all my experience I know of only a very few cases where people have bought oleomargarine knowing what it is, except in the case of boarding-house or hotel keepers.

In the very beginning, allow me to say that we come from a city and a State where we claim that we have the finest butter in the countrythat is, Philadelphia and the State of Pennsylvania. Let us take the county of Bucks, for instance. There it has been the custom for years and years for the people to make their dairy butter up into round prints and pack it up in a certain way, and the people have been accustomed to using their butter in that way. Now, these oleomargarine dealers (who, from what I can gather here and from the eridence that I have heard at different times, are trying to make you believe that they are honest in their dealings and that they want to have their goods sold for what they are) made up their product in semblance of Bucks County dairy prints to suit a certain class and ship them into our market. They know at the time that they are making it into that style of print in order that they may and and abet and help the retailer of oleomargarine to sell those goods for what they are made to imitate and counterfeit.

Then we have another section of our State, up in Bradford County, 
for instance. There it has been the custom of the people to have their butter packed in what they call Bradford County tubs or half firkins. Now then, in order to suit the people in that section of the country and deceive them they have Bradford County tubs made, and pack their oleomargarine into tubs of that kind and ship it into that district, and the oleomargarine is sold there by retailers for Bradfort County butter. That is part of the history of the past.

Then we have another section of the State, that adjacent to Pittsburg. Up until a very few years ago it was the custom all throuch the State of Ohio for the farmers to make up their butter principally into rolls; and then they would take a little paddle and mark it on the top, and pack the rolls into a $60-$ pound tub-a thin-staved tub. And in order that the oleomargarine people might deceire the people of Pittshurg into buying their stuff for pure butter they have tubs made in semblance of the Ohio tubs and then they'have their oleomargarine made in semblance of the Ohio dairy rolls, with the little marks on the top, and packed with the same sort of cloth on top, and have it shipped into Pittsburg - knowing at the same time they do that they are helping the retailer to deceive the unsuspecting public into buying an imitation of Ohio rolls for the pure Ohio rolls.

Now, later on, as we go on in years, the manufacture of butter has changed; and they have got to making it more generally in creameries and the dairies have been dropping out. 'The creameries through our' State have been in the habit of making up their butter into square prints, with a sheaf, I think, or some sort of a monogram, stamped on them. In order to compete with that these oleomargarine manufacturers throughout the country, who have been telling you here how honest they are and how it is their purpose to have the stuff sold for what it is, make it up into square pound prints and ship it into our market, knowing that if it is sold in that way it is sold for Pennsylvania creamery prints.

That has been the history of this matter all through in our State. I do not know how it is in other States; but in the State of Pennsylvania, not only is the oleomargarine made in semblance of our different styles of butter, dairy and solid-packed and rolls and prints, but it is put up in packages so that there is no question about the disposition of it.

Now, I personally went into the butter business in 1878. I stood behind the counter, and retailed butter to the amount of $\$ 35,000$ a year'; and I have ret the first person to come to me and ask me for oleomargarine - that is, a prirate individual. My experience in the business all through is that oleomargarine is a fraud from the beginning to the end; that it is made in the semblance of butter and is sold for butter. There is only one thing that we desire in the line of legislation, and that is that such a law may be enacted as will compel these "honest" oleomargarine manufacturers and dealers to sell the goods for what they are. We are not at all afraid of that kind of competition-not at all. And if any one will take the trouble to hunt up the business from the factory to the consumer, he will find beyond any question of doubt in his mind that it is one of the most stupendous frauds that was ever fostered upon the people of this Commonwealth. There is not any question about that. I know that it is insidiously covered up. I know that. It is a lie from the beginning. I am not afraid to make that statement, because I know it to be a fact; and I can make it 
honestly. You can take all the branches of the combined agricultural business of the country, and put them together, and you will find that the whole combination is not as corrupting in its influence as oleomargarine.

Now, I can show you very clearly how that is. For instance, take a market like some of our markets in Philadelphia. Here is a mar. who buys oleomargarine to sell. Let us say that he has the privilege of doing it. He buys oleomargarine; and a person comes and asks, "Is that pure butter?" He says, "No, that is oleomargarine;" and the person leaves and goes to another stand. He incquires of that dealer whether what he sees is pure butter. The dealer has oleomargarine on his stand, but he is unscrupulous, and he says that it is pure butter. 'Then the party buys it, believing it to be pure butter.

Now, under those conditions the balance of the men in that market have either got to become corrupt and liars themselves, or they have got to get out of the business; and the temptation is strongly in favor of their becoming liars. So that if you follow the thing up closely, you will find that it is one of the most corrupting things that has ever been fostered upon the people. We are honest in this matter. I will admit that there is not a man here who has not a measure of selfishness in him. I will admit that. Take the farmers, and there is a measure of selfishness in them; and in the retailers, and in the wholesale dealers, and the buyers of ordinary butter. We have all got a measure of it; but there is one truth here and one fact, and that fact is this - that oleomargarine is a frand. It is a cheat. It is not fair to call it an imitation. It is a counterfeit, and it is the most deceiving thing that has ever gone in the mouths of the people.

I went home not very long ago and our folks were out of butter and I found a very nice half pound of "butter" on our table. As soon as I saw it, being aceustomed to butter and knowing what it is, I of course readily detected that it was oleomargarine. I said to my wife, "Where did you get that?" "Well," she said, "I bonght it around the corner. We just happened to be out of butter." Said I. "What did you pay for it?" "Twenty cents for half a pound." "Well," said I, "that is oleomargarine." And I was one out of probably ten thousand people who would have noticed it.

Gentlemen. I do not want to take any more time. I am rery much obliged to you.

MIr. JELKE. Will the gentleman permit me a question?

Mr. Habecker. Certainly.

Mr. Jelke. You are in the butter business?

Mr. Habecker. I am in the butter business.

Mr. Jelke. Do you know anything about process butter?

Mr. Habecker. Tes, sir; I do.

Mr. JELKE. You handle that?

Mr. Habecker. I do, sir; have you got anything to say against it? Mr. JeLKe. That is all, sir.

Mr. KaUffian. Mr. Chairman, the next gentleman who wishes to address you is Mr. Joseph C. Sharpless. 


\section{STATEMENT OF JOSEPH C. SHARPLESS, OF PENNSYLVANIA.}

Mr. Sharpless. Mr. Chailman, I have only a few words to say. As Mr. Kauffman stated, I am a ereamery mair. I put up most of my butter in half-pound prints with my full name on them. My attention was called a little while aro to some butter that was found in the maxket with my nume on it, a half-pound print, and when I came to examine it it was oleo. Somebody had gotten that block made and gone and printed oleomargarine with my print, wheress if the stuff had been white, as we want it to be, and not colored in imitation of our goods. the people would not have bought it as my butter. I simply wanted to make that statement.

Mr. Schent. Mr. Chairman, may I ask a question, please? I would like to ask the two gentlemen whether, if a law could be prepared which would compel colored oleomargarine to be sold for what it is, they would then object to the color in the oleo?

Mir. HABECKER. How is that?

Mr. ScherL. Would you object to colored oleomargarine being on the market if some law could be framed by which the dealer would be compelled to sell it for what it is ?

Mr. HABECKER. It could not be.

Mr. Scuel.. Well, if it conld be?

Mr. Habecker. I do not think that is the question.

Mr. Kaumwan. I will answer that question, if yon please.

The Acting Chatrmax. We will defer the answer to that question until the turn of this gentleman to speak, because I imagine that he, who is trained in the law, will perhaps know more abont statutes than the gentlemen who are trained in the creamery business.

Mr. Schect. I understand; but that simply goes to the question of whether or not such a law can be made. I want to get at the intent of the people who are actually in the business, and who are here adrocating this bill. I want to know whether they want colored oleomargarine stamped out, or whether they simply want it subjected to such restrictions as will insure its being sold for what it is.

Mr. Kaufruan. I will answel that question when my turn comes. You can ask me all the questions you please, and I will be glad to answer them.

The next gentleman who will speak is Mr. Isaac $\mathrm{W}$. Cleaver, who is manager of 65 grocery stores in the city of Philadelphia.

\section{STATEMENT OF ISAAC W. CLEAVER, OF PHILADELPHIA, PA.}

Mr. Cueaver. Mr. Chairman, I represent the Acme Tea Company, which operates not 65 but 63 retail stores in Philadelphia.

WV are known as cut grocers. Consequently, we think that we reach the masses of the people. It has been our desire and our policy, and our practice, to conform strictly to all the laws with respect to pure food. We have found that we were beaten by our competitors, who sold an imitation or a counterfeit for butter at about a cent a pound less than we were selling it. We know this because we bought it from them as butter, for butter, had it tested, and it proved to be oleomargarine. 
About two years ago we were asked to join the Pure Butter Protective Association, whose objeet was to enforen the laws against the illegal sale of oleomargarine. WV at once united with them, and have been paying our money and using all possible efforts to have these laws executed so as to stop the illegal sale of oleomargarine for butter. We have not been successful.

We are in no way interested in the manufacture of butter; only in the sale of it. If we could sell oleomargarine legally and there were a demand for it, we would just as lief sell it as we would butter.

With reference to whether or not there is a demand for it, I have only this to say: We have a printed slip, with questions on the slip which must be answered every week by every manager in each of our stores. One of those questions is this: "Has there been anything asked for during the week that we do not keep? If so, what?" WV have yet, from all those 63 stores, to have an inquiry for oleomargarine or butterine. Consequently, we are convinced that the masses of the people in Philadelphia do not want oleomargarine or they would ask for it.

Mr. Springer. Is the sale of oleomargarine prohibited by law in Philadelphia?

Mr. Cleaver. No, sir; it is not.

Mr. JeLke. What is the law in Pennsylvania relating to the sale of oleomargarine?

Mr. Cleaver. I do not know exactly what the law is. All that I know is that we have been assisting, in every way in our power, with our money and with our efforts, to have that law enforced, and without success. We still find that our competitor's beat us, right alongside of us, because they offer for a penny less something that they sell for butter.

This is all, I believe, that I have to say, unless questions are asked me.

Mr. KNIGHT. About how much butter do you sell a day?

Mr. Cleaver. We sell from 4,000 to 6,000 pounds of butter per dav.

MI. JELKE. Have you ever handled process butter?

Mr. Cleaver. We do, as process butter. We handle it in conformity with the law-every package stamped. In everything connected with pure food we adhere to the law strictly, both literally and in spirit.

Mr. Schell. Do you have calls for process butter?

Mr. Cleaver. Yes, sir.

Mr. Scrienc. Is it distinguished as such? When the customer asks for it does he say, "Let me have some process butter"?

Mr. Cheaver. Every packinge is marked, "Renovated butter."

Mr. Scinel.. I know; but when the customer, the consumer, comes in does he ask for "process butter" or "renovated butter" ?

Mr. Cleaver. Renovated butter.

Mr. Scinelr. Does he speeify that he wants that kind?

Mr. Cleaver. That I can not answer. You understand, I am the buyer and the manager of the butter, egg, and cheese department. I an not in the stores, you know. I am the general manager, with my office at the headquarters, at our warehouse, and I do not know about all those little details. But I am familiar with these questions, because the same sheet contains any complaints that are made. So I say that any complaints that are made ahout butter or eggs come to me on those sheets, in the way I have stated. 
Mr. JELKE. Do these sheets specify that you have calls for renovated butter?

Mr. Clesaver. Oh, we keep that, you understand. We keep that. The question I refer to, you must understand, is this: "Have we had calls for anything that we do not keep!" Now, we keep renovated butter.

Mr. KNight. To what class of trade do you cater?

Mr. Cleaver. I think I said that we are known as ent grocers, and of course we reach the masses, those who want good goods for little money. Of course our aim is all the time to improve our quality, but we are known as cut grocers, and of course our customers want goods cheap. I should suppose, therefore, that if these dear people who are said to want oleo are anxious for it they certainly would come to us for it.

Mr. Springer. You would not sell that which the law prohibits you from selling?

Mr. Cleaver. Well, there is no way that they would know our reputation in the pure-food line exeept by coming and finding out. We do not publish to the world that we are strietly reliable and straightforward. They wonld have to find it out by coming and asking.

Mr. Springer. You doubtless have a good reputation in the community where you live?

Mr. Cleavel. Well, we try to have.

Mr. Kauffuan. Mr. Chairman, the next gentleman will be E. D. Edson, who is one of the largest wholesale butter dealer's in the city of Philadelphia.

\section{STATEMENT OF E. D. EDSON, OF PHILADELPHIA, PA.}

Mr. Edson. Mr. Chairman, I ean only indorse the sentiment that has been expressed by those gentlemen that have preceded me. As a business man and a butter dealer. I can but add to what they have already stated, that in a business of eighteen rear's I have been in constant touch with the creamery men, the dairymen, and the butter makers throughout the East and the West, and right in touch with the retail butter dealers, a great many of whom during the past several years have sold oleomargarine. Recently a number of them have gone out of the oleomargarine business, on account of the prosecutions in Philadelphia. And in almost all cases, without any exceptions, those men with whom I have discussed this oleo question have admitted to me that they could not sell oleo unless they sold it as pure butter.

Now, as a matter of business, if the public wanted oleo, erery representative butter house in Philadelphia wonld sell it to them if it conld handle it legally. I might venture to say that there is hardly a respectable commission butter house to-day in Philadelphia which would entertain the idea of selling oleomargarine, because they all have the knowledge before them that they ean not sell it legally. That is, if they were to sell it legally, they would have to sell it as oleomargarime, and they know that they ean not do that, and they also know that the retail dealers to whom they would sell this oleomargarine would have to sell it as butter in order to dispose of it.

Now, in order to get at the marrow of this oleo business, just compare the way the farmers or the butter makers dispose of their prod- 
uct with the way the oleo manufacturers dispose of theirs. The butter maker's make their butter and send it to reputable commission houses, where it is disposed of for the account of these shippers on a commission basis. The oleo dealer's, after having exhausted every means in their power to interest the respectable element in the butter trade, and induce them to handle their oleo, without avail, with the aid of expert salesmen encourage illiterate people, this low class of Riussian Jews, men who have been unsuccessful in business, who can not compete legitimately with up-to-date business men, to embark in this trade, with the guilty knowledge before them that these men to whom they are selling this oleo must violate the law in order to dispose of their product.

I think that speaks for itself. If the people wanted oleo, every butter man in Philadelphia would endeavor to get it for them, if he could sell it legally.

I believe that is all I have to say.

Mr. JeLke. Just one question. You have been in the butter business eighteen years?

Mr. EDson. Eighteen years; yes, sir.

Mr. JELKE. Have you ever sold oleomargarine?

Mr. Edson. Yes, sir; I have.

Mr. JELKE. How long ago?

Mr. EDson. Not for the last ten or eleven years. I should be very glad to answer questions here for an hour, as far as I am concerned, gentlemen.

Mr. Knrght. Mr. Edson, why did you cease selling oleo?

Mr. Edson. Because it was against the law to sell it.

Mr. Springer. Do you not recognize this difference, Mr. Edson? The law prohibits the sale of any imitation of butter, colored-anything colored in imitation of butter. If the dealer were to sell it for either butter or oleomargarine, he would be guilty of riolation of the law.

Mr. Ensor. No; the law, as it stands now, as I understand it, permits him to sell it if he sells it for oleomargarine.

Mr. Springer. No, sir; no sir!

The Acting Charrman. The law of Pennsylvania prohibits the manufacture or sale of oleomargarine made in semblance of butter.

Mr. EDson. Oh, the law of Pennsylvania! I did not know you meant that.

Mr. Springer. So, Mr. Edson, if they sell it for oleomargarine, they confess that they are guilty?

Mir. Edoson. Yes.

Mr. Springer. If they sell it for butter, the burden of proof, on the other hand, is upon the Government to show that what they sell is not butter, but oleomargarine?

Mr. EDson, Yes, sir.

Mr. Sprrnger. So that it is to their interest to sell it as butter unless they want to confess themselves guilty?

Mr. JELke. Just one question, please. Do you sell process butter?

Mr. Edson. Yes, sir.

Mr. Kauffuan. Mr. Chairman, the next speaker will be W. F. Dremnan, who is also one of the largest butter dealers in the city of Philadelphia. 


\section{STATEMENT OF W. F. DRENNAN, OF PHILADELPHIA, PA.}

Mr. Drennax. I would like to state my reasons for being in favor of the Grout bill; and I will try to eonfine my reasons to faets.

As a commission merchant, of course I might be called somewhat selfish in the handling of genuine butter. We used to handle oleomargarine many year's ago. We handled it largely up to the time the first law was enacted, and we have handled it pending the decision on the constitutionality of our State law. After it became a settled fact that we could not handle it without violating the law, we quit it.

As a dairyman, as a land owner and a man interested in the dairy business, I am in faror of the Grout bill, because $I$ think it offers the best protection to the legitimate industry of butter making.

I also would be glad to offer what testimony I ean gire you as to some points which I have heard diseussed here to-day, and which I have seen through the medium of the press. One is the claim that olemargarine is largely sold for what it is; that the people demand it and want it, and that the manufacturers and wholesale dealers are anxious that it shall be sold for just what it is.

Now, I deny that in toto. Our experience, which I will try to verify here to-day, has been exactly to the contrary. After being in the commission butter business over twenty years I can call to mind only one instance in which a consumer ever admitted that he bought it willingly or bought it for what it was. That may seem very strange to you, and yet it is true. I repeat that I can recall but one instanee in all $\mathrm{my}$ lifetime where any person admitted that he bought it knowingly for what it was because he wanted it on his table.

Now, then, I think the facts will bear me out in that. As chairman of the executive committee of the Pure Butter Association, we were compelled two years ago to enforee our State law through the medium of what money we could raise on the street and through appointing our own attorney and our own detectives. After haring purehased about 161 samples and haring them analyzed, and having those purchases reeorded in a book where we conld have access to them, the question came up: "How many purchases were made in which the render gave them to the purchaser for oleomargarine?" Butter was asked for, of course. Out of 161 cases, one was sold for exactly what it was. The 160 were sold for butter and at praetically butter prices.

Now, are those facts suffieient to convince anyone here that these goods are not sold for what they are? Less than 1 per cent in that particular instance was sold for what it really was.

You can have those facts if you want then. It has been stated here on this floor to-day that there is only a small percentage of oleomargarine sold for other than what it is or what it purports to be. I think that this case disproves that claim, and eren if it does not, I have enough knowledge of the oleomargarine business to know that it is not sold for what it is; that there is no wholesaler who wants it sold for what it is. and that in fact there is no manufaeturer who really wants it sold for what it is. for the reason that he can make a great deal more out of it and sell a great deal more of it through having it sold for butter.

My friend Mr. Jelke, here (a man whom I have known a long time, and whom I respect), would probably tell you that he would prefer that these goods should be sold for what they are. I think that the 
Grout bill gives such men the opportunity of building up their inclustry on its own merits, and that it simply draws the line so that every human being can tell exiletly what he is luying.

It may be a hard job to do that just at once. And yet there is nothing unfair about the Grout bill, mnless you take the stand that you can not make or introduce white oleomargarine or oleomargarine without color. But eren that is nothing. If that is the fact, then let it stand on its own merits instead of posing as pure butter.

There is not a man here who, if he went to a dealer's stand and asked for butter and was given oleomargarine after he had paid the pure-butter price, would not kick. Mr. Jelke himself would do it. Any gentleman who has spoken to you would do it.

Now, I state this fact, that according to my positive knowledge there is not over 1 per cent of oleomargarine sold for what it is in our market. I would not make the statement if I conld not prove it.

If there are any questions anyone wishes to ask me, I will try to answer them.

Mr. Sprivger. This is in Philadelphia, is it not?

Mr. Drennan. Yes, sir.

Mr. Sprivger. Is what you have stated due to the fact that if the merchant sold it for anything but butter he would confess himself guilty of a violation of the law?

Mi. Drennas. I have not any doubt that that has a rery great bearing; but even that is no argument.

Mr. Springer. It explains the fact, however, that men do not go into the community and say, "I am guilty of violating the law by doing this." If a dealer sells it for oleomargarine, the law prohibits that, and he confesses himself guilty. If he sells it for butter, the State has to prove that what is actually sold is oleomargarine in order to convict him.

Mr. Drencax. Yes.

Mr. Sprixgel. People do not convict themselves, as a rule.

Mr. Drenxan. Mr experience as a man and as a merchant for the last twenty years has taught me positively that the average buyer of butter does not want oleomargarine, and that when he buys oleomargarine he gets it when he asks for butter. and he would not hare it did he know it. Now, then, I will admit that it is possible to work up a trade for oleomargarine on its merits. That is all we ask them to do. The Grout bill gives them the opportunity to do that. It remores part of the tax. It leaves the color out. "It puts it squarely on its merits. There is no one who can deny that.

Then there is another thing: We have a lot of irresponsible dealers who take up oleomargarine because of the immense profit in it. I do not need to stand here and tell you what it costs to make it or what it costs to put it into the hands of the wholesale dealer. We all know that. Evervbody knows that. But when the retailer, in its colored rondition, can bring it up to within 1 or 2 cents of the price of genuine butter and sell it to the customer at that price, he has a protit of anywhere from 10 to 12 cents. Therefore he is bound to go into that husiness if there is any such business; and just as long as there is color in it we can not reach him.

You may talk about the Wadsworth bill. I am sorry to say that the revenue department of our city does not enforce the revenue law. It will prosecute a ease if we will make it and bring it to the depart- 
ment with the evidence; that is all. But it is the worst law we ever could have enacted, according to my best judgment.

Mr. Krignt. You mean the Wadsworth bill?

Mr. Drennan. The Wadswolth bill.

Mr. Jelis. I ust one minute, Mr. Drennan. Do I understand you to say that you have had no call for oleomargarine as oleomargarine?

Mr. Drennan. Why, while we were in the business we had a great many calls for it. We were in exactly the same position, Mr. Jelke, that you were. We could not sell it for butter if we had tried to sell it for butter. We kept it stamped in our own house for sale. The man who came there, if he wanted it at all, wanted it as oleo. He would do the other work.

Now, then, I do not want to forget anything. I came neal forgetting a point that I wished to make. IVe formerly sold to one man perhaps $\$ 50,000$ worth of high-grade oleomargarine every year. That man had a rule behind his stalls, where he had four cutters, that if one of them ever gave away the fact that oleomargarine was being sold in that stall he did it at the peril of his position, and he maintained that rule for years. I can think of three gentlenen in Camden who bought it and sold it, and they will tell you to-day that a pound never went out of their possession except for genuine bitter, and they would not tare do it, and they would not do it. They sold it all for butter.

Now, those are the facts. I would be glad to be permitted to sell oleomargarine if there were any demand for it as such. But 99 per cent of it is sold fraudulently. "That is absolutely my candid conviction, and it is what I gather from facts that have come under my own knowledge. Every dealer to whom we sold oleomargarine would tell you that he never could sell it, or would not sell it, except as butter, for the reason that he would not want his trade to know he was handling oleo. If he did, the customer would say, "Why don't you let me have it at a reasonable price?" The dealer would sell it at a price about a cent below that of fancy butter; hence the enormous profit.

Now, that is the way the thing is run in our market. There are wholesale dealer's there who would contradict me, but I know that those wholesale dealers-and you may take the most respectable of them-have insisted that our trade, in coming to us and buying butter, must take up the oleo. They have said, "If you will only take it up we will see that you are not at one cent expense for legal matters. We will bear all the expense. We will stand behind you and protect you as legards that part of it. Go in. You might as well go in and sell it as somebody else. We will stand back of you." If one man has said that thing to me in the last six months, in the endeavor to urge us into handling oleo, fifty have done it, and everyone with assmrance (whether or not it would have been carried out I do not know) that they would stand back of us and protect us.

That is the way it in sold in Philadelphia, and there is not a man here in the business but what kuows it.

Mr. Jelke. Mr. Diennan, just one question. You handle all kinds of butter, do you not?

Mr. Drennin. Yes, sir; pretty much.

Mr. Jelke. Process butter?

Mr. Dliennan. No, sil'; we do not.

Mr. IELKE. Renovated hutter?

Mr. Drenvar. No, sil. We do not handle it; not because we have any s'ruple against it, but because we have no particular trade for it. 
Mr. .Jelke. Well, you know how it is packed or put up, do you" I refer to process butter, renovated butter.

Mr. Diennan. Yes. We have handled it in years gone by ; but-

Mr. J J ELKE. It is put up in these same square prints and round prints. just the same as ereamery butter?

Mr. Drennan. Yes.

Mr. Jelke. And dairy butter?

Mr. Drennan. Yes, sir. I suppose every man here knows what renovated butter is. In the course of my business I have sold millions of dollars' worth of this dairy butter-real butter, put up in tubs, rewashed, and repacked. We have sold it for what it was. We have sold it for dairy butter, sold it for ladle butter, and all that sort of thing. We have sold earloads of it every week. Now, then, the difference between that and process butter is that they simply take that raw material and render it and take out a great deal of filth, although you understand I do not handle it, and I an not speaking for it myself. Our law in Pennsylvania compels them to stamp it for what it is; but it is a mueh better product than it originally was. Still, I do not handle it.

Mr. Jelke. The proeess removes the filth in the butter?

Mr. Drenvan. Yes, sir. I do not know of anything under hearen that has more of it than common butter-the ordinary roll butter, such as is not made in the creameries. I think it is filthy.

Mr. Ebsox. Mr. Drennan, you do not wish to conrey the impression that all dairy butter has the rancidity of which you speak?

Mr. Drennax. Oh, no. You will allow me to qualify that. There is a gentleman here from Chester County who makes butter in such a way that the finest product in the world could not be made any finer, and there is no finer product than dairy butter. I am speaking simply of the butter that is brought by the average country farmer throughout the West to the store and traded off for goods. It gets rancid. Some of it is dirty; some of it is clean.

Mr. Kaufrman. Now, Mr. Chairman, these gentlemen are but a few of those who are here. I think I can safely say of the wholesale dealers here that they represent three-fourths of the wholesale butter trade of the city of Philadelphia; and they, of course, will indorse what these two gentlemen have said as their riews in relation to the Grout bill as affecting the wholesale trade.

Now, I have one more speaker to introduce. That is Mr. Thomas Sharpless. He is a farmer, a dairyman-not a creamery man, but a farmer-and he will talk to you, if you will permit him, from the standpoint of a farmer.

\section{STATEMENT OF THOMAS SHARPLESS, ESQ., OF CHESTER COUNTY, PA.}

Mr. Sharpless. Mr. Chairman and gentlemen, my profession in life does not lead me to be a public speaker, but this is a question which affects me and all us farmers very nearly.

I live in Chester County, Pa. Chester and Delaware counties are giren up, body and soul, to the keeping of cows for the making of butter and the production of milk. We think it is an outrage that we 
men who manufacture genuine real butter should be compelled to compete in the market with a fraudulent article which is made in imitation of our butter.

I do not think the wholesomeness which I heard discussed here this morning enters into the question at all, pro or con. The question is simply the fraud that these men perpetrate when they make an article which is not butter and sell it as butter.

Now, we color our butter. There is no use denying that; because we have never attempted to deny it at all. We color it to suit our trade; but it is what we sell it for. It is butter; we say it is butter. It is not made of tallow and cottonseed oil and lard, or anything else of that kind. It is butter, and it is nothing but butter, and we sell it for just exaetly what it is.

I say that these manufacturers have no moral right to color another produet and sell it in the market as butter in competition with our product. They have no moral right to compel us to compete with an article of that kind. It is not justice; it is not right.

Pennsylvania has profited by the protective tariff. It has been one of the great protective-tariff States, and every one of our industries is proteeted except us farmers who manufacture butter.

I have been making butter for twenty-five years. In that time I have seen the actual value of our lands depreciate 40 per cent. Within one mile of my place there are seven farms owned by aliens and run by tenants. Within a mile and a half of my place (and we live in a fairly good country, on the Brandrwine Hills) I have seen two farms put up for sale withont a single actual bidder for them. They were fine farms, too, one of them containing 137 aeres and the other some 160 odd acres. and they nerer had a bidder. That is simply because our busines has become so unprotitable that only those who are compelled to stay in it or go bankrupt stay there.

Mr. Springer. What is the business?

Mr. Sharpless. Making butter-making dairy butter. I do not furnish milk to a creamery at all. I make my own butter in my own spring house on the place, and furnish it to private trade.

Mr. JELkE. At what price do you sell your butter?

Mr. Sharpless. I sell my butter at 35 cents the year round, wholesale. I have no secrets at all about my trade. I make butter and nothing else, and I sell it for butter, too. I sell it to people who appreciate butter, and they do not buy oleo. Now, I have eaten oleo, and, for anything that I could taste about it, I knew I was eating oleo when I ate it. For anything that I could taste about it, it tasted fairly good. But that is not the question - whether it is good or whether it is bad. There is bad butter made as well as there is good butter made. The question is simply, "Shall I, who make an honest, square article of butter, be compelled to compete with an article that is not butter, made in the semblance of my prodnet?" I say it is not fair; it is not right. Whether the Grout bill is the remedr for it or not I do not know, but it looks that way to me.

Mr. Miller. Mr. Sharpless, do we understand you to say that you can make nothing on butter at 35 cents a pound?

Mr. Sharpless. I did not say that.

Mr. Miller. What do you say then? I understood you to say that the business is very unprofitable, and that the value of land is decreasing. 
Mr. Sharpless. Because I make a fair article of butter, and sell it to a fair trade, and get a little bit better price than most people do, that is no reason why everrbody gets that price. You can buy any amount of butter around in our neighborhood, say at 25 cents-probably not just at the present time, but you can through the summer season, any amount of it. The farms of our neighborhood can not make buttel out of their land and sell it for 25 cents and make any money out of it. They simply can not do it for that; and I know it, because I have been right there, and my accounts will show it.

Mr. Minfer. From the statement made yesterday by Mr. Hamilton, the dairy commissioner of Pennsylvania, we should judge the Pennsylvania hutter business to he in a very healthy condition.

Mr. Sharpuess. We have a law regulating the sale of oleomargarine in Pennsylvania, and the enforcement of that law rests with Professor Hamilton. He claims that he is not able to enforce that law. Either that is a fact, or else he is unwilling to do so. Some of us are uncharitable enough to believe that he is unwilling. We have not had very much faith in his attempts to enforce that law.

Mr. Tilminginast. Have you any idea how much oleomargarine there is sold in Pennsylvania?

Mr. Sharpless. No, not to my certain knowledge; but I will tell you what I do know, that one of my friends who was in Pittsburg went into the stores there and asked for butter, and he bought what they sold him as butter and took it out and had it analyzed and it proved to be oleomargarine.

Mr. Edson. Mr. Sharpless, will you tell me how many quarts of milk there are in a pound of butter?

Mr. Sharpless. It varies; it depends altogether upon the cows.

Mr. Edson. At this time of year', I mean.

Mr. Sharpless. It varies; it takes about 9 quarts, or a fraction less than 9 quarts, of my milk to make a pound of butter.

Mr. Edson. On an average it takes more than that, does it not?

Mr. Sharpless. The ordinary creamery does not make it under ten.

Mr. Enson. Then, at the present price of butter, how much does a farmer get for a quart of milk?

Mr. Sharpless. It depends altogether on the price he gets.

Mr. EDson. Based on 25-cent butter-22 to 25 cent butter?

Mr. Sharpless. He would not get but 2 cents and a balf.

Mr. Enson. Does he get 2 cents and a half?

Mr. Shalipless. He has to pay the creamery for manufacturing his butter.

Mr. EDsox. Well, finally, when the farmer gets his money, how much a qualt does he get for his milk?

Mr. Shalipless. He gets about 2 cents.

Mr. EDsox. He gets about a cent and a half, I should say, or somewhere around that neighborhood. He gets about a cent and threequarter's to two cents a quart at the best of times. 'That is what it costs.

Mr. Sharpless. He can not produce milk in our county and sell it at that price and make a profit out of it.

Mr. Edson. Mr. Chairman, it is a well-known fact that there are from 10 to 11 quarts of milk in a pound of butter. At the arerage price of butter throughout the year a farmer in the East or in the West will net about a cent and a half a quart for milk on butter sold at from 18 to 20 cents. 
Now, you can see that that is little enough. The actual cost of the production of a pound of butter is about 16 or 18 cents; so that where butter is compelled to compete with oleomargarine, which is made at 10 or 11 and 12 cents a pound and sold at identically the same price, the farmer has got to go out of business.

Mr. Thllinghast. WTas the price of butter any higher before oleomargarine was used?

Mr. Sharpless. Yes, sir. I never thought anything of getting 50 cents a pound for butter.

Mr. SPRINGER. When?

Mr. Sharpless. When I first began; when I first entered into the dairy business, twenty-five years ago. It was gradually cut down to 45 and 40 , until it got down to 30 cents.

Mr. SPRinger. When the country got on a gold basis it went down to 30 cents, I suppose?

Mr. Sirampless. When I got down to 30 cents, I thought I was pretty near the bottom. Now, I do not want to take up your time, gentlemen, but the only point I have in this matter is that I say it is unjust and unfair that we farmers, who make an honest, fair article, should be compelled to compete with a fraudulent article made in imitation of our product. That is all I have to say about it.

The Acting Chamman. You have made your point very clearly, sir.

Mr. Kaufruan. Now, Mr. Chairman, before I eall the next speaker, I desire to say about Mr. Sharpless, that the Sharpless butter is known all over the United States. It is the highest brand of butter that is known in the United States.

The next speaker whom I want to introduce, Mr. Chairman, is the president of the Produce Exchange of Philadelphaia, Mr. Isaac W. Daris.

\section{STATEMENT OF ISAAC W. DAVIS, ESQ., PRESIDENT OF THE PRODUCE EXCHANGE, PHILADELPHIA, PA.}

Mr. Davrs. Mr. Chairman, I do not know that I have anything at all to add to what has already been said. I did not expect to be called on, and I have very little to say. What I have to say is simply by way of confirnation of what has already been stated.

I believe that one of the reasons for our coming here is our belief that the passage of the Grout bill will be the most effectual means of correcting what has been very emphatically stated here as a fraud. 'That is our belief, and it is mine. The history of the traftic has been one of illegality, and all the legislation that has been enacted, so far as I have known of it, has been necessarily of a restrictive character.

The legitimate butter interests have been compelled, by way of defense, to hedge abont this thing, when, if it had been legitimate and fair, as it has been claimed here that it is, there would not have been the slightest necessity for that kind of legislation. And all the laws that have been enacted have more or less failed. We think the Grout bill will meet the case in every particular, for the reason that it will compel the manufacturers of this product to compete fairly; that is, they can not get away from it. It will compel them to sell their product for what it is, and it will bring the article down to the consumer. For instance, under the Wadsworth bill, if this product goes 
to a hotel or a restaurant, or into a private house, these supposed safeguards, or wrappers, or whaterer they may be, which are used to identify it as oleomargarine. are taken off, and the consuner does not know anything about it: and he is imposed on. The sane kind of imposition goes all the way through, and all the methods, so far as we have been able to discover, of the manfacturers and dealers of oleomargarine have been those of systems of deceit-to put off on the people articles of food which they did not know they were using.

Now. I do not know that I can say anything further ahout this matter. The only point is that we are here in the butter interest-dairymen, dealers, and consumers-to state om belief in the effieacy of this Grout bill. We want it. We think it is a remedy for all these ills in the butter trade, and that it will compel legitimate competition. The butter dealers do not want to destroy this product. They have no idea of doing that. If people want oleomargarine. they are entitled to have it. But, as I understand it, statistics show that 90 per cent of this stuff goes into consumption as butter, and that very fact ought to stamp it as a fraud.

Mr. Tillinghast. What statisties do rou refer to?

Mr. Davis. I have not them in my possession: but I have heard the statements made and the facts given, and they have not been contested at all.

Mr. Kauffinan. We will give them to you.

Mr. Davis. 'That is all I have to say.

Mr. Kaufamax. Now, Mr. Chairman, there is only one more gentleman who will speak to you-Mr. Jamison, who is a very large wholesale dealer in Philadelphia.

\section{STATEMENT OF SAMUEL JAMISON, ESQ., WHOLESALE BUTTER DEALER, PHILADELPHIA, PA.}

Mr. Jamison. Mr. Chairman and gentlemen, we speak in faror of the Grout bill for the reason that we have tried, by experience, all the previous legislation, and we are still spending our money to have the laws enforced. I suppose it has been ten years since the butter trade of Philadelphia has made an effort to control the sale of oleomaroarine according to the laws which were passed by the United States. to enfore the national law, or our own State law. IV find great difticulty in enforcing the laws as individuals. Te have probably spent in the neighborhood of $\$ 50,000$ of oul own moner to have oleomargarine sold according to the laws of Penusylvania. IT e have been compelled, from year to year. to have additional legislation passed. making it harder and harder for oleomargarine to be sold as butter.

Mr. Tillinghast. Will the gentleman permit a question?

The Acting Chamisax. Allow the gentleman to proceed, please.

Mr. Timlinghast. I will, unless he desires to be interrupted.

The Acting Champuan. You can ask him questions at the end of his remarks, muless he desires to be intermpted now.

Mr. Jamison. It does not make any difference.

Mr. 'Tillinghast. I will ask if, during that period, you have not had in Pennsylramia a prohibitive law, absolutely prohibiting the sale of all oleomatrgarine?

Mr. J Amsox. We had a prohilitive law for some tine, and we found 
that there was no appropriation made by the State to enforce it. I think the trade, as a rule, has spent its own money to have that law enforeed. During that period, I think, we have also had a revenue law, which requires oleomargarine to be marked plainly, so that all consumers would know what they were buying; and we found both the State and the national laws absolutely void. They were not enforced, except through the efforts of the trade. We have our own business to attend to. WV are not the police power of the State. We have been forced, notwithstanding that fact, to that attitude. Fortunately, a few rears ago the State appropriated a, sum amounting to about $\$ 25,000$, which, I think, had been obtained indirectly by license, but the dairy and pure food commissioner of the State has stated here that he has found it exceedingly difficult to have that law enforced.

We ask for additional legislation because we find that the goods can not be controlled except at the factory. The minute they leare the factory the deception begins. As repritable merehants, merchants of standing, with eapital behind us, and with prominent locations in the center of a large eity, we ean not violate these laws. We are the first men to be arrested if we do violate them. But we have customers who sell these goods at retail. After they get possession of those goods, they remove all marks absolutely. They remore the revenne stamp; they scrape the word "oleomargarine" off the boxes. They receive the oleomargarine itself without any marks whaterer on it. 'Then, they proceed to sell it as butter. And of all the retail dealers in oleomargarine who have a Gorernment license in the eity of Philadelphia-how many are there, Mr. Ḱauffman?

Mr. Kauffian. Only 32, now.

Mr. JAunson. I doulbt very much whether any individual can go to any one of those retail dealers who has a Government license to sell oleomargarine and succeed in obtaining oleomargarine if he asks for it. I have repeatedly asked retail dealers who had a Gorernment license (generally under some assumed name; instead of taking their own name, they (all themselves some (reamery company or" other) for oleomargarine. I have said to these men, "Are you handling oleomargarine?" "No; I do not sell it." Still, we know that they pay for a Gorernment license. We know that they receive the goods. We know that they sell to their regular trade, every day, oleomargarine for butter. A stranger who comes to one of their places of business and asks for butter will probably receive butter. because he is an unknown buyer; but to their regular trade we find that they sell oleomargarine to this day, in spite of what may be called the prohibitory law of the State of Pennsylyania and a national law which requires oleomargarine to be marked. We find it simply impossible to control the sale of oleomargarine as oleomargarine atter the goods leare the factory. I have had considerable experience with oleomargarine; we sold it ourselves previous to the legislation in the State which made it impossible to sell it legally, and that is why I say these things.

As I was saying, these retail dealers have continued to sell oleomargarine as butter to this day, and that is the reason I think the goods ought to be controlled at the factory, because as soon as they leare the factory they are in such a shape that they ean not be conitrolled by either the State or the present national law. If they are taxed at the factory or put in such shape that they must go to the consumer as oleomargarine we will be perfectly satisfied. Individually I hare 
no objection to oleomargarine and would probably sell it to-morrow if I could sell it aceording to the laws, and if the people to whom I sold it would comply with the laws so as not to get me in a position like they did a few years ago. If a retailer was eaught riolating the laws of Pennsylvania he would take advantage of the laws and simply siy. "Well, I can not pay you, beeause you are in an illicit business," and he would give that as a reason for not paying his bills. The traflic is in a very serious condition. As I have said before, I have no serious objection to the sale of oleomargarine as oleomargarine; but the trade to which we sell can not compete with the men who are willing to take the chances of arrest for violating the present State and national laws.

I hope, therefore, that the bill will pass because it will relieve, in a great measure, the present expensive srstem of enforeing the national as well as the State law. The States know that they can not control the sale of this product without the use of a great deal of moner, and it is impossible to wateh the thousand and one small dealer's. A great many of them are unlicensed. There are in the eity of PhiladeIphia and in the State of Pennsrlvania a great many unlicensed dealers. The revenue men are not able to find illicit dealers sufficient even to collect the revenue. One revenue collector himself told me that he went to Pittsburg and in a few days found 35 illieit oleo dealers who had not paid the Government tax at all, and were violating both the national and State laws.

Mr. Springer. Mr. Jamison, let me ask you a question, please. You are a commission merchant?

Mr. Jamison. Yes.

Mr. Springer. Could you not devise a law which would so identify, at the factory, manufacturer's of oleomargarine. that it could be carried in that condition to the consumer without any risk of coming into competition with creamery butter?

Mr. JANison. I know of no way of accomplishing that result. I have given it serious thought. IVe supplied the best hotels at one time. We sell butter to hotels from Maine to Florida. We supplied this town here for years with probably 90 per cent of the time butter used here. And I do not see how, after the goods leave the factory, they can reach the hotel, the restaurant, the boarding house, or the retailer, and not be used as butter. The retailer can take a machine, and no matter how you brand it, even if you put something in the interior of the butter, he can take it out and print it over and sell it for butter.

Mr. Springer. If the law required the retail dealer to sell it to the consumer in the original package, without the paper being broken, would it not then reach the consumer as it came from the factory, in the original package?

Mr. JAuison. The national law requires to-day that every package of oleo sold at retail must be marked with the word "oleomargarine," the address, and the number of pounds. Every retailer in Philadelphia, you may say, violates that law to-day.

Mr. Springer. But if they were required by the law to sell it in the original package, without breaking the seal or the internal-rerenue st:mp, and deliver it in that shape to the consumer'. wonld roul see any danger then from its coming in competition with the sale of creannery 
butter, as far as the retail merehant is coneerned, or as far as you are concerned?

Mr. Jamison. So far as the manufacturer and the wholesale dealer are concerned, the business is thoronghly legitimate. And yet, even before these absolutely prohibitory laws were passed in Pennsylvania, we were asked by dealers to enter fictitions names on our revenue books, and to do other things which we did not eare to do, and which we refused to do. But I an sorry to say that there are other dealer's in the business, competing with ns, who have not hesitated to do these things.

Mr. Springer. That was because the law made it a erime to do these particular things. If it had been lawful for you to sell the oleomargarine in the original package, just as you got it from the factory, withont breaking the seal and without breaking the internal-revenue stamp, would you have had any embarrassment in delivering it so to your consumers-to your purchasers?

Mr. Jamison. Not as a wholesale dealer; no.

The Acting Chamman. I will ask Judge Springer, is there anything that will prevent the retail dealer from removing the article from the package?

Mir. Springer. Nothing but the law. The penalties of the law would prevent that.

Mr. JeLKe. May I ask Mr. Jamison one question? Do you handle renovated butter?

Mr. Jamison. We do; but nobody wants it.

Mr. Knight. Mr. Tamison, do you handle ereamery butter?

Mr. JAMISON. We do.

Mr. Knight. Do you handle ladle butter?

Mr. Janison. Very little. That is another thing they do not want.

Mr. Knight. Do you handle dairy butter?

Mr. Jnirsor. We get no dairy butter of any consequence.

Mr. Knigut. Do you handle packing stock!

Mr. JAurson. Whenever' we can get a consignment, but not often.

Mr. Tillinghast. I want to ask the gentleman if he has any information as to the amount of oleo that there is sold in the State of Pennsylvania?

Mr. Kauffmax. I will answer that.

Mr. Jamison. Mr. Kaufliman has the figures.

Mr. SPRINGER. 11,000,000 of pounds.

Mr. Scheld. Mr. Chairman, I think yon will bear me out in stating that I have been very patient, and have interrupted but rery little, and have always been the last one to ask questions.

The Ciraminan. That is true.

Mr. ScneLL. The point I want to make now, while all these gentlemen are here, and one on which I think I have a right to insist, is that they go on record before this committee as to their attitude toward colored oleomargarine. That is, I want then to state whether they want to drive it entirely out of the market or whether they are willing that it shall be sold for what it is, if it can be sold for what it is.

Mr. KaUfFMAN. I will answer that question.

Mr. Schell. Now, they have been headed off; they have not been allowed to answer it. I would like them to say for themselves.

Mr. KaUfman. I will answer that question.

Mr. SCHELl. I know; but we do not want your answer. 
Mr. Kauffuan. I represent them all, and you can put all the questions to me you want to put.

The Acting Chairuan. There has been no restraint upon questions.

Mr. Schell. No; but when I ask the question this gentleman says he will answer it.

Mr. Kauffuas. You are just taking up my time, sir.

Mr. Schell. No; you are taking my time. I should have gone on to-day.

Mr. Kauffian. No; you are trespassing upon my time.

Mr. Jaunson. I have no objection to answering that question. Personally, I have no objection to colored oleomargarine as colored oleomargarine. The fact is that butter is sold white. The highest priced butter made in the United States is sold white. It goes to New York City, Philadelphia, and the best parts of the United States. The color question is immaterial. It varies in every State and in every market. All we want is a law which will compel oleomargarine to reach the individual as oleomargarine. I donbt very much if there is a manufacturer of oleomargarine, a jobber, retailer, or anyone else who would eat oleomargarine himself; but he will sell it to other people for them to eat.

Mr. JELKe. I serve it on.my table to my family every day, and every man in our employ takes it home for his own use. Mr. Brown. the president of our company, has used it for years on his family table, and prefers it to butter.

Mr. JAuIson. Well, that is a vitiated taste.

Mr. Drennan. Gentlemen, as long as it is sought to make a point here about colored oleomargarine I have no objection at all to going on record. If you will give me a law which will compel every man to sell these goods for exactly what they are I have no objection to the color; but, then, that is not the point. They know just as well as they know they are asking the question that it can not be done.

Mr. Kinght. That is the point.

Mr. Schell. We are only asking if you would have any objection if it can be done.

Mr. Drexnan. I stand here to contradict you. You know it can not be done; and you are trying to drive us into a corner. You know that as long as those groods are colored they will be sold for butter, and don't you forget it. I know it, too.

The Acting Chamrinan. Order, gentlemen.

Mr. Drexnan. I want to state emphatically that my experience for twenty years has been that as long as those goods are colored they will dodge any law under heaven. You talk about the revenue law! The revenue agency in our city pays no attention whaterer to the enforcement of the law. If a man is found selling oleomargerine without a license they will simply ask him to go and take one out. They say, "Go and take out your"license," and that is the end of it.

Now, you talk about a certain law called the Wadsworth law. It is no better than the present revenue law, and not half as good as the present law.

The Acting Chamman. We will now hear Mr. Kauffman. How long a time do you want, Mr. Kauffman?

IIr. Kaufrian. I want to have all the time you can give me. I do not want to trespass upon your patience, however.

The Acting Champin. Are you ready to go on, Mr. Schell. after this gentleman is through? 
Mr. Scrielu. I am ready at any time, Mr. Chairman.

The Acting Crumman. I wonld like to hear this gentleman, and also to hear you, to-day.

Mr. Kaufranan. How much time have we left?

The Acting Cimarman. It is now quarter to 4 o'clock; and if we close our session at 5 , that will leave us an hour and a quarter.

Mr. Kaufruan. Whenever you have heard enough of me, just tell me to stop.

The Acting Chamman. We do not like to do that. Proceed, Mr. Kauffiman.

\section{STATEMENT OF LUTHER S. KAUFFMAN, ESQ., ATTORNEY FOR THE PURE BUTTER PROTECTIVE ASSOCIATION, OF PENNSYLVANIA.}

Mr. Kauffuax. Mr. Chairman, first let me say, in order that you may know that I am speaking from experience and with authority, just who I am and just what I represent, and what experience I have had in relation to oleomargarine.

I am the attorney of the Pure Butter Protective Association. My experience in this matter dates back to November, 1890. At that time I was retained by the butter dealers of Philadelphia-these gentlemen, my clients then as now-to enforee the law against olcomargarine in the State of Pennsylvania. The law then (that of May 21, 1885) was an absolutely prohibitory law. That law had been passed in the State of Pennsylvania because although two prior laws had been passed, one in 1878 and an amendment in 1\$S1, which permitted the sale of oleomargarine and butterine if properly marked, they had been so utterty inefticient to restrain the illegal sale of oleomargarine that the legislature of Pennsylvania, in the exercise of its judgment, passed an absolutely prohibitory law on May 21, 1855, absolutely prohibiting the manufacture and sale of oleomargarine in the State of Pennsylvania.

In 1890, when I was retained by the butter men of Philadelphia, I found just this-that the whole city was filled with oleomargarine. We organized a detective force, and sent them out, and we found that there was not a pound of oleomargarine, as far as the experience of the detectives was concerned, which was sold as oleomargarine. Everything was sold as and for pure butter, at pure-butter prices, in unmarked packages.

Now, mark you, gentlemen of the committee, at that time, in 1890, this very law which you are trying to amend, that of August 2, 1886, had been in existence for four years. The law provides, you understand, that every retail dealer in oleomargarine, when he receives his oleomargarine from the factory, shall sell it out of a stamped package. He must make up his new wooden or paper package, and mark it clearly, in letter's, the size of which is defined lyy the act, "Olcomargarine," one-half pound, or 1 pound, as the case may be. Then he must put his name and address thereupon, to the end that everybody may be advised that what he is selling is oleomargarine. and not butter.

Now, I say that law had been in force for four year's. The penalties provided for under it were drastic. For every violation of that act, the law provided that there should be imposed a fine not exceeding $\$ 1,000$, and imprisonment for not exceeding two years. It was a 
dreadfully drastic law. One would suppose that the retail dealer's would not dare to violate a law with such penalties, a fine and imprisonment, with no diseretion at all in the courts. But they did violate it, and apparently with impunity, with utter defiance of the law; and the conseguence was that when I began, as the attorney for this association, to bring the prosecutions in the State courts, I also went to the United States court. Now, I want to show what the operation of the United States law was.

Mr. Springer. Excuse me-were those the penalties of the State law or of the national law?

Mr. KaUfFuas. I said both. I am going to talk about the national law now.

Mr. Springer. But were the penalties to which you refer those under the national law?

Mr. Kauffuan. I refer to violators of both. When you violate the State law. you also violate the United States law.

Mr. Springer. But I refer to the serere penalties.

Mr. Kaufruan. Oh, those are the penalties of the United States law; yes, sir. Under the State law the penalty was fine or imprisonment, at the discretion of the court; whereas the present law of August 2,1856 , which is proposed to be amended, makes the penalty fine and imprisonment. I refer to seetion 6 .

I went to the revenue authorities in 1891, and I ealled their attention to scetion 6 of that law. There never had been, in the eastern district of Pennsylvania, any prosecution by the revenue authorities for violation of that aet, although it had been in existence for four years. We presented a lot of evidence of violations of that United States law to the revenue officers, and they absolutely refused to swear out the warrants. I was compelled to come over to the Secretary of the Treasury, at that time the Hon. Charles Foster, of Ohio; we had to summon the Commissioner of Internal Revenue before us; and we eompelled the Commissioner of Internal Revenue to issue orders to the revenue agents in Philadelphia that evidence should be received and the warrants sworn out. They did not do it until we did that very thing. Then, when the eridence was submitted, the officer's performed their duty, and we convicted and sent to jail the men against whom we brought the evidence: and that stopped the illegal traftic in the city of Philadelphia. We drove the retailers out of the business. We created the office of dairy and food commissioner of the State of Pennsylvania in 1893, and then that association, at that day, went out of business, beeause this department had been ereated to accomplish the sime end.

Now, to show you how frandulently this traffic is earried on, not quite two years ago these gentlemen eame to me, in February of 1899, and said: "Our butter trade in the eity of Philadelphia is absolutely paralyzed. We can not sell our butter in midwinter. It is coming into the market and going to the cold-storage warehouses, and we can not sell it. Why? Because the oleomargarine dealer's hare come into this market, and absolutely taken possession of the market. and are selling oleomargarine as and for butter, and pure butter can not be sold." Is not that true, gentlemen?

Again we began to enforce the law; and we put our detectire force to work, and I am going to show you the results of it here, the cases that we found. 
We found again, in February of 1899, with this same United States law still in foree, not a dealer in oleomargarine in the city of Philadelphia but who was selling oleomargarine as and for butter; and the detectives went out and paid butter prices for it, paying as high as 40 cents a pound for oleomargarine bought as butter.

I have the cases here. There [exhibiting paper] is the list of cases, with the date of purchase and the name and address of the party. These are purchases made during that time by this association. There they are, right straight along, page after page-more than 500 cases of purchases of olcomargarine in the city of Philadelphia. I am going to give you a summary of them. There are in this list more than 500 cases of purchases of oleomargarine in the city of Philadelphia. The deteetives, in every single case, without exception, asked for butter; and they got oleomargarine at butter prices, without any indication from the seller that it was oleomargarine. There you have a frand directly upon the purchaser.

Now, let me give you a summary of these cases. How many were marked? There are 508 cases here. I have the details there. I am not talking about fupposititions cases. Every case is there, with the name and date and the result. These detectives went into these places, places kept by men who were supposed to be selling oleomargarine, and who had paid revenue taxes. They asked for butter. Five hundred and eight purchases were made. Of those 508 purchases, 49 were butter and 459 were oleomargarine.

Gentlemen, I have have heard a great many theories, but one ounce of fact is worth tons of theories. That is a fact. There was not a single case of oleomargarine sold as oleomargarine. Of this large number of purehases there were marked surreptitiously, marked on the paekages inside, marked with the word "olromargarine" turned down, perhaps 50 cases. Oh, if I were to go on to tell you the trickery, the fraud, the schenes resorted to to deceive the purchasers, I could talk to you bere for two hours. But I will not go into such detail. The simple statement of the matter is that every one of these purchases was made as butter, while out of 508 purchases only 49 were butter and the balance were oleomargarine.

Now, then, is it true that if you simply have a color clause, they will obey the law! No. Why! 'Just as the Good Book says, "The love of money is the root of all evil," and that applies to this oleo traftie as much as anything else. When a retail dealer ean get oleomargarine at 11, 12, or 13 cents a pound, and can go out and sell it for 30 and 35 cents a pound by lying, by deceiving the public, the temptation is greater than poor human nature can bear, and he does it. Why, there in the city of Philadelphia, Mr. Chairman, before we began this crusade a year and a half ago, there were hucksters with no capital whatsoever, having an old horse and an old wagon. who would buy olemargarine from the wholesale dealers at 14 and 15 cents a pound, and go among our citizens, represent themselves as farmer's from Bucks and Chester, our adjoining counties, get up a butter route, and sell this stuff as butter, as if they were from the farms. They would sell 1,000 pounds a week, on which they made an average of from 10 to 15 cents a pound profit. You can see what they did. A thousand pounds at 10 cents would be $\$ 100$ a week, with a eapital of $\$ 200$ or $\$ 300$ invested.

How in the world ean anybody compete with men who can buy stuff of that kind and sell it fravdulently? 
Now, let us look at this thing for a moment, and see where we stand. I think the very statement of this fact shows the fraud in the retail trade. Are the wholesalers any the less to be censured? Let us see.

We have driven lots of these poor fellows out of the business. When we lregan this crusade in 1599,162 retail dealers in the city of Philadelphia had paid the special revenue tax. Now there are about 32 for this year, and the rest are ont. Some we have put in jail, some we have fined very hearily, and the rest ale ont of the business. I could connt seores of men who have been selling oleomargarine who are no longer selling it. 'They have learned that the way of the transgressor is hard, and they do not sell it.

Now, let us look to the wholesalers. In the first place, the wholesalers, to help the retailers to defrand in this matter, do what? Why, some of these wholesaler's adopt fancy creamery names for their product. "Lakeside ereamery!" Where is the creamery? "Lakeside creamery!" Oleomargarine! But the word oleomargariue is not left on it. The only place where the name "oleomargarine" appears is in the Government stamp. And then what? Why, these honest manufacturers, desiring to spread the sale of an illegitimate article of production that everybody may know, go to work and cover the original packages, when they ship them from Chicago, with brown-paper corcring. They put them in bags, in hurlap, covered all over; and this product comes to Philadelphia so that nobody sees the Grovernment stamps at all. And one mannfacturer goes to work and puts up tenpound packages, and puts half a dozen of them in a crate, and ships them in, and puts the Gorermment stamp on the bottom of the erate, so that the public will never see the Government stamp.

They put the oleomargarine in such a shape, understand, that the retailer can go to work immediately and sell it as butter. There is not a mark upon it, as far as the wholesaler is concerned, inside.

Now, you asked me the question. Mr. Chairman, and my friend here has asked the question, whether or not, if we will put it in the original package, they can sell it in that way. Now. we say, if you mannfacture oleonargarine in the semblance of butter, there is no legislation whatsoever that will prevent the retailer, if disposed to he dishonest, if disposed to sell butter at butter prices, from effacing the marks, and selling it as butter. There is only one thing that will accomplish the result we are seeking, and that is to make the color of this material so distinctly different from that of genuine butter that the purchaser, when he sees it, will instantly see that it is not pure yellow butter. That is the only thing.

Now, if, according to the Wadsworth bill, oleomargarine shall be put up in these 1 and 2 pound prints and colored and sent on, what will happen? The Wadsworth bill provides for another fatal thing, and that is that each one of those little packages, 1 pound and 2 pounds, is to be an original package. What does that mean, gentlemen? It means a great deal more than at first sight might appear. If it is an original package, then there is no let or hindrance to selling it anywhere in any State. becanse of the interstate-commerce law. That is exactly the bone of contention. If we had not that interstate-commerce law to contend with we could prevent the sale and the manufacture of oleomargarine in the State of Pennsylvania. But the very defect of our old prohibitory law was that the manufac- 
turers from Chicago could sell their material into the State of Pennsylvania becanse it was an original package. Now, if you pass the IV adsworth bill reducing the size of the original packages to 1 and 2 pounds, it will simply open wide the door for the sale of oleomargarine in original parkages of $1 \mathrm{or}^{2}$ pounds; and no law of any State could interfere with its sale under any circumstances.

Why, this Wadsworth bill would be vastly more damaging than any legislation that Congress could enact in relation to this subject. It would thoronghly and absolutely establish the oleomargarine trade in this country, and no State conld interfere with it in any way whatsoever.

Mr. Knignt. Colored oleomargarine, if you please.

Mr. Kaurbuan. Yes; colored oleomargarine.

Now, gentlemen, let us look at the facts. Who are asking here for the passage of the Grout bill, and who are opposing it?

The gentlemen on the other side say that we are interfering with their trade. Why, the shoe is just on the other foot. It is the oleomargarine business that is interfering with the butter trade. The butter trade was here long before the oleomargarine men were here. The butter trade has been here since the country has been here. The oleomargarine interest has only sprung up within the last twenty-fire years. It is they who are interfering with the butter trade, not the butter trade interfering with the oleomargarine trade by any means.

What do we ask! Wre ask that the Congress of the United States, having recognized oleomargarine as a legitimate article of traffic, shall simply prohibit the sale of a fraudulent article in semblance of butter.

Who asks for that? The dairymen of the United States. Who are they? The farmers, the creamery men of the United States. What does that interest amount to? Why, I have some figures here from the report of the Department of Agriculture for 1899 which show that there were last year 11,000,000 cows in the United States in the dairy industry, and that the product of these $11,000,000$ cows anounted, in round numbers, to $\$ 500,000,000$.

In my State of Pennsylvania we have a thousand creameries. There are, on an arerage, a hundred farmers who are the patrons of those creameries, delivering milk to them every day; that means 100,000 farmers are interested in the production of butter in my State of Pennsylvania. These 100,000 farmers added to their fellows all through the United States constitute a rast army of producer's asking for the passage of this bill to prevent a frandulent article from interfering with a legitimate product.

Now, who is on the other side? Seventeen manufacturers.

Mr. KNight. Twenty-six now, Mr. Kauffiman.

Mr. Kaufrian. Well, that is under the late law. The last report I had gave the number as 17.

Mr. JELke. Allow me to correct you, Mr. Knight. There were 25 the 3oth of last. Inne, and there are now more-I do not know how many more.

Mr. Kaufranan. Well, I will take the best statement for them. They can make it 27, or, say, 30. Suppose there are 30 men with unlimited capital, largely confined, three-quarters of them, to the cattle slanghterers of the W' est. These few men, as against the great army of producers I have named, come to you and ask you for protection for a counterfeit article. That is all there is to it. We say that men are worth more than money. We say that this great army of pro- 
ducers through the Unitod States is more to be considered than ac'olmulated capital in the hands of a few men. We say that these producers of the genuine article have a right to protection against a fraud which seeks to dig away the very foundation of legitinate traftic.

Let us look at this thing for one moment. Counterfeit money is manufactured in this country. It is a counterfeit. It employs labor: it employs paper; it employs ink; it employs presses to manufacture it: and as far as the money is concerned, if the man who gets it belieres it is genuine, it is just as good ats good money. If you get a counterfeit ten-dollar bill, and you can buy something with it or pay a debt with it, it is just as good as genuine money. It is good until it is found out that it is not genume money; and the moment it is found out that it is counterfeit, then it ceases to be good.

Suppose the comterfeiter's of this country should so increase their business, by reason of eapital, that they should come to this Congress and say: "We demand protection, because we have got money invested in this thing and it is profitable. We are employing so many men: we are using so much manufactured paper; we use so much ink; we use so many presses, and we demand protection for counterfeit moner because there is money in it.'

That is the only reason oleomargarine manufacturers can come here and demand protection for a fraud, because there is money in it. Now, it is not right. All the butter producer's of this country want is protection against a fraud. That is all.

Now, IIr. Chairman, rou hare heard this morning about oleomargarine being healthful. We say that that question is in doubt; but we do say that if any man helieves it to be healthful. and wants to buy oleomargarine and use it, believing it to be healthful, he ought to have a right to do it; but as to its being healthful, that is a question in doubt. Will you pardon me for a moment if I read to you from a Gorernment authority as to that, beeause you must understind just what this produet is. Permit me to read to you from this Gorermment report:

[At this point Mr. Kauffman read from a paper on "Butter substitutes," by E. A. De Schweinitz, of the Biochemic Lahoratory, Bureau of Animal Industry, the same being reprinted from the Yearbook of the [Tited States Department of A griculture for 1895.$]$

"The point next to be considered is the possibility of the tramsmission of infectious diseases by oleomargarine made from impure nuaterials. That such can occur is undoubtedly true. A comparison of the germs present in oleomargarine and butter showed three timen as many in the one as in the other, with a difference in the charater of the germs. The germs in the butter were the harmless ones found in milk and necessary for the production of a good butter. Those in the oleomargarine were fungi and numerous varleties of bacteria.

"The writer has made a number of inoenlation experiments upon guinea pigs with different samples of oleomargarine. The samples were purchased in open market, near the places where they were manufactured. Sample No. 3 (102) proved fatal, causing the diath of the animal in the one instance in two months, in the other in two weeks. An examination showed the lungs congested, the liver soft and pale one of the kidneys badly congested, and fire distinct uleers in the intestines like typhoid-fever ulcer's. The bladder was distended and urine alluminous. At the present writing the nature of this disease has not been determined, lnt the fatal eflects were produced ly the 
oleomargarine. Another guinea pig inoenlated with a sample (No. 1) of oleo oil, taken from a lot used in the manufacture of oleomargarine, died within three weeks, the autopsy showing badly eongested lungs, liver dark, blood vessels congested, and the small intestines containing bloody mueus."

Mr. Springer. Would not the effect have been the same if you had inoculated these animals with creamery butter?

Mr. Kauffuan. No, sir. Now, I submit, Mr. Chairman, that if oleomargarine bought in the open market has that effect upon guinea pigs it will have the same effeet upon human beings.

Mr. Mrller. May I ask a question!

Mr. Kauffuan. Certainly, sir.

Mr. Milfer. How about the 150,000 people who die every year from tuberculosis, and how about the large number of cases where it is eaused from eating butter and drinking milk, and so forth?

Mr. Kauffuan. I will answer that question. How about the large number of people who die from diseases that come from eating oleomargarine when they do not know any thing about it?

Mr. Miller. There are none.

Mr. Kauffuan. None? [Laughter.] There are lots of people who die every year of tapeworm and similar diseases transmitted by oleomargarine.

Mr. Miller. Mr. Kauffiman, do you not know that the oleo oil and neutral lard of which butterine is composed are heated to such a temperature that it kills the germs? Do you know that?

Mr. Kaufruan. No, sir; I do not know that, because it is a cold process.

Mr. Mrtuer. Well, Professor Wiley, of the Agrieultural Department, says it is true. He ought to know. I think he is an anthority; don't you?

Mr. Kauffuan. Well, Professor Heffman, of Philadelphia, who is equally an authority, says just the opposite-that the process is conducted at such a comparatively low temperature that it does not kill the germs. And that is one of the difficulties in the manufacture. It is a cold process. Why, the very process you start from is a cold process, and you do not heat the materials above $120^{\circ}$ Fahrenheit.

Mr. Millek. Well, we have to take the opinion of the man who is considered the best scientist in the United States.

Mr. Kaufruan. Now, let me say another thing, Mr. Chairman. When the opinions of ehemists are given we must remember that chemists are not physiologists. Chemists ean tell you what the constituent parts of oleomargarine are; but not being physicians, they are not eompetent to tell what the physiological action of oleomargarine is. Now, then, we have in Philadelphia a chemist, Professor Hefliman, who is both a physician and a chemist, and he says that the question of the healthfulness of oleomargarine is as yet undetermined. He is both a chemist and a physician. The fact of the matter, then, is that the hest that can be said about the healthfulness of oleomargarine to-day is that it is not yet determined positively. The facts are that the opinions of chemists, as a rule, as presented by oleomargarine factories, are based upon samples of the very best oleomargarine they produce, and it is not the ordinary oleomargarine that is sold in the market. Therefore that aceounts for the difference between certain statements. When the oleomargarine men want to have a nice state- 
ment they make up the very best sample of oleomargarine they have got, put into it a certain percentage of butter in order to make it as near like butter as possible, take it to a chemist, and ask him to analyze it; and of course it is good. But go out in the open market and buy the oleomargarine that is sold in the open market, and the results are entirely different from the analysis of the chemist on a special sampleentirely different.

Now, Mr. Chairman, we oppose the sale of oleomargarine when colored in imitation of yellow butter because the temptation is constantly to sell that article as and for butter, and the temptation is too great for ordinary human nature to resist, because of the money in it. And the better the price that butter brings, the greater the temptation. But now we say, "Add 10 cents a pound to the price of this product in the shape of a tax, and there is not so much temptation to make that money." Why should not 10 cents a pound be added to it? Why do we pass our protective-tarifï bills? Why do we impose protective tariffs upon products brought from foreign countries except to give protection to our American industries? Here is an industry which competes with another industry that has been established for year's. Why ought not the farmers who have been in this industry, these farmers whose all depends upon the butter trade, to have that protection?

Now, what can our oleomargarine men complain of? They have their choice. We say to them, "If you want to color" oleomargarine and compete with butter, then pay 10 cents a pound to the Gorernment for that privilege. If you think that money ean be made by selling colored oleomargarine, pay a revenue tax of 10 cents a pound for it, and come in on equal terms, in a fair competition in the market, and sell your product. But if you think that that is too big a tax, you are not compelled to pay it. Then manufacture your uncolored oleomargarine and pay a quirter of a cent a pound for it. "Tou pays your money,' as the Dutehman says, 'and you takes your choice;' that is all."

If oleomargarine is a healthful product, if the people want it, the matter of color has not anything to do with it. If people want oleomargarine they will buy it as oleomargarine without the color. They are not eating color. They want oleomargarine, we are told, hecause it is such an absolutely healthful and nutritious article. It is better than butter, as our friends maintain. They prefer it to butter, as our friends maintain. Then, for hearen's sake, let the people have it at this reduced price. Let them get this very superior article at a price that is within their reach; and let these manufacturers spend their millions to advertise the advantages of this delightful and superior and healthful article, and to induce people to buy it instead of the vile butter!

That is what they ought to do. Why, we do not interfere with their rights, Mr. Chairnian. All we ask them to do is to manufiacture good goods-to manufacture oleomargatrine out of good materials. Do not put any color in it. Sell it for oleomargarine. Teach the people that oleomargarine is better than butter. Sell it as oleomargarine. and not as butter. But if you do not want to do that, put your coloring in, and pay the Govermment 10 cents a pound for it. "Come in and sell it as oleomargarine, colored, and come in free competition with butter-a free and fair fight for all. 
Mr. Timunghast. Will the gentleman permit a question?

Mr. Kauffaran. Certainly.

Mr. Tiluinghast. Do you say that we could sell colored oleomargarine in the State of Pennsylyania by paying the 10 cents extratax, if we so desired?

Mr. Kaumbian. Not under our present law; no, you could not. has.

Mr. Drennan. You would have as much profit as the butter man

Mr. Tininghast. But we would have no right to sell colored oleomargarine in your State, in any erent.

Mr. Kaufrman. No, sir; and we do not propose that you shall have the right to sell it there, either, as colored oleomargarine. But that is not the question. There are States where you can sell it.

Now, let me call your attention to the question of desire to obey the law. According to the statement made by somebody here this morning, 107,000,000 of pounds of oleomargarine are manufactured annually in the United States. Where is it sold? Why, it is on the stands everywhere. It is sold-where? Largely in the States prohibiting or restrieting the sale of oleomargarine. How is that? Simply because the men who sell this stuff are law-defying and not law-obeying men; that is all. These manufacturers, these dealers, know that it has been against the law to sell oleomargarine in the State of Pennsylvania in years gone by, becanse of the prohibitory law. They know that it is against the law to sell oleomargarine now in the State of Pennsylvania, and yet they defy the law. WFould law-abiding men do that?

Mr. Springer. Will the gentleman allow me a question right there?

Mr. Kauprian. Certainly.

Mr. Springer. I think he ought to take into consideration the fact that in the State of Pennsylyania, up to the passage of the present law in May, 1899, the lawyer's and the courts disputed the question as to whether this legislation was constitutional or not, and the seller's of oleomargarine were adrised on the one hand that it was not a valid law: and those who took that position were finally sustained by the Supreme Court of the United States, in the Shallenberger case, which decision declared that that law was invalid. Then the legislature passed another law. So that those people who you say were violators of the law up to the act of May, 1899, were not violating any law at all, as the supreme Court has since held.

Mr. Kaufran. Well, sir, I must correct you. You are simply misinformed about the decision. Let me say that in the State of Pennsylrania, under the law of May 21, 1855, the situation was this-and I had the honor to earry the fight all the way up to the higher courts: The supreme court of Pennsylvania and the Supreme Court of the United States held that the law was perfectly constitutional in so far as it related to the retail dealer's of the State of Pennsylrania, but that it was only unconstitutional in so far as it related to the original packages manufactured in another State and coming into the State of Pennsylvania. It only affected the wholesalers-not the retailers. I argued the question before our State courts; and our supreme court affirmed the constitutionality of the act also in relation to the wholesale dealers. But there nerer has been a time, since the passage of that law of 1885 , when, so far as the retail dealer's were concerned, it was legal for oleomargarine to be sold. 
Mr. Grout. It was the intelstate commerce point that the case was decided on.

Mr. Kivffuan. That is all.

Mr. Springer. Every pound of oleomargarine that was sold from 1885 to 1899 in the original package was legally sold.

Mr. Kaufruan. It was legally sold, yes, except that our State supreme court had decided otherwise. I argued the question before the supreme court, and they decided my way; but that decision was reversed in the United States Supreme Court. Still, the retail sale was always and has always been regarded as illegal; and even the Supreme Court of the United States, in that decision in the case of the Commonwealth v. Shallenberger, affirmed the fact that the law was constitutional as far as the retail dealers were concerned.

Mr. KNight. Will you pardon an interruption?

Mr. Kauffuan. Certainly.

Mr. Knight. Did you ever know of any kind of an oleomargarine law being passed the constitutionality of which was not questioned by the oleomargarine dealer's?

Mr. Kauffinas. Not one.

Mi'. Springer. 'They have a right to question it, too.

Mr. Knight. Well, have they the right to go on and do business while questioning it?

Mr. SPRInger. They have a right to go into the courts and ask for the decisions of the courts, and abide by them.

Mr. Kauffian. Yes; but they have not any right, as it seems to ne, when a law is enacted, to keep on defying the law until the law is passed upon. A man has not any right to carry on a manifestly illegal husiness when it is prohibited by law. It is his business to stop carrying on that business until the courts decide the disputed question.

Now, then, Mr. Chairman, this act, the Grout bill, particularly remedies this original-package feature. Mark you, the Wadsworth bill distinctly makes the 1-pound and the 2-pound packages original packages. If that provision were to pass - and that is the riciousness of the Wadsworth bill-it would absolutely and positively prevent any State from passing any law in relation to oleomargarine, because the packages are cut down to 1 and 2 pound packages, and under the interstate law nothing whatsoever could be done in the States to restrict their sale. Where would we be then? What is the effect of olconiargarine upon these butter dealers and these farmers? Let me tell you.

As I said a little while ago, in February of 1899 the butter trade at Philadelphia was absolutely paralyzed. 'The dealer's here will testify to that fact. We began to enforce the law which we had. Now, what was the result? We have advanced the price of butter in the city of Philadelphia, in the wholesale market, on an average of 5 cents a pound orer what it was two years ago, before we began to enforce this law, simply because we have driven out the illegal sale of oleomargarine. More than that, the price of cows in the State of Pennsylrania, because of the driving out of this illegal competition of oleomargarine, has adranced from 25 to $t 0$ per cent. If oleo had been permitted to remain in the market, being sold illegally as and for butter, the price of farms would hare kept on going downward, the price of cows would have kept on going downward, and the price of butter would have been going downward. Now, I am going to say, 
further than this, that in the years gone by, from 1895 up to 1899 , numbers of creamery men were driven out of business because of the competition of oleomargarine - driven clean out of business; and it is only in the past two year's that the tide has changed.

Mr. Sreninger. Do you think that $t$ per cent of the whole product will materially interfere with a business that amounts to two billions of pounds annually?

Mr. Kaufriman. Oh, I will answer that question. I was shifted ofl from what I wanted to say. Where is oleomargarine sold? There are $107,000,000$ pounds nanufactured! Where is it sold? In the States where the restrictive legislation has come in. In the State of Pennsylvania not less than from twelve to twenty millions of pounds are sold, in defiance of both United States and State law; and they are sold as butter-that is where this stuff is sold. Why do not these gentlemen sell it otherwise? They come into a dairy State in defiance of law, and sell it there. How do I know?

The Acting Chairman. You say 12,000,000 pounds of butter are manufactured in your State. Is that it?

Mr. Kaufrman. No; I say sold in our State.

The Acting Chambian. Do you mean butter, or oleomargarine?

Mr. Kaufriran. Oleomargarine. I say there are about $12,000,000$ pounds of oleomargarine sold in our State. How do I know that?

Mr. Drensan. Why is so much sold there, and so little sold in New York?

Mr. Kauffuan. Mr. Flanders has gone, but I will tell you why. Beeanse the laws in our State have not been enforced as they ought to have been.

Mr. Grout. And yet you are making an appropriation of $\$ 60,000$ a year to enforce the law?

Mr. Knight. Two hundred and forty thousand dollars a year, Mr. Grout.

Mr. Grout. Not for this law alone.

Mr. Kauffian. No.

Mr. Grout. There are $\$ 60,000$ a year, as I understand, appropriated and assigned to the enforcement of the oleomargarine laws in New York; and that has been the case for half a dozen years or more.

Mr. Kauffinn. Tes, sir; but in our State there was an appropriation of $\$ 12.500$ a year, which makes all the difference in the world, of course. Then there were some disputes as to the construction of the law, ete. But the laws, for some reason or other, were not enforced; and because of that the oleomargarine manufacturers simply flooded the States with their agents, who have proceeded to induce small dealers to embark in this business. I have been told, over and orer again, by retail dealers who have come to me begoing for merey, "We have been led into this thing. The wholesalers have come to us and said, "You can go into this business; the law is no good; you can go into it with perfect safety and we will take care of you, and pay all your legal costs, and your fine. Go into the business." "And because of the profits, and these people not knowing any better, they are led into it by the wholesalers. They furnish them the stamps and tell them all the schemes. Why, I have in my office an application given to me by a retail dealer. who brought it to me, and said that a wholesaler had given it to him, and said, "Now, go to work and make out your application for the revenue license in the name of some 
creamery company." Oh, there are lots of "cleamery companies" not handling a pound of pure butter in Philadelphia. There are not so many of them as there used to be, because some of them have been put in jail and fined, and we have driven some of them out. But these wholesaler's come and induce these poor fellows to go into the business, because they think that the law will not be enforeed and they will be protected against prosecutions.

Mr. JELKE. Will you permit a question?

Mr. Kaufrian. Certainly-a dozen of them.

Mr. J ELkE. What stamp is this that the mannfacturers use?

Mr. Kaufwuan. The manufacturers would come and give them a revenue stamp, and show them how to use it, and tell them how they might use it.

Mr. JeLKe. What was on the stamp, please!

Mr. Kauffuan. "Oleomargarine"; and then they go to work, as was the case with one fellow we convicted before the United States conrt only last term, and tell them how to violate the law.

Mr. Jelre. Was the stamp made in accordance with the law-the proper size, and so forth?

Mr. Kaufruan. Oh, yes, sometimes-sometimes.

Mr. Springer. It is not the tax stamp?

Mr. Kaufruan. Oh, no-not what is ealled the tax stamp. It is the stamp that the present United States law requires to be put right on the wrapper. Now, to show you one of the schemes they have got to deceive people, to show you just how deceptive they are, there was one dealer in Philadelphia who thought he was very sharp. He went to work, and he put the stamp right across that corner [indieating]. Then he folded it down in that way [indicating].

Mir. Grout. Oh, he folded it very many more times than that - he folded it in three or four times.

Mr. Kaufruan. Yes; he did. Our people would go in and ask for butter, and they would get "butter;" and when they would go ont and look it over they could not find any thing about oleomargarine upon it until they tumed down the corner and looked underneath there, and then they found the wold "oleomargarine" hidden away there. And we convicted that fellow because, although he supposed his little scheme complied with the law, the courts differed with him.

Mr. Scurel. Would that customer go back to that store, do you think?

Mr. Kauffuan. It does not make any difference whether he would do that or not; he was deceived, and he was defrauded-willfully deceived and defranded-because the very fact that the dealer had the acuteness to do that showed that he intended to do it.

Now let me show you another trick. Oleomargarine is wrapped in parchment paper or thin paper. There is another dealer in the city of Philadelphia (he is doing it now, and we are going to convict him before the United States court) who goes to work and stamps on this thin paper "Oleomargarine." He puts that stamp right next to the oleomargarine, in that way [indicating]. The moisture in the oleomargarine absorbs the stamp, and by the time the purchaser has it in his possession for a few minntes you can not see it unless you hold it up to the light, and then you can see very faintly "Oleomargarine." It is so faint as not to be discernible.

Why, it is deception on the face of it. And that is only one of a 
multitude of schemes by which these oleomargarine dealers try to comply with the law, technically, and yet deceive the people. It is fraud from the beginning to the end.

Now, then, we urge, Mr. Chairman, that this Gront bill shall be passed, for two reasons:

First, that it will prevent fraud-that is all. If the oleomargarine dealers are honest in their desire to push a legitimate product, we say that they can sell oleomaroarine on its merits, pure and simple, and adrertise it and create a demand for it. If they want the adrantage of having oleomargarine colored in imitation of yellow butter, if they think that will make the sale better, then they ought, because their product costs so much less than ours, just as foreign goods are put on a par' with ours, to pay to the Government of the United States such a tax as to make it an equal and fair competition.

Mr. Springer. Pardon me. If you ean sell oleomargarine on its merits without color just as well, why not sell butter on its merits without color?

Mr. KaUfFuan. Well, there are a great many men who do.

Mr. Springer. It does not come out with a much better color than olcomargarine, as I understand.

Mr. Kauffuan. No; and there are some men who sell purely white butter. I think some gentleman on the committee this morning ealled attention to the fact that some of the first-class hotels are serving white, unsalted butter. That is simply a question of taste. But the whole question that is at stake in this matter is not a question of taste; it is a question of legitimate trade and fraud.

Secondly, there is the question of allowing to the States that jurisdiction, as a police measure, orer the sale of oleomargarine which of right belongs to them. As it is now, understand, the present act of August 2, 1886, having recognized oleomargarine as a legitimate article of commerce, the States are prevented, by the interstate-commerce law, from passing any legislation which would interfere with the original packages coming in.

All we ank is that this act shall be passed so as to prevent fraud, and to put the oleomargarine dealers on a parity, in competition, with the dairgmen of this country. If they will come in on equal terms, if they will pay to the Government this revenue tax of 10 cents a pound, then the dairymen of the country have gota fair chance with them.

Now, gentlemen, I am ready to answer questions. I will stop talking now.

Mr. HABECKER. I would like to ask you whether there is any moral law in this matter, aside from any legal law.

Mr. Kadffman. Moral law?' Yes; there is a moral law-that "Thou shalt not rob thy neighbor." If a man sells oleomargarine for butter, he is robbing his neighbor. That is immoral.

Mr. Schell. Right on that line, then, let me ask you the question which I raised originally, and which some of your people did not answer. (Mr. Sharpless, howerer, wants to place hinself on record on that subject presently.) Is your attitude one of extermination-

Mr. Kauffian. No, sir.

Mr. Scrisul (continuing). Of colored oleomargarine, or is it merely to prevent its being sold as butter?

Mr. Kauffuan. I thought I had made myself clear about that.

Mr. Scheis. No you dirl not touch on that point. 
(Mr. Tillinghast rose.)

Mr. Kauffuan. Now, let me answer one at a time, for I cun not answer more than one at a time. I will answer every question $1 \mathrm{am}$ asked, gentlemen. Oleomargarine does not cost the imanufacturer to exceed 8 cents a pound to produce.

Mr. Mrluer. How do you know that, Mr. Kanffman!

Mr. Kauffunas. Oh, it has come to me orer and orer again, from various sources.

Mr. Thlminghast. Do you mean stamped and all, or without the stamp?

Mr. Kaufrman. Yes; stamped and all.

Mr. Tillinghast. No; you are wrong.

Mr. Kaufruan. Well, tell us how much it does cost then, gentlemen.

Mr. Brennan. That is the point.

Mr. Kadffinan. How much does it cost?

Mr. Brennan. I will answer that question for you, Mr. Kauffman.

Mr. Kauffinas. Oh, do not answer that, Mr. Bremman; let them answer.

Mr. Brennan. A year ago the average make was sold in Philadelphia to the wholesale dealers at 11 cents. Fancy goods sold for a little more, of course.

Mr. Miller. I will say to you, Mr. Kauffiman, that we are making some goods that cost 14 cents.

Mr. Kauffmax. Yes; but the great proportion of your goods cost what?

Mr. Milluer. Well, I do not care to say.

Ir. Knight. Those are the goods that have butter in them?

Mr. Miller. We can not give away the secrets of our trade.

Mr. Kauffunas. Oh, of course not. Now, Mr. Chairman, I said it cost them 8 cents a pound, and they denied it; and when I asked them what it did cost, they would not answer. Mr. Drennan has said (and this I know to be so) that the goods are sold to the wholesalers in Philadelphia at prices ranging from 11 to 12 and 14 cents a pound, according to quality. There are grades of oleomargarine, you understand.

Mr. Jelke. Mr. Kauffman, the better grades of oleomargarine that sell for 14 cents a pound, or higher, contain butter, do they not?

Mr. Kauffuan. I understand so.

Mr. Grout. So much butter that you ean hardly tell them from pure butter.

Mr. Jelke. This grade of oleomargarine, which contains such a large percentage of butter, contains colored butter. It is colored butter which is put into the oleomargarine, is it not?

Mr. Kauffuax. That I do not know.

Mr. JELKE. Well, will this law permit us to make the hest grades of oleomargarine, and use colored butter?

Mr. Kaufruan. Unquestionably, if you pay the 10 cents a pound. That is what I say.

Mr. Tillinginast. But you would not permit the sale of colored oleomargarine in Pennsylvania?

Mr. Rauffuas. Oh, we are not talking about the Pennsylrania law, but about the United States law.

Mr. Tillinghast. But I say that the law of the State of Pennsylrania to-day does not permit the sale of colored oleomargarine. Does it ! 
Mr. Kaufruan. No, sir.

Mr. Trllinghast. And that is so with 32 States, as I understand.

Mr. Kaufruan. Ies, sir. I do not know

Mr. Tillinghast. So that no matter if we pay 10 cents a pound tax, we have no more right to sell colored oleomargarine in Pennsylvania than we had before.

Mr. Kaufruan. No; but we are not talking about the Pennsylvania law, but the United States law.

Mr. Knight. Do you not believe that if this Grout bill were to become a law, and colored oleomargarine should be taxed 10 cents a pound, there would be no difficulty in repealing our present law in regard to oleomargarine in the State of Pennsylvania?

Mr. Kaufruan. I can only speak as an individual. I think if this Grout bill is passed, the legislation of the States will conform to the United States law. That is only a matter of personal opinion, however.

Mr. Tilinghast. I do not know that I understood you in reference to the original-package question. Do I understand you to say that if the Wadsworth bill were adopted, and if there were no sales of oleomargarine except in the original package, the police laws of the State would not apply to that original package?

Mr. Kaufranan. Not a bit.

Mr. Tillinghast. Do I so understand you?

Mr. Kauffian. Yes, sir.

Mr. Tilminghast. That would be exactly contrary to the ease of Plumley $2 \%$. The State of Massachusetts!

Mr. Kauffuan. Yes.

Mr. Thlunghast. Does not the police regulation already extend to oleomargarine shipped in from another State?

Mr. Kaufranan. Ies; when colored.

Mr. Trlunghast. Now, would not that same decision, if it is law to-day, be law after the Wadsworth bill were passed?

Mr. Kaufrman. My impression is that if this Wadsworth bill were passed, Congress having acted upon it, the decision of the United States Supreme Court would be changed to conform to that legislation. Congress would then have passed upon the matter, and that would have been the law.

Mr. 'Truminghast. I think your opinion is contrary to the opinion of lawyer's generally.

Mr. Kaufrman. Now, the United States Supreme Court was almost equally divided on this question; it was three against four. 'There was only a difference of one. It was a very narrow question; and if the Wadsworth bill were passed, I would not be a bit surprised if that decision should be changed.

Ask your questions, gentlemen; I shall be glad to answer them.

Mr. Sprivater. Before you conclude I want to correct one misapprehension under which I think you are laboring. That is, you claim that the friends of this bill comprise all of the farmers of the country. I want to enter the appearance of the farmer's who are engaged in the raising of eotton, hogs, and cows in the South as opposed to this bill, who ontnumber the farmers engaged in raising butter three to one. (Langhter.)

Mr. Kauffuan. Oh, I must differ with you as to that. Why, just of it! Just think of it! Here are 11,000,000 cows that are interested in dairying. We have 100,000 men in that line of business in the 
State of Pemsylvania. I think I can safely say that there are at least from $1,000.000$ to $2,000,000$ of independent farmers in the United States interested in the passage of this Grout bill. I do not think there are that many engaged in the business-in the cotton business-in the South.

Mr. Springer. The cotton business of the South produces an enormous yield, amounting to sereral hundred millions of dollars a year.

Mr. Kauffinan. Yes.

Mr. Springer. And the people engaged in raising live stock-hogs and eattle-I can not tell how many they are, but they represent a capital in that business of over $\$ 600,000,000$. They are all on record in opposition to this legislation; and you will find it is a great mistake and misleading the public to say that the farmers are all supporting this measure.

Mr. Massey. Is it not true that in the West the raisers of hogs are largely dairymen? The dairymen all raise hogs, do they not?

Ir. Springer. Ol, yes; they raise some of the hog's that go to the local market. But the National Livestock Association represents all those associations for the meat market. 'They are all arrayed against this proposition.

Mr. Knight. Mr. Springer, may I ask you a question?

Mr. Springer. Certainly.

Mr. Knight. Have the live stock association ever had the dairymen's side of the question before them? Has this bill ever been explained from the dairymen's standpoint to the live stock association?

Mr. Springer. They are all reading men, and they all understand this legislation, and they have been following it for years; and now they have become aware of the fact that this legislation is inimical to their institutions, to their business. They want to enter their appearance before this committee; and throughout the country, from this time forward, they propose to give yon gentlemen "a Roland for your Oliver." They are going to contest this legislation in Congress and in the States, becanse it does depreciate the value of the live stock of the country, in which they are interested. And it is so with the cotton men of the Sonth. You will find them as a unit upon this subject.

Mr. Kaufruan. Now, Mr. Chairman, permit me to say this: My friend $\mathrm{Mr}$. Springer has called attention to the great amount of money invested in the cattle interest. That is not the question. The question is one of righteousness, of judgment, of equity. Is it right for the United States Govermment to sanction a fraud?

Mir. Splinger. That point you make now. You made the other before - that the people who are interested in this matter were numerous, and they were farmers, and good people ; and upon that argument I want to put these other men on the other side. You hare no right to claim that the farmers of this country are supporting this legislation.

Mr. Edsox. Mr. Springer, is it not a matter of record that the rolume of business done in butter in the United States erery year is heavier than that done in wheat? I have heard that it was.

$\mathrm{Mr}$. Springer. Yes; and it is getting heavier every year, too, and prices are getting better every year. In the face of all this clamor about injury to your institutions, you are getting better prices for your butter now than you ever did, and making more out of it. 
Mr. Kauffman. I want to answer .Judge Springer's question. We misapprehended each other a little, I think. My friend Springer says that we are getting better prices for butter every year. Now, I will say that we are getting better prices in the Philadelphia produce market to-day than we did two years ago. But prior to those two years, for three year's before, the trend of the butter market was downward, because of competition from the illegal sales of oleo. The reason we are getting better prices to-day is because of the work of this association in enforeing the law.

Mr. Springer. We want to help you enforce the law.

Mr. Minfer. Mr. Kauffman, I would like to say just one thing. I can say this: I will give my oath to-day that the cheapest grade of butterine we manufacture costs a great deal over 8 cents.

Mr. Kauffman. It will not cost you 10 cents.

Mr. Mrluer. I am not saying what it costs. I say it costs a good deal over 8 cents. [Laughter.]

Mr. Edson. Mr. Kauffman, there is one thing I would like to correct before you sit down.

Mr. Kaufruan. What is that?

Mr. Enson. Yon stated that the price of butter was so much better than it was two years ago. Now, I will tell you, from a business man's standpoint, and from the standpoint of one who does a pretty good business in Philadelphia in the butter line, that the butter business in Philadelphia or in Pennsylvania shows its sensitiveness to the oleomargarine law, inasmuch as that the moment we began to prosecute the law and punish the offenders the rolume of our business increased. During the last year, with these prosecutions under way, there is not a butter man in Philadelphia whose rolume of business has not very largely increased, so that that will aceount for a much larger output of butter in the State of Pennsylvania.

Fow, answering the Judge's question in regard to the increase of the butter business in the United States yearly, I would state for his information that we are exporting large amounts of butter out of this country every year, and our export trade is growing at the expense of a good deal of our consumptive trade right here in this country, owing to the competition of oleomargarine.

Mr. Schell. Now, Mr. Chairman, if I have the floor, Mr. Kauffman has answered my question at length, and I want to see if I received the right impression. You and your elients are not opposed to a law which would so regulate the sale of colored oleomargarine that conviction would practically be certain?

Mr. Kauffian. No.

Mr. Schell (continuing). If a man sold oleomargarine for hutter?

Mr. Kaufrian. No.

Mr. Schell. Yon are willing that colored oleomargarine should be sold?

Mr. Kauffuan. Provided

Mr. Scheld. But it must be sold for oleomargarine?

Mr. Kauffiran. Oh, yes.

Mr. Schell. And not for butter!

Mr. Kaufruan. Provided-we insist that a part of that regulation shall be the imposition of this 10-cent tax, because oleomargarine can be produced at so much less that it ean absolutely undersell and drive out of the market the production of butter. 
Mr. Sches.. Then you do not agree that it shall be sold on its merits, without a 10 -cent tax?

Mr. Kauffiran. No, sir; not colored. [Laughter.]

Mr. Davis. It will not be sold on its merits.

Mr. SchemL. We want to get these gentlemen on record either as saying that if such a law ean be enforced-

Mr. Kauffulan. Now, I say-

The Acting Chailinan. One at a time, gentlemen.

Mr. Scriflu. I have the floor now, and I think the chairman will bear me out in saying that I have observed the courtesy of debate light along.

The Acting Chairman. Yes, that is true. Mr. Schell has the floor, and should not be interrupted.

Mr. ScheLL. We want you gentlemen on record either as being in favor of an absolute extermination of colored oleomargarine, except under heavy penalties, or we want you on record as being in favor of having colored oleomargarine sold on its merits for what it is. We want you on one side of the fence or the other.

Mr. Kauffuas. Now, I am going to answer that question.

Mr. Schell. That is what we want.

Mr. Kauffuan. We simply say that no possible law or regulation can be made to prevent the sale of colored oleomargarine as butter.

Mr. Schell. But if it can?

Mr. Kauffuan. Let me answer. I say it is impossible to pass any law

Mr. Drennan. We have been trying for twenty years to do that, Mr. Schell.

Mr. Kaufrman. Let me answer the question. He simply asked whether, if a regulation could be made to prevent the sale of colored oleomargarine except under restrictions, we would object to it. I say that that "if" is an impossible thing. No law or regulation can be made to prevent the sale of colored oleomargarine as and for butter. I do not care what your penalties are. Therefore, because of the impossibility of selling colored oleomargarine under restrictions, we ask that if colored oleomargarine shall be sold at all, the manufacturer shall pay 10 cents a pound tax upon it, so as to make the expense of the article so much more.

Mr. Scrielu. You are not willing, then, that it shall be sold on its merits alone, mencumbered by this tax of 10 cents a pound?

Mr. Kaurman. We say that colored oleomargarine is an imitation and a fraud, and therefore we-

Mr. Grout. You are willing that it should be sold, though, if its sale could be so regulated as to prevent its being sold for butter?

Mr. Kaufrian. If it conld, yes; but that is impossible.

Mr. Grout. That is it exactly. As long as there is a temptation of 150 per cent protit on the cost of production, it will be impossible.

Mr. Scueld. Well, General Grout, we know-

Mr. Grout. That is why you want your tax?

Mr. Kauffian. Yes, sir.

Mr. Grout. You want to take away the temptation?

Mr. Kaufruax. That is it, exactly.

Mr. Grout. If you do not, you can not do it.

Mr. Scheld. 'There is just one other question I want to ask here, and that is this: Would you and your clients be willing that this pres- 
ent law should be amended, if it could, so that the man who wants colored oleomar'uarine can order it made and have it made to his order, and supplied to him by the manufacturer without this man, the consumer, having to pay this additional tax?

Mr. Kaufriman. It can not be done.

Mr. Schell. But if it could?

Mr. KaUfFuan. But you are supposing that which is absolutely impossible.

Mr. Schell. No, no. We want to get you where you are, but when we think we have you, you are not there. [Laughter.]

Mr. Kauffman. No; I will explain. Since 1886 you have had a law upon the statnte books-your present law-which provides as a penalty for its violation a fine not exceeding $\$ 1,000$ and an imprisonment not exceeding two years. You have that law, which was enaeted expressly to prevent the sale of oleomargarine, colored or uncolored, as butter; and yet it is ineffective.

Mr. Davis. You have been operating under those conditions for years. fair.

Mr. Drennan. You are stating an impossibility, sir. It is hardly

The Acting Chatrman. One at a time, gentlemen.

Mr. Tillinghast. A question I would like to ask, but which I think you have substantially answered, is this: I understood you to say in your remarks that with reference to the State of New York-

Mr. Kauffulan. The State of Pennsylvania.

Mr. Tillinghast. (Continuing:) And with reference to the State of Pennsylvania also, that they have substantially produced a compliance with their anticolor law, and that in consequence of that there has been an increase in the price of butter?

Mr. Kaufrman. In the city of Philadelphia-not in the whole State of Pennsylvania.

$\mathrm{Mr}$. EDson. I corrected that statement.

Mr. Drennan. Yes; and it is not fair to state that if we had enforced a compliance with the law, such and snch a result would follow. We are not the parties to do it at all.

The Acting Chairman. Have you finished, Mr. Kauffman?

Mr. Kauffuan. Oh, I have finished; but I am always perfectly willing to answer questions.

The Acting Ciraminan. Then I declare the committee to stanc adjourned until 10.30 o'clock on Monday morning.

\section{Washington, D. C., Monday, January 7, 1901.}

The committee met at $10.30 \mathrm{a} . \mathrm{m}$.

Present: Senators Hansbrongh (acting chairman), Foster, Bate, Money, Dolliver, and Heitfeld.

Also, Hon. W. D. Itoard, ex-governor of Wisconsin and president of the National Dairy Union; C. Y. Knight, secretary of the National Dairy Union; Hon. William M. Sprnger, of Springfield, Ill., representing the National Live Stock Association; Charles E. Schell, representing the Ohio Butterine Company, of Cincinnati, Ohio; W. L. Miller, representing the Armour Packing Company, Kansas City, Mo.; John F. Jelke, representing Messrs. Braun and Fitts, Chicago, Ill., and others. 
ARGUMENT OF ATTORNEY CHARLES E. SCHELL, REPRESENTING THE OHIO BUTTERINE COMPANY, OF CINCINNATI, OHIO; THE DOLD BUTTERINE COMPANY, OF KANSAS CITY, MO.; THE UNION DAIRY COMPANY, OF CLEVELAND, OHIO, AND OTHERS.

Mr. SoHell. Mr. Chairman, I was sent here by the Ohio Butterine Company, of Cincinnati, Ohio.

The Acting Crairian. Is that institution being operated now?

Mr. SCHELl. The institution is being operated now.

The Acting Chairman. Has it ever been closed?

Mr. ScHELL. It has never been closed. It only came into existence a short time since. The charter was issued, I think, the same day that the Gront bill passed the House.

The AC'IING Chairman. It is very new, then?

Mr. SPRINGER. An infant industry.

The ACting Chairman. Yes; an infant industry.

Mr. Schell. I am also attorney for the Jacob Dold Packing Com. pany, of Kansas City, Mo., and I want to state that although originally manufacturing oleomargarine under the name of the Jacob Dold Packing Company, yet in order to more elosely associate what has been called the "legislative name" of the product with the product, they have incorporated their oleomargarine departmeut under the name of "The Dold Butterine Company," and were, as I am told, the first company to adopt a name identical with the product. I am duly authorized to speak for them.

I am also attorney for the Union Dairy Company, of Cleveland, Ohio, and have been for years; but Mr. Seither, the president and general manager of that company, will be here to speak for it, and I will only quote him as favoring any law which will distinctly and withont discrimination place butter and butterine distinctly ou their separate and individual merits, but as being against the Grout bill as being class legislation of the most vicions kiud.

I am also attorney for wholesale and retail dealers in oleomargarine; for commission men, whose main business is butter and eggs; for dairymen; for farmers; for consumers, who have within two weeks personally expressed to me their condemnation of this bill.

In the years I have been fighting the State color laws, I have discussed the question of color discrimination in dairy laws on all possible occasions, opportune and otherwise; and I have hundreds of expressions from all classes and conditions of mankind uniformly condemning the discrimination between the two products-allowing the farmers to color their butter and not allowing the oleomargarine manufacturers to color their product.

Reference has been made from time to time to people appearing here as "paid attorneys;" and intimations have been made that the same degree of consideration should not be given to what they have to say as to what might be said by somebody directly interested.

I must resent that. So will any fair-minded attorney. So will every man who has had dealings with the legal profession. Attorneys do not, as is sometimes supposed, accept employment for the purpose of winning by fair means or foul; but merely to see that their clients receive every benefit to which the law and the facts entitle them.

Now, since this heariug is what it is called, "a hearing," and not a trial, as I argue for my clients, I want to go beyond the bounds with which custom has hedged an attorney, and within which I generally try to confine myself, and mingle some testimony with my talk and 
appear as a witness on behalf of all these people who have expressed thenselves against this speeies of legislation and as a witness on behalf of every loyal, liberty-loving citizen of this great United States. Whatever may be the situation of paid attorneys in some cases, in this my dnties to my client and my country are the same.

Gentlemen, I believe that the mind of every member of this committee is made up, to an extent, on this subject, but I believe that every one is open to conviction on either side. That is evidenced by the patience and consideration with which every one has been receiven. 'This has been a very liberal hearing. From my point of view I would have prefierred that it be more in the nature of a trial; that the friends of the bill should have presented their case; that they should have presented their witnesses, not statements, not allegations, not bunches of testimony which appeared before the Honse, and which, of comse, is admissible as evidence in this case; not that they should come in and read at random statements from books or pamphlets issued fiom some source, we know not what, but that their evidence should have been submitted to a rigid, searching crossexamination, and that then we should liave come in with our side of it and been subjected to the same cross-examination. Then they could have closed their case. As it is, we have appeared at a disadvantage. We are under arraigument. The specific combs of the indictment are not named. We do not really know as yet what it is we have to face except that it is a threatened destruction of our industries.

The burden of proof, you will remember, is on the friends of the bill in this case. As yet they have failed. As yet they have not tried to mike a case. As yet they have not stated their case. And before I go any furtlier, let me say this: I see Mr. Kuight is present. I would like to have on record Mr. Knight, who seems to be the main spoke in the wheel; Mr. Hoard, who is his first assistant; General Grout, who seems to be second assistant in the case; Mr. Adams, Mr. Flanders, and others who have appeared here. I would like to have these gentlemen on lecord, so that we may know just exactly where they stand. And I am going to ask Mr. Knight this monning-and I think I am entitled to ask the question-that he place himself on record; that he tell us whether the object of this agitation, the olject of this bill, is to alusolutely prolibit the nanufacture and sale of colored oleomargarine. or whether he is willing that the manufacture and sale of this product shall be so hedged about with law, with regulations, with provisions, that it will be compelled to be sold on its merits, and not to encroach (if it ever luas encroached) npon the particular province of dairy or creamery butter. Will you kindly alvise me, Mr. Kuiglit?

Mr. KNIGHT. I will siy to Mr. Schell that if he will present a measure which the people who have had experience in enforeing the dairy laws believe will hedge it abont with such safeguarls as that colorerl oleomargarine can be pnt to the consumer withont deceit and frand, I am sure we will all accept it. That is my answer. Ancl I want to say further that if it had been possible in the twenty years we liave been enclevoring to have framed such laws, we never would have been before Congress to-day asking for a 10-cent tax on colored oleomargarime. [laughter.] I will prove my case, gentlemen. You veed not smile so audibly.

Mr. Schel. That is the point, gentlemen. I am glad to hear Mr. Knight speak as he does. His statement is the most nealy direct explanation of their desires that we lave as yet had. But does he mean it? We will see. I wish he had made his case in the beginuing 
and given us a chance at it. And I will ask, gentlemen, that if in the course of the presentation of their case (which seems to be coming later) the gentlemen on the other side of this questiou should adduce any new arguments, any new theories, any new facts or alleger facts which they have not yet placed before your committee, our side may be given the right-aul we claim it as a right, not a privilege-to reply to any thing we deem wortly of notice.

The ACring CHAIRIAN. I think the committee has been very liberal in that respect thus far. We have allowed the interruptions and crossquestioning all along the line by both sides.

Mr. Schell. Yes; we concede that the committee has been very lib. eral, and we have no fault to find with the committee.

The Acting Chammax. This has been purely a Congressional hearing. It is exactly what it is represented to be. It is not colored at all.

Mr. Schell. It is sailing under the proper colors. I conceded that in the start.

Now, the attitude of the friends of this bill, gentlemen, can perhaps be clefined as a good old Methodist minister (I forget his name nowyou will probably all recall the story) defined Presbyterianism. Now, with Presbyterianism or Methodism I have no fault to find, and I do not relate this story with the idea of any reflection on either deuomination. But, in speaking of the Presbyterian doctrine, you will recall that he defined it as "I ran and I can't; I will and I won't; I'll be dammed if I do, and damned if I dou't." [Laughter.]

Now, I am going to do what has not been done by our side as yet. I am going to lignify with a rcply some of the things which have been said by the other sicle, and which have been presented to your committee in a buncl, perhaps with the idea of their receiving attention and perhaps to coufuse the record.

My colleagues have, each in his own way, stated their views. Not one has claimed to be the favored of the Lord, entitled to protection. Not one has asked a favor. They have only asked their rights, equal rights with all men, as guaranteed by the Constitution.

I shall give some attention to the other side and, since we shall follow largely what has heretofore been said, I can not be as logical as I would like. I3ut I will aim to treat the subject under three general heads. These heads are:

First. The bill.

Second. The friends and foes of the bill.

Third. The alleged rival products. (WVe do not concede that they are rival products, but they are claimed to be.)

A great and good man once said: "By their fruits ye shall know them." And it would appear from that and other reasons that an examination of the bill wonld be sufficient; but sometimes it is well to examine the tree, especially when the fruit is such a Dead Sea apple as the Gront bill. But the Good Book also says: "The last shall be first." So we will take up first the alleged rival products, or the subject-matter of the bill.

Butter and butterine are almost identical in every respect. As to their ingredients, they are identical, except that butter contains just a little more butyric aciel. You gentlemen will recall, from you studies of chemistry and physiology, that there are only four kinds of fatolcin, stearin, palmitin, and butyrin. In butter there is just a little more butyrin; and the presence of this butyrin is the only weans by

$$
\text { S. Rep. } 2043-17
$$


which the chemist can distinguish definitely between butter and but. terine.

Mr. HoARD. Will the gentleman allow me to ask him a question? What becomes of the other fatty acids that are in butter, and that are not in butterine-caprin, and the other acids?

Mr. ScHELl. Why, Governor Hoard, I want to say in reply to that that when I have finished-my time is not limited, I am glad to say, but at the end, if the Committee wants that I should say something more-I will be glad to answer any questions that may be asked. But since you are here

Senator MoLLIVER. If there are any other differences, perhaps yon had better go into that matter now. You have spoken of one element of difference. I wonld like to know if there are other differences besides this butyric acid of which you speak.

Mr. Schell. That is absolntely the only difference, as I am advised by chemists whom I liave had examine this product, and by the testimony of the chemists who appeared before the Honse Committee. In the revised regulations sent ont by the revenue department it is stated that it was conclusively shown to some investigating committee, whose authority scemed to have the sanction of that department, that it was the only difference. I have cross examined State chemists time and again, and have always dwelt mon that one subject; and I have been advised by them, by their sworn statements, the statements of witnesses for the other side, that it was by an estimate of the amount of butyric acid contained in the samples that they were able to distinguish between butter and butterine, and to tell what per cent of butter fats a]peared.

Senator DoLLIVER. Is there any butyric acid in oleomargarine?

Mr. sunell. Yes; there is some, but it is not present in as large a quantity as in butter.

Senator DoLtiver. Well, wonld it be possible to add enongh of that product to make the articles absolutely identical?

Mr. Schell. It wonli; and I have also asked the State chemists that quistion.

Mr. HoAR1. What chemists, please? What chemists do you refer to?

Mr. SCHELL. Governor, I want to state to you now that if you will kindly wait I have promised the chairman to aid him in getting through as soon as possible; and I recall so well your questions to ny predecessors on this side that I see the time would be fully taken by you if I sliould answer all your questions.

Mr. HoARD. I beg your pardon, sir, for asking the questions, if it interferes with rour leillarks.

The AC'Ting Uhalrian. Governor, you will be given an opportunity to question him at the close of his remarks.

Mr. HoARD. Thank your.

Mr. ScHeLL. One of the chemists I have in mind nom (to go right on, and perhaps answer the question at the same time) was Professor Louis Schmidt, chief chemist of the pure food department of the State of Ohio. I asked him this question directly: "Professor, wonld it not be possible, by the use of free butyrin by the mannfacturers of oleomargarine, to make an article which chemically conld not be distiugnished from butter?" And he replied in the affirmative. Now, while I have not questioned all the manufacturers, yet I have been advised by those engaged in the business that it would be possible to do this, but they say, "We do not want it. A very little of the free 
butyrin would be sufficient to Havor, to give that particular property to the entire daily output of the factory, and it would render the product less desirable, because it would then become rancid, the same as butter does."

Now, as far as the various chemists are concerned, I shall not go into the chemistry of this subject. The testimony before the House committee covers that subject; and as far as I am advised-and, remember, the burden of proot is on the other side-they have not introduced any evidence, they have not shown by a single chemist, that there is anytling in butterime not contained in butter, nor in butter which is not contained in butterine, except this butyric acid. And this acid, this butyrin, adds nothing to and takes nothing from the value of the product.

The Acting CHAirMan. It has to clo with the taste, as I understand?

Mr. Schell. It has to do with the taste and the keeping qualities of the article. Our friend, Mr. Flanders, from New York, kindly refers to the chemists who have testified as "third-rate chemists." Mr. Hamilton, of Pennsylvania, pronounces them eminent chemists. Mr. Knight, in his statement before the House committee, I think, waived the subject of an investigation by chemists, saying that it would simply result in conflucting opiuions of paid experts, and with that remark dismissed that pliase of it.

These two articles are also similar in purpose. They are user for identically the same thing. They are also similar in natural appear. auce and in artificial appearauce. They both need the same artificial coloring.

Senator Dollivir. Now, I would like to have you go into that question a little. What is the natural color of oleomargarine?

Mr. Scheld. The leaf lard, whish is one of the ingredients of oleomargarine, is, as I understand, pure white.

Senator Dolctiver. Does that dominate the color of the product?

Mr. Schell (continuing). And the other ingredients are not exactly white. So that the natural color of oleomargalline is a very sliglit tinge toward yellow, or perhaps gray, from the pnre white, which color we would be compelled to give to the article if this law were to go into effect.

Senator HeI'TFELD. Has it not a sort of muddy color?

Mr. SCHELl. No; not exactly a muddy color, I think.

Senator FosTER. It luas been described as a rlirty gray.

Senator Dolliver. Do you muderstand that to be the natural color of butter?

Mr. Scuell. Why, if the committee please, I have in almost every year of my life spent a part of each year in the country, in the mountains, in the forming districts of Ohio, Indiana, and Inlmois, and in the mountains of Virginia, West Virginia, and Maryland; and I have seen more white or dirty gray butter on the tables of the filmers than 1 ever saw any other kind. From my own experience and from what 1 have heard and read, it is the greater part of the year more nearly the dirty gray than it is the rich goliten color we see in the butter which we get at first-class hotels.

Senator HeITFELD. I think you are mistaken, though, as to the dirty gray being the natural color. I bave been in the butter business myself; that is, I have had it made on my firm. I think if the milkers have their hands cleaned, and do not get the bucket kicked 
over, and handle it carefully, the tint is a purer tint. It is not a dirty gray.

IIr. SCHELL. If!

Senator HEITFELD. Of course the "if" is there.

Mr. SCHELL. I am going to come to that later on.

Senator HEITfELD. I have done a great teal of churning in my time, and seen a goou deal of it done, and been in the business of making butter. I smpposed that it approached a yellow color, from long and careful observation.

Mr. Scmell. I have no doubt, gentlemen, that the butter which either one of you gentlemen would make would be a yellow butter.

Senator DoLLIVER. The poets have always described butter as sellow.

Mr. SCHELl. Yes, the highest class of butter, perhaps, and even then were exercising a poetic license.

Senator HEITFELD. I am afraid the rural districts you got into were not of the best.

Mr. ScHELL. All kinds, gentlemen; but, I will treat that subject later on, in spealing of the different linds of butter.

Senator HEITFELD, I think we are satisfied as regards that part of it.

Mr. ScheLL I am afrail you are satisfied the wrong way. [Laughter.] I want to eonvince.

As to the mutritive yualities of butterine, I think there can be no question. The chenists agree on that subject. The other side very faintly claim that the mutritive qualities are not the same as those of butter; but they have not made their case or even introduced any testimony. Until they do, we do not liave to go into that. We do not think it necessary. It would be presuming on the intelligence of the committee to do it.

As to the melting point, there are various claims made by the other side. In the testimony of Mr. Miller, in the hearing before the House committee, at page 200 , this matter is gone into; and Professor Wiley, I think, makes the claim (at least it is a fact) that the mere melting point does not make any particular difference; because the melting points of apples, meat, etc., if they have any melting point, are considerably higher than that of butter; and their nutritive qualities are not questioned.

There has been no serions question or claim on the subject of nutrition and the perfect healthfulness of the article, except by Mr. Flanders and Attorney Kauffman. Mr. Hamilton thought the matter not decided; and Governor Hoard and Mr. Knight merely raised the question, but brought in no evidence.

Mr. HOARD. Tou say I did not bring in any evidence? Turn, if you please, to my statement before the agricultural committee, and yon will find the evidence there stated specifically.

Mr. SCHELL. I will state from recollection that Governor Hoard, in that statement, after tonching on the subject, passed on and spoke of the condition of certain alms.houses in England.

Mr. HoARD. I gave the eridence there

Mr. SCHELL. But there is nothing there that will be considered as evidence betore any court, or before a committee, in passing upon a matter according to the rights. We are charged in this case with being guilty of something. It must be proven, and it must not be proven on hearsay, loose, random statements of some partisan in a partisan paper in regard to the condition of alms-houses over in England. But be that as it may, no question can honestly 
The Acting Chairuan. Just a moment, Mr. Sehell. The charge, as I molerstand it, is that you sell oleomargarine for butter. Is not that the specific charge that is made?

Mr. Schell. That is the specific charge; and yet the plaintiffs, as I term them, in this case, have gone beyoud the lines of legitimate iuguiry in making the case upon that question, and re feel entitled to make some reference to the claims which they have adducerl.

Un the question of the alleged iujurious effects of this product, oleo. margarine is, as I am adrised, used in the majority of the National Soldiers' Homes all over the country. There have been no complaints from them. (ientlemen, the intelligence of the members of the Grand Army of the Republic is such that if there were any question about it, it would have been raised. These gentlemen come in here and with their other accusitions acense the mation of feeding its old soldiers on something that is absolutely injurious to health, it they. serionsly make that claiu, which I do not think they do.

Mr. Honrd. Its use is forbidnen in the old Soldiers Home in Wisconsin.

Mr. Miller. He refer's to Natioual Soldiers' Homes, Governor Hoarl.

Mr. HoARD. And protests have been raised there repeatedly.

Mr. Schell. Now, Governor, I have said that you would have your turu after a while.

Gentlemen, these prodncts are both butter, aud nothing else; many of us have had experience on the farm; and in the country we have heard the dairy product distinguished from the other butter used on the table of the farmer by desiguating it "cow butter." We have eaten on those same tables apple butter, peich butter, quince butter, and jumpkin butter; and yet nobody disputes that they are butter. Oleomargarine-butterine-is bntter. As a gentleman stated the other day, it has been given the name of butterine legislatively. The pro. ducers, the manufacturers of the product, have accepted that name. We do not object. We are willing to be distinguished. As Commissioner Wilson stated in his report, if the name conld be branderl on the article it would be one of the best recommendations to the consumer the article could have. The only difference is the may in which this finisher product is prolured. Is Hour any thr less Hour becanse, instead of being turned into flour as it used to be by the different proc: esses through which it used to have to go, it mow goes throngh different and improved processes? Formerly the grain was cut with the sickle, thrashed out with Hails on the baru floor (oi loy the stock. as the case may be), put in a sack, thrown over a barebicked mule, and carried to the mill by the farmer's boy, barefooted. and with the hair sticking through the top of his straw hat, aud then turued to flomr by the old process. Is it any the less flour because now the grain is reaped in the most improved fashion, thrasher in a way that will sa ve all the product. and put through the latest improved joncesses, shil as are nsed by Pillsbury and others? None the less. And yet they are making this distinction between butter and hutterine. It is an unfain distinction; and yet we accept it. We take the name" "butterine," and ask-_-

Seuator Dolliver. But the laws of the [uited States have distinguished between flom and mixed thom-that is, flomr whose ronemical properties are reenforcel from the outside with crustalch, and simd, and things like that.

Mr. ScuEı. That is an adulteration; and, gentlemen. I walut to gro on record herr, in the interests of all the people I rejurent. that any law passerl by the Luiter States or by ally State for the purpose of 
preventing adulteration will have our hearty support. There is too little attention given to legislating against adnlterations; and had half the energy which has been expended in getting an unfair discrimination between these two prodncts been expended in the interest of the suppression of alulteration of every product that goes on the table, the country would have heen benefited to a much larger extent.

Now, as to the difference in these two products. The material difference is in the manufacture aud price only.

As to the mannfacture of oleomasarine, I will simply refer the committee to the testimony of Mr. Hobbs, on page 13S. I think, of his testimony hefore the Honse committee, in which he followed it through from the beginning to end, and commended it. He said in his testitimony, at some point, that since he has fully investigated it he uses the product on his own table in preference to butter. I also refer you, gentlemen, to the testimony of Commissioner WVilson, at the bottom of pages 170, 171, and 1S4 of the House hearings. I do not turn to these places and real them, becanse I do not want to encroach upon the time of the committee; but I want the places distinctly noted, so that the committee may fully investigate if they wish.

And I want to add a statement here from the rigid regulations of the Ohio Butterine Company. Everything there is conducted on the same scrupulously cleau plan referred to by $11 \mathrm{r}$. Ilobbs. But another detail might be mentioned. The entire fore-they employ none but men in the factory-have their bathrooms and dressing looms, and before they go into the factory proper they are compelled to don white duck suits and wooden shoes and pass before an inspector; and cleanliness is comsidered the very first law of the falctory.

Again, the factories must be ready at all times for Govermment inspection. The local people, it will perhaps be claimed, conld be provided against. They wonld know them, and perlaps wonld know of their coming: Fellow-citizens of the same town are not apt to take mudue alvantages, possiby; but the Gorermment, the revemue officers, have their secret agents who go about from time to time, and the manufacturers know not the day nor the hour when they are going to appear. They must be ready at all times. And so far as I am acquainted with any factories, they are ready at all times; and on belnalf of our Cincinnati factory, and on behalf of the Jacob Dolel Packing Company, and on behalf of the Union Dairy Company, I extend to any and every member of the committee, or anyone, an invitation to come at any time, and they will be shown through the factory, and shown that everything which has been said in tavor of the cleanliness and godliness of the factories is observed.

Now, as to color, there really is a difference. Both of these products are colored. They have to be colored in order to be marketable commodities to day. There is, however, a difference in the coloring matter used. The large ('reameries and prominent dairymen, of course, use a harmless color: The oleomargarine factories are compelled to do so. Not only is it their desire, but if they were to use any thing else it would subject them to heavy penalties under the United States laws. I think that in a case of nsing any substance deleterious to health there is provided a confiscation as well as a tine.

Senator Foster. Do they color creamery butter at all times of the year?

Mr. Schel. I will not say, alsolutely, at all times; but my

Senator Foster. When thry are making the nost of the butter, along in the summer time, May, Jume, and July, do they color it? 
Mr. SchelL. My impression is that it is all colored, at all times; but in the summer time less coloring is required; and I am advised that the creameries use exactly the same coloring matter that is used by the oleomargarine factories.

But there is not the same restriction in regard to the coloring unatters used by the dairy farmers, the small farmers. In Cincimnati years ago we liave had prosecutions of farmers under our Ohio laws for using poisonous color in their butter. 'The farmers have improved their methods since; and perhaps in justice to them it might be well to say that there is very little, if any, poisouous coloring matter used now. Yet the easiest coloring matter is the coal-tar product.

Mr. KNIGHT. I beg parclon, hut is that the coloring matter that you refer to, Mr. Schell-the coal-tar product?

Mr. Schell. Tow, Mr. Kuight, I must remind you people again-

The Ac'Trng Chairisas. Do not intermpt the speaker.

Mr. ScHELL. In view of past experience, the experience of my prerlecessors, I find that it will not do to give you any leeway at all.

Now, the paraffin subject was treated by Mr. Hobbs-

The Acting Chairian. Before you leave that question of color, Mr. Schell, allow me to introduce a brief letter here which has been handed to me. It is from Mr. O. Sands, of Chicago, Ill., and is ad. dressed to Mr. Knight. The heading on the letter is "Elgin C'reamery Company," and it says:

Replying to yours, at hincl, have to say that I have gone over our hooks, and fini that we use about 70 gallous of oil butter color, rumning through the entire twelve months of the calendar year, to each $1,000,000$ pounis of butter we make. For abont six weeks or two months from the time the cows are first turnect on grass in the spring, until the first or middle of July, we use no butter color, it being high enongh in color withont using any.

'That is the substance of the letter.

Mr. Schell. That in substance, I think, Mr. Chairman, is what I have stated as my opinion.

The ACTING CmaIRMAN. I thought I would make the record complete.

Mr. SCHELL. I believe I stated that if any was used in the summer time, the quantity was small compared with what was used during the rest of the year.

Mr. JELKE. If Mr. Schell will allow me to make a statement, I will say that there are certain markets in the Lnited States where the natural color of the butter is not high enough at any season of the year to suit the demaud; and if Mr. Sands supplies those marliets, he uses artiticial butter color in his butter at all times. I speak specially of St. Louis aud of Washington.

Mr. KNigh'T. They have elıanged their standari on butter in St. Louis. Mr. IELKE. I am thoroughly aequainted with the standard of butter in both markets.

Mr. KNight. So am I.

The Acting CHAIRyan. The speaker will proceed.

Mr. SiHell. Now, gentlemen, to turn from the manufacture of oleomargarine to the mannfacture of butter, we can divide butter into three main classes. 'The creumery butter, the good country butter, and the packing stock.

As to creamery butter. we may say that it is the very highest class that is malle, except perhaps that made by some farmer, some clairy. man like Mr. Sharpless, who was here the other clay, and who has the art down to such a tine point that the creameries can not interfere to 
any appreciable extent with the market for his product, or improve upon it.

This butter is made from the milk and cream of herds of cows properly bred, properly fed, and properly milked, or from milk purehised from the farmers. In making those purchases of milk. the creameries have been going abont over the teritory, inspecting the cows, instruct. ing farmers as to how they shomld be bred, kept, ferl, milked, etc. This product is bought by the percentage of butter fats contained in the milk as it is delivered in the creamery. They have what is known as the Babcock tester, a machine which makes abont 1,200 revolutions per minute, I think. In it are placed test tubes containiug milk, together with some other ingredients, which are shaken up thoronghly, and the exact anomnt of butter fat can be determined; and in order to do justice to the creameries and the farmers, they make what they call a composite test, rumuing over quite a period of time, so as to get the average of the butter fat in the milk. Then, from time to time, from theu on, they test to see whether or not it is heing kept up to the standard, or whether it is exceeding the standard originally shown.

I was talking with different members of the firm of French Brothers' Dairy Company, at Cincinnati, before I came here. I might say that Mr. Tilden R. French, one of the present brothers, has been our county treasurer. He stands high politically, socially, and financially. The family have been in the dairy business from a "time whence the mind of man runneth not to the contrary." I)r. Findley was telling me the o:her day that his mother had bought both cream and milk from Freuch Brother's, the gentlemen now in the business, and their ancestors for more than thirty years. And I was talking with a Cincinnati man on Friday, and he said that ever since lie conld lemember the French Brothers were in the dairy business in Cincinnati. They have creameries in Hamilton County aud ereameries in the other southern counties of the State. Mr. Albert French told me very recently that they had over $\$ 100,000$ invested in creameries in Warren Comty, one of our adjoining connties.

These gentlemen, the French Brothers, tell me that according to their estimate the farmer who hrings his milk to their creamery and sells the butter fat, and gets his milk back, realizes-because of the perfection of their process of making butter and the prices they can get thereby, and the fict that tley can separate and use all of the butter fats, and lie can not-abont three times as much for his product as he would it he made it mp according to the old farm methods and sold it; besides he has his milk back for any purpose for which he wishes to use it. They dicl not state any specific price that they paid, but said the price was based on the price sent ont from Elgin every Monrlay.

The general manager for the Dohl Butterine Company, Mr. Clark, who was here the other day, but who had nothing to say because the time was occupied, adrised me that the Dold Butterine Company pays an average of 29 cents a pound for the butter fats usod in their oleomargine factory, and find difficulty in getting a sufficient amount at that.

I want to add here the statements of Tilden R. French and Mr. Albert French, of Frencin Brothers-to the efluct that they do not recognize oleomargarine as a competitor in their business at all. On the contrary, they commend the manufacture and sale of oleomirgarine, in that it supplies people who are not able to buy their product.

Our next class is good comntry butter; that is the kind perhaps which you gentlemen were talking about-that which is worked out by 
hand with proper eare and with a regard for cleanliness. But sometimes, as was suggested, the cow will put her foot in the pail; and in that case cleanliness, of course, is not guaranteed.

Senator Heitfeld. But they are not compelled to use that milk.

Mr. Schell. They are not compelled to use it, but how many prosperous, enterprising farmer's are going to throw away that pail of milk, especially if they are supplying the market? They will probably see that it does not go on their own table.

Now, we also know, everyone of us, that good butter makers in the country have a market for their product. They have eontracts, the same as Mr. Sharpless, to supply their neighbors, even neighboring farmers. They have their contracts to supply the residents of little villages; and they get the same price the year ronnd, whether butter is more or less than the price they are getting. In some of the cases abont which I know, the farmers' wives who have these contracts supply butter the year arom at 25 cents a pound. Sometimes their neighbors are getting 10 cents and sometimes they are getting the full 25 cents. That is another class of bntter.

Now, gentlemen, I am going into details, partly on the suggestion of the two gentlemen present aud partly because, while every politician is not a statesman, every statesman must necessarily be or has been a politician, and as such he must have gone throngh the varions districts, good, bad, aud indifferent.

Senator Moner. A statesman is a dead politician.

Mr. Schell. Yes; that is very true. Then, perhaps we can confine onrselves to politicians, if you insist upou it.

Now, we are not going to take you through the green fields, and babblingbrooks, and sliady laues, and watch the pretty milkmaid who "pails" the cow. We are going to get down to actual facts. We are going to go through the stubble fields, grown np with ragweed. We are going to recall the taste of that butter which comes on the table made from the milk of cows fed on this ragweed. We are going to call attentiou to the barnyard in winter, often fenced in with a rail fence, which also serves as a pigpen, and the cows and the pigs sleep together, with mud knee deep. Sometimes they hunt for a high and a hry place, and sometimes they do not even take that trouble, they are so accustomed to the mud. We are going to call attention to the hired man, when he goes out to milk the cows-to the condition of his hands, to the cold in his head, etc. Sometimes he takes water from the pump and washes off just a little bit of mud from the teats, so that it will not be quite so masty for his fingers; but as he milks, we wateh the melted proceeds of the night's repose drip down from his hauds and go into the milk pail. We also notice the general condition of many of those cows. Some novelist, writing a few years ago, spoke of the general condition of the cows in New York; and the active interest the hero took, for the lore of humanity and the little ones, to get better sanitary conditions, ete. His experience is not a circumstauce compared with some barnyards we have all seen. Take the case of cows with the hollow horn, in the winter time

Mr. HOARD. Cows with what?

Mr. SCHELl. Hollow horu.

Mr. HOARD. I will give you s100 for a case of hollow horu.

Senator Moner. Well, I will give you $\$ .500$ to demonstrate that it don't exist. I have bored the horns for it many times.

Mr. HOARD. As a disease?

Senitor Moner. They will die if you do not bore them, too. 
Mr. SCHell. That is right. We will call attention to the cows you bave all seen.

Senator Moner. They have the hollow tail, too. They are both recognized diseases.

Mr. JFLKE. Dickens speaks of the cow with the iron tail. [Laughter.]

Senator MoNeY. Then we have some with the hollow belly. That is what is the matter with most of them.

Mr. SCHELL. That is what is the matter with most of the cows with the hollow horn, too, and the cows with the rumning sores on themthe cows, as described by the novelist, with the ends of their tails rotting oft, switching during the milking process. God only knows what we are getting from that pail of milk.

We will also refer to the churn-the children who work the churn dasher, the eats and ehickens and toads and roaches about the milk house or spring house. A gentleman was telling me the other day whit he claimed to be a true instance about a poor family of tenants, in which the supply of wooden ware was limited, and they used the churn between churning days for the purpose of soaking the baby's clothes, and then on churning days they scoured it ont and got the butter ready for the market.

Senator DOLLIVER. Did you believe that story?

Mr. SCHELL. I can rearlily believe it.

Mr. KNIGHT. And yoll want to initate that butter?

Mr. SCHELl. No; we do not want to imitate that butter. We do not want to imitate any butter.

Now, we will follow this product. We will go with the farmer's wife to the comntry stores, or we will be there when she arrives. We will see her trading it in for what she can get-5, $6,7,8,10$ cents a pound. We will see the grocer's clerk, before he puts it away, perhaps, run a ease knife through it to see how many hairs it contains, and see the case knife come ont with the hair adhering to it. And in order to get a hetter price by preventing the same discovery, when he sends it to his market-the merchant at the rail'oad town-me will see him have that butter worked over and some of those hairs taken out. But of conrse he can not renove the filth, about which our Philadelphia friend was speaking the other day, unless he has a renovating factory, which he usually does not possess.

IVe will see what sbe gets for it. Usually the trade is divided up into tobaceo and snuff, New Orleans molasses, brown sugar, a little calico, etc. Speaking of sulft, we will go back and see this same woman at the ehurn, driving the children away to see why the butter does not come, with a sunff brush in her mouth. We will see her pour in a little hot water around the churn dasher, and a little cold water, aud sometimes we will see her take off the lid, to the destruction of the flies hanging about there, and then, as she is working the butter, we will see her picking out the mangled remains of the flies.

Now that, gentlemen, is another kind of butter. That is the kind of butter which we do not recognize as a competitor of oleomargarine any more than French Brothers, or any up-to-date dairymen, recognize oleomargarine as a eompetitor of their goods.

That butter goes throngh various hands, until it finally reaches the renovated butter man, where it is made into process butter-resurection butter. Most of it goes to the creamery district of Illinois. I think I can follow the same roll of butter, from personal knowledge of the people, from the monutain districts of West Virginia, from the small farmer to the comitry store, to the store at the railroad town, to the 
commission men in Cincinnati, and from there to Ohicago, where it is sold to the process butter factories.

Now, as to the method of renovating butter

Senator Dolurver. One moment. You have just spoken of having butter in oleomargarine. What class of butter do they purchase to mix with the oils that go to make oleomargarine?

Mr. Screll. I can only state for certain factories. There are other gentlemen here who can speak for their own. In the factories of which I know, so far as butter has been userl, it has been the very hest-not faucy butter, perhaps, but the best ereamery butter. They insist that they must have the best butter, as well as the best of the other products, or the result is a failure. But the factories I represent are now using, not butter, but milk and cream. And after a while I will submit to you one of the stamps required by the Govermment, which contains approxinately the materials which enter into the prosluct.

Senator FosTER. Do all of these first-class oleomargarine waumfarcturers use the same formula?

Mr. Suhbll. Tot exactly. I think I am safe in saying that. If they did, they would have the same class of product, while it is a well-recognized fact that some of them can sell a great deal more goods than the others. And they sell them on their merits, and in competition, not with butter of any class or description, but in competition with the product of other factories.

Coming back to the point I was about to make as regalds the man. ufacture of process butter, the question has been raised here, and it was stated by someone that it was not necessary to use sulphuric acid in clarifying and washing this packiug stock during the process of making it up into resuruection butter. I want to say that sulphuric acid is used. I want to corroborate the statement which was made at that time and contraclicted, and $I$ know it. I an not betraying any professional secrets (if I clo not go too much into details), but I was aur am attorney for people who were in that business and they did use sulphulic acil to help in washing and clarifying and deodorizing packing stock that went into process butter.

Senator MIonky. That is injurious to health, is it not?

Mr. ScHELL. It is, indeed; any particle of it.

Mr. ADAMs. May I ask the gentleman a yuestion?

Mr. Schell. Yes; all right.

Mr. ADAMs. It is simply this: Are you willing to have questions asked"?

Mr. Schell. When I finish, if the committee say that there is time for it, I am willing. I would like to ask Mr. Ailams a question, though, and $I$ an willing to answer a question for him in turn.

Mr. ADAus. I lo not wish to iusist mpon it. I just wish the gentleman would exereise his own will in the matter. I clon't wish to urge it.

Mr. Schell. Well, it is the time of the committee that is being used, not my own. I am willing to stay here for a month, as far as I am concerned; but if Mr. Aclams wishes, I will be glarl if he will place himself on record now, that l may know how to use him later on, as to whether or not he would consent to a bill as a substitute for the Grout bill rhich wonld so herlge oleomargarine around with penalties and conditions that it would be practically impossible to pass it off for butter.

Ml. ADAlis. I am very g]ad the gentleman las reiterated by asking me a question; and I am perfectly willing to answer it. I would like to say that I would he in favor of a law that- 
Senator BATE. Is that the question here? Why not have the speaker go ahead?

Senator Doldivel. I presume the committee would prefer to have Mr. Schell proceed.

Mr. SCHELL. Why, Senator, the ouly question is this-you were not in when I began. I find, on examination of the record, the evidence presented, that the friends of this measure are not on reeord as to exactly what they want-whether they want to absolutely prohibit the manufaeture of colored oleomargarine, or whether they simply want it, as it is claimed by some, so hedged about that it would be impossible for it to encroach upon the territory of pure butter. That is all.

Senator BA'TE. I was not referring to that so mueh as to the irregularity of a colloquy between the witness and an ontsider. I do not think they should both go on and proceed to oceupy the time of the committee in that way. I thonght that was exactly the thing we were not to do.

Ir. SCnfll. Being anxious in every way to comply with any rule or regulation, we will drop that.

Senator BATE. I have no objection to it, sir, if the eommittee desires to lave the hearing proeed in this way. I was simply calling attention to it.

Senator Dolliver. In view of the cireumstances, I see no objection to what has oceurred.

Mr. ADAMs. Well, gentlemen of the eommittee, I did not ask the question for the purpose of getting an opportunity to answer another one. I imagined that the gentlemen perhaps might prefer, as many men do in appearing before a committee upon a subjeet of this kind, to have the subject opened up with the greatest latitude possible, in order to get all the information which we ean. But, waiving my own question, and replying to the question of the gentleman, I wish to say that I would be heartily in favor of a law whieh would make all men reigh 16i5 pounds. I do not think that sueh a law is possible. I do not think that you eonld execute it. I believe that such a law as the gentleman names is an impossible proposition. I do not believe that you can draw any law whieh will absolutely prevent the frandulent sale of oleomargarine colored in imitation of yellow bntter. If the impossible were possible, I should be in favor of it.

Senator Moner. That ean he said of any law whieh ever has bcen or ever will be passed. There never was a law passed anywhere whieh conld not be evaded in some way.

Mr. SCHELL. I am obliged to Mr. Adams.

Now, I come to the question, "Are these varions products competitive?" We insist that they are not. Every article sold in the United States, not governed by a trust, is sold on its merits. I take that to be a coneeded fact. There is an immense narket for the creamery produet at prices according to the grade of goods. Even the different grades of creamery butter must sell on their own merits, and not in eompetition with the higher grades.

Mr. Hamilton, of Penusylvania, as I understood him, said that the production of ereamery butter in his State conld be donbled and still find a home market. There is no question of any competition with creamery butter, I take it. Now, good butter makers, as I have stated, have a market the year around from 25 cents a pound up for their product. As an evilenee, Mr. Sharpless gets $3 \pi$ cents a pouml. His only oljection seems to be that he wants to get that to 50 . There he is in competition with the creameries, and the ereameries are in "ompeti- 
tion with Mr. Sharpless; oleomargariue does not enter into the matter at all.

As to packing stock, as to the final end of the bntter abont which we have talked, and into the details of which we have gone pretty closely, it is regulated by the supply and demand. It is not used in its raw state on the table of auybody who purchases something to spread on his bread, nuless in some rare instances. The price of packing stock now is, I think, about 1 [ $\frac{1}{2}$ cents in Chicago. I only estimate that, but I am in a position to know it, becanse the first thing I will do when I get away from Washington will be to go to Chicago to straighten out a tangle in regarl to a carload of this stuff which has been tied up there in litigation.

As to the price of the renovated butter, I can only say that it depends upou whether it is fresh when it gets to the cousumer or whether it is a few days old. By the most improved methods they bave ouly succeeled in getting it to keep, I think, six or eight days.

The oleomargarine factory and the creamery are only competitors in any sense in the attitude of purchasers; not of sellers. They compete for the milk of the farmers; and in that way their competition is a benefit to the farmer and the dairyman, rather than otherwise.

I was advised by Mr. Babbitt, one of our men who was in Detroit recently, that there was a conference of butter men there during the lioliclays.

Mr. Lestrade did not say the other day whether that was one of the meetings to which he ras invited or not. But I was advised by Mr. Babbitt (who usually knows what he is talking about) that the object and attempt of that meeting was the forming of a butter trust; that they met prematurely, expecting this bill to pass before the holiday recess, and that they adjourned to meet again, after the bill passed, so that they could perfect their organization.

Senator MoneY. That has been denied, though, luas it not?

Mr. Schell. 'The Detroit meeting has not been mentioned as yet, but the fact that they are contemplating a butter trust lias been denied.

Now, on the subject of prices, I want to refer to an advertisement in the Cincinnati Times-Star, the 5th edition of December 28; this also shows that oleomargarine is being sold in Cincinnati for what it is and that it is a very willing victin who is vietimized in that city by buying it for butter.

The advertisement to which I call attention is that of B. Н. Krroger, who advertises "forty tea and grocery stores."

Now, I do not know Mr. Kroger. He is not a client of mine. I have represented at different times a great many of the dealers there, but never Mr. Kroger. He advertises butter at 25 cents per pound, creamery butter. He does not advertise comntry butter at all. He advertises two grades of oleomargarine-one at 12 cents per pound, the other at 15 cents per pound.

Senator Fos'ER. What is it that makes that difference?

Mr. Scholl. The difference in the materials used. For example, the more of a higher priced material is used, the higher must be the price of the oleomargarine; and the higher priced materials used in this case, I take it, consist of butter fat.

Senator FoscER. Is it the butter that they use?

Mr. Schell. The butter fats, milk and cream, that enter into its composition.

Senator MoNEY. What do you mean by "butter fats?"

Mr. ScheLL. The butter fat is the fat- 
Senator Moner. The grease that is in the butter\%

Mr. ScHELL. It is the fat that is extracted from the milk and eream, and by improved processes the ereamery man can extract more of this butter fat than the dairy man. That is where they have such an immense advantage.

Senator Moner. By this centrifugal force?

Mr. Schell. By centrifugal force. Now, while I am on this subject, there has been a great (leal of talk (not testimony, but talk) here as to the selling of oleomargarine for butter, aud how a man groes in a store and calls for butter aud gets oleomargarine. But the statements have been a unit, with the exception of the Philadelphia men, as to the fact that the stamp always appealed on the wrapper, and the customer found it when he got home, and then he knew that he had gotten oleo.

Now, if B. H. Kroger were to sell one of his customers oleomargariue for butter, aceording to the testimony, or the talk of our opponents, lie wraps it in one of these wrappers containing the stamp. The customer goes home. He finds out that he has been swindled. Well, B. H. Kroger is not going to victimize that man, if he is an intelligent man, more than once. So he not only loses his butter tralle, but he loses his trade in coffee, in cammed pumplius, canned string beans, and all canned goods here advertised, corn, starch, tomatoes, peaches, asparagus, Hour, sugar, anl everything else that is hamlled at that store. He loses his entire custom, all for the difference between the price of a pound of oleo and a pound of butter. Gentlemen, it stands to reason that that is not lome to any great extent.

Gentlemen, in regard to this subject generaliy, I want to say that industries, like inlividuals, have their periods of growth, of matnrity, and of decay. In the butter industry the ehurn is rajiclly following the sickle, which was used iu the age when Dutch churus were invented. The sickle was displaced by the cradle, that by the reaper, that hy the binder; and they tell me that in the wild and woolly but prompessive West a machine thrashes the grain as it goes along. And tire Dutch churn must follow the example of the crooked stick attached to the horns of an ox with a hickory withe, which the Dutch-churn farmer used to cultivate the soil, but which has been displaced, step by step, by a wooken plow, a single shovel, a double shovel, and so forth and so on, until we liave the labor-saving eultivator and riding-car of the East and the immense steam plows of the mighty West. liecall your last visit to the National Museum, and compare the woolen-wheeled Wagon of the same gencration as the Dutch elum of the unprogressive farmer's wife with the wagon of to-ray with which the progressive farmer loanls his milk to the nearest ereamery and the carriage in which he drives his family to church on Sunday. Examine everything, gentlemen, that has ever been produced by the ingenuity of man to aid in the process of extracting wealth from the soil. or from the animals over which God gave man hominion, and you will fiud immense improvements in all, except that in the old Dutcin churn the limit did not seem to have been reached until science took a hand and creameries were established to supply the wealthy, aud the manufacturer of oleomargarine came into the fiell in the interest of the workingman.

Senator FostER. Did not this gentleman from New York the other day say that the old Dauish way of making butter was the best?

Mr. SchelL. It is the slowest.

Senator Foster. Did he not say it made the best butter?

Mr. SCHELL. It makes the best butter under the proper conditions; but he also said that the ordinary butter makers do not understand 
any more about that process than a pig does about side pockets, or something to that effect.

Now, gentlemen, we are coming to the opponents of the bill.

They have assembled here from day to day almost as patiently as this committee. They are law-abidiug, God-fearing citizens. 'They have appeared personally and by comnsel. They have testified when they conld aud listened to the other side when they conld not. They lıave dome nothing to detract from the dignity of debate, have spolien when invited. aud with confidence in God, the Constitution, and the Congress of the United States. They liave presented, wlien allowed, the reasons why they are entitled to enjoy the inalienable rights of life, liberty, and the pursuit of happiness, including, as has been said, the riglit to hold their property secmre from molestation and confisca. tion. They have made less noise, but really ontummer and are infinitely better behaved than the friends of the other side.

Among the opponents of this bill we find the oleomargarine mannfacturers, who are here resisting practical confiscation of their property.

Some years ago, before my general practice became as extensire as it is now, I dill a great deal of loaning of money for certain realtliy clients. Among other things I was called upon to inrestigate was the subject of making loaus ou factory property. And those who have had experience will bear me out in stating that a factory property is not considered a proper subject for a purchase for any bnsiness other than that for which it was erected; and even when in active operation is good for a loan of but a small per cent of its actual cost.

We have our machinery, which could not be used for anything else. We have our sigus-and I want to say right here that the oleomargarine mannfacturers have speut thousands and thousands of dollars in sending signs broadcast over the conntry, not for the purpose of aiding in any deception, but for the purpose of adrertising their prodrict. These necessarily are a complete loss. There is the good will which has heen bnilt up, the money which has been spent in advertising and sending men orer the conntry and talking np their product. On all of this expenditure returns are not yet in. It is an investment for the future.

Now, as to the plants of the other people, I do not know; but I do know this-that onr little factory in Cincimnati paid, not for the building site, etc., but for the plant proper, sitnated on a leasehold, $\$ 18,000$; and that property would be practically valueless if this bill were to become a law. And, gentlemen, are we not entitled to have our property taken from us, if it must be taken from us, only by dne prorcess of law? Are we not entitled to be paid for it if it is talien? And ret there is no provision in this bill to take care of any ruestious of this kind.

The Acting Chairman. Do you think it would entirely destroy the value of these properties?

Mr. SCHELL. I think so; and I make that statement from experience in estimating the values of factory plants. Even when a plant is in operation, it is not considered a good subject for a loan, becanse if the business should fail, the factory is considered a dead loss.

The Acting CHairman. That statement admits, it seems to me, that the only chance to sell this prodnct is by giving it this yellow color. You have said that color does not affect the healthfulness of it-it is simply a concession to the custom and taste of people, and is a mere matter of appearance. Have you considered the question whether it wonld be possible to cultivate a taste for an article not colored in 
that way. I am endeavoring to get at the question of how far this bill would totally wreck the business.

Mr. SCHELL. We have consiriered that.

The Acting Chamman. You say you have a business which depends for its life solely upon its ability to produce an article of a certain color, whereas these other people are complaining that it is their color you are imitating.

Senator Money. It is not the other people's color'; it is their own color. It was introduced by the oleomargarine people, and the butter men adopted it.

The Acting Chairman. I guess Goul established it originally, sir.

Senator MONEY. Tho oleomargarine manufacturers discorered it, and the other people united in initating it.

'The Ad'ring Cirairman. I liave an idea, from what you have said about the character of these goods, that this color is an incidental matter which wonld soon be overeome by the ordinary process of advertisement and the ordinary good sense of the community.

Mr. Schell. I think it has been stated here by one side, and conceded by the other, that taste constituted a large per cent of the attractiveness of a food prodnct, and color the balance. Professor Wiley, an expert on the subject, I think, stated that the eye aided the palate; and that no matter if an article was just as good as any of its class, if it did not look as you expected it to look, you were not going to have nearly the appetite for it that you otherwise would. And I think that statement will be borne out by your everyday experience. You go to different hotels, to a certain hotel, by choice, in preference to another, not becanse they give you anything better to eat, but because they get it up better, in better style. They please the palate and they please the eye. The eye aids the palate; and you enjoy the food better even if the cooking is not any better, and they have not really as much to eat.

Now, in addition to the oleomargarine manufacturers, there are interested in this bill the cattle growers, the sheep growers, who have been represented; the cotton growers and cotton-seed oil mills, who will be represented; and I might say, in addition to the interests of the cattle and hog growers, the people interested in the raising of every competitive animal-sheep, poultry, or whatever comes into competition with the prodnct of the cattle or the hog-are interested in this bill, because the prices are correspondingly advanced as the prices of cattle and of hogs are advanced.

The ACting CHaIRMAN. How much longer do you intend to proceed? We must adjourn the session for at least half an hour, I suppose.

Mr. SCHELL. I can go on this afternoon; I do not know how much time I will want, Mr. Chairman.

The Acting Chairian. What is the custom about meeting in the afternoon? bling.

Senator Fos'rer. Half past 2 has been the usual hour for reassem-

The Acting Cmamrian. Then you will be prepared to resume at half past 2.

Senator Foster. You have the floor, Mr. Schell.

The A C'Ting CHAirman. You will be conceded the floor at half past 2.

Mr. Springer. Mr. Chairman, the cotton-seed oil men are here, and may be here this afternoon when Mrr. Schell gets through.

The ACTING CHAIRIAN. All right; we will be ready to hear them at that time. 
(Therenpon, at 12 o'eloek m., the committee took a recess until 2.30 o'eloek p. in.)

At the expiration of the reeess the committee resumed its session.

Present: Senator Dolliver (aeting chairman); C. Y. Knight, secre. tary of the National Dairy Union; Hon. William M. Springer, of Sringfield, Ill., representing the National Live Stock Association; Frank W. Tillinghast, representing the Vermont Manufaeturing Company, of Providenee, R. I.; Charles E. Sehell, representing the Ohio Butterine Company, of Cincinnati, Ohio; Patrick Dolan, president of the United Mine Workers' Association; John Pieree, representing the Amalgamated Association of Iron and Steel Workers; W. E. Miller, representing the Armour Packing Company, Kausas City, Mo.; John F. Jelke, representing Braun \& Fitts, Chicago, Ill., and others.

Mr. SCHELL at this point permitted an interruption to hear from Mr. Patrick Dolan and Mr. John Pierce, whose statements against the bill appear later.

\section{CONTINUATION OF STATEMENT OF CHARLES E. SCHELL.}

Mr. ScherL. Befole I go ahead I want to say that what these gentlemen have said has cut down my remarks somewhat. But I want to add to what they have both said, and in reply to your questions, before going on with my argument, that the poor nan has his pride just the same as the rich man; and, as the first gentleman put it, they do not want their poverty legislated on their table three times a day, as would be the ease if they were compelled to use white oleomargarine or go without anything to spread on their bread at all.

On the subject of frands that are perpetrated I will speak later on, and will invite any questions which the Chair or the committee may deem proper to ask as to what I know about it.

This morning I was enumerating the various people who were before the committee, by their duly authorized representatives, asking that this bill should not become a law. Not that that should have any effect; it is not the people who comnt; it is a question whether or not it is a just and proper measure. Of course, they all want to be heard. Every man who is interested is entitled to be heard and entitled to be consiclered. But the main question still remains, "Is it a proper subject for legislation, and does the bill properly legislate on this subject?"

In addition to the people I named this morning, we have on our side every intelligent farmer-not the farmers who are dictated to by the dairy-paper publishers or the representatives of the would-be butter trust, but the farmer who thinks for himself, beeause he knows that everything that is on his farm is enhanced in value by reason of the increased market for a part of what he raises. Every time that his beef is increased in value its competitor, the sheep, goes up just that much; poultry will bring a great deal better price, and so on through every product that he raises that goes into the markets for people to eat.

Now, these two gentlemen who have just spoken are bere direetly representing $6 \overline{5}, 000$ of another elass, a very small portion of another elass, who must eat either white oleo or gravy, as the case may be, in case this bill beeomes a law. The ordinary "sop" which you as politicians have probably found on the tables of a great many of your constituents, the same which I have found on the tables of many people with whom I have stopped when out bieycling, ricling, hunting, or fishing, does not parade the poverty of the inan who has it on his table

$$
\text { S. Rep. } 2(1)+3-18
$$


as much as the white oleomargarine would. Somebody has said that we make a greater effort to appear liappy than to really be so; and that is the fact. That, perloaps, prevails more in the wealthier class than it does in the poor class; but it prevails in every class of humanity.

On this subject I might also quote the remark that "a hole may be the accident of a day, but a patch is premeditated poverty." The gravy might be the accident of a day, but white oleo wonld be premeditated poverty; and the man must so advertise to his children aud the visitor who sits at his board.

In addition to these classes, every man who is willing that others shonld have the same right which he claims for limself is on our side of the fence; and the man who denies to me any right which he claims for himself is a robber and a thief just as much as if he should rob me of my money.

Now, gentlemen, I had intended going into an analysis as to what was presented by our side before the House committee; but I will have to cut that out, and will merely refer to some testimony which I want to use in argument. I quote Conmissioner Wilson, at page 168 of the House report, where he says:

"I should regard the tax of 10 cents a pound on colored oleomargarine as prohibitive. I do not think the manufacturers can do much with it with a tax of that amomnt. I think the bill would defeat the end of deriving any revenue from the sale of co'ored oleomargarine. I think that would be largely the result of its passage."

Then he goes on to recommend a change in the existing law. He says:

"I wonld recommend a change which would reruire the manufacturer to put up statutory packages in subpackages to meet the lowest demand of the retail trade and the highest demand of the wholesale trade, upon each of which subpackages should be impressed, in such a way that it could not be obscured or obliterated without manifest effort and intention, the word "Oleomargarine;" and that, Mr. Chairman and gentlemen of the committee, would so hedge about the sale of colored oleonargarine that the only place in which it conld be palmed off on an unsuspecting consumer would be at the hotels. It would practically be driven to a corner. And then these food commissioners, who come here in the interests of their jobs, or perhaps in the interest of their constituents who furnished them jobs, would ouly have to go to the hotels; and how many hotels conld stand an exposé of that kind more than once? Why, they could not stand it at all.

Let them attach penalties. Let them fix it so that every conviction will add to the revenues. It is charged by the friends of the bill that the internal-revenue people will not enforce this act because it does not aff'ect their revenues. Let them attach such fines, such penalties, as will enable them to get wealthy, so that every other revenue can be abolished, if need be. We do not care. We want it sold on its merits. Hedge it about as you will, but do not say to the poor people, "You can not have colored butter"-for it is butter-"on your table," and to the rich people, "You can have yours colored."

It is just as bad to legislate that the man with a limited income should wear a certain colored suit of clothes, while the rich man could wear anything he pleased. It is identically the same proposition.

Commissioner Wilson goes on to say-and he ought to know-this:

My judgment is that the amount of this material that is sold as butter is not nearly so large as some people beliere; and my judgment is that there is not nearly so much vicionsness as is commonly suyposed in the sale of that which is not marked. I make a distinction, in other words, between that which is sold as butter and that 
which is handerl ont in a passive way without its being indicated whether it is butter or oleomargarine. I do not think there is as mueh of that which is actuated by gain as has been represented (p. 169).

I will add my personal testimony to that later on. He also said (p. 170):

There has never been any evasion of the law with respect to paying the tax on oleomargarine, except in a vers incidental and limited was. Neither the special tax (although it is high), nor the 2-cent pound tax have ever been evaded. We have no tronble in collecting them,

And before leaving Cincinnati I asked the Hon. Bernard Bettman, collector of internal revenue there, if lie cared to be quoted, or would allow himself to be quoted, on that subject; and if so, what he had to say. He said: "They give me no tronble at all."

Then Commissioner Wilson goes on to speak as to the necessary absolute purity of the article, because the materials must be used at once, and he quotes from some one whom he considers good authority.

Then Representative Allen asked him (p. 171): "Now, sir, have any complaints been made to your Department of any deleterious or injurious effects cansed by the consumption of this article?" To that question Commissioner Wilson answered: "No, sir; no, sir. The only complaint that has ever reached the office was a letter that Mr. Tawney pnblished here, in the Star, I think-at least, it was the same letter that he read to me. I took a copy of it and sent it to the agent in charge of the territory where most of these oils are produced, and had a very complete and thorough investigation made, and have here a copy of his report.

Representative AlLEN. That is a copy of the report?

Commissioner Wilson. A copy of the report of the agent; yes, sir. He does not find any gronnd whatever for the charge made in that letter. He sass it is false and utterly unworthy of belief; and be shows pretty conclusively. I think, that his statements are true. And without his knowing anything abont the doctrine laid down here, in this investigation to which l have referred, he brings out in this same report the fact that the same coudition of things exists.

There is an extensive report. I wish you would read it.

Senator Dolliver. Is that the report of the House committee?

Mr. SCHELL. Yes; it is in the report of the Honse committee.

Senator Heitfeld. Just give us a reference to the page.

Mr. Schell. It is on page 171. I am not going to read the report, but I am going to call attention to one part of it, to use later on. This man was unable to locate the writer of the letter. It seems that they, like some of the food commissioners, pay attention to every letter that they receive, anonymous or otherwise, and they act upon them. But the report further says (p. 175):

However, it is the general impression among nearly all of the packers, as well as the oleomargarine mann factnrers, that the author of the published letter is Charles $Y$. Knight, manager Chicago Dairy Prodnce, a publication published in the interest of dairy products, 188 South Water street, Chicago.

(Mr. Knight arose.)

Mr. SCHELl. Yoll will have your turn later on.

Mr. KNIGH'r. I insist, Mr. Chairman-

Mr. SCHELl. I am keeping within the record.

Mr. KNIGHT. I insist that if my name is mentioned I should have a right here to enter the record and make a protest.

Mr. Schell. No; your side has reserved the right to close.

The Acting Chalriran. Are you the man referred to?

Mr. KNIGHT. I am the man whom he accuses. I can bring a man within fifteen minutes who knows the writer of that letter personally, 
and will substantiate what he says. I will bring him from the Public Printing Office. He is a man of whom I never heard.

The Acting Chairian. We will have no controversy; but $\mathrm{Mr}$. Knight disclaims the responsibility for the letter.

Mr. KNIGHT. He will be vonched for by Representative Cooper, of Wisconsin, who got him the position there, and who vonches for this man Loelıbler, and can tell Mr. Cowan or Inspector MeGinnis where he will find him and what his position is. And he will also give this committee, if it desires it, some information which will substantiate what this man wrote.

Senator HerTfeco. Where do you find that letter here?

Mr. Schell. The letter is not shown here. The report on the letter is given at page 171 .

Mr. KNIGHT. I will further give the name of the man that I will bring. His name is Reed. He is foreman of a department at the Pub. lic Printing Office.

Mr. SchELL. On that subjeet I want, before J go any further, to say that I am going to stick to the record; I am not going cutside of the reeord.

Mr. KNigh'T. All right, sir.

Mr. SCHELL. And, as I understand, these gentlemen elaim the right to elose.

The Acting Chairian. Yes.

Mr. Schell. They have not presented their case, but they want to close.

The Acting CHAIRMan. The ehairman permitted Mr. Knight to speak simply because I understood he had been charged with the authorship of a letter which he denied writing.

Mr. SchelL. I am willing that he should go on record now as denying it.

The Acting Cirairian. Now, the gentleman will proceed without interruption.

Mr. Schell. That is all right. Commissioner Wilson goes on further and says, on page 177: "I think everybody buys it. I think it is clean and reputable"-referring to oleomargarine. Representative Allen asked: "Do you regard its mannfaeture as a fixed industry in the country, which ought not to be abolished?

"Commissioner Wilson. Tes, sir; I certainly do; and, if I may ven. ture this statement (you will pardon me if I go beyond what I should say), I will say to you, gentlemen, that any legislation which you may enact here with respect to stamping or identifying as an entity the quantity of eleomargarine that goes into the hands of $\mathrm{A}, \mathrm{B}$, or $\mathrm{C}$ to be used on their tables will give it a badge of eredibility that it would not get anywhere else."

That is his opinion. Speaking of the factories, he says: "They are wonderfully eleanly conducted affairs." Then he touches on the question of revenue-showing an income of a million and a half per year. On that point, I believe, there is no doubt.

Then I want to call attention to just one statement of Professor Wiley; and as to the other testimony, I will simply refer to it for proof, if wanted, that the millions of individuals and investments are aetually opposed to the passage of this bill.

Professor Wiley condemns anything being sold for otherwise than what it is, and he wants it so that the purchaser may know what it is. That is right. Then he says (p. 196):

And that is the attitude that I hold toward pure-food legislation-that it should be general and not special in its character. I believe that the dairy interests would 
be far better protecterl under the Brosins bill, which is pending before Congress, than under a special bill, becanse all the interests would be placed on the same footing. The Brosins bill absolutely prohibits the sale of any product as an imitation or under the name of another, and provirles penalties for that specific purpose; so that it would be ahsolntely impossible nuder the law, if that bill were passed, to sell oleomargarine for butter answhere in this country.

Now, I have not seen that bill, but I have heard of it from time to time. It is backed by all the pure-food congresses and commissioners and everyborly else, I think, in any way interested in the absolute purity of all that goes on our tables. I do not know what the bill is; but if such a bill could be conceived it would have the support of every oleomargarine manufacturer in the country, and, I think, of every labor organization, of every farmer, and of everybody who eats. And most of us subsist largely on what we eat.

Mr. ADAMS. If the gentleman permit me to correct a statement, which he undoubtedly made in good faith, I will say that he is mistaken in saying that that bill is supported by all the dairy commissioners in the States. While they concede certain merits in the bill, the dairy commissioners of this country, as a rule, are not in favor of that law, as at present informed, so far as my knowledge extends.

Senator Heitfeld. To what do you refer?

Mr. ADAns. The Brosius bill, the national pure-food law.

Senator Heitfeld. You say the dairy commissioners are not in favor of it?

Mr. ADAMs. They are not in favor of the bill in its present form. They are in favor of some of the essential principles of the bill, but not as worked out in that particular act.

Senator HeitfeLd. I have read that bill, and I have heard of it. It is universal, of course, is it not?

Mr. Adams. Yes.

Senator HeITFELD. It would also compel dairy products to be labeled as to coloring matter and everything else?

Mr. ADAMS. Well, that depends npon the interpretion of the general principles laid down in the law. They do not object to that part of it at all.

Mr. Schels. Whatever it is, such a law shonld be enacted and should be enforced. We have a splendid law in the State of Ohio which wonld be well to incorporate into some national law.

The ACTING CHAInMaN. I think the main difficulty in that matter is to frame a law which would be within the jurisdiction of Congress on the subject.

Mr. SCHell. Exactly, Mr. Chairman. I was going to touch on that later on, when I came to discuss the bill. Then I want to call special attention to the statement of Professor Wiley at page "2S of his testimony, in which be distinguished between the chances of contagion or chances of danger in the two rival products, if they are rival prodnetsoleomargarine and butter. He discriminates in favor of oleonargarine as containing the least danger to the public health.

So much, gentlemen, in a general way, for the enemies of the bill, for those who are opposing this legislation.

Now as to the friends of the bill. I can not give them the attention I would like. I will try to be very brief and I will try to keep within the record.

They rest on alleged numbers. They say, "We, the people-we, the dairymen, want it as a remedy for (imaginary) injuries." They have neither proven their numbers or their injuries.

Their argmment is to abuse oleomargarine, every one connecterl with its manufacture or sale, and branch out to judges, juries, revenue offi- 
cers, pure-food commissioners, chemists, and so forth ad infinitum. They remind me of the story of the old Scotch woman, who was dwelling on the wickedness of the world. Her minister said: "Well, if what you say is correct, nobody is sure of heaven but you and John." "Oh, well," said she, "I am nae so sure abont John." (Laughter.)

They submitted their pretended case briefly and announced that they were through. The record shows it. But they have taken most of the time allotted to us and half the time of our speakers, either in actual talking or in diverting the speaker from his course of thonght, as a result of which he has necessarily to repeat himself-except Mr. Gardner, who spoke before they recovered from their surprise that we were to be allowed to be heard at all; and Mr. Pirrung, who would not permit of interruption. And later, after their case had been submitted, as we supposed, they claimed the right to close.

We do not objeet to that. But we do not want to impose on the committee. Nor do we want to help the other side. They are certainly entitled to rebut-not to make their case later on, but to rebut any testimony which we have offered. And we claim the right then to rebut any new testimony which they offer. And I know, from the fairness heretofore displayed by this committee, that we will have it.

Mr. ADAMs. Has the gentleman any record of any claim made by the friends of this bill that they should close the thing?

Mr. ScHELL. Ol, yes; it is in the record. Then again, they are really entitled to close, but not to make their case in the closing presentation.

Mr. ADAms. I have not heard of it.

The Acting Chairuan. There comes a moment, of course, when this reciprocity of winding things up must cease.

Mr. SchelL. Certainly, certainly. The late lamented Edgar W. Nye once said: "Some people want the earth. Others are content with the fullness thereof." "These gentlemen seem to want both tha earth and the fullness thereof. I want to briefly mention the prominent friends of the bill, beginning with Governor Hoard. I would rather that the gentlemen would be present-

Senator HEITFELD. Had you not better confine yourself to the sub. jeet itself? We will hear from these men after a while. I think you are mistaken about their reserving the right of closing. They may have said that they reserved it and it may have been granted. Of course we have changed chairman quite often and the members of the committee, as they have attended, have varied from two to four and six. We have not had time to be present continuonsly and we may be mixed on this subject. You say that this is in the record. I do not know, but I think you had better confine yourself to the subject itself, so that we will get through sometime.

Mr. ScHel. That is right. I want to eonfine myself to the subject itself, and if it please the committee, I will aim to keep strictly within the reeord. But we have been attacked. There have been elaims made. We will not say that we will analyze Governor Hoard. That is not the intention, but we will analyze his statements.

Senator HEITFELD. The committee is able to julge of these matters.

Mr. Schell. But it is for the purpose of pointing out the reak points in his claim, which is submitted here as a part of the introduction of the case-the statements that were made by him and others before the Honse Committee. I will be very brief.

The AC'ING CHAIRuAN. The gentleman will proceed, abstaining as far as possible from any eontroversial personalities. 
Mr. SCHeLL. Oh, yes-certainly, certainly. I want to say that I will sit quietly throngh anything which may be said in reply to whatever I may say, and I will try not to transcend the bounds-

Mr. ADAxs. I wish to say, Mr. Chairman, in behalf of these gentlemen who are to be subjected to analysis, that we have not the slightest objection to it and are quite curious to hear it.

Mr. KNIGHT. Only, Mr. Chairman, I want to say that I have been accused of forgery in this committee and-

Mr. ScheLl. I have mot accused you of it.

Mr. ADArs. You certainly did. You certainly said that it was the general opinion that I wrote the letter to which the name of a man named Loebbler was signed.

Mr. SCHELl. No; I simply quoted from the record, and never heard the name Loebbler till you just now used it. I do not vouch for any statement that appears in this record produced by one side or the other; but it is before the committee, was introduced by your side, and we want to talk about it.

Mr. KNIGHT. Was that in the record of the House that I was accused of that?

Mr. Schell. It was in the record of the House. You will find it on the page I mentioned. Now, I lıope my time will not be too linited, but I want to get ahead.

The Acting Chamman. You can see the necessity of not accusing people of this, that, or the other.

Mr. Schell. I can, but a greater necessity exists for going fully into what appears in the record.

The Acting Chairman. Otherwise we will have that much more to go into.

Mr. SCHELL. That is right.

Now, Governor Hoard, as appears by the record (Senate Committee Hearing, p. 34), was artificially coloriug cheese forty-five years ago in New York.

He is presilent of the National Dairy Union, serving without money and without price. He does not say that he is serving here for nothing, but leaves that impression. He is not so adroit with the $5,(100,000$ farmers whom he claims to represent as his colaborer, Mr. Knight. If he could only get 50 cents apiece for the same proportion and $\$ 1,000$ apiece for the balance, he would not need to longer deuy the farmers of his district an interest in his ten ereameries, as suggested last Friday by Mr. Lestrade.

But to turn to the testimony, he begins:

"Whom do we represent? The united dairy sentiment of the nation. That means over $5,000,000$ farmers, and an annual cash value in their product of over $\$ 600,000,000 . "$

That is produced as an argument. I would not prodnce such an argument before this committee. It is not an argument. It is simply a statement to the eflect, "Here we are, with these numbers back of us; and you must do as we say."

By what authority does he represent these people? He has not shown it. He has not proven it.

Then he goes on to say, also:

A rast army of consumers of dairy products who are constantly duped and swindled by a counterfeit substitute for butter.

He has not proven that. These gentlemen who are here to day as consumers deny it. One factory I represent sells direct to more than one thonsaud consumers. One of the Providence manufactnrer's told 
your committee that three-fourths of his product went direct to the consumer.

The consumer is defraurled of his money and the dairs farmer of his rightful market, the first being compelled to pay a bitter price for that which is not butter.

The testimony is to the effect that the farmer still has his market for butter; it is everywhere increasing in price, and milk has gone up in price. That all appears in the record. And as to the consumer being defrauded, we have some testimony on that subject, but the reverse of the claim; and I want to add my individual testimony very shortly. He goes on-

The oleomargarine combine consists of less than 20 manufacturers, who have entered into a couspiracy to break down these State laws.

I will say that there are not any more bitter competitors in any business in the world than the oleomargarine manufacturers of this comntry. I represent part of them, and I know how they are fighting among themselves, and how they are doing business at a bare living profit.

He says, "Who have entered into a conspiracy to bleak down these State laws, and, by bribing merchants"-they have not shown it-" by deception of all kinds"-they have not shown it-"by subsidizing eity newspapers"-they have not proven it_" by employing leading politicians"-we do not know of one. We have not shipped any masters of State granges here. We have not sent any telegrams, to my knowledge, except one that came to Senator Foraker asking that he delay the hearing until I could get here-"to so neutralize the effect and administration of those laws that they may force their counterfeit upon the public." We have shown that we are not forcing a counterfeit upon the public.

These manufacturers are assuming to override all law. They stand behind all infractions of State and national laws, and furnish noney for the defense of their agents when arrested.

That has not been shown.

The Acting Chairian. Is it so?

Mr. SchelL. It is not so. I can answer for three factories. It is not the fact.

Mr. KNIGH'T. May I ask a question right here?

Mr. Schell. No; because my time is limited. You can answer this argument. That right has been reserved.

Mr. KNigH'1. I wanted to ask what your business was.

Mr. ScheLL. I know; but you break up the continuity of my statement. He continues:

" (On one side stands one of the greatest of our agricultural interests, together with the millions of consumers"-millions again; numbers, not arguments-6" who are tirerl of being swindled." They have not so testified. I have not heard the testimony of one. I do not think it appears in the record.

"On the other side stands the oleomargarine trust" - there is no trust. If there is, we are not in it_-" engaged in manufacturing a coun. terfeit," - we are mannfacturing butter by a different process-"depending on lawbreaking, falsehood, and deception for its success, backed up with millions of capital."

They have not shown where the millions of capital come in. On the contrary, later on they speak of the combined rating of the two firms 
who put out fully one-third of the product, being, according to Dun, only $\$ 400,000$. Then they go on:

The dairy sentiment of the county would be willing that the uncolored compound shouid he relieverl of all taxation. The tax as provided in the bill, however, is trifling and noninal. This is done in the spirit of fairness.

It is done as the grossest kind of unfairness. He then goes on:

To give added force to the first section of this bill, it is also provided in the second section that a tax of 10 cents a pound shall be imposed on all oleomargarine in the color or semblance of butter. In plain words, this is repressive taxation.

That is the nearest we have been able to get them on record. I want it remembered, and want to comment on it later on; but I must pass the larger part of this. He goes on to say:

It has been found, through the inefficient administration of Stute laws and the powerful influence of this oleomargarine combination, that this protection is insufficient.

The only testimony we have here is from the States of New York, Pennsylvania, and Ohio. The New York laws are in force. The Ohio laws regarding fraululent sales are enforced. The Pennsylvania laws were allowed to run riot, but now they have them in hand. As soon as they took charge they enacted a law, a necessarily unpopular law, and put in a commissioner, and expected him to enforce that law over the Commonwealth of Pennsylvania for $\$ 12,500$ a year! Mr. Sharpless does not think that Mr. Hamilton tries. I do not know Mr. Hamilton, but I have no doubt he does the best he can with the amount of money at his disposal. But when they get together and contribute, and pay an attorney, and go after the firauds, the laws are capable of enforcement. According to the testimony, they have reduced the licenses from some 500 down to 32 , I think, in the eity of Philadelphia. This shows that they are capable of enforcement.

The hoped-for effect of the legislation asked of Congress is not to destroy the oleomargarine industry, but to force it over onto its own ground; to compel it to be made in its own guise and color. Is there any thing unjust or unreasonable abont this?

There is nothing unreasonable abont a law to force it onto its own ground. The factories to a mnit will help to enforce auy such law. I want to speak of the attitude of the factories on that point later on. But to try and get one of the main advocates of this bill where the committee will know where he stands, and so we may know where he stands and what he wants- whether to tax us out of existence or merely to confine us within our proper limits-is a thing that I have not been able to do. He goes on:

We are met by certain alistractionists with the question, "Would you tax one legitimate indnstry out of existence for the benefit of another?" 'To this I would answer "No." The olenmargarine business is not conducted legitimately. It is based, from manufacture to sale, on wrong and illegitimate methods.

They have not proven it. They concede that the manufacturer complies with the law now. It is only the retailer; and the manufacturer will help to compel the retailer to sell his product for what it is.

Mr. Hoard refers to the unhealth ful part. That is a matter too plain for discussion. He then says (p. 4):

The whole proposition is in a nut shell. lorce out the color or semblance to butter and you put a stop to its being imposed on the consumer for butter.

He evidently means to force out the manufacture of colored oleo, no matter how badly the people want it. 
Right there I would suggest that if no other privilege is granted us, we would like to bave the ability to make colored goods to the order of the consumer. He does not grant that.

Now, we quote from his statements before the Senate committee. He says:

I will only add that the bill is for the purpose of preventing the counterfeiting of food, so far as the constitutional power of the Federal Goverument can go.

Now, the main point. He says to you, gentlemen:

The Federal Government is limited in its constitutional power. It has no right to enact prohibition.

If this is probibition, and is so shown to the committee, Governor Hoard says you have no right to enact it. "It has no police power." If it is police power, you have no right to enact this law.

Those things you are as well aware of as I am, but it has taken gronnd apon certain lines, like the taxation of State bauks in the interest of a sound currency, etc.

And he brings in his "great army" again. He alleges that the coloring of butter is not a vehicle of deceptiou. And Senator Allen, at page 12 , asks him the question:

Why does the prudent farmer orlinarily in June endeavor to put down enough butter to carry him through the winter for lis own use?

Mr. Hoard. Senator, that is nut done at the present time to any appreciable extent.

Senator Allen. It has been done ever since I was a boy.

Mr. Hoard. It may have been done when you were a boy and when I was a loy. As to that you are right, but at the present time the whole system of butter making is changed.

That is what we claim.

Not one man puts down butter in June for the next winter where 10,000 did it forty years ago. This wonderful change has come through the organization of creameries, where now a very large proportion of the best butter is made.

We also claim it comes throngh the organization of creameries, as we aimed to show, and not through any competitive work of the oleomargarine interests.

The next witness is Mr. Charles Y. Knight, who was the main witness before the House. And I want to disclaim in the start any personal attack on Mr. Knight. I am only attacking his argument. An argument can not be proven bad by proving the man who made it is bad, and the man is not necessarily bad becanse it is a bad argument. But we must look at motives and the inducements to get on the wrong side. I think Mr. Knight is honest, but mistaken.

Mr. KNIGHT. Thank yon.

Mr. SchELl. He began, aceording to the record before the House, fourteen years ago; according to his statement this morning, twenty years ago. It seems he can not quit. He can not realize the changed conditions. We might say it is due to his phrenological construction. We admire a man who sticks to a proposition. He starts after a thing and can not stop nutil he gets it, even if it is no longer desirable. And this is not desirable now, as we will show later on. But then, he represents the farmers; and he is better' off, a better manager, than Goveruor Hoard, because from 24,600 farmers he has been able to collect 50 cents apiece, and from some of the balance of his 30,000 , as he states in his testimony (1. 62, House Com.), some of whom might have contributed as high as $\$ 1,000$. He was probably paid in advance, and he must earn his money. The only tronble is that he is working them-no, working for them-too much for that amount. 
Now, to take his statement, he begins:

My business is that of editor of the Chicago Dairy Produce, a publication devoted to the dairy and butter business. I have for the past three years been secretary of the National Dairy Union, an organization of farmers who keep cows, and others engaged in pursuits allied therewith. This organization at present comprises about 30,000 members who are farmers, and they are scattered all over the United States.

Now, I do not kuow whether he is representing the same farmers Governor Hoard represents or not; they are officers of the same organization; but if he is, they have diminished on the same scale as did the subject matter of the story of the boy who came in at night frightened and told his father that there were 100 ) cats fighting under the barn. That number was questioned, reduced to "50, anyway;" then to 25 ; then to 10 ; and it kept on until they got down to "our old tomcat and another one." And these five millions of people who are represented by Governor Hoard, according to his statement, appear to have dwindled at about the same ratio.

Mr. KNigitT. That was almost a year ago, Mr. Schell.

Mr. Scyell. Mareh 7, 1900, is the only date we have here. And when yon call for another contribution you will find the rest have faded awav.

Then on the next page he states:

I have had charge of the work of organization and the collection of facts regarding the oleomargarine traffic of this country, and it is the enormous illegal and frandulent growth of the business during the past few years, in face of the best restrictive laws the States have been able to devise, that has brought us to Congress as a last resort to ask for relief.

It was two years in that case; immediately after, fourteen. He says:

For the information of the committee, all of the members of which may not be faniliar with tlie history of national legislation along this line, I will state that fourteen years ago, finding the powers of the State belpless to cope against the peculiar character of this frand, the dairymen of this country arose en masse and came to Congress for relief, feeling that nothing but Congressional action would save their business from absolute ruin.

And yet, in spite of all, and in spite of fate, the dairy interests have been increasing in value all over the country, and the extent of it appears somewhere in the record. I will not attempt to quote it, as I want to be absolutely accurate.

Mr. KNIGHT. They got what they called for then?

Mr. SCHELl. No; they called for a 10-cent per pound tax then, and they did not get it.

Mr. KNigitT. We got part of it.

Mr. Schell. Now, to quote Mr. Knight again, I want particular attention paid to this (p. 6, House Com.):

The matter of legislating against a counterfeit article, however, was found to be a complex proposition for Congress, becanse of the constitutioual restrictions which prevent the Congress of the United States exercising police powers except for the protection of its revenue receipts, interstate commerce, and other matters absolntely within the linits of the ('onstitution; and after months of tedions investigation and effort what is known as the Hatch bill was finally originated by the Committee on Agriculture and brought into the Honse.

They concede the limitation of the police regulations.

To pass on rapidly: At jage 10 he quotes the Shollenberger case as sustaining the Plumiley case.

In the Senate hearing; at page 4, he advises General Gront that the cases conflict.

Mr. KNIGH'T. Do you mean that I advised General Gront that the Shollenberger and Plumley cases contlicted? 
Mr. Schell. Someone will kindly look at page 4 of the hearing here before the committee.

Now, he says further (1. 10):

All that we ask is that the people be protected in the right to choose between the two articles.

We agree to that, to a man. We want the same thing. We want to have the right to choose between the two articles. But does he mean it? The evideuce is conflicting on that point.

He goes on to say:

We have not appealed to Congress for aid along the line of discouraging the sale of oleomargarine made in semblance of butter, nutil the matter of accomplishing the same l'esult through State legislation has been thoroughly tested and proven a failure.

The evidence is not to the effect that it has proven a failure where it has been tested.

Mr. KNIGHT. Mr. Schell, will you permit me to make an interruption?

Mr. SCHELL. In just a moment.

Mr. KNIGHT. I wish to make a correction in the record. I want to call your attention to the fact that the stenographer made a mistake in attributing this remark to me. It is evidently something which Mr. Flanders said. I did not make the statement. It was the stenographer's error, and that should be corrected in the record.

Mr. Schell. We are willing that that should be done. We do not want to misquote anybody.

The Acting Chairman. While you are right there, this thought occurs to me: Of course, I think, nobody wants to destroy this industry.

Mr. Schell. I think Congress does not.

The AC'IING ChaIRuan. If it can be preserved in some way which will do justice to other industries. Is there not some point where you could select an oleomargarine color which would be agreeable to the taste and attractive to the eye, and which would not collide with this ancient butter color?

Mr. Scheli. Why, if you please; we will select and will adhere to the same color which we have used since our beginning.

The Acting Chairman. I know, but that happens to correspond with the color of butter. It is identical with it.

Mr. Schell. It happened to correspond, according to the evidence and the facts, with the color of butter adopted by the creameries, which came into existence after we began to color oleomargarine, and has since been adopted by the dairies and the farmers. We are the first in the field with a uniform color; and if they will stick to their natural color, there will be no danger of any conflict.

The Acting Ohairman. But in that case this question of family pride, which was referred to in connection with these families in Pennsylvania, would still arise.

Mr. Schell. It is custom; it is pride. Pride never gets too hot or too cold; and pride affects the appetite and everything else.

The AC'Trng CHaIRMan. But if butter makers should uniformly adopt the artificial color of white, these gentlemen who spoke a while ago wonld still be left in the shabby situation of buying an article which was in some disrepute in the neighborhood if they took oleomargarine.

Mr. ScmeLL. I think that is a little far-reaching; but if they should complain, in that event they would be complaining without just cause. And unless a complaint is made with cuuse, it ought not to receive much consideration. 
Now, Mr. Knight says (p. 11):

We have not appealed to Congress for aid along the line of discouraging the sale of oleomargarine made in semblance of butter until the matter of accomplishing the same result through state legislation has been thoroughly tested and proven a failnre. And this fact we believe to beour strongest argument in favor of Congressioual action.

If that is the strongest argument they have, it is entitled to a little attention. They began fourteen years ago. According to the synopsis of the State laws, the majority, almost all, of the color laws have been in existence only since 1896 . Some of them date back to as early as 1888 and 1859, but the majority of them were passed abont five years ago. I would like to comment further on this point, but the mere mention of the facts is sufficient.

Mr. Knight further states: "As far back as 1886, when this matter first eame before Congress, the States had learned of the impossibility of controlling this traffic throngh State laws." Fifteen years' experience, and the testimony here, prove that the traffic can be controlled by State laws; and I will further testify on that subject myself, from my personal experience.

Mr. Knight says (p. 18):

For a few sears these laws forbidding the coloring of oleomargarine in semblance of butter were effective.

I do not know just what he refers to, but if they can be enforced part of the time, they can be enforced all the time. I do not suppose, however, that he meant the present laws, because they could not be referred to in those terms. They are too recent.

The Acting Chamrian. Let me ask you abont these State laws. Is there a State law in Ohio against coloring oleomargarine to correspond with the color of butter?

Mr. Schell. Yes, Mr. Chairman; and if you will permit me, I want to take up that matter presently in detail. I am trying to pass these matters as rapidly as possible. I have a copy of the laws here, and I want to submit them. They are morlel laws, except that they are partial to the farmer, and except the color part. Of course we object to the color clause.

The Acting Chairman. Is the sale of colored oleomargarine prohibited in the State of Ohio?

Mr. SCHELl. It is prohibited in the State of Ohio, absolutely. Both manufacture and sale.

The Aoting Chairinan. What effect on the traffic in the local market has that had, as far as your Cincinnati factories are concerned?

Mr. ScHELL. The effect has been

The Acting Chairuan. I want to ascertain how far this abolition of the yellow-oleomargarine color would tend to wipe out the industry.

Mr. SchELL. I do not know that I can give you the statistics on that point; but I will tell you presently just the effect it has had in Cincinnati, the fights that have been made, and the effects or results.

Mr. Knight then goes on (p. 19):

The ordinary State's attorney can not cope with these experienced practitioners upon this subject, as a rule; and never is money spared to make the prosecution as expensive to the State and as disagreeable to those connected therewith as possible. * * * Upon the other hand, every time an arrest is made, the fight is taken up by the entire oleomargarine industry, with its millions of mney and enormous influence among a certain class of politiciaus, who at times manage to reach the sacred ear of the juclige who presides in the caso. 
No practitioner who had any conscience, any self-respect, any pride in his profession, would attempt to reach the sacred ear of the judge, as is intimated in this statement. And I want to say for our Cincinnati judges and juries and justices, so far as I know, that while I have had cases decided against me, I have always felt that whether I won or otherwise, the case was decided by the judge according to his very best efforts, and that he was entirely honest in every particular. And that has been my experience in the various State and Federal courts in which I have practiced law. As to our using every honest effort, we have a right to do it. We would not be true to our elients, we would not be true to our profession, if we did not do our best within legitimate bounds.

\section{Mr. Knight goes on:}

The prosecution of such offenders requires the very highest grade of talent; and their conviction, experience aud a statute which will stand the onslanght of the most resourceful lawyers. A law may have answered for years in regulating other evils, but, when contested by such ability as is employed by the oleomargarine millions, might be picked to pieces and rendered absolntely worthless through the manipulations and researches of the experienced tricksters.

The experience of every member of the committee and every other intelligent man has gone to show that a trickster never gets very high in his profession; and a trickster is not a man who is competent to work havoc with all these statutes, which are so carefully prepareil.

No technicality is too small for them to take advantage of and nake the prosecution the expense of a test case in the Supreme Conrt.

That is all right. We are entitled to that.

I will omit quite a good deal which 1 had intended to quote. But he says further on (p. 45$)$ :

In this matter the people of the States have expressed themselves by a four-fifths majority as being opposed to the existence or commerce in the article we seek, if you please, to discourage by taxation. The legislatures of thirty-two leading States have declared traffic in oleomargarine colored to resemble butter to be a menace to the individnal rights and welfure of their people.

Any horse can win a race when there is only one entry; and, so far as I know, there lias been vo effort on the part of anyone to prevent the passage of these State laws.

The Acting Chairman. Now, why bas the trade in oleomargarine quietly acquiesced in criminal and other statutes in thirty-two States, the effect of which would be to totally wipe out their business, if in point of fact such statutes wonld have that effect?

Mr. ScheLL. Mr, Chairman, I was coning to that matter later, but I will answer you now. Contrary to the evident belief of these gentlemen, every man is presumed to be innocent until he is proven guilty; and in deciding that question he is entitled to have the judgment of twelve of his fellow-men. And the sentiment against this class of legislation, "their millions of people" to the contrary notwithstanding, is so strong that a jury will not convict unless a very clear case is made.

The Acting Chairman. Now, do you mean to say, Mr. Sehell, that the oleomargarine trade has relied on its ability, by litigation, to defeat these State statutes, and for that reason has regarded the legislation of the States as unimportant?

Mr. SCHELL. No; I do not mean to say that; and in speaking as I do in this case, I do not want to appear as outlining the policy of any factory, either my own clients or others. But my experience has been that good people make good laws. Good laws, however, do not make good people; and when bad people pass bad laws, the fair-minded 
American juror rises up in his might and says, "Geutlemen, that law will not be enforced." And the testimony of the Ohio commissioner here the other day (you did not hear it, Mr. Chairman) was to the effect that he had practically no trouble in enforcing the law which provides that oleomargarine must be sold for what it is, and not for butter, but that he did have trouble in convicting on his color laws.

Now, another reason is that if the oleomargarine people were to attempt to combine to fight these laws which are brought up from time to time in different States, they wonld have to increase the profits of their business to such an extent that the price of oleomargarine would be raised to the extent that it would no longer be a boon to the laboring man. They also wonld be compelled to array class against elass to an extent that would disturb the barmony of the nation.

The Acting Chairman. Have these State laws, as a rule, been declared constitutional by the supreme courts of the States which have enacted them?

Mr. Schell. The decisions are eonflicting. I have not the statistics before me, but I know in a general way_

Mr. ADAms. Will the gentleman permit me to ask him a question?

The AC'Ing Cirairinan. I would like to have this question answered first, if you please.

Mr. SCHELl. My recollection is, in a general way, that some of them have been rleclared constitutional, and some unconstitutional. Take the State of Michigau, for instance. There the law has been deelared invalid. The Supreme Court of the United States held in the Collins case in Vermont that the pink law was unconstitutional; but I want to make just a brief reference to that later on.

Here is another question which Mr. Knight asked in the House hearing, referring to our general scoundrelism, etc. He does not put it in just those words; but he says (p. 46):

Can a member of Congress afford to be influenced by a citizen who has no respect for the laws of bis State?

Gentlemen, we do not ask you to be influenced by a citizen. This is not a question of numbers; it is not a question of the moral standing of our citizens, or what we want. It is a question of what is right. If I can produce an argument that is good, no matter how bad I am, that argument ought to have its eftect.

But, to pass on rapidly:

Both Mr. Knight and Governor Hoard have placed themselves on record as serviug in their respective offices without compensation. They do not say what they are getting for appearing here; but it is presumed they are merely acting in their usual capacity. Mr. Knight speaks of having collected 50 cents apiece from 24,600 farmers-

Mr. KNIGH'r. Is not that a pretty good indication of the interest the farmer takes in this matter?

Mr. Schell. Yes; but it does not establish Governor Hoard's statement that he represents $5,000,000$ farmers, and it is not an illustration of the interest of the farmer, either.

The Acting Chairuan. I do not regard it as material to go into that inatter, Mr. Schell.

Mr. S'HELL. I think not. Yet it is their main reliance. The rest of them do not say anything. We will concede that 24,600 of them are actually represented by Mr. Knight. That is all right.

Senator DoLliver. We can save you the tronble of going into that question. The varions members of the Senate have facilities for knowing the feelings of the farmers, outside of Mr. Knight. 
Mr. Schel.. Have they exercised them, though? That is a question I want to know about.

Senator Heitfeld. Oh, yes. I think I can illustrate that by showing you some of the petitions we have received.

Mr. Schell. Petitious? Gentlemen, I could have brought you here

Senator HEI'FELD. Oh, well; we understand all about that.

Mr. ScHELL. Since I was here before, 1 conld have had thousands of letters and telegrams. I could have had Senator Foraker's time, when he was in Cincinnati, completely taken; I could have had the hallway leading to his office, and his office, crowded with people protesting against the enactment of this bill. I could have blocked the elevator and had a waiting line three blocks long on the pavement.

Senator DoLLIVER. The point I am making is that if it is important to know the condition of public opinion as to this measure, the committee will neither rely upon your statement nor those of Mr. Knight.

Mr. ScHell. Or statements that emanate from either one of us, through whatever source they may come?

Senator DoLliver. The committee will have a thousand ways of finding out what the public wants.

Mr. Schell. But, gentlemen, that does not enter into this controversy, or ought not to do so.

The Acting Chatrian. I think not.

Mr. Scmel. We now take up something that is material; and that is, how well these laws have been enforced and how largely they have been violated. Mr. Knight accounts before the House committee (p. 61) for $\$ 1,670.13$ of this fund which was contributed, which was used for the purpose of prosecuting the Chicago dealers. He also says at page 4(1, regarding why he ceased efforts, that the funds were exhausted. No 1 quote correctly?

Mr. KNight. I do not think so. That is an entirely separate thing, Mr. Schell-a separate organization.

Mr. SchelL. The record speaks for itself, pages 40 and 61.

I read from page 40 :

These cases were dismissed by the jnstice of the peace upon grounds that a snbsequent statute liall repealed the law under which the warrants were drawn, but not until after $\$ 1,600$ had been spent by the parties interested in an effort to stop this gigantic fraud in the eity of Chicatro. The decision admitter of no appeal. The Dairy Union's funds were exhausted.

Now, I want to call attention to the fact that in all of these cases, in every instance, except in the case of one Broadwell, the stamp was always found on the wrapper. And as Mr. Bailey said:

There could be no question about a man's finding the mark on any package yon have shown to me this morning; and with the publicity yon have given it, I should think that they would not find it profitable and people would not buy it.

Then Mr. Knight goes on to say that the farmers are losing confidence and losing heart. Mr. Bailey says (p. 64): "Is not that contrary to the evidence that Governor Hoard gave here the other day to the effect that this industry has increased more than any other in the conntry to.day?"

Then the chairman asked the question: "Do yon think Congress has a right to legislate so as to make one article higher and another lower, or to drive it out of the market?"

Mr. KNigut. I do not think Congress bas any busiuess to look into that phase of the matter at all. I think Congress sliould look out for protecting the consuner and the health of the consumer. 
We agree about that.

(At this point an informal recess was taken for a few moments in order to allow members of the committee to return to the Senate Chamber. After the recess had expired the following occurred:)

Mr. ADAus. Mr. Chairman, the statement was made Saturday, I think by the chairman of the committee or by the acting chairman, that these hearings would probably he concluded to-morrow or Werluestay. However explicit or biuding that was I do not know.

'The Acting Uhamuan. If that is true the present speaker ought to be admonished as to the consumption of time.

Mr. SchkLL. The speaker, Mr. Chairman, has been admonishing himself, and has c:ut ont quite a good deal of what he intended to say, because he feared to trespass too much on the patience of the committee.

Mr. ADAus. Mr. Chairman, if I may be permitted at this time, and if the gentlemin will suspend for a moment-and it is only with your consent that I will continue-

Mr. SCHELL. I would rather, since my time is limited-

Mr. ADAus. What I am abont to say does not relate to any questions you are discussing, Mr. Schell, but simply to the order of the discussion and the extent of it.

Some of us are here representing the other side. We have had only about 20 per cent of the time, perhaps. but we are not complaining. We feel, however, that we can properly be heard by this committee, and we would like to have a time designated, either to-morrow or Werluesdily, when we ean be lieard.

The representatives of the oleomargarine interests have peen heard here during the entire day-a day which it was arranged last week should be taken up by the representatives of the cotton-seed oil people. Those representatives, as I understand, are here. They will undoubtedly want to be heard to-morrow. Now, as representing the friends of the Glout bill. I would like to request of the committee that either to-morrow or the day following be assigned for a hearing on our side of the question. That is all I wish to say, simply to make everything explicit and regular.

The Acting Chairman. The present chairman would not feel at liberty to make any designation of that sort, but I think I can assnre tho gentlemen that that will be clone at the first of the session to-morrow morning. That is to say, some orderly arrangement will be desiguated by which these hearings can be womnd up.

Mr. ADAMs. 'That is all 1 ask.

Mr. Schell. Mr. Chairman, I desire to call attention to a statement of Congressman Gront before this committee. I mention this only to get as nearly as possible on the record to what features of their claims I am leferring, and how nearly they axe a unit on what they claim, and to enable us to get an understanding of the case, so that we may know what they expeet to realize from this bill, and their views of its constitutionality.

General Gront says, on page 6 :

The power to tax, and tax out of existence, is unquestioned, as I believe, gentlemen.

Senator Allen silys:

Suppose it is apparent on the face of this bill that the motive for imposing the tax is to lestroy the thing taxed?

Mr. Grout says:

IVe deny this. Wo say that is not the motive.

S. Rep. $20 \pm 3-19$ 
Then, if they do not want it, and there is no reason for it ontside of their wishes, the committee certainly will not do something which will tax it out of existence.

General Grout says further:

All that it seeks to destroy is the fraud that is perpetrated when it is colored like butter.

At page 9 he says:

But if you will put this 10 -cent tax on it, and stop coloring it like butter, the game will then he "11.

On page 11 (sustaining my statement as to the friends of the bill having closed their case) lie says:

The friends of the bill submit their cas', and give the field to those who are opposerl to the measure.

I wanted to mention, at some lengil, Mr. Hamilton's argument; but I will only refer to the fact that in Pennsylvania now, arcording to his testimony, as I interpreted it, and acoording to the statement for the commission men who were here, the State law is practically enforcedat least, in Philadelphia.

The Ac'Ing CmaIRMAN. Is that a law which forbils the sale of colored oleomarganine?

Mr. Scmell. It forbirls the sale of colorel oleomargarine. They have reduced the licenses in Philadelphia from over ion to some :3:. I will say from my knowledge, which is hearsay, but accurate, that in western Penusylvania they have not been as successfinl in enforcing the color law as they have been in the eastern part of the State, because there is such a sentiment against it that the people rise up (.n masse and sily, " IV wou't have it."

I now want to lefer to the statements of the Ohio commissioner, who believed in the untional law. He says he can enforce the oleo-for-butter elause in the Ohio law, but can not enforee the color law. He says that is per cent of the oleonargarine sold in his State was sold for butter. He is wong there, I think. He is basing his statement on the pereentage of oleo-for-butter cases that he wins rather than mpon actual knowledge. I think he stated that he had no actual knowledge of the case.

Mr. Flanders, of New York, was so violent and so evidently prejudiced, that while there were a great many things I wanted to say about his argument, I think it will probably speak for itself on our side. He claimed general rottenness, scomndrelism, and so torth, and then owned up voluntarly that abuse was no argumeut.

Mr. Flanders claimed that the Government did not enforce these laws, and the States conld not. Yet he has shown that the laws of his own State (and it is a fact) are very rigidly and successfully enforced, and that bis department had time and money to make a "gum-sloe" expedition to Chicago.

The Penusylvania crowd which appeared yesterday was rather ammsing. They were here for the same purpose that farmers are sent to camp in the yards of State legislatures when their dairy laws are to be cons dered; and for the same canse that members receive telegrams and letters; but they were all evidently actually interested, since they handled process butt'r, with one exeeption. That exception was Mr. Sharpless, who wauts 50 cents per pound for his butter.

Mr. KNight. Mr. Sharpless was not a dealer.

Mr. SснеlL. No; I say, except him. One objected to the filth of country butter. They were all kept pretty well in hand until about 
the time of the committee adjommment, when some were thinking for themselves. Despite the eftorts of their overseer (who was himself coached by General Gront), and althongh they did not get on record, about half of them expressed themselves in favor of a law that would hedge about colored oleo, keep it on its own merits, but not drive it out of the market. I think that is the expression of the majority of the people who are interested in tle dairy product.

Mr. Kauffman I wanted to treat at length: but his argument is reduced to the statement that the color laws are enforest in l'liladelphia; that they always have been whenever they have male the effort; and I think in his argument somewhere will be fond the fact that only 812,500 a year is appropriated for the pulpose of enforcing the law of the State, and that that is not enougl. The farmers who expect these laws to be supported and enforced should furnisin the people who are charged with that duty with enough money to properly enforce the law.

Now, our side, Mr. Chairman, does not attempt to convinee by an array-although on analysis we would outumber in actual representation-that is, anthorized representation before the committee; and if the sentiments of the other side, the friends of the bull, were actually made known, "e would infinitely ontumber as to the sentiment. But that does not control.

From the first hearing mutil now I conll have had on Ohin Senators and the members of the committee deluged with thousands of letters and telegrams, the samc as you lave had from the other side, by using my oftice force, the Cincinnati wholesalers, 300 retailers to whom we sell in Cincinnati; by the same process in Clevelant; and an equal number from Columbus and T'oledo combined, to say nothing of the Kansas City honse with its nmmerons ramifications-the retail clealers, their employees. "their sisters and cousins and aunts." But we have not resorted to such measures; and we condemn, just as positively as did Senator Allen thr other day, that method, and hope that none of that has heen found in presenting our side.

Now, Mr. Chairman, to come to the consideration of the bill-the fruit by which you can recognize the tree.

We have examined the tree. It has been said, "A goorl tree brings forth good fruit, and an evil tree evil truit." This bill, we insist, is dishonest in every partieular. It is the illegitimate child of avarice and ignoranee-the avarice of the people who pander to the prejudices of the poover elass of farmers, and the ignorance of some of the people they represent. The pmipose of the bill, on its face, is revenue. It comes before you painted, colored. Its rvoved purpose is the regulation of fraud. Its actual purpose, as ereeps ont, evidenced by the other side and apparent to all, is to destroy an iudustry-to destroy the produet of colored oleomargarine.

As to the avowed purpose, the regulation of fraud, is it necessary? We claim not. Are the present laws sufticient, if enforced? We elaim they are. And if it is for this purpose, why not accept the substitute bill, to which I will refer presently.

Have they really proven that there is any considerable amount of fraurl? The most direct testimony on that yoint, and, in fact, the only testimony, is that of the Philadelphia attoruey. That was direct and to the point, and should be considered. One of the gentlemen, perhaps two of the gentlemen here to-day, in auswer to the questions of the chairman, testified that butter was called for and oleomargarine was given; but they said that the dealer knew that when the child, or the 
servant, or the housewife called for butter she meant oleomargarine, and the deal’r, by long experience, kuew what she wanted, what she used.

I know that to be the filct. I know it is the case. I have watched when dealers were selling it, and I have seen customers come in and say, "Give me a pound of butter," or "two pounds of butter." The dealer would wraj) up oleomargarine. I have said: " Ithy did you do that? Those are against your instructions." "Why, I know what she wants. She comes in here and buys it every day. She understands it." And I have tollowed the purchaser out and said: "Do yon know you are gettiug oleomargarine?" "Yes; what business is it of yours," or words to that effect. I know it to be the case, and I will tell you why and how.

Some years ago I was employed by the Union Dairy Company to defend their retail cnstomers in southern Ohio who were prosecuted under the Ohio color laws. These retailers would appeal to me for my services in cases where they were charged with selling oleomargarine for butter. Mr. Frank Neither, the president and manager of the company, said to me, "Under no circumstances defend for us a man who is selling oleomargarine for butter. I don't want it; I won't have it. I will coutribute to a fund to prosecnte them if they do it. I am making a product that I want to go on the market for what it is." And that has been my experince with all the factories.

However, I have been employed by rutailers to defend oleo for butter cases, among them one of the big. Cincinnati firms who have some twentyfive or thirty stores over the city. 'They handle all kinds of groceries. 'They advertise oleomargarine. They have been accused of violating the laws. The same question was brought to my attention, "What will we do? Somebody comes in and wants oleomargarine, but he does not want to parale the fact on account of the sentimeut which has been created against it. He does not, want to parade the fact before the public, before people who are standing by. I know that is my customer. I know that is what lie or she wants. What am I to do?" I made it a rule that in every case the clerk was to ask something to the effect, "Do you want oleo?" "It is oleo you want"? "It is butterine you want?" I instructed them to say it so that there could be no question about it. And my experience was that ordinarily the reply was "Yes." And my experience was also to the efiect that when the question was asked and no reply given by a customer, who proved to be a detective, that the jury founl my client guilty-so strong is the feeling that oleo shonld be sold for what it is. It is even harder to defend under oleo for butter laws than it is to prosecute under the color laws.

(Thereupon, at 5 o'elock p. m., the committee adjourned until Tuesday January 8,1901 , at 10.30 o'clock a. m.)

\section{Wasmington, D. C., Tuesłay, Jammary 8, 1901.}

The committee net at 10.30 a. $\mathrm{m}$.

Prosent: Senators Proctor, Hansbrongh (acting chairman), Heitfeld, Foster, and Money; also Charles Y. Kniglit, secretary of the National Dairy lnion; Frank W. Tillinghast, representing the Vermont Mauufacturing Company, of Providence, R. I.; Cliarles E. Schell, representing the Ohio Butterine Company, of Cincinnati, Olio; W. E. Miller, representing the Armom Packing Company of Kansas City, Mo.: Jolun F. Jelke, representing Messrs. Brann \& Fitts, Chicago, Ill.; Henry E. Davis, representing the National Butteriue Company, Washington, D. C., and others. 


\section{CONTINUATION OF STATEMENT OF CHARLES E. SCHELI.}

Mr. Schell. Mr. Chairman, it is my purpose to treat to day the avowed purpose of this bill-the regulation of fraud-and our claim that the bill is not necessary for that purvose, since a proper enforcement of the present State and national laws (and it has been shown that they are capable of enforcement, and are enforced) will be sufficient to rectify all the evils of which complaint is marle, without any adclitional legislation.

In support of the claim that if the arowed purpose of this bill is its real purpose it is not necessary, since the existing laws are sufficient, I want to introduce some of the present laws on the point directly in coutroversy.

First, the reveune law. We will take a very small part of this; and let me state generally that the law relating to manufacturers is that if any manufacturer attempts to defraud the Government on any part of this revenne, the manufacturer forteits his fictory, the completed product therein contained, all raw materials, the machinery, and everything connected with it, and is subjected to a fine of from $\$ 500$ to $\$ 5,000$, and (not "or," but "and") an imprisonmeni from six months to turee years. That question was raised here two or three days ago between Mr. Pirrung and Mr. Knight. Mr. Pirrung claimed a forfeiture; but he was alvised he did not know the law. That is the law.

There are other penalties for other offenses, and then there is a sweeping penalty of $\$ 1,000$ for all offenses not specifically provided for. But I believe it is admitted that the factories practically do comply with the law. It is claimed, however, that the retailers do not, and that it is with the iclea of hedging in and about the retailers that this bill is proposed.

The first part of the law relating to retailers, to which I wish to call your attention, is as follows-and here I quote from the revenue laws:

Retail rlealers in oleomargarine inust sell only from origiual stamperl packages, in fumbtities not exceeding ten ponnds, and shall pack the oleomargarine sold by them in suitable wooden or paper packages, which shall he marked and branded as the commissioner of iuterual revenue, with the approval of the secretary of the Treasmy, shall prescribe. Every person who knowingly sells or ofters for sale, or delivers or offers to deliver, any oleomargarine in any other form than in new wooden or paper packages as alove tescriherl, or who parks in any package any oleomargarine in any mamer contrary to law, or who falsely brands any package or aftixes a stanp on auy package denoting a less amount of tax than that required by baw, sha!] he fined for earli oflense not more than one thomsand dollars and be imprisomed not more than two years.

They are subject to the regulations prescribed by the Secretary of the Treasury, and a part of those regulations are:

As the retail dealer is required to sell from original stamped packages, and can not, as a retail dealer, sell in such packages, he is compellerl to make up his own packages. * * New wooden ol pajer packages similar to those usually employerl in selling butter and lard at retail may be used by the retail dealer in olemargarıne.

Each retailer's woolen or paper package must have the name and adilress of the dealer printed or linuded thereon, likerise the words "pomm " and "oleomargarine," in lettris not less than one-rnuarter of an inch sınare, and the gnantity written, printed, or branted thereon in fignres of the same size (one-fluarcer of an inch square), snlistantially as follows:

Then a form is prescriber. That is the form we use-"Blanks for name and address, $\frac{1}{2}$ Pound Oleomargarine."

Thre words "Oleomargarine" and "l'omul," which are required to be printed or branded on retailer's" woolen or paper packiges, in letters not less than one-puarter 
of an inch sfuare, and the fuantity which is required to be written, printed, or branded thereon in tigures of like size, must be so placed as to he plainly visible to the purchaser at the time of delivery to him, ete.

It provicles that the color of the ink in which the words are printed must be in the strongest contrast to the color of the package.

Now, I have here, Mr. Clairman, the stamp which we used in conl. pliance with that law. Since coming here I wrote to one of our men to send me a sample copy of it.

The Acting Uhamman. Mr. Sehell, let me ask you how long you expect to occmpy the attention of the committee?

Mr. SCHELL. I think I can conclnde in fifteen minutes more.

The Acting Cinaminan. I would like to ask, then, if the representatives of the cotton-seed industry are here?

Mr. Miller. Yes, sir.

Mr. Schell. They are, I think.

'I he Ar'ing Chairman. How many of them are there, Mr. Miller?

Mr. Mílller. Four.

The Acting Chatrian. Have they arranged so that one or two will present their views; or do they all want to be hearl?

Mr. Millek. They all want to be heard. One party will present the main argument; but they all want to be heard.

The ACting Chairman. Yon will reeall that the eommittee arranged for these hearings to continue until this afternoon on the part of the oleomargarine people, and that the butter interests were to be allowed to-morrow to close. I do not fecl like changing that arrangement. It was wade by the chairman of the committee, and I think we shonld conform to it. So the representatives of the cotton-seed industry ought to be able to put in their testimony this afternoon and get through with it, and allow the butter people to go on to-morrow and close the hearings.

Mr. MILler. Mr. Chairman, there is one member of the committee from Texas who was not able to get his statisties together yesterday. He intended to be here this morning, and ask for a hearing to-morrow morning.

The Amting Cirairman. I to not feel like changing the arrangement made by the chairman of the committee, and really do not feel at liberty to do so. This hearing has been open and very liberal. We have sat here a long, long time; and we ought to bexin to see the end somewhere, it seems to me. I sluall expect the representatives of the cotton-seed industry to go on this afternoon, and to allow the butter men to go on to-morrow, unless the chaiman or the committee arrange otherwise.

Mr. Schell. Now, Mr. Chairman, I want to call your attention briefly to the ()hio State pure-food law. I muderstand that the laws of otber States do not liffer materially from it; and if they do, and these laws are proven sufficient, and others are not, it will be a very easy matter, from the past experience of butter people with legislatures, to change the laws so that they are sufficient.

We have a general food law to provide against the adulteration of fools and drugs. Section 3 of the act begins: "An article slrall be deemerl to be adulterated within the meauing of this act: (11) In the case of drugs: (1)," and so forth. The third provision of that section is: "If its strength, quality, or purity falls below the professed standard under which it is sold." That has, I think, been lield constitutional and found sufficient in every cise as to drugs. 
Now, in the case of food:

(1) If any sulustance or sulustances have been mixerl with it, so as to lower or depreciate, or injurionsly affect its guality, strength, or purity; $(2)$ if any inferior or chicaper substance or substances lave been substituted wholly or in part for it; (3) if any valuable or necessary constituent or ingredient has been wholly or in part abstractid from it: (4) if it is an imitation of or is sold under the name of another article; (5) if it consists wholly, or in part, of a diseased, lecomposed, putrid, infected, tainted, or rotten animal or vegetable substance or article, whether manufactured or not; or, in the rase of milk, if it is the procluce of a diseased animal; (6) if it is colored, coaterl, polished, or powdered, wherehy damage or inferiority is concealed, or if by any means it is inale to appear better or of greater value than it reall $\Gamma$ is; $(\bar{\tau})$ if it contains any arded snbstance or ingredient which is poisousous or injurious to health.

This, gentlemen, I claim would cover and is sufficient to cover any possible adulteration. A moug some of the prosecutions which have been brought nuder this section are prosecutions for alulteration of milk. The guileless farmer brings to town and sells us milk which we find is preserved sometimes with borax, sometimes with salicylic acid, sometimes with formaldehydle; but they seem to know how to preserve their milk, if they do not know how to make butter.

We have another act to nrevent adulteration and deception in the sale of dairy products, passed later on. Part of one of the provisions of that act is:

And the words "butter," "creanery," or "dairy," or any word or combination of mords embracing the same, shall not be placed on any vessel, package, roll, or parcel containing ans imitation dairy product or substance not wholly made from pure milk, or crean, salt, and harmless coloring matter.

\section{And another provision:}

No person shall sell any oleomargarine, snine, imitation cheese, or other imitation dairy proiluct, at retail or in any quantity less than the original package, tul, or firkin, unless he shall first inform the purchaser that the substance is not butter or cheese, but an imitation of the same.

Still another act-the act under which most of the prosecutions now are brought-a first-class act, excepting the color clause and the provision about adrising the purchaser. This act was passed May 16 , 1894:

Sectiox 1. Lie it enuted by the general assembly of the State of Ohio, That no persom shall manufacture, ofter or expuse for sale-

\section{And I want the committee to remember the "shall manufacture"} clanke-

sell or deliver, or have in bis possession with intent to sell or deliver, any oleomargarine which contains any methyl orange, butter yellow, annotto, aniline dye, or any other coloriug matter.

That prevents the factory from mannfacturing, even for exporting purposes, colored oleomargarine. It can not make it at all.

Sic. 2. Every person who sliall offer or expose for sale, sell or delivar, or have in his possession witl intent to sell or deliver, any oleomargarine, shall lieep a white placaril, not less in size than $10 \mathrm{bJ} 14$ inches, in a conspicuous place where the same may be easily seen and rearl, in the store, room, stand, booth, vehicle, or place wher snch substance is offered or exposed for sale, on which placard shall be printed in black letters, not less in size than one and one-half inches sijuare, the worls.

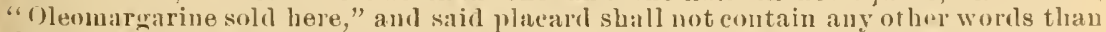
the ones described; and no person shall sell or deliver any rleomargarine unless it be done nnder its true namo, and each parkage has on the inper side thereot a label on which is prunted, in letters not less than five-oigliths ot an inch square, the worul "Oleomargarine," and in letter's not less than onc-eighth of an inch syuare the name and per cent of each ingredient therein. 
And section 3 provides, in regard to hotel proprietors, restanrants, and boarding-house keepers having a sign on the wall, "Oleomargarine sold and used here," and that in no instance sliall they serve oleomargarine, even if that sign is mp, when butter is called for.

SFc. 4. The word "Oleomargarine," as used in this act. shall be construed to mean any snbstance not pure butter of not less than eighty per cent of butter fats, which substance is mide as substitute for, in initation of, or to be used as butter.

This act provides a penalty for manuficturers of not less than $\$ 100$ nor more than \$5ı0, aud for each subsequent offense, in addition to the above fine, the oftender may be imprisoned in the connty jail not more than ninety days.

Any other person riolating any of the provisions of this act sball, upon conviction thereof, be fined not less than fifty dollars nor more than one hundred dollars.

Gentlemen, with these laws in force, and with the intention of complying therewith, I adrised my clients that the retailer must stamp or label the parchment in which the butterine was wapped, the woolen dish in which it was placed, and the wrapper which was placed over all, and that he must also at the time of the purchase in some way (unostentatiously, of eourse) alvise the customer what he was buying. For instance, it butter was called for, even if it was known that the prospective purchaser wanted oleomargarine, the clerk slould say, "You want rleo?" "You want butterine?" or sonething of that kind, so that the name should always be mentioned between the parties, so that there could be no mistake.

In addition to that, in the season when it is not necessary to keep) the butter and the oleomargarine down in a refirgerator the retail dealers whom I representer had racks arrangel mpon which they placed their oleomargarine and their butter tubs, something on the order that I have outlined here [exhibiting diagram]. There would be, say, the two tulus of butter. Two tubs of oleomargarine, I thint, came on top, one at 13 and one at 15 cents, and over that was a placard, "Oleo, 13 cents," "Oleo. 15 cents." The other tubs were marked "Dairy butter, 18 cents," and "Creamery butter, Then over all would be the label required by the State laws, "Oleomargarine sold here"-so plain, gentlemen, that the wayfaring man, thongh a fool, nced not have erred therein.

The Acring Charrman. That was simply a request on your part that the dealers do this?

Mr. Śchell. Yes: that was simply a request.

Senator Foster. Dirl that comply with the law of the State of Ohio? Mr. Schelc. That complied with the oleo-for-butter law of the State of Ohio, and went firther, in order to fully advise the customer.

Senator Foster. How many dealers are there in the State?

Mr. ScHELL. One firm. whom 1 represented and who to my certain knowledge complied with n!y instructions in this case, operated 25 stores in lifferent parts of the city.

The ACTING CHAIRMAN. But how many were there in the city who did not comply with this system?

Mr. ScHeLL. So far as I know, not a single indiviclual.

Senator Foster. Hare there been any jrosecutions in the last year there in Olıio?

Mr. Sohell. Yes; there have been. And, as the food commissioner stated here the other slay, in the majority of cases of selling oleomargarine for butter there have been convictions.

The Acting Cilamuax (referring to a book hamded him by Mr. Knight). There seem to be 1,439 retail dealers in the State of Olio. 
Mr. Scmell. Now, if I knew what sort of statistics the gentlemen were handing in, as courtesy entitles us to know in cases at law before anything goes to the juclge or the jury

The AC'Tng CHAIRuAN. I have here the report of the Commissioner of Internal lievenne.

Mr. SonELL. \ow, gentlomen, I personally watelied the carrying out of these rules, and it was amusing to see the resentment on a woman's face when she would point to the oleomargarine tubs, so placarded and priced, and say, "Give me some of that 15-cent butter," and be met with the remark, "Yon want oleomargarine?" or "You want butterine?" It was not a pleasant task for the sales girl. But I think the rule was largely carried out, except in cases of regnlar customers, regarding whom mention has been made: and in those eases there was not even a technical violation, since they bad most of them been theretofore informed orally and by a multitude of stamped wrappers.

Senator Proctor. Allow me to ask how it is with the people who eat it? Are they notified at hotels and restaurants and boarding houses? Do they eat it as oleomargarine or as butter?

Mr. Schell. As was said yesterday, I think that the law as it stands at present, especially if nodified in accordance with the recommendation of Commissioner Wilson, contines the question of frand to the hotels and boarding houses. And as was, I think. fairly stated, the hotels conld not stand the prosecutions that would follow and the advertisement that would be given. As to boarding honses, they rould come under the same ruling, exrept that they could better stand the prosecutions. But they could better afford to display the required sigu, as most of them do. As to the people who live largely in boarding houses, I think they are principally limited to old bachelors. We have too many boarding houses and not enough homes; and if something conld be done to drive those bachelors away from boarding houses and get them to establish homes of their orn, I think it would be a good act rather than otherwise. [Laughter.]

Senator HANsBrougir. And mutil they get married yon think bachelor butter is good enough for them? [Langhter.]

Mr. ScHELL. The bachelor who ran not look ont for his interests and find what he wants to eat, by changing boarding houses or otherwise, had better get married and get a wife to take calc of him. I am speaking from the stanrlpoint of the hachelor.

To (ontinue. I have seen the package, brancled aceording to instructions, handed back by the customer for rewrapping on account of the stamp showing on top of the wrapped package.

Some time ago one of the Cleveland (Ohio) justices of the reace decider that this provision that each package should have on its upper side a label on which the work "olenmargarine" was printerl did not merely mean that the paper, the wrapuer. should be stamperl, lunt that it must have a separate, distinct label-a label printed and stuck on the tol of the package. That ruling was attempted to be complied with, with the result that the keeper ot the maliet rased ruite an objection in regard to these labels bring so used, because the enstomer, in the furtherance of that false pride. perhaps-that pride which exists in the poor and the rich alike, as a result of which they lo not want to be advertiser as buying anything but the highest pricel in the market, even if they are getting better gools for less money-womld tear that label oft and throw it rown in the market house: so that it was yuite a great deal of extra trouble for the market-honse keeper while this system was euforced. 
I want to say further in regard to these stamps, and the fact that the law regarding the sale of oleomargarine for butter is complied with in the state of Ohio, that in all the trials with which I have ever had anything to do there has never been a package of oleomargarine produced in the justice's court that did not have the three stamps-the stamp on the wooden package, the stamp on the parchment, and the stamp on the outsicle wrapper. It was always there.

The Acring Chairman. Mr. Schell, I have to go to another committee; but before I go I will state that in a consultation with the chairman of the committee it has been deemed advisable to extend the hearing until and including Thursday, and that that will be tinal.

Senator MONEY. Has there been any vote of the committee on that arrangement?

The Ar'ing Cuarrian. There has been no vote of the committee.

senator MoNEY. There will have to be before there is any cletermination of it.

The Acting Charranas. Then we will be obliged to get the full committee here.

Senator Monry. That is all right; but we ean not cut these hearings short when a lot of men have come here to be hearl, and have not yet had an opportunity to be hearl.

The AC'ING CHAIRman. I will state, Senator, that last week the chairman, who was presiding during the morning hearings, thonght that arrangements should be made so as to close the hearings on to-molrow. That is the 10th, I believe.

Senator Moner. I understook what the chairman thonght; but the committee have taken no aetion.

The Acring Chamian. But he made a statement here to the effect that that would be the sitmation here, and we have been proceeding upon that hypothesis.

Senator Moner. I have not proceeded upon that hypothesis at all.

The Ad'ING ChaIrian. Iust a moment. Others have come since then to be heard; and Senator Proetor, who has just left the room, stated to me that he thonght we had better extend the hearings until Thursday, including 'Thursday, allowing the butter people to close on that day. Of course the committee cau do as it pleases.

Senator Money. I want to say, as one member of the committee, that. I object to any closing of the debate at present; and I lo not see any particular reason why the butter people, having had all the time they wanted here, should close the debate, either. So far as I can under. stand, there is nothing to entitle them to the last day in court. In my opinion they have not shown any case at all; and I shall insist that the men who oppose this bill shall have an equal hearing to the very last moment of the argument.

The ACTING Cnamian. Senator, you will pardon me if I make the objection that I have been here at all the hearings, except part of the time yesterday, and that I am quite safe in saying that the opponents of this bill have ocempied fully three-fonrths of the time.

Senator MoneY. That may be. Now, I will tell you what we will do. We will hear the butter men filst and let the other people close.

The Acting Cimarisan. But the butter men, I think, opened the ease here by making some statements; and it was generally understond, and has been understood all the way throngh, that they should close the ease.

Senator MONEY. I have not had any such understanding as a member of the committee. My understanding was that they were to have equal 
righ ts before the committee, which they are entitled to have. Both sides are entitled to that. Bnt it seems to me that it is asking a little too much for them to want both the opening and the closing of the case.

The Acting Chairifan. The gentleman who has the floor at the present time had all day yesterlay, part of the day before, and is going on this morning enlightening us with the facts on his side.

Senator MoNEY. Yes; and he is making a very gond speech, too.

Mr. MILler. Mr. Chairman, Mr. Schell did not oceupy all day yesterday. When you were absent yesterday afternoon some labor people from Pennsylvania spoke for part of the afternoon.

Senator Foster. But we must draw these hearings to a close some time. It seems to me we are getting abont all the information there is on this subject. I do not know that we have had very much repetition, but we have had some.

Senator Moner. As far as that is concerned, I have made the suggestion to the cotton-seed oil people, who are particularly my constituents, that they might present their case

The ACTING CHAIRMAN. They are liere now and are ready to go on as soon as this gentleman eloses. There are four of them who desire to be heard. We wanted to give them the balance of to day and all of to morrow, and then to allow the butter people to close on their side. That was the suggestion of the chairman of the emmittee as he went out.

Senator Moner. Do the butter people think it is any particular advantage to liave the closing? If so, it ollght not to be allowed them.

The ACtrng Chairman. It has been generally conceded to them, I think, by the opponents of the bill. These hearings, as I will state to the Senator, have been rather irregular.

Senator MoNEY. I know they have; and I have been rather irregular myself, becanse during the afternoon sessions I have been compelled to be up in the Senate Chamber most of the time.

Mr. Tillinghast. If the gentlemen of the committee will permit me, I will eall attention to the statement of $M r$. Gront, marle at the opening of the hearings, in which he says this:

I simply want to say, gentlemen, that with this testimons the friends of the bill submit their case and give the field to those who are opposed to the neasure.

Senator Hansbrongh replied:

It is understood that Governor Hoard is present and desires to be heard.

Whereupon Mr. Hoard spoke. And until the hearings had progressed for several days there was no intimation that the butter men desired to be heard any further.

The Acting Chairinan. Do yoll object to their closing the case?

Mr. 'Tillinghas'. Not in the least.

Senator Money. I have only been contending for what I consider to be fair play.

Senator Heitfeld. Before Mr. Sehell proceeds, I would like to ask the chairman a question. Are the eotton-seed oil people here, the parties Mr. Culberson spoke of yesterday? Did be not see you about them?

The Acting Champan. Yes: he said he had someconstituents here. I do not know whether they are from his state or not.

Mr. JELKE. Will you permit me just one moment? Mr. Peters is here from Texas, representing the oil-mill interesis of that State. He came liere in obedience to a telegram from Senator Culberson, after having had an interview, as I understood, with Senator Proctor, it being understood that they would not be heard later than Wednesday. 
He is having some figures prepared here in the Agricnltural Department, and will not be able to obtain them before 4 o'clock.

The Acting Chalritar. To-day?

Mr. JELIE. To-day: yes, sir. I have just seen Senator Culberson in regard to the matter. He will be here in a few moments. He said he spoke to several members of the committee, and thought there would be no objection to bis being heard to-morrow.

The Acting Chairman. The committee has not taken action on the matter; but it has been suggested by the chairman, whom we all delight to support in matters of this kind, becanse of his great wisdom, that the hearings be held open nntil 'Thursday, and that to-morrow be given to the cotton-seed oil people.

Mr. JELKE. Yes, sir.

The Acting Cimingas. We understand that there are four representatives of that industry here.

Mr. JELKE. Yes, sir. I do not know their number. The statistics which one of the gentlemen wanted are being prepared now in the Department of Agriculture, and he will be ready to present them tomorrow morning.

Senator HeitFlid. That is what they asked for in the first place.

Mr. JELkE. Yes, sir; he came here in pursuance of that arrangement, and he can not possibly present his statement any earlier, if it meets the approval of the committee.

Senator MoNEY. There is another gentleman here by the name of Culbertson, too.

Mr. Jelke. Yes; he is in the room now.

Senator HeITFELD. I would suggest that we go on now.

The Acting Chairuan. Shall we go on, then, with the understanding that the eotton industry and others of the oleomargarine side of this case conclude their testimouy to-morrow, and that on Thursday the butter people shall close the case? Can we get ronsent to that proposition?

Senator Moner. I do not want to compel the cotton-seed oil people to go on to-day. If they have more to say than we said to day I think they ought to be heard. Still, if they think that that is enough time for them it makes no difference to me.

The Acting Chalrmax. Mr. Schell, who has been speaking for quite awhile (as I stated awhile ago), announces that he will be throngh now in a few minutes. I assme that the remainder of today and the whole of to-morrow can be devoted to the hearing of the cotton-seed oil interest.

Senator MoNeY. Whenever they get throngh I am quite willing that they shall stop.

Mr. SCHELL. Mr. Chairman and members of the committee: I think I am the only one speaking against this bill who has said anything about conceding the right of the friends of the bill to close. I have already said that when one side opens the case and then claims the right to elose, the person speaking on that side must present their full case in the beginning, and must in the end confine their testimony, or what they have to offer, to rebnttal of what the other side have had to say. At the same time I sail that if they introdncell any new evidence or any new features in the case whatever, we wonld claim it, not as a privilege, hnt as a right, and one which we thought the committee wonld not deny us, in view of the fairness it has shown in the past, to be heard in rebnttal of any new argumeut which they advanced.

The Acting Cirairman. Under those eirenmstances I can not very 
well see the end of this hearing, becanse if we wait until everyone is satistied that his last word is tinal we will never get throngh.

Senator Moner. We can say, though, that the last word shall be divided equally. We can say that.

The Acting Chamban. The committee ean say, of course, exactly what it pleases.

Senator Moner. But is not that fair? Is it not fair to say so?

The acting Uharman. I should prefer to have it befole the com. mittee in the form of a motion.

Senator MoNEY. Very well; we will put it before them in the form of a motion.

The Acring Cuamman. That can be done when we get the full committee here.

(Senator Foster therempon took the ehair.)

The dc'ing OHairman (Senator Foster). Mr. Schell, you may proceed.

Mr. SeHELl. Now, in support of my contention that probably all over the comntry, as in Cincinnati according to uny positive knowledge, oleomargarine is not to any extent sold for butter, I want to quote Representative Bailey at page $10 \mathrm{~s}$ of the House hearings. He said there:

Let me give a little personal experience on that subject. I have spent parts of two days in this market here. I have made two trips down through it for the purpose of getting information on that very point. I went down there absulntely incosnito, and I tried my best to buy oleomargarine for lutter. I went to this place and to that, and did my best to do it without their knowing auything alwut-

Representative LAwB. What lid yon ask for?

Representative BAllir. I asked for bntter. I would say, "What do you sell your best creanery butter for?" "Thirty-five aurl 40 rents." "What liave jou got some other grade for?" "They wonld say that the had a cheaper grale ilown to 28 cents, and I think the lowest butter I know of or harl pricerl to me was 25 cents. When it got below that it was oleomargarine or bntterine every time.

Now, l was unable in that market to buy a single pound of it, and I conld not get a single man to adıit. to we lown there that it was solı-not a singleman. Now, I want you to yo down there, Mr. Lamb. I will tell jou what I will do. I will bet vou a sell oleomargarine to you for butter.

Senator HEITFELD. Was that in the market here?

The Acting Chammax. That was in the eity of TTashington?

Mr. ScHELL. Y'es; that was in the city of Washington.

During the holidays I took dinner one day with IJP. IV. A. Young, at Dayton, Ky. At the same dimuel table were lis fither-in-law and his brotler-in-law, both doctors. I reeognized oleomargarine on the table, and I made some comment about it. His wife Hushed np, but Dr. Yomng said, "Of conrse it is oleo." I said, "What do sou buy it for?" "For oleomargarine." "What do you call for?" "We called for butter and thought we would get this, aceording to reports; but we found out that we had to call for olcomargarine in orler to get it."

"You did get butter, then, when yon called for it?" "Yes, and we got a very unsatisfactory produc:t." I said, "Where do yon get yonr oleo?" "We get it at one of B. H. Kroger's stores." Those are the stores operated by the gentleman whose aldvertisement appeared in the Cineinuati Times-Star, and to which I called your attention resterday.

Now, in regard to this liotel talk about white butter, and so forth. I travel baek and forth over the country quite a good deal. I am in Uhicago, I suppose, two or three times a month; in New York fre. quently, and in IVashington, Philadelphia, Baltimore, Cleveland, and other large cities, and I have never as yet been given uncolored butter. 
I aim to stop at the best hotels, or at least the highest priced. My clients pay the bills, and I have no object in going anywhere else. In New York I stop at the Wallorf-Astoria, and I know their butter is fine butter, creamery butter, but it is colored artificially. On my last trip here before the holidays I stopped at the Arlington. There we had butter artificially colored, I am stopping now at the shoreham, where I get butter artificially colored-highly colored. And that has been my universal experience in all the eities which I lave visiter.

Now, this is my conchnsion on this phase of the subject: No factory, through me, or in any ease in which I was engaged, or with which I was connected, has ever paid a fine, or defencled a dealer for selling oleomargarine for butter. And I want to say that as far as 1 know (and I am in position to know pretty accurately) there is not a factory in existence which clefends the dealers for selling oleomarganine for butter, assertions of the friends of the bill to the contrary notwithstanding. They do not show any instances; and I defy them to show any instance where it has been done.

'The factory says to the dealer, "If' you break the law you must pay the penalty. If the violation is mine, throngh nse of color or in any other way my fanlt, then I will hold you liarmless. I do not answer for you, but I answer for myself." And what else could the factories do? I do not know that they all do that; but my people do it. If they break the law they pay the penalty.

The Ohio laws are all right, except the eolor rlanse, and the one as to informing the purchaser. The latter I think is idiotic-the " inform the purchaser" part, Hamnting in a purehaser"s face the suggestion, "Yon alle too poor to buy butter; consequently you bave got to take something that is less costly."

The color clanse is mujust; and with these exceptions, I say, gentlemen, the laws are obeyed and are enforcel. I think the Department misses but few dealers who are gnilty of any actual frand, and it sometimes arrests the innocent. I have known that to be the case. I admit that the color laws are hard to enforce. In a case recently tried by a justice withont a jury in Cincinnati, he fonud the defendant guilty, but is said to have remarked that he considererl it an mijust law, but conld not overrule the supreme court of the State of Ohio. But they say they do not want a color prohibition. They merely want us to "shinny on our ow side," so to speak. If so, where is the hardship of nonenfincement of the color liw, so long as the oleo-for-butter laws are enforced?

So much, gentlemen, for their alleged purpose in this bill. The bill, like oleomargarine, like butter, is permeated through and through with the false color'; and then they cover it up on the outside with a cont of shellac. If the purpose is what we belive the attual purpose to be, to destroy the production of colored oleomargarine, why not say so? Why are they not honest about it? Why are they not fair?

How much better are they, when they come bere asking you to pass a bill under a false name-a bill which is not what it purports to be, a bill which they concede could never stand a constitutional test for a minute except under false colors - than the man who sells oleomarga. rine for butter for the purpose of defranding his customers? And how infinitely worse are they than the man guilty of a mere innocent deception, not deception at all, but an inuocent sale where he knows that the purchaser wants oleomargarine, although he says butter in order to conceal his poverty from bystanders.

Let them name the bill properly. Let it stand for what it is. Do 
not cheat the nation. If they seek to desinoy one industry for the benefit of another, or to foster one industry at the expense of another, or to regulate prices, let them tell the truth about it aud name the bill accordingly. But they do not do it.

Now, geutlemen, the effect of this bill

Sendor MoNiy. Excuse me. Have they not saicl the bill was to destroy oleomilyarine? Has not that been stated?

Ml. Schell. Senator. I have been trying to get them on recori on that subject ev(r since they began.

Senator MoNwl. Was mot somebody on record at the hearings before the House our that point?

Mr. Schell. They came here and disputed it. They said it was a mistake, and that the minority members of the commit tes were wrong.

Now, geutlemen, "hatever the purpose of this bill-and w. cham the purpose is to destroy the industry-irlatever purposs they intend, it will destroy the oleomargarine inclustry. The ofticial comblemution of the Congress of the United States, stamped upon this product by a bill similar to the Grout bill, will lill the export tracle not only of the product int of all that enters into it. That has been gone into in detail.

Now, gentlemen, the main thing to be moged about this matter is the fact that the oleomargarine mannfacture is cam ght between the mpler. and the nether millstones. With the aid of the Giout bill he is ground in between the State and the Federal laws. As the matter stands he can say to the State which is enforeing an mujust law, "Prove it." There he has some show, some rhance. But accorling to this Giont bill he must make an accurate sworn statement to the Govermment, moler penalty of an absolnte contiscation of his factory, bis prorluct, his equipment and everytling, and fine and imporsonment alded. This sworn statement is a plea of guilty of a violation of the State law. They say, "We are willing that you should sell it for what it is." Some of them have said that, in a half-herrted solt of manner. They say, "We are willing." I think the great bulk of the people who are alleged to be represented her( (but I claim their true sentiments are not represented here). those who luave at the instigation of lobbyists and others been writing letters to the Senators on this matter, while they are not by their representatives detinitely on re:ord here, are too tair-minded to ('rush an industry ont of existence and confiseate our property withont giving us anything for it. I think the majority of the people who are opposed to the alleged method of traffic of oleomargarine are will. ing that it shonld be sold on the right side of the fence. That is all we want. I think they are willing it should be lone. I think every fair-minded citizen must concede that it onght to be done. And ret, accorling to the provisions of this bill, it can not be done. ()nr factory there in Cincinnati must close down, after just expending $\$ 18,000$ for a plant, and I do not know how much mole for other equipment, to get ready to do business. They must quit. Their sworn statement which they must make to the United States Govermment wonld condenn them. They would thus plead guilty of a violation of the State laws. They simply can not make this product. They can not make it for export or on orcler of the consumer. They must close the factory.

The supporters of the bill say that the 10-cent tax raises the price of oleomargarine so that it is on the same basis of the price of butter. It does not merely raise the price. In 32 States of the Union it absolutely prohibits the manufacture or sale of oleomargarine, colored. They can not even manufacture it to send to a State where it is all right to sell it, colored or otherwise; and those "i2 States represent 
four-fifths, as they say, of the population of the Union; and yet they pretend to defend their position by saying that they ouly want the thing enualizerl. Gentlenen, they do not want it equalized. They are not playing fair. They are not capable of playing fair.

And, gentlemen, it will not lielp the people they purport to represent. 'They have not shown that we hurt them. 'The testimony shows that butter commands a highel price now than it has for twenty-ive years; that milk is higher than it has ever been. Not only have they not shown that we hare hurt them, but they have not shown how the proposed legislation would help them.

They tail entirely in the claim which they have made before you. They have unt even shown any considerable bona fille conutry call for this legislation. We analyzerl that claim yesterilay. II e analyzed the

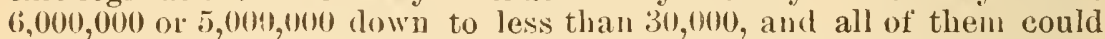
not be induced to put 11,50 cents apiece; and we do not know the exact sentiments of those who did put 11 , the 50 cents apiece. They are not on record here. Their representative is not on record definitely. Every pressure (we will not say argument, we can not say argument) brought to bear has borne the ear'marks of some politician or publisher who makes a urarious-no, a precarious-living through creating dissatisfaction among the farmers and getting employed to relieve their wants. Even the Philadelphia commission men who appeared were in leading strings, with an extrastring attached to their leader in the presence of the author of the bill, who came in and sat down there; and when the leader was going to put his people on record he was coached loy liepresentative Gront. He asked questions, both suggestive and learling questio:ıs, of the wituess for his side, and tiren told him what he really wanted him to say, and he said it.

When we analyze "the united dairy sentinent of the nation," as alleged in the ontset in the House hearing, we invariably end up with Mr. Knight, Governor Hoard, and General Grout. They remind me of that well-known story of Mr. Lincoln, in which he told three persistent office seekers that they reminded him of the Sunday-school boy who was reading the chapter in the Bible about the Hebrew children and the fiery furnace. He had repeaterly stumbled over the three names, Shadrich, Meshach, and Abednego; and tinally he broke down, and said, "Well, here are those three rascally fellows again!" [Laughter.] Aud in whatever way we turu, we run up agaiust this same trio. Whe can not get around them. They are what is alleged to be the "united dairy sentiment of the nation;" and they have not shown their credentials to this committee.

But that is not our main contention. Although they have demanded onr property without price or process of law, and hare not shown why we should give it mp, or what good it would do them if they did, nor have they really tried to produce arguments. They say, "We are backed by $5,001,000$ farmers. Give it to us, or we will turn them loose on you in your next campaign!"

They employ this alleged army as advance skirmishers, to show their supposed mightiness, by having letter's and telegrams galore sent to members of your homorable body. Such methods should receive the censure they deserve; and the gentlemen should be shown that such methods, like packing stock butter, belong to a past age.

The present laws are sufficient if enforced, and they are capable of enforcement. That is shown by their own people, their own testimony. But that is not reason enough. We want the best possible legislation. The substitute bill will do what it is claimed is wanted. The factories 
want the same result. The mills and ranches, and dairies and creameries, and packing houses that smplyly the oleomargarine factories do not care. 'The fair-minded eitizen eau not object. Şo, let us have the substitute bill-not because we want it, or anyone wants it, but becanse it a wise and, probably, a legitimate piece of legislation.

Mr. MIller. Mr. Schell, excuse me. Mr. Tompkins, of Charlotte, N. C., is liere this morning, and can not be here this afteruoou, as he leaves at 3 . 11 e are quite anxious that he should appear. Can you give way to him?

Mr. SCHELL. I will finish in five minutes.

Mr. MILLER. All right.

Mr. TompKins. I am better satisfied to have Mr. Schell finish, beeause I am conviuced that he is roing good work.

Senator Heitfeld. Iet us have the present speaker conclude his argument.

The Acting Chairuan. Ies; go on, Mr. Seliell.

Mr. SCHELL. I want to say that the only substantial difference between the substitute bill and the existing law is that the mannfaeturer is compelled to put up his product in 1 and '2 pound packages, imprinted, wrapperl, and stamped at the factory, which can not be broken mitil they go to the consumer. That, you will mulerstand, does what I have claimed. It puts fraud practically out of the question. And the only point in that bill about which they have raised any question is this sentence: "That any number of such original stamped packages may be put up by the manufacturers in erates, boxes," etc. They object to the word "original" as bringing in the "original pacliage."

Now, for my part-and I think I can speak for all on that point-it is not the intention to put that word in there for the purpose of making the law different fiom what it is, or taking any undue advantage of any "original package" decision, and we are willing, or I am willing that that word may be changed so that it may not apparently designate these packages as origiull packages, although the mere fact that the word appears here does not make them original packages any more than the law itself woulı make them original pickages withont that word.

I had intendro to speak upon the Gromt bill at length and show the frand upon the face of it, but I think it is so evident that I rlo not need to tolich upon it all. Besides, the attention of the committee lias been called to almost every featule of it.

Another good reason against the Grout bill is that it totally fails to do anything more than retnce the tax on oleomargarine $1 \frac{3}{1}$ cents per pound. If anyone wants to talie and vantage of defects and violate the spirit and not the legal meaning of the statute-l say "it," for I know of no one in the business who wonld not try to ohey the spirit and the letter of any act of Congress. My clients, at least, are law-abiding citizens, and would probably want to obtain the repeal of tise statute by its striet entorcement-the best way to guarantee the repeal of any unjust, nufair, iniguitons legislation. IIowever, allow me to retire for a moment from my callacity as attorney for a contending interest, from my position as a witness for the integrity of a nation, and give my opinion as a lawyer with some conceded ability on technical interpretations, and say that this so-called Gront bill would no more stand the technical test than a snow ball would keep its proportions in perdition. [Langhter.] Ben Butler must have had a bill of this kind in view when he said he could drive a four-horse team througlı any stat-

$$
\text { S. Rep. } 20+3-20
$$


ute that was ever put on the books. This is that kind of a bill; and in this statement I am not referring to a constitutional test. The bill fails of its alleged object regardless of the Supreme Court. The bill makes business for lawyers and lobbyists, but all others suffer, including the people who are supposed to be interested in the passage of this law-" the dairymen of the nation."

But to return to my clients and my conntry: The bill is not fair on either side. I have womlered if it was drawn by the lawyers who bronght forty cases under the repealed statule in Chicago, or by one who knows his business. The enactment of this bill would mean, in my opinion, that the same fight would be fought over next session. But, then, there are 24,600 farmers at 50 cents to $\$ 1.000$ per liead!

Now, as to the main question, its legality or otherwise: What is itgood, bad, or expedient? Certainly not the former; and assuredly no circumstance has been shown to justify a bad measure on the grounds of expediency. In this ase the ends do not justify the means.

Is the bill police, revenne, or repressive legislation? If police legislation, Congress has 110 power to enact it. It is not rlaimed. If repressive legislation, Cougress has no power to euact it. That is not claimed. If for the purpose of raising revenne, it fails of its pnrpose. See the testimony of Commissioner Wilson. See the concession hy Governor Hoard, who admits of record (1). 7. Senate liearing) that the one-fourth of a cent per pound tax is scarcely enough to police the bill, and will not bring in any revenue.

But it is repressive legislation, alleger to be such. Governor Hoard says (p. "2, House committee): "ln plain words, this is repressive legislation," justified by police puetemsion, and at tempted to be legally clothed by a revenue cluak.

Gentlemen, the United States Supreme Comt decisions have been ably argued by my brothers Gardner and Springer and by others, with different conclusions. I need not comment mpon them. We do not need the interpretation of any court. We who oplose this bill are conviuced that the bill is wrong', is nufair, is dishonest, is illegal. 'The friends of the bill have the insolence to admit of record its dishonesty, its illegality. They venture to question both the intelligence and the integrity of the Congress of the Tnited States. They come here and say, "We will admit you can not openly exercise police power in a State. We admit that you can not exact repressive legislation aud call it so; but you can, and for ns you will and must, pass this act as a revenue measure. Ton must pass, under a false nime, a law to prevent the oleomargarine manufacturer from giving his product a color which has been given it from the beginning."

Then, while asking you to do an mufair thing for them and stultify yourselves before the nation and the whole world, they are not playing fair witl you. They clain that they only want to keep oleomargarine on its own werits; and yet the only resilt of an enforcement of the act would be an absolute prohibition of the manufacture of the colored article, if not of the article itself, and they know it.

Gentlemen, I have talked long. I hope not ncedlessly.

I woul! have liked to have smmmed up) all that has been said, brietly; but I will omit a summing np of the whole subject.

But regardless of any general summing up, the subject is reduced to the questiou, "Is the bill right? Is it just? Is it honest? Is it what it purports to be? Is it constitutional-colored or nucolored?"

If so, consider it. Int if it is wrong-if dislonest-if class legislation-if not what it purports to be-if not a revenne measure, and a wise one-relegate it to the oblivion which it so richly deserves. 
Gentlemen, I thank you.

(The following statements of Mr. Dolan and Mr. Pierce were pre. sented on Monday, January 7, and are inserted at this point in order to preserve the continuity of Mr. Schell's remarks:)

Mr. SchelL. Mr. Chairman, allow me to introduce Mr. Patrick Dolan, president of the United Mine Workers" Association, 411,0010 strong, and Mr. John Pierce, representing the Amalgamated Association of Iron and Steel Workers, 15,000 strong. The people they represent would indicate that they have sufficient interest at stake to entitle them to a hearing before this committee.

The ACIING CHAIRIAN. It will be rery satisfactory to hear the gentlemen.

\section{STATEMENT OF PATRICK DOLAN, PRESIDENT OF THE UNITED} MINE WORKERS' ASSOCIATION.

Mr. DoLan. Mr. Chairman, the people whom I represent are somewhat interested in this measure, as they are all working people. Representiug them, I liave come here and have preprared a short statement, which I will read:

The question involved here, so far as it affects the section of country from which I come (western Pennsylvania) and the people I represent, despite the verbiage of the bill, seems to be whether or not white oleo. margarine is good enough for the workingman and consumer, whose needs demand a cheap and wholesome article. In former times, before the general introduction of oleomargarine and the manufacture of cream. ery butter, the grocers and merchants in our section used to have their regular butter day. It might oceur on any day with different merchants, but when that day was set by any one of them it was an immovable feast-but such a feast! Almost any of us can eall to mind the strange collection of colors and shapes, accompanied by as many different and distinct perfumes as ever emanated from the ancient and distingnished city of Bagdad-the source of a thousand and one individual orlors. The few rolls of really palatable and passable butter were seized on the arrival of the consignment and stored away for the pet customers (who didn't mind the price), and the balance was spread out in that portion of the establishment known as the butter counter for the iuspection and sampling of those who were not so fortunate as to be able to pay the long price or to figure high in the affections of the merchant.

But this is all gone in our markets, I find, except in a very few isolated instances. Two things seem to find sale, namely, first-class creamery butter and oleomargarine. The butter at present sells for from 30 to 35 cents, the oleomargarine at from 2 pounds for 25 cents to 20 cents per pound; aud while the latter all seems palatable, I have found a markel hifference in the quality, which to me accounts satisfactorily for the wide variance in price, viz, from 121 cents per pound to 20 cents per pound.

That some oleomargarine may be sold for butter I do not doubt, but I am convinced that it is triflng; and to propose such a measure as this as an alleged remedy for that is unfair, to my mind. This bill does not pretend to remedy an evil, but to exclude and prevent the sale of a healthfil product-which seems to have been the real spirit of all the laws on the subject.

I am convinced that the true intent of the pending bill is to make a market for the axle-grease portion of the butter product, which oleomargarine, by reason of its cheapness and wholesomeness, has run out 
of our section, doubtless into the kettles of some soap works, which is the sphere of its real fitmess.

In this age of progress let us not go backward, to say nothing of the injustice it will work to onr people. What moral right have these butter people to ask you to pass a law that will compel those of us who have only $10 \mathrm{or}$ 15 cents to pay for a pound of some spread for our bread, to either use white oleomargarine, ghastly in its mattractiveness, or to go back to the raneid product they foisted on us in years gone by? There is no interest save theirs which would have the sublime nerve to ask such a thing, and none but theins which would have influence enough to half get it, as they have done. It is this sort of abuse of legislative and governmental power that has always been a menace to republics since republics were, and this sort of folly that has wrecked and ruined them-sinee history proves that they do not always last.

I bope that this committee and the Senate will defeat this measure. It would be a step in a dangerous direction. Many of onr individual States have already covered themselves with disrepute by passing crushing and unjust laws, dietated by this coming butter trust, which seeks to frighten and has frightened legislators by bawling "the granger vote," even to the extent of overlooking the rights of the consumer, and the fact that we are one people, and entitled to justice.

The present United States oleomargarine law is unjust, as the '2 cents per pound tax comes off those least able to bear it - the poor. The man who has but $10 \mathrm{or} 15$ cents to pay for a pound of oleomargarine can ill afford to pay a tax on it of from 10 to 20 per eent; and since that is the case, how can he afford to pay about 100 per cent, as proposed by this bill, and at the same time have his poverty legislated before his eyes and those of his family every time he sits down to a meal? We of western Pennsylvania understand this, and oleo is as firmly placed and as staple with us as sugar. To say that oleo could be sold for butter, to any extent, seems to us preposterons. I an really of the opinion that not one housewife in one hundred in our section conld be so misled. Even if such were the case the logieal remedy is simple. It is not found in this miscarriage of justice known as the Gront bill, or in legislation off the usual lines, which is invariably proposed by butter interests; but in the just and common-sense ideas embodied in the Wadsworth bill, which was turned down by the House, proving conclusively that what was sought was not to honestly regulate the industry, but to destroy it.

Now, Mr. Uhairman, the reason I an interested in this bill is because I user to be in the grocery business, and I sold oleomargarine in large quantities to our people. They knew that they were buying it when they got it. It was cheaper, and as good in many instances as the creamery butter that I used to sell and paid a high price for and had to get a high price for from the consumer. I kuow that our people would be placed at a great disadvantage if this measure were passed.

The Acting Chairman. Let me ask you a question, Mr. Dolan. Do you use the article yourself?

Mr. Dolan. Yes, sir'; every day.

The ACTING CHAIRMAN. What objection have you to having it of a color easily distinguishable from the yellow color of butter? What objection would there be to that?

Mr. Dolan. Well, I will tell your.

THE ACTING CHAIRMAN. In other words, do you eat it on account of its taste and its nutritions character, or simply on account of its looks?

Mr. DoLan. I eat it hecanse it is wholesome, and cheaper than the other article for me to provide for my family. 
The ACting UrIarman. But its color has nothing to do with its wholesomeness or palatability, lıas it?

Mr. DolaN. Well, the point about the color of it, Mr. Chairman, is this: People, while they are poor, liave some pride; and they do not like to go into a store among other people who have money and buy this article, because everyone knows that it is oleo they are getting when they purchase it.

The Acting Chatrman. So, instead of the mercliant deceiving them they want to be put in a position where they ean deceive their neighbors?

Mr. DolaN. They want to go in and buy it as butter.

The Acting Chairian. Do they call for it as butter?

Mr. JoL $\Lambda$ N. They all know what they are getting. Mr. Chairman, you know that when people go into a store and get three rolls of buttel for 50 cents they know they are not getting country butter.

The Acting Chairman. But do they call for butter when they go to the store?

Ir. Dol $\Lambda$ N. Some do, yes; they have done it many times with me.

The ACTING CHAIRMAN. And they get oleomargarime?

Mr. Dolan. Yes; they get oleomargarine. They know that it is oleomargarine. They will be told that it is. Every man who sells it will tell them.

The ACTing Chairian. They use the word "butter" simply to preserve their general reputation in the community?

Mr. Dolan. Yes; that is my understanding. But they know that they are getting oleomargarine; and it would be unfair to the working people-

The Acting Chairman. Why should it be regarded as disreputable to purchase an article which is wholesome and nutritive, and in every respect equal to creamery butter, simply because it sells for 15 cents a pound instead of 30 ?

Mr. DoLAN. I do not know that it is disreputable; but -

The ChaIRiran. Well, uncomfortable, then?

Mr. Dolan. People have a little pricle about it, you know.

The Acting Charrian. They have a pride, usually, in getting what they want as cheaply as possible.

Mr. Dolan. Yes; and I do not think that that should be any reason for having this color takeu out. You might as well pass a law to say to men if they were going to eat candies, they would have to eat white candies ouly. Some people prefer pink. And so it is with whisky. When it comes from the still. the worm, it is white; and then it is after. wards colored, because people like it that way. I would rather have it that way than have it white. That is a plain statement of the matter.

Our people, Mr. Chairman, are against the passage of the measure. I represent over 40,000 miners and their fanilies; and I know from the sentiment in other sections of the country to whir'h I go, from talking to people who are interested in our organization, that they do not want to be deprived of the ability to purchase this wholesome article of food. If it is not made in a wholesome way, then they do not want it; but if it is just as good to them to sprearl their bread with as 35-cent butter, they do want it. And if this measure passes, the chances are that butter will go up to 50 cents, and poor people will not be able to purchase it at all.

Mr. KNIGH'T. May I ask a question, please?

Mr. Dolav. Yes, sir.

Mr. KNIGHT. Do you mean to say that caudy manufacturers color their product for the same purpose that oleomargarine manufacturers color theirs? 
Mr. Dolan. No; I maintain that the eandy manufacturers do the same as the ereamery and butter manufacturers. They color it for the purpose of making it palatable, or becanse people prefer this pink color to white.

Mr. KNIGHT. Does the color in candy make it resemble any other article so that the people can not tell it from another article, and does it endanger the people being defrauded?

Mr. DOLAN. I do not know that it does; but, althongh I have been in the business for over four years, I do not know of anyone who ever was defranded through buying oleomargarine for creamery butter. If there are such cases they are isolated ones.

Mr KNIGHT. Your experience las probably been limited to your own dealings with the people, has it not?

Mr. Dolan. Well, that is a good experience; and I now travel around among the people. I am on the roal all of the time, and I get in among the working people, and they are the people who are interested here. I am not here in the interest of the oleomargarine mannfacturers or the creamery butter manufacturers, but in the interest of my owu people, for I know that this bill will be an injury to them if it is passed.

Mr. KNIGHT. Do yon know that the lighest priced butter in the United States is absolutely as white as it can be made?

Mr. DoLAN. Do I know that the highest priced butter is absolutely white, you say?

Mr. KNIGHT. As white as it ean be made?

Mr. DOLAN. I will agree with you that it is as white as it can be marle. I have hat some experience in that line. I used to own two cows, and my wife used to make butter. I thought she was a cleanly woman, but she could not make it white.

Mlr. KNIGH'T. She conld not?

Mr. Dolan. No-not absolutely white.

The ACting Chairitan. But these gentlemen this morning proved that it is the dirt that makes it white. [Langhter.]

MIr. Dolan. Well, I do not know. There is one thing that I will tell you: It is not absolntely white, but it is not the color that you get it from the farmers. In my section I have known farmers to buy oleomargarine. What they did it for I did not know.

The Acting Ghatruan. I believe that is all, Mr. Dolau.

Mr. Dolan. Thank you, sir.

\section{STATEMENT OF JOHN PIERCE, REPRESENTING THE AMALGA- MATED ASSOCIATION OF IRON AND STEEL WORKERS.}

The Acting Chairian. Are you the presiclent of the Amalgamated Association of Iron and Steel Workers, Mr. Pierce?

Mr. Pierce. No; I am one of its trustees. On last Saturday we had the regular quarterly meeting of onr arlvisory board, and they selected me to come down here and represent the association. As you know, all of our people are workingmen, too. They all work in the rolling mills.

When my attention was first called to the Grout bill by newspaper comment, after its presentation in the Honse of Representatives, I had no idea that such an iniamous measure wonld ever receive serious consideration, much less pass that body, as it has done. The interest of the consumer seems not to have been considered at all, the sole idea apparently being that the ereameryman and dairyman should have a 
monopoly of the entire market for thein' wares, by reudering a coupeting product so mattractive that moboly would care to purchase it. Do you think that all the workingmen of western Pennsylvania or of these Uniter States (a portion of whom I represent in the Amalgamated Association of Iron and Steel Workers) can aftord to pay 35 cents per pound for creamery butter, which is the present price for the first-class article in Pittsburg? Everyone, I think, will admit that all can not.

If this lill passes, what position are we iu? On examination we find that we will have three options, viz: (1) Ureamery butter at 35 cents, if the conditions are no worse; and I am not snre but that the passage of this bill may make it 50 cents per pound. (2) Colored oleo at 25 cents per pound, on account of the 10-cent tax. (3) White oleu at 15 cents.

Colored oleomargarine is at present retailed at from $12 \frac{1}{2}$ to 20 cents per pound. On iuvestigation I am satisfied that most of our people are paying about 15 cents per pound for it, and I can not aduit that those who buy it can afford to pay more. I therefore arrive at the conelusion that they must either find 10 cents per pound more to pay this proposed robbery (for I can not dignify it by the name of tax), or buy aud eat white oleomargarine. And this to satisfy the green of the manufacturers of butter, who think that white oleomargarine is guod enough for those who can not afford to pay 10 cents additional for yellow. or the 20 ceuts or more additional for creamery butter, or use the off grades of butter now musalable as food!

Shall those thus defrumderl of what should be their inalienable constitutional right be compelled either to wear in their homes, on their very tables, flaunting before the eyes of their children and of those who may share their board, a badge of their poverty, aurl an emblem of their inability to pay a legalized robbery; or, on the other hand, to contribnte from their neager board to the hellish greed of the butter iuterests, of whom it has been doubtless truly said that they seek to follow the fashion and form a trust, but are deterred by the existence of oleomargariue?

I believe that every pound of creamery lunter to lay is artificially colored. I have been told so by dealers and chemists; and it puzzles me, as a layman, where they get the basis or reasou to ask for the exclusion or taxing of color in olemmararine, when they use it ad lilitum themselves.

It has been said with truth that some oleomargarine has been sold for butter. I do not defent this. Every houest man would condemn it. If there are not laws to prevent it, there shonld be and would be, and they would be enforced: but the dairyman and the butter interests have never sought to have falssed and enforced anything like that. They seize on every legislative opportunity to try to wipe out the sale of oleomargarine-not to regulate it, but to tax aud legislate it ont of existence. Have not a dozen States, throngh the immense intluence of the butter interests, and their misstatements, in times jast, enacted laws ntterly forbidiling the manufacture and sale of oleomalgarine within their borklers on the lying and shillow pretense that it was inimical to public: liealth? And this claim has becu selionsly ald ranced, despite the fact that scientists to a man have declared jt just as wholesome as butter, and Justice Prokham, of the United States Supreme Court, in rendering a decision said it was a "notorious fict" that it was a healthful article.

New York liad such a law on her statute books for years, as had Pemsylvania from 1885 to 1899 . Now we have a color liw. Our first 
statute was more commendable than the new one is, as there could be no mistaking its frank intent; but the second, despite its pretensious, would be as effective an exclusion as the first, were it possible to carry ont its provisions, which are so unpopular in some places that a jury can not be secured to convict anyone muler it.

To aftimatively recommend and pass this bill would be a crying injustice to the rorkingunan in my section, and to consumers every. where. Oleomalyarine, nuder its own name, should have the same freeclom in onr markets as any other article of commerce; and if legislative bodies will ignore the greed of the self-seeking butter interests, and pass stringent laws regulating its sale for what it is, and not hampering or prohibiting its mannfucture (as has been the sole intent of every law ever proposed), then all this fuss and feathers will cease.

Now. Mr. Chairman, there are a good many of our people who make pretty good wages, and of course they cau buy butter; but the majority of them make small wages now, especially since we got into thus trust business. I know there are lits of men who do not like to buy this white oleomargarine, because it looks more like lard than anything else. It does not look like butter at all. Why should they be malle to pay 10 cents a pound more because they get butter that resembles conntry butter, aud looks a little better on the table? That is why I am here to oppose the passage of this bill. It is for our people alone, for of course I do not know much abont the butter business myself:

The acting Ghairyan. It is a question of family pricle, you think?

Mr. PIence. I think it is, yes; for I tell you, I would not like to eat it white.

The Acting CHatrman. Iou think that if a person goes iuto a store to buy this article, he does not like to be heart calling for oleomargarine?

Mr. PIERCE. That is right.

The Acting Chairman. Therefore lie calls for butter?

Mr. PIERCE. He calls for butter; but the merchant mulerstands that he wants oleomargarine.

The Acting Chamman. But how does the merchant get the idea that he really wants oleomaryarine?

Mr. PIERCE. Well, I will tell you. In the case of families dealing at certain stores, the man who ruus the store generally knows what they want. They will come in, or they will send the rhild in, and say, "I want three pounds of butter." The dealer knows exactly what they want; but they will say "butter," of course. He knows that they buy oleomargarine all the time, however.

The Acting Chairman. That is, he kuows he sells them oleomargarine?

Mr. PIERcE. Tes; and tiley will come in and ask for it in that way, even if there is nobody in the store. If I "ere sent on an errand of that kind, I would not care about going up and asking for oleomargarine.

The A cting Chatrian. Why not? Let me understand that. Is it regarded as a disreputable thing to have it on your tible?

Mr. PIERcE. ()h, well, every nuan does not lilie to expose his poverty.

The Acting Chamman. I know; but it is not exposing his poverty if the articl is nearly as good as butter, and very much cheaper. You can, almost any day, see a bargain counter crowded with the best women in the community, who are trying to get a cent rednction on the price of a thing they want.

Mr. SCHELL. That is the fashion. 
The Acting Cimarian. Now, then, why should it be regarded as disreputable to have this product on your table? Why should it disgrace the children to wake up to the fact that they are really eating oleomargarine?

Mr. Pierce. Well, I have heard children say: "Oh, look at that old stuff! It looks like lard."

The Acting CHAIRian. Do they have that kind of oleomargarine now?

Mr. Pience. They will say that of the white stuff. They will do it. I have heard them say it.

Mr. Knight. May I ask a question? Do you not know that oleomar. garine is largely lard?

Mr. Pierce. I do not linow what it is made of.

The Acting CHairuan. Yon eat it largely on faith yourself; I should judge, Mr. Pierce?

Mr. PreRce. I do not. I never eat any.

The AC'TING CHaIRMAN. You do not eat it at all?

Mr. Pierce. Oleomargarine? No, sir.

The Acting Chairian. Why not?

Mr. Pierce. Well, I just don't have to.

The Acting Chamman. So you regard it as the last resort, do you? (Lauchter.)

Mr. PIERCE. Well, I would not be ashamed to eat it if I had to.

The ACring CHAIRMAN. If it is as good as butter, I should not think a sensible man ought to complain against it because it is cheap.

Mr. PiERCE. I don't know that it is as good; I don't know. I can't answer that question.

The ACTING CHAIRMAN. If you should go into a store and call for butter, you would expect to get the genuine product, I take it, $\mathrm{Mr}_{\boldsymbol{q}}$ Pierce?

Mr. PIERcE. Yes; but there is such a thing as farmers coloring their butter.

The Acring Chairman. Oh, yes.

Mr. PierCE. I know it.

The ACTING Chairman. But, from all the testimony, I understand that the coloring matter adds nothing to the nutritive or palatable qualities of either oleomargarine or butter.

Mr. Prerce. Oh, no; it simply makes them look better. And why should they pay 10 cents a pound for making a thing look a little more palatable? Even if it is not, it will look more pralatable.

The ACTING CHAIRMAN. Suppose it could be shown, Mr. Pierce, that a large number of these people who call for butter at the grocery stores of the comntry are looking forward to getting butter, and in point of fact are getting oleomargarine, and that they have the same prejudice against it that you personally have. Wonld it not be fair to so fix the law as to prevent their being swindled?

Mr. PiERCE. I believe there are some of them being swindled now through buying country butter. I know that some of these farmers buy oleomargarine. What they do it for I do not know. I do not mean to say that all farmers do it, or that they would all of them do anything like that; but I know it is lone by some. And I know another thing: I saw a lady, when she came liome from market one time, cut her 3 -pound roll of butter in two, find a snowball in it, and a little stone in the middle of that. [Langhter.]

The ACTING Cuarrian. A little what?

Mr. Pierce. A little stone in the middle of the snowball. That was "country butter," too, mind you. 
The Acting Chairman. What time of the year was this?

Mr. Prerce. This was in winter. [Langhter.] It would not be apt to have any snowball in it in summer.

Mr. KNIGHT. It was to refrigerate it, I guess.

Mr. Pierce. So you see you can't depend altogether on the farmers.

The Adring Champran. Of course not. The idea is, that if this bill were passed it would put a stop to impositious of that sort, whether practiced by farmers, grocers, manufacturers, or anybody else. Do you think the workingmen of yonr association would serionsly resent being guaranteed that they would get what they called and paid for?

Mr. PIERCE. Well, I know that they don't like this 10-eent business; and they want to buy oleomargarine that is colored. "They like that style of it; and they don't like to have to pay this extra 10 cents, or 8 cents, or whatever it is going to be.

Now, that is why our people object. I think the cheaper yon keep this oleomargariue the cheaper we will get our country butter, too. That is the way I look at it. If you raise this tax to 10 cents, don't you thiuk the farmer will rum his butter uip, too?

The Ad'Ing ChairuaN. Well, I will not undertake to go into that question.

Mr. PinRCe. I don't know, either; but I just think that way about it. I am looking at it for my own sake there, because I don't want them to raise the price of butter any more. I think 35 cents a pound for butter is enongh for anybody.

The Acting Chairiran. That will do, so far as the eommittee is concerned, Mr. Pierce.

\section{STATEMENT OF D. A. TOMPIINS, OF CHARLOTTE, NORTH CAROLINA.}

The Acting Chamman (Senator Foster). Mr. Tomplins, do I understand that yon represent the cotton-seed interest?

Mr. TompKins. The cotton-seed oil interest--yes, sir.

The ACTIng CuaIRHaN. From what State are you?

Mr. Tompkins. North Calolina.

The Ad'Ting Chairuan. How long a time do you wish? Would yon like the full time, thirty minutes?

Mr. TompKins. If I cau have thirty minutes, I will be very much obliged to the committee.

The ACting Chairian. That is all the time we have this moruing.

Mr. Touprins. The committee will be very liberal, then, if it gives me all the time it has.

Senator HEITFELD. We convene at 12 o'clock, you know, and we can not give you any more time this morning.

Mr. Toypriss. Yes, sir. What I say will be more of a general nature than an attempt to go into specific details; because, I believe, you have liad any quantity of them.

I have built a great many cotton-seed oil mills, and have given a great deal of time and attention to the subject of finding new uses to which to put the oil. It is a product which is a result of "liscoveries of the value of cotton seed, and the liew uses to which it is being put from time to time exhibit the great value to humanity which is being realized from cotton seed in the way of getting a good, wholesome food product.

English literature is absolutely full of the fights of old methods with new methods-of the resistance of peoples who are behind the times against those who have marle a step for warl, and who have put something into the field of competition. And you will admit the value of 
competition as having been acknowledged in all indnstrial occupations. In putting forward something which puts the old processes at a disalvantage a fight has always resulted, and the fight has always ended in exactly the same way. The new and better thing has always won in the end, and it is going to do it in this case, in my opinion.

The value to humanity to any new discovery or invention may be tremendously hidden by the action of a body which exercises such tremendons powers as the United States Senate. But that one class of people shall be legislated for to the exclusion of all humanity getting the benefit of the advanced method of putting food stufit's on the market I do not believe, or that the inferior of those propositions will succeed as against that larger one which appeals to the whole of humanity as against the interests of a small class in one occupation alone.

When the power loom was invented there was the same fight. The hand-loom weavers made a great growl abont the power loom tearing up a domestic industry by the roots, about the unfairness of having machinery to put cheaper goods on the market than conld be made by the hand loom, and there was riot after riot over it, just as in these moderu times there is appeal after appeal to the United States Senate to protect something which in the first place does not need protection, which is against tlie interests of 90 per cent of the people and in favor of the interests of 10 per cent. And it is just as in the case of the power loom, or in the case of the introduction of aniline dyes as against indigo. You might as well be legislating npon the snbject of whether we conld dye our cotton goods with aniline dyes or whether we ought to be made to dye them with indigo, because it is a farming industry which ought to be protected.

Whatever the ontcome of this particular investigation may be, whatever the Senate may do on this particular occusion, if a food stuff has been found ont, extracted from vegetable products, largely made up of perfectly healthful prodicts on the other hand, which is a good thing for all the humanity of the United States, and especially a good thing for the working people of the United States, then in time, if yon pass this law, it is going to be repealed. Some Senators have told me that they feel constrained to rote for it becanse they lave heard from their constituents. I say that if they pass this legislation, they will undo it later, becanse they will hear from their constitnents again when they do do it. And why? Because, for instance. if you pass this law, throughont the whole Sonth you will apprecinte the products of corporate dairies, of men with large fortunes, while yon will depreciate by \$2 a ton all the cotton seed that is sold in the South to a cotton-seed oil mill.

If petitions from farmers were any good, and if these cotton-seed oil people had had the foresight to go abont it, they could have gotten a petition signed by every cotton farmer in the Sonth, because practically none of them have any interest whatever in the clairy business, and every single one of them has an interest in the cotton-seed oil industry to the sake of making or losing 82 a ton, according to whether you pass this bill or whether you do not pass it.

The ACTing Chatruan. Do you think it would depreciate cottonseed oil?

Mr. Tonpkins. I know it,

The Acting Chairman. What is cotton seed worth now? What is the price of it?

Mr. Tompriss. It varies from $\$ 8$ to $\$ 12$; and if you put this tax on oleomargarine, and destroy the market for it, the cotton seed will have 
to be bought that much clieaper in order to sell the oil at the depreciated price, becanse of the absence of this market. It has got to be shipped, then, to Rotterdam to make butter, which is done now to a very large extent. There are enormous shipments of cotton-seed oil made now to Rotterlam, and the butter of a large proportion of those people in Enrope who can not afiorl to use anything but cheap butter comes from this cotton-seed oil product, just exactly as the olcomargarine made in this country is largely made mp of it.

Now, in respect to other interests which are interfered with, you have heard from the stockmen, and you know the extent to which the bill is considered adverse to their interest. But there is still another interest: which I have not heard auybody speak of. I was tormerly an employee of the Bethlehem Iron Works, in Pennsylvania. I lived with the working peoplo, becunse I was one of them, and the ford stuffs that were bought there lial to be economical food stuffis. It was exceedingly desirable that they should be able to buy wholesome food stufis; and if your bill were rlirected to the question of whether these products are wholesome or not, it would be quite a lifferent situation. But that is not the proposition. And as far as this bntter being more or less manu. factured is concerned, the daily bntter itself is really manufactured; while the very coloring matter which ron are proposing to refuse the use of in commection with butterine is iclentically the same thing, and is used to identically the same extent in many cases in the butter that comes from cattle, and there is just as much deception in the one case as in the other. Is a matter of fact, there is not any deception in either case.

If in the.renovation of butter it is considered desirable to give it a uniform color, that is all right. If it can be done without injury, it is all right. If the same thing can be done in butterine, I do not see any objection to it, any more than you should attempt to object to a grirl's wearing a pretty color on her clothing to make her look better. The dressimg up of goods is practiced all the world over all the time. The exhibition of goods in slow winclows, with the briglitest colors put forward, is simply creating an attraction by which the goods can be sold. And to molertake to pass upon coloring matter simply because it is coloring matter and nothing else is identically the same thing as to attempt to prevent one class of women from wearing a particular color because it makes them look like another class of women who are assumed to liave the right to wear those colors.

Take the matter of ginghams. We have the same situation all the time. We buy a French or a Scotch gingham over here that costs anywhere from 30 to 60 cents a yard. Immediately, the next year, those patterns are all copied and sold for 10 cents a yard. Now, is the fiact that the same colors are used, the fact that a girl who perhaps works in a factory undertakes to (lress herself up in a similar manner to a woman who is wortl a fortume, but in a very much 'heaper way, a legitimate subject for legislation? And is not this proposition to legislate with respect to the color of food stuff's iclentically the same proposition?

For this reason, Mr. Chairman, practically the whole farming interests of the South are very much interested in seeing this bill defeated. The stock interests in the whole United States are very much interested in seeing this bill defeated; and there are undoubtedly working people from Maine to California who are interested in seeing that a whole, good, and cheap foodstuff, made at a price which they can afford to pay, is not legislated ont of existence-not because the richer man wants the poor man not to eat butter at all (and I am not making any 
special plea about the poór man; I am simply speaking about the facts), but because the fellow who makes the butter and himself colors it wants his particular business to be legislated into a monopoly.

Now, in respect to this matter of petitions, about which I have heard a good deal, there is not to my mind the slighest doubt in the world that they have beeu manufactured. The dairy interests have gone out amoug farmers and persuaded them that their interests were being interfered with by this product, and having gotten their names on petitions without their ever having come voluntarily forward to sign any of those petitious at all. Ind I assert, withont the slightest hesitation as to the truth of what I am stating, that 90 per cent of the farmers of the South could be gotten to sign a petition asking for every one of you to vote against this bill. I have not the slightest doubt that 50 per cent of all the working people of every State in this Union would do the same thing; and I know I could go to the Bethlehem Iron Works and get !) per cent of the people there, by a representation of what you a e doing and what you propose to do, to sign a petitiou demanding that you should not vote to destroy the best improvement in foodstufts which has been made for the last quarter of a century for the benefit of those who have to live economically, whether they are working people or whether they are not.

I assert another thing, which is a repetition of that which has already been stated-that if you are passing this bill in the belief that it is in accordance with the wishes of your constituents, when you pass it you will hear from your coustituents again. Your constituents on the other side have not any appreciation of what you propose to do. The people who are interested in the cotton business and the cotton-seed oil business have been absolutely iclle in this matter, whereas the friends of the bill have been securing petition after petition, using money and labor, and getting the names of people who were not interested in it at all. Now, I would like to make a wager that the petitions you will get if this bill is passed, after it is passed, will immensely exceed those which you have gotten before. 1 claim that those you have gotten have been manufactured to a very large extent, while those which you will get will be spontaneous and energetic. And they will come from Maine and from Pennsylvania and from Olio and California and Texas, and from every other State of the Union; becanse there are too many people interested in this subject, vitally and in their homes, too many people who wonld look npon it as being exactly the same thing as a law which would prevent an osdinary girl from wearing a gingham which initated somebody else's fine frock-the same thing as a bill which would permit the use of aniline dyes, which are cheaper and in some cases better, because somebody wanted to promote the indigo dye business; or a bill to try to prevent by legislation the use of a power loom, because it would destroy the domestic industry of liand loom weavilig.

Now, if there is anything the matter with this coloring matter which it is proposed to put into either butter or oleomargarine, then you can properly put a high tax upon it or forbicl its use entirely as being injurious to liealth. It would be perfectly proper to inquire into the whole. someness and into the healthful character of all the processes and all the ingredients that go into either butterine or butter: and if $50 n$ should undertake such an inquiry, I predict that you would find just as many fanlts in one as in the other in all probability, and that if in the processes or in the materials that are nsed, or in the raw materials with which the processes start, there should be any advantage one way or 
the other it wonld be on the side of cotton-seed oil every time. There is not a more wholesome article made, and it so closely appronches olive oil, which is one of the finest foodstnffs that has been known for centuries upon centuries, that you cau searcely tell the difference, even if you are an expert, while those who are not can not tell the difference at all.

Senator MIONFY. Will you allow me to interrupt you?

Mr. Tomprins. Certaimly.

Senator MoneY. A few years ago the Italian Government prohibited the importation of cotton-seed oil because it was destroying the oliveoil industry.

Mr. TompKins. And what was the result? That the exportation of olive oil fell off abont two thirds, as I understand.

Senator MoNEY. Yes.

Mr. Tomprins. That is just what I am predicting will follow in this case. They found that it injured an industry mueh greater than the one which they were making laws abont, and that they had to promptly repeal the act which they had passed just as soou as they could get to it. They found that the interests of the olive-oil people themselves were interfered with by an act which practically destroyed a large part of the trade in oil.

Senator Dolliver. They mixed the cotton-seed oil with the olive oil and sold it to the purchasers as being the geuuine stuff, did they not?

Mr. Tomprins. Sometimes they mixed it and sometimes they did not. Sometimes they sold it without any mixture as the genuine stuff; aud it was the genuine stuff. It was just as good an oil. It was a v'getable oil. It was refined to the same degree of color. It was used for the same purpose, and you could not tell it from the other. Why was it not the same stuff?

Senator Money. Why, the Senator himself is using it every day.

Mr. Tomprins. Of course he is.

Seuator DoLliver. No; I avoid all suspicious mixtures.

Mr. Tomprins. Then you do not eat anything but cotton-seed oil, for there is nothing suspicions abont that. I think about a great many of these other things, and especially anout dairy butter, there wonld be quite a suspicion attached to them. I am not criticizing it, you understand, but I say there would be quite a strong suspicion attached to dairy butter as regarils simply whether it was nothing but dairy butter or whether it was something made in a dairy, and was oleomargarine or butterine, as you call it. For it is a fact that even the buttermen use coloring matter. It is probably harmless, and is all right enongh, but in many cases they also use more or less stearin and cotton-seed oil in their products. In fact, when they put the coloring matter in the butter, I understand they use cotton seed oil as a medium for the color, so that all the so-ealled dairy butter has more or less cottonseed oil in it, wherever it has been colored, and cottons-seer oil has been used as the medium.

Senator Monex. All the higher grade butter has cotton-seed oil in it?

Mr. Touprins. All the higher giade butter has cotton-seerl oil in it. [Laughter and applause.]

I had occasion once in my life to be sent to Germany to put up a lot of machinery, and in going to the place where I boarded, I observed that there was some trouble about the qnestion of iny sheets. On investigation I found that they were straining a point consilerably to give me linen sheets to sleep on instead of cotton slseets. When I 
found that out I told them that they were worrying themselves about something which I did not eonsider of any conseyuence at all. I said: "Go ahead and put the cotton sheets on; I would just as lief sleep on them as sleep on linen sheets"-like the fellow in a storm, who, when the ship ran on a mud bank, told the captain to put him out, that he was bronght up in a muddy country. I told them that I was brought up in a country where cotton grew-that I had no prejudice against it at all, and that it was all right.

But in that country they had identically the same prejudice against the use of cotton-cotton clothes and cotton sheets-as we find exists in this country with reference to a food product made by another process than in a churn. Now, I knew that that was a prejudice, and nothing but a prejudice. I knew that it was a prejudice which would break down with absolnte certainty. And yet all over Germany, beranse the habit had existed for century after century for a girl who was going to get married to get a whole lot of linen sheets and linen tableclotlis and linen napkins, it was not thought respectable to have a honse with cotton sheets in it. Yet cotton was a good clothing prodnct. I told them that they would get over that prejudice. And since that time-it has been twelve or fourteen years ago-I have heard that a tremendons increase in the use of cotton cloth has taken place, because it is cheaper, because it is just as good as linen. And it is simply a question of time when the whole prejudice will be totally brokin down, and cotton goods will go in Germany just as they go here. Some will use linen where linen is better, aud some will use cotton where cotton is better; but the great bulk of the plain people will use cotton. and it will fall to a condition where linen is only used, not because cotton is not just as good and just as agreeable, but becanse people are rich and want to pay more for something in order to make a little distinction abont it. Now, I predict that this product of cottonseed oil and other ingredients which go to make a good, wholesome, ordinary butter will come to be used all over this country; that the United states Senators and the other aristocracy [langhter] will not question whether it is that or anything else; that only a few people who want to be finicky about having something a little different from anybody else will pay a bigger price for the dairy butter, the supply of which will always be inadequate to meet the demand, and is inadequate now. But the great mass of the consumption will be of a butter made of wholesome products from the cow, in the way of beef, stearin, and tallow, and other things, and of cotton-seed oil, and whatever other ingredients are necessary to make a butter just as satisfactory, when compared with the dairy butter, as cotton is satisfactory when compared with linen.

Senator DoldIVER. Do you think the curiosity on the part of the average citizen to know what is in it will disuppear in the course of time?

Mr. Tomprins. Except on the part of the dairymen. I think their curiosity will continue throughout the investigation.

Senator Moner. Like hash; they do not care what is in it. [Laughter.]

Mr. Tompkins. Take the case of the poor workingman. You know perfectly well that they can not aflord to pay 3.5 cents a pound for dairy butter. They do not question whether the butter sold to them at 15 or 20 cents a pound was made by this process or that process. They simply question whetiner it is wholesome and whether it tastes all right; and I will tell you that there are no more particular people in 
the world than those working people of Philadelphia and Bethlehem, where I formerly worked, as to the matter of the wholesomeness of the food they eat. The housewives there keep the best houses in the United States. They use cotton slieets, and they use cotton all the way through.

Senator IIONEY. They have good sense.

Mr. Tourpins. Yes; they have good sense. They make our armor plates and armor forgings and build our ships. Those are the people who do these things.

I take it that the United States Senate can handicap the progress of improvement. They can pass a law saying that a power loom can not be rmu except by paying a tax on it, in order to try to protect the handloom weavers. That is what the English people did a hundred years ago, but it did not succeed. 'The opjosition did not last. 'There were people killed. There were riots. 'There was intinite trouble. Yon can stay the progress of an improvement for a time, but if it is an improvement it will succeed in spite even of legislation. Political economists tell us that on one oceasion in England, and on more than one occasion in other comntries, trade had been maintained by smugglers when the tariff' attempted to destroy it, or was put so high as to make it practically prohibitory. It is well known in making tariff lists that if you attempt to put an embargo on a certain class of goods, you can not put more than so much on it, beranse if you do you will throw the business totally into the hands of sming gilers.

I ain one of those who believe that this cottonseed oil business, together with its outgrowing industries, is one which you are not going to stop by legislation. It is a food stuff which is too valuable, which goes to tou unany people, to have a stop put to it even by law; and you will liave a whole lot of people arrested in the year during which the bill lists if you pass it. You will have a whole lot of trouble abont collecting these revenues; but the industry will go on, and in time you will get tired of it and you will repeal this bill, and the improvement will live, as almost all improvements live. And some of the people who helped to pass the bill will live at home and run dairies, instead of legisliting in Congress.

I may say that if there are any questions which the gentleman would like to ask I will be happy to answer them.

Senator Dolliver. Have you gone over the question of how far cotton-seed oil enters into the oleomargarine product?

Mr. Tomprins. It is a very valiable quantity, more or less; and in many cases cottonseed oil is used for coohing purposes wi hont any mixture at all. I think the secretary of the Treasury has iuvestigated the subject, thongh. Mr. Miller, can yon tell me what the percentage is? It is something like 10 per cent.

Mr. MILLER. Ten million pounds, I understand, were used during the past year.

Senator Dolliver. What is the percentage in that particular formula?

Mr. ToMpкins. It is a matter of investigation by the Secretary of the Treasury. You will find his statement accurate, I think.

Senator DoLliver. What is it-the oleo oil, or the nentral oil, or the butter oil?

Mr. ToMphins. The butter oil.

Senator Dolurver. It seems to be $s$ per cent. Of course this legis. lation does not affect the ordinary domestic use of cotton-seed oil. Fou have said that considerable of that was being used without admixture. 
Mr. Tompkins. Well, the whole proposition is this: Here are two food stuff's. Put one through identically the same tests that you do the other, and the only difficulty about that, so far as the dairy people are concerned, would be that the oleomargarine and cotton-seed oil products would come out aheal every time.

Mr. ScHELl. If the committee and the speaker please, that formula which is given there is only the formula usecl in one paiticular grade of oleomargarine at one particular fictory. It is not a criterion of all that that factory turus out or of what any other factory turus out.

Senator DoLLIVER. Is there any accessible criterion to which we could turu?

M1. Tompkins. The Secretary of the Treasury lias made an investigation, and you conld ultimately get the result of his investigation by applying for it. But, as I tell you, it is very variable. Some factories use s' per cent, some-

Mr. KNIGH'. The Secretary of the 'Treasury says 10 per cent is the average.

Mr. JeLkF, About 10 per cent.

Mr. Tompkins. The Secretary's report gave 10 per cent as an average of the whole sum of oleomargarine. There is oleomargarine made without any cotton-seed oil at all, I think.

Senator MoNEY. That is the lowest grade.

The Ac'ing CHairisan. Then you cotton-seed oil men are rather opposed to some kinds of oleomargarine?

Mr. Tomprins. No; we are not opposerl to any good thing. We think a good thing is all right and onght to be let alone. It is only the dairy men who are "gmming for it."

Mr. Tillingmas'T. I call the attention of the gentleman to this fact, which probably will not be plovided against as the bill now stands: Cotton-seed oil, under this bill, conld not be used at all, because cottonseed oil has quite a little color iu it, and, as I suggested when I was speaking betore the committee, it wonld be one of the ingredients which would cause it to lonk like butter.

Mr. Tomprins. Then, in that phase of the bill, I do not understand low a committee of the United States Senate conld consider for a moment the passage of an act which would permit the use of a coloring matter in one case and prohibit it in another, any more than yon would permit the wearing of a dress of a certain kind by one woman and prevent the use of the same color by another. I do not see under what pretext it could come about.

Senator Money. It appears, from what they claim here, then, that everything needs coloring except cotton-seed oil. [Laughter.] Butter needs coloring, and oleomargarine is colored, but cotton-seed oil does not need anything in it.

MI. TompKixs. Cotton-seed oil really, on its merits, needs absolutely nothing. This is a controversy between other products.

The Acting Chamrian. Your time is up, Mr. Tompkins. We must go to the Senate.

Mr. KNIGIT. If there is any other representative of the cotton-seed interest here I would like to get him to give me the figures as to the interests of the cotton-seed oil people here. According to a little calculation I have made, the amount of cotton-seed oil used in oleomar. garine constitutes less than two-thirds of 1 per cent of their gross ontput.

Mr. Toupkixs. I can tell you right now that they have $\$(;, 000,000$ worth of interest a year in it, if this bill is passed in depreciation of 
the value of cotton sced. According to my estimate of $3,1100,000$ tous of cotton seed which are used for making oil every year, their loss would lie $\$(j, 1)(0,000$ a year-the loss of the eotton-seed penple alone. Now, you would bleed the working people of the comntry of ten millions more, and rou would bleed the stock people of five. That is what you would do. 'That is an estimate of the value, in dollal's and cents, of these interests.

The Acrisg Oharman. We lave been informed that $107,000,000$ pounds of oleomargarine were male last year, at about "z0 cents a pound.

Mr. SirneLL. You are forgetting the effect of this legislation on exportation.

Mr. Tonprins. Yes; its effect on the market mice, in decreasing the market price of oil, and increasing the price of the food stuff's of the working pople, who now buy oleomargarine. You must not forget those two filcts.

Thereupon, at 12.05 o'clock, p. m., the committee took a recess until 2.311 o'clock, 1). 111.

At the expiration of the recess the committee resmmed its session.

Present: Senator's Dolliver (acting chairuan) and Foster.

Present, also, Charles I. Knight, secretary of the National Dairy Tnion; John F. Jelke, representiug Brann \& Fitts, Chicago, Ill.; Frank W. Tillinghast, representing the Vermont Manutacturing Company, of Providence, R. I.; Charles E. Schell, representing the Ohio Butterine Company, of 'incinmati, Ohio, and others.

The ACTING CHatruan. Who is the next speaker?

Mr. Tillinghast. Mr. Couley is ready to be heard, as I understand.

The Arring CHAIRIAN. You are here in the interests of cotton seed?

Mr. Conler. Tes, sir. I represent the De Soto Company, of Greenville, Miss.

\section{STATEMENT OF J. B. CONLEY, OF GREENVILLE, MISS.}

Ir. Conley. Mr. Chairman, I am lıere representing the Crushers Association, and more patienlarly the mills of Mississippi. There are other gentlemen here from different sections of the comntry representing the same interests, who will enter their protest with mine against the jassage of the bill known as the Grout bill.

1 feel sure, Mr. Chaimun, that the passage of this bill will be far more leaching than you now contemplate. It will affect the cottonseed oil mills very materially, to a greater extent than we can now realize if we take into consideration only the loss of the sale of the oil that goes into oleomargarine. The effect of the passage of the bill woull be to leave a surplus on ham which we rould have to in some way dispose of; and the best that we could comt on, assuming that we could dispose at all of this accumulated surplus of oil (and I will ald here that the mills generally carry over a surplus of oil) would be to dispose of it at a lower price. As you know, Mr. Chairman, a smrplus of any commodity means a lowered price.

There are something over 400 mills in the cotton States, about 240 mills east of the Mississipli River, '21 in Arkansas, and 2 in Missonri. As to the number of mills in Texas, I am not aceurately informed, but. will estimate it at about 150 . We have 45 mills in Mississippi; and if this bill becomes a law it will entail a very serious loss to the mills and to the planters and to the laborers and everybody interested. We lave 4 mills in the little city of Greenville, where I live, representing a capital of something like $\$ 400,000$; and I do not think I exaggerate 
when I say it would be likely to result in a loss to the mills of anywhere from 3 to 5 cents per gallon, each cent being equivalent to 40 cents per ton on seed. Or, taking the whole consumption of cotton seed for manufacturing purposes, it would mean a loss of from $\$ 3,(100,000$ to $\$ 5,000,000$ per annum to the oil industry, each cent per gallon of oil being equal to $\$ 1,000,000$ per annum on the whole crop of rotton seed. This would mean, furthermore (viewing it in another light), that there would be a clear loss to the oil industry of from 10 to 20 per cent of their total earnings. Of comrse, there is no loubt that this loss would ultimately fall on the planter, who in a large majority of instances is the small white planter and the negro, and as the working men in the northern and western comntries would be deprived of a cheap and healthy substitute for the butter, the poor farmer of the South would get less for lis cotton seed.

The passage of this bill unquestionably means a blow to the inclustrial interests of this entire country. I do not mention the raisers of eattle and hogs, as their case has been already ably represented before your committee. They would also be lieary losers, and who would be the gainers by it? As half of the oil manufactured is exported, it would mean that the foreigner would gain to half the extent of the Southern losses, while in this country the only gainers would be the dairymen of a few States of the Union. In our own State of Mississippi, where practically all the available seed is used by oil mills, the loss on the above basis would amount to three-quarters of a million of dollars, which would be equivalent to placing a tax of about 75 cents per bale on the planter's crop.

If the object of the bill be simply to prevent the sale of oleomargarine as butter, we have no objections whatever to a more stringent and searching regulation than now exists, but we certainly protest against the injustice of lampering an industry in which we are largely interested by putting oleomargarine under regulations that do not apply to other products of a similar nature, and branding it thereby as an unlealthful article of food. It seems to me that it is entirely against the spirit of the Constitution of our country to tax one industry for the benefit of another industry. Moreover, the passage of this bill would be an entering wedge and a new argument to the Enropean nation for putting prohibitive duties on our products, for the slur cast upon oleomargarine by the Gront bill will be eagerly seized npon by the foreigners, who wish to keep out products, as an evidence that we ourselves believe oleomargarine to be nuhealthy.

It seems to me very unfair that, the manufacturers of oleomargarine are not to he permitted to color their product to suit the public taste, under a heavy penalty, while the manufacturers of butter are not to be hampered in any way, althongh it is a notorious fact that nine-tenths of the butter put on the market is colored artificially. I think all that the oleomargarine people ask, and all that we ask, is fair treatment; and if there is to be a tax on color, then let both industries be taxed alike.

Mr. Chairnan, I would like to call your attention to the fact that our industry has been built up in comparatively a few years, until now it is one of the most important industries in the United States, after cotton and grain. While cotton seel was formerly a waste product, it may be said that our industry has sprung from a waste. The South now realizes from it a revenue of from $\$ 30,000,000$ to $\$ 50,000,000$ per anumm. If this Grout bill should pass and the oleomargarine industry is thereby crippled or wholly destroyed, it will mean that one avenue 
of consumption is cut off from the oil mill, and the ammal snrplus of production over and above consmmption will be doubled. Any busi. ness man will know what this would mean. It would mean a redurtion of the price of the product, especially at the begimning and the end of each season.

In view of all these facts, Mr. Chairman, we beg leave to enter our most earnest protest against the passage of this bill.

\section{STATEMENT OF HENRY BOND, OF CHATTANOOGA, TENN.}

Mr. Bond. The gentleman who preceled me said just about the same thing that I am going to say, but I did not know he was going to do so.

I aw engaged in the cotton-seed-crushing business and mannfacture crutle cotton seed oul.

There are 15 cotton-seed oil miils in Tennessee, representing. in investment and rapital, abont s.,(104,00(1). They employ about 1,0(10) men and have a weelily pay roli of about $\$ 10,000$.

I am requested by these interests to protest before this committee against the passage of the (iront bill-first, becanse we are opposed to chass legislation, and, secondly, becanse we think this particular bill will work a gleat hardship to onl community. I lesire to give briefly onr reasons for so thinking.

I hive here the credentials anthorizing me to represent the mills of which 1 speak, and I will say that the company of which I am the vicepresident owns and operates 2 of the lij mills in the State of 'Temnessee.

Testimony heretofore given before your committee indicates that abont 0,100 larrels of cotton seed oil are used in the manufacture of that portion of oleomargarine that is comsumed in this country annually, and while we have no definite clata, the impression prevails that more magane oil is "xported than is userl here.

The n:ills of 'Tennessee will crush this year about 1,j0,000 tons ot seed and make over 100,000 barrels of oil, or probably just abont enomgh to fill the reguirements of the oleomargarine trade.

The oleomarganine manufarturels, however, use only the very lest grades of cotton-seed oil wherever they can find it, and pay higher plices than the mills ran obtain fom any otler sumce, and we believe that their demands go a long way toward setting the market wice for the whole cotton seed oil production.

After it was known last spring that Congress wonld not for some time, at least) further imperle the oleomargarine business the price of cotton seel oil at once advanced. and the advance was maintained all during the summer and tall, until Congress reassembled and renewed the attack npon it. Since then, althongh other conditions seemed to warrant the expectation of higher prices, oil has declined abont 5 cents per gallon, or soson per barrel, and we believe this deeline is dne to the threatemed legislation against oleomargarine, which deters the manufacturers from making purcluases for future use.

Favorable weather all fill and winter had expedited the picking and giming of the cotton and the marketing of the seed. That part of the unsimess is practically over now, and there is mo way in which the mills can protect themselves, so that they alone will have to bear the burden of the loss this scason.

Hereater, however, should the Grout bill or any similar prohibitory measme become law, and these conclusions be correct, the mils, in self-protection, will be forced to rednce the price of seed to correspond with the reduced price of oil, and the farmers will then have to bear 
the loss. A decline of $\$ 2 . \check{0}$ per barrel in the price of oil will necessi. tate a reduction of $\$ 2).(1)$ per tou in the price of seed; and upon that basis the Tennessee mills alone would pay ont for the quantity of seed used this year $\$ 375,000$ less than they would otherwise do, even if there should be no further decline in the market price of oil; and this loss wonld fall mpon the class of farmers least able to bear it.

This statement applies with equal force and truth to every oil mill, and on the same basis will indicate, on the 2,000,0000 tons of seed bought lyy the $f(00$ mills, an anmual loss to the farmers of the South of \$.T.(100,000; and this, mark you, is eaused merely by the fear of the enactment of the law. What depression would result from its actual enactment can only be conjectured.

A ferr worls about our product:

The manufideture of cotton seed oil is conducted entirely by means of machinery, and with the ntmost cleanliness. From the time it leaves the fields as seel cotton until it leaves the mills as oil, it is not touched by hand. As it is the cheapest edible oil known, it is not possible to profitably adulterate it. Its nutritive ynalities are so well recognized by physicians that its use is often indicated by them, even in its crude state, to those of their patients who, suffering from tuber(ulosis and other wasting diseases, are mable to buy the higher-priced olive and cod liver oils. Its palatability is known by everyone engaged in its manufacture. Thongh oil mills run only a few months in the year, they never luave any tronble in getting hands, and at the time of starting up are usually overwhelmed with applicants. A negro will quit any other job to ret where he can inhale the fragrant odor of the oil and drink as much of it as he pleases.

Mr. KNight. May I ask the gentleman a question?

The Acting Uhamman. If he will permit it.

Mr. KNight. Do you use any chemicals in the purification of cottonseed oil?

Mr. Bond. We do not refue, sir. We manufacture only the crude oil.

Mr. KNignt. Are yon cognizant of the process of refining?

Mr. Bund. No, sir.

Mr. KNight. In spealing of the loss that is likely to oceur to the planter in case the amount of cotton seed oil used at present in the mannfacture of oleomargarine in this country is displaced, you spoke of it as $\$ 5,000,0000$.

Mr. Bond. Five millions of dollars; yes, sir.

Mr. KNIGHT. Do you know what the actual amonnt of cotton-seed oil used in the mannfacture of oleomargarine in this country is?

Mr. Boxd. Approximately.

Mr. KNIGIT. What are your figures, please?

Mr. BoNd. Wrell, sir, I have stated that abont 40,000 barrels are used in the manufacture of oleomargarine in this country. That enrresponds with the figures from the Treasury lyepartment here. There are something like $10 \%, 000,000$ ponuds of oleomargarine made, of which amount about 10 or 11 per cent is cotton-seed oil.

Mr. KNIGHT. And what is that oil worth? That wonld be $16,000,000$ ponnds. What is that oil worth per pound?

Mr. BOND. I have just stated in what I have said that it is the rery best grade of oil, and we think it goes a long way towarl setting the price for our whole production. It is a matter of fact, not of speculation, that the price of oil advanced at soon as Congress adjonrmed last spring and declined when this bill came up again. The mills of Ten. 
nessee have already actually experienced a loss, I think, of $\$ 2.50$ per barrel on all oil that had not been contracted for.

Mr. KNIGHT. Well, it is worth 6 cents a pound, is it?

Mr. BOND. Oil?

Mr. KNight. Yes, sir.

Mr. BOND. Six cents a pound?

Mr. KNight. Yes, sir-that is, bntter oil?

Mr. BOnd. Not crude oil; no, sir.

Mr. KNIGHT. The refined oil, I mean?

Mi. Bond. I am not familiar with the refined oil. I do not handle refined oil. The price of crude oil in last May varied from 30 to $31 \frac{1}{2}$ cents per gailon of $7 \frac{1}{2}$ pounds.

Mr. KNIGH'. Five cents a pound, then?

Mr. BOND. Not as much as j cents a pound.

Mr. KNigut. Yes; that is true, there being $7 \frac{1}{2}$ pounds to the gallon. Mr. Bond. Yes, sir.

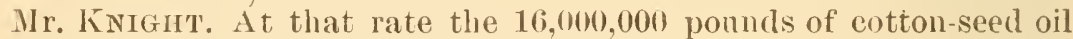
would be worth about $\$ 7.50,(000$, would they not?

Mr. Boñ. What $16,000,000 \%$ ?

Mr. KNigit. The 16,000,000 pounds probably used in the oleomargarine prolucel last year.

Mr. BOND. In this comntry?

Mr. Kinight. Yes, sir.

Mr. BoND. Well, the oleomargarine people buy the very tinest graule of oil, and this number of pounds, as you will understand, is after it luas been refined. There is a considerable loss in refining. How much it is I do not know; but the $16,(000,000$ of pounds represent more crude oil than they would in pounts of refined oil.

Mr. Kinight. Yes; I see.

Mr. BuND. So I think the estimate I have made there of $\mathbf{1 0 0 . 0 0 0}$ barrels is probably as near as we call get to it.

Mr. KNigh'T. One hundred thousand barrels?

Mr. Bond. One hundred thousand barrels in this country; yes, sir.

The Acting Unairuan. Is this cotton-seed oil used in the manufacture of other food products besides oleomargarine?

Mr. Bond. Why, sir, I presume a good deal of it goes into ereamery butter. It goes into olive oil, which is largely used in lard. Componnd lard has a large per cent of it. It is nsed in linseed oil, undoubtedly. It is used by the soap makers.

The Ac'ing Uharinan. It is used by the lard people, you say.

Mr. Bond. Wlıy, yes, sir.

Mr. I'ERson. Ies, sir; it is very largely used by them.

Mr. BOND. I donot know the per cent that is usen in compound lard, but I reuember that in $18 \%$, I believe it was, Swift \& Co. said they used $50(1,000$ barrels of cotton-seed oil in their compound lard. I have no statistics as to the quantity that is used now.

Mr. PERson. It is used in butter color, always. It is the medimm that carries the color for butter color.

Mr. KNigur. 'That is a very slight use, however.

Mr. Bond. But the oleomargarine people are the best customers we have. 'They buy the finest grale of it and pay the highest prices, and if we are deprived of their trade we feel that we will lose the best customer we have.

Mr. KNIGH'T. But is there not any way of getting at the value of that refined oil, that butter oil? 
Mr. Bond. Why, you could probably get that from the oleomargarine people, sir.

The ACTING CHAIRIAN. There is this oil refined?

Mr. Bond. There are several refineries at Louisville, and there are refineries at Cincinnati, New York, New Orleaus, Kansas City, Savannah, Atlanta, and Memphis.

Mr. KNIGH'T. To get back to the subject, the oil that is user hy the oleomargarine people could not at the outside amount to more than a million dollars in value, conlel it?

Mr. Bond. A million dollars? I have not made the calculation that way. If, as I figure it, they use 100,000 barrels of oil, that would be, at, say, 25 cents a gallon, about a million and a quarter dollars. But the oil which is used by the oleomargarine manufacturers sets the price for all of our oil. We estimate, in round numbers, that there are about forty gallons of oil in a ton of seed. In practice we do not get ont that much. So you will see that a difference of a cent a gallon on the oil will make a difference of abont 40 cents on a ton of seed. The price of seed has been redneed about \$2.50 a ton.

Mr. KNight. You mean that the value or price of bntter oil, and not particularly what these people buy, sets the value of your product. do you not?

Mr. BOND. Well, the quintity is small. I estimate that the quantity is abont $7 \frac{1}{2}$ per cent of our total prorluction. 'There are abont "2,(100(0), (1) tons of seed erusherl in the Sonth, and I figure that about 150,000 tons go into oleomargarine, or about 7.1 per cent.

Mr. KNIGHT. Do you know the amount of exports of cotton-seed oil?

Mr. BoND. No, sir; of cotton-seerl oil entirely, you mean?

IIr. KNIGHT. Ies, sir.

Mr. BoND. No, sir: I do not.

I will say that when I received notive from these mills to appear here to represent them, I went around in the town in which l lived to make some inquiries about the sale of oleomargarine. I was not familiar with it. I went to my grocer and he told me that his exclusive sale at this season of the year was in 1-pound bars, each of which was wripped I1) and branded in large letters "Oleomalgarine." He had two grades, apparently alilie, one of which he sold at 15 cents and the other at 20 cents; and he sold his best butter at 35 cents. He said: "Herp is a grade of butter that I sell to you, but I have a very great difficulty in getting enough of it to supply my trade." He said: "I sell abont as much oleomargarine as I do butter. I sell about 500 poumbls of earh every week; and no man has ever bought from me oleomargarine thinliing he was getting butter. There is no occasion for any deception, because they "all for it and buy it tor what it is."

I want to say further that I was in Sheftield, Ala., two or three weelis ago. We rm an oil mill there. As I went into the office of the hotel, there was a notice written in lange landwiting and stuck np conspicuonsly on the wall in the hotel office, "We use butterine in this hotel." Iou do not find that everywhere. That man was probably a little more homest than some others. daw.

'The Acting Chairuan. Probably he was conforming to the State

Mr. Bond. No, sir; not at all.

Mr. KNIGHT. I think that is in accordance with the state lan of Alabama. They liave a law in Alabama forbidrling the coloring of oleomargarine, and something regarding signs. 
Mr. Bond. I think that indieates that there is very little prejudice against it.

The Acting Chairman. Has anyone here a list of the Southern States which have prohibited the sale of colored oleomargarine?

Senator HeI'TELD. Oh, yes; it is right here in the House report.

1Ir. PEkson. Yon ean find that in Bulletin No. 26. I will give you a synopsis of the laws of all the States.

The Acting UhaIRMan. Before the present speaker retires, I would like to ask some questions abont this matter.

I notice, Mr. Bond, that a number of the Sonthern States seem to have forbidden, by law, the sale of oleomargarine colored in semblance of butter. The State of Alabama, the State of Georgia, the State of Kentucky, the State of Sonth Carolina, the State of Tennessee, and possibly other of the cotton producing States seem to have made it a violation of their statutes to sell colored olemmargarine.

Senator Hertfeld. Those statutes, you know, differ. You can find the statutes in this report, I beliere.

The Acting Champran. Yes; but they appear to agree in the respect that yellow oleomargarine is prohibited. How does it happen, then, that these great cotton-raising communities have taken that kind of action against this healthfnl food prodnct?

Mr. BonD. I think there must be some mistake about the State of Tennessee, because it is largely sold there. This grocer has it on his counter.

The ACTING CHAlRman. That is what it says here.

Mr. Bond. And he told me he soll 500 pounds of it a week.

Senator Heitfeld. I have the Tennessee law here. It provides that any article which is in imitation of yellow butter, and not made exclusively from pure milk or cream, is prohibited; but oleomargarine, free from color or other ingredient to cause it to look like butter, and made in such form and sold in such mamer as will advise the consumer of its true character, and other imitations, if mucolored and labeled with their correct nime, are permitted. Wholesale packages are requested to be plainly labeled, and a label must aecompany retail sales.

That permits the sale of oleomargarine free from color.

The ACTING CHAmRMAN. How does it occur that in great cottonproducing States like South Carolina, and Tennessee, and Mississippi, it is a crime under the State laws to sell an article which is so essential to the cotton industry?

Mr. Bond. I think that must mean under the name of butter.

The AC'IN CinARMAN. Well, under the appearance of butter?

Senator IIErTFELD. The language here is, "Oleomargarine free from color or other ingredients to canse it to look like butter."

Mr. Bond. What is the date of that law?

Senator Heitweld That is the law of 1895 .

IIr. Bond. Well, sir, that is ex post facto. 'That is not the present law.

Mr. Knigirs. Here is the latest publieation from the Agricultural Department, dated 1900. The Temnessee law is given there in full.

'The ACting CuAlrman. Now, I suppose that law is observed by the oleomargarine people, is it not?

Mr. BOND. I do not know how they do. The grocers sell it there on their counters.

The Acting Chairunan. Do they sell oleomargarine?

Ir. Bond. It has the appearance of cow butter.

The Actincr Chairman. Do they sell it for oleomargarine? 
Mr. Bond. Yes, sir.

The Acting OHatrman. Or do they inform their customers that it is butter?

Mr. BoND. Each brick or print of it is wrapped up separately, and has the worl "oleomargarine," in large letters, printed on the outside of the wrajpler.

Senator HEITFELD. 'That is in accordance with this statute, which says that it can be sold, but not in imitation of butter. It must be free from color.

Mr. Bond. It is not sold in imitation of butter. It is sold as oleomargarine.

Senator HeI'fFud. It says here plainly, "But oleomargarine, free from color or other ingredient to cause it to look like butter," can be solit.

The Acring Chamman. Would you expect this committee to be more tender of your cotton-seed interests than the legislature of Tennessee has been?

Mr. Bond. Well, sir, oleomargarine is sold there openly. I did not know of this law. I do not think that is the law now.

The Acting Chamrian. I have no loube it is. This is a compilation of the Department of A griculture, giving a statement of the national and State dairy laws.

Mr. MILLER. Mr. Chairman, I will say here for the benefit of Mr. Bond that there is a law in Tennessee, but it is practically inoperative.

The Ac'ring Chairuan. That is to say, the oleomargarine manufacturers and dealers violate it? Is that the idea?

Mr. Miller. The goods are sold in the state as oleomargarine by the retail dealers as well as by the manufacturers. There is no attempt at violating the law. The goods are sold exactly on their merits.

The ACring CHAmman. But the law seems to prohibit the sale of the article if it is made in imitation of yellow butter and not made exclusively from pure milk and cream. It is stated here that any article which is in imitation of yellow butter, and not made exclusively from jure milk or cream, is prohibited.

Mr. Mlluer. Well, Mr. Chairman, as you know, there are thousands of laws on the statute books which are offensive to the mass of the people and are not enforced. That is one of them.

The AC'ing CHamman. There ought not to be any law in the State of 'Tennessee which would be in violation of material interests such as our fiend here has described, I should say.

Mr. Coxley. Mr. Chairman, I would like to call your attention to the Mississippi law for a moment. Have you it?

The Acting Umainmar. I have it liere. In Mississippi the law provides that packages of oleomargarine or similarly mannfactured butters shall be plainly labeled with the correct name of their contents, and the product shall be sold by that mame. A privilege tax of $\$ 5$ is imposed upon persons selling the article named.

Senator HeIrFeLD. That is simply a label law.

Mr. CoNley. I merely wanted to call your attention to the fact that the Mississipul law does not prohibit the sale of colored oleomargarine. Mr. Prrson. It recognizes its legality.

Semator HEI'PELD. Ob, yes; you cau sell oleomargarine of any color there.

The Acting Chamman. Now, in South Carolina, which is one of the great cotton-producing regions of the conutry, I notice that the state has enacted a law which says that any article not made wholly from 
pure milk or cream, and in imitation of pure butter, is prohibited: but oleomargarine, colored pink, and in such form and sold in such manner as will advise the consumer of its real character, is permitted.

Now, do you expect Congress to deal more tenderly with the cottonseed industry than the legislature of South Carolina has?

Senator Heitfeld. What is the date of that act, Senator?

The Acting Chairian. That seems to be the present law.

Senator HEITFELD. The present law given hare is different fiom that.

Mr. Knight. 'This is a later one, Senator.

Sellator HertarLd. What I have here is the law of 1896.

The Acting Chairinan. This publication is dated 1900. It is a compilation by R. A. Pearson, well known as an expert on the dairy question.

Senator HeInfELD. What I have is the report of the House hearing. They have the last year's law.

Mr. KNigirT. That report was printed last March, and this one was just printed in the last few days, Senator.

The AC'TING UHAIRMAN. Now, the point made by me is whether or not the cotton-seed industry will be disturbed if oleomargarine is put upon a basis which will not disturb the butter business-that is to say, if it is put upon the market in such packages as would not, by the imitation of butter, deceive the community as to the character of the goods. That seems to have been the view taken by these Sonthern States.

Mr. Bond. Yes, sir. As I said in that paper, I do mot believe the cotton-seed oil interest will sustain any further loss after this year, because they will throw it mon the nan who sells the cotton seed. They will take care of themselves. They will not pay him as much for the seerl; that is all.

The Acting Chairman. But it seems to me that the legislature of Tennessee ought to be looking ont for the raisers of seed, too.

Mr. Bond. How is that?

The AcTing CHAIRIAN. Would not the legislature maturally be taking care of the interests of the agricultural population of the State?

Mr. Conler. Mr. Chairman, allow me to intermpt you. Are not all those laws old laws, enacted six or seven years ago?

Senator HeITFELD. Oh, no. The law of Sonth Carolina is that of 1896; 'Tennessee, 1895. They are not old laws. Virginia has a color law which was passed in 1898. Lonisiana has a law passed in 1885; Florida, 1881; Georgia, 1885. Now, the Georgia law, according to this synopsis, is:

Imitation butter and cheese are defined as any article not produced from pure milk or eream-salt, renuet, and coloring matter excepted-in semblance of butter or cheese, and designed to be used as a sulstitute for either. Shall not be colored to resemble butter or cheese. Evers paekage must be plininly markerl "Substitute for butter" or "Substitute for ebeese," and each sale shall be accompanied by rorlyal notice aud by a printed statement that the article is an imitation, the statement giving also the name of the proclucer. The use of these initations in eating places, bakeries, etc., must be matle known by signs.

Mr. KNIGH'T. That is an anticolor law.

Senator HeITFELd. Of conrse; but it roes not prohibit the sale of these articles.

Mr. KNIGHT. It does if they are colored.

Senator HeI'PFLD. Yes; you are right about that.

Mr. MILLER. Mr. Chairman, I would like to say just here that about three weeks ago Governor Hoard was down in Georgia trying to stir 
up some sentiment in favor of the Grout bill, and incidentally ine got a few people in Atlanta to introduce a bill placing further restrictions on butteriue. The cotton-seed oil people found it out and killed the bill in a few days. 'That happened three weeks ago.

Mr. ConLEY. I was going to state, Mr. Chairman, that if yon will go back a few years in the Sonth everybody had prejudices against the use of cotton-seed oil in cooking. 'They raise it there, and as I stated, it comes from the waste. We used to throw it awa and never marle any nse of it. Everybody was prejudiced against it, and it is only in the last year or two that it has become so notoriously healthful a food. Since then I am satisfied the laws have not been changed; but at the same time the product and the article are sold in all those States right along withont any interruption.

The ACTing Chamran. That wonld simply indicate the lawlessmess of the business.

Mr. Conley. How is that?

The Acting CHarrman. That wonld indicate a disposition on the part of those interested in the business to disregard and violate the statutes. That is not a healthy sign.

Mr. Conley. Well, I think any one of our Sonthern States can riolate a statute when they want to lo it, you know.

The Acting CHairian. I should think that was so.

\section{STATEMENT OF WILLIAM PERSON, REPRESENTING AMMON \& PERSON, JERSEY CITY, N.J.}

Gentlemen of THE CommitTeE: In speaking to you of the subject under consideration, it will perhaps be dificult to present it to you in any way more convincing than it has already been given to yon by those who have heretofore had your patient and conrteous attention.

Representing a firm reputed to be one of the largest-and let me here impress upon you at all times legitimate-dealers in oleomargarine, I may be pardoned for the belief that as a clealer 1 can give you some facts which will merit your full consideration, if not your indorsement.

In our State, New Jersey, we have several hundred retail dealers in the product duly licensed and nuder the constant espionage and control of the revenue department of this great Government, and as is conceded by the Commissioner, with ample means in men and money to rigorously enforce every requirement of the severe regulations which have from time to time been promulgated. Besides this, New Jersey has a clairy commissioner, who, as his title inclicates, is clothed by law with full authority to control the sale of all butter substitutes within the State. Let me here say that New Jersey has the exceptioual distinction of being abont the only State the law of which closely dovetails or harmonizes with the Federal law in requiring every suller of oleomargariue to convey with each sale his full name and address, together with the amount and nature of the article he sells as a substitute for butter.

As proof of this I desire to have go in the record these examples of tickets commonly used by dealers throughont New Jersey:

10 lbs. oleomargarime,

Anmon \& Person,

138-140 Ninth street,

Jersey City, N.J. 
By the last census you will find that the State of New Jersey is not far belind those which lead in the magnitude and variety of its manufactures, which leads me to suggest that in this continuing controversy between oleomargariue and butter (good or bad) the mechanics, operatires, artisans, or other workers for a modest wage have rights which a white man is bound to respect, be he butterman or Congressman, and should at least be permitted to exercise his God given and Constitutional right to cater to the normal requirements of his inuer man.

This brings me to the point I. wish to make, that butter, the best of it, is now retailing at 23 to 30 cents per ponnd, and in some instances double and treble these figures when sold under the mark of cattle which carry the preteusions and prestige of a long lineage and small fortunes invested in them because of their pecligrees. As contrary to this condition, consider the prices of the "poor man's" butter, which muler a name designed to hinder its sale steadily and continously sells at a much lower price to the everlasting eredit of the little French chemist, who first evolved it from the fat of the steer and gave to the cattle interests of the United States an added impetns and value, and to the world at large a food product, which, measured in the light of coming generations, will be beyond human calculation or measurement in its benefit to mankind.

This may seem like an orerrirawn statement from an enthusiast, yet let us probe into the future a tritle to see how far away we are.

In the hnudred years interveniug between 1790 and 1890 the population of the United States increased fiom $3,929,214$ to $62,6,2,2,250$ people, or an increase of 1,493 per cent.

Is it a wild proposition to suggest that in the next hundred years our population will increase half as much as it did in the preceding lnundred years, or, say, 700 per cent? If you will concede this, let me nirror the future for you in four sections of time and you will have in-

1925

$12 \overline{5}, 000,000$

1950 $230,000,00 i)$

1970 $3.50,000,000$ 1990 $500,000,000$

Now, let us bear these figures in mind while we consider their relation to the question of butter versins butteriue. If the estimate of future population is correct, I am bold to assert that in the period between 1925 and 1950 there will be no milk available for the making of butter, which of course would be $n 0$ great hardship, provided you or your successors do not tax butterine out of existence. Yon may smile at the gloomy outlook, yet it is a fair prophecy in saying that if the present rate of increase of population is maintained with the estimated shortage of the cow supply, the supply of milk in the coming years will all be required for table purposes, invalids, and let us hope as a saving and salvation for our race-butterine.

In confirmation of this I may cite Secretary of Agriculture Wilson, who stated a short time ago that there are $10,000,00$ ) less cattle in this conntry than there were ten years ago. Think of it, a clecrease of $1,00(0,000$ a year. His reason for it was the conceded impoverishment of the grazing lands, which he stated would only feed the present number of cattle at hest.

Some of you gentlemen will recall the drought of last summer, especially in the eastern section of the conntry, when many farmers sold a part of their herds becanse of lack of pasturage and feed, the effect of Which is still felt in an enhanced cost of those products largely dependent npon a good grass crop, of which may be instanced condensed 
milk, of which one factory alone was short $1,000,000$ cases of 4 dozen cans each which they had sold but were unable to deliver because of the milk shortage. The denuding of the forest lands has in many instances lowered the beds of the rivers, and an open winter such as we are now experiencing, with a lack of snow, often results in poor erops and poor pastures. Such conditions mean great searcity of milk, with invariably high priees for butter. Wull it not-does it not follow logically that people of limited or moderate means will be compelled to use some substitute because of their inability or unwillingness to pay a high price for the cow product?

This line of thouglit prompts an answer to tre question put by one of the committee at a previons session, as to whether "the continued production of butterine "ill tend to decrease the price of milch cows"?" An answer may be found in the Orange Judı Farmer, which is anthority for the statement that in 1891 there were in the United States 20 (is cows to every 1,000 inhabitants, and that the average value of these cows was \$21.62 each. The figures given for 19010 are "259 cows, at an average valuation of $\$ 31.12$ each, an advance of $4 t$ per ceut in cost and a decrease of abont $3 \frac{1}{2}$ per cent in ratio of increase.

If this is so, as I think our friends on the cow side of the fence will be forced to admit, the predictions for the future must he taken as more than conservative. Further anthority is found in the Sussex independent, of Deckertown, N.J., published in a connty which sup)plies one-fifth of the total milk product of that state, and in its issue of February explains the scarcity of cows as follows:

The time was, and not ful distant either, that the bntter-making farmers of these grass-growing milland eounties male it a point to raise the greater poution of their "alves and sell off those they dicl not want in septruher and Octoher for prices linging from 43 to $\$ 5$ a hearl. "lf late sears they feed the rall well until it is six or eight weeks old and get about donhle for it what they disl when they kept it from four to six months moler the oll style. The new methorl has bad a wreat deal to do with making the supply of cows less, and there is not half the number of cows from up this way marketed in (1range Comnty that here was fifteen years ago.

In further confirmation of the proposition that the supply of cors or milk will not leep pace with the increase in popnlation, it will not be gainsaid that the increased demand for milk in the cities has alrearly caused a tremendons deerease in the production of butter in all the States known as the eastern and middle divisions, and has ransed the milk to flow firom the farms to the consumers in the cities and towns of those States. Indeed, so much is this the ease that statistics of the railloads know as milk roads will show that the average haul of milk has donbled, and in some instances trebled, in the past ten or fifteen years, showing beyond cavil how widely the territory has extended which contributes to the milk supply of the centers of population. Are there any who will hazard a prediction that in twenty-five years butter will not be a luxury and butterine more of a necessity than it is even now? If, as I beliere, the finture has this in store for us, why not prepare for it, and make ready for the inevitable condition which will confront those who will come after us, but who, if this tax is permitted to become a law, will certainly not build monuments to your statesnanship or pronounce enlogies on your foresight. It these suggestions do not meet your approval, let me in all serionsness ask your approval of a plan which I am sure will quickly lave the indorsement of every farmer in the land and will certainly relieve you gentlemen of all pressure from your constituents to rote for the present bill.

Remove all tax on oleomargarine and instead leave to the States such regulations as will permit the farmer to work up his milk with the 
materials which are also raised on the farm and which go to make oleomargarine, and so render him independent of the creameries, which are rapidly growing into a monopoly or trust and who pay what they like to the milk producer.

Another reasou, and a strong one, for the removal of taxes, especially the special tax of $\$ \pm 8$ per anmun on retail clealers, is the inability of small storekeepers to pay it. The larger ones do not find it a hardship, lout the poor widow or old man struggling to eke out a bare living does not ordinarily have $\$ 48$ in a lump at one time; besides, does not sell sulticient to make the $\$ 4 s$ in the course of a year. On the other hand, he can not compete with large tea and grocery companies, who, with hundireds of branch stores, buy butter in large quantities and rutail it at cost price as an advertisement to draw custumers for tea aud coffee, which yield large protits. Thus the poor yeople trading with the lone widow and old man are prevented by law firom sharing in one of God's richest blessings in the shape of a healthful, wholesome food.

To a layman, it would seem that oleomargarine is no more an object of Federal taxation than any other of the thousands of food products, original and simulated, all of which are susceptible of proper control by State legislatures. In disposing of this feature of the question let me ask, is it not crowling the monmers pretty close, especially in dis. tricts where butter is not made, to compel its residents to pay tribute to Uncle Sam who now has an annoying surplus of quickly acquired wealth, and to the private firms engaged in the creamery bisiness?

Doing lmsiness in a State where the law is regulative, not prohibitive, our experience in the selling of oleomargarine may be rifferent from those who do husiness in States where its sale is not permitted at all. In New Jersey, with its thousands of mechanics, mill operatives, aud other earucrs of small wages, there has been developed a large and widely distributed trade in olemurgarine, which is called for and sold as suclı, bearing every mark and label called for by both the Federal and State laws.

That the tracle is large and constantly growing larger is clue to the fact that we advertise our goods constantly and extensively, and persomally urge mpon the grocers of the State the merits of our gools as a cheaper and better article than the process or other grades of butter that their class of trade permits them to purchase.

The Acting Ciraminar. Will you allow me to interrupt you just at this point to ask a question?

Mr. Person. Certainly, sir.

The Ac'ing Chairian. It appears that the law of New Jersey provicles that any article made wholly or partly ont of any fat, oil, etc., not from pure milk or cream, artificially colored in imitation of pure yellow butter, is prohibited.

Mr. PERSON. Ýes, sir.

The Acrixg Umarmax. How do you manage to do business in yellow oleomargarine in New Jersey, then?

Mr. PERson. We have had that question settled by the courts, Mr. Chaiıman.

The Acting Charrian. What was the settlement?

Mr. Person. I can not recall just what the decision of the court was, but it was sufficiently in our favol to enable us to sell the goods as we sell them.

The Acting Chairman. What was the decision of the court?

Mr. Person. The decision of the court was that if the goods carried 
ally artificial colol they were not to be sold, but we have goods in our market made from a richer oil that gives us a color that will sell in our market.

The Acting Chamman. Then you find it possible to get a good trade in oleonargarine that is uot colored in imitation of pure yellow butter?

Mr. Person. No; om goods have a color.

The ACring CHAIRIAN. But is it the color of pure yeliow butter?

Mr. PERson. It is the color of yellow butter. I will show you the color's direetly, Semator, if you will allow me to go on.

The Acting Chamina. I was simply curious to know how you did such a good business there with that law.

IIr. P'ERSOx. This is the situation in our State, and has made many of the grocer's rearly eonverts to the sale of oleomargarine, aud, being in elose touch with eustomers in their neighborlood, has helped to popularize oleomargarine in all the large cities and tomns of the State, while even in strictly farming sections farmers are buying it openly and above board, and blessing their lucky stars they ean sell their milk and for a part of its retmos purchase an article which they admit is better and more uniform than they conld thenselves produce.

Let me now speal of the color phase of the question. If you gentlemen could get out and among the dealers of a great State, is me do in onr business, I am sure you would get some new and peenliar ideas of the so-ealled color of butter. Like the human race, butter is of all sorts of colors and eouciitions, with suffieient and varying shades of color as to well typify almost every race on the globe, except our Afriean brother, the black. I have here fourteen different standard shades of yellow (and there are still others) which you can find reproduced in the butter of commerce.

[Mr. Person at this point exhibited samples of eolor to the eommittee.]

Mr. I'ERson (continuing). Every one of those, Senator, is a yellow.

The Acting Cimarman. Do you find it possible to sell oleomargarine of that color [indicating rery dark shade] in New Jersey?

Mr. Pelison. No, sir.

The ACTING OHAIRMAN. That is labeled "95-D."

Mr. Person. Bnt I will promise you, on the word of a man, that those are all homest, straight yellow colors or sliades.

The Acting OHAirman. But do you find it jossible to sell oleomaryarine in New Jersey of the eolor indicated upon that slip?

Mr. Person. No, sir; not here.

Mr. Jelíe. But it is sold in Cuba.

Mr. Persox. In the French islands, in Martinique, and Porto Rico they demand a very high, rich color.

The Acting Champuan. This [inclicating another eolor] appears to me to be a light orange.

Mr. Person. Ies, sir.

The Acting Chairman. Will oleomargarine colored in that shade sell.

Mr. PERson (interrupting). We have seen some of the high-priced Sharpless butter in the lieight of the seasou that was I think I may fairly say, colored as highly as that; was it not, Mr. Jelke?

The Acring Chaminas. What I mean to inquire is, "an you sell oleomargarine that is colored in that sluade?

Mr. Person. Yes, sir.

The Acting Cilairinan. In New Jersey?

Mr. Persin. Yes, sir. 
The ACring Chamman. Without any prejndice on the part of the poor people?

Mr. Person. Oh, there is some prejudice as to that, because that is a very high color.

Mr. JELKE. I lıave seen that color of oleomargarine and butter both sold in St. Louis.

Mr. PERson. But I do not think the majority of people would care to have it as highly colored as that.

Mr. JELKE. Of course that is not a reasouble color.

Mr. PERson. No; that is what we would call a highly-eolored butter.

Mr. JELKE. Those are only a few shades, practically.

The Ac'ling CHaIRHan. IVill you point out the color there which is salable in New Jersey?

Mr. Person. That [inclicating sample] is about it, is it not, Mr. Jelke?

Mr. JELkE. I think that would be nearer [indicating another sample].

Mr. Person. We have a very light yellow there.

The Arring CHarrian. What i want to get at is this: Your law there seems to pohibit the sale of oleomargarine if it is artificially colorer in imitation of pure yellow butter. That seems to be prohibited.

1lr. Person. 'The trade in our State is in the highest fulality of goods. We require the highest quality.

The Ar'JING GHARMAN. But I waut to know what decision your courts have made which enaliles you to sell oleomargarine in New Jersey.

Mr. l'ERson. We are prinitted to sell it where the State can not prove, by allalysis, that the gools carry an artificial color.

The Actinir Uirarian. But you rlo not color the goods?

Mr. I'ERson. We have them male for us.

Mr. ADAys. Mr. Chairman, I have a reference to that decision, if the gentleman will permit me to give it.

Mr. Person. Not until I am thromgh, if you please.

'I'he Acting UHAIRMAN. I would like to see it.

Mi. Person. I am perfeetly willing that you should show it to the Senator.

The Acting Champin. Your ram procech, sir.

Mr. PERSON (continuing his remarks). I have here 14 diff'erent standard shades of rellow (and there are still others) which yon can find reproiluced in the butter of commeree; but let me say, in justice to the monld-be monopolists of the national color of China, that the darker shades are used by those who export butter to the French and ofler islands near our new possessions. It is singular, yet true, that rifferent localities in the same State often call for lighter or clarker shades in their butter; and while nature often responds to new and peculiar demanrls of lummaity, she has not yet prouluced the cow that will give 14 shades or more of yellow butter that are required to meet the demand. If, thelefore, the Grout bill becomes a law the creamery men of the West will have the privilege of using any number of so-termed yellow colors, while the maker or seller of the substitute will be limiter to a solitary, separate, and painfully distinctive white, which only the sense of taste will enable a cousumer to detect from lard.

It is eonstantly asserted and reiterated by those behind this bill that it is in the interest of and primalily for the benefit of the "poor farmer," which, I take it, eliminates the rich farmer firom any interest or concern in its outcome. If so, I oppose this bill as a farmer myself, owning a few acres in New Jersey, whereon I assure you I can beat all my 
neighbors in securing a crop of stones, slowing that I am the poorest farmer in the bunch, yet with my two little. Jersey cattle I gain a revenue sufficient to compensate me for my ignorance in of her clirections, as my milk pays me much more handsomely than any other part of nyy operations as a farmer, and is a proposition which applies to every other farmer in the county, the majority of whom sell milk to its residents and are better satistied with the returns than those from any other prodnct.

'There is, however, a inore serious aspect to this bill from the farmer's point of view which, if they rightly understood it. they would be less ready to be used and quoted as disciples of the false creed and doctrines which have been conceived in selfishness and sin, born under misconception and falsehood and practiced with deception toward the cow ownels and consumers until the real merits of the ryestion have been hiclden and obscured in a mighty clamor which has been manu. facturea for the present occasion, until even the representatives of the whole people have been cajoled and misled into an indorsement of an act intended to but partially, at most, benefit a class, instead of the mass, of the people they are sirpposed to represent.

I contend that, far from injuring the farmer, the olenmargarine industry can be marle a positive, lasting benefit to lim. At present in States prohibiting oleomargarine the milk producer must sell either to the milk dealer or to the creamery man. If this is true then would it also be true that if oleomargine maker's were operating in all the States a langer and still more profitable market for milk would be gained, as the milk producer would have another large and steady competitor for his product, with a certainty of still better prices; in proof of which many firmers in New York and New Jersey are on record who formerly sold their total product to the factories in those States.

Now, in harmony with what I have just stated, I want to digress and say this: 'That we have in New Jersey a connty called Sussex, which, as I have already stated, produces the great bulk of the milk that is sold in the State as milk. Owing to the agitation in the State legislature regarding oleomargarine, I have personally visited hundreds of farmers in Sussex Comnty, all of whom were in accord in saying that they got better prices for their milk when we had oleomargarine factories in New Jersey and New York than they have ever been able to get since.

That I am not alone in this contention I submit the following extract from the July report, 1895, of the Hon. George W. Roosevelt, United States consul at Brussels, Belgimm:

Some tiue since, France sent a fleleration to Holland for the purpose of studying the methods emplojed there for the suppression of frands in butter makinu, and also to asceltain if the manufacture of margarine (oleomargarine, butterine) has been favorable to arricultural interests. The report contains the attestation of seven mayors of communes in southern Holland, showing that since the introdnction of the marmarine industry in that country (Holland) not only has the price of milk increased, but also the number of cattle, which plaiuly shows that the industry in question has isecome a source of profit to the tarmers.

That butterine is a "large" subject is already well attested by the mass of testimony that has been adiluced before the lower House, likewise by the testimony which has been presented to this committee, and by the more painful fict that an extraordinary large tax is sought to be placed upon the product which is the subject of this discussion. I ask the committee to bear with me a few minntes longer, in orkler to say that the most bitter of om opponents no longer oppose oleomargarine on the gromur of unhealthfulness or impurity. On the contrary, the con- 
sensus of expert, authoritative opinion throwghont the world is in favor of its absolute purity in its inception or basic materials, and thorongh cleanliness in their manipulation and the completed product, and to-day, if exact justice were lone, the sign and synonym of perfect purity, without suspicion of dross or alloy, wonkl be the words, "Pure as but. terine." Hor what other food product under the sun can the same be saiı? Take any list of foods sold by the glocer, or any other purveyor of eatables, and instantly yon will be confionted with the suggestion that the bulk of them are open to the suspicion of sophistication or substitution of their most important or essential elemonts. This assertion applies to butter more readily than to many other food necessities, as is evinlenced by the efforts that have been made for sume years past to coutrol the sale of renovated or jucess butter, and which in truth is mole urgently required than the commonly advertised and open sale of oleomargarine.

It is the good fortune of this Govermment to have in its Department of A griculture one who has a rolld-wide tame as an expert on dairy products. I refer to Prof. Henry E. Alvord, chief of the dairy division. This gentleman is on record as a consistent arlvocate of the purity of our dairy prodnets and as opposed to all sham and firand in the sale of substitutes; willing that oleomargarine shall be sold as such, and maintaining tlat the greater and more subtle fraud-renovated buttershould be under the legulation of the Govermment.

To show this 1 am permitted to read a letter from Professor Alvord to a plominent jhysician, giving his views on renovated butter. It is as follows:

Dr. J. J. BaUnaNi,

Februali $8,1900$.

G61 Jersey Arenue, Jersey City, N.J.

DEAR SIR: Your inquiry has been received relating to process or renovated hntter.

We have nothing printed upon this snbject, and it wonld be impossible to give you a full account of it within the limits of a letter.

Brietly, it is butter which has become nnmerchantable, or what we would call bad butter, running through all the degrees of balness, bought up cheiply, bronght together in linge ynantity, reduced to a limpid oil by melting, and elarified by both chemical aud mechanical processes, which are more or less secret. The oil is then drawn off, a semblance of the crystallization or graunlation of butter fat is obtained by chilling, usnally loy spraying the fat into ice water, and then it is rechurned with more or less sour milk or buttermilk to give it the uew flavor, salted, aud made up for market.

It is in this form just what the name "renovated" implies. Unless adulterated with other fits, which is not usual, it can be claimed to be pure butter, as far as chemical composition is concerned. But many of the characteristies of goou and fresh butter are lacking, and the renovated article deteriorates very rapidly nnless it is kept quite cold.

The chief objection to this renovated butter is that it is sold in large quantities under misrepresentation in place of fresh creamery butter, and at prices mnch above its actual value. Frand upou purchasers and consnmers is thus perpetrated, and this is the feature counected with the business which needs goverunental interference anil regnlation.

Very respertfully, yours,

HENRY E. ALVORD.

I have here the original letter, which substantiates what I have read.

Further evidence of the necessity for the regulation of this frand is found in the laws which have been passed here in the District of Columbia, as well as in some of the States, and are published in Bul. letin No. 26 of the Department of Agriculture, which you now have before you. These laws are intenced to secure in this District and in the States mentioned a standard for pure butter, and require, in the District of Colnmbia: $\$ S$ per cent of fat, 12 per cent of water, 5 per cent of salt. Iowa: 80 per cent of fat, not over 15 per cent of water, not over 
(6 per cent of salt. Indiana: 80 per cent of fat. Georgia: 80 per cent of fat. Oregon: Not over 14 per cent of water.

I might say, in addition, that these figures of water and salt open up vistas of considerable adulteration or "filling."

Besides this, New York, Massachusetts, Pen'sylvania, and one or two Western States (I think they are Wisconsin and Michigan, are they not? have laws providing for the selling of process butter minder its true name.

Mr. AdAMs. Yes.

Mr. Perison. But all of which are evaded or defied becanse of the difficulty of its detection when sold as the pure butter of the "poor farmer" or his master, the creamery man. Contrast this with the conditions surrouuding oleomargarine, which is subject to the laws of thirty-two States and the Federal law, which spreads over and embraces every sale of over 10 pounds from the dealer to the consumer through the monthly reports which the reveune law exacts.

Taking the figures of the New York butter market-the largest in the country - as an index, the receipts of butter there during 1900 show an increased production of that article, the excess in 1900 over 1899 being $48,(1)(0)$ packages, the large falling oft in exports proving that the home consumption is increasing rapidly, and also proves that the price of butter in other countries is less than in the United States, as Canarla and Anstralia nudersell the United States in the English and other European markets, which all tends to illustrate clearly that through the operation of the tax laws against oleomargarine and the import duty against butter, the people of the United States are compelled to pay more for their butter than people of other comntries.

Mr. KNigir. May I interrupt you a moment. Do you know what the receipts were in New York in 1898? Have yon got those figures there?

Mr. Person. No, I have not; but these are figures that I liave taken-

Mr. KNIGHT. That is, to show an increase in receipts in New York? Mr. Person. Yes, sir. I had no idea of making a dig at the Chicago butter market.

Mr. KNIGIIT. Oh, I do not care about that. I do not belong to Chicago.

Mr. PERsur. I have but recently learned of the proposition made by a gentleman who has previously appeared before this committee, which, in my opinion, is a fair aud full solution of the mufortunate condition you gentlemen have to consider, and if our friends on the opposite side desire to meet us on a fair basis, it will, I think, be found in that suggestion. Which is, that the butter and oleomargarine interests agree upon distinctive well-defined shades of yellow color, by which their respective products can instantly and positively be identified. The numerous shades of that color, some of which are very marked, certainly afford full opportunity to sharply define the limit of color which either product sliall not transgress or appropriate, and which will afford the public every chance to exercise its judgment in deciding which article they shall select as a lubricant for their bread or other purposes.

Believing in the honesty of many of thoce who wonld have the Grout bill as a remedy for their supposerl wrongs, and in the rights of the oleomargarine makers and dealers. whose interests wonld he annihilited by a law which forces them to bleach out whaterer shade of yellow their goods might develop, from the basic materials used, it will, I think, appeal to you, as fair-minded men, that the suggestion as to separate shades of yellow should be accepted by both sides. and so end this unpleasant 
and interminable warfare between two large and equally important industries.

For this much to be desired enlmination there are almost unlimited opportunities, some of which may be fond in the ereamery associations on one side and the maker's of oleomargarine on the other-the representatives of both of which could privately, or in public convention, arrange finll details. I am sure that one-half of the effort made by the butter interests, if rightly directed toward a mutnal understanding and purpose to protect the right of the olposing side, would be promptly and effectively aided by the butterine or oleomargarine arlvocates.

The Acting Chairman. Now, I want to ask you a few questions.

Mr. Person. Certainly, Mr. Chairman. But do not ask me as a lawyer. Ask me as a layman.

The A Cring Chaminn. Tes, as a busiuess mau. It appears here that the legislature of New Iersey has passed a law making it a criminal offense to make or sell oleomargarine which is colored with so-called annotto, so as to make it resemble the color of butter.

Mr. I'ERson. Yes, sir.

The A ctrni: Cha IRman. Now, you say that there has been a decision of the supreme court of New Jersey which permits you, as a citizen of that State, to sell oleomargarine in the State of New Jersey regardless of its color"?

Mr. l'Erson. No; I dirl not say that, Senator.

The Acting Chamman. On the theory that the color arose from the material out of which it was maunfactured?

Mr. I'ERson. Yes, sir.

The Acring: Ciramuan. Now, lo you mean to say that without artificial coloring matter the oleomargarine mantufaturer's, by the use of the natural ingredients that enter their prodnct, can prodnce these colors?

Mr. Person. Not these colors-110. I simply say this, Senator: That the oleomargarine maker's ean, by a selection, at the proper time of the year, of the cotton-seed and animal or oleo oils, pick ont the richest oils, which carry with them a color of their own. I think any gentleman will bear me ont in saying that eotton-seed oil has a color of its own and so has oleo oil.

The Acting Chamman. Can they produce, for example, the color of June butter?

Mr. Person. No, sir; far from it.

The ACTING Ciralruan. Can you sell oleomargarine that is not of that color?

Mr. Person. The Jume color?

The Acting Ohamman. Yes.

Mr. Person. Yes, sir. What is the June color?

The AC'Ting Chairman. Now, as I understand, the ordinary constituents of oleomargarine produce a white product.

Mr. Person. No, sir; that is an error.

The acting Chatrian. Then we have been misinformed here.

Mr. JELKE. You are mistaken in that.

Mr. Person. What do you mean?

Senator HeiTfeid. I do not believe anybody testified that it was a pure white color.

Mr. PERSON. White is not a color.

Mr. JELki. It is a solt of grayish white, I think.

The Adring Chamisian. (On the order of the color of lard, for example? 
Mr. JELKE. It the Senator will allow me, I will state that cotton-seed oil has a sort of greenish tinge. You will notice that in those colors there is a great variety of tint, and none of the 14 yellows that are there look like butter colors. They bave a sort of greenish tint.

The ACTing Cinarmax. 'They do not all of them look like yellows, for that matter. I may be a little blind on color.

Mr. Person. Well, I may be blind myself, sir.

Mr. JELkE. Themixture with lard and oleo oil (which has a pale straw (color) makes a combination of color that is not pleasing to the sight. It is not a cleir white, like butter.

The AC'Ing CmaIRMAN. Now, then, I understand from what has been said by the present speaker that the manufacturers, without aiding any artificial coloring matter, but by selecting the materials properly, can produce oleomargarine witlont that objectionable color.

Mi. JELKE. I have been told that they conld.

The Actinf CHAIRIAN. Who is your mannfacturer?

Mr. PERson. Well, I do not know that I shonld answer that question lieve, Senator. You are opening up a field that I am not prepared to go ilito.

The Acring Ciramanan. What I want to know is liow the product finds its way into the open market in the 32 States where it has been prohibited by law.

Mr. PEIson. I think that question has been met by the answer given you some time ago - that if the laws are not in consonance with public thonght and feeling, and are not indorsed by the public, they will not be sustained.

The ACTing CHampuar. But you, as a merchant, do not stop to inquire whether the laws of New Jersey are in consonauce with public thought and feeling before you proceen to violate them, do you?

Mr. KNIGHT. Mr. Chairman, you will have him incriminating himself presently.

The AC'IING CHAIRuAN. I am simply interested to know about this matter.

Mr. PEnson. Your remarks are rather leading, Senator.

The Acring CHARman. I do not waut to make my remarks oftensive at all. I fincl here, however, these statutes preventing this thing, and yet you are a good merchant, proceenling to do a good business in the State of New Jersey.

Mr. Pkrson. We have the comage of our convictions.

Mr. Miller. Mr. Chairman, allow me to say that Mr. Merson is at wholesale dealer. He sells goods in the original packages only. Is that not so? .

Mr. Person. That is right.

Mr. MILLER. We have had a number of opinions from the Sinpremo Court, giving us the privilege of selling original packages, mbroken packages, manufactured in otler States.

Mr. PERson. I have referred to the fact that we we handling original packages there, Mr. Uluaiman.

Mr. MILLer. There is a decision in Minnesota and one in New Hanıshire to that effect.

The AC'IING Cmamiran. But the supreme court of New Jersey seems to have recided that that law is constitutional, even as applying to interstate commerce-that is to say, to articles shipned in from the other States and sold in tho original packages.

Mr. PElison. 'That law has been upset by a more recent llecision of the United States Supreme Court, Senator. 
Mr. KNIGHT. Oh, no.

Mr. Schell. Why, Mr. Chairman, on the color question I agree with your view. I never saw butter that looked exactly like that particular combination. But is the ordinary butter what might strictly be termed yellow, after all? Is it not more of a golden color? Of course it is a sliade of yellow, but it is not-

Mr. PERson. I have not spoken of these as colors. I have spoken of them as shades.

Senator HeITFELD. Yon can find butter here in the Center Market that has a tint approaching that third deepest color-that is, that would be the color, but it is reddish. It is a reddish yellow, just the same. It is the Elgin butter, I believe.

Mr. Knight. Senator, I want to say that in the butter trade we liave made a great many efforts to replodnce the color of butter in some way so that a standard conld be printed, and we find it impossible to print anything that looks like the real butter color. The color of butter is on a grease, and it appears that no printiug ink, on paper or anything of that kind, will look like the actual butter eolor. We have tried that and we have failed.

Senator HerTFELD. Then there are so many shades of color, even in Jume and Iuly; and different grasses make different colors. Take our W $\mathrm{T}$ esteru country, for instauce. The blue grass gives color different from that of butter from alfalfa. The color of butter from alfalfa, again, is different from that of rye. In fact, the color of butter from rye is so deep that it is rather objectionable.

Mr. KNIGHT. Ton are something of a butter man, Senator, I see.

Senator HuIfFend. Well, I have been in the dairy business all my life; and I know all about it so far as the farm goes. We liave even wrapperl it in all sorts of cloths when we conld not get the butter cloth.

The Acting Chatrman. Now, is there anyone else desiring to be heard this afternoon?

Mr. SchelL. Allow me to say further on the color matter that my chemist advises me that there are over 700 different kinds of named colors as a result of the coal-tar produet, and that there are thousands of other colors and shades which have not been named. 'The color question, then, is one withont limit, and if they will not define their butter color, how are we to know what it is? They say we are not to color oleomargarine in imitation of lnutter. How can we tell what the color is that we are not to initate? There should be some standard. They say, "Yon are using our color," but they do not give us any staindard.

Mr. Adams. Yellow is the standard.

Mr. SCHELL. What yellow?

Mr. KNIGHT. Any shade of yellow.

Mr. ScHELL. Then white is another shade of butter. TVe ean not color our oleomargarine white, or we will be acensed of imitating butter.

Mr. KNIGII'L. No; we say yellow butter.

Mr. Schell. What shade of yellow?

Mr. KNIGHT. Any shade.

Mr. Sohell. Any shade? There are over 700 different shades of yellow, and we can not have any, but yon are entitled to all?

Mr. KNIGHT. Oh, no.

Mr. JELKE. If you will allow me to say one word on the subject of color, I will say that I have been told the production of a color for use in silks and other dress goods means a fortune to a chemist, and that some of them spent their lives, in Germany and France, studying to 
produce a new and attractive shade. Very often we see the ladies adopt a certain new shade that comes out. If the color is attractive and new and pleases the eye, such a demand is immediately created for it that its producer becomes rich.

Mr. KNIGH'T. Mr.Jelke, may I ask a question at this point? Do you know whether there is any one color of silk to which the consumer is so attracted that he refuses any other color?

Mr. JELKE. Well, yes. They will not take a color of silk, Mr. Knight, that is displeasing to their sight if they can get what they want.

Mr. Tillinghast. The question which the chairman asked has not, to my mind, been satisfactorily answered. Perluaps it can not be; but I think I can assist in answering it to some degree. That question was as to how colored oleomargarine can be sold in those States which bave the anticolor law without a violation of the statutes of those States.

For instance, Rhode Island borders on Massachusetts. The factories in lihode Island take their orders from the consumers in Massachusetts in such a way that the sale takes place in Rhode Island, where it is perfectly lawful. In that way the goods enter Massachusetts in a way which is not in violation or even in evasion of the Massachusetts statutes.

The Ac'ing Chamind. How does the Massachusetts merchant handle the situation after lie gets over there?

Mr. 'T'illingmast. I do not say that the Massachusetts dealer can sell his product to his consumers without a violation of the law, sir. What I mean is we sell them directly to the consumer. Of course, to cal'y that argument out, if a person in Massachusetts came over the liue of Rhode Island, bought a package of oleomargarine, and took it home, that would be no violation of the law of Massachusetts; and that is precisely the theory upom which the whole business is conducted, in so far as it applies to those places which are near enongh to libode Island to supply the Massachusetts customers. In other words, in Massachusetts the sale takes place in the State where it is lawful that it should take place, and there is no violation or even evasion of the statutes.

Mr. KNIGHT. That is just exactly what we are after.

\section{STATEMENT OF J. J. CUIBERTSON, OF DALLAS, TEX.}

Mr. Culbertson. Mr. Ohairman, as secretary and treasurer of the Continental Cotton Oil 'ompany of New York, and also as representing a number of cotton mills in the Southern States, I want to bring before you some facts on this question that are intimately associated with our industry.

We are what might be termed an infant industry, in our swaddling: clothes, perhaps. WVe have har some pius sticking in us years since, and they are pricking us now. We do not ask for protection; but we do ask to be let alone.

The cotton-seed oil industry is a comparatively new one. Thirty years since it was practically unknown. We liave to day some four hundred mills throughout the South; and in the State from which I come we bave some 11: or 120, including the Territorics.

The development of the industry, I think, has shown more progress than anything in the industrial line in the South, and has become one of its leading industries. The products that are made are practically new to the inanufacturing and commercial world, and they naturally 
displace articles of kindred nature in the various channels into which they liave gone.

The chief channels in which the oil has been consumed have been developed since the recent large development of the industry. The consumption of cotton-seed oil is very large as an admixture of lard for use as a cooking oil and as a componcut part in the manulacture of oleomargarine or lutter substitnte. We naturally have to find new outlets to keep pace with our increased production, and while the business las grown considerably in this country it has increased to a greater extent abroarl. The uses to which it is put there are chiefly as a substitnte for higher-priced oils. and for the manufacture of what is termed there "margarin," which is identival with the oleomargarine or butterine of this comitry.

We want to protest against anything that interferes with the use of our prodnct wliere it is legitimately employed on the same grom that we think the paper which is made fiom the rood of the forest to-day is entitlerl to as great a position in the commercial world as the paper matle fion rags by our forefathers. We consiter that we are in the same line of alvancement and development as other industries of a progressive eomentry, and l want to say that the trend of those in the mannfaruring husiness generally-in the conmercial world and in the arts-has been toward improvement in whatever line they are following. In onr particnlar line our aim has been to produce from an article that has been wasted in past years something that is good and wholesome as an article of human diet. We think we have succeeded.

Cotton is grown, not for the seed, but for the lint it produces. The progress in the development of its eulture once made the sonth rich. Since the civil war the growth has increased mutil, at this time, the whole world relies on that part of the comntry for its main supply of cotton. The seed is a by-prodnct, and a bulky one; and it was formerly a burden to the planter. It was burned or dnmped into the river to get rid of it: and frepuently the gins were compelled to move to get out of the way of the accumulation of seed.

Some ingenious mind discovered that cotton seed contained oil; and he who first made oil from cotton seed became, to my mind, a benefactor of the race. Cotton-seerl oil plants were built for the production of this vegetalble oil, which was found to be pure and wholesome, and as an article of human diet, in the varions trades and manufnctures in which it entered into consumption, it at once tound faror. It is nsed in itself as a cooking fat. The prejudice that formerly existed agaiust cotton seed or any of its products has so far prevented it from coming forward for what it is-a pure and wholesome article of human diet. It is used largely as an admixture to olive oil. The varions grades of olive oil prodnced in the south of Europe require the use of an article of this character to mild and blend them down. The people themselves use it. Aud while in Italy (as Mr. Tomplkins noted this morning) a praetically prohibitory duty was imposed on the auticle, the exportation of olive oil to other comntries from that comntry has in no wise decreased its consumption for that particnlar purpose; and I think the time will come when we shall have cotton oil put up as a pnre vegetable oil, on an equality with olive oil. Its character is abont the same, so far as its organization is concerned. It is a matter purely of an acquired taste-purely. An article of high grade, refiverl cotton oil is as good for human diet as is olive oil, the latter being used in the sonth of Europe very extensively as an article of diet, and largely as a cooking oil. 
This product, as I have said, also enters into and is part of the conposition of oleomargarine, or butterine; and I want to say that the man who first produced oleomargarine was, in my opinion, a benefictor to the race. The ingredient of cotton oil that enters largely into the manufacture of oleonargarine, butterine, or butter substitnte, as is shown. is a pure and wholesome vegetable oil, free from any possibility of disease. The people of other comtries have gone into this suliject more fully than our own.

In Great Britain I think the question of pure food has been given more attention than perhajs in any civilized nation in the world; and anything that is pure and good and wholesome and healthful for human diet is welcomed there by the penple of the country-anything in the food product line which will lessen the enst of living to the mass of people. The colonies of Great Britain have been very large prodncers of butter, notably Australia and New Zealand. I think they liavo subsidized boats with refigerating apparatus in order to bring that product on Great Britain for the purpose of lessening the cost of that food to its working people.

The butter countries of the Continent, especially Holland, produce more "margarine," as they call it, than they used to produce of butter. The organization of that product or article is about the same as that produced in this country. That prodnced in those comntries is exported and sold in all the large manufarturing towns of Great Britain by the side of bntter. If they are able to frame a law which will protect the butter manufacturer there, why can not we? If there is anything deleterious in it, the scientifie mien of that country would certainly find it out. I think they have not more stringent laws than we have, although they have given more attention to the subject; and the prodnet is sold openly for what it is, of course-margarine. And by its means the mass of people are able to obtain a food product that is at once as healthful and good and wholesome as butter itselt".

It seems to me that the claim which has been made here that a law can not be framed which will protect the interests of the butter maker and of the maker of the butter substitnte can not be well founded. I do not think that in any country of the world is the Government as zealous of the health of its people as that of Great Britain. In the shops in all the manufactming towns and the other large towns of that country where butter and kindred products are sold there are displayed side by side for sale butter and what they there term "margarine." In the conntries in which it is mannfactured it is used in the same way. Its manufacture lias become a great industry; and that industry is being developed and tostered. When I was in liotterdam last spring I visited a very large "margarin-fabrick," as it is called, and the proprietor took especial pains to show me a tablet in marble that had just been placed there in commemoration of a risit of Queen Wilhelmina, of Holland, showing that it has the approval not only of the mass of the people, but of the Government. Its mannfacturer contributes very largely to the rrork of the people there, and the export business is a great source of income.

We want to protest against the passage of such a bill as is before your committee as being lourtful to our interests at large, and especially hurtful to those mills in which I and my friends are clirectly interested. They are located in Texas, where there is prouluced a quality of oil that averages better than that made in the other Sonthern States. And while in the aggregate the total production of oil used in this particular line may seem small, to us it is very large. 
Mr. Bond stated that in his opinion, if I am correct, about 40,000 barrels of cotton oil were used in the West in the manufacture of oleomargarine, or butter substitute. I do not think that nearly covers it. In fact, the mills in which I am directly interested wouk, if that is correct, have supplied 25 per cent of that quantity.

The total production of oil of all grades, I think, equals from $1,500,000$ to $2,000,000$ barrels per year. Of that quantity I think there are consumed in this country, for oleomargarine purposes, from 125,000 to 150,000 barrels. Thare are exported for the same purpose about 300,000 barrels, showing that the total quantity used in that particular line is equal to at least 25 per cent of the whole.

Mr. TILlingHAST. Will the gentleman pardou a moment's interruption?

Mr. Culbertsun. Certainly.

Mr. Tillinghast. Will you explain to the committee how you get the better butter oils and the lesser grades of cotton oil?

Mr. Culber'son. All right; I will touch on that in a minute.

The exportation of this large quantity of oil has been bronght about by hard work on our part, by the development of other businesses, particularly in the oleomargarine line. And if you gentlemen fiame a law that is practically prohibitory of an article that has the Goverument stamp of approval on it in the shape of the 2 -cent tax, how can you expect us to maintain our export trade?

The exportation of cotton oil for that particular purpose forms a small part of our exports. What is to become of the trade in oleo oil or in nentral lard? The countries that make this product rely on this country for its ingredients. What is to become of that business, that has taken years for us to work up, if you gentlemen pass a prohibitory, mujnst, and vicious tax on something that has been approved by this Government? I think there ought to be some consistency in things of that character. We have at times been importuned to join export associations for the development of export trade, on the gromind that our export business would be increased and that our business would be enlarged It seems to me they conld turn their attention to the development and maintenance of their domestic trade. It seems to me that legislative bodies like yours should not be called npou to protect internally one interest as against another.

We hear of oleomargarine. What is oleomargarine? When the stamp of approval of the Government was put on it it was an article that was sold for what it was or supposed to have been. Yon want to take out now one ingredient, that of the butter color, an article that has been produced and manufactured since butter was made. Have they a patent right to that particular thing for their particular mixture? 'The butter color, as I understand, was originally made, and the velicle by which it was curried was olive oil. They found they could lessen the cost of the production of that article by using cotton-seed oil, so that, as Mr. Tompkins has stated this morning, every pound of butterJune butter, if you may so call it, made in December-luas cottou oil in it, where it is colored. 1 do not see why the butter people should claim a patent right to that particular ingredient. It seems to me that the butter-color manufacturers would cry out against such a procedure. You might just as well compel by law the elimination of any other principal ingredient in oleomargarine or butterine, or butter substitnte, whatever you may call it.

The Acting Chaminan. Wonld it disturb you if I should ask a question on that point? 
Mr. Culberson. No, sir.

The ACTING CHAIRIIAN. It has been stated here that the butter color could be produced without the addition of coloring matter, by taking advantage of certain grades and states of the cotton-seed oil and other materials. What grade of cotton-seed oil is used in the manufacture of oleomargarine?

Mr. Culberson. What is kuown as butter oil.

The Acting Cimatruan. Refined oil?

Mr. Culberson. Refined oil.

The Acting Chairian. What is the color of it?

Mr. Culberson. The color of it is straw or light yellow.

The Acting Ohamisan. And would the use of that proportion that enters into oleomargarine give that color to the produet?

Mr. Culberson. The light-yellow color?

The Acting Chairman. Yes.

Mr. Culberson. No.

The acting Chamrian. Is there any possible mixture of the oil and other materials, in the absence of other distinct coloring matter, that would produce the butter color?

Mr. Culberson. I think not.

Mr. SCHELL. Mr. Chairman, on that sulject allow me to suggest that one of my clients is the oldest man in the oleomargarine business in this country, and he has experimented all his life with the idea of avoiding the use of any artificial color; and, so far, his eftorts have been unsuccessfiul.

The acting Chairman. He onght to consult with this firm that furnishes it for New Jersey. [Langhter.]

Mr. Tillinghas'T. The gentleman will pardon me a moment; but the use of your cotton-seed oil does give to the oleomargarine a slight color.

Mr. Culberson. Perhaps so, but not sufficient color to bring it to the color that the Government approved at the time they taxed it.

I would like to know what the butter makers of the country colored their butter witl before this butter color was manufactured? Our grandmotliers. I take it, nsed carrots. If this is an improved method, why should it be confined to butter itself? Why should any legislative body give to any mannfacturing enterprise a patent right to use that exclusively? I can not see it. Oleomargarine or butterine has always been made with a certain amount of color-butter color, if you will. I think the mannfacturer of that color considers it just as much an oleomargarine color as a butter color, becanse it is nsed for such, and why it should be restricted to one branch of trade to the exclusion of everything else I can not see.

What shall wo say of this free and iiberty-loving country and people drafting measures practically forbiddiug the manufacture of an article because it comes in competition with an article-with butter-and condenning it becanse it is used as a substitute for butter, and thus robbing the mass of poor people of a smbstitute that is at once pure and wholesome and good, and lias been so proved.

Mr. Tillinghast. As you are from Texas (I do not remember whether we have anyoue else from that State or not), can you tell me how oleomargarine is placed on the market there, and whether you have any opinion as to how much of it is sold for butter, if any?

Mr. Culberson. In Texas?

Mr. Tillinghast. In 'Texas. 
Mr. CUlmerson. I must confess that I am not fully posted on that matter. I do not think there is any law governing its manufacture or sale.

The Acting Chatrian. There is mone.

Mr. Culberson. There was an attempt made a year or two ago to frame a law, which was defeaterl. An attempt was made to follow some of the laws of the North and East in that respect, but the venture did not go throngh.

Mr. TrLinghast. Do yon hear any complaints about it being' sold for butter in your State?-A. No. I think I have mentioned in regard to a certain percentage of the total puantity of oil produced as being used for butterine or olenmargarine purposes. At some of the mills in which I am rlirectly interested one-half of the production of those particular mills is sold either in this conntry to butterine manufacturers or is exprorted for that same purpose, so that the passage of this bill would hurt us very materially.

Mr. KNItHT. Will yon parion a question?

Mr. Culberson. Yes, sir.

Mr. KNIGHT. Are von a refiner of cotton-seed wil?

Mr. Culibison. We have refineries at our plants; yes, sir.

Mr. KNIGHT. Do yon use any chemicals in refining cotton-seed oil?

Mr. Culberson. There is no other way to refine it other than by chemicals.

Mr. KNigntr. What chemical is used?

Mr. GULBERSON. Varions.

Mr. KNIGIT. What is the prineipal one?

Mr. UULBERSON. The same chemicals that have been used ever since cotton-seed oil was refined.

Mr. Kinght'. I am not a cotton-oil man, so I do not know what those are, and I do not think the committee does.

Mr. Culberson. We use eaustic sola in diluted form. We furthermore have our own processes by which when the oil is finished it is perfectly neutral. There is absolutely no sign of chemical or of color. ing watter.

Mr. KNight'. Yon can refine cotton-seed oil and make it absolutely white-make what they eall a winter oil?

Mr. Culberson. Yes; that cau be done.

Mr. KNIGHT. Do yon think it is possible that any of that eaustic soda will be left in the oil after the refining?

Mr. Culberson. It is possible, but not for butter oil purposes.

Mr. KNIGIIT. Then in all of the oleomargarine that we eat we eat an oil that has been throngh a process of refinement by eaustic soda or with caustie sola?

Mr. Culbekson. Not necessarily.

Mr. KNighr. Well, some other chemical equally strong.

Mr. OULBzerson. Not necessarily. There are other processes. I tell you what we use.

The ACTING CHAIRIIAN. Are there others to be heard this afternoon?

Mr. JELKE. Mr. Chairman, it was expected that Mr. Tompkins, who spoke this morning, would continue this afternoon, and there has been no provision male for a further speaker. Mr. Tompkins was called away to Richmond at half past 3 .

The Acting Chatritan. Then on behalf of the committee, thanking those who liave spoken for their attendance npon the committee, we will stand adjourned until to-morrow morning at half past 10 o'clock.

The committee, at 4.32 p. m., adjourned until Wednesday morning, January 9, 1901, at 10.30 . 
Washing'Ton, D. C., Wednesday, Junuary 9, 1901.

The committee met at 10.30 a. $m$.

Present: Senators Proctor (chairman), Foster, Money, and Allen. Also Charles Y. Knight, secretary of the National Dairy Union; Frank W. Tillinghast, representing the Vermont Manufacturing Company, of Providence, R. I.; Charles E. Schell, representing the Ohio Butterine Company, of Cincinnati, Ohio; John F. Jelke, representing Braun \& Fitts, Chicago, Ill.; J. J. Culbertson, representing the Continental Cotton-Oil Company, of New York City; Henry E. 1)avis, representing the National Butterine Company, of Washington, D. U.; John F. McNamee, representing the Columbus Trades and Labor Assembly, Columbus, Ohio, and others.

Mr. Davis. May it please the committee, it has been ny wish, in behalf of the oleomargarine industry, to appear before you; and I have several times endeavored to make an arrangement for a brief part of your time that would be consistent with the couvenience of the committee and of the gentlemen who are here from other cities.

I learned from the newspaper this morning that it is the purpose of the committee to close this hearing finally to-morrow. That being so, I wonld, still yielding to the convenience of those who are from other cities, ask the committee to do me the favor to specify some hour at which I can take a little of your time. My special justification for this request is the fact that, although oleomargarine is not mannfactured in any Territory of the United States, a large establishment is under process of construction here which will involve an ontlay of several hundred thousand dollars. It is manifest to the committee, without argument, that that industry is peculiarly within the reach of Congressional legislation, which makes it proper, it seems to me, that some suggestions on this subject which have occurred to my mind should be laid before the committee.

'The Chalrian. 'There is no objection on the part of the committee to your goung on to day at any time.

IIr. DAVIS. I want to accommodite myself to the convenience of these other gentlemen, and I am at the command of the committee so far as the time is concerned.

Senator ALLEN. Mr. Chairman, so far as I am concerned, I can sit here all afternoon.

Mr. JELKE. I spoke to Mr. Knight this morning, and he las some gentlemen here from ontside of the eity who wonld like to be heard this afternoon.

The Chairifax. Who is there here who wants to be heard this morniug in bchalf of oleomargarine?

Mr. JeLke. There is Mr. MeNamee, of Ohio, and Mr. Peters, of Texas.

The Cifarrman. Why ean not Mr. Davis go on now?

Mr. JELKE. If Mr. Davis thinks he will have time. I cau see no objection to that; but these gentlemen are from outside of the city, while MIr. J)avis lives here.

The Champun. 'That is true; but he says he will not require a great deal of time.

Senator Foster. How much time will you require, Mr. Davis?

Mr. Davis. I shall be vely brief. I can save time, however, if the committee will give me a later hour, for the reason that in conversation with Jurlge springer-

Senator Fos'ter. Then how wonld it do for you to some in at half past 2 ? 
Mr. JELKE. I believe if Mr. Knight's friends are heard this morning and Mr. Davis comes on in the afternoon Mr. Knight will be satisfied.

The Chairman. We wonld rather have the dairy interest heard from to-morrow as far as possible and the oleomargarine interest to-rlay.

Mr. JELKE. These gentlemen are from ontside of the city, if you please.

The Champran. We will try to accommodate them, but the oleomargarine interest has the right of way to-day.

Mr. KNIGHT. Senator, as to the matter broached by Mr. Jelke, we will not want over ten minutes' time.

The Chairman. All right; you can have that. Let Mr. Davis come in at half past 2.

\section{STATEMENT OF JOHN F. MCNAMEE, VICE-PRESIDENT AND CHAIR- MAN LEGISLATIVE COMIMITTEE COLUMBUS TRADES AND LABOR ASSEMBLY, COLUMBUS, OHIO.}

Mr. MoNAyreE. Mr. Chairman and Senators, it has not often been my privilege in the capacity I occupy to appear before a committee representative of so diguified a body as the Senate of the United States. I ain not a mannfacturer of oleomargarine, nor, in fict, a manufacturer of anything. I bear from the Central Labor Union of the city of Columbus, Ohio, officially known as the Columbus 'Trades and Labor Assembly, credentials which, with your permission, I will read to you:

To whom it may concern:

Columis, OHio, January 5, 1901.

This is to certify that the learer, Mr. Jolin $\mathrm{F}$. McNamee, vice-president of the Columbus Trates and Labor Assembly, is anthorized and empowered by said body to esert every rffort and nse all homorable means in accomplishing the defeat of a measure now pendiug in the Lnited states. Senate, and known as the Gront bill, the object of which is to destroy a legitimate industry in the interest of its competitors, said Grout bill being regarded by said Trades and Labor Assembly and all it represents as a gross injustice, class legislation, an iuvasion of citizenship rights, and a serious menace to the best interests of all citizens, particularly those in moderate circumstances.

Any comrtesies extended to our representative, Mr. McNamee, will be filly appreciated and remembered by the Columbus Trades and Labor Assembly.

[SEAL.]

Frank B. Cameron, President.

Williai F. Harck, Secretary.

Senator Money. Mr. Chairman, I have to go to the Committee on Foreigu lielations. A bill is under consideration there in which I am very much interested-the reciprocity treaty. Mr. Bate and Mr. Warren told me that they had to attend the session of the Military Affairs Committee. At any rate, they are not here; I thought they would be here. Mr. Heitfeld told me he had to attend the meeting of the Committee on Patents, where a bill involving filtered water for the District, I believe-I do not know just what it is-is to come up. I hope there will be no vote taken in the committee about the final hearing or closing.

The Chamian. We do not expect to take any.

Sellator Money. All right.

Mr. MrNAmEe. Gentlemen, if the labor organizatious of the United States were possessed of sufficient capital to enable each one of them to send a representative here to convey to you their sentiments regarding this Grout bill, I assure you that you could not possibly concinde this hearing before the next Presidential election. This letter of intro- 
duction which I have presented represents but faintly the bitter antagonism which prevails in the ranks of organized labor to said measire.

When any class of men are organized, matters bearing upon their interests generally receive full and exlaustive discussion in the organization representing that particular class. And so it is with the Grout bill. In nearly every labor organization in our comntry it has been up for discussion; and I myself have heard iron molclers, blacksmiths, electrical workers, and members of almost every craft discuss the matter, making such familiar use of techuical chemical phrases as to impress one who did not know what their occupation really was with a belief that they were either chemists or deep auateur students of that profession or art.

The members of organized labor are thoronghly familiar with all of the phases of this bill. 'They speak about the chemical analyses which have been made of oleomaryarine by official chemists, and they discuss all of the varions components and ingredients of the produet with almost as much familiarity as the manufacturer's themselves are capable of doing. So I say that they are wide awake to the necessity, in the protection of their own interests, of having the bill defeated. Not only that; but as patriotic American citizens they feel deeply the indignity to which our legislative bodies have been subjected by this attempt to ntilize them for the promotion of the interests of certain individuals and corporations in violation of every sense of right and justice and at the expense of the constitutional prerogatives of other citizens. They feel that the legislative bodies of some of onl States and the Congress of the United States have been insulted by this attempt tu utilize them as tools for the protection of certain interests which can not sustain themselves against competitors.

Senator ALLEN. Mr. MeNamee, would it interupt you if I should ask you a question or two?

Mr. MCNAMEE. I shall be very glad to bave jou ask me all the questions you wish.

Senator AlLEN. How many laboring men are engaged in the manufacture of oleomargariure?

Mr. McNAMEE. How many laboring men, you say?

Senator AlLEN. Yes; how many men are there who earn their daily living by that industry?

Mr. MCNAMEE. There are thousands of laboring men who earu their living by manufacturing oleomargarine.

Senator Allen. How many thousands would you say, in round numbers?

Mr. MCNAMEE. I am not in a position to state exactly or even approximately the number of men.

Senator ALLEN. Then your contention is that the man of moderate means has a right to purchase an article which is cheaper than genuine butter, if he desires to do so, and use it?

Mr. MCNAmeE. My contention is this, Senator: That we ale desirous of perpetuating the employment of the men who make the butterine, althongh we may not know to within tive or six how many men are so employed. But we are mainly desirons of perpetuating the existence of this product, with which we have had amply sufficient experience to know that it is healthful, wholesome, and palatable.

Seuator AlLEN. Then the whole thing is summed up in this one remark-that the laboring people whom you represent are desirous of 
having the right to purchase a product that is cheaper than butter if they desire to do so?

Mr. McNAMEE. Not necessarily to purchase a prodnet that is cheaper than butter; no, sir.

Senator AlLex. Well, I should not say "cheaper." but they have a right to a choice between the two?

Mr. MCNAMEe. They should have a right to a choice between the two. Senator AlLEN. That is your eontention?

Mr. McN AMEe. That is the snbstance of it, Senator; and, moreover, it is a fact that if the manufacture of butterine is prohibited, the butter mannfacturers, whetlier they are individuals or a combination of inclividuals formed for the purpose of monopolizing that particnlar industry, will have the opportunity of manufacturing ahmost any sort of product they please that can be used as hitter generally is, and of charging for that product any price they please. We hold that if the mannfucture of butterine is prohibited, then men nsing butter or using a spread of that kind for their bread who desire to use it will then, as now, have the choice of either buying it or going withont it; and the chances are that the price will be so high that a great many such citizens in moderate circumstances will be compelled to go without it. On the other hand, if the mannfacture of hutterine is perpetuated, it will equalize the butter market.

Senator AlLEN. The competition will bring down the prices, of course.

Mr. MCNAMEe. And it will keep butter within the reach of those who do not eare to use butterine.

Now, I appeared before the eommittee on agrienlture of the Ohio legislature, and after having dissecterl all of the various arguments in favor of eertain measures for the destruction of the butterine industry (and I guess they had five or six of them up there), there was a fumer who said to me:

Suppose fou fellows are permitted to go aliead and bave this butterine manufactured withint limit. Suppose there is no restraint put upon its manufacture, or it is not stopled in some way-what are we going to do with our cows?

That expression of that farmer represents as plainly as it is possible for words to express it the one and only object that is songht in the passage of this Gront bill, viz, the legislative destruction of a legitimate industry in the interest of its eompetitors, after those competitors have failed, by their inability to maintain their goods up to a proper standard, to themselves successfully compete with the product of that industry, and the desecration of our legislative bodies having such glorious traditions and such sacred duties to perform in the accomplishment of such a base purpose.

Gentlemen, there are hundreds of thousands of our eitizens in moderate circumstances who are now looking to the United States Senate for protection against the perpetration of such a gross injustice. 'They are depending absolutely upon that sense of justice, that sense of honor, fair play, and eonservatism which has always eharacterized this body to protect them from this, one of the most culpable violations of their rights which any individual or combination of individuals has ever attempted to perpetrate mpon the American public. They are looking to this body with the firm hope that its traditional love of justice will prevail and predominate in this crisis. Shonld this measure become a law, arising from the mists of the near finture there will come a monster into whose insatiable maw the eontributions of our eitizens shall continnally flow, and whose appetite shall be increased by all attempts at its gratification. This monster we have all, in our alplurehensive conviction of the certainty of its existence, learned to regard as the creamery trust of 
the future-the combination of creamery interests into one great organization, which shall inonopolize the manufacture, not only of the food product known as butter, but of everything of that nature. That octopus is now being conceived. It the Uniterl States Senate should consent to the passage of a bill so outrageously unjust as this one is, then its birth will have been accomplished.

I am not an attorney and have never had the advantage of studying law. My intercourse with the world has been principally upon the deck of a locomotive. But by virtue of that instinctive sense of justice, that untutored, instinctive, layman common sense constituting the jury feature of and recognized as being as essential in the maintenance of onr common courts as is the learned judge on the bench-by that instinctive sense of right, I can not but realize that the passage of this bill or the establishment of a law of this kind is class legislation. I can not, as a common, everyday citizen, see it in any otber light, ancl I am satisfied that the Supreme Court of the United States will take the same view of it that my colleagues and I have taken, and there is no question but that if this bill becomes a law it will meet the same fate that the income-tax bill has met. If the income-tax bill has been declared to be class legislation by the Supreme Court, I cau not see how that court can hesitate to place this in the same category.

Not only that, but a precedent will have been established which must either be sustained or subject some of our honorable Congressmen to submit to the charge of inconsistency. You will have every corporation which has a competitor, a small competitor, that it wants to crush, coming here to the United States Uongress and trying to get it to enact legislation based upon one pretext or another, none of which can be more tlimsy than the alleged justification upon which the passage of the Grout bill is sought.

In contending for the defeat of this measure I do not make the claim that wage earners are all poverty strickell-not at all. There are many wage earners who are iu very comfortable circumstances. But even they shall suffer by being compelled to pay an enormous tribute to the god of monopoly by virtue of the existence of the institution of which I have spoken, which will be as sure to arise upon the destruction of this industry as the sun will upon to-morrow morning. The poorer classes being compelled in such event to go without a material of the kind altogether, they will simply have to eat dry bread, or use some of this glucose, of which some of our dairy and food commissioners in some of our States, so industrious in the endearor to destroy this legitimate industry, permit to remain upon the market.

Much of the zeal evinced is more an effort on the part of some of those gentlemen to establish themselves politically than it is the expression of a desire to protect the public interests. In proof of that statement, I will, with your jermission, read to you a circular which, prior to the last election, was cireulater broadeast amongst the farmers of our State. 'This will explain itself, gentlemen, and I am sure that it needs no elaboration on my part.

April 13, 1900.

DEAr: SIn: Case No. 6000, supreme court of Olıio, referred to in Bulletin No. 1 of this department, inclosed herewith, was decided in favor of the dairy and fool department on 'Inesday last.

A colpy of the Colmmlus Citizen of April 10, 1900, telling the whole story, has bern mailerl you. As the course I have pursued in this matter sets the pace for the food commissioners of other states of om. Union whose oleumargarine laws are practically copies of ours, this rictory means that the death knell of oleomargarime has been sounderl, not only in Ohio, but in the entire Wnited States. 
Think, gentlemen, of a public official appealing for political support to a particulal element with which, on accom of their numerical superiority over their competitors, he has allied himself, not that the manufacture and sale of oleomargarine may be regulated. but that its reath knell may ring in the crechlons ears of those tinaucially interested in its destruction aud, drowning temporarily the voice of their protesting consciences, permit of his reelection.

Just think of such prostitution of the dignity of the office of our State dairy and foon conmissioner:

The many assurances of good will and expressions of gratitude I have already received from the farmers and dairymen of ohio are all the more appreciated beeause of theil antagonism of the past, an antagonisa that was engendered by a few persons who placed a greater value 11 jon their own opinions as to the most effective methol of making war aginst oleonargarine thiu upon the arlvice of able lawyers, whose conusel I sia lit to follow.

So that is one of the duties of a dairy and food commissioner-to make "war" upon a certain product, and then try to use the Congress of the United states as an ally in that warfare.

I submit to you whether or not my course has been vindicated by the results obtained

Believing that I am deserving of some evirlence of gratiturle aud confirence from the farmers and dairymen for this victory, the benefits of which acerne to them, and knowing that their intelests will be best subserved by making uo change in the personnel of this oltiee, besanse of the possibility that some of the points in the abovementioned rase may he taken to the sinjeme Court of the I nited states, I respeetfully ask you to use your influence in behalf of my renomination with the llelegates of youl county to the Republican State convention.

WV should stand together in a fight to a finish against oleomargarine. I will appreciate very much an acknowlergment of the receipt of this, with any expressions you may care to make.

Very truly, yours,

J. E. BLACKBI'RN.

Now, gentlemen, if that is not conclusive evidence of the fact that one of the main objects of the attempted enactment and enforcement of legislation of this kind is the sacrifice of a useful, legitimate, and (except with competitors) popnlar industry on the altar of political ambition, then evidence is worthless in proving anything. However, it is not necessary to $\mathrm{dwell}$ upon that point before a committtee constituted as this is.

Now, we cam not see that there is any justice whatever in placing any tax upon oleomargarme. Heaven knows that its manufacture is already sufficiently restricted and that it is an utter impossibility, moler the stringent laws which exist in almost all of our States regulating its sale, for any deception to be practiced therein. And I want to assure you, gentlemen, that if any deception in this conuection slould be attempted in our part of the comntry it would be, and often is, in undertaking to palm off inferior butter for the product known as oleomargarine. I am myself a constant consumer of the article, and I propose that it shall be continually used by my family, because I know, and so do all of the nembers of organized labor who have listened to the discussions relative to this product in their various mions, that it is absolutely free firom all disease germs; that the process of its maunfacture is such as to destroy all the bacilli of tuberculosis and various other disease germs that exist in the cow, and throngh the medinm of butter consumption are conveyed to the human system, and that butter is not subjected to any process which will eliminate that element of danger.

The CIAIRMAN. If that is so, would you not use it if it were of its natural color?

Mr. MrNaneE. Well, I will tell you, Senator; if, in eating a nice ripe apple, it were harmlessly colored green, I would not eat it with 
the same relish that I would if it bore a nice natural rosy color. In the same way, we from our childhood have been used to eating butter, and in a great many instances have relished it. Now, if we are presented with a white product, even thongh we are convinced that it is as good aud as wholesome as butter, I say to you that it is impossible for us to relish it as much as if it bore the proper color.

Now, I ean not see why, when this coloring matter is absolutely laarmless, and at the same time makes the product attractice and appetizing, the Congress of the United States shonld say to the citizens of the United States, "Ton shall not enjoy that advantage; you must eat it white." We say, "Why?" "Well, because we say so." "But is there any particular harm in eating it if it is colored with a harmless and wholesome coloring matter?" "No: there is no particular harm in it; but we want you to eat it white. For reasons we do not care to explain, the future welfare of the nation depends upon people eatiug this product white."

Gentlemen, I can not see any argument in favor of compelling us to eat it white, if we prefer to eat it yellow, as long as it will not injure, our health.

For example: Suppose I, when working in my capacity as locomotive fireman, come in from a hard run, and there are two tables set-one a bare boald, greasy and black, such as our oil cans temporarily rest upon in the oil room; and that is laden down with the most attractive and luseious viands. Suppose that ou the other side there is a table with a nice white cloth on it, glistening silverware, sparkling water in clean glasses, clean cups for the coffee, etc., but the food is not up to the standard of that which is resting upon the table of inferior appearance, and I, being very hmmgry, have a choice as to which table to eat from. Why, I would most certainly go to the clean table and eat a much heartier meal, and a meal that I can digest better, notwithstanding the inferiority of the food. There is no question, gentlenen, but that the appearance of the food we eat lias a great deal to do with it, and also with the relish we may experience in consuming it.

But, speaking about the tax on oleomargarine, I can not, nor ean any of my colleagues, mderstand why there should be any tax upon it. We luave laws in Ohio regnlating the closing of saloons at certain hours on week days and all day on the Sabbatl. Quite a large number of saloons violate these laws, jet I have never heard of legislation being attempted for the abolition of the saloon business in Ohio. They remain at the old stand, and do business right aloug, although bundierls aud thousands of our good citizens are clamoring for their abolition, or for the enforcement of those laws. We have in the Lnited States a product known as whisky. 'The Govermment has exerted all of its powers to try to enforce a celtain tax known as the interual. revenue tax upon the manufacture of that product. But we all know that there are still illicit distilleries in operation. IVe all know that at the present time there are being manufactured large quantities of whisky fom which the Govermment does not derive one cent of reve. nue. Yet the Congress of the Cniter States has never nndertaken to enact legislation alolishing the manufacture of whisky.

Some of om ambitious officelolders in Ohio-Brother Blackburn, for instance, or his attıruey-tell us that because it is difficult to secure convictions under the existing laws we should have legislation enacted wlich will absolntely prohibit the manufacture of this article. It would be just as sensible for a man to say that as humanity is liable to commit murder throngh the possible moral perversion of one or two or three of its individuals in each community a proper preventative precaution to 
take would be to annihilate humanity altogether. There is just as much sense, gentlemen, in one argument as there is in the other. And I want to say to you that the men who constitute organized labor, the men who are sufficiently appreciative of the necessity of organization as to band themselves together for the protection of their own interests, are also sufficiently intelligent to appreciate thoroughly and fully the injustice of this attempt to abolish this industry and the nonsense of the arguments which are produced in support of that attempt.

I have been speaking about members of organized labor. I will say that there are hundreds of thousands of wage earuers who ale not organized, and who have not had the same opportunity of investigating the varions phases of this eontroversy that the men have had who meet in their longe rooms, and local union halls, and give it full and intelligent discussion. These men are not yet aware of the danger whieh menaces theil future interests. But whenever, in the very improbable event of this bill being passed and sustained by the Supreme Court, these men are informed by their various grocers, "You must eat this product white," you will hear a protest from all over this comntry that will certainly demand your attention, gentlemen. There is no question about it. Why a man who from choice or necessity uses butterine should be compelled to eat it white, is something that he can not understand, and is something that no other good citizen can understand, and no living man can satisfactorily explain, so long as the coloring substauce which has made it heretofore attractive and appetizing is in itself not only not deleterious to health, but wholesome and gool for human consumption.

To my personal knowledge, mmeh of the butter that is presented upon the market is made and kept in bedrooms. There is no question about it. It is the easiest thing in the world to prove. A trip into the country is all that is necessary.

WTe all know that there are not many health offieials out in the country, and that the vigilant eye of the sanitary officer is not watehing the mannfacture of this butter. And we all know that people will get used to almost anything. It is only necessary for them to be confronted with the necessity of taking such a course temprarily, and not being in a position to experience any of the disadvantages of that particular method they can not see why they should discontinue it. Consequently, in a great many instances, butter is made amidst environments that would not be tolerated for a moment were it known to the proper health authorities.

Senator AlLEN. Exeuse me for interlupting you to make a suggestion. My idea is that the butter made by the farm wives is superior to all other kinds of butter.

Mr. MCNAMEE. I know, Senator. But you will pardon me if I suggest that farm wives differ in their habits, however.

Senator AlLEN. Yes; that is true, of course.

MI. MCNAnEE. And while there may be a great many farm wives, and while I will admit that there may be a majority of farm wives, who understand the proper method of manufacturing butter, I clesire to say to you that it has been my personal experience that there are a great many farm wives who do not understand how to make bntter properly, and if they did understand it, butter used in general commeree would be more easily cousumed than it is at present.

Take it anong us railroad men, for instance. When a eonductor goes out on a run, as we call it (it is called a trip by the general public), he takes along with him enough food to last until he gets back 
home. In his basket he carries a certain amount of butter. I remember, before the use of oleomargarine became as general as it is is now, the complaints that these men used to make about butter getting sour. The heat of the caboose would canse it to become rancid and unpalatable in a very short time, and in a great many instances they would simply have to throw it out. But since the use of oleomargarine has become general, these men, without an exception, take it along with them on their runs, and they never have any complaints to make about it.

Now, I speak from practical experience, and I myself, when going on a long run, have taken with me a certain amount of it in my dinner pail. We used freqquently to fix things so that we can make tea or coffee, or something of that kind, and try to have a hot meal when we are ont on the roar. I am not, at the present time, engaged in railroad serv. ree, but l have been mutil a comparatively recent rate. Vight or nine of the best years of my life have been devoted to it. And my experience is that the introdnction of butterine has been a boon to the men who want sometling that is healthinl and palatable in the way of a spread for their bread-men who are compelled to take it along in their lunch pails as these men are, and to use it whenever the necessity for its use arises

There are a great many members of organized labor who are familiar with the methods made use of in the manufacture of oleomargarine. They have visited these factories. They have noticed that without exception they are spotlessly clean, and are kept up to that standard. They know that this product is heated to such a degree as to preclude the possibility of any disease germs remaining in it. Chemists have proven that snch is the case, and the members of organized labor are thoroughly satisfied that there is absolutely no danger of the spread of disease or of contracting any lisease from its use. On the other hand, it has been clearly demonstıated that in a great many instances cows which yield butter are afflicted with consmmption. The germs of consumption exist in them, and they will necessarily get into the product kuown as butter. Now, of course, there are lots of people who can not contract consumption, as the condition of their system will not permit the growth of the germs, but there are hundreds of people who are predisposed to it. and as soon as such persons consume butter of the kind I lave nimed the germs commence to develoy, in them, and, as a consequence, humbleds and hondreds of our citizens are lironght to premature graves through this dread disease.

Relative to the restrictions of the sale of oleomargarine that already exist, I can not see that they (an he improved npon as protective measures. Every package of oleomargarine must be stamped, in the first place. Une of the provisions of the Grout bill is as follows:

But when colored in imitation of butter the tax to be paid by the mannfacturer shall be 10 cents per pound.

Now, gentlemen, I want to state to you, upon my honor as a man and as a representative of thousands of members of organized labor, who have empowered me to come here and in their name and in their behalf to protest as vigorously as it is possible for me to rlo against the enactment of this law, that the people in the section of country from which I have eome insist, as a protective measure, upon seeing the proper stamp is upon the paper or package inclosing the oleomargarine that they buy, so that they can be sure it is oleomargarine. and so that they shall know that no deception is being practiced upon them. 
Why talk about substituting oleomargarine for butter? The danger exists now in the other direction. That is absolutely true. There is butter at present being sold, or at least on the market, that is utterly unfit for use, unfit for human consumption; and when our eitizens, knowing what they are purehasing, desire to purchase a eertain article of food in preference to some other article which is not, in their estimation, just as good, and when the article which they prefer is in no sense injurious to their health, I can not see, nor ean anyone else who looks at the matter properly or studies the question thoroughly, eonceive how it can in any sense be a province of government to say to them, "You shall not use it, or you shall use it only under certain conclitions."

The CIIAIR IIAN. If they prefer oleomargarine, and wish to have proof that it is oleomargarine, why would they not prefer to have it in its natural color, so that no further proof would be rerguired? That would settle it.

Mr. MCNAMEE. Why, Senator, my answer to your last question would also answer this. They have been used to a certain color. They have become aceustomed to consuming this product colored as it is at present. Now, as long as they prefer to use it under that color, knowing what it is composeci of, knowing what its ingredients are, where is the justice or right or sense of saying to them, or wherein is it within the province of government to say to them, "Yon shall not be permitted to use it colored in this way; yon must use it white?" The same old question comes up over and over again-"Why?" "Becanse the Congress of the United States says so." "But why does the Congress of the United States say so?" etc.

The gentlemen defending the butter side of this proposition wonld be in the same position then that a certain famer, a member of the agricultural committee of the Ohio louse of representatives, before which borly I, appeared on behalf of the Columbus Trades and Labor Assembly as chairman of its legislative committee, who said to me, "What will we do with all our cows if you fellows are permitted to mannfacture and use all the oleomaı garine you want to?"

Just as I told the gentleman at the time, if each of the farmers present had a yuarry upon his property, they would probably consiler themselves justified in coming to the Ohio legislature as representatives of that body and endeavoring to enact a law prohibiting the mannfacture of brick. Why? Simply becanse it would interfere with their quarry industry and enrtail the sale of stone for building purposes.

I can not see any other argument in support of the Grout bill; and there are thonsands and hundreds of thousands of our citizens who are in the same unfortunate plight as I am at the present time.

There is no question, gentlemen, but that the object of this Grout bill is not the protection of the public in general, but the abolition of the oleomargarine ind nstry. This tax is not a reasonable tax. It is a prohibitive tax. Tliere is no question about that. Put 10 cents per pound additional tax upon butterine, and if its use is continued who will pay that extra 10 cents? 'The consumer will pay it-no one else. Who is at the present time paying the two-cents-per-pound tax which our paternal Congress has placed upon this product? The man who earns a dollar and a quarter per day; the railroad man who goes out at the risk of his life to earn a living for himself and his family; in short, the citizens who consume the oleomargarine are at present paying this two-cents-per-poumd tribute to the existence of this already unjust law. As soon as this tax was imposed the price of the product to the consumer advanced 2 cents per pound and has remained so ever since. since. 
I have here with me a pile of protests coming from organized labor. Organized labor, being familiar with the danger which confronts its interests, has taken advantage of the opportunity which that familiarity gives it to protest before the bill is passed, and, if possible, by such protest, to prevent its passage. But the thousands, the hundreds of thousands of men who are not organized can only protest (by virtue of the fact that they are not organized) against this measure after they become its victims. Then they will protest, as all morganized indi. viduals generally do.

A great many people seem to think that the consumers of oleomargarine regard its use as a disgrace or as an evidence of impoverished circumstances. This is not the case, gentlemen. I myself know of a great many people in very good circumstances who use it from choice. Some of our best families in Columbus use it from choice. I will venture to say that I conlal secure fiom a great many members of our board of trade in Columbus, with many of whom I am personally and intimately acquainted, statements to the effect that oleomargarine is constantly consumed on their tables. It is no evidence of penury, and consequently it is no disgrace for any man's child, or wife, or servant, or messenger to go away from the grocery bearing in his hand, for consumption by the family, a package of this oleomargarine, stamped as oleomargarine. And it is no disgrace for such an individnal or honseholder to go into the grocery and before, or in the presence of, a great many other people to say, "Give me a pound" or "two pounds of oleomargarine; and let it be stamped, so that I shall know it as such." And our officious incumbents of certain State positions know this as well as they know they are living.

This precantion has become almost unnecessary now, becanse a great many, and in fact nearly all of our grocers have become aware of the necessity of giving people what they want; and in a case of this kind 90 per cent of onr people, I will venture to say, want this product. If the product should become inferior, or if it should be adnlterated, no one would detect the fact more quickly than the intelligent eonsumers; and at the present time it is to the advantage of the oleomargarine manufacturers that the general public know that they are buying oleomargarine, because, as I have said, it is preferable to butter. Any deception that might be practiced would work a great injury to their interests, simply becanse the people want oleomargarine and ask for it.

I will state, gentlemen, from practical experience and from iuterconrse with the general public in and around Columbus, Ohio, that it is the general impression of the people that this bill can not get through the Senate of the United States. In conversation with a great many citizens I have heard them say:

There need he no fear of that. Congressmen have motives of their own in sustaining such a bill-ther can not consistently avoid doing so; but members of the Senate need not entertain my such fears. There is no possible danger of the bill getting through the senate. The Senate is composerl largely of men who have graceil judici:il benches, of the most prominent and learned citizens of our country, of men who have a proper appreciation of justice, and those men will not fur a moment tolerate any attempt to enact a law of this kind, which upon its face is so grossly unjust and so apparently an attempt to ntilize their body for the promotion of private interests.

As I was coming away from Columbus the other morning I passed a blacksmith shop. There were brawny horseshoers in there, three or four anvils ringing. They hailed me, called me in, and said:

Off for Washington, Mac? Yes; going at 11.35. Well, good lnek to you, boy. God speed yon. We all hope yon'll do good work for us up there. low whit yon can 
to keep, that bill from passing. You tell the Senators up there that if they need any further yoof of the truth of the statements yon make, we'll all write them a letter. We'll block the mails if vecessary. All they've got to lo is request it, and we'll give them practical proof, in our own handwriting, over our ow siguatures, what our seutiments are.

And everyone of those men shook liands with me most cordially, most enthusiastically, and expressed an earnest and siucere hope that my mission here would be successful.

I honestly wish it were possible to convey that scene from Columbus to the floor of the Senate of the United States when this bill is up for diseussion-that is, if it ever does come up for discussion, and I sincerely trust that it will not. In fact, I am conficlent that it will not. I am confident that this committee will take jroper steps in regard to it. But if they conld only witness that scene it would need no further argument on my part to convince them of the sincerity of the masses of workingmen in demanding its defeat.

Senator ALLwN. I think you had better file the papers you have there, which you desire to present to the committee, withont reading thrm. 'They are too volmminous to read. They will all be printed and put in the report.

Mr. MCNAMEE. With your permission, Mr. Chairman, I would like to refer to some of the points contained in some of these resolutions, and whenever I have takeu up too much of your time, I will very gladly yield to a suggestion to quit. But as long as you decille to tolerate me I wonld like to refer to some of the points in these resolutions.

Here is au expression from one of the largest representative labor bodies in the United States-the Chicago Federation of Labor, and here is what they say relative to the tax:

We believe the efforts to place a tax of 10 cents per pound on colored butterine is inspired by selfish motives, so that the mannfaeturers of butter may elarge an unreasonable price for their commolity, and enable the large creameries to establish surely and securely it butter trust which may raise prices as their cupidity may dictate.

\section{Here is another expression:}

Justice denauds equal rights for lotl manufarturers of butter and butterine, both prodncts baving equal merit. Any alverse legislation against either uust be condenmed.

At the present time butter which, in its original state, would be too unsiglitly for use, is being colored continually with impunity by the farmers of Ohio. There has never been a protest raised against this coloring, although I understand it is illegal. But it would not serve the political purposes of our dairy and food commissioner to enter such a protest, although it would be strietly in the line of his duty. Consequently, that law, if such exists, is not enforced, and if none such exist, no attempt has been ever made to enact one, although such coloring is certainly for the purpose of deception.

I will venture to say that a vast proportion of our urban eitizens, if compelled by law to nse butter as it appears originally, and at the same time if forbidden to use oleomargarine, would abstain from its use altogether. They wonld prefer to eat dry bread or to use some sort of substitute, in the way of jam, or sometling of that sort, used as a spread, confining themselves, for cooking purposes, to the use of lard or something of that kind. That does not apply to all butter, but it does apply to the larger proportion by far of the butter that is placed upon our market for sale. Yet why is it that it is right to color butter and to deceive the people into believing that it is good Jersey butter, or some other kind that may be desirable, when it is really the 
product of a living liactory, in the form of a cow, frequently unclean and disease infected, and which can not be regulated by health pre. cautions, as a butterine tactory can?

Here is another specific protest against increasing the tax on oleomargarine:

We believe that the present Federal law taxing butterine 2 cents per pound, and the additinal regnlations imposed by the Commissioner of Intelnal Rev'nue, are suffieient to properly regulate the manufacture and sale of butterine.

Here is an expression from some of the gentlemen to whom I referred recently as having met in the blacksmith shop.

This is from the Journeyman Horseshoer's' Union:

We feel that all people having arrived at the age of discretion should be left to exercise their own choice as to whether they shall nse butter or oleomargine: Therefore, be it

Resolved by Jomrneyman Horseshoers' Trion No. 40, of Colmmbns, (Jhio, 'That as long as butterine is cololed with a healthful iogredient suid coloring should be encourageil, as it improves the appearance of the product; that we do most emphatically condemn the persecution being waged against the butterine industry; that we protest against the attempt to increase the tax thereon, and that copies of this resolution be forwalded to every Congressman, with the reguest that they each and every one exert the most strennons efforts to erushingly llefeat once and for all any and all measures proviling for the futher taxing of hinterine.

Now. gentlimen, I know, and so does the average citizen who knows. anything about the lives of public men and how their time is oceupied, that it is absolutely impossible to bring to the attention of each and every Senator or member of Cougress every letter and every appeal and every communication that is sent them. I myself have a hard time in reading and disposing of the mail which I in my humble capacity receive. And when I realize how your time, gentlemen, is taken up I ean not but come to the conclusion that it is absolutely impossible for you to read all of these communications or to give very much attention to them. In a great many eases I know that they never get past the private secretary, particularly if the Senator or Congressman is busy, and it must be something of a very important personal nature on those occasions to receive his attention,

The Chamman. We know of the fact that they do protest. These labor union protests have been coming in for a long time. Now, in view of the fact that we have a very short time and are to liear Mr. Davis next this afternoon, there being only a few minutes left before we adjourn, is it not sufficient to file these protests? If you luave any new facts to present, I want to give you all possible opportunity to state them.

Mr. MCNAMEE. I have already, you know, asker for permission to refer to various points in them.

The CHairman. We should be glad to have you do so as rapidly as possible, for we shall have to arljour'n very shortly.

Mr. MCNAMEE. When will you adjourn, Senator?

The Chatrman. We will have to adjourn now in ten minutes, at 12 o'clock.

Mr. McNaneE. Can I use those ten minutes?

The UHAIRMan. Yes.

Mr. MoNAMEE. That was what I understood when the gentleman gave me permission to proceed.

The Chairman. Yes; I simply wanted to be sure not to cut you off short, and to let you know that you ouly had a few minutes left.

Mr. MaNAMEE. I appreciate that courtesy on your part, Senator; I do, indeerl. 
Here is something from the Painters and Decorators of Cleveland, Ohio. It speaks in very plain language. This is in the form of a letter signed by Mr. Peter Hassenpflue, 442 Erie street, Cleveland, president of said union.

I have been instrneted by onr union, containing over 400 members, to write and inform you that we are unanimonsly and bittrily opposed to the bills now pending in Congress providing for the persecution of the butterine industry. As yon clonbtless know, there are law now that are being carefnlly enforced and lived up to that make it impossible for butterine to be manufactured and sold tor anything else but butterine, and it is the unanimous opinion of onr members that butterine made according to these laws is better for all uses than three-fourths of the butter that can be bonght. It won't get strong, and it don't come from feverish cows that are full of dicease germs, and butter frequently dwes.

Now, gentlemen, it may seem to you that this language inclicates a familiarity with such matters on the part of these workingmen that is not consistent with their usmal occupation, or with the very limited time they have to devote to the consideration or study of matters of this kind. But 1 assure you that they are familiar with all these points; that they are discussed continually, pro and con, in their unions; that they are giving deep and continnal attention to this whole matter, and that the more this question is discussed in the labor unions the more and more do they become aware of the advantages of using oleomargarine in preference to butter. These points are all considered-the points about the feverish cows, the spread of disease, the destruction of disease germs by the process by which oleomargarine is manufactured, ete. All of these things come up for discussion, and organized labor is generally familiar with then. Unorganized labor may not be as faniliar with them, and may depend altogether for their information on the subject mon what may appear in the daily newspapers. But, as I saicl before, its protest will come, as protests always come from men who are not organized, after the damage has been done, after the injury lias been inflicted.

Here is what these men say, and they say it in very plain language:

We fee] this way-that if butterine is wrong, or poison, or liable to injure public health, then ro away with it altogether; but if it is not (aud years of experience in using it have tanglit us it is not) then why persecute the industre and keep passing laws against it? ()ur belief is that this is kept up just for political reasons, and that some prople in Cougress that :re sworn to protect the rights and interests of all the people are willing to increase on alvealy too high cost of living and add to our taxes just to catch the farmer vote and imerease the husiness of the hutter trust or trusts (and if butterine is killer they will soon boin one), and make them a present of the bntter market so they cun cither rob the people or make them go withont butter. It is the rankest kind of injustice to kill one incustry that is right and legitimate in order to accommodate another. We want butterine; we know what it is: we would rather have it than hutter, and it is an outrage, in order to gratify the people who make butter, that we should have to go withont it and pay two prices for buttel which we are compelled loy law to eat, and which, nine cases ont of ten, is not tit for homan nse. It is getting to bo pretty serions when the Congress of the United States is asked to go into the business of booming certain interests, and for their accommodation driving their competitors out of existence, simply because they are competitors, and for no other reason on earth. A great deal is being said ahout butterine being a certain color. Now, the only reason that a kick is made on that color is because it helps to sell that commodity. It the butterine makers were to nse red or black or blue, these patriotic statesmen, and others so solicitous for the people's protection, wonld raise no objection, because that would make the same point that they want to make hy law, and that is to hnrt its sale and thereby tickle the farmers and advance the interests of the creanery trusts. The ingredient used in butterine which gives it its color has been proven by ofticial chemical analysis to be a natural aud healthful product. As there is no reason to kill bntterine bnt because it hnrts another business, then why not do away with these hose painting machines because they hurt our business?

These are painters, gentlemen. The hose painting machines displace a great many painters, and deprive a great number of the men who wield 
the biush for a living of employment. They take a hose and run it up and dowu a wall, and in ten minutes a half day's work is done. But these men very wisely say that if Congress will abolish or prohibut the manufacture of butterine in order to accommodate the manufacturers of butter, then why not, on the same principle, do away with these hose painting machines to accommodate the painters, who are in proportion to the mannfacturers of hose painting machines more numerical by far than the farmers and creamery people are in the same proportion to the manufacturers of oleomargarine. That is precisely the same principle upon which is based the Grout bill. It is the only motive for its attempted enactment, and can not be concealed.

Mr. Schell. Mr. Chairman, if the gentleman will permit me, allow me to suggest now, before t, lie time comes for arjournment, since I see he is not going to be allowed to say all that he wants to say, that he be allowed to tile these resolntions from various people whom he represents, marking such parts as he wishes copied into the record, so that all he wishes to have appear prominently may appear as part of his remarks this morning, and be regularly before the Senate. I see these papers which he has are too voluminous to go bodily into the record; and it ocenr's to me that that disuosition be made of them, in order that the committee may have the allvantage of having the important portions of them before it. That is merely a suggestion. If it meets with no disapproval, I think the gentleman will gladly avail himself of it.

Mr. MCNAmeE. Yes; thank you. I have just a few minutes more, gentlemen. (Reading:)

We know it would be nureasonable to ask this, but it wonld be no nore so than for butter makel's to try, as they are doing, to drive butterine out of existence because it hurts theil business.

I will close ly saying that we consider any further legislation by Congress tampering with the butterine business as a prostitution of that dignified boly to the greed and avarice of certain corporations and individuals, at onr sacrifice and that of the people in general who don't own farms or creamery factories; and in the name of my union, under its seal, and by its unanimous iustructiou, I earnestly request sou do eversthing you can to defeat all measures that provide for the increase in the tax ot, or further interference with tlo manufacture or sale of, but. terine.

When railroads first eame into existence, the proprietors of stage coaches and other methods of conveyance and transportation were very much displeased, and they kicked vigorously; but of course their lick did not avail them anything, berause probably their political intluence was defective in some way. Now, if the farmers should have to surrender to the manufacture of that side industry, the making of butter, because the manufacture of butterine has been demanded by the people in general, they would eventually come to a realization of the fact that after all they had not lost much, because in the raising of stock they wonld make as much, or at least, accorling to my impression and the impression of those whom I represent, they would be as well off eventually as if this progressive industry were sacrificed now for their special benefit.

Now, gentlemen, as the time is very limited, as I have only one or two minutes mole, and as you have kindly consented to permit me to submit my argument in brief form, as I understand it, Mr. Attorneyyou are an attorney, are you not?

$\mathrm{Mr}$. SCIELL. Yes.

Mr. MCNAMEe (continuing). I will not refer any further to this butterine question. I simply wish to tender to this committee, and its dignified nembers individually, the sincere thanks of the Colnmbus 'Trades 
and Labor Assembly, and of the other organizations which I represent, for the courteous hearing you have given me on this occasion and for the patience with which you have borne with me.

I thank you sincerely, gentlemen; and I trust that it shall be our most pleasant duty to tender this committee a sincere vote of thanks for that protection of our interests which I feel confident they will give us.

The Criariran. There is very little time left. Is there anyone else who wishes to be heard in that time?

Mr. KNIGHT. How mnch is there-ten minutes?

Senator ALlen. I was going to snggest, Mr. Chairman, that if all these gentlemen desire to be heard, some one or two of us can remain here and continue the hearing.

The Chamrian. Juring the session of the Senate?

Sellator Allerr. Yes, sir.

The CHAIRMAN. Is there anybody else rearly to go on on this side of the question!?

Mr. 'Tilminghas'1. Acting under the suggestion of previous days, that the committee would adjourn at noon mutil 2.30 o'clock, it was understood that Mr. Davis would go on at that time. He is not present now.

The CHarkman. Mr Knight, perhaps those inen of whom you spoke, who are going away, can be heard now on the other side of this question?

Mr. KNIGHT. The gentlemen are here, but there is just one thing to be considered, Senator. We do not want to break in or repucliate or chauge in any way the arrangements which were made to permit us to have to morrow.

The Chairmas. We will not do that; but as nobody else seems to want the time to-day

Mr. ScHELL. As I understanl, it is not arranged that they are to have all of to-morrow. I do not think that has been the case. We do not want to concede that on the record at all.

The CHAIRMAN. I so understand it, unless there is something very special which wonld require a change in the plan. That was the antiouncement. You have had the flool 1o-day.

Mr. Schell. As the question was raised yesterlay, I think, it was understood that these gentlemen were not to be allowed to really bring in their presentation of their case at the close. In other words, they are not to be allowed to wait nutil we have concluded, and then bring in new arguments or new facts, or new alleged facts, withont giving us the right to have something to say in reply.

Senator ALLEN. Is it not true that the whole matter at issue between these two sides can be reduced to one or two questions?

Mr. SchelL. To two questions, perhaps.

Senator ALLEN. Now, why is there any necessity for going on with greater elaboration?

Mr. SCHELL. I see no necessity at all.

The CHAIRMAN. If you will act on that plan, we can simplify matters considerably.

Mr. Schell. The point is this, Mr. Chairman: The gentlemen who, as we claim, or as I claim, have the burden of proof, have come in here aud arraignel us on certain charges, and say we should submit to certain things. We put in a plea of not guilty. They claim to present their case, and say, "We close;" but they really present no case. It is a general charge-not even the statement of a case. 
The Chairman. That is for us to consicioi.

Mr. ScHELL. I nuderstand that; but if they have really reserved an actual case, or a slow of a case, to bring in after we have said what we have to say, then we insist upon the right to reply.

Senator AlLEx. Yon will muderstand that much of what is said here is familiar knowledge to every member of the committee.

Mr. Schell. It is; I molerstand that.

The Cinarrman. You say that you did not expect a hearing until half past '2, so that any time which is taken now by the other side will not be taken from you.

Mr. ScHell. Oli, we are not objecting to their taking any time the committee sees fit to give them under these circumstances.

Mr. JELKE. Do I understand that Mr. Davis will go on at half past 2?

The Chamman. Tes.

Mr. JELKE. I did not expect Mr. MeNamee to speak so loug this morning and had hoperl that I would be heard.

The Chamman. You will be given time this aftermoon. Mr. Davis will not be veiy long.

Senator AlLEN. One or two of us can stay here and contiune the hearing. I can stay here, for one.

The CHAIRMAN. Yes; if Senator Allen will stay here, you can go right along now.

Mr. KNIGHT'. Then, with the committee's permission, I will introduce Mr. F. J. H. Kracke, assistant commissioner of agriculture of the State of New York, for the metropolitan district.

(Senator Allen therenpon took the chaix as acting chairman.)

\section{STATEMENT OF FREDERICK J. H. KRACKE, ASSISTANT COMMIS- SIONER OF AGRICULTURE, METROPOLITAN DISTRICT, STATE OF NEW YORK.}

Mr. KRАCKE. Mr. Chairman and gentlemen of the Committee: What I have to say will be very brief.

I have charge of the enforcement of the clairy law in the State of New York, and more particularly the city of New York. It is in that line that I will give you a few facts as they appeal to us, as explaining why this pending bill is of particular interest to the people of the State of New York.

In New York State, bordering as it does on New Jersey, we are laboring under a great disadvantage. The people of our State are pro. hibited firom selling oleomargarine. The people of New Jersey-

Mr. KNIGH'. Wxcuse me, Mr. Kracke; quality that, please. You will be misquoted on that point. Yon mean, do yon not, that they are prohibited from selling oleomargarine in imitation of butter?

Mr. KRACKE. Yes; they are prohibited fiom selling oleomargarine in imitation of yellow bntter.

Mr. KNIGHT. It is well to be specitic on these points.

Mr. SchELL. I suppose the law itself explains that.

Mr. Kулінт. I feared he wonld be misquoted; that is all.

Mr. KRACKE. Now, from New Jersey these perlders with wagons come over and deliver oleomargarine to private houses and boardiug houses in this way:

An agent will come along, calling at the different houses, asking for the mistress of the house, and tell her a story about how he can deliver 
her some nice creamery butter for a certain price if she will contract with him for a year. Of course, that price will always be from 5 to 10 cents below the creamery butter price-5 cents, as a rule. Then, after she has seen the cheapness of the thing, the saving in the price, believing this to be gennine butter, she will give che order. Then, a few days later, these wagons come over from New Jersey into New York to deliver these goods. They are bought for and as butter.

We have male a fight there on this matter, but we are handicapped by reason of the fact that these wagons come over as express wagons. Under the interstate commerce act they can conie from one State into another, carrying this commodity, and we have no jurisdiction over them. In otlier words, the citizens of another State are privileged to deal in our State, and given a right which the citizens of our State are denied.

Senator loster. Do you New York people do the same with New Jersey-take your oleonargarine over tliere and sell it"?

Mr. Kracke. We lo not prohibit the manufacture or sale of colored oleomargarine in our State at all.

Mir. KNIgHT. You do not mulerstand the question. He asks if you do the :ame with the New Jers'y people-sell them oleomargarine for butter?

Senator Foster. Do you send your wagons over to New Jersey with oleomalgarine to supply the people over there?

Mr. KRACKE. Well, Senator, there is not any made in the State of New York. Consequently they conld not take any over there.

Mr. TillinghasT. Will the gentleman permit me a question?

Mr. KRACKE. Yes, sir.

Mr. Tillinghast. Do you mean to tell this committee that the New Tork law is not operative against the citizen of New Jersey who sells oleonal'garine in New York or who takes an order for oleomargarine in New York?

Mr. KRACKE. The law of the State of New York is operative against a citizen who takes an order in the way you state, but the point of that is this, that he comes from another State into ou State, takes this order, and returns to his own state, and then has it delivered in this way, which makes it next to impossible to stop the traffic.

Mr. TullnghAst. But the oleomargarine, when it arrives in the State of New York, is subject to the juriscliction of that State, if the sale and delivery take place in New York, is it not?

Mr. KRACKE. It is not subjert to law.

$\mathrm{Mr}$. 'TullinghasT. It is not?

Mr. KRACKE. It is not subject to law.

Mr. Tillinghast. Then you differ with the Supreme Court of the United States in the case of Commonwealth $v$. Plumley?

Mr. KRaChe. No; I do not.

The Acting Chairman (Senator Allen). After the article comes into the State

Mr. KRACKE. After the article is delivered to the party, then it becomes subject to the law of New York, of course.

Mr. Tillinghast. That was my question.

Mr. KRACKE. You did not clearly state it in that form, then.

The Acting Cuamman. Your idea is that the State of New York can not prohibit a citizen of New York going into Now Jersey and making a New Jersey contract for oleomargarine?

Mr. Tillinghast. That is right. 
Mr. KRACKe. That is the point.

The Acring Crampuan. I think that is true.

Mr. TIllinghast'. That is true.

Mr. KRAritE. Take the case of delivering oleomargarine to boarding houses. Boalding houses in New York are prohibited from using colored oleomargarine or serving it to their boarders. But the point is this-that it is sold to them as butter hy the preliminary process of the agent coming there and selling it to them as creanery butter.

Senator Dolciver. But the law of New Jersey seems to be very nearly the same as the law of New York ou the subject.

Mr. KRACKk. I believe it is; but I am not speaking for New Jersey. The point of my starting out in this way, Senators, is this-simply to bring to your minds the question of frand. The question of fraud in the whole business is what appeals to me most thoroughly and positively. It was said here by some of the firiends of the bill that 75 per cent of the oleomargarine sold is sold as and for butter. Now, I rather disagree with them. From my experience in New Tork, and I have had five years' experience there in enforcing the law, I rather disagree with that proposition and that statement. Every onnce of it that is sold in New York is solk as and for butter, wilhout any question.

To give you an illustration: We had reason to suspect a certain grocery store of sulling oleomargarine. I sent the inspectors there to look the matter up, but could not find any of the material. There was a renewed complaint. I went there myself with the inspectors, and in looking the place over we found some butter on hand; and among the empty tubs which I looked over the middle hoop of oue contaiued a small comer of a revenue stamp, which indicated to me that the grocer had been handling oleomargarine. Shortly after that a clerk who had formerly been in this man's employ came to my office and told me that the goods were kept upstairs in his living rooms; that this man kept oleomargarine, but kept it upstairs in his living rooms, and only dealt it out discreetly to certain custome.s. He said that he would not dare keep it in his store for fear of being detected by our inspectors.

This former clerk said furthermore:

The methorl is this: 'The man has a boy there in thestore. Noxt time yon go there you will see this hoy walking in the place. As the men, about 10 or 11 oclock in the mornibg, get their orslers rearly and they are put in the wilgon for delivery, this bny will be walking np and clown, watching the orders. He will have on a very large coat. This coat is very heavily lined, ind it is interlined and intersowed so that it will permit a 11 umber of ponnd prints of oleonarearine to be places in the lining. The boy will go with the wagon, and when it gets to a certain house where he wants to deliver oleomargariue with the order, whereas bntter has been ordered, be will take one print or two prints out of the lining of his coat pocket, put it in the order, and take it in the honse.

That is au illustration of how they sell oleomargarine for butter, gentlemen.

Mi. Miller. What do they do on hot days?

Mr. KiaCkE. 'This was not a lot dily. [Laughter.]

Mr. MILLER. How many pounds did this boy carry at once?

MI'. KRACKE. He carried '2s pounds.

Mr. Til.linghast. Now, do you mean to tell the committee that the person to whom that oleomargarine was delivered was deceived in the purchase?

Mr. KRACKE. Unçuestionably.

Mr. Tillinghast. Do you know that, or is it simply a question of opinion? 
Mr. KRACKE. I know it absolutely; becanse we went there and asked them, and after that they testified to it. Moreover, they paid ¿8 cents a pound for it.

Mr. Tillingmast. In low many instances did you find that to be true?

Mr. Kracke. In every instance.

Mr. Trllinghas'T. How many were there?

Mr. KRACKE. What do you mean?

Mr. Tillinghast. Of how many cases of that kind have you any recollection?

Mr. KRACKE. One thousand. [Langhter.]

Mr. Tillinghas'T. Do you meau prosecutions?

Mr. KRACKE. One thonsand prosecutions.

Mr. Tillinghast. What was the prosecntion for-selling oleomargarine for butter?

Mr. KRackE. Selling oleomargarine for butter.

Mr. TILLINGHAS'T. Or was it for selling oleomargarine colored?

Mr. KRACKE. Selling colored oleomargarine for butter.

Mr. Tillinghast. 'That was what the prosecution was for?

Mr. KRACKE. That was what the prosecntion was for, and there were 1,000 convictions, too.

Mr. Tillingirast. In how long a time?

Mr. KRACKE. In the last three or four years. Do you want me to go back further?

Mr. 'Tillinghast. Yon say three or four years?

Mr. KRACKE. Yes, sir.

Mr. JELKE. And yet the sale of oleomargarine is not stopped in New York! Does not that show that the people want it?

Mr. KRACKE. No; I rather think it shows the people do not want it. The people do not want it; the consumer loes not want it.

Mr. KNIGIT. It shows that the grocer wants it.

Mr. JELKE. Mr. Kracke speaks for New York only.

Mr. KRACKE. 'There is one other point to which I want briefly to call attention, and that is the fact that there appeared before this committee last week a man from New York who stated that he was a commission merchant and a dealer in butter. In making his statement he took up an interview of mine in a New York paper and attempted to distort it so as to have me say something that I did not say. I refer to Mr. Lestrade, who came here and made a statement before the conmittee. I wish now to ask the committee if Mr. Lestrade told the committee that he was an oleomargarine manufacturer?

The Acting Chairinan. I do not know, Mr. Kracke, what the record shows in that respect. It is all printed wherever it may be.

Mr. KRACKE. Mr. Lestrade is a member of this mercantile exchange of New York, which is composed of 500 or 600 commission merchants, dealers in butter, who passed a manimous resolntion favoring this bill. Then he came here representing himself to be (as he is) a merchant in New York City, a dealer in butter there. I would not have made this reference, however, if it had not been for the fact that he attempted to distort a statement of mine so as to construe it as favorable to lis side of the case. For that reason $I$ raised this question.

The AC'ing Chairman. Mr. Knight, you may read the statement referred to, if you find it.

Mr. KNIGH' (after examining printed report of hearings). It has not been printed yet.

Mr. KRACrE. I liave not anything further to say, gentlemen. I simply wanted to call attention to that matter. 
Mr. ScheLL. If the gentleman will permit me a question. Your laws in New York are considered as being practically enforced, are they not?

Mr. KRACKE. I think they are.

Mr. SCHELL. Then your State laws are capable of enforcement, if they get competent men like yourself and Mr. Flanders to enforce them?

Mr. KRACKE. I think they are.

Mr. KNight. Mir. Kracke, about what does the State of New York expend per year in the enforcenent of those laws?

Ir. FRACKE. Particularly for this line of work about $\$ 140,000$ a year.

Mr. KNight. And how many men are required to cover the State?

Mr. KRACKE. Sixty-odd men.

Mr. Knighr. And how long lias it taken you to organize this department up to its present efficiency?

Mr. KRackE. Seventeen years.

Mr. Tlllinghast. You say you expend $\$ 140,000$ yearly in this line of work. Do you mean particularly adulterations of butter?

Mr. KRACKE. No; dairy products. We have other branclies in our worli, too.

Mr. Tillinghas'r. Precisely. How much of that sum, iu your judgment, is used in the prosecution of persons selling oleomargarine as butter?

Mr. KRACKE. Well, I could not tell you that, particularly. There is one thing that I will say, and that is that there is very little oleomargarime found in New York ontside of the city of New York.

Mr. Tilminghast. Then, so far as New York is concerned, its citizens are not deeply interested in this bill? Their owu State laws are quite sufficient for their protection?

Mr. KRACKE. Well, no; because that would be selfish.

Mr. Tillinghast. Well, they have a right to be selfish.

Mr. KRACKE. But they are not selfish. A man coming from New Tork would not be selfisb. [Laughter.]

Mr. KNigut. Mr. Kracke, about what proportion of the time of your department, in your district, is devoted to the oleomargarine question?

Mr. KRACKE. More than two-thirds of the time.

Mr. Miller. How much butter is sold in the State of New York in a year?

Mr. KRACKE. I can best answer that by referring you to the report given by the Treasury Department, which stated that last year there were a little over 200,000 pounds sold there.

Mr. KNight. But, Mr. Kracke, that does not include the amount that may be brought over from New Jersey in these wagous of which you speak.

Mr. KRACKE. Well, of course I have no kuowledge or record of what is brought over. There is some brought over.

Mr. KNIGH'T. Have you ever had any trouble, Mr. Kracke, with any Providence concern shipping stuff in through Jersey City?

Mr. KRACKE. Well, there was tronble with this particnlar oneLestrade Brothers.

Mr. KNIGHT. Well, are there any others? Have you ever had any trouble with any other Providence concern?

Mr. KRACIE. Not that I know of particularly; and we do not make a specialty of looking up any particular manuficturer. Oleomargarine palmed off in New York is oleomargarine; and we have tried to steer clear of making a bee-line for any particular manufacturer. That is not our province. Oleomargarine, to us, is oleomargarine, and contraband to the law.

$$
\text { S. Rep. } 2043-24
$$


Mr. Tillinghast. Now, do yon know anything about the amount of butter that there is cousumed in the State of New York?

Mr. KRACKE. I conld tell you more particularly as to the amount of butter that is consmmed in the city of New York.

Mr. Tillinghast. Very well; what is that?

Mr. KRACKE. There was consumed last year in the eity of New York a little over $\$ 1 \$, 004,000$ worth.

Mr. Tillingmast. And that would represent how many pounds?

Mr. KRACKE. Twenty cents a pound.

Mr. KNI(iHT. About 110,000,000 pounds, then.

Mr. Tillingiast. I make it $\$ 0,(16),(000$ poumds.

Ir. KNistit. No; $110,000,000$ pounds.

Mr. Tillingirast. Why, yon say there is $\$ 18,000,000$ worth sold?

Mr. Kracke. Abont $\$ 18,000,000$ worth.

Mr. Tillinghast. Then that wonld be $90,000,000$ pounds of butter consumed in the city of New York last year?

Mr. KRAcki. About, as 1 remember it.

Mr. KNInItT. That is in Greater New York?

Mr. KRACKE. Yes.

Mr. ADdMs. Mr. Kracke, I monld like to ask you a question. I understand that you have spent a very large portion of an appropriation of $\$ 140,10(1)$ a year in enforcing the dairy laws of New York with reference to the sale of olemangarine. Wonld it be necessary to expend that amount which you now expend. or any considerable portion of it. if oleomargarine were made nurler its own color, and not colored in imitation of butter?

Mr. KRACKr. It certainly would not.

Mr. Tilminghast. But it wonle if it were sold for butter. As I understand, colored oleomargarine can not be sold in New York at all, excejt in violation of the law.

Mr. KRACKE. That is correct.

Mr. TillingHAST. So that if oleomargarine should continue to be sold as butter it would be sold colored, and pou would have the same difficulty in enforcing the law then that you have now, would you not?

Mr. KRACKe. I do not eatch your question. In the event that this law is passed, you say-

Mr. Tillinghast. If this bill goes into effect, we will say, the cost of oleomargarine would be enhanced?

Mr. KRACKE. Yes, sir.

Mr. Tillinghast. But even at the enhanced price it would still be able to compete with butter, would it not?

Mr. KRACKE. At certain times of the year it would; yes.

Mr. Tillinghast. And therefore there would be the same temptation then to sell it for butter there is now?

Mr. KRACKE. Well, not quite.

Mr. TillingHast. Not quite; but there would be some temptation?

Mr. KrackE. Because putting an adlitional tax of 8 cents per pound on it would take away quite a good deal of the protit on it.

Mr. SCHELl. Do we understand you to say that the entire annual appropriation for your department is $\$ 140,000$ ?

Mr. KraCKE. Ño.

Mr. SCHELL. What is the entire appropriation?

Mr. KRACKE. The entire appropriation will run up to between three and four hundred thousand dollars.

Mr. Schell. Now, what per cent of this $\$ 140,000$ that is appropriated for the particular enforcement of the dairy laws is used for the 
purpose of preventing the nse of preservatives in milk, the using of poisonous coloring matter in butter, and things of that kind? Or do you pay any attention to those phases of the matter?

Mr. KRACKE. Oh, yes, yes. Just duling this past montl we received fines amomn'ing to $-1,800$ for adulterated milk and milk that had preservatives in it-that is, in New York Uity alone.

Mr. Tullinghas'T. Just one more question. As I understood you, there are $90,000,000$ ponnds of butter consmmed in the city of New Tork yearly. One per cent of that amount wonld be 900,000 pounds?

Mr. Kracke. Yes.

Mr. Tullingirast. So that the amonnt of oleomargarine consumed in your state, assmming it to be 200,000 pounds, is less than one-quarter of 1 per eent of the whole amomnt of butter sold in the city of New York aloue?

Mr. Kracke. Right you are.

Mr. Trulingras'. Now, assuming that there is quite a large a mount of butter sold in the State of New York in addition to wlat there is sold in the city of New York-

Mr. KRACKE. Ies.

Mr. TullingIIAs'T (eontinuing). Can you figure up what possible effect the small anount of olemmargarine cousimed by your state would have upon the farming industry of that State?

Mr. KRACKE. Well, l have not gotten down to figuring just yet.

Mr. Ditlon. Mr. Kracke, is there not some colored oleomargarine which comes into New York from New Jersey and other States, and is sold on the maxkets there as bntter that you do not know abont, and that does not enter into the reeords at all?

Mr. KRACKE. I liave so stated, but that does not amount to very muel.

Mr. DILlon. And, Mr. Kracke, this gentleman speaks of the effeet on the New York farmer alone. Is it not true that a good cleal of the New York product goes ont of the State and out of New York City to find a market where it meets the competition of this colored oleomargarine, marle in initation of butter, where the States are not so strict in enforcing the laws as you are in New York State?

Mr. Kracke. The point is this: Most of the bntter made in New Iork State, especially in the easter'u and northeastern sections, goes to the Boston market. Only a very littie of it (if I remember correctly, only 200,000 pounds) comes into New York City from New York State. Conserumently-

Mr. KNIGHT. Yon mean 200,000 packages, do you not?

Mr. KRACKE. I mean 200,000 packages. Consequently, it is of vital interest to the people-the farmers and the clairymen of the State of New York-to have a law that will prohibit this frand all over this conntry.

Mr. Tillinghast. But you have the same law in Massachusetts that you have in New York, have you not?

Mr. SCHELl. And it is enforcerl?

Mr. KRACKE. Oh, yes. Oh, yes.

Mr. KNIGHT. Now, I want to ask Mr. Kracke a question. What proportion of the butter which comes to New York City is from the State of New York? You said abont 200,000 paekages, did you not, out of "2,000,000?

Mr. KRACKE. Yes.

Mr. KNIGHT. About 10 per cent. Is that true?

Mr. KRACKE. Ies; a little less than 10 per eent. 
Mr. Knight. Now, why is it that Illinois and Ohio and Miehigan and Pennsylvania, we will say, are compelled to come to New York to find a market for their butter in competition with your New York prodncers?

Mr. KRAoKE. TThy, very likely for the reason that they find no sale for it ont there.

Mr. KNIGHT. 'Then, as a matter of fact, when a million pounds of oleomargarine are sold in Illinois, displacing a million pounds of butter in the State of Illinois, that amonnt of butter has to come to the city of New York for a market, because it is crowded ont at lome, and, so far as the farmer is concerned, in the question of supply and demand, it might as well he oleomargarine?

Mr. KRACKE. As a matter of equalization, it affeets the farmer of New York as well as it does the farmer of Illinois.

Mr. KNight. And as a matter of fact the State laws of New York, which you are jraying $\$ 140,000$ a year to enforce, are 90 per cent of protection to other States where they are 10 per cent of protection to New Iork. Is not that true?

Mr. KRACKE. Well, that is largely true.

Mr. ScHell. I want to eall the attention of the Chair, however, in answer to the suggestion a little while ago that these things conld be boiled down to ome or two propositions, to the fact that these statisties are in regard to the competition of oleomargarine and butter, and not in regard to ally fraud whatever in the case. We are getting out of the question of frand.

'The Acting Chairian. Yes; I see that. Of colurse your time is limited to to-day and to-morrow; but if you see fit to fritter it away-

$\mathrm{Mr}$. Schall. You must remember that these are the friends of the bill frittering away our time.

Mr. KNIGH'T. Oh, no; this is not your time.

The ACting Chamman. Not until half past 2 o'elock.

Mr. KRACKE. In was only for that reason that I went on-because it was nobody's time-just lunch time.

The AC'ring CHarrman. You will muderstand that this evidence is all printed and read over. From time to time everything that ocenrs here comes out in this pamphlet form, and then is printed in book form. After it is printed, it is read over thoroughly and carefully by each member of the committee; and then the committee comes together and determines what to do. So if members are not here to hear you, they will hear you by reading your eridence.

Mr. KNight. Was it intended, senator, that any other of the dairy representatives sliould take this time at noon? Are you willing to stay?

The Acting Chamrian. You can go on and take this time until half past 2. I think, however, that we had possibly better take an adjournment of five or ten minntes, after a while, for some luneh.

Mr. KNIGHT. Mr. Dillon, editor of the Rural New Yorker, is here from New York, and would like to say a few words in behalf of the farmers.

The Actring Chainman. You ean select your own order of presenting your speakers.

Mr. KNIGHT. Then I will introduce Mr. J. J. Dillon, editor of the Rural New Yorker. 

YORKER.

Mr. Dillon. Mr. Chairman and gentlemen, I will take up vely little of your time on the pendiug question.

I am commected with (and, in fact, am pulslishing) the publication called the Rural New Yorker. My duties in that connection bring mo in contact with a great many of the farmers throughont the whole country, and I am interested in farming and in dairying myself.

IVe farmers look at this matter as simply one of right and wrong-a matter of frand. We have been making a product of human consumption for a great many years. We have been putting it ul, in a certain form, under a certain color, and have established a trade for it as a bealthful and nutritions artiele of lımman food.

Now, there come along these manufacturers. They recognize the value of our trade; and they put up a product that costs them to manufacture something like one-half of the eost of the genuine article of butter; and by coloring it in imitation of butter. putting it up as $\pi \theta$ put up butter, and putting it on the market just as we put butter on the market, they liave been able in certain cases to work into our trarle.

The majority of the States have said, through their State laws, that this should not be. IVe have endeavored to put certain restrictions on the manufacture and especially on the sale of oleomargarine. We have tried to get them to sell oleomargarine for just what it is. Our State laws have been, for the most part, failnres, however. We have succeeded fairly well in New York State in keeping out a large portion of what formerly came there; but it is coming in to some extent (as Mr. Kracke has said) from New Jersey and from other States. Some of it is detected and some of it goes undetected.

Then, some of it comes into competition with our butter in another way. If the local laws of other States are not enforced and it goes into consumption there, then the butter made in those States enters into competition with our butter in our home markets. But for all that, it resolves itself into a matter of imitatiug our proluct.

Now, in the absence of State laws that are able to proteet us, we come to Congress, and say: "Give us a law which will simply prohibit the manufacturer of oleomargarine from imitating our product and from selling it as butter." That is all we ask. We do not care how muel they sell, if they sell it for just what it is. All that we ask Congress to do is to simply give us some protection in the product we have been making for years, and for which we have built up a trade.

Mr. TILLINGHAST. Will the gentleman permit a question?

Mr. Dillon. Yes, sir.

Mr. Tillinghast. Do you consider that this law for which you are asking is a prohibitive law?

Mr. Dillon. We do not consider it a prohibitive law.

Mr. Tillinghast. But you said that that was mhat you wanted.

Mr. DILloN. A prohibitory law?

Mr. RoycE. For selling it as butter-not for selling it as oleomargarine?

Mr. Dillow. Yes; we want its sale as butter prohibited; that is all. We simply want Congress to say to the manufacturer of oleomargarine, "You must not put up your product in a form that imitates and that will enable you to sell it as butter." That is all we ask. 
Now, we farmers look at in this way: Our cream has a certain color, a certain appearance. It is refrigerated and frozen, and we sell it as ice cream; and as such it has a certain color. Many manufacturers go on a little further and give it different colors. They give it at chocolate color, they give it a pink color, and they give it various other colors. That does not interfere with its use at all. We go on eating ice cream just the same; in fact, we often have different colors on our plate at one time.

But these gentlemen come in from their oleomargarine factories, and they say: "That is all right, but we cau't sell our product in its natural condition. We must have the same color for it that you lave for butter, in order to sell it."

Well, that is true. They must have that color, or they can't sell it. But if people will eat ice cream colored pink or given the color of chocolate, what is the objection to their eating oleomargarine under those same colors? Why is it that they have to come right in here and imitate our product?

That is all that we ask.

Mr. MUNAMEE. Will the gentleman yield to a question?

Mr. DILLON. Yes, sir.

Mr. MCNAMEE. If the coloring of oleomargarine is so reprehensible, why is it that so many farmers resort to that practice in making their butter?

Mr. Dillon. Coloring oleomargarine is reprehensible for the reason that it imitates another product, and it tries to deceive the consumer by making a product that is not butter appear as butter, and tries to poke it down the throats and into the stomachs of people who do not want it and who wonld not have it if they knew what it was.

Mr. Tillinginast. But this bill does not prevent the coloring of oleomargarine.

Mr. Dillox. No; it does not prevent yon fiom coloring it.

Mr. MICNA IIEL. Then it is not wrong to color it, is it?

Mr. Dillan. It is not wrong to color what?

Mr. MCNAMEE. Oleomargarine. The bill does notsay that it is wroug.

Mr. Diclon. It does not make any difference to me what the bill says. To my mind it is wrong to imitate butter in the manufacture of oleomargarine. That is, it is always wrong to take one article aud try to sell it on the reputation of another.

Mr. McNamee. Then what do the farmers endeavor to imitate when they color butter?

Mr. Dillon. They do not endeavor to imitate anything. They do not imitate anything. Now, let me ask you a question. I am a sort of a Yankee; and we have a way of answering questions sometimes by asking them. Did you ever know a man to be deceived in buying butter?

Mr. McNanee. Did I ever know a man to buy butter and be deceived in it?

Mr. Dillon. Yes; did you ever know a man to be deceived when he bought butter?

Mr. MCNAJEE. In what way?

Mr. JELKE. I think it has been stated here that he sometimes got oleomargarine.

Mr. DILLON. That is all right, now. Did yon ever know a man to be deceived in bnying butter by the color of that butter?

Mr. MCNAMEE. I have often known men to buy butter for good butter, and after it had been in the honse two or three hours they could not use it. I have had that kind of experience myself. 
Mr. Dillon. That does not ansirer the question at all. Mr. Chairman, our point is just this: We make butter. We have made it for centuries. We have an lonest product, and all that we want these people to do is to keep their hands off and let us alone.

Mr. TILlinghast. 'Then you are satisfied with your own State law?

Mr. Dillox. We are not satisfied with our own State law. Uf what avail is our ow State law to $u \mathrm{~s}$, when right over in New Jersey and Illinois and Ohio and those other States they go right on and ignore the laws and consume oleomargarine there, and then send their butter into our markets and into other markets where we ought to go, to compete with us?

Mr. MCNAMEE. Is it not a fact that there is being manufactured very extensively at this time in New York a product known as process butter, that is colored and fixed up in imitation of good butter?

Mr. DILLON. I do not think there is. I thiuk not; no, sir.

Mr. McNajeE. Now, Mr. Dillon, on that same principle (pardon me for being so persistent), would you not do this? You say that you have an honest industry, which has been in existence for centuries?

MIr. MILLON. I do.

Mr. MoNAMEE. Now, would you, on the same grounds, be in favor of doing away with the pneumatic tubes or the little cash railways in dry-goods stores, simply becalise the cash boys have been displaced, and because there has been au honest method of securing cliange in the stores displaced?

Mr. DILLON. I would if the manufacturer of those tubes got them up as antomaton boys, and tried to make the users of them believe that they were genuine flesh and blood. [Langhter.]

Mr. MCNAMEk. That is reducing the argument to an absurdity.

Mr. DILLON. Well, sir; you started it, and I hope you will get all the benefit there is in it.

Mr. ScInLL. Just one question, which I think the gentleman will take pleasure in answering, and which I think is pertinent, and about the only question I have aimed to put during the entire proceedings:

Your only object, as I understand, is to force oleomargarine on "its own side of the fence." Now, if (mark the if) it is possible to get a law by which the oleomargarine manufacturer and dealer would be compelled to sell their product for what it is, you would not object to his coloring it with harmless coloring matter, would you? And if it were shown to you, as an honest man, that the effect of this bill would be, not to regulate the color question, but to practically irive the colored product ont of existence, whether sold lonestly or not, you would be with the opponents of the bill rather than with its friends, wonld you not?

Mr. DiLlon. Well, you imply quite a good many ifs.

$11 \mathrm{r}$. SchELL. It is only conditioned in that way that I want your allswer.

Mr. DILLon. In order to answer that question intelligently, let me say this: In the first place, we have been trying to do for you for seventeen years what you propose now to lo in a certain series of ifs. We lave been trying to get you to sell oleomargarine for what it is.

Mr. Tillingmast. On the contrary, have you not been trying to put colored oleomargarine out of your State? That is the law is it not? Your law is entirely prohibitive as to colored oleomargarine, is it not?

Mr. KRACKE. Just one moment. For seven years it was trier, in our State, to compel the sale of oleomargarine for what it really was.

IIr. Dillon. Mr. Kracke has said wliat I was about to say. 
Mr. KRACKE (continuing). And then it was fiually found to be absolutely impossible. Hence the law that prohibits the sale of colored oleomargarine.

Mr. Drllon. Now, Mr. Chairman, alter we have tried year after year and in various ways to get these people to do what they come in here now and surround with a lot of "ifs," and after having tried in every way that we conld possibly devise, and having failed to find any. thing that would restrict this imitation, then they come around here now, and get to the last ditch, and ask us if we will agree to a certain thing nuder certain conditions.

I auswer that it it were possible for us to do that, if it were possible for it to be done in another way, it would have been done before. We have mothing whatever against this prodnct, except to prevent them from making it and selling it in imitation of onr prorluct. Now, that is our whole case.

Mr. Scmell. The factories, so far as I am advised, are right with the gentleman on that proposition, and they faror to a unit, as I am told, the substitute bill in the Honse, nnder which they are compelled to put np their product in original packages of not to exceed 1 and 2 pounds, with the worl "oleomargarine" stamped therein, and wrap them and stamp them with the Government stamp, so that no consumer can purchase the prodnct except with full knowlerlge of what it is.

Mr. DILLON. I am familiar with the "substitute bill" of which you speak, and I recognize the very able work done by the oleomargarine interests in framing that substitute. It will do the work they want done, but it would not answer our purpose wortl a cent.

Mr. Scmell. It would answer your purpose, but it would not answer the purpose of the friends of the Grout bill. It would answer the purpose of compelling oleomargarine to be sold on its merits, but it would not drive the colored product out of the market. As it has been expressed hele, it wonld not "legislate a poor man's poverty on his table three times a clay."

Mr. DIllon. Now, uy friend, look here. Suppose I were a restaurant keeper in New York or a boarding house keeper, and you were so unfortunate as to be obliged to live at my table. What would there be to prevent my going over into New . Jersey and (under this bill of which you speak) buying oleomargarine, bringing it into my cellar, putting it ilown there in the dark where there was nobody but myself and a tallow dip--I might make the tallow from the oleomargarine, I suppose-taking off those marks, and bringing it up and putting it on my table and giving it to you to eat? IVlat would there be to prevent ny doing that?

Mr. ScirelL. It has been conceded by all the opponents of the bill, I think, that it would be possible (for the time being, at least) for a boarding-lionse keeper or a hotel proprietor to palm off oleomargarine for butter if he wished. But, on the coutrary, if a man gets dissatisfied with his boarding house it is a very easy matter to move; and it finally comes to the point where these (in some instances) very efficient pure-food commissioners

Mr. ADAMs. Mr. Chairman-

Mr. ScHELL. One moment; we are both talking. We have observed the conrtesy of debate all along, and we expect you to do the same. A wan can change his boarding house and he can change his hotel; and it finally drives it to a point where these very efficient pure-food commissioners, such as Mr. Kracke, for instance, know right whele to go and investigate. 
Mr. Dillon. That is all I waut. You admit that it is possible for me, as a boarding.house keeper or as a restaurant keeper, to palm off oleomargarine on yon as butter. Now, that is the whole scheme of your job all the way through, and it has been for the seventeen years that I have been watching you.

Mr. Tillinghast. Let me make a suggestion. Have you not a law in the State of New York, as in the State of Massachusetts, that where oleomargarine is used in restaurants and boarding houses there shall be a notification of the fiuct to the guests? Have you not such a law as that in New York?

Mr. KRACKE. No, sir; we have not. The law of the State of New York forbichs the manufacture or sale of oleomargarine to any person, whether it be in a stall or restaurant or boarding house. Fou can not even feed it to your servant in a private family.

The Acting Chairuran. Now, let us hear this gentleman [Mr. Alams | speak.

Mr. AdAys. Mr. Chairman, I would like to say a word if I ean have permission. The gentlemen on the other side of this question have appeared before this committee and made very extended arguments, and have been treated with the utmost eourtesy. The questions which we have asked have been rare in number. Mr. Schell himself appeared before this committee and talked for nearly a day and a half. I asked him one or two questions with the utmost politeness. He did not care to answer them.

Now, a gentleman appears here with limited time, and while the representatives of the dairy interests are perfectly willing to be submitted to any searching cross examination which is reasonable, $w \theta$ do feel that when one of them appears here to conduct a discussion upon our side of the question the six or seven or eight attorineys and representatives of the oleomargarine interests should not take up all his time in extended questions and in extenled arguments.

The Acting Ciraminan. It is always within the power of the witness to decline to be interrupted.

Mr. Schill. I was just going to say that. We apologize if we are doing what we ought not to do.

Mr. Dillon. I have just one or two other points to make, and that is all I am going to say on this subject.

The Acting Chamman. You can decline to be interrupted, if you wish.

Mr. DiLlon. I will exercise that right now for the remainder of what I have to say.

Up in the country where I was born and brought up, and where my farm interests are yet, I frequently meet farmers. It is a section of country to which people from New York and Philadelphia go in considerable numbers to spend the summer, and they meet a good many of these dealers from New York and adjacent cities. Last summer when I was up there one of my old neighbors was telling me of a market which he had formerly liad for his dairy butter in Paterson, N. J. He lost the trade, and he went down there to see what the trouble was, why he could not get any more orders from those people to whom ho had been shipping. He sairl that they told him confidentially that all or many of his competitors around there had been selling oleomargarine; that they were making a profit of $S$ or 10 cents a pound on it; that if they handled dairy butter it was impossible for them to compete with these competitors; and consequently they had thrown out dairy butter and gone to handling oleomargarine entirely. 
Now, those people do not undertake to come in and sell this oleomargariue as a "poor man's product." We hear a great deal abont its being a poor man's jroduct, about the labor mions, and all that sort of thing, but they do not sell their oleomargarine at a price that makes it any advantage for a laboring man to buy it, even if he were willing to be influenced by the lower price. The object is, all the time, to sell it for butter, as butter, and at butter prices. And it all comes right back again to the fact that all we ask is something that will protect us in our legitimate industry and business. During the last six months I suppose I have received at least an average of 1,000 letters a day from our farmers. I do not say that I have read them all, but I have gone through them. And all through those letters, or frequently through them, there are references made to this Grout bill. Never in the fifteen years that I have been in the publishing business have I known of any question that created so much interest among the farmers as this question lias, and they have gotten to the point when-

The Acting Chairman. Your farmers in New York are largely dairymen, are they not?

Mr. Dillon. Well, there are large dairy interests there.

The acting Chamian. Yon do not feed cattle to any extent?

Mr. DILlon. Not for beef: no, sir.

The ACIING CimAIRMAN. That is what I mean.

Mr. DilloN. No; not very mueh. But of course I hear from farmers ontside of the State, and they are very much in earnest about this bill, and they are not asking anything nureasonable. Back of all of their arguments and their talk is the fact that they do not want anything mmeasonable. They are perfectly willing that oleomargarine shonld stand on its own merits. But they do not want it sold as butter. They do not want to stand that mujust, dishonest competition.

That is all that we ask of this committee and all that we ask of Congress in this matter-to protect us, to protect our trade-mark. Let us sell butter for what it is, and let them sell oleomargarine for what it is. They can give it any other color they wish, so long as they leave us butter.

Mr. Tillinghast. I muderstood yon to say, in some part of your argmment, that it was your opinion that it conld not be sold white. Am I correct?

IIr. JILLON. It is my opinion, sir, that there are very, very few people who will want to eat it if they know what it is. If it is made white, they will probably know what it is, and then they will not want it.

Mr. Tillingmast. Then you believe that this act wonld be entirely prohibitive?

Mr. Dillon (after a panse). Well, we are willing to let this art work ont its own course. We du not ask its enactment for the purpose of prohibiting the mannfaeture of oleomargarine; but we ask it simply as the only means that we have been able to devise to prevent the oleomargarine interests from imitating our jroduct and selling their cheap product as our genuine prolluct.

Mr. Tillinghast. And yet you admit that your laws in New York are so thoroughly enforced that ouly the small amount of 200,000 pounds is sold in your entire State in one year?

Mr. DiLlox. Well, only that mnch that we know about. The part that comes in that we don't know about we are mnable to estimate.

Mr. TillingHAST. There is no oleomargarine manufactured that the Goverụment does not know abont.

Mr. Dillon. Still it is manufactured, and it goes into other States. How much goes into New Jersey? How mneh goes into Ohio? How 
much goes into Illinois? How much goes into the Southeru States? Now, the butter of all these States which is displaced by oleomargariue comes into competition with the New York product just exactly the same as if the oleomargarine itself were sold in New York.

Mr. 'Thloinghast. Oh, no.

Mr. 1)II.LON. I say that it is the fact, beeause there is more TVestern butter cousumed in New York City than there is State butter.

Mr. JELkE. Then the only interest that you have in this question is the protection of the New York dairy interest?

Mr. DILlon. The only interest that I have is to protect butter from a dishonest competition; and it is the interest of the dairyment thronghont this whole country and throughout every State in the Union. I do not contine myself to New York State at all.

Mr. Tillinguast. Do you think the price of butter would be any higher if oleomargarine were out of the ray?

Mr. Dillon. I know that there are facilities in this country for making all the butter at a reasonable price that is required, and that question does not ent any figure liere, anyway, to my mind. I beliere, and I know from my familiarity with the farming and dairy sections of this country, that we could make double the amount of butter that is made here to day. But that is not what I am argning abont. I want to confine myself right to that one point. I do not want to have you make your inferior product to imitate mine and sell it as mine.

Mr. Tillingmast. But you have no objection to my selling it for what it is?

Mr. Dillon. Not at all; not at all.

Mr. Tillinghast. That is the way three-quarters of it is sold.

Mr. RoYcE. Well, we are after the other quarter. Mr. Chailman, if there is any more time now I would just like to occupy two or three minutes. I rill not be much longer than that. I have not much to say, in fact I believe there is not much to be said on this question, anyway.

\section{STATEMENT OF C. H. ROYCE, ESQ., OF NEW YORK.}

Mr. Royce. My name, Mr. Chairman, is C. H. Royce. I believe I am a representative farmer. I was brought up within a few miles of this gentleman here [Mr. Dillon]. We went to school together, and while I am a farmer now, he is an editor, and that is the only respect in which we differ.

I am engaged in making a faucy grade of butter; a butter that sells to our eustomers for over half a dollar a pound net to us. And I want to say to you right here and now that I believe that the manufacture and sale of oleomargarine as butter interferes with the sale of our grade of lutter at 55 cents a pound.

Mr. TILlinghast. Then it is a good thing.

[Langliter.]

Mr. Rorce. That may appeal to you, sir; but there are plenty of men in this comntry who are perfectly willing to lay down that amount, or more, for hutter which they consider to be worth the price.

Now, I want to say one thing that I believe is true, and in which I think you will agree with me, that we have the better right to use the yellow color for our butter than have the oleomargarine manufacturers, becanse if the Almighty had any designs or plans in reference to this thing at all, it was that a c'ow, given June grass, would make a certain color of butter, and that that should be her trade-mark or copyright forever. 
Now, as has been sairl here before, the only thing that we as producers of butter hope to do and want to do is to have a law, which sliall be operative throughout the whole conntry, which shall allow us to sell our butter as such, aud prohibit anybody from selling something elso as butter.

Now, theonly thing that these gentlemen arecontenuing for is the color. Why are they conteuding for it? Simply beeanse they know that that is the only method whereby they mav be able to put their product on the market as butter. If there is an element in this country who want to use oleomargarine-and I am satisfied that there is; I am not sure that I would not use it if I were in the position of some men -if they want to nse it as sirch, we have no objection to their being allowed to do it. If they are satisfied that it is a wholesome, healthful product, let them use it as such. But let us protect those who do not want to use it, either as such or as butter.

Now, I get aromud this country quite a good deal-not so much as some men, but still consilerably-and the guestion that is asked me is this: "Hlow are you able to detect oleomargarine that is not marked ?"

In our section of the comntry there are very few people who want to use oleomargarine. They want to use butter. And we hope, in the interest of our trade in owr own State, in all the States arljoining it, and in all the States of this comtry, and in fact of the whole world, that nobody will be allowerl to foist off on the credulous public a prouluct which, while it may be pure and wholesome, imitates and is sold for our product.

Mr. Chairman, that is all I have to say on this subject.

Mr. Tillinghast. Will the gentleman permit a question?

Mr. RoYck. Ask all the questions you wish.

Mr. Tullinghast. I wonld like to have you explain to the committee, if yon ean, how this bill would in any sense protect you from competition with butter at 50 cents per pound?

Mr. Rorce. Simply in this way, sir: I sell you butter at 50 cents a ponnd; the next man to you buys creamery butter at 30 cents a pound; the next man buys creamery bitter at 25 cents a pound, and the next man buys oleomargarine at 15 cents a pound. Now, if I move away the man who is buying oleomargarine-that is, bnying it for butter, I mean-

Mr. JELKE. He buys it at 15 cents a pound, yon say?

Mr. Royce. Supposing that he does. If I remove him, then the man who will conusme my butter is one nearer me, isn't he. Is not that logical?

Mr. Tillingmast. But how conld you remove that man when there is a temptation of his getting .0 cents a pound for his product by paying a 10-cent tax on it? In other words, have you any other protection under this bill than your own State laws?

Mr. RoycE. But we need a law which operates in other States as our law operates in our State.

Mr. Tuluinguast. But this law can not operate in other States as your law does. Yon understand that, do you not?

Mr. Royce. I thiuk it will have that effect, simply because people will not use the stuff if it is sold as such.

Mr. Tillinginast. But this law does uot have anything to do with that. This law permits you to sell colored oleomargarine just the same as before.

Mr. Royce. Most assuredly. I agree to that, sir. I want to say that it is my honest conviction that it interferes with us only inasmuch as it is sold for what it is not-for our product. 
Mr. Dillon. My friend, the tronble with you is just the trouble with that-

Mr. Tilmingrists. There is no trouble with me.

Mr. Dillon. Well, then, the trouble with that dealer to whom I referred when I was in the field. Now, yon tempt the dealer by a little profit of 8 cents a pound to violate the laws of the State, and to sell this product for what it is not. We come in now with this 10-cent tax, and we remove that temptation from the dealer, and then you can not bribe him in that way.

Mr. Tillinghast. Well, you would not remove the temptation to sell it as butter at 35 and 40 cents a pound, would you?

Mr. Dillon. We are talking abont the average product of butter.

The Acting Chamian. Gentlemen, I think we will take a recess here until the regular time.

(The committee therempon took a recess until 2.30 o'clock p. m.)

At the expiration of the recess the committee resumed its session.

Mr. Scrielt. Mr. Uhairman, I would like to state that I have from my client, Mr. Seither, of Cleveland, Ohio, a list of 1,083 consumers who buy direct from the factory. They want to enter their protest of record, and he has sent the names to put iu. There is no use of encumberiug the record, but I ean furnish their letters, if necessary.

Senator Allex. You may condense it in such form as you want and omit the list of names.

Mr. SCHELL. I will just let a note be taken of the number of consumers who wish to go on record as opposed to this bill from this one particular locality.

Senator AlLEN. Are you ready to proceed, Mr. Davis?

Mr. DAvis. Mr. Jelke, who represents one of the Chicago industries, desires to be heard by the committee, and suggests that perhaps as my argument is to be of a legal charaeter almost exclusively the committee might prefer to hear him first and let me follow him this afternoon.

Mr. JeLkE. My address will be short. It will not take much time.

Senator ALLEN. I do not think it makes very much difference who comes first. Just condense your argument as much as possible.

Mr. JELKE. I will try to do so. I shall perhaps find it somewhat difficult to make myself clearly uuderstood in a matter that is of vital importance to me without these memoranda. I am altogether a man of cletail.

STATEMENT OF JOHN F. JELKE, REPRESENTING BRAUN \& FITTS, OF CHICAGO, ILI.

Senator ALLEN. You may give your name and place of residence, Mr. Jelke.

Mr. JeLke. John F. Jelke, vice-president of Braun \& Fitts, Chicago.

Senator ALLEN. What is their business?

Mr. JELKE. Maunfacturers of oleomargarine.

Senator AlleN. You may proceed.

Mr. JELKE. I am a manufacturer of oleomargarine, and represent a lifetime of eftort in building up a business which is in the same line of progress that all other improvements and developments have been that have become necessary by the increasing population of the world. All progress, in whatever line, has been stubboruly fought and hindered by individuals and associations, who, through selfish motives, opjosed what ultimately turned out to be for the benefit of the large majority. For instance, there was an antifast mail party in England in the time 
of Charles the Second, and the King and council were petitioned to decree that 10 public coach should be permitterl to liave more than foul horses, to start oftener than once a week, nor to go more than 30 miles a lay. Macanlay's comments on this historical record reads like prophesy. We smile at these things he said and predicter. It is not impossible that onr descenclants when they real of the hostility offered by cupidity and prejuclice to the impovements of the nimeteenth century may smile in their turn.

At the ontset let me make myself thoronghly understood on one point, and that is, I an not here to try in any way to lisconrage legitimate legislation nor any legislation that will result in the identilieation to the comsumer of oleomargarine as oleomargarine. Sinch legislation will have my learty approval and moral support. But with great emplasis 1 object to class legislation, or legislation on any subject that favors one individual at the expense ol another. If the Grout bill, which I am here to oppose, becomes a law, the result will be the absolute annihilation of a legitimate industry. The olject of this bill is to prohibit and exterminate the sale of olemalgarine, and not to regulate it. A tax of 10 cents per ponud womld plare oleomargarine at an average mrie per yomel orey that of the hest creamery butter for six mouths in every year. The (iront bill is urged by its friends as a protection to the dairy interests. It has not been shown that it is for the benefit of the large consmming chass of the comntry, nor what is expedient, $n o 0^{\circ}$ what is wise in the way of legislation to protect the interests of the larwe majority of the people living muler the protection of the Constitution of the United States. The reduction of tax on uncolored oleomargarine is only a subterfige, the fianers of the bill knowing in their hearts that sueh a product wall not be sole. The guise muler which it attacks the oleomargarine interest is that of frand, and I am opposerl to fiaud in every shape whatever. But becanse one individual may prefer his butter white and another prefer his butter vellow it does not mean that the one who prefins the vellow butter is deframied when his taste is catered to in soucthing that his sight malies palatable in his eress.

Nothing can be pleasing to the palate and satisfactory to the digestive organs that is not first good to look upon. Nature has provided harmless coloring inatters for this purpose, and, by miversal custom, it has been deemed desirable to have a gencrally yellow tint to butter. Oleomargaine, which in foreign comntries is abbreviated to the word "margarinc" (and which I believe would be well tor this committee to consider in any legislation that might ocemr, inasmuch as the word "oleomargarine" has thirteen letters and superstitious people believe that is the one hodoo that has followed this business thus fiar), is a natural, wholesome, and economical substitute for butter in every sense. I do not believe that a single member of this honorable committee believes that oleomargarine is more or less wholesome with or without an infin. itesimal aniount of coloring matter, such as is used by the mannfacturers of butter, nor that any single ingreilient that enters into the production of oleomargarine is more or less wholesome than butter, and particularly to what is the average quality of commercial butter. It has been urged that the price of butter has been kept down by the production and sale of oleomargarine. Is that a hardship to the wage earner and the consumer who, in the colder sections of the United States, require a fatty, heat-producing food?

In the far North of this continent the Eskimo consumes whale blubber and tallow for the purpose of maintaining a warmth in their 
bodies to oftiset the outside cold. It is not uneommon that a bride of an Eskimo receive as a briclal present a box of tallow eandles. If oleomargarine does keep down the price of butter why do we not have an export ontlet for a large surplus of our butter? The development of the butter business of foreign countries is continually expanding and growing, yet our exports are less than before so much oleomargane legislation was enacted, and within the last two years butter has been retmoned from London to New York because the price was higher in the United states than in England. The I nited States-the weatest agricultural country on the globe-bringing back butter from Eugland, all on acconnt of the high price in this conitiy, manipulated by the dairy mion. If we can not produce butter of a quality and at a price that will supply the demand of Europe with our prodnet is it right to urge any legislation that will inclease the price of a necessary food product to the cousmmers of our own country?

If the dairy muion will look to thejr own business with the idea of increasing the commercial greatuess of the United States they will sturly to improre the quality of their butter and reduce the cost of maninfactue so they may suecessfully compete with any romutry that seuds butter into England or otler foreign nations. Totwithstanding the enormons sale of butter in England, England is one of the largest consumels of malgaline. In this comnection I would say that not a single comntry in kinrope, not even England with her war expenses, has deemed it alvisable to place a tax. on oleomargarine. The United States alone has burdened its people with a tax on a necessary food product, the greatest burlen of the tax now imposed under the Fedelal law now existing falling on the retail clealers.

It has been urged by the friends of the Gront bill that the retail dealer is the principal violator of the law in selling oleomargarine. If this is so it is becunse he is abused and his rights as a citizen of the United States minustly intertered with by an ontrageous tax.

Just think, $\$ 48$ per anmum for selling oleomargarine. The tax on food being greater than on whisky. Is it not an vutrage that a little corner grocer has to either pay this exorbitant tax or supply his patrons with a eheap quality of butter at a high price? Will the increase of the tax to 10 cents per pound on oleomargarine stop all framds in the sales of butter and protect the consumer from getting rancid, impme, and nuwholesome butter at high prices? Hoes the Dairymen's Union expect to increase the prestige of the United States among nations by stunting the growth of the oleomargarine industry, or do they rlesire to increase manufactures and industries by eularging the outlet for all agricultural products of the United States? Remember that every article entering into the proluction of oleomargarine originates and is a product of the finus.

We, as manufacturers, have always recognized tue fict that oleomargarine in itself loas sufficient merit to stand on its own bottom for what it is-a substitute for butter; but at the same time oleomargarine must not be robbed of one of the ingredients that is absolntely the same as is contained in butter, and which adds the first recommendation to its palatableness-that of pleasing the siglit. We have always sold and advertised our product and endeavored to elucate the consumer to the use of our brands of oleomargarine as oleomargarine, evicleneed by the statements of the Chicago daily papers, herewith presented.

These statements are from the lending Chicago newspapers. I will not weary you with reading them, but I would like to have them entered in the record. I will simply call off the names of the news. 
papers: The Chicago Record, the Chicago Daily News, the Inter Ocean, Chicago; the Chicago Tribune, the Cbicago Journal, the Illinois Staats-Zeitung, Chicago; the Chicago Times-Herall, the Chicago Evening Post, aud the Chicago Chronicle. It might be well for me to read one of these.

The Acting Uhamman. You might make a brief statement as to what they contain.

Mr. JELKE. These statements all go to show that Braun \& Fitts advertise their goods as oleomargarine under their brand. They want the goods sold as oleomargarine with their name on them. We believe that by presenting our goods to the consumer we can not only increase our business, but by onr superior knowledge and by our attention to detail of mannfacture in every way we believe we can remain what we are now, the largest mannfacturers of oleomargarine in the United States.

The above statements are as follows:

DeCEMBER 19, 1900.

GENTLEnen: Referring to four communication of recent date, we would say that during the past two years we have published a number of advertisements of your oleomargarine in the Chicago Record and Daily News. These advertisements have stated plainly that your prodnct-Holstein oleomargarine - is put up in packages and every package is plainly marked.

Very truly, yours,

VICTOR F. LAWSON.

Messrs. Braun \& FitTs,

187 No. Union St., Chicago.

THE INTER-OCEAN,

Chicago, Deccmber 18, 1900.

GEN'TLEMEN : In reply to your letter of inquiry wonkl say that you have advertised with us quite a little your "oleomargarine." The packages have been plainly marked and the advertisement so specified.

Yours, respectfully,

Messrs. Braun \& Fit's, City.

Fredk. C. Pierce, Advertising Manager.

The Chicago Tribune,

Chicago, December 18, 1900.

To whom it may concern: This is to certify that Messrs. Braun \& Fitts, 187 North Union street, Chicago, have during the past three or four years extensively advertised their Holstein brand of oleomargarine in the Chicago Tribune, in which the statement was made that every package is plainly marked.

Respectfully,

Tribune Company, HugH W. MonTGOMeRY, Business Manager. 
Chicago Journal,

Chicago, December 1\%, 1900.

DEAR SIRs: In compliance with your request we are pleased to state that the Chicago Journal has been favorerl with your business during the past three years, running your advertisements of Holstein oleomargarine. The last order was for 55 lines, to be run Mondays and Wednesdays, ending April 30, 1900.

We attach copy of your advertisement herewith.

Very truly, yours,

Messrs. Braun \& Fit'ss.

Joseph H. Boотh, Publisher.

Nutritious, delicious, economical.

BRAUN \& FITTS'S

HOLSTEIN.

The only high grade

OLEOMARGARINE.

Every package plainly marked.

OFFick of Illinois S'TAA'T-ZEITUNG Co.,

Chicago, December 19, 1900.

GeNTLEMEN : In reply to your inquiry we beg to state that our files show that you have advertised for some time an article under the name of oleomargarine, and further that the advertisement stated every package was plainly marked as such.

Yours, respectfully,

Illinois StaAts Zeitung Co., E. G. WALLE, Receirer.

Messrs. Braun \& Fit'ts, Chicago.

Bу Рнil H. DiLG, Manager.

The Chicago Thies-Herald,

Chicago, December 19, 1900.

GENTLEMEN: $\Delta$ t your request we are pleased to certify that you have published your Holstein brand as "oleomargarine" in the columns of the Times-Herald.

Yours, very truly,

Grant Pierce, Business Manager.

Messrs. Braun \& Fitts, Chicago.

The Chicago Evening Postr,

Chicago, December 19, 1900.

GentLenen: At your request we are pleased to certify that you have published your Holstein brand as "oleomargarine" in the columns of the Post.

Yours, very truly,

Gerald Pierce, Business Manager.

Messris. Braun \& Fitts, Chicago, Ill.

S. Rep. $2043-25$ 


\title{
Tire Chicago Chronicle, Chicago, Decemlier 19, 1900.
}

To whom it muy concern:

Messrs. Braun \& Fitts, of Chicago, mannfacturers of high-grade oleomargarine, have advertised their product excensively in the Chroniele for several years. Be it said to their eredit and honor that they have advertised the exact article which they mannfacture, under its proper name. There has been no deception in their advertising, and they have given the public exactly what they claimed to do in their advertising, so that anyone buying their arlvertisen prodnet did so with the full knowledge of the charaeter of the goods he would receive.

Yours, truly,

H. W. Seymour, Pullisher.

Lester L. Jones, Business Manager.

Mr. JELKE. In connection herewith we present some of our printed wrappers, which go direct to the consumer wrapped around the oleomargarine. The word "Oleomargarine" is conspicuonsly placerl, and I will say that the sale of our Holstein brand would make probably 25 per cent of our entire business.

The wrapper referred to, which was handed to members of the committee for examination; is as follows:

\author{
BracN \& FitTs, \\ the only high grade \\ HOLSTEIN. \\ Trade-mark. \\ OLEOMARGARINE
}

Mr. JELKE. We also put up many other brands. Here is one that we put up for one of the retail dealers in oleomargarine.

The wrapper above referred to, which was handed to members of the committee for examination, is as follows:

\author{
W. G. Putwan's \\ 222-2?4 South Adums St. \\ "PEERLESS." \\ Strictly High Grade. \\ CHURNED BY BRAUN \& FITTS. \\ OLEOMARGARINE.
}

Mr. JELKE. The reason the ink is put on in this manner is because it is almost impossible-Mr. Knight will understand this-to get these inks that will not blur if they are put on in a heavier way; and when it is wrapped around the butter it brings ont these points very prominently. This parchment paper does not take the ink well.

We pnt up very many brands similarly branded with the word "Oleomargarine" in as large type as the largest letter on the brand, and, as a rule, not less than a one-half inch letter. The reason we do not put up all our goods in the same manner is because many of the 
retailers object to advertising a manufacturer, and it is absolntely necessary, according to the internal-revenue regulations, that the manufiacturer put his name on in connection with the wold oleomargarine in connection with any wrapper he uses. Some of the retailers object. Then, again, in certain sections of the country people have been accustomed to buying their butter or oleomargarine in cloth, and it we put the ink on the choth it goes throngh and stains the butter.

The honorable Commissioner of Internal Revenue, (ieorge W. Wilson (now deceased), planly stated before the House Agricultural Committee that in his judgment not 5 per cent of the oleomargarine manufactured is illegally sold, and I believe his statements were made according to the facts in the case. Gentlemen, can this be sait of butter, or of vinegar, spices, baking powder, and oue hundred other food products, all of which are not only mixed and adulterated, but in a harmfinl manner? Butter, for instance, as shown by patents in the Enited States Patent Oflice, is not only adulterated with harmless ingredients, but with poisonoms ingrenlients. I wonld herewith eall attention to some of the patents that liave been issued by the United States Patent Office on the subject of improrement in the manufacture of butter, in the process of treating butter, in the process of making butter, and for increasing the yield of butter from milk.

I will not take the time of the committee in reading the full specifications. I will simply submit them and call attention to a few little remarks like that that I have penciled.

Senator Allen. What is the substance? You have one of them there. What patent is that?

Mr. JELKE. That is a specitication of a process of treating butterLetters Patent No. jo5137, dated September 19, 1893.

Senator AlLEN. What is the process of treatment?

Mr.JELKE. This is one of the improvements. I will read it and the others.

3. The process of improving butter which consists in remoring the solid impurities therefrom and treating the residne with an air blast, an alkaline solntion, and then washing in pnre water aided loy an air blast, maintaining the mixture in a liquid state by heat during the operation, substantially as set forth.

[Process of treating butter. Sperification forming part of Letters Patent No. 327636. ilated October 6, 1885. Application tiled August 17, 1885. Serial No.174671. No specimeus.]

To each gallon of milk nsed I add certain ingredients, in abont the proportions named, as follows: One gallon of milk, 1 teaspoontul of white wine rennet, 1 teaspoouful of sugar, 1 teaspoonful of salt, one-finth teaspoonful bicarbonate of sola, 5 grains of bicarbonate potassium, 10 grains of alum, 4 pounds of wood hutter. These ingredients, in about the proportions herein stated, are placed in a churn of any usual or clesired construction, and agitated in the usual manner, and the butter will be prodnced in much less time than usual, and all the solid natter withdrawn from the flnid, leaving only a thin water as a residue.

[Process of making butter. Specification forming part of Letters Patent No. 3350s4, dated January 26,1836. Application filed Angust 5, 1855. Sorial No. 173674. No specimens.]

1. An improvement in the art of making butter, which consists in mixing 1 gallon of sweet milk witl 1 ounce of liquid reunet. "25 grails (troy) of nitrate of potash, 1 ounce gramulated sugar, half teaspoonful of hutter coloring, and 8 pounds of butter, chnrued together and workerl, in the manner substantially as describer.

[Improvement in the manufarture of bntter. Specification forming part of Letters l'atent No. 70417. dater Norember 5,1867 ; anterlated October 29, 1867.1

To 1 gallon of swect milk is added 8 pounds (avoirnupois) of bntter, 1 ounce of loaf sugir, 20 grains (tros) of nitrate of potisli, 1 lluid ounce of liguid rennet, and 10 grains (troy) of annetto. These are mixerl and chmrued tourether in the same manner as cream in the common process of making butter. After the butter is separated from the milk by tle process of chnruingr, it is gathererl and worked in the usual manner. The chemicals and butter added to the milk cause a speeds sepuari- 
tion of the hutter globules from it, causing it to yield all or nearly all that it. eontains' and producing au article of good quality aud flavor. The ammetto simply gives the butter a vellowish color, and having heretofore heen used tor a similar purpose no claim is made to it separately considered.

[Process of treating butter. Speeificatiun forming pirt of Lelters I'aten ${ }^{2}$ No. 253820, dated February 14, 1882. Application filed Norember 17, 1881. No specimens.]

Ve take, sar, about 100 pounds of rancidl lutter and melt it in a suitalile vessel. To this we adi "ibont 30 pounds of vegetable oil, preferably the erude or the refined cottou-seed oil, for "cutting" the butter and to ficilitate tiltration, and after leing thoronghly stirred the mixture is filtered throngh homeblack or animal charcoal. After filtration the mixture is run off into a settling tank and allowerl to cool. but still in a lipuin state, when the coloring matter is added, and alout 20 pounds of fresh, swert, and tinely flavmed ilairy butter adled to the mixtme for the purpose of flavoring the same. After the mixture has heen eolored and tlavored as deseribed, broken ice is put iuto the tank with the mixture and all stirrerl together, and when partly congealed salt is adled to suit the taste. When in a proper condition for packing and scoring, the bntter is transferred to suitable vessels of the desired sizes, and is then ready for sale, trinsportation, and use, and will stand any and all changes of climate without deterioration in quality.

[Componn for inereasing the yield of butter from milk. Specification forming part of Letters Patent No. 489775, dated January 10, 1893 . Application tiled June 7, 1892. Serial No. 435915. No specimells.]

The compound consists of the followiug ingredients: Sixty grains of pepsin, 125 graius of pulverizerl gum aralie, $3 \frac{2}{2}$ onnees of powdered alum. These ingrealients are thoronglily mixed and kept tightly stopped in a linttle, to be nserl before the milk is churued. The ingredients when mixed in the aloove proportions are mixed with the milk before it is chnrnerl, ahout from 1 to 3 teaspoonfuls to a quart of milk, a ceording to the richness of the milk.

The alum sonrs the milk, the pepsin rigests or separates the cream globules from the milk, and the gum arahie collects the glolules and canses tliem to stick together.

by uning the above compound with milk before it is churned the yield of butter therefrom is yreatly increased and the churning thereof facilitated.

\section{Senator Dolliver. Are those patents in use, "r are they simply patents?}

Mr. JELKE. These are patents, and the first one I read is, I nnderstand, the process under which most process butter, this impure butter that has been discussed before the committee, is handled. In connection with that it would be well, according to my standpoint as an oleo manufacturer as well as an experienced dealer in butter, that processes for the manipulation of butter should be investigated before any legislation is enacterl.

Oleomargarine has been for the last fourteen years the subject of the most careful scrutiny and inspection on the part of the InternalRevenue Department of the United States. Before passing an opinion on the merits of the Gront bill, wonld it not be desirable to inform the public on the so-called processes for treating butter, and call for an investigation by your servants (the Internal-Reveuue Department) as to the manner and methorl of treating so called pure butter? I know positively that the developments wonld be such as would astound the publie: that the most rancid, impure, and unwholesome butter is rechurned, revamped, and made into a presentable article by the use of chemicals and drugs of various kinds, some of which are absolutely poisonous, and that the principal backers of the Grout bill are the makers of this vile concoction known as process or reboiled butter. The ereamery men and makers of pure butter in the United States have nothing to fear. It is only the speculators and manipulators of the rancid butter that is unfit for food who have anything to cover up. Why would it not be to the interest of the consumer, as well as to the interest of the maker of pure putter, to impose a tax on all butter that was artificially colored after leaving the farm, or all butter colored with mythl, orange, or coal tar derivatives? 
I desire to call attention to some of the proceedings during the consideration of the present internal-revenue regulation in the Senate of the United States. This is from Mr. Ingalls:

Mr. INrals.s. I hold in my hand a vial of "Wells, Richarlson of Co.'s perfected butter color," which, the euvelope assures us, "gives to white bntter a beantitinl danclelion color; price, 25 cents," anil, as a commentary on the sngerestions manle by the Senator from Iermont this afternoon that this bill was intended to prevent one man trom cheating assother, I will state that this preparation pretenls to be manufactnred by "Wells, Richardson it Co., proprietors, Burlington, Vt." [Langliter.]

Opren this enil.

Keep the

bottle

in this box at all times

to protect from

the

action of the light-

says the label. This vial, so the manufacturer's assure us, put uj) in Burlington, Vt. [langhter], for dairy purposes, is-

\section{Warranted to color \\ 300 lbs. \\ winter butter.}

"In using onr perfected butter color it must be borue in mind that no two dairies will often require the same amonnt of color. C'ows ferl on poor hay. and kept with only ordinary eare, will make whiter butter than when well caled for and fed on tine hay and grain; also young cows give loss color than old.

"Different seasons alio malie much difference. Care should be taken," say these friends of the lairyuen, "to get just the right amount, and never overcolor.

"Coloring butter vicely is an art, and one mnst expect to learn something by practuce anil experience. Cantion!"-In large letters with an interjection point after it-"This preparation is nade by a process entirely new and original with us. No other process can proiluce so pure and harmless nor so nniform and roliable a color, and consumers should be careful to use ouly the genuine, which is always put up in bottles, and each bottle in a box bearingour dandelion trade-mark. Bewareof preparations sold in bulk or nnder similar names, for you will find them but poor imitations.'

This is somewhat protracter, but the advice to the dairymen of Anerica is so important and they have been presenterl in the light of a loug suffering class of afthicted people, engagen in their bucolic honesty in Vermont and elsewhere in a struggle with the hercnlean ettorts of the manufacturers of oleomargarine to put a spurions article on the narket, that I feel that perhaps the Senate will bear with me, aul the senator from south Carolina also, while 1 contimue to give the country information as to the inethols in which butter color is proparenl aud the purposes for which it is employtod.

Mr. Butler. I shail be delighted.

Mr. INGALLs. "We take pleisure in offering to the dairymen of America "-not to the oleomargarine men-"this preparation as the perfect result of our long-continned experiments in the preparation of au artiticial color for their use. In our perfected butter color we have succeeded in combining the sane bright-yullow coloring principle fonnd in the dandelion blossom with our previonsly well-known "Golrlen Extract," -

Now notive this-

"thereby securing a bright golden tint so exactly like the highest grade of Jersey butter that no expert can letect it [laughter], even by actual comparisou of the artificial color with the natural.

"We clain for it every point wanted in a perfect butter color, namely:

"First. l'erfect color. The butter never turus to a redlish tinge, but al ways keeps the bright golıen color.

"Necoml. Perfect freeilom from any taste or smell that can be imparterl to the butter.

"Third. Perfect keeping qualities. It does not mold, sour, or spoil ill any way. Heat or cold have no effect on it."

It is apparently one of the unchangeable elements of nature-

"It has in clecicled teudency to preserve butter, whereas butter colored with carrots, annatto, etc., will often spoil"-

Notwithstamling the statement of the Senator from Now York, who is supposerl to be an expert in these matters-

"will often spoil or turn to a lull rerldish tint.

"Fourth- 
And here comes the wut of this whole nutter. Thr Seuate is now ahont to learn why this butter color is used, the purpose for which it is employed, the reasons why it is put unto the market, and why these innocent, mosoplisticated conntrymen in the valleys of the streams of New England, that have nu kuowledge whatever of the plumet, whose prodncts have berome syuonsmons with purity and excellencewhy it is that mannfirtories turn out burrels of butter color, and why it is, as the Senator from New lork says, "from time immemorial, wo long that the menory of man rumeth not back to the contrary," the innocent dairyuan has colored his butter.

"lompth. Perfect economs in nse. It repuires no labor, as it is a fluid that is put ju with the cream in the churn. It is cheaper than any other coloring, being put up in three sizes, selling at 25 cents, 50 cents, aud $\$ 1$ cach, which color, les]ectively, 300,750 , and 2,000 pounds of butter."

1 almost liesitate to read the last paragraph:

"We warrant it to add at least 5 cents per pound to the value of white butter, a returu of $\$ 1$ tor every cent it costs."

In connection with this, I ean say that I recommend Wells, Riehardson \& Co.'s butter color as a first-class color.

Mi. KNignT. I thought so.

Mr. JELKE. It is a very good color.

Senator ALLEN. What is the composition of the color?

Ml. JELKE. I do not know; but if you desire, I can write to Wells, Rivhardson \& Co. for it.

Senator HEI'IFELD. I do not think they will give it away.

Senator A LLex. I did not know but that it had been analyzed and that you had the analysis.

IIr. JELKE. No; we have never had it analyzed. Wells, liehardson \& Co. are a reliable firm, and they guaranter the color to be pure and harmless. I think probably the chairman will bear me ont in the fact that Wells, lichardson \& Co. are a reputable concern.

There is a sincere need for legislation against process, renovated, and boiled butter.

The reports of the Internal-Revenue Department will show that by fal the largest number of complaints made by consumers liave been on samples of so-called pure butter that they were deceived into bnying, believing it to be fresh-made creamery butter, which was in reality nothing more than this remixed stufi. I repeat, have the Juternal. Rereme Department investigate the dairy and process hutter manufacturem before leciding wh wat is best, most wise, and expedient in this legislation. The Grout bill is cleverly drawn. It purports to increase the tax on the well-known commercial oleomargarine to 10 cents per pomm, and at the same time the promoters of this legislation say that 3.2 States prohibit the sale of colored oleomargarine. Yet the bill also provides that coloped oleomargarine becomes amenable to the State law as soon as it crosses the bonndary of these States. How many States do the buttel dealers expect us to sell colored oleomargarine in? If they helieve we can sell umcolored uleomargarine, give us just one year to try, by reducing the tax on uncolored oleomargarine to onefourth of a cent per pound, as proposed in the Grout bill, leaving the tax on colored oleomargarine at 2 cents jer pound.

If you pass the Grout bill to more effectually idlentify the goods to the cousumer, add to it the provisions of the Wadsworth bill, viz:

Provided, That when snch packages are parked in prints, bricks, rolls, or lumps, the word "Olenmararine" shall he impressed in sunken letters, the size to be preseribed by the Commissiomer of Intemal lievene and apjored by the secretary of the Treasury, on all prints, bricks, rolls, and lumps so packed.

We rant our goods known to the purchaser, but rechristen the child and call the gooks margarine.

'Then your eommittee, the Honse of Representatives, and the Senate of the United States can plainly see what the adrantage is in having 
an article pleasing to the sight. By increasing the sale of mcolored oleomargarine the farmer loses nothing, because he stands his share of the burdensome tax that is now imposed. He gets that, much less for the prodncts that enter into the production of oleomargarine.

Ex-President Clevelaud, in August, 1856, stated in lis message to Congress:

It has been nrged that while purporting to be legislation for revenue its real purpose is to destros, by the use of the taxing power, one industry of our people for the protection ajd benefit of another. If entitled to indulge in such a suspicion as a basis of official action in this case, and if entirely satisfier that the consequeuces indicater would ensue, I should doubtless feel constrainerl to interpose Executive dissent.

T'his was on a tax of 2 centsper pound on commercial oleomargarine, and if such a levy imposerl raised a question of class legislation, what about a tax of 10 cents per pound? If it is fair to erush our industry, if it is fair to the population of this country to deprive them of what they want, if it is fair to enhance the price of butter in favor of the butter speculators at the expense of those in ordinary eircumstances, then it is right to pass this bill; but I believe if the Grout bill becomes a law the day will come when every man who goes on record in this legislation as favoring this destructive measure will be called mpon to express themselves in further legislation of the same character, viz, to relegate to the States their police power, and to tax one class at the expense of another. I would snggest that a commission be appointed, made up of experienced business men, together with oflicers of the Interual-Revenue Department, together with representatives of organized labor, to frame a law that will identify oleomargarine to the consumer; at the same time investigate the butter maker, particularly the process-butter maker, and have a bill introduced in the next session of Congress, and it will have our hearty approval and support.

Anything to islentify oleomargarine as oleomargarine. Protect the consumer, but do not rob oleomargarine of one of its first qualities.

Senator Proctor. What was your extract from President Cleveland. Was it a veto message?

Mr. JELKE. No, sir; it was when he signed the bill. He did not veto the bill.

Senator Proctor. But sent a special message?

Mr. JELKE. Yes, sir.

Senator Proctor. I notice that you do not all plonounce this word the same. How is it prononnced?

Mr. JELKF. In Europe, it is everywhere ealled "margarine," with the hard "g." In Germany I bave been 11 the principal factories, and in Holland; and, by the way, in hoth Germany and Holland there are single manufacturers who produce as much oleomargarine as all the manufacturers of oleomargarine in the United States.

Senator Allen. The standard dictionaries give it as "oleomargarine," with the hard "g."

Senat or DOLLIVER. Is the number of oleomargarine factories increasing in the United States?

Mr. Jelke. Yes, sir: they have been increasing recently. In Germany they have increased to a wonderful extent. In fact, in the old eity of Nuremberg there are two margarine factories. I visited one of them.

Gentlemen, I thank you very much for your attention. 


\section{STATEMENT OF MR. HENRY E. DAVIS.}

Mr. Davis. Mr. Chairman and gentlemen of the committee, I would not have tronbled you with appearing before you were it not that my relation to this question is peculiar, growing out of the fact that I represent the only concern engaged in this industry or interested in it over which the Congress of the United States has direct and exclusive jurisdiction. There is no oleomargarine factory in any Territory of the United States. There is an oleomargarine factory in process of erection here by the Standard Butterine Company, which is a company organized with a capital of $\$ 1,(100,000$ and which has started the erection of a building to cost $\$ 300,000$, which, if it goes into operation, will employ several bundred persons, who it is estimated will have depending upon them, including themselves, a population of 1,500 people right in the District of Columbia, within the shadow of this Capitol-almost within the shadow, and surely within sight of the Capitol.

In presenting the interests of this concern to your attention, it will of course be necessary for me to say something a little outside of the special establishment itself, but I have read with a great deal of care and interest the entire proceedings before the House Committee on Agriculture, and I have also read so much of the proceedings before this committee as have been accessible to me, including the very able and thorough argument of Judge Springer. As a result, I will spare the committee a great deal that I had intended to say, because the ground has been to an extent occupied before me. But there are certain considerations that I have failerl to observe as having been brought to the attention of the committee. aud it is to get these before the com. mittee principally that I have asked this privilege.

This bill, as you know quite by heart, is entitled "A bill to make oleomargarine and other imitation dairy prodncts subject to the laws of the State or Territory in which they are transported, and to change the tax on oleomargarine."

The first section of the bill provides that when oleomargarine or any similar product shall arrive in a State from another it shall be subject to the police power of the State in which it arrives, just as any other similar product within the State itself, with a proviso, to the peculiarity of which I wish to ask your attention-

that nothing in this act shall be construed to permit any Stat" to forbid the manufacture or sale of oleomargarine in a separate and distinct form and in such manner as will apprise the consuuer of its real character, free from coloration or ingrediout that canses it to look like butter.

I shall presently call your attention to the fact that that proviso by implication anthorizes every State in this Union to forbid the sale of colored oleomargarine, even though the color be due to an ingredient of the oleomargarine, which in the case of cotton-seed oil is unavoida. ble. The next section of the act simply provides for a cliange in the tax as to oleomargarine, making it one.tourth of a cent per ponnd when the same is not colored, and when it is colored then it is to pay 10 cents.

I submit, gentlemen, that the first section of this bill can not be defended upon the ground that it intends to submit oleomargarine to the taxing powers of the States for revenue purposes, for it is not open to argument that a State has such power as to an article of interstate commerce. The only taxing power which a State has as to such articles-that is, articles of interstate commerce-is to make laws imposing taxes to the extent of what may be absolutely necessary for executing its inspection laws; and even as to those, the net profits of 
all duties and imposts laid by any State on exports or imports shall be for the use of the Treasmy of the United States, and all such laws shall be subject to the revision and control of Congress. That is a provision of the eighth article of the Constitution of the United States.

So that it ronld uselessly consume your time and waste words to add to the statement that a State has no power of taxation upon any article of interstate commerce, except such as is involved in an inspection, and the net proceeds of all taxes laid for such purposes belong to the United States.

The section can not be defended upon that gromnd, nor can it be defended upon the ground that it involves a delegation by Congress to the states uf any portion of the police power, for a double reason. In the first place, it Congress has the police power, it can not delegate it, and, in the second plice, it has no police power as respects the States.

Senator ALikn. Let me ask you a question there.

Mr. Davis. Yes, sir.

Senator Allen. Did not the Supreme Court in the Iowa liquor cases hold that Cougress could delegate the power?

Mr. DAvis. I an coming to that, senator. I love that in mind and I want to point out what seems to have been overlooked in all this discussion as to that very question. I say, in the first place, Congress can noc delegate any power, and in those cases to which you refer, and which I will come to presently, the conrt vinclicates its conclusions by a distinct declaration that the act of Congress does not involve such a delegation, as I will show you.

This tirst reason-that is, that Congress ean not delegate the police power, assuming it to have it-is aptly illustrated by the cases citerl by Mr. Justice Shiras in his dissenting opinion, concurred in by Chief Justice Fuller and Justice Mchenna, in the case of Vance $r$. W. A. Vandercook Company, No. 1, in 170 U. S., 43s, and notably in the case of Stoutenburgh $v$. Henning, which is in 129 U. S., 141.

'That case came up from the District of Columbia and involved this proposition. 'The Constitution of the United States, in this same eighth article, gives Congress exclusive jurisdiction over such territory as should be selected for the seat of government, that is to say, the District of Columbia, and Congress enacted a law creating a Territorial form of government, providing for a legislature and giving the legisla. ture general legislative powers. The Supreme Court said that a certain law of the local legislature, although it was within the guant of Congress, according to the laugnage of the act of Congress, was void, because Congress had undertaken to delegate something that the Constitution conmitted to itself, and that therefore this local legislation, although within the line of the grant of Congress, was meonstitutional and roid.

Now, in this very same opinion, this dissenting opinion to which first I want to call attention-that is, the dissenting opinion of Justice Sluiras in Vance $r$. The W A. Vandercook Company-Justice Slin'as convincingly maintains that Congress can not delegate to a State any of its powers over interstate commerce and points ont-and this comes to your question, Senator Allen-what is as yet manswered, that in none of the precerling cases flecided by the Supreme Court was this question necessary to be decided, or, in fict, rlecided, for the reason that intoxicating liquors, from their very nature, were conceded to threaten the public safety, the public morals, and the public liealth, to which matters the police power extends, and that as to such articles the right of self protection in the States was obvious and proper to be preserved. 
I doubt if there is a parallel to these decisions in the whole of the reports of the Supreme Cont of the United States, a case in which the monthpiece of the cont in the main opinion-that is, the South Carolina case following the lowa case to which you refer-in which the montlpjece of the cont in the main opinion in a subsequent dissent protested to his fellows that they did not mean to say what they claim in their subsequent majority was the effect of the decision, and jroclaiming that had that been the intention of the court at the time he would have been on the dissenting sinle instead of on the majority side.

Senator Dolliver. But in the Iowa case the court hinted at that legislation, and Congress followed the hint of the cont and did conmit to the States an absolute control over original packages of liquor.

Mr. MA VIS. That is exactly what I am considering now.

Senator IOLLIVER. Has the validity of that act of Congress ever been brought into dispute?

Mr. DAvis. That is exactly the point to which I am arddressing myself, Senator Dolliver. In the case of Scott $v$. Donald (165 U. S., 58), in general terms, withont qualification, speaking of the intoxicatingliquors law, the Supreme Court did decide that that was a constitutional exercise of the powers of C'ongress. That was the first of the dispensary cases from Sontl Carolina. Judge Shiras delivered the opinion in that case. In a subsequent case, when the court songht to make it appear that that was a broad decision as to the validity of that act of Congress, so as to make it applicable to all subjects of interstate commerce, he protested that that was not the meaning of the decision; that it never was in his mind to say so when he delirered the opinion, and I am going to quote you his words to show you that he distinguishes that case very clearly and shows that what the court meant to say was that in respect to such a thing as intoxicating liquors it was a valid exercise of the constitutional jowers of Congress, but that as to any other wholesome subject of eommerce Congress had no right so to do. I will reacl you his words in a few moments, and that is the point, if I may say so, which has not been observed in any of the discussions, either before the other committee or before this one; and to me it presents the real point in connection with the consideration of the question of the constitutionality of this section.

In support of Jurge Shiras's opinion in the later case, he quotes from the initial case, this case of Scott $x$. Donald, in the superne Court of the [nited States, under that act of $18 ! 10$. That is the act you speak of, Senator Dolliver, as having been passed on the hint of the decision in the Iowa case. This law subjects intoxicating liquors to the effect of State laws upon their arrival in the States. In that case Judge Shiras delivered the opinion himself, and, speaking of the original South Carolina dispensary law, which was then under consicleration, he said, in $165 \mathrm{U}$. S., 100:

It is not a law purporting to forbid the importation, mannfacture, sale, and use of intoxicating liquors as letrimentil to the welfare of the state and to the loalth of the inhabitants, and hence it is not within the scope and operation of the act of Congress of August, 18.9() . That law was not intended to confer npon any State the power to discriminate injuriously against the products of other states in articles whose manuficture and use are not forbidrlen, and which are therefore tho subjects of legitimate commerce.

He distinctly put his opinion, which was the majority opinion, in Scott $r$. Monald, "npon the proposition that the act of 1890 was confined in its operation to intoxicating liquors, because, to use the language of the conrt in another case, they are confessedly conducive to pamperism, idleness, and crime, and recognized as having such a tendency. 
You will olsserve that in this Scott $r$. Donald case the Supreme Court liad before it for consideration and ronstruction the act upon which the first section of this act is framed. It related to intoxieating liquos. Justice Shiras emphatically protests that he was confining himself in deeiding the case, which liarl been citerl as a precedent, to the fact that it was intoxicating liınors that were dealt with, and he said it was never intended to reach the manufarture and sale of articles the manufacture and sale of which were not injurious, and which were therefore the legitimate subject of commerce.

Now, in the Schollenberger case, which has alrearly been cited to you in $171 \mathrm{U}$. S.. the Supreme Court distinetly declared nleomargarine to be a healthful and nutritions article of fond and a proper subject of commerce, and in lis concurring opinion in the case of Mugler $v$. Kansas, $123 \mathrm{U}$. S., 623, at page 676 , Justice Field states this unanswerable proposition :

If one State can forbid the sale within its linits of an imported article, so mar all the States, each selecting a different article. There wonld then be little mnjformit of regnlations with respect to articles of foreign commerce carried into different States, and the same may also be said of regulations in respect to articles of interstate commerce, and we know it was one of the objects of the formation of the Federal Consfitution to secure miformity of commercial regulations araiust discriminating State legislatiou.

Mr. Justice Shiras, in this case I have already referred to, the case of Vance against the Vandercook Company, vigoronsly protests against any suggestion that in delivering the opinion of the romet in the ease of Scott $r$. Donald he was assenting to the validity of the aet of Angust S, 1890, as to all articles of commerce. I read you his exact words:

I am altogether unwilling to attribute to Congress an intention to ahandon the protection of interstate eommerce in articles of food or drink. Whether for persoual nse or for sale, where similar articles are treaterl by a state as lawfiul subjects of domestic commer'e. If surh were the intution of Congress in the act uf Ampust, 18!n). I shomlel he compelled to regard such legislation as invalid. Thle control and rewnlation of toreign and interstate commerce are among the most important powers possesserl ly" the Vational Legislature, and. as las often been sabl by this court, were among the most potent eanses which led to the estahlishment of the Constitntion. The conceded inpose of protecting commores from hostile action het ween the states wonld be defeated if Congress comld withliraw from the raeleise of its powers in such matters and turn them over to the legislatures of the States, but there is no reasom to suppose that Congress intencled any such art of alonegation in the present instance. Reasonable meaning and effect 'an loe given to the act of Angust 8, 1890, withont giring it sneb a enustruction as wonld rase the serious question of its constitutionality.

I have not time to read the rest of this opinion, but Indge Shiras goes into this aet over again, and he points ont how the act can be sustained withont any referenee to its enstitutionality, and he makes his vigorous protest against being comnted amoug those who at any time would be supposed to believe this act constitntional if it had reference to anything else but intoxicating liruors.

I commend this opinion to your most careful consideration. Of course in orlinary I would not cite from a dissenting opinion: but, as I say, this is a mique case. Here is a case in which the justire, delivering the opinion of the majority of the cont, finds that opinion turned to a meaning which he never entertained when delivering it, and in justice to his intelligence and his own constitutional views he puts his protest on record at the first opportunity.

Senator Dolliver. Who would be the judge whether the artiele interdicted was properly subject to the police nowers of the State in relation to public health? 
Mr. DAvis. I am very glaul you asked that question. I freely concerle that the State wonld; but I wish to ask your attention to the fact that Congress here is proposing to submit to the tender mercies of the States an article which the Supreme Conrt of the Uniter States has said that Congress itself has recognized as wholesome and nutritious and not a fit subject of prohibition. I will show you that to a demonstration I concede that the police power of the state can tonch articles of food, but it must tonch them for a reason.

Justice Peckham, delivering the opinion of the court in the Schollenbarger case, says, in effect:

Congress has, by the act of 1886 , recognizon this as a fit subject of commerce. We say, as the suplene Court of this land, as matter of judicial notice, withont any witness having appeared before us, that this article is wholesome and mutritions, and that stays the hand of the United States from anthorizing the police power of any State to iutertere with it.

Mr. Dolliver. The legislation of 1886 , I suppose, is what the Supreme Conrt bases that statement on, that Congress has recognized the article as not a fit subject for the state to exercise the police power 11)

Mr. Davis. As a legitimate object of commerce; yes, sir.

Senator Dolliver. At the time, I recollect, that law was not supposerl to be a certiticate of high moral character.

Mr. DAVIS. That is exactly right; and I only regret that my time has not enabled me to unearth an extremely clever thing that was published in the Washington Post just the day after . Ir. Cleveland sigued this bill. It was a most interesting acconnt of a barnyard convention in the lot back of the White House. It described the sensations through which the President went as he listenerl to the cackle of the hens and the lowing of the cows and overheard their discussions and their threats of political punishment if he did not sign the oleomargariue bill. [Laughter.] It was intensely entertaining, but I did not have time to recover it.

You have come right to the point, Senator Dolliver, and I am coming back to it. I have that noted in the subseqnent part of my mem randum here, aud I am coming back to it, but I will stick a pin in it right now. The Supreme Court in that Schollenbarger case, speaking by Mr.Justice Peckhan, said, in effect:

There has not one wituess appearerl to testify abont the wholesomeness or the nutritionsuess of this article. There has not a witness appeared to tell us ahout the constituents of it, bnt we take julicial notice of the fict that it has been a known article of commerce for a quarter of a century. We take jullicial notice of the fact that in all the reports of the chemists, and in all reports of the rlepartments of arriculture of the States and of the United States, this thing has been prober, and we are bound to say, as the court of last resort and the highest judicial authority of this land, that the stamp of wholesomeness and of nutritionsness is on this article, and it is a fit subject of commerce.

Senator Dolliver. Do you mean that by the mere act of taxing it it puts a stamp of that kind on it?

Mr. Davis. No; I beg your pardon. You llo not take me, Senator. He did not say that. He said that the act of making it a source of revente recognizen it as a tit subject of commerce. Then he arlied: "Moreover, in arldition to that, we rlo take juclicial notice of the act that it is wholesome and nutritious."

Senator DOLLIVER. I believe that same opinion was givell by one justice on the subject of tobacco the other day.

Mr. DAVIs. No; that was a speech in the House of Representatives by Hon. Peter J. Otey. 
Senator Dolliver. No; I think Ml. Justice Harlan made the same proposition in the cigarette case.

Mr. 1)avis. I am perfectly ready to arlmit that.

Senator DoLLIVER. In other words, I want to get at how fiar the act of $18 \delta 6$ conclutes Congress upon the question of wholesomeness.

Mr. I)A Vis. Excuse me, sir; I do not say it does. I leave that altogether. I care nothing about it. What I do say is this, that the power that has the largest office in declaring the law of this lancl, namely, the Supreme Comrt of the Tnited States, has said that this is an article that ought not to be touched by the police power becunse it is wholesome and nutritions; that it onglit not to be given over.

Senator Doluiver. That was in the mature, then, of mere admonitory advice to the legislatures of the States.

Senator ALı.en. Is not that carrying the doctrine of judicial notice to quite an extent?

Mr. DAvis. I can only answer you by saying, Senator, that they have carried it to that extent; and until the Supreme Court changes its view that stands as its opinion in regard to the wholesomeness of this article.

Senator Dollivei. Does not the principle you have stated collide with the proposition that the State is the supreme judge of the welfare and convenience of its inhabitants as regards the exercising of its police power?

Mr. Davis. On the contrary, Justice Shiras said that in delivering that main opinion he thought he was guarding that very proposition. I am very glad of this interruption, because it gives me a clance to refer to the matter twice. Inasunch as the Supreme conrt of the United States has said that this is a wholesome and a nutritions article of food, it will not lie in the mouth of the legislative branch of the Govermment to throw the glove in the face of the Supreme Court and say, "Hele, we are going to pass laws subjecting to exclusion from the States the very thing that you say is wholesome and nutritious or to subject it to unreasonable regulations in the States;" and I submit that this committee will not revommend to the Senate of the United States that it put itself into the position of being rebuked by the Supreme Court of the United States.

Senator DoLhIVER. We want to avoid that, and yet we do not want to be constrained by the opinions of the court on a question of law.

Mr. MAvis. I recognize the distinction between the legislature and the judiciary, I take it, quite fully; but in the subsequent part of this memorandum I make the suggestion that when we are making law we are entitled to take into acconnt those considerations which we might not take into account after a law has been placed noon the statute bonks, for then we look at the letter of it.

Senator ALLEN. I do not know that I am wholly prepared to accept the doctrine that the Supreme Court can bind the legislative department of the Government in determining the desirability or the qualification of any food product. In other words, is it not a legislative question rather than a judicial one?

Mr. Davis. May I put a question to you in return, Yankee fashion, if Senator Proctor will excuse me?

Senator AlleN. Yes, sir.

Mr. Davis. What would you think of any legislature attempting to regulate the size and shape of hats? I say that the legislature has no more right to deal with this subject of oleomargarine, except within the limits of the Constitution-that is, to inspect it and see that it is pure 
when it comes into the State-than it has to pass a law requiring every man who crosses the State to rear a plug hat.

Senator ALLEN. Suppose there was something entering into the eomposition of the hat which was deleterious, which would make it injurious, or suppose it was believed to be so, to the extent that the legislative department shonld pass a law that that material should not be used in a hat. Is not that a legislative question"

Mr. DAvis. I grant it. That is not this case. Nobody says that oleomargarine coloring is deleterious.

Senator Alckn. It seems to me it covers this case pretty closely.

Mr. DAVIs. I grant your that a State has the right to pass any inspeetion law to see that articles that contain deleterions substances are not imposed upon its citizens; but beyond that it has not the right to go. I agree with the gentlemen here who are willing to have this sub. stitnte bill pass. Pass the most stringent inspection laws you please, but let us sell oleomargarine as oleomirgarine, and do not tell us that we can not sell it at all.

Mr. KNoGH'. Will you pardon an interruption?

Mr. I a vis. Certainly.

Mr. KNrghT. I think I can throw a good deal of light on the decision in the Solonllenbarger case.

Mr. Davis. Excuse me. It you are going into that, I decline to be interinpted. I thought you wanterl to ask me a question, and I am prepared to answer that.

Mr. KNIGHT. I will ask you a question, then.

Mr. Davis. What is it?

Mr. KNIGHT. What was the Schollenbarger case?

Mr. DAvis. An original package case.

Mr. KNIGH'l. What kind of oleomargarine was it, colored or uncolored?

Mr. Davis. It is immaterial whether it was colored or moolored.

Mr. KNIGHT. I think it is quite material.

Mr. Davis. Excuse me. The Supreme Court decision was point blank that the Pennsylvania law which had been previonsly sustained in the Powell case, so far as it affecterl interstate commerce and oleomargarine in the original package, was an invasion of the iuterstatecommerce powers of Congress, and therefore to that extent unconstitutional. It does not make any difference whether it was colored or uncolored. Their decision flatly was that an attempt to deal with oleomargarine coming from an outsicle state in an original package was an invasion of the constitutional powers of Congress.

Mr. KNight. But did not the Scholleubarger case distinguish between colored and uncolored margarine?

Mr. DAvis. No, sir; it did not, and you gentlemen have but to read that opinion to see that it is a plump decision against that much of the Pennsylvania law as interferer with oleomargarine in original packages. Since then Pennsylvania has cluanged its law. It no longer prevents the manufacture of oleonargarine; and it only prohibits the manufacture of oleomargarine that is colored or contains ingredients making it look like butter. I had the pleasure of defeuding a number of gentlemen engaged in this enterprise in the western part of Pennsylvamia last fall, aud the very intelligent judge who presided ruled to the jury that if the coloring was incident to an ingredient that entered into it, that provision of the Pennsylvania law was inconsistent with itself, mreasonable, and not to be observed, and the men were acquitted; as they should have been.

Mr. KNigint. How about the upper courts? 
Mr. Davis. It could not go to the upper courts. The men were acruitted.

Mr. KNigit. Has not that question been decided in some other case in Pennsylvania in the uppel comsts?

Mr. DAvis. Not that 1 know. It had not been deciderl, mufortunately for me, last September when I was ont there.

In aldition, althongh it is not essential to the argument, I want to say this: Assume that you have the power to pass this law, the first section of this act. I do say it wonld be a most unwise and a most unjust exercise of the legislative power. It would be nuwise for the reasons that have been so finlly stated by Iustice Shiras and onstice Field; aud the Supreme Contt reports are alight with observations of the same kind. Assume a man in the State of Virginia to make oleo. margarine. If this bill becomes a law, he has to run the chances of 44 varying sets of regulations in order to get that into the commerce of the United States. He not only has to deal with the sister State of Marylaud aud the sister State of Kentucky, or of Tennessee, but he has to reckon with Pennsylvania, and New York, and the Western States, or the far Sonthern States; and it is a prohibition of the manufacture of oleomargarine by sleer necessity, for the man who makes oleomargarine will have to know the regulations of every State, which are the subject of constant change. He has to know the laws of every State, which are the subject of constant change; and he may shape his ruterprise to-day for next spring's market, only to find that that market has been destroyed by a legislature that has sat in the meantime. It is most muise legislation. It is most mupractical legislation. It is most impracticable legislation. Not only is it unwise, but it is unjust. It is grossly unjust.

I perhaps speak with a little more warmth abont this than is essential to the argument; but I have been engaged in rejresenting these interests for a number of years. I have seen this industry growalthough I have had nothing to do with it except as a lawyer-I bave seen from time to time the extension of the industry; I have seen the prejudice agaiust this artiele when it was at its leight, and I am happy to say that I have seen its gradual disappearance, until presently the man who votes for this oleomargarine bill, if he lives long enough, will be able to say what the late Senator Harris said of himself when the bill was before Congress to give Morse the money to build a telegraph line from Baltimore to Washington. Senator Harris said: "Why, I wonld just as soon think of voting the Government money to open communication with the moon?" He always said, in after life, that he did not like anyborly to remind him of that fact. But when this prejudice shall have entirely passed away, some of us who are discussing this subject will wonder at the feeling that has been got up over it.

Now, apart from its being unwise, as I say, it is mnjust. Here are, throughout this country, numberless factories making this product and putting it on the market. Hundreds of thousands of dollars are invested in the enterprise. Thonsands on thonsands of men are employed. Tens of thonsands of families are supported by it. This industry is turning out a product that the poor man wants-not only wants, but is anxious to have-that he knows is wholesome and nutritious. He dloes not want to be deprived of it, and there is no reason that be should be deprived of it, it having the stamp of the leading chemists of the world and of the highest legal tribnnal of the world as to its wholesomeness and nutritiousuess. 
But this belongs a little farther down, more properly, and I will pass from that to the second main proposition that I wish to lay before you, and that is that Congress has no police power to delegate, and never did have. In the case of Rahrer, which is in 140 U. S., the Supreme Court disposes of that matter in a very few words at page 155:

It is not to be lonbted that the power to make the ordinary regulations of police remains with the incividual states and can not be assmed bj the National Governuent.

The clear and weighty language of Mr. Justice Catron in the license cases in 5 Howard, yuoted at some length at pages 5.57 to 559 of this Rahrer case, has already been read to you by Judge Springer, so I will not trouble you with it again; but I ask your special attention to the case of Plumley $r$. Massachusetts, which is the case upon which our friends, the enemy, principally rely as to the attitude of the Supreme Court. In that case the Supreme Court distinctly held, at page 471, that the grant to Congress of authority to regulate foreign and interstate commerce did not involve a surrender by the States of their police powers; and such has been the uniform holding of the Supreme Court as far back as Prigg $r$. The Commonwealth, 16 Peters, 529, which was decided at the January term, 1542, in which Mr. Jnstice Story, speaking for the entire court, says that the-

police power extends over all subjects within the territorial linits of the States, and has never been conceded to the United states.

So I say that not only can Congress not delegate any police power to a State, but also that it has not any to delegate. But just suppose, now, for the purposes of argument, that Congress has the power-and I am obliged to concede that as to my particular client Congress has the power in the District of Columbia-suppose that Congress has the full police power over the subject, I still contend that this bill, as to neither its first nor second sections, proposes an exercise of the police power.

That we may inquire into this, notwithstanding the title and langnage of the act, is too clear for argnment. I wish to real you from the lan. guage of the court, speaking by Mr. Justice Harlan, in the case of Mugler $v$. Kansas, 1:3 U. S., 623. I read first from page 661:

It belongs to that department [speaking of the Legislative Department] to exert what are known as the police powers of the State, anl to determine primarily what measures are appropriate or needful for the protection of the public morals, the public health, or the pmblic safety. It does not at all follow that every statute enaeted ostensibly for the promotion of these ends is to be accepted as a legitimate exertion of the police power of the State. There are limits beyond which legislation can not rightfully go.

\section{Then, a little farther down the page:}

The conrts are not bound by mere forms, nor are they to be misled by mere pretenses. They are at liberty, indeed are under a solemin duty, to look at the substance of things whenever they enter upon an inquiry whether the legislature has transeenced the liuits of its authority. If, therefole, a statute purporting to have been enacted to proteet the pululic health, the public morals, or the pulitic safety has no real or substantial relation to those objects, or is a palpable invasion of rights secured by a fundamental law, it is the duty of the courts to so adjudge and, therefore, give effect to the Constitution.

And in delivering this opinion the court quoted at large from cases in New York and a number of other States in which the identical langnage in some instances, and in others the substance of it, has been used. In any event, that is the clear langnage of the Supreme Court.

Again, on on page 663 of this same report, the opinion proceeds:

Undoubtedly the State, when providing by legislation for the protection of the public health, public morals, or the public safety, is subject to the parmonnt 
anthority of the Constitution of the United States aud may not violate rights secured or guaranted by that instrument, or interfere with the execntion of the powers confided to the Geueral Government.

Moreover, in the very late case of the United States $v$. Collins, in 171. U. S., to which also Judge Springer called your attention, the case in which the pink color law of New Hampshire was reclared unconstitutional as to oleomargarine, the supreme Court held that law unconstitutional because, in its own words:

"It was, in necessary effect, prohibitory"-not from its language, but in necessary effect prohibitory; and the court further declared that-

In whatever language a statute may be framed, its purpose must be determined by its naturil and reasonable eftect.

Now, as the Supreme Court says, and as the courts of this land without exception say, we have the right to look behind the language of an act to find what its meaning is and what its purpose. Let us see. In the first place, I say the title of this bill shows its purpose. Its title is "A bill to make oleomargarine and other imitation dairy products subject to the laws of the Stite or Territory into which they are transported, and to change the tax on oleomar.gariue."

It is the judgment of the highest court of this land, and it is the common knowledge of everybody who has ever given this subject as much as a day's attention, that oleomargarine is. not an imitation of butter; that it is a substitute for butter; confessedly so, professedly so, advertised as such, manufactured and sold as such. It is not an inuitation of butter. It is merely a wholesome and nutritious substitute for butter. So I say that this act starts out in its very title with a mis. description, which, whatever its purpose, laas the effect of discrediting this article and thereby putting a stigma upon its manufacture and use, which-clearly reveals the object of this bill.

In the next place, I say there is no pretense in this title of any object in changing the tax on oleomargarine. It is not described as a bill to increase or even to raise revenue, but only as a bill to change, for some unstated reason, which is the same as no reason, an existing tax.

And again, in neither the title nor the body of the bill is any reason given or even hinted at for the extraordinary action proposed by the Congress of the United States in singling out of the myriad of nutritious and wholesome products of the land a single class, which, by a coincidence, which of course is purely accidental, conflicts with the personal interests of the promoters of this bill.

Now, in ordinary, as I said a while ago, when a statute has become the law of the laud. is on the statute books, we can not go back to the debates of Congress or the arguments of counsel before coumittees, or the reports of committees, to find what the law means; but the Supreme Court says, notwithstanding, that you may probe a law and fund if it is honest in its declared purpose, and if not, and it onght not to stand, you may strike it down. Furthermore, while we are in the act of making law it is eminently proper that we should take due account of these considerations before oversight of them leads us into making objectionable and regretable laws.

I say, therefore, that we may look into this bill and we may find what it means; and we have the right to lo it notwithstanding its language. We have the right to clo it notwithstanding the interests that are back of it. We have the right to do it, and turn the search light of honest pmrpose on it and see what it is meant to do. I say that it has but one object, and that is to crush the oleomargarine inclustry; and whether

$$
\text { S. Rep. } 2043-26
$$


that is expressed or not, it is so plain that he who runs may read, and the Congress of the United States is now asked to pass a law to suppress and strike down an iudustry in which thousands on thousands of dollars are invested and which is supporting thonsands on thousands of people, in respect of an inclustry which the highest court in the land has set its approval upon as being wholesome and nutritious in its product.

Suppose you call this a bill to raise revenue or to increase revenue. It would not stand the scrutiny of a minute. Why? Because I would send to the document room and bring yon the pending bill to reduce the reveune, beeause you have too mnch of it. I would call to your attention the indubitable fact that if you want to collect revenue in the face of what these gentlemen have told you here you are going to eut off' revenue instead of collecting it, becanse you are going to put a tax on it so high that the manufacture will be stopped and your source of supply will be stopped.

I do not speak too strongly when I say that the object of this bill is perfectly plain to any man who can use his eyes and will indulge in a moment's reflection. It is not an honest bill in the sense that it means what it appears to show upon its face-that it is for the regulation of an industry. It is intended to destroy an industry; and I ask you if that be not so what is the meaning in this second section of this very great discrimination between colored and meolored oleomargarine.

You are doing what? You are putting this tax on colored oleomargarine, if you do it, only in order that the butter industry may not be trespassed upon. You are not doing it to collect revenues, because the higher the revenne you exact the less of it you collect. You are not doing it to prevent fraud, becanse the greater profit yon hold out to the man who commits fraud the more you tempt him to do it. Tested from every molal point of view, the bill will not staud a monent's scrutiny; and, as I have already said, this proviso that has been put in here, "Provilled, That nothing herein contained shall prevent the prohibition of the sale of oleomargarine that is in a separate and distinet form, and in such manner as will advise the consumer of its real character, free from coloration or ingredient that causes it to look like butter," enables the States, by implication, to forbid the manufucture of oleomargarine into which cotton-seed oil enters, because-I say this on my own responsibility, aud as a fact-when I was trying these cases in western Pennsylvania I demonstrated to the jury and to the court that the reason for the color in the product then under consideration was the use of cotton-seed oil, and they put upon the standI can not give you the name, but I can furnish it-the chemist of the Western University of Pennsylvania, who, under my cross-examination, admitted that to be true, that cotton-seed oil inevitably canses a yellowish color to the product.

If you pass this bill with that proviso, you destroy the manufacture of oleomargarine with cotton-seel oil throughout the United States. I know that by my own experience in trying these cases. It is a fact that I have not seen adverted to in any statements that have been made before either committee.

Senator Dolliver. On the contrary, Mr. Davis, the statements have been quite numerons here that the natural color of oleomargarine with cotton-seed oil was not the color of butter, but a white color.

Mr. DAvis. I will tell you that the State chemist, whose name I can furnish you, so stated under oath to me in the presence of that jury and trial judge.

Senator DoLliver. Then there has been a good deal of misinformation unloaded on us here. 
Mr. Davis. I can tell yon the name of the trial judge, the judge at Uniontown, Pa. He told the jury that if they believerl that was so they should acquit, and they did it.

Senator DoLlrver. That would not be conclusive.

Mr. DAvis. No; but he said so, and the jury found it as a fact that the coloring in that particular article which was said to be improperly colored was due to the cotton-seed oil in it, and that struck me when I read this bill. Yon are going to saly to the States, "WV give up our interstate-commerce regulations so far as this thing is concerned, but you nust not prohibit the manufacture and sale of oleomargarine that has not any ingredient in it that will make it look like butter." But the State of Pennsylvania has passed a law, and other States have passed laws, forbidding the manufacture and sale of oleomargarine that has any ingredient in it that makes it look like butter. That is as much as to say that while you forbid prohibition of the one kind you by implication permit the otler, and the State may suppress the manufacture of oleomargarine into which cotton-seed oil enters. It was entirely new to me.

Senator Dolliver. I do not think that the verdict of that jury should be taken as conclusive upon that point.

Mr. DAVis. No; I agree with you about that, becanse we know there are three things that Providence, it is said, can not foretell, and one of them is the verdict of a jury; but the State chemist so testified under the State's examination in part, and in part uncler mine.

Senator DoLlIVER. These cotton-seed oil men, who talked very intelligently to us yesterday, did not seem to have heard of that.

Mr. DAvis. Probably they have not heard of it. They do not know all about oleomargarine.

Mr. Schell. It is possible that the cotton seed oil contained color before it went into the oloemargarine.

Mr. DAvis. The chemist testified that he was familiar with the formula of oleomargarine; that he knew about the manufacture and all that sort of thing; that he himself was familiar with the ingredients. When I asked him about the formula according to which it was testified in this case this oleomargarine was made, one of the ingredients being cotton-seed oil, he had to admit that it would give it a jellowish, butterish color traceable only to the cotton-seed oil. But the point of it is, whether that be true or be not true, you are excepting the prohibition by the States of the manufacture of a certain lind of oleomargarine and leaving it open to them to suppress absolutely the manufacture of any other kind; and that is "neither fish, flesh, nor fowl, nor good red herriıg."

Then, furthermore, it is said in support of this bill that this coloring is put in for purposes of fraud. I am not going to take your time by going over the question of the coloring of butter. You have heard ail about that until probably you do not want to hear any more; but I protest that oleomargarine is not colored with fraudulent intent. I say that the reason oleomargarine is colored was given by MIr. Wilson, unfortunately now dead, when he was before the House committee. It is because the eye assists the palate in respect to palatability; and, as he said, the poor man has a right to have his eye tickled by the color of his butter just as well as the rich man; and I call your attention especially to what Professor Wiley, who has been so often misquoted about this matter, has to say on that subject, as reported on pages 190 and 191 of the proceedings before the House committee. He is a most intelligent man. I do not know whether he has been before this com- 
mittee or not. He needs no encomium from me. Professor Wiley is too well known the world over. Says he:

Now, the value of a food is measured solely by two standards. First, its palatibility; and second, its mutritive properties. You need not try to convince human beings that palatability is not an elenent in nutrition, because it is, and set yon get a great cleal more out of a food if it is palatable in its taste and attractive in its appearauce, bucause the attitucle of the digestive organs changes absolntely with the appearance of the food. If rom were to put hutter " p in the form of ink, it might he just as digestible, and all that, and pet it wonlil not he so useful as a food. The appealunce of the food has a great deal to clo with the attitule of the digestive organs tow aril it.

A Membr. It is simply a reaction from it?

Dr. Wilfy (continuing). Yes: becmuse the mind, the mental attitude, influences the secretion of the ferments which produce the digestion, and hence we must have soure regard to that appearance.

Senator DOLLIVER. Would you regard it is a inatter altogether free from criticism for a new business like the manufacture of oleomargarine to attempt to get the adrantage of the mental attitude that has been created toward butter throngh the centuries that it has been in use?

Mr. Davis. I will come to that with another quotation from Judge Peckham in a few minutes. You liave put in a mutshell the whole argument on the other side, that because a thing is first in the field it has the right to keep everything else out of the field, and I propose to show you that that has not the sanction of the highest court of this land.

Yhtilis

Now, I give another personal experience. I lave a number of farmer friends here within striking distance of Washington, among whom I spend a great deal of my time. One of them, a most prosperous farmer, for years was the maker of his own butter. Instead of making it now he furnishes it to a neighbor, because he finds it more profitable to sell his milk and cream than to take the time to churu, but the same cream comes back to him on his table as the same butter he has beeu eating since he was a boy, and that I have been eating at his table for years. The other day when 1 was at his table his good wife asked him, please, to caution the man to whom he was furnishing his cream to do the mixiug of the butter a little better, because, she said, "when it looks that way I can't eat it"-a perfectly natural experience. The very thing that had gowe from her own farm, and which she had been eating for years and years, was made into butter by exactly the same processes she had been used to, but it did not look like it, and so it was unpalatable. What Dr. Wiley says is a perfectly plain and intelligent remark, a perfectly sage remark. The appearance to the eye is a part of palatability. Tou hear people say they can not eat calf's brains because they make them think of certain things that are not altogether proper to mention to ears polite, especially in mixed company. And so with other articles of diet. The eye is offended and the palate rebels, and the object of putting this color into the butter is to avoid that. ,I will come presently to the other aspect of it.

Now then, it is said, in the next place, as to the coloring of butter, Why is it that we can not enforce the State laws? You have plenty State laws. Why are they not enforced? That is the reason we have to come to Congress. I want to ask our friends on the other side why they are not enforced? That is not for us to answer; it is for them to answer; but I will answer it. There are several reasons why those State laws are not enforced. 'The first reason is hecause they are unpopular; the second reason is because they are against the poor man; the third reason is because the public approval is not behind then, which is the same thing as to say they are not popular; and never 
since Solon himself could any law make its way in administration through a community that did not have the community back of it.

I was considering the proposition that is advanced on the other side, that the coloring of oleomargarine is for the purpose of fraud, and that the State laws are ineffectual to protect agaiust this fraud. I had called attention to the fact, as 1 bad believerl it to be a fact, that the coloring of oleomar garine is for the same reason that there is coloring of butter, namely, that it adrs to the palatability of the article. I had read from what Commissioner Wilson stated before the House committee, and what Prof. Wiley stated before the House committee, as to the "ye assisting the palate, and the mental attitude of the cousumer toward that which he was eating, and so on. I had passed on to point out the fact that complaint is made here that the State laws are ineffectual, and that the reason that they are ineffectual is that the public opinion is not behind them. They are not popular. The poor man feels that they are bearing unduly on him. He is being compelled to pay 25 cents for what he can get for 15 cents, and he does not see the reason $w h y$. It is an unpopular law. The public heart is not in it, and so long as that is true of any law it never will be enforced.

Referring to the matter of color, we are not driven to mere inference as to what is the object of this proposed legislation. The purpose of it is avowed. I have been following the proceedings of this committee, and I have observed that two or three gentlemen complained that they were misrepresented before the House committee. One gentleman, I believe, dicl claim that something was put into his mouth at a time when he said there was no stenographer there, and another gentleman corrects something that he is reported to have said. I an going to give another one an opportunity to correct and convict the stenographer. Mr. James Hewes, president of the Produce Exchange of Baltimoreand vice-president of the National Dairy Union of the State of Maryland, when he was before that committee on the 24 th day of last March, said in so many words, as he is reported, that the object of this legislation is " to tax that yellow color;" and in reply to an interruption, he wound u) by saying:

If you will put it under your elose supervision, such and such will be the result. We will give you a million aud a half dollars of revenue, and we ask you simply to act as policemen.

That is the appeal that the promoters of this bill are making to this committee and to the Congress of the United States, arowedly, leaving all the others out of the accomt. This man, who is at the head of the produce exchange in Baltimole and the vice-president of the National Dairy Union of the sitate of Maryland, comes before the House committee and avows that the object of this bill is to tax the yellow color and make the United States their policemen to see that the butter industry is not invaded.

Now, a plainer, more open appeal for class legislation I never heard. A plainer, more open appeal for the violation of all the fundamental principles of our institutions, by giving protection to one local industry over another local industry, I never heard: and I say, apart from what is to be got here by reading this law and analyzing it, we have here the avowed purpose, which is to suppress this industry and to tax the color, as they say.

Now, in reply to your question, Senator Dolliver, about the color, whether the butterine men or oleomargarine men have any right to appropriate what the buttermen having been using for so long. I have read these proceedings before the House Committce on Agri- 
culture-I do not know how far they have been repeated before this committee-and I call your attention to the fact that it is demonstrated by the testimony of all concerned that artificial coloring was an invention of the oleomargarine men; that is, in the manner in which it is now done. It is true that butter, at one time and another, took on this color, and carrots and the like were resorted to to give the winter butter something of the appearance of summer butter. It yet remained, however, for the discoverers of oleomargarine aud its promoters to give rise to this standard butter color which is now in general use, so that if there is any borrowing, the buttermen have done the borrowing.

Senator DoLLIVER. They borrowed the ingredients, but I doubt if it may be said they borrowed the color.

Mr. DAVIS. They did not borrow the principle of trying to make butter in winter look like what it was not. They are the initial sinners, I will concede, so far as that is concerned; but they could not do it. They did not have the natural means at hand, and they did not know how to do it, and it remained for the oleomargarine men to show them how to make butter look like what it was not in order that they might work it off on the public. Let us take our full share of blame-buttermen and oleomargarine men alike. I come back to the proposition by answering your question that the buttermen have no vested interest in color and that they never had, for while they were ou the way, if you please, to getting that device so well advauced as to be commercial, the oleomargarine men came upon the scene and made perfect what they were tinkering with; and if anyborly is entitled to the credit of being in the field first, and having his device protected, it is the manufacturer of oleomargarine.

But I go further and say that it makes no difference which was in the field first. The Congress of the United States has not any right to tax a color, which this bill asks them to do, and confessedly by your own question, your object is to protect the buttermen. If you say it is not, then I ask you what is the object? If the object is to prevent frand, I have answered it already. The people are not behiud this kind of legislation, and you can not administer it until they are and unless they are.

Senator Hansmougir. You say the people are not behind this legislation?

Mr. Davis. I say that is the reason the State laws are inefficientbecanse it is not popular.

Senator HANsinougH. Then why are not these State laws repealed, a portion of them? Instead of that there is an increased number.

Mr. DAvis. Do you want me to answer that question plainly and bluntly?

Senator Hansbrough. Yes.

Mr. DAvis. It is too much money. That is why they are not repealed. The dairy interest is too big.

Senator Hansbrough. Too much money on the butter side?

Mr. Davis. Yes; the butter side, and the butter trust; and the butter interests are too extensive to permit of a repeal of these laws, becanse you know better than I do, as you live in a State and are in polities, that the farmer or the laborer has not time to leave his work and go tagging after legislators.

Senator DoLlIVER. The farmers come mighty near it in some cases. [Laughter.]

Mr. DAvis. Yes; I know that abont certain times they are numerous, more than convenient altogether. But how do you account for the unanimons opposition of the federations of labor to this bill? 
Senator Doluiver. The federations of labor that I lave heard here tell a very curious story. They state that in western Pennsylvania, where the cases that you refer to were tried, invariably everybody who goes into these stores calls for butter and invariably gets oleomargarine; that there seems to be a sort of free masonry between the merchant and the customer.

Mr. DAvis. That is exactly in accord with what I am saying. It is the customer that will not let the law be enforced. It is exactly that; and I thank you for recalling that to me. These people go there and "wink the other eye." They want butterine and they ask for butter.

Senator Hansbrough. Is it not true that the companies' stores in the State of Pennsylvania prefer to sell oleomargarine for butter?

Mr. DAvis. I am not informed about that, sir.

Senator HANSBRoUGH. Because of the greater profit.

Mr. DAVIs. I am not informed on that point. That is a matter that can be settled. But what Senator Dolliver is talking about is not the companies' stores. He is talking about the stores that are scattered all throughout the western part of Pennsylvania, where a great deal of its product is sold. You have hit it exactly, and the man who told you that has hit it. The customers do not want this legislation made. They go and ask for butter, and, as I say, they wink their eye and they know they are going to get oleomargarine.

Mr. JELKE. If Senator Hansbrough will permit me, the company stores in Pennsylvania would like to handle oleomargarine, but they do not. They do not want to be annoyed with the regulations and the lawsuits; and I understand there is also a State tax upon retail dealers of $\$ 100$ in Pennsylvauia, $\$ 500$ for the wholesale dealer, and $\$ 1,000$ for a manufacturer, in addition to all this regulation of the internal revenue.

Mr. DAvis. Now, I do say that it is an open insult to the adminis. tration of justice in the States for men to come here before the senate of the United States and ask the Senate to make the United States act as policemen, because they can not get their own laws enforced by their own home people; and, notoriously, the States are more jealous of the enforcement of the United States laws than they are of laws of their own. This very appeal turus on itself and makes a demonstration that we can not hope to enforce a law like this, and that the more stringent your regulations are in point of money penalty the greater temptation you are holding out to frauds and violations of the law. It is not a matter of mere conjecture or opinion on my part.

Senator HANSBRoUgh. Of course, the States can not tax an article of commerce.

Mr. Davis. No. But, Senator, it is conceded by the men themselves that the States have enacted laws which are as yet untouched by any constitutional decision as to prohibiting the mannfacture and sale of colored oleomargarine, and yet they say it is being mannfactured and sold colored. You can not stop it. That is the point. You can not stop it. You call not stop it any more-as has been shown by the history of the world-than you can stop anything that the public is determined to have.

Seuator Dollrver. Do you not think the United States could not collect a tax of 10 cents a pound?

Mr. MAvis. What have these gentlemen told you about that? Have they not told you that the United States internal-revenue agents are not doing their duty?

Senator DoLLIVER. Is there any complaint that the 2-cent tax is not collected? 
Mr. DAvis. Plenty of it, but without foundation.

Senator HANSBROUGH. The advocates of oleomargarine here have said that the internal-revenue ofticers, in the matter of inspection at the several factories, are doing their duty. I myself very much question whether they do their whole duty.

Mr. DAVIs. Senator Hansbrough, read what Mr. Hewes says about the United States attorney in the eity of Baltimore. If he does not come right to the edge of accusing him of shutting his eyes I do not know the English language.

Senator Dolliver. I have rather understood these gentlemen to boast of their law-abiding disposition in respect to the present internalrevenue laws.

Mr. UAVIs. I tell you, sir, as was said before the House Committee, there are violations of this law. 'That is not to be denied. Nobody denies it, and the violations of this law are induced by the cousumers. They are perpetrated by the little dealers, and they can not be perpetrated without some sort of laxness.

Senator Dolliver. I notice that there is a factory proposed to be eapitalized in the district here for $\$ 1,000,000$.

Mi. Davis. Yes.

Senator Dolliver. I'ou do not believe, since these factories are large institutions, that they could escape the internal-revenue agents in the mere matter of the collection of the tax?

Mr. Davis. There is not a wholesaler in the country that escapes; not one. That is not the point. You get your tax all rignt. The violations are made in the sales, as they sily, under circumstances making oleomargarine a competitor with butter. Yon get the tax all right. The tax is paid at the factory. Nobody makes any eomplaint about that. They are law abiding, and the Internal Revenue Commissioners will tell you so. Their factories are open to inspection. They pay their tax, but they are not going to pay any 10 cents a pound and keep alive. I say you are going to invite a violation of the law where it never has been violated, and that is among the wholesalers, and you are going to invite a further violation down among the retailers, beeause the profit is so much greater when the tax is 10 cents and not paid. The profit is very much greater, and the temptation is very much greater.

But, gentlemen, I take these gentlemen on the other side, if I may use the term, on their own dunghill. What do they mean when they tell you these State laws are not enforced, and what do they mean when they say they want the United States to act as policemen? They must give some explanation of it. If these laws are on the books, why don't they repeal them, you say. What is the use of repealing them when they are as dead as Julius Cresar, and that is their own ery. Are they dead? There is only one of two answers. One is that there is a deliberato blinking at the violation of the law, and the other is that the public sentiment is too strong. How is your State anticolor law enforced in Iowa?

Senator Dolliver. I do not think there is much oleomargarine sold ont there, though probably-

Mr. DAvis. Yon have had a law on the books since 1873, and how many prosecutions have you heard of, or how many convictions have you heard of under it?

Senator Dolliyer. I think our State dairy commission ont there does not believe there is much sold of any color. Yon see we are in the heart of the butter belt.

Senator HEITFELD. I think there is a doeument giving the number of pounds sold in Iowa. 
Mr. DAvis. Yes; there is a statement of Judge Springer here, I believe, as to the quantity that is sold out there. There are three dealers, and there are 79,000 pounds sold.

Mr. JELKE. If Senator Dolliver will permit me, I will say that before the anticolor law was passed in Iowa there was quite a large business done; but we can not sell uncolored oleomargarine in Iowa, and there is a rigid enforcement of the law against colored oleomargarine there.

Mr. DoLliver. I never met anyone in Iowa who wanted to purchase the article, because there would be very little difference in the price there.

Mr. JELKE. I will say we have some customers who buy it for their owu use in some of the towns in Iowa.

Mr. DAvis. I will try to relieve the committee in a few minutes. I want to know if the United States officials are going to do any better for these people than the States' officials do, except in the one jarticular in which the United States can help; that is, the collection of the tax. If you say yes to that, and that that is the only way, you concerle at once that the object of this bill is to suppress the inclustry. There is no other outcome to it. I put it to you thus: If the laws restricting the fraudulent sale of oleomargarine can not be enforced by the States, they can not be enforced by the United States; and if for the reason that they are not enforced aud can not be enforced by the States this legislation is desired, its object exclusively is to reach above the State laws and above the laws which have merely to do with the fraudulent violation of the act and stop the sale and manufacture of oleomargarine; and I protest that Congress has no right to do that in the face of the decisions to which I have asked the attention of the committee.

As to your question a while ago about the color, which I bave already answered in part, I protest that no interest, no matter how long it has lived, has a right to protection against a newer and a better industry. It is the fate of all commerce and of all business that new things come in and push out the old; and it wonld be a most interesting thing, indeed, if Congress or a State legislature were to attempt to close down a shoe factory where shoes are made by machinery in order to save the village shoemaker. Why, I do not know of anything that has impressed me more in my life than the experience that I have been through, and that you have been through, and every man here of my years or older has been through, and that is the painful experience of. seeing the gradual destruction of the country village. I have gone through Maryland, around this city, all my life. I can recall one village after another through which as a boy I went and through which I have passed only lately. There was the village blacksmith, the village tinker, and the village carpenter, and the village tailor-name then all. Who is left? Only the village blacksmith, because as yet God in his providence has not endowed the human mind with sufficient intelligence to shoe a horse by machinery; but the carpenter is gone, because the manufacturers of doors, sashes, and blinds have taken his place. The tailor is gone, because the manufacturer of clothing and the sellers of them by wholesale have taken his place. The tinker is gone, for the same reason; and so through the list.

Now, what would have been thought of any man introdueing in his legislature a bill to suppress the manufacture of shoes at Lynn, Mass., because the village cobblers were going to be put out of business? That will not do. A very apt expression on that subject is to be found in the language of Mr. Justice Peckham, in the case of The United States $v$. The Freight Association, reported in $166 \mathrm{U}$. S. I read from page 323. This is one of the trust cases. The argument was pressed 
on the court that every trust in the country is an octopus, reaching out its tentacles aud strangling industries, and all that sort of busiuess; and after stating the business very plainly and bluntly, the court says this :

In any great and extender change in the manner or method of doing business it seems to be an inevitable necessity that distress and perhaps ruin shall be its accompaniment in regard to some of those who were engaged in the old methods. A change from stagecoaches and caual boats to railroals threw at once a large number of men out of employment; changes from hanil labor to that of machinery, and from operating machinery by hand to the application of steam for such purposes, leave behind them for the time a number of men who must seek other avenues of livelibood. These are misfortnnes which seem to be the necessary accompaniment of all great industrial changes. It takes time to effect a reudjustment of industrial life, so that those who are thrown ont of their old employment by reason of such changes as we have spoken of may find opportunities for labor in other departments than those to

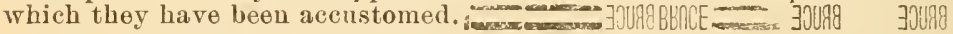

The same thing exactly is true of industries. When an industry comes in it takes the place of another. When the cotton seersucker was invented, the silk seersucker had to step aside. When the l'aisley shawl came into the market the camel's-hair shawl had to take a back seat. It is the same old story. It has been so ever since the beginning of industries. It is simply a repetition of the old ery that this wholesome and nutritious product, which is the poor man's butter, is to be kept out of the market and its manufacture to be suppressed because a part of that same market has been preempted by the butter men. I protest that that is not within the legislative power. Certainly it is not within the legislative wisdom, and I think it is not within its power at all.

So far as my particular clients are concerned-these people here in the District of Colnmbia-if you are going to put out your hands in exercise of the revenue power, say so: but you do not say so; this bill does not say so, and it does not pretend to say so, and it does not mean so, because, as I have already said, if you say that I will show you in a minute that you have more money than you can spend. You do not need this money. You are now engaged in the very act and effort of reducing the Government revenues. That is not what you want. If you say you are going to stop this particular industry bere, which will be the one most nearly affected, because you are exercising the police power, I ask you, Why? Is this thing detrimental to the public safety? That is one of the things that the police power has to do with. Is it detrimental to the public health? The Supreme Court tells you that it is not: the chemists the world over tell you that it is not. Is it detrimental to the public morals? How? The manufacturer here has to pay the tax like everybody else. And if you tell me, as these gentlemen say, that it is detrimental to the public morals in that it puts a temptation before a man to sell something for what it is not, I say to you in perfect earnestness that your increasing the tax is increasing that temptation instead of diminishing it, and instead of helping the public morals you are simply doing the oipposite.

Now, gentlemen, I am thankful to you for the very patient attention you have given to me. I have taken a longer time, perlıaps, than you thought was necessary, but I conld not be too earnest in my endeavor to get before you my attitude toward this matter. I conld not be too earmest in my endeavor to convince you, as I believe in my heart, that this is a very vicious piece of class legislation that is being attempted here. I do not believe it to be constitutional, for the reasons that I have stated. If it were constitutional I would believe it to be a very unwise act, and certainly a very mujust one; and with respect to the 
industry at large, and certainly with respect to this industry which I represent here, it means absolute destruction; and that neans not merely the forfeiture, the practical confiscation, of large sums of money, but also the deprivation of employment and means of support of thousands of people; and at the bottom of it all it means the denial to the poorer and the more moderate classes of an article of food that they want; that they have a right, before God and the laws of this land, to have, and from which they can not be kept except by what I am constrained to characterize as an abuse of legislative power.

I thank you very kindly.

Senator Dolliver. The committee is very much obliged to you for your statements, and to all others who have addressed the committee to-day, and if nothing further is to be suggested the committee will now adjourn.

Mr. DAvis. Senator, some meutiou was made about Mr. Tompkins. Mr. Jelke will state that.

Mr. JELKE. A gentlemen from Texas, Mr. Peters, came 1,500 miles to address the committee, and he thought he would be heard this afternoon; but on account of Mr. Davis and myself occupying the time he has gone, and he would like to be heard for a short time in the morning. Mr. Tompkins would also like to be heard.

Senator DoLLIVER. Let them report here in the morning and we will determine that question.

Senator HANSBRoUGH. Is it understood that the adrocates of the Grout bill are to occupy to-morrow?

Senator DoLcrver. I think that is the nuderstandiug.

Senator Hansbrough. And that the meetings will end then?

Mr. KNIGH'. 'That was the understanding with Senator Proctor.

Senator DoLLIVER. Will you require all of to-morrow?

Mr. KNight. Yes, sir; we certainly shall, and that will be very short.

Mr. Culberson. Mr. Tomplins wants to conclude what he started to say to the committee.

Senator DoLLIVER. That question may be determined to-morrow; but in the meantime it may be said that written arguments can be filed with the stenograplier and printed.

Senator HansBRougr. I nnderstand that the Secretary of Agriculture is to be before the committee to-morrow morning for a short time, and I make the suggestion that if this gentleman from Texas has any additional information to lay before the committee he might put it in writ. ing, because, as you unclerstand, there are only from two to three members of the committee present at any one time, and it will be necessary before we can consider this bill to have all the committee have these proceedings on their desks and examine them.

Mr. ScHell. The gentleman from Texas has not been before the committee at all. It was Mr. Tompkins who started his remarks and who did not finish.

Senator DoLliver. I think it wonld be well to advise Mr. Tompkins that he can liave leave to file a supplemental argument, as if it were delivered before the committee.

Senator HeiffELd. Are those the men who came here from Texas, whoun Senator Culberson spoke to the Chair about?

Mr. Culberson. Yes, sir; Mr. Peters is, 1 am quite sure.

Senator Her'fFed. They have come all the way from Texas on the assurance that they will be heard.

Senator Hansbrough. They have all been heard excejt one, as I understand. 
Mr. Culberson. Mr. Peters has not been heard at all.

Mr. KNIGHT. There were two gentlemen here who stayed almost a week, but did not have an opportnnity to be heard, and they have left their statements, which they ask to be filed.

Senator Dolliver. They may be tiled with the stenographer and printed with the proceedings.

The statements referred to are as follows:

Washington, D. C., January 5, 1901.

GENTLEMFN: I hereby respectfully request to be permitted to file with your honorable body, to be printed in the records, the indorsement of the Watertown Produce Exchange, of the State of New York, of the so-called "Grout bill." That boird, composed of a large num. ber of representative citizens of the State of New York, through me, as their delegate, request your honorable committee to report the said bill favorably, to the end that the frandulent practices now in vogue in the sale and use of oleomargarine by the retailers and its nse in hotels and restaurants fraudulently represented as butter may be stopped.

This board would not favor the bill if its only object were to drive competitors out of the market. It believes firmly in giving free scope to honest competition, but it believes that no fraud should be the vehicle or avenue of commerce whatsoever, and it therefore believes that this is a question worthy the notice of the Congress of the United States, and asks that your honorable body provide against such fraud by the enactment of this measure into a law.

$$
\text { Respectfully, }
$$

W. A. ROGERS.

\section{The Comyittee on Agriculture and Forestry}

of the United States Senate,

Washington, D. C.

Chatrian Commttee on Agriculture and Forestry, UNITED STATES SENATE,

Washington, D. C.

Mr. Chairman: On account of the pressure for time in your committee by those conducting the oleomargarine side of the questions involved in the Gront bill, I have been unable to be heard, although I have been present here for nearly a week. The press of business at home demants that I return. I therefore beg leave to lay this written communication before you, to the end that a few facts may be placed upon record relative to the attitude of the National Grange aud of the State Grange of the State of New York in the matter of the so-called "Grout bill."

It has been stated by those opposed to this bill that the farmers of this country are not interested in the measure and do not want it. The National Grange represents over three hundred thousand agriculturists of the United States, and the State Grange of the State of New York represents over sixty thousand, and yet both of these bodies, after due consideration of all the questions involved, passed resolutions indorsing the sail bill and requesting the Congress of the United States to enact it into a law.

I am master of the State Grange of the State of New York and a member of the executive and legislative committees of the National Grange, and come here in such official capacity as the representative of 
both these bodies to arge your committee in their interest to report favorably the said bill to the Senate of the United States for its consideration, withont amendment in any respect whatever.

The Granges of the United States, aside from any financial considerations in their own interest, beheve this bill shonld be enacted into a law, because they believe:

First. That oleomargarine is relatively, if not entirely, an unhealthy product; and

Second. That it is a fact so notorious as to need little argument that, while producers of oleomargarine in the first instance sell it for such, hardly a pound of it reaches the consumer under its true name and in its true guise. It is almost invariably sold as and for butter, and in the hotels, restaurants, and boarding honses where it is used it is always served as butter.

If this condition of things is allowed to continue the consuming public will be forced to use the commodity, whether they desire to do so or not. Plainly, this state of things wnght not to be. In the isterests of mutual integrity in commerce and justice between man and man these goods ought to be placed upon the market in such guise as that the consumer may be notified. in their appearance of their true nature.

Respectfully submitted.

\section{E. B. NoRRIs,}

Master of the State Grange of the State of Nen York.

Mr. ADAMS. I ask permission to file the statement of Governor Hoard at this time.

Senator Dolliver. That may be done.

The statement above referred to is as follows:

\section{STATEMENT OF W. D. HOARD.}

This law is demanded in the interest of a broad public policy, for the protection of legitimate industry against illegitimate counterfeiting and fraud. Compare the policy pursued by the United States with that of Canada. The Dominion government guards the purity and honesty of her dairy products to the extent of absolute prohibition of any adulteration or counterfeiting of the same. As a result her export of cheese to England alone has grown in twenty years from $\$ 3,0 \% 0,000$ to $\$ 20,000,000$, while ours has declined nearly the same amount, because we did not plạce the strong hand of the law on the adulterated product, filled cheese, until we had lost the confidence of the foreign consumer.

Denmark sells $\$ 30,(000,000$ of butter abroad annually. Do you think that Government would allow her commerce in butter to be endangered by the shipment to foreign consumers of a counterfeit butter? Not so. The Danish Government rigorously prohibits the exportation of oleomargarine. Here are two conspicuous examples of two nations who have guarded well the reputation of their dairy products and exports, and well have they thrived by it.

This law is needed in the interest of the promotion of honesty and fair dealing in our own home markets. This is a policy of taxing heavily a traffic which flourishes by deception. Two benefits will accrue to American society by the passage of this law. Cheating, both of the producer and consumer of butter, will be lessened, and the burden of taxation correspondingly shifted from the shoulders of honest and legitimate industry. It is time the Federal Government instituted a vigorous policy in this direction. It has no right to stand before the 
conscience of the people and excuse itself for not distinguishing between legitimate and illegitimate industry and enterprise in the burden of taxation which is laid. The Govermment has the power in this way to discourage wrongdoing and encourage honest industry, and the people will hold it responsible for the exercise of that power when the opportunity comes, as in the present case. I ask, can the Senate of the United State, can any Senator, afford to deny to the great dairy interests of this country this prayer for relief from competition with an acknowledged counterfeit and fraud?

The committee (at 5 o'clock p. m.) adjourned until Thursday, January 10,1901 , at 10.30 a. 11.

Commitee on Agriculture and Forestry, UNITED S'TATES SENATE, Washington, D. C., Junuary 10, 1901.

The committee met at $10.30 \mathrm{a} . \mathrm{m}$.

Present: Senators Proctor (chairman), Allen, Dolliver, and Money; also, Hon. William M. Springer, Charles Y. Knight, Mr. H. E. Adans, Mr. Schell, Mr. 'Tillinghast, Mr. Culberson, Mr. Miller, and others.

The Charrinan. The Secretary of Agriculture is here this morning, and we shall be glad now to have him proceed, if he will.

\section{STATEMENT OF HON. JAMES WILSON, SECRETARY OF AGRI. CULTURE.}

GENTLEMEN : In response to the courteous invitation of your chairman, I have the honor to submit the following comments upon the so-called "Grout bill," now under consideration by your" committee (being H. R. 3717, eutitled "An act to make oleomargarine and other imitation dairy products subject to the laws of the State or Territory into which they are transported, and to change the tax on oleomargarine").

From my examination of this bill and the attention I have been able to give it, I understand the proposition to be to apply the powers of the Goverument in regulating interstate commerce and taxation for the purpose of preventing connterleiting and fraud in an important article of food and for assisting the several States in the exercise of their police powers to the same end. This object of promoting and enforcing honesty and purity in food products has my full sympathy. It seems to furuish the main argument, and a sufficient one, for the euactment of the proposed law.

Although the act aproved August 2, 1886, has served well to identify oleomargarine and prevent deception on the part of merchants generally, it has not furnished adequate protection to producers and consumers. It must be admitted that for the latter State laws have been far more effective. In States which have not only stringent laws, but which have providerl efficient machinery, the element of fraud in butter and its substitutes has been reduced to a minimum. In all the States which have made earnest efforts to protect consumers the most serious obstacle has been the introduction of colored oleomargarine in original packages. Hence, I deem the first section of this bill of pressing importance. There ought to be no question of its propriety, expediency, and strict justice, and there seems to me every reason to believe that such a law will be most salutary in its result. 
The increase in the manufacture and sale of oleomargarine in this country during the past twenty years has been very rapid. The latest reports show a total produetion of $83,000,000$ pounds, and as only about $3,000,000$ pounds are exported, the domestic consumption is in excess of 1 pound per eapita, as against an estimated consumption of $1 S_{2}$ pounds of butter. These figures are in marked contrast with those of some foreign countries. For example, the per capita consumption per anuum in Great Britain is supposed to be $3 \frac{1}{2}$ pounds of oleomargarine, and 15 pounds of butter, and in Dennark the consumption is $15 \frac{1}{2}$ pounds of oleomagarine and 20 pounds of butter. But while in these foreign countries the element of substitution and frand has been largely eliminated, and margarine is generally bought and consumed knowingly and under its right name, it is understood that in this country a very large part of the oleomargarine used is believed by the consmmers to be genuine butter. This deception is made possible by the custom of coloring the substitute in imitation of yellow butter. Without this coloring feature it would be impossible to deceive consumers to such an extent. Hence, it is the purpose of this bill to so exercise the taxing power of the Government as to render the connterfeit product unprofitable, and thus protect gennine butter and prevent existing frand.

While generally believed that nearly all the oleomargarine used in the United States is artificially colored and that a very large part of it is actually consumed under the belief that it is butter, statisties npon these interesting points are not available. It appears, however, from official reports that in States where numerous prosecutions have been made under the so called oleo laws the great majority of cases have included proof of oleo sales as and for butter. In compliance with a resolution of Congress the Seeretary of the Treasury has furnished a statement showing the ruantity of oleomargarine shipped into the respective States during the tiscal year ended Jnne 30, 1899. From this it appears that nearly four-fiftus of the prodnct went into States which are known to have laws prohibiting the sale of the colored article. If this oleomargarine was sold in compliance with the State laws, it was not artificially colored, and hence the proposed discriminating tax upon colored oleo conld be no hardship upon the manufacture, so far as this large proportion of the trade is concerned. And if this 78 per cent was sold without color, it seems reasonable to assume that the consumers of the remaining 22 per cent (or the colored part of it) could easily be edneated to use the uncolored product. But if the 78 per cent of the domestic trade was largely colored, it was manifestly sold in direct violation of State laws, and this fact furnishes sufficient evidence of the need of further action to aid in the enforcement of these salutary laws.

Considering the provisions of the second section of the bill as a whole, I do not see why it should be opposed by oleomargarine manufacturers and merchants. If the higher tax upon the product when eolored in imitation of yellow butter serves, as it is hoped, to prevent deception and fiaud, that must be a satisfaction to all who believe in honesty in production and trade, as well as among consumers. This discriminating tax may interfere for a time witl the market for oleo by diminishing the sales of the colored article.

The dairy cow is the most valuable agent of the producer, and her milk is one of nature's perfect rations. She gives profitable employment to all who care for her or her products. She gathers her food from the fields withont intervening help in summer, and turus cheap forage into high selling products in winter. The grasses that grow for 
her in her pasture return humus to worll-out lands, enabling them to retain moisture and resist dronghts, in addition to inviting nitrogen from the atmosphere through the agency of the legumes upon which she grazes. She is the mother of the steer that manufactures beef from grasses, grains, and the by-products of the mills.

The farmer who keeps a herd of dairy cows returns through the herd to the soil all the crops he gathers from it, except the prodncts of skill that take little plant food from the soil. The lint of cotton and the fine flour of wheat are among our leading exports, and take little from the soil; the fats of the cow and the plants take nothing whatever. The cow and her calf are prime necessities in reclaiming worn ont land. The cotton-growing States that have reduced fertility by too much cropping can bring back the strength of the soil by growing the grazing plants and feeding the meal of cotton seed to the dairy cow and her calf, but the farmers of no part of our country can afford to keep cows for the sole purpose of raising alves, except free commoners on the public domains, whose privileges are being contracted to such an extent by injudicious grazing that every year fewer cattle are found on the ranges of the semiarid States.

The meats to feerl our people in future must come, in large measure, from the high-priced farms east of the one hundredth mericlian of west longitude. The feeding steers will be bred on those farms from the dairy cows that are now, and will become more and more, a necessity.

Population is increasing faster than cattle in the United States, as the following table will sliow:

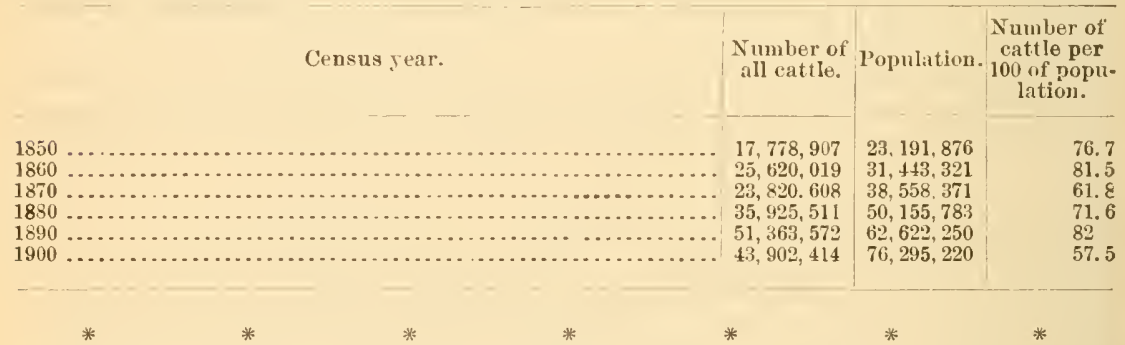

Demand in our island possessions for meats will increase, and demand abroarl will call for more of the product of the cow that is only profitable when placed in the dairy. Dairying will increase in the mountain States as homesteaders take possession of lands on which to raise families, and it will increase in the cotton-growing States as farmers realize the necessity of rotation of crops, and the increase of grazers and feeder's that come through this industry. The benefit that comes to the cotton grower through the sale of a little oil to be used in making oleomargarine is very small compared with the dairying and feeding that mnst be increased to use the by-product of the cottonseed mills, and the consequent return to the soil of this most valnable of all mill feeds and fertilizers. The best interests of the cotton-seed belt lie in increasing its dairy and feeding interests, rather than in contributing a little oil toward the serious injury of dairying and feeding, that shonld use all the cotton-seed meal produced there.

* * * * * * * * * * * * * * * * * *


A 10,000,000-bale crop of cotton gives $\tilde{5}, 000,000$ tous of seed. 'Two hundred aud twenty-five million gallous of oil from this seed may he sold withont injury to the soil npon which the plant grows, but the residue slould not be exported. 'The sale from the land of this nitrogenous by product results in shorter crops and ultimate sterility, which, however, may be arrested by encouraging dairying and teeding for meats.

There is an impression abroad that the oleomargarine industry is as legitimate and praiseworthy as making hutter from the eow. As far as the making of oleo oil, to be sold as such, is concerued, there is no controversy, but that the mixture of ingredients that compose oleomargarine is as healthy as the butter from milli of the cow nobody who has inquired in to both cau believe. 'The Havor of butter, a prime el.ment in palatability and digestibility, comes from bacteria universally present whenever milk is exposed to the atmosphere. Fine butter has a fine flavor, one of its priucipal characteristics. Pacteria feed upon caseiu, an element not fonnd in vegetable fats nor in the tallow of animals. The imitation of butter known as oleomargarine is washed in milk in order that some of the easein may be present as the basis of the flavor. The imitation, in as far as it varies from genuine butter, lacks both the flavor that comes from a full complement of casein and the rligestibility uatural to the cow's product. It is well known that the scalding of milk kills the bacterial growth, after which it will keep longer, but its digestibility is greatly impaired. Butter for immediate consumption is but sliglutly worked, so that the leaving within it of a considerable amount of casein will grow bacteria and develop flavor. If it is to be consumed in a week it is worked over more, and if within two weeks still more. If it is to be kept for months the buttermilk with the easein is thoroughly worked out, unless it is to be put in cold storage and kept at a temperature at which bacteria will not multiply.

Milk coutains a ferment that changes casein into a cligestible nutrient. The imitation of butter made by the ehemist is a mixture of fats that should be sold for what it is. It is not as palatable nor as digestible nor as grateful to the human system. The rligestible juices thow fieely. When palatable food is eiten, the mouth waters. Oils and fats as such have their uses, but the coloring of them deceives the people and induces a consumption as libelal as with butter, which, while not so injurious to people in full vigor as to children and invalids, is nerertheless unclonbtedly harmful. The yellow coloring of butter in winter, wlien it has a light shade, if green cured hay or roots are not used, deceives nobody. The yellow coloring of a mixture of fats is with intent to deceive.

The present law is not well enforced; it is evidently difficult of enforce. ment. The effacement of marks and brands is easily done. The greatest sufferers are the pourer classes and cousumers who have not the opportmity to select their food. If there were no coloring there would be no framd. The most intelligent are deceived, lowever, with good imitations, and from careful inquiry I am satisfied tlat most of us are using the bogus product at greatly inceased pxpense over the price of the oils of commerce, and with dinger to health from the less digestible and less palatable imitation.

Mr. ScHeLL. If the Secretary will allow me, I would like to ask lim just one question. You speak of the majority of oleomargarine that is produced being sold and palmed off upon the consummer for butter. I would like to know upon what basis yon reason out that conclusion. 
Secretary WILson. Did you listen to my reading?

Mr. SOHELl. Yes.

Secretary WiLson. Yon will find it in there.

Mr. SCHELL. I would like to ask further, if yon know from your own experience or from the reports that have come to you of a single case where the consmmer has ever been prosecuted because of being defrauded by the dealer"?

Secretary WILsON. I can find plenty of such cases in this very city. The great difficulty comes in a provision of the internal-revenue law that permits compromising. The more empromising there is done by the Internal Revenue Burean the more money they have for use in their Burean. I have inquired very carefully into the behavior of penple of this District, and it has been exceenlingly difficult to get revenue peolile to take cases through the comrts. There is no question about the everyday deception of us people who have to buy butter.

Senator ALLEx. Were you throngh answering the question, Mr. Secretary?

Secretary WiLson. Yes, sir.

Senator Allfin. Will you permit me a question?

Secretary Wilson. Y'es; certainly.

Senator ALLEN. Have you inquired into the effect the passage of this bill will have npon the value of animals raised for food purposes, not for dairy purposes.

Secretary Wilson. Tery carefully.

Senator ALLEN. What will be the effect of the passage of this bill on that class of animals?

Secretary IVILion. I tried to reason that in my short paper which I have read. There is a little oil furnisherl by cotton-seed people, and a little by the people who grow steers; but the old-fashioned steer that had lots of fat in him is not the steer that is used to day. The young beef, under 'z years of age, put into the market and prejared for the shambles, is not an animal that produces much body or intestinal fat. That is the animal that is wanted to-day.

The old-fishioned steer that was $3 \frac{1}{3}$ years old before he got to market had a large amount of fat, running uj in some cases to 150 and as high as 180 pounds.

Now, then, the tendency in the South, where they have destroyed the lands by perpetual cropping, and the tendency west of the Missouri, in the semidry belt, where they are destroying the grazing lands by injudicions overgrazing, is to take greater interest in the dairy cow than in the steer, and in the case of settlers who want to raise families out west of the one hundredth meridian the interest grows every day on behalf of the dairy cow, and with regard to the production of steers east of the Missonri River on the farms there is no comparison whatever. The small amount of cattle that commerce calls for in making oleomargarine is infinitesimal in value compared with the injury that the growth of this bogus industry will intlict upon legitimate agriculture that requires a dairy cow.

Senator ALLEN. The meat-growing country of this section of the country is west of the Missomri, is it not?

Secretary WILSON. Oh, no. I made careful inquiry into the condition of the ianges and their capacity to support animals a year ago last summer, and I fonml in two States, where I made particular inquiry, Wyoming and Nevada, high lying, Iry States, that they do not support now more than 50 per cent of the aninals they supported ten years ago. 'The ranges are being destroyed by injulinous overgrazing with sheep, 
and the meat products of the country are being prepared in the Mississippi Valley, east of the Missonri River, more and more. A dairy is an absolnte necessity on the farms now. because while the man who is a free commoner on the ranges conld afford to keep a cow for a calf, those east of the Missouri can not.

Senator AlLen. But the gieat herds of this country are west of the Missouri, are they not?

Secretary WILson. They were west of the Missonri, but the decrease in the number of eattle is due, to a great extent, to the destruction of the grazing west of the Missonri River and the contraction of the nunber of stock there.

Senator Money. Will you allow me to ask a question, Mr. Secretary? Secretary WiLson. Yes, sir.

Senator Monfy. You express yourself favorably in your paper to the provision that prevents the coloring of oleomargarine. Would you also faror a provision in the bill that would prevent the coloring of butter?

Secretary WiLson. I have had that ruestion askerl me before and have thonght a great deal abont it. The reply is simply this: The coloring of butter in the winter time deceives nobody. The coloring of the fats of commerce to make an imitation deceives everybody.

Seuator MoNEr. The testimony here has been that there are several grades of butter, as well as of oleomargarine, and there is a grade of butter which is denominated by some "renovated" and by some "resurrected" butter, and they said that it was white, sour, rancid, and had a great many other obnoxious features to it; that it liad goue through a certain process of ladling; that a little oil was added to it, aud different things that go into the composition of oleomargarine were added to it, and then the coloring. Does that decuive anybody?

Secretary IY'ison. It does.

Senator MoNEr. You then favor putting in a clause here that will prevent everyborly frou coloring butter?

Secretary Wilson. No, I would not. I would have no objection to a clause which would prevent the coloring of renovated butter. Cow butter is uaturally yellow.

Senator MoNEY. This manufacture of oleomargarine, as I understand. is a la ruful industry, is it not?

Seeretary WILson. Oh, there is no doubt abont that.

Senator Moner. Now, the testimony of experts here has been that it is nutritious and wholesome.

Secretary WiLson. Yes; I know what your testimony has been here. That is the testimony of the chemists.

Semator Money. And also the physicians.

Secretary WILson. I ain giving you the testimony of practical knowledge.

Senator MoNEY. That is what the manufacturers said also. The testimony has also been that there has been no deception on the part of the manufacturer toward the wholesale dealer, and no deception on the part of the wholesale dealer toward the retail dealer, but the deception comes or is practiced upon the consumer to some extent by the retail lealer. In view of that, are you justified in ealling it a bog'us industry?

Secretary WILSON. I am. You and I need protection, Senator, and we ought to liave it.

Senator Moner. We do not. We neer letting alone.

Secretary WiLsox. We are eating that bogus article on our tables every day minless we are sure wa send to a creanely and get the gemuine article. 
Senator Mlonfr. I never know that I have got the genuine article exeept when I go home.

Secretary Wilson. After living a wiuter in Washington and eating bogus butter our taste becomes vitiated. Some of the first class hotels and first-class restaurants here do get first class butter from reputable dealers, but the majority of them use oleomargarine.

Senatur. MoNer. If we are all eating bogus butter and we can not tell it by the taste and we can not tell it by the color and we can not tell it by the effect. what harm has happener to anybody?

Secretary WILson. The bogus bntter deceives you in your pocketbook. It costs you far more than it should. There is where the trouble comes. It costs you too much.

Senator MONEx. Would I get the fine-grade butter any eheaper if we abolish oleomargarine?

Secretary WiLson. If you abolish the coloring proposition. I would not abolish oleomargarine. The mannfacture of that is legitimate, but the moment you buy it rou are deceived by someborly. We are not the men who select the butter that we eat if we board at a hotel or boarding house, and the boarding house man can deceive us and he does.

Senator IIONEY. I am afrail he does sometimes, and $1 \mathrm{am}$ also afraid we are deceived in a great many other things. 1 think in the bread we eat we get a fair amount of tersa alba.

Secretary WILson. That may be, but we are dealing with butter just now.

Senator MoNEY. I know, but there is uot a solitary thing we eat or drink, including the whisky that some of us drink-I do not-that is not poisoned in some way. We get cabbage leaves in bright wrappers for cigars; and a young man traveling on the train with me, who introduced himself to ine list March, said that in a great manufacturing establishment in Cleveland, Ohio, mannfacturing all kinds of table delicacies-pickles, marmalades, tlavoring extracts, etc.-there was only one genuine thing in the whole line that conld not be imitated, and they had been trying to imitate that.

Secretary WILson. If the commeree among the States regarding foods is not regulated, we will become like some uations in Europe by and by. We will be unable to reproduce ourselves.

Senator Money. The next thing we know we will not be able to eat anything without getting sick from it.

Secretary WILson. That is not the proposition, Senator Money. It is illustrated by a story in one of 'Sir Walter Scott's novels, where a fellow built a castle on an island in the middle of a lake. Everybody said that the man that built that castle was a thief in his heart. The man who manufactures oleomargarine and colors it intends to deceive.

Senator Money. What about the man who colors the poor butter; is he a thief also?

Secretary WILson. The renovated butter is as much of a swindle as oleomargarine.

Senator Moner. What about the butter man that takes the color that is used in oleomargarine and puts it in his butter, high grade or low grade?

Secretary WILson. I ean not admit your premises there.

Senator NoNer. That is what I am told.

Secretary WiLson. The cow made yellow butter before ehemistry was discovered.

Senator MIoNer. I know that some cows do.

Secretary Wilson. All coms do. 
Senator MoNEY. That is not my experience, though.

Secretary WILson. If you feed cows in the winter time green cured hay, or sugar beets, or mangles, or carrots, you color your butter.

Senator IONEY. I believe they used to color butter with carrots after it was made, after the cow lad ceased to perform her part of the function.

Secretary WrLson. There is no diffieulty about having naturally colored butter. It is colored by the grass in summer. That is nature's way, and when you imitate nature you are probably not going very far wrong; but we do not know enough abont milk, any of us yet, to be able to form a substitute that will stay on the stomach the same as butter.

Senator MoNEY. Did I understand you correctly awhile ago-I do not know that I did-in the readin of your very elear paper, to say that you favor baeteria as an agent for producing digestible food?

Secretary WILson. No; the position I take is this: When you draw milk from the cow, the moment you expose it nature has bacteria germs falling into it.

Senator J[oner. Exactly.

Secretary Wruson. That is the flavoring agent.

Senator MoNEY. You want to maintain that flavoring agent, do you? In other words, do you want the bacteria in the milk?

Secretary Wruson. Nature has arranged that. Without that you can not get any flavor, and the oleomargarine nen, knowing that, wash their product in skim milk.

Senator Moner. That is true; but do they not heat that product to such a degree that it is absolutely fatal to all sorts of germs?

Secretary WiLson. I do not know what they always do.

Senator Money. That is what they do.

Secretary Wilson. If they do, then there is no element to make a flavor, and without a fine flavor digestibility is not as good.

Senator MoNEY. I do not, want any germ flavor in my butter, or in my oleomargarine, either.

Secretary WrLson. Yon cau not get cows' butter withont it.

Senator Money. That may be true, but yon can get oleomargarine witlıout it.

Secretary Wrisson. Well, you have a perfect right to buy oleomargarine, but I lo not want you to be deceived and pay 10 cents a pound too much. The poor people are being robbed by this deception to the extent of 10 cents a ponnd; and you and $I$, who have to take butter from second or third hands in this city, are deceived regularly. If you will send me samples of the butter you are eating between now and spring I will tell you the percentage of it that is olenmargarine. I will have it analyzed. In fact, we have been analyzing it for members of Congress who have sent samples to us.

Senator MONFY. I will send you some over.

Secretary WiLson. I seut a reply yesterday to Cougressman Dahle, who had sent us a sample.

Senator Heitfeld. You spoke about paying 10 cents a pound too mueh. What price ought it to sell at?

Secretary IVILson. I suppose fats vary in value on the markets the same as butter does, but you will always find that the fats of commerce are cheaper than the fats of the cow.

Senator Dolcrier. I prospectus of the great butterine corporation which is about to put up a plant here, with a eapital of a million dollars, as an inducement to an investment, states that the aggregate value of 
the materials and mannfacture of a pound of oleomargarine is a frac. tion more than 11 cents.

Senator HEITFELD. It sells here on the market for 18 cents per ponnd.

Senator Money. We have here an advertisement from a grocer in Cincinnati, I believe, who alvertises three grades of oleomargarine, and my recollection is that the prices were $11 \frac{1}{2}, 12 \frac{1}{2}$, and 13 cents. Then he advertises his butter at about 25 cents. He may be all exceptional trader, and I think honest traders are generally exceptional.

Secretary WILsov. A gentleman has handed me a table of prices here showing that it costs five and a fiaction cents a pound. I do not kuow how that is.

-The Chammin. Mr. Secretury, in regard to this process butter, would not the self-interest of the famer iradually tend to cure that evil-the mannfacture of poor butter, rancid butter?

Secretary Wilson. The eduration at agricultural colleges is doing that. Process butter, or renovated butter, as we understand it, is the butter picked ul, through the grocery stores throughont the country where they have no creameries and shipped to central points.

The Charrian. Where they have no proper training and do uot know how to make goor butter?

Secretary IVILsin. Exactly. It is shipped by these people to the markets and sold for what they can get; and generally the merchant handles it withont a profit, becanse he sells goods by it.

The Cmaminan. So that self-interest wonla temel to-

Secretary WiLson. Yes. They take a mass of this stuff with as many rolol's as Jacob's coat and rednce it to one color, and they use chenicals. I have known lime to be used for that purpose. That kind of butter gets a bacteria, the bacteria of decomposition, and they have to use strong ehemicals m order to destroy and kill that bacteria. 'Then they mot the thing on the market, and if we happen to eat it we have to take chances on those chemicals.

The CIIAIman. I want to ask one more question in that connection. On accomnt of self-interest-that is what governs the hnman race usnally-would not the tendency be in the manufacture of oleomargarine more and more to use cheaper and improper materials as competition grew greater?

Secretary WILson. Oh, there is no limit. They will take the cheapest materials, no matter where they find them. iVithout any question self-interest will reguire them to do that.

Senator ALLen. The country groceryman all over the United States receives bntter from his customers in exchange for goods?

Serretary Wilson. Yes.

Senator Allen. Very much of which is not salable even in the county where it is manufictmred?

Secretary Wilson. Yes, sir.

Senator AlLEN. It is put into barrels and kept sometimes for weeks. Where is that butter shipped?

Secretary WILson. That butter is shipped to centers, where it is renovated.

Senator Allen. And that goes in process butter?

Secretary WILson. That is the fonndation of process butter; but in our country, in the West, where the creameries are extended, it is not known any more. There are whole connties in your State and mine where no such butter originates at all, because they sell the milk to the ereamery, and it makes fine Elgin butter. 
Senator Allen. Almost every little town has some butter dealer, and he has a little machine by which he takes much of this butter and renovates it, as he calls it. 'This is true in little towns of 800 or 1,1$)(1)$ people. What kind of butter is that, and where loes it go?

Secretary WILSON. The best of it-a great deal of it-is good butter. The best of it is put on the market as second or third grade butter. 'The very poorest of it, that is beginning' to become rancid, is shipped to centers where they manufacture the process article.

Senator ALLEN. In these little towns and the comntry surrounding: them there is about one good butter maker ont of a dozen.

Secretary WILson. That is right.

Senator Altwin. That good butter is always sold at lrome-sold to private fansilies.

Senator Money. At a big price?

Senator Allks. At a big price. For instance, in my State, where butter in June is only 8 or 9 cents a pound, I pay 20 cents a pound for it the year romud.

Secretary WiLson. Weil, factories are established in your State, and they make a tine Elgin brand, using that name as representative, and they get just what it is worth in Elgin, minus the transportation.

Senator Alufin. The thing I wanterl to call your attention to particularly was this: This fine-gralle comntry butter made by the farmer's wife or daughter is all consumed in the little villages where it is nuade. The great bulk of butter that is shipped ont of these little villages either goes throngh a process of renovation at home-I have seen them work it myself; small, cheap concerus-or else they are put in barrels and shipped somewhere else.

Secretary WILSON. That is correct.

Senator AlLwN. What I want to know is, what becomes of that butter?

Secretary WiLson. Oh, that is marle into renovated butter. Con. gress, in its wistom, in 186: provided for experimental agricultural colleges, and in 1837 provided for experiment stations. There is an admirable one started in your state, and there is one in my State which is very near the forefront of anything of its kind in the world. There they train from 100 to "00 young men every wiuter to make first-rate butter, so that the training of people is overcoming the renovating teature.

The Cinaminan. In our State years ago the comntry merchants took in a large amount of butter, more tham his village trade would take. He then sent the best of it to eommission merchants in lBoston and New York to be solel. The cracker maunfaeturers and others would pick $u p$ the cheapest of it and (lump it into a barrel and treat it in some way, I suppose.

\section{Secretary WiLson. Ies.}

The Uimarjiax. Now, that is aimost a thing of the past. 'There is no store that I know of that takes in butter enough for its own cus. tomers. It is very rare that they take any of a famer. 'They have to buy good butter of a creamery or of first-class dairies.

Secretary IVILSON. Yes.

The UHanmas. That change has taken place. Dairying has become protitable there, and the only profit is in making a nice article.

Secretary WILson. The education of the people along these lines will do away very soon with the renovated feature of butter. 'Tho great danger does not come from that. It comes from the imitation of the genuine cows' butter by coloring, so as to deceive the consumer. 
Mr. SPRINGER. Will you allow me to ask you a question, Mr. Secretary?

Secretary WILSON. Surely.

Mr. SPRINGER. You stated, I believe, that the consumption of butter in the United States amounted to abont 83 pounds per capita. Was that your statement?

Secretaly W'ILson. No; I think not.

Mr. SPRINGER. What was the statement you made?

Seeretary WILSON. The eighty-three you have in mind was $83,000,1000$ pounds of oleomargarine. My statement was 18.1 pounds per capita, if I remember correctly.

senator MONEY. Yes; $1 S_{2}^{1}$ pounds of butter.

Mr. Si'RINGER. How many pounds of butter were consumed last year in the United States? Was that stated by you to day?

Secretary WiLsox. No; I dealt with oleomargarine, but if you will multiply 1 s. by $76,000,000$ you will get it very closely.

Mr. SPRINGER. You stated, however, that the consumption of oleomargarine anomnted to but a little over 1 pound per capita.

Secretary WILSON. A little over 1 pound per capita in the United States; yes.

Mr. SPRINGER. Then you did state what the consumption of butter was, and it seemed to me it was 80 pounds per capita.

Secretary WiLson. Eighteen and a half pounds.

Mr. SPRINGER. If the consumption of oleomargarine is only 4 per cent of the consumption of butter, do yon think that the competition up to this time has been such as to enter into all of these hotels and that we are all eating more oleomargarine than butter.

Seeretary WILson. Without any question, all over this District of Colunbia. I have looked into it with the utmost care. I have had my experts go and inquire, and there is not the least doubt, Judge, but that you and $I$ are eating it right along all the time when we buy here.

Mr. Springer. What has become of the butter that is made, then?

Secretary WiLson. That is used also.

Sentator HEITFELD. Is not one reason we are consuming so much oleomargarine in this country because we get such a poor lot of butter here? I have been here four years, and I have not yet been successful in finding a dealer who keeps good bntter all the time.

Secretary WiLson. No, senator; that is not the reason. The reason is there is such a grent profit in olemargarine.

Senator HEITFELD. A Senator told me the other day that his wifo went to the market and deceived hin with oleomargarine. He said it was the best butter that has been on his table. He had tried for three years to get the best butter, and he sald now he was against oleomargarine because he did not waut to get deceived any longer.

Secretary WiLson. This was a bad place to try that experiment. I get my butter direct from the creamery, and I will furnish you a sample, at any time, of genuine butter.

Senator Moner. Tou say the best butter has a generic name-Elgin butter?

Secretary Wilson. Yes, sir; we call fine creamery butter Elgin butter.

Senator Money. Is it true or not-because it has been stated to me that it was true-that these fine Elgin creameries that make fine butter are very great consumers of oleomargarine?

Secretary Wilson. No; I think not.

Senator IIONEY. I have been told so by a gentleman here who said 
he was agent for Armour \& Co., and that his largest customer was one of the most celebratel creameries at Elgin, Ill.

Secretary WiLson. Filgin butter is made all over the country. There may be one scoundrel living at Elgin.

Senator Moner. I suppose there might be.

Mr. Trluinghast. I lesile to ask you, Mr. Secretary, if I may, if there is not quite a large amount of the best creamery butter that does finally become rancid and poor?

Secretary WiLson. If you do not take care of butter it will become rancid.

Mr. 'Tillinghas'T. I am asking you if it is not a fact that a large part of it does become in that coudition?

Secretary WILson. Oh, no.

Mr. TILlinghast. So that there will always be quite a quantity of butter to be renovated?

Secretary WILson. No, sir. Fine butters are handled so as to be kept in cold condition to prevent the levelopment of bacteria until they are sold. Now, let me illustrate that point. If you make butter this moruing and want it consumed this evening, you press a very little buttermilk out, so as to leave the casein there in order to derelop bacteria rapidly and bring up your flavor at once. If you are going to ship it, so that it will not be consumed for a week, you must work it over and get nearly all the buttermilk and casein out, becanse the casein is the element in which the bacteria multiplies. If jou send it from here to Great Britain, you nust work it twice over; and the habit in old times with the Dutch women when they wanter to furnish butter for the Dutch navy was to work it trelve times. They worked in those days with their hands, and when they had worked it twelve times they had all the casein washed out. Then they put it into a keg, put it in the hold of a Dutch man-of-war, and it crossed the Tropics twice and came back sweet, because all the opportunity for multiplying bacteria had been taken out of that butter. 'That was the old way, and butter is worked now so as to suit the times intervening when it will be consumed.

Mr. Tillinghast. Then, you say by the improved methods of handling butter in time the renorated butter will go out of existence?

Secretary Wilson. I think so. We had a letter yesterday from the Iowa Agricultural College in which they told me they liad four students there in the short course. Every year they turn ont hundreds of educated dairymen. Ont in Nebraska there is a fine school doing that very work; and the time will come when you will not find a bit of renovater bntter in Iowa or Nebraska: and in Termont and many other dairy States I do not believe there is auy now.

Mr. SPRINGER. I see that in your statement, Mr. Secretary, you say the domestic cousumption of oleomargarine is in ejcess of 1 pound per capita as against the estimated consumption of $18 \frac{1}{3}$ pomms of butter. I was mistaken about the amount. It is $18 \mathrm{~s}$ pounds. Is 1 pound in 18 a serious competition?

Secretary Wilson. Very serious.

Senator DoLLIVER. I received a telegram from a cattle dealer in Iowa stating that this bill was likely to very greatly damage the value of beef cattle.

Secretary WiLson. Yes; he does not know what lie is talkingabout, that same cattle dealer.

Senator DoLLIVER. I wonld like a little fuller statement from you as to the relation of the cattle industry and the dairy farm. 
Secretay Wilsox. Well, take Iowa, where I am personally acquainted. We have been getting our feeders from beyond the Missomri and they are getting seareer and scarcer, and it is becoming evident that we innst prodnce the feeders on onr own grounds. We can not keep a eow to raise a ealf only in the Mississippi Valley. We must milk our cow to make a protit. The great feeder in Iowa will become a thing of the past. It has not existed for centuries in European comntries. The feeding steer in European comtries is raised on the farm and finished on the falm, and that will be the case in Iowa. We Western farmers like to farm on horseback, and the man who feeds steers likes to buy them and buy corn to feed them, or feed them his own coln: but the day is coming when he ean not buy them, because the dairy farmer will find it profitable to raise his own calves and finish his own calves on his own farm with his own products.

Senator Dolliver. Then, you hold that the destruction or fatal injury of the dairy tiarm wonld destroy the whole eattle business?

Serretaly WILson. Yes; for this reason. I have discussed the Southern fuestion here. I am very much interested in those people. I go down there often, and tind them a lovable people; but I find they have grown erops and oxidizod the lumus out of their soil until in many cases they do not get more than a quarter of a bale of cotton to the acre. If it had not been for the cotton erop of the great state of Texas, the world would have been suftering for cotton $110 \mathrm{w}$. There is no way by which they cum ever bring the suil batek to full fertility except by putting the limmus back, and that will be done by letting the cow and her walt araze. iThat little intelest they lave now in selling a little bit of cotton-seed oil is intinitesimal compared with the great benefit that will come to them from correct farming, aurl a well-organized farm means the dairy cow present overy time.

Senator MoNer. Yon are not going to have it with the increase in population.

Secretary Wisson. Let me tell you something on that point. There is a man who lives ont here abont 2.5 miles in Maryland, naned Boyd. He keeps 200 or 300 1"ows, if I remember correctly, and he sends in excellent milk into this city. He has colored people to milk them. I do not say that every colored man or colored woman is tit to milk a cow. 'The dairy cow should be treaten as delicately as you wonld treat a fine laly when, rou take her ont to dinner. The negroes will not all do that, but some of them will, and yon ean make anceess in the South of the dairy with colored people for milkers.

Mr. W A Dsivor'Lr. They have never been made a success, have they, Mr. Secretary?

Secletary ificson. It has. I have given you one case where a man has 200 or 300 cows and milks then with colored people. He sends the milk into this eity.

Mr. MuLfer. Is it not a fict that the beef cattle of the West do not go in the dairy liercls, and is it not a faet that the large herds of the West are inbred Herefords, which are not dairy cows?

Secretary IVILson. Oh, bless your soul, 110.

Mr. MrLler. Is it not a fact that all Western herds are headed by Hereford bulls?

Secretary WiLson. No; not exclusively. You ask Senator Harris, who is a Kansas stockman, and he will tell you that men who have been using the Hereford blood find that they have gotten them too small.

Mr. MILLER. My dear sir, the Hereford are large cattle; that is why 
they have them. Mr. Armonr, of Kamsas City, owns the largest Ferefore herl in the world, and he sells them on the Western ranges.

Secretary Wilson. Iow many does he sell?

Mr. Miller. Generally from 40,000 to 50,000 four times a year.

Secretary Wilson. How many head does he own?

Mr. MilleR. I don't know.

Secretary WiLson. I guess you will find that others own as large nerds.

Mr. MrLlen. He has the reputation of owning the largest herd in the Wrest. He holds a sale three or four times a yeur at Kansas Uity, and all these bulls go to the Western herds.

Secretary WuLson. If you will examine the reports of the experiment station, you will find my report on that subject. They make excellent feeders, but the difficulty with them is they are not goorl milkers. They can not be used in the dairy. The man who originated them is on record as saying that he could have made good dairy cattle of them if he had turned his attention that way, but he did not. He turned his attention to beef making, and he repressed the tendency to give milk. The result is that they can be used tor beef cattle, but the demand to-day is for cattle that will give milk as well as raise calves, and the peoplein the West who are grazing on the free commons eould not afford to keep a cow for the calt if they had to pay rent for those lands.

Senator AlLwr. I think this gentleman is mistaken, Secretary. The four beef producing herds are the Shorthorn, Hereford, the Angus Borden, and the Galloway.

Secretary Wruson. 'That is riglit.

Senator AlLEN. Yon call not sell anything else for beef producing. Secretary WILson. That is right; but you can develop milk giving in any of those breeds if you feed for milk. The Shorthorn is a famous milker. Iou can make the Angus or the Galway or the Hereford milch cattle if you will feed for milk and milk them. 'The difficulty has been with the Herefords that they have been bred away from nilk. That is where the trouble is. Are there any other questions, gentlemen?

Senator Dolliver. One more question, Mr. Secretary. Is it possible to prodnce this oleomargarine, according to your scientitic report, of the butter color, without coloring it artificially"?

Secretary Wilson. Oh, no. You can get the dairy cow's butter yellow, if you feed right: but the chemist can not put in any other color witlont using the coal-tur ijyes.

Senator MoNer. If you put in enough cotton-seed oil, you call give it a good color, and that is the best thing that goes into it, anyway.

Secretary Wruson. I think there is only a very light shade of yellow in the tine cotton-seen oil.

Senator MonEr. 'They lo refine it, and we eat it on our table every day.

Secretary WiLson. There is no possible direction in which the Sonth can renovate its worn-out lauds so fast as to feed that cotton seed to stock. It is the finest feed on earth.

Senator Moner. I linow that. I am a farmer. I raise cotton.

Secretary WILSOx. And you can not do it without the dairy cow.

Senator MoNEY. I raise cows, too.

Secretary Wilson. The dairy cow is the only instrumentality. Tou can not do it hy commereial fertilizers, because it will not put the hum in the soil.

Senator MoNey. You are right about that. 
Senator Dolliver. We had a merchant here from New Jersey, where the law forbids the sale of colored oleomargarine, who stated that he obtained his oleomargarine under special order from the manufacturer with the buttel color-the yellow color-produced, not by artificial coloring, but by a careful and judicious collection of the ingredients entering into the manufacture of the article.

Secretary WILSON. I am not familiar with any process of that kind. That may be. We can not limit the capacity of a chemist, but I do not want the chemist to produce an article that will cost me 10 cents nore a pound than it is worth, withont coloring it.

The Chamman. Mr. Secretary, oleomargarine is manufactured and sold abroad, is it not?

Secretary WILSON. Oh, yes; my paper shows that.

The Chairman. Yes; I noticed it. Is it colored there?

Secretary WILson. Oh, no; we are the only people on earth who do not take care of what onr people consume and what they eat, and the purity of onr foocl.

The CHAIRMAN. It has a sale there for what it is?

Secretary WiLson. Yes; it is a legitimate business, if they do not deceive someborly-entirely so.

Mr. MILLER. Mr. Chairman, we are exporters of butterine and we color every pound we send ont. In some of the West Indies we color it red.

Secretary WiLson. Have they laws down in the West Indies on that subject?

Mr. Miller. Some of the comntiles have laws; yes, sir.

Secretary Wilson. I presume you do not sell oleomargarine to Great Britain and color it, do you?

Mr. MILLER. We have no export trade to Great Britain, but that is because they manufacture their own prodnct.

Secretary WILson. Do you ship oleomargarine to foreign countries?

Mr. Mlller. I'es, sir.

Secretary WiLson. Where do you send it?

Mr. Militer. We send it to a number of countries. We do not send it to Great Britain and some other countries. The little conntry of Holland has 19 factories as against 27 in the Uniter States, and it is not bigger than the State of Missouri.

Mr. CHaIRInan. And yet they sell it as white, do they?

Mr. Miller. No, sir ; they sell it colored.

Secretary WrLson. You are only telling what Armour \& Co. do; but the United States does ship butter to foreign countries.

Mr. MiLler. We ship oleomargarine: we do not ship butter.

Secretary Wilson. You do not ship it to any foreign country where they have got laws and sell it for butter.

Mr. Miluer. We do not sell it for butter at all. We sell it for oleomargarine in this country and in other countries.

Secretary WILson. But the people down in these countries where you seud it do not happen to have any laws, and if they did have laws we know the character of people they are down there.

Mr. Tillingriast. Do I understand the Secretary to say that in Holland they do not color the oleomargarine?

Secretary WiLson. You understood him to say that.

Mr. TILlinghast. I ask if the Secretary says that.

Secretary WILSON. No; you did not nuderstand me to say that.

Mr. Tillinghast. How did I understand you? 
Secretary WiLson. That is a fact 1 am not possessed of. The gentleman representing Armour \& Co. made a remark along that line.

Mr. WADSWORTH. But the Secretary did assert that no oleomargarine abroad was colored. Ile did not tonch Holland or any one country, but he said that, and I thonght it was a mistake when he uttered it.

Secretary W'ilson. I may have made that too broad, but I mean the European countries. I will modify that statement. They may send it to the West ludies, down among those colored people.

The Chairian. I meant Europe. I did not say so, but I meant Europe.

Secretary W'ILSON. 'That is what I meant. Oh, no, you can not sell colored oleomargarine there and sell it for butter.

Mr. WADSwORTH. No, bnt you can sell it for what it is.

Secretary WiLson. Yes, you can sell it for what it is.

Mr WADSWORTH. The point is whether it was colored abroad, if I may be allowed to interrupt.

Secretary WILsoN. With that I am not familiar

Mr. WADsWoRTH. You said it was not, and I felt confident that it was. That is why I called your attention to it.

Secretary WILson. I think the majority of the stuff of that kind that is sent abroad goes as oleo oil.

Mr. WADSWORTH. I am not speaking of what is sent abroad, but what is manufactured over there.

Secretary WILSON. The manufacture over there for sale to the people is not the same as it is over here. Those people enforce the laws over there. They will not permit any deception along those lines.

Mr. WADSWoRTH. That is not the question. Mr. Chairman, you asked the question whether oleomargarine is manufactured in foreign conntries and whether it is colorerl. The answer of the Secretary was that it was not colored. I thought at the time that was a mistake or an oversiglit-not our oleomargarine, but the oleomargarine that is manufactured abroad by Europeans.

Mr. JeLre. May I ask one yuestion?

Secretary Wilson. Yes, sir.

Mr. JELKE. Are there any conntries in Europe in which there is a tax imposed on the sale of oleomargarine, either colored or uncolored?

Secretary WILson. That I do not know. Probably you know.

Mr. JELKE. There is none.

Secretary Wilson. Very good. Now, you liave given us a fact.

Mr. Culberson. Mr. Secretary, may I ask you a question?

Secretary WiLson. Surely.

Mr. Culberson. You speak of the infuitesimal quantity of cotton oil used in the manufacture of oleomargarine in this country.

Secretary WiLson. As compared with the benefits of the dairy.

Mr. Uulberson. Are you aware of the quantity consumed for that purpose? Are you aware of the quantity that is exported for the same purpose?

Secretary WiLson. We can find those things very readily. The Secretary of the Treasury can tell about it.

Mr. CULBERSon. I want to say as a manufacturer and as a live-stock owner that the quantity that is used in this comntry and that is exported for the same purpose abroad is equal to nearly 25 per cent of the whole quantity of oil produced in the South.

Secretary WILson. Do you know how much oil is produced in the South? Give us that as you go along.

Mr. Culberson. About a million and a half barrels. 
Secretary Wilson. Can you let us have it in pounds? Then we will understand it.

Mr. CULBERSON. If you multiply that by fifty and by seven and a half yon will get it. A million and a half times fifty will give you the gallons, and multiply that by seven and a half and it will give you the pounds.

Secretary WILson. I am speaking of what is in the cotton seed.

Mr. Gubinson. You spoke of the fact that oleomargarine abroad was not eolored, dicl you not?

Secretary Wruson. Oleomargarine sent from here to Europe?

Mr. Culizeison. No; manufactured abroad. Is it colored or uneolored?

Secretary Wilson. That I do unt know.

Mr. Culierson. I will say that I know of my own personal knowledge that it is colored.

Seeretily Wilson. Very good.

Mr. Culberson. And is almost identical in appearance with that sold here as oleomargarine.

Sellator ALLAN. Is that shipped from this country abroad?

Mr. CUlberson. No, sir; it is made in liotterdam, in Holland, and is made in Germany.

Senator ALLEN. That is not the question. Is the oleomargarine you export colored before it leaves this country?

Mr. Tillingilast Yes, sir; every pound of it.

Mr. MiLLer. All the butterine we export is colored. We do not sell any in Europe or in England, because there are large manufacturers over there. There is one factory in London that makes more butterine in one year than all the factories in the United States.

The Chatrman. Those are statements you can make. I hardly think it is necessary to detain the Secretary in this general disenssion. We are very mueh obliged to you, Mr. Secretary, and we shall be very glad to hear any thing further from you that you wish to say.

Secretary WILson. I have uothing further to say, and I am very much obliged to the committee for their attention.

Senator ALLEN. If the Secretary has any further information that he would like to submit to us before we make our report, I think we should be glad to lave it.

Secretary WILSON. I shall be glad to do so, and I shall see to it that you get some genuine butter in your family before the winter is over.

(At this point Senator Proctor left the room and Senator Hansbrough took the chair.)

The Acting Chairman. Mr. Adams, are you ready to proceed?

Mr. ADAMs. Yes, sir.

\section{STATEMENT OF H. G. ADAMS.}

Mr. Adams. Gentlemen of the committee, I will take up this subject at a point where it was dropped by Secretary Wilson.

The statement lias been repeatedly made that the friends of the Grout Bill are endeavoring to destroy the oleomargarine industry, and they base their argument upon the statement of our position. They have proceeded to ittack ns as being men who are striving to fight down one legitimate industry in the interest of another. These gentlemen can not be permitted to state our position for us. We appear here for ourselves, amd I desire to say to this eommittee on my own belalf and on 
behalf of the people whom I represent, and of the sentiment of the State which I represent, that we are not here to make any fight on oleomargarine as oleomargarine under its ow form and umler its own color. We are here, as Mr. Flanrler's said, to, if possible, legislate the fraud out of oleomargarine.

The central argument which our friends on the other side have made here is that if yon take the color ont of oleomargarine you can not sell it; that you are going to absolutely destroy that industry. I rleny the proposition, and I can prove that that denial is male in goou faith and warranterl by the ticts of the oleomargarine business, not only in this conntry but abroarl.

Some figures were given here this morning by Mr. Wilson with reference to the oleomargarine trafice and the consumption in this country and abroad, and I want to sily to you that in Demmark, which is a dairy comntry, where the (rovermment lias used its power to educate its people and instruct them in the business of making goon butter, where it is under careful goverumental supervision-a little country, less than ourhalf the size of the State which 1 represent (Wisconsin), with $50,1(10)$ square miles of territory-they export every year into the Furope:n markets $130,000,000$ pounds of the best butter which goes into the markets of the worlil, and in that country the farmers buy oleomargarine. I admit it. They buy it. How? They buy it white, the color which nature gives it. Mr. Wilson says they consmme :3. pounds per eapita over in Denmark, and that we consmme 1 pound over here in the Cuiter States. Yet Prof. W. A. Hemry, of the experiment station of Wisconsin, one of the men who has dome more to educate the farm sentiment and the farm judgment of this comntry, perhaps, than any man in it, returued fiom Europe only a few weeks ago, and told me that he had traveled in Denmark and gone into the stores of that conntry and studied the laws of Denmark with reference to the manufacture and sale of dairy pronlncts and dairy imitations, and he found that in the stores of Denmark, where they sell oleomargarine, they are compelled to sell it on one sille of the store and butter on the other side of the store, and that they are compelled to sell that product in the color whirh nature gives it, which is substantially white. Anl there in Denmark, where they are compelled to to what the producers of honest butter want the mannfacturers of this substitute to to in this conntry, they are selling three and one-half times as much to the inhabitants as they are selling here in the United States, manufactming and selling that product in numerous States in violation of the law, simply because it is in initation of a more costly and more valuable product.

I tell you, gentlemen, and i say it in all sincerity, that if I were an oleomargarine manufacturer, conscious of the value which my substitute had in the markets of this conntry, instead of coming to the Congress of the United States and demanding as a right that I should liave the privilege of coloring my profluct in imitation of the natural substance of which it is a comnterfeit, I would come here and say: "Gentlemen, regulate the color of my product by national legislation if you will. It is wholesome. The poor people in this eonutry want it. It has its merits. There is a place tor it in the markets. We call sell it. We are now under the ban of law in 32 states. IT are constantly hampered by prosecutions on the pant of State anthorities. We are constantly stung by the eriticism of honest men mpon the chanacter of our business, and we are willng to have the eolor knocked ont of oleomargarine and put it on the malkets of the conntry and sell it nucler its own color, and for precisely what it is." 
Gentlemen of the committee, we have not come here to Congress asking for anything that is wrong in any way, shape, or manner. We are not bere represonting an interest which is to crnsh down any other legitimate industry in the United States. We have been cliarged with coming here as mannfacturers of an inferior lloduct, butter, some of which is mannfactured as it shonld not be, and asking legislation which is dishonest; and these gentlemen have stood mp here day after day, and I have quietly and patiently and calmly listened to their indictment not only of the dairy judgment of this nation, but of the people of 32 States, of the legislatures of 32 States, of the courts of 32 States, and of the Supreme Court of the United States, which has declared that a State prohibiting the manufacture of butterine colored in imitation of butter is exercising a legitimate police power-for what? To protect the pnblic health? No, sir; to protect aud compel honesty in trade. That is the basis of this legislation, as stated in the judgment of the conrts. Why, our firiends come up here ancl say that these laws are passed by chicanery; that they are passed because dairymen's associations have political intluence. Do these gentlemen pretend to say that the 32 gleat States in this Union which have passed these laws have passed them in obedience to a cheap and dishonest and class sentiment?

I have here a map of the United States showing the States which have passed anticolor laws. Yon find there a good portion of the Sonthern States. Yon find anl of New England except lihode Island. You find the great States of New York, and Penusylvania, and Ohio, and Michigan, and Illiuois, and Minnesota, ant North and South Dakota, and Nebraska, and Iowa, and the great State of Missouri. In $1 S 86$ onr firiends, the Democrats, endeavored to make that a party question. It is not a party question. We went before the member's of the other Honse upon this qunstion, ciaiming there. as we claim here, that we are not endeavoring to interfere with the rights which belong to any man or any class of men, and ont of the Southern Stutes we got 20 votes; ont of the Democratic vote in the lower House we got 49 votes, and leaders of the Republican party and leader's of the Democratic party on both sides of that question stood together.

Senator Allen. How were the Populists?

Mr. ADAMS. I think they stood by us, because the Populists as a rule have some appreciation and knowlelge of the work which a man does who tills the soil and works upon the farm for his daily bread. I want to say to you, gentlemen, that we are not bere to do injustice to the cotton-seed oil man. We are not here to do injustice to the men who raise steers. We are not here to do injustice to any iuterest; but I want to say to the men who represent the cotton seed oil interests and the men who represent the beef interests aud the hog interests of this eountry that if we can prove to them that this bill is right, that it is designed to stop a frand, and that it probably will stop a frand, it is their business as honest men and as good eitizens of this Republic to line up with us, no matter whether it hurts their business or not.

This is not simply a question of class interest. It is a question of public policy; and I want to say to this committee that yon ean strike all the color ont of oleomargarine and have it sold in the markets of this country and have good demand for it. In proof of that I want to show you what we have up in the state of Wisconsin.

I have here samples of butterine which may interest this committee, and the gentlemen upon the other side of the question are invited to inspect them. These samples were obtained in obedience to my orders 
by $\mathrm{X}$. J. Field, of Milwaukee. He was instructer by me a week ago last 'Thursday to go to the stores of Oshkosh, Milwaukee, and Racine, in our state, and purchase samples of uncolored bntterine, and to write upon those samples the date of purchase, the name of the firm from whom they were jurchased, and the cost. I now have the pleasure of submilting these samples to this committee for their inspection.

Senator H $\mathrm{A}$ NsBrougr. You say he was instructed to procure samples of nncolored butterine?

Mr. ADAMs. Yes, sir; of oleomargarine. I would like to say that one or two of these samples, possibly more, are slightly colored, but they were purcliased for uncolored oleomargarine.

Mr. JELKE. If the chairman will permit me, I wonld like to make a suggestion that these samples be submitted to the Goverument chemist to find ont whether or not they contain artificial coloring, and also to report on whether they contain any unwholesome ingredient. I do not know where they come from, or anything abont it.

Senator ALLwx. I think that onght to be done.

Senator HANSBROUGII. I shall direct the clerk of the committee to tak care of these samples after they have been exhibited, and send them to the chemist at the Agricultural Department for examination.

Mr. JELKE. May I suggest that the analysis be made for the purpose of ascertaining the percentage of butter fats in each one, as well as the color and wliat kind of color.

Senator Hansbrough. Yes; he will be directed to make a thorough analysis.

Mr. ADAMs. I wish to say, gentlemen, that all these samples, with the possible exception of this one, were sold by the dealer in response to a call for meolored butterine, they claiming that they had received it from the manufacturers as uncolored butterine.

Mr. JELKE. The test will show that.

Mr. ADAIs. I now wish to present to the committee and have incorporated in the testimony the bill for this. It is as follows:

\section{William L. MoxLey,}

Manufactrok of Fine Butterine, 66 and 67 W. Monrof Street,

W. R. WRIGHT \& Co Chicago, January $25,1900$.

$4 S 45$ N. Clark street, Rogers Park, Ill.

Uncolored oleomargarine: 2/56 D. 2 pts. $11213, \$ 14.56$.

Senator HANsBrougr. Did all this come under an ordel for uncolored goods?

Mr. ADAns. These all came under an order from my inspector, Mr. N. J. Field, to Jeusen \& Beck, Racine; Hanley Rrothers, Racine; D. C. ddams, Milwankee; J.Linehan, Milwankee, and Hoenig \& Co., Ushkosh. He purchased samples of nncolored butterine for the purpose of demonstrating the fact that some of the grocers of our Sta te think they are endeavoring to comply with the law, and some of them are endeavoring to comply with the law, and some of them sell oleomargerine uncolored.

Senator AlLEN. You are using the word "oleomargarine" and the word "butterine" as the same thing?"

Mr. ADAMs. They are substantially the same thing. The term used in the internal-revenue law is "oleomargarine," and it covers butterine.

Mr. 'Tillinghast. Will you answer a question?

Mr. AdAMIS. Ies.

Mr. Thllinghast. Would you think it fair for the dealers in uncolored oleomargarine who are honestly attempting to sell it as uncolored oleomargarine to pay a tax of $\$ 48$ a year? 
Mr. ADAus. As far as my iudividual judgment is concerned I wish to say with perfect frankness to this committee what I have said all the time-that I do not care about any governmental tax upon oleomargarine under its own form and color. The principle I am contending for here in this bill, not simply in the interest of the competing class except as they have a right to be considered in making an honent profit, is that the color shall be taken out of oleomargarine whereby it becomes a connterfeit of an honest and more costly prodnct.

The figures given to me or to my assistant by gentlemen connected with the firms which have been cited here as to their sales of what they call nucolored butterine, a portion of which is evidently uncolored butterine, aud a portion of which is faintly colored, possibly, and possibly not-that is to be determined by a chemist, are: Jensen \& Beck, 3,000 pounds a year; Hanley Brothers, 3,000 pom ds a year; D. C. Adams, Milwankee, 1!,000 ponuts a year; L. Linehan, 5, 100 pounds a year, and Hoenig i Co., of Oshkosh, 6,000 ponuds a year. These are approximate tigmres. Perhaps 1). C. Adams, of Milwanke, who said he sold tio pounds a day, sells more or less than the tigures I have given. Sixty pounds a day during six days of the week, calling 320 days to the year, would amomit to about 19,1n0 pounds.

IIr. Tillingiras's. Would you in the enforcement of the laws of your State prosecute anyone for selling goods of that character under that clause, that it had an ingredient that causes it to look like butter?

Mr. ADAms. I expected that guestion, and I am very glad the gentleman asked it, becanse what we want to get at are the facts. So far we liave confined our prosecutions to more flagrant violations of the law that appear upon the surface. In that case, for the leason that the bntter is so light, the violation of law is so small, and they have gone beyond the border line to such a limited extent that it is extremely difficult in presenting a sample like that to convince them that it is colored at all, even it the chemist can extract from it a very faint indication of color.

Mr. 'Tillinghas'T. Suppose you should find no color whatever, and yet the ingredients were so used that it resembled bntter?

Mr. ADAms. I understand the question of the gentleman to be thiswe might just as well state it. 1 think I can state it better than he can.

Mr. Tillinghas't. Very likely.

Mr. ADAMs. Do I believe that oleomargarine shonld be manufactured by the use of other ingredients than mere coloring matter in infinitesimal qriantities, so that it can resemble yellow butter? I say that I do not. I think it is against public policy. I think it means deceiving: the customer just as much in the one case as it does in the other.

Now, our friends on the other side come up here aud say that we are prejudiced, that we are simply operating throngh class interests; and they say that the courts, in passing upon these laws, have simply said that the States, in the exercise of their police power, can do extraordinary things, and that the courts can not inquire into the exercise of that police power by the States. Do you lawyers upon the other side say that it is possible for a State legislature to pass any law doing any injury to any legitimate interest, label that an exercise of police power, and go to the courts of your State and the Supreme Conrt of the United States and claim that the courts can say nothing about that legislative act because they have labeled it an exercise of police power? Not by any means.

Senator ALLEN. Does not the police power of a State extend to all things that affect life and health? 
Mr. ADAiss. And public molals; yes, sir.

Mr. Tillinghast. And public safoty?

Mr. AD AMs. Yes, sil.

Senator ALLEN. Gromped muder those three heads are a great many hundreds of thousands of things. Anything that affects your health, anything that affects the public morals, anythiug that affects your personal rights or the public rights, comes under the police power of the Stide.

Mr. Adars. That is true.

Senator ALLEN. If this article is deleterious to health-and that is probably the elaim-is it not clearly within the plenary powers of the State to dispose of the question and the duty of the courts of the State to enforce that levislation?

Mr. ADAIS. Why, certainly; but that is not the primary claim, Senator. The claim is made in these various States, in the 3"' States which have passed these laws, aud the legislative judgment of those States has been convinced, that the sale of colored oleomargarine deceives the fimal purchaser, and they regard that practice as against public policy.

Senator ALLEN. The only ground upon which the Cougress of the United States can interfere is to say that this article, which has an interest in conmerce, in trade, shall be labeled, or that trade shall bo conducted in a given way; that is, that it shall be sold white or sold colored when shipped from one State to another as a part of interstate commerce. But when the article passes one State line and into another State, and becomes mingled with the commerce of that State, it falls clearly under the police power of the State and the jurisdiction of Congress ceases.

Mr. ADAMs. What do I understand the Senator to wish me to say with reference to that? A very amusiug thing in a way to me has appeared in this discussion. A gentleman representing friends of this bill has insisted that there is some doubt as to whether the Plumiey decision gives the right to a State to deal with original packages in the State, and other gentlemen on the other side have insisted that that decision was reversed in the Schollenbarger case.

Senator ALLEN. That was all settled in the case of Brown $v$. The State of Marylaud, away back pretty nearly a hundred years ago, where Brown imported from Europe certain liquors. The question was whether the revenue ofticers of the State could levy a tax upou those liquors before they became mingled with the commerce of the State. The Snpreme Court of the United States, Mr. Chief Justice Marshall writing the opinion-it is a very celebrated case and has always been followed since then-held that until it was mingled and became a product of the commerce of the State the power of the United States continued over it, but the moment the package was broken, the moment it became mingled with the commerce of the State, the jurisdiction of the General Govermment ceased and that of the State attached.

Mr. Adams. But, Senator, in the Plumley case it was decided by the conrt that the legislature of Massachusetts, prohibiting absolutely the manufacture

Senator AlLEN. Excuse me for interrupting you. I do not want to interrupt you with a view to aunoyance, but to make the suggestion that the legal distinction between the jurisdiction of the state and the jurisdiction of the United States is possibly well understood by the coinmittee.

Mr. ADAMs. I understand that. Of course we must refer to the question because our friends on the other side have made something of an 
argument here; but I am perfectly willing to leave that question with the gentlemen of the committee.

Senator ALLEN. You must not construe anything I say or anything that is said by any member of the committee as iudicating any opiniou on the subject.

Mr. ADAMs. I have not the slightest sensitiveuess in those matters; but the Supreme Court of the United States has decicled in the Plumley case that the State lad a right to prohibit and that it was a proper exercise of police power to prohibit within its bouders the manufacture and sale of oleomargarine colored in initation of yellow butter.

When we come to the Schollenbarger case some of our friends on the other side claim that was a reversal of that decision, and other gentlemen, lawyers, on the other side, better informed, claim it was not a reversal of that decision, and Iudge Lochran, up in Minnesota, a Federal judge, who hat made a decision in accordance with the Plumley decision, reversed that decision after the decision in the Plumley case. I am perfectly willing to almit the decision in the Penusylvania case overcame the decision in the Plumley case so far as original packages are concerned; but within sixty days after that Judge Adams, the judge of a district court in St. Lonis, made exactly the same decision as Judge Lochran, and the first section of the bill was put in there, not because we believe the decision in the Plumley case had been reversed by the decision in the Schollenbarger case, but because we knew that Federal district judges disagree and had disagreel in two specific cases as to the meaning of that decision. We wished to write into the law of the land the views, as we believe, properly laid down and the principles properly established in the decision of the Plumley case.

I am not going to take up very much tine reading decisions upon this law, and it is not for the purpose of arguing about the constitutionality of the law, but to give to this committee, not only for its benefit but for the benefit of sucl Senators as may read this report, and who may desire by the reference to this decision and the few sentences which are read here, to have the decisions and read them and see upon what grounds the comts have made the lecisions that they have made.

Here is an extract from a case in Twellth Missonri Appeals:

The mere fact that experts may pronounce an article intended for buman food to be harmless loes not render it incompetent for the legislature to prohibit the manufacture and sale of the article. The test of the reasonableness of the police regulation prohibiting the making and vending of a particular article of food is not alone whether it is in part unwholesome and injurions. If an article of food is of such a charicter that fow persons will eat it, knowing its real character, if at the time it is of such a wature that it can be imposed upon the public as an article of food which it is not, and yet to which and against which there is no protest, and if in addition to this there is probable gromur for believing that the only way to prevent the public from being defrauded into the parchasing of the comnterteit article for the cemnime is to prohibit altogether the nanufacture and sale of the former, then we thimk that such a probibition may stand as a reasonable police regulation, although the article prohibited is indeed innocuous, and although its production might be found beneticial to the public if in buying it they conld distinguish it from the production of $w$ hich it is an imitation.

\section{Further:}

The manufacturer may brand it with its real name. It may earry that brand with it into the hands of the broker and commission merchant and even into the hands of the retail grocer, but there it will be taken off and it will be sold to the consumer as real butter or it will not be sold at all. The fact that the present state of the public taste, the public judgment, or the public prejudice with regard to it is such that it can not be sold except by cheating the ultimate purchaser into the belief that it is the real butter stamps with frand the entire business of making and vending it and furnishes a justification for the police regulation prohibiting the making and vouding of it altogether. 
I have not very much time, Mr. Chairman. The views which could be presented to this committee will take more time than I could be allowed. I am solry for it, because I helieve I can present facts which will be considered by the Senate of the United States. In my State what happens". We have, comparatively, a good execution of the law there. We have a stringent law. I drew it myself, with the assistance of an able attorney, scrutinizing at the same time the statute of Massachusetts upon which it was based, and after the decision of the United States Supreme Court in the Plumley case, and up to that time we had been unable to stop to any extent the frauclulent sale of oleomargarine in the state of Wisconsin. I was appointed dairy conmissioner shortly after that law went into effect.

Mr. Tuldinghast. Will you state what your law was before that time?

Mr. ADAMs. It was simply a labeling law, nothing else. I arrested three men at my home, one of whom was a neighbor and a friend. The oleomargarine manufacturers of Chicago supplied the gentleman arrested with the means of defense. They employed an ex-AttorneyGeneral of the United States, a bright, able, vigorons, and skilled man before a jury. It took us two rlays to get a jury. The citizens knew me, knew the ex-Attorney-General, and knew the defendant, and they did not want to go into the jury box at all. We finally secured a jury. We had a three days' trial, and then we had a disagreenent, seven men voting for convietion and tive for acquittal.

Mr. TillingHast. What was the charge?

Mr. ADAMs. The eharge was that of selling colored oleomargarine in violation of law for exactly what it was. We tried the case again. The jury went out and returned a verdict in favor of the State in less than five minutes. I went down into the city of Milwaukee and made 16 arrests, 13 for selling in violation of the color law of the State and 3 under the old labeling law, which had not been repealed. My purpose was to find out which kind of a law I could entorce; and I found out. I won every solitary case under the anticolor law in that court, although the julge said he did not beliere in it. He was opposed to it and criticised the law from the bench. Ofticials about the court room were opposer to it, public seutiment in the court-house was opposed to it, and there were half a dozen lawyers on the other side opposed to the one lawyer representing the State; and yet in spite of that the principle underlying these laws, the compelling of men to be honest in the sale of a counterfeit food product. was so strong that a judge and a jury prejudiced and opposed to the law were compelled to make such decisions and such a verdict as that the law was sustained; and not only that, but the demonstration was so strong that the principal defendant in those cases came to me and admitted that he was wong, aud that never again wonld he violate a statute as just as that.

Semator Dolliver. Yom have stated that it is possible in the State of IVisconsin to sell the uncolored article?

Mr. ADAMs. I do.

Senator Dolliver. And that it is sold in the ordinary course of business?

Mr. AdAis. Will the Senator permit me an explanation, to say what I forgot to say before? Up) in ()shkosh this gentleman from whom I have obtained an uncolored sample was violating the law. I went up) there and arrested him. I talked with him about it and I said: "Why do you do this? You have a good business. This is the best butter 
shop in the city of Oshkosh. You have the best trade. Why do you violate this law?" "Why," he said, "I did not suppose it was a violation. The representatives of the Chicago manuficturers came up here and said there was no reason why I should not sell it; that if there was any law it was unconstitutional; that the courts liave turned it down;" and he said: "Not thinking very much about it, I have been selling it." I want to say to this committee that when my inspector went up there and bought a sample of colored oleomargarine that man was selling it at either 23 or 26 cents a pound; and he stopped the business and went to selling the nncolored butterine at 16 cents a pound. The price of butterine sold from that store was reduced 7 cents a pound, and the laboring people of Oshkosh who were buying it got the butter for less money simply because the law of the State was enforced.

Senator ALLEN. Then it is possible to sell to the consumers uncolored butterine?

Mr. ADAMS. Certainly it is.

Senator Dollrver. You mentioned a country in Europe, Denmark, where that is done.

Mr. Adams. Yes, sir.

Senator Dolliver. Do you know the condition of that trade in other countries in Enrope?

Mr. ApAns. I know that so far as England is concerned they have a law there prohibiting the sale of oleomargarine for butter. As to the details of that law, and the extent to which it is carried out, I am not informed.

Mr. Tullinghast. Do you not know that in all foreign countries wherever oleomargarine is sold it is sold precisely of the same color as the butter that is sold in those comutries, whether it is one thing or another?

Mr. ADAMs. The one country of which I have definite knowledge is Denmark. There they prohibit its coloring and compel it to be sold in its own color and in a separate place in the store in which it is sold.

Mr. Tillingmast. Is butter colored there?

Mr. ADAus. I think very likely it is. I hope so.

Mr. Tillinghast. What proportion of the 107,000,010 pounds of oleomargarine that was sold last year do you think conld be sold in the United States if it was not colored?

Mr. ADAMS. My estimate is based on these samples, provided none of these samples are colored. These gentlement think they are selling uncolored butterine. I will concele that some of these samples are a little colored.

Sellator DoLLIVER. This one is certainly highly colored.

IIr. ADA.ns. I should jurlge so. Providiug this law goes into effect, and providing that it piohibits the manutacture and sale of colored oleomargarine, and provided there are as many licenses out in the Tnited States after the passage of the law as there are now-there are now 9,028 licenses in this comntry-I believe there wonld be sold on an average at least $\tilde{5,000}$ pounds a year by each of the 9,000 retailers of the Uniterl States.

Senator DOLLiver. Do you not think if every merchant, instead of becoming an apologist for oleomargarine, practically, in many cases, denying that it ss oleomargarine and claiming that it is butter, should become literaliy an agent for the sale of the legitimate article, without these prosecutious and fears of prosecution, that it would greatly increase the sale of it?

Mr. ADArs. There is no question about it. These gentlemen mpon 
the other side know perfectly well, as I know, who have come in contact pelsonally with hundrerls of merchants in my State, that they would be glad to sell oleomargarine under those conditions, but they do not want to sell it in competition with other merchants who are willing to sell it in violation of law. This will be a preminm upon honesty. Many of the manufacturers are perfectly willing to make their butterine uncolored, aud do not desire to build np a frandulent business. One of them has admitted it to me, and he said to ne: "I will concerle to you that the time is coming when we shall make this article nncolored, sell it at a reasonable profit for what it is, and build up) a business here in this conntry which will make the dairymen shake in their boots." I said: "Very well, gentlemen, if you can do that we shall be compelled to shake, because we will have no argument in our defense."

If this substitute is reasonably wholesome, why do you not take it and go into the markets under its own color and do what you can with it aud obtain a reasonable busiuess? But the trouble is, they come up into my city, and they say to some of the grocers there: "You sell this in violation of law and we will protect you. We will pay the expenses." Some of these firms are practically in a conspiracy to break down the laws of the various States in this Union; and so we come to Congress knowing that you gentlemen in the United States Senate and in the lower Honse know perfectly well that it is not dishonest to exercise the taxing power of this Governuent to stop a great fraud. It has been done before. It was done in 1S86. It was done in the passage of the filled-cheese bill. It was done when we passed a law taxing adulterated flour and providing for labeling. Our friends said these measures were all unconstitutional. They said they were dishonest. They said that Congress could not do it; but did they ever take a case to the Supreme Court? Did the law of 1886 ever go to the Supreme Conrt? I came down bere three times in behalf of the filled-cheese bill. I went before the Committee on Ways and Means over in the other House.

Julge Crisp), of Georgia, and Mr. Grosvenor, of Ohio, insisted that I shonld discuss the mattel of the wholesomeness of filled cheese. I said: "Why, I don't propose to waste a minnte on that. It is not a question of the public health; it is a question of honesty. Here are a lot of fellows taking skimmed milk, taking the natural butter fat all out, putting the artificial fat in, and making an inferior product, calling it full cream clieese, sending it into the markets of the Sonth, sending it across the ocean, and thereby, by placing that inferior prorlnct in the markets of Europe, cuttiug down our exportation of cheese from $120,000,00(1)$ pom by the American Cougress simply to stop that fraud and to builrl up and maintain the tralle of this nation. We do not come here represent. ing the farming interests of this country to demand class legislation. We do not want it. We have no right to come here and ask an unjust thing simply because there are millions of us. By no means. If I were a Senator of the United States and every man in my district wanted me to vote for au unjust and an mnfair law, I wonld not do it. We come here and ask you to do what we believe is right. We do not want any protection from legitimate competition, but becanse of our number's, because of our industry, becanse of the way in which we have placed States and built up a wholesome prosperity, we come to the American Congress and we ask for justice and protection, not against competitiou, but against fiaud.

Mr. JELKE. Is not your industry more prosperous now than it ever was before? 
Mr. Adams. Yes, sir,

(The committee, at 12 o'clock and 10 minutes p. m., took a recess until 2.30 o'clock p. m.)

At the expiration of the recess the committee resumed its session.

Mr. ADAms. I should like to give way for tive minutes to a representative from Maryland, Mr. Medairy, for a simple statement of not over five minutes in length.

\section{STATEMENT OF SUMMERFIELD B. MEDAIRY.}

Mr. Medarry. Mr. Chairman, I feel that there is very little for me to say in the interest of the dairy more than has been said by those who have preceded me. I have listened with great satisfaction and instruction to those who have addressed the committee with respect to this bill. I realize the fact that there really is nothing mole important before the committee than the bill itself, which curries with it the charge that oleomargarine, as manufactured and sold to day, is sold surreptitionsly, which accounts for the magnitude of the industry. That is demonstrated by the experience of those who are practically engaged in the dairy business.

The city of Baltimore about two years ago was flooded with the sale of oleomargarine, surreptitionsly sold to such an extent that it was felt by every one engaged in the dairy business. We felt that something ought to be doue. The ontcome of it was the organization of an association for the protection of the dairy interests and of the people of our city against the imposition that was being practiced by the muscrupulous vender of oleomargarine, made possible by the fact that oleomargarine was colored in semblance of yellow butter.

During two years I personally supervised the administration of our law, and I found that we were deficient by virtue of the fact that many people were unable to distinguish oleomargarine from butter and thereby sutfered the penalty. At the last meeting of our legislature, Mr. Hewes, our attomey, and I went to Annapolis and succeeded in having passell an anticolor law, which has aided greatly in the result we sought to accomplish. During that time, as well as my memory serves me, out of nearly one hundred and forty-one cases-I think that was the exact number, althongh I may be mistaken in regard to one or two casesthere was not a single retail sale in the course of prosecution but what was sold as and for butter by the storekeeper or the restaurateur, and in many instances we found that the people who were bring prosecuted were innocent of any intention of violating the law, but had been deceived by the vender, who in turu had hought his product from the manufacturer's agent, but lıad, subsequent to its purchase, taken the product from the original package and placed it in a basket or a box, a vessel of some kind, and sold it as and for butter. The uninitiated, not being able to distinguish one from the other by virtue of its semblance, bonght the same for butter and in turn sold it as such.

We had many such cases in the course of prosecution, the henefit derived therefrom inuring to the manufacturers, to the discomfiture and to the detriment of those who innocently bonght the stuff for butter. We found that to be the case not only with respect to a few storekeepers, but with respect to the hotel keeper, to the restauranteur, to the lunch-comnter proprietor. We found withont an exception that they bought their goods from the manufacturer's agent as and for what it was, but in turu palmed it off on the cousumers as and for butter. That has been onr experience for the last eighteen months. Out of the hundred and forty-one cases there was not an exception but that the 
stuff was sold surreptitionsly, and all accomplished by the fact that this stuff was sold for that which it was not, made possible by the fact that the manufacturer's colored it.in semblance of yellow butter.

Mr. Adams, who has preceded me, has very clearly demonstrated the iniquity of this state of affairs and how the frand is made possible. It requires an expert to determine one from the other, and as an evidence of that, no later than this very day, within the last hour, in company with Mr. Hewes, I repaired to oue of your principal hotels in Washington. We called for our dinner. The waiter brought us our dinner. Upon the table he placerl two plates, upon which was something supposed to be butter. We examined it, and I immediately called the waiter to my side. I said: "Take this back. Tell your proprietor that I want butter, and not oleomargarine." In support of that statement I have bronght both here to you to-day. These are actual facts, Senators. The proprietor I afterwards called to my side and asked him the question, "Did you buy this for butter or oleomargarine?" I said, "I want a direct answer." and he admitted that he bought it for oleomargarine and served it to us as and for butter. We then called for a piece of butter, which he furnished.

Mr. HewEs. Here [exhibiting j is the oleomargarine he served first and there is the butter which he gave afterwards.

Mr. IEDAIRY. That came from a hotel this very day. It is an object lesson.

Mr. Tillinghast. Did yon ask for butter?

Mr. Hewes. We asked for dimer.

Mr. MEDaIRY. Then we asked him to bring some butter, and I tasted it, as I always do.

Mr. Hewes [exhibiting]. They are almost identical.

Mr. Meidarry. These are the two samples. That has been my experience almost without interruption in-I do not know how many instances.

Senator ALLEN. Which do you say is the butter?

Mr. Medair Y. I can tell you.

Mr. Hewes. Anybody can tell.

Senator ALLEN. Yoll can tell which is which?

Mr. Mediary. I am an expert in the business and claim to be able to tell at any time.

Mr. Hewes. Anybody can tell. If you smell it, you can determine.

Mr. MedarRy. Do you prefer that I shall tell you?

Senator ALLEN. My judgment is that that [indicating] is the oleo.

Mr. Medarry. Yes; that is right.

Mr. Hewes. You can smell it.

Mr. Medami. That is why we ask for legislation to preclude the possibility of such deception, and by such deception as this the business has grown to the magnitude which they have admitted that it has. Gentlemen on the other sille have stood up in this room in my presence and have admitted that unless they colored the oleomargarine as you see that sample colored they can not sell it. I think, with all due respect to the representative of every industry that goes to make up oleomargarine, that it is a reflection upon a Senator of the United States to come here and ask him to support a measure that will tend to such fraud. I do not doubt for one moment that the city of Baltimore is but an inclex to the principal eities of the United States.

Senator ALleN. What hotel did this come from?

Mr. MEDAIRY. The hotel opposite the Baltimore and Ohio depot. I think it is called the $B$. and $O$. hotel. I called the proprietor to the 
counter and asked him the question, and he admitted to me that it was oleomargarine.

Mr. Tillinghast. What law did he violate?

Mr. IEDAIRY. I do not know, sir. I am not competent to argue that question. I simply know that in my own city we have a color law passed by our last legislature. We have yet to have an arrest of a dealer, other than a manufacturer's agent, and my statement can be verified upon investigation, wherein anyone, withont exception, man, woman, or child, sold colored oleomargarine as and for such. I do not want to trespass too long upon the courtesy of my friend. I thank the committee for its courtesy.

\section{STATEMENT OF H. E. ADAMS-Resumed.}

Mr. ADAIIS. I hold in my hand the prospectus of the Standard Butterine Company, organized, I think, under the laws of WVest Virginia, having a capital stock of $\$ 1,000,000$. The purpose of this company is to manufacture butterine in the District of Columbia. 'The total cost of $\mathbf{1 0 0}$ pounds of butterine or of oleomargarine-those two terms are used interchangeably and mean the sane thing in this discussion-is $\$ 8.9^{\circ}$, a little less than 9 cents a pound, including the tax thereon. In the statement of this prospectus I find the following:

It will be seen that the above cost, when dedncted from the market price of 13 cents a ponnd, shows a net profit of $\$ 4.08$. It will be seen that even if the company prodnce only the 400,000 pounds yer month for which it now has defiuite orders, a net profit of over $\$ 16,320$ a month, or $\$ 195,810$ a year would be assured. This would be 8 per cent ou the prefelred stock of the company or 20 per cent on the entire capitalization. The Standard Bntterine Company is incorporated with a capital stock of $\$ 1,000,000$, divided as follows:

An attorney of this company appeared before this committee yesterday and made an argument against the Gront bill. The burden of his argument, as I understood it, analyzing it and getting at his purpose, is that this is a sort of philanthropic institution, designed for the purpose of giving the poor men of this country a cheap substitute for butter. In other words, he practically made the claim before this committee that this company, with a million dollars' worth of capital, should be permitted to do business muestricted by state or mational law; a business wbich would enable them to manufacture a counterfeit of butter in the form and under the color of butter, and in the main be sold at or apploximately at a butter price to the laboring men of this country, and that it is a right which the laboring men demand they should have. The mere statement of the ease is argument enough against it. In the course of his remarks he drew rather a poetic picture of the present conditions of the country village. He alluded to the disappearance of certain industries in these country villages, and regretted, in a way, the disappearance of the village carpenter, and called attention to the mysterions disappearance of the village tinker. I do not know where the village tinker has gone. I know some of them have gone into the practice of the profession of law; some of them are undoubtedly upon farms: but the whole tenor and drift of his argument was to this effect that, in the march of progıess that is going on, in the changes which are going on in the industrial world, some men and some industries are liable to be wiped off of the face of the earth, and that all these changes are legitimate. The inference from his argument was that this oleomargarine was of such superior character that if it was not restricted by State or national law it would go on and eventually eliminate the dairy farms. That was the inevitable deduction from the logic of that illustration. 
Now, I want to say to him, and I want to say to this committee, that we appreciate the way in which modern inventions come in here and change things. We are perfectly willing to accept the fact that oleomargarine under its own color is a product of modern genins and is a substitute, to a certain extent, of legitimate products; but we insist that it is not in the line of progress to bring into the American market something in the form of a counterfeit; that it does not pose as being in the line of progress simply because it has some merits, because it exists in the market and masquerades there in the form of a more valuable and a better product. Why, our friends say that we have not bronght any evidence to prove here that oleomargarine is not as good as butter. We have brought some evidence, as a matter of fact, and I want to suggest to the consideration of this committee, so far as the relative merits of these two articles are concerned, that I do not believe-this is a statement of belief-that any member of this Senate Committee on Agriculture, in view of all that has been claimed for oleomargarine, or that any of the 90 Senators of the United States, or that any one of the 357 members of the lower Honse, at any time or any place, ever went into a restaurant or a hotel or any other place where food could be found and called for oleomargarine. No matter what the attorneys or the persons interested in this business may say, the judgment of men in this country is that butter is superior to oleomargarine as a food produet. They go into these hotels and restaurants and places where it is sold, and call for what? Did yon or any of you ever know of a man who went in and called for butterine?

Our friends say the Wadsworth substitute is a proper substitute for this measure, and that substitute is designed to prevent the sale of oleomargarine for anything except what it is. Let me tell you what the facts are. In the State of Wisconsin, from which I come, and where for six years it has been my purpose and my effort to enforce the dairy and food laws of that State, this is the way they deceive the people there. To a very considerable extent we enforce the law. The manu. facturer sells his oleomargarine for what it is. The wholesaler sells it for what it is. The retailer, as a rule, buys it for what it is; and the retailer in Wisconsin, as a rule, sells it for what it is, but the men and the women who buy the great bulk of that product in the State of Wisconsin, buying it for what it is, place it upou the tables of their boarding houses and hotels and restanrants and along the connters, and sell it in response to a call and a desire for what? Oleomargarine? Not for one instant. It is sold in response to a call for butter, to people who do not want oleomargarine and do not ask for it. Not only that, but in the State of Wisconsin the law is evaded in another way. Our friends in Chicago have agents in that State. These agents go around to the different people whom they think may want to buy oleomargarine. They take orlers and those orders are sent to the Chicago dealer and the goods are sent to the final purchaser in the care of this agent and delivered by him to them; and mondoubtedly, althongh we can not prove it in prosecutions, these agents take the difference between the wholesale price and the retail price.

Under the law of Wisconsin an agent is not a seller, and we are unable to reach the traffic. That is the way they avoid it in our State. In the main onr prosecutions are sueressful, but not always. Let me give you as an illustration one case where they were not. I sent my inspector into a city in northern Wisconsin liaving a population of 30,100 . He bought some colored oleomargarine sold by a dealer in violation of law. We appeared in court. Our testimony was abso- 
lutely perfect so far as proof was concerned. It was not doubted or denied in any way by the attorney for the defense. The attorney for the defense was the mayor of that city-a skilled lawyer. He came before the jury. He did not put a single witness upon the stand-not one. He simply said to the jury, "Gentlemen, this man who has been arrested has been a citizen of this city many years. He is a good man. He pays his taxes. He is regarded as honest. These men who are trying to enforce this State law have come up here and induced him to break it. He is a good fellow." There was a saloon keeper in the jury. He said, "This law is like the Sunday closing law, not designed for enforcement. Now, what yon want to dlo, gentlemen of the jury, is to go out and acquit this man." They went ont and in three minutes they acquitted him, in spite of the evidence, in spite of the law. We go down to the city of Racine and arrest men for selling colored butterine, and they are aided by their friends in Chicago. They employ the most talented attorneys in the eity. He comes in and secures postponements and motions from one court to another, and it comes up for final trial in the circuit court. The circuit judge disappears-properly, no donbt-and another judge from a distant connty comes in and throws the case bodily out of court, because he says the complaint was improperly drawn; and yet every ease in the State of Wisconsin that has been brought before the best judges in that State has been based upon the same form of complaint-a complaint user in Mlassachnsetts, a complaint used in New York, a complaint which has practically been passed upon by the highest courts in the land. That is the way this law is evaded in the State of Wisconsin. I can not give you all the details. I give you some of them because my time is limited.

Senator AlLEv. It ought to be a very easy matter to draw a sufticient complaint.

Mr. ADAus. It was sufficient. The judge simply turned it down. All the anthorities were arrayed behind that complaint, without a single exception. But I just give this as an illustration of the diffieulty of enforeing the laws of my State.

One of the gentlemen on the other side, fair-minded, as I believe, as a rule, and courteous always, came in here the other day and made a statement which I think on reflection he would be willing to change. He says the representatives and triends of this Gront bill have come in here and made the cowardly statement to this committee that their laws were not enforced. I would ask the gentleman and ask the committee if it is cowardly for the representative of any interest to come in here and tell the truth. We say it is not enforced to the extent that we desire. We say that in the great State of New York, represented before this committee by a dairy and food commissioner who tor seventeen years has been improving by his own mind and judgment the laws of that state by necessary amendments, and who has enforced to a great extent the laws of Now York, the facts are honestly admitted. The admission includes his assistant, who eame before this committee and said that in one thonsand cases in the eity of New York during the last three or four years in every solitary one of them he secured convictions, and in every case the product was bought for and as butter by the people who wanted butter.

Why, gentlemen, you talk about the merits of this law and you say that yon men who represent the lairy commissioners ought to go out and enforce it. We do go out. We do the best we ean. In the State of Wisconsin only 700,000 pounds were sold last year, and that is only one-third of a pound of oleomargarine to every inhabitant in that State. 
They say, "If it is so small, why do you want it?" We want it becanse Wisconsin is a great dairy State; because we manufacture anmually $80,000,000$ pounds of butter: becaune that butter is sent into all the markets of the world. We are willing to meet any competition which is legitimate in those markets. We are willing to stancl up acrainst any product of science or art or skill which these gentlemen may devise in the open markets, but we do not want to stand up against a connterfeit which, as the courts have said, is of such a character that the average consmmer can not distinguish, and is thereby compelled to buy a thing which he does not want.

Have we no testimony? Is it not true that as against the testimony of the gentlemen interested in the oleomargarine business and, their attorneys before this committee every dairy commissioner in the United States who has expressed himself npon this subject has said that there is need of national legislation to wipe out what is one of the greatest evils in food products in this country of onrs? Is not that testimony before this committee? Our frienrls ou the other sicle have endeavored to array the stork interests of the comntry against us upon the ground mainly of personal interest which those stockmen may have in this question. For just a moment I will refer to that.

During the last year, as I understand it, there were in round numbers $5,000,000$ heev's killed in this comntry. The tot:l amount of oleo oil which went into the production of the 1899 oleomargarine product was $24,000,000$ pounds. In round numbers the value of that product was $\$ 2,000,000$. That is about 40 cents per heal, as against the statement of the representatives, so called, of the live-stock interests before this committee that the loss, if this bill is enacted into law, would be from $\$ 3$ to $\$ 4$ a head. Now, that is on the supposition, which is not correct, that if this bill is enacted into law the oleomargarine industry will be crushed. It will not be crushed. Ion will dowhat is done in Denmark, in my judgment. In years to come-I don't know how many it will take-yon will sell a goorl lair portion of your prodnct in the American market as it is sold in Denmark. Three and a half pounis to each inhabitant are sold there of uncolored oleomargarine to 1 pound to each inhabitant in the United States, even with all the aids that color can give anıl all the frauıs that are perpitrated in the different States in this Union. Why, gentlemen, even if they conld not sell their oleomargarine product for this purpose, they can sell it as tallow, and they can get half the amount which they get now, and the actual loss under those tigures would be less than 20 cents a head.

Out west of the Missouri River what is most valuable to those people who have been raising wheat year after year and year after year and exhausting their soils? We have had some experience in II isconsin. When I was a boy. away back in the serenties, the farmers in Wisconsin were in financial distress. They had cropped and recropyed their fields and cropped again, as they have in the State of Iowa, until the production of wheat had dropped from 20 bushels to 10 bushels per acre. They turned to the business of keeping cows. They have made Wisconsin a dairy State. 'They have made a product which has not taken fertility out of the soil-butter-which is sun like, and does not come from the valnable elements of plant food that lie in the soil; aud because of that business they have bronght back to the State prosperity and nore wealth and more comfort not only to the farming population of Wisconsin and lowa and Minnesota, but also to every class of penple in those States; and in Nebraska and in those States beyond the Missonri that process is going on. The coming industry in those States is going to be the 
industry of the cow. We do not want to build np this butter business upon the ruius of any other legitimate business, and least of all upon the ruins of that business which is compriserl in the making of meat foods for the donestic and foreign markets.

A gentleman came here the other day and said he represented the labon organizations of a portion of the state of Pennsylvania, and lie said before this committee, claiming to represent the real interests of labor, that he did not buy oleomargarine himself-that he did not have to; and he and his friend testıfied before this committee that when those men went into the stores of Pennsylvania they invariably called for butter and they got oleomargariue, and knew they were going to get it. Why? Because he said they were ashamed to buy oleomarga. rine nuder its own name. It is an astonishing proposition. What will be the effect to the laboring men of this country of the passage of this law? It will be that oleomargarine will be sold nnder its own color and at an oleomargarine price. You go into the markets of Wisconsin, yon go into the markets anywhere, and you buy uncolored oleomargarine and you get it at a reasonable oleomargarine price. There is no more disgrace in buying oleomargarine under its own form and color than there is for a member of Congress to go up here to this vandeville show and buy a 2.;.cent seat instead of a 5().cent seat. I have seen them do it. 'There is no more disgrace in a woulan's going into a store and buying a calico dress than there is in buying a sillidress. It is simply ille nonsense. Pass this bill and the laboring men of this country will get their substitute for butter at exactly what it is worth. Permit oleomargarine to be sold uncolored, and these men claim they have an actual right to it, given to them by the Almighty, and they will be compelled in the majority of instances to pay a butter price for it.

Gentlemen, I do not want to crowd upon the time of the gentlemen who are to follow me, but 1 want to read just a little, simply to enter it in this testimony, with reference to the direct testimony which we have brouglit.

Senator ALLEN. Do you not think it would save time and do just as well to file it and let it become yart of the record?

Mr. ADAus. Except this, Senator; part of these letters are personal. I am going to read extracts, and they will be very brief.

I received a short time ago from the Vermont J)airymen's Association the following resolution:

Resolved, 'That we, the members of the Vermont Dairymen's Association, in our thirty-first annual meeting assembled, do heartily approve of the Grout oleomargariue bill now pending in Congress.

Resolved, We believe it for the best interests of the producer of pure dairy foods, as well as the consumer, that such a bill be enacted.

Resolied, That the members of Congress from Vermont be asked to use every legitimate effort in securing the passage of said bill.

liesolied, 'That a copy of these resolutions be sent at once to each member of Congress fiom Vermont.

Here is a letter from the dairy commissioner of Michigan:

\author{
State OF MICHIGAN, \\ DAIRY AND FOOD DEPARTMENT, \\ Detroit, Nich., December 21, 1900.
}

Hon. H. C. ADAMs, Madison, IIis.

DWAR Mr. ADAMS: * * * If I can arrange some matters here in Michigan, I shall try and leave sometime Wednestay, and shall reach Wasbington eariy on the morning of the 3d. I will do my best to bring this about, but, as I say, the chances seem against it. Had I known a little while ago that you might desire my testimony I should have held myself in readiness, but coming as unexpectedly as 
sonr summons does, it places me in a very difficult position. I earuestly desire to assist in the passacre of the flout bill, and believe that the story I can tell of the situation in Nichigan might do something to secme the end. Fnrther, I feel that the consuming puolic, as well as the rairymen of llichigan, have a right to expect me to at least reveal conditions when important legislation like this is pending:

The principal reason why I can not leave Michigan is the fact that I am about to turn over the dairy and food department to $u y$ successor just in the midst of a bitter milk fight here in Detroit.

Very sincerely, vours,

Ellot O. Grostenor, Commissioner.

I have also the following letter:

STATE OF IOWA,

OFFICE OF DAIRY COMMISSIONER,

Cresco, Iou'a, Necember 39, 1900.

Hon. H. C. ADAMS, Madison, Wis.

DeAR SIR: * * $*$ Will you not kindly express for me my strong indorsement of the bill in its present form. The undersignet has yet to find a siugle man who objects to the bill when he understands its provisions and its purpose, unless his personal interests are along the line of selling oleomargarine under present conditions. I am firmly convinced of the necessity of this law, and know only too well the futility of our present State anticolor laws. The 100,000 creamery patrons of Iowa are anxiousls awaiting the passage of this bill, and it has the indorsement of almost all our farmer's, whether interested in dairying or not. Respectfully,

B. P. Nortos, Dairy Commissioner.

I have a letter here from J. B. Noble, dairy commissioner of the State of Connecticut:

State of Connecticut, Darry Commssionel's OfFice, Hartford, January 3, 1901.

Hon. H. C. ADAus,

Hainy Conmissioner, Madison, Tis.

DEAR SIR: * * * This is one of the most important measures connected with the dairy interests which has been before Congress for a loug time. 'l'be dairymen all over the country are recognizing its importance and are extremely anxions for the passage of this bill.

Important matters in regard to our own business in Connecticut will keep me here for the present. I have tro oleo cases which must be attended to this week, and I can not leave them, and other business connected with the office, to go to Washington now.

Yours, respectiully,

J. B. NOBLE.

Here is a telegram from the Commission Merchants' League, Cleveland, Ohio:

Convention has just passed resolution indorsing the Grout bill, and wired Proctor at Washington.

Charles T. MatThews.

Now, then, Mr. Chairman and gentlemen of the committee, we submit here as testimony in behalf of this bill the experience of the dairy commissioners, who are brought directly into contact with this business and have the facilities which few men can have of knowing the character of that traffic. We come here to Congress and ask tor its passage, because we believe it is a proper exercise of Congressional power to place a tax which is substantially prohibitory, in our jurlguent, upon oleomargarine colored in initation of butter. We have behind us not only the statements of the commissioners, but we have also behind ns the expression of $62,000,000$ of people who have legislated in belialf of absolute prohibition in their several States.

If you will excuse me a moment, I wish to made reference to certain cases which I have not taken the time to read:

In McAllister $v$. State ( $\%:$ Md., 390), the court of appeals of Maryland sustained the validity of a statute of that State declaring it unlawful to offer for sale as an article of food in imitation and semblance of nat- 
ural butter. 'The object of the statute being to protect purchasers against frand and deception, the power of the legislature the court said, following the previons decision in Pierce $x$. State (63 Md., 596), was too plain to be questioned.

In Waterbury $v$. Newton (21 Vroom, j34), the New Jersey supreme court sustained the validity of an act that forbade the sale of oleomargarine colored with anuato. In response to the suggestion that oleomargarine colored with annato was a wholesome article of food, the sale of which could not be prohibited, the court said:

If the sole basis for this statute were the protection of the puhlic health, this oljection would be pertinent, and might require ns to consider the relicate questions whether and how far the judiciary can pass upon the adaptability of the means which the legislature has proposed for the accomplishment of its legitimate ends; but, as already intimated, this provision is not aimed at the protection of the public health. Its object is to secure to the dairymen aud the public at large a fuller and fairer enjoymant of their property by excluding from the market a commodity prepared witl a view of leceiving those purchasing it. It is not pretended that anuato has any other finction in the manulacture of oleomarcarine than to make it a counterfeit of butter, which is more generally estcemed and commands a higher price. That the legislature may repress such comnterfeits does not aduit, I think, of substantial question. Laws of like rharacter have been frequently assailed before the courts, lut always without success.

It was further held by the comrt that the statute of New Jersey was not repugnant to the clanse of the Constitution empowering Congress to regulate commerce annong the States, but that the package there in question, and which had been brought fiom Indiana, became, upon its delivery in Jersey City, subject to the laws of New Jersey relating genevally to articles of that nature. (50 N. J. L., 535, 537.)

In the case of State $r$. Marshall $(64 \mathrm{~N} . \mathrm{H} ., 549,551,552)$, arising under a statute of New Hampshire relating to the sale of imitation butter, the court said:

Butter is a necossary article of food, of almost universal consumption; and if an article componuled from cheaper ingredients, which nany people would not purchase or use if they linew what it was, can be made so closely to resemble butter that ordinary persons can not distinguish it from genuine butter, the liability to deception is such that protection of the julblic requires those dealing in the article in some way to designate its real character. *** The prohibition of the statute being directed against imposition in selling or exposing for sale artificial compounds resembliug lutter in appearance and flavor, and liable to be mistaken for genuine butter, it is no defense that the article sold or exposed for sale is free from impurity and nnwholesone ingredients, and healthful and nutritions as an article of food.

Senator AlLen. Can you furnish the committee a copy of that brief?

Mr. ADAMs. I can. I will submit the entire brief, which is a protest of the National Dairy Union against the adulteration of food products.

I would like also to submit some references here which I would like to discuss with reference to certain points concerning the legal phase of this question, but which I will not take the time to discuss.

The references above referred to are as follows:

CONSTITUTIONALITY OF A LAW PLACING AN INTERNAL-REV'ENUE TAX UPON OLEONIALGARINE.

The Snpreme Conrt in MeCulloch $v$. Maryland, 4 Theat., 428 , says:

"It is admitited that the power of taxing the people and their property is essential to the very existence of the Government, and may he legitimately exercised to the utmost extent to which the Government may choose to carry it. The people give to their Government the right of taxing themselves and their property; and as the exigencies of the Goverument mar not be limited, they prescribe no limits to the exercise of this right, resting confidently on the interest of the legislator and on the influence of the coustituents over their representatives to guard them against abuse."

Desty, in his work on taxatiou, says:

"One purpose of taxation sometimes is to discourage a business, and perhaps to put it out $0^{*}$ existence, and it is taxed without any idea of protection attending the burden." 
In 1886 Congress passerl a law imposing a tax of 10 per rent on all rulrency issned lyy State banks. 'This was intended clearly not as a measure of taxation, brit as a measure of prohibition. The Supreme court of the Lniterl States held this law to be constitutional, and said:

"The tax can not be hell invalid for heing so excessive as to indicate a pnrpose to destroy the franchise of the state banlis."

Chief. Justice Marshall, in the case of McCulloch r. Maryland, also suid:

"That the power to tax involves the power to destroy is a proposition not to be denicl."

Justice Story, in his work on the Constitution, book 1, pages 677-678, says:

"Nothing is more clear from the history of" nations than the fact that the taxing power is often, very often, applien for other purposes than revenue. It is often appliol as a virtual prohibition; sometimes to bauish a noxions article of cousumption: sometimes as a suppression of particular employments."

Alexamuler Hamilton sajs:

"I moler the taxing power there is no limit as to the amount which mas be charged. It often happens in certain avocations that llo power to tax is nsed in aid of the police power, either hy devoting the fund to the payment of the police powel or by makiug the tax so high as to be in its natme prohibitory.

Jnstice Woodbnr, in the case of I'ierce et al. $\%$ N. H., 5 Wheat., 608, said:

"lint 1 go finlther on this point than some of the court, and wish to meet the case in front and in its worst bearings. It, as in the view of some, these license laws are in the nature of partial or entire prohibitious to sell certain articles, as being dangerous to public bealth and morals, it does not seem to me that their conflict with the Constitution wonld br any means le clear. T'aking for granted that the real design in passing then is the avowed one (probibition), they wonld appear entirely defensille as a matter of right, thongh prohibiting sales."

In Waller's science of Wealth this rule of taxation is also general:

"The heaviest taxiss shonld be imposer "pon those commodities the consumption of which is especially prejuclicial to the interests of the people."

Mr. HEwEs. I would like to add one case to the references given by Commissinner Adams. That is the case of Fox, 89 Maryland, page 389. That is where Judge Fowler says it is impossible to restrict the sale of original packages when the article is not deleterious to health, if it is not proven loy the state that it is deleterious to health. That is a very important rase, showing the absolute necessity for this legislation, so far as the first section is concerned.

\section{STATEMENT OF S. C. BASSETT, PRESIDENT OF THE NEBRASKA STATE BOARD OF AGRICULTURE.}

Senator ALlen. Give your name, place of residence, and occupation. Mr. BAssetT. S. C. Bassett, Gibbon, Nebr. Mir. Cliairman and gentlemen of the committee: As president of the Nebraska State Board of Agriculture, I appear before you to-day in behalf of the farmers and dairymen of Nebraska wlio desire that the so-called "Grout" bill shall become a law.

If you will pardon a personal allusion, I might say that thirty years ago I made settlement on a homestead in that State, upon which I have since resided: that much of that time I bave been engaged in the dairy and live stock business, and that in this matter I represent the views and wishes of the thousands of farmers of my own State.

It was stated by a gentleman who appeared before you that tho farmers were not asking the passage of tilis law; in fact, that the farmers were not particularly interested in the matter.

In view of the great interest which this measure has created in Congress; in view of its ridespreal discussion in the public press; in riew of the fact that every agricultural newspaper in our land adrocates its passage; that every State dairy and food commissioner who has appeared before you is in favor of the bill; that State boards of agriculture, State dairymen's associations, national and State granges hare all adopted resolutious in favor of this measure and urging that

$$
\text { s. Rep. } 2(1)+3-2 ?
$$


it become a law; in view of all these facts, it seems to me that one must be willfully ignorant who says or intimates that farmers or dairymen are not asking or particularly desiring that this measure become a law.

In my own State very few measures before Congress have ever created the interest among our farmers that this one does.

We have been struggling for years to suppress the fraurlulent sale of oleomargarine as and for butter. By a large majority in the Honse and with but two dissenting votes in the Senate we passed in 1895 a law prohibiting the sale of imitation butter colored yellow.

This law is openly violated. Large quantities of oleomargarine of a yellow color are sold, and I fully believe 90 per cent of the same is sold to the consumer as and for butter.

In $189 \mathrm{~s}$ we ereated the office of food commissioner, whose duty it was to enforce the dairy laws of the State. In attempting to enforce said laws it became necessary for the deputy fool commissioner to employ a ehemist and have analyzed samples of oleomargarine sold for butter. When about realy for use of the testimony of the eliemist in eases where parties were to be tried for violation of the dairy laws, the ehemist refused to proceed with the analysis or to remain louger in the employ of the food commissioner, giving as a reason that he lad been employed by other parties, and later it appeared that the other parties were those engaged in the sale of oleomargarine.

When the constitutionality of the law creating the office of food commissioner was raised in our courts, the oleomargarine interests asked to be allowed to appear by their attorneys as against the law. I mention these matter's to slıow that a very large per eent of the people of my State are opposed to the fraudulent sale of oleomargarine; that by legal enactments they have endeavored to suppress this frand, using every reasonable effort in their power to that end: that the fiand continues to be perpetrated and the dealers in oleomargarine eontinue to violate the law.

It ought not to be forgotten, but shoulu be liept constantly in mind, that the exceedingly large profits which dealers in oleomargarine receive is the reason why its sale is so stremnonsly pushed. Those who divide the profits of this most profitable business are comparatively few in number, and the retail dealers, who are the principal violators of the law, receive the lion's share of the profit, consiclering the amount handled. With ns a retail dealer makes not to exceed an average of 2 eents per pound on butter sold, while the retail dealer in oleomargarine makes a profit of 8 to 10 cents per pound.

By State legislation we seem well-nigh powerless to control this fraud, and this is why we come to the National Congress, believing that this is the only power. which can compel the sale of this produet on its own merits and for what it is.

There is one phase of this question which has been presented to your committee which is of vital importance to the people of my State. We not ouly produce dairy products of considerable value, bnt we also raise and fatten for the market large numbers of cattle, hogs, and sheep. The live stock industry is, with us, the leading industry. Hence, any legislation ealculated to injurionsly affect this industry or materially lessen in the markets the value of our live stock is of prime importance.

Both hefore this committee and elsewhere the oleomargarine interests have eudeavored to make it appear that the manufaeture and sale of oleomargarine increases to a markerl extent the value of each animal slanghtered in our paeking centers, and that the passage of this bill 
will cause a direct loss to the farmer or ruser of live stock on each animal marketed. There has been created among stockmen a manufactnred sentiment that the passage of this measure would injure their business. At a meeting of live-stock owners in my own State within a year a resolution was presented protesting against the passage of this bill on the ground that it would greatly lessen the value of live stock marketed. It was explained that this statement was not true, and so proven. The resolutiou was finally adopted, one prominent stockman statiug iu oyen meetiug that while he knew nothing as to the facts in the cise he should vote for the resolution on general principles.

The National Live Stock Association has adopted resolntions oppos. ing the passage of this measure, aud a representative of the association has appeared before this committee and attempted to show by statisties and otherwise that this proposed law would very materially lessen the value of all live stock marketed.

On December 17 last, by means of the Associated Press dispatches, there was broadeasted over the country the following statement. purporting to come from Mr. John IV. Sipringer, presideut of the National Live Stock Association. It is dated at Deuver, Colo., and is as follows:

"The stockmen of the West :tre all interested in this bill," said Mr. Springer to-rlay, "and so are all manufacturers. If such a measure as this can become law no industry in the country is safe. If it should become a law and take effect it means simply that the stockmen of the West will lose from $\$ 3$ to $\$ 4$ on every steer the market. We also claim that the on] people directly interested in the passage of this law is the butter trust.

A neighbor of miue who anumally feeds large numbers of cattle for market, after reading this statemeut, said. to me: "If that statement be true I certainly am opposed to your Grout bill."

Gentlemen of the committee, as I understand this matter, this statement is not true, and neither by statistics nor otherwise can it be shown to be true. Statisties published by the United States Department of Agriculture for the fiscal year ending June 30,1899 , show that at 41 packing centers the uumber of eattle inspected before slaughter was $4,654,812$. Ontside of those inspected by the Department it is estimated that enongh more were slaughtered to make the aggregate number slanghtered for the year, 5,000,000 head.

The report of the Secretary of the Treasury of the United States to Congress in May last shows that in all the $\$ 3,000,000$ pounds of oleomargarine manufactured in this country last year there were bnt $24,491,769$ pounds of oleo oil used. This at 9 cents per pound has a

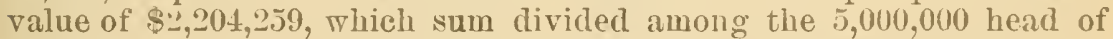
cattle who prodneed this oleo oil makes an average of 44 cents per head.

In some cases this product is priced at 10 ceuts per pound, but I think that is unjust from a prolucer's standpoint, for the reason that at 10 cents a pound oleo oil is a mannfactured prodnct into which labor, ete., goes, and on which profit is realized, but the man who markets the cattle dloes not receive 10 cents a pound for it, and I have used the figmre 9 cents, which, in my judgment, is a proper estimate. No one believes or for a moment seriously contends that if this oleo product used in the manufacture of oleomargarine could not be so used it would be a total loss, and lessen by the sum of 44 cents the averago amount received by the owners of cattle for each auimal sold for slaugh. ter. But suppose it needs be sold at the price of other fats-i cents per pound-it would mean a mere nominal loss of 20 cents on each animal sold for slanghter, which sum every owner of live stock well knows is hardly given a thonght when his stock is being disposed of for slaugliter at packing centers. 
Twenty ceuts is but 5 per cent-the one-twentieth part-of the $\$ 4$ claimed by the president of the National Live Stock Association. Twenty cents represents the valne of about an average of five pounds in the live weight of an animal sold for slaughter, while the 84 claimed would represent about oue hundred pounds of live weight.

As showing that the sentiments expressed by the National Live Stock Association do not represent the sentiments of the majority of the people in the States in which the rattle are owned, I desire to call attention to the number of head of cattle in each State as shown on page 95 of the published report of the hearing of this matter before the House committee.

Mr. John C. McCoy, in his argument before the committee, gives the number of head of cattle in each state, and for convenience I have arranged them in two classes, as follows:

Number of cattle in States having laws prohibiting the sale of oleomargarine colored yellow:

\begin{tabular}{|c|c|c|c|}
\hline (................... & 511,080 & New York $\ldots \ldots \ldots \ldots \ldots$ & $2,059,715$ \\
\hline C'alufornia............... & 913,753 & Nortli Dakota............ & 431,371 \\
\hline Colorarlo................... & $1,115,421$ & Ohio $\ldots \ldots \ldots . . . . . . . .$. & 1. 455,558 \\
\hline Connecticut .................. & 210,717 & Oregon............ & 637,433 \\
\hline Delaware .................. & 58,035 & Pennsylvania .. & $1,494,126$ \\
\hline ... & 666,147 & Soutli Carolina..... & 260,223 \\
\hline & $2,324,254$ & South Dakota ..... . & 69,200 \\
\hline & $3,442,012$ & Tennessee ........ & 235 \\
\hline $\mathrm{ky}$ & 539,419 & Utah ...... & 336 \\
\hline (n..... & $316,53 \pi$ & Vermont & \\
\hline & 257,435 & Virginia ... & \\
\hline isetts. & 254,967 & Washington ... & \\
\hline & $1,23 \overline{7}, 003$ & West Virginia............. & 408 \\
\hline & $2,047,346$ & IVisconsin . . . . . . . . . . . . & $1,598,529$ \\
\hline briska. & $2,206,792$ & Michigan ..... & 801,818 \\
\hline ire & $\begin{array}{l}214,618 \\
263,157\end{array}$ & Total & \\
\hline
\end{tabular}

Number of cattle in States and Territories not hariug latrs prohibiting the sale of oleomaryarine colored yeilox.

Arkansas.

Arizona

Florida

Idaho

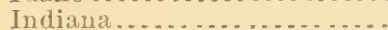

Kansas..................

Louisiana

Mississippi................

Montana

419,422
381,861
412,821
397,928
234,930
867,224
294,961
517,809
459,808

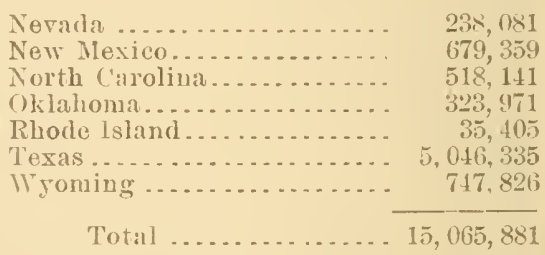

23. 081 679,359

518,141

35,405

046,335

$15,065,881$

It seems to me it is fair to presume that, in the 3: States in which laws have been enacted prohibiting the sale of oleomargarine colored yellow, the sentiment of a considerable majority of the people of eacli of those States is in opposition to the fraudulent sale of oleomarnarine as and for butter, and in favor of the passage of the Grout bill. Of the $43,891,814$ liead of cattle owned in the United States, 28,825,933, or more than 65 per cent, are owned in States where laws have been enacted to prevent the traudulent sale of oleomargarine.

There seems to be an impression here that you can separate the livestock interest into two classes, as it were, men who raise live stock for selling purposes and men who are engaged in the dairying businessthat is, that the men engaged in the dairy business have no interest in live-stock matters. This is not for a moment true. A man engaged in dairying raises the calves the same as the man engaged only in livestock raising. Those calves go to market for slaughter, and further- 
more, in the State in which I live, a consiclerable portion of that State is what we eall the range section, altogether given mp to the rasing of live stock. In western Nebraska and in western Kansas there is not much farming done. There is not much raised in the way of crops. The business of the people is the keeping of live stock.

Senator ALlex. Will you permit the to ask you a question, Mr. Bassett?

Mr. Bassetw. Certainly.

Senator Allex. The dairy interests of our State raise an entirely different elass of cattle from the meat-producing interests, do they not?

Mr. BasseTT. We used to, but we have realized that the calves, the steer calf especially, has a value to the dairyman, and instead of raising and keeping Jersey cows and Holsteins for dail'y purposes, we are going back to what is caller the common-purpose cow, that produces a reasonable profit in a dairy way and at the same time we raise steers that can be fattened for market.

What I was going to say was that mpon the range where their entire business was the raising and marketing of live stock is now one of the most promising industries of our state, in a dany way. Out on the range, where men raise no crops whatever, we have sone skimming stations. A skimming station is where milk is brought and the cream separated from it and the eream shipped to the manutactory to be man. ufacturul into butter. We have three skimming stations where I ain under the implession that more pounds of milk are brought in a year 10 be skimmed than at any other like stations in the United States and possibly in the world. The live-stock owners on the ranges are beroming dairymen, and that is why I protest that the National Live Stock Association does not represent the people of my state in this matter. The people upon the range section of the State are interested in the passagne of this measule.

I clo not wish to discredit the National Live Stock Association before this committee, but in its appearance here it does not represent either the wishes or sentiments of the very large majority of the tarmers and stock raisers of my State. It undonbtedly does reprisent the sentiment rit the packer's, commission men, ormr's of live strck on the ranges, and like interests, wut it does not represent the sentinent of our finmer's and dairymen who are by far the largest raisers and uwners of live stock.

When I say "owners of live stock on ranges," I have reference to that class of men who own large interests in live stock.

Senator AlLEx. Large herds?

Mr. BASSETr. Large herds, yes; and those men do not do much in a dairy way. I have reference to men who own comparatively small herds of eattle.

Senator Allex. Have you any idea of the number of antle in the State of Nebraska at this time?

Mr. BassetT. Something over $2,000,000$ head, 1 think.

We make no eomplaint concerning wleo sold as such, but we do make complaint against oleo sold as and for butter and at butter prices. The whole and entire reason that it can be thus sold is that it is colored in semblance of butter.

If a laboring man wants to eat butter lie can buy it at the market price. If through necessity or choice he wants to eat "pork tat" or "beef fat" he ean buy it for $\bar{j}$ cents to 7 cents a pound.

A gain, we say, it is the color that enables all who desire to defrand the people to ilo so. A color law is the only law devised that protects the eomsumer at the table. 'This law protects the comsmor and the prodicer. 
When Germany amb other nations placed or threatemed to plare restrictions on the importations of the packing houses, the whole power of the General Government was called upon to keep the markets open. They fought against these markets being taken from them.

On the other hand, why should they, if they believe in fair dealing want to take the lome market away from the rank and file of the people? Why should they seek to diminish the outlet of the American farmer for his products?

And more especially is this true when this outlet and this market is taken from lim by fraud which the yellow artificial color given to oleo enables the retailer to work on the comsumer.

There are only two questions involved:

1. This "Grout" bill will suppress fraud.

2 . It will keep open our domestic outlets and markets for the genuine product of the cow.

Will the Government, through its Senate and House of Representatives, stand with the farmer or against him? Will they stand for common honesty or despicable fraud?

\section{ADDITIONAL STATEMENT OF JAMES HEWES.}

Mr. Hrwes. I would like consideration for a moment, if the committee please, as a veteran. I do not believe that this idea has been advanced here at all. I am one of those who came here in 1856 to have the oleomargarine law, as it is called, passed. Of course it was movel legislation in Congress at that time, and we sought to liave the policing feature as prominent as possible in that law. We are now only bringing that law to you here for revision, tinding that the niueteen sections that look to policing are almost disiegarded. There are ouly two revenue sections to the law of 1586 . The other nineteen look to the policing of 1 lic conntry, and we ask you now to revise that becanse we fiuc that State laws are powerless. We can not prosecute people for selling oleonargarine in the original lackage, because, as Brother Adams here has told you, we are met by the varying opinions of the diftereut judges, and they are as various as the leaves from Vallombrosa's sharles. Judge Adams says one thing, Judge Lochran says another, and Judge Fowler says another.

I have had the hour of jrosecuting all offenders under the oleo. margarine law since 1878. It has been a long fight. First it was a regulating law-a law of inspection. Then it became the prohibitory law. Now it is the anticolor law. We come to Congress and we say to you, "Jhis is om law; this is the law of the dairy. We brought this to you. If there is any revenue feature to it, we brought it to the Government," and we promised them a million and a half revenue. We have more than kejt our promise. We have given them more than a million and a half revenue from tlie time the law was passed in 1836 to the present time, and now we say we find that will not do. That does not proteet the consumer at all from the practice of deception that the color produces, and we ask you to eliminate color. We show you by samples produced here that it is possible to make oleomargarino white and still sell it. We lo not crush out the industry. Furthermore, we are almost ready to predict now that uncolored oleomargarine will produce a revenue to the United States Gorermment of half a million dollars. But suppose it does not. Does the dairy interest of the country stand in any different position from what it did before the introduction of the law of 1886 ? Not at all. Was there any revenue 
from this thing at all prior to 1886 ? Not a dollar. There is not a single gentleman who represents the other side but who is confident, perhaps, that with uncolored oleomargarine properly put before the public they can get a revenue of half a million dollars at least.

Mr. WADSworTH. What do we get under the color law at 10 cents?

Mr. HEWEs. I do not believe there will be very much uncolored oleomargarine sold, and therefore the public will be protected from this frand that is perpetrated 1 pon them, illustrated to day by what occurred down here at this restanrant.

The two eases that have been decided in Pennsylvania (in 133 Pennsylvania State Reports)-and they are the leading eases now on that subject-go to show that if a man juts up a meal and serves oleomargarine, he sells oleomargarine. That is a retail sale of oleomargarine, because the cost of the olemargarine is included in his bill of fare.

Senator MONEY. Providing he has got butter on the bill of fare.

Mr. Hewes. He bas got no butter on the bill of fare, but the presumption is you are going to get butter.

Senator HEITFELD. Suppose you go into a restaurant and ask for a meal aud do not get any butter at all.

Mr. Hewes. You eall for bntter, or refuse to eat.

Senator HeITfELD. Not in our part of the comntry. We often eall for it and don't get it. Yon go into a mining camp, and I will defy you to get butter.

Mr. Hewes. I never heard of that East.

Senator HeITFELD. You could not earry it in there. There is no possibility of it getting in there. It would be strong and rancid before you conld get it there.

Mr. Hewes. Where is that?

Senator IlEITFELD. That is in the mining camps.

Mr. Hewes. We are talking about east of the Mississippi River.

Senator Heitfeld. I do not consider it fraud, as a rule, to set up oleomargarine in a hotel, unless the bill of fare contains butter and it is palmed off on you as butter. .

Mr. HEWEs. Take it from the standpoint of a mining camp or any other place, as rude and primitive as it may be. If you go into a restaurant and they put mp anything at all, the presumption is it is butter. You do not presume that a man is going to put oleomargarine on the table for you; and if it was white, yon would detect it immediately.

There has been a great deal of talk here about the different grades of butter. II friend the Secretary of A grienlture did not tell you about the laws of foreign conntries as fully as he conld have told you, because he knew weil enough that was not evidence. The law of Belginm is just the same as the law of Hlolland. The law of France is just as restricted as the law of IIolland.

Senator DoLLIVER. How do they prevent people from getting the connterfeit goods?

Mr. Hewes. Senator, they make oleomargarine to be sold in a place that is different from where butter can be sold. You can not go into the oleomargarine division in l'aris and ask for butter, and yon can not go into the butter division and ask for oleomargarine.

Mr. Tillinginast. How does that protect the table?

Mr. HewEs. That proterts the people who buy it. We have our own sins to answer for, however. We can not regulate the law of l'aris.

Senator Dolurer. But we are struggling tor some method by which to regulate our own affairs.

Mr. Hewes. Yes; you want to get the best. 
Senator Dolfiver. I would like to know how a hotel in Paris is prevented from selling me oleomargarine if I sit down at irs table?

Mr. Hewes. My impression is that in Paris you are subject to the deprerlations of plunderens the same as you are in Washington, because of the color being in oleomargariue, and we ask you to eliminate it. Suppose you went to the best hotel in Paris, or suppose you went to the Hotel Netropole or any other place in London and they bronght you oleomargarine

Senator DOLLIVER. I understood the Secretary of A griculture to say that the United States is the only comtry in the world which allows its people to be plundered in this way.

Mr. HEWEs. He made a mistake about that, I think. I believe he admitted he made a mistake and tried to correct it. He said that oleo. margarine that was exported from this country was exported mostly as oleo oil, and when they got it to the other side, they conld do as they pleased with it; but the laws on the other side are so well enforced that even if a man perpetrates a frand, he does not violate the law openly as he does here.

Senator Heltweld. Will you allow me to interrupt yon a moment? Mr. Hewes. Yes, sir.

Senator HEITFED. This oleomargarine that I find in the market here sells for 18 cents.

Mr. Hewes. What market?

Senator HEITFELD. Herein the Center Market in Washington it sells for 18 cents a yound. There is now a tax of 2 cents a pomnd, and if 10 cents a pound is added to the tax the dealer would receive 26 rents. There is $n o$ butter to be had in that market worth taking out for less than 30 cents a pound. How are you going to prevent the sale of it? Will not the hotels still use it in preference to butter at " 6 cents when they have got to pay 30 cents for poor bitter?

Mr. Hewes. I suppose they will.

Senator HertFeld. Then, where are you benefiter?

Mr. HEwEs. If the hotel nses that oleomargarine it will not put it before you for butter.

Senator Her'TFELD. Why shonld it uot?

Mr. Hewes. Because the hotel people will simply say to you, probably, "Do you want oleomargarine or llo you want butter?"

Mr. MEDAIRY. I rould like to say this, Senator: You are adding $S$ cents additional to the profits of the retailer. That is where you are in error. The alditional tax is put on the manufacturer's price. The retailer now gets 18 cents a pound for the product, but if you put the $S$ cents additional tax mpon the cost of manufacture, it does not inure as much profit proportionately to the retailer, and consequently the consumer gets the benefit of it.

M1. HEWEs. To resume where I left off. In the prosecutions in the State of Maryland ever since 1578 it has been my privilege-

Senator ALLEN. I do not want to interrupt you munecessarily, and if it is disagreeable to you I will not do so.

Mr. HEwEs. It is not disagreeable at all, Senator.

Senator AluEN. Yon said that in Paris and other Eastern cities oleomargarine was set $n$ in one restauraut, for instance, and no butter could be sold there.

Mr. Hewes. Only in. France, Senator.

Senator AlLEN. And eouversely where butter wạs sold oleomargarine could not be sold?

Mr. HEwEs. That is right. 
Seuator AlLEx. But suppose in searchiug for butter I walk into one of these oleomargarine stores, not knowing but what oleonararine is sold there, and I see an article like this, and I say "I want 10 pouncls of this buttre." They will sell it to me, will they not?

Mr. HEwEs. It you call it butter?

Senator Allwi. I do not know. I am in search of butter; I walk in and see this article.

Mr. HEwEs. You see that article, but you walk into the oleomargarine side, you mean?

Senator AlLEN. But I do not know the oleomargarine side.

Mr. HEwEs. But they have got big placalds there in 4-inch letters. Senator HEITFELD. Thiy have that here at this market now.

Senator ALLEN. Suppose I buy a cigar and give the gentleman a $\$ 5$ bill. He gives me back the change. I do not stop to count it. I do not know whether he has given me the right ehange or not. So I walk into one of these stores and I want some butter. I do not look at placards or signs. I suppose he is a reputable dealer, and I call for butter. He gives me oleomargarine, and there is an open opportunity to perpetrate frand, is there not?

Mr. Hewes. No, sir: not over there, because those laws are too strictly enforced. I will tell you what the restrietion is. I say this to the sorrow of us Americans. I am so American in my composition that I do not like auyborly who is not American; but when it comes to the enforcement of laws, they beat us on the other side. I am sorry to admit it. When the liw over there rerpures then to put a label on the outside of this package, it goes there, Senator; and when you buy that 10 pounds, and you may call it anything you please, you get a label on the outsicle "Oleomargarine," or, as they call it, " Margarine."

Mr. ADAus. Will you permit ne to interrupt yon a moment. Mr. Hewes?

Mr. IIEWEs. Yes, sir.

Mr. ADAus. I want to get into the record this case on the question of whether or not the placing of oleonargarine upon a table is construed as a sale or not by the comts. The case to which I refer here is the case of Commonweulth $x$. Worcester, 26 Mass., „256. 'That is a case where a man bought a breaklast for $3 j$ cents and found the milk was arlulterated. An action was bronght against the hotel keeper, who was iguorant of the fact eren that the milli was adulterated. It was proved that it was a sale of adulterated milk, and it was so decided.

Mr. ThlingHAsT. Perliaps there was something in the milk that was deleterious to health.

Senator ALLEN. That is upon the well understood principle of the law that a man can not plead his ignorance of the law.

Mr. Hewes. If I understool the Senator right, the suggestion was that this committee were too good lawyers to need any leail references or references to cases. ()therwise I would simply strew the table with cases from Maine to California.

Mr. TiLlinghas'T. While I am on this question I will ask you this: Do you understand that in foreign countries-you spoke of France and Holland and Belgim-what oleomargarine is sold is sold as of the same color as butter?

Mr. Hwwes. Oftentimes, yes. That is a good general question and a good general answer. In foreign conntries oleomargarine is sold of the same color as butter.

Mr. Tilinghas'T. And they are able to enforce their laws without having aus anticolor law? 
Mr. Hewes. But the correlative also follows-that is, that the trend of taste over there oftentimes is toward uncolored butter, and in France particularly.

Mr. Tillinghast. Where yon have uncolored butter you have uncolored oleomargarine?

Mr. Hewes. Oftentimes.

inr. Tillinghast. And where you have colored butter you have colored oleomargarine?

Mr. Hewes. That is the case oftentimes, but that is neither here nor there.

Mr. JELKE. Mr. Hewes appears to be familiar with the laws of foreign countries. In which country in Europe is there a tax on oleomargariue?

Mr. Hewes. None that I know of. I do not think even in Germany there is a tax.

Mr. KNignt. May I interpose here, and say that those countries have stations and are enabled to handle this matter from a central point without the use of a tax?

Mr. HEwEs. If you are going to introluce these international questions, I would like the privilege of reading to this committee right now the report of the speed of Von Buelow yesterday. I do not know whether you bave read it or not, but it is rery apropos, and I think it onght to goveru our Congress as well as theirs:

VON JUELOW FAYORS TIE CANAL, BILL-IHS ARGUNENT IN THE LOWER HOUSE OF THE DIET FOR THE MEASUIE.

[By cable to the American.]

BERLA, January .

The imperial chancellor (Count von Buelow), in the low r house of the Diet, to-rlay strongly supported the claims for the protection of agriculturs. He sairl:

"I consicler it the foremost duty of the Government to effect a recouciliation in the existing economic difficnlties and the adjustment of the varyiug interests supportiug those who are muble to help themselves through their own strength. I shall abide by the opinion that when one member of a social body suffers all the others sutfer, and especially that as long as such an important member as agrirulture is nulsealthful the entire organism nust be undermined. I am convincei that it is the iluty of the Government to afford tracle, industry, and agriculture an equal measure of protection, but that one of them, agriculture, absolntely needs strong protection. It is in pursuance of this principle of eren-handed justice that the bill for the completion and improvement of the canals has been chrawn up. If the measure favored industre at the expense of agriculture, or the west monarchy to the detriment of the east, I would not have supported it.

" "With the view to solidify the agrienlture of the east and the industry of the west, a series of further schemes had been bound uj in the Rhine-Elbe Canal project, of some interest to navigation, but chielly for the henefit of the tillers of the soil, by the establishment of a contiumons network of waterways, advantageous to all parts of the empire, opening the industrial territory of the west to the agricultural products of the east.

"It is my cleliherate conviction," said the chancellor, "that the agricultural prodnets of the east, with these cheap means of transit, ailed by an assurerl protective taritr, for which we must provicle and for which we will provide, will be enalilerl to hold their own in the west, which in turn will seenre facilities for the distribution of the products of the factories."

Von Buelow's idea here is that you must protect agriculture. Why? Because the wealth of the nation lies in the land, and the strength of the land is in agricnlture. That is an economie principle that has been established from the foundation of this Government, and Ton Buelow only echoes that. It is one of the agrarian maxims of foreign governments that if yon do not protect agriculture your country must decay, and that is the reason why he is in favor of it. 
Senator ALLEN. As one member of the committee, I entirely agree with you upon that proposition.

Mr. Mrller. Does lie not refer to the tax upon agrienlture from imported goods, not the section from liome industries?

Mr. HEwes. Suppose he does. He does not want colored oleomargarine to come in there and interfere with agriculture in that country.

This is onl bill. This is the bill of the dairy interests of this country. This is the bill to amend the bill we originally bronght here. We ask for its cousideration. We clo not ask you not to listen to these antagonistic interests on the other side. We are liberal people. We presume they have to come here and speak for their pockets; but is it not asking too much to ask you to malie secondary the great industry of the country that these few, these seventeen or twenty-seven manufacturers of oleomargarine, may thrive upon the fraudulent article they are producing? I say it is preposterons and yet we are willing to sit and listen to them; to listen to whatever they have to say; to listen to their legal representatives, and have yon listen to them.

Senator Allen. We must do that.

Mr. Hewes. You must do that. You can not help it. But we dlo say this: Admitting, or, as we say at law, demurring to their evidence, then what have we? We have $60,000,000$ people in the United States who say, "Pass the Grout hill." They have, to give them the most liberal construction, about $14,000,000$ people who are oleomargarine people, or their friends are people who want oleomargarine, and they say, "Do not pass it." What is this committee here for" What is this Congress here for? To listen to the will of the people, to be governed by the will of the people; and when sixty million appear against ten, what is your duty? Your duty is to listen to the sixty million.

Senator ALLEN. Suppose the $60,000,000$ people, in the judgment of a Senator, were wrong, would you insist that he should follow ont their wishes?

Mr. Hewes. Is the Senator to sit in julgment against $60,000,000$ people?

Senator Allev. He must sit in judgment. His final judgment ujon the correctness of a thing after he hears it must be his sole gnide.

Mr. Hewes. Then he must do as his lieart prompts him.

Senator Alles. Yery well. That is what he slould do.

Mr. HEwEs. If the Senator says that $60,000,000$ people are wrong

Senator AlLEN. Suppose my people instructed me to rote for this bill or against it.

Mr. Hewes. You would not heed them.

Senator AlLex. Suppose my conviction was contrary to their will? Mr. Hewes. You wonld be guided by your conviction.

Senator Allen. Would it not be my cluty as au officer to follow out my best judgment?

Mr. Hewes. I wonld, and I would tell my constituents if they did not like my action they conld ask for my withdrawal, and I would resign.

Senator Dolliver. Or would you seek some method by which to compromise the thing?

Mr. Hewes. I would not. There is no compronise possible.

Let me get back now where 1 started.

Mr. Millen. Referring to the enforcement of these laws in foreign countries, is it not a fact that the word "margarine" is printed on the manufacturers' original package and that the retail dealer does not brand the package at all whell he sells it? 
Mr. Hewes. No, sir; it is not that way in England. In England he has to make up his own package and mark it "margarine," just the same as we do here; and he must mark it so that the buyer can see what he is buying.

When we eame into this Congress in 1836 we said to you gentlemen, "We want you to do the policing for this thing. We want you to put this under your jealous eare, so that no man can sell oleomargarine for butter," beeause we thought they could do it. We knew how zealous they were in trying to enforce the law in respect to tobacco. IVe knew that no man could possibly work up lialf an ounce of tobacco unless he had the Commissioner of Internal Revenue or his deputy upon his heels to say what the product was, and we thought they conld enforce this law. They do not enforce the law. They do not see that people carry out the nineteen seetions of this bill.

Senator DoLLiver. In the matter of tobaceo, do they go further than to collect the tax?

Mr. Hewes. That is that compromise you were talking about.

Senator Dolliver. No; do you mean to say that the tax provisions of the law of 18.86 have not been executed?

Mr. Hewes. I mean to say that whenever they find a person who is not doing exaetly as that law says, they send for him and they make some settlement with him.

Senator Doldivkr. Do they do the same with the tobacco people aud the whisky people?

Mr. Hewes. They eompromise.

Senator DOLLiver. 'They arrest them for violating the law.

Mr. HEWEs. But nine times ont of ten they send for them to come up and settle, and they do settle.

With respect to this oleomargarine business. In the State of Maryland last year we had 141 cases, and we are now standing before the bar of our eourt of appeals with this original package ease, with no hope of winning it. That is the tronble. We have no hope of ever winning that. Wliy? Beeause Judge Taylor, who is as fair a man as ever sat upon any court whatever, and who is a friend of the dairy and a friend of ours, has told me, and he has written in that Fox ease, in 8! Maryland, that yon ean not restrict or prohibit the sale of oleomargarine in its origival package unless you prove that it is deleterious to health.

You see low impossible it is for us to ilo it. It throws the burlen of proof, it is true, upon the traverser to show that it is not deleterions to health, and what does he do? He brings in his expert testimony, and you have listened to it here by the volume. When these chemists tells you that au article is chenically pure, what do they mean by that? They mean simply this, that sulphuric acid is chemically pure, that nitrie acid is chemically pure; but when it comes to a question of pure food, all the testimony of the chemists falls to the ground. It is not a question of a chemically pure article. It is a question of pure food you are talking about.

So we ask you to make a favorable report on this Grout bill, beeause of two things. In the first place, it reduces to a minimum the ehance to deceive ultimately. It is a potential frand that is reprehended and deprecated in the Plumley Case (15j Mass., +21). That is the trouble. It is a potential frand, where this man may deceive in the restanrant, or where the purchaser may be deceived.

Mr. MILLER. What is the difference between pure food and ehemically pure food?

Mr. Hewes. Pure food is something that is pure, and ehemically 
pure food is what a chemist says is chemically pure, the same as he must go to work and analyze all the fats of oleomargarine. He shows they are chemically pure; but suppose they come out of cats. Every one of these fats in oleounargarine can come from dogs and cats and horses. Some of them come from Shoemaker's place and Horner's place in Baltimore.

I thank you for your attention.

\section{STATEMENT OF C. Y. KNIGHT, SECRETARY OF THE NATIONAL DAIRY UNION.}

Mr. KNigin. Mr. Chairman aud gentlemen, I want to open this matter by reading a statement which is a copy of a letter which I rereived from a retail grocer's clerk in the city of Chicago some time last year. I am familiar with the gentleman's name, but I lave not put it in here. I will vonch, however, for the condition, and prove it to you, but I merely read it as an introdnction.

During the past twenty-two years I think I have worked in nearly every firstclisss glocery in Chicago, and I can truthfully saty that eight ont of every ten have been and are still selling butterine for pure bitter. I recently was emplosed in one of the largest groceries and markets on one of the most prominent streets of the city. buring the time I was employed there we never sold one ponnd of butter, for we nerer hal it in the house to sell. We clerks would talk anong onrselves about it, and wonkl often compare notes with other clerks, and to satisfy myself I made quite a canvass of all the stores in the mile and found only one that did not impose on its trade.

Gentlemen, from experience I can vonch for the accuracy of that statement, and I want to give you a little experience and I propose to demonstrate it right here. The evening before I left Chicago I took my stenographer at 4 o'elock and started ont on a tour to visit the so called butter stores. I went, and was gone just one hour, and visited ten stores; and while I did not think of it at the time, it corresponds with that statement. Eight of those stores sold me each a package of goods. At two of them they told me they had no butter. They said "We do not keep butter at all;" but the other eight sold me what purported to be butter. Now liere is a package of what was bought for pure butter at $2 t$ cents per pound, and the signature of the girl who bought it is on it. There is the package [exhibiting a package.] Tou may be able to find a nuark on that. It was bonglit as butter for 24 cents a pountl.

Mr. JELIE. Do yon know now that it is not butter?

Mr. KNIGHT. We will demonstrate that, Mr. Jelke, before we get throngh. The store which sold that butter had this sign in front:

$$
\begin{gathered}
\text { Try our best } \\
\text { Elgin creamery butter, } \\
5 \text { poumls } \$ 1.00 .
\end{gathered}
$$

Here is a package from the store of Hughes of Schick. I will give to the gentlemen of the committee a little pamphlet that we got out some time ago with a photograph of a sign in the front of that place, "Grass Dairy, 15c. a pound." I openly denounced those people as swindlers in a prblication, 150,000 copies of which I have sent broadeast. That is the place where I bought that package.

Here is a place where we bought a pound of so-called butter, at No. S Wells street. These are all on one street. We went from one place to another on the same street within a distance of sereral blocks. That we bought at 25 cents a pound. 
This package was bought at a place which was originally known as the Ohio Butter Company, but later as the Metropolitan Market, No. 44 Fifth avenue, an illustration of the sign of which you will find on page 3 of this pamphlet, at the bottom-the Ohio Butter Company. Those are all photographs which I made myself.

Here is a package from William Broadwell's place.

Now, I would like, Senator, to have you open that, if you will, and just look at the package.

(Senator Allen then opened the package.)

Mr. JELKE. Is the price on each package?

Mr. KNIGHT. Yes, sir; every package is plainly marked. Senator Heitfeld, here is one from the same place, and Senator Dolliver, here is another one from the same place.

Senator DoLliver. What place is that?

Mr. KNighr. William Broadwell's place.

Senator DoLliver. You seem to have patronized him very extensively.

Mr. Knight. Tes, sir; and I will show you why in a minute. Have you found the mark "Oleomargarine" on it, Senator?

Senator AlLEN. No, I have not.

Mr. KNIGHT. That is the puzzle. Find the mark. If you will open it this way [indicating], and get around there, I think yon will find something of the inark.

Now I want to read from a pamphlet issued by William Moxley, of the city of Chicago:

Facts about butterne. Compiled and published by William J. Moxley, for the use of the geueral pulblic.

\section{He says ou page 6 :}

Before the Senatorial committee, previously mentioned, a Mr. William Broarlwell, one of the largest dealers in high-grade butterine, spoke of millionaires and men with silk hats being his most inmerous customers, in fact, forming in line to get a pail of William J. Moxley's butteriue. Ilis remarks caused considerible langhter among the andience, but created consternation in the ranks of prodncers of creamery butter, who realized the impossihility of successful contraliction.

I will show you the frout of Mr. Broadwell's store as it was pliotographed, in that corner down there where he sells Mr. Moxley's highgrade butterine-one of the largest dealers in the city of Chicago. That is his sigu [inclicating]. I photographed that in September myself. It stood there for two or three years until I photographed it, and when he found we hall used it, that part of the sigu was torn down, and these are the remains.

Mr. ADAMs. Is that the store where the gentlemen in silk hats go to ask for butterine?

Mr. KNIGH'T. Tes, that is the one.

Mr. JELKE. Have you any photographic views of Siegel, Cooper \& Co.'s, or Rothchild's, or auy of the leading merchants of Chicago?

Mr. KNight. I will not answer any questions now, Mr. Jelke; I am busy. I have got this thing on hand, and I liave waited a good while.

Now, I want to read you an extract from the report of the assistant fool commissioners to convince you what kind of business Mr. Broadwell is doing with Mr. Moxley's butterine:

The other case is No.27, that of IVilliam Broadwell, where the defendant and his witnesses swore that they sold nothing lont oleomargarine, aud that they had a sign behind the cennter, "No pnre butter sold here; only oleomargarine;" that they al ways informed those asking for butter that they had only oleomargarine, and they had uo signs reading "creamery butter;" that the stamp was always on the ontside of the package when hauded to custemers, aud that for seven years they had always wrapped it in that manner. 
And yet I have 21 packages gotten by 21 different people, all wrapped the same as that from thit party, and William J. Moxley defends him every time anyborly attempts to prosecute him, and one of his men is here spoken of as a witness in the case where the food commission has prosecuted that man and endeavored to convict him.

What are the facts in the case? 'Two inspector's of the food department went and purchased samples of that stuff as butter aud for butter. He sold it that way. They went into court aud made an affidavit as to what they had bought it for and where they bonght it. He brought three witnesses to swear that they called for oleomargarine, and that he gave them oleomargarine, all properly stamped. 'That is the way they do business in Chicago.

Now, going back to wliere we started, I want to give you a little bit of history of local conclitions. 'There a re prodnced in Chicago $46,50(0,0) 00$ of the $107,000,000$ pounds of oleomargarine male in the United States.

Senator J)oxLiver. How do you get at the 107,000,000?

Mr. KNighr. Why, from the last report of the Interial Revenne Commissioner.

Semator DoLLIVER. The Secretary of Agriculture seemed to state it at less than that.

Mr. KNignt. He was a year belind.

In the State of Illiwois, and pretty near all of that is in the northern district, there are 2,6!11 of the 9,000 dealers in the United States. Of the 9,068 retail dealers doing business in the United States for the year euding July 1 last, 7,173 mere violating the various anticolor laws of the United States and 1,995 were doing business as permitted by the laws. Of the $107,000,000$ pounds of oleomargarine produced in the United States for the year ending July 1, 19010, 66,520,196 pounds were produced in States which prohibit the maunfacture and sale of colored oleomargarine, and 40,240,859 pounds were produced in those States which permit such production.

But to go on with my little story. Here is another package which I bonght at No. 65 Randolph street, personally. I went in aud said to the man, "I want some creamery butter." He said, "We have no creamery butter; we have dairy." I said, "All right; I will take some dairy. How mnch is it"? He said, "Nineteen cents." Senator, you will find a little faint attempt there to make a mark on that. I have found it, but uobody else would. I said to him, "Look here; this is not dairy butter."

Senator ALLEN. What does that [indicatiug] signify?

Mr. KNIGHT. That is the Government stamp. I said, "What is this? This is stamped oleomargarine. I do not want oleomargarine." He said "I will tell you. This is dairy butter. We have to stamp it oleomargarine, because it is dairy butter in which a little tallow has beeu mixed, and when there is any tallow mixed with it we have got to mark it oleomargarine, but it is mostly butter." That is the way he puts people off when they go to him and call him down in the matter.

Here is another package that was bought at a place called the Madi. son butter store, at 25 cents a pound. They call it Price \& Keith's creamery butter. Price $\&$ Keitl is a butter firm that has goue out of existence, and they have adopted the name and put it on oleomargarine. This man, as are most of the others, is under indictment there in Chrcago aud their cases will probably never come to trial. His clerk admitted to me that she was instructed by her employer that when anybody came in and asked for oleomargarine, to go and show them a little package of 3 pounds of butter that they had had in the store 
for about a rear, and that was rancicl, and tell them that was oleomargarine. Then of' course they did not want oleomargarine, and she wonld turn around and sell them that oleomargarine, which was really oleomargarine, at 25 cents a pound, as butter.

Here is the Cold Springs Creamery, No. 72 Randolph street. The price does not seem to be on there at all.

Now to eome back to what I started out with. I have got here a package which I pnrchased in the markets in this eity; and I want to say to Senator Heitfeld about this market that the management of it itself looks after it and sees that the people who are trading there are not deceived or lefranded. That is one reason why there is not any frand in the market down there. Here is a piece of oleomargarine I bought from Wilkins down here this morning; and I am going to put that in our test tube here, and show yon what oleomargarine melts like, if I can get my apparatus together. That is oleomargarine, and I am going to mark it on the top "O." If anybody has any doubts about it they can have it sent out and have it analyzed, or I will leave it here with the committee if that question is raised. I also liave here some pure butter--something thiat I believe to be pure.

\section{Senator HeITFELd. Are you sure about it?}

Mr. KNIGHT. Yes; I will show yon whether it is or not in a minute. I am going to junt that in a tube with a black cork.

(Mr. Knight then put some samples from the different packages that he bad exhibited into test tubes, corked up, and he put the test tubes in a bncket containing warm water.)

Mr. JELIE. Have you any process butter?

Mr. KNIGHT. I thiuk it might be possible to get some in Washington; I do not know.

Now I want to open these packages, and see whether there are any concealed marks abont them. They were all bought as butter. Ah, there it is. It is turned under and concealed. I just want to show yon how the thing is done. If there are any upon which we do not find the marks, I will put them in that test.

Now, here is another trick-using a colored paper so that the stencil will not show. These samples were bonght from the stores as I came to them. Inasmuch as there is no mark on this one [indicating] I will put that in the tube, but, gentlemen, I am coming to the most interesting part of this programme later on, when it comes to speaking of the violation of the law. To my positive kuowledge, of eight stores ou Fifth avenue six of them are selling oleomargarine for butter. There is not a store on Fifth avenue that is selling anything but oleomargarine, and there is not one of them that is selling it for anything but butter. There, gentlemen, is what they use as a handle [indicating] That comes from the Madison butter store.

Senator ALLEN. Do they put the handles around these little packages?

Mr. KNIGHT. Yes; or if yon take a larger one. They do not handle a pound of butter. Here is a package from Hnghes \& Schick. Let us look at that. (The package was opened by Senator Allen.) The cheapest kind of brown paper is used, so that nobody will ever expect to use it for anything else, so that when it is taken off it will be thrown asicle always.

I sent last year a detective to seventy-eight places and got samples, and seventy.two of them we found to be oleomargarine, all sold as butter. I had my attorney send out this letter: 
DEAR SIR: I have been emploser by the Illinois Dairy Inion to prosecute any cases of violation of the dairy laws of this State which may result trom the arrest of any cealer selling oleomargarine when butter is called for. As you probably know, a commission, consisting of a food commissioner and eight assistants and inspectors, was provided for by the late legislature, whose duty it is to enforce these laws. The commissioner has been appointed, and until he bas appointed his assistants and gotten to work the lllinois Dairy Union's inspectors will look after the protection of consumers of hutter and ste that those who sell them oleomarnarine for butter are prosecnted und'r the state laws, and also repolted to the in ternal revenue department as violators of the internal-revenne laws. I herewith inclose extracts from three state laws. These laws are not tied np in the courts, and the oleomargarino manufacturers will not place themselves in the light of protecting those who sell ol romargarine tor butter, although they may consistently fight the law forbidding coloring, which has not yet been passed upon by the supreme conrt.

If you sell oleomargarine this year, rest assured that the state food commissioner and the Illinois Dairy Union will see that you are not permittel to sell it as butter.

Respectfully, rours,

HIGH V. MLRRAY, Attorney for Illinois Dairy Cuion.

The extracts from the three State laws which were inclosed were simply extracts of laws forbidling the sale of oleomargarine for butter. That was all there was to that. We did not attempt to do anything with our anticolor law, because it was tied up in the conrt. I have the extracts of those laws just as they were sent out.

That was a letter that was sent out in an effort to get these people to conform to the State laws requiring the informing of the custoner of what he was buying and the marking of the package. Everything was done just as you find it on these packages. There was no mark in sight. The oleomargarine was advertised as butter at every place. They put up their signs just as that is shown there. I suppose there are a thousand just such signs as that in the city of Chicago.

That letter of Mr. Murray was sent out July 29, 1899. On Angust 2, 1899 , this letter was sent out by William J. Moxley to his retailers, and probably to all the licensed dealers in the city. I will not say it was sent to every one, but I know it was generally received by those who traded with Moxley. This is his letter:

[William J. Moxley, manufacturer of fine butterine, 63 and 65 West Monroe street.]

Ciricago, August 2, 1899. City.

DEAR SiR: Our attention has been called to two circulars which have been mailed to you-one signed by Hugh $\mathrm{V}$. Murray, an attoruey, and the other by Charles Y. Kuight, erlitor in chief of a periodical, withont subscribers, namerl the Chicago Dairy Produce. The cirenlar bearing Mr. Knight's name has at its head an imposing lot of names, gentlemen whose aim it is to prevent the manuticture and sale of butterine, so that the butter trust wight be enabled to get from 30 to 40 cents a pound for butter, lepriving, as they wonld, a great mans of the industrial classes from being able to use hutter throngh its excessive price.

With the hirel attornes, who is earning his fee, we have nothing to say, only to inform you that these gentlemen are trying to ring in a bluff. Yon will notice in their circulars that by insinuations they would have people believe they ropresent some official anthority. The interual-revenue department looks after their own business, and the State after tbeirs, and should this so-called rlairy union interfere with your business in the way of prosecution as to the state laws, we herehy guillantee you protection to the extent of paying all fines, costs, etc., nntil the color law is clecided unconstitutional in the supreme conrt of the State of lllinois, and will further, on receiving complaint, take such action for llamares as will wake it unpleasant for some of those who are attempting to interfere with your and our own legitimate bnsiress.

We were under the impression that the severe censure they received from the judges during their filibustering of last year would have been sifficient for all time,

$$
\text { S. Rep. } 2043-30
$$


but have been informerl that to be successful in obtaining money from farmers and butter men a few circulars with imposing hearllines are requiled.

We strongly recommend yoll to pay no attention to those circulars. We have always bcen in a position to protect onr customers from injustice and blackmailers, and will be over at your service should you reruire onr aid.

Respectully, yours,

Now, our firiend the enemy, there is the pure butter right there [exhibiting a test tube]. You will notice that is absolutely clear and that the casein and water are precipitated, whereas this [exhibiting] is muddy. It never will clarify except at a temperature of about 150.

Seuator HANSBRoUGH. What is the object of this test? Is it to show the indigestibility of oleomargarine as compared with that of butter?

Mr. KNIGHT. It is a test between oleomargarine and butter. Senator Allen asked me something about proeess butter, and I wanted to show him that; but I brought the test tubes here primarily in case there should be any lack of evidence that what I had bought was oleomargarine at the ten places I bonght it from.

Our friend Jelke's firm-Bran \& Fitts-in reply to this letter which Mr. Murray sent out, sent the following reply:

Every licensed butterine dealer in Chicago has receiverl circular letters from the secretary and attorney for the Illinois Dairy Union, promising all sorts of tronble to dealers in butterine (that honest and pura article of food). Well, now, don't you beliere : worl of it; there is a law against blackmailing, and we want now and here to go on record to the assertion, as an atfidavit, that we shall civilly and criminally prosecnte any nan or party of men interfering unlawfinlly with the butterine business in this or any other state. We know exactly where we stand; we are properly advised on the subject, and now we nuke you a "fair offer:" "Hanlle onr goods as you always have; we in turn promise and gnarantee full protection agaiust the State law (which has been reclared nnconstitutional) to the extent of paying cost of prosecution, fines, and paying all costs pertaining thereto." In declaring the law unconstitutional one of the julges stated to the effect "that the butter ring were, in his opinion, liable to prosecution to recover rlamages done an honest industry." Fair enough, isu't it? Renew ronr efforts, and be assured that we will be prepared to fight any nnmber of ronnds in any lind of a legal fight to the finish. Handle our butterise and be safe.

Mr. JELKE. Mr. Kuight, I think that letter was instigated by the condition of the law regarding the sale of colored oleomargarine in Illinois.

Mr. KNighT. In what way, Mr. Jelke?

Mr. JELKE. It was tied up in the courts.

Mr. KNIGHT. But I did not threaten to prosecute anybody for selling oleomargarine.

Mr. JELkE. I do not know the date of that letter.

Mr. Knight. I do. It was two days after the date of Mr. Moxley's letter.

Mr. JELKE. And we had just gotten through with a ease of blackmailers who had taken our customers ont to Maywood.

Mr. KNignt. That was two years before that.

Mr. JELkE. They took six of our customers out to Maywood, a suburb in the eountry about 15 miles farther than it was necessary to go. They took them out there at 6 o'clock at night when they could not get bail or anything else. 'That is the character of the prosecutions we had.

Mr. KNight. I will refer you back to the original letter in which they were threatened only with prosecution for selling oleomargarine for butter.

Mr. JELKE. We have never protected one customer in the sale of oleomargarine for butter, and never attompted it. We never had any idea we would do it. 
Mr. KNIgHT. Let me tell you something. The representative of the firm of Bram \& Fitts, Mr. Lowry, attended every trial in which we made a prosecntion for selling oleomargarine for butter. He went their bail and lookerl after them.

Mr. JELKE. No, sir; not for selling oleomargarine for butter.

Mr. KNIGHT. I beg leave to differ with you. Did you not go with Mr. Moxley and employ Mr. Worth E. Caylor as attorney?

Mr. JeLKE. No, sir; Mr. Worth E. Caylor has never been in our employ.

Mr. KNIGHT. Did not your man Lowry attend all the trials?

Mr. JeLKE. He may have done so. He has such instructions, to keep thoroughly informed on the character of the prosecutions we are having.

Mr. KNIGHT. Gentlemen, this is a matter of record, that when we began proceedlings, a number of times when I was in the justice's court, they telephonerl over to Braun \& Fitts for Mr. Lowry to come and go the bail of people whom we hal arrested for selling oleomargarine for butter.

I have the briefs in the case. We brought suits in the justice's court in Chicago. We had seventeen people arresterl and they were defended by Worth E. Caylor, whom at least MIr. Moxley admits having employed. I do not need to read from the warrant under which these arrests were made, because I can read from Mr. Caylor's brief, in which he states the case, although the warrants are here complete. I read from page 24 of the brief of Worth E. Caylor, attorney for the defendants in these cases, employed by the butterine men to lefend the dealer's.

Senator ALLiN. What is the title of the case?

Mr. KNignt. The title of the cases are "The People of the State of Illinois, plaintiff, v. M. A. Wright," and "The People of the State of Illinois, plaintiff", $v$. Charles R. Horrie, defendant." The two cases are in one brief. Probably I had better read the warrant.

Senator Allen. Oh, it is not necessary. They can be put into the recold if yon want them.

Mr. KNigh'T. The warrants, anyhow, were sworn out for the sale of oleomargarine as butter without informing the purchaser of the fact that it was oleomargarine, and withont stating the quantity of ingredients therein. What was their defense? Their defense was, in the first place, that oleomargarine is butter-that it is oleomargarine butterand consequently is entitled to be called butter; in the second place, that the law of the State of Illinois requiring you to do as the Ohio law does-the Ohio laws were here yesterday, and I believe I have a copy of them here-was unconstitutional. We never have had a law yet that they did not call unconstitutional.

The brief says:

It is very evident that a man who sells an article can not know the proportions that any alulterant enters in to the butter, unless he mixes or manufactures it. Nere hearsay from the person from whom the seller purchases the article would not be evidence of the correct proportions or ingredients, so as to relieve the seller from any liability. The labeling by the manufacturer or the mixer of the article would not bind the seller with the true knowledge of the coustituents of the article sold.

Manifestly it would be impossible for the retailer or seller to make a chemical analysis of every article of this kind that euters his place, becanse it would make such additional expense that it would prohibit the sale of the article. If it would prohibit the sale of the article, the statute is unconstitutional.

That is the same objection they raise to every law that is passed to restrict the sale of oleomargarine-"wo can not sell it under that law;" consequently that is unconstitutional. I just want to bring your attention to that point to show you that their ery that a law is prohibitory 
and that they can not operate under it is raised against every law that has ever been hronght up.

We went ahead and endeavored to prosecute. We brought the matter before a justice of the peace. In one case I think we went into conrt twelve times. The first case we brought before the court-and we thought we were doing a pretty shrewd trick at the time-was the case of a man who sold oleomargarine mannfactured by an illicit mannfacturer. We thought we would at least get a case with this man defending, because he was not a customer of theirs. What was our surprise to find their attorneys defending this man who was selling oleomargarine manntactured by an illicit concern.

Senator Hansbrough. That is, a concern that had not paid the regular tax?

Mr. KNIGHT. Yes, sir. Ancl the amusing thing about this whole business is that in this little statement I read from here, Mr. Moxley speaks of how his attorney ronted us in that case. The effort was made there to frove, and they did prove, that this man whom we had arrested had bought this oleomargarine as butter. When we had determined ourselves that he was innocent of knowledge of the kind of goods he was selling we dismissed the case, because we did not care to proceed against the man who really thought he was selling butter. They made their boast abont how they got that man dismissed, ete.

A few weeks ago the internal reveme department took that factory up and exposed it and arrested the man and put him in $\$ 5,000$ bonds, which was evidence enongh that our proposition and our claim that this was oleomargarine, which we proved by two chemists, was true. In none of the cases that came up in Chicago-we prosecuted seventeen of them at an expense of $\$ 1,600$-did they once deny the allegation that oleomargarine had been sold as and for butter. That was never denied. They simply defended on technical grounds, and in the five years I have been in Chicago, endeavoring to prosecute these people, we never have been permitted to go as far as the jury with the case.

There ras a young man here who raised the point and asked the Secretary of A griculture, "Did you ever know a case where a consumer made a complaint and prosecuted a dealer for selling oleomargarine for butter?" I have had dozens of eumsumers come to me and offer to go on the stand as witnesses against people who sold them oleomargarine for butter. Why did we not take them? Instead of taking their evidence, we went ont and got evidence. In the tirst place, a consumer who knows enongh of law to get evidence in regard to an article like this is very difficult to get. Yon ean not let the article go out of your hands from the time you get it nutil you put it in the lands of a chemist. None of them understand that. bardly. They put it in their ice box, and then the qnestion of identity of the goods would come up, and they can not make the connection between the sale and the time it goes to the chemist, becanse they never think of it at the time.

Another thing. Every time we have had a case up we have had to go into cont from at least three to a dozen times. The food commission, when they first started to proserute cases in Chicago, mndertook to nse some of the consumers, and there were two or three cases in which consumers did go to the fond commission and bring them samples and offer to give evidence. Wliat did they do? Mr. John S. King, employed by William J. Moxley \& Co., is defending to-day the cases in which the fool rommission is charging the people with selling oleomargarine for hutter. There was a letter carrier, for instance, who came into the food commission and offered them a sample. The chain was 
complete so that they conld prosecute, and they brought the case up. This letter carrier was working in the post-office. He came over to court and sat around three or four hours. Then the case was put off for several days more. They sent for the letter carrier again and took him away from the post-ofice for three or four hours more. That went on four or five times until the letter carrier said, "I can't devote any more time to it." There are not many cousumers who can go into court half a dozen times at any time they may be called on. I know, from the fact that we have to pay a chemist $\$ 25$ a time for ten appearances, that it is expensive business to prosecute those people, and it is absolutely impossible to get a consumer to come as a wituess five or six times to prosecute one of these cases unless you pay him, and the minute you pay him that thing is brought out, and you know how it would stand in court.

I realize that my time is limited and that I will have little opportunity to present very much. I am sorry I liave not more time, because I have devoted a great deal of attention to this matter.

I want now to call attention to another letter of $\mathrm{Mr}$. Moxley, advertising his oleomargarine, dated October 2:2, 1598, in which he says:

Your profit will be donble the amount made from the butter you are now handling, and your butter trade will be more satisfied if you will sell them such butterine as you ean buy from nie.

That is one of the inducements offered, double the profits on butter that is sold.

Now I want to read a letter from the food commissioner of the State of Illinois:

State Food Comission, State of Illinois, Chicago, December 17, 1900.

Mir. Cimarles Y. Knight,

Secretary National Dairy Tnion, Chicago, Ill.

DEAR SIR: In reply to your inquiry, [ beg to say that it is my impression that about 75 per cent of all the oleomargarine retailed in Chicago is sold as butter. The stamp required by the Inited States revenue office is generally so indistinct and wrapped up so that no one can see it unless ther hnnt for it, and consequently is altogether ineffective as far as it warns the enstomer. No one who has not tried it has any conception of all the titficulties in enforeing the honest sale of oleomargarine. While I believe the oleomargarine manufacturers sell theil produet honestly, it is my inipression that they are backing the retailers' defense. At least, the lawyer defending these retailers in the justice's conrt inciclentelly made the remark in my presence to the effect that he could stay all day, as the people behind him had plenty of money.

And I know absolutely that the man who is defending those people for selling oleomargarine for butter is paid in Moxley's interest. Moxley's own man told me so.

In order to illustrate this, I inclose copy of a part of my report to the commissioners referring to case No. 27. Two of our inspectors harl called at that store, and one of them asked distinctly for a pound of butter, and he was handed a pound of oleomargarine, wrapped up in the manner peculiar to that retailer; and these two inspectors, as well as the state analyst, who witnessed the opening of the package, swore that the stencil was not visible until the package had been unwrapperl and examined.

$$
\text { Yours, truly, }
$$

J. H. Monral, Assistant Food Commissioner.

Now I want to pay my respects to two other matters, and particularly to the gentleman who has come before you and held himself out to represent the laboring men of this country. I hold here a copy of a price list or a letter sent out by the Capital City l)airy Company, of Columbus, Ohio, a concerı whose charter last August was revoked by the supreme court of the State of Illinois for repeated defiant violations of the law. I have the decisions in those cases liere, but I will not stop for that.

Mr. JELKE. Will you pardon one question? 
Mr. KNight. Yes.

Mr. JeLKE. Why have not the Capital City Dairy Company closed up? We wish they would close up.

Mr. KNIGHT. They did not close up becanse they changed into a partnership and got arounil a decision of the supreme court. The supreme conrt revoked their charter and appointed receivers to wind up their busiuess on account of these violations of the law.

Mr. JeLke. Can not Mr. Blackburn close them up?

Mr. KNIGHT. He got that far toward it. They have dodged, however, and made themselves into a partnership.

Mr. MCNAMEE. Is it not a fact that that case is pending before the Supreme Court of the United States?

Mr. KNIGHT. They have given it $u p$, and resolved themselves into a partnership.

Mr. MoNAune. Have you any evidence to substantiate that statement?

Mr. Knight. Only what Mr. Pirrung, one of the partners, told me in this room a few days ago.

'This is the letter:

[The Capital City Dairy Company, makers of butterine, highest quality only, Nos. 145 to 197 Third a venne cast.]

Columbus, OHio, Necember 1, 1899.

DEAR SrR: With the appended change in price list we cau only reiterate that our "Purit," grade is equal, if not superior, to most makes creamery butterine; therefore "Purity" selling at 20 cents, "Buckeye" or "Pride" should sell at 25 to 30 cents. If you want a popular-priced grade, our "Silver Leaf" is particularly appropriate. Ever remenber this indisputable fact: Yon can obtain for our butterine a better retail price than for any other make in the United States.

Purity, 14 cents per pound.

Silver Leaf, 15 cents per pound.

Bnckeye, 17 cents jer pound.

C. C. l'ride, 18 cents per pound.

Prices subject to change without notice.

Goods billed at price in effect on day of shipment.

F. O. B. Columbus, Ohio, net cash.

\section{DIFFERENTIALS.}

One-half cent advance for solids under 25 pounds and rolls or prints 2 pounds and over.

One cent for rolls and prints 1 ponnd and less than 2 ponnds; also small tubs in crates and boxes; also nnsalted butterine.

One and one-lialf cents for rolls or prints of one-half ponnd and less than 1 pound.

Two cents for rolls and prints under 8 ounces.

Mired, cateh, or comntry rolls figured at prices of smallest roll or print in package. Very truly, yours,

The Capital City Dairy Co.

Now, gentlemen, I want to ask you if anybody would be foolish enough to think that any grocer wonld try to sell butterine at 30 cents as butterine; and here is the suggestion that he can get 30 cents for that grade of their bntterine. It is quoted at 18 cents a pound to him, and that means a margin of 12 cents a pound to the dealer.

Seuator DoLLrver. Where is that factory?

Mr. KNight. That is at Columbus, Ohio; and I am informed by Senator Scott, who was at one time Internal Revenne Commissioner, that he was compelled to levy a fine of $\$ 5.000$ on those people for violatious of the internal-revenue law. He told me that over in the room of the (Jommittee on Manufactures of the United States Senate. I want to say to you, gentlemen, that if you will introduce in the Senate a resolution asking for the records of these different concerns that have 
appeared before you, you will find a long string of prosecutions behind almost every one of them. I do not say every one.

Mr. MILLER. I dispnte that, Mr. Knight.

Mr. KNIGHT. I will except Armour \& Co. and Swift \& Co.

Mr. JELKE. Find one against ns, Mr. Kuight.

Mr. KNIGHT. I will find an offer of $\$ 7,500$ to compromise a case.

Mr. JELKE. Not one dollar.

Senator Hansbrougr. Proceed in order, gentlemen.

Mr. KNIGHT. I have made the statement here that Bram \& Fitts, of which Mr. Jelke is a partner, offered to settle a case where one Roney and two other men had shipped something like $\$ 140,000$ worth of oleomargariue, with the stamps scratched off, as butter into the varions States, one of whom was detected; and you can not deny that you came to the commissioner's office and that you and Mr. Dady were there and that you looked ont for bail for these people.

Mr. JeLKE. That is right.

Mr. KNIGHT. You were there and you looked out for bail for them, anr Mr. Clark J. Tisdell, assistaut United States attorney for the northern district of Illinois, informed me that in those cases Braun \& Fitts had offered $\$ 7,500$ compromise. 'That is my information.

Mr. JELKE. Your information is not correct, Mr. Knight.

Mr. KNIGHT. I want to say further that in the case of a concern whose attorney appeared here last night, a new concern in the city of $W$ ashington, the president of that company has three indictments hanging over him in this District of Columbia to-day, which have been there for three or four years, for scratching stamps from oleomargarine. They are in the Federal courts, but have never been tried. His brother was sent to jail for six months, and it was only the slip of the United States attorney that this man was not included in that indictment. The attorney himself said he should have been inclucled. But those indictments you will find pending, and I think you will find that he is uncler bond, if you go down to the district attorney's office. I am only speaking of those things to show you the character of a great many of these people and their business. There are a great many things I would like to present, but here I think is one of the most important. A gentleman named McNamee, I believe-

Mr. MCNAMEe. At your service, sir.

Mr. Knigh'. Coming from the city of Columbus, Ohio, where the Capital City Dairy Company is located, brings you a lot of resolutions. On sifting them down, I believe you will find there are "S labor organizations which have passed resolutions against the Grout bill. I received from Cleveland, Ohio, a paper containing a report of a meeting of one of those organizations, where this matter was bronght up by $\mathrm{Mr}$. McNamee. It appears, I believe, that Mr. McNamee is all organizer of labor organizations. He presented this case, and from my understanding and $\mathrm{my}$ information from Cleveland-I may be mistaken; I am giving this second hand-it was stated before them that two big corporations, Swift and Armour, in the city of Chicago, were makiig an effort to get a law which would crush the Ohio companies ont of existence. The account of the proceedings of that meeting says:

"Moved that the Cleveland Fecleration of Labor do not interfere between two capitalistic corporations." I have the proceedings and I expected to produce them here. But, Senator Hansbrongh, you are pretty well acquainted with union labor. You are a newspaper man. I am a union printer, and was brought up at the case. I belonged to the typograplical union. I know it is not the policy of labor unious to 
antagonize any class of men who are endeavoring to protect their interests. Labor unions are organized for the protection of their own interests: they are organized to get better prices for their product, that of their own hands, and they are in favor of everybody else doing the same thing. I never saw a fairer lot of men in this matter than the laboring men whom I have talked with.

Mr. MCNAMEE. Will Mr. Ḱnight yield to a few questions?

Mr. KNight. No: not right now. When I read this, I will.

As an evidence of this fact, in 1897 , when we had before the legislature of the state of Illinois a law which sought to prohibit the coloring of oleomargarine in the semblance of butter, known as the Fuller bill, which I was looking after at the time, and which passed the legislature finally, I went to the Federation of Labor of the city of Chicago and called on its legislative committeo. I called those gentlemen together and I told them the condition of things in Chicago. I showed them what we were attempting to accomplish, and asked their cooperation in the matter. I asked them if they could not give the iudorsement of the Federation of Labor. They said they did not think there was any doubt but what they conld. I now want to read yon from the Chicago Federationist, a labor paper, of the date of April !, 1897:

WORKINGMEN INDORSE IT-ANTICOLOR BILL APPROVED BY THE CHICAGO FEDERATION OF IABOR-COLORED OLEOMARGARINE CONDEMNED AS A FRAUI-A RESOLUTION PASSED AT LAST SUNDAY'S MEETING INDORSING TIE FULLER BILL IS UNANIMOUS-LABOR IS AGAINST THE FRAUD.

The defenters of the colored oleomargarine frand have had their last prop knocked from under arguments.

For years they have pleaded for protection of oleomarwarine "in lehalf of the working man." Olcomargarine was christened "the poor man's bntter" liy those who were aiding wannfacturers in making millions of" the same "poor man."

The anticolor bill was brought before the Chicago Federation of Labor by the legislative committee of that body Sunday, April 4, hy Cbairman Williams, who has claimed that large quantities of oleomargarine were being dealt out in the eity by retailers to those who ealled for butter and paid for butter. This fraud was made possible, he stated, because of the fact that the substitute was made in perfoct semblance of butter, and the workingman was the chief vietim. He explained that the only remedy tor this framl was the enactment of a law which would make it possible for bnyer and consumer to distinguisl the compound whenever he saw it.

Only one delegate in the entire body objected to the indorsement of the measure, and after he thoroughls understood the question he moved to make the vote for its adoption unanimons, which was done.

The sentiment expressed by the different delegates to the federation at the close of the meeting was that, should a petition be circnlated among the army of workingmen of Chicago calling for the passage of the Fuller anticolor law, it would meet with no opposition.

Then the resolntion which was passed at that time, and which I have in my possession in the city of Chicago, reads as follows:

Charles Y. KNight,

Chicago, April 4, 1897.

\section{Secretary Dairy Union.}

Dear Sir: At a mereting of the Clicago Ferderation, held on the th instant, that body unanimousl. indorsed the Fuller bill, and requested all subordinate bodies to use their $n$ tmost to secure its passage.

Very truly,

VICTOR B. WILLIAMS,

Chairman Legislatire Committee, Chicugo Federation of Labor.

I will tell you something in connection with that. When the bill was passed the box-makers' muion, which was a member of this Federation of Labor, found out that they had been making the boxes for olenmargarine, so they began to see the matter in a different light. After they found their boxes were userl to hold oleomargarine they came to the 
conclusion that oleomargarine was a good thing after all, and they rescinded the action of the Federation of Labor of the city of Chicago, and called on the legislature, I think, to repeal the law, or something like that.

Further than that, here last fall, before I came to Washington, I was called on by the chairman and secretary of that Chicago Federation of Labor. They showed me a resolution which had been put before that body condemning the Grout bill, and they said they thought the whole thing should have thorough investigation before it went through. I took them along this Fifth avenne. They came to me at a hotel which is on Fifth avenue, and I went along Fifth avenue with them, because it is within half a block of my office, and I conld find throughout the city 2,000 places like that where I bought the alleged butter. I showed them these places. They were perfectly dumfounded that such a state of affairs should exist, and they gave me their word that no resolution of that kind should be passed, and that the Dairy Union should be assisted in its position in asking for this 10-cent tax. I knew nothing further than that until this resolution came floating down here and was put into the House.

Senator HANsBRough. For or against the Gront bill?

Mr. KNIGH'I. A gainst the Grout bill.

Mr. MrNAMEE. Do you mean to cast such an imputation as that against the representatives of organized labor as to say they had been seen and influenced?

Mr. KNight. I saw a couple of them myself.

Mr. McNamee. You acknowledge here before this committee, do you, that you have been trying to bribe members of organized labor to

Mr. KNight. No, I do not.

Mr. MCNAMEE. You make that insinuation-that they had been seen in order to change their opinion. We all know what that meaus.

Mr. KNIGHT. No; they could not make any arrangements without seeing them, I think.

Senator AllEx. I think you are under a little apprehension, Mr. MeNamee.

Mr. KNight. I want to pay my respects now to my friend from Cincinnati. He has had a good deal to say here. I have heard from Ciucinnati since he has been talking. I can not rearl all I have heard from Cincinnati, but I can put it in the record. I am very pleased to have him vouch for one concern in Cincinnati with which I am well acquainted-that is, the French Brothers Dairy Company. If you will look over the record you will find that he spoke of them as being very nice people, and he said the president of the company was treasurer of the county of Hamilton, or something of that sort, and that they were not in such business as that they would be interfered with, and that in the city of Cincinnati the business was done in a public wayand everything of that kind. I have a telegram here from French Brothers Dairy Company, as follows:

Cincinvati, OHio, Jannary 9, 1901.

Secretary National Dairy Union, National Hotel, Washington, D. C.:

Large percentage oleo sold here as butter. Hurts legitimate butter business. We want Grout bill passed.

The Frexch Bros. Dairy Co.

Mr. SCHELL. In order that there may be no conflict, I wish to call attention to the statement that I made, which was that I had talked with the Messrs. French personally, and with some young man in their 
office who was a relative, but I do not recall his name. I just met him that day. It was their personal experience. I do not know from whom that emanates, or whether it is anybody in authority or anything of that kind.

Mr. KNIGH'r. I believe you told me that if they found me with a letter signed with their name on it, I would be held responsible. Was it not you who told me that on the House side? It was someborly.

Here is another letter:

[Chas. Heidrich \& Co, commiswion merchants, butter, eggs, poultry, calves, game, green and dried fruits, ete., 33 Walnut street.]

Charles Y. KNight, Esq., Washington, $U . C$.

Cincinfati, Jamuary \%, 1901.

DFAR SIR: As the Gront bill is hefole the Seuate, and as we are anxious for the bill to pass, we take pleasure in writing you a few lines.

'This butterive is sold here by retailers, grocer's, market hucksters, aud everybody else, and is pauned oft to the trade for butter. The wholesalers here have told us that they rharge one-half cent a ponnd advance, and lay that mones aside to tight the food inspertors. Every time a man is arrested, and that from 5 to 20 a week are arrested for panning off butterine for butter, these wholesale nen protect them. They come up and par the fine and the retailer sells it again.

Now we hope that this bill will pass and this evil will be stopper. We shall write to one or two Senators also.

Yours, respectinlly,

CHAS. Heidrich i Co.

\section{This one is from the firm of Herman Westerman :}

[Herman Westerman, generul commission merchant, 120 West Court street.]

Mr. Charles Y. KNigu't, Hashingtou, $l$. $C$.

Cincinnati, OHio, January 7, 1901.

DEAR SIR: In reply to your iuquiry addressed to a neighbor of mine, I am informed that the "Grout bill" is to be taken up Wednesday by the Senate. The butter business is alunost at a standstill in Cincinnati, owing to a fight on between the dealers of oleomargarine. I am informed that some is being sold to retailers at 10 and 13 cents per ponud; you can see why butter is not selling.

If I aw informed rightls, you want to know if oleo is being sold for butter. It is not sold for butter by the wholesale dealers, but the deeeption practiced by the retailers is where the mischief is lone. Every now and then a raid is made on these dealers. They are arrestel, fined $\$ 50$ and costs, which is paid by the wholesaler who furnishes, and in turn he charges one-half cent extra on the oleo for this protection.

I regret that I dicl not hear from you personally, but trust you will be as successful in passing the "Grout bill" by the Senate as you did the House.

Wishing you every success, I am,

Yours, very respectfully,

HeruaN WESTERMaN.

\section{Here is a letter from Charles H. Hess \& Co., of Cincinnati :}

[Office of Clias. H. Hess \& Co., general produce and commission merchants, also dealers in cheese. No. 24 West Court street.]

Cilarles Y. KNight,

Cincinnati, Ohio, January \%, 1901.

National Hotel, ITashingtou, D. C.

DEAR SIR: I learu from some of the members of the produce exchange of our city that a comnittee of oleomargarine men have reporter in Wrashington that oleomargarine is solıl as oleomargariue only in our city, which is false in its entirety. I know positively that there is sold daily thousands of pounds of olenmargarine for pure butter. And that the food and dairy comwissioners are either powerless or are indisposed to antagonize.

While there are some arrests being made, it seems to be on acconnt of local petit jealonsies anong dealers, and not tomching on the main offense. The oleomargarine dealers have a corruption fund with which they enconrage the retail dealers to sell oleomargarine for butter.

In conelusion, will sily that yon certainly deserve the praise of all honorable dealers in pure food tor the progress jou are making.

Very respectfully,

Chas. H. Hess \& Co. 
Here is one that covers the ground pretty well, I think, firom T. L. Brundage, of Cincinnati :

[T. L. Brundage. Estublished 1s93. Commission merchant. Butter and eggs, 2s West Court street, Cincinnati.]

Chas. Y. Knight, Esq.,

Cincinnati, Ohio, January 7, 1900.

National Hotel, Washington, I). C.

Dear SIR: We replied promptly to your wire of to-day, regarding statement made by Cincinnati oleomargarine man before the senate committee having charge of the Grout bill. In 80 far as that statement refers to the retail trasle of Cinciunati, it is absolutely false. Of course the wholesaler, in selling to the retailer, sells oleomargarine for what it is; he could not do otherwise. The retailer sells 90 per cent of what he buys for butter, and gets butter prices for it. More than 100 retail grocery stores in Cinciunati are to-day advertising the best Elgin Creamery at retail for 25 cents, while it is worth $25 \frac{1}{2}$ cents in a jobbing way. The only opportunity, in such trausactions, for profit, is to substitute oleomargarine for butter, which is being done to a very great extent. The present law compels the small grocer, if he hanclles oleomargariue, to become a criminal. I have had a great many of them tell me that they wished the stuff was done away with entirely, or some such restrictions placed on its sile that deception would be impossible. The small grocer would then be in a position to sell his bntter for what it is and not be compelled to meet the ruinous competition of the larger dealers who use butter only as a "stool picreon" in their business. While the Grout bill, as a law, wonld uncuestionably benefit the clairy interests, it would, at the same time be a great help to the small retailers all over the country, for the reason that it would destroy the opportunity for frand and place them on the same footing as their competitors in business who are unscrupulous in their methods. Summed up briefly: The oleomargarine traffic in this State is wholly illegal, and the only parties who realize any benefit therefrom are the manufacturers, jobbers, and the unscrupulous retailer who sells it for butter. Very nearly $2,000,000$ pounds were sold in this city during the year 1900.

I am, yours, truly,

T. L. BRundage,

E. I. Burridge, Manager.

\section{The rest of them are as follows:}

[Office of Conrad Giebel \& Co., wholesale dealers in high-grade butter, cheese, and provisions, commission merchants, 57 Walnut street.]

Mr. Charles Y. Knyght, Washington, D. C.

Cincinnati, January $\%, 1901$.

DEAR SIR: In regard to the sale of oleomargarine for pure butter, we know to be a fact, especially in the retail trade, which is very injurions to the sale of pure creamery butter. Hoping that you will put forth your best eftorts in the passing of the Grout bill, we remain,

Yours, very truly,

Conkad Giebel \& Co.

[S. J. Stevens \& Co., wholesale butter and cheese, Cincinnati, Ohio.]

JANUARY 7, 1901.

Mr. Charles Y. Knight, Washington, D. C.

DEAR SiR: As the representative of the Chicago pure butter men, we write to yon to use your utmost endeavors in meeting and refuting the arguments of those opposed to the passage of H. R. bill 3717, known as the "Grout bill," who say the manufacturers aud wholesalers of bntterine never sell it for pure butter. We are aware of this fact, as is everyboly, becanse they dare not do it. It is the retailers who offer it to the nnsuspecting public as the genuine butter, and this without any interference. We know this to be a fact from transactions of this nature in ('incinnati.

Use all the arguments yon can to promote the passage of the bill at an early late, and that without amendment of any kind, as amendment would only delay the prassage of the bill and probably kill it.

Yours, very truly,

S. J. STEVENS \& Co. 
[Telker \& Dunker, wholesale fruit and produce commission merchants, No. 118 East Court street.]

Mr. Charles Y. KNight, Washington, I). C.

Ciscinnati, Jamuary $7,1901$.

DEAR SIR: We hear to-day that it has been argued that every pound of oleo sold here is solil as oleo. This is deciderlly not the case, as any amount is sold liere as butter.

Respectfully, yours,

TELKER \& DUNKER.

[Office of Blome \& Dreifus, commission merehants, 1010 Race street.]

\section{Mr. Charles Y. Knight, Washington, D. C.}

Cincinnati, January 7, 1901.

DEAR SIR: Have been shown your telegram saying oleo is solıl in our market for such; it is very easy said as the wholesalers sell it for olen as they are compelled to, but the retailer sells it for what he can, but invariably for butter. The writer has bought on several occasions (just to find ont) butter and received oleo. The state officers occasionally make some arrests, but the job is too big. The wholesalers guarantee the retailers protection and pay their fines. If the Goverument does not pass the Grout bill, butter will soon be a thing of the past, as honest dealers in pure butter can not compete with fraud. Some of the retailers make no effort any more to sell for olpo as the wholesalers pay the fines. There is nothing too mean or low for the oleo dealers to do.

Yours,

DAVID DREIFUS.

[Finke \& Schwier, commission merchants, 1008 Race street, near Court.]

Mr. Chalizes Y. KNight, Washington, D. C.

Cincinnati, OHIo, January $7,1901$.

DEAR SIR: We have just seen a telegram that a statement had been made to the committee that all oleomargarine was sold as such in Cincinnati. We wish to emphatically deny such statement. The wholesale dealers may, as the United States Government compels them to. but the retailers sell it anyway just to sell it, because they are protected by the wholesale dealers, who pay their fines, if eanght. We know it is sold as butter from personal observation. We also kuow that the retail dealer is protected in selling it, as our customers tell us when they take out licenses that they have no fear, as the wholesale dealers pay their tines, if arrested. If no check is put on this fraud or imposition on the consumer, it is only a question of time when the dairy interests will be overwhelned. Hoping the facts alove stated may be of some benefit to the crusade against the colored oleomargarine fraud, we remain, Yours, truly,

Finke \& Scitwier.

[Halfhill \& Kolb, general commission merchants, 134 West Court street.]

Mr. Charles Y. Knight.

Cincinnati, OHio, January \%, 1901.

DEAR SIR: We were shown a telegram on 'change here in which it is asserted that oleomargarine is being sold in this market as such, which is an untruth, as it is a very common thing to go into our market and ask for a pound of butter aud be handed oleomargarine.

The State authorities here have been unable to cope with the combine hére and it has been sold openly before them as butter. We therefore ask you in the interest of pure food, and the chances of killing one of the largest industries in our States by this adulteration of butter, to do your utmost in briuging about a fair and equitable law in behalf of pure butter.

Yours, very sincerely,

Halfhill \& Kolb.

The purport of all these letters is the same-that is, that it is sold in Cincinnati as butter and for butter, and that there is a protection fund of a half cent levied upon the wholesale sales to protect those who do the selling. 
Mr. JeLKE. Dirl Mr. Blackburn go to Cincinnati?

Mr. KNight. No, sir; he dill uot.

A volce. Would it not be well to state to the committee that this Mr. Brundage is a broker in pure butter?

Mr. KNIGHT. All of these people are dealers in pure butter-all kinds of buttel.

A voICE. In fact, more process butter than pure butter.

Mr. KNIGH'. I do not know how much process butter, or how much dairy butter, or how much latle butter, or how much imitation ladle butter.

A VoICE. Anyone who knows anything about Mr. Brundage knows he is a process-butter man.

Mr. KNIGHT. I do not think so.

A voicE. He sells more process butter than he does pure butter, I think.

Mr. KNight. If he sells it legally, I can not see the objection. You do not claim he sells it illegally?

A VOICE. Certainly not; but process butter is something like oleomargarine.

Mr. KNight. I want to call your attention, gentlemen, to a circular sent out by Braun \& Fitts, under date of March 17, 1899, in which they say :

Eggs are selling at cost, but "the only high grade" will give jou profit, so keep pushing its sale and build up a reputation for good butter.

Senator Dolliver. Did I understand you to say they are making artificial eggs?

Mr. KNight. Yes, sir; they are. They are making eggine. It is an artificial egg, but not an imitation of eggs. There is the difference between a substitute and a counterfeit.

Senator ALLEN. Are these letters you have read reciting the sale of oleomargarine from jobbers in oleomargarine to their customers, the retailers?

Mr. KNight. Letters from jobbers of butter?

Seuator ALLEN. I es. You have read several letters here in which the writer would say to the person to whom it is sold to go ou and sell it and the cost and expenses of prosecution wonld be met.

Mr. KNigh's. One of them is the letter of Mr. Jelke's firm and another-

Mr. JELKE. Ol, no.

Senator ALLEN. They are either the manufactnrers or jobbers.

Mr. KNight. The manufacturers in Chicago, if you mean the first letters I read, Senator.

Senator AluEN. Yes.

Mr. KNight. Yes; one of them was Mr. Jelke's firm, and the other was Mr. William J. Moxley's.

Senator ALLEN. These letters were either from the manufacturer's or the jobbers in this article?

Mr. KNight. Those are the mannfacturers.

Mr. JELkE. Excuse me. Does not the Seuator mean these letters [indicating]?

Mr. KNIGH'. He is not talking about the Cinciunati letters; he is talking about the other letters.

Mr. Sonwll. I would like to have it go on the record right here that I want an opportunity to look into the gentlemen who bave written these letters. I only recognize one name, and that is the name of a man who is not responsible financially or in auy other way; and as to 
this corruption fund, I want to deny it in toto as to any of my clients, or as to anybody whom I know in the wholesale business, as regards defending cases for the sale of oleomargarine for butter.

Mr. KNight. I liave also statements from the Secretary of Agriculture about them, if you want me to give them. Now, gentlemen, whenever I tire you, I want you to tell me.

Senator HANsisougH. Have you concluded?

Mr. KNIGHT. No; I have not gotten throngh anything like what I should; I wanted to say something on the price of butter. In fact, I have a tremendous lot of information in this matter that has not been presented and that is very vital, but, as you see, the time I had intended to occupy was somewhat occupied by other people.

Senator Haxsmrougr. Can you boil down what you have to say and present it in an hour to-morrow?

Mr. KNight. I might.

Senator Hansirough. Try to get the essential points, so as to present it in an hour to-morrow.

Mr. KNIGHT. I will do this, Senator. If yon will let me take up a few minutes on butter prices I will be content to leave it to you and not bother any further.

Senator Hansbrough. Mr. MeNamee desired to ask a question, I believe.

Mr. MCNAMEE. Yes, sir. Mr. Knight says he is a member of organized labor. What organization?

Mr. KNIGH'T. The 'Typographical Union, when I was at work at the trade.

Mr. MCNAMEE. What local?

Mr. KinighT. Minneapolis lodge.

Mr. MCNAMEE. You are an ex-member?

Mr. KNIGHT. I said I had been a member. I employ nothing else but mion labor all the time.

Mr. McNamee. That is a matter of policy, of course.

Mr. KNIGHT. Yes; it is a matter of policy.

Mr MCNAMEE. What is your present occupation, Mr. Knight?

Mr. KNiGH'T. Nèwspaper man.

Mr. MCNAMEE. What is the circulation of your newspaper?

Mr. KNigHT. Am I supposed to stand here and be questioned about circulation?

Mr. MCNAMeE. What is its policy?

Mr. KNIGHT. None of your business, absolutely, in that case. It is a question that does not concern you or this case at all.

Mr. MCNAMEE. Is it not a fact that you at present make your living as an officer of the dairy unions?

Mr. KNIGHT. I have got an opportunity to answer now. I have worked in this case for the last three or four years and our paper has contributed liberally 10 the expense of what we have had to do in it, and I have never received one cent salary. I have only received my expenses, and every cent that has ever been spent has been accounted for, and the vouchers and accounts are open to you or anybody else.

Mr. MoNAMEe. You are at present merely receiving your expenses?

Mr. KNIGHT. I am.

Mr. MCNAMEE. You are making this patriotic effort, then-

Mr. KNIGH'T. Can you say as much?

Mr. MoNamee. Yes, sir, Mr. Knight; I can say as much.

Senator Hansbrough. You have said you could, so you are even.

Mr. McNamee. I am not through, Mr. Chairman. In regard to the 
Cleveland matter. Are you aware of the fact that the Buildiug Trades Council of Cleveland pasised a resolution-

Mr. KNIGH'. I don't know anything abont it except what I stated. I told all I kneT. If you have any information about it you might, state it to the committee.

Senator AllEN. I suggest that we adjouru until half past 10 to-morrow morning.

Mr. MICNAMEE. Mr. Chairman, before the committee adjourns I desire to say that I am a traveling salesman for a business firm in Cincinnati, and that I am here on private business. If it were not for that I should not be here.

Senator Hansbrougu. That is sufficient.

Mr. KNight. That is all right. We understand each other, I guess.

The committee (at 5.15 p.m.) adjourned until Friday, January 11, 1901, at 10.30 a. $\mathrm{m}$.

\section{Washington, D. C., Frillay, Jamury 11, 1911.}

The committee met at 10.30 o'clock a. m.

Present: Senators Foster (acting chairman), Money, and Dolliver. Also, Hon. W. J. Bailey, a member of the House of liepresentatives; Charles E. Schell, representing the Ohio Butterine Company, of Cincimmati, Olio; W. E. Miller, representing Armour \& Co., Kansas City, Mo.; John F. Jelke, representing Braun \& Fitts, Chicago, Ill., and others.

\section{CONTINUATION OF STATEMENT OF CHARLES. Y. KNIGHT.}

Mr. KNigirt. Mr. Chairman and Senators, the first thing that I want to do this morning is to comment on this color question. Why do we color butter and why not color oleomargarine? And I want to speak relative to the elaim of the oleomargariue people to have originated the color that is used, and to say something about the natmal color of butter.

It is conceded by everybody that the natural color of butter varies at different seasons of the year, under different conditions of feed and pasture, and in different breeds of cattle or cows. So how are we to determine whether or not butter is naturally yellow, and how long it is yellow, and how yellow it is?

The report of the Secretary of the Treasury on what is known as the Tawney resolution, calling for the ingredients used in the making of oleomargarine, for the fiscal year 189S-99 showed that there were used, in $83,000,000$ pounds of oleomargarine, 145,500 pounds of coloring matter. Figuring that by the gallon, it takes 240 some odd gallons to the million pounds of oleomargarine to bring it up to the standard color, which is the same as that of butter.

I went to the leading creameryman of the United States just before I left Chicago. He is the head of a concern which makes several million pounds of butter a year. I asked him to give me a statement of the quantity of butter color used in a million pounds (taken the season over) of their butter to bring it up to the standard color. He got the statement from his books of the amount of butter color used last year, and showed it to have been 70 gallons per million pounds of butter. So the difference between the color of butter, naturally, and the color of oleomargarine, naturally, is as the difference between 70 gallons of 
color for $1,000,000$ pounds of butter and 240 gallons of color for $1,000,000$ pounds of oleomargarine-that is to say, if we take 100 as a basis and make "40 gallons of color the amonnt necessary to bring oleomargarine from white up to the normal color of butter, then the natural color of butter would be $66 \%$ per cent of the color that it bas the year round.

Mr. JELKE. Mr. Knight, will you permit just one questiou?

Mr. KNight. Yes, sir.

Mr. JELKE. Does your creamery man state what strength of butter color he uses? Sometimes it is double and triple strength. I understand they make a sperial color which is very powerfinl.

Mr. KNight, No. Wells, Richardson \& Co.'s colors are what they use. Mr. Jelke, the same as your firm does.

Mr. JELKE. I think they make more than one standard.

Mr. KNIGHT. No, sir; not unless they make it especially strong for you.

Mir. JELkE. We do not use a specially strong color; but they make it, and I know it has been offered to us. We have not used it, however.

Mr. KNigHT. Wells, Richardson \& Co. make but one kind of butter color that is used in the West for butter. I an very familiar with their business in that respect. Moreover, we surely do not need for butter (which is partly yellow in the first place) a strong color. It is the oleomargarine people who need the strong color, because they have got to bring their color from a white up to a standard. Aud I think they found, when they first attempted to color their product, that carrots were neerled in very large quantities to make their substitute as yellow as they wanted it; and it was the necessity of getting a very strong color that lerl them to the use of the aniline colors for that purpose.

Mr. MILLER. There is one reason why there is that difference in the amonnt of coloring matter used-at the time of the year when the cows are on grass they need very little color.

Mr. KNIGHT. Yes; that is true.

Mr. MILLER. That accomnts for the difference of which you spoke.

Mr. KNIGHT. ()h, not entirely. That is ouly a third of the year.

Mr. Miller. You will acknowlerge, however, that that is the time of the year when they make the largest amount of butter.

Mr. KNight. Yes; they make the liargest amount of butter then. So that is a concession that a large amount of the butter profluction is naturally yellow.

Representative BAILEs. It takes just as much coloring matter to make white butter yellow as it does to make white butterine yellow, does it not?

Mr. KNIGHT. Yes; but the butter is never as white as oleomargarine.

Representative BaIley. Oh, yes, it is.

Mr. KNIGHT. That is a difference of opinion, then, which we can not settle here in the eommittee.

Representative BAlLEY. Why, everybody who has lived on a farm and who has eaten butter malle in the winter knows it.

Thi' Acting Cinarian. How expensive is the color?

Mr. KNigh'T. That color costs the oleomargarine people about $\$ 1.70$ a gallon, I think. It costs the butter people more.

The ACting Chairman. For the reason that the oleomargarine manufacturers buy such large quantities?

IIr. KNIGHT. Yes; they do buy large quantities. As a matter of fact, there is more butter color used in the oleomargarine that is made in the Uniter States than there is used in all the creameries in butter. I have investigated that snhject, and I know what the business of the concerus in butter color is, because I have gone into the matter. 
Mr. Mrluer. No you mean to say that there is more butter color used in the $107,000,000$ pounds of oleomargarine than there is in the $1,500,(000,000$ pounds of butter"?

Mr. KNigh'T. No; I said creamery butter. Only 20 per cent of the product of the United States is creamery butter.

The next thing to which I wish to call your attention is a statement made by a gentlemen who came down here from New York the other day, and pretended to be a butter man. He is in the butter business, I believe-the export bntter business; and it is to his interest to have butter as low as possible, because when it is low he can export it from this country more protitably. When butter is selling at a price which brings any thing like a firir return to the producer, he does not get much of all opportunity to export it; and he is therefore interested in low butter prices. He made a statement to you about the tremendously large increase-or at least about an increase; I will not say "tremendously large" increase-in the production of butter, as slown by the leceipts of butter in New York City; and he attempted to make this committee believe that the dairy business $110 \mathrm{w}$ is better than it ever has been, by citing the fact that last year the market for butter was, I think, higher than it had been for twelve years.

I hold in my hand the statistics for receipts of butter in the city of New York luring the past twelve years.

The Acting CHAIRMAN. What is that taken from?

Mr. KNIGH'T. This is from the official report of the mercantile exchange of the city of New Tork, and can be verified. I do not think it will be contradicted by anybody, however, Senator.

With the exception of the vear 1897 , there has never been as much butter received in the city of New York as there was in the year 1890, tell years ago.

In 1890 the receipts of butter in the city of New York were 2,092,115 packages; in 1s91, 1,543,702 packages; in 1892, 1,750,8:6 packages; in $1893,1,654,198$ pacliages. You will see from these figures that there was a decrease right straight down from 1890, from 2,092,115 packages in that year to 1,654,198 packages in 1893, in the city of New York. The receipts began to increase at that time, owing to a reaction in the market, and in 1894 they were $1,711,466$ packages. In 1995 they were $1,7118,576$ packages; in $1896,1,923,1161$; in $1897,2,156,187$ packages; 1897 , then, was the first year when the receipts got up as high as they were in 1890 , when they were "2,09:2,115 packages. In 1598 the receipts fell off from those of $18 !) 7$.

(Semator Allen at this point took the chair as Acting Chairman.)

Mr. KNIGHT. As I say, the receipts of butter in the city of New York reached the figure of $2,156,187$ packages in the year 1897. In the year 1899 the production of butter began to fall oft again, as shown by those receipts, and reached ouly $2,079,120$ packages. In 1899 it fell off again, and was $2,000,357$ packages. In 1900 there was a falling oft, and it reached only $1,911,061$ packages.

'The Acting Chairman (Senator Allen). That is the export butter, is it?

Mr. KNignt. No; these are the receipts in New York, Senator. I am giving these figures in reply to a gentleman who was down here from New York the other day claiming that more butter was received in New York last year than in any other. I have just shown that, with the exception of one year, the receipts in New York have not been in ten years what they were in 1590 .

The Acting Cuarrman. I recall his evidence.

$$
\text { s. R('P. } 2043 \text { - }: 31
$$


Mr. JELKE. Mr. Kuight, just one question: Those figures represent the number of parckages?

Mr. KNight. Yes.

Mr. JELKE. Are they of the same size?

Mr. KNigu's. I do not know, Mr. Jelke.

Mr. JELKE. I know that years ago a large number of packages of butter went into New York in the shape of firkins containing 100 or 112 pounds.

Mr. KNIGHT. There is no way of arriving at that information.

Senator Foster. Are these tubs or firkins?

Mr. KNIGHT. There is wo way of telling that.

Mr. MILLER. Is it not a fact that the receipts of butter since May 1 last in New York show an increase over the previous year?

Mr. KNıGHT. Yes; they are increasing a little over the previous year.

Another thing to which this gentleman drew your attention very foreibly was the fact that last year the price of butter was higher in New York City than it had been for twelve years.

Well, he simply misrepresented the facts in that case. Here is a publication fiom the Agricultural Department giving a diagram of the price of butter for the last ten years; and 1 have carried it out to eleven years. I aun sorry I have not enough copies of this publication to hand one to each nember of the committee. There it is, in this chart-the line showing the production of oleomargarine. It shows the amount produced in each month as compared with the preceding and successive inouths.

That will reveal to you, gentlemen, a little of the cause of our alarn in this matter. If you will follow that cliagram you will see, Senator, that the price of lutter lias gradually been going down, down, down. You will see that in 1895 or 1899 there was a marked advance. In 18 !s you wiłl notice a slarp jump. The market went wpward. The cause of that has not yet been explained to you.

The jump in the price of butter in the year 1 s9S was due to droughts all over Europe. There was a tremendous export demand for butter in that year, as a result of a scorching drought all over the continent, and all over the islands of England and Ireland. The importers of Europe came here in Angust for our butter, and they cleaned out everything ihat we could possibly sell to them. They cleaned up our storage supplies, among other things; and the result was that when we came to the winter there was no stock in storage from which to draw. The surplus had all been wiped out. That was the cause of the high prices of that year. It was not a natural condition at all. What is the condition to-day? A year ago the price of butter in the New York market was about 30 cents a pound as a result of that drought. To-day the market in New Tork is either 24 or 25 cents, I am not prepared to say exactly which.

Mr. JELKE. The market reports in the newspapers will give you the exact figures.

Mr. KNight. Yes; but I have not them.

The Acting ChaIrian. Mr. Knight, permit me to suggest this: Mr. Peters, from Texas, a very large cattle owner, is here, having come from quite a distance. He wants to make a statement, and possibly you will want to reply to what he says.

Mr. KNIGHT. Very well; I am willing to give way, if you suggest it, Senator.

The Aoting Oharrman. I am simply suggesting to you the propriety of the step. You can use your own discretion about it. 
Mr. KNight. I sliall be very glad to accommodate the gentleman. Does he want to be heard now? Is that the idea?

The Acting Chairman. Would you prefer to be heard now, Mr. Peters?

Mr. PE'TERs. Either now or at a subsequent time. I do not want to interupt Mr. Knight or you gentlemen of the committee.

The ACTING CHAIRMAN. I thought possibly you might want to reply to some of Mr. Peters's statements, Mr. Knight.

\section{STATEMENT OF E. S. PETERS, PRESIDENT AMERICAN COTTON GROWERS' ASSOCIATION.}

The Acting Ciramian (Senator Allen). Mr. Peters, kindly give the reporter your uame, place of residence, and business.

Mr. Peters. My name is L. S. Peters; my residence is Calvert, Tex.

The ACTING ChaIRMan. What is your occupation?

Mr. PETERs. I am a planter.

The Acting Chairman. 'To what extent?

Mr. PExers. I have over 4,500 acres of land in cultivation. 1 represent the Cotton Growers' Association of Texas, and I am the president of the American Cotton Growers' Association.

The Acting Uirarian. You may proceed with your statement.

Mr. PE'IERs. I would like to state, gentlemen, in this connection, that I did not come here prepared with a speech or anything of the kind. I came here on very short notice, and I have simply gotten up a few statistics to show the amount involved; in other words, to show that the cotton-oil industry will really be affected very materially by this bill. I have here, figures from IIr. Hart, the statistician of the Department of Agric'ulture, giving the acreage, production, and value of lint cotton and estimated production of cotton seed in the various States of the Union. I obtained them from the Department of Agriculture so as to be able to speak from official data.

The acreage of cotton in 18!18-99 was 24,$91 ; 7,2 ! 5$ acres. The production of lint cotton was 11,1S9,2(1) bales; and the production of cotton seed 5,594,60'2 tous. In 1900-1901 (the crop coming in now) the estimated crop of lint cotton is $10,100,000$ bales, and of cotton seed 5,050,000 tons. A ton of seed has been selling at about $\$ 15$ to $\$ 16$. That is what we have been getting for it. Of course I do not know anything at all about oleomargarine; but I know that a certain percentage of the cotton-seed oil goes into that prorket.

Senator MIONEY. You say you produced 11,000,000 bales?

Mr. PETERs. It is the estimate of the Department that the crop will be $10,100,000$ bales.

Senator Fos'rf.R. And about half that number of tons of seed?

Mr. PETERS. I es, sir; 1,500 pounds of seed cotton will make a 500. pound bale of cotton, and about a thousand pounds of cotton seed.

Mr. KNight. What is that worth a bale?

Mr. PETERS. It is worth to-day, I think, about $9 \frac{1}{2}$ cents in Galveston.

Mr. KNigh'r. Five hundred pounds to the bale, you say?

Mr. Peters. Yes, sir. You are talking about lint cotton, are you not?

Mr. KNigh's. Yes, sir. I wanted to arrive at the value of a bale of cotton, and to get, as a matter of fact, at the value of the cotton produced.

Senator Moner. That would be $\$ 47.5()$.

Mr. KNIght. \$ $\$ 7.50$; yes. And how many bales comprise the product of the United States? 
Mr. PETERs. The Department's estimate of this year's production is $10,100,000$ bales. Last year it was $9,14 \%, \$ 3 S^{\prime}$. The year before last it was 11,1 s9, 20 ().

Now, Texas is more interested than any other one State. According to this statement, we raise at least a third of the crop of cotton of the United States. I say Texas; Oklahoma and the Indian Territory are included in that. Last year the amount of cotton actually raised in Oklahoma was $66,5.55$ bales, and in the Indian Territory, 119,939) bales. Now, the crop this year for the Territories and Texas is $3,570,000$ bales, representing $1, i \$ 5,000$ tous of seed. 'That seed, at \$1.i per ton, which is about the average price that the mills pay, would make abont-

Senator Moner. Oh, you have that too high.

Mr. PETERs. The price of seed?

Senator MoNeY. Ies.

Mr. PETERs. No, sir; I think not.

Senator FosTER. Someone stated here the other day that it was worth from $\$ S$ to $\$ 10$ a toll.

Mr. PETERs. Allow me to rearl you this statement, as bearing on that question:

Prices of cotton seed (Houstom) per ton of 3,000 ponnds, 1S2S-1900.

[From Bradstreet's quotatious.]

l)ate.

\begin{tabular}{rrrr}
1898. & 1899. & 1904. \\
\cline { 2 - 3 } & & \\
\hline 9.50 & $\$ 9.00$ & $\$ 12.00$ \\
9.50 & 9.00 & 16.00 \\
9.00 & 8.00 & 15.50 \\
10.00 & 8.50 & 15.50 \\
10.100 & 8.50 & 15.50 \\
10.00 & 8.75 & 15.50 \\
9.75 & 8.75 & 15.50 \\
9.50 & 9.00 & 15.50 \\
11.00 & 9.00 & 15.50 \\
9.00 & 11.00 & 17.35 \\
9.00 & 12.50 & 15.00 \\
8.00 & 12.50 & 15.50
\end{tabular}

January 1

February 1

A pril 1.

May 1.

July 1

August 1 .

September

October 1

November 1

Necember 1 .

Senator Foster. Then the prices are going up all the time?

Mr. PeTERs. Yes; they are higher this year than they were last year.

Senator MoNEY. They have been going up.

Senator Foster. For the reason that they are making so much more oleomargarine?

Mr. PETERs. No; I suppose they are finding more uses for it; there is a larger demand.

Senator Moner. The reason cotton has gone $u p$ is because everything else on earth has gone up-on account of the abundance of money.

The Acting Chairman. You are a practical raiser of cotton, are you, Mr. Petel's?

Mr. Peters. Yes, sir. I did not raise much last year, though. The flood hit us pretty heavily, and we had a pretty bad time this year, although I raised a good deal of cotton. I have raised over 2,000 bales in one year. But it is coming over now.

Senator Foster. Yes; you are all right now.

The Actinc Chatrian. Go on, Mr. Peter's.

Mr. PETERS. On the basis of these prices of Bradstreet's and the figures I got from the Department of A griculture, the valuation of the crop of Texas and the Indian Territory, at $\$ 15$ a ton, would be about $\$ 30,000,600$. 
Senator Foster. For the cotton seed?

Mr. PETERs. For the cotton seed $-1,785,000$ tous at about $\$ 15$ per tou. Senator MoNEY. If it will not interrupt you, I would like to have you go back to the price of cotton seed for a moment, because the prices you gave are contrary to my experience. Do you refer to the price per ton of cotton seed, or the price per bushel?

Mr. PETERS. No; the price per tou of seed at Houston. Let me read to you the prices of cotton seed at Honston, per ton of 2,000 pounds, from $189 \mathrm{~s}$ to 1900 . These figures are taken from Bradstreet's quotations. On the 1st of January, 1835 , the price was $\$ 9.50$; in 1899 it was $\$ 9$; in 1900 it was $\$ 12$.

Senator MoNer. Sixty bushels make a ton, you know.

Mr. PeTERs. That is the way it is usually estimated.

Senator MunEr. Well, that is the basis on which every fasmer and every oil-dealer buys and sells.

Mr. PETERS. In our section they buy and sell entirely by the ton, by weight.

Senator Money. Well, 60 bushels of seel will make a ton. I have livel on a cotton farm. In fact, I am a farmer myself. Now, that will make 25 cents a bushel for cotton seed, there being 60 bushels in a ton.

Mr. Pe'iers. That is right.

Senator Monwy. The point is that in my State we are only getting about $\$ 8$ a ton now.

Mr. PETERs. I sold mine last year at $\$ 15.50$.

Senator Moner. Ffteen dollars and a half a ton?

Mr. PeTERs. Fifteen dollars and a balf a ton.

Senator Moner. That is 25 cents a bushel. That is higher than I ever knew it to be soll before.

Senator Foster. You had better send yours over to Texas, Senator. Senator MoNEY. Yes; we might ship ou cotton into Texas at a profit, at that rate.

Mr. PeTERs. No; you do not know the railroad people there. The railroads charge us double price west of the river there for everything we ship. It takes about $\$ 2.50$ a bale to get a bale of cotton to the ports west of us, while east of.us it is only about a dollar.

Senator Fos'wr. These are Galveston prices, are they?

Mr. l'E'TERs. These are Houston prices.

Senator Dolliver. You are being robbed by somebody in some way, Senator Molley.

The Acting Cha irman. The "oetopus" has got hold of you. [Laughter.] But go on with your statement, Mr. Peters.

Mr. PETFis. This is the letter I receivel inclosing the figures to which I referred a moment ago.

\section{Unitel, States Department of Agricultere,}

DIVISION OF STATISTICS, Washington, D. C., January \&, 1901.

Mr. E. S. Peteirs,

$$
\text { Hotel Raleigh, City. }
$$

DEAR SIl: In eompliance with my promise of yesterlay, I beg to inclose such iuformation as is available with regard to the production and price of cotton seed. The information with regard to prices is rather meager, and I do not know whether it will meet with your requirements or not, but it is the best that can be dome on snch short notice. So far as production of cotton seed is concerned, it has been figured ont on the generally accepted basis of two-thirds seed and one-third lint; in other works, it is assumed that 1,500 pounds of lint and seed will make 500 pounds of lint and 1,000 pounds of seed. In the figures for 1900-1901 of production of cotton, it is inpossilble to separate the production of 'Texis and the 'Territories, but this is explained in a footuote.

Vers truly, yours, 
Acreage, production, aud ralue of lint cotton and estimated production of cotton seed in named States and Lnited States, 189S-99 to 1900-1901.

UNITED S'TATES.

\begin{tabular}{|c|c|c|c|c|c|}
\hline & \multirow{2}{*}{ Tear. } & \multirow{2}{*}{ Acreage. } & \multicolumn{2}{|c|}{ Lint cotton. } & \multirow{2}{*}{$\begin{array}{l}\text { Cotton seed. } \\
\text { estimated } \\
\text { production. }\end{array}$} \\
\hline & & & Production. & Value. & \\
\hline $\begin{array}{l}1898-99 \ldots \ldots \\
1899-1900 \ldots \\
1900-1901 \ldots\end{array}$ & 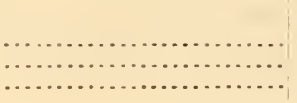 & $\begin{array}{l}24,967,295 \\
23,403,497 \\
25,034,734\end{array}$ & $\begin{array}{l}\text { Bales. } \\
11,189,205 \\
9,142,838 \\
10,100,000\end{array}$ & $\begin{array}{r}\$ 305 \quad 467,041 \\
334,847,868 \\
\ldots \ldots \ldots \ldots \ldots .\end{array}$ & $\begin{array}{l}\text { Tons. } \\
5,594,602 \\
4,571,419 \\
5,050,000\end{array}$ \\
\hline
\end{tabular}

TEXAS.

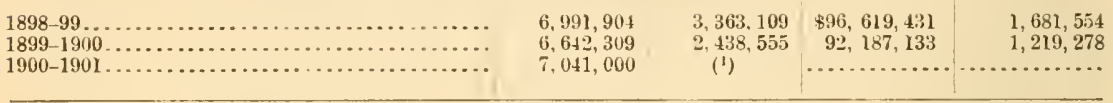

OKLAHOMA.

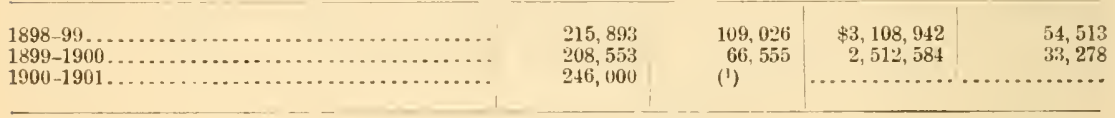

INDIAN TERRITORY.

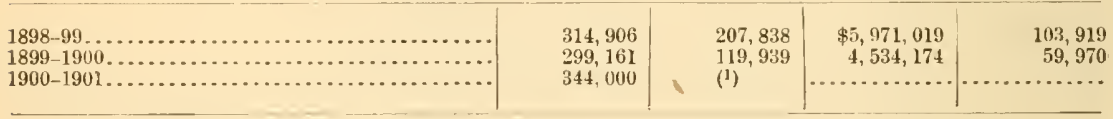

\footnotetext{
1 Texas and Territuries, 3,570,000 bales; this represents 1,785,000 tous of cotton seed.
}

Now, I have said what I wished to state in reference to how this bill will affect us cotton planters.

I would like to say this in reference to the merits of this case: I see no reason why the products of one agricultural section shonld be legislated agaiust for the benefit of another section. We all use butter down our way; in fact, I presume they use it as much there as they do anywhere else. I know I always have plenty on my table and never have to buy any. But there is no right or justice in taking one prod. uet for the benefit of auother agricultural product.

I would suggest, in place of placing the tax proposed by this Grout bill on oleomangarine, that if the butter men are honest in what they say, and simply do not want butter imitated, that can very easily be remedied, accorling to my idea. I would suggest that the products of the process-butter factories be put up round or oval packages, so that they can be designater is process butter, and that oleomargarine be put np in square or rectangular packages and marked as it is now. If they will make it compulsory by a law with penalties attached to put oleomargarine $u$, in bricks, a blind man or a child can tell exactly what he is getting, and there can be no imposition; and it would not work a hardship upon the dairy people at all.

Senator MoNEY. Then you want the renovated butter marked, too, do you?

Mr. Peters. Yes. Let the process-butter people put their product up in oval or round packages. I think they are the men who need looking after, if I can judge from some little testimony I have read and heard.

I do not know, Senators, that there is anything further that I wish to submit to you, unless it is a letter I received from Harvie Jordan, 
president of the Georgia Cotton Growers' I'rotective Association, directed to the committee. I will read it:

To the honorable Committee on Agricullure.

United States Senate,

Wasingtor, D. C., January 5, 1901.

Mr. Chamman ani Gentlemen: In behalf of the agricultural interests of my State, which might be affected adversely or otherwise by the passage of the pending Grout bill, now in your hauls for consideration, I beg to herewith sulumit my earnest protest against its favorable consideration. The people of my State are opposed to any legislation which fosters one industry at the expense of another.

Georgia is rapidly developing the dairy iudustry, and bas also extended cottonseed oil milling interests. From a careful reading of the Gront bill, I feel alssured its passage would work serious detriment to the cotton-seed oil industry of the South. The sale of our farm products shonld be based upon legitimate demand, and every article given a fair slowing in the markets.

The rlifferent States will and are enacting laws which will fully protect onr butter industry against the improper sale of oleomargarine, and will shnt the sale of that article ont of the market as an aetive competitor, save upon its actual merits.

A bill was introduced at the last session of the legislature in this State, and passed, which guaranteed absolute protection to the butter industry of (ieorgia, and at the same time left the ehoice of purchase and consumption of butter and oleomargarine on a fair and equitable basis.

Sectional or class legislation is always objectionable, aurl should never be tolerated in a country of such wide and varied interests as ours. I can sce no good reason for national legislation on the interests of the Grout bill. I am chairman of the general agrienltural committee of the honse of representatives of (ieorgia, and can assure you that we have secured the passage of a State law which gives satisfaction and ample protection to the dairymen of Georgia, so far as the future sale of oleomargarine is concerned.

I am exceelingly anxions for the rapid development of the dairying industry in Georgia, but I do not want it fostered and protected by the passage of unjust laws; which will be detrimental to the future of other higbly valuable and equally important agricultural products.

$I$ trust that your committee will give to the provisions of the Gront bill most careful and thorongh consideration, and tbat your final judgment will be hased upon a fair and just solution of the questions involverl in that bill, which I feel assured is the earnest desire of erery Senator who has the honor of representing the American people in the highest branch of their National Legislature.

With highest respect, I beg to reniain, gentlemen,

Yours, truly,

HARVIE JORDAN.

Senator MoNEY. Who is the writer of that letter?

Mr. Peters. Harvie Jordan. He is the president of the Georoia Cotton Growers' Protective Association, and chairman of the Commit. tee on A grieulture of the Georgia senate.

Gentlemen, I thank you very kindly for allowing me to be beard.

\section{CONTINUATION OF STATEMENT OF CHARLES Y. KNIGHT.}

Mr. KNIGIrT. It was stated by Senator Allen that probably I would want to answer something that the gentleman preceding me has said In regard to cotton-seed oil.

From his figures I gather that the value of the cotton production of this country is $\$ 475,000,(100$. From figures presented by other people here, I take it that the value of the cotton-seed-oil industry is $\$ 50,000,000$, making a total of $\$ 525,000,000$. Of those $\$ .525,000,000$ in value of the cotton and cotton-oil product, the oleomargarine people of this country use less than one-half of $\$ 1,000,000$ worth. The amount of cotton-seed jil used in the manufacture of oleomargarine in this country, in proportion to the product of oleomargarine, basing it upon the figures of the cotton-seed-oil people themselres, is about two-thirds of 1 per cent. So that we ean not see, gentlemen, any great harm that 
can accrue to the manufacturers of cotton-secd oil as a result of this legislation, even if it would (as they claim) erush out the industry entirely, which we deny.

Mr. Miller. I would like to eall the attention of the committee to the statement made by Mr. Culbertsom, representing the Paris $\mathrm{O}$ tton Oil Company, of Pais, Tex. That statement was to the effect tuat the amount of oil made for the manutacture of oleomalgarine was 2.5 per cent of the total amount of oil marle.

Mr. Knigir. I do not know what $M \mathrm{r}$. Culbertson said; but I do know that the Secretary of the Treasury has reported that in the $83,000,000$ pounds of oleomargine made in this country last year there were less than !,00(0,00(0) pounds of cotton-seed oil. I can not give you in pounds the amonnt of cotton seed oil produced; I am only giving it in dollars, as shown by this report, which does not give it in pomms. So that that statement will hardly stand the test of reason, when it is seen that the value of all of the cotton seed oil is $\$ 50,000,000$ yearly, and there is only \$500,000 worth used in the oleomargurine mate in this conntry, and 25 per cent of the $\$ 50,1100.000$ would be $\$ 1 \%, 500,000$.

Mr. MiLlik. You are not taking into consideration the amount exported.

Ih. KNIGH'. Ho we make into oleomargarine in this country the cotton-seed oil that is exported?

Mr. Miller. IVhat would be the effect mpon the export trade if you shonld place a ban on the oil used in this conntry?

Mr. KNIGH'. I want to speak in comnection with this matter of "placing a ban" on the oil in this country. When this bill was up for consideration in 18S6, the cry was, "If you place a "2-cent stamp on oleomargarine, you will place a ban on the article, so that nobody in the United States will use it." Pint the minute the tax was placed on oleomargarine, its mamfaeturers began to call it an imlorsement by the Government of oleomargarine; and the matter has been carried into the comrts, and it has been elaimed that this taxation gave the Governmeut's stamp of approval to olemargarine.

Now, if "2 cents a pound tax will give you the Government's stamp of approval, a tax of 10 ceuts a pound will give you five times that mueh approval. [Langhter.]

Senator Moner. Let me ask you a question: Do you want to repress or destroy the manufacture of colored oleomargarine in this country? Is that your wish?

Mr. KNight. Why, I think it lias been demonstrated here, Senator, that white oleomargarine ean be solk. I know very well that if its manulacturers want to build u] a trade in white oleounargarine, they ean do it.

Senator Moner. I would like to have you answer my question.

Mr. KNight. Jes, sir.

Senator MoxeY. I think we should have a caudicl taik about this matter.

Mr. KNight. Yes.

Senator Moner. Do you wish to diminish the oleomargarine production, or not? Do you want to injure it, or do you want to suppress it, or do you want to get it out of the way as a competitor?

Mr. KNIGHT. We do not want to compete with oleomargarine, colored so closely to resemble butter that the people can not have a choice between it and gewuine butter.

Senator MoNEY. Then is your iclea that hy taxing it 10 cents a pound you will get rid of a competitor? Is that it? 
Mr. KNI(iIT. I think we will get rid of the incentive of people to use that product to defiaud the public.

Senator MONEY. Now, withont using any roundabout expressions at all, you want to get rid of a competitor, lo you; and you want to get rid of it by a tax of 10 cents a pound?

Mr. KNight. We want to gret rid of a fraud, Senator.

Senator MoNEY. I am not talking abont fiamd. We rlisagree on that subject, you know; for I think there is as much frand in your husiness as there is in ours.

Mr. KNIGHT. 'There is fraud in every business.

Senator Moner. Neveltheless we have har testimony here to show that you take rancid and sour butter, and paddle it up, and put chemicals in it, anul sell it for butter.

Mr. KNIGHT. And we have also had testimony, Senator, to the effect that these oleomargarine people want to color their butter in imitation of that "rancid stuff."

Senator MoNEy. All right. 'That is another matter'. Now, you want to get rid of this industry whether it is a frand or not; and that is the object of this measure, is it not-to get rid of oleomargarine?

Il. KNIGHT. I do not see how I can explain to you my views-

Senator Moner. Fou can explain them by answeriug the question.

Senator Foster. Do you waut to get rid of it if it is not a frumd?

Mr. KNighr. We want to get rid of the fraululent competition.

Senator Foster. The illegitimate competition?

Mr. KNIGH'T. The illegitimate competition.

Senator Moner. And in order to do that, you want to tax the whole production 10 per cent?

Mr. KNighr. No, indeed, we no not.

Senator MoNEr. Is not that the proposition?

Mr. KNIGHT. No, sir; the Grout bill only taxes that which is colored.

The Arting Chairuan. Will there be any tax on the pure uncolored oleomargarime moler this bill, as you molerstand it?

Mr. KNigh'T. There will be a guarter of a cent tax, Senator, for this reason. The illea of putting a quarter of a cent fax on the uncolored article is to place it within Govelument restrictions, so that when a man puts up a factory he will le located by this tax and the Government can keep its eye on him.

The Acting CuAIRMAN. I mean apart from that. That is a mere bagatelle. Do you want any substantial tax mpon the nncolored oleomargarine?

Mr. KNIGH'. Oh, no; 110, indeer.

Senator Monfy. Now, I want to ask you this question: Are you willing to insert in this bill a provision that no dairyman shall color his butter"?

Mr. KNigu'l. No, indeed; we are not.

Senator Moner. No; but you are willing that the manuficturer of process butter sliall be restricted there, are rou?

Mr. KNight. No; now, I will explain tlat. That has been brought up here several times.

Senator Monfy. Excuse me: I woull prefer to have you auswer my question.

Mr. KNIGHT. I can not answer it. sir, yes or no; because I have got to explain to you that removated butter is made out of butter which is already colored, either by nature or by the farmer artificially. The manufacturer of renorated lutter, in choosing his stock, has no choice at all in this particular matter. He could not be compellerl to make 
his butter uncolored. He gets yellow butter that is as yellow as any butter that you have ever seen-which has absolutely no artificial coloring matter in it. That is one grade that he gets. Now, you can not make him make that butter white. On the other hand, it is within the province and jurisliction of the oleomargarine manufacturer to make his product of one color the year round.

Senator MoneY. You do not object to the oleomargarine manufacturer coloring his product red, then, when he sends it down to the West Indies?

Mr. KNıGHT. No; he can color it red, just like currant jelly, and it can be put on bread just as people use currant jelly on their bread. We will not object to that at all.

Senator MoNEY. You only object to it when it is colored in competition with your product.

Mr. KNIGHT. That is it exactly.

Senator MoNEY. In other words, you want something done by the United States (xovernment which will put money in your pockets at the expense of some other person?

Mr. KNIGHT. No; we do not. But we want our pockets locked up against the plunder of other people.

Sentator MONEY. Nobody is taking anything out of your pockets.

Mr. KNIGHT. Oh, no!

Senator Money. Now, here is another thing: Suppose I were to introduce a bill, let us say, placing a tax upon butter of 20 cents a pound.

Mr. KNIGITT. Yes.

Senator MONEY. And suppose that bill forbade the coloring of it.

Mr. KNIGHT. Yes.

Senator Money. Aud suppose I taxed oleomargarine 10 cents a pound, as you propose to do in this bill.

Mr. KNIGHT. Yes.

Senator Moner. In other words, suppose I proposed to erush you both out of business in order that the people might be compelled to use a product of cotton-seed oil. What would you think of that?

Mr. KNigrit. I think it would not pass. (Laughter.)

Senator MoNwY. I am not talking about whether it would pass or not. I do not want your opinion abont that. I have my own opinion on that question. But what about the morality of it, and the constitutionality of it, and the justice of it?

Mr. Knign'T. But, Senator, you can not claim that either of those products are imitating your product.

Senator Money. That makes no difference.

Mr. KNIGIT. That is our whole claim here. The best part of our whole claim is that lhis other product is a frumdulent imitacion of ours, and that oleomargarine is being used to displace our product illegiti. mately ancl fraudulently.

Senator MONEY. Does not the first provision of the act suffieiently provide against that? Now, as I understand it-excuse me for arguing with you.

Mr. KNIGHT. That is all right; I am very glad to have you.

Senator MoNer. I am trying to get at the facts of this matter. I have only been here during a part of the hearings, because I have had to be in other places. But in the first place, it seems to be conceded that the manufacturer himself does not deceive anybody.

Mr. KNIGHT. Ob, no!

Senator MoneY. He sells his product as oleomargarine; he never pretends to sell it as butter. Is that so? 
Mr. KNIGH'T. I will tell you. I have two cases right here to which I can refer you, which bear on that subject. I will tell you the trouble about that, Senator. Whenever that is done, it is done in such a way that we cau not get evidence against those manufacturers to connect them with the firaud. But if you will permit me to do so, I will give you a little incident here which I thiuk will eonvince you that possibly the manufacturers are pretty well in sympathy with those who do pass off oleomargarine as butter. That is as close as we can get to it.

Senator Money. That does not meet the point at all.

Mr. KNIGH'. It meets it as nearly as we can meet it.

Senator Mloney. Then you fail to meet that point. The next is

Mr. KNight. Well, what point is it you want me to meet, Senator?

Senator Moner. I want to know where there is any fiand.

Mr. KNIGIT. Yes; and I will show you right here. I did not want to be forced to do this, but I am-

Senator Money. Oh, yes; let us hear the whole truth. Do not hold anything back.

Mr. KNIGH'. I simply did not want to be persoual in this matter, and for that reason I have left out a great many things that might have been said.

Senator Money. You can suppress names if you do not want to be persoual.

Mr. KNIGHT. I hold in my hand here an answer to a complaint which was made by the collector of internal revenue for the first district of Inlinois against the largest manufacturers of oleomargarine in the State, in which they were accused, in twenty counts, of fiaudulent entrythat is to say, of having sent to the collector's office wrong or fictitions names of people who bought oleomargarine. What wis that complaint for? It was for what is known as "covering up" "dealers.

For instance, suppose I am a manufacturer and yon are a licensed dealer. By law I an compelled to report every pound of oleomargarine I sell to you and your post-oflice address. The object of that requirement is to enable the Government to go to you and see that you have the necessary license to sell it, and have paid your tax to sell it. Here comes a man who wants to sell oleomargarine for butter, we will say, or who does not want the Goverument to trace him out and put a tax on him, so that he will be identified, and so that any person can go to the ofice and find out that he is a dealer and watch him.

Senator Fos'l'ER. It is a species of green goorls, is it?

Mr. Kxight. Yes, that is it. Now, instead of his billing the goods to the man he wauts to cover up be bills them to you. You are none the wiser, because those reports are confidential. And this particular matter was brought out in this way, as I understand it: In the city of Aurora, I1l., there was a company folmed, kilown as the Aurora Produce Company. That Aurora Produce Company, as nearly as the internal-revenue collector has been able to find out, sent out broadcast through the country $\$ 140,000$ worth of oleomargarine, with the stamps scratched off, as and for butter. That oleomargarine was sold as butter in New York State. The company sold it by the carload. They sold it to one man in Buffalo, $\mathrm{N}$. Y. The food commissioner became aware of it, and it cost that man $\$ 1, \$ 00$ in fines for buying something innocently, which he supposed to be butter, because it was colored and he could not tell the difference, as it came there in tubs. Another man, up in Milwakee, had to go up and pay a \$ \$SO internal-revenue liceuse as a wholesaler, because he got hold of some of that oleomargarine, thinking it was butter, and bought it innocently, and sold it as butter. But the 
internal-revenue collector went after him, with the result I have stated. I do not know how many more men were traced in that way.

When the man who was the head of this concern was arrested, it was not through the activity of the internal-revenue office, but through the department of agriculture of New York, which sent detectives to Chicago, traeked him down, got evilence against him, and turned him over to the internal-revenue collector. When he was arrested two of his people fled the country and got into Camada, and one of them, before he went, burned his books, and permitted nobody to see anything abont his transactions. The people were absolutely irresponsible, and yet they liad done a business of $\$ 140,000$ within a few months.

When this man was arraigned before Commissioner Mason (who, by the way, is Senator Mason's son) the leading oleomargarine manufacturers of the city of Chicago came and put up bail for him, and kept hin from going to jail. I ean not say that they furnished counsel for that man, for you can not find out from their chesk books who they pay money to for such purposes. But the point I was coming to was that this thing started an investigation (commenced, as I understand it, by the lnternal Revenue Department) for the purpose of finding out where these goods were being shipped by the manufacturers, so that they conld "get on to them," and that investigation led to the lorating of some twenty places where olsomargarine had been shipped by the mannfacturers, without making the proper report.

When that matter was bronght up, and this man was arrested and put under bail, an offer of $\$ 7,500$ was made as a compromise for his case and the twenty eases bronght against this firm for frand. That offer was rejected. The man who was eanght in the act of distributing this oleomargarine was fined $\$ 1,000$. He got off'. 'Two of his other people are over in Canada to-lay, waiting for an opportunity to either come home and be eleared by the people who are back of them or to turn State's evidence.

This conceru, in orler to clear up this matter, offered $\$ 7,500$ to the Internal lievenue Bepartment. The Internal Revenue Department recommended the acceptance of that offer. The collector at Chicago recommended the acceptance of the offer. The Commissioner of Internal Revenue at Washington recommended its acceptance, but AttorueyGeneral Griggs sat down on it. He said: "No; we will try these people, and go to the bottom of the matter."

What is the condition to-day? In ouder to find out what this firm was doing in the way of sending out these goods sur'reptitiously, withont retuling the proper names, the collector of internal revenue (as the law gave him a right to do, as he supposed), lemanded the private books of this concem, alleging in his eomplaint that they had reported fraudulently to him, and had not given him the correct report according to law.

The firm refused to give up the books. They set up the plea that the Government liad no right to the books. The Government insisted. The collector insisted that lie had the right, and he went before Judge Kohlsaat and asked for an order for contempt to bring them into court and compel them to give up the books. They came into eourt and made the plea that they had given everything the Government required, and that the Government had no right to go into their private books further than what they had submitted.

The judge-I think it was Judge Kohlsat, or else the other Federal judge there, Jndge Grosscup-ruled that their plea was not suffieient, and that they must bring those books into court, under the order of 
the Commissioner of Internal Revenue. Here is the reply, the amended answer, of the concern; and I am not going to real names, gentlemen, becanse I do not want to do that. This is the plea which, they set up, and which the judge tinally said excused them firom revealing the secrets of their business so far as the Government had requiled, although they had practically agreed when they went into business to comply with the liovernment's requirements in that respect:

That the allegation of the collector that the returus marle by sairl Braun of Fitts are false and fraululent in that they ilil not, as saill colleetor allegres, trutlifully state the name and place of residenee of each person to whom gonds were sold or consigned, and the allegation of the collector that such charge wonlu be sustained by an exanination of the books for whieh saiul collector askis of this court an oreler for their production, woulu, if the ouder prayed for be granted, compel your respundents to finruish, by their said books so ordered to be prodnced, evidence that might and wonld tend to criminate them and each of them; that these respondents and each of them hereby personaly expressly claim the privilege aml right guaranteed to them by the fifth amendment to the Constitution of the United States, and olject to the order sought for in said petition, or any part thereof, on the ground that anch oriler if granted would compel these responilonts, and each of them, to gives and furnish testimony that would tend to criminate them and each of them.

Now, let me sliow you another case. These people have said a good deal to your commitiee down here about the inspection of the Internal Revenue Department, and about how they are compelled to report every ingredient, and that they are compelled to do this, that, and the other.

As a matter of fact, the present oleoniargarine law can not compel them to do anything that they lo not want to do. Ali that lhey need do is to hide behind their constitntional right, and claim that the evidence called for will incriminate then.

Here is a case which is entitled "In re Kimmey, collector of internalrevenue." The heading is "Examination of books."

W. F. Kinney, eollector of internal reveme, district of Connecticnt, issued a summons, under section 3173, Rerised statutes, against the Oakdale Hanutacturing Company, a corporation engaged in the mamnfactnre of oleomargarine. The parties refused to comply with the summons, and the collector petitioned the Uniter States district judge for an attachuent against $r$. M. Mathewson, president of the company, directed to the United states marslial of the district, commanding him to arrest said Frank M. Mathewson and bring him before the judge to show eanse why he should not be adjulged in contempt and punished according to law, as provided by section 3175 , Reviseil statutes.

In this connection it may be said that this talk about these people being compelled to make a return of the materials and products is all bosh. They can not be made to do it if they do not want to. They make the return if they wish, and if they do not wish they will not do it, and they do not liave to, according to this decision.

The decision of the judge was adverse to the collector. He held that-

The provisions of Revised Statutes, section 3173, anthorizing a collector of internal revenue to summon before him for examination any person charged by the law with the duty of making returns of objects subject to tax, do not apply to persons requiresl minder the oleomargarine law to make returns nt materials and products. Such provisions relate only to olyjects of taxation upon which the tax is collected by the methor of return and assessment, and not to those mon which the tax is required to be paid by a stamp; and a collector has no power under sertion 3173 to compel a person to appear and testify to the correctness of the returns made under the oleomargarime law. (102 leel. Rep., 468.)

The AC'Ting Chairman. Let me ask you a question. I do not want to unnecessarily interrupt you; but do I understand you to say that some Federal judge or court judge held this. answer which you read a moment ago sufficient in response to a writ of at tachwent for contempt? 
Mr. KNight. Yes; he did.

The ACIING CHaIRMAN. Without himself proceeding to examine the evidence, and to determine from the evidence itself whether it was incriminating or not?

Mr. KNigH'T. He did, Mr. Chairman. I will say that the collector has taken an appeal in the case; but it is not known whether the appeal will stand or not under the circumstances.

The AC'ring CHAIRMAx. I should think it ought to stand.

Mr. KNight. The matter is now up in the comrts.

The AC'ING Chairuan. I suppose you understand that the rule in such a case is that the judge himself inust examine the evidence and determine from such examination whether it is ineriminating or not. It is not left to the witmess to determine that.

Mr. KNIGHT. The witness, in this case, made this aflidavit.

The ACTING Chamman. But that is his own rletermination.

Mr. InIGIrT. I understand that from that affidavit the judge decided that there was no futher cause of action.

The Acting Cmairuan. Any man living who is competent to draft an answer in reponse to a writ of attachment for contempt may exculpate himself if the julge can not go any further and examine the evi. flence said to be incriminating.

Senator Mones. That was a Ferleral judge, was it?

Mr. KNigit. That was a Federal judge.

The Actini: Umarman. Such a decision makes the witness instead of the conrt the juclog of the matter.

Mr. KNIGHT. That is true. This matter was before th, Holl. Christian C. Kohlsatt, judge of the Inited States court of America for the northern ristrict of Hlinois. 'That is my understanding of the case, at least-that the judge diıl not examine the evidence at all.

The Acting Onarman. That is the first exception to the rule of which I have ever knowi.

Mr. KNIGHT. Well, you wanted to know something about the manufacturers, Senator. 'That is one case.

Senator MONEY. Now, you have undertaken to give circumstances to prove a case against two manufactnrer's. Do you consider that that is the rule or the exception?

Mr. Kinigit. These two manufacturers, Senator, malie 25 per cent of all the oleomargarine produced in the United States.

Senator Money. They do?

Mr. KNight. They do; yes, sir. I know that to be a fact, as I have seen the records of the Department, which show the amount manufactured by those two concerns.

Mr. Milder. What is your experience with the packers who manufacture butterine?

Mr. KNight. My experience with your concern, Mr. Miller, is that if they were all like you we would never be here. Unfortunately, they are not.

Mr. Miller. Thank you.

Mr. JELKE. If the committee will permit, I would like at this point to rearl a telegram from Collector Coyne, received last night. Statements have been made here before this committee as if it were a court of trial. There are always two sides to a question. I do not care to go into a discussion of detail, but it is sufficient to say that the Internal Revenue Department ought to be ealled on to substantiate everything which has been offererl before this committee. I would suggest, therefore, that the Internal Revenue Department be asked to come here and present their side of this question. 
This telegram from Mr. F. E. Coyue, collector of the first district of Illinois, Clicago, spealis for itself. I clid not care to bring it "l, but Mr. Kuight yesterday made some personal allusions which were entirely uncalled for, I thiuli. (Reading:)

I have ceased to pay any attention to rash statements of Charles Y. Kinight, except to request him to report violations of the oleoulargarine law to my office or the Lnited States district attorney. As he has made no snch report, I take it for granted he bas no evidence, or be is witholding valuable information from the Uniled Statcis fovernment. F. E. Coyne, collector.

Mr. KNigh'T. Gentlemen, I have an answer to that right liere, and I am very glad this point lias been hought out. Mr. Coyne made just exactly that kind of a statenent when I was before the Agricultural Committee of the House. I went home to C'bicago; I went to the office of the Chicago kecord, told them the situation, showed them what Mr. Coyne had sild, and asked them to come out with me. Accorringly, lieporter Harkett was assigned the luty, and with me proceened to the store of Willian Broadwell, which was just a"poss the street from the Record office. He went in and asked for a pound of the best creamery butter, for which he was chargerl 25 cents. When he came out the package was examined, aul turned under the corner, ingenionsly folled to defy detection by the nuwary, was the oleomargarine stam]). A lualf block down another store was visited, the Olio Butter Company, aurl best creamery butter called for here. It was sold for 20 cents at this place, and the packige was wrapped in a purple paper with the oleomargarine stamp stamped thereon in purple ink, which was detected only after a carefiul search for some minutes to locate the outlines. Still anotlıer store, that of Huglıes \& Sullick, was visited in the same block, where 22 cents was charged for "best creamery butter," the stamp on this occasion being concealed by turning the paper over the end of the roll. Mr. Hackett went straight to the oftice of Collector Coyne, iuformed him that he had personally purchased these packages as creamery butter, and exhibited the internal-revenue rulings which such practices violated. In the issue of Saturday, March 17, the Record published the following interview with Mr. Coyne, which corroborates the statements frequently made by the collector of Chicago to me.

Now, this is the statement which Mr. Coyne gave the newspaper reporter right there. I will say, in this comnection, that Mr. Hackett took these packages right up aud asked Mr. Coyne how it was that within a tew blocks of his oftice these violations could have been going on for years, as was reported down at Washington. I read the interview:

Internal Revenne Collector Coyne's attention was called to these violations of the law jesterday and the wrappers exhibited. He said:

"I an always willing to prosecute violators of the revenue laws, and I am glad to have these cases called to my attention. It is untortunate tliat $I$ have to repend on the public for $115 \mathrm{j}$ information, bowever. I have nineteen counties, including Cook, to look after, and the fifteen depnties I am allowed have about 2,000 special taxpayers in their respective listricts. These include hreweries, saloons, cigar dealers and manufacturers, oleomargarine makers and dealers, and many other's. The force is not large enough for me to watch every retailer- 2,000 nen would be requirerl to do that."

The collector of internal revenue told me personally that that was one of his excuses for not enfoleing that law-that it would talie one man to every retailer to see that it was enforced. (Reading:)

\footnotetext{
"Nor can the depnties make cases by purchasing butter or its substitute, for they have no fund for that.

"Whenever a citizen comes to me and tells me of a case of this kind I am always willing to do my duty as the law sets it forth. I have been accused by both sides of
} 
leaning towal the other, but neitler party is right in making these cluarges. If I am called before the agricultnval committee, I slall be glad to tell what I know, and that is more than I can tell the public in my present position. The books of this department are not open to the people, but 1 can assure sou that many violators of the oleomargarine laws have sutfered"

Now, I want to say in this comection that I lave worn the soles oft my shoes going "1p to that collector's office and giving bim evidence of violations of the internal revenue laws. And i will give yoa a case which we took to the supreme court there on mandamns. I lave it right here.

Mr. JELKE. I think Mr. Coyne onght to have an opportmuity to be heard in self defense.

Mr. KNigitT. I lave no doubt that a good many people would like-to be heard here, and it would prolong this hearing until after the th of March; but I will give you the facts right here, and then if .1r. Coyne wants to make a statement, all right.

M. A. Wright, a retail dealer in oleomargarine, sold to myself, in the presence of another witness, a wholesale lot of oleomargarine as butter. Now, in selling that oleomargarine to me as butter, he did not violate any internal-revenue law, becanse the internal-revenue jeople do not care whether it is sold as bntter or not, so long as it is stamped. Ho sold me two 10 jound pails. A retail dealer there is not permitted to sell over 10 pouncls at a sale, with a retail license for which he pays $\$ 40$ a year. He must take ont a license, for which he pays $\$ 480$ a year, in order to be able to sell more than 10 pounds at a time.

These pails were stamped faintly on the bottom, as was the case with many of these packages I have shown, the marks being conceaied.

I took that evidence, anil had a chemical analysis made by Mr. Delafontaine, one of the leading chemists of Chicago-a chemist of forty years' experience. I took that chemical analysis to Coyne, offered him the evidence in the case, sealed the packages up, and put them away for him. Gentlemen, that was in September, 1899. I have never been called on for that evidence yet; and yet there was an opportunity for him to make a case against this man.

There is one specitic case. Then we proceeded agaiust this man in the justice conrt, and tried to do something with lim; but there is one specific case in which I offered that man evidence which was absolutely indisputable, and absolutely no attention whatever was paid to it. Further than that, we have been told, when we go into that interual-revenue collector's office, that the more oleomargarine there is sold, the more revenue the Government gets, aud the higher class the internal-r'evenue officers are.

Senator Dolliver. Now, Mr. Knight, while all this is very interesting, I doubt the propriety of making an attack upon an officer of the United States, of a character which would tend to prolong this investigation.

Mr. Knight. That is true; but I had to do that, Senator, in answer to the telegram which was introduced here.

Senator DoLliver. But I would suggest to the committee the query whether this whole matter is not somewhat immaterial to the question before us?

Mr. KNight. I wonld like to be able to state this, Senator, that the refusal of the interual-revenue collector of the city of Chicago to enforce these laws, and my contimued hammering at him to do it, has made him very sore toward mo, and that fact is exhibited in this telegram. There is no other reason in the world why he should feel that way. 
Senator MoNeY. You would not have any objection to his coming here and making a statement in his own behalf, would you?

Ir. KNight. I would have a great deal of objection to prolonging these hearings any further, if I had anything to say abont it.

Senator MoNer. That is another matter.

Ir. KNight. Ol, certainly; I would have no other objection; no, indeed. But Mr. Jelke's point about telegraphing to Collector Coyne was very poorly taken, becanse I did not meution Collector Coyne's name in the matter at all. When I stated that an offer of $\$ 5,500$ in compromise was made by Mr. Jelke's firm, I stated that my information was from Assistant United States Attorney Clark J. Tisłell, and not from the collector of internal revenue; and I think if you will go to the commissioner of interual revenue in this city, or the courts, or whatever the proper place may be, my statement can be verified.

Mr. JELKE. Mr. Kuight, just permit me to interrupt you for a moment, if you please. I did not take auy notice of what you said yesterday afternoon, except this: I think if you will refer to the record, you will find that you made the statement that there were 2,000 dealers in Chicago who were selling oleomargarine as and for butter. I think the record will show that.

Mr. KNigh'T. That is my opinion, Mr. Jelke; and I do not know any way to prove it except to go out and sample them, and get analyses of what they sell you.

MI. JELKE. If you will investigate the most respectable and responsible dealers in Chicago you will find them haudling oleomargariue as oleomargarine. I refer to the leading merchants of Chicago.

Mr. KNigh's. I do not deny that.

Mr.Jelk . Take the Siegel-Cooper Company, the Boston Store, “ The Fair,", the Rothschilds, Charles H. Schlatt, and others of the best of them.

Mr. KNIGHT. Let me state that if you investigate some of the mannfacturers of oleomargarine you will find that one or tro of them are not upholding this kind of business; but, unfortumately, the majority of them are.

Senator DoLLIVER. The point I endeavored to make was this, that the more contentious personal matter there is introduced here the more interminable this thing will become.

Mr. INIGHT. That is true, Senator, and I will endeavor to avoid it. As you saw just now, I did not, want to bring any names into this matter at all. I endearoled to avoin that.

Mr. JfLke. That is the difficulty-class against class.

Mr. KNight. Now, I want to say a few words on this "class-againstclass" question.

The Actrng Onamman. Oh, I think the committee understands the question of "class against class." We have heard it discusser here time and time again.

Mr. KNIGHT. Bnt here is something that has not been brought ont, Senator; and that is the fuct that the oleomargarine people to-day are largely people who have been butter people in time past. W'hen oleo. margarine first came in it was handled by butter people. Almost erery butter man in the Lnited States handled it. What made thedifference between oleomargarine dealers and butter dealers? When the laws went into effect which malle it mulawful and illegal to handle butterine in the only way that it would be honestly sold, a part of the dealers got out of the business. Those who wanted to comply with the law got out of the business because they conld not remain in it legally. The

$$
\text { s. Rep. } 2043
$$


people who are now the oleomargarine dealers are largely-I will not say all-those who stayed in it notwithstanding the laws.

Now, you have this condition of affairs:

Here is a man who is doing an honest butter business, endeavoring to sell butter in compliance with the law. He is a butter man. He conld just as well sell oleomargarine, bcenuse it all goes to the same trade. The retailers who sell oleomargarine sell butter; and he could just as well sell oleomargarine and make the profit on it that oleomargarine dealers make if he wanted to violate tbe law. What is the condition to-day? He is asking you, as a law-abiding citizen, and a man who will not resort to such practices, to protect him against the man who is willing to take his chances and violate the law in order to make that profit. That is the condition which exists to day, and that is the difference between the oleomargarine man and the butter man.

Mr. Peters. Mr. Knight, will you allow me to ask one question?

Mr. KNIGHT. Certainly.

Mr. PETERs. What objection would you have to liaving oleomargarine put np in square packages, so that anybody conld distinguish it from butter at a glince?

Mr. KNIGHT. I do not think that square packages have anything to do with the distinction. It has been my experience that there is nothing easier in the world than for a man to take ten square packages of 1 pound each, put them in a 10-pound jar", and make "butter" out of them.

Mr. PeTers. That is not the question which I asked. You have not answered it.

Mr. KNIGIIT. My objection is that it is absolutely no bar to fraud. And I can not answer the gentleman any further, because I do not consider that he is an expert in the butter business and in the enforcement of lams.

I want to say liere, gentlemen, that one of our greatest difficulties in trying to do anything with the illicit sale of oleomargarine is the fact that there is a class of hucksters, who were described to you by the gentleman from New York City the other day, who take this oleomargarine, take all the stamps and wrappers off of it, put it in jars, and all kinds of shapes, and take it and sell it around at the houses, or take orders for it. I know I tried to catch one fellow of that class who came to my house. I live in a suburb of Chicago. He came to the house, and offered us butter the year round at 23 or 25 cents a pound. He said that the people whom he represented owned creameries in Iowa, and that fact made it possible for them to sell butter cheaper than anybody else could sell it.

My wife would not buy any, but when I heard of it, I told her, if he came around again the next day, to give him an order for some. I did that expecting to catch the fellow. He came around about a week after that, and she gave him an order. Then I "laid" for the gentleman when he came around to deliver the goods. What did I find? Wben the goods came, they were delivered by an expressman, somebody absolutely not connected with the thing at all, and I could find no one to arrest and prosecute. The expressman came to collect for the stuft, and bronght it $\mathrm{O}$. O. D. He disclaimed any connection with the concern, and I was not able to locate the people at all:

Under such conditions it is absolutely impossible for us to get any kind of legal testimony unless we trace them down, and even then there is no way to do it. 
Senator HANSBROUGH. What was the character of the goods-oleomargarine?

Mr. KNight. Oleomargarine. They went through the whole neighborhood and took orders. They killed the butter trade in the neighborhood absolutely, by claiming that because they had creameries they could sell butter much cheaper than anybody else.

Representative BAILEY. Mr. Chairman, may I ask Mr. Knight a question? IVill Mr. Ińnight tell the committee, in case the Grout bill becones a law and the manufacturer of oleomargarine continues business and pays this tax, where any fraud will be suppressed, and where in any particular the manufacturers can not do just exactly as they are doing now?

Mr. KNigit. Mr. Bailey, I will answer that question as I have answered it a dozen times to you and anybody else.

No man goes out and commits fraud for fun. No man goes and vio. lates our State laws for the fun of violating them. No man riolates the internal-revenue laws for the fun of violating them. He violates them because there is $S$ or 10 cents a pound profit in violating them. With a 10-cent tax on colorect oleomagarine, the profit would go to the Government in case oleomargarine were used. I think that is a full answer, Mr. Congressman.

Representative BAILET. No; the fraud would be perpetrated exactly the same.

Mr. KNight. I do not think people perpetrate fraud for fun.

Just one other point, and I will close, gentlemen.

A great deal has been said to you about the inspection of the Inter. nal-Revenue Department. A gentleman from Ohio was telling you about what rigid inspection and supervision the Government maintained over this oleomalgarine traffic. He told you that inspectors visit their factories and inspect their goods and keep a lookout for the purpose of ascertaining whether there are any deleterious substances in those goods or not. It has been attempted in that way to lead you into a belief that the industry is really under Government supervision, in spite of the fact that the manufacturers refuse to report the mate. rials they use when they are called on, as shown by this case up in Rhode Island.

There are, in the United States, over 9,500 dealers, I believe, and 30 manufacturers of oleomargarine. The report of the Commissioner of Internal Revenue for the year 1!00, which I hold here, shows that during the year 1900 the chemical department of that bureau made 177 analyses. You can figure the proportion 177 bears to nearly 10,000. That will show you how many times a year they get around to these retailers and inspect their goods, and inspect the wholesalers, and inspect the factories.

There has been an attempt here to make it appear that the manufacture of this product is really under Government inspection, when the Government absolutely cares about nothing except to get the rev. enue out of it. That is all the Internal-Revenue Department cares for in any place. It is not a police department; it is not a pure-food department, and you can not make that out of it.

There is where the trouble has been-in the attempt to compel the Internal Revenue Department to enforce a provision of the la r relating to the stamping and brauling, which is absolutely apart from its business. As (Jommissioner Wilson said before the House committee, they enforce the law from a revenue standpoiut, not from a pure-food standpoint. 
Senator Moner. Would it not be worse then? They would not be so anxious to make money out of it, would they?

Mr. KNIGHT. Commissioner Wilson himself states, and it is in the testimony here, that he had no fear but what the tax part of it would be enforced if they made the tax 10 cents a yound.

Senator MoNEY. In other words, they would be divested of the desire to make money out of it by increasing the tax?

Mr. KNight. Let me tell you, in answer to that, that the fraud in oleomargarine is not inspired by the desire to evade the tax, but by the desire to get a price like that of butter-to get the butter price. There is where the fraud comes in.

Representative BAILEY. Now, following out that same argument, would they not be compelled to sell it as butter if they harl to pay this 10-cent tax? Would you not compel the retailer to sell it as butter by virtue of that fact?

Mr. KNIGH'. There is no incentive in any man to sell oleomargarine as butter muless there is a profit in it-that unless it is better than butter; and if it is better than butter it can go on its own merits.

liepresentative BAILEY. If you take the price to-day and add 10 cents a pound $10 \mathrm{it}$, and make the manufacturer or dealer pay that extra 10 cents, you will compel him to sell the product as butter. That would still leave the frand unrestricted.

Mr. KNight. No; there would be $S$ cents a pound less profit in the transaction if he did it, and that is a good deal.

Now, Senator, I will leave these books here, showing you the downward trend of prices of butter during the last ten years, and with that I shall close.

The dCTing Chairnax. It strikes me, before going any further, that a time limit ought to be set here, and that we ought to determine whell these hearings shall close.

Senator Moner. Mr. Chairman, I want to say that I had an muderstanding with the rhairman of the committee that there would be no action of that sort taken mutil Senator Warren came back from Boston. There is mobody here to day but myself in oppposition to this course.

The Acring Chatrian. When will he be here, Senator?

Senator Monwr. He is to speak to 11 ight to the Boston Wool Manufacturers' Association, and he will certainly be here by Monday. I do not think he could possibly be here by to-morrow. He asked me particularly to see about this matter, and at his reguest I suggested to the chairman of the committee that no executive business of that sort be transacted mutil his return.

The ACTING CIIARMAN. Of course, it is evident to anybody that whatever the report of this committee may be, pro or con, if the bill is to be acted mpon at this session of Congress it must be reported upon within a reasonable time.

Senator MoNEr. Well, we can not put out of joint any of the appropriation bills, which are coming up right along, so far as that is concerned; so a week more would not make a bit of difference in that respect.

The ACTING CHAIRMAN. I formed no opinion thus far upon the merits of this bill, and shall form none until the hearings are conchuded. But it is due to all parties, in my judgment, that we report upon the measure as speedily as we can conveniently do.

Senator Moner. Now, I am going to make a motion, Mr. Chairman. That motion is that Mr. Coyme be invited to appear here as speedily as possible-say next Monday. If he has anything to say in reply to 
the remarks of the gentleman this morning, I think he should be given an opportunity to be heard.

The Acting CHAIRuAN. Is there ang objection to that, gentlemen?

Senator HaNsBrotgh. Why, Mr. Chairman, if we are going into matters of that kind, there have been accusations made here which would bring a hundred people to this Capitol in order to present the other side of these matters and dispute accusations mhich have been made. I think Mr. Coyne's telegram states everything that he can say.

Senator DoLliver. I beliere that his settlement should be with the Treasury Department rather than with us, anyhow.

Senator MoNer. The point is just this: You are asking for testimony upon certain points which seem to be considered important by some people. I do not consider them so. They are of no importance whatever to me. Une side of this matter, however, has been heard. The question now is, Are yon willing to hear the other side or not? Are you willing to hear rebuttal?

Senator DoLliver. Senator, no reference was made to Mr. Corne, as I understand it, until the gentleman who had a telegram from him here to day read it, disparaging the statements made by the witness and the witness himself; whereupon hereplied. I cautioned him against contiuning the personal controversy. I think it would be an endless matter if we allowed it to continue.

Senator Moner. If the committee does not want to hear him, if it wants to prevent his being heard by a vote of the majority, that is all right. But I want to ask the committee if it will not instruct the stenographer to send the remarks of Mrr. Knight by mail this evening to Chicago to Mr. Coyne, and ask lim to make a reply, to be submitted as part of the evidence? Nobody is under oath here.

'The Acting Chairian. I suppose he could send a résumé of Mr. Knight's statement. Mr. Knight, however, has been talking here for two or three days. He could hardly transcribe his notes of his entire remarks in time to do what you suggest. I suppose the clerk conld send a résumé of what has been said this morning.

Senator MoNEY. I only mean that part where he referred to $\mathrm{Mr}$. Coyne this morning.

Mr. KNight. Mr. Chairman, may I make a suggestion? Inasmuch as they seem to want some specific instance of where they have been offered evidence and have refused to present it. I will state that the case of M. A. Wright ( $\mathrm{I}$ think that is the name) is a matter of the kind. The Acting Chairuan. The case involving the two tubs of butter? Mr. KNight. Yes; I will give you the name, so that you can have it. The Acting Chairman. 'That is a part of what you said about Mr. Coyne?

Mr. Knight. Yes: that is specific.

The Acing Chairmax. Then, Mr. Reporter, the extract fiom the proceedings to be sent to Mr. Coyne will embrace this precise state. ment about these two tubs of butter, as you have it there.

Mr. KnigitT. No; I beg your pardon. That is the wrong case. The case abont which I luve been speaking here to day is not the case me carried to the Smpreme Court; it was another case. We have had so many of those cases that it is difficult for me to remember them all. I canl look it up.

The Acting Charriras. But it is the one that embraces these tro tubs of oleomargarine you speak of?

Mr. KNIGHT. Yes, sir; that was a clear violation of the law. 
Senator Money. I do not doubt that every law which was erer passed is violated every day by somebody. But when a specific charge is made against a man charged officially with collecting revenne, to the effect that he does not enforce the law at all, I think he ought to be given an opportunity to be heard in self-defense. If the committee does not want him to come here then I think the charge that is made against him onght to be sent to him at once, and, as it is not a very lengthy one, I suggest that it be telegraphed to him muder the frank of the Senate.

Mr. KNIGHT. Then, if that is to be done, I onght to give finl details here, so that there will be no mismulerstanding.

Senator IIansbrough. Senator IIoney, I observe by the telegrain sent by Mr. Coyne that lie says that he lias "long since ceased to pay auy attention" to what Mr. Kuight says. Do you think he would respond to a message of the lind you propose sending?

Senator MoneY. That is not the point at all. I want to hear what he has to say. I do not eare whether lie wants to come or not.

Senator DOLLIVER. Do you regard it as material here, or merely as a matter of justice to him?

Senator Moner. No; I regard it as somewhat material to the case here. A charge is made here that this stuff is sold all over the city of Chicago, and that the revenue officials do nothing at all abont it, and will not bring the cases before the judges, becanse they can make more money ont of them in fees.

Mr. KNight. Why, gentlemen, I conld bring you 50 witnesses who have taken eases of violations of the law to him

Senator Moner. I simply want this man to liave a chance. He may or may not be an honest oflicial. I do not know any thing abont him. I never heard of him before, personally.

The Acting Chairian. It seems to me this is altogether a collateral issue.

Senator Money. It makes no difference whether it is or not. It is an important issue.

Senator Hansmeougir. I understand the committee has decided to send this charge to lim.

The ACTING Crramian. Certainly; the reporter will do that.

Mr. KNight. Now, Mr. Chairman, if this matter is to be taken up specitically, if you are going into it, I slonld give you the exact details of the affair, so that $M 1$. Coyne will understand what I mean.

Mr. ADAns. Mlr. Chairman, with the consent of the committee and of Mr. Kuight I would like to make a suggestion with reference to this matter of the internal-revenne collector of Chicago. It may not meet with Mr. Knight's approval, and it may be presumptuous in me to sug. gest, it to this committee; but with consent, I would like to do it. It seems to me to be a reasonable solntion of this matter. Have I the consent of the committee?

The Acting Chambian. Go alead.

Senator HANsBrovgr. What is the suggestion"?

Mr. ADAMS. I will give it.

Senator 11 oney, in the course of the witness's testimony, calls upon him for explicit evidence as to violations of the law. In the course of his general answer to that question, properly made, properly answered, a gentleman here representing the oleomargarine interests introdnces a telegram, as the Senator has indicated, criticizing Mr. Knight, substantially; and in self-defense he makes reply, and brings ont a statement of facts of the correctuess of which he is no doubt thoroughly convincerl. 
Now, that excites some feeling among our friends upon the other side. But I want to say to Mr. Inight and to this committee that we do not base our ease before this committee or before Congress 1 pon any particular act of a single Federal ofticial, lowever discreditable it may have been. The case which we are endeavoring to establish before this committee is simply this-and we have provel it; I will not take the time to recite the proof-that this business of selling oleomargarine, colored in imitation of butter, is permeated with frand at some stage or other of the proceedings. it is not vital to this case that a single instance like this should go into the record. And I will ask Mr. Knight's consent, and that of the gentleman on the other side and of the com. mittee, to strike ont of the record everything which relates to the internal-revenne collector of Chicago.

Senator HANsBrough. I think myself that the record onght to be elited with a great big blue pencil.

The Aoting Chamman. It must be, or it will make a volume bigger than this desk.

Senator Money. Mr. Chairman, here is Mr. MacNamee. representing the Confederated Labor Union of Columbus, Ohio, who wants to make about ten minntes' remarks.

The Acting СHarmas. We have heard him, but I think we will lear him agaiu.

Before he begins, however, do yon insist, Senator Money, upon this matter being telegraphed to Mr. Coyne?

Senator MoNEY. Oh, no; not if the whole matter is to be striclien out of the record, although the impression will be left upon the winds of the committee.

The Acting Chairian. And do the gentlemen who have made these statements conseut that they shall go out altogether?

Senator Monwr. I believe, Senator, that I will insist, if you please, upon this statemeut being sent to Mr. Coyne. Then we can take the liberty of striking them looth out of the record if we choose to clo it.

The Acting Cinarinan. Tery well.

Mr. KNigir'. Senator, I will appeal to the committee to sustain me in the statement that I did not bring these things in voluntarily.

The Acting CHAIRMAN. The record shows that.

Mr. KNigur. Aud so far as I am concerued, I am willing that they should be stricken out.

The Acting Chamian. Now, what futher are we to do this moru. ing, gentlemen?

Senator HANsmRoUgH. I think it would be a good idea to adjourn.

I would like to ask now who desires to be heard this afternoon?

Senator MonEr. I'retty nearly all of the g'entlemen who havo appeared thus far have talked indiscriminately; but I should like to suggest to the committee that on Momday I shall more to close these hearings by Wednesday.

The Acting Craminan. By the following Wednesday?

Senator Moner. By the following Weduesday.

Senator HANsBrotgil. Oh, I think that is too long a time.

The ACring CHAIRuAN. Very well; then I will make this sllggestion, and I want Senator Money to heal it, that if we can get a finll committee or a majority of the committee here this aftermon I shall move to close these hearings by Monday night.

Senator Moner. You can not get the full committec lere, that is cer. tain, because Senator Warren will not be here.

The ACTING Cmanman. Well, if we can get a majority of them here. 
Senator Moner. I will try to be here, although I am attempting to keep up with the Army bill at the same time.

The ACTING CHAIRIIAN. I shall make the motinn, then. I think the hearings onght to be closed and the report, whatever it may be, made.

Senator MoNET. Well, gentlemen, I do not think you are going to facilitate business by taking this sort of course. I do not want to be dilatory, but I do want fair play. If you are going to take adrantage of your majority to press us to a conclusion here, when other men want to he heard, aud when members of the committee who are absent especially request that the thing be delayed for a day or two -

Senator DoLLIVER. There will be no difliculty about that, Senator. Semator ITarren can be cointed as present.

The ACTING CHAIRIAN. The evilence is altogether cumulative $110 \%$.

Senator Moner. That may be true, too. I do not know abont it, however. Nobody can say that positively. They donot know what uew matter may be sprung at any time. But I rant to ask that this gentleman [Mr. McNamee] be heard tor a few minutes before we adjourn. He is a representative of the l,boring people.

The ACting Cuarrman. Go ou, Mr. MeNamee.

Senator Moner. And he simply wants to reply to certain strictures made upon him by a tormer spealier.

The ACring CHaIrman. Let it be mulerstood, however, that there must be nothing in the ray of persomalities here.

Senator Moxer. No new matter; he simply wishes to reply.

\section{ADDITIONAL STATEMEUT OF JOHN O. MCNAMEE, OF COLUMBUS, OHIO.}

Mr. MCNAMEE. Mr. Chairman and gentlemen: I simply desire to submit this as my reply to the remarks of Mr. Kinight last night.

It would be a very great hardship upon me to be compelled to stay here any longer, as I must transact this afteruoon some private business, which I have come to Washington to look after, and be gone to-morrow morning. I have no personal feeling toward any gentlemau who has been conmected with either side of this controversy. As for Mr. Knight, personally, I think that he is, muder normal circumstances, a good fellow, and if it were in my power to do him a favor I would gladly do it. But I have a duty to perform and I must perform it.

I desire to take exception to Mr. Knight's method of designating my representative power. He has, in referring to me, used the expression, "the gentleman who represents himself as representing organized labor."

Permit me to panse to say that I will not submit to any questions, that I will submit this as my answer, aud then go. This will be positively my last appearance before this committee at this session.

The crelentials which I bear, gentlemen, from the Columbus Trades and Labor Assembly, bearing the seal of that organization and the signatmres of its officers, should, I thiuk, be sufficiently authentic to shield me from implied imputations of that nature on the part of even those gentlemen interested in the destruction of the interests that I have been instructed by my constituents to protect. I would, therefore, request that this reference to my representing myself to represent organized labor be stricken from the record, as my credentials alone make such representation. Mr. Kuight clains that there are but 28 labol organizations which have taken action against the Gront bill. I 
desire to i:mpress upon you, gentlemen, that some of the organizations included in that number, even though Mr. Knight be correct in his estimate, represent in turu hundreds of subordinate organizations affiliated with them, the membership of which will go into the hundreals of thonsands. They are what is known in the labor world as eentral bodies, and although it has been now some months since these resolutions were adopted by them, and although the delegates of which they are com. posed have reported back to their various suborgauizations, the fact that those resolntions were adopted, we have yet to hear the first protest against or objection to sueh adoption of such resolutions on the part of any of the hundrerls of local or subordinate organizations which constitute such central bodies. What, I ask you, eonld be more evidential of eomplete aeruiescence?

Regarding the statement the gentleman makes relative to the Chicago Federation of Labor having in 1897 adopted certain resolutions condemning the colnring of oleomargarine, I desire to say that Mr. Knight has aeknowledged that sueb action was taken as a result of his representations to two nembers of the legislative committee of that body, who in tnrn conveyed to their fellow-members the information imparted by himself. This is by his own aeknowledgment the only enlightenment those gentlemen had on the subject. It is ericlent from the resolution atlonted by the same body on March 1, 1901), more than three years later, and which I herewith submit, that as a result of full aud complete investigation they have discovered that the representations of Mr. Knight were incorrect, and bave not only resciuded their former aetion, but in the most vigorous terms, and speaking ont boldly and elearly for all they represent (and that means thousands and thousands of workingmen-workingmen who by their aftiliation with organizations instituter for the protection of their rights and interests have demonstrated their possession of a high standard of intelligence and the fact that they are fully alive to a rigid observance of nature's first law-that of self preservation) protest in the most vigorous terms against the legislative jerseention and destruction of the legitimate industry, manufacturing butterine.

The following is a colly of those resolutions:

Hon. Willian MCALEer.

Cuicago, March 21. 1900.

DEAR SIR: The following resolntions were nuaninonsly adopted by the Chicago Federation of Labor at regular meeting, suudar, Feluruary 4, and I was instructed to forward a copy of same to yon:

Whereas the Chicago Fedriation of Labor is deeply interested in and desires to eneonrage every legitmate industry which furnishes employment to the laboring classes ; and

Whereas efforts are being attempted br eontemplated legislation at Washingtou to destroy the minnfincture and sale of butterine, therehy displacing large numbers of the industrial element and preventing them from gaining a livelihond as well as the use of an article of food which has received the highest testimonials of every chemint in this country aud the indorsement of every standird work that treats on the subject of by giene; and

Whicreas we beifere the eftorts to place a tax of 10 cents per pound on coloced butteriue is inspired by selfisl motives, so that the manufacturers of butter may charge an unreasonable price for their commonlity and unale the large rramerios to establish surely and securely a butter trust which nay raise prices ats their cupidity may dictate; and

Wh reas justice demanuls eanal rights for both mannfacturers of butter and but. terine, hoth prolucts having equal merit; any adverse legislation agaillst either must be coudemmerl; and

Whereas the late pullished reports furnished to Cougress lis the Secretary of the Treasury proves the legitimate and growing lemand for butterine and discloses the large amount of revenue deriven therefrom; and 
Thereas we believe that the present Federal law taxing bntteriue 2 cents per ponnd and the additional regulations imposed by the Commissioner of Internal Kevenue aresufficient to properly regulate the maunfacture and sale of butterine; therefore be it

Piesolved, That we, the reprosentatives of the industrial classes in Chicago, and voicing as we know we do the sentiments of the merbanic and the laborer throughout the country, protest against the passage of the 'Tawney, Gront, or any other bills that have for their object the further increase of tax or the relewating to the different States the right to enact laws that are opposed to the interests of the people and in no way in harmony with the iuventive and progressive spirit of the age; and bo it further

Resolved, That we instruct our secretaly to have sufficient copies of these resolutions printed that one he mailed to every Senator and Congressman in Washington and one to each of the labor organizations affiliated with the Fecleration of Labor, requesting them to iudorse same or pass others of a similar character, so that a full expression of our conclemnation of sneb legislation may he made known.

Respoctfully submitted.

\section{WaLTER CARMOIYY, secretary Chicago Fideration of Labor.}

Mr. Knight has intimated that my presence bere has been influenced by gentlemen representing the butterine interests. This statement I most empluatically deny. Were my presence in Waslington or before this committee (lependent npon any financial assist:nce, past, present, or prospective, given or promised me by or upon the generosity of the gentlemen here or elsewhere, or any other person representing direetly or indireetly any butterine industry in any part of the United States or of the world, I assure you gentlemen, I would not yet, were I depend. ent upon such assistance in coming here, l would not yet, I say, have been able to cross the eastern corporation line of my home city of Columbus, Ohio. I eame here a perfect stranger to all of these men. They did not know me. They did not know of my enming, nor were they, as far as I know, aware of the fact that any action had been taken in this connection by our body. Having been instructed and empowered by the organizations I represent to oppose, in their name and in their behalf, the passage of the Gront bill to the fullest extent of my ability, for the reasons as expressed in my credentials, I propose to demonstrate to them that the conficlence they have reposed in me is fully justifiable, and to carry out their wishes and their instructions to the letter. That and that only, together with my own instinetive sense of justice and right, is the motive which actuates my present course in this connection.

Another central labor organization, representing in turn hundreds of eubordinate organizations which has taken action against the Grout bill, and taken such action unammonsly, is the Onio Federation of Labor. I refer to the action of this body particularly because its protest is not, as far as I can learn, on file here. Now, gentlemen, I desire to say that the first intimation that I have had of the fact that said federation had adopted resolutions condemuing the Grout bill was when the delegate representing the Columbus Trudes and Labor Assembly at the convention of said Ohio Federation of Labor, held in Newark, Ohio, last November, reported that fact to a subsequent meeting of said Columbus Trades and Labor Assembly as part of his official report to said body. I was not present at the Ohio Federation of Labor when this resolution was presented, and never knew that such a conrse was contemplated, but now regard it as a matter of course that said bill, together with all unjust leyislation which aflects the interests of wage-earners, should receive, as it is receiving, general condemnation by all such central bodies and organizations. I would be safe in saying that my present opposition to this Grout bill is representative not 
only of the sentiment of organized labor in the premises, but of that prevalent generally among our mban citizens. Speaking particularly for Columbus, Ohio, I will say, and withont the slightest fear of successful contradiction or contraversion, that such sentiment is general from our wealthiest and most representative eitizen, the retired or active business man, to the very humblest and poorest. The fict of the matter is, gentlemen, that this present contention las resolved itself into an attack upon urban rights by rural influences, as manipulated and (lirected by the collective intelligence, experience, and designing capacity at present identified with the operation of creamery concerns, on one hand, and the tirm determination on the part of the men representing such urbau rights to defend themselves against such persecution and unjustifiable invasion of their constitutional rights.

It speaks badly tor the merit of the contention being macle by the gentlemen at present engaged in attacking the butterine industry that some of them should be compelled, as a leatmre of their effort, to resort to reprisal by way of making an attack on labor legislation, as some of them have to me personally threatened they rould do. They propose to have the Senators. Whom they seemingly profess to own anil operate by right and virtue of their connection (whatever its nature) with agricultural infiuences, oppose all labor legislation which may liereafter be introduced in the United States Senate. We fear not such threats, and defy these gentlemen, or any others, to put them into operation. Wo have too much contidence in that sense of independence, prudence, and justice which characterizes the United States Senator to believe that any one of such Senators would lend himself to these gentlemen, or any other men or set of men, for the sheer purpose of gratifying a desire for revenge, or of satiating or attempting to satiate or gratify that narrow-minded and un-American sense of intolerance, prejudice, and brow-beating tyranny which has characterized every action, expension, and argument of the supporters of this measure in their efforts to secure its passage, based as it is, and as they know it to be, npon a childish, seuseless, miserable, contemptible, threadbare, and transparent subterfuge.

We have no quarrel with agricultural Senators or agrienltural interests. We are simply endeavoring to protect ourselves from the evils sure to result from the complete formation of the creamery monopoly, the foundation of which is already laid upon the anticipated strangulation of the infant industry producing oleomargarine. Should such strangulation be successfully effected, said creamery monopoly will establish itself as the Standard Oil Company is at present established. They will own little creameries located in every village, and within easy access to all farmers of our country, to which said farmers will deliver their milk just as the Standarl Oil Company at present secures its oil. Sair creamery monopoly will regnlate to its own suiting the selling price of butter, and to the farmer's sorrow the purchasing price of milk. They will alopt the methods in general use by monopolies to destroy other competitors if they succeed in utilizing the United States Congress in destroying the oleomargarine industry, and the result will be that the citizens of the United States will have the pleasure of paying 55 or 60 cents per pound for butter, or going withont it altogether. It will be the same old story of our citizens paying tribute to monopoly, vainly endeavoring to satiate monopolistic cupidity, which as we all linow is insatiable and merciless. We recognize, and if necessary will defend the rights of the farmers, but we do not propose to have the farmer trample upon the rights of the manufacturer at our expense if we can 
prevent it. We happen to have interests ourselves, and when they are attacked we propose to devote organized effort to their protection. I beg to sulmit in conclusion one of the great number of resolutious adopted by labor organizations, viz, that of the Cleveland Bnilding Trades Council, a central body representing over 6,000 Clereland workingmen.

\section{Building Tranes Courcil,}

Clereland, Ohio, April 27, 1900.

Dear Sin: The Builling Trades Conncil, of Cleveland, Ohio, and vicinity, representing over 5,000 mochanies, has by unanimons vote indorsed the action of the Chicago Ferlerition of Labor and all the other lab or organizations who are so doing in opposing the persecntion of the batterme industry.

We cam not see any justification in placing a larger or, in fuct, any tax on butterine or oleonarmarine. The article is sold on its merits, and it wonld rather hurt than help its sale to attempt to sell it for batter, as it is more popular and generally regarled as in re healthy than butter. Ans of our people that may not want butterine can, while it is on the mariset, bay butter at a reasouable price, but if the attempt to kill it by lerislation is successful, the butter manufucturers will have no competitors, and the result will be that the present butter trust will absorib the bntter iulnstry and control the purchase of milk by haring little creameries in every farming locality on the plin of The Standard Oil Companf, aud we will have tho pleisure of 5 ) or 60 cents per pound for butter, or going without it altugether, the chances lieing in firor of the latter.

We feel that as butterine is demanded and sold for what it is, and as the linws regnlating its mannfacture and sale are operating successfully in preventing its adulteration, that the legislative budies of our conntry have gme as fir as they have any right to go, and that further interference on their part is persecution and in tended to alvance private interests at the expense of the rights of the people.

There is, muloubterlly, political motives behiul all this.

There are a hundreil difierent eases in which legislative vigilance could protect the people from alulterated foods where such yigilance is a it exercised, of if in any remote way ever applied it is unt being taken alvantage of by the ofticials supposed to enforce it; and why? simply hecanse the mann facturers of arlulteraterl foorls or the beneficiaries of their existence have no inthential eompetitor's to be served by thenr suppression.

Butterine hats been the victin of legislative attacks for a number of years, and we feel it is now time to let up on it and devote the effort wasted in the persecntion of this legitimate inlustry to some more worthy canse in the protection of the real interests of the people.

There is an old saying that "He who is bent on an eril deed is never lacking for an excnse," and it is certainly applicable in this case, the exclnse being that it is wrong to color bitterine hecanse it is likely to be sold as bntter, whereas, in fact, owing tu the extreme popularit,y of the former, there is more liability of an attempt being male by some bntter munfacturer to initate it, and the only reason why an attempt is made to prevent the use of the material in butterine imparting color to it is to hurt its sale, as it has been proven this material is perfoctly healthy. And where is the justice of prohibitiug its use simply becanse it helps the sale of an lionest product?

As long is the poople want butterine and it is good to use, as the Goverument chemists have proven, why should it be abolished? "Ve can not see that there is neerl to siy more. Yon ean not but see the rank injustice of this whole business, and we would, therefore, earnestly request, in the name of common American justice, that yon would strennonsly oppose and exert every means in your power to defeat all such legislation.

This letter has the hearty indorsement of our body, and as a testiınony of which it bears our seal.

$$
\begin{gathered}
\text { IV. C. Davis, } \\
\text { President. } \\
\text { Graxt Morgas, } \\
\text { Secretary. }
\end{gathered}
$$

Seuator Moner. Are you a member of the Knights of Labor?

Mr. MCNAMEE. No, sir; I am vice-president of the Columbus Trades and Labor Assembly. That assembly is affiliated-

Senator MoNEr. Do you know how the Knights of Labor stand on this question?

Mr. MIN NMEF. Well, the Knights of Labor and the Federation of Labor are two different bodies. 
Senator Moner. Then you do not know as to how they stand?

Mr. MiNAMEE. As to the Ínights of Labor I will say that they are intermingled all through the labor world the same as the other labor organizations. Now, the Kinights of Labor are a general body with mhich smaller organizations are affiliated; but I will say that it has been my discovery, wherever I have heard this matter discussed in the ranks of organized labor, or amongst wage eurners at all, that they are absolutely and emphatically in favor of retaining the oleomargarine industry in competition with the butter industry, because they see, and they are absolutely honest in contendiug, that if the oleomargarine industry is at present crushed out (as it will be if this Grout bill is passed), a monster in the form of a monopolistic octopus will arise and gather in all muler its protecting care-the butter industries of the United States.

I care not how extensive they may be. Look at the Standarl Oil Company. It has monopolized the oil industry of the world. And it will not be long before we will have a "Standard Butter Company" which will be stronger than the United States Government.

Senator DoLLIVER. I noticed that the Standard Butterine Company is about to be established here in Washington, with a capital of $\$ 1,000$, 000. That looks threatening.

Mr. MoNAnEE. But they have permanent competitors in the form of certain creamery institutions.

Senator DoLLIVER. Did you hear the testimony of the gentleman who stated something here about oleomargarine being sold in this city for butter, at the price of butter? What would the workingmen think of a situation like that?

Mr. IICNAMEE. Sold for butter?

Senator DoLliver. Yes. What would the workingman think if he went to buy butter, and paid a butter price, and got oleomargarine?

Mr. NCNA.rik. Well, I will tell you, Senator. If our present city and State and district governments are not powerful enough to enforce the laws as they exist, they ought to go out of business.

Senator DoLliver. But, ny friend, the chairman of the committee was telling me that he caught a little oleomargarine on his butter plate this morning. at his hotel.

Mr. McNAnEE. Where?

Senator Dolliver. In this town. He was not looking for it.

Senator MIONEY. Did he have a testing apparatus?

Senator DoLLIVER. He has had a great rleal of experience.

Senator MlonEY. What gentleman was that?

Senator DoLLIVER. I refer to Senator Allen, the chairman of the conmittee, here.

Senator ALLFN (the acting chairman). I discovered that I had been eating it all winter.

Senator Dolliver. And he had been paying for butter. Now, suppose the rorkingman got into that situation?

Senator MonEY. Well, if Senator Allen could not tell it by the taste, the effect, or anything else-__ [Laughter.]

Mr. MCA A IIEE. Senator, I mant to tell you a little story. I hare got an old German mother-in-law, who is as bitterly prejudiced against butterine as she is against the average suake. She loes not want any of it near her. She will not use it, and will not have anything to do with it. I myself continually use the prorluct of the Capital City Dairy Company, in Columbus, as do a majority of Columbus citizens. My mother-in-law was telling my wife about the man who came around to 
her house, and who had such lovely butter, and all that. My wife said: "Well, I don't know that that butter is any better than ours;" and when my mother.in.law would come over occasionally and have a meal with us, she would eat some of the butter that we had. My wife did not detail to her the fact that it was butterine. After quite a length of time the old lady said: "Carrie, that is good butter that you have got. I don't know but what it is as good as mine." "Well, mamma," said she, "that isn't butter; it is the butterine you hate so much." [Laughter.]

Senator DoLLIVER. Do you regard that as a fair deal with the old lady? [Laughter.]

Mr. MCNAMEE. Well, I will tell you, Senator. I don't know how fair it may lave been to my mother-inllaw; but I do know that it is a demonstration of the fact that after all there is not much of any difference between butter and butterine. Now, if one is as nutritious as the other, and one exists as a competitor of the other, to keep these big monopolies from cornering the butter market, why not let them both aloue?

Senator Moner. Senator Allen's testimony stands for all that. ITe ate it all the winter and did not know the difference.

I want to ask a question. The secretary of the Knights of Labor has told me that his organization was very much opposed to this bill. They want butterine and oleomargarine, if they choose to buy them. Doyou know auy thing about any resolutions passed by that organization?

Mr. MoNAMEE. The Knights of Labor?

Senator MoneY. Yes.

Mr. MCNAMEE. No, Senator. I simply refer to the Ohio Federation of Labor. But it is a sentiment that is instinctive with labor all over the country-everywhere. It is instinctive.

(The committee thereupon took a recess until $2.30 \mathrm{p} . \mathrm{m}$.)

At the expiration of the recess the committee resumed its session.

The Acting Chairman (Senator Hansbrough). The committeo will come to order.

Senator Allen. There has been considerable diseussion here about "oleo oil." Will some one of the gentlemen present tell us what it is?

Mr. Miller. Oleo oil is made from the caul fat of the beef. When a steer is killed it is eut open and this fat is taken off-this yellow fat that lies under the stomach of the steer.

Senator Allen. About low much of that fat do you get from the steer?

Mr. MIrLer. We get about 40 pounds from the steer. That fat is put into water that is partially chilled by ice. It stays in there until the animal heat is elimimated. Then it is thoroughly washed. Then it is put in tanks and heated to a temperature of about $155^{\circ}$ to $160^{\circ}$ Fahr. enheit. Then they take a cloth about the size of a large towel, and it is put in that cloth. Each side of the cloth is thrown over this way [indicating]. Between each two eloths, of course, there is a sheet of tin. Then it is put in a large press and pressed, and the oil comes out. That is oleo oil, and the residue is stearin. The stearin is not used in the mannfacture of butterine, but it is used with oils, wax, and various other things. While Professor Wiley said there was stearin in butterine, that is true; but it is the body of all oil. Take a bottle of cotton-seed oil and let it stand until to morrow morning, and there will be a lot of sediment at the bottom; that sediment is nothing but the stearin.

Senator HansBrougr. Where does paraffin come from? 
Mr. Miller. That is a by-product of petroleum. That is not used in the mannfacture of butterine at all.

Senator ALLEN. What are the other ingredients?

Mr. Miller. Nentral is made from the leaf larl of the hog. We get about $s$ pounds of that to the hog. That is churned together with refiner cotton-seed oil.

Senator DoLLiver. What is the average product of oleo oil to the steer?

Mr. Miller. About 40 ponnds we get.

Senator DOLLIVER. How many steers are slanghtered annually in the United States from which this fat is taken?

Mr. MILLER. I think it has been stated here by the cattle people that it is about $5,000,000$.

Senator DOLLIVER. Is that a correct statement?

Mr. MILler. I judge it is.

Senator Allen. How is oleo oil made?

Mr. MILLER. The oil expressel from the fat is churued together with cream and salt and the coloring.

Senator Dolurver. What is the annual export of oleo oil from the United States?

Mr. MILLER. I think in the neighborhood of $140,000,000$ pounds.

Senator DoLliver. And what is the annual product of oleo oil entering into the mannfacture of oleomargarine?

Mr. MILLER. I think it is about $30,000,000$ pounds of nentral and $26,000,000$ pounds of oleo oil.

Senator DoLliver. So that the aggregate product of oleo oil you think would be about $16: 5,000,000$ pounds?

Mr. Miller. That is right.

Senator HANSBRoUGII. What is the proportion of cotton-seed oil used?

Mr. Miller. It varies at different times iu the year. Sometimes we use 15 per cent and at other times 20 or 25 per cent.

Senator ALLEN. Let 100 represent a pound of oleomargarine of fair grade; what are the percentages of the different ingredients?

Mr. Mrller. Of course it varies. All of the manufacturers have different formulas, and again they vary at different times in the year.

It wonld average, I should say, about 30 per cent neutral, 20 per cent cotton seed oil, and the balance butter, cream, salt, and coloring. The statement was made by the Secretary of the Treasury last year that there was only about 10 per cent of cotton-seed oil used. That was true; but that must be conpled with the fact that some manufacturers clo not use it in their product.

Senator HANsBrovgH. So that it is not a necessary ingredient?

Mr. MrLler. No, sir. And it is for this reason that the high grade of butterine is rather a small percentage of the total amount of butterine sold. In other words, there is more of the grade that contains cotton-seed oil sold, I guess, than of the higher grades.

Senator Hansbrougr. Is cotton-seed oil put in the higher or the lower grades?

Mr. MILlER. In the lower grades.

Senator DoLLIVER. In regard to the oleo-oil product from the steer, I would like to get, if it be possible to do so, the average oil product, not from the heary steer, but the average.

Mr. MILler. The average is about 40 pornds.

Senator HANsBrougr. Including corvs and all beef creatures?

Mr. Miller. Yes, sir.

Senator Hansbrougr. The eaul fat? 
Mr. Millen. Yes, sir; we use that in order to get the proper taste. Oleo oil as we make it is pure neutrul oil, and it lias no taste. If we use the poorer fats of the beef, re should get a tallowy taste.

Senator HANSBRodGH. I talked yesterday with an old butter man. I said, "Can you tell the difference between oleomargarine and butter?" He said," Tes." I said, "How do you do it?" He sairl, "I take a little piece and allow it to melt on my tongue." Then I saicl, "IT hat happens?" He said, "If it is good butter, 110 disagreeable taste follows; if it is oleomargarine, there is sure to be a tallowy taste."

Mr. Miller. That is not true of all grades.

Senator HANSBRoUGH. He spoke generally, and that was his taste. He said he had dealt in hundreds of thousands of pounds of butter, and he had also dealt in oleomargarine; and he gave it as the result that the oleomargarine always had that tallowy taste.

Mr. Miller. Take nentral oleo oil and cotton-seed oil, and it is the endeavor to get those oils just as nentral as possible.

Senator AlLEN. Usually, I believe, it takes a less amount of heat to melt butter than it dloes to melt butterine?

Mr. Miller. No, sir. They had that point up before the House committee and had Professor Schweitzer, a very intinate friend of Professor Wiley, of the Agricultural Department, make a test. He took samples from the market; he did not take simples made 1!p for the occasion, as stated here; and the melting point for the best grade of butterine and of the best grade of ereamery butter was exactly the same, $96^{\circ}$ Fahrenheit.

Senator Hansbrough. I think that Governor Hoard, who was here last week, made a statement to the effect that, there was, perhaps, a difference of two or three degrees in the temprerature.

Mr. MILLER. There is not. I have had onr chemist and several other chemists make the test.

Senator HANsBRoUGH. I reeall the statement he made at the time.

Mr. KNighT. In this report of 'schweitzer, that Mr. Miller speaks of, he reports the following as the melting point of wach of the different samples he had: Lotus S:.95, Magnolia S1.65, Silver Churn 93.65, Princeton 96.80, Best Butter 96.s(). Those samples of oleomargarine here yesterday when subjected to a test of orer 120 degrees clarified here in half an honr. That was the melting point. Why does it clarify?

Mr. MILLER. The tests were perfectly elear at 82.9 z to 96.80 .

IIr. KNIGH'T. In yonr tests yesterlay, when you heated butter or butteriue it separated, but that was not the case with oleomargarine.

Mr. Miller. The butter clarified, but the butterine did not.

Mr. KNIGHT. What is clarification?

Mr. MILLER. The clarification of a thing is when the sediment goes to the bottom.

Mr. KNight. I wish you would have some samples tested here by Professor Schweitzer.

Senator HANSBRotGH. We have sent a lot of samples to the Department, and have askerl for a fill report.

Senator A LLEN. Not loug ago I was coming to Washington on the Baltimore and Olio Railroad to enter upon the diseluarge of my eminent duties liere. On entering the dining car and sitting at the table, I found a couple of pieces of butter, not extriordinarily large, which had a kind of greenish appearance, that is, while it was yellow, yet it seemed to have a shade of green. What was that?

Mr. JELrE. That was occasioned by the use of some peculiar shade of butter-coloring matter. I remember a few years ago, when some of our eustomers preferred butter with a sort of reddish tint to the yel- 
low, rather than the greenish tint of yellow, while others preferred the greenish tiut.

Senator ALLEN. I notice that the cotton-seed oil has a greenish tint.

Mr. JELKE. Yes, sir.

Senator AlleN. I made up my mind at that time it was possibly cotton-seed oil that had given it that slightly greenish color.

Mr. JELKE. I shonld not like to express an opinion upon something I had uot seen. Cotton-seed oil may have been in it.

Senator AlLEN. I am not a chemist or specialist of any kind; I conld not reproduce it; I call only tell you how I remember it; but while the general color was yellow, it seemed to have a slightly greenish tinge to the yellow.

Mr. JELKE. I also remember, when I was in the butter business, of boiling it for twenty-four to thirty-six hours with annato, and then putting in what we call turmeric, something of a similar character, only of a different color; it is a vegetable, and it has a greenish tint; that is, if you get a little too much of the turmerie in with the annato that greenish tint preslominates, and if you get a little less, then the reddish tint predominates.

Senator Hansbrougr. How do you get the butter taste into the oleomargarine?

Mr. JELKE. By the nse of milk and cream; in the better grades by the addition of a percentage of the tinest butter we can bny.

Senator Hansbrougr. You are not obliged to use milk and cream to make certain grades of oleomargarise?

Mr. JFLKE. We ean get a butter Havor without the nse of milk and cream, but I lo not think any oleomargarine is made without the use of milk and cream.

Senator Hansbrovgh. Tou have to liave some product of the cow, then, to get the butter taste?

Mr. JELKE. Always; yes, sir. In fact we are now taking into our factory every diay the milk and cream from 300 or 400 cows-cans of milk and cream of 8 gallous each. That all comes from the farm.

\section{STATEMENT OF MR. D. A. TOMPKINS.}

Mr. Chairman, in the disenssion of a subject like this, it seems to me to be important to keep it in the direction of what constitutes the merits of the whole industrial subject, and not have it take a course that would simply put the subject in the attitule of an argument as to whether one phase of an industry were being created by another phase of industry; and legislation should have reference to any fanlts that were found in the whole industry, and not have reference to any kind of tax that wonld be ealeulated to handicap one end of it and throw money in the direction of the other end of it.

In the development of the industries of the United States we have coustantly found, from time to time, industries that were put in the situation where improvements, energy, the working of more time, and talents were handicapped. That was notable in the case of Bessemer steel. When that was first introduced into this country it was a bogus inclustry; it was unreliable; not a great deal was known about it. And yet, in the face of all the opposition it transpired in the end that it was the best thing that ever happened to our metallic industries.

And in the business of flour and wheat that went West, they had methods of getting whiter flour, perlaps not better: flour, but the people are still buying the whiter flour; so that business went out of 
existence in this Eastern section of the country, either becanse of the lack of enterprise or becanse the conditions here were not so filvorable. At any rate, we all know that that industry lett New England and went West on account of the energies of the Western people.

We also know that the manufincture of Corliss engines has practically gone from New England to the West, simply because of the energy, talent, and capability of the people of the IVest to make better and cheaper engines than can be mannfactured in New England.

In the drvelopment of this business of food stuffs for the human race, it seems to me that what ought to be considered is only whether the processes are injurious to anybody; that whatever you do in respect of one industry in the matter of producing food stuffis, as respects their proeesses, onght to be equally applicable to the other branches of that same industry.

Whether these food stuff's are wholesome or not, the distinguished Secretary of A grieulture yesterlay expressed an adverse opinion. Yet in the testimony before the House committee we find that on examination of his chemist, we have a very clear-cut expression of opunion from him, on page '2us:

Representative BaIlex. Dr. Wiley, let me ask you this question : Do you cousider oleomargarine a wholesome article of food?

Dr. WILEY. I do.

Also on page 196 there is similar testimony:

Dr. Wriley. 'Two years ago I was addressing farmers' institutes in southern Iudiana-

That relates to a subject you have already had presented to you, of various kinds of butter's packed together in barrels to be shipped for renovation.

On page 93 there is a statement relating to the finding of a subcommittee appointed by the United States Senate Committee on Manufactures, of which Hon. W. E. Mason was chairman, "that the product known as oleomargarine is healthful and nutritious, and no further legislation is necessary."

iVith reference to the processes of manufacture, if it is right to undertake to eliminate certain points of the processes of the manufacture of oleomargarine, because they are immoral or because they are injurions, it is equally proper that they should be elininated from the processes of the manufacture of butter.

You have had the most ample testimony as to butters of all dlegrees of purity. Butters of varions kinds were taken, and by chemical means more or less purified, and by the addition of coloring matter made to resemble spring butter by means of growtlis of bacteria knowu as Pond's culture, for the purpose of giving the flavor of spring butter. In the production of an article of food in the shape of oleomargarine, if it is improper to use coloring matter simply because it gives some semblauce to the product of spring butter, is it not equally immoral and equally unfair in trade to use bacteria? If you forbid the renovation of butter so as to give it the flavor of spring butter, if you unlertake to forbid the manufacture of butter fiom the product of cows fed on swill, is it not equally improper to undertake to forbid the uniform coloring of this food product, in whatever way, or whence it comes? If, by means of coloring matter, butter is made of other foods than are in yellow butter, and butter is produced that is similar to spring butter, made from the product of cows fed on spring grass, by the addition of the product from the cotton-seed mills or other food stuffs, if there is 
any immorality in the one, there is certainly a similar immorality in the other.

Senator ALLEN. Yon would not claim that butter made from the product of swill-fed cows is wholesome, would yon?

Mr. Tonprins. I understand that people object much more serionsly to eating that kind of butter than they do to eating many proulncts that are entirely liealthful.

Senator ALLEN. I have eaten it, and often found it as smeet as any butter in the world.

Mr. Tomphins. Of eourse it depends upon what the swill comes from. But in the great majority of cases, of course, we know that the use of any of the swills produced in cities is very much objected to for the production of milk or for any food purpose.

To my mincl the Secretary of Agriculture day before yesterday struck the keynote of the whole remedy when he was talking about the subject of the edncation of a lot of young men, as the result of which the dairy business has beeu put in a very improved coudition. To the competition of the valuable products that go into our milk we must look in the future, as we have in the past, to giving the very freest opportunity for the exercise of talents, of new inventions, the development of raw materials for cheaper and better products; and there is llothing in the world that will so much contribute to an understanding of the subjects they are handling as the education of the youth of the country. At the present time what the agricultural and iajry interests of the conntry want is not a law putting an embargo, as it were, upon the encrgies and talents of those who are Torking the cotton-seed-oil business, who are developing the production of stock; upon the consumers who are using the products, and upon the advancement that has been brought about by these occupations, but leave them in a situation in which competition will drive them to the sime intelligent endeavor to find ont in what way they can better their products, in what way the people who aro furnishing this cheap butter at railway stations can be inclueed to furnish good butter, thus enabling the consumer to get a higher class and a better quality of butter at better prices, just as the oleomargarine people have found a way, by means of cotton-seed oil-a most wholesome product-and the application of chemical science and the best mechanical applianees, to make a good, wholesome, and cheaj) food for the people.

Then in whatever respect either one of these ocenpations misrepresents its goods to the trade it onght to be forbilden. To any extent which either one of them is furnishing an unwholesome article of food to the penple it ought to be prevented But to simply handicap improvements that one set of people have found out; to handicap the new food stuffis that, by energy and talent and education. have been brought to the people, by a tax for the bencfit of the other people who are not giving proper attention to the levelopment of their trade, is to depart from the principles upon which all the industries in America have been built up. IVhenever a man has had the freest opportunity to find ont something that was not known to other people, thereby enabling him to make as cheap goods or cheaper goods than other people furnished, something that ras not unwholesome, that should do no harm to anybody, he has the right to put that article on the market and enjoy the emoluments arising therefrom. We ennally know that when an industry finds itself in that condition where, in competition with others, by the application of more intelligent methods or the application of new processes, it can not work to equal advantage with or 
better than its competitors it must go down and the other business takes its place.

The conditions in Europe have been frequently spoken of. We find that rast quantities of cotton-seed oil have been shipped to Germany and to Holland every year, and that the use of it in their dairies has given them the very best results. They are making butters both for their own use at home and for export. It has been used both in their dairy processes ind in their oleonargarine processes, and in both with ample knowledge of the very best methods; and for that reason we hear nothing of this competition over there. Whatever is not injurious is permitted; whatever is frandulent is not permitted; and whatever is unwholesome either in the jrocesses of dairy butter making or in the oleomargarine making is strictly forbidden both in Germany and Holland, and onght to be forbidden in this comntry. There is no discrimination in respect of one being taxerl in favor of the other, but the law simply provides that the processes must be such as will give wholesoure products; that no ingredients must be put in either that will be injurions, and the coloring matter is not so considered.

Senator DoLLIVER. Some time ago Congress jassed a law taxing what is known as mixed Hour. The testimony taken before the Ways and Heans Committee of the Honse was quite distinctly to the effect that a common mixture with flour was comstarch. It was very dubious in the minds of everybody whether pure eornstarch added to the mill product of wheat was injurions. Many testified that it was a common practice for honsewives, in making bread, to arld cornstarch to the flour in the process of the domestic manufacture of bread, and had been for a long time. But Congress found that there were a large number of people manufacturing flour, or what was put ujon the masket uncler the name of Hour, which contained a percentage of starch in addition to the products of the grain of wheat, and that that article was being sold here and abroad under the name of Hour, greatly to the injury of those who were in competition in that business and diel not so mix their thonr. So Congress, in placing that tax upon mixed Hour, proposed this: simply that whoever sold tlour shonld sell what the world commoniy called and understood to be flour. The main object of the Government was to prevent people from being swindled in buying flour which contained ingredients that did not belong to pure flonr. Is there any objection to that kind of legislation?

Mr. T'OMpkins. I see no objection to that kind of legislation. Neither is there objection to legislation which requires that people who make bntterine or oleomargarine or butter should brand it for exactly what it is. 'The fault in the case you speak of, Senator, was not that people might not mix their 10 per cent of staruh with 90 per cent of the product of wheat, if everybody who bonght it so understood.

senator BoLLIVER. It appears here that 32 States, including the great commercial and industrial cities of the conntry, have prohibited the mannfacture and sale in their borders of oleomargarine made in the imitation of butter-made so that it looks like butter. Nevertheless, it wonld seem, from what is said here, that the business goes on thriving, often best in those great cities that are located in States that have male that prohibition. The testimony here seems to show-I speak more particularly in respect of the retail trade of chicago-that this article is sold to the public for butter at a price which ouglit to command the gennine article. What objection is there to some scheme of legislation that would utterly prevent that, so that everybody who 
sits down to a hotel table, or at his own table, may be secure against the swindle involved in paying for pure butter and getting oleomargarine?

Mr. Tompknss. There is not the slighest objection to any scheme being devised which will do that, but which, on the other hand, does not take away from an industry its right to bandle its business muler conditious that are given to auother industry, to the disal vantage of the first industry. Is it any more right for butter collected at railroad stations, appearing in various sorts of slapes, to be doctored $"$ ith a growth of bacteria, to be colored so as to look like spring loutter, to be otherwise doctored and manipulated and sold for what it is not on the proposition that it is spring butter"

What this committee wants to do-and that is exactly what I am dwelling upon-is to molertake what is right in both instances, and not adopt a scheme of taxation that takes away from one side of the question in order to prevent the proper handling of their goods under favorable conditions, and gives to the other side the advantage in that respect, and disregarding in both cases the question of the extent of the misrepresentations made and giving to the untaxed side the right to do absolutely all the things you forbid the oleomargarine people to do.

Senator DoLLIVki. There is great force in what you say.

Mr. TompKins. 'That is my whole proposition-that whatever test of honesty is to be on one side, be put on the other; that whatever test of competition is put on one side, should he put on the other; if me color is to be eliminated on one side, let it be eliminated on the otherbut inasmuch as it is not injurions at all I do not see the use of forbidding it at all, any more than I see no use in forbidding a woman to attempt to make herself attractive by wearing beantiful clotlies.

All goods used in the maunfacture of wearing apparel are put upon the market in nice and attractive shape. A little starch is added to the cloth. It might be sair that is not honest. It is said that certain goods weigh + pounds to the yard; as a matter of fact, they do not; they only weigh 3. pounds; the other half pound is starch. That starch is put in beciuse people clemand that goods shall have an at tractive and smooth appeirance. If that question of put ting in starch to adrl to the attractive appearauce of goods, when it actually falsifies the condition of the goods, should ever come before this committee, then it would be your proper province to undertake to stop it. If you find occasion to undertake to stop) it in one line of trade, you ought to nndertake to try to stop it in another.

But as a matter of truth, here we luave a totally different proposition. We have a condition in which conpetition has bronght new articles of food on the market. Here is an old-established institution overslanghed in their methods, as acknowledged by the distiuguished Secretary of Agriculture-and we all know that they are- finding themselves competing with new methods, not keeping their business up to the demands, and failing by reason of competition. Is it fair and proper that they should come here and call down methouls that have heen devised by energy, by talent, by edncation, by preparation, and by discovery, and eliminate a great part of the just rewards for that prouresiveness, for the benefit of those who do not do anything of that sort?

Besides that, if you take this snbject to relate only to dairy batter, the people who have cows, who make the best sort of hutter, in every case where these people have developed the best methoils they have been able to get ample pricus tor their product. I have understood that two dairymen in the last two or three days liave testified here, one testifying that he got 3.5 cents a pomnd for his butter, and the other 
that he received 5i cents a pound. It is simply a question of getting laws passed that will still further enhance the value of the product of dairy butter proulnced from cattle that are known often where the milk is bought. But when the dairymen know the surrounding conditions, the "fnantity of that kind of butter I acknowledge is exceedingly limited and the prices are very excellent. The great complaint that is being put $n$ u here is not by the prodncers. The great bulk of cheap butter is produced by people who do not give any attention to the production of butter. They have not learned what the proper food stutts are. The complaint is not being made by them, but by the men who buy exceedingly eheap, butter and have it renovated, give it a taste by bacterial gruwth, and give it color, just exactly as the oleomargarine people give their product color. Those are the people who are making the biggest fight, and it is practically oleomargarine against oleomargarine.

Mr. Kinigir. Will the gentleman yield to a question?

Mir. Tomplins. Go aliead.

Mr. KNIGIT. Upon what anthority do you base statement that the makers of process butter are the ones who are making this fight here?

Mr. Tomplins. Well, upon the general proposition that we have seen a good deal of them here, and we have heard a great deal of testimony on the subject.

Senator Dolliver. The Secretary of Agriculture, it seems to me, denounced the process butter worse than oleomargarine.

Mr. Tomprins. I know he did. Nevertheless the support of this bill comes largely fiom those manufacturers.

Mr. JELKE. The bulk of the testimony introduced under the applieation of the butter dealers of Philadelphia all went to show that they were dealers in frocess butter, with the exception of two dairymen, one who realized 35 cents a pound the year around for his butter, and the other who averaged 55 cents a pound the year around for his butter and said he never sold butter for less than 50 cents. Otherwise the testimony all through has gone to show that there have been no farmers here, no consumers here.

Senator Hansbrougir. From my own State $I$ am in receipt of 6 to 20 letters a day, and have been for several weeks past, from individnal farmers who are interested in creameries there, who are furnishing milk to them, or are stockholders in them, requesting me to favor the passage of the Grout bill. Those farmers, of course, can not come all the way to Washington. I simply state that as a fact.

Mr. JELKE. I married my wife on a tarm; I liave in central lllinois as large a following of good friends who are farmers and the finest people I know of anywhere; but I shonld like to state that there is not one of them that has had the other side of the question, the oleomargarine sicle of the question presented, who would not come down here, if necessary, and take the Capitol by force of arms.

Mr. KNIGHT. Let me inject a remark.

Senator Hansbrough. Mr. Tompkins, do you object to any more of your time being occupied?

Mr. Tompins. No, sir.

Mr. KNIGHT. I want to say this, that two or three days ago there was a resolution introduced at the instigation of the oleomargarine people, in the chamber of commerce in St. P'anl. A lot of the business ment there failed to pass resolutions condemning the Grout bill. An attorney cane before the meeting and gave the oleomargarine side, talked an hour on that proposition, and talked all about the oleomargarine side of it. Congressman Tawney went up there and gave the 
other side. Instearl of passing a resolution condemning the Gront bill, the chamber of commere then instructed their resolution committee nuanimonsly to bring in a resolution indorsing the Grout bill. That is the kind of verdict we get from disinterested and fair-minded people.

Senator Doluivier. I do not regard that question as material.

Mr. Kinight. No; but it is being introduced here.

Senator Dolliver. So far as Congressmen should be goverued by the views of their constituents, they have superior meaus of finding ont what their constituents want. But I do not regard it as material to go into that.

Mr. SCHELL. I would like to say that Senators have not alone received these letters and telegrains. It might be suggested that they have been instigated by some dairy-paper publisher. Last evening we had some letters coming from Cincinnati, and before we are through here I will find out and send to the committee the reasons why.

Mr. Kinigh'T. I can explain it.

Senator Hansirough. Perhaps they came here after the fashion of the telegram of Attorney Coyne.

Mr. INIGH'T. I ean explain that. That interests Mír. Schell; he is from Cincinnati. I will say that I telegraphed that one man from Cincinnati, an attorney for the oleomargarine people, had made a statement to the effect that oleomargarine was sold only as oleomargarine in the city of Uincinnati; that it was all properly stamped, and that there were no violations of the law.

Mr. SCHELL. I beg pardon. I did not put that in that report. I said they were violations of the color law.

Mr. KNIGHT. I asked this friend of mine in Cincinnati to find out and have merchants of Cincinnati write me if that were so. He went to them and submitted my telegram, and they answered it and furnished me that information. I have furnished it to the committee, and if you waut it I will give you a copy of the telegram I sent him. I don't know but I have it in my pocket.

Mr. JELKE. Regarding the statements or letters presented from Cincinuati by MIr. Knight, I shonld like to call attention to some clippings from the Ciucinnati Euquirer of January 9 and 10. It appears that some years ago there was a produce exchange in Cincinnati. That produce exchange was an association of the small commission merchants aud butter dealers and dealers in butter and eggs and poultry. The produce exchange went to pieces largely on account of a comer on eggs that was engineererl by a conple of inembers who had bought futures in eggs for December delivery. The contract stated that they were to be delivered "fresh in season." Natmrally the parties who bought the eggs supposed they were fresh-laid in December. But there happened to be a majority of the people who were on the short side of that corner, and they ruled that they were supposed to be such eggs as could be called fresh eggs in December, 110 matter whether they had been laid in the previons June, July, or August. So there was quite a bitter feeling stirred up, and the produce exchange uractically went to pieces in consequence of it. Now, Mr. Knight brings in some letters from just such merehants: I do not question but that they are all good people. But let me read his extract from the Cincinnati linquirer of Jantuary !):

The board of directors of the chamber of commerce-

That is the leading body of merchants in Cincinnati, corresponding with such a body as do business in Chicago, known as the board of 
trade, or in New York as the produce exehange, where grain is dealt in

The hoard of directors of the chimber of commerce yesterclay reopened the rase in which the butter men were arayed arainst the oleomargarine manufieturers. The latter opposed the Grout hill, and a majorits of the board of directors signed a protest against the passage ot the bill, which protest was forwarded to the House of Representatives at $1 I^{T}$ ashington. The bill puts a heavy inereaserl tax on oleomargarite, if colorel, and the manuficturers held that it wonld drive them ont of the business. The dirertors considered the matter at length, and finally confirmed the action of the majority of the boarl taken some time ago, as stated.

\section{This is from the Cincinnati Enquirer of January 10:}

There is dissemsion among the produce aud commission men on change that threatens to call into question the legal existence of the body that is generally known as the Produce Exchange of Cincinnati.

The question has been hromeht np by the action of the members of that body jesterclay in passing a rexolntion in which exceptions were taken to the action of the directors of the chamher of commerce in calling on Congress to defeat the passage of the Gront bill, which is hostile to the interests engaged in the maling of oleonargarine. The creamery-butter men want the bill passed, as it puts a tax of 10 cents a pound on colored oleo, and thus makes it easier for the creamery-butter makers to sell their produet without the competition ot the oleo men.

At yesterlay's session the butter men in the prodnce exchange passed the following resolution:

Whereas the boarl of directors of the Cincimmat Chamber of Commerce lias memorialized the senate of the United States that the organization is opposed to the passage of the Gront bill:

Be it resolved, That the Cincinnati Prounce Exchange, members of the Cincinnati Chamber of Commerce, do condemm the action aloove taken, and do respectfully urge your speedy and favorable action upon the Grout bill.

Senator HansbrougiI. That resolution was sent to the ehaiman of the committee, I will state. I have it here, signed by David Dreifus as president and H. J. Finke as secretary.

Mr. JELKE. Also, in reply to some statements made regarding the sale of oleomargarine for bntter in Cincinnati, I have a telegram from my brother living in Cincinnati, whom I notified last night by telephone. His answer reads as foilows:

Collector Bettman authorizes me to say for hin that it is not true that large quantities of oleomargarine are sold in the Cincinuati markets as butter; that the law is more closely observed, and there is less violation of the law and revenue regulations in regard to oleomargarine than in regard to either whisky or tobacco; and that he will make this statement over his own signature if asked by the Commissioner of Internal Revenue.

Mr. Toupkins. With reference to communications from farmers, I want to say that I have not the slightest donbt that the farmers, who are very much interested in this subjeet, up to the present time do not know about it, and those who produce the eotton seed and are interested in the eotton seed that goes into the cotton-seed-oil mills do not know about it. If it is a question of getting communications from farmers I have not the slightest donbt that at least .5) per cent of the farmers eonld be got to petition against the bill, which will depreciate their interest not less than $\$ 2$ a toll on $2,000,000$ tons of seed.

On the subject of the interests that are affected we have some testimony that was given before the House committee on the subject of the eattle interests, that since the fall of 1895 there has been a depression in the value of live stock to the extent of $8152,000,000$. I have not the slightest doubt that the passage of the bill wonld affect the farmers' cotton-sced interests to the extent of at least $\$ 2$ a ton on all the seed that they sell.

Mr. KNight. Will you yield to a question? 
Mr. Tomprins. Yes, sir.

Mr. KNigh'T. How do you figure it out?

Mr. Tomprins. By taking the quantity of oil off the market where it is sold at present; it will depreciate the value of the whole amount of cotton-seed oil, because the surplus prouluet is what controls prices, not the whole quantity.

Mr. KNIGH'. What is the quantity of oil?

Mr. Tomplins. The quantity of oil is from 1,500,000 to $2,000,000$ barrels. It is clifficult to state the amount exactly.

Mr. KNIGHT. What is that quantity?

Mr. Tomprins. It is from $1,500,000$ to $2,000,000$ barrels of oil that is produced.

Mr. Kinigh'T. You do not grasp my question. That is what I have been trying to get at in the cotton seed busiuess. What do you consider to be the relative value of the production of oleo in this country to cotton seed oil?

Mr. TompKINs. I consider the finest pressed oil about 5 cents a gallon.

Mr. KNIGHT. That is not the question at all. What is your market for cotton-seed oil to these manufacturers? How much do you market?

Mr. Tourkrns. We have their testimony for that. I think they can give you a more aceurate estimate of it than I ean, probably.

Mr. KNIGHT. Is it not true that the Internal-Revenue Commissioner shows that you sold to them last year less than \$500,000 worth of that oil?

Mr. Tomplins. I rould not answer that question.

Mr. KNIGHr. Well, it is a fact. I think the committee will accept my statement. because this is a matter of record.

Mr. Tumplins. But that may not be any measure at all of the quantity of oil that goes into the prouluet, because it may have gone through several other channels. We know that they nse cotton-seer oil to the extent of 10 to 30 per cent and that it furnishes a large market for it.

Mr. KNigh'T. Do you not kuow how much they aetually use?

Mr. Tomprins. Accorling to their testimony. I say.

Mr. KNIGH'. Do you not know how much, exactly, they use according to their own testimony?

Mr. Tomprins. That testimony stands for itself:

Mr. KNIGHT. What I want to get at is, what is the value of the product? According to the Secretary of the Treasury it was about $\$ 8,800,000$, as I understand.

Mr. Tomprins. It is not a question of the value of that. It is a question of what will be the canse of destroying that market aud limiting the sale of cotton-seed oil in the markets that are left.

Mr. KNIGHT. I want to ask you this question: You elaim there, as I understand, that the loss of a market of a half million dollars' worth of cotton-seed oil would lower the value of vour product to the extent of $\$ 2,000,000$ ?

Mr. ToMpKrns. In a differential market it might easily.

Mr. KNIGH'. Then why womld it not be a good investment to burn up a half million dollars' worth and thus advance the price?

Mr. Tompins. We are not in the business of burning up. Each man would have to burn his own oil, and you can not bing about a situation of that kind. It might bring about the same result if you did. No individual man is going to burn his own product, and I doubt if the law would permit a combination to do it. That is not the question at issue. We have this example before us: That the production of a cotton erop of $11,000,000$ bales carried the price to 5 cents, and the production of 
$55,00,000$ bales doubled the price. Isı't it reasonable to suppose that a like eanse would have a similar influence on the prices of ot her goods?

Mr. KNIGHT. I do not think that any man who is engaged in business will assent to the statement that the destruction of a market for a half million dollars' worth of goods will cause a loss of $\$ 2,1000,000$. I will ask you this: If the displacing of the product of half a million dollars' worth of cotton-seed oil will depreciate rour stowk $\$ 2,000,000$ in valne, what do you think will happen to the dairymen, or is happening to the clairymen, where they are cleprived of a market for $\$ 20,0100,000$ worth of their products? Would it not be that they were heaten ont of $\$ 80,000,000$ a year?

Mr. TompKins. If all other honest oceupations rere elininated, your argument wonld be all right, but we are disenssing the subject of its being untairly done.

Mr. KNIGIT. On the other hand, why not apply the sane rule to the cotton growers, and say if the other occupations were closed to them that the value might be so and so?

Mr. Tompkivs If it were, 1 dare say eotton would go to 25 cents a pound-that is, if you were to forbid the produetion of wool and flax.

Mr. KNIGH'T. Then, as a matter of fact, it is easy to destroy the value of butter to the extent of $\$ \$ 0,000,000$ a year on that basis, or to decrease the price of cotton-seed oil $\$ 2,000,(100)$.

Mr. Tomprins. And decrease the value of cattle and charge the laboring elements of the country that mueh more than they ought to pay.

Mr. KNIGHT. All right. , That is what I have been trying to get out.

Senator DOLLIVER. There seems a very much larger production of cottonseed oil than enter's into the mannfacture of oleomargarine, and a vastly larger production of oleo oil than enters into the manufacture of oleomargarine. If these laws restraining the sale of oleomargarine, such as exist in 32 States, were wiped out, and no action at all taken by either State or local governments, would it be possible for oleomargariue to ocenpy the whole field for butter, thereby totally destroying one of the chief commereial products of the country?

Mr. Tomplins. It wonld not, on aceount of the variety of tastes. There are people who will not have any lard but lard rendered from hogs raised under circumstances that they themselves know about, people who will not buy commercial lard at all. Equally there is a large consumption of dairy butter by people who will not eat anything else. 'The province of this committee is to put itself in the position of a purchaser who wants to know what he purchases. It is not a question of elimination.

Senator Dolimver. My question was based upon the theory that the oleomargarine produet has now become so perfect an imitation of butter that people would be mable to discern whether it is butter or not.

Mr. Tompkins. But I do not think you wonld have any difficulty under the police regulations in reference to that matter. We have the testimony of a gentleman from Cincinnati here, who is a State official.

Mr. JeLkE. He was colleetor of internal revenue.

Mr. Tomprins. I will undertake to say he wonld keep track of that difficulty. There is no trouble in organizing a body of agents or inspectors, just as is done in the ease of whisky and tobaeco.

Senator DoLLIVER. Abont four years ago we received an elegaut speeimen of oleomargariue that had taken the first prize as butter at the State fair of Peunsylvania.

Mr. Tompkins. Yet your proposition would be to totally eliminate a food product_- 
Senator DoLLiver. I was incyuiring whether, in the absence of any regulations, State or local or national, a situation is not possible, owing to the volume of oleo oil and cotton-seed oil, by which the dairy interests of the comntry might be totally expunged without the knowledge of the jublic.

Mr. 'TompKINs. If it were totally expunged by competition or putting something else on the market that was better, by means of processes that affected larger interests, by furnishing the working people and all other people a better article at a eheaper price, is not that the standard by which American commerce has always been judged? I absolutely feel that I know that the dairy business would never go down; that it has within it possibilities which, by edncation and by a better muderstanding of the processes of feecling and of utilizing manures from the food of the cattle, butter can be produced excellently and cheaply in a way to keep always in competition with the other products of the same animals exactly, excepting only the vegetable part that goes in from cotton.seed oil.

Now, what you want, is to leave tlat rompetition exactly free. What ought to be done is simply to require that these things shall be sold on their merits and without any misrepresentation, to which the gentleman acquiesces promptly. Nevertheless, all the arguments here are that you must eliminate butter, you must eliminate everything that gives this product a fair show on the market. If you eliminate in both instances I am witl you, and I think all the people are with you. The elimination of coloring matter is not the elinination of an injurions ingredient. But if you cause the butter people to put a label on their packages that it is butter, and they renovate it to give it a taste by culture and grow th of bacteria, and give it an artificial color, all that is as absolutely deceptive when the butter is put on the market, when its appearance is changed, when its taste is changed so as to represent grass butter, as it is to put oleomargarine, otherwise wholesome, on the market, and color it velluw, but call it by its own name. Indeed, there is no deception at all in that. 'There is not the slightest objertion to the regulation of the article, to the making of everybody stand the same tests and make the same degree of houest representations.

It is absolutely no use to eliminate something that is simply used for the purpose of making that article wole attractive to the purchaser without doing him any harm. If you will require a wholesome article of oleomargarine to be made, let them color it if they want to. Require them to put on the formula by which it was made, if you desire, just as is the case with cotton-seed oil, and then do exactiy the same with the butter business, and there will be no trouble about honest competition, and neither sicle will have any right to ask that the other side be handicapped with an eubargo of a great big tax, or of being deprived of the alvantage of putting a good appearance on their goods for the market, while they themselves are allowed to put identically that thing on the market under circumstances that are more deceptive in the one case than in the other. Everyboly linows that oleomargarine is colored; but not a great number of people know that butter which is alleged to be spring butten, with the color made by grass or by cotton-seed meal, actually contains that thing at all. The color is artificial and the taste is artificial.

Mr. Kxight. Will the gentleman yield?

Mr. Tomplins. Certainly.

Mr. Kingutit. You speak of spring butter and bacteria. Do you think it is a fraud to mse what you call an artiticial flavor caused by bacterial development? 
Mr. Tomprins. When you conceal the fraud it is.

Mr. KNight. Do you know what produces the flavor in butterine?

Mr. Toupkins. It is said to be bacteria.

Mr. KNIGH'T. Nothing bnt bacteria. All flavor is produced by bacteria.

Mr. TompKINs. That is what they say. I am not a chemist.

Mr. KNIGH'T. In giviug butter a spriug color, in what way is that deceptive?

Mr. TonpKins. In the fact that the whole truth is not made manifest on the package.

Mr. KNicirT. Do you know that there is butter without bacteria in it?

Mr. TombKins. I do not know. That is one of the complaints made by the Secretary of Agriculture about oleomargarine, that there were no bacteria in it.

Semator HANsBRouGH. I understand that it is necessary for the oleomargariue manufacturers to use a certain proportion of milk and cream in order to get the butter bacteria into their product, thus securing the butter taste. Is that right?

Mr. 'Toupkins. 'That is right.

Sevator Hansbrough. So that there can not be much harm in the one case if you use it in both cases?

Mr. Tompliss. Nor is there any harm in using coloring in both. Yet it is set up here as the very essence of fraud that it is done. I suppose there are many people who would object to the use of grass butter if they knew that it contained bacteria.

Senator Hansbrough. Ton were speaking of a certain class of worms and bugs which were pretty large in size.

Mr. ToMPKINs. I did not say bugs.

Mr. KNicut. To retuln to the deception in coloring butter to make it look like spring butter, I do not understand where the deception is. I want to understand whero you think the deception is. Will you please explain?

Mr. Tompkins. In coloring one butter to make it look like another butter?

Mr. Knight. Yes. Where is the deception?

Mr. Tonprins. The deception lies in the fact.

Mr. KNIGIT. I know that spring butter is yellow naturally, is it not?

Mr. Tompkins. Yes.

Mr. KNIGHT. When is this butter colored to make it look like spring butter, and when is it necessary?

Mr. Tompkins. Whenever yon gather it up in barrels at the varions railroal stations throughout the country and take it and renovate it.

Mr. KNIGHT. When is it white?

Mr. ToMpKins. If you feed the cow on cotton seed, the butter will be white; that is also trne with many other kinds of food.

Mr. KNIGח'r. But that is not spring butter. When you speak of spring butter you intend to convey the idea of butter that is naturally yellow, do you?

Mr. Touprins. Butter that comes from cattle tlat have been fed ou spring grass; that is butter that is most attractive and that most people want to eat, and butter that most people feel, as a matter of sentiment, is the purest.

Mr. KNIGIT. I want to ask another question: Do you know at what periorl of the year this artificially colored bntter is marketed? Do you understand the matter sufficiently to know when the hutter is white? 
Mr. Tompkins. It wonld be white at any time of the year if the cow were fed on food stuff that would produce white butter. If you feed the cow on cotton seed, the butter will be as white as cotton.

Mr. KNIGHT. What I want to get at as to that is 10 lming ont this point about the alleged deception in color. You talk about the coloring of butter as being deceptive. Do you know that butter is colored in the winter and not in the summer?

Mr. TompKins. No, I don’t.

Mr. KNIGHT. Then I will say for your information, and you will find ont that it is true, that white butter comes in the winter. I think the olenmargarine people will tell you that.

Mr. JELkE. I believe that if Mr. Knight will wire to a half dozen of the leading creamery men of the United States that furnish butter for Washington or St. Louis lie will find that they use artificial coloring twelve months in the year.

Mr. KNIGHT. No; that is not tiue.

Mr. JELKE. I am making that as a suggestion to the committee. If you wish to controvert that, simply send your telegrans.

Mr. KNIGIT. I have a statement which has been filed with the committee on that point. It appears that I can not bring it out by these questions, and I wonld like to make a statement right here, so that it will go in the record.

Senator Hansbrougir. I suggest that you give Mr. Tompkins a chance to finish his statement.

Mr. Tomphins. I am perfectly willing to yield to Mr. Kinight.

Senator HANSBRougr. For a short statement.

Mr. KNignt. This great deception that is claimed in the practice of coloring butter is based on the supposition that in the winter time, when butter is naturally white, people are deceived into buying it, thinking it is spring butter becanse it is colored. Now look at the proposition. You come down here in December or January and buy some butter; it is higbly colored, but it is butter. Do you buy that butter because you think it was made last summer? Do you want butter made last summer?

Mr. Toupkins. It may be made with cotton-seed meal, which is perfertly wholesome; but as against butter made from cows fed on swills, many people cousider it poor stuff and object to it.

Mr. KNIGHT. I will say in that comnection that I have been in the butter trade for twelve years, and I have never heard that the color of butter was indicative of its quality, so far as its wholesomeness is concerned. Senator Dolliver has had experience in New Iork to the effect that at the Waldorf-Astoria, they serve you with butter perfectly white. I was in England for the Agricultural Department investigating butter in that country, and they served me there with white butter all the time I was there, and I never heard anybody complain because it was white.

Mr. Tomprins. Why do they ever want to bave the color in it?

Mr. KNIfHT. The average natural color of butter is two-thirds normal. You take our dairies thronghout the Lnited States, and one cold wave or storm will change the color of the butter. One cold wave that will drive the cows from feeding on the green pastures to feeding on hay or any kind of grain food will make the butter white this week which last week was yellow. That is true of any place.

The teulency of all commerce is toward uniformity in everything. Butter is put up in packages or in tubs. Everybody puts up everything with this idea of miformity in view. That is what the public 
demands. It does not make any difference in what shape the packinges are, but all the packages must be miform in order to be merehantable. So with butter. Butter must be muiform in packages, mniform in body, uniform in the amomnt of salt, uniform in flavor, uniform in color. The weather conditions may be such that one day will nuke white butter and another day will make yellow butter. I tell you that it is revessary that we do something to keep the color uniform. When 1 tell you that, I am telling you what I know. I say to day that it wonll be better for the butter trasle if butter conld be made white miformly and all the time, rather than yellow part of the time and white part of the time. The eonsumers would soon become used to that uniformity. But we ean not accomplish that. In the winter time butter might be nearly white if the eolor is kejt ont of it. If oleomargarine were white, where ronld our distinetion be? In this bill we seek a distinction between the two articles. If a bill could be passed that rould cause the color to be kept out of butter and oleomargarine in the winter time, then the oleomargarine men wonld go to their letailers and tell them, "You know there was a law passed at the last Congress which praetically forbids coloring butter." Where wonld the value of the law be that wonld bring the two articles down to the same basis as regards color? It is true that would be an advantage in the summer time, wheri butter is eheap, aud oleomargarine has no market to amount to anyhow. But when it eame to the winter time the eolor might be taken out, and the two articles standing side by side would show the same color, and then frand would be praticed just the same. Every man who wanted to sell oleomargarine for butter would convince the consumer that it was natural butter, and rould tell him that color had been forbidden by law, and that butter is white in winter.

Mr. MILLER. It is a fact that crenmery butter is eolored in the winter time.

Mr. KNIgHT. That is in Kansas.

Mr. Mnlfer. Yes. Why? Because they want to keep it unifirm. Mr. Tompkins's point is this: This renovated butter is reworked and sold on the market as creamery butter.

Mr. KNIGHT. I am going to talk about that renovated butter for five minutes.

Senator Hansblougr. I suggest that Mr. Tompkins be allowed to finish his statement first.

Mr. Tomplins. The proposition seems to rednee itself, even after the gentleman's explanation, to one thing-that we want to keep them from putting their articles of manufacture into nice and attractive shape, and we want the liberty to do so ourselves; that we want you to fine them for doing it, but we want to go scot-fiee. That is the whole proposition. That is my interpletation of all that he has said.

Now as to the question of who is affected by this bill. There is an enormous number of small farmers aud many of them have been persuaded to send deputations here when their interests practically lie on the other side, or only on the side of improving their methods. The fellow who sells butter to dealers, who, in turn ship it to the dairymen, gets very little, if any, more for his butter than the oleomargarine people do for theirs. 'The number of that class of' people who make a kind of butter that does not go upon the market in these attractive shapes, is very large, whereas the number of people who protuce the high kind of butter, either naturally on the farms or in dairies for lenovation, are the interested parties, and are comparatively few. So that the great bulk of the small tarmers who feel that they are getting entirely too 
little money for their butter would, after the passage of this bill, not be materially improved, for the reason that the dairymen, the renovated butter men, or other people who buy their butter, wonld give them just about the same price as they now get, and would get the benefits of this taxation and a curtailment of production for those who are now enjoying the very best benefits of the dairy interests.

A fter them, the next interest that is affected is this enormons interest in the South in the production: of cotton sced, where, by means of improved processes and more work, they have learned to produce beef steers, and are producing a great many beef steers, and are fattening them on cotton seed oil and meal. 'Their interests will be affecterl.

But the largest of all interests to be affected is the working people of the country, who have to consume the product. There is no quesbut that, if the propositions relating to legislation brought here ly the dairymen is carried through, the prices of that article of food to the people will be the biggest part of the tax.

Senator ALLEN. Do you know approximately how many milch cows there are in the United States?

Mr. Tompkins. I do not. I think it is stated somewhere in the testimolly.

Mr. KNIGHT. Sixteen millions.

Senator ALLEN. The average prodnetion of butter per cow would be how much per week?

Mr. KNight. Eleven millions in the production of butter.

Senator ALLEN. What is the average production?

Mr.'Tumpkins. I am not a dairyman. These otlier gentlemen will tell you that.

Senator AlLEv. Say 4 pounds per week. That is reasonable, is it not?

Mr. ToMpkins. I suppose so.

Senator ALLEN. How much butter will be produced per week?

Mr. TompKins. Four pounds a week, and fifty-two times that.

Senator ALLEN. In roumd figures, what will that be?

Mr. KNIGHT. I have figured it at abont $1,500,000,000$ pounds.

Senator ALLEN. Divide that by $75,000,000$, the population of the United States, and what rould the result be?

Mr. ToMPKINs. A bout 18? pounds per capita.

Senator AlLEN. Do you think we ought to resort to a substitute for butter uuder tlose circumstances?

Mr. Tomplins. They do not want a wholesome article of food, or at least they do not want to pay 25 per cent more for that food than they are now paying. It is the differential quantities of food, I suppose, that enter into the prices in the estimation of the values of the actual quantities concerned. They are by no means a measure of what the increased prices would be. I am sure that the working people would not want to be made the victims of any law which materially increased the price of what they buy, whether butter or oleomargarine.

Senator HANSBRoUGH. If you knock ont the color from oleomargarine, would not the working people be able to buy it at a lower price?

Mr. Tompkins. If the color was knocked out of butter, would they not also be able to buy it at a lower price? Why should the principle apply to one and not the other?

Senator HANSBROUGH. It is stated here by butter experts that for about two months in the year the butter is naturally colored, that you can not take it out.

Mr. Tomprins. That is all right. Leave it in. 
Mr. KNighT. And butter is the cheapest at that time of the year.

Mr. Tomprins That is all right, too.

Senator AlLEN. Some time, jurbably before the 1st of Angust, the butter begins to get pale. so that unless the cow is fed other than food in the pasture mintil alom about December, the butter would be almost white, having but a slight yellowish tinge.

Senator DoLliver. Silppose it shomlit tum ont, as some of the testimony would seem to indicate, that in large cities, like Washington, poor people, anxious to supply their table, are inveigled by the appearance of your oleomargarine goods into paying the better prices for it unler the impression that they are getting butter, whereas in point of fact they are getting an article which, in the ordinary state of the market, ought to be worth very much less?

Mr. TOMPKiNs. Is not that sime thing applicable to white butter as well as to colored bntter? The principle of the deception in the one, it seems to me, is quite as important as in the other.

Senator Allex. One is butter and the other is not, and the consumer buys the oleomargarine under the impression that it is butter. It is a substitute for butter now. I am not prepared to say that it is now wholesome, so far as I an concerued.

senator HANBBrougr. It is a wholesome artiele of food. That is not disputed.

Mr. Toupkins. I do not think anybody disputes it except the Secretary of Agriculture.

Senator ALLEN. What is the color point of butter?

.11. JELKE. I think butter dealers count color at 15 points.

Mr. KnIGHT. Ten points, I think.

Senator ALLwiN. So far as I am individually concerned, I do not care anything about the color of butter.

Mr. JELKE. If butter is perfectly sweet to the taste it is immaterial abont the color. But the trouble is abont butter that is not perfectly pleasant to the palate.

Senator ALLEN. I know that butter oversealded on the farm will be almost as white as paper and at the same time very palatable.

Mr. I'AUL. Allow me to submit the standard official score from the trenty-sixth report of the Philadelphia Produce Exchange:

Forir B.-Standard official score.

1'oints.

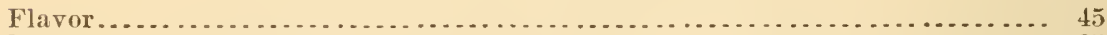

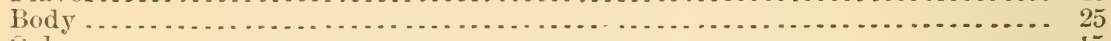

Color................

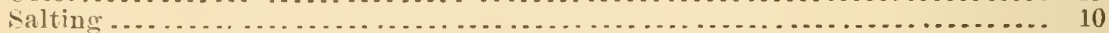

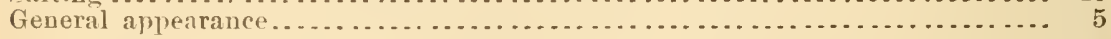

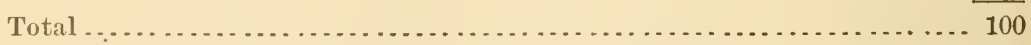

Senator ALLEN. What is the estimated value of colored oleomargarine? What points do you count?

Mr. JELKE. We have never made an estimate of those points; but I should think it worth fully as muel to us as to the butter dealers.

Senator DoLLIVER. I haven't got it in my head how you can place a label on a package of oleomargarine, showing that it is oleomargarine, and theu expect the pnblic to bny it. It seems to me it would have the effect of destroying the industry.

Mr. JELKE. That wonld be practically the effect.

Mr. Tompkins. It would put us in a situation where poor people would not buy, because it would have a brand of condemnation, as it were. 
Senator DoluIVer. It would seem to indicate that it was univer. sally disreputable in itself.

Mr. Tompkins. Another thing about it is

Senator DoLliver. If you put up an article that a man is ashamed to have on his table it seems to me there would not be much sale for that article.

Mr. Tompins. Suppose an attempt were made to put an honest man in the penitentiary and put the stripes on him, don't you think he would object? You can put marks upon anything in this world that will create prejudice. In fact, this question of color is a question of sentiment or prejudice, and nothing else.

Senator DOLLIVER. If a man without stripes were honest, but still fonght everybody and shmmed society, it would seem to indicate that there was something constitutionally defective about him.

Mr. Tomprins. But this is not that case. You propose, in the case of butter, to permit them to make this very distinction you talk about, to the detriment of the reputation of oleomargarine, as though it were marked by the Government exactly as a man would be marked by stripes in the penitentiary.

Mr. JELKE. I want to answer Senator Dolliver. In Chicago oleomargarine has the stripes of condemnation on it, in consequence of the sentiment created by a partisan press, and promulgated throughout the country, and the statement was made in one instance before the com mittee, but afterwards they wanted the statement stricken out.

Senator ALLEN. What would be the objection to using carrots in the manufacture of oleomargarine for the purpose of giving it color?

Mr. JELKE. This bill would not allow it.

Senator Dolliver. It all looks to me as if the oleomargarine business, by this fight against State and United States laws, had invited a lot of opprobrium, which I believe shonld not attach to the business.

Mr. JELKE. There has not been any fight against United States laws, as shown in the statements of every interual-revenne collector and the Commissioner, or otherwise.

Senator DoLliver. But we had on our table yesterday a dozen packages upon which the United States law had been dodged.

Mr. TompKins. If yon make a law of any kind relating to butter it will be dodged. Yon can not make any kind of a law that will not be dodged more or less. We have the testimony, by telegram, of an officer of the United States Government that he does not believe that the law is being dodged in one large and important commercial city of the Union. There is no reason why it should be done more anywhere else than it is there. It is simply a question of proper regulation.

Senator Hansbrough. Yon recall the statement of Secretary Wilson yesterday, I think it was, in regard to the conditions of Denmark, where $3 \frac{1}{2}$ per cent of butter substances was oleomargarine, and that it was uncolored?

Mr. KNIGHT. Three and a half pounds per capita.

Senator DOLLIVER. And that they found a ready market to that extent in Denmark?

Mr. KNIGHT. The public taste is educated easily. I ate white butter for four weeks in England, and in fact got so used to it that when I returned to this country yellow butter was repulsive.

Senator HANsBrough. I make that statement to show that it is not the purpose of Congress to injure the oleomargarine business as an oleomargarine business.

Mr. Tompkins. Then don't put any bill on the comntry that is discriminating in its terms and in favor of butter. Revise and reconstruct S. Rep. $20 \pm 3-3 \pm$ 
the bill so as to make it a good bill that will be applicable to the butter business as much as to the oleomargarine business.

Mr. KNignt. What would happen to you if you should go on the streets of Washington attired in woman's clothes?

Mr. Tompriss. I lo not see the relevancy of the question. The question at issue is whether in this bill there is an unfair cliscrimination against one product and in favor of another; not with reference to whether a proper and legitimate industry ought not to be allowed and all legitimate occupations pursued with perfect freedom. I can not but feel that the bill does $t$ wo things: It discriminates in the first place in favor of the butter business, in allowing the manufacturers to use processes for coloring and to use flavoring compounds; that these things are permitted, whether they are right or wrong, whether the processes are clean or not clean: while, in the case of oleomargarine, you pernit absolutely nothing, even though the article is perfectly wholesome. The distinetion between right and wrong should be made by police regulations, and there are ways of doing that without discriminating in favor of one and against the other.

Senator ALLEN. I suppose you recognize the fact that almost the entire quantity of butter consumed on the farms is never colored?

Mr. Tompins. I do not think it is colored.

Senator ALLEN. I refer, of course, to the butter that is consumed on the farms.

Senator Hansbrovgr. It is taken in its natural state.

Mr. Tomprins. What I am contending is that both butter and oleomargariue ought to be allowed to be colored, or not, according to taste, provided that the color is not injurious; and all injurious methods ought to be forbidden in both cases. I think the whole matter can rest on that proposition, and I thank you for your kind attention.

Senator DoLLIVER. Let me say that I find a natural prejudice in favor of butter, and a very strong indisposition to do any real damage to a legitimate business that has invested capital. I am extremely anxious to know what would be the actual effect of putting oleomargarine on the market in its natural condition and leaving it to make its ray without a continual conflict with laws and prejudices and customs in thirty.tro different States, but give it its true reputation, and rescue it, if possible, from the general disrepute in which it seems to be, so far as has been showu generally by the testimony.

IIr. JELKE. I will say here that if the Grout bill passes, providing a tax of 10 per cent, it will lill the industry. Last winter a dealer was arresterl in Council Bluft's, Iorra, through the efforts of the dairy commissioner of that State, and we had to go to the expense of paying for the return of the goods. The goods were absolntely moncolored except for a slight grayish tint. We defeated that case in the police court there. 'Then the dairy commissioner presenterl the case to the grand jury, the dealer was indicted, and we bad to defend another ease brought against him there. A dealer in Des Moines said, "I am going to undertake to sell butterine." The commissioner said, "If you do I will prosecute every sale you make. We don't want it sold in our city, colored or uncolored."

Senator DoLLITEI. The State of Iowa would be an exceedingly discouraging place to undertake to sell angthing for butter, very much as a man would not carry coals to Newcastle. But in the city of Chicago, where there is a great demand by the poor people, who have been spoken of, for cheap butter, what would be the practical difficulty in selling authenticated oleomargarine under its owu name without any 
tendeney to deceive anybody by dealers, if the article were left uncolored.

Mr. Tompkins. Your proposition is that all grades of butter be made in imitation of a butter that costs 5 cents a pound, because it certainly can be produced for people who want it. On the other hand, you have forbidlen any apjearance of that sort of thing on the part of the oleomargarine people themselves, and made a great distinction. The two subjects would naturally lap if you let them both alone and let all color's take care of themselves absolutely, simply forbidding artificial color's anywhere. But by means of artificial color yon so criticise one product in connection with this traffic that the otlier becomes opprobrious at once.

Senator DOLLIVER. There is some force in that, but I would rather take the testimony as to the grades of the manufactured article called oleomargarine, whose business methods are less subject to criticism, I think, possibly, than any other.

Mr. JELKE. I think those reasons have been stated here by a laboring wan.

Senator Dolliver. That story, I will say to my friend, sounded a little fishy to me.

Mr. JELKE. A man does not seek here to display the quality of food on his table three times a day.

Mr. Touprins. I assert that the whole aim of the human family seems to be to get food and other necessary articles as cheaply as possible. I have never heard it was a reproach that cheap goods were satisfactory to the purchaser.

Mr. JELKE. Would you want to eat uncolored oleomargarine on your table?

Senator Dolliver. No; I have a constitutional prejudice against it, I must confess.

Mr. JELKE. Would you want to eat white butter?

Senator DOLLIVER. Oh, yes; I have eaten it the year round, and in youth I churnerl it. As Senator Allen says, everybody eats white butter on the farm.

Mr. JELKE. As soon as that butter is shipped to the city it is colored.

Senator DoLLrYER. I am talking abont my own taste.

Mr. Schill. The wholesale dealers in Cincinnati have tried to put white oleomargarine on the market, but have reported to me that it was absolutely impossible to do it. Mr. Seitler, who claims to be and I beliere is the oldest man in that business in this country, tells me he has trierl it from time to time, but it is utterly impossible; that the people will not take it. He has not told me the reason why, but I think one of the principal reasons is the fact that there is an mumarranted sentiment attachell to it, an unwarranted prejudice against it, and people do not want to put it on their tables for the criticism of their neighbors. Ton know how a neighboring woman will say: "Mrs. Smith uses oleo," ete.

Senator ALLEN. Is not this the fact: That the man does not want to put oleomargarine on his table knowingly, becanse of his natnral inclination tor butter?

Mr. Schell. No, I think not. I was telling the committee about an experience I had during the holdalys on one occasion where I found what I knew to be oleomargarine on the table of a physician, a man amply able to have the rery best. I called attention to it, and brought blushes to his wife's face at the same time. But he explained it, and said it was all right. Why? Because he liked something upon which 
he could depend; that he liked it better than the eountry butter that he could get, and better than the creamery butter that he could get in the city stores.

Senator Dolliver. Have you studied the question of how far this continual conflict with State laws, and the almost nniversal duplicity of the retull trade in dealing with its customers, such as was deseribed here yesterday by Mr. Knighit, with an appearance of truth and veracity at least-how far that has contributed to bring the whole business into disrepute and reproach in the eommercial world?

Mr. ScInell. I have not considered that, becanse in Cincinnati we have not the same situation which Mr. Knight described as to a certain portion only of Chicago.

Mr. KNight. It is all over Chieago, every place.

Mr. Schell. After all, that is largely hearsay, and covers only a very small amount of business. IVe do not have that condition in Cincinnati.

Senator Hansbrougir. Yoll say all over Chicago?

Mr. KNight. Yes, sir. I do not say every dealer, but I will say eight ont of ten dealers in Chicago, and that will leave about 200 honest dealers in the city. I consider that 90 per cent of the oleomargarine that is sold in Chicago is sold as butter.

Mr. MILLER. I thiuk if the oleomargarine manufacturers would put up these goods in packages so that retail dealer's conld not break them that would settle the difficulty. For instance, say we put it up in 2 -pound packages for the retail dealer, with the word "oleomargarine" printed on the wrapper.

Senator DOLLIVER. Is that the Wadsworth bill?

Mr. MILLER. That is practically the Wadsworth bill.

MH. KNIGHT. Hay I ask why he conld not break the package just as well as he conld mark the package? The present law requires it to be marlied; and a recent ruliug of the Commissioner of Internal Revenne plainly and explieitly states that any hiding of the seal or stamp is a violation of the law, and subjects the violator to a punishment. I do not lnow how much. What is the difference between laying himself liable to a fine for a violation of the stamp law as it is now and laying himself liable to a fine for taking off the stamp, as he would under the Wadsworth bill?

Mr. MrLLER. Increase the penalty.

Mr. KNIGHT. I want to say to the committee now that in my judg. ment the higher the penalty the less possibility there is of enforcing the law. It is almost impossible to procure the evidence, and, besides, to fine a man a thousand dollars for selling 15 eents' worth of oleomargarine for butter only defeats the ends of justice.

Senator ALLEN. It seems to me there is an insuperable objeetion to your proposition, Mr. Miller. Suppose the retail dealer has his goods in 2 or 3 pound packages, with the wrapper properly stamped with the word "butterine," what is to hinder him, when he gets 100 or 200 pounds, from taking those packages down cellar and taking off the wrapper, and running the stuff throngh the maehine and recasting it and selling it as butter?

Mr. Miller. I do not think he would do so.

Mr. ToupKINs. That kind of work is done with liquor all the time.

Mr. - It seems to me that the greatest preventive of frauds of this kind wonld be a reduction in the retail dealer's tax. I think that would reduce 99 per cent of the frauds.

Mr. KNIGHT. So far as the enforcement of the law by the Internal 
Revenue Department is concerued in regard to branding, or in regard to selling oleomargarine for butter, there is not the slightest interest in that Department on that question. I am speaking from experience.

Senator DoLliver. Why is it that the Goverument has an interest in the enforcement of the whisky tax?

Mr. KNIGHT. Whenever a man finds out illicit whisky, he attaches 90 per cent of the tax; but in the case of oleomargarine he does not attach auy of the tax. The point of this 10 per cent tax is to fix it so that if he colors it in imitation of butter, he will have to pay enough to relatively cost the retailer a figure that will not leave him an incentive to take his ehances under State laws. The minute that you descend into the interual revenue with a tax on it and say you will collect a tax of 10 cents on every pound, they will collect it. We know that. There is our position about enforcement; but they care nothing for the police measures.

Senator DoLliver. 'They enforce the provisions as to packages of tobacco, 1 suppose, as to size and weight?

Mr. KNIGHT. I am not well informed on tobaceo laws, but they require a stamp of so much on erery paokage containing so many pounds.

Senator Dolliver. They regulate the size of the package.

Mr. KNIGH'T. Yes; they simply require that that amount of revenue goes on.

Senator Allen. They require an adhesive stamp.

Mr. KNIGHT. In any other internal-revenue article there is absolutely nothing in the shape of imitation that causes people to throw off the stamp. What incentive has a man to remove the stamp from cigars or tobacco? None at all.

Mr. MLLLER. The putting of a stamp upon a package is what we want. We would like to have that to day.

Senator ALLEN. You would be willing to put on a regular adhesive stamp?

Mr. Miller. Yes, sir.

Mr. InRIGH. Does Mr. Knight want to insinuate that our revenue ofticers throngliout the country do not attend to their duties?

Mr. KNIGHT. les; and in confirmation of that I wonld like to read from the Commissioner's report.

Senator ALLEN. I do not think we want to go in to that.

Mr. SCHELl. In reply to Senator Allen's question, I think I ean emphasize the point quite a good deal. He wants to know what would prevent the taking off of the wrapper and remixing the stuff down in the cellar. I presented here yesterday, as the Senator will recall, a list representing 1,083 consumers who buy directly from one of my elients, and they all unite in asking that this Grout bill be defeated. If this bill become a law, they will be unable to bny, and we will be mable to manufacture for them or to export any of the product colored.

Senator DoLLIVER. The man down cellar would be handling the oleomargarine, and the margin between the retail price of it and the price of real butter would be practically wiped out, and there would be no incentive to firand.

Mr. SchelL. The dishonest retailer would have $13 \frac{3}{1}$ cents and the 8 cents extra tax that is put on, which would make 93 cents extra inducement for frand. He could easily take the uncolored prorluct to his cellar and work it over with the proper color. There is no law to prevent, and a ruling of the Department that would allow him to do so with safety. 
Mr. Tompkins. Why not put a revenuestamp on all of them, whether butter or oleomargarine?

Mr. KNighr. The first time the tax is attempted to be evaded you will find the Department down on him.

Mr. Schell. We insist that an adhesive stamp on each package, with a heavy penalty attached for obliterating it or taking it off, will rednce the whole fraudulent business to boarding houses and hotels. We do not clain anything more. All we want for the manufacturers is that the article be sold absolntely on its merits, so that the public will know what it is getting when it buys.

Senator HANSBRoUGH. In regard to the collection of the tax, I may as well read two or three lines from the House report:

liepresentative BAILEY. Do sou think that this law is enforced as well as any other interual-revenue law?

Commissioner WILson. Witb respect to eollecting the tax, better; with respect to the incilental matters, so far as the pure-food law is concerued, no.

Mr. INIGHT. That was the Commissioner's testimony before the House committee.

\section{ADDITIONAL STATEMENT OF MR. C. Y. KNIGHT.}

Senator HansBrotgh. The committee will listen to Mr. Kuight, for five minutes, 1 thiuk he sáid.

Mr. KNIGHT. 'To begin with, I will say that when process butter first came out and was being mannfactured there were, as Mr. Jelke read yesterday, a great many patents taken out for its making, just as there were when they first male olemargarine. Those same patents were brought out and are $110 \mathrm{w}$ on file at the Patent Oflice. 'The first process butter that was marle was maile from about as rank stuft, I suppose, as anybody conld conceive of. The goods were gathered up in the comntry, as they are now. But at that time they had lain a much longer time than is now eustomary. It was then the eustom of country storekeepers to keep everything lying around until they got a barrel full before sending it off. But to-day-I am telling the absolute truth, without prejulice in the matter-in the system of mannfacturing proeess butter it is not permitted to get out of condition, with rare exceptions. There is no doubt, as has been stated to the committee by a gentleman from P'hiladelphia, that there is some awful stuff that goes into process butter. They say that fat is not easily contaminated, and when it is once contaminated there never has been an acid discovered that will successfully bring it back. Yon can no more bring back dairy butter to its original sweet condition than yon can bring back contaminated fat of any kind. They have tried it. They have made experiments with alkalis, etc., but it only saponifies the fat, makes it soapy and fluffy, and takes the life out, so that it is soft like lard.

The butter is collected and taken to the central factories; there it is melted in a temperature from 102 to 120 o in large tanks by the use of hot water and steam. Those vats are placed on a slant; they are crisscrossed with pipes with hot water ruming through them, and the fit melts and is drawn off into a vat. That fat is left there in the vat so that the casein and water may be precipitated, leaving a clear amber oil on top, and taking the casein and water and salt out underneath. That water and salt and casein are drawn off from the bottom, leaving the elear oil on top. There are various methods for getting out what may remain in the shape of casein that does not precipitate immediately. The process used to be to leave that fat at a 
temperature of abont 102 and $103^{\circ}$ for two or three days, and then whatever residue would not precipitate was drawn from the top instead of the bottom to get the fat from the top. 'They have varions methods now for precipitating the casein, but those are business seerets. They are mechanical, not involving the use of acids at all. It is those matters that the manntacturers of process bntter keep secret-the methods of finally precipitating what remains of the casein in the body of the oil. I have been through a great many faetories in the United States, and seen their methods, one after the other, and was offered $\$ 5,000$ for a deseription of the method of clarifying the oil finally. Of course, it was given to me in confidence, and I rould as soon steal $\$ \overline{j, 000}$ from a man as I wonld give away his secret. But I give you my word of honor that there is 110 acid used in that clarifieation. It is simply a mechanical method which has been diseovered, the construction of which probably cost $\$ 5,060$ to $\$ 6,(000$. It is merely a centrifugal arrangement, but that centrifugal arrangment has been studied for years on the part of these people. But no acid is nsed for that purpose, so far as I lnow. It was always left for gravity to perform that function.

After that oil is elarified it is taken out and put into what is called an air-blast eliuru. I have forgotten what they eall those things. But it is a conical-shaped arrangement, holding probably 200 or 300 gallons of that oil, and with an air blast or an air pipe eoming from the bottom. They take, say, 100 gallons of milk which has been ripened, and then they put in an emulsion of 5no gallons of butter oil. Then the air is turued on at a pressure of 108 to 110 degrees, so as not to cool the liquid oil. That makes the most nearly perfect emnlsion. They have never been able to find so perfect an emulsion as the air blast. That mixes the butter oil and emulsion together and puts back into the bntter the casein and moisture taken ont by the precipitation as it was before melting.

After it is blown five or ten minntes with that air, so that the milk and oil are thoronghly mixed, it is dropped suddenly into ice water in tanks. The object of that ice is to bring back the grain into the butter, bocanse the minnte it was melted it lost its grain and looked like lard. In that condition it conld never go on the market at all, any more than oleomargarine wonld. So the grain is put back. When it is dropped into the water it congeals so quickly that the particles of milk and oil practically stick together. If any of you have been in a shot tower and seen how they (lrop lead from the top) of the tower into the bottom of the tank, that is the same process that is used here. The globules of milk congeal. Then they skim it off', take ont, salt, and work it. It does not need to be ehurned. It has been churned in that conieal-shaped concern.

After that it is salted and worked, and put up just as ordinary but. ter is.

I would say, in this commeetion, that the butter that is used in making that process butter is of valious grades. They have inspectors, who take ont the different grades of butter and classify it, and they make different grades of process lontter from the different grarles of dairy butter. With the finest grades of process butter they take the finest comntry butter, and they classify it into grades-first, seeond, and third grales. These butters that eome in are of all shapes and colors But they are all butters that are largely made in the summer time, so that they are largely of a natural color, and very little color is required to bring them up to the natural color, because the butter from 
which it is marle is of the natural color, or it has been artificially colored by the producer.

So that you see an anticolor law can not be made to apply to an article, which already has a natural color, that is put on the market. This process butter largely goes on the market in the winter. The stock is very largely bought up in the summer, frozen, and stored away. At the same time there is a good deal of winter butter. In the winter there are a good many people who ship their butter by rail, and there is a good dleal of butter that is not shipped in the summer because the higher prices of butter in the winter makes it desirable for people who do not make it in the summer to make it in the winter in certain sections of the country.

I am not here to tell you that no undesirable butter goes into process butter, because I know there is. I know there is some rank butter put into it. But the grades are classified as I have stated.

Senator DoLLIVER. What about its keeping?

Ir. KNIGIT. I do not think there is a great deal of difference between the process and the other butters in their keeping qualities. I have not discovered that there is. There was a time, for instance, in the making of process butter when the oil was kept three days in the tank to precipitate the brine.

Mr. SpRinger. Have you any means of knowing what relation the quantity of process butter bears to the whole quantity of butter?

Mr. KNigh'T. About three-fourths of 1 per cent. The amount of process butter last year was between $9,000,000$ and $10,000,000$ pounds.

Senator DoLliver. How does it sell on the market?

Mr. KNIGHT. The value of process butter is based entirely upon the value of the materials that enter into it. There is some margin, but I do not know how much: about 3 or 4 cents a pound I should judge. There is a considerable loss between the stock from which process butter is made and the mannfactured article for this reason, that the country butter usually contains a great amount of moisture and overloss, as we call it, and, then, butter that goes on the market is contaminated to some extent: so that where the original butter has 8.5 per cent of butter oil the butter by which process butter is made will contain only alont so per cent, so that there is a loss of $5 \mathrm{per}$ cent between the two articles in the way of shrinkage.

Senator Dolliver. Is the final product of the highest grade substantially equal, in market value and in the public estimation, to the creamery butter?

Mr. KNignt. There is a difference in price of 2 to 4 cents a pound usually.

Senator Doldryer. A re dealers deceived in it?

Mr. KNIGHT. I do not believe that jobbers are deceived in it at all, any more than they are in oleomargarine. I believe that every jobber knows every process butter manufactured in the Cnited States. I believe that to be true. I do not believe that there is one pound of process butter solil as process butter to where there are three or four pounds sold as butter alone. There has never been a distinction made in the general market between butter and butter. There are creamery butter, dairy butter, and different butters, but the consumer does not usually make the distinction. II goes and asks for butter, and if butter is shown him he buys it largely by his own judgment and taste. You never can get the melted taste ont of that butter. After butter is once melted it has that old taste, and an expert can always tell it.

Mr. SpRingER. I presented the other day a letter from Jolun F. Dab- 
ney, of Danville, Ill., who stated that he sold about 5,000 pounds of rancid butter on hand, the kind that is used in making process butter. That represents the amount in one county of Illinois. If he gatlered up that amount in one county the average amount gathered up in the whole State, of 100 counties, would probably amount to 500,000 pounds.

Mr. KNrGH'T. That is no criterion at all, because he may have a big trade in that county, and the other counties, many of them, might produce a very small amount of that kind of butter. Besides, the Thole amount of all the butter gathered up in the counties of Illinois does not go into process butter. They make their selections.

Mr. SpRINGER. Do the creameries take any of this?

Mr. KNIGHT. No; they do not do that at all-not one in a thousand.

Senator ALLEN. Much of it is worked over by dealers.

Mr. KNIGHT. That may be true.

Mr. JELKE. In the sale of this process butter is the retail dealer deceived or is the consumer deceived?

Mr. KNIGHT. That is something that I think you will have to investigate to find out. I want to say, in this connection and in connection with this bill, that I do believe consumers are sometimes deceived, and I will say frequently-led to believe that this process butter is creamery butter. That is one of the things that, when the Grout bill is passed and oleomargarine is a distinct product from butter, will tend to take away our business. If they can go out and convince the public that by getting this oleomargarine they have an absolutely pure product and that there is no danger of getting auy rancid butter or anything that is worked over, they have got to convince the public and prove to the public that when they are buying pure butter they are getting something which is wholesome.

Senator DoLLIVER. You agree with Secretary Wilson when he says-

Mr. KNIGH'. I agree with the Secretary when he says that something has got to be done. The anticolor law does not apply to it, because it is already colored by nature. How are you going to do it? We can not make a color distinction. I will say that the dairy interests are in faror of any kind of an internal revenue law that will reach it. We wonld be in favor of an auticolor law if the article were not already colored. These gentlemen here are howling abont a 10-rent tax. They know that if there was a 10 cent tax put on colored butter it would exclude all process butter.

Mr. Miller. We do not believe in unjust taxation of any kind.

Mr. SCHELL. Where is the most of this process butter made?

Mr. KNIGHT. There are factories in Philadelphia and in different parts of Penmsylvania; there are one or two in Baltimore, five or six in Chicago, two or three or four in Ohio, a few in Michigan, one or two in Iowa, one in Minnesota, some in Nebraska, and some in Kiansas.

Mr. MILler. Is it not a fact that most of it is made in Elgin, Ill.?

Mr. KNight. No; there is only one factory there. It has developed there a great deal in the last few years because the whole process has developed in that time.

Mr. Miller. I know that Weaver \& Barber, of Chicago, scour our conntry.

Senator DoLLIYER. I suppose that the general production of creamery butter has left the average poor farmer without any market.

Mr. KNigrT. Yes; that is true. That is a fact. I do not put this out as an algument in favor of butter. It is a fact that the manufacture of process butter has increased the price of the farmers' butter practically 
almost 100 per cent. It is worth from $\delta$ to 10 cents a pound more than it was. It is a fact also that the people used to eat this butter with the filth in it, whereas now the filth is taken ont of it, if it ever was in it; but whatever filth was in it used to be consumed.

Mr. JELKE. It is made on the farm.

Mr. KNIGHT. I want to point to another conclusion. I think you will all agree that butter made under any kind of favorable circumstances, where the cows have eaten the natural grass or prepared food, is better than butter that is left lying around and has become rancid aurl then sent to Chicago to be made into oleomargarine in the winter. Every year the retail dealer gets ont his oleomargarine license, and his cus. tomers, who have beeu buying butter all the time, suddenly change their minds, and he consernently does not bny any more butter at all. Onr butter piles in our cellars, stands there three or four weeks, depreciating from 3 to 5 cents on every pound; there is no sale for it. There is where there is a tremendons loss to the dairymen.

Senator DoLliver. That is a very interesting statement.

Mr. KNIGHT. I think I will have to tell you how I happened to go into the factories. Mr. Pierson, of the Agricultural Department, came ont W West and asked the maunfacturers of process butter to let lim inspect their plants. The process-butter makers did not want him to inspect their plants, for the reason that he was publishing bulletins of everything he had got hold of, and they did not want their secret in regard to their machinery to get out. But I was told that I might go through the factories at any time I wanted to, and that I might take all the time I wanted to. So I have been through the factories whenever I have wanted to. I have been though one of them a dozen times. I have got every process; I know every temperature that oil is subjected to; I know the details of every piece of machinery; I know every churn; I have seen the butter when it was put in there; I know everything from A to $Z$. I know it sufficiently so that I was offered $\$ 5,000$ for $\mathrm{my}$ information by a man who knew that that concern was making the finest kind of process butter in the country. I have been in other process factories besides that one.

Mr. Springer. Have you any means to suggest by which fraud upon consumers can be preventer in the sale to them of process butter when they think they are buring creamery butter?

Mr. KNIGH'T. The great trouble so fiur has been that the chemists have been muble to discern in their analyses the difference between process butter and creamery butter or any other kind. Butter is but. ter. The same kind of casein enters into both, the same kind of fat, the same kind of acid, the same amount of salt.

Senator DoLLIVER. Are these bacteria present?

Mr. KNight. Those worms occur in everything. Bacteria is life. Everything contains bacteria. Without bacteria there would be no flavor in anything. This culture you talk about, the more you have the better it is. Bacteria are used in the process of making process butter to give it an absolutely pure flavor, notwithstanding it is oftentimes an artificial tlavor. It is introduced there to give a uniformed flavor; aud at the same time it is a mild flavor. It is nothing more nor less than that.

Mr. Tompins. If the people knew that, they would have as much prejudice against it as they would have against oleomargarine.

Mr. KNIGHT. I do not think so, because all fermentation is a growth. of bacteria. Let me explain to you about this, gentlemen. There are bacteria and bacteria, all kinds of bacteria. Bacteria are in the air. 
Bacteria are in milk. They enter the milk fiom the air as soon as it comes from the cow, and start a growth which predominates until the milk comes up to that state of ripeness when it is fit to churu. The idea of pnre culture is that we get normal bacteria, and we try to keep all others ont of that milk. For instance, milk may be Pastenrized, or taken to the creamery and skimmed before there is any bacteriological development in there. Then the bacteria have such strength that they multiply and occupy the whole field and erowi ont all others, and in that way we get a desirable flavor that is pleasant and uniform. The best plan of producing flavor is to take the milk of a mem cow, Pasteurize it, sterilize it, and use that as a basis for the growth of this eulture: put it in there becanse there are no other bacteria then in there; and then you cultivate your germ: then churn it into the newly slimmed cream, and that goes through it and starts the bacterial growth which makes it of uniform tlavor. 'That process is used for the purpose of obtaining a nniform flavor, as nniformity is resirable in all other things.

Senator HANsBrougi. How are bacteria cultivated in limburger clicese?

Mr. KNighr. It is a bacterial giowth.

Senator Hansbrocgh. Of course, I understand that, but I ask the question seriously.

Senator DOLLIVER. It certainly is not microscopic.

Nr. TonpKins. It is parallel with oleomargarine. Everybody admits that it is wholesome. I quite agree that it is not nuwholesome. But I think that if the public had to be informed that it is necessary for butter to be impregnated with bacteria the public would be prejudiced against that butter. We need a process of bacterial puritication. Colonel Waring, of New York, has invented such a process. I have seen him take the worst sort of sewage and pnt it through his purifying process, and as the water came out at the other end the resichual product was perfectly pure, and l have seen him drink it withont prejudice, but I think the public would object to that. At the same time that water, after its purification by his process, is better water than the cities furnish, provided the process be carried far enongh. I acknowledge it is offensive to see a man drink it, much less drink it yourself. Prejurlices apply to all these processes, even if the result obtained is perfect. It is nothing but prejudice. But in another case where that sentiment and prejudice exist, if you make a requirement against one you ouglit to make it against the other.

Mr. KNIGHT. Let me tell you something about these bacteria, which you say are an artificial cnlture. It is not necessary to nse them. Exactly the same results can be obtained from skimmed milk. There is not one creamery in a hundred that uses them.

Mr. TompKIss. That might do in making butter, but they do use it, and there is a prejuclice against it.

Mr. KNight. I want to take issue on that, because I an in the butter trade and am the publisher of a paper devoted to the business. I do not believe there is any such prejulice. The amount of the artificial culture is merely a clrop in a tincupful.

Mr. Tompkins. How many basteria are there in a drop?

Mr. KNIGIT. There might be $4.000,(000$. There is nothing there but the milk. 'That (lop) starts the whole thing and the lest is derelopment.

The committee adjourned until Siturday, Jannary 12. 1901, at 10.30 a. 111 . 
Comititee on Agriculture and Forestry, United STATES Senate, Washington, D. C., January 12, 1901.

The committee met at 10.30 a. $\mathrm{m}$.

Present: Senators Proctor (chairman), Money, Dolliver, Bate, and Hansbrongh; also, Charles Y. Knight, secretary National Dairy Union; Mr. Sehell, Mr. Miller, Mr. Jelke, and others.

The CHamman. It there is anybody who desires to go on this morning, he may proceed.

\section{STATEMENT OF GEORGE E. PAUL, OF PHILADELPHIA, PA.}

Mr. PAUL. Gentlemen, to start with, I will have to give my experience as a dealer in butter, oleomargarine, ete., from the time that I started in business in Philadelphia. I started in the produce business in Philadelphia in 1871. At that time, or prior to that, I was a merchant in Ohio, shipping large quantities of butter to Philadelphia. That quality of butter was eagerly sought after in the Philadelphia market at that time. The Philadelphia market was a peculiar market, accepting rolls and prints as the principal butter. The different colored butter that was eoming onto the market at that time was from fresh-milked cows, and also from green-fed cattle. Other cattle that were not fed so well produced white butter.

Senator Money. You had several grades of color?

Mr. PAUl. Yes, sir.

Senator MoNEY. In natural butter?

Mr. Pavl. Natural butter; yes, sir.

Senator IIONEY. Which shade was the dominant color?

Mr. PAUL. White.

Senator Money. White was the predominant shade?

Mr. PAul. I'es, sir.

Senator Money. White would be called the color of butter, then?

Mr. PAUL. Yes, sir; and that butter was eagerly sought after in that time of the year back in the early seventies. Of course later on we had a butter prodnced in New York State that was held from summer until spring, which was. pretty highly colored, owing to the grass-ferl cattle. Thiat butter is practically out of the market at the present time, owing to the existence of creameries. Solid packed butter, which is the predominant butter of the WVest, was never songht alter in the Philadelphia markets, and yet to this day prints and rolls are the principal butter in Philadelphia. Nearby butter in the neighborhood of Pliladelphia is the very tine butter made in the United States. We do not except anything.

Senator UONEY. What do you mean by prints and rolls?

MIr. PAUl. Prints are 1-pound packages. which were put up by the farmer's' wives, and they used to bring them into the market and sell them to the different gentlemen for their fine butter.

Senator MoNEY. What are the rolls?

Mr. PAUL. One pound, "-pound-any sized roll of comtry butter.

Senator Money. It is the same butter?

Mr. PAUL. The same butter; yes, sir. This grille of butter coutinued coming along to the market for quite a while; but on account of a proportion of poor butter from the West coming in there, it became difficult to dispose of this butter at a profit to the people who purchased it. On the top of the packages there would probably be good rolls, and in the bottom and in the center there would be white, cheesy, and 
milky rolls whieh lost to the purehaser more than they made of good butter that was on top of the packages.

In the spring of the year, as I have been saying, we had this New York State butter, that had been speculated in and held over, and the holding of that butter had producerl a peculiar tlavor. We used to eall it a fishy flavor. A bout the years 1877,1878 , or 1379 oleomargarine was introdnced in the market. It was uniform in color, uniform iu size of packages, and uniform in rolls. It was very nice, fine-looking goods, sweet and fresh as the summer-made goods. It drove that class of butter out of the market; and I may say that class of butter was finally driven into the creameries that are in existence at the present time.

Senator MoNkY. I do not want to interrupt you, so as to canse you to lose the thread of your argmment, but I want information on this subject. What became of that butter? You say it was driven ont of the market. Where did it go?

Mr. PAUL. Those small dairies were driven into the creameries. They delivered the milk to the creameries.

Senator IIONEY. The material went into the creameries?

Mr. PaUl. Yes, sir; the milk went into the creameries. The introduction of oleomargarine showed these people that the people of the eomntry wanted something fresh and sweet all the time; that they did not want summer butter palmed off on them in winter as fresh butter. People had been accustomed to that old flavor or taste, but at the present time you can not get people to eat it. There is a sort of butyric acid arises in old butter, and while it is not strong in flavor, it has a sort of nanseating taste. After you eat it it produces gas, and a sort of fishy, nasty taste will arise from it. That class of butter is practically driven ont of the market by the introrluction of oleomargarine.

That continued, as I said before, and we were large shippers of this Ohin butter, shipping probably 50,000 pounds of Ohio rolled butter into the market. I was sent to Ohio as a representative of our firm to sell our goods. Of course it was my disposition to do all I possibly could to place our butter on the market and receive the very highest price for it. I continned along in that line of business until 1851, practically breaking up the men that I sold butter to, aud breaking up the people that I sold butter for, for the simple reason that these people in the country, when they would bring their butter to the markets, would expect to sell it.

The woman who used to bring the ponrest butter to the market was the best customer at our store. We conld not discriminate and say to Mrs. Jones, "Your butter is not so good as Mrs. Smith's, and we will have to discriminate and give yon 5 cents a pound less for your butter than what Mrs. Smith receives." Therefore onr butter was sent to the market in all these conceivable shapes and styles, the good, bad, and indifferent together. I continued in this kind of business until 1881. In 1881 I went to the National Butter and Cheese Makers' Assoeiation, at Nilwankee, and was placed on the committee there with a gentleman from Wisconsin, and another one from Boston, I think, to examine the different qualities of butter, etc. I came back to Chicago and stopped one day in an establishment manufacturing oleomargarine. I asked for a consignment of oleomargarine. At that time they were sending goods in consignments. The gentleman asked me whether we were selling oleomargarine. I told him no, and I explained my situation exactly. I told him the quality of onr butter was such that we were compelled to get something that would give satisfaction to the trade, give satisfaction to the poor people, and afford a profit to the 
people who were selling these goods. He said he would be very glad to ship me some of the goorls. Since then 1 have been a seller of oleomargarine in the city of Philadelphia-since 1881 continuously, except probably a few months when the law was so severe that I had to quit.

senator MoNkY. What law?

Mr. PAUL. Onr State law. The State law, though, from 1881 to 1885 was of no accomnt at all. The gentlemen who were here the other day representing the butter interests were the largest handlers of oleomargarine at that time. From 1851, probably, to 1855 the competition in oleomargarine becane so great and the profit became so small that these people who are fighting olenmargarine to-day were the canse of having the national law made at that time. It was not made for the regulation of oleomargarine, but it was made to drive it out entirely. They puta a - cent tax on the product and a license of $\$ 600$ for the manufacturing of the goods, $\$ 180$ for the wholesaler and $\$ 48$ for the retailer; and no man wanted to go into the business. Very ferv of the conmission men of our state pay that much rent for their buildings, for their storerooms. They can not afford to do so, on account of their expenses and the smallness of their profits, etc. The competition of oleomargarine had becone so great that there was very little profit in it. They thought they would drive it ont by putting on this excessive tax, as they called it at that time. A prohibitory law was passed in Penusyliania, but they believed that law was unconstitutional, and some of them continued along until 18s6. When the 1886 United States internal-revenue law went into effect we immediately took ont a license there and commenced selling oleomargarine as the Chicago Butterine Company of Philadelphia, and we have continned from that time up to the present time. We have sold it for what it was. The people have bought it for what it was. We had been harassed on the street by these men continually.

Senator Moner. In what way?

Mr. PAUL. By bringing suits against is under the State law.

Mr. KNIGH'T. Mr. l'aul, will you pardon an interluption?

Mr. PAUL. Tes, sir.

Mr. KNIGHT. Were you not violating the state law?

Mr. Paul. Yes, sir; the prohibitury law; but we believed it unconstitutional.

Mr. KNrent. Had not the courts prononneed it constitutional?

Mr. PAIL. No, sir: they had not.

Mr. Kinghi. What law was that?

Mr. Paul. The State law of Pennsylvania.

Mr. KNIGHT. Passerl at what time?

Mr. PAt'L. Passed in 1885 or 1886, I don't know which.

Mr. KNight. The courts have since passed on it and pronounced it constitutional, have they not?

Mr. PAUL. No, sir.

Mr. KNight. Did not the Pennsylvania court pass on it?

Mr. PAUl. No, sir.

Senator Money. How many States have legislated on this subject? Can you tell me that, Mr. Knight?

11r. Kinight. Thirty-two States hare the anticolor law. I was under the inpression that the supreme conrt of Pennsylrania had passed on the law Mr. Paul refers to.

Mr. Paul. I will come to that. In 1889 they forced this to an issue, under this State law. The first package we sold in 1889 was sold to a detective. I recollect when the gentleman came into our 
store. He let on that he was a huckster. He came in tapping his leg, ete., and asked me if we were selling oleomargarine. I said we were. I turued him over to my brother, and my brother said: "1)o you want to buy some goods?" He said lie did. He bonght one package, and immediately suit was brought on that first package of goods that we sold. The case was decided agininst us before the magistrate, and was carried up to the common pleas court, before Jndwe lieed, of Philatelphia. 'The decision was hauded down in December, 1S!n, in our tavor, showing that the interstate commerce law was constitutional, andallowing the original package to be brought into the State of l'ennsylvania and to be sold for what it was, in the shape and size that was regulated by the internal-revenue law. T'his resulted in a good trade for us. Immediately two of the firms who were before you last week took out their special license and commenced selling the goods. They were quite prominent houses in Philadelphia. They commenced selling goods quite freely until in the month of April, 189(), this organization of people who had been fighting us considered that the law was unconstitutional. and they immediately went to Chicago-two of the prominent firms who were here, and two of the prominent firms we were fighting, and they were also officer's of the Butter Protective Association, I believe it is called. They went to Chicago and called together the mannfacturers of Chicago and asked them if they would allow them to sell their product in Philadelphia. They showed to them where they would be able to dispose of a great many goods. They got the right to sell the goods as distributing agent.

One of these other parties who had taken out a special license, when he found he had to buy his goods wholesale through the agents in I'hiladelphia, immediately went to work to enforce the State prohibitory law. During the months of April and May I suppose there were fifty or seventy-five retail licenses taken ont through the influence of these other gentlemen who had gone to Chicago. This one old gentleman became incensed because he had to buy his goods through the agents in Philadelphia, who were his enemies in business. He came to me in my office, and he said to me, " Mr. Paul, must I buy my goods from you people and from these other people who have been appointer here as distributing agents in Pliladelphia?" I said, "The understanding is we are to be the wholesale ayents for these goods here in this market at the present time until the market gets settled, and we are to give up) all our jobbing interests. We must sell our goods to the wholesale trade." He said, "I woull willingly buy my goods from you, but if I have got to buy iny goods from these other people who have been my friends, I will go in and figlit them to the teeth. If ron were standing in the middle of the street, and those people were on the other side of the street," said he, "if I luave got to knock you down I am going to knock you down. I am going to bring suit right away against you, and I am going to carry it up to the higher courts." Immerliately suit was brought against $\mathrm{ns}$, with the same result, before Judge Hare, who is considered one of the best constitutional judges we had in Philadelphia.

Mr. KNIGHT. What year was that?

Mr. PAUL. I think it was in 1891. That case was carried into the State supreme court; but other suits had been brought against other persons who came in a fter that-for instance, Mr. Schollenbarger. Then our attorneys and the Butter Protective Association and the State's attorueys agreed on a case stated, taling up first the Schollenbarger case, although the Paul case, or the Chicago Butterine Company case, was also taken up at the same time. Mr. Schollenbarger's name being 
first on the list, he got the preference, and the case is known as the Schollenbarger case. The supreme court of the State of Peunsylvania decided adversely to us.

Mr. KNIGHT. It decided the State law to be constitutional?

Mr. PAUL. It rlecided the State law was constitutional. We carried that case to the Supreme Court of the United States. In the meantime they persecuted our firm to the extent of 41 cases. These same men who were down here talking against oleomargarine had been sellers of oleomargarine up to that time; but because they could not just buy it as they expected to buy it they commenced to persecute us.

Senator Moner. You mean prosecute, do you not?

Mr. Paul. Y'es; but it was persecution.

Mr. KNIGHT. That was after the supreme court of your State had declared the law constitutional?

Mr. PAUl. It was after the supreme court had decided that the law was constitutional, and after that time until we carried that case to the Supreme Court of the United States we located on the other side of the river, in Camden. We remained in Camden nearly two years, until our case was decided in our favor in the Supreme Court of the United States. Then we immediately brought our goods back and we commenced to sell oleomargarine for what it was. Then they went before the legislature at Harrisburg and had a law passed taxing the manufacturers of oleomargarine $\$ 1,000$ as a State license, taxing the wholesaler $\$ 500$ in addition to the United States tax, the retailer $\$ 100$, the restaurant keeper and hotel keeper $\$ 50$, and the poor butterine-honse keeper, $\$ 10$; but they did not stop at that. They went to work and said, "You dare not sell it colored in imitation of butter." We believed that law to be just as monstitutional as the former law, and therefore we were selling the goods to the trade.

Mr. KNIGHT. Mr. Paul, you maintain, do you, that you do not have to comply with a law until it has been passed on by the Supreme Court of the United States?

Mr. PAUL. Well, we consider that we have the right to sell these goods.

Senator MoNer. I do not think that qnestion is admissible here. It does not have any effect or bearing on this question before us.

Mr. KNIGHT. It only brings out the attitude of dealers in oleomar. garine in connection with the laws, Senator. The facts are that any law that we have passed attempting to regulate the traffic is carried to the Supreme Court, and it is absolutely ignored and defied until we get it through the Supreme Court of the United States, as a rule, and they claim to be persecuted if they are prosecuted nuder those laws.

Senator MoNer. I understand that, but still it is a matter which is perfectly immaterial to the discussion here.

Mr. JELKE. Do you call a law which imposes upon a retail dealer in a corner grocery a special tax of $\$ 100$ a law to regulate the sale of oleomargarine or to prolibit it?

Mr. KNIGHT. That would be for the courts to pass on, Mr. Jelke.

Senator Money. We will have no time to hear these colloquies. You will have to talk about them on the outside. We want to hear the witness here, with only such interruptions as are pertinent to this case.

Mr. KNIGHT. I thought it was pertinent to bring out that point, because that has been our trouble, right in that very commection.

Senator MoNer. That does not make a bit of difference.

Mr. PAUL. The animas which was exhibited in this whole business was on the part of people who had been violators of the law in the extreme. This one person I had in my mind was going about the streets 
of Philadelphia making bets of $\$ 100$ that he would send me to prison, and giving $\$ 5$ for the bets. He was betting people to a standstill. He could get very few bets, because they all thought. I was violating this law aud that I would finally be sent to prison. Of course he brought as many suits as he possibly eould. I think there were 41 cases against us standing on the rlocket when the case was called in the United States Supreme Court as to our right to sell goods in the original package.

I went to Harrisburg after this regulative law and the uncolored law were passed. I went before the dairy commissioner and asked him-I said: "In regard to that part of the law which refers to coloring oleomargarine like butter, I want to say that butter has no color." I said: "You have been tanght to color butter by the oleo people. We believe that part of the law unconstitutional. Do you intend to enforce that, if men sell oleo for oleo?" He said: "We can best find that out by going aeross to the attorney-general." I said: "I want to sell oleomargarine, but I do not want to be luarassed any more like I liave been for the past teu years iu Philadelplia."

I went with him over to the attorney-general and we had a talk with the attorney general. He saicl: "Mr. Panl, it is a matter of opinion whether that law is constitutional or not, but we will try a ease in Harrisburg, onc in Pittsburg, and one in Philadelphia. If the cases are deciled in our favor they will be carried to the higher courts, and if they are decided adversely to you you will liave to quit selling oleomargarine." We went to work and took ont our license. We went to our tracle and told them just exactly the situation of aftairs. They immediately took out their retail tax in the State, and also the Uniterl States lieense, and commeneed selling the goods. I am tolıl that they had an income of at least $\$ 60,000$ last year in the State of Pennsylvania for State licenses, even with that embargo of color on it.

Now, I want to say this, gentlemen. If you drive oleomargarine out by this excessive tax of 10 cents a pound on colored goods, you will drive the manufacturing of butter baek in to the same old rut in which it was in 1870 and 1871 and 1872 , and on up to 1881 . You will drive the creamery system out of existenee. They have been taught how to make fine butter by the introduction of oleomargarine. The price of butter is sueh at the present time that it pays the farmer very well for what he is getting for his milk and eream. If this Grout bill becomes a law the farmers of the eountry will commenee making butter in a slipshod way.

Senator Money. I do not understand exaetly how, if oleomargarine were driven out of business, the creamery business would be suppressed as the best way to make butter and the farmers get a good return.

Mr. PAUL. For the simple reason that on aecount of competition among the trade, among the business people, among the mannfacturers of process butter, who are aetive and energetie, more so than farmers, they will be bidding higher prices for this renovated butter, mueh higher than the priees for milk and eream that can be made into ereamery butter during' the summer months. This butter will be held from the summer until the fall and winter in cold-storage places and then remilked, rechurned, and brought onto the market again. The first ereameries that were started got exorbitant prices for their butter in the early seventies, but they did not get sufficient to carry on the busi. ness. I believe the first prize awarded at the Centennial at Philadelphia was to Mr. Stewart, of Iowa, and he finally failed in business beeause he could not get suffieient goods at the time for the manufacture of ereamery butter.

Senator MoNEY. He could not get milk and cream enough?

$$
\text { S. Rep. } 2043-35
$$


Mr. PAUL. He could not get milk and cream enough to make butter enough to continue his business.

Senator MonEY. The price has gone ul, has it?

Mr. PAUL. No; the price lias come down, but at the same time everything else has come down in proportion, so that they are getting a very good price for their butter.

Senatol Monex. Do you sell butter now?

Mr. PAUL. Yes, sir; as a commission merchant. I am selling kutter, eggs, and cheese.

Senator Money. Yon sell both butter and oleomargarine?

Mr. Paut. Yes, sir.

If oleomargarine is legislated out of existence by an excessive tax you will destroy the creamery system of the United States. It will be a step backward, because the renovated butter system will become the butter of the day. My reasous for saying so are that during the summer months, or when butter is cheaj), butter will then be made, as I said before, in any slipslıorl way and held for better prices through the winter season, and renovated, and forced on the pnblic as butter. It will so cripple the creameries now in existence that they will be forced to retire or adopt that plan of making their butter. I believe that the creameries will finally have to adopt the system of making butter as the process-butter people are doing at the plesent time if this law is passed, because there will be no money in creamery butter.

Oleomargarine does not affect fine butter. It, however, drives poor butter out of existence, or makes poor butter makers, owing to the low price they receive, sell their milk and cream to the creamery men. The creamery men had better stop fighting oleo, because it is their best friend. What we want is fancy butter for those who can afford to pay for it, and we want oleomargarine as the butter for the poor man. A creamery man who can not make better butter than oleomargarine had better retire.

Senator MoNEY. The testimony here by gentlemen on your side has been that you can not tell the difference; and Senator Allen said he had been eating oleomargarine here all winter and did not know it.

Mr. PAUL. That probably is taste with some people, but a fiue butter is the finest thing that goes into a man's stomach. There is so much of it, however, that is not fine that these people want to foist onto the public as fine butter.

Senator ALLEN. How can a man tell whether he is eating poor butter or oleomargarine?

Mr. PAUl. On the same principle-how can a man tell that an egg is counterfeit?

Seuator MoNEY. I suppose that I have eaten pounds of oleomargarine, but I never knew it. I don't know that I ever ate a mouthful of it, but they tell me since I have been here I am eating it all the time, although I am boarding at the Senate restanrant, the best restaurant in town.

Mr. PAUL. I would not eat it on my table; I will tell you that.

Senator MoNEY. Could you tell wliether it was butter or not?

Mr. PAUL. Yes, sir; I can tell. In 1893 I took a trip West with my little family, and after we left Denver the butter that was on the table was not fit to eat. Where we got oleomargarine it was all right. I stopper in a certain hotel in one of the Western cities, and when we sat down at the table I said to my daughter, "Helen, this is oleo." She said: "Well, it is a plagued sight better than the butter we had down at Pueblo." So that is the difference. People will not consume so much poor butter. For instance, in my little family at home, consist- 
ing of my wife and daughter and one servant and myself, we consume on our table 3 pounds of butter per week, the very finest that I can get, because I like fine butter, and because I believe I can afford to pay for it; but if I could not I wonld buy fine oleomargarine.

If we have oleomargarine with the regulative law now enforced by the United States, and the States repeal their useless prohibitory and nomsensical color laws, you will find competition will force dealers to sell oleomargariue for what it is. I claim tlat competition will do all this if you will allow the people to sell the goods. When a retailer must pay 145 a year to sell oleomargarine, as he must in Pliladelphia, and a wholesaler must pay $\$ 980$ a year, there are always chances for a man to commit frand under those circumstances. If a 10 cent tax is put on thire is much more chance for frand.

Senator MoNEY. Of conrse we can not regulate the State legislation. That is a subject we can not deal with.

Mr. PauL. I understand that.

It is impossible to sell uncolored oleomargarine or uncolored butter for the table or for family use at the present time. We have a regulative uncolored law in the State of Pennsylvania, with an excessive State tax, which, so far as selling uncolored oleo is concerned, is prohibitory. For ourselves I would say that the proportion of uncolored oleo that we sell at the present time is about 1 pound to 1,000 pounds of colored oleomargarine.

Senator MONEY. How would it be as to the uncolored butter and colored butter?

Mr. PAUL. We can not sell uncolored butter for any other purpose than for baking purposes.

Senator MoNEY. I do not care what it is for. What would be the proportion of uncolored and colored butter that you would sell? You have given us the proportion of colored and uncolored oleomargarine. What would be the proportion of colored and uncolored butter?

Mr. PaUL. There is just about that proportion of uncolored butter comiug into the market-about 1 pound in 1,000 pounds.

Senator MoNEY. It is all sold, is it?

Mr. PaUl. Yes, sir. Ion see, it is all colored in the factories.

Senator MoNey. I mean all the uncolored butter is sold?

Mr. PAUL. The uncolored butter is bought up by the manufacturers of process butter. They are the best buyers of uncolored butter at the present time. They are the best buyers we have.

Senator MoNEY. I meant to the consumer.

Mr. PAUL. The consumer will not buy uncolored butter any more. A few cracker bakers may buy it. As I stated yesterday, what constitutes first-class butter on the I'hiladelphia market, according to the Philadelphia Produce Exchange, is this: Forty-five points in flavor, 25 in body, 15 in color, 10 in salt, and 5 in general appearance, making 100 points. Now, by referring to this memoranlum of the annual report of the Philadelphia Produce Exchange of Jauuary, 1900, extras in the way of creamery butter show an average of 95 points, or higher. There is required 15 per cent to make that butter extra by being colored. If 15 per cent was taken out of that butter it conld not be sold at-

Senator MoNer. You mean below the present prices?

Mr. Paul. Yes.

Senator MoNEY. I confess I do not understand your grading there. Mr. Paul. These are official reports.

Senator MoNEY. I know, but I do not understand what you mean by butter having so many points. 
Mr. PAUL. It is in relation to making sales of butter on the Philadelphia Produce Exchange. The butter is examined by a gentlemau who has been appointed for that pnrpose-an inspector.

Senator MoNEY. You mean that 100 is the best quality?

Mr. Paul. Yes, sir.

Senator MIONEY. One hundred is taken as a basis, and the flavor would rount as 45 points?

Mr PAUL. Yes, sir; in quality. Then it must bave 25 per cent in body, in texture. 'That refer's to its being firm, elastic, etc. 'Then it must have 15 points in color. If you had mixed goods-that is, if you had a lot of loutter that was mixed in color-it would be graded down.

I have not the prices for last year. They have not been compiled yet; but this is from the Philadelphia Produce Exchange report for January, 190(), giving the highest and lowest price of fine butter during the different months of the year. Those prices are as follows: In January, 189!, the lighest prive was 20 ceuts and the lowest price 19 cents for Penusylvania goods. The same prices prevailed on Western goods. In February the prices were 20 ('ents aud 1!) cents; in March, 20.2 cents and 20 cents; in April, 2.11 cents and 17. cents; in May, 19! cents and $17 \frac{1}{2}$ cents; in June, 19 cents and 18 cents; in $.1 n l y, 19$ cents and $18 \frac{1}{2}$ cents; in Angust, 21 rents and $18 \frac{1}{3}$ cents; in September, 23 cents and 21 cents; in October, 24 cents and 23 cents; in November, 27 cents and $24 \frac{1}{2}$ cents; in December, $28, \frac{1}{2}$ cents and 27 cents.

These are the official prices of butter on the Philadelphia Produce Exchange dnring the year 1r99. The prices for Western butter were the same-an average of about $2: 3$ cents per pound for the highest and $20 \frac{1}{4}$ cents for the lowest. making an averace of alnost "22! cents per pound during the entire year.

Senator Moner. Have you the oleomargarine list there?

Mr. PAUL. No, sir; I liave not.

Mr. KNIGI'1. Mr. Paul, is there any published market price on oleomargarine? In any market reports that you can find, is there any regular quoted price for oleomargarine?

Mr. PAUL. I will answer that question by saying that the exchanges are dominated by butter people. and they will not allow the price of oleomargarine to be posted up.

Mr. KNIGHT. But I mean in the newspapers.

Mr. PAUL. Of course they do not get it from anybody. They do not inquire for it, and they do not want it.

Senator MonEY. It is like certain stocks that are not listed. It is sold on the curb.

Mr. PAUL. This goes to show that the amount of oleomargarine being sold in Philadelphia causes a good price to be received for butter in all seasons of the year. The State of Pennsylvania manufactures abont $90,000,000$ pounds of butter a year. The state consumes about $: 00,000,000$ pounds a year. According to the statistics in the Revemue Department there are between $11,000,000$ and $12,000,000$ pound s of oleomargarine sold in the State of Pennsylvania in a year. Therefore there are between $90,0(10,000$ and $100,0(00,000$ pounds of foreign butter that comes into the State of Pennsylvania to supply the demands of that State alone.

Senator BATE. How do you get at that fact?

Mr. Paul. From the State board of agriculture at Harrisburg.

Senator BATE. It is estimated, I suppose?

Mr. PAUL. I smppose it is estimated; yes, sir.

Senator Mloney. They get the returus on it?

Mr. PAul. They get the returns from the Interual Revenue Department on oleomargariue. 
Senator Money. Have you any figures about New York? That is a great bntter State.

Mr. PAUL. I liave not. We think we have got a very good State for making butter. We claim that we make the best butter in the world right around Philadelphia. They are getting $\$ 1$ a pound around Philadelphia, the year round, for their butter, and fiom $\$ 1$ down to 75 and 55 and 35 cents.

Senator Muney. It is the same thing in New Tork and, I believe, in Vermont and Massachusetts.

Mr. KNIGHT. I think the $90,000,000$ pounds is based on the census of 1890 .

Mr. PAUL. I have never figured that out. That is from the department of agrieulture at Harrisburg.

Mr. KNIGHT. We have nothing from this census yet.

Mr. Miller. I liave the agricultural statement here. It does not include the last ten years, but I would like to read the figures showing the increase in the amonnt of butter produced. The total amount of butter made in the United States in 1850 was $313,345,000$ pounds; in $1860,41 ! 1,681,000$ pounds; in $1870,514,092,000$ pounds; in 1880 , $S 06,77:, 000$ pounds; in $1890,1,205,508,000$ pounds; and from an estimate made by the Secretary of Agriculture the other day the production for 1900 will be $1,50(1,000$ pounds, showing a steady inerease since 1850 .

Mr. PaUl. It is impossible to furnish eheap butter to supply the working classes of Philadelphia, or any other city, unless they use oleomargarine. The working people of the agrieultural district of Pennsylvania-in the part of the country where I was brought up, near Carlisie, Cumberland County-on an average do not make $\$ 100$ a year.

Senator MoNEY. What do you mean by working people-the farm laborers?

Mr. Paul. Yes. sir; the farm laborers. Machinery has driven the laborer out of existence almost.

Senator Money. Somebody has to work the machines.

Mr. PAUL. Yes; but you do not require as many of them as were required to do the mannal labor. For instance, you nsed to go into a prosperous little village and you would find a shoemaker and two or three blacksmiths and a carpenter. You would find a miller and a boot and shoe makel and a tailor. Those men have gone out of existence mactically. You will find cobblers there. These people are compelled to buy butter at these exorbitant prices, and they can hardly afford to do it.

Senator Hanserough. Is the proportion of idle men in that conmunity any greater now than it was ten or twenty or twenty-five years ago?

Mr. Paul. Yes, sir.

Senator HANsBough. There are more idle men?

Mr. Paul. Yes, sir; more idle men.

Senator HANsBrougr. Is there not a greater demand for labor now than there was then?

Mr. PAUl. No, sir; there is very little. A great many of the men of that country are going into the cities.

Mr. Schell. I do not think Mr. l'aul just understood the question. I think he wishes in his reply to state, if 1 may interrupt him-

Mr. Paul. Certainly.

Mr. Schell. That there is not the demand for libor in these localities that there was years ago, and that there consequently would be 
more idle men; that they have been shifted to other centers where they found employment. Is that correct?

Mr. Paul. Yes, sir.

Senator BATE. As a matter of fact, machinery has done away with manual labor to a certain extent.

Senator HANSBRough. Still the proportion that is employed to-day is greater than it was in years past? There are more hands at work thronghout the country, generally speaking, than there were ten or twenty or twenty-five years ago?

Senator MONEY. The popnlation has donbled in that time.

Senator Hansbrougir. I am speaking proportionately, Senator.

Mr. PAUL 'The proportion of poor laborers, both in the cities and in the country, is alarmingly great. I have made the suggestion there in Philadelphia that if I were to advertise for 5,000 men at $\$ 1$ a day, 360 days work in the year, the next morning $I$ would have the streets in frout of my place crowded so much that nobody conld get into the place. For instance, a few year's ago I wanted to distribute a lot of circulars, and I put an advertisement in the paper, "Wanted-Persons to address :-0,000 envelopes," and asking them to state the price they would address them for. In the next morning's mail I harl 286 answers, offering to do it at from 10 to 55 cents a thousand. That will show you the amount of labor that is unemployed.

Mr. KNIGHT. The displacing of a pound of butter by a pound of oleomargarine drives labor from the farms to the eity, does it not?

Mr. PaUl. No, sir; it does not.

Mr. KNight. Why not?

Mr. PAUl. For the simple reason that they have to have as much labor on the farm as they had before to milk their cows.

Mr. KNIGHT. If you take the business of making butter from the farm and transfer it to the oleomargarine factory in the city, where is your laborer employed?

Mr. Paul. Yon ilo not transfer it to the oleomargarine interests. You transfer that butter in the shape of milk to the creameries.

Mr. KNight. But your oleomargarine smpplants the creamery butter.

MIr. PAUl. No, sir; it does not supplant creamery butter. It only supplants poor butter. We do not ask as much for oleomargarine as is paid for creamery butter.

Senator Money. What do you get for your oleomargarine? There seems to be three grarles of it. What do yon get for it?

Mr. PAUL. We are handling the high-grade goorls, and we sell the goods at 15 cents a ponud.

Senator MoneY. Is that the best you have?

Mr. PAUl. Yes, sir.

Senator Moner. What is the next best?

Mr. PAUL. There are grades of oleo that are sold as low as 10 cents a pound.

Senator Moner. But yon only handle the first-class goods?

Mr. l'aUl. Yes, sir.

Senator HANSBRoUgh. The best grade sells for 15 cents a pound wholesale?

Mr. PAul. Yes, sir.

Senatol HansBrougri. Yon sell to the retailer?

Mr. Yaul. Yes, sir.

Senator HANSBRougr. Can you give us an idea of how much they get at retail per pound?

Mr. PAUL. They are selling those goods at about 20 to 22 cents per pound as olemmargarine. 
Senator MONEY. What is the finest grade of butter worth in your market? I mean the creamery butter, not that fancy stuff that comes and is sold, as you say, at $\$ 1$.

Mr. PACL. A fancy creamery butter has been selling in the neigh. borhood of 26 to 28 cents all winter. The last two weeks we have had a slump in the market and prices are down to 23 or 24 cents.

Mr. KNight. What was it a year ago?

Mr. PAUL. I think about the same price.

Mr. KNight. Twenty-three or 24 cents?

Mr. PAUL. I think it was higher than that, 26 or 27 cents; but the proportion of oleomargarine sold then was larger than it is at the present time.

Mr. KNight. I presume that is true. I do not know what the statisties are.

Mr. Paul. Yes, sir. Whenever butter is high, we are selling more oleo. Whenever butter is low, we are selling less oleo, so that whenever they have a low-priced butter they attribute it to the oleomargarine sold in the market, but that is not the case. Whenever there is a good market for butter, we have a good market for oleomargarine.

Senator MoNEY. What you want the committee to understand is that the eloser oleomargarine and butter get in price the more the people prefer the butter?

Mr. Paul. Certainly.

Senator Moner. But as the difference gets willer, they have to get the oleomargarine becanse they can not pay for the butter?

Mr. PAUL. Certainly; that is it exactly.

Mr. KNIGHT. Is it not a fact that when a man starts in to milk a cow and she is fresh for the year, he has got to go through and milk her anyhow, no inatter what the price is?

Mr. PAUL. Of course they milk their cows.

Mr KNIGHT. If he goes through one year and butter is only 14 cents a pound, does he not get disgusted and say the next year he will not milk cows?

Mr. PAul. They do not in our country.

Mr. KNight. They do out in our comntry; and the next year, when he quits milking his cows and the supply of butter is short, up goes the price. and he can not get a fresh cow in the middle of the season to proluce that butter with.

Mr. PAUl. Do you not consider the price quoted hereas a very good price for ereamery butter?

Mr. KNIGHT. What is that?

Mr. 'AUL. An average of about 21 cents the year romd. Do you not consider that a good, paying price?

Mr. KNIGIIT. It has not been that for some time.

Mr. PAUL. This is the second year. This last year it is higher thall that.

Mr. KNIGHT. We have got the statistics right here for a number of year's.

Mr. PaUL. I will ask you whether you do not consider it a very good price?

Mr. KNIGHT. I think 21 cents might be a very good average price, but it has not run that way.

Senator HaNsBrough. What is there for us this afternoon? Is there anyborly else to appear on your side this afternoon, $11 \mathrm{r}$. Schell?

Mr. Schell. I do not know, Senator. I understood that Secretary Gage had been notified to appear. 
The Chamman. He has not answered, but he may come MIonday. There are none of you to be heard, you say?

Mr. ScheLL. There are none that I know of.

The Chairian. Then we will consider the hearings closed except as to Secretary Gage.

Mr. Miller. There are one or two gentlemen who would like to be heard on Monday.

The CHAIRIAN. Have they anything different from what you have alrearly said?

Mr. MILLER. I think they have; yes, sir.

(The committee, at 12 m., adjomrned until Monday, January 14, 1901, at 10.30 a. 11 .)

MONDAY, January 1.t, 1901.

Tlie committee met at 10.30 o'clock a. m.

Present: Senator's Proctor (chairman), Hansbrongh, Foster, Money, Allen, and Dolliver.

Also, Charies Y. Knight, secretary of the National Dairy Union; Hon. Willian M. Springer, of Springfield, Ill., representing the National Live Stock Association; Frank W. Tillinghast, representing the Vermont Manufacturing Company of Provilence, R. I.; Charles E. Scliell, representing the Ohio Butterine Company, of Sincinnati. Ohio; John F. Jelke, representing Bram \& Fitts, of Uhicago, Ill.; W. E. Miller, representing Armour \& Co., Kansas City, Mo., and others.

(In response to an inquiry by the chairmin, the gentlemen present stated that they knew of no one who had not yet alpeared before the committee who desired to be beard by it on the pending bill.)

\section{ADDITIONAL STATEMENT OF CHARLES Y. KNIGHT.}

Mr. KNigh't. I have something here in the shape of documentary evidence to which I would like to eall the attention of the committee.

The Acting Chairman (Senator Allen). File it with the reporter.

Mr. KNignt. I can hardly file this, can I, Senator? It is very voluminous. I thought I wonld simply call your attention to the material parts of it, and let them go into the record.

The ACTri CHAIRMAN. What is it?

Ir. KNIGHT. There was a question betwcen Mr. Jelke and me here last Thursiay. I stated that his firm, Brimn \& Fitts, defended certain cases which I had brought against dealers in the city of Ohicago for selling oleomargarine as butter. He denied it. I stated that I knew that his man, Lowrie, was on the bonds of those people, and had continually gone on the bonds of those people, and appeared in court every day. He denied that, as the recold will show. I further made the statement that I had communicated with this man Lowrie over the telephone regarding the matter, and that I knew he had been on their bonds. That was disputed.

Now, I have here the original bonds of A. M. Wright, who was prosecuted for selling oleomargarine for butter.

The ACting CHairian. These are sureties on appearance bonds?

IIr. KNiGHT. Yes; on appearance bonds.

The Acting Chaminan. How many are there of them?

Mr. KNIGHT. There are four. I liave the originals here in four cases.

The Acting Chairifan. Does Mr. Lowrie's name apjear upon those bonds?

Mr. Kxignt. Mr. Lowrie's name appears upon these bonds five or 
six times each, in continuances, having been there at each hearing. What is more, Mr. Lowrie's name appears upon the bouds where that man was prosecuted for selling oleomargarine for butter.

Senator DoLliver. You refer to this "pure grass" butter man"

Mr. KNight. Yes; and the evidence was that he had handled noth. ing but oleomargarine. When he came into conrt the last time, either Mr. Lowrie or his agent went on his bond, and I have the original bond right here. There it is-"William Broadwell." There are the papers in that case.

Mr. JELKE. Was that a prosecution for selling oleomargarine for butter, Mr. Knight?

Mr. KNIGHT. Here is what the record says: "Broadwell. Selling oleomargarine as butter." Look at that. I would like to have the committee look at it aud observe it. And that is on all these bonds here-"Selling oleomargurine as butter." Here is another one of A. M. Wright's bonds that he is on.

Mr. JELKE. What was done with those cases? Were the parties convicted for selling oleomargarine as butter?

Mr. KNIGHT. The facts in the cases were never denied. The defendants nerer raised the point that they did not sell oleomargarine as butter, as was alleged.

(Senator Proctor resumed the chair as chairman of the committee.)

Senator ALLEN. I think Mr. Knight's only object in referring to this matter was to show that Mr. Lowrie, as a matter of tact, signed these bonds.

Mr. KNight (to Mr. Jelke). You disputed the fact.

Mr. JELKE. I would like to have Mr. Lowrie heald on that matter. I am unt sufficiently fimiliar with the details to discuss it myself. I know that Mr. Lowrie had no instructions from our company to rlefend any dealer for selling oleomargarine as butter, and has never had. I can state that positively.

Mr. KNight. Well, he did it, at any rate.

Mr. JuLKE. How many of those bonds are there altugether?

Mr. KNIGHT. I lave the originals lıere in four cases. Mr. Lowrie appenred on these bonds a number of times. Not ouly that, but here is the number. Let me give you the dates, please, Senator; because I regard this as being somewhat important.

Mr. ScHELL. Those are merely continuances.

Mr. KNight. Yes; but I simply want to show the number of times he appeared on those bonds.

Senator Horer. What is the use of doing that when everybody admits that it is trile?

Mr. KNight. Well, all right; I will let it go at that.

Senator Moner. It is admitted that it was done. Tou have the proof there.

Mr. KNight. But Mr. Jelke denied that this was done.

Now, in that connection I want to state that two of these are eases where Brann \& Fitts's agent appeared on the bouds, and two are cases where Willian J. Moxley \& Co.'s agent appeared on the bonds. And I will say that, according to information which I think is trustworthy, those two concerms made (luring the month of December, 1S!)9, one-third of all the oleomargarine manufactured in the United States. Their combined product was $3,(6)(0,000)$ pounds, whereas the combined produet of the whole 26 mantacturers of oleomargarine who were in the business at that time was $111,(10(), 00()$. So that these two concerns which have been backing mp these defenses are making pretty nearly 33 per cent of all the oleomargarine that is made. 
Senator Allen. I understand, Senator Proctor, that the hearings are substantially closed, muless the Secretary of the Treasury desires to be heard.

The Chairiran. Yes.

Mr. JELKE. If Mr. Knight is through, I would like to submit a couple of telegrams which I have received in regard to what was called the Produce Exchange, of Cincinnati, alleged communications from which were presented here by Mr. Knight.

Mr. KNIGHT. No; I beg your pardon; they came to the chairman of the committee.

Mr. JLLKE. Oh, was that it?

Mr. KNIGHT. Y'es.

Mr. JELKE At any rate, in regard to this "Prodnce Exchange" of Cincinuati, I would like to submit these two telegrams, which it will only take a moment to rear. The first is from my father. He is a man 71 years of age, and is getting too far along in life to nse any deception, if it were ever necessary for anybody to do so [reading]:

There is no bona fide produce exchange in Cincinnati. Some years ago it was abandoned and merged in Chamber Commerce. Rerently two attempts were made to have Chamber of Commerce indorse Gront bill. Both voted down. Then a few butter dealers, acting muder foreign iustructions, organized this fake exchange, for the sole purpose of making a false showing of snpport to Grout bill.

This is a telegram from the superintendent of the Cincinnati Chamber of Commerce, Charles B. Murray :

Replying to inquiry, there is no prodnce exchange in this eity. The Chamber of Commerce boarl of directors adopted expressions opposing Gront bill tax of 10 cents on colored oleomirgarine.

Now, Mr. Kuight, what irlea have you as to how much oleomargarine we or anyone else conld sell if the police power of the States is invested absolntely in them by Congress to regulate this trañic, whereas they, in 32 States, have prohibited the sale of eolored oleomargarine?

Mr. KNIGHT. I think you wonld sell just as much as you have any legal right to sell. That is the only way I can answer that question, Mr. Jelke, not knowing the fignres.

Mr. JELKE. Bnt yon seem to intimate that if we paid the 10 cents a pound tax you would allow us to sell it.

Mr. KNIGIIT. If tre had some way to keep you people from doing what is not the proper thing and the right thing to do-forming a conspiracy to violate these laws, or, rather, to defend those who violate them-we would have very little tronble. The ordinary retailer, when he is prosecnted, would very soon obey the law if you people did not come back of him with all of your capital and all of your attorneys and all your guirantees.

Mir. JELKE. 'I'hat is yonr opinion.

Mr. KNIGH'. That is my opinion of it. Now, as I have the floor, I just want to say a few words in connection with another statement that was contradicted here. This is a letter from the Chicago Butter and Egg Board. I will read it.

Chicago Butter ani Ega Boalid, Chicago, January 1\%, 1901.

At the regnlar meeting of the Chicage Butter and Egg Board, held .Iannary 12, 1901, the following statement was presented by George IV. Limn, president of the Illinois Dairy Union, and generally clisenssed by the members of the board, and by a munimons vote it was declared to he the sentiment of the individual members, as nearly every member has been familiar with the unfair and nnlawful methods pursued by the dealers in oleomargarine for years. 
Cinicago, Janucry 12, 1901.

Whereas wo are informed by newspaper reports and other sources that the manufacturers of oleomargarine are inclined to deny the assertion of the officers of the National Dairy Union that the retail trade sell oleomargarine almost exclusively as butter; and

Whereas from onr long experience in competition with this class of goods we have repeatedly and continually been brought face to face with the fact that fully 75 per cent, and possibly as high as 95 per cent, goes to the consumer as pure butter, we, as an organization and as individuals, desire to go on recorcl as corroborating the statement made in that particular by the officers of the National Dairy Union.

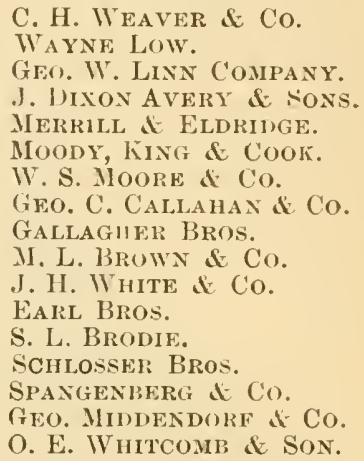

Mr. JELKe. Mr. Knight, is it not a fact that C. H. Weaver \& Co., who signed that statement, are one of the largest, if not the largest, manufacturers of process butter in the United States?

Mr. KNIGHT. Yes, sir; and so far as I know they are not violating any law. I desire also to read you this quotation from the market report of Saturday, January 12, 1901. This is the official report of the Chicago market, published by Howard, Bartels \& Co., and is used by the butter trade generally.

Receipts May 1. 1896, to Jannary 16, 1897, 1,083,130.

A demoralized feeling was shown at the closing of the week and prices some 2 to 3 cents lower. All the week trade has dragged very slowly, anil receivers were unable to close ont their consignments. Goods kept piling up-not very freely, but to a greater extent than dealers cared to have on their hands. The home trate was not sufficient to make any impression on the stock, and there has been scarcely any order demand. The receipts have been fair and show some increase over last week, but comprised a greater proportion of roll aud packing stock, which came forward more freely. Other markets have all ruled dull and weaker, and possibly this accounts for the increased receipts Lere.

It has not been so much a matter of price as it has been to sell. Of conrse dealers wisherl to sustain the market as long as they conld, but they dails nudersold the quotations when they had an opportunity to sell.

To-day the market was dull, and fiurther concessions were made by holders to effect sales. Dealers believe the only way to place the market on a solid basis is to make prices that will enahle them to clean up late accumulations and to enconrage buying or at least consumption.

It is generally admitted by lealers that the demoralized condition of the butter market at present is dne to the nse of butterine. Dealers estimaterl that at least 75 per cent of the retailers are selling butterine.

Mr. Miller. Is it not a fact that the open weather accomis for the dull butterine aud butter business?

Mr. KNight. The open weather? I do not know, Mr. Miller.

Mr. Miller. Well, it is a fact.

Mr. KNight. Now, I would like to ask for information regarding the condition of the matter between Collector Coyne and myself. There has been some testimony sent out to Mr. Coyne for him to pass upon, I believe. 
Senator Allen. That statement was sent out the other day. I sup. pose a response will be made.

Mr. KNIGHT. I am not going to be in Washington all the time, and I do not know what course Mr. Coyne will take. But in case there is any answer made, I have a statement here which I will not read, but which I will leave with the committee. I do not ask that it shall go into the report.

Senator Allen. Hand it to the clerk, then.

Mr. KNIGHT (after complying with Senator Allen's request). I have here a number of statistics and facts-not arguments, or anything ontside of facts-that I should like to file with the committee. Here, for instance, are some facts which you gentlemen will want-a detailed statement of the number of oleomargarine dealers in the various States, for instance, and the number who are doing business in States where it is contrary to law to sell colored oleomargarine, and the number who are doing business in States where it is legal to do it. There are quite a number of other things here which I think the committee will find of value.

Senator DoLliver. What is the basis of your statistics?

Mr. KNigit. The Goverument reports. All of them come from Gov. ernment reports.

Senator Money. We will get that information from official sources, Mr. Kuight, and would very much rather have it in that way.

Mr. KNIGHT. These figures are from official sources.

Senator Money. I know it; but they come throngh you. We would rather have them through the regular official channel. We are at liberty to call on the Departments for all the information they have, you know.

Mr. KNight. The only thing was that I wanted to call attention to those things here.

Senator MoneY. That may be.

Mr. KNIGHT. I will at least ask permission to file this map [exhibiting map], to be printed in the proceedings. There is a diagram there showing the price of butter, and a map showing the laws of various States.

Senator DOLLIVER. Is that official?

Mr. Knight. One is from Senator Mason's report and the other is from the Agricultural Department. They are both official. Here is a resolution passed by the Chicago Butter and Egg Board.

Senator AlLEN. Will inserting these things delay the printing of this report?

Mr. KNignT. No, Senator. I think you will find that they are all made up and in the possession of the Government Printing Office.

[The papers referred to above are as follows:] 
OLEOMARGARINE.

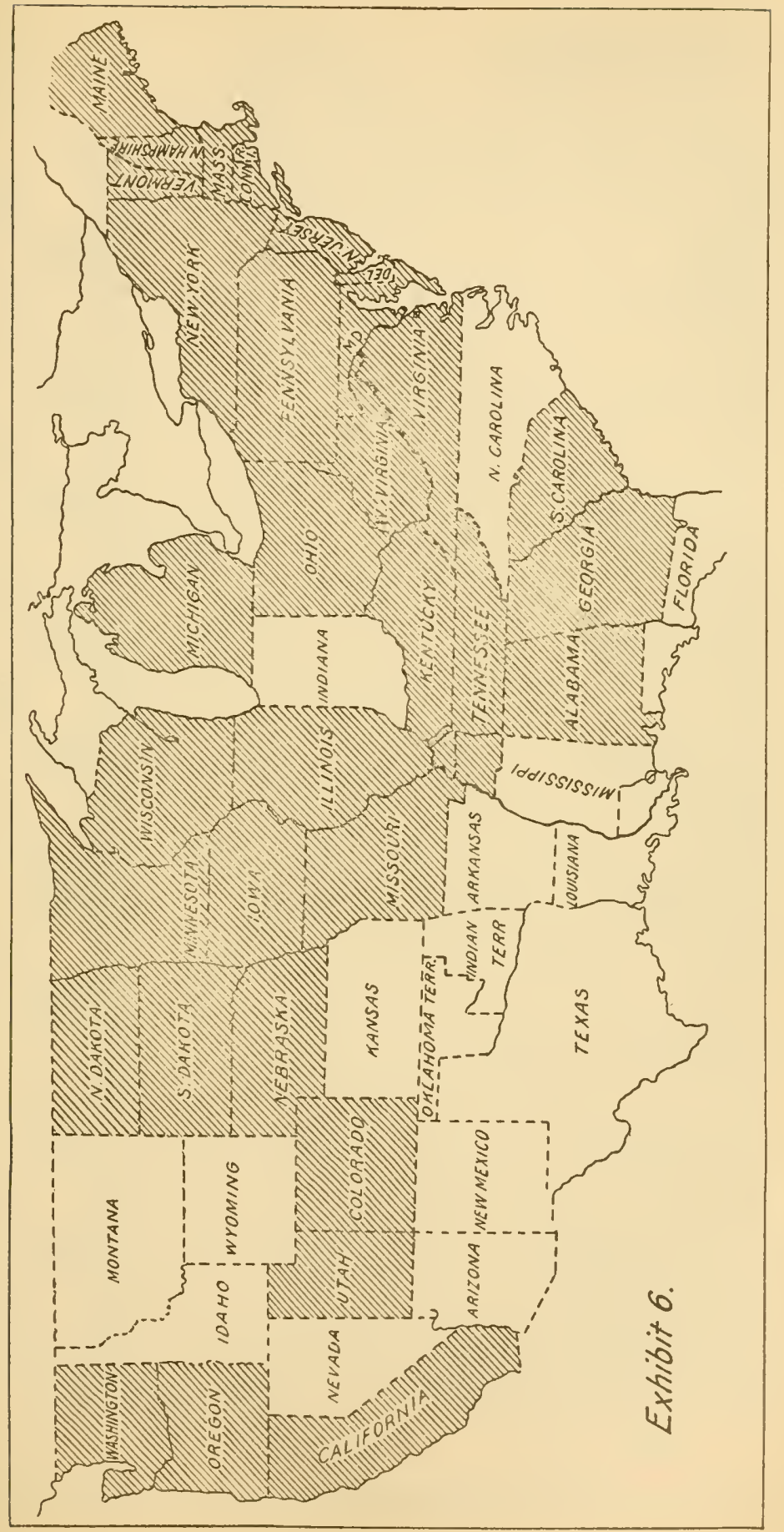




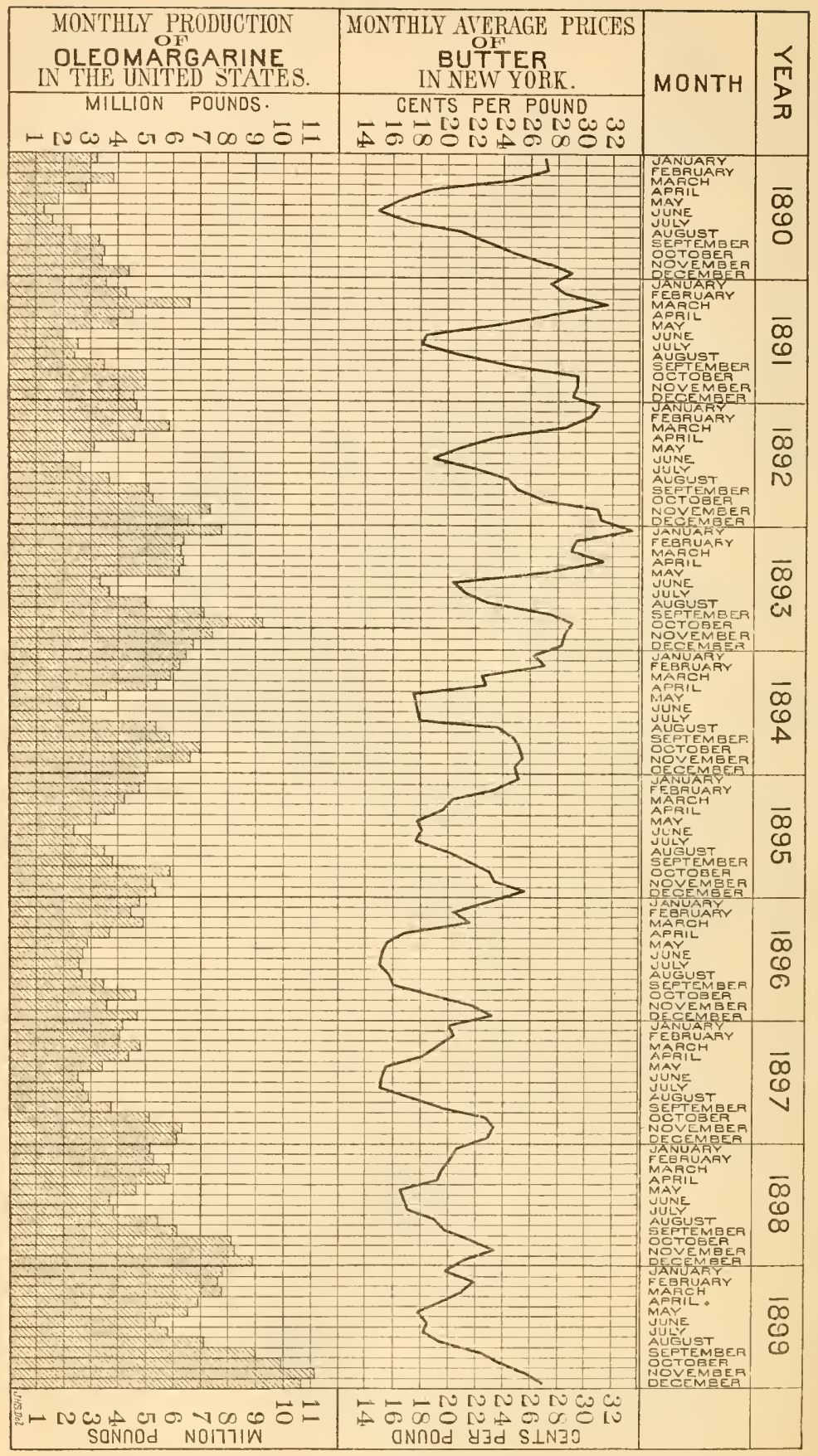

FIG. 15.-Diagram showing monthly average prices of butter and total monthly production of oleo. margarine for the years 1890 to 1899 . 
Now, there is another matter that has been in question here. Mr. Miller made the statement to you that some $41 \%$ or 50 pounds of oleo oil eame from the caul fat of a steer. I have here Iowa Agricultural Bulletin No. 20, showing the weight of 18 fatted steers fed at that station, and the amount of canl fit therein, as taken out by Swift \& Co., of Chicago, and reporterl to i) irector James Wilson, now Secretary of Agriculture. That bulletin shows that the average amount of caul fat in steer's weighing on an average 1,508 pounds wals 37.66 pounds. The statement made before the Agricultural Committee of the Senate-

Senator Allen. That is a pretty good steer.

Mr. KNight. The statement made before the Senate Committee on Agriculture in 1886 by Elmer E. Washburu, a live-stock dealer in Chicago, showed that from 148,593 heal of cattle slanghtered in that eity by one of the largest packing eoncerns, there was an average of 61.5 pounds of tat in those animals used in oleo oil; and that those 61.5 pounds made 28.1 pounds of oleo oil, which goes to prove that there is less than 1 pound of oleo oil to 2 pounds of fit.

The oleomirgarine people, in all of their claims before this committee and in other places, have stated that the fat used from the steer or cattle was only the fattest and choieest caul fat; and Mr. Miller made the statement to you that if they used any other it would be tallowy.

According to this report of Secretary Wilson, there are on an average but 37.66 pounds of caul fat to the steer of 1,508 pounds, and it is well known that cattle that are marketed will not average over 1,200 ponnds. That would be a heavy average, would it not?

Senator AlLen. I should think it would be'a full average, at least.

Mr. KNignt. Under those eircumstances, l think you can go to the bottom of the thing, and find that they can not make more than 15 pounds of oleo oil from the caul fat of the average animal. Counting 15 pounds to the average animal, and counting $5,000,000$ eattle slaughtered last year, they have recourse to caul fat for the making of but $75,000,000$ pounds of oleo oil. There were $142,000,000$ pounds of oleo oil exported, and $24,4110,000$ pounds used in oleomargarine, a total, I think, of over $166.000,000$ pounds, with a capracity of but $75,000,000$ pounds of oleo oil from caul fat.

Senator Dolliver. I supposed they used all the fat.

MIr. KNIGHT. They inust do it in order to get out everything, I should say. Now, those are simply statisties, gentlemen.

Senator DolLIVER. Would that lift them out entirely?

Mr. KNight. Not at 28 pounds to the head; no, sir.

Senator AlLen. Many of these animals, as I understand, are calves and other animals that have not much fat in them.

Mr. KNight. On an average, according to Mr. Washburn's statement, they get an average of 28.1 pounds of oleo oil from each animal.

Mr. Miller. That was one special lot.

Mr. KNIGHT. Oh, no. One hundred and forty-seven thousand head. Senator Money. Whose report is that?

Mr. KNIGHT. That is the report of EImer E. Washburn, a live-stock dealer of Chicago, who appeared on behalf of the oleomargarine makers. It is in that reeord.

Senator MIONEY. I suppose you want to discredit that report by those figures, do you?

Mr. KNIGHT. No; I am not diserediting it at all.

Senator MONEY. Oh, yes; you make it 15 pounds, and he says it is 28 . 
Mr. KNight. No; I say caul fat. He does not say canl fat. He has some figures there giving the amount of oleo oil made from those animals at $2 \$ .1$ pomuds. Now, if you can get 25.1 pounds of oleo oil direct from the animal, from $5,000,000$ animals you are getting $140,000,000$ pounds. But we have records of $166,000,000$ pounds which are used. Now, where does it come from?

Mr. Scheld. Well, we are willing to have the matter investigated.

Mr. KNIGHT. Oh, rather than have it investigated, I will cut ont the whole thing, on acconnt of time. I do not propose to put in anything here that is going to continne these hearings.

Senator lloney. You are entirely willing to conclude the hearings, provided you have the last word?

Mr. KNiGHT. Oh, no.

Senator MoneY. Whenever anyborly has made a speech on the other side you have come in here with a whole lot of fresh matter. That is what you have been doing all the time. After it has been announced that your side has closed, and the majority of the committee has voted to close the hearings, and every time anybody else said anything, you came out here with a lot of new matter; and then you want the pro. ceedings closed.

Mr. KNihg'T. Ol, no.

Senator Moner. That is a fact; that is the record of the committee. Now, I have not the slightest objection to hearing everything you have to say. You have brought ont some very interesting inatter there. But, still, it is a fact that you happen to be here, and you take the floor and bring ont a lot of new things and then propose to shut down on the investigation.

Mr. KNIGHT. No; I made the statement before the committee that if what I said was to prolong the hearings, I would shut off' right away.

Senator Money. Yon never shnt off as long as anybody says anything on the other side; I have noticed that. Now, you can give us all the information you have. I am willing to stay here and listen to you for a week; but-

"r. KNight. Well, Senator, will yon put to the committee the suggestion that I made regarding the condensation or the briefing of this testimony?

Senator Allen. I think the committee will take up this matter and edit it. I have no doubt the chairman will attend to that.

Senator Money. As Senator Allen very truthfully said, an immense amonnt of what has been said here is merely cumulative evidence. The same things have been stated over and over again by the people on both sides.

Mr. KNIGHT. I suggested, Senator Proctor, that we should take up on onr side the testimony which has been submitted, and point out our strong points. My suggestion was that we should make it in the shape of an index rather than a brief, and not make an argument at all, but simply call attention to the facts which we claimed to have proven. It was my ide:ı to state the different points we made, and under those heads to gronp the statements of the people who have appeared here and adiressed your conmittee.

The CHAIRMAN. That would facilitate matters very much indeed, I think.

[After informal diseussion it was agreed, and so announced by the chairman, that after the printing of the testimony both sides wonld be expected, within a reasonable time, to brief the case according to their 
respective views, calling attention to those particular parts of the tes. timony deemed important.]

Mr. Knight agreed to present, in due time, the views of his side in favor of the bill. Mr. Schell agreed, for his clients, to tiuruish a brief résumé of the proceedings before the committee, and to furnish a brief on the constitutional questions involved, as he had theretofore promised members of the committee.

It was therempon anmomeed by the chaiman that after the honora. ble Secretary of the Tieasury and Hon. James IV. Wadsworth, a nember of the Honse of Representatives, should have been heard, the hearings on the pending bill would be closed.

The committee tlıereupon, at 11.40 o'clock, took a recess until 12.15 o'clock 1. m.

At the expiration of the recess the committee resumed its session. Present: Senators Hansbrough (acting chairman), Warren, Foster, Bate, Money, Heitfeld, Allen, and Dolliver.

Also, Charles Y. Knight, secretary of the National Dairy Union; Hon. William II. Springer, of Springfield, Ill., representing the National Live Stock Association; Frank W. Tillingluast, lepresenting the Vermont Manufacturing Compauy, of Providence, R. I.; Charles E. Schell, representing the Ohio Butterine Company, of Cincinnati, Ohio; John F.Jelke, representing Braun \& Fitts, Chicago, Ill.; W. E. Miller, representing Armour \& Co., Kansas City, Mo., and others.

\section{STATEMENT OF HON. LYMAN J. GAGE, SECRETARY OF THE TREASURY.}

The Acting Chairman (Senator Hansbrotgh). Gentlemen of the committee, Secretary Gage was invited to appear before the committee to answer some questious that were to be put by Senator Money, I understand.

Senator Moner. No; I do not care to trouble the Secretary. I merely asked that he be invited here, as the Secretary of the 'Treasury, to express (if he saw fit.) his views on the pending bill, which is a revenue measure. At all events, it purports to be a revenue measure.

Senator BATE. Of course you have s'en the bill, Mr. Secretary.

Secretary GAGE. Yes, sir. I always respond to the invitations of the committees, whether it is agreeable or not. I would prefer to answer questions, if any gentleman wishes to ask them. If, however, you wish me to state my views of the bill, I can do so very brietly.

Senator ALLEN. I should think that would be better, Mir. Secretary. We should be very glad to hear your views of the bill.

Secretary GAGE. Of conrse I only feel at liberty to state my views as the Secretary of the Treasury, and only upon that part of the bill which involves the question of revenue. I might have personal views which go far beyond those; but you would probably not care much about them.

There is, in my opinion, an objection to the bill on either theory. If it is a revenue producer, it is superflnous; we clo not need it. If it is not a revenue producer, then the title of the bill is a misnomer, and it is inoperative in the name of revenue. It seems to me that on either theory there are serious objections to it.

I think that covers all I care to say directly on the subject.

Senator MoNEY. That is pretty good.

Senator Foster. It is right to the point, Mr. Secretary.

$$
\text { S. Rep. } 20 \pm 3-36
$$


Senator Allen. Have you some statistical matter there, Mr. Secretary, which you desire to submit?

Secretary GaGE. No, sir.

The de 'ilng Chairman. Do any members of the committe desire to ask tlie Secretary any questions?

Senator Foster. I suppose the points you have made bear directly on the question of revenue, and not at all on the merits of the bill otherwise?

Secretary Gage. So far, I have not expressed any views on the merits of the bill.

Senator MoNEY. You only speak of it as a revenue measure?

Secretary GaGE. Only as a revenue measure.

The Acring Chairian. Mr. Secretary, can you tell us what has been the experience, in a general way, of your Department in the collection of the revenue on oleomargarine? You know, of course, that there is now a "2-cent tax on it.

Secretary G $\Delta$ GE. Yes, sir; I think the revenue is well collected. There las been considerable discussion of that subject between the Commissioner of Internal Revenue (especially Commissioner Wilson) and myself, at different times; and we think we are cheated to some extent, as we are in all revenue matters.

The AC'TING CHAIRMAN. There is bound to be a certain percentage of loss, of colluse.

Secretury GAGE. There is bound to be a certain percentage of loss. That is evidenced by the fact that we receive "conscience money" from people who say they have detranded the revenue department, and it has come to be a matter of conscience with them.

Senator Fos'IER. Then you think there is "moonshine butterine" made?

Secretary (iAGE. Undonbtedly. Judging by the best means of information we liave (and we have to guess at it to some extent, for, of course, the unknown is not knowu) we estimate that we are cheated out of perhajes 7 or $S$ per cent of the revenue.

Senator ALLEN. I suppose there is no surplus in the conscience fund, is there?

Secretary GAGE. No; and there verer will be. |Laughter.] That is the only fund which will never be troubled with a surplus.

Senator MoNEY. In collecting other revenue taxes, like that on whisky, for instance, is the loss as great as on oleomargarine?

Secretary G $\triangle$ GE. Yes; I should suppose it is about the same percentage. That loss occurs mostly in the "moonshining" business. In the large establishments it is probable that the tax is absoiutely and fully collecter.

Senator BATE. Then I suppose the losses in oleomargarine internalrevenue collections are about on a jar with the losses in all other revenue collections?

Secretary GAGE. Well, they are on a par with the losses in most of the revenue collections. There is not any great disparity.

The Acting Chairinan. Mr. Secretary, what about the percentage of prosecutions, as compared with the prosecutions in other lines?

Secretary GAGE. Offenses against the oleomargariue interual revenue law are as vigorously prosecuted as any of the other offenses against the reveuue laws, when they come to our knowledge. It is the duty of the collector of internal revenue in each district to use his agents and inspect as thoroughly and carefully as he cau the manufacturers of oleomargarine and dealers in it, and to see that they are paying the 
revenue. Complaints frequently come to us that they are passing it off as butter. We always inquire into such matters. While the internal revenue department dloes not consider itself clotherl with police duties, exactly (its duty being to collect the revenne), we pursue all cases of persons violating the regulations in regard to stamping and marking the product when they are brought to our attention; and there have been a grent many prosecutions.

I have here a letter which I picked up this morning, dated November 24,1900, which illustrates something. It is a letter fiom one of our agents in Cleveland, Ohio, addressed to Commissioner Wilson. This agent was directed to inquire into the realings of a certain gentleman in a small Ohio town, because the report of one of the manufacturers of butterine set forth sales to this gentleman, whom we will call Mr. Brown for the purposes of the illustration. You know, gentlemen, that all of the manufacturers have to report their entire siles to the Department; and the report of this particular mannfacturer came along, showing the sale of :20 pounds of butterine, in three dillerent lots, to this Mr. Brown, in this town in Uhio. Mr. Brown harl no license to sell butterine, and we made an investigation. We found that he was not selling butterine, but was simply orleling it for sundry persons, in their behalf, and orlering it to be sent to them direct for consumption. Now, it is a somewhat singular fact that these parties for whom Mr. Brown acted were all dealers in milk, and were selling all their milk to Mr. Brown, who was in the cheese business.

Senator AlLEN. Mr. Secretary, was that a mere cover, or was it a bona fide transaction upıou Mr. Brown's part?

Secretary GAGE. Oh, it was entirely in good faith. Mr. Brown lived in this village, and these milk dealers brought him all their milk, and they wanted butterine.

Senator Alden. Of course you will recognize the fact that if Mr. Brown, in collusion with these other parties, was simply resorting to that device as a method of avoiding the tax law, he would be guilty of violating the tax law and should be prosecuted?

Secretary GAGE. Oh, yes. He did not retail the butterine; he made no protit on it. He simply acted in their behalf.

The acting Charrman. Were the parties for whom he acted in the retail bnsiness, or simply consumers?

Secretary GAGE. They were simply consumers-farmers.

Senator ALLEN. Is your inspecting force in these districts adequate to investigate and proserute these cases?

Secretary GAGE. Well, fairly so. We have a good many of what are called revenue agents miler the collectors of internal revenue. They pay attention to all the departments of revenue. We do not have special agents to inquire into the butterine business who are separate and distinct from the agents who look after violations of other branches of revenue.

The Acting Cinarran. No; I understand that.

Secretary GAGE. They watch the tobacco dealer; they watch the whisky dealer; they watch the brewer; and they watch the oleomargarine man. They plan to cover them all, and to drop in and inspect, and catch them if they can.

Senator AlLEN. They depend largely on outside sources for their information, do they not?

Secretary GıGE. A good deal. They get a good many "tips" from the outside. 
The Acting Chairman. Your revenue agents, Mr. Secretary, are expected to visit these factories and to take observations with respect to the quality of the ingredients coustituting oleomargarine, are they not?

Secretary GaGe. Yes, sir.

The Acting Chairian. What are their opportunities for observation in that direction?

Secretary GAGE. Oh, they are ample in these large establishments. They are all open to onr agents.

Senator BA't'E. Have you scientific inspectors to investigate what the component parts of this product are?

Secretary GAGE. No; I do not think we have. We put it to the test frequently, however. We get samples and have aualyses made of the product. That is to say, we have done so in the past; I do not know what we are doing just at this moment.

Senator Allen. Your agents, however, are not all experts in the examination of oleomargarine, are they?

Secretary GaGE. Oh, no-no.

Senator AlLEN. So that they might be imposed upon, as well as the ordinary intelligent citizen?

Secretary (iAgE. Very easily.

Senator Allen. They might walk into a place and call for butter, and oleomargarine might be handed to them as butter; and unless they took it to some person competent to make an analysis of it, they might not know the difference?

Secretary Gagr. That is quite true.

Senator BATE. Do you keep agents at any of these large establishments?

Secretary GAGE. I do not think we do keep any regular watch on them.

Senator Allen. Yon take the same precautions respecting this article that you do regarding liquors?

Secretary GaGE. Except that we do keep gaugers-men who gange the quantities of liquor-or storekeepers, in the bonded warehouses. We go a little further with the liquors, because the temptation to evade the law is immensely greater.

Senator Allken. Then you do not keep such agents in these large establishments which manufacture oleomargarine?

Secretary GAGE. No.

Senator MONEY. These storekeepers take note of the quantity of liquor made, do they?

Secretary GAGE. They take simply the proof and the quantity.

Senator Allen. Of course the liquor can not go ont without the consent of the Government?

Secretary GAGE. No, sir; but the tax on liquor is $\$ 1.10$ a gallon, while that on butterine is 2 cents per pound, so that the temptation is very much greater in the one case than in the other.

Senator Allen. The only thing with which you are concerned is the tax?

Secretary GAGE. That is the main thing, of course.

Senator Money. The remark you have just made, Mr. Secretary, suggests this question: You say the greater the tax the greater the incentive to fraud. The same rule would apply here, wonld it not?

Secretary GAGE. Undoubtedly.

The Acting Chairman. Do the instructions of your Department, Mr. Secretary, require the agents who visit these mannfactories to report to yon with respect to the purity of the ingredients used? 
Secretary GıGE. No; I do not think so.

The Acting UHairisan. So that you have no means of knowing exactly what constitutes oleomargarine?

Secretary GAGE. Except by inspecting the processes and methods of the manufacturers.

The ACIING YHAIRIAN. And the product itself, I presmme?

Secretary GAGE. And they make a general examination of the product itself.

Senator ALLEN. I suppose the processes of manufacture are as different as the shades of color, are they not?

Secretary GAGE. [ do not exactly know how many methods of com. pounding the manuficturers have. I think, however, that they follow pretty closely the same general line.

Senator DoLliver. Mr. Secretary, have you a sufficient revenue force to look after the obsurvance of that portion of the oleomargarine law which relates to the putting up of the packages and the quantities in which it may be sold moler these licenses?

Secretary GAGE. Well, I think, perliaps, we bave not. No; I do not think we liaves.

Senator bolliver. We had here the other day packages of oleomargarine said to have been bought in retail stores in Chicago, in which the mark, the name required by law to be affixed, was turned under in such a way as not to be noticeable.

Secretary GAGE. Yes.

Senator Dolliver. Then there were other packages on which the mark was placed in such an obscure way that it would require a person of good eyesight, in some instances, to hotice it. 'The packages were very faintly marked. We also had statements in regard to quantities being bought above the amount permitted by the law to be sold by the retailer, and the general impression was left on the minds of the committee that your revenue collectors were somewhat indifferent, at least in some cities, after they had collected their tax The impression was also left that they were withont adequate force to give attention to all these details.

Secretary GAGE. There is no doubt that the Department has its main eye to the revenue, for that is really its business. It is not clotlied, except indirectly, with what you may call police power. Besides, there are places where the force would be entirely inadequate. Take the city of Chicago, for instance. I think there are 4,0(1) retail dealers there, and it is impossible with a dozen men to keep a close watch over 4,000 dealers scittered over ¿(1 square miles. But when we do find them infinging the law, we make it tronblesome for them.

Mr. SPRINGER. Mr. Chair,ian, may I submit a question to the Seeretary?

The Acring Chairuan. Yes, sir; if it is agreeable to him.

Secretary GAGE. Certainly.

MI. SPRINGerR. The difficulties which have been called to the attentron of the committee in rogard to the selling of oleomargarine or butterine seem to relate to the fart that the retail dealer may break the original package and deal it out in smaller quantities to suit the desires of the purchaser; and in so doing he can sell oleomargarine or butterine to a consumer who presumes that he is buying buttor.

Now, I desire to ask you whether it would be jossible to make such rules aud regulations (if the law so anthorized) reyniring the selling of oleomargarine to the cousumer by the agent of the manufacturer or the retail (lealer in the original package, without breaking even the stamp) itself around the original package, that the selling of oleomargarine for 
butter would be prevented, and it would have to be sold for what it really is?

Secretary GAGE. I think so. I have read the amendment or substitute bill recommended by the minority report of the House committee.

The ACTING CmaIrman. That is what is known as the Warlsworth bill?

Serretary GAGE. It provides a method of putting up oleomargarine in packages of 1 pound or not more than '2pounds, I believe. Am I right?

Mr. SPRINGER. Yes, sir; that is right.

Secretary GAGE. They are, as I understand, required to be separate and distinct from each otlier, with the revenue stamp wound around them and sealed as effectively as a box of cigars is with its stamp. I can not imagine any reason why that would not be a very effective means of preventing the dealer from opening packages and selling the product as butter. The abuse in that respect wonld be rednced to an infinitesimal amount. Of course the dealer conld cut a package in two, obliterate the stamp, and sell half a pound at a time as butter.

Sellator MONEY. That is possible with eigars and everything else, is it not?

Secretary GaGE. It is possible in every department; but the temptation wonld be so small and tie penalties so great that my opinion is that such deception would scarcely be practiced at all.

Mr. Springer. That is to say, if the dealer is required to sell it to the consumer in the original parliages and is not allowed to break them?

Secretary GAGE. That is what 1 mean.

Mr. SPRINGER. It would almost do away with the possibility of frand on the consumer?

Secretaly GAGE. Yes, sir.

Mr. KNight. Mr. Clıairman, may I ask a question, please?

The Acting Chalrman. Do you consent to answer a question by Mr. Knight, who is the secretary of the Dairymen's Association?

Secretary GatiE. Tes, sir.

Mr. KNIGHT. There is a penalty, is there not, Mr. Seeretary, for failing to stamp the retailer's' packages now?

Secretary GAGE. You mean for failing to stamp the word "(Ileomargarine" on the wrapper?

Mr. KNighr. Yes, sir.

Seeretary GAGE. There is.

Mr. KNIGIIT. And that penalty is quite severe, is it not?

Secretaly GaGe. Yes, sir; it is.

Mr. KNIGHT. And it is a fact, is it not, that the Commissioner of Internal lievenue has also made a ruling to the effect that it is an erasion of the law to conceal the marks or to place them on paper of the same color as the ink?

Secretary Gage. Yes, sir.

Mr. KNIGIT. Now, what is the differenee between the two classes of evasions-one of removing the stamp and the other of failing to affix the stamp?

Secretary GaGe. I think there is a great deal of difference. Under the proposition which we have just been discussing the package of oleomargarine itself will have deeply imprinted into it the word "Oleomargarine." It would make very little diflerence, indeed, whether the wrapper had a stamp on it or not. The stamp on the product itself Tould have to be clear and distinct, and it would have to be imprinted by the manufacturer. Once fairly imprinted, it could only be obliterated by the dealer taking it and nixing it up, packing it in a tub, calling it butter, and then retailing it as butter. He conld do that if he did not get caught at it. He conld evale in that way the proposition 
we have just been talking about, as he can evade the present law by having his wrappers printed just on the borler line between readability and obscurity. And many do muloubterlly try to keep just on that border line, where they ean say to the revenue agents, "It is printed," and to the man who buys it, "It is not printed."

Mr. Knigh'T. I see.

Secretary GAGE. There is a border line that is hazardoms for us and hazarlons for them, too; bnt it exists in every other branch of the business.

Senator Allen. Is not that a practical evasion of the law as it now stallds?

Secretary GAGE. They do evade it in that way; yes, sir.

Senator AlLeN. Should not they be proseented?

Secretary GaGE. We do prosecute them where it is a fair, clear violation.

Mr. Tillinginas'r. Mr. Secretary, if the manufaeturers were directed to put up their original 1 and 2 pound packages in such manner as the Department preseribed, could they not be put 1 p in such a way that it would be almost impossible to have any fraud perpetrated until the package itself was broken?

Secletary GAGE. The package wonld have to be broken first.

Mr. Tillingiast. Then, if the manufacturer himself put up the product in original packages in the way preseribed, would there be very much danger of anyone's attempting to break those original packages?

Secretary GAGE. I think very little. That is my judgment.

Mr. Tillinghast. Now, Mr. Secretary, as to the 7 per cent of fraud which you estimated might possibly exist at the present time, is any part of that attributed to the present manufacturers known to the Department, and who are payiug the 'sent tax? You have no difficulty with frand in that line, have you?

Secretary GAGE. None at all.

The Acting Chairman. That is, so fur as the manufacturers are concerned?

Secretary GAGE. Yes, sir.

Mr. Schell. And if the sale of packages were limited to those inclosed by adhesive revenue stamps it would compel the collector to properly enforce the law to protect his revenue, would it not?

Secretary GAGE. Yes; it would.

The Acting Chairman. Unless members of the committee have further questions to ask the Secretary, we will conclude the hearingor unless you have some further statement to make, Mr. Secretary.

Secretary GaGE. No, sir.

The AC'TING UHAIRMAN. The committee is very much obliged to you, Mr. Secretary.

Secretary GAGE. I thank you for your courtesy, gentlemen.

(Thereupon, at 12.45 o'clock $\mathrm{p}$. m., the committee adjourned until Tuesday, Jaunary 15, 1901, at 10.30 o'clock a. m.

\section{Washington, 1). C., January 15, 1901.}

The eommittee met at 11 a. m.

Present: Senators Proetor (chairman), Foster, Heitfeld, Money, War. ren, and Bate.

Also, Hon. William W. Gront, Representative from Vermont; Hon. J. W. Wadsworth, Representative from New York; Mr. Tillinghast, Mr. Schell, Mr. Jelke, Mr. Miller, and others. 
Mr. SchELl. If the committee please, 1 want to real two telegrams which I received last night. The first one is:

Charles E. Schell (trị Shoreham),

Cincinnati, OHio, January 14, 1001. Trashington, D.C.:

Sentiment of labor unious on Grout bill questioned in papers. Get hearing for Cincinuati representative.

\author{
- Michael Kiennedy, \\ Secretary of' L'uilding Trudes L'nion.
}

With the permission of the committee, I want to wire back to him saying that the hearings are closed, and if he wants to send on a paper it will be printel, but he can not be heard personally.

Senator Foster. I think that had better be done.

Mr. Schell. I have also a telegram from Freidman \& Co., of Chicago, the largest handlers of nentral, I suppose, in the country. They are also manufacturers of oleomargarine. Their telegram is as follows:

\title{
C. E. SCHELL
}

UNION STOCK YAlDS, ILLINOIS, January 14, 1901:

(Care Senate Committes on Agriculture), Senate Chamber, Washington, I. C.:

We have exerted every eftort to sell uncolored linterine in the States where coloring is prohilited, and find it absolutely impossible.

Friedian \& Co.

I can say, further, for Frielman \& Co. that I am attorney for them in. Ohio, and that they do not protect their customers in selling oleomargarine for butter.

\section{STATEMENT OF HON. J. W. WADSWORTH, OF NEW YORK.}

Mr. WADSWorTH. Mr. Chairman, I am simply here, in the absence of Mr. Lorimer aud at the request of others, to give you what may be called an ocnlar demonstration of the practical working of the substitute bill offered by the minority of the Committee on Agrienlture of the Honse. That is all; I do not care to go into any other points unless the committee wish me to.

I think we all admit, Mr. Chairman, that the present law, allowing oleomargarine to be solı in large bulk, is perhaps an incentive to fraud. The frand is not committed by the namufacturer's at all. It is committed by the retail butter dealers. The retail oleomargarine dealer cun not commit frand, becanse he sells it with his sign up, open and above board. It is committed by the retail butter dealer, and he is tempted to do it on account of the wholesale price of oleomargarine and the retail price of butter. The minority of the Committee on Agrienlture of the House are just as much in earnest in their desire to rednce this frand to a minimun as are the majority of that committee. There is simply an bonest difference of opinion as to the best meaus of accomplishing the best results.

After we had examined the thing carefnlly and found that the proof was that oleomargarine is a wholesone and nutritions product, and is therefore entitled to a place among the food prodncts of the comitry, we consilered one or two measures. We thought the Gront bill was altogether too radical and too drastic, and we did not approve of it. Finally, after consultation with some people in the West, Mr. Wilson, of the Elgin Dairy Reporter, I think it is called, and other people, we made up our minds that this was the best way of reducing the fraud to 
a minimum. We went to the Internal lievenue Commissioner and requested him to have his law officer amencl the law which is now in existeuce, the law of $18 S 6$, so as to cover the points which we marlethat is, to tell the mannfacturer to manufacture and sell only in 1-pound or '2-pound prints.

Now, I have here before you these samples, because I think these will show you in a better way than language just the practical worling of it. That [indicating] is a "2-pound print. We first compel the manufacturer to imprint oil the brick or roll, or whatever you call it, the word "Oleomargarine." "That should be in one word. The factory has no stamp fitted on that, but the depth of those letters and the size of those letters, if you will read the substitute bill, are to be determined by the Commissionel of Internal Revenue. The word "()leomargarine" is first stamped on that brick; then we compel the manuficturer to wrap it up in thin paper like that, on which is to be printed the word "Olcomargarine" aud the name and address of the manufacturer. 'Theie is the first wrapping. He is then to put aromd that wrapping this second wrapping of paper, or, I believe, they have some wrappings of thin wood pulp on which the word ": Oleomargarine" is again printed, and around which the revenue stamp-that green hand represents the revenue stamp-is to go. It is to go completely around, just like a logshead of tobacco. When he sends that ont to the retail dealer or the wholesale dealer the law provides that he shall pack it in boxes or ciates, and on the crate is to be printed the word "Oleomargarine," the number of his factory, and so on. The size of the print and all that is left under the Commissioner of Interual Revenue, with the approval of the Secretary of the Treasury. Now, he ships it out that way. It has to go that way to the dealer.

We put in a proviso in the bill which I thiuk will at least couvince you gentlemen of the sincerity of our pupose to stop this frand. We say :

Retail dealers in oleomargarine shall sell only the original package to which the tax-paid stamp is affixed, and shall sell only from the original package or boxes in which they receive the ponnil or 2-pomnd prints, bricks, rolls, or limps.

In other words, wheu you go in and ask for a pound of oleomargarine, he has that box in evidence. He las got to take his butter right out of that, with this stamp on the outside, with the stamp around it, with the printed word "Oleomargarine" there, and printed on the inside wrapper, and stamped on the article itself.

Senator WARREN. If the dealer is dislonest and he takes this and melts it up or pounds it up into another mass, and then does it up into packages and sells it for butter, you provide for that, I suppose?

Senator Foster. That is a fraul on the revinue, of comrse.

Mr. II Adswortu. Tes; we have not altered the license fee of $\$ 600$ a yen to the manufacturel, $\$ 4 \$ 0$ to the wholsesale dealer, $\$ 48$ to the retail dealer, or the tax of " $\not$ cents a pound. 'That all remains. All the penalties provided by the act of 1581 remain.

Senator IVARREN. Do you increase the penalties at all?

Mr. WADswoRTH. I think they are not increaserl over those fixerl in the original act. Of comrse, it is possible for a dislıonest man to take that and do as you say. Murder is committed in this country. Larceny is committed in this country. There is a law against it, but the peculiar part of it is that the fraud is not committed by the oleomargarine dealer. It is committed by the butter dealer. Senator Money, you introduced a bill which you call the Wadsworth bill. We abandoned that as not going far enough. I want to say that very frankly to 
you, because it was open to the same objections exactly as the original bill that allowed this thing to be sold in too large quantities.

Senator Moner. Looking at it from anotlier point of view, we impose upon an honest, legitimate industry an additional tax in that wrapper. I do not know how much that will cost to put the product up in a changed form. Can any of you gentlemen tell me that?

Mr. JELKE. About lialf a cent a pound.

Mr. WADsworth. Therefore the tax is $2 \frac{1}{2}$ cents a pound.

Senator Fos'ER. I do not sumpose those wrappers cost a fifth of a cent.

Mr. JELkE. It is not merely the expense of the paper. You must include also the printing and handling of the paper.

Mr. WADsWroRTI. It is the liandling and packing, Senator. As the law is now, they pack it into a big tub. They shove it in or sroop it in, and there is very little work attached to it; but in this case all this wrapping has to be done. I should think it would be worth half a cent a pound.

Mr. JELKE. I should hardly think half a cent a pound wonld cover it, for this reason: We now pack 50 pounds into a solicl packed tub. In printing it in the 1 or 2 pound blocks there is a certain amount of moisture eliminaterl from it. You can not make ont of 50 pounds of solid-packed oleomargarine 252 pound prints or i) 1-pound prints. The pressing of the oleomargarine into that form eliminates a certain amount of moisture.

Senator Foster. It would be more attractive in the 1 or 2 -pound prints than it would the other way?

Mr. JELKE. Yes; very much more attractive.

Mr. Tillinghast. It is generally understood in the factories that prints cost half a cent a pound more than the tubs.

Senator Foster. I suppose it would sell for perhaps that much more in that shape than it wonld when it is scooped nut of a tub.

Mr. JELKE. That is undonbterly so.

Senator FosTER. Is that all, Mr. Wadswoıtlı?

Mr. WADswor'T. That is all, unless the committee want to ask something. I simply wanted to show the practical operation of the law.

\section{ADDITIONAL STATEMENT OF HON. W. W. GROUT.}

Mr. Grout. I would like to submit just a word, if the committee will hear me, illustrating the workings of this substitute bill.

Senator Proctor. We will hear you.

Senator MonEY. Let me ask a question before you begin. Mr. Wads. worth, did the minority of the House comnittee consider the expediency of making a provision in regard to renovated butter?

Mr. WADsworTH. No, sir; that was not brought up before us at all.

Mr. Grour. Mr. Chairman and gentlemen, Mr. Wadsworth says he regiets the absence of $M r$. Lorimer, whose scheme I understand this to be, but he lias made the plan quite plain, I think, as to the purpose it would serve. I am not going to say but that so far as the retail dealer is concerned this might somewhat limit his ability to work this off as butter, but only a little, a very little, as I will show you later. I presume you have been told in this investigation that a large part of oleomargarine is clisposed of to purchasers who know just what it is. I have not been present all the tine during these hearings, but I saw a letter to that effect written by an oleomalgarine manufacturer from Rhode Island to the chairman of this committee, to the effect that over forty-odd per 
cent of the oleomargarine sold the person receiving it knew precisely what it was. The writer refered in that letter, as I understood it, to the hotel keejer, the restaurant keeper, the boarling-house keeper, the mine owner, the lumberman, and that class of men, who buy in bulk large quantities of oleomargarine from the mannfacturer direct, sometimes throngh the intervention of a wholesale dealer, possibly, and that this was over 40 per 'ent of the entire product.

Now, this proposed substitute would not affect at all that ('lass of trade. It does not reach it at all, because while they are obliged to carry it into their camp-into their hotel, if you please-in this package, and have its stamp put upon it, yet it is not sold, and so the provision which the gentleman read in closing wonld not apply. That provision relates to the retailer alone.

Mr. WADSWoRTH. That is what I said.

Mr. GrouT. Exactly; that is the provision in your substitute. It relates alone to the retailer. It does not touch this large class which haudle probably two thirds of all the oleomargarine that is put out. It is through the liotel man, I repeat again, and the restaurant keeper and boarding house keejer that it is worked off npon an unsuspecting public more than in :ny other way.

Senator WARREN. May I ask you a question?

Mr. GRout. Certainly.

Senator WARREN. You do not propose to prevent the nse of oleomargarine in the boarding house and in the botel in cooking and in every other form except where it is placed before the boarder to be put upon his bread?

Mr. GRouT. We do uot propose to prevent its use at all if sold in a form to apprise the person using it what it is.

Senator WARren. You assume they will go on using it for that purpose?

Mr. (iRouT. All the bill before you aims at is to have this stuff go on the market and be consumed for just what it is. That is all the bill we ask. We do not prohibit the use of it for cooking or anything else.

Senator WARrEN. As far as the consumption of it is concerned, the individual sale at the hotels, if a hotel desires to use oleomargarine, no matter whether it is colored or not, the guests will each one be a tank for oleomargarine to some extent, throngh the cooking and otherwise.

Mr. GkoU'. Yes, ungnestionably; but the color of butter will not show as in the chicken liash which a gentleman ordered in my presence in an eating house in this city not long since while we were lunching together. I am just as morally certain that it was cooked in oleomargarine as I could be of anything, and he became satistied of it, too. It will, I say, not carry the color of butter if you will pass this bill.

Mr. WAUSWORTH. How did you satisfy him?

Mr. Grovt. By comparing it with a sjecimen on the table which we knew was oleomargarine, in eolor, as contradistinguished from a lump of butter on the table much less highly colored.

Mr. WADSWOR'H. In color only?

Mr. Grout. Yes, sir; because the color of the article in the hash corresponded exactly with the oleo before us.

IIr. WADSWOR'IH. 'That comparison was only by color?

MI. GrouT. That is all. I will not say that it was absolutely conclusive in that case, but we were entirely satistied.

Now, not to be diverted from the joint 1 was making, what is there to prevent the hotel man from cutting this up in little stringlets as wide and half as long as your finger, putting it nyon your lntter plate, 
and selling it to you at $\$ 5$ a day or $\$ 4$ a day, or whatever you may chance to pay for board, for butter?

Mr. WADSWORTH. lie can not get it from the retail dealer except as oleomargarine.

Mr. GRou'r. Ah, but he does not take it from the retail dealer. He gets it straight from the manufactory or throngb the wholesaler.

Mr. WADSWonTH. Very well; he can not get it from the mannfactory, he can not get it from the wholesale dealer, he can not get it from the retail dealer, except in that form.

Mr. Grout. Precisely so.

Mr. WADSWOR'Y. Lit him take that to a hotel, and he immediately puts himself in the hands of his help. He quarrels with a waiter or a cook and dismisses him, and the man turus on him and says, "You have been selling oleomargarine to yonr customers tor butter." That is the objection.

Mr. (iROUT. Yon will not find a first class hotel, I believe, in the city of Washington but yon will know, when you talk this matter over with them, that they feed oleomargarine to the help, and that will acconnt for its entranee into the honse; and once in the honse its nses can not be so easily traced.

Senator WARREN. If it is your idea to protert the hotel guests and the restanrant guests from oleomargarine, has it suggestell itself to you in what way you will protect them from the use of oleomargarine that is uncolored?

Mr. Grour. Why, the color tells the whole story. If they bring an uncolored article on the table the guest knows it is not butter. He knows it is hog fat or cattle fat.

Senator WARren. A great many men do not eat bntter at all on bread; others eat lictle. No one eats much in that way, but everyone eats a great deal that is nsed in cooking.

Mr. Grout. Very well.

Senator WARREN. So that it seems to me if you take the matter of color only, and only probibit as to color, you are not reaching the consumer, and he is the one we are trying to reach. You are not reaching the matter of the consumer getting oleomargarine instead of fresh butter, except as it may come before him, put upon his plate. The great mass of butter that is used for cooking, it seems to me, is not reached by this bill.

Mr. GROUT. It would not reach the butter that goes into pie crust or into shortening eake, but fat is frequently, almost always, used for that instead of butter, and the hotel man uses fat almost exclissively for that purpose. I am not saying that it would alssolutely exclude the use of it for cooking purposes. There is no pretense that it would, and yet there are many kinds of cooking in which it betrays its color, as it did in the chicken hash the other day, that I referred to. If it were seasoned or made suitable for some people to eat with the slortening, and that were an molored article, it would falsely pretend to be but. ter; and the same with whatever may be put on your toast in the name of butter.

Senator Money. Is not the butter and oleomargarine color the same thing?

Mr. Grou's. How is that, sir?

Senator MonEY. Is it uot true that the butter and the oleomargarine that is offered are colored the salme?

Mr. Grou't. Yes, sir; sometimes butter is colored. There is no debate about that. 
Senator Moxer. How can we distinguish them?

Mr. Grout. I did not intend to go into that, and I do not care to now. If the committee want me to do so, however, I am willing to stand here and have a convelsition, and a long one, on that subject of coloring butter. I expressed myself fully in my opening statement on that subject and I do not think I need repeat it, but still if you desire I will gladly discuss it witl yon.

Senator Moner. I have no desire to hear anything further abont it, except you male the statement, and it was in answer to that statement, that you detected oleomargarine by its color in the liash, that I asked you the question.

Mr. Grout. l'recisely.

Senator Moner. Then I wanted to ask you if the same color did not enter into the butter that enters into the oleomargarine?

Mr. Grout. Yes, sir; it cloes. It belongs to butter. Yellow is the natural color of butter and always has been, and if you allow them to color oleo just like butter, that enables them to make you believe it is butter whether you spread it on your loread on see it in chicken hash.

Senator MoNEY. It has been testified here that the natural color of butter is white.

Mr. Grout. Can that be possible? Excuse me, but I should not suppose anyone would make that claim. I had always muderstood that butter is always yellow. The cow makes it yellow.

Mr. WaDsworTH. What is the color of the butter that Delmonico uses in New York?

Mr. Grout. I llo not think Delmonico uses white butter.

Mr WADsworTH. And it is unsalted?

Mr. Grout. Yes, but not white butter. He uses butter, very likely, without any coloring matter, and my own taste approves that. Tastes vary as to degrees of the yellowness for butter, or which should belong to butter, and of course it is colored to meet those varying tastes; but it is all the time a butter color. It is ouly a little more colored or a little less. It is always in some degiee yellow. Nobody ever saw butter but what it was in some degice yellow.

Senator WARREN. You speak of a case of chicken hash. You would naturally be an expert, and especially so at this time when your mind is turued toward this. Do you think the presence of oleomargarime in that chicken hash you speak of would easily be detected by an ordinary boarder?

Mr. Grout. Not without the clue which we lad in the difference of color between the butter and the oleo, which we had before us, both of which were in the house. Of course chicken hash would be more palatable to the man who ordered it if it disclosed the use of butter in serving it up than it would if it disclosed a white grease simply like lard or oleo without color. And so, as in this case, oleonargarine is put into cooking where it will show to give the guest the impression that they have made a free use of butter in serving clicken liash or whatever, and it goes off at the rate of 35 a day, or whatever price may be paid.

Senator WARREN. It seems to me that the oleomargarine in the chicken hash would be less discoverable if it was white than if it was colored. I do not want to take from your argument, but what I am getting at is the purpese of this bill. I want to get at whether the purpose is to protect the buttermen, whether it is to protect the boarding-house men, and the percentage of plotection; whether it is one-half of the consumers and one-half of the buttermen, or two-thirds one 
way and one-third the other way. That is why I am asking these questions.

Mr. GrotT. I can not divide the protection arithuetically. It would be impossible to do so; but 1 may say in brief-

Senator Foscer. To protect the public.

Mr. Grout. Precisely so, Mr. Senator. It is for the protection of the public. It is for the protection, also, of an honest industry against a fraudulent product. It is for the protection of everybody who uses butter in any form, and for the protection of the hard-working men and women who produce it at small profit.

Mr. Wadswor'H. Who says oleomargarine is a fiadudent prodnct?

Mr. GRuUT. I do; it is sold as butter.

Senator Warren. You have given it a great deal of attention. The bill does not go far enough, it seems to me, if this is to protect the public. If this is a fraululent product, and if three-fourths, perhaps, of the oleomargarine that is nsed is nsed in cooking, and a man must take it anyway, whether he will or not, it does not seem to me we are protecting the public in this matter. That is what I want to get at.

Mr. GROTT. I am glad you have asked how it protects. It proterts the public in this wa!, by stripping from o'comargarine the dress of butter, so that it can not longer impose itself on the public as butter. Put this 10-cent tax on the colored article and it will become unprofitable to culor it. Jo this and it will no longer be sold as butter, but will go upon the market nncolored, so that it shall deceive nobody.

Senator WARREN. But it will be used all the more for cooking purposes.

Mr. Grout. Perhaps so, where it can be concealed; but where it can not be concealed they will have to use butter instearl of oleomargarine. If you call for buttered toast, they will not bing you toast with hogs' fat unou it. They will bring toast with genuine butter upon it, and the color tells you what it is. This will be accomplished by reducing the total profits on the oleomargarine business from $\$ 13,000,000$ to $\$ 3,000,000$ annually. Yes, gentlemen, you may laugh, but between the consumer of oleomargarine and the cost of the prodnct there was last year from $\$ 1:, 000,(1000$ to $\$ 15,000,000$ profit, and there is no escape from the fact. I think it perfectly safe to call it $\$ 13,000,000$.

Mr. Tillinghast. There is no foumdation for the statement.

Mr. Grour. I will make it clear right here in just a moment. This article costs 7 cents a pound to mannfacture.

Mr. 'I'illinghast. How do you know that?

Mr. Grout. On the statement of a prospectus issued by the builders of a new oleo factory in this city; on the statement also of not Philip D. Armour himself, but a man representing his concern, some six or eight years ago, that it did not exceed 5 cents a pound-materials are more expensive now-in a local investigation up in the state of New York by the New York State 1)airy Union. In New York they enforce their color law more thoroughly and completely than in any other State, but still there are infractions of the law there. On the strength of those statements, the last of which was made under oath, I say that it does not cost over 7 cents a pound now to mannfacture it, and it is worked off on the public, through the hotel men, the restaurant keepers, the boarding-bouse keepers, and retailers for the price of butter, anywhere from 18 to 30 cents a pound. We may call it on au average 22 cents a pound, and that is perfectly within bounds. When I pay $\$ 5$ a clay or $\$ 4$ a day at a hotel where oleo is nsed, they are selling the stuff to me at the price of butter, and the great bulk of it is worked off 
in that intangible, untraceable way. Take the difference between 7 cents and 22 cents and you bave if cents. There were 104,000,000 pounds of oleomargarine manufactured and stamped last year.

Mr. W ADSWoRTH. Where is your tax lirense fee and all that?

Mr. Grour. I thank the gentleman for the reminder. Add the tax to the cost of the prorluet and it makes it 9 cents. That will leare a margin of 13 cents profit on every pound with the selling price at $2 \cdot 2$ cents, which is a low tigure. There were $104,(100,090$ pounds mannfactured and stamped list year and two or three million pomids more not stamped. Now, there is your $\$ 13,520,000$ profit on the product of last year between the eost of production and the price paid by the man who consumes it. There is no escaje from this conclusion, my frieuds.

Now, if yon take what they elaim to be true, that, as one maunfacturer puts it, the great micldle class wants oleomargarine, prefer it to butter, and take what the oleo folks say abont the dirt and filth and all that sort of thing in butter, which they talk about to help make oleomargarine palutable-I say if it be true that anyoue wants oleomargarine at bntter prices they ean manufacture oleomargarme and pay the 10 cents tax and still not have it eost more than it is costing to-day. But I do not believe it to be true. I believe it is not true that people want oleomargarine in preference to butter at the price of butter, and that when yon will mstitute measures which will insure the article going upon the market for exactly what it is, all will prefer butter, excepting those, perhaps, who want a very cheap article. And under the last clanse in the last section of the bill, which proposes to rerluce the tax on uneolored oleomargarine to one-fourth of 1 cent per pound, they ean have it at less than one-half what it costs them now.

I am not going to elaim here now that oleomargarine is unwholesome or unnutritious. There is no question, however, that it is more diffienlt of digestion than butter, because butter melts at 920 and oleomargarine does not melt short of from $1010^{\circ}$ to $107^{\circ}$. That is the faet about it, correctly expressed. I refer you to the testimony which was taken before the Honse Committee on Agrienlture, in which that fact is distinctly stated by Governor Hoard; and it is not only ehemically but absolutely true it is because of the stearin or paraftin that it carries. Paraffin, however, has become so expensive that they do not use it now. Stearin has been used within the last few years in oleomargariue.

Mr. Tillinginast. Not to any extent.

Mr. GRour. The New York agriculture department found 10 per cent of paraffin in 6 ro-pound tubs; but leaving that out, it is not used now beeanse of its great cost. Stearin is used, and that is what you make tallow candles out of.

Mr. Tillinghast. Paraffin was never used by any manufacturers in this country since oleomargarine was made, and if it was found in oleomaragine it was put there by an enemy to the oleomargarine industry.

Mr. GrouT, It was found in the course of some experiments made by the assistant secretary of agriculture, whatever his name may beCracke, I think. The report of the secretary of agrienlture for New York of that year tells you all about it. It was some oleomargarine they captured that was being sold for butter, and on inspection they found this paraftin.

Mr. WADSWORTH. It seems to me you onght not brand a trade on aecount of the black sheep in it. Will you condemn the butter business on account of the black slieep in it? I suppose there are some who will palm off' process butter for ereamery butter. 
Mr. GRouT. I expect the gentleman knows better about black sheep than $I$ do. All $I$ know is that in the oleo business they are all black sheep. I clid not care, however, to be drawn into a general discussion of this whole oleo question. I only songht to reply to the particular points raised by the gentleman from New York in connection with this substitute bill. But if I were to say what I thought about it, I would not exculpate, as the gentleman seems swift to do, the oleomargarine manufacturers from complicity in this fiaud. They are as deeply steeped in it as the retailer is. You take up the testimouy which was taken before the Committee on Agriculture in the Honse and you will find that they say to the retail trade in their printed cirenlar's, "Sell our goods and we will stand between you and all expenses, fines, costs, and the like." Wore than one concern issued such a circular in Chicago. Now, if that does not mean that they are ready to back the retailer in practicing this frand, I would like to know what it does mean.

But, as I say, I did not intend to go into that, gentlemen; I have been drawn into it, as you will witness. What I wanted to reter to was this system of stamping this article will not prevent disposition of oleomargarine throngh the mediumship which the bulk of it is now worked off upon an mnsispecting public, nanely, the hotels, restaurants, and boarding houses, from cutting this up into strips and serving it on the table, and in cooking also, making the guest believe that he is eating a well-seasoned dish, or a dish well seasoned with butter instead of with ordinary grease. That is the only point I wished to answer in the gentleman's statement, and to show that while it may tonch, perhaps, the retail trade and contravene in some slight degree the fraud practiced by them. It wonld not be effectnal with them, for what is there to prevent the retailer from packing these "z-pound lumps into a butter firkin and selling it for butter?

Senator MoneY. You sild the only way to discover whether it was oleomargarine or butter was by the color. Do you mean to say to the committee, Mr. Grout, that a consumer of oleomargarine or butter at a table can not discover it in any other way than by the color?

Mr. GROUT. The color would not ordinarily help. It helped us in the last case I eited, because its color corresponded with the oleo before us and did not correspond with the butter. The oleo was highly colored, and the butter not so highly. Oleomargarine can be detected only by very careful tasting. If oue takes it with his food he will not discover whether it is oleomargarine or butter.

Senator Moner. I mean if he takes butter on his plate. You do not think the ordinary consumer can distinguish?

Mr. Grout. No, sir; it wonld pass as butter unless you taste very carefnlly and wait for the after effect in the month. 'There is only a very slight flavor of butter in oleo, and sometimes in the poorer grades none at all, and that is what betrays its character.

Senator MoneY. If it is wholesome and nutritions and nobody can tell it from butter, what is the difference?

Mr. GRout. The difference is that it is not butter; the difference is that it is foisted upon the people for that which it is not, at an enormous profit, aud as a counterfeit. The same difference that there is between good money and connterfeit money-butter is the geunine article, oleomargarine is the connterfeit.

Senator Money. We have had circulars of the retail dealers in which they offer three grades of oleomargarine, for 11,12 , aud 13 cents a pound, and butter from 2e' cents up. 
Mr. (irout. Yes.

Senator Honky. Now about the digestibility. I know nothing about oleomargarine, becunse I may have eaten it and I may not; but I have a member of ny family who can not digest butter at all, and consequently when he is at home he does not eat butter. Wo ean not get oleomargarine in my State. I do not suppose there is a pound of it sold in the State; but wheu he comes to Washington he hunts np oleomargarine because he ean eat it and can digest it. It may be an idliosyncrasy of his stomach, but there must be some digestibility abont it.

Mr. Grout. Under this bill he could get it for one-half what he gets it for now, lacking the color which the article now has, and color only feeds the eye, anyway.

Senator W You have, no doubt, given this so-ealled substitute bill attention. Is there anything in that which makes the hotel keeper liable for serving it as butter"?

Mr. GRotT. That wonld be a matter of loeal regulation. We do not attempt to enter into that here; we hardly could do so for want of jurisdiction. That is a matter for police regnlation in the States. The first section of the bill gives those laws supreme control, whatever they may be, when once enacted.

Senator WARREN. If I understand you, and I am seeking light, your criticism of this proposed substitute bill is that, while it would cover the family purchiser who goes to a grocer and buys a pound or two pounds, it would not cover the great mass of the people, growing greater all the time, who eat at restaurants and hotels. It would still be in the power of the restaurant keeper and hotel keeper to deceive his guests.

Mr. Grout. Ies.

Senator Warren. And there is no way to reach him for imposing upon his eustomer's.

Mr. Grout. Excepting the law which we prescribe in this bill. We make it unprofitable for him to bny oleomargarine instead of butter. He now pays for it, say, 12 cents per pound. 'This 10-cent tax instead of 2 would make it cost him at least 20 cents per pound, and he would buy butter. The bill deals with the subject fundamentally.

Senator WARREN. If I muderstaud you in doing the best you can in this matter, you seek to protect the consumer at the hotel and the restanrant so far as the butter that is brought to him and placed in front of him is concerued. All others you allow could be protected with other legislation. You do not attempt to reach the use of oleomargarine for eooling, etc.?

Mr. GRoit. That would be beyond our juriseliction. That is a matter of State regulation. The first seetion of this bill gives the States supreme anthority. The States may go on and institute just such methorls in the exereise of their police power as they see tit to rectify all those things, and undonbtedly they will do so.

Senator WARren. But your direct purpose is to feel sure that you can reach that much of it?

Mr. Grout. We reach the whole of it, sir. We claim we reach the wlole business, because this bill will take away all temptation to sell it for butter when we take away the profits by putting such a tax upon it as makes it muprofitable to manufacture colored oleomargarine and sell it for butter. Then we take away the dress of butter and correct the evil. It may fall short of it, but we believe it will work the result desired.

S. Rep. $2043 \longrightarrow 37$ 
Senator WARREN. It makes no difference with the cooking part, of course?

Mr. Grout. No; we can not in this legislation enter into the minutiæ, as I say, of local regulations. It would be beyond our jurisdiction.

Senator Money. Then the raising of the tax is of no particular importance in protecting the consumer if it is the color that is the most important?

Mr. GRout. It makes unprofitable the sale of colored oleomargarine, and when it is not colored it will have to go for what it is. It matters but little whether they do their shortening or cooking with oleomargarine or logs' fat or beef tallow. There is mighty little difference between them. It is all the same; but when they undertake to make the public think they have shortened up with butter, the color is wanting, and they can not carry the deceit to that extent. To that extent it will prevent its use in eooking.

Senator WARREN. Could they not add a little of the coloring matter in the cooking and thereby deceive the guests?

Mr. Grout. Possibly they could color it so that they could spread your toast with it and make you think it was butter. Possibly they might recook and color it in quantities, but no one has suggested that that is practicable. But everyone can see that the provisions of this substitute bill can be evaded by the retailer, to a certain extent, as well as the hotel, restaurant, and boarding-house keeper. All the retailer wonld have to do would be buy, say, 200 pounds of oleo, stamped like these specimens and delivered to him in a box like this, take off the wrappers, and then, with an ordinary butter eutter, mold, or mallet, pound these 2-pound lumps into butter firkins and then sell it out of the firkins for butter. How easy; and after he had used the box and wrappers to kindle the fire, no vestige of oleo would be left on his premises. All this is very easy to do under Mr. Wadsworth's substitute. But if you take away the color, as this 10-cent tax will do, the game is up.

Mr. JELKE. The object of your bill, I understand, is to prevent the retail dealer

Mr. GRouT. It is to prevent fraud along the whole line.

Mr. JELKE. Will you permit me to ask a question?

Mr. Grout. Certainly.

Mr. JELKE. It is to prevent a fraud in the sale by the retail dealer and to protect the consumer against this fraudulent sale?

Mr. GRout. Yes.

Mr. JELKE. Is there any provision in the bill preventing the purchase, by the retailer, of uncolored oleomargarine on which there is but a quarter of a cent per pound tax-

Mr. Grout. Oh, no.

Mr. JELKE. And then coloring the oleomargarine himself and making 93 cents per ponnd additional profit?

Mr. Grout. But he would have to work it all over and melt it in order to work in his color. If he colors the uncolored article, which I am told is highly impracticable, he would have to have a caldron, kettle, or something of that kind to make that transformation, and it certainly could be traced; but see how easily he could take that stuff and pound it into a 50-pound butter tub and sell it for butter. Who can trace him? Who can follow him? He burns up this wooden box and wrapper in which it came and there is no way to trace it.

Mr. JELKE. For your own information, Mr. Grout, I would like to say that if this roll of oleomargarine were absolutely white, without spoil- 
ing the brick, I could, without melting it, put a few drops of color in it right here in this room and prorluce just that same thing there.

Mr. Grout. Diffusing the color thronghont the whole wass?

Mr. JELKE. Yes; by taking a ladle and working it.

Mr. Grour. Well, the ways of this craft, gentlemen, are past finding out.

Mr. MiLLER. Speaking of the use of butterine by hotels, is it not a fact that the contention of your side has been right along that there was fraud by the retail dealers?

Mr. Grout. Yes, sir.

Mr. Miller. And is it not a fact that you claim all the fraud has been practiced by the retail dealers? You say two-thirds of the butterine sold gaes to hotels.

Mr. GRoUT. I say that I am not sure it is two-thirds, but it is a very large proportion. I did not say it went into the hotels, but the claim was that a large portion of it went to purchasers who knew just what it was. The hotel man knows just what it is. The restaurant man knows just what it is. The lumberman and the mine man know just what it is, and so on.

Mr. Tillinghast. Mr. Chairman, just one suggestion on the police regulations of the States. Most all of these States which have oleomargarine legislation and the anticolor law have also the police regulation that boarding-house keepers, hotel keepers, and restanrant keepers shall give notice to the guests of those places that they are using oleomargirine, if they are using it, under severe penalties if they do not do that. That is one of the easiest regulations to maintain in the States, as the dairy bureaus have often told me, because any of their men may go to any of those places where it is suspected that oleomargarine is used and call for a dinner, and after his oleomargarine is served to him, he takes a sample out and analyzes it, and he has the man canght, unless he has been personally notified to that effect. So that any fraud that exists, or might exist, on the part of the hotel proprietor or restaurant keeper or boarding-house keeper can be, and is, provicled for, and this bill would be of no assistance to the States in euforcing that legislation. They have ample protection in that line.

Now, gentlemen, just one word in reply to Mr. Gront's statement. He says the larger part of this oleomaruarine is worked off in hotels, etc. His statement with reference to that has no better foundation than the statement with reference to some other things. His means of information are not any better than mine, and I do not believe they are as good, because he has not given as much attention to it as I have. The greater part of the oleomargarine that is sold in this comntry is sold to men who use it in their families, and who bny it for what it is; and frand does not exist to the extent he claims it exists with reference to the hotel keepers, restanrant kcepers, and boarding-house keepers, and if it did, then the police regulations of the States concerning such places are amply sufficient to protect that matter.

Senator Foster. You say they buy it because they want it?

Mr. Tillinghast. Yes, sir.

Senator FosTER. What effect would it have if it was uneolored?

Mr. Tillinghast. They would uot have it at all.

Senator Foster. That is the same old question.

Mr. Tillinghast. The same old question that has been discussed so often.

Mr. Schell. Just one question. I presented here a list of 1,083 consumers who buy direct from one of my factories. We also-all of us- 
have an export trade. In 32 different States, including Ohio, where two of my factories are located, there is a law absolutely prohibiting the manufacture or sale of colored oleomargarine. I would like to know how, under this bill, my people can manufacture, either on the order of these consumers or for the export trade, colored oleomargarine at all, since every time they do it they are pleading guilty to a violation of the State statute.

Mr. Grou'r. That is a question that enters into the secrets of the oleo business, and I do not think anybody could answer it. I must confess I do not see myself how there is any plea of guilty to a charge in such a case as stated by him.

The committee (at 11 o'clock and 45 minutes) adjourned, subject to call. 


\section{E A R I N GS}

BEFORE THE

\section{COMNITTEE ON AGRICULTURE,}

HOUSE OF REPRESENTATIVES. 



\title{
OLEOMARGARINE.
}

\author{
HOUSE OF REPRESENTATIVES, \\ Committee on Agriculture, \\ Washington, D. C., March 7, 1900.
}

\section{ARGOMENT OF W. D. HOARD.}

Whom do we represent? The united dairy sentiment of the nation. That means over 5,000,000 farmers, and an annual cash value in their product of over $\$ 600,000,000$. A vast army of cousumers of dairy prodncts, who are constantly duped and swindled by a counterfeit substitute for butter. The consumer is defrauded of his money and the dairy farmer of his rightful market, the first being compelled to pay a butter price for that which is not butter.

The consumers and producers of butter ask Congress to enact into law House bill 3717, which provides by the first section that all counterfeit substitutes for butter, when taken into any State or Territory, shall be subject to the laws of that State or Territory concerning such counterfeit, the same as the Wilson law in regard to liquors, enacted, I think, in 1891. It was deemed for the public welfare to enact that law. We claim it is for the public welfare to place oleomargarine under the operation of a similar law.

Already thirty-two States have laws on their statute books forbidding the manufacture and sale of fat mixtures when colored and made in the semblance of butter.

The Oleomargarine combine consists of less than twenty manufactur. ers, who have entered into a conspiracy to break down these State laws, and, by bribing merchants, by deception of all kinds, by subsidizing city newspapers, by employing leading politicians, to so neutralize the effect and administration of those laws that they may force their counterfeit upon the public. These manufacturers are assuming to override all law. They stand behind all infractions of State and national laws, and furnish money for the defense of their agents when arrested.

On one side stands one of the greatest of our agricultural interests, together with the millions of consumers who are tired of being swindled.

On the other side stands the oleomargarine trust, engaged in manu. facturing a counterfeit, depending on lawbreaking, falsehood, and deception for its success, backed up with millions of capital.

The situation is significant, whether viewed from a political, economic, or patriotic standpoint.

The serond section of this bill provides, first, that on all oleomargarine which stands in its own color and not in the semblance of butter, on this mixture the present Federal tax shall be reduced to a fourth of one cent a pound. The dairy sentiment of the country would be willing that the uncolored compound should be relieved of all taxa- 
tion. The tax as provided in the bill, however, is trifling and nominal. 'This is done in the spirit of fairness. If there are any persons who wish to eat this mixture in preference to butter, who ask it because they are poor, they would then be enabled to buy it for what it is worth. They conld not be cheated into paying a butter price for something that in no honest sense is butter, or like butter.

The oleo combine and their apologists and defender's have a great deal to say about oleomargarine being a cheap food for the "poor." There is consummate hypocrisy in this plea. You will notice that the poor people are not making this plea. It is made for the purpose of overreaching the poor.

The friends of this measure are the true friends of the poor, for they ask that the force of law and the burden of onerous taxation be turned against the comnterfeit, while the artiele which is not colored to deceive can have free course.

What does oleomargarine cost? Armonr \& Co., of Chicago, testified before a Federal district conrt in New York that, with the "2-cent Federal tax added, the cost was less than 7 cents a pound. If it was nncolored, the poor conld buy it for 10 cents, or at most 12 cents a pound. Yet I saw the colored article selling in Ashland, Wis., to the poor, for $2 S$ cents a pound.

'This plea for the poor, by these exploiters of poverty, finds conspicnous parallel in the history of Judas Iscariot. When the women annointed the feet of Christ with alabaster ointment, Judas had a great deal to say why the ointment was not sold and the money given to the ponr. Yet I imagine it is not necessary to inform this committee that Judas was a traitor to botll Clirist and the poor.

To give added force to the first section of this bill it is also provided in the second section that a tax of 10 cents a pound shall be imposed on all oleomargarine in the color or semblance of bntter. In plain words, this is repressive taxation. In 1886 Congress, in response to the demand of the people, placed a tax of 2 cents a pound on this counterfeit, and exacted heavy license fees for its manufacture and sale.

This was done in the interest of the public welfare. Congress has the undonbted right to exercise this power. It has exercised it in the tax on State bank cirenlation, on filled cheese, and adulterated flour. This is a part only of the duty and policy of internal protection.

It has been found, through the ineficient administration of State laws and the powerful influence of this oleomargarine combination, that this protection is insufficient.

The manufacture of the counterfeit has grown from $34,000,000$ ponnds in 185 's to $\$ 3,000,000$ in 1899 , and, be it remembered, 90 per cent of it consumed under the supposition that it is butter.

This prodnet of 1899 would make $1,383,68160$-pound tubs. If placed side by side they wonld reach 3,400 miles; if loaded into farm wagons, a full load in each, they would reach 400 miles in length. The ontput equaled the ontput of $415,650 \mathrm{cows}$, worth $\$ 12,469,500$.

The hoped-for effect of the legislation asked of Congress is not to destroy the oleomargarine industry, but to force it over on to its own ground; to compel it to be made in its own guise and color. Is there anything unjust or unreasonable about this?

With a tax of 10 cents a pound on the comnterfeit substitute, we believe the temptation for mujust profits, deceptive sale, dishonorable and dangerons conspiring against law, and fraudulent competition with an honest industry will be greatly modified. 
A great many people ask why it is not as permissible to color oleomallarine as it is to color butter. I would answel becanse they are not colored for the same jurpose. Butter in winter is too liglit to suit the taste of most comsmmers. 'The highest value is in fresh butter not more than ten clays old. Tho consumer asks that it bear the yellow summer color of butter. That is a matter of taste, not deception, for it is not colored to resemble something it is not. But olenmargarine is colored to make it resemble butter, which it is not. It is colored, not for the benefit or taste of its consumer, but to deceive the consumer.

Said President Cleveland, in his message approving the oleomargarine legislation of 1856 :

Not the least important ineident related to this legislation is the defense afforded to the consmmer agaiust the fraudulent substitntion and sale of au imitation for a genuine artiele of food of a very general honsehold use. * * * I ventur to say that harrly a pound ever entered a poor man's house under its real name and in its true charaeter.

The argument still holds good. Congress was then asked to place a tax of 10 cents a pound on the counterfeit. Had it clone so, the relief would, in my opinion, have been ample and sufficient. But it lias been proved inadequate, and we ask for the passage of this measure in its entirety.

We are met by certain abstractionists with the question, "Would you tax one legitimate industry out of existence for the benefit of another?" To this I would answer, No. But the oleomargarine business is not conducted legitimately. It is based, from manufacture to sale, on wrong and illegitimate methods.

We believe Congress has the right, for the sake of public welfare, for the sake of smpuressing frand and deception in any industry, to tax its illegitimate outeome burdensomely, and for this reason are the farmers and cousumers of the country making their wishes known to this Congress on this bill.

Is oleomargarine a healthful food? There is no way to determine this question except by actual trial; not for a day, a week, or a mouth, but for several successive months, and not with strong, robust men with plenty of outdoor exercise.

Uhemistry can not answer. For example, the chemist will tell you that he finds the same elements in swamp peat that are found in the grasses and hays that are fed to our cows, and in approximately the same proportion. And the chemist is at a loss to determine from the staudpoint of his science why cattle should not feed on swamp peat. Chemistry ean not determine whether any particular substance is poisonous or not. It must take a stomach to do that.

There is no eredible evidence to show that oleomargarine is innocuous; no evidence to show that when eaten continuously in place of butter it is not harmful. But there are reports in great abundauce to the effect that oleomargarine is harmful.

Mr. Edmund Hill, a member of the Smmerset County council, England, reports that the great bulk of oleomargarine, or "margarine" as it is called there, is eaten in public iustitutions, convents, schools, etc. At the Wells Asylum, with which he is connected, the inmates receive oleomargarine. In the asylums of Dorset, Wells, and Hants-the adjoining connties-butter is furnished, and the death rate at Wells is 30 per cent ligher. At the Taunton Hospital there were 11 deaths in thirteen months. Oleomargarine was substituted, and in nine months the deaths rose to $2:$.

This accords with the experience in France, where its use in hospi- 
tals is forbidden. In the United States, in institutions for the blind and for girls, it has been noticed that the use of oleomargarine lowered the vitality of the inmates very perceptibly.

There is abuudant reason for this. The normal heat of the human stomach is $98^{\circ}$. Butter melts at $92^{\circ}, 6^{\circ}$ below the heat of the stomach, passes into pancreatic emulsion, and digestion. Nature designed this fat in its raw state for food.

Oleomargarine melts at the varying temperature of $102^{\circ}$ to $108^{\circ}$, a temperature no healthful stomach ever attains. As a consequence, this unnatural foreign fat must be expelled by sheer gastric action and force.

Butter fat is found in the milk of all mammals. It is chemically and physically unlike any other fat in existence. It was designed by nature for the food and sustenance of infant offspring, having the most delicate of all digestion. Because of this most evident purpose and provision of nature, butter forms a healthful and important article of food in milk, cream, and in its separated state.

No matter what paid chemists may say, no counterfeit, even in its purest state, is wholesome or healthful.

But there is another phase of this question. There is absolntely no protection for the public against most dangerous introduction of positively unhealthiful compounds into oleomargarine.

The Journal of the A merican Chemical Society and the department of agriculture of New York abound in proof of the adulteration of oleomargarine with parafin, a substance which the strongest acids even are unable to affect. There is no reason on earth why the foulest of germ-laden fats should not be used in the making of this componnd, when once they are deodorizeel by the aid of chemistry.

But with butter it is different. Any contamination or hurtful manipulation is instantly shown in a loss of flavor. Butter always advertises its condition.

It should be considered that the distinction proposed in taxation against colored oleomargarine will bring no hardship to the consumer who may want this article as a cheap, fat substitute for butter. The coloring of it ards nothing to its digestibility or food value, if it have a food value. The whole proposition is in a nutshell. Force out the color or semblance to butter and you put a stop to its being imposed on the consumer for butter. In addition you protect this great army of producers, the dairymen of the United States, from competition with a framd and comnterfeit.

It is high time that Congress entered upon this work of protection of all honest and legitimate industries against the dishonest greed of the counterfeiter and adulterator.

The Dominion of Canada has taken from us nearly all of our once magnificient export trade in dairy products. Canada absolutely prohibits the making of counterfeit butter or cheese.

Consequently the Dominion stands high among all foreign consumers as to the purity and honesty of its foods.

Our National Government can proceed repressively only in the way of taxation. We believe we are riglit, fair, and just, and in accordance with a wise public policy, in asking of the members of this committee an earnest support of House bill 3717.

One of the most preposterous arguments advanced in support of the oleomargarine business is that which is unwittingly put in the mouths of the beef and hog raisers by the oleo combine. The Nebraska Farmer 
ot February 15 exposes the fallacy of this argument in an able editorial, from which we quote the following extract:

The National Live Stock Association, at its recent meeting at Fort Worth, Tex., passed a lengthy and stringent resolution condemning proposed oleomargarine legislation. This resolntion, as it appears in the circular letter sent out over the nane of President Springer, is a remarkable document-remarkable alike for its arraignment of one class of agriculturists by another and in its disregard for facts in its general narration.

Some of the false "statements of fact" in the general narration are as follows:

"The 'butter fat' of an arerage beef aninal, for the purpose of making oleomargarine, is worth from $\$ 3$ to $\$ 4$ per head more than it was before the advent of oleoniargarine, when the same had to be used for tallow; which increased value of the beef steer has been added to the market ralne of the animal, and consequently to the profit of the producer. To legislate this article of commerce out of existence, as the passage of this law would surely do, would compel slaughterers to use this fat for tallow, and depreciate the market value of the beef cattle of this country $\$ 3$ to $\$ 4$ per head, which would entail a loss on the producers of this country of millions of dollars.

"The use of this fat for the purpose set forth is an enconragement to the producer to improve his herd and raise a class of grade or thoronghbred cattle capable of making and carrying this fat, rather than the common or scrub animal, which is so hard and unprofitable to fatten; and the eattle raiser or producer has come to know the ralue of this product, and that the amount of the increas. in the market value of his matured animal depends somewhat on the value of the 'lutter fat' carried by the animal."

'To show the absurdity of the above statements it is only necessary to call attention to the fact that every steer or cow butchered by manufacturers of oleomargarine, if good enough to sell for "dressed beef," is sold with the kirney tallow in the quarters. This being true, nothing but the "gut fat" remains in the packing honse.

Therefore every oleo manufacturer that ever lived and all his ageuts are chronic liars, if gut fat of beeves and "bntter tat" of oleomargarine are one and the same thing. More than this, the gut fat of beeves averaged as many pounds per animal in 1890 to 1896 as it does in 1900, and there were "workinguen and their dependencies" (we quote from the resolutions) then as now, and oleo sold as a connterfeit and substitute for butter then as now, without ajpearing to add materially to the "market value of the animal, and consequently to the profit of the producer." "Cattlemen will please take note that swine men claim that they are the people who sufferfrom legislation which hampers the sale of bogus butter. Now, what is jour "butter fat" for oleomargarine? Is it gut fat of cattle or hogs' fat?)

The next fact of importance in connection with the resolutions is the ignorance of cattle breeding shown in the text, therefore the fair presumption that not livestock breeders, but a packing-house attorney, wrote the resolution. We call attention to the statement, "The use of this fat for the purpose set forth (making a counterfeit of butter) is an encouragement to the producer to improve his herd and raise a class of grade or thoroughbred cattle capable of making and carrying this fat, rather than the common or scrub animal," etc.

Every breeder of cattle understands that the value of improved breeds depends on the eapacity of the improved animal to give a larger proportion of euts of good meat to the rough fat (gut fat or "butter fat," just as you choose), and that the chiet objection to the scrub steer or dairy-bred steer is the excess of fat, as compared with meat cuts, due largely to a failure of the serub animal to carry the surplus fat among the meat tissue. Hence the falsehood of the assertion that increase of rongh fat in beeves encourages improved breeding.

This resolution seems to have been introduced to the stockmen's convention by one C. W. Baker, of Illinois, and it seems to be one of those cases where the stock men have been trapped into pulling the packing-house chestnuts out of the fire.

\section{STATEMENT OF CHARLES Y. KNIGHT.}

My business is that of editor of the Chicago Dairy Produce, a publication devoted to the dairy and butter business. I have for the past three years been secretary of the National Dairy Union, an organization of farmers who keep cows, and others engaged in pursuits allied therewith. This organization at present comprises about $30,0(100$ members who are farmers, and they are scattered all over the United States. The organization has for its aim the protection of producers 
and consumers of dairy products against fraud, and its officers serve absolutely without further compensation than their actual and necessary expenses incurred in the discharge of their duty. No officer has ever received one cent salary, but upon the other hand they have spent hundreds of dollars in expenses while working in the interest of the cause, for which no account has ever been rendered the organization.

I have had charge of the work of organization and the collection of facts regarding the oleomargarine traftic of this country, and it is the enormous illegal and frandulent growth of the business during the past two years, in face of the best restrictive laws the States have been able to devise, that has brought us to Congress as a last resort to ask for relief.

\section{THE ORIGINAL OLEOMARGARINE LAW.}

For the information of the committee, all of the members of which may not be familiar with the history of national legislation along this line, I will state that fourteen years ago, finding the powers of the State helpless to cope against the peculiar character of this frand, the dairymen of this conntry arose en masse and e:me to Congress for relief, feeling that nothing but Congressional action would save their business from absolute ruin. They convinced Congress that national legislation was necessary, and the result was that nmmerous measures were introduced for their relief. The matter of legislating against a counterfeit article, however, was found to be a complex proposition for Congress because of the constitutional restrictions which prevent the Congress of the United States exercising police powers except for the protection of its revenue receipts, interstate commerce, and other matters absolutely within the limits of the Constitution, and after months of tedious investigation and effort, what is known as the Hatch bill was finally originated by the Committee on Agriculture, and brought into the House.

\section{PROVISIONS OF THE HATCH BILL.}

At that time it was thonglit, as many have become to believe since, that the mannfacture and sale of oleomargarine could not be permitted and at the same time protect the public against fraud. Acting upon this theory the government of Canada did and has ever since absolutely prohibited the traftic in any character or condition and oleomargarine is not permitted to be sold in that country in any way, shape, or manner. France, where oleomargarine originated as a necessity during the Franco-Irussian war, found it impossible to protect its people against fraud, and even its present law forbidding the sale of that article in any store or shop where butter is sold is not considered adequate-a law which would not stand under our Constitution a week becanse of the great scope of liberty afforded under our form of government. Germany has also adopted the same plan, which has not proven satisfactory, and various other measures are being suggested in that country. In fact, Denmark, Australia, Russia, Italy, Spain, and every other European, antipodean, and Asiatic comntry has found the same trouble in endeavoring to control this deceitful substitute for butter.

It will therefore be seen that the A gricultural Committee had before it a perplexing problem, and one which it seemed to finally despair of solving and at the same time permit the article to survive in commerce, the result of which was the recommendation of a measure which would 
have been pretty close to entire prohibition of the entire traffic had it been passed as recommenderl. I simply cite these facts and conditions to give the committee something of an idea of the great provocations which existed at that time, as reflected by these recommendations, it having been found almost impossible then to secure butter whose purity could be guaranteed, unless it came direct from the farm to the collsumer.

\section{RECOMMENDED A TEN-CENT TAX.}

The recommendations of that committee were many, and the outcome of their investigations a complete scheme for the taxation and regulation of oleomargarine through the Internal-Revenue Department, which taxation would put the article within the constitutional control of the Government and thereby permit the branding requirements which were desired at that time to be enforced by the National Government. A tax of 10 cents per pound was recommended, regardless of color, by that committee.

\section{EXPECTED LAW TO BE ENFORCED.}

The Agricultural Committee, however, did not then know as mueh as the public knows to-day about the Intermal Revenue Department. It was the impression of Congress that when the revenue law required every retailer to brand his package sold the consumer, that this, as well as all other provisions of the measure would be enforced. It was because of the impression that this branding clanse alone would give the public protection that the 10-cent tax was fiually cut down to 5 cents in the House and 2 cents in the Senate, the argument being that the 2-cent tax would give about revenue enough to permit the revente department to pay the expenses of enforcing the branding clause.

\section{WHAT HAS BEEN THE RESULT?}

We have now had about fourteen years of that 2-cent tax. And what has been the result? Has the fraudulent sale of oleomargarine ceased? Not at all! It only required two or three years to develop the fact that the Internal Revenue Department was not in sympathy with any measure that required the exercise of a police surveillance where revenue was not absolutely at stake. For instance, the payment of this 2-cent tax is enforced of the manufacturer when the oleomargarine is produced. No package is permitted to go out of the factory until the tax has been paid. So far as the article itself is concerned all its liabilities to the Government are discharged when that 2-cent tax is paid and the proper brands and stamps are placed upon the original importers' packages. It then goes to the retailer to sell to consumers, and it loses the Government no money if the retailer does not comply with the police regulations requiring each package to be marked. Therefore there is no incentive for the Government to follow up the matter and see to it that the branding clanse is complied with.

The following communication from the dairy commissioner of $W$ isconsin as to the attitude of the Internal Revenue Department toward this feature of the law of 1886 exactly describes the experience of the people of Illinois and many other States in this respect. This letter has just been received, and is therefore late evidence:

Chas. Y. KNight, National Hotel, Washington, D. C.

DFar SIr: Some tine ago you asked me concerning the enforcement of the Federal oleomargarine law by the internal-revenue department in Michigan. I can ouly 
say that iny expcrience covering the last three years as dairy commissioner fortifies me in saying that, outside of the collection of the revenue tax, the Federal authorities in Michigan do absolutely nothing to enforce the national law. I have personally offered to furnish the proof for violations of the Federal law, but no steps were ever taken to change existing conclitions or to punish such violators. It is a fact that scarcely a retuiler in Michigan conforms to the requirements of the Ferleral law-a condition which has existed, to my certain knowledge, for the past three Jears.

Very respectfully,

Elliott O. Grosvenor, Commissioner.

And I will further quote from a recent interview with Collector Coyne, of the city of Chicago, who was visited by a reporter of the Chi. cago Record with packages of oleomargarine which he had purchased for butter, not stamped according to law. The Record said:

Interual Revenue Collector Coyne's attention was ealled to these violations of the law yesterday and the wrappers exhibited. He said:

"I am always willing to prosecute violators of the revenue laws, and I am glad to have these cases called to my attention. It is unfortunate that I have to depend on the public for my information, however. I have 19 counties, including Cook, to look after, and the 15 deputies $I$ am allowed have about 2,000 special taxpayers in their respective districts. These include breweries, saloons, cigar dealers and manufacturers, oleomargarine wakers and dealers, and many others. The force is not large enough for me to watch every retailer-2,000 men would be required to do that. Nor can tho reputies make cases bj purchasing butter or its sulistitute, for they have no fund for that.

"Whenever a citizen comes to me and tells me of a case of this kind I am always willing to do my duty as the law sets it forth. I have been acensed by both sides of leaning toward the other, but neither party is right in making these chargos. If I am called before the agricultural commission l shall be glad to tell what I knowand that is more than I can tell the public in wy present position. The books of this department are not open to the people, but I can assure you that many violators of the oleomargarine laws have suffercd."

This is not intended as a criticism of the department, but is introdinced to show the utter weakness of the law of 1886 , and to prove that we lave grounds for coming again to Congress for relief.

\section{WHX THE 10-CENT TAX ON COLORED OLEOMARGARINE?}

We expect to slow to the satisfaction of Congress that national legislation of the character embraced in H. K. 3717 , known as the Grout bill, with its 10 -cent tax provision, is absolutely essential to prevent the almost absolnte destruction of an industry bringing to the agriculturists of this country fully $\$ 500,000,000$ per year.

First. Because oleomargarine, when made in exact imitation in package and color of butter, is an icleal connterteit, furnishing a commodity which can be readily, and in nime cases ont of ten, with safety, palmed off' upon the known but unskilled ('onsumer as butter at butter prices, as oniy a chemical analysis will, with a degree of certainty necessary in evidence, establish the identity of the substitnte.

Secoud. Becanse the large profit resulting from the sale of oleomargarine as butter in itself furnishes incentive to practice frand and meaus of protection in case of detection, and to-day, with the traffic aggregating close to $100,000,000$ pounds per year, the sum collected through the assessment of even a fraction of a cent per ponnd as a fund for defense is sufficiently large, when judicisusly expended throngh organized channels, to render prosecutions so expensive that in many of the States the comrts have scarcely the capacity to handle offenders, so numerous have they become muler the persistent and aggressive solicitation of the wealthy manntacturers.

Third. Twenty years of experience has demonstrated the fact that oleomargarine, colored in semblance of butter, placed in the hands 
of a dealer, can be sold at his discretion as either oleomargarine or butter. He need not be susceptible to detection in frand so long as he confines his dealings to known customers, whom he knows will not spend days of time upon the witness stand to convict him of a frand small in detail, but enormous in aggregate; therefore, the only sato methoc for preventing these fiauds, so enormons in the agriegate, is to prevent the article being placed in the hauds of the trade in such form that it can be used with profit for deceptive purposes.

Fourth. This policy has been adopted by 32 States, containing, according to the census of 1890 , over $50,000,000$ of the $62,0(10,000$ veople of this country, each of which has passed a law absolutely forbidding the sale of oleomargarine colored in semblance of ycllow butter. These laws have been in force in some States for twelve year's, and no State has ever repealed one.

Fifth. The laws of all these 32 States are continually and systematically violated, clandestinely in some and in open defiance in others. Oleomargarine mannfacturers make no pretense of observing State laws where the legal marhinery for their enforcement is not absolutely invincible, and do not hesitate to come before Congress in protest against an act which at best would simply give the States the assistance of the National Goverumeut in protecting their people as they desire to be protected.

Sixth.-The oleomargarine manufacturers, while openly professing a desire to have their product sold for what it is, secretly sometimes and openly at others, urge clealers to sell it for butter, and cilcumstances connect a number of these manufacturers with some of the most gigantic and widespread swindles ever perpetrated in business affairs.

Seventh. The only persons who really profit from the sale of yellow oleomargarine are those who practice deception in its sale or are the beneficiaries of such deception; the color in the article, conflicting with State laws, causes the dealer to hesitate to sell it unless the profit is sufticiently large to compensate him for the injury likely to accrue to his business in case of prosecution. Manufacturers openly assure dealers that there is double the profit in the sale of oleomargarine that caul be had from the sale of butter- - which in itself is evidence that there must be something peculiar about the trade, and they do not hesitate to openly guarantee protection against the efforts of the State to enforce the laws.

Eighth. The present internal-revenue law, enacted in 1886, has entirely failed in its purpose. In this act Congress placed a tax of 2 cents per pound upon oleomargarine, not as a revenue measure for the General Government, but to raise sufficient funds with which to enable the Government to enforce the clause recuiring the branding of every package, even to the sale by the retailer to the consumel. 'This reveune has been faithfully collected by the Goverument. But throughont the entire country but one exclusive inspector has ever been furuished to see to its enforcement by the interual revenue department. Notonly does the internal revenne department make no effort to carry out the intent of the framers of the law, but those who have endeavored to secure the enforcement of such clauses requiring branding by the retailer have been led to believe that for the purpose of increasing revenue the various collectors wink at such violations. The law of $1586^{\circ}$ now does little else than furnish violators of the State laws the defense that their business is "under the supervision of the Govermment, which provides a complete system of regulation."

Ninth. A system of regulation, to be effective, must be one which 
can be applied to the responsible manufacturer in whatever part of the country he may be found. Any tax imposed will be collected. No regulation prescribed will be enforced by the interual-revenue department unless its violation is likely to impair the revenue. The more the branding clause of the 1854 law is violaterl the greater the revenue, because the oleomargarine pays the tax whether sold for what it is or as butter, and more is sold for butter than oleomargarine. A tax of 10 cents per pound, if levied, would be collected upon all oleomargariue, colored to resemble butter. The collection of this tax alone would accomplish the result of taking out of the counterfeit article the large profit now held up before the eyes of the retailer's as an incentive to commit fiaud and violate State laws, and, profits on oleomargarine and butter being equalizetl, each would have a fair chance of sale.

Tenth. The use of the taxing power of the Government to accomplish this result would not be the usurpation of the rights of the States to regulate their own affairs. It would simply be the cooperation of the General Government with the States upon petition of their people to do a thing they had failed to accomplish individnally, and enongh people, through their legislatures, have already autopted the policy of excluding yellow oleomargarine to have the moral force of a constitutional amendment,

Eleventh. The claims of damage to the beef-raising, cotton-growing, or hog industries is an impudent and easily exploded argument to secure the antagonism of the cattle raisers of the North and cotton growers of the South to this measure and induce them to rush to the clefense of a class of manufacturers who, with their records as lawbreakers, can hartly have standing before a body of law-makers representing States whose statutes they are openly ignoring, boldly defying, or secretly erading.

Tweifth. 'The policy of prohibiting the coloring of oleomargarine in imitation of butter has the approval of the highest authority in the decision of the United States Supreme Court in Plumley v. Massachusetts (15jth W. S.) in which such a law as is now in force in thirty-two States was strongly upheld upon the grounds that it was plainly a regulation in the interests of honest dealings, and again in Schollenberger $v$. Pennsylvania(171st Federal Report). Such laws have been before the supreme courts of many States and never in a single instant has such policy been declared contrary to their constitutions.

Thirteenth. While the questions of healthfulness might be an interesting one in this connection, we do not feel called mpon to permit ourselves to be drawn into a controversy which at best would resolve itself into the expensive and time consuming confusion of a war of paid experts, which was thoroughly investigated in 1886 by the Agriculture Committee, with a result of recommending a 10 cent tax on all oleomargarine, and is now a matter of record easily accessible to all who desire to consnlt it in the files of the Congressional Record.

All we ask is that the people be protected in the right to choose between the two articles. If the makers of oleomargarine can convince the public that their product is all they claim for it, we are willing that the people thus convine shomld be enabled to purchase that article $1 \frac{3}{4}$ cents per pound cheaper than can be done under the present law. Our eharge is frand in selling to the people an article they do not intend to buy at the price of what they desire to purchase. Because an article may be proven to be healthful is no reason why it should be permitted to be firaudulently substituted for another. Can the arlulteration of pepper with corn meal be excused and defended upon the 
ground that coln moal is a liealthful article of food? What would be said of the defense of a butcher who sold horse meat as beefsteak to his cnstomer and set up the plea that the horse flesh was as " uutritious and healthitul as beefsteak?"

\section{CONGRESS OUR LAST RESORT.}

We have not appealed to Congress for aid along the line of discouraging the sale of oleomargarine made in semblance of butter until the matter of accomplishing the same result through State legislation has been thoroughly tested and proven a failnre. And this fact we believe to be our strongest argument in favor of Congressional action.

The various States have tried all kinds of legislation. The attempt to control the aetions of the retailer with a counterfeit article in his hands has been abandoned by practically every one of the leading States. To.day thirty-two States, witl four-fifths $(50,117,440)$ of the population, according to the ceusus of 1590 , have passed laws absolutely prohibiting the sale of oleomargarine made in imitation of butter. This issue has been fought out in the legislatures of these various States, and these measures have receivel the stamp of approval of their law-making borlies and the indorsement of their governors.

The following compilation of the substance of the dairy laws of the United States was published by the Agricultural Department under the seal of Secretary IVilson a year ago, and copies of the laws in full may be had from the Secretary of Agriculture:

ALABAMA-ANTICOLOR LAW.

(Approved Fobruary 18, 1895.)

No article which is in imitation of pure yellow butter, and is not made wholly from pure milk and eream, shall be raanufacturerl, sold, or used in any public eating place, hospital, or penal institution, etc.; but oleomargarine, fres from color or other ingredient to cause it to look liko butter, and marle in snch manner as will arlvise the consumer of its real character, is permitted. It must be stamped with its name.

ARIZONA.

No dairy laws.

ARKANSAS-MUST BE LABELED.

(A pproved April 2, 1885.)

Substitutes for butter, whether in wholesale or retail packages, sluall be planly labeled "Arlnlterated bntter," "Oleomargarine," or such other wanes as shall properly describe them. In hotels, etc., dishes contaiuing said articles must be plainly marked in same mauner.

\section{CALIFORNIA-ANTICOLOR LAW.}

(Approved March 4,1897.)

Imitation butter and cheese is defined as any article not prodnced from pure milk or cream, salt, renuet, and haruless coloring matter, which is in semblance of butter or cheese and designed as a substitute for such. Shall not be colored to imitato butter or cheese, and must be in such form as will advise consumer of its real character. Every package must be plainly marked "Substitute for butter" or "Substitute for cheese" and accompanied by a statement giving name of mannfacturer, iugredients, etc., a copy of which must be given to oach purchaser, with verbal notice, at the time of sale, in counection with which worls like "creamery," " dairy," etc., are prohibited. Patrons of eating places shall bo notified if substitutes of butter or checse are used. Prohilited in State charitable institutions.

$$
\text { S. Rep. } 2043-38
$$




\section{COLORADO-ANTICOLOR LAW.}

(Approved April 1, 1895.)

All articles not produced from pure nilk or cream, in imitation of pnre cheese or yellow butter, are prohibited; but oleomargarine and filled cheese are permitted if free from color or other ingredient to cause them to look like butter or cheese; they must be made in such form and sold in such manner as will advise the consumer of their real character. Cheese containing any foreign fats, oleaginous substances, rancid butter, etc., shall be branded "Imitation cheese."

\section{CONNECTICUT-ANTI-COLOR LAW.}

(Public Acts, 1895.)

Imitation butter, defined as any article resembling butter in appearance and not made wholly, salt and coloring matter excepted, from cow's milk, is prohibited; bnt oleomaryarine or imitation butter, free from color or other ingredient to cause it to look like butter, and made in such form and sold in such manner as will advise consumer of its real character, is permitted. Words like "butter," "dairy," etc., shall not form a part of its name or appear on its package. Imitation butter shall be sold only in labeled packages, or registered places which display signs, and purchasers shall be informerl orally of the character of the article at the time of sale. Use of imitation butter in public eating places, bakeries, etc., must be made kuown by signs.

\section{DELAWARE-ANTICOLOR LAW.}

(Passed May 8, 1895.)

The manufacture or sale of any article not produced from unadulterated mille or cream, which is in imitation of pure yellow butter or designerl to take the place of pure cheese, is prohibited; but oleomargarine is permitted if in a distinct form, free from butter color and sold in such manner as to show its real character; it shall be plainly marked "Oleomargarine."

\section{DISTRICT OF COLUMBIA-BRANDING LAW.}

(Approved March 2, 1895.)

Substances in semblance of bntter or clieese, not made exclusively of milk or cream, but with the addition of melted butter or any oil, shall be plainly branded on each package "Oleomargarine," and a label, similarly priuted, must accompany each retail sale.

\section{FLORIDA-MUST NOTIFY GUESTS.}

(Approved February 17, 1881.)

The sale of any spurious preparation, purporting to be butter, is prohibited. Gnests at hotels, etc., must be notified if oleomargarine or other spurious butter is used.

\section{GEORGIA-ANTICOLOR LAW.}

(Approved December 16, 1895.)

Imitation butter and clieese are defined as any article not produced from pure milk or cream-salt, rennet, and coloring matter excepted-in semblance of butter or cheese and designed to be used as a substitute for either. Shall not be colored to resemble butter or cheese. Every package must bo plainly marked "Substitute for butter" or "Substitute for cheese," and each sale shall be accompanierl by rerbal notice and by a printed statement that the article is an imitation, the statement giring also the name of the producer. The use of these imitations in eating places, bakeries, etc., must be made known by sigus.

IDAHO-BRANDING REQUIRED.

(Approred January 27, 1885.)

Brand required for sale of oleomargarine or butterine, imitation butter, or mixture imitating butter. These shall not be sold as butter. 


\section{ILLINOIS-ANTICOLOR LAW.}

(Approved June 14, 1897.)

Imitation butter is defined as any article not prorluced from pure milk or creamsalt, rennet, and coloring matter excepted-in semblance of butter and designed to be used as a substitute for it. Shall not be colored to resemble butter. All packages must be plainly branded "Oleomargarine," "Butterine," "Sulustitute for butter," or "Imitation butter." Each sale sliall be accompanied by notice to the purchaser that the substitute is imitation butter.

\section{INDIANA-LABEL LAW.}

Butter other than that made from pure milk, when sold or used in hotels, etc., must be plainly labeled "Oleomargariue."

\section{IOWA-ANTICOLOR LAW.}

(Passed in 1893.)

Imitation butter or cheese is defined as an article not produced from pure milk or cream-salt, rennet, and coloriug matter excepted-in semblance of butter or cheese and designed to be sold as a substitute for either of thenı. Shall not be colored to resemble butter or cheese. Every package shall be plaiuly marked "Substitute for butter" or "Substitute for cheese," and each sale shall he accompanied by a verbal notice and a printed statement that the article is an initation, the statement giving also the address of the maker. The use of these imitations in hotels, bakeries, etc., must be inado known by sigus.

\section{KANSAS.}

No law.

\section{KENTUCKY-ANTICOLOR LAW.}

\section{(Act of 1898.)}

Oleomargarine, butterine, or kindred compound, made in such form and sold in such manner as will alvise the customer of its real character, and free from color or other ingredient to cause it to look like butter, is permitted.

\section{LOUISIANA-LABEL LAW.}

(Approved Jaly 6, 1888.)

Such substances as oleomargarine, butterine, bogus bntter, etc., shall be plainly labeled to indicate their composition. They shall not be sold as butter.

\section{MAINE-ANTICOLOR LAW.}

(Approved March 27, 1895.)

Any article in imitation of yellow butter or cheese and not made exelusively of milk or cream is prohibited.

\section{MARYLAND-ANTICOLOR LAW.}

(Passed in 1888.)

The manufacture, sale, or use in public eating places of any article in imitation of aud designed to take the place of pure butter or cheese, and not made wholly from milk or cream, is probibited. Mixtures of any animal fats or animal or vegetable oils with milk, eream, or butter shall be uncolored, and marked with names and percentages of adulterants, and this informalion shall bo given to purchasers.

\section{MASSACIIUSETTS-ANTICOLOR LAW.}

(Approved June 11, 1891.)

An article made wholly or partly out of any fat or oil, etc., not from pare cream, and which is in imitation of yellow butter, is prohibited; but oleomargarine, freo frour color or other ingredient to cause it to look like butter, and made in such form and sold in such nanner as will advise the consumer of its real character, is 
permitted. It shall not be sold as butter, nor shall words like "dairy," "creamery," etc., or the name of auy breed of dairy cattle, be used in counection with it. All packages exposed for sale must be plainly marked "Oleonargarine," and lalıels similarly marked must aecompany retail sales. Stores where it is sold and wagons nsed for delivery must display sigus, and hotels, etc., using it must notify guests. Persons selling oleomargariue inust be registered and conveyors licensod.

\section{MICHIGAN-ANTICOLOR LAW.}

(Approved April 15, 1897.)

Any article not made wholly from milk or cream, and containing molted butter, fats, or oils not produced from milk, and which is in imitation of pure butter, is prohibitel; but oleomargariue, free from color or any iugredient to cause it to look like butter, and made in such form and sold in such manner as will advise the consumer of its real character is permitted; its sale as butter is prohibited; signs must be displayed where it is sold or used, and its original packages must be plainly marked "Oleomargarine" if the article contiins snet or tallow, or "Butterine" if it contains lard; retail sales shall be made from a package so nlarked, and a label similarly printed and bearing the name of the manufaeturer shall be delivered with each sale; shall not be used iu any public institntion. (N. B.-The above law was invalidated in 1897 by the supreme cout because of the fact that the enacting clause was omitted when it passed the senate.)

MINNESOTA-ANTICOLOR LAW.

(Approved 1899.)

This law prohibits the sale of oleomargarine made in imitation of butter, and took the place of the pink law of 1891.

\section{MISSISSIPPI-LABEL LAW.}

(Approved March 9, 1882.)

Packages of oleomargariue or similarly manufactured butters shall be plainly labeled with the correct name of their contents, and the product shall be sold by that name. A privilege tax of $\$ 5$ is imposed upon persons selling the articles named.

MISSOURI-ANTICOLOR LAW.

(Approved April 19,1895.)

Imitation bntter is defined as every article not produced wholly from pure milk or cream, made in semblauce of aud clesigned to be used as a substitute for pure butter; it shall not be sold as butter; shall not be colored to resemble butter unless it is to be sold ontsicle the State; original packares shall be plainly stamped "Substitute for butter;" in hotels, etc., vessels in which it is served must be marked "Oleomargarine" or "Impure butter."

\section{MONTANA-TAXED 10 CENTS A POUND.}

(Penal code of 1895.)

Any article in semblance of butter or cheese, and not made wholly from milk or crean must be plainly labeled "Oleomargarine" or "Initation cheese," and a printed label bearing the same word or words minst be delivered to the purchaser with retail sales. Places where these articles are sold or used must displily signs, and in formation as to their cliaracter be given if requested. Dealers must pay a license of 10 cents a pound on each pound solil.

\section{NEVADA-BRANDING LAW.}

(A pproved Feb. 14, 1881.)

Any article in semblance of butter but not made exclusively of unilk or cream, or containiug melted butter, shall be in packages plainly marked "Uleonargarine."

\section{NEBRASKA-ANTICOLOR LAW.}

(Approved March 16, 1895.)

Imitation butter aud cheese are defined as any article male in semblance of and designed to be used as a sulustitute for pure butter or cheese aud not produced 
wholly from pure milk or cream, salt, rennet, and harmless coloring matter. These articles, including any having melted butter added to them, shall not be eolored to resemble butter or cheese; shall be plainly marked "Imitation butter," or "Imitation cheese;" verbal and printed information of the character of the articles, and address of the maker, shall be given at time of sale; signs shall be displajed in public eating places where used.

\section{NEW HAMPSHIRE-ANTICOLOR LAW.}

\section{(Approved March 29, 1895.)}

Any article not made wholly from unadulterated milk or cream, which is in imitation of pure sellow butter or cheese, is prohibited, unless in packages plainly marked "Adulterated butter," "Oleomargarine," or "Imitation cheese." A label printed with the words on the original package shall be delivered with each retail sale. Oleomirgarine, free from color or ingredient to cause it to look like butter, and made in such form and sold in such manner as will advise the consumer of its real character, is permitted. Notice of the use of substitutes for butter in hotels, etc., shall be given to patrons.

\section{NEW JERSEY-ANTICOLOR LAW.}

(Approved March 22, 1886.)

Any article made wholly or partly out of any fat, oil, etc., not from pure milk or cream, artificially colored in imitation of pure yellow butter, is prohibited; but oleomargarine and imitation cheese are pernitted, if free from artificial color and in original package, encircled by a wide black band bearing the name of the maker and having the name of the contents plainly brauded on them with a hot iron. Retail sales shall be accompanierl by a printed eard on which the name of the substance and the address of the maker are plainly printed, and the customer shall be orally informed of the character of the article at the time of sale.

NEW MEXICO.

No law.

\section{NEW YORK-ANTICOLOR LAW.}

(Approved April 10, 1893.)

The terms oleomargarine, butterine, imitation butter, or imitation cheese mean any article in the semblance of butter or cheese not the usual product of the dairy and not made exclusively from unadulterated milk, or having any oil, lard, melteil butter, etc., as a component part. Imitation butter.-The manufacture of oleomargarine or any article in imitation of butter wholly or partly from fats or oils not produced from milk, or the sale or the use in botels, etc., of such articles, is prohibited. No article inteuded as an imitation of butter and containing oils, fats, etc., not from milk, or melted butter in any condition, shall be colored yellow.

\section{NORTH CAROLINA-LABOR I.AW.}

(Ratified February 28, 1895.)

Oleomargarine and butterine are defined as articles mannfactured in imitation of butter, and which are composed of no ingredient or ingredients in combination with butter. Original packages shall be labeled with chemical ingredients and their proportions.

\section{NORTH DAKOTA-ANTICOLOR LAW.}

(Laws of 1899.)

Law prohibits manufacture and sale of oleomargarine colored in semblance of butter.

$$
\text { OHIO-ANTICOLOR LAW. }
$$

(Approved May 16, 1894.)

Oleonargarine is defined as auy substance not pure butter of not less than 80 por cent butter fat and made for use as butter. It is permitted if free from coloring matter or other ingredient to cause it to look like butter, and made in such form and sold in such manner as will advise the consumer of its real character. 
No laws.

OKLAHOMA.

\section{OREGON-ANTICOLOR LAW.}

(Filed February 21, 1899.)

Forbids the manufacture and sale of oleomargarine colored in semblance of bntter.

PENNSYLVANIA-ANTICOLOR LAW.

(Passed in 1899.)

Prohibits manufacture and sale of oleomargarine made in semblance of butter.

RHODE ISLAND-BRANDING LAW.

(Laws of 1882.)

Any article not made wholly from milk or cream, but containing any melted butter or animal oil or fat not the product of milk, shall be plainly markerl "Oleomargarine," and a label similarly printed shall be delivered with all retail sales.

\section{SOUTH CAROLINA-ANTICOLOR LAW.}

(Approved March 9, 1896.)

Imitation butter and cheese are defined as every article not prorluced from pure milk or cream, with or withont salt, rennet, and harmless coloring matter, which is in semblance of, and designed to be used, as a substitute for butter or cheese; they shall not be colored to resemble butter or cheese; original packages shall be markerl "Substitute for butter," or "Substitute for cheese;" shall not be sold as genuine butter or cheese, nor used in hotels, etc., unless signs are displayed.

\section{SOUTH DAKOTA-ANTICOLOR LAW.}

(Laws of 1897.)

Auy article not made wholly from pure uilk or cream, and in imitation of pure butter, is prohibited; but oleomargarine, colored pink and made in snch form and sold in such manner as will advise the consumer of its real character, is permitted; notice of its use in public eating places must be given.

TENNESSEE-ANTICOLOR LAW.

\section{(Act of 1895.)}

Any article which is in imitation of yellow butter and not made exclusively from pure nilk or cream is prohibited; but oleomargarine, free from color or other ingredient to canse it to look like butter, and made in such form and sold in such manner as will advise the consumer of its true character, and other imitations if nucolored and labeled with their correct names are permitterl; wholesale packages shall be plainly labeled and a label shall accompany retail sales.

TEXAS.

No law.

\section{UTAH-ANTICOLOR LAW.}

(Approved March 8, 1894.)

Any article in semblance of butter or cheese, and not made wholly from milk or cream, shall be plainly marked "Oleomargarine butter," or "Imitation cheese," anil retail sales shall be made from packages so marked. Such articles shall not be colored to resemblo butter or cheese.

VERMONT-PINK LAW.

(Laws of 1884.)

The manufacture of any article in innitation of butter or cheese which contains any aninal fat, or animal or vegetable oils or acids not produced from pure nilk or cream, is prohibited.

Imitation butter.-Imitation butter for use in public eating places, or for sale, shall be colored pink. 


\section{VIRGINIA-ANTICOLOR LAW.}

(Approved January 29, 1898.)

The manufacture or sale of any article made wholly or partly from any fat or oil not profluced from unadulterated milk or cream, which is in imitation of pure yellow lintter, is probibited; but oleomargarine, butterine, or kindred compound, made in such form and sold in such nanner as will advise the consumer of its real character, and free from color or other ingredient to cause it to look like butter, is permitted. Signs, with the words "Imitation butter used here," shall be displayed in eating places, bakeries, etc., where the articles above named are used.

\section{WASHINGTON-ANTICOLOR LAW.}

(Approved Mareh 11, 1895.)

No article which is in imitation of pure yellow butter and is not made wholly from pure nilk or cream, with or withont harmless coloring matter, slall be manufactured, sold, or used in any public eating house or eleemosyuary or penal institution, etc., but oleomargarine, free from color or other ingredient to make it look like butter, and made in such form and sold in such manner as will advise the consumer of its real character, is permitted.

\section{WEST VIRGINIA-PINK LAW.}

(Approsed Febraary 16,1891.)

Any substance in semblance of butter or cheese, and not made wholly from impure milk or cream, and packages containing such substances, shall be plainly inarked; printed statements explaining the character of the substance must be given to -onsumers.

Oleomargarine.-Oleomargarine and artificial and adulterated butter shall be colored pink.

\section{WISCONSIN-ANTICOLOR LAW.}

\section{(Laws of 1895.)}

Any article made partly or wholly out of any fat or oil, etc., not from pure milk or cream, and in imitation of yellow butter, is prohibited; but oleomargarine, free from color or other ingredient to make it look like butter, and made in such form and sold in such mauner as will advise the consumer of its real character, is permitted. It shall not he sold as butter. All packages exposed for sale must be plainly marked "Oleomargarine." Signs must be displayed in selling places and on wagons. Hotels, etc., using it must notify guests. Use not permitted in charitable or penal institutions.

No dairy laws.

WYOMLNG.

\section{STATES WITH ANTICOLOR LAWS.}

The population of the States which have passed laws forbidding the sale of oleomargarine colored in semblance of butter, as shown by the census of 1890 , is as follows:

\begin{tabular}{|c|c|c|}
\hline \multicolumn{3}{|r|}{ Population. } \\
\hline Pennsylvania........... & & \\
\hline Illinois ....... & & $3,826,351$ \\
\hline Ohio ........ & & $3,672,316$ \\
\hline Missonri ...... & & $2,679,184$ \\
\hline Massachusetts & & $2,238,943$ \\
\hline Michigan ...... & & $2,093,889$ \\
\hline Iowa....... & & $1,911,896$ \\
\hline Kentucky.. & & $1,858,635$ \\
\hline Georgia..... & & $1,837,353$ \\
\hline Tennesseo... & & $1,766,518$ \\
\hline Wisconsin $\ldots \ldots \ldots \ldots . . .$. & & $1,686,880$ \\
\hline Virginia ................ & & $1,655,980$ \\
\hline (........... & & $1,513,017$ \\
\hline 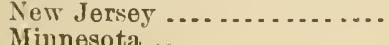 & & $1,444,933$ \\
\hline $\begin{array}{l}\text { Minnesota } \ldots \ldots \ldots \\
\text { Califor ia } \ldots \ldots \ldots \ldots \ldots\end{array}$ & & $1,301,826$ \\
\hline & & \\
\hline
\end{tabular}

Population.

$\begin{array}{ll}\text { South Carolina.............. } & 1,151,149 \\ \text { Nebraska ................. } & 1,058,910\end{array}$

Maryland .................. 1, 042,390

West Virginia ............ 762,794

Comnecticut ............. 746,253

Maine ................... 661,086

Colorado................. 412, 198

Now Hampshire.............. $\quad 376,530$

Washingtou ............... 349,390

Oregon ................... 313,767

Veruiout.................. 332,442

Sonth Dakota............. 32 8,808

Utah.................... 20.

North Dakota............. 182, 711

Delaware................ 168, 493

Total ............. 50,117, 140 
The States and Territories which have not passed laws forlidlling the sale of oleomargarine colored in semblance of butter are :

\begin{tabular}{|c|c|c|c|}
\hline Tex & $\begin{array}{l}\text { Population. } \\
2,235,523\end{array}$ & New Mexico... & $\begin{array}{r}\text { Population. } \\
153,593\end{array}$ \\
\hline Ind & $2,192,404$ & Montana.... & 132,156 \\
\hline North Carolina................... & $1,617,947$ & Idlaho....... & 84,385 \\
\hline ansas.......... & 1,42 & Oklahoma................ & 61,834 \\
\hline Mississippi. & $1,289,700$ & Wyoming ....... & 60,705 \\
\hline 然 & $1,128,1$ & Arizona ........... & \\
\hline onisiana. . & $1,118,587$ & Nevada... & 45,7 \\
\hline ........ & 321,422 & & \\
\hline Rhorde Island $\ldots \ldots \ldots \ldots \ldots$ & 345,506 & Total & \\
\hline istriet of Columbia ......... & 230,3 & & \\
\hline
\end{tabular}

MAKE NO PRETENSE OF OBEYING STA'TE LAWS.

"Why." you will ask, "if you bave State laws in these States do you neerl national legislation?"

As far back as $\mathbf{1 S S 6}$, when this matter first eame before Congress, the States bad learned of the impossibility of controlling this traffic throngh State laws. The article oleomargarine when made in semblance of butter is an absolute counterfeit. The dealer himself could not distinguish one from the other should they lose their labels. The retailer carries the butter and oleomargarine in the same refrigerator. When butter is called for by a customer whon be knows is not likely to be an inspector, he can with little fear of detection take the order from the oleomargarine tub instead of the butter tub. Maybe the strange or nncertain customer will receive pure butter, if he clesires to take no chances, but upon those of whom he feels certain are not detectives he can practice deception day in and day ont with little chance of detection, and in case of detection it is a very easy matter to plead unintentional mistake, and thus at least allay the wrath of the custoner, who has no desire to appear from time to time in conrt in order to punish the dealer for an offense which alone seems insignificant. Then, aside from this conclition, the former laws gave no protection to the guest of the hotel, restanrant, or boarding house, who asks and pays for pure butter and is given a counterfeit.

It was such a condition which provoked the States to an absolute prolibition of the traffic in colored oleomargarine. This was not done until every effort had been made to enforee the branding laws, and until it was demonstrated that the Internal Revenue Department was giving no attention to that clause in the national law requiring the retailer to brand every package of oleomargarine plainly.

For a few years these laws forbidding the coloring of oleomargarine in semblance of butter were effective. However, they demonstiated to to the oleomargarine makers one fact, which the majority probably knew before: The success of the oleomargariue business liad resterl wholly upon the ability of the seller to sell at least a portion of the goods he handlerl as butter at butter prices, and upon the success of the hotel and restanrant keepers to make their patrons believe they were consuming butter. If they were not allowed to color their grease in such imitation, and its identity was made known through such lack of color, the opportunity for deception and large profits were entirely wiped out. The man who really desiren oleomargarine insisted upon buyiug it upon the basis of values of tallow, lard, and cotton-seed oil instead of paying butter prices. This would result in a business with 
only moderate profits, with an opportunity for broad competition, which scemed small compared with former profits and prices.

'The ontcome has been a new policy upon the part of the makers of oleomargarine. No place in the comntry, so far as we are able to ascertain, are they making an effort to create a market for their goors under its own true color and in accordance with State laws. In Illinois two year's ago, when the anticolor law was first passed and some retail dealers made an effort to sell the uncolored article in compliance witl the law, they were discouraged by an extra charge of " 2 cents per pound for oleomargarine without coloring in it. It was at this time that the firm of Armour \& Co.. of Chicago, through the decision of Philip D. Armour, retired from this business entirely and has not since handled a pound of oleomargarine, Mr. Armour giving it ont that he was a law-abiding citizen and would not countenance the violation of the laws of his own State.

The remaining manufacturers, however, throughout the country, ent:rely abaudoned any pretense of obeying State laws. They adopted the policy of going to the retail dealers and urging them to violate the laws of their State. They provide for a defense fund, and whenever prosecutions are made those prosecuted are defended by the best of legal talent, attorneys who have made a study of the question of harassing the State and securing continuances or dismissals through legal technicalities. The ordinary State's attorney can not cope with these experienced practitioners upon this subject, as a rule, and never is money spared to make the prosecution as expensive to the State and as clisagreeable to those connect'd therewith as possible.

Therefore, in attempting to enforce its laws the state is not dealing with the retailer, who, if unsupported, would remain a law-abiding citizen. Upon the other hand, every time an arrest is made the fight is taken up by the entire oleomargarine industry, with its millions of money and enormous influence among a certain class of politiciaus who at times manage to reach the sacred ear of the judge who presides in the case.

The prosecution of such offenders requires the very highest grade of talent, and their conviction experience and a statute which will stand the onslaught of the most resourceful lawyers. A law may liave answered for yeal's in regulating other evils, but when contested by such ability as is employed by the oleomargarine millions. might be picked to pieces and rendered absolutely worthless through the manipulations and researches of the experienced tricksters. No technical. ity is too small for them to take advantage of and make the prosecution the expense of a test case in the Supleme Court.

However, the actual condition of the oleomargarine traffic as it exists to-day is probably the best indication of the inability of the States to enforce their laws against this subject.

The oleomargarine makers contend that the people will not eat their product unless it has the color of butter. They will not admit that it is possible to sell any quantity mncolored. Therefore it is entirely safo to assume that the oleomargarine made during the fiscal year ending June 30,1399 , was made in semblance of butter almost to a pound. The statement of Secretary Gage in response to Congressman Tawney's resolution showed where the prorluct of this year had been consumed.

The table below exhibits the number of pounds sold in each State as shown by Secretary Gage's report, the compiler hereof having divided the list into two classes; first, showing the amount sold in States 
where the sale of olenmargarine made in semblance of butter is absolutely prolibited, and, second, the States in which it was legal to sell such oleomargarine:

Yellow oleomargarine sold contrary to law in 1899.

\begin{tabular}{|c|c|c|c|c|c|}
\hline & $\begin{array}{l}\text { Number } \\
\text { of dealers. }\end{array}$ & $\begin{array}{l}\text { Quantity } \\
\text { sold. }\end{array}$ & & $\begin{array}{l}\text { Number } \\
\text { of dealers. }\end{array}$ & $\begin{array}{l}\text { Quantity } \\
\text { sold. }\end{array}$ \\
\hline 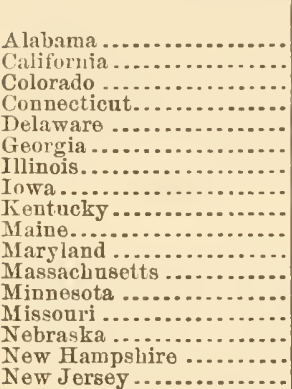 & $\begin{array}{r}21 \\
95 \\
5 \\
48 \\
61 \\
2,020 \\
3 \\
217 \\
17 \\
58 \\
108 \\
30 \\
231 \\
73 \\
19 \\
296\end{array}$ & $\begin{array}{r}\text { Pounds. } \\
226,053 \\
74,923 \\
1,123,537 \\
134,255 \\
40,475 \\
495,004 \\
18,638,921 \\
79,922 \\
1,490,577 \\
102,274 \\
1,791,950 \\
2,083,889 \\
1,343,865 \\
3,133,313 \\
1,024,985 \\
445,583 \\
5,875,975\end{array}$ & 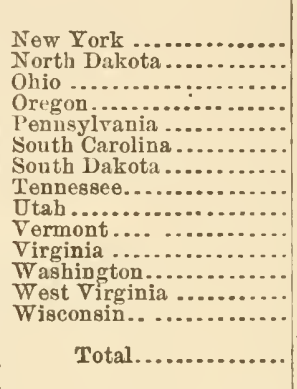 & $\begin{array}{r}14 \\
18 \\
1,005 \\
3 \\
717 \\
24 \\
4 \\
83 \\
1 \\
121 \\
5 \\
172 \\
23 \\
5,492\end{array}$ & $\begin{array}{r}\text { Pounds. } \\
222,788 \\
7,710 \\
8,830,969 \\
41,250 \\
11,433,341 \\
258,159 \\
55,432 \\
714,640 \\
8,450 \\
2,990 \\
1,159,400 \\
63,345 \\
1,206,865 \\
714,742\end{array}$ \\
\hline
\end{tabular}

Oteomargarine sold in States where legal to color.

\begin{tabular}{|c|c|c|c|c|c|}
\hline & $\begin{array}{l}\text { Number } \\
\text { of dealers. }\end{array}$ & $\begin{array}{l}\text { Quantity } \\
\text { sold. }\end{array}$ & & $\begin{array}{c}\text { Number } \\
\text { of dealers. }\end{array}$ & $\begin{array}{l}\text { Quantity } \\
\text { sold. }\end{array}$ \\
\hline 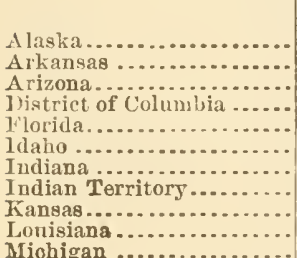 & $\begin{array}{r}5 \\
35 \\
5 \\
61 \\
82 \\
3 \\
306 \\
21 \\
186 \\
140 \\
109\end{array}$ & $\begin{array}{r}\text { Pounds. } \\
18,080 \\
380,389 \\
78,767 \\
816,848 \\
590,225 \\
58,224 \\
3,923,228 \\
152,278 \\
1,658,544 \\
1,043,502 \\
2,092,521\end{array}$ & 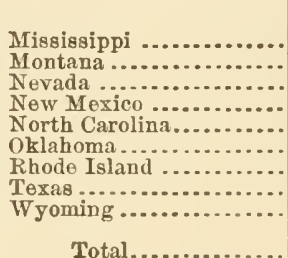 & $\begin{array}{r}17 \\
12 \\
9 \\
10 \\
333 \\
162 \\
5 \\
\end{array}$ & $\begin{array}{r}\text { Pounds. } \\
104,622 \\
446,022 \\
625 \\
115,850 \\
110,224 \\
117,398 \\
3,594,984 \\
1,518,264 \\
39,547\end{array}$ \\
\hline
\end{tabular}

Thus it will be seen that $62,825,582$ of the total of $79,685,724$ pounds reported shipped into the various States were sold in violation of the laws of the rarious States. There were but $16,860,142$ pounds sold legally, and a very large percentage of that was unquestionably sold as butter.

We feel, therefore, that in setting forth the above facts and conditions we are basing our appeal upon evidence which is nnimpeachable. The record of the existence of these anticolor laws for years in the various States without a single repeal or demand for repeal by the actual consumer is evidence that the people are not anxious for oleomargarine colored in semblance of butter. The expansion of the traffic the past two years has not been the result of the demand of the people for oleomargarine, but is the result of the greed for profit which lias induced retailers by the thousands to risk prosecution, with a guaranty of protection, in order to secure the large profits in the sale of oleonargarine for butter.

Is it right, therefore, that the will of four-fifths of our people, as reflecter by their legislatures, should be defied by a few mannfacturers of an ontlawed article? When an expression of four-fifths of our people favors this policy of discouraging the manufacture of colored 
oleomargariue, and no protests come from the actual consumers among the remaining one-fifth, should Congress hesitate to accept it as practically the unanimous wish of the people that everything possible be done to discourage this fraud by whatever means in its power?

Possibly the most comprehensive way in which to get at the merits of our case is to answer the objections to the imposition of a ten-cent internal-revenue tax upon oleomargarine colored to resemble butter, as urged by Swift \& Co., of Chicago, one of the lealing manufacturers of that article. who are now doing business in the State of Illinois in contravention and defiance of a State law passed with a twothirds majority by the Illinois legislature in 1897. Swift \& Co. say, in a letter mailed every member of Congress under date of January 27, 1900:

\section{THE MAGNITUDE OF THE INDUSTRY.}

"First. Oleomargarine has been mannfactured in this country for about trenty-five year's, and in its mannfacture there is now invested more than $\$ 15,000,000$, furnishing employment to many thousand men. The wholesale and retail sale and delivery of oleomargarine lurnish employment to $25,000 \mathrm{men}$. There is probably $\$ 15,000,000$ to $\$ 20,000,000$ invested in the wholesale and retail trade, separate and apart from the manufacture of the article."

Here, as well as in every other effort to influence Congress by holding up to public gaze the "enormous proportions" of the olcomargarine industry, Swift \& Co. have evidently included in what they term the "manufacture of oleomargarine" the neutral lard and oleo-oil industry, which will be treated thoroughly under the department devoted to the effect of the Grout bill upon the live-stock interests.

It is a well-known fact that Messrs. Braun \& Fitts and William J. Moxley, of Chicago, produce almost if not quite one-third of all the oleomargarine manufactured in the United States. The combined extreme rating of these firms by Dun is $\$ 400,000$. While we do not doubt that their resources, from profits earned during the past few years, is greatly in excess of this amount, anybody who is acquainted with their establishments can readily realize that the rating, so far as money actually invested is concerned, is amply liberal. If it took an investment of $\$ 400,000$ to produce one-third of the oleomargarine made in this country-not the oleo oil and neutral lard-then their estimate of $\$ 15,000,000$ as the amount invested in the oleomargarine manufacturing business is more than twelve times too high.

\section{SOME ABSURD FIGURES.}

Just contemplate, if you please, the statement of Swift \& Co. that "there is now more than $\$ 15$, (10(1),0(0)" invested in the manufacture of oleomargarine, "employing many thousand people."

And "the wholesale and retail sale and delivery of oleomargarine furnish employment to 20,000 men." Also that "there is probably $\$ 15,000,000$ to $\$ 20,000,000$ invested in the wholesale and retail trade separate and apart from the manufacture of the article."

If this is true, let us sum up the total cost of handling this product of 83,000 pounds made in $1898-99$, according to the statement of Swift $\&$ Co. as to the number of people employed outside of those in the 
factories, and the interest mpon the capital which they claim to be invested:

Six per cent on $\$ 20,000,000$ claimed to be invested by wholesale aud retail dealers.

Six per cont upon the $\$ 15,000,000$ capital employed in mannfacturing, as claimed by Swift of Co.........................................

Wages of 25,000 persons engaged in the handling of oleomargarine, at $\$ 750$ per year each . ............................................

Total cost of ove year's husiness of handling oleomargarine, outsicle of wages of factory employees aud cost of materials....... 20,850,000

Add to this claimed expense the actual expense of manufacture of probably 2 cents per pound, $\$ 1,660,000$; the present 2-cent tax, aggregating $\$ 1,660,000$ more, and the average cost of materials, probably 8 cents per pound, and we have a total cost of $83,000,000$ pounds of oleomargarine, according to Swift \& Co., as follows:

Interest on eapital, cost of handling, as shown iu foregoing table..... $\$ 20,850,000$ Cost of mannfacturing........................................... 1,660, 000

Cost of 2 -cent $\operatorname{tax} \ldots \ldots \ldots \ldots \ldots \ldots \ldots \ldots \ldots \ldots \ldots \ldots \ldots \ldots \ldots \ldots \ldots \ldots \ldots \ldots \ldots . \quad 1,160,600$

Cost of raw material, at 8 cents per ponnd....................... 6, 640,0 0 Paid for wholesale, retail, ancl minuticturer's licenses (estimatea)..... 300,0 C

Total cost of $83,000,0 c 0$ ponnds......................... 29, 110, 0n0

Or, to reduce it to pounds and cents, it requires an expenditure of 35.06 cents to produce a pound of olcomargarine, which, the same firm says a little fulther aloug, "sells at an average of 10 cents per pound"!

What does Congress thiuk of such an attempt to mislead its members upon this matter?

Were not the statement of Swift \& Co. made ridicnlous in itself by the claims of the importance of the oleomargarine traffic, their plea might find an answer in the counterclaim that every man employed in the oleomargarine traffic displaces at least three men who hitherto had found employment upon the farm, and that the greater the showing made by this industry the greater the necessity for Congressional action to check a growth which is prima facie illegal.

\section{THE INGRFDIENTS OF OLEOMARGARINE.}

In their statement Swift \& Co. have the following to say regarding the ingredients of oleomagarine:

Second. Oleomargarine is an absolutely pure and healthful product. It contains the following ingredients:

1. Oleo oil: A selected fat from beef that is obtained from the canl fat. This is the principal ingredient. This fat is thoronghly washed, thrown into a vat of ice water to remove the animal lieat, then thoroughly cookesl, cooled, and put into hydraulic presses, by which the oil is extracted, the residue being conmercially known as stearin.

2. Nentral: This is the leaf lard of the pig. The leaf fat when taken out of the animal is thoroughly washed and put into a refricrerator, where it renains twentyfour hours. It is then thoronghly cooked. It is absolutely without color, being snow white, and has neitler taste nor odor. Both pigs and cattle are examined by Goverument iuspectors before aud after killiug, thereby insuring protection against disense. England, France, Germany, Holland, and wany other foreigu countries where oleomargarine is mannfactured more extensively than in the United States depend entirely upon American manufactnrers for oleo oil and nentral.

3. Cotton-seed oil: This ingredient is not always used; it is nsed in limited quantities in the medium grade. The oil is extraeted from selected cotton seed and then high!s refined. It is a pure, sweet product and is used quite generally for cooking purposes. l'rominent chemists have asserted that it has the same qualities as and is equally digestible with the best of olive oil.

4. Milk.

5. Salt. 
Specific reports do not sustain the statement above that oleo oil is the principal ingredient of oleomargarine. These proportions we find vary according to the interestaddressed. When the cotton-seel oil interests are being appealed to for opposition to this measure, cotton-seed oil is a principal ingredient; when the aid of the cattle growers is solicited, oleomargarine is made almost wholly of oleo oil.

When the oleomargarine interests were before Congress in 1886 , one of the leading manufacturers gave the A gricultural Committee the following description of the ingredients of the two principal grades:

Creamery butterine is usually composed of 25 per cent creamery butter, 40 per cent neutral, 20 per cent oleo oil, and the balance nilk, cream, and salt.

Dairy buttcrine differs from creamery ouly in the proportions. It is a cheaper product, and its proportion of butter abont 10 per cent, neutral 45 per cent, and oleo oil 25 per cent, the balance being made up of cream, milk, and salt.

The closest research indicates that 30 per cent on the average is a high estimate of the proportion of oleo oil contained in oleomargarine. The highest temperature to which such oil can safely be subjected is $150^{\circ} \mathrm{F}$., which does not "cook" anything, not being up to the boiling point, and the higher the temperature of the fat in rendering, the poorer the grade.

While cotton-seed oil may not be used always, it is certainly a very important ingredient in the lower grades. We have nothing to say regarding the healthfulness of cotton-seed oil. The fact that caustic soda and potash are used in refining may not be detrimeutal to its healthfulness.

However, it may be interesting in this connection to read a paragraph from a handbook on "The manufacture of cottonlseed oil and allied products, includiug cake, meal, foots, soap stock, etc.," published by the National Provisioner, of New York City. In describing one grade of oil it says, on pages 32-33:

The winter oil is a proluction of the yellow (summer) oil, made by the foregoing treatment, together with the supplementary process of filtration, and is olstained by the chilling process, the solid natter formed being known as stearin, used in the butterine and sony-making industries.

\section{PROCESS OF MANUFACTURING OLEOMARGARINE.}

\section{Continuing, Swift \& Co. say:}

Third. The process of manufacturing is somewhat as follows:

The ingredients are churned together for about thirty minntes in a large steel churn; after churning, the oleomargarine, which is then in a liquid state, is chilled by passing through ice water, worked thoronghly to get out the moisture, packerl in tubs and cases, branded according to the requirements of the revenne laws, and is ready for market. There is a sniall quantity of coloring matter introduced in the product to gire it the rich yellow color which has always been a feature of this product, and was such feature long before it became a feature of butter. All tho ingredients are strictly pure, clean, and thoroughly cooked, so that there is no nced of any preservative other than salt, nor is any other erer used. If the olcomargarine is properly made it does not become rancill and will keep in any climate. In respect to its purity, cleanliness, aud freedom from becoming rancid, it far exceeds the best of butter.

Regarding the process of manufacture we have nothing to say, except, however, to challenge the attempt upon the part of these oleomargarine makers to make it appear that butter is an imitation of olenmargarine in color instead of oleomargarine being an initation of butter. 
This is made clear and the whole fraudulent practices of the oleomargarine makers laid bare by a circular letter sent out April 5, 1899, by William J. Moxley, of Chicago. The letter follows:

[William J. Moxley, manufactarer of fine butterine, 63 and $65 \mathrm{WV}$. Monroe street.]

Chicago, April 5, 1899.

NOTICE TO TIE TRADE.

Inclosed find a color card, which is as near the color of our butterine as the printer's art can represent. Our aim in sending you this card is to aid you in selecting the proper color suitable to your trade. Mistakes are easily made, but hard to remedy.

In nearly every section of the country there is a difference in the color of butter, and even in certain seasons of the year there is a change, as you will have noticed. In winter butter is of a lighter color than in summer. In many sections this is the result of the difference in feed or pasture.

We can gire you just what you want at all seasons if we know your requirements. As an example, No. 1 has no coloring matter; No. 2 a little coloring, and so on to No. 8, which is the highest colored goods we turn out. Preserve this card, order the color you want by number, and we will send you just what you want.

Yours, truly,

\section{W. J. Moxley.}

Is there any necessity of going further to learn of the reasons why the oleomargarine makers are willing to spend liundreds of thousands of dollars to defeat laws forbidding the coloring of oleomargarine?

If Moxley can find a market for oleomargarine withont color at one seasol, why not at another? He gives the whole case away in the one statement, that "in winter butter is of a lighter color than in summer", and offers to "color to suit" the shale of butter at any season of the year or for any section.

Has it ever been claimed that the tastes of the people varied with the season? Would a customer who knew he was buying oleomargarine say in December, "No, we don't like such a high color in winter. Please make it a little lighter?"

No, indeed. Any departure from the color of butter at any time of year might excite the suspicion that he was not getting pure butter. The manufacturer even provides for the chance of a consumer living in a section where butter is not highly colored becoming suspicious, and advertise to color it "to suit the section."

Butter has been a staple article of food for more than 4,000 years. It is, as a rule, yellow nine months of the year. It is colored in winter and fall to preserve a uniformity. It would sell just as well as near white as it is ever made, provided it could be kept a uniform sharle through. out the year. Trade in all commodities requires miformity. That is the most exacting requirement of the butter trade. Conditions can be adjusted to fit the degree. If butter were not colored for uniformity to the June shade in order to make a uniform color it would have to bo bleached nine months in the year, which would be impracticable or impossible.

There is no deception in coloring butter. It is not colored to make it look like anything else. The color doesn't deceive anybody into thinking he is getting a better article than he receives. Everybody knows butter is colored, as they know candy is colored. Some say the highly colored June butter is richer and more to be desired. The high color, however, is not indicative of quality. The season alone creates that, new grass imparting a delicious and desirable fiavor just as much to the light-colored butter as to the highly colored. One prominent Senator said, in the course of a hearing in Ohicago last summer, "But 
you color your butter in winter to make it ions jiko june bnttrerthat which is rich and has high flavor." "It would scarceiy be good business to color for that purpose," was the response of the witness, "because if the buyer thought it to be June outter offered for sale ir winter he would want to buy it at. June butter prices, which are from 2 to 4 cents a pound lower in winter than fresh made goods."

So it will be seen that this argument of endeavoring to deceive people into thinking they are getting Inne butter in winter isn't very good. logic.

\section{THE LAW OF 1886 FAS XOT A REVENUE MEASURE.}

Swift \& Co., in commeiting upen the amount of revenue produced by oleomargarine since the yresent law went into effect, in 1886, say:

You will note the fact also that since the present oleomargarine law took effect it has turned into the Treasury, in less than fifteen years, the large amount of $\$ 15,942,101.43$ taxes.

We are painfully aware of that fact. This law of $18 S 6$ was enacted as the only remerly the General Government could afford to check the enormous frands being practiced in the sale of oleomargarine at that time. The tax was placed at 2 cents a pound, this being regarded to be about the figure needed to raise sufficient revenne to enable the Government to enforce the other provisions of the bill. What has been the result? No attention whatever has been paid to the intent of the law. Fevenue collectors have been satisfied to see that the taxes were paid. It has not been possible to interest them to any extent whatever in the enforcement of the provision requiring the branding of packages by the retailer, which was the entire intent of the law of 1856 .

The internal-revenue collector of a certain prominent district made the statement that it would be poor policy for his department to interfere with the volume of trade in a revenue-producing article by enforcing regulations which would have such effect. In the city of Chicago about the only part of the law that is enforced is that requiring the payment of the 2-cent tax and the license stamps. No attention is paid to complaints of the sale of oleomargarine at retail not properly branded. T'hese complaints have been made and ignored dozens of times, and what is said of Chicago can, we are informed by those who have investigated, ve said of other districts.

\section{FIGUREN USED TO FRIGHTEN LIVE-STOCK IIEN.}

But in the fifth statement Swift \& Co. play their strongest card against the Grout bill and 10 cent tax, and a more brazen attempt to mislead Congress his probably never been brought to the surface. They say:

Fifth. The enactpaent of these bills would seriously afiect the cattle industry. The manufacturer of oleomargarine has created a demand for oleo oil, which is made from the choice fats from the beef, and is worth to-day 10 cents per pound. If these cloice fats were noe utilized in the manufacture of oleomargarine they wonld have to be sold as tallow, which is worth 6 cents per pound. A steer will yield 50 pounds of oleo oil; therefore, should the oleomargarine industry be destrojed each steer would depreciate in value $\$ 2$. The same is true of the hog. Leaf lard (or neutral) is used in the manufacture of oleomargarine. Neutral is to-day worth $8 \frac{1}{2}$ cents per pound, lard is worth 6 cents per pound; a hog will yield about 8 jounds of nentral. If there was no demand for neutral as an oleomargarine ingredient it would have no greator value than lard; hence each hog would bo worth 20 cents less than present prico. 
For the year ending December 31,1899 , there were $1,702,572$ cattle slanghtered at the Union Stock Yards in Chicago; at $\$ 2$ per head this wonld make $\$ 3,405,144$. For the samo period there were 7,032,430 hogs slanghtered at the Union Stock Yards in Chicago; at 20 cents per head this wonld make $\$ 1,406,486$. Therefore, shonld Congrcss pass a law which would destroy the oleomargarine bnsiness the cattle and hog raisers marketing their stock in Chicago would actually lose in tho course of a year $\$ 4,811,630$ by depreciation in valne of stock, and this will apply to every other slanghtering point in the United states-Kansas City, Omaha, St. Louis, etc.

Let us analyze this statement. It ean be done in two ways. First, let us look at the live-stock interests. Caftle were slauglitered as follows at the leading cinters during the past year:

Chicago ............................................... 1, 821, 061

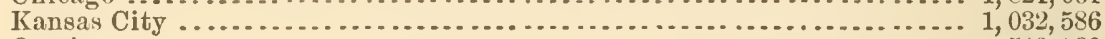
Omaha ....................................................... 549,089 St. Louis .................................................... 506,249

Total. $\overline{3,908,985}$

It is safe to say that in other centers combined enough more cattle were slaughtered last year to bring the total number up to $5,000,000$ head.

During 1899 there were $83,000,000$ pounds of oleomargarine manufactured. Making a liberal allowance, one-third of this product was oleo oil. This is too high an estimate, but we can afford to be liberal. Therefore in $83,000,000$ pounds of oleomargarine there was used $27,600,0,40$ pounds of oleo oil. Eight cents a ponnd upon the average is about right for the price of oleo oil for the year, as it is not all high grade, nor was the market high all the year. This would make the oleo oil going into the $\$ 3,000,000$ pounds of oleomargarine worth $\$ 2,208,000$. This wonld nean that an average of 44 cents' worth of oleo oil was used from each head of cattle killed in the country. Grauted, for argument, that this oleo oil could find no other market than to the manufacturers of this country for oleomargarine, except as tallow, which is worth a little over half the price of oleo oil. In that case the 44 cents' worth of oleo oil would have to be sold at 22 cents as tallow, which would result in the loss of 22 cents a head on a steer worth from $\$ 30$ to $\$ 60$ or $\$ 70$, which is figuring a little finer than people figure in business matters.

But let us bring to light the facts which Swift \& Co. endeavor to lide from Congress. They endeavor to convey the impression that if they are not permitted to imitate butter with the color of their oleomargarine the entire oleomargarine industry of the world will be wrecked. In no other way can they justify the claim of a loss of \$2 per head upon cattle.

But here are the facts. It has been shown that about 27,600,000 pounds of oleo oil were used in making oleomargarine in this country last year. This is but a small percentage of the oleo oil prodnced. The Goverument statistics of exports for the year 1899 show that compared with $27,600,000$ pounds of oleo oil used at home there were exported 142,000,00: pounds, largely to Rotterdam, where it is used. They would endeavor to lead Congress to believe that any act affecting the initation-butter business in the United States would bring about the destruction of the export trade in oleo oil, which trade could, it necessary, also take all the oil nsed in oleomargarine in this country.

The same is true of the claim regarding the threatened depression in the price of hogs.

But let us view this question in another light. According to the stat ment of Swift \& Co., the average price of oleomargarine is about 
10 cents per pound. The $83,000,000$ pounds made last year would be worth, according to this, $\$ 8,300,000$.

Now, if the $5,000,000$ head of cattle wonld be depreciated $\$ 2$ per head by the passage of the Grout bill, the loss to the live-stock man would be, according to their claim, $\$ 10,000,000$. Then upon the conservative estimate of $15,000,000$ head of hogs marketed last year, upon which this "vicious measure" would entail a loss of 20 cents per head, would bo an additional loss of $\$ 3,000,000$. This makes a total loss, according to their statement, of $\$ 13,000,000$ upon a business aggregatin $\$ \$ 8,300,000$ per year. And this is not taking into consideration the "Ioss" claimed by the cotton-seed oil men, who sell the oleomargarine people in this country about $3,400,000$ gallons of oil, valued at about $\$ 1,000,000$, compared with the $40,230,7 \$ 4$ gallons, valuert at $\$ 10,137,619$, which they export, in addition to that used in soap making and as salad oil in the United States.

\section{THE COLORING OF OLEOMARGARINE AND BUTTER.}

\section{Here is the next statement of Swift \& C o.:}

Sixth. The qnestion of color is urged against the nse of oleomargarine. It goes without saying that we have the right to make our goods as attractive and as pleasing to the eye and as desirable to the purchaser as we can, provided that we do nothing to injure the quality of the goods. The same color is used in coloring oleomargarine that is nsed in coloring butter, and the use of this butter color (so called) in coloring butter is just as much a deceit and a fraud upon customers as is its use in coloring oleomargarine. It is further a fact that the oleomargarine manufacturers were the first to see the advantage of having a uniform color in their goods and were the first to use butter color (so called). The creameries throughout the country were quick to take advan tage of the new idea, and to-day it is rare to see bntter on the market which is not colored a bright yellow, althongh the natural color of butter ranges all the way from white for the ordinary winter butter to a light yellow for summer butter.

The above is certainly a bold position to openly assume before Congress. We would refer Swift \& Co. to the noted speech made by Congressman Tayler, of Ohio, upon the question of Brigham H. Roberts's right to a seat in Congress. Mr. Taylor said:

This is a representative Government; it springs from the people, from the people who make the law, and their representatives are such becanse they are believers in the law and subject to the law. Many may entertain opinions as to the nuwislom of certain laws, and a hope that these may be erased from the statute books; but in the very nature of things they can not stand for defiance of law. And as they can not stand for defiance of any law, how much the more must they stand as respecters of and obedient to such laws as have proceeded from the people, at the people's initiative, and sustained by the deliberate and intelligent approval of snbstantially all the people.

Swift \& Co. stand for defiance not only of the laws of their own State, but of the laws of more than two thirds of the States of the United States. They come before Congress, a large majority of which represent States whose laws they are violating, and openly say: "It goes without saying that we have the right to make our goods as attractive and as pleasing to the purchaser as we can, provicled that we do nothing to injure the quality of the goods."

State laws are as naught. The opinions of our most learned jurists are not worthy of cousideration. What four-fifths of the people throngh their legislatures have condemned, in the estimation of Swift \& Co., "goes without saying."

But let us see what the courts say about this right which Switt \& Co. claim "goes without sayiug."

In December, 1S94, the Supreme Court of the United States handed S. Rep. 2048 $-3 ?$ 
down an opinion regarding this right which Swift \& Co. says "goes witlout saying." It was the case of Plumley $v$. Massachusetts. Plumley harl been convicted under the Massachusetts law of selling a compound known as oleomargarine, colored in semblance of butter. The matter was carried to the supreme court of the State, where judgment was affirmed; it was then taken to the Supreme Court of the United States. The defense was that Plumley was held under a statute which was unconstitutional for two reasons.

The statıte in that case prevented the sale of this substance in imitation of yellow butter produced from pure unadulterated milk or cream of the same, and the statute contained a proviso that nothing therein should be "construed to prohibit the manufucture or sale of oleomargarine in a separate or distiuct form and in such manner as will advise the consumer of its real character, free trom coloration or ingredients that canse it to look like butter." The conrt held that a conviction under that statute for having sold an article known as oleomargarine, not produced from unadulterated milk or cream, but manufactured in imitation of yellow butter, produced from jure, unadulterated milk or cream, was valid. Attention was called in the opinion to the fact that the statute did not prohibit the manufacture or sale of all oleomargarine, but only such as was colored in imitation of yellow butter produced from unadulterated milk or cream of such milk. If free from coloration or ingredient that caused it to look like butter, the right to sell it in a separate and distinct form and in such manner as would advise the customer of the real character was neither restricted nor prohibited. The court held that under the statute the party was only forbislden to practice in such matters a fraud upon the general public; that the statute seeks to suppress false pretenses and to promote fair dealing in the sale of an article of food, and that it compels the sale of oleomargarine for what it really is by preventing its sale for what it is not; that the term "commerce among the States" did not mean a recognition of a right to practice a fraud upon the publie in the sale of an article even if it had become the subject of trade in different parts of the country.

\section{Judge Harlan, in delivering this opinion, said:}

And set it is supposed the owners of a compound which has been put in a condition to cheat the public into helieving it is a particular article of food in claily nse and eagerly songht for by people in every condition of life are protected hy the Constitution in making a sale of it against the will of the States in which it is offered for sale becanse of the eircumstance that it is in original packige aud has become a subject of orlinary traffic. We are unwilling to accept this vicw. We are of the opinion that it is within the power of a State to excIncle from its markets any componnd mannfactured in another State which has been artificially colored or adnlter. ated so as to canse it to look like an article of food in gencral use and the sale of which mas, by reason of snch coloration or adulteration, cheat the general public into purchasing that which they may not infend to bny.

The Constitution of the Uniter States does not secure to anrone the privilege of defrauling the public. The deception against which the statute of Massachusetts is aimed is an offense against society. The States are as competent to profect their people against such offenses or wrongs as they are to protect them against crimes or wrongs of more serions character, and this protection may be given withont violating any right secured by the national Constitntion and withont infringing the anthority of the General Govermment. A State enactment forbidding the sale of deceitful initations of articles of food in general use anong the people does not abridge any privilege secured to citizens of the Tuited States, nor in any just sense interfere with the freedom of commerce among the several States.

\section{We further quote from numerous authorities:}

It has been uniformly held that the lrgislature, in the exercise of its police powers for the protection of the general welface of the community and the promotion of the public health, has the right to prohibit the manufacture and sale of any artich. 
of food in imitation or semblance of another well-known article of food in a form which is caleulaterl or likely to deceive the buyer or the consum(2), and in any substitutes for butter, where the act is aimed at a designed and intentional imitation of butter in the manufacture of the new product aul not at a resemblance of fualities inherent in the articles themselves aml common to both. (Plumley $v$. Massachusetts, 155 U. S., 461; Commonwealth v. Plumley, 163 Mass., 169; Waterbury v. Newtou, 50 N.J. Law, 534; People r. Aaren-burer, 105 N. Y., 123; MeAllister $r$. State, 72 Mo., 390 ; State $v$. Addington, 77 Mo, 110; Commonwealth $v$. Schollenberger, 155 Pa., 201; State v. Mlarshall, 64 N. H., 549; Weilmon v. State, 56 N. W. Rep., 688 Minn.; Cook v. State, 20 Southeru Rep., 566 Ala.)

Swift \& Co. and their associates have no respect or regard for State laws. They absolutely hold the lower courts of the various States in contempt. The adverse decisions of the State supreme courts do not trouble them one iota, and five years after the Supreme Court of the United States told them they had no legal right to sell oleomargarine colored in semblance of butter in Massachusetts, in support of the State supreme court, we find them bolstering up 108 dealers, who disposed of $2,(183,889$ pounds of oleomargariue in twelve months, which they do not deny is sold contrary to the State larws and the ruliugs of the supreme courts of the State and United States.

What kind of a standing is this to be possessed by mannfacturers before a body of representatives of the 32 States which have laws copied after that of Massachusetts?

The claim of priority in the use of yellow color is so absurdly ridiculous as to be unworthy of notice. Under a prior heading the object and original reason for coloring oleomargarine has been disclosed by one of the Chicago manufacturers.

\section{FRAUDULENT SALE OF OLEOMARGARINE.}

Swift \& Co. then take up the question of fraud in the sale of oleomargarine, and upon this question have to say:

Seventh. We would further state, in reference to the claim that it is a fraud upon the sale of butter, that it is absolutely impossible to.day, minler the internal-revenue laws and regulations, to sell oleomargarine as butter to customers of ordinary intelligence, as all oleomargarine sold is required to be branded in large letters and there are stringent penalties for the failure to comply therewith.

No linw can make more stringent reguirements to protect customers than the present laws, and the fact that the output is yearly increasing shows that there is a rlemand for oleonargarine as such in spite of all hostile agitation and legislation. That there is fraud sometimes practicerl in the retail sale of the product is quite possible, aud laws have been and should be enacted for the purpose of preventing such fraud, but all that is no reasou for stamping out the industry of mannfacturiug and selling oleomargarine.

If it is claimed that an increase of the tax would not stamp out the industry, it is at least certain that it would cause an increase in the illegal sale of the article, and therefore would fail of its object in protecting customers from fraud. The present tax of 2 cents a pound on the article which sells at an average of 10 cents a pound is excessive, being 20 per cent of the selling price, and it is midoubtedly a fact that a large proportion of the fraul now claimed is due to this excessive tax, for it is well known, and is vouched for by the experience of the internal-revenue department in its collections of revenue on tobaceos and liquors, that taxes and violatious of revenue laws increase and decrease in the same proportion.

Now, let us see abont that. It is true the internal-revenue laws and regulations are strict with regard to the stamping of oleomargarine by the mannfacturer and retailer. However, in all the fourteen years which this law has been in effect the Government has never imprisoned but two offenders for failure to brand or for removing brands, and the interual-revenue department was very much against bringing this case to trial and making an example of these men, who had been for years persistent swindler's. It was only through the greatest efforts of the 
Secretary of Agriculture and an appeal to the Attorney-General to refuse to compromise that Wilkins and Butler were sentenced to prison a few months ago for removing brands from oleomargarine packages, and they had no more than gotten well settled in prison than gigantic frauds of a similar nature came to light from Chicago.

The Wilkins case gives a clear idea of the enormous frauds that are being practiced in the oleomargarine traffic, which do not affect the revenue, because the goods used for this fraudulent business bave all pail the 2-cent tax.

Attorney-General Griggs's statement of facts and refusal to recommend the pardon of Wilkins and Butler will give the realer a clear idea of the character of frand which is being practiced, the lamentable phase of the question being the fact that this case which eame to light is only one of the hundreds of swindles which are being carried on in a large way and of the thousauds being practiced upon consumers in all portions of the country.

\section{The Attorney General wrote to President McKinley as follows:}

The petitioners, Joseph Wilkins and Howard Butler, were convicted of fraudnlentls removing labels from packages containing oleomargarine in violation of the act of August 2, 1886, and were sentenced on March 17, 1895, as to Wilkins, to imprisonment for six months and to pay a fine of $\$ 1,500$ and costs, and, as to Butler, to imprisonment for four months and to pay a tine of $\$ 500$ and costs.

The judgment of the district court was subsequently affirmed in the circuit court of appeals, to which it was taken by the defendants, aud an application subsequently made to the Supreme Court for a writ of certiorari was denied. Thereupon, in November last, the petitioners were committed to serve their sentences of imprisonment.

The grounds of the applica ion for a pardon as to Joseph Wilkins are, that he has a wife and child, and that each of the prisoners is of good reputation and standing, and has never been convicted of any other crime. They request, in view of the humiliation and disgrace already suffered by them, as well as of the heavy fines imposed, and in view of their good reputation and standing in the community, and of the fact that no revenue has been lost to the Government, that that portion of the sentence providing for inıprisonment be remitted.

The records of the office of internal revenue show that Wilkins has been a persistent violator of the oleomargariue laws, and that prior to the present prosecution he has escaped ptuishment by means of money payments in compromise. The records show that on December 14,1893 , Wilkins filed a proposition to pay $\$ 2,100$ and costs in compromise of all liabilities, civil and criminal, incurred in the first district of Illinois for selling oleomaryarine as butter, and by violating various sections of the law relating to wholesale dealers in oleomargarine. This offer was accepted December 26, 1893.

April 4, 1895, less than a year and a half after the last settlement, IVilkins again filed an offer of compromise, agreeing to pay $\$ 2,000$ in settlement of his liabilities for alleger frauds under the oleomargarine law committed in connection with a firm in West Virginia. This offer was aliso accepted.

A year later, April 2, 1896, Wilkins was indicted with anotler in the District of Columbia for selling unstamped oleomargarine. On June 20, 1896, he offered to pay $\$ 1,000$ in compromise, but this being rejected the case went to trial and the accused was acquitted. There are three separate indictments against him pending new in the District of Columbia for selling oleomargarine in unstamped packages. These indictmonts were found Jannary 4, 1897.

The offense of which the petitioners are now convicter was committed December 20,1896 , two days after the verdict of acquittal in the trial in the District of Colnmbia. The petitioners were discovered by a revenue agent in the act of scraping off the stamps, narks, aud brauds from packages of oleomargarine.

In conncetion with the present case, an offer to pay $\$ 8,000$ and costs in compromise was made, but rejected February 23,1898 , aud thereupon the case went to trial with the result above stated.

It is obvions that the business in which Wilkins was ongaged must have been one of great profit, otherwise he could not have afforded to make the very large payments in compromise which he did make or offered to make.

That he was aware of the frantulent and dishonorable nature of the business in which he was persistently engaged appears from his own statement made in a letter addressed to the Conmissioner of Intermal Revenue, Oetober 31, 1893, from which I quote the following: 
"Having a thorough knowledge of the hntterine business, and knowing the possibilities of that business if worked in certain directions and ways, I determined to try it, having the desire to make large gains quick. * * * After I fouml that some of my goods had been seized in Cincinuati I settled mp my business as quickly as possible and did not ship any more. I came to you voluntarily, and I sincerely trust you will deal with me as leuiently as the law will allow yon, promising you faithfully that no snch thing as this will ever occur again with me, and, if I am allowed to make a request, I ask that I be allowed to settle withont having the Western houses know any thing of my doings, because I know it was very dishonor. able in me to do as 1 have done, and if $I$ am allowed to go along in life without the public knowing of $m y$ misdeeds, then I feel sure that. I can make a new start in sonie way that is entirely honorable. I realize full well that I could have in some way kept away from the hands of the law, but to do this wonld mean the staying away from home and relatives, and, above all, the constant strain on my mind, and with the sense that I had done a great wrong, I conld not stand it. Trusting that you will allow me to settle immediately, which will allow me to drift back into the channels of straight, legitiuate business soon, I remain."

Notwithstanding that the anthorities were indnced to settle with him upon his pronise of abstention in the future from similar violations of the law, it appears that he straightway resuned his operations, undoubtedly taking conrage from the success with which he hal compromised the first offenses in which he had been discovered.

It is absolutely clear that for snch a persistent violator of the law somethiug more than a money penalty was essential. The sentence of imprisonment imposed in this case was peremp,torily required by the circunstances. Nor can 1 say that the sentence was anything but moderate. It is less than the average sentence imposer upon persistent violators of the internal-revenue laws relating to the distillation of spirits, and much less than the ordinary sentences imposed for violation of the laws against the use of the mails for fraudulent purposes.

Not only is the diguity of the law to be upheld against such persistent violations, but the public is entitled to be protected by the salutary influence of stern punishment against fraud and leception, such as were practiced in this case, by means of which the petitioners were enahled to impose upon innocent purchasers as geuuine butter a counterfeit article, which, if sold for what it really was, would have brought very much less in the open market.

I do not think that the sentences should be interfered with.

Who is this man Wilkins?

As soon as detected in the act of removing oleomargarine marks at Philadelphia, so that his Washington business was no longer profitable, being indicted by the Ferleral grand jury, Wilkins was brought to Chicago by Messis. Branu \& Fitts, the largest mannfacturers of oleomar. garine in the country, and given the responsible position of directing the salesmen, which class have for years coached retailers in the art of swindling the public.

Wilkius held this position as confidential man with Braun \& Fitts during the time his case was being fought in court and the effort being made to pardon him, and went directly from their employ to prison at Philadelphia.

During the time when Wilkins's pardon was being most actively sought by the influence of the oleomargarine mannfacturers two other swindles of even as great magnitude and of the same character were unearthed, not. however, by the internal-revenue dejartment, but by the agricultural department of $\mathrm{New}$ York.

These swindles were gigantic in their proportions. The details were excellently set forth in the Times-Herald, of Chicago, in its issue of Sunday, February 11. The Times-Herald's account of this swindle follows:

SEEK FRAUD IN "OLEO"-SUSPIOIOUS OF PRIME BUTTER-REVENUE AGENTS CLAIM TO HAVE UNEARTHED A SWINDLE ON THE GOVERNMENT-SHIPIFENTS SEIZED AND ARRESTS MADE-MORE TO FOLLOW.

Government officials from three States are investigating what ther belicve to be the largest oleomargarine frand in the history of the local internal-revenue department. The work of the officers has resulted in the arrest of John F. Rooney, who 
has had a preliminary hearing before Commissioner Mason and who is now on bonds of $\$ 2,500$.

Rooney is charged with selling oleomargarine as lntter. The business was conducted in the names of the Aurora l'rotnce Company and the Elgin Prodnce Company. Cheeks produced in evidence mpon the preliminary learing tend to show that Rooney and his associates bought as high as $\$ 1,000$ worth of the prodnct daily and shipperl it to enstomers in several States who had purchased it in the leclief that it was high-grade butter. It is eharged that in the three or four months that Rooney has been operating he has disposed of between $\$ 80,000$ and $\$ 124,000$ worth of oleomargarine, upen wlich be made at least 40 cents om the dollar. Romey's arrest occurred nearly three weeks ago at the Coylon and Japan Toa Company's place, 700 West Forty-seventh street.

\section{REVENUE AGENT AT WORK.}

Since Rooney's arrest several of the eleverest special agents in the employ of the Government have been further investigating in the belief that certain manufacturers of oleomargarine were back of Rooney. It is also believed that hat the selieme proverl safe the frandulent dealings wonld have been increased to a point limited only by the alility to get customer's.

Last Novem ler the Agricultural Department learned that large quantities of suspieious butter were being shipped into eastern New York, and W. H. Butcher, of Troy, was cletailed to look the matter up. On November 27 a consignment of $623 \mathrm{tubs}$ was found in J. B. Wattles's store in Buffalo. Samples were taken and the consignment allowed to go. A gents followerl it to Chicago, where the Wabash officials were told that the shipment here was a mistake, and that the stuff shonkl have been sent to Liverpool. It was reshipped and the Government agents seized it in Detroit. This lot is said to have been sold by Edward Marhoffer, of the Eigin Prorlnce Company, 6242 Halsted street. O. S. Martin, special agent of the internal-revenue departinent for Indiana, was sent to Chicago and found that large quantities of oleomargarine had been shipped to John Schmitz, of Milwaukee. The latter told the agent that a man representing the Aurora Prodnee Company had ealled to see him and had said that his coneem had a lot of high-grade butter which they eould sell at less than prevailing market prices. Schmit\% had at various times purchased several lundred dollars' worth from the eoncern in the belief that he was buying good ereanery butter.

\section{SCHMITZ PAYS HIS LICENSE.}

Schmitz was a witness before the commissioner and has since paid the Government $\$ 480$, which is required for a wholesale oleonarmarine license. The faet that he did not know lie was selling oleomargarine did not ent any fignre with his being liable for the license money. The department here has a list of forty or fifty dealers who will have to pay $\$ 18$ for a retail license for having bought "prime butter" of the concern.

Agent Martin went to Aurora after seeing Schmitz and began looking for the Anrora Prodnce Company. He learned that a man named liooney had rented a box at the post-offiee with instrnetions to have placed in it all his mail and that addressed to the Aurora Protnce Company. Later he had given up the lox and left instructions to have his mail forwarded to 196 La Salle street. At this place Attorner Maurice Langhonse told the officer that Rooney had asked him to permit his mail to come there, and had paid him $\$ 10$. Every day a boy came in, and, placing the mail in another envelope, forwarded it to Rooney at 700 West Forty-seventh street.

The agent's next move was to rent a room opposite the tea company's store. He soon discovered that wagons from Bramn \& litts, oleomargarine manufacturers, matle almost daily deliveries of oleomargarine at the stere. There the stamps wonld be removed and Expressman J. IV. Foley would take the stuff to varions freight offices for shipment.

\section{SEIZCRES AND ARIESTS.}

When the evidence was conclnsive, eeizures were made and a warrant sworn ont for hooney's arrest. It was learned that his brother, Elmer K. Rooney, was in the deal, and a telegram was sent to Joliet, where he happenerl to be sellini "bntter," to eanse his arrest. Some one gave him timely warning and he fled. It is said that Edward Marhoffer, George E. Brannen, and a man named Casey have also disappeared.

In connection with Rooner the officers arrested Patriek F. Butler, who worked at the Forty-seventh street place. His arrest was due to the fact that all ehecks in payment for the oleomargarine were made ont to Walter $F$. Butler, and a bank clerk identified Patrick F. Butler' as the man who drew the meney on them. 'The evidence was insuffieient to connect Butler with the fraud, and he was discharged. 
The earload of oleomargarine seized at Detroit is valued at $\$ 5,000$, and $\mathbf{w}(\mathrm{nl}) \mathrm{d}$ indicate that the framinlent realings were even more extensive than appears fiom the evidence attrined thus far. It is sair that the loeal department is prepariug to milke other arrests in a few days, althongh the warrants have not been sworn ont. IV. J. Moxley, who sold Rooney small anounts of oleomargarine; Johu Dadie, and former Mayor John P. Hopkins went on kooner's bond. Officers who have investigated the Rooness' history before the time they came to Chicago claim that they were supplied with large cupital before engaging in the sale of "prime butter." When an attempt was made to gain possession of the books of the Anrora Prodnce Company, it was learned that Rooney and another man had burned them in the kitelen stove.

There were a number of very peculiar things about these cases, one of which was the ability of these adventurers, with no known financial responsibility, to obtain credit for such large amount. Another was the fact that the salesman who went into New York and sold the "butter" proved to be a traveling salesman for one of these Chicago oleomargarine manufacturers, and still another peculiar thing was that the representatives of the firms of Braun \& Fitts and $W$. J. Moxley, the Chicago manufacturers who sold this oleomargarine to these swindlers, appeared before Commissioner Mason and either went bail for these men or secured acceptable boudsmen with their guarantee.

When the Senate Committee on Manufactures was in Chicago investi. gating the adulteration of foods, the condition existing in the traffic in oleomargarine was brought to the attention of Senators Mason and Harris.

A the conclusion of the investigation of the subject of oleomargarine, Senator Mason is quoted by the Times-Herald of Thursday, May 11, as follows :

At the elose of the session Senator Mason said: "We have at least developed this point to-day, that although oleomargarine pays the tax it is being sold generally as pure butter."

\section{The Chicago Tribuue, of the same day, said:}

The committeo devoted the forenoon session to the snbject of oleomargarine, and brought out the fact that oleonargarine is sold in the city every day for pure butter in violation of the national interual-revenue and the State laws. Four dealers in this artiele gave evidence. Packages of oleomargarine purebased the day before and submitted to the eommittee by C. Y. Knight, who had bought them for creamery butter, was examined. They did not bear the required stamp "Oleomargarine" on the ontsicle, but the word appeared on wrappers ingenionsly folded, so that it was entirely hidlen from view until the paekages were opened.

The Ohicago Democrat said of this hearing, on May 10:

Praetical violation of the oleomargarine law is admitted by Chicago dealers. Such fraul, they say, is necessitated by the aristoeratic purchasers.

This evidence was brought out by the secretary of the National Dairy Union, who, in the few blocks between his office and the hotel where the investigation was being conducted, purchased four packages of what was given him in response to his call for creanery butter. These packages were purchased at random at stores similar to which there are hundreds in Chicago. One dealer, J. F. Somes, of the Ohio Butter Company, which never sells a pound of butter, testified as follows:

[From the Ofineial Record.]

James F. Somes, being first duly sworn, testified as fullows:

Examination by the CHanmaN:

Q. What is jour name?

A. James H. Somes.

Q. What is jour linsiness?

A. I am selling butter, eggs, and eheese. 
Q. Where is your place of business?-A. No. 44 Fifth avenue.

Q. Do you sell oleomargarine?-A. Yes, sir.

Q. Are you familiar with the law in regard to the sale of it?-A. Why, somewhat.

Q. Mr. Somes, I show you an exhibit, which is designated "No. 4." Do yon recognize it as from your place [handing same to witness] - A. We sell something of that kind, similar to it.

Q. Is your name ou the paper:-A. Yes, sir; I guess so. [The witness examined the wrapper.] Yes, sir. Not my name; it is the name of the Ohio Butter Company. Q. You represent that company?-A. Yes, sir.

Q. Did you put this package up pourse]f, yesterday?-A. I don't kuow. I put up one or two packages of the kind yesterday. I may have done so. I don't know.

Q. Do you know what there is in this?-A. It is supposed to be oleourargarine or butterine.

Q. Do you remenber what was called for when that was furnisher?-A. No; I do not. I would sas in that connection that the majority of people come iu and want oleomargarine or butterine. T'hey do not ask for it. They say, "Give me some butter," and they know what they are getting, most of them, when they are getting this bitterime.

Q. What is the price of this butterine?-A. Butterine runs from 15 to 18 cents.

Q. Then if a man says he wants some butter, you hand him out oleounargarine?A. Not always; no, sir. We try to do a fair business, and to do an honorable business.

Q. What we want in this connection, Mr. Somes, is to find out-we are investigating the question of tile arlulteration of food products and how they are circulated. We are not seeking to incriminate jou or anybody else.-A. I would say this-that I think the majority of my eustomers understand that they are buying butterine or oleomargarive. For a long time I stamped my packages all on the outside, and they would come and say, "What is this? I lon't want this. Give me another wrapper." They knew what they were buying. They did not want to carry it along the street with a sign on, and to accommodate them I had to do it, and to wrap another wrapper arumd them. And then the butterine people, or the agents of the butterine people, advised me that it was not necessary; that if I stamped my paper, that was all that was required. And I have always tried to stamp ny paper properly, and to see that it was properly stamped. There was no intention on my part to deceive anybody. The majority of the people waut butterine, and they don't want a sign on it, so that everybody knows that they are buying butterine. People are fussy alout such things. And I think the reason they buy it is because it is the only thing they can get that is sweet and good.

The Chairian. We will excuse you.

The package purchased from Mr. Somes was purchased for creamery butter. A few months after this, finding him continuing this practice, he was arrested and plead guilty under the State law for selling oleomargarine for butter. He paid a fine of $\$ 25$ and costs, the Chicago manufacturers refusing in this case to come to his rescue, because he purchased his oleomargarine in Ohio. Then they immediately circulated the report that only dealers who bonght goods of the Chicago trust would be protected. But these matters will be treated further along. This, however, was the only fine imposerl in Chicago in ten years tor this fraud, so far as is known, under the State law.

William Broadwell, claiming to be the largest retail dealer in oleomargarine in Chicago, was also called before the committee and confronted with a parkige that was bought at his place for butter that morning, but inside of the wrapper of which was found, ingeniously turned under and concealed, the Goverument stamp.

Following is an extract from his evidence, as brought out by Senator Harris :

By Senator Harris:

Q. You think generally in the trace there is a disposition to sell the oleomargarine on its merits?-A. Yes, sir: and a man don't have a particle of tronble.

Q. Without attempting to conceal its true character, or sell it as butter?-A. Don't have to, at all; but there is a class of people that coule into my store, who aro up in the world and who have got lots of money, and they come in and call for a pail of butter, the same as they had before. They would not come in and ask outright for oleo.

Q. If it has the merit that you elaim for it, why should you people object to saying "oleomargarine?"-A. They don't want the iuan that is next to them to know that they are using oleomargarine. 
Q. They think there is some social degradation in it?-A. I shonld say there was. If you only knew that much about the class of people that bny that in my store, youl would almost fall dead, as true as you are living.

Q. I don't see anything humiliating or embarrassing in the purchase of an article which is good, and satisfactory to the taste, and which will retain its good qualities. Of course, I am a mere countryman, but I don't see why a man should not come in aucl say, "I want some oleomargarine, becanse it suits my palate, ancl becanse it will keep longer than butter."-A. Yes; but they don't want to let anybody else know anything abont it, and they will come in and call me off to one sicle and whisper to me, "Can't you make it ten cents cheaper this time?" You'd be surprised, I tell your. I don't want to call any names, lut I tell you it is dreadful. 'Then do you think they don't know what they are buving? And then they ask me abont the goods I handle, that I shall see that they don't get Swift's or Armour's. I tell them I handle Moxley's and Braun \& Fitts's. All right, then, so long as it is theirs.

Q. There are different grades, even in the nobility of oleomargarine $-A$. That is what there is.

Q. Some is good, and some is better?-A. There is some that I would not handle at all. It might be all right, but in my opinion it is not.

Q. What do you think makes the difference?-A. Well, of course, there is a certain kind of cream and butter that is put into the higher grades that makes it sweeter and nicer, and a better smell and taste to it.

Q. Would not that have a tendency to make it deteriorate, the more butter that was in it?-A. There is not enough butter put in it to turn it. There are other articles put with it to keep it.

$\mathrm{Q}$. It does not get so good as to be hurt by it?-A. It is just like a man making coffee-rubs the coffee can up against the grounds, and that is as near as the coffee gets to it.

Q. You say that this mixture is what makes the higher grades of oleomargarine A. Yes, sir; it gives it a nicer, sweeter taste, and a nicer flavor.

Q. Makes it better?-A. Makes it better; but I think the inferior quality will keep lnnger.

Q. It is a contest between flavor and quality and durability?-A. Yes, sir.

Q. And if you improve the quality and flavor you do it at a certain expense of durability $-A$. Yes, sir.

Q. And permanence?-A. Yes, sir. I never handle any cheap grades at all, whatever. I never did in my life, and never will. That is the reason I do the business I do.

Q. Do you think there is any thing else in these inferior grades of oleomargarine?A. No, I don't think there is, becanse it is composed mostly of tallow-

Q. The nearer they come to tallow the more permanent it is?-A. Yes, sir; becanse I never saw a piece of tallow spoil in my life. I don't think there is any such thing as its spoiling.

Q. You never have seen rancid tallow?-A. I don't know as I ever did. There might be such a thing, but I don't know as I ever saw it. The more cream you put into oleo the shorter time it will keep. That is the way I figure abont it.

Q. It is a balancing between the two qualities?-A. Yes; and seeing as I have such a terrible big trade, and I get it fresh every morning, I never have any complaints.

Q. But there is a disposition, for social reasons, to stick to the old-fashioned word "butter" $-A$. There is a millionaire comes in and he says he wants another pail of butter for a dollar twenty-five.

Q. How about the fellow who is not a millionaire?-A. He is just as proud as the millionaire.

Q. The fellow who works for $\$ 1.50$ a day; does he care whether his package is labeled "oleomargarine" or not? Does he object to it:-A. I never saw one that ever did.

Q. Aud he will come in and walk right up like a man and ask for oleomargarine?A. Yes, sir; and I have had them come in and discover thestamp. The stamp wonld be on the ontside. And they say, "Here, I don't want any more butterine." I say, "All right; I will show you all kinds." And I will get six or eight pails ont, and say, "Take your pick," and he will pick ont butterine 99 times ont of 100 .

Q. But he does not want butterine?-A. No. And I have to say, "Here is butter, and here is butterine; which will you take?" He says, "That tastes the finest I ever saw in my life. I guess I will take that." And that settles his argument. He never argues any more.

Q. There is a prejudice against the name annong all classes $-A$. Among all classes, in regard to calling for it.

Q. Against the use of the name?-A. Yes, sir. I knew of a gentleman the other day. I met him ont on the west side, and mother man says, "How do you know this man here?" and he said, "I buy butteriue from him." And he is a millionaire, too. 
Q. He was not afraid ?-A. No; he was not afraid. He did not care. But he would not come into my store and call for oleomargarine, in front of a crowd, but he will go outside and say, "I buy oleomargarine from this man." He buys it for I5 cents.

Q. Do you think a man is entitled to know just what he is getting?-A. Certainly he is.

Q. In your business you offer him every opportunity to know business I don't bave to lie to him. They bny it anyway. I don't have to lie to him. I am doing the real, genuine thing, in chicago, and I dun't bave to lie for it. And I am making the money. I don't have to lie to them. If thes don't like it, let them go somewhere else, and get beat, and then they will come back to me later.

Q. Yon have no knowledge of any practice or custom in your establishment of folling the corner of the paper, such as we have seen?-A. Not in any way, shape, form, or manner.

Q. No snch idlea as that is given ont to your employees?-A. We had some tronble about folding the paper. I will show you how it can be folderl in in many ways. We will suppose the stamp is on this corner [illustrating], and the stamp comes from this end, as you see, down to this, comes riglit around the outside. You can take that aud fold it over like that [illustrating] on the ontside, and still it is on the outside. I don't do it, but they done it, and they claim it is folded on the inside. Do yon see it is right here across this top? Then they take it and fold it like that [inclicating] and fold it in again, and you see it is on the inside.

Q. 'Ihat is done with a stamp?-A. Yes.

Q. And yon put your rubber stamp on the pad, and then put it on the paper?-A. Yes, sir.

Q. It would be a simple Inatter, when the package is wrapped $n p$, to put that stamp on the outside, would it not?-A. Yes, sir. 'T hen they take it and turn the paper over, and put the word "oleo" on the other side, and put it on the inside.

Q. So far as jon are concerned, that would be the simplest possible way?-A. Yes; and many times, just as soon as he makes the discovery that this is oleo, on the ontside, he says, "Put another wrapper on it to hide it." 'They don't want to be walkiug along the street showing people that they are buying oleomargarine, but still they want it. When this new law came up, about a year ago, I went to sell pure hinter, and it came loack just as fast as I sold it.

Q. It did not have keeping qualities?-A. No, sir; it did not have keeping qualities, and I never saw any that ever did have.

By the Chairian :

This resolves itself into a question of veracity between yon and this gentleman [inclicating Mr. Knight]. In other words, he says be bought these two packages from your store. $-A$. Yes, sir.

Q. I have opened both packages in the presence of the committee, and they were both folded.-A. Yes, sir.

Q. Each folded in the same way. Now, what is your explanation; that it has been changed after it left your store?-A. It must have been, without this man that I have there has a new way of wrapping them up, and contrary to my advisement. Of conrse, a man ean go on, and pick for a flaw, such as he has done, and make trouble, and string it along, if he wishes. And, as I say, a luan can wrap it up a dozen diff'erent ways, and bring it up here and swear that he got it that identical way. I would not say that he did it, but I have my opinion. He is getting pay for this, you know, and I am not.

\section{By Senator Harris:}

Q. There is one question I want to ask you further. The pure butter which you sell is wholly or partly colored, or how is that?-A. Some of it is as yellow as gold.

Q. What proportion of it is artificially colored?-A. I conlel not just state; there is a good deal of it, becanse in January butter is white as snow, almust, very nearly, aull we get it yellow in the winter time.

Q. If genuine butter were not artificially colored, would it not be easier to distiugnish it from oleomargarine?-A. Yes, sir; because all oleomargarine is colored.

(2. That is, uniformly colored?-A. Yes, sir; uniformly colored, just as you see there [referring to samples of oleomargarine on the table].

Q. And in the actual process of proilucing the gennine butter, the color varies with the season:-A. In January it wonld be almost white.

Q. In June it would all be about the same color?-A. No; in June you get the green grass.

Q. Then, I say, it would be the color of oleomargarine.-A. Yes, sir; and, as I understand, the two articles are colored by the same thing.

Q. There is a very decirled contest, practically, between the creamery men and the manufacturers of oleomargarine, as to who shall have the exclusive privileges of coloring their prodnct?-A. Yes, sir; I believe there is. These people [referring to the interests represented by Mr. Knight $\rceil$ want the oleonargarine men to quit color- 
ing it, bnt they don't want to quit themselves. They want to lire in glass houses all the tiue, aul they want to pritect the poor man. We charge 15 and 18 cents; they want 25 and 30 now. What would they get in cold weather-in. Jannary and Februars? They waut to get 60 ceits. 'They want to protect the poor mam.

Q. If the oleonargariue should be all colored pink, wonld that affect the sale of it $8-A$. You could aot sell a pound of it.

Q. Why?-A. It kills it right there.

Q. Because everylody would know that it was oleomargarine?-A. Yes, sir. Just as I was telling poil abont the milliowaire buying oleomatgarine. We will su ppose 1 inviterl you to my house to take dinner, and I had some of this piuk butter on the table. Would you eut it? You would say I was a rleap skate, woulut you?

Q. Very well. Then, practically, the oleomargarine has to masinerade as butter:-A. It has to resemble butter.

Q. It has to manquerade; it has to assume to be butter?-A. Not if you can whisper to the man; it is all right.

Q. That is just the same thing. Now, is it not the plain, palpable fact, that oleomargarine is a fraud upon the public?-A. No, sir.

Q. In the sense that it is masquerading as butter?-A. No, sir, it is not; becanse, I will tell you why. A man will come in and step np to you, and whisper, and say, "I want a pail of oleo." He is not going to go out in front of the push and say, "I wint a pail of uleo."

Q. He is not willing to deccive himself, but he is willing to deceive his friends?A. Yes, sir; just the sume as when you come into my house to dinner, and see this pink stuff on the table.

Q. If we are all in the same boat, why not throw aside the concealment? Why not simply let it be known, and make a distinctive color distinction?-A. IVell, sir, it has killed it in other States.

This man Broadwell is to-day practicing the same fraud as he was when called before Senator Mason's committee. The matter has been reported time and again to the internal-revenue collector, and he has been arrested upon complaint of selling oleomargarine for butter, but 110 conviction has ever been secured, although lundreds of dollars have been expended in the effort.

The other two called before the committee were Richard Pollok and Angust Clifi, both of whom pleaded carelessuess in some employee in selling withont stamping, and both of them are to-day selling oleomargarine as butter, Cliff advertising in the street cars and newspapers for victims.

In his testimony Somes is shown in the foregoing to have stated under oath that the agents of the manufacturers had advised him to conceal the oleomargarine mark, required by the internal-revenue law to be plainly and legibly printed on the outside of the wrapper.

However, later developments in the Chicago situation brought to light the true policy of the oleomargarine people, as practiced throughout the United States.

During the month of July, 1899, some 840 retailers took out Government licenses to sell oleomargarine in the eity. As nine out of ten were known to be selling it for butter, and the tremendous increase in dealers forecasted a complete annihilation of the butter business in the city, the Illinois Dairy Union became alarmed and decided to make a desperate attempt to at least stop a small proportion of the frand. The law forbidding coloring was tied up in the courts through the efforts of the mannfacturers of oleomargarine, and any attempt to enforce it would only result in the release of the defendant throngh labeas corpus proceedings upon the grounds of unconstitutionality, although the same law had been upheld by the Supreme Court of the United States and varions State supreme courts, and never otherwise passed upon by a supreme court.

As a result of our determination, our attorney, Hon. H. V. Murray, on July "29 sent out the following letter to every retail dealer in oleomargarine in the eity of Chicago who had been licensed the previous year: 
[Office of H. V. Murray, attorney at law.]

CHICAG 0, Ill., July 29, 1899.

DeAR SIR: I have been emplojed by the Illinois Dairy Union to prosecnte any cases of violation of the dairy laws of this State whieh may result from the arrest of any dealer selling oleomarcrarine when butter is called for. As you probably know, a commission, consisting of a food commissioner and eight assistants and inspectors, was provicled for by the late legislature, whose duty it is to enforee these laws. 'The commissioner has been appointed, and nntil he bas appointed his assistants and gotten to work the Illinois Dairy Union's inspectors will look after the protection of consumers of butter and see that those who sell them oleomargarine for butter are prosecuted under the State laws, and also reported to the internal revenue department as violators of the internal-revenne laws. I herewith inclose extracts from three State laws. These laws are not tied up in the courts, and the oleomargarine manuficturers will not place themselves in the light of protecting those who sell oleomargarine for butter, although they may eonsistently fight the law forbidding coloriug, which has not yet been passed upon by the supreme court.

If yoll sell oleomargarine this jear, rest assnred that the State food commissioner and the Illinois Dairy Union will see that you are not permitted to sell it as butter.

Respectfully, jours,

Hugh V. Muriay, Attorney for Illinois Dairy Union.

It will be noticerl that Mr. Murray only threatened prosecutions in case oleomargarime was sold for butter.

T'his letter, however, created consternation in the ranks of the oleomargarine retailers. Arrests followed at once, aurl the results oi business the next few weeks in butter furnished evidence of the fraudulent character of the oleo. traffic. Hundreds of dealers who had not been seen in wholesale butter houses come to buy butter for the trade they had been selling oleomargarine.

The field was too large to be handled in the usual manner of sending agents persomally to each dealer to assure him of protection, and thus the hands of the oleomargarine makers were forced, and they were brought out in open light.

William J. Moxley, claiming to be the largest manufacturer in the United States, sent the following letter to the retail dealers in the northern district of Illinois, under date of August 2, 1899:

[William J. Moxley, manufacturer of fine butterine, 63 and 65 West Monroe street.]

Chicago, August 2, 1899.

\section{City.}

DeAr Sir: Onr attention has been called to two circnlars which have been mailed to you-one signed by Hugh V. Nurray, an attorney, and the other by Charles Y. Knight, editor in chief of a periodical, wlthout subseribers, named the Chicago Dairy Produce. The cirenlar bearing Mr. Knight's name has at its head an imposing lot of names, gentlemen who:e aim it is to prevent the manufactnre and sale of butterine, so that the butter trist might be enabled to get from 30 to 40 cents a pound for butter, depriving, as tliey would, a great many of the iudustrial classes from being able to use butter throngh its excessive price.

With the hired attorney, who is earning his fee, we have nothing to say, only to inform you that these gentlemen are trying to ring in a bluff. Yon will notice in their circulars that by insinuations they would have people believe they represent some official anthority. The internal-revenue department looks after their own business and the State after theirs, and shonld this so-called dairy nuion interiere with your business in the way of prosecution as to the State laws, we hereby guarantee you protection to the extent of paying all fines, costs, etc., until the color law is recided unconstitutional in the supreme conrt of the State of Illiuios, and will further, on receiving complaint, take sueh action for damages as will make it mpleasant for some of those who are attempting to interfere with your and our own legitimate business.

We were under the inpression that the severe eensure they received from the judges during their filibustering of last year would have been sutficient for all time, but have been informed that to be successful in obtaining money from fismers and butter men a few circulars with imposing headliues are required. 
We strongly recommend you to pay no attention to those circulars. We have always been in a position to protect our customers from injustice and blackmailers, and will be ever at your service should you require our aid.

Respectfully, yours,

WM. J. MOXLEY.

And for fear the above manufacturer might get some of their trade, Brann \& Fitts sent out the following letter at about the same time to the same dealers:

Every licenserl butterine dealer in Chicago has received circular letters from the secretary and attoruey for the Illinois Dairy Union, promising all sorts of trouble to dealers in butterine (that honest and pure article of food). Well, now, don't you believe a word of it; there is a law against blacknailing, and we want now and here to go on record to the assertion, as an affidavit, that we shall eivilly and eriminally prosecute any man or party of men interfering unlawfully with the butterine business in this or any other State. We know exactly where we stand; we are properly advised on the suliject, and now we make you a "fair offer :" "Handle our goods as you always have, we in turn promise and guarantee full protection against the State law (which has been declared unconstitutional) to the extent of paying cost of prosecution, tines, and paying all costs pertaining thereto." In declaring the law unconstitutional one of the judges stated to the effect "that the bntter ring were, in his opinion, liable to prosecution to recover damages done an honest industry." Fair enough, isn't it? Renew your efforts, and be assured that we will be prepared to fight any number of rounds in any kind of a legal fight to the finish. Handle our butterine and be safe.

\section{THE RESULT OF PROSECUTIONS.}

Despite these prosecutions, however, the Illinois Dairy Union went forward with prosecutions. Some eighteen dealers were arrested charged with selling oleomargarine for butter. The warrants for their arrest were uniform, and the following is a true copy thereof:

\section{State of Illinois, County of Cook, ss:}

Charles Y. Knight, being first duly sworn, on his own oath states that he is informed and bas just and reasonable grounds to believe, does believe, aud so on oatl states that N. A. Wright, late of the county of Cook and state of Illinois, whilst engaged in business as II. A. Wright in the eity of Chicago, county of Cook, and State of Illinois, on, to wit, the 15th day of Angust, 1899, at his place of business a foresaid, in said county and State, unlaw filly, willfully, maliciously, and knowingly elid sell and deliver as butter and canse to be sold and delivered as butter an article of food in to the composition of which oleomargarine or suine had entered, to one John Fewer, of the city of Chicago, in the county and State aforesaid, without at the same time informing the said Joln Fewer of the fact, and of the proportion into which said oleomargarine, suine, butterine, beef fat, lard, r r other foreigu substance had entered into the composition of said article, contrary to the form of the statute in sucli case made and provided, and against the peare and dignity of the people of the State of Illinois.

Affiant therefore asks that a warrant issue herein for the arrest of the said M. A. Wright, and that he be prosecuted according to law.

Charles Y. Knight.

Subscribed and sworn to before me this 16th day of August, A. D. 1899.

[SEAL.]

G. W. UNDERWOOD, $J . P$.

These cases were defended by attorneys employed by the two manu facturing firms, W. J. Moxley and Braun \& Fitts. Roy O. West, Mr Moxley's regular attorney, was counsel, assisted by Worth E. Caylor* The cases were fought for about two months and briefs were submitted in justice court. The defense did not deny the charge of selling oleomargarine for butter. They set up the claim that the law was unconstitutional, and the clief grounds upon which it was alleged to be invalid were stated in their brief, as follows:

[From the oleomargarine manufacturers' brief.]

The crime charged in the complaints is that the defendants cansed to be sold and delivered as butter an article of food into the composition of which oleomargarine or suine had entered to one John Fewer, etc., and without at the same time informing 
the said John Fewer of the fact and proportions in which said oleomargarine, suine, beef fat, lard, or other foreign substances had entered into the composition of said article, contrary to the form of the siatute, etc.

The langnage used in the complaints is almost exactly the same as that used in the latter part of section 28 of the criminal code, as aloove quoterl.

There can be no convictions under these complinints for the following reasons:

lirst. The act in itself is not an act to prevent the selling of oleomargarine for butter. It is "An act to prevent and punish the adulteration of articles of fool, drink, and medicine and the sale thereof when adulterated." "To be more specitic, this section is liniter to the mixing of oleowargarine or any other foreign substance with any butter intenderl for human fool. If oleomargarine or butterine are sold, there can he no convietion under this section, even though they are sold for butter.

It is very evirlent that the man who sells an article can not know the proportions that any adulterant enters into the lutter unless he mixes or manufactures it. Mere hearsay from the person from whom the seller pureluases the article would not be evidence of the correct proportions or ingredients, so as to relieve the seller of any liability. 'The labeling by the mannfacturer or the mixer of the article wonld not biul the seller with the true knowledge of the constituents of the article solu.

Manifestly, it wonld be impossible for the retailer, or seller, to make a cliemical analysis of every article of this kind that entered his place, becanse it wonld make such alditional expense that it wonld prohibit the sale of the article. If it would prohibit the sale of the article, the statute would be unconstitutional.

The above is one of the most remarkable defenses ever set up in any food case ever brought into court, as in order to make a defense where a law requires laboling the claim is marle that no retailer cum be sure of what he is selling unless he has it anulyzed, and that analysis would cost so much that it would pohibit the business. It is a denial of the right of the State to protect ils eitizens in any way in the purchase of food, as it elaims that the retailer himself can not know what he is selling, and that any law which forced him to ascertain that fact would be uncoustitutional.

The above illustration is given to prove that sellers of oleomargarine defend their customers in the sale of oleomargarine as butter, which sale was in open violation of both State and Federal laws, and to show that they will not comply with the most reasonable regulations. In other words, they hold themselves to be wholly above the State laws, and defend violations of such laws, which violations are in effect violations of the Federal laws and which would have been prosecuted in the Federal courts but for the fact that the collector of internal revenue refused to make the prosecutions upon evidence of ontsiders, and stated that he had neither time for the work nor money to murchase samples with which to do the prosecnting in his own department.

These eases were dismissed by the justice of the peace upon grounds that a subseguent statute had repealed the law under which the warrants were drawn, but not until after $\$ 1,600$ had been speut by the parties interested in an effort to stop) this gigantic frand in the city of Chieago. The decision admitted of no appeal, the Dairy Union's funds were exhausted, and while the decision was looked upon as the most ridiculous piece of justice erer perpetrated upon the public the oleomargarine manuficturers stood rearly to enter into other controversies upon any points or under any laws we might proceed under in orcler to stop their swimlling of the public in the city of Chicago, where not one in twenty-five clealers has ever pretended to comply with the national law, and not one ever observes any State law.

\section{CAN A STATE PROTECT ITS CITIZENS FROM FRAUD?}

\section{Swift \& Co. go on to say:}

Eighth. Some of these bills propose to withlraw from oleomargarine all the rights and jrotection of interstate commerce, and to turn it over to the tender mereies of the various state legislatmes, which may he iuteresterl in restricting or prohibiting its manufacture or sale, because of its competition with local interests or products. 
If this principle of legislation is once conceded, where will it end? It New York can exclud wleomargariue from the markets of the State becanse it comes into competition with its dairy interests, why should not Vermont prohibit the sale of bet sugar to protect its maple-sugir crop? Why should not West Virginia prohibit the sale of all anthracite coal "designed to take the place of" bituminons coal as an article of fuel," or Louisiana prohibit the use of heet sugar or glucose or saccharine because these may be used as substitutes for the local product of cane sugar? Is Congress ready to affirm that in order to protect the business and products of one State the business and products of another state may be exclu.led?

Upon this point Swift \& Co. can be directly answered by an extract from Justice Harlan's decision in the ease of P'lumley $v$. Massanchnsetts, previously referred to. Says this honored jurist, l eferring to the rights of the State to regulate and control the oleomargarine traffic, then under review:

If there be any subject over which it wonld seem the States ought to have plenary control and the power to legislate in respert to which it ought not to be supposed was intended to be surreudered to the General Government, it is the protection of the people against fraud and deception in the sale of food products. Finch legislation may, indeed, indirectly or incilentally affect trade in such products transported from one State to another State. But that circumstance does not show that laws of the eharacter alluded to are inconsistent with the power of Congress to regulate commerce among the States.

Let us, however, look at the illustrations eited by Swift \& Co.in a manner consistent with this question. Does any one donbt that if citizens of West Virginia should so manipulate its bitnminous coal as to make it an exact imitation of the anthracite of Pennsylvania, using a polish to give it luster and a mold to imitate the anthracite form, and the Pennsylvania people found that citizens of that State were daily purchasing this bituminous coal for anthracite and at anthracite prices, that the State of Pemusylvania should have the legal right to say that West Virginia's bituminous coal must not be so manipulated as to cause the citizens of Pennsylvania to think it anthracite and thus be defranded? Should ofticers be stationed at every coal pile to see that every customer was advised that the fuel which resembled anthracite was a cheaper and less serviceable grade? And would the people of Pennsylvania accept as an excuse for the connterfeiting of anthracite coal such reasons as are put forward by the oleomargarine makers in justification of coloring their product to resemble butter-that it is absolutely necessary for the purpose of pleasing the eye?

The tronble with Swift \& Co.'s comparisons are that they endeavor to compare things that differ. They are now preparing to make an onslanght a gainst the laws of the State of New York and encleavor to foree their connterfeit product into the only State in the comntry which has protected its people with any degree of success with State laws, but which has been doue at enormous expense to the State and at the expense of eternal vigilance, necessitating at times the dispatching of agents as far west as Illinois to seek out violators and expose them to the internal-revenue department.

Thus fir, with the exceptions of two Federal lower courts, the rights of the State to exclude oleomargarine made in semblance of butter has never been denied. But the lack of specific legislation npon this subject has befogged some of the tribunals, and nothing but direct legislation to the point will elear the matter up and protect the laws of the States.

The States whose laws are thus threatened are such ones as have provided for the powerful State machinery and support to enforce their laws against the invalers. This provision alone would not greatly benefit such States as llinois, Pennsylvania, Ohio, Massachusetts, and other States where the retail dealers-always amenable to State laws, 
so far as any protection the interstate-commerce laws may afford-are being backed up in their defiance of the laws by the manufacturer's, who can simply afford to spend more money in defense than the State can aftord for prosecution.

\section{IS OLEOMARGARINE THE "POOR MAN'S BUT'IER""}

\section{Following, Swift \& Co. have something interesting to say about} prices:

Ninth. The varions grades of oleomargarine mannfactured range in price, on an average, from 10 cents per pound for the cheapest grade to 15 cents per pound for the highest grade. The arerage price of the cheapest grade of oleomargariue for the year ending December 31,1899 , was exactly 103 cents per pound. This is the price charged by both manufacturers and jobbers to the retail dealer, the price to the jobber being one-half cent per ponnd less than to the retailer. From this it will be seen that a tax of 10 cents per ponnd would equal the price obtained for the product and wonld completely destroy a business which has been recognized by law, which furnisles a large anunal revenue to the Government, which provides employment for large numbers of men, and in which citizens of the Uniterl States lave invested their fortunes and their energies, for it is a fact which mnst be apparent to all who will reflert that the tax proposed by these bills is prohibitive and therefore destructive. Congress is now asked to destroy that which it lias heretofore recognized as lawful, and from which it has derived large revenues each year.

The foregoing is also a subject upon which we may be able to offer some information. Swift \& Co. say it could not stand a tax of 10 cents per pound and live.

At what price does oleomargarine sell at retail? Here is the test. The manufacturer makes a good, liberal profit, but the retailer is the man who is compelled to do the disreputable work of disposing of it for butter, and he demands extraordinary margins for so doing, which is quite natural. Let us see what arguments besicles the guarantees of protection are advanced to induce the retailer to violate the laws of his State and face the possibility of indictment and trial in court.

One of the most interesting exhibits in this line is a circular letter issued by the Capital City Dairy Company of Columbus, Ohio, Decem. ber 1, 1899. It follows:

[The Capital City Dairy Company, makers of butterine, highest quality only, No. 185 to 197 Third avenue east.

Columbus, Оніо, December 1, 1899.

Dear Sir: With the appended change in price list we can only reiterate that our "Purity" grade is equal if not superior to most inakes creamery butterine, therefore, "Purity" selling at 20 cents, "Buckeye" or "Pride" should sell at 25 to 30 cents. If you want a popular priced grade our" "Silver Leaf" is particularly appropriate. Ever remember this indisputable fuct: Yon can obtain for our butterine a better retail price than for any other make in the United States.

Purity, 14 cents per pound.

Silver Leaf, 15 cents per pound.

Buckeye, 17 cents per pound.

C. C. Pride, 18 cents per pound.

Prices snbject to change without notice.

Goods billed at price in effect on day of shipment.

F. O. B. Columbus, Ohio, net cash.

\section{DIFFERENTIALS.}

One-half cent advance for solids under 25 pounds, and rolls or prints 2 pounds and over.

One cent for rolls and prints 1 pound and less than 2 pounds; also small tubs in crates and boxes; also unsalted hutterine.

One and one-half cents for rolls or prints of one-half pound and less than 1 pound. Two cents for rolls and prints uniler 8 ounces.

Mixed, eatch, or country rolls figured at prices of smallest roll or print in package. Very truly, yours, 
At the time this circular was issued butter of best quality was worth at wholesale about 25 cents in Chicago.

The Capital City Dairy Company tells its customers that they ought to get from 25 to 30 cents for "Buckeye" or "Pride" oleomargarine, which they will sell the retailer at 17 to 1 s cents f. o.b. Columbus. This means from 8 to 13 cents per pound profit, or fiom 33 to almost 80 per cent profit on the "poor man's butter."

But no, that is not what this means. The mention of 30 cents per pound means to convey to the retailer the suggestion that "Pride" or "Buckeye" can be sold at butter prices-for that is about what the best butter would be worth at retail-and as butter.

And this concern, as well as the others, are not satisfied with imitating butter color, butter tubs, butter rolls, and butter prints, but needs must put up "mixed, cateh, or country rolls"-that is, place in a box various sizes, shapes, colors, and designs of oleomargarine to cause the contents of said box to resemble country butter as it comes fresh to the stores from the farmer. That is why the price is figuresl at "price of smallest roll or print in package." Can the manufucturer plead in justification of this scheme to defraud and mislead "a desire to please the eye?"

But let us look a little further into the ability of yellow oleomargagarine to stand an increase of tax.

The average cost of raw materials can not be much more than 8 cents per pound for the best that is made without butter-and of course very little butter-that article "devoid of keeping qualities and of 'doubtful' cleanliness"-would be used in the immaculate product, oleomargarine. It has been shown that the manufacturer sells it for from 10 to 18 cents a pound and the retailer is arlvised that he ought to sell it at from 20 to 30 cents per pound. Between $\delta$ cents cost of raw materials and 30 cents at retail is a margin of 22 cents, furnishing plenty of room for the 10-cent tax, which amount and profit is now serving as an incentive for the retailer to sell the stuff as butter and giving the manufacturer a profit that will permit him to pay costs and fines and otherwise defray all expenses incurred in the defense of such suits. It is this umnatural, abnormal, unfair, and corrupting profit that we desire to be taken away from the traffic in order that our laws may stand some chance of being enforcerl without having to expend as much State money as these counterfeiters can afford to spend of their ill-gotten gains.

But let us see what some others have to say about the profits derived from the sale of oleomargarine.

In a circular letter sent the Chicago trade October $22,1898, W \mathrm{~m} . J$. Moxley says, among other things:

Your profit will be double the amount uade flom the butter you are now handling, and your butter trade will be more satisfied if you will sell them snch butterine as you can buy from me.

Under date of March 17, 1899, Messrs. Braun \& Fitts, of Chicago, sent out a circular containing the following:

Now is your chance to build up a first-class trade by handling only first-class butterine. Eggs are selling at cost, but "the only high grade" will give you profit, so keep pushing its sale aud build up a reputation for good butter.

Please note, the circular doesn't say, "build up a reputation for good butterine," but for "good butter."

We could supply Congress with humdreds of instances of where the retailers advertise butter and sell nothing but oleomargarine. But our endeavor here is to reveal the connection of the mantafeturer with the 
imposition now being practiced upon the public-to show what the men are doing who will appeal to you to spare their industry upon the grounds that while there may be fraud practiced in a small way by some irresponsible retailer, their interests should not be made to suffer therefor.

We charge that the manufacturers are dirertly responsible for the fraud; they devise schenes, and instruct retailers in their consummation; but for their law.defying attitude the State laws would be as easily enforced as the laws against any other fraud.

Another phase of this question is the position in which the law-abiding retailer is placell.

Where oleomargarine is really sold at reasonable figures it is usually advertised as a "bargain sale in butter." It is used to draw trade for other lines. In some instances lonest grocers are hampered by competitors who sell 15 -cent butterine as butter for 25 or 28 cents, and take the 5 or 8 cents of profit off some other article or articles, thus cheating the consumer on butter when he believes he is getting a bargain all aronnd.

The following from a circular letter sent out by W. J. Moxley Decem. ber 10, 1898, shows up this side of the question:

When a woman goes to buy groceries there is one article of goods she must have, and that is butter. She puy want sugar, coffee, aml other articles, but she wants butter and wants it at a price to suit her means. If yon can not supply her don't expect her to buy her coffees, teas, aud other articles of you, aud then go a block to another grocery to buy four or five pounds oi" "Moxley's Speriul." It" she is a practical woman she will go to a store where all her wants ean be supplied. Some are deterred from going into the butterine business throngh haring to pay for a license. This is a mistaken idea. Ninety-five per cent of the dealers whotake out a license for one year bake it ever after, the other 5 per cent fail in bnsiness. Nothing can save them.

Note again, Mr. Moxley, doesu't say, "there is one article of goods she must have, and that is oleomargarine." $\mathrm{Oh}$, no. She must have butter. And if you don't deceive leer in to thinking she is getting butter at a lower price than it can be lionestly sold, then you lose her trade and fail in business. And there is considerable truth in this. The dealer who is dishonest has an unfinr, unjust, and illegal advantage, and such a condition places a premium upon crime.

The 10-cent tax will take away this injustice by depriving yellow oleomargarine of its corrupting powers.

\section{DOES THE EXISTENCE OF OLEOMARGARINE DEPEND UPON ITS YELLOW} COLOR?

And now in closing Swift \& Co, make a remarkable omission. They say :

Tenth. It is a well-known fact that the people who use oleomargarine are the intelligent, prudent, and thrifty people of the mirldle elasses, who buy oleomargarine becanse they prefer it to that which is sold as butter in their markets, and who are too intelligent to be deceived even if anyone wisbed to deceive them. 'These bills propose to make it impossible for these people to buy what they wish to bur, although it is known to be absolntely clean, wholesome, aud health ful, for these are facts which have been establisherl in courts and by reports of officials, State and national, and by investigations of various kinds carried on in all parts of the country, and the results widely published.

Oleomargarine, then, has ceased to be "The poor man's butter?"

This is a remarkable change in conditions. There is only one explanation for such a change in the claims of the oleomargarine maliers. A resolution was presented to the central body at Chicago a few weeks 
ago condemning the Grout bill and instructing the secretary to call mon kindred and allied labor organizations to pass the same kind of resolutions and send to Congress. A committee was sent out to investigate the matter; the fiaul was slown them in a half dozen shops within a stone's throw. The question was fully explained to them, and they returned with the assuranee that if they made any recommen. dation it would be for the passage of the measure, as they had never imagined such an appalling coudition of aflairs could exist as was demonstrated to them when they were taken intostores where ereamery butter was asked for aid packages brazenly taken from boxes which the sellers were later forced to admit had concealed upon them the revenue stamp showing them to contain oleomargarine.

The committee which made the investigation was President Daley and Dileetor Carmody, the latter remarking after visiting the place of the Ohio Butter Company, at 54 Fifth avenue, and seeing the frauds practiced there, that the tax ought to be 25 cents instead of 10 cents. The above statement I will make afficlavit to, although it appears the resolntion was really passed at the instigation of the box makers' union, which makes boxes for the manufacturers of oleomargarine.

\section{THE USE OF THE TAXING POWER.}

Now, a word regarding the advisability of employing the taxing power of the Government as an internal protective measure. This question is admitted to be one demanding mature deliberation, and the use of the taxing power, it is conceded, must be carefully exereised. In 8 Howard, 82, we tiud the following:

The taxing power of a State is one of its attributes to sovereignty. * * The only restraint is fonnd in the respousibility of the legislature to their constituents.

While in 4 Wheat., 316, we find:

If the end be legitimate and within the scope of the Constitution, all the means which are appropriate, which are plainly arlapted to that end, and which are not prohibiterl, uay constitutionally be enployed to carry it iuto effect.

If a certain means to cary into effect any of the powers expressly given by the Constitution to the Govermment of the Union be an appropriate measure, not prohibited by the Coustitution, the degree of its necessity is a question of legislative discretion-not of judicial cognizance.

But probably the best argument for the use of the taxing power for such a purpose is found in 9 Wall., in one of the original tax cases, where a retail liquor dealer claimed immunity from the jurisdiction of the State because of the faet that he held a license from the Government. The court said in this ease:

There is nothing hostile or contradictory, therefore, in the acts of Congress to the legislation of the State. What the latter prohibits the former, if the busiuess is found existing notwithstanding the prohibitiou, discourages by taxation. The two lines of legislation proceed in the sante direction and tend to the same results.

Here the court judicially recognized in the taxing power a tendency to discourage what the State prohibits.

And again, Congress might well hesitate to select at random one inclustry, the stauding of which with the people might be open to question, aud discourage or hamper it with taxation.

But courts have uniformly held that in the exereise of its taxing power Congress is reponsible only to the people; that the remedy of the people for excessive taxation lies in an appeal to their representatives and not to the courts.

In this matter the people of the States have expressed themselves by 
a four-fifth's majority as being opposed to the existence or commerce in the article we seek, if you please, to discourage by taxation. The legislatures of thirty-two leading States have declared traffic in oleomargarine colored to resemble butter to be a menace to the iudividual rights and welfare of their people. Thirty-two legislatures lave thor. onghly investigated the matter and in both branches came to the same conclusions. Our charge of frandulent similation has been sustainen by the representatives of four-fifths of the people of this comntry, and the high courts have invariably pronouncerl their grounds well taken and their reasoning somd. It is not a case of Congress oppressively taxing the peopli, or wrongfully employing its taxing power; it is a case of where the people of practically every State arise aud appeal to Congress for aid in accomplishing something which they have sought but failed to do with State laws specially enacted. There can be no protests from the people, because they themselves have sought the legislature as the only practical solution of a condition which is rapidly becoming oppressively intolerable.

Need any Congressman hesitate to support a measure the intent or effect of which may be to discourage traffic in an article totally forbidden in his State? Upon the other hand, should lie not, as a lawabidiug citizen and a representative of his people, endeavor to use his best efforts in Congress to advance the interests of the people of his State? Can a representative in Congress question the wislom of the policy of the legislatures of the learling States when their actions have been so uniform in the treatment of the subject under discussion?

And further, what right has anybody in any State where the sale of yellow oleomargarine is forbidden to object to this tax? Where can his interest lie? If he is a law-abiding citizen lis interests can not be affecter. If he is not a law-abiding citizen, what claim has he upon the representative of his people in Congress? Can a member of Congress atford to be influenced by a citizen who has no respect for the laws of his State?

It is the will of the people of Illinois, expuessed by two-thirds of the legislature of the State, that oleonargarine coloren in semblance of butter should not be sold. swift \& Co. and other manufacturers practically come before Cougress and say:

Now, soll see here, this is our fight. We are too big for the State of lllinois, as well as many other States, and we're having things our own way. We don't care for State laws at all, beeause we can get around them. We are selling more colored oleomargarine now than we were before the laws forbidding its manufueture and sale were enacterl. But if you Member's of Congress go and put a tax of 10 eents a pound on this stutf it would ruin our business. We can't figlit the Government when it gnes after its taxes, although the Interual Revenue Department doesu't bother our retailer's by maling them comply with the law regarding branding, becanse the Government doesu't lose any revenne through these violations, but is pather a gainer. You jnst let us alone and we'll do as we please. What business have the people of the state making laws that will interfere with an industry that produces a healthful article, anyway? Of course, we realize that oceasionally some oleomargarine is sold for butter, but why not ehase around among the thousands who retail the stuff and punish them if yon ean catch them? No, gentlemen, we don't care what the States say; our busin'ss is such that they ean't reach us. But it would be ontrageous for the Representatives of these states in Congress to get together aud fix up a selieme whieh wonld prevent us dome as we pleased in their States hereafter. All we ask is to be let alone in onr fight with your people, whom we are foreing to eat our produet whether they want it or not.

WHY SFCTION 2 IS NECESSARY.

The dairy interests of the United States are divided into two classes. One represents the class located in States where the legal machinery has been unsuccessful in coping with this fraud. Statistics of the 
internal revenne slow that New York is about the only important consuming State thus situaterl.

The other class comprises the other States which have fomd it impossible with State laws to prevent the sale of oleomargarine contrary to their State laws.

The New York rairymen, as well as the rairymon in other Eastern States, fear an onslanght npon their laws which will break the hither to impenetrable barrier and Hood their markets with the forbiden counterfeit article. Their fiar is that some Federal courts may interpret some rather ambiguous decisions in the same way they were interpreterl by the court of appeals of Marylanrl and a district Federal court of Minnesota, denying the right of the state to exclude yellow oleomargarine in the original package. It is to forestall any such a probability that State control is asked, as in section 1 .

But the very large majority of the States will not, under present conditions, be at all bencfited by section 1 alone. Sneh decisions wonld have no effect upon their laws, becanse the violations in these States do not consist of the sale of the article in the original package, which might be protected by the interstate-commerce laws, but it is retailers, over whom the State, so far as liederal interference is concerned, has never been denied jurisdiction, and which right to regulate has never been questioned by the judiciary.

The obstacle these States find to the enforcement of their laws is the persistent, systematic, and powerful opposition of the manufacturers, who regularly appropriate a portion of their earnings to cover legal expenses, and whose fixerl poliey it is to induce retailer's to berome lawbreakers and protect them against the prosecutions of the State.

Nothing but the (mactment of the 10-cent tax elanse, which will take the abmormal profit out of the sale of this comntertieit, will ever make it possible for the States to enforce their laws against dealers in oleomargarine, as they would against violators of otler laws.

\section{DAIRY FARMERS DISCRIMINATED AGAINST.}

The ehief argument agaiust our bill now is that the oleomargarine manufaeturers onglit to have the same rights to color their goods that the dairymen enjoy; that depriving them of that right would be placing them at a disadvintage which we onght not to do; that it is not right to make their goods muattractive by prohibiting the coloring of them.

The manufacturer of oleomargarine, mpon payment ot $\$ 600$ license fee and ' cents per pound tax, is given the right to use for producing a substitute for butter a fat enabling him to make it for 10 or 1'丷 cents per pound at the outside, including the 2-cent tax. He has the right to nse a 6-cent fat, and can, if he chooses, mix butter with it. The dairy farmer is confined by law to the use of butter fat that can not be produced, even under the most favorable eircumstances, for less than 12 cents per pound, and in winter montlis the cost to him is nearer 18 and 20 cents per pound. If he were permitted to use neutral lard, oleo oil, or cotton-seed oil in his production, as does the oleo mannfacturer, he could make the cost much less, and might make goods for 10 or 12 cents that would onteliss in quality the oleomargariue maker's goods. In this way the oleomargarine mannfacturer is given a monopoly on the trade for a cheap substitute, and restrictions are placed upon the dairyman which keep him ont of the fielsl and ont of competition. If he is to be barred ont of this field by restrictions, is it any more than fair that the oleomargarine manufacturer shonld be barred out of the field of pure butter by some restrictions? And can anyone 
levise restrictions that will apprise the ennsumer of the identity of the substitute other than through the agency of color? What we call the field of pure butter is that portion of the consuming public that calls for butter either at the store or at the table. It is at the table where the invasion of our rights is being earried on. Of course, it might be said that the dairy farmer has the same right to obtain a license and engage in the business that the present oleomargarine manufacturer has. We answer that he would then be a mannfacturer of oleomargarine, and not a dairyman. And, besides, where is there a farmer, or a neighborliood of farmers, that conld afford to pay $\$ 600$ a year for the privilege of going into the business?

\section{ALL MUST ADUL'TERATE OR NONE.}

Fonrteen years ago the dairymen of this comntry were confronted with this crisis: They must either become adulterators and meet the competition of those who made oleomargarine withont restriction (as was the case prior to the passage of the law of 1886), or they must crush out the connterfeit in order that they might deal honestly with the public and preserve their business.

They ehose to be honest and force others to be the same. That is why they eame to Congress for the Hateh bill then.

Stop and consider a moment, if you please, that the dairymen and creamery men have all the facilities for adulterating butter, and might with profit be adulterators if not forbidden by law. They chose, however, to make the pure article, and the laws they secured were as restrictive upon themselves as upon those who prefer the dishonest business of adulteration.

Now look around at the wholesale butter business. Not a wholesale butter dealer in the eity of Chieago handles oleomargarine at whole. sale. Why? Because they will not violate the laws of their State and encourage the violation of the laws of the Government. Every wholesale butter man is as well qualifierl to sell oleomargarine as the oleomargarine dealer. He sells to the same trade.

Because the butter merehant obeys laws and refuses to encourage their violation, his business is being ruined by other merehants who are willing to defy law and ineite violators by guaranteeing protection in case of prosecntion.

Is it not an outrage that the law-abiding citizen should suffer as a result of his good eitizenship, and should not every lawmaking body do everything to protect those who respeet the deerees of this branch of the Govermment?

The dairymen fight for the preservation of the purity of the dairy prodnet. They do not want to be foreed to become ailulterators, as has been the ease with manufacturers of nearly every other article of food, as shown by Senator Mason's report. They will fight angboty, no matter who he be, who comes brfore the pnblie with a comnterfeit of their article which ean not be detected by the unwary consumer.

In whose interest are they doing this? Is it in their own interest any more than in the interest of the public?

MARCH $14,1900$.

The committee met at 10.30 a. m.

The CHAIRMAN. The meeting this morning is for the purpose of hearing a delegation of gentlemen from Philadelphia on the Grout bill. 


\section{STATEMENT OF MR. B. F. KIMBALL, OF PHILADELPHIA.}

Mr. Chairman and. gentlemen of the committee, the merchants of Philadelphia believe that the passage of the Gront bill wonld solve the oleomargarine question, inasmuch as it strikes at the foundation of the manufacture of oleomargarine by permitting it to be sold for what it is and not in initation of butter, which it is when it is colored, so that it will come in legitimate competition with butter in that shape.

Mr. LAMB. What would be the effect of the operation of this law in Philadelphia on the retail merchant?

Mr. KInBall. At present in Philadelphia abont nine-tenths of the oleomargarine sold is sold as butter. It may be stamped or it may not be. We seldom see it stampel We simply ask that they be compelled to comply with the law. The wholesalers now do comply with the law.

Mr. Allen. Do you know that from personal knowledge?

Mr. KinbalL. I know it from contact with eustomers and seeing the product in the stores. We liave it in our store for examination. We know that the butter trade has fallen off becanse of the sale of oleomargarine.

Mr. White. What is the pereentage of the decreased sale of butter in consequence of the sale of oleomargarine as butter?

Mr. Kinball. It is fully 50 per cent.

Mr. DAVIS. In the State of Pennsylvania there are 11,000,000 pounds of oleomargarine sold, and about nine-tenths of it is sold as butter. The only State which sells more is Illinois.

Mr. KMmBall. 'The butter merchants of Philadelphia are largely interested in creamery products, and have no objection to the sale of oleomargarine itself as such. They recognize it as an article of commerce. We object to the sale of oleomargarine at butter prices as butter.

The Champiran. Is it sold in that way?

Mr. KIMIBLL. There is no indueement to sell oleomargarine by the retailer unless lie can get butter prices.

The ChaIrifan. I supjose it is sold at a slightly less price?

Mr. Kimball. It is sold at the price of butter. Last week we had three persons convicted for violating the United States law. Since that time you can buy oleomargarine cheaper. The price to day is 20 ceuts. Before that the same man was selling it for 28 ceuts.

Mr. ALLEN. You say they are selling it fraudulently. Is that under the State or Federal law?

Mr. Krmball. It is under the Federal law.

Mr. Allen. Have you a State law?

Mr. Kimball. We have. They can not sell it except when it is uncolored.

Mr. Allen. You say they can not enforce that law?

Mr. Kinball. They are arrested and brought before magistrates. Last year the butter men spent $\$ 4,000$ for the purpose of preventing the sale of it by the prosecution of offenders. 'Two cuases were brought 11) last week and both were convicted, but to-day they are making arguments for new trials.

Mr. Co $N E Y$. Have you spent money to obtain convictions under the State law?

Mr. Kimball. Yes, sir. We had it down fine at first, when the State repealed the prohibitory law and made it a license law. Since that time we fiud we are able to prosecute better in the United States courts. 
It ean not be sold if the people know what they are getting. We can do nothing in the State courts. If this Grout bill prevails, then the retailer will be obliged to buy from the manufacturer. If he obtains it colored, in imitation of butter, he will have to pay the tax, which brings it up close to the price of butter. As it is now it is in competition with butter aud needs regulating.

Mr. Allen. Don't you think that we should provide against the coloring of butter?

Mr. Krmbalt. No, sir; because butter has been eolored from time immenorial.

Mr. ALLEN. Don't you think the same objection obtains against the coloring of butter as obtains against the coloring of oleomargarine?

Mr. Kimball. All the white brtter produced to-rlay, that which you see in the conntry stores, is ouly used in making it over. It is sold as packing stock and nsed for manufacturing purposes. The legitimate butter, much of it, is colored yellow. Some people prefer to have color. ing matter added. We do not want to speak about coloring one way or another. We want to do a legitimate business and obey the laws, and we want our customers to obey the laws, but dealers will buy oleomargarine and rewrap it and sell it for butter. That hurts the butter man who is trying to earn an honest living in the sale of butter, and it also hurts the mau who purchases butter.

If this Grout bill prevails, then oleomargarine, if it is a good thing, and we admit it is a good thing, will be sold at a price to reach the poor man, and it is intended to reach him, and the legimate butter will sell at a price which the people are willing to pay for it. It will do away with the practice of deceiving the eustomer who goes into a store and asks for a pound of butter and gets a pound of oleomargarine.

The Chairman. Whose fault is that? It is not the fault of the manufacturer?

Mr. Kmball. I do not know. Persons would not sell it unless they made a profit out of it.

The Chairiran. You say that you can not convict persons under sour law?

Mr. Kimball. The law has only been in force a year. The grand jury has found true bills, but the cases do not come up. I am sorry I am not better posted on the merits of this particular bill. I only speak from the standpoint of a Philadelphia merchant. We are not speakers, but simply butter men.

Mr. AlLen. Do you mean to state that the district attorney will not enforce the law?

Mr. KImbalL. No, sir; I do not want to give that impression. We do know, however, that we have had to make the fight ourselves. There is an absolutely prohibitory law.

Mr. BAILEY. In Philadelphia is oleomargarine received in rolls, so as to have the semblance of dairy butter as to different shades?

Mr. KimbaLL. The bulk of it is in the shape of print butter.

Mr. BaIley. I mean as to size. Does it come iu tubs?

Mr. Kiniball. Yes; tubs, rolls. and prints.

Mr. BAILEY. That which comes in prints or rolls-is it all of the same color, or are there different shades of rolls in the same box?

Mr. Kimball. We never see that in Philadelphia.

Mr. LAMB. Is it marked "oleomargarine?"

Mr. Kimball. The retailer buys it with the brand on it, but afterwards there is no mark on it. That is a violation of the law. If we could obtain such evidence as that the district attoruey may prosecnte. Special agents of the revenue clepartment do not bring eases. 
Mr. AlLEN. Since the sale of oleomargarine has increased has the death rate of the city increased?

Mr. Kinball. We do not know that there is anything unhealthful in oleomargarine.

The CHAIRMAN. You want it sold for what it is?

Mr. Krmbalt. Yes, sir; we want it sold for oleomargarine. Under the State law every pound bears the stampl tax. It is male by four or five people, what we call the "Big Four." This law will not work a hardship. If they want it colored and want to sell it as butter, let them pay the 10 cents tax, and then there will be no clifference in the price of the legitimate butter and the oleomargarine, and there will be no incentive to cheat.

Mr. Allen. What is the effect on the consumer?

Mr. Kimball. Anyone who wants cheap butter can get it for 5 to 6 cents a pound lower to-day.

Mr. Willians. Why is it right, or is it right, in your opinion, to tax oleomarganine in its natmal condition, when not colored in the semblance of anything?

Mr. Kimball. Personally, I don't believe in taxes any more than possible. I do not believe in taxing any industry.

Mr. Allen. Can the manufiacturer afford to pay 10 cents and produce it at a profit?

Mr. Kmiball. We do not want him to sell it as butter.

Mr. Allen. Could he pay that tax and compete with butter?

Mr. Kimbali. With its natural color oleomargarime would not sell at all, because people wonld not buy it.

The CHAIRIAN. When butter is lown to 14 cents and you tax oleomargarine 10 cents, that wonld only leave 4 cents for the manufacturer. Would that not be absolutely prohibitory?

Mr. Kimball. No, sir. The price of butter is very seldom 14 cents in the country.

The CHAIRiAn. I have sold for less. I have seen it in westeru New York sold at 7 and $S$ cents. In pntting on this tax, it would take off 5 to 10 cents of its value. Suppose butter is selling at 14 cents a pound.

Mr. KmBalL. Butter is not in its natural state white. It is only so in the winter months.

The CHAIRman. I understand that the best butter served on Delmonico's table is perfectly white.

Mr. Williams. The toniest people mse it.

Mr. KrmBaLL. The only coloring used in butter is for the purpose of obtaining the yellow tint, which color comes from the fresh grass.

The Charrman. That is the ouly time it is colored. We use coloring matter in our cremmeries.

Mr. Whi'te. Uncolored oleomargarine would sell the same as it does now?

Mr. Kimsalt. It would.

Mr. WHITE. This resolution wonld not affect it unless it is colored?

Mr. Kimball. No.

Mr. HEnRY. I have a letter from a butter dealer in western New York, and he wants me to support the Gront bill, and adds that the farmers are briugiug this stuff in and selling it for butter.

Mr. Krmball. That only goes to show how far this practice obtains. The lucksters in Philarlelphia are the worst men, and now the farmer comes in with his good conntry butter, but it is oleomargarine.

Mr. MAvis. The matter we are liere to present to the committee, as I mulerstand it, and as Mr. Kimball has detailed it, is that the law. abiding dealer has always harl to contend with those who are violating 
the law. It is the experience of butter dealers everywhere that if they undertake to sell oleomargarine for what it is, they will not sell it at all. The working people who want cheap goods and are compelled to have it do not want oleomargarine. It is sold to most people for an article which it is not. It is sold under a misrepresentation. With reference to the movements that have been tried by the producers to protect themselves from this fiaululent imitation-and many movements have been tried-there does not seem to be any thing likely to be more effeetive than this bill, for the reason that they can not sell this thing as butter, beeause the 10 rents tax will bring it up to the cost which is now paid by the consumer for butter. The difference represented by this tax now goes into the pockets of the illegal dealers.

Mr. LoRmer. You say that if this tax is put on oleomargarine then there will be no sale of it in competition with butter?

Mr. DAVIs. That is about it. They can not sell it.

Mr. Lorimer. You mean to say they can not sell it in competition. They can sell it if anybody buys it. Would not that virtually mean the driving of colored oleomargarine out of the market as a matter of trade?

Mir. Davis. That might be incidental to the operation of the law.

Mr. Lormer. If they can not pay this 10 cents tax, would that not drive it out of the market?

Mr. Davis Not necessarily.

Mr. LORIMER. You do not believe it would interfere with the sale of it?

Mr. Davis. I do.

Mr. LORIMER. Is it not the intention of many who favor the passage of this bill to drive colored oleomargarine out of the market?

Mr. DAvis. The object, as I take it, of the men interested in this is to prevent illegal competition with butter-to protect the law-abiding people. In Philadelphia we believe that 90 per cent of this traffic is done illegally. Of course that operates to the disadvantage of people who do business in a proper way. For instance, I am alongside of a man selling oleomargarine for butter, aud he makes an enormons profit, whereas the butter seller make only a legitimate profit.

Mr. LORMnER. Yon say you think the passage of this bill will prevent dealing illegally. If you have a tax of 10 cents, how will that prevent the illegal traftic in your eity?

Mr. DAVIS. There would be less inducement offered. It would be that much accomplished. Everything helps for the protection of the dealer who is law abiding.

Mr. LORIMER. Is not the object to drive colored oleomargarine out of the market?

Mr. Davis. We want to prevent this illegal traffie which operates to the injury of the law-abiding people who are doing a legitimate business.

Mr. LorIMER. The reason I am asking this question is because a gentleman who appeared before the committee a week ago to-day said it is the desire of the butter men to drive oleomargarine out of the? market-that they want to drive the oleomargarine manufacturer out of business. I wanted to find out whether or not that sentiment prevails over the conntry.

Mr. Davis. If driving it out would be incidental to the operation of this law, then oleomargarine would have to be sold upon its merits.

Mr. Loniner. In its white state?

Mr. Davis. Yes, sir. 
Mr. Whiтw. What has been your observation with reference to the healthfulness of this oleomargarine product?

Mr. DAVIs. I do not know that there is any evidence as to its injurious effect upon consumers. 'That is a subordinate matter.

Mr. WhiTE. I wanted to see what your observation had been.

Mr. DAvis. I have never leard of any bad results from it.

Mr. WIITE. In your opinion, it is a healthful product?

Mr. Davis. So far as we know there is nothing in it deleterious to health. The main point we wanted to present is the fact that this traffic is done illegally, and that we think the provisions of this bill, if passed, would be a great remedy and would prevent that thing.

Mr. Lorimer (to Mr. Kimball). Do you know that the Grout bill provides that when butterine is shipped into any State in the Uniou it shall go in under the control of the State law?

Mr. KInBALL. I do not know that that is in the bill, but it would seem natural for it to be there. The State should have police powers in anything of that kind.

Mr. LoRImer. 'That is oue of the provisions of the bill. You say there were last year $11,000,000$ pounds of butterine sold in Pennsylvania?

Mr. Kimball. Yes, sir.

Mr. DAvis. And about 10 per cent, or about a million pounds, was sold as butterine?

Mr. Krmb LLL. I did not make that statement; but in Penusylvania oleomargarine is sold and butterine is sold. My stitement was that fully nine-tenths of the oleomargarine sold in Philadelphia was sold fraudulently. In the western part of the State it is more openly sold.

Mr. LORIMER. You of course would not make that statement unless you knew it to be true?

Mr. Kimball. No; I state that as my belief. I have no figures on the matter.

Mr. Lorinus. Do you know who the dealers are who sell butterine as butter?

Mr. Kimball. I could not specify any. If I had knowledge of those facts it would be my duty to present them to the clistrict attorney. We go in and talk with men who are buying our goods, and we know they have this stuff and we seo it there.

Mr. Loriner. What you know about it is what you have heard?

Mr. Kimball. Yes, sir.

Mr. Lormer. Suppose we pass this bill-I have heard it contended by butter men of the country that the principal feature is the first section-in what way would it assist you to prosecute those men now in your State violating the law?

Mr. Krmball. Only insomuch as the law would make oleomargarine shipped into the State colored subject to the State law.

Mr. LorminR. 'The first section simply says it shall be under the State law, and what I wanted to know is in what way it will benefit you if we pass that section of this bill?

Mr. KImB LLL. I do not see that it would benefit us any more than we have been benefiter, unless it prohibits the manufacturer shipping it in except under the State requirements. The manufacturer can ship it to day.

Mr. Lorimer. You say that the amount of butter sold in your eity has flecreased $5(1)$ per cent since oleomargarine was first shipped in. On what do you base that?

Mr. KinBALL. Our books show the amount our eustomers were using thee or four years ago and what they are using now. 
Mr. Lorimer. Have you any statisties that show how much butter has been sold in your city each year for the past ten years?

Mr. Kmmall. No, sir. There is no way of determining how much has been sold each year in the State.

Mr. LoR mier. As a matter of fact, on what do you base that assertion?

Mr. Kimball. From my personal experience. Where men used to buy 300 pounds, they do not to day buy more than 100 .

Mr. LoR IMER. How long have you been in business in Philadelphia?

Mr. Kinmall. Twenty-one years.

Mr. LoRIMER. Do you sell as mucli butter as you did ten years ago?

Mr. KimbaLl. Yes, sir.

Mr. LORIMER. Do you sell as much as you did five years ago?

Mr. Kimball. Yes, sir.

Mr. LORIMER. How about two years ago?

Mr. Kimball. I do not think we sell quite as much as we did then. We do not stand still if we can help it.

Mr. I OORINIER. I simply wanted to find ont on what you base this estimated decrease.

Mr. Kmiball. We have this from Mr. Edison, one of the largest wholesale print-butter dealers in Philadelphia, and I think he will bear me out in saying that the sales have decreased at least 50 per cent by oleomargarine being sold as butter.

Mr. LuRIMER. I understand you are willing to have oleomargarine shipped in and sold in its natural state?

Mr. Kmmall. Yes; I believe it is healthful. It is a good thing for the poor man, but it should be sold on its merits. Where it is sold as butter there is a profit of 15 cents a pound on it.

Mr. Lorimer. Mr. Adams, who is secretary of the Pure Food Association of $W$ isconsin, marle the statement here a week ago to-day that the tax of 10 cents a pound was proposed to be put on colored oleomargarine in order that it may not be able to compete with butter, and in that way wonld drive oleomargarine ont of the market. Is that sentiment general in your State, or is there any sentiment on the subject.

Mr. Knrball. I do not think so. I think it will to a large extent drive colored oleomargarine out of the market. I lo not believe that in one or two years it will have any effect for the reason that people who want the eheap product will buy oleomargarine. Only colored oleomargarine will be sold, and it can be gotten for a less price.

Mr. W HIте. What difference do you have to pay between colored and uncolored oleomargarine?

Mr. Kimball. We do not handle it.

Mr. WHite. Only the frandulent article is sold at all?

Mr. Kimball. Yes, sir.

Mr. DAHLE. What is good butter quoted at in Philadelphia to-day, wholesale?

Mr. Kimball. Twenty-seven cents.

Mr. DAHLE. That is what you pay for it?

Mr. Kimball. Yes, sir.

Mr. DAHLE. How much do yon pay for oleomargarine?

Mr. Knnball. We do not handle it. The price of the oleomargarine sold in Philadelphia is bought at 16 cents a pound. That is the popular brand.

Mr. DAHLE. There is practically a difference of 11 cents a pound? Mr. Kimball. Ies, sir. 
Mr. DAHLE. Then if oleomargarine is equal in quality, as it is claimed by its friends, it conld still be sold in competition with butter, even if the tax were 10 cents?

Mr. KmIBALL. Yes; on the present market price.

Mr. LoRIMER. What is the average price of butter in Philadelphia the year round?

Mr. KIMBaLL. The average price of that class of butter, I think, would be over 20 cents. I think last year it was something like 223 cents.

Mr. LORIMER. So that if bntterine costs 26 cents a pound it could not be sold in competition with butter at 23 cents?

Mr. Kimball. No, sir; it could not.

Mr. Lormier. What is the average price of butter in Philadelphia?

Mr. Kimball. Yon can buy ereamery for 22 cents.

Mr. LoRINER. What does the retailer pay for it?

Mr. KImball. It is 2 cents higher this year than it was formerly. Adjourned.

WEDNESD 4 Y, March 21, 1900.

The subcommittee on the Burean of Animal Industry of the Committee on Agriculture met at 10.30 o'clock a. m., Hon. William Lorimer in the chair.

STATEMENT OF MR. C. Y. KNIGHT, SECRETARY OF THE NATIONAL DAIRY UNION.

Mr. KNignT. Mr. Chairman and gentlemen of the committee, when I was here two weeks ago the testimony that I gave before the committee, particularly that in reference to the exhibits that I made, was published very consuicuously in all the Chicago papers, and there was a great deal said abont the matter, and interviews with the collector of interual reveuue, Mr. Coyne, were also published. Last week, on Friday, two or three of the papers came ont with extensive headlines and articles regarding the frauds in oleomargarine, and being inspired by the other side, claiming that there was not a great deal of fraud in Chicago. I went into the Record office-we regard the Record as one of our most reliable papers-and told the city editor that I did not want any more interviews in the matter, because what I said would simply be contradicted the next day; but I said, "If you will give me a reporter for one day 1 will show you whether there is any frand in Chieago in the oleomargarine business." They gave me the reporter, and we went to three places. The result of the trip to those three places was published the next morning there in the liecord. With your permission I will pass these papers around [producing a number of small bundles]. Mr. Haltman, I believe, is the name of the reporter whom I had with me.

I want to show you some of our expeil'uces at these same places. Of course the articles that we purchased together he took up to the managing editor, to show him what he had found. That was mecessary. So right after him I sent out a number of people to make purchases at the same places. And here are the bundle of the purchases which they made [indicating bumlles already mentioned]. When it came to a test of the matter I sent a man into Broadwell's, the same place where 
I got the oleomargarine that I exhibited here once before, and I asked a man to go to Broadwell's and buy a pound of butterine, aud I told him to eall for their very best butterine, and he went in and bought that pound of butterine. Here it is, right bere [holding up small package]. He bought that pound of butterine. They charged him 20 cents for that when he bought it as butterine. Another man followed him in there ten minntes after and called for the best butter-the best creamery butter. They charged him 25 cents for that when he called for the best creamery butter. There are the two samples with the mark on them. I would like to have some member of the committee taste them.

Mr. NEVILLE. Were they out of the same box?

Mr. KNIGHT. The man handles nothing but oleomargarine, and if when one of these men went in there and called for butter he got some of this, and the other went in and called for butterine and he got the same thing, I must say it is something that I do not understand and am not familiar with. I would say that the gentleman in question has got an improvement since the articles came out in the papers, and instead or putting the stamp on the inside he puts it on the outside of the package.

Mr. BAILEY. Was not this all published at the time of the pure food hearing?

Mr. KNIGHT. Yes; it was all published.

Mr. BAILEY. It is generally understood that this fellnw is an oleomargarine dealer?

Mr. KNIGHT. When he came before the pure food hearing he stated himself to be in business as the Stock Yards I'rovision Company. He is not doing business under his own name. No one knows by the publication of William Broadwell's name that he is doing business.

Mr. DAHLE. He is a dealer in butterine, or in butterine and butter?

Mr. KNight. No; he handles no butter, but his signs say butter. These grades are all the same, and when you eall for butter he charges 25 cents and when you call for butterine, 20 cents. Now, I tried the same thing again. 1 sent three or four people into one of the other stores and they inquired for creamery butter. The first one got the price of 20 cents, the second 22 , and the third 24 cents for the best creamery butter.

Mr. White. Do you know anything about the use of paraffin in these adulterations?

Mr. KNIGHT. There is a pamphlet from the State of New York in which they show up the paraffin trade.

Mr. WHiTE. I would like to ask you as to the healthfulness or want of healthfuluess in this oleomargarine.

Mr. KNIGHT. I know nothing about that from my own experience. I know very well a man who sells oleomargarine and he told me that he ate it for about a year and it gave him indigestion and he had to quit eating it. I am not a physician, and could not speak from that point of view.

Mr. Allen. What does this man say, that sold this butter?

Mr. KNIGHT. You will find his testimony which was taken before Senator Mason's committee. I had him brought up before Senator Mason's committee when Senator Mason was in Chicago with the manufacturers' committee. His testimony is in this little book. That is the way the business is done. I want to call your attention to these pack. ages here of oleomargarine marked as oleomargarine on the ontside. I would like to have these passed around. (A number of packages were 
here passed around among the members of the committee by Mr. Knight.) This, now, is another class of the fiand. This is all marked on the outside, and it is intended as an evasion of the oleomargarine law. You can see the testimony on this point I am spealking of on page 31 of this little pamphlet which I have here.

Mr. ALLEN. Where is the stamp on this package [holding up package in his hand]?

Mr. KNIGHT. It is on the outside. If you will hold that up between yourself and the light you will probably find the mark.

I have here a eopy of the revised revemue laws, publisherl June, 1895, five years ago.

Mr. Allen. I still do not see this stamp here.

Mr. KNIGHT. If you will look long enough, you will find it. Every package I have here, I possess the sigued statement of the persou who bought it to the circumstances under which he bought it. 'That wrapper is used for the purpose of having a wrapper so near the color of the ink that is put on there that the people will not detect the oleomargarine stamp. The stamp is on there, and, knowing that it is there, you can find a faint part of it. I want to read this to you from these regulations, published five years ago and whieh shows two things: First, that this kind of fraud has been brought to the attention of the Interual. Revenue Department five years ago; and, second, that there is a ruling against printing the stamp so that the color of the ink with which it is printed shall be practically indistinguishable. The law says that the color of the ink with which it is printed shall be in the strongest eontrast to the paper of the package.

Mr. BAILeY. Have you ever called the attention of the interual-revenue collector to this?

Mr. KNIGHT. I should say so.

Mr. BaIley. What does he say?

Mr. KNIGHT. He says it will tako one agent for every dealer, to look after each dealer in the retail oleonal'arine business. And that is what we say-that so long as it is permitted to go ont as butter this frand can not be preventerl.

Mr. BAILEY. I have heard that when they conld not put the color in the oleomargariue they would mix it with their butter and sell it as oleomargarine.

Mr. ALLEN. Then they become manufacturers of oleomargarine?

Mr. KNIGHT. I have never heard of a case of that, becanse that would be avoidiug the interual-revenue tax, and that is a much more serious matter.

Mr. Neville. Mr. Henry E. Kemp wrote me that it was true; that they would mix it with butter.

Mr. KNIGHT. These packages here [indicating several packages on the table] are another kind of evasion. It is all according to the looks of the man that goes in to buy. If he looks as if he might eatch on to it, they don't soak him so heavy. This was bouglit for the best creamery butter-all of these packages were bought for butter, none of them for butterine. There was ouly the one case where we called for butterine, and that was just to test that man Broadwell.

Mr. BAILEY. This was bought for butter?

Mr. KNIGH'T. Yes; the best creamery butter, and was bonght from Hughes \& Schaick. There is the mark, right here indicating on pack. age . It is a pretty faint proposition, but it is there.

Mr. WiLson. What is the material in them all?

Mr. KNigHT. That is a point I want investigated. 
Mr. DAHLE. I can not see any mark on this package [indicating package he bell in his hand].

Mr. KNIGHT. Well, it is not intended that you should see it, but it is there.

I only went into this one place with the reporter there, but I conld pile up this sort of thing in any number of places until our money was exhausted. I sent a man ont for 72 samples. They were butterine. He went aronnd and got those i2 samples in as many places.

Now, you heir a good deal about Chieago. I will tell you why. It is beeause, as we want to show you, the mannfacturers are the men who are making this fight, and they are the people who are hacking these dealers up, and it is right in Chieago that this fraudulent practice is being backed up.

The Chaminan. Right on that point, Mr. Knight. Yon make the statement that the manufacturers are backing these people up in this fralld?

Mr. Knight. Yes, sir.

The CHaIRMAN. How do you know that?

Mr. KNIGHT. I know that by their letters, in which they say that they will defend anybody who is prosecnted under the State laws, copies of which letters are published here, and the originals of which I showed at a meeting of this committee.

The Chairman. Do you mean to say that they told them to violate the law?

Mr. KNight. They tell them in this letter, which is an answer to a letter that we sent ont, in which we told them that we would prosecnte them if they sold butterine for butter, that they will protect them or back them up if they are so prosecuted.

The Chairman. Where are those letters?

Mr. KNIGHT. Copies are right here, and I have the originals in my office.

The Chairisan. And when were they written?

Mr. KNIGHT. One of them was written August 2, 1S99; the Bram \& Fitz letter was written practically the same date.

The Chamman. You stated at the last hearing that a bank of judges declared the oleo law in fllinois unconstitutional?

Mr. KNIGHI. Not the law we prosecuted under. We have two cases that come under that decision of the bank. The third one gave us the best decision we have ever had.

The GHAIRMan. It was a bank of judges that decided against the law?

Mr. KNIGHT. We have three laws in Illinois.

The Ghaminan. And that one you speak of was the only one you ever operated under with ainy success?

Mr. KNigitT. No; we never operated with any degree of success uncler that one.

The Chairman. I simply want to clear up the statement that these men are backing or encouraging the violators of the law. They merely say to them to go ahead and mell their prodnet and they will back them if they are prosecuted. Now, they have the decision of this bank of judges of which you speak stating that the law is unconstitutional.

Mr. KNignt. Yes; that is what they try to hide behind.

Inasmuch as Mr. Lorimer has tried to raise this question, I should like to sily that two or three year's ago-almost three years ago-an anticolor law which we had passer in the session of the legislature of 1897 was held by a bane of judges to be unconstitutional, although 
the law of another State, from which that had been very closely copicol, had been held to be constitutional. 'The third judge gave us the best decision we have had in its support. But we dropperl that law entirely at that time becanse we could hold no one mnder it, for the reason that anybody seized would be released immediately under habeas corpus proceedings upon the ground that the law was unconstitutional. So, in this situation I thought of the old branding laws which were discarded as useless yeal's ago, and we had found them useless for the purpose at that time. I thought of those old laws and I concluded to try some proseeutions under them, because they had not been declared unconstitntional, and we did not think that the manufacturers would dare to come up and defend a man for selling oleonargarine as butter. Here is the letter which our attorneys sent out to the manufacturers, telling them what we were going to do:

\section{Office of H. V. Murray, attorney at Law, Chicago, Ill., July 29, 1899.}

DeAR SIr: I have been employed by the Illinois Dairy Union to proseeute any eases of violation of the dairy laws of this State whieh inay result from the arrest of any dealer selling oleomargarine when butter is ealled for. As you probably know, a commission, consisting of a food eonmissioner and eight assistants and iuspeetors, was provilled for by tho late legislature, whose duty it is to enforee these laws. The eommissioner has been appointed, and untii he has appointed his assistants and gotten to work the lllinois Dairy Union's inspectors will look after the protection of eonsumers of butter, and see that those who sell them oleomargarine for butter are proseented nuler the State laws and also reported to the Internal lievenue Department as violators of the internal-revemu laws. I herewith inelose extracts from three State liws. 'lhese laws are not tied up in the eourts, and the oleomargarine manufacturers will not place themselves in the light of proterting thuse who sell oleomargarine for butter, although they may consistently fight the law forbidding eoloring, whieh has not yet been passed upon by the supreme court.

If you sell oleomargarine this year, rest assured that the state fool commissioner and the Illinois Dairy Inion will see that you are not permitted to sell it as butter. Respectiuliy, yours,

\section{Hugh V. MurRay, Attorney for Illinois Dairy Union.}

Now, that is the letter that we sent out threatening to prosecute them under the sitate law for selling oleomarwirine as butter. Within four clays after that letter was sent out came an answer signed by William J. Moxley, and dated on August 2, which is as follows:

[William J. Moxley, mannfacturer of fine butterine, 63 and 65 West Monroe street.]

Chicago, August 2, 1899.

DEAR SIR: Our attention has been called to two circmlars which have been mailed to you, one signed by Hugh V. Murray, an attorney, and the other by Charles Y. Kuight, editor in chief of a periodieal without subseribers, named the Chicago Dairy Produee.

I will say that my eircular was simply a copy of the laws that I pro. posed to act under. I did not put it in there because it would make four or five pages and I did not want to take np so much space.

The circular bearing Mr. Kinight's name has at its head an imposing lot of names, gentlemen whose aim it is to prevent the manufaetnre and sale of butterine, so that the butter trist might be enibled to get from 30 to 40 eents a pound for butter, depriving as they would a great many of the industrial elasses from being able to use butter throngh its excessive priee.

That is to say, people conld not use butter, they conld not afford to use butter, if there was no butterine.

With the hired attorner, who is enrning his fee, we have nothiner to say, only tor inform you that these gentlemen are trying to ring in a blutt. You will notice in 
their circulars that by iusinuations they wonld have people believe they represent some ofticial anthority. 'The Internal Revenue Department looks after their own business and the state after theirs, and should this so-called Lairy Uniou interfere witl your husiness in the way of prosecntion as to the State laws, we hereby guarantee you protection to the extent of paying all fines, costs, etc., nntil the color law is decided unconstitutional in the supreme court of the State of Illinois.

That was put in there for the pupose of squaring things on the sur. face, as if they were protecting them, and endeavoring to protect them, against an anticolor law, whereas at that time the anticolor law was not an issue.

The Chamman. Of course you wrote your letter and sent it out to the people in good faith, and you now undertike to say that these people wrote their letters and sent them out to their customers, and that it was not done by them in good faith; they say in their letter that it was in reference to the judgment which was decided unconstitutional by the judges in Cook Commly.

Mr. KNigit'T. 'They endeavored to make their letters so to read, but we had quit trying to enforce the anticolor law, and threatened now to prosecute them for selling butterine for butter. 'They thought their business was going to smash, and they found it was impossible to get aromml and see $1,(0)(1)$ or 1,500 people in time to save their business. so this letfer was written, and so worded as to throw people off from the real point in the case at that time. If you can find any instance where we have sent ont any letter threatening to prosecute people for selling oleomargarine colored, you have got me. We never did that.

The Ciramiran. Then they did not say anything in that letter to the effect that they would protect them from prosecution?

Mr. KNIGH'. Certainly they did. Let me read further:

And will furtlier, on receiving complaint, take such action for lanages as will make it minleasant for some of those who are attempting to interfere with your and our own legitinate business.

Mr. Nevilue. Your letter had been directed to the individuals, threitening prosecutions for selling colored butterine for butter?

Mr. ḰNIGHT. No; not colored butterine.

Mr. Neville. Not colored butterine, but butterine altogether?

Mr. KNight. Yes, sir.

Mr. Neville. Now, what is your State law?

Mr. KNIGIIT. The State law provicles a penalty of $\$ 250$ fine for people who sell butterine to a customer without at the same time informing him that it is butterine.

IIr. NEville. Any reference to color?

Mr. KNIGHT. No, sir; no reference to color whatever.

Mr. Neville. Have you any law relating to color?

Mr. KNIGHT. Yes; and that law was tied up in the courts. These laws we speak of in this last letter are not tiel np in the courts. IVe said so. We wanted to make it plain and clear that we were not doing anything under the anticolor laws, becanse they were tied up in the courts. Now, taking this letter of the manufacturers to the dealers, they worded it so that it might be supposed we were threatening prosecution moler the two laws that were tied up, and withont putting the two letters together you would not understand it. They go on in the last paragraplı:

We strongly recommend you to pay no attention to those circulars. We have always been in a position to protect our customers from injustice and blackmailers-

'That was us, of course.

and will le over at your service should fou rednire our aid. 
Now, that of course-anybody can call you or me a blackmailer, or can say "Charles $\mathbf{Y}$. Knight is the erlitor of a paper withont subscribers."

Another firm, Braun \& Fitts, almost as large a firm as Moxley (I believe they claim to be larger), about the same time sent ont auother letter, in which they usel the following language:

Every licensed butterine dealer in Chicago has receivel circular letters from the secretary and attorney for the Illinois Dairy Union, promising all sorts of tronble to dealers in butterine (that honest and pure article of food).

I submit to you, gentlemen, that if you can find anything in our circulars that we sent ont threatening to prosecute auybody for selling oleomargarine or butterine we will surrender our whole case before Congress. We did nothing of the kind, becanse we knew that that anticolor law was hopelessly tied up in the courts.

Mr. Neville. The State laws provided against the selling of butterine for butter, and you can not prosecute them under the other law?

Mr. KNIGHT. No, sir. This letter goes on to say:

premising all sorts of trouble to dealers in butterine (that honest and pure article of food). Well, now, don't yon believe a word of it: there is a law against blackmailing, and we want now and here to go on record to the assertion, as an afticlavit, that we shall civilly and criminally prosecute any man or party of men interfering nulaw fully with the butterine business in this or any other State.

Yon, gentlemen, are intelligent enough to see how he was conveying here the idea that he wantel to convey, and at the same time not lay. ing himself liable to the charge of protecting some one that rvas violating the law.

We know exactly where we stand; we are properly advised on the subject, and now we make yon a "fair ofter"- Landle our goods as you always have.

That is, "sell our goods for butter as you always have," and that is what they always have done in Chicago.

We, in turn, promise and guarantee full protection against the State law-

They thought they were very cute, now, in saying "dleclared unconstitutional," thereby leading the dealers to suppose that these laws had been declared unconstitutional.

(which has been declared unconstitutional) to the extent of paying cost of prosecu. tion, fines, and paying all costs pertaining thereto. In declaring the law unconstitntional one of the judges staten to the effect "that the butter riug were, in his opinion, liable to prosecution to recover damages done an honest industry." Fair enough, isn't it? Renew your efforts, and be assured that we will be prejared to fight any number of rounds in any kind of a legal fight to the finish. Handle our butterine and be safe.

Now, there was no call for those letters unless they were protecting the dealers from prosecution for selling oleomargarine for butter. If we could have prevented that we would have cut down the sales of the article 25 per cent in Chicago. We went ahead ans diul prosecute, and I will show you what we went up against when we prosecuted those people. We prosecuted these same people named right here. We bronght, I think, seventeen cases in all that cost us 8120 ; that is, for chemists' analyses and witness fees. We lid not stop at those seventeen cases, but we had cases a ainst about 200 peopl(', which cost us for witnesses, for collecting evidence, and appearing in court \$312.10. Our attorneys we paid \$570; stenograplers for reporting trial, \$57.\$0; court costs, warrants, etc., $\$ 59.90$; printing briefs, stationery, copies of laws, circulars, etc., $\$+14.43$; traveling expenses to sulleme court, for going ont there, $\$ 54.90$; and for postage $\$ 71$, which makes a total cost of $\$ 1,670.13$. 
Mr. WADSWORTH. May I ask how much the postage on the letters you sent out to these dealers threatening to prosecute them cost you?

Mr. KNIGHT. I do not remember; that was not included in this.

Mr. WADSWOR'TH. How was that money raised?

Mr. KNIGHT. All the money we have spent on this work has been subscribed by 24,000 farmers, in 50 -cent subscriptions.

Mr. WADSIORTH. By the ereameries?

Mr. KNight. No, sir; by the farmers themselves; and I can give you the list of these farmers who have subscribed 50 cents each for this purpose.

MIr. BaILEY. Some of them gave more than a dollar.

Mr. Kinight. Oh, yes; some of them may have given $\$ 1,000$, but 24,600 of them have contributed 50 cents each. We have not asked any creameries to contribute. The people who have supplied the money and subscribed for this work, I would have you understand, are the horny-handed, horny-fisted farmers who milk the cows.

The ChaIruan. What was the result of that decision?

Mr. KNIGHT. We submitted the test case to Justice Underwood, and Roy West defended the case. He snggested that these laws had been repealed by the purefood law and the creation of the Pure Food Commission to enforce it. The judge took his view of it, and the result was that he dismissed all the cases, and they had a statement sent out through the county and throughont the State that Justice Underwood had decided the case in that way, and the result was we could not get anyone to issue warrants for the ar'rest of anyone. They never denied that oleomargarine was sold for butter. We went to the Supreme Conrt of the Uniter States then, and endeavored to get a writ of mandamus to compel the supreme court to issue warrants.

'The CHAIRMAN. This which you have shown here is undoubtedly a violation of the law, but how do you expect to prevent it by the passage of this lill?

Mr. KNigh'r. If this bill becomes a law, the manufacturer then will make it according to law, which he does not do now.

The Chamman. How do you expect to prevent this violation of the law?

Mr. KNIGHT. If a man pays the tax of 10 cents a pound it will remove his reason for violating the law.

The Chatrman. If lie pays the 10 cents a pound, you do not care whether he violates the law or not?

Mr. KNight. I know that he will not. A man does not go out and cheat another man unless he is going to make some gain. The gain in this ease is besween what he can buy oleomargarine for and what he can buy butter for. One he can buy for 13 cents a pound and the other for 23 cents, and he can sell them both at the same price as long as no one knows the diflerence.

The Chatrman. Yonr idea is to tax him 8 or 10 cents a pound on the color, so that when it is sold it must of necessity be sold at 8 or 10 cents a pound more than it is to-day; is that correct?

Mr. KNIGHT. My point is that when a colored oleomargarine, which is prohibited in 32 states, is sold that it must be sold for 8 cents a pround more than it is. I do not believe there is any necessity for a colored oleomargarine being sold.

'The Chamman. In other worls, you increase the price of one of the necessary articles of life?

Mr. KNIGHT. It is no more so than whisky. 
The Chatrman. Is there the same necessity for putting this additional $S$ cents on this article that there was for putting a tax ou whisky? Is this a luxury?

Mr. KNigirT. It seems to me it is a luxury if people pay 18 cents a pound for it instead of 12 .

Mr. NevilLE. Will that not virtually drive it out?

Mr. KNIGHT. It is prohibited now. All those States prohibit traffic in it, but the 10 cents profit is an incentive for people to viulate the law.

Mr. Neville. Why do they sell it?

Mr. KNIGH'T. They find that so long as it is an exact counterpart in appearance of butter that they can sell it and make this large profit. You understand, gentlemen, that it is the coloring of it that we wish to prohibit. 'The oleomargarine that is under diseussion here is colored oleomargarine, and it is prohibited in 33 States. Now, it the State has made that kind of law prohibiting that kind of thing, it is for the purpose of protecting the consumer.

Mr. Wilson. Is it a fact that it does lunrt the consumer? Does it not really protect the man who makes the butter?

Mr. KNIGHT. It protects the consmuer and m.lkes it possible for him to get oleomargarine when he wants it and butter when he wants it. In the city of Chicago the city is overrum with yeople selling oleomar garine for butter, and for 10 or 15 cents a pound more than it ought to be sold for. Every man who buys butter is not a chemist, and if they want oleomargarine, they should buy it for the oleomargarine price12 or 13 cents a pound. The only reason that they pay 20 cents is that they think it is butter.

MIr. ALLEN. It is wrong for allything to float around under a false color, because that would be a fraud. But since your own State has undertaken to protect its own individual citizens under its own law and can not do it, why is the necessity of coming to Congress for it?

Mr. LAyB. What is the law? The law of Virginia-the anticolor law-is as follows:

The manufacture or sale of any article made wholly or partly from any fat or oil not produced from unadulterated milk or cream, which is in imitation of pure yellow butter, is prohibited; but oleomargarine, butteriue, or kindred compound, nuade in such form and sold in such manner as will advise the consumer of its real character, and free from color or other ingredient to cause it to look like butter, is pernitted. Signs, with the words "Imitation butter used here," shall be displayed in eating places, bakeries, etc., where the articles above named are used.

That is a system which it seems to me they ought to be compelled to follow, because you cau not get the stuff to see it, and you can not tell whether it is butter or oleomargarine.

Mr. Allen. You have got to attack the manufacturers. We have got to go to the fountain head. You have got to press every opening. It is just like it is with a band of connterfeiters who are flooding the country with comnterfeit money, you will have to go out over the country and find the counterfeiters before you can stop the splead of the counterfeit money. You can not stop it by merely arresting and prosecuting the people in whose possession you find it.

Mr. KNIGHT. Yes; but you can go to the retailer and take that $\mathbf{1 0}$ cents a pound incentive out of his way, so that lie will not find it exceedingly profitable, as he does at present, to sell the stuff at all. As it is, you would have to go in and tap every tub of butter or butterine that was sold in order to find out wliat it was. You take a tub of but. terine, and with that profit on it it will bring him in $\$ 6$ of profit, aur he will sell that out in oue or two days. 
Mr. BAILEY. There could be no question about a man's finding the mark on any package you have shown to me this morning, and with the publicity that you have given to it I should think they would not find it protitable and people would not buy it.

Mr. KNigh'. We can not interest yon people 365 days in the year, and we can not keep the nemspapers going all the timc. We have tried to control this question of color for twenty yeirs, and we have failed, and it is growing worse and worse all the timu. Gentlemen suggest how it might be done this way or the other way, but I tell you we have made the trial, and the result is we have lost, and we have exhansted absolutely every means at our command; and here is a point that I want to impress npon you gentlemen, that we have fonght this fight and kept fighting and fighting all the time until our people aro good and tired. Pretty soon butter is going to get down to the basis of lard and tallow, and it is not good to fight all the time, and we will have to give it up eventually. Farmers are losing confidence and losing heart-

Mr. BAILEY. Is not that contrary to the evidence that Goveruor Ford gave here the other day, to the effect that this industry las increased more than any other in the comitry to day?

Mr. KNight. Let me show you this diagram here [referring to diagram on page 14 of pamplilet]. This will give yon some irlea of the results that have followerl from this defiance of the State laws. In $18: 99$ the production of oleomargarine was increased 50 per cent over that of 1598 .

Mr. BAILEY. How much cheaper is the butter?

Mr. KNIGIT. I can not answer that question without explaining. The prices of butter were so low during that year, and oleonargarine was crowding it so close, and so many farmers went ont of the business and gave it up during last year and the year before, that there was a shortage in the butter production, which the statisties will show. That made a shortage, so that last winter it gave the oleomargarine a chance to go further in still, and drive out the butter more aud more, as it is loing all the time.

Mr. ALLEN. Suppose this bill should pass, it would drive oleomargarine up to the plice where it would sell for s cents higher than it does now, so that it would almost drive the colored part out of business.

Mr. KNight. Yes, sil; almost.

Mr. ALLEN. Would it not drive butter out?

Mr. KNight. But has not a man the right to the best price he can get for what lie has to sell?

Mr. Allkin. Yes, sin: and there was at common law the name of a crime given to this kind of embracery, where a man would take posaession of a business and raise the prices on the eomsmmers.

The Champin. You say a man has to get the best price he ean for what he has to sell?

Mr. KNIGHT. Yes, sir.

The CHAIRMAN. Do you think Congress has a right to legislate so as to make one article higher and another article lower, or to divive it ont of the market?

Mr. KNIGH'. I do not think Congress has any business to look into that phase of the matter at all. I think Congress should look out for protecting the consumer and the health of the cousumer.

(Thereupon, at 12.45 p. 11., the committee adjourned.) 
SATURDAX, March 2.1, 1900 .

The Committee on Agriculture this day met, Hou. James W. Wadsworth in the chair.

\section{STATEMENT OF MR. JAMES HEWES, PRESIDENT OF THE PRO- DUCE EXCHANGE OF BALTIMORE AND VICE-PRESIDENT OF THE NATIONAL DAIRY UNION OF THE STATE OF MARYLAND.}

\section{Mr. Hewes said:}

I was going to say, Mr. Chairman and gentlemen, that there are two classes of audieuces to whom it is pretty hard to sjeak. One is an andience of children and the other is an andience conlessedly at variance with the ideas of the speaker, and I am now speaking to these latter- -

\section{Mr. Allen. Yow do you know that?}

Mr. Hewes. From what I have heard you gentlemen say.

The CHAirian. We are all amenable to reason.

Mr. Hewes. I hardly hope to convince you, and I only want to speak a few words, particularly for the first clatuse of this bili-the first section of this bill, known as the Grout bill. You will pardon me if I recall a little history eounected with the oleomargarine legislation in the Houses of Congress, as well as in the States. I began to fight against oleomargarine twenty-two years ago. I wrote the first law which was pissed in the State of Maryland, and at that time we wanted to regulite the sale of oleo because we did not fully appreciate the effeet of the introchction of it, which at that time was only supposed to be a plaything.

Oleo, as you know, was the outgrowth of a necessity at the time of the siege of Paris, and when it was introduced here and went into the l'atent Offiee, and the inventor received the patent for making it, no one supposed it was ever to be an attack upon the butter interests of the State and be of sich great importanee as it has grown to be; no one dicl. Therefore we had regulatiug laws throughout the country, and we tried to regulate the sale and tried to compel them to sell oleo for what it was; but it was sapping the morals of the country, and, as one of the Commissioners of Agriculture here said before the committee in 1886 -he spoke altogether as to the morale of the subject-lıe said it was corrupting the morals of the people, and we verifierl his statement, because we could see in Maryland women and children out on the street selling this stuff, and when they were arrested for selling and asked where they obtained it, who sent them there, they did not know anything about it, and we would have to let them go. If they were successful and were not ariested those people would come in and take the proceeds of the sales, and so it went on until the year 1886, when we appeared here for the purpose of having Cougress exercise its police supervision, and of course we could only eome to Congress and ask for a revenue measure, and, as the late lamented $\mathrm{Mr}$. Dingley said to me only a year or two ago, "Mr. Hewes, you know well enougli that was a luse of yours to get this thing into Colngress under the head of a police measure by drawing a revenue to the Government," but we knew what we were talking about.

We said to the Congress of the United States, "If you will impose this tax for the purpose of a revenue provision, which is always jealous and seeking where it cau find something to put in to the Treasury; if you will do that, then we believe these people will be deterred from doing 
what is wrong, and, incidentally, if you act as policemen, why that will be to the benefit of the country, and particnlarly to these States we represent here." It was thought at that time that if the internalreienue department did its duty, as it had always done-we were proud of what the internal-revenue department had done with respect to other things, particularly tobacco ; no man could buy a carat of tobacco and put out less than the carat would produce in cigars withont being liable to investigation and fine, so we were thinking here the internal-revenue department of the United States would compel these people to do what the States were powerless to do. That was to put a label upon the article when they wonld sell it, so the people might be apprised of what they were getting and buying.

If you gentlemen will examine the law of 1886 you will find that there were practically two or three revenue sections, and there are 21 sections, all told, in the bill. It has been our misfortune to note what Mr. Kninght told you a few moments ago, that the revenne officers unfortunately did not attend to the police part of this law, which is the greater part of the law. And I will tell you my experience in the State of Maryland has been this: I hate to talk about myself, but I have been largely instrumental in prosecuting offenders in both courts. I am attorney at law in aldition to all these others; I am a sort of Pooh Bah of the butter trarle; I have not only written laws for the State of Maryland but prosecnted offender's under the laws of the state of Maryland, and 1 have been also engaged in the prosecution of offenders under the act of 1886 in the United States courts up to a certain time, and all of the cases, I may say-with tro exceptions-all cases coming out of the district court of the United States for the district of Maryland in our city have been cases that have been furnished to the Goverument by the butter men, by the State officers, and it was my custom and my pleasure to take those cases simultaneously into both courts, and at that time offenders under the law were punished by both governments, and that thing continned until the state of affairs that I am now about to speak of, with regret, took place; and as I told Secretary Wilson the other day, it is a misfortune-it is deplorable and a lamentable fact-that when the method of paying district attorneys changed from the commission to salary, that minnte prosecutions ceased and there has not been one case brought into the court of the city of Baltimore for the district of Maryland emanating and arising from the Government.

Mr. ALLEN. Who is the district attorney there now who has failed to prosecute since the change of the law?

Mr. Hewes. Not one prosecntion has been had. Now, who are our district attorneys is a matter of history.

Mr. ALLEN. I mean the one who now holds that office.

Mr. Hewfis. It is Mr. Rose, Mr. John C. Rose is the present district attorney in Baltimore. Prior to Mr. Rose's incumbency Mr. Marbury was the district attorney, and prior to that-

Mr. ALLEN. It does not matter abont that.

Mr. Hewes. Now, I want to emphasize this fact, becanse this is only incidental; it is only leading up to what I want to talk abont-why we want this commerce clause of the Constitution limit as to oleomargarine-but at the same time it is interesting. I will relate a conversation which occurred between myself and the district attorney for the district of Maryland only a short time before, when he was inducted into his office. I went over to him with a case and I stated to him, "Mr. Rose, I want you to prosecnte au offender under the act of 1886 
for the selling of oleomargarine without conforming to the requirements and the regulations which have been made under the law, as everyboly knows, who has anything to do with the prosecntion of offenders under that act." "What are the facts?" Mr. Rose asked. I said, "The facts are these: Snycler, who has a special-tax stamp from the internalrevenue dejartment to sell oleomargarine, Las sold to one of our officers, in the presence of another one, a piece of oleo withont conforming to the requirements of the law, and, of course, in violation of the State law, and I want to know what you are going to do about it?"

"Well," he said, "low do you know that he did that willfully?" I saiı, "Is that your answer to me, Mr. Kose?" He said, "Yes." I said, "That ends it; that terminates the interview; good day, sir." How did I know he did it willfully, when a man had a special stamp for selling oleo, and when lie sold the oleo and the facts conld be substantiated that le did it; what more knowledge are you going to fasten upon a m:In than that? How can you tell; how can anybody say that he knew that this was oleo except from the circumstances? What other way for you to prove the facts? Oftentimes the strongest proof you can addnce is but circumstances. But it has been stated by one of the wise jullges in Pennsylvania, in charging the constables there as to their duties under the law of the State, that when a person has been found with a special tax-stamp that is to be considered prima facie evidence that be is selling oleomargarine, and to report the case to the grand jury.

You do bot have to have any more facts than that he is selling oleo, and when we bring witnesses to them and show them by those witnesses that that is oleo, we always follow that up by giving a chemical analysis of the article. 'That is sufficient for any district attorney to proceed upon. I have been to see Mr. Wilson and have stated abont it, and prior to Mr. Wilson's incumbency of this office I was here and saw the other incumbent and stated that there were no prosecutions at this time, when prior to that we used to have sometimes in the city of Baltimore, with 110 more offenses than are being committed $110 \mathrm{~W}$, as high as 20 to 30 cases coming out of the district court for violations of the national law audl- -

The Chairman. Do you attribute that entirely to the difference in the method of paying district attorneys?

Mr. Hewes. I stated that was a lamentable coincidence; I do not want to attribute it to anything, but it is a deplorable condition of affairs.

The CHAIRMAN. When we had fees they prosecuted these cases, and now they have salaries they neglect them?

Mr. HEWEs. I can only tell you what occurred, and it is just as I state, and I deplore tliat state of affairs. I am not going to impute anything to anybody, but I simply give rou the statement of the facts, which can be verified. Yon could go to the records of the district conrt of the city of Baltimore and find what prosecutions have been liad of oleo offenders.

'The ChalRman. How about the other prosecutions; does the same thing apply as in this?

Mr. HEwEs. I would not like to say one word abont anything else. This I do know. The question was askerl me this morning, "Are the two branches of the Government there in perfect harmony?" And I said, "I rather think not, unless it is a recent state of affairs, becanse it is generally considered that the revenue branch of the Goverument and the judicial branch of the Goverument are not in perfect harmony in the Uuited States building." 
A BYSTANDER. I would like to ask if the two cases we read in the press of to-day on the train were not an exception to the rule?

Mr. HewEs. Yes; I have not come to that point yet. I want to say I was going to follow that right up by stating that there were two cases to-day reported from Cumberlaud. Now, when the Plumley case, which is the case that was decided in the Supreme Court of the United States and reported in 155 - when that case was decided it was supposed we would not need any further legislation on the subject, that then the State's right to legislate on this subject was recognized as a valid exercise of the police power of the State and would be supported in every instance, and when we came down here and asked for the passage of the IIill bill and the Grout bill before, we were met with the objection in the Honse and in the Senate, "Have not you enough law in the opinion of Justice Harlan in the Plumley case?" and we said, "Yes; we would have enough law but for the fact that the personuel of the Supreme Court is liable to change, and will change in all hnman probability, and then we do not know how it is going to be." Now, onr fear's were verified in the Schollenberger case; and when Justice L'eckham delivered his opinion and declared in that opinion-

The CHAIRMAN. Where is it reported?

Mr. Hewes. 171 U.S., p. 1. When he declared that that was not reversal of a decision in the Plumley case, Justice Gray and Justice Harlan filed a dissenting opinion, showing it certainly did overturn the law in that case; and what was the consequence? The consequenc has been that there have been varying interpuetations of the Srhollen berger case now going on over the United States. Only recently two habeas corpus cases, one in Missouri and the other in Minnesota, were decided, different cases; and the judge said in those cases that they were at variance; and the most remarkable thing of all, Judge Lochren, in the Minnesota case, has always been a friend to butter and has in all bis decisions heretofore decided rather in favor of butter and against oleo nutil that time, and he said, "I am confronted by the opinion in the Scliollenberger case," and discharged the petitioner. On the other hand, Judge Adams, in the Missouri case, stated that the Schollen. berger case did not overturn the opinion of the Plumley case, and he would be be bound by the Plumley case.

In our own court of appeals in the State of Maryland, in the Fox case, tried since the Schollenberger case was decided, the opinion from Judge Fowler simply stater that it was the opinion of the court that nuder existing law since the Schollenberger opinion had been delivered it was impossible to prevent the introdnction into a State of an original package of pure oleo, but, he said, the State having made its prima facie case, the burden shifts from the defendant to show that the article was not deleterious to health. How has that been construed? There are 45 cases hanging up, criminal cases, in the city of Baltimore, and four or five of them: original-package cases, and the city's attorneys do not attempt to do anything; they will not lo anything, because they are satisfied that when they go to the court of appeals it will be impossible for the State to make a case, and they do not want to try to make a case.

That is one of the principal reasons why we want a commerce clanse linit in respect to oleomargarine, so that we may be able to meet this article upon our bolders with our laws, meet them there aud say, "You can not introduce your stuff' into this State because we do not want it." Let it be as good as it may, let the article be just as wholesome as Mr. Allen suggester, let the stuff' be melted in the human stomach, although I have heard that oleo was not melted under such temperature, let oleo 
be all tlıt it is elaimed to be, and yet I will tell you onr experience in twenty two years in the State of Maryland shows you can not regulate the selling of oleo so as to perent the consumer from being deceived, and that is the reason why I think that this tax ought to be raised to 10 (ents and it is a fail proposition.

Mr. AlLEx. Let me ask you, to get your views, do you think that ought to be done with a view of prohibiting the manufacture of butturine altogetlıer?

Mr. IIEwEs. With a view of prohibiting all manufucture of oleo yellow muless they want to pay the penalty; it is to tax that yellow color. There is not a soul who would see uncolored oleo who would be deceived.

Mr. Allen. Do you think that if you require them to make and sell it in the natural color your natural-colored butterine could find a sale upon the market?

Mr. HewEs. I am almost sure it could, and to show the fairness of this proposition it says to them, "If you will make this oleo uncolored we will relluce tlie tax to a quarter of a cent a pound." This bill of Mr. Grout says, "Do right, be fair, make your oleo in just whatever color it can be without the introduction of yellow color and we will reduce the tax to oue-fourtl of a cent." Now you say to us, "Are you in any position here to come and take this revenne from the Govermment?" How did this revenue get to the Goverument except by our eflorts? We reposed this trust in the United States, may it please the chairman and gentlemen of this committee, we reposed this trust in the United States. We said, "If you will put it under your close supervison, such and such will be the result; we will give you a million and a half dollars of revenue, and we ask you simply to act as policemen;" and they are not policing the State as we expected they would, and we have given them a million and a half and more every year.

'The UHAIRMAN. Who is that?

Mr. HEwEs. The butter men of the country, who passed this law. Who passed the law? The butter men of the country. Look at the records and see who brought it here, and worked for it, and who passed it. We clain we did it. Of course I only speak for the butter men. I, lowever, was here; I spoke before both committees, and I did all I possibly could for it. Now, I say the dairy interest is imposing no hardship; it simply says, "Now, go on and try this other schene; you are not crying for reveuue; the Government is not so poor it has to bemoan the fact that this tax upon oleo can be reduced or can not be reduced. The quarter may yield you more than a million dollars before you get through." Suppose it turns ont that oleo nncolored is salable the same as uncolored butter is? You know well enough that at the best hotels in New York you find uncolored butter there. Whyshould it not be with nucolored oleo, and I say it is not a supposition to say that uncolored oleo will sell.

A BYSTANDER. But it will not sell as butter.

The Chamman. How much more whitish is uncolored oleo than uncolored butter?

Mr. Hewes. Nome. Uncolored oleo is no whiter than the white, crumby butter Mr. Allen was speaking about this moruing. Uncolored oleo has a texture that commends itself, no doubt, to people. It has that cloudy white color that will not impose upon anybody, but there is plenty of butter with no rleeper color than uncolored oleo. The Govelnment now has prohibited oleo from using the emblem, etc., of butter. It says you must not do that. 'T'hat is the regulation of the Internal Revenue Department to protect the people and prohibit the use of names of creameries, etc., and all that, so the people may be protected; and 
when a person sees that upon a table naturally he will say, "If that is butter, it is all right." It may be oleo, and then he may not eat it. Justice Ilarlan, in the opinion on the Plumley case (155 U. S., p. 461), says that the contention that the coloring of oleo yellow, as a fair contention, will fall to the gronnd; and there is only one reason why they should want to color it yellow, and that is that they maly enhance its value and to deceive people into thinking they are getting what they do notwant; and he says that the reason why it shonld be uncolored is so as to compel the selling of the stuff for what it is aud to prevent it selling for what it is not; and the language of Jnstice Harlan on that case is worth reading, and it is a fair exposition of the proposition.

Gentlemen, I am very much obliged to you.

The Chairman. What do you say as to the proposed addition to that clause of a tax on all colored butter?

Mr. Hewes. On bntter that is artificially colored I think we wonld hail that with great pleasure, but I think it would be very hard to tell where nature left off and art began. The coloring matter is only a trace, and in all analyses that are furnished of butter and oleo. wherever there is a color used, it is simply a trace. It is an imponderable quantity and you can not tell what it is, and I wonld defy the greatest chemists in the world to tell you whether that butter was colored or not by an analysis.

Mr. Neville. If colored butter was intended to deceive people and palm it off on the people for something else then it would be a different case?

Mr. Hewes. Yes, and-

Mr. Neville. Have yon any statistics as to how many butter makers there are in the comntry?

Mr. HewEs. I think those can be furuished.

A BYS'IANDER. There are 10,000 creamery butter makers.

Mr. NEViLLE. In what proportion does it relate to the manufacture of oleo?

Mr. HEwEs. About 50,000 to 1.

Mr. Neville. Have you ever stopped to think a little voting would fix this?

Mr. HEwEs. Where?

Mr. NEVILLE. In the right direction.

Mr. Hewes. We are voting here; we hope to vote here.

Mr. Nevilue. Have you not discovered that a man with a million dollars has more power than a million men with one dollar each?

Mr. Hewes. Unfortmately, yes.

At this point, the members of the committee having to go upon the floor of the House to atteud its session, the committee adjourned.

\section{MARCH 28, 1900 .}

The subcommittee on the Burean of Animal Industry of the Com. mittee on Agriculture met at 10.30 o'clock a. m., Hon. William Lorimer in the chair.

STATEMENT OF MR. S. H. COWAN, OF FORT WORTH, TEX., GENERAL ATTORNEY OF THE CATTLE RAISERS' ASSOCIATION OF TEXAS.

The CHAIRMAN. Will you just state to the committee, in a general way, what yon wish to say?

Mr. Cow $A$ N. Mr. Chairman and gentlemen of the committee, the object of $\mathrm{my}$ appearance here is to present to your committee the desires of a 
large number of persons engaged in the cattle-raising business in Texas, Kansas, Colorado, Indian Territory, ()klahoma, and New Mexico, and a considerable number of the members of this association also reside and have their places of business in Montana, Wyoming, and the Dillotas, and elsewhere in the range country.

At an ammal meeting of the Cattle Raisers' Association, composed of about 1,200 menbers from the different sections of the comntry which I have naned, which anmual mecting was held at fort Worth on the 1:3th and 14th of March, 1900, the following resolution was passer, and it was adopted mnaninously without a dissenting voice; and it was requested that the secretary of the ('attle Raisers' Association have it printed aud have copies placed in the hands of the members of Congress and prescnted to the committees. It so happened that I was coming to Washington in connection with a case known as the Terminal Charge Case that we have, as between the Cattle Raisers' Association and the railroads at Chicago, and I was directed by the committee to see if I conld get a chance to liave a liearing before the committees of Congress and present these resolutions, among some others that I have from the committees, and call the attention of the committees to the desires of these people, who I believe to be very estimable people, who are engaged in the business of raising cattle, along the lines mentioned in this resolution; that is to say, in opposition to the proposed law to increase the tax on oleomargarine, which is a product which is unade from the eattle which our people grow, as well as other ingredients that go into it as component parts. If I may read this resolution, I will do so.

The CHAIRMAN. Certainly.

Mr. CowaN (reading aloud):

To the honorable the Senate and House of Representatives of the United States:

Your orator, the Texas Cattle Raisers' Association, respectfully represents unto your bonorable body that it is an association composed of 1,200 cattlemen, engaged in breeding, raising, foeding, shipping, buying, and selling cattle, and that its menbers are ow uers of cattle aggregating over $\$ 100,000,000$ in value.

Your orator desires to file its emphatic protest against the enactment of the several bills now peuding before the different Congressional committees seeking to impose a heavy tax and other restrictive measures upon oleomargarine and to deprive it of all rights and privileges as an article of interstate commerce.

I will explain that the Cattle Raisers' Association in this meeting was not definitely informed as to just what the provisions of these vari. ous bills were, but they were informed that there were a number of different bills, some of them having the object of depriving oleomargarine of the benefits of the interstate-commerce law. I do not know, but we were so informed, and hence this paragraph of the resolution:

These measures are a species of class legislation of the most dangerous kind, calcnlated to build up and resture one industry at the expense of another equally as important. They seek to inpose an unjust, uncalled for, and unwarranted burlen upon one of the principal commercial industries of the conntry for the purpose of prohibiting its manufacture, thereby destroying competition, as manufacturers can not assume the additional burdens songht to be inposed by these measures and sell their product in competition with butter.

The enactment of such laws would completely destroy a business which has been recognized by law, which now furnishes a large anmul revenue to the Government $(\$ 1,956,618$ in A. D. 1899$)$, which provides employment for thomsands of ineu, and in which citizens of the United states have invested fortunes. It would serionsly affect the cattle industry, as the maunfacturers of oleomargarine have created a demand for oleo oil, made from the choice fats from the lieef, at a price at least $\$ 3$ per aniual greater than it would be worth if it hid to be userl, as liefore the arlvent of oleomargarine, for tallow, thereby entailing a loss on the proclucers of nillions of dollars anuually. 
No law can make more stringent requirements to protect consumers than those now in force, and the fact that the output is yearly increasing shows that there is a demand for oleomargarine as such, in spite of all hostile agitation and legislation.

It is a well-known fact that the principal consumers of oleomal garine are the intelligent, prudent, and thrifty people of the middle class, who buy oleomargarine berause they prefer it to that which is sold as butter in their markets, and these bills propose to deprive these citizens of the privilege of purchasing that which they wish to have, although it is known to be an absolutely clean, wholesome, and nitritions article of diet.

The rights and privileges of the producers of beef cattle should be as well respecter as those of others; and as they are the beneficiaries in the manufacture of this wholesome article of fool they shonld not be burlened with unnecessary special taxes or needless restrictious in the mannfacture of this prodnct.

'This product of the "beef steer" should receive at the hands of Congress no greater exactions than are imposed on competing food products. It has by experience proven to be just what a large majority of the people of this country want, and we do hereby record onr solemn protest against the enactuent of legislation caleulated to ruim a great industry and to deprive not only the working classes but many others of a cheap, wholesome, nutritious, and acceptable article of food.

'The Cattle Raiseis' Assuciation of Texas.

I certify that the above is a correct eopy of a resolution adopted by the Cattle Raisers' Ássociation of Texas, in annual session at Fort Worth, Tex., March 13 and 14,1900 .

\section{J. C. Loving, Secretary.}

Mr. STEVENs. I will call your attention also to a similar statement from the Cattle Raisers' Association of Missouri, whose meeting was held at St. Joe.

\section{Mr. CowAN. This resolution reads as follows:}

A memorial to Congress adopted by the Sonth St. Joseph Live Stock Exchange in opposition to the Tawney oleomargarine bill, which, if passerl, will effect the value of the beef cattle of this comntry. It is desired, therefore, that all fecclers and dealers will use their influence through their lepresentative in Congress against the passage of this bill.

\section{To the Honorable the Senate and the House of Representatives of the L'nited States:}

Your petitioner, the South St. Joseph Live Stock Exchange, respectfilly represents to your honorable bod̄ that it is an association composed of all the commission men, firms, and corporations engaged in the live-stoek business at Sonth St. Jostph, Mo., transacting business to the enormous amount of $\$ 50,000,000$ annually, with a memhership roll of more than 100 members actively engagerl in breeding, raising, feeding, shıping, buying, selling, and slanghtering all kinds of live stock, and was organized, among other things, for the purpose of promoting the hest interests of the live-stock industry as a whole, jealously guarding the interests of the producor and consumer alike, and is the recognized and official morthpiece of the live-stock industry on all questions of an interstate or iuteruational character, especially when the interests of the producer or consumer are in any way affected.

Yonr petitioner, in behalf of its constituency, desires to enter its emplatic protest agrainst the enactment of $\mathrm{H}$. li. bill No 6 , introduced in the House of Representatives lecember 4, 1899, by $\mathrm{Mr}$. Tawney, providing for an amendment of " $\mathrm{An}$ act defining butter; also imposing a tax rpon and regulating the maunfacture, sale, importation, and exportation of oleomargarine," and in support of its protest llesires to record a few of the many reasuns in support of its contention.

This measure is a species of class lecrislation of the most dangerous lind, calculated to build mp and restore one industry at the expense of the other, equally: is important. It seeks to impose an nnjust, nncalled for, and unwarranted burken upon one of the most important commercial industries of the country tor the purpose of prohibiting its manufacture, thereby destroying competition, as the manufacturers can not assume the additional burdens sought to be imposer by this neasure and sell their product in competition with butter. The enactment of this measure would throttle competition, renler nseless the immense establishments erected at great expense for the mannfacture of olemmargarine, leprive thousands of employees of the opportunity to gain a livelihood, and deny the people, and especially the workingmen and their dependencies, of a wholesome article of diet.

In olem margarine a very large proportion of the consumers of this enmiry, especially the working classes, have a wlolesome, nutritious, and satisfactory article of diet, which before its advent they were obliged, owing to the high price of butter and their limited means, to go without. 
The "butter fat" of an average beef animal for the purpose of making oleomargarine is worth from $\$ 3$ to $\$ 4$ per head unore than it was before the aclvent of oleoinargariue, when the same had to be used for tallow, which increased value of the beef steer has been added to the market value of the animal, and consequently to the profit of the producer.

'fo legislate this article of commerce out of existence, as the passage of this law would surely do, wonld compel slaughterers to use this fat for tallow, depreciate the value of the beef steer of this comntry $\$ 3$ to $\$ 1$ per head, which womld entail a loss on the prollucers of this country of millions of dollars.

The use of this fat for the purpose set forth is an encouragement to the producer to improve his herd and raise a class of grade or thoroughbred cattle capable of making and carrying this fat, rather than the common or scrub animal, which is so hard and unprotitable to fatten, and the cattle raiser or producer has rone to know the valne of this prodnct, and the amount of the increase in the market value of his matured aniual depends somewhat on the value of the "butter fat" carried by the auimal.

The rights and privileges of the producers of beef cattle shonld be as well respected as those of others, and as they are the beneficiaries in the wanufacture of this wholesome article of food, they should not be burdened with nunecessary special taxes, other than is absolutely necessary for the support of the Government and the proper governmental regulations surrounding the handling of same.

The product of the "beef steer" should receive at the hands of Congress no greater exactions than imposed upon competing food products. It is already surrounded by numerons safeguards, which Cougress, in its wisdom, has seen fit to provide, stipulating severe punishment for selling same nuder misrepresentation as to its composition. It has by experience proven to be just what a large majority of the people of this country want, and in behalf of the prodncers and consumers of this great country we do solemnly protest against the enactment of legislation calculated to ruiu a great industry, and to deprive not only the working classes, but many others, of a cheap, wholesome, nutritious, and acceptable article of food.

Very respectfully submitted.

The South St. Joseph Live Stock Exchange,

By Horace WoOd, I'resident,

JoHN P. EMmert, Secretary.

Mr. Chairman and gentlemen of the committee, there is very little I can add to what is contained in this resolution. I can simply say that I know, by having been present at these meetings, that the cattle raisers are opposed to this oleomar'garine bill. Of course, it is to their interest, you can say, to be opposed to it, and yet it seems to me that the Congress of the United States should be very slow to pass a measnre which is so clearly class legislation when there is no great benefit to be derived from it to the people generally, if any benefit at all, except such taxes as might be collected; and it ought not to be taxed just simply for the purjose of benefiting any other industry. I do not know how it is elsewhere, but it is a fact that I believe the committee onght to consider that in most parts of the Sonthwestern States, and I personally know that it is a fact, that they do not produce enongh butter to supply the people who want to buy butter. It is a fact in Texas, and it is a fact in most parts of Kansas, and to a very large extent in the State of Colorado, and if you go up there to that country as a summer resort you will find it to be so. Butter sells, as a result, at a high price. We pay in Texas and Kansas for creamery 25 cents a pound for some and 30 cents for others at certain seasons of the year.

What it sells for at wholesale I do not know. There is a large class of people who might desire to buy oleomarganine, and that is a class of people that ought not to be legislated against. They have the sane rights as anybody else, and it will affect the value of onl-I can not give you the figures exactly on that-but it will affect the valne of our cattle from \$2 to $\$ 3$ a head, as I am informed. That can be ascertained definitely from the different packing honses and stock markets of this country. It can be ascertained just what it will do, and there is no occasion for quibbling npon that; but I do not pretend that I know. 
But I do know that there is a similar protest on this point, and I do not think there should be any legislation passed for the purpose of benefiting the butter men simply. I do not know that this is the purpose of the bill, but our people think that way down in that part of the country. Perhaps they are wrong. Perhaps it may be for the purpose of regulating an article that is pernicious, but I think investigation will show that it is not pernieious. It is an article that is wholesome, anl if the people want to buy it, let them buy it. And if the people like it better when it is colored, I see no reason why they should not be permitted to color it just as people will color a silk waist so that it will make your wife want to buy that.

With these suggestions, I want to submit this resolution to your favorable consideration.

Mr. Neville. Will the other members of the committee other than those who are member's of the subcommittee be permitted to ask questions?

The Chairman. I think it is so understood that they are to have the privilege.

Mr. CoWAN. When you go to ask mequestions in regard to the manufacture of oleomargarine, I do not kuow anything about that. I was simply asked to present these resolutions and the protest of our people aguinst the passage of this law, and I do not believe you will find in a lilge part of the western part of the United States, or possibly in the sonther'n section of the country, any number of people who desire any snch law to be passed, and, in my juilgment, it would be certainly class legislation.

Mr. NEVILLE. You do not claim any knowledge of the details of the manufacture of oleomargarine?

Mr. CowAN. No, sir; I am a lawyer; and you know we know very little abont such things.

Mr. NEVILLE. Lawyers are supposed to know everything.

Mr. CoWAN. Well, that is a very violent supposition.

Mr. NEVILlE. You say that if a man should want to buy oleomargarine he ought to be permitted to do so.

Mr. Cowan. I think so.

Mr. Neville. Now, if a man does not want to buy it he ought to be protected so that he will not have to buy it?

Mr. CoWAN. Ol, no; if a man has his money in his pocket he can buy it or not as he clooses, and I do not think the law should protect him.

Mr. Nevilue. Yon say you think if he had the means he should be permitted to buy. But, suppose that he could not make the necessary test iu order to discriminate and tell what he was bnyiug.

Mr. Cowan. I do not know but what he would be in the bad position I am in here in Washington about the whisky. I can't tell which is the gooul whisky and which is the bad, and the law can not protect me against my barl julgment.

Mr. Neville. 'That would depend a good deal upon the time of clay, I smppose?

Mr. CoWAN. Just so; aud the time of night too, and donbtless some of the rest of you have had the same experience. I lo not mean to say anything against the whisky here; it is pretty good. But I mean to say that I can not tell the difference between the good and the bad.

Mr. Nerille. Do yon believe that if people want to buy oleomarga. rine that its not being colorerl wonld prevent their buying it?

Mr. Cowan. It might in a good many eases, and it would with butter, too. 
Mr. Neville. Then you say it would enable them to soll it for a higher price than they womld sell it for if it were not colored.

Mr. Cowan. I do not know whether it is the cause of it or not. My dairyman sells me colored butter, and it is made from cows that are fed on cotton seed, and that butter when it is made is as white as can be, but I would not buy it if it was not colored. It might be the same with oleomargarine.

Mr. NevilLE. You would not buy butter that is not colored?

Mr. Cowan. I might, but I would rather buy it colored.

Mr. Nerille. Were you at this meeting that passed this resolution?

Mr. Cow $A$. I was. I was at the Live Stock Association meeting that was composed of all the live stock interests of this country. I was present at the anmul meeting of the Live Stock Association at Fort Worth, on January 20 , when a resolution like this was passed, and it is inclorsed by all these associations wlose names are compriserl in this list, which I now subnit to the committee.

Mr. NEVILLE. I did not ask the question for the purpose of cliscrediting the fact that there was snch a meeting.

Mr. Cow ${ }^{\prime}$. I did not so muderstand you, and I mention this in order to show you that this is not trumped "up evidence nor on the part of any manufacturers. I do not know any manufacturers.

Mr. NEVILLE. This speaks of increase of tax on oleomargarine colored in imitation of butter. Did they also know that it would decrease the tax if it was not colored?

Mr. Cowan. That was not discussed in my presence, and I was there at both meetings.

Mr. NeviluE. If, as a matter of fact, oleomargarime was not colored in imitation of butter, and if in its natural state, as manufactured without coloring, it would sell for a less price than it does with coloring, do you believe the consumers would want to buy it in its colored or incolored state?

Mr. Cowan. That is a speculative matter, and I could not determine. That depends.

Mr. NEVILLE. Speaking of whisky, of which you and I perhaps are better judges, do you think that we might want to buy more whisky if it was colored?

Mr. Cowan. Yes, sir; in the town where I was raised we had two brands of whisky - the Lincoln County whisky and another kind. The Lincoln County whisky was higher colored than the other aud it was also higher priced, and I lon't know that there was any other particular difference between them, but we always bought the Lincoln County whisky.

Now, I waut particularly to call the attention of the members of this committee to the list of associations that belong to this national association which met at Fort Worth, and I want to say that everyone of these had a good delegation there.

Mr. Williais. Please just read that list.

(Tho list referred to was here read by Mr. Cowan, and is as follows:)

Oneida County Wrool Growers' Association, Idaho; Colorado Cattle Growers' Association, Colorado; Kansas ('itj Stock Yarts Company, Missouri; Union Stock Yards Company, South Omaba, Nebr.; Denver Union Stock Yarls, Coloralo: Pueblo Union stock Yards, Colorado; Arizona Stock (irowers' Association, Arizonal; Fort Worth Stock Yards Company, Texas; South Omaha Live Stock Exehauge, Nebraska; American Feeders and Breeders' Association, St. Panl, Minn.; Larimer Connty stock Growers' Association, Colorado; Cattle Raiser's' Association, Texas; Custer ' 'ounty Cattle Grower's' Association, Colorodo; Stock Feeders' Assoiiation, Eastern Rontt County, Colo.; Sioux City Stock Yards Company, Iowa; Siomx City Live Stock Exchange, Iowa; Live Stock Sanitary Board, Arizona; Sagnacho stock Growers' Association, Coloralo; Kern County Cattlo Growers' Association, California; West-

$$
\text { S. Rep. } 2043-42
$$


ern South Dakota Stock Growers' Association, Soutl Dakota; Live Stock Exclıange, St. Joseph, Mo.; South st. Josoph Stock Yaris Company, Missouri; Utah Wool Growers' Association, Utah; Sontherm ('olorallo Stock Growers' Protective Association, Colorado; American Hereford C'attle Breeder's' Associatıon, Missouri; Union Stock Yarls and Transit ('ompany, Chicago, Ill.; Cattle Sanitary Board, New Mexjco; State Veterinary Board, Colorarlo; Live stock Association, North Dakota; jort Collins Sheep Feeders' Association, Colorado; American Short-Horn Breeders' Association, Illinois; Roaring Fork and Eaglo River Stock Association, Colorarlo; Uinta County Wool Growers' Association, Wyoming; Cattle and Horse Protective Association, District 9, Colorado; Elko County Cattle Association, Nevada; American Galloway Breeders' Assoeiation, Nissonri; Nortl Fork Valley Cattlo Growers' Association, Colorado; Park County Cattle Growers' Association, rolorado; Grand and Eagle River Stock Growers' Association, Colorado; Fan Juis Valley Cattle and Horse Protective Association, Colorado; Lincoln Count $\bar{y}$ Cattle Grower's Association, Colorado; Texas Live Stock Association, Texas; Lincoln and Elbert County Wool Growers' Associatiou, Colorado; Kansas City Live Stock Exchange, Missouri; Weld County Live Stock Association, Colorado.

Eastern Colorado Stockmen's Association, Colorado; Sheep and Wool Growers' Association, Idaho; Black Range Protective Association, New Mexico; Western Nebraska Stock Growers' Association, Nebraska; State Board of Live Stock Commissioners, Illinois; Board of Trade, Tucson, Ariz.; Chamber of Commerce and Board of Trade, lleuver, Colo.; Union Commercial Club, Lincoln, Nebr.; Logan County Cattle and Horse Protective Association, Colorado; Suake River Stock Growers' Association, Wyoming; Gunnison Connty Stock Growers' Association, Colorado; Cincinnati Union Stock Yards Company, Ohio; Colorado Midland Railway Company, Colorado; Coloralo and Southeru Railway Company, Colorado; Oregon Short Line Railway Company, Utah; Yuma Connty Cattle Growers' Association, Colorallo; Fremont, Elkliorn and Missouri Valley Railroad, Omalıa; Rio Grande Western Railway Company, Salt Lake City; American Shropshire Registry Association, Indiana; St. Louis Live Stock Exchange, Illinois; Sheep Sanitary Board, New Mexico; Board of Sheep Commissioners, Wyoming; Oklahoma Live Stock Association, Oklahoma; American Shetland Pony Club, Indiana; Iowa Improved Stock Breeders' Association; Cincinnati Live Stock Commission Merchants' Association, ()io; Chicago and Northwostern Railway Company, Illinois; North Park Stock Growers' Association, Colorado; Chicago Live Stock Exchange, Illinois; Pacific Nolthwest Wool Growers' Association, Uregon; Dominion ShortHorn Breeders' Association, Canada; Fremont Comuty Cattle Growers' Association, Colorado; Crystal Iiver lailioad Company, Colorado; National Association Exhibitors of Live Stock of America, New York; Northern Wyoming Wool Growers' Association, Wyoming; Pecos Valley Railroad, Now Mexico; Cincinnati Chamber of Comnerce, Ohio; Red Polled Cattle Club, America, Iowa; State Board of Agriculture, Kansas; State Irrigation Association, Utah; Union Pacific Railroad Company. Omaha; State Agricultural College, Wyoming; Saguacle County Wool Growers' Association, Colorarlo; Polled Durham Cattlo Club of America, Indiana.

Mr. ALLEN. Were you present at this meeting that passed the resolution that you first read?

Mr. Cowan. Yes, sir; I was.

Mr. Allen. Do you know personally the men who were there representing those different breeders' associations?

Mr. Uowan. I know some of them. I knew a good many of the men who were delegates to the convention at Fort Worth. I was also a delegate to the convention at Denver of last year.

Mr. WiLliais. Do yon kuow personally whether those geutlemen are interested in the breeding and raising of cattle?

Mr. Cowan. Nearly all of them.

Mr. ALLEN. Nearly all of them?

Mr. Cowan. Yes, sir. Of course, this national association is composed of these various other associations. It is not composed of individuals. It has 110 individual membership. 'the Texas Cattle Raisers' Association is a member of the national association. In that live stock association the breeder's' assuciation have representation, and send their delegates there in proportion to the representation that is made by the excentive committee of that concern. I can not remember now just what is the amount of representation which each one receives. 
Mr. Allen. You have heard the discussions there at the meeting?

Mr. Cowan. Yes; and they passed the same sort of a resolution at Denver, and I was there.

Mr. AlLEN. Is it claimed by the breeders of eattle that the mamm. facture of oleomargarine increases the price of cattle by reason of the "xtraordinary demand for fits?

Mr. Lowan. That is what they do, sir. This paper that is published by the Denver Chamber of Commerce, and which makes quite a book, will show you, and if anybody wants information upon that subject they will find some splendid papers in that book. John W. Springer, the president of the National Live Stock Association, who lives at Denver, can furuish copies of the annual preceedings of the National Live Stock Association in which is contained all the paper's read and all the resolutions passed. That has been printed for 1899, and I think is ready to be printed for 1900 , if not already out.

Mr. Allen. Where do you live?

Mr. Cowan. At Fort Worth.

Mr. Allen. Do you know anything of the retail sale of oleomargarine in your city?

Mr. CowaN. Not a thing. I see it in the stores, but I do not buy it, and know nothing about it.

Mr. Allen. What do you know, now, about the process of the retail merchants in relerence to the sale of this product?

Mr. Cowan. Not a thiug.

Mr. Allen. Have you ever heard any complaints of your citizens of its being sold as butter, and of their being deceived by reason of mis. representation?

Mr. CowAN. I have seell cases sitting around, but it looks a good deal like the kind of butter I buy, and I buy Kansas creamery, and I do not know the difference. I am like I am with the whisky. I may not know the difference.

Mr. AlLEN. A re there any dairy interests in your part of the country?

Mr. Cowan. No, sir; not creameries; no ereameries in Texas that I know of. There are a good many in Kansas. I go very frequently over there and I see little sheds near the station where they mantucture butter, and I see them hanling in the milk. They manufacture butter there.

Mr. DaIILE. This was the opinion, the consensus of opinion, of the cattle raisers' associations?

Mr. CowaN. There is no doul,t about that.

Mr. DAHLE. It is elaimed by the National Dairy Association that this was gotten up by certain individuals, and that these people did not know what was in it. Was it discussed, and did there seem to be any interest in it?

Mr. Cowan. Yes, sir; the matter was discussed, and papers read upon the subject, but I can rot recollect just exactly the extent of it.

Mr. DAHLE. And they unlerstood what they were voting upon?

Mr. Cowan. Yes, sir; and a more intelligent convention has not met in this country, muless it be a convention of professional men, than this National Live Stock Association which met at Denver a year ago, and at Fort Worth this winter. They know what their interests are, and it is conceded by cattlemen; and $I$ had a telegram from the former presilent of the Cattle Raisers' Association asking me to present these resolutions. He has no interest in the vackers at all. I think this is the honest, and I think intelligent, judgment of these people, and an investigation by this committee of the sources from which I get my 
information will make that fact appear. Mr. Tomlinson, from Chicago, is here, who represents the Live Stock Lxchange, and he can speak of that also.

Mr. NevilLe. This resolution speaks of placing a tax on oleomargarine, and does not seem to include the fact that it is merely upon the colored oleomargarine. Did these people nuderstand that the object of this tax was to reach the oleomargarine colored in mitation of butter?

Mr. Cowan. I do not know that they did. I never heard that discussed or mentioned.

\section{STATEMENT OF T. W. TOMLINSON, RAILWAY REPRESENTATIVE OF THE CHICAGO IIVE STOCK EXCHANGE, OF THE UNION STOCK YARDS OF CHICAGO.}

Mr. Tomlinson. There is very little I cau say abont this that will not be practically a reiteration of what has been said by Judge Cowan. I might, however, ald that the various bills on this matter have been very carefully considered by the National Stock Exchange and the Live Stock Association, and these organizations and the Chicago Live Stock Exchange are very fully aware of this. I will say this, in reply to your question to Mr. Cowan, as to whether they know that the tax on oleomargarine is to be reduced. They are fully aware of the features of the bill. They are very practical people, and not interested directly in butter or the cattle of the comntry. 'They are of course very much interested indirectly in the people whom thry represent, who are primarily the raisers and growers of live stock; that is, the cattle and sheep and hog men. The Chicago Live Stock Exchange and the National Live Stock Exchange are primarily composed of commission men, who represent the producers aud raisers of these cattle. I came to Washington for practically the same reasous that Judge Cowan did, but was directed by wire to represent the National stock Exchange, and to present to this committee the resolutions which were passed by that exchange in opposition to this bill. I have not with me the resolntions, but I will see that they are filed with this committee-both the resolutions of the National Live Stock Exchange and of the Chicago Live Stock Exchange. The constituent members of the National Live Stock Exchange are composed of the members of the varions exchanges in the large cities of the comntry, as Chicago, St. Louis, Cincinnati, Lonisville, Indianapolis, and so forth.

I believe that is all that I care to say, except that the gentlemen of the executive committee of the National Live Stock Exchange and the Clicago Live Stock Exchange are people who are thoroughly familiar with the manufacture of oleomargarine, and are practical men, and know the effect which it wonld have upon the value of cattle if this bill were passed, because their business is to sell cattle.

Mr. Neville. Are there any of them here who are acquainted with the manufacture of olsomargarine?

Mr. Tomlinson. No, sir; I think not. I do not claim to be familiar with it myself. I an simply their monthpiece before you.

Mr. ALLEN. What relation do you bear to that exchange?

Mr. Tombinson. I am the railroad representative of the Chicago Live Stock Exchange.

Mr. AlLEN. A sort of traffic manager?

Mr. Tomlinson. Yes, sir.

Mr. Alten. You have no interest in the railroad?

Mr. Tomilnson. No, sir. 
Mr. Willians. You represent this association of commission merchants, who sell cattle for the stock raisers, in their relations to the railroads?

Mr. Tomlinson. Exactly.

Mr. Neville. You make arrangements for traffic and represent them in that respect?

Mr. Toun inson. Yes, sir; the commission men. Their opinion, it seems to me, in regard to the effect of legislation against oleomargarine would be probably better than anybody else's so far as its effect on the price of cattle is concerned, because they are the people who sell the live stock of the country; and their resolution points out that it would cut down the price of cattle from $\$ 3$ to $\$ 4$ a head.

Mr. Neville. Do you know the relative number of cattle raised in this country now and last year, and the amount of fat in each animal on the average?

Mr. Toulinson. That would depend.

Mr. Neville. So as, I mean, to be able to determine the actual value in the animal of this fat?

Mr. Toulinson. I could furnish you with some accurate figures on it, but I should dislike to make a rough statement. I should think, however, it would run forty to fifty pounds. I am satisfied that is a conservative estimate.

Mr. NEVILLE. How can you determine that if you know nothing about the manufacture of oleomargarine?

Mr. Tomlinson. The Chicago Live Stock Exchange slaughters all the animals suspected of any disease, such as tuberculosis, and a number' of them are passed as fit for food after inspection, and they sell the various portions of the animal so slaughtered at the market value of it, and butter stock constitutes one part of that. I have occasion to look over their reports, and know about what it would average. That is the basis of my statement in that respect.

Mr. NEVILLE. All you know about it is from looking over those reports?

Mr. Tounlinson. Do not misunderstand me. I have been present at a number of meetings of the execntive committee of the National Live Stock Exchange, and have talked with the officials of that exchange, and, of conrse, my information is largely hearsay to that extent, but it is what they say on the matter. They had no occasion to misrepresent it, of conrse. It was a matter they were considering.

In the annual meeting there were two papers read on the matter, one by Colonel Hobbs, of New York, and some other gentlemau whose name I do not remember, but there was, I think, but very little discussion regarding the merits of this pending legislation.

Mr. Finville. You were there"

Mr. Toulinson. Yes, sir.

Mr. Neville. Can you explain why this measure, which, if passed, would tax oleomargarine, why the resolution did not contain the fact that the tax of 10 per cent was simply to be imposed upon the colored oleomargarine?

Mr. Tomlinson. No, sir; I can not. It is readily understandable that an association, while they might have some notion of such a thing as this, might not have the exact details of it.

Mr. NEville. Does it mention the 10 per cent at all?

Mr. Tomlinson. No, sir.

Mr. BAILEY. The reference was in a general way to the bill?

Mr. Tomlinson. Yes, sir. They all thought that it was very impor- 
tant as affecting the value of their steers to the extent of a conple of dollars a head. It was really one of the most important things done there.

Mr. Nevilue. Is it not true that practically ali of the cattle shipped to Chicago from the Sixth Nebraslia District, which I represent, there being 33 counties there whose chief product is cattle, sheep, and horsesis not it true that those people ship practically all of their cattle iuto Chicago?

Mr. Tolilinson. Yes, sir.

Mr. Neville. So that, in your opinion, you onght to be familiar with the individual eattlemen of that country as to their notions of this matter?

Mr. Tomlinson. Well, I know a few of them. I have attended a good many of those meetings at Rapid City there, and I gness a good many of you come down there. I notice that the Western Nebraska Stock Raisers' Association was represented there.

Mr. NEVILLE. If you had received personal letters and petitions from nearly every cattle owner in that country, urging this tax, you would not feel that the people had been represented there, wonld you, when this resolution was passed?

Mr. Tomlinson. From that country? Do you mean to say that the cattlemen out there are not opposing this?

Mr. Nevilue. I mean to say the cattlemen are not opposing it.

Mr. Tomuinson. Answering your cuestion, I must say that on the premises of your statement I would say that they were not represented. I think there must be some grave mistake.

Mr. Neville. Do you remember the name of the chairman of the committee?

Mr. Tomlinson. Matt Daugherty.

Mr. Neville. Was John Bradt there, too?

Mr. Toulinson. I could not tell you. There were 1,500 delegates down there, and while I know a good many of them I would hardly undertake to say who was and who was not there from Nebraska.

Mr. Neville. I am satisfied that Dangherty oploses this bill.

Mr. Cowan. Are not the range cattlemen out there opposed to this bill?

Mr. Nevilite. No, sir; except a few range cattlemen who have a few thousand head of eattle and are interested in the Omaha stock yards, and I do not know but they are interesterl in some of the packing houses. They are opposed to this bill. But my opinion is that the cattlemen of that market are the other way.

Mr. Tomminson. If there is any other information the committee desire me to give to them with reference to oleomargarine, I shall be glad to do so.

The CHAIRMAN. If you have anything in addition to what you have said which you would like to send to us, address it to the committee in writing at any time, and we shall be glad to liave it.

Mr. STOKES. Mr. Chairman, we have here to-day a committee representing the cotton-oil industries of South Carolina, North Carolina, and Georgia, and I ask that they be heard in this connection. The following gentlemen are present in this delegation: Fred Oliver, Charlotte, N. C.; George S. Barber, Angnsta, Ga.; C. Fitzsimmons, Columbia, S. C.; Thomas Taylor, jr., Florence, S. C.; F. K. Barlen, Gollsboro, N. C., and A. C. Phelps, Sumter, S. C. These gentlemen have their counsel present, Mr. Fred Oliver, of Charlotte, N. C., who will present their cisse. 
Mr. Stevens. Mr. Chairuan, I wish to be hearl just a moment to indorse what Mr. Cowan har to say in regard to the cattle interests, and I would stite that there is no set of men on earth more alert to their own interests than the cattlemen of the United States, and they meet and diseuss these questions, and the oleomargarine question, in the interest of eattlemen, and they certainly would not make a mistake.

I have received numbers of letter's from my district from eattlemen opposing this bill, and 1 liave yet to hear from any one of them who is in favor of it, and I disagree with Mr. Neville when he says that the cattlemen of the comtry are in favor of its passage. I represent certainly the largest cattle district in the United States. I represent eighty eounties in the northern jart of Texas. I represent the owners of probably onehalf of the cattle of Texas. You know that Texas produces more live stock than probably any other two States of the United States, and I think my people are universally opposed to this bill. In the first place, I think it is a species of class legislation, and second, it will probably add 10 per eent a pound to the value of the prodnct of the men who make butter or have their money in that industry, and lake off that much from the cattle raiser, and we find that it would be a class discrimiuation.

\section{STATEMENT OF MR. FRED OLIVER, REPRESENTING THE COTTON SEED-OIL INTERESTS OF NORTH AND SOUTH CAROIINA.}

Mr. OLIVER. To facilitate the presentation of our views in regard to these bills we have prepared a paper addressed to the honorable Committee on Agriculture, which I will ask permission to read. Mr. Stokes has said that we represent the cotton-seed-oil interests of North Carolina, South Carolina, and Georgia, but I wonld like to state that the greater part of that industry is in the States of North and South Carolina, there being but one delegate from Georgia.

Mr. Oliver here read the paper referred to aloud, as follows:

We appear before you as a committee representing the cotton seed-oil interests of North and south Carolina to protest against the injustice aud damage to our business that would be eansed by the passage of any of the proposed bills now before your committee and varions other committees of the House and Senate relative to the manufacture of oleomargarine. We do not expect to be able to present to your bonorable eommittee any new facts or arguments why these proposed laws should not be enacted, for we realize that all arguments and reasons pro and con have been presented to you before, and all we call, therefore, do to-day is, perhaps, to present them in a new light, and impress upon you the injustice and damage to our particular business that snch elass legislative enactments would canse. We propound two questions to your houorable boly, and will give our auswers in the light we see it:

First. Why are there each year one or more bills introduced to regulate the manufacture of oleomargarine?

Second. By whom are they introduced?

The answers to the above questions are apparent to you and every one, for they are always originated and introduced by a speeial class of the country's population-the dairy farmers; not as a unit. however, for there are many bonorable, eonseientious, justice-loving dairy farmers who do not approve of such class legislation. The object to be obtained by haring these proposed laws enacted is to ereate a scareity for the lower grailes of genuine eow butter, and thereby enhances its price to an artifieial figure for the special benefit of a certain class of dairymen and 
to the damage and loss of various other producing classes, and at the expense of a very large class of worthy consuming citizens of moderate means. We doubt if there ever has been any prolucers of genuine, high-grade, gilt-edged butter who have been spending their time and money trying to pass such unjust class laws. It is only the producers of low-grade butter, who find their wares shelved or required to be sold at less price than oleomargarine, who are always agitating the subject of taxing oleomargarine to make its sale prohibitory. We firmly believe that there is now produced by the small country butter makers large quantities of adulterated butter or oleomargarine, which, under the present law, enacted years ago, should pay a tax of 2 cents per pound and be subject to all the vexatious sale regulations that are now on the statute books, but which goes scot free, simply because the butter is offered by a so-called "guileless farmer."

Any farmer keeping half a dozen or more cows for butter making can run his own little oleomargarine factory by mixing neutral lard oil, cotton-seed oil, oleo oil, etc., in his churn with cream or milk, thereby producing an inferior oleomargarine, which lue sells as "homemade," "pnre country butter," witlout tax or restriction: and it is this class of dairymen and prodncers of dirty, unscientifically made "pure butter" that are asking for a tax and sale restrietions on the produets of the large manu facturers of oleomargarine who are now paying the unjust 2 cents per pound tax and submiting to all the vexations regulations necessary to sell same. No manufacturer of "Philadelphia print" or "Elgin creamery" grades of butter is asking for " tax on oleomargarine. Why shonld "genuine butter," so called, be allowed a monoply to use the butter coloring article of conmerce, "annotto," that has hicen for about thirty years, or ever since oleomargarine was invented, one of the ingredients in its mannfacture? There is no question or doubt but what the present artificial butter coloring was used in the first oleomargarine placed on the market, and has always been so used; also, that its use in so-called "gennine butter" has been brought about by the impossibility of "genuine butter" when uncolored to compete with the oleomargarine of commerce, that has always the same color becanse it has always used the artificial coloring agency. If a monopoly of artificial coloring should be enjoyed by anyone it should be the oleomargarine manufacturers, not the cow butter makers.

If it was possible to educate the small producers of butter and thereby make their production of "genuine butter" equal in quality to the product of the best dairymen and creameries, there would be a ready market for it all at about the present price for the very best grades of cow butter, in which case oleomargarine would sell for several cents less per pound and be used almost exclusively by those consumers with linited means who are willing to nse an article that is sold at less money and which suits them about as well as a higher-priced article; but it is not possible to so educate the mass of dairymen, and as long as the large proportion of the dairymen abuse their production by making bad butter, just so long will the oleomargarine find favor with the consumers with limited means, for it is recognized by all as being far superior as an article of food to at least half if not two-thirds of the butter, genuine and artificial, produced by the farmers and others. Legislative enactments should be for the benefit of all, not for a favored class. The enactment of any one of the proposed 10 cents per pound tax or anticoloring bills will prohibit the manufacture of oleomargarine openly and aboveboard but will not prevent its being carried on by an increased number of farmers and moousline manufacturers in defiance of the laws and without paying taxes. 
There will be a marked increase of "molasses" and such articles apparently consumed by the farmers, but which are in reality lard oil, nentral oil, cotton-seed oil, or oleo oil, which the farmers will take to their homes to mannficture into "genuine butter," so called. There will be a decreased anount of country tallow and lard bronght to the markets, for farmers will sell to each other to use in increasing their yield of butter from their small dairy herd. There will, no loubt, be propagated new breeds of so-called butter cows that will excel in the production of butter the Jerseys and other famons breeds. The limit in the production of butter from any one dairy will be regulated only by the supply of nentral oil, lard oil, etc., that the farmer cau smuggle to his home. Farmers will become as skillful in evading these laws as the western North Carolinian is in evading the liquor laws. Increase the tax on whisky to $\$ 2$ per gallon, and then see how many more men all over the United States will be making "moonshine" goods. Reduce the tax to 25 cents per gallon and you will reduce the number of cases before each United States criminal court in North Carolina to probably one-tenth the present number. It the proposed laws to impose 10 cents per pound tax on oleomargarine are enacted you will have to increase the revenue detective service many times its jresent number and loold criminal United States courts every week in every district. Butterine or oleomargarine will be produced, and the laws will not prevent it. The proposed laws, if passed, will prevent open, aboveboard, taxpaying, honorable manufacturers from continuing to carly on their present business, but it will not prevent the secret manufacture of the article by a class of men hard to detect and still harder to convict.

We earnestly protest against the passage of the proposed bills as being unnecessary and very harmful to our business, to the country's bnsiness at large, and to the morals of many farmers and others. It will be a temptation tliat a great many present law-abiding, honorable farmers will not be able to resist, and they will become the same as a great many westeru North Carolinians, "moonshiners," for the manufacture of oleomargarine.

The-cotton-seed-oil interests of the South have invested in plants not less than $\$ 50,000,(100$. The working capital necessary to conduct the business is not less than $\$ 50,000,000$ more, making $\$ 100,000,000$ employed in the business. The mills have converted a product, namely, cotton seed, which was once considered a perfect nuisance by the farmers and ginners, into an article bringing to the cotton planter millions of dollars and to the laboring man millions more and to the railroarls a large and profitable tonuage in and out, amounting to millions of dollars in freight. There has been paid to the cotton producers this season not less than $\$ 40,000,000$ for about two-fifths of the seed produced. There has been paid to the railroads to hanl the seed in and the products of oil mills out not less than $\$ 15,000,000$. There has been paid to laborers dependent upon the manufacture of cotton seed at least $\$ 10,000,000$, making a grand total paid out by the oil mills of not less than $\$(\$ 5,000,000$, and this for a product that forty years ago was considered absolutely worthless, and for only two-fifths of the seed produced, the balance being used on the farms for fertilizing and for cattle feed.

It the oil mills are not crippled by alverse legislation in this country and others it is only a matter of time when all cotton seed not required for planting will be worked up in oil mills, creating a market value for the seed, money paid ont for tramsportation and labor, from a 'rol' of $12,000,000$ bales of cotton, a grand total amounting to at least 
$\$ 150,000,000$, or about one-half of the value of the cotton crop itself. Oil mills employ colored men exclusively in every department excepting superintendents and skilled mechanies - at least 95 per cent of all the help employed being colored. These colored men earn from 75 cents to $\$ 2.50$ per day, and are a very worthy, self-sustaining, law-abiding class of citizens. Why should the product of their lab ir be legislated against simply to give another class of citizens-the daiı ymen-a monopoly as against oleomargarine, a food product that the buying consumer is now satisfied to furnish to his family and himself. The consumer knows that this product, oleomargarine, is healthy and clean, and it costs him much less money than cow butter and is equally as satisfactory, and suits him much better than low grades of dirty butter costing the same or less money.

It is simply a fight in which the "survival of the fittest" should be allowed to prevail, and it is not right or just, no matter in what light it is looked upon, to handicap, by a 10 cent per pound tax, or any other tax or regulation, a manufactured article that has been, is now, and always will gradually overcome the public prejudice and work itself into public favor to the detriment of much so-called butter that is only fit for the soap-boilers' kettle. Why not tax cotton clothing of all kiuds, simply because it is supplanting woolen and silk goods? Why not tax beet sugar because it will, in the end, drive ont cane sugar if left to a free fight on their merits and cost? Why not prohibit by tax, or impose restrictions upon electric light and power, becanse it is driving ont of use gas and horse power"? Why, oh, why, did not the farmer that furuished tallow to the cancle makers look far enough into the future, years ago, and prevent the almost total annililation of the candle manufacturing by the products of petroleum? Why not pass laws to prevent all inventions and improvements to the conditions of the human race just because there are some farmers selfish enough and self-satisfied to live and die as their fathers and grandfathers lived and died years before them?

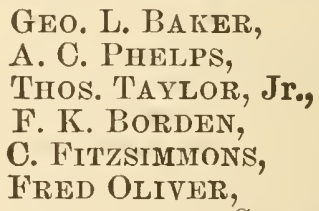

Committee.

Representing mills in North Carolina, South Carolina, and Georgia as follows:

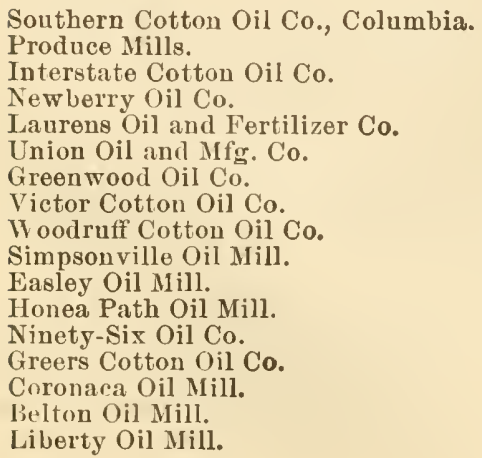

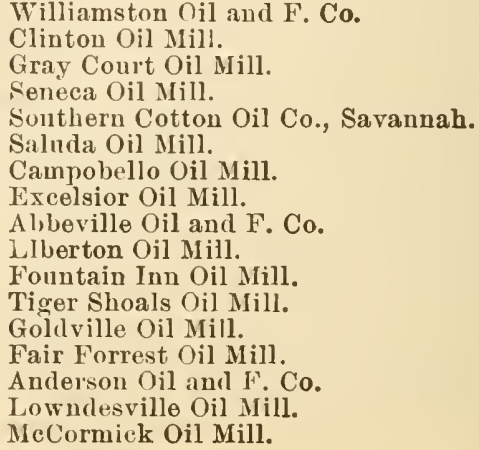


Atlautic Cotton Oil Co.:

suniter,

Bennettsville.

Southern Cotton Oil Co., Columbia.

Southern Cotton Oil Co., Baruwell.

Darlington Oil Co.

Dillon C'otton Seed Oil Co.

Orangeburg Oil Mill.

florence Oil Mill.

Marion Oil Mill.

Edgefield Manufacturing Co.

Rirlge spring Oil Mill.

st. Matthew's Oil Mill.

Chester Oil Mills.

Fairfield Oil and $\mathrm{F}$. Co.

Kathwood Mfg. Co.

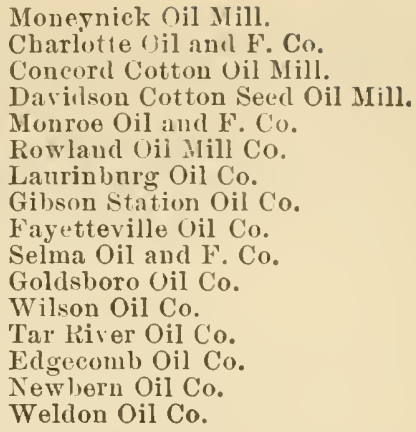

This paper is subscribed by a committee representing in North and South Carolina and Georgia about 70 oil mills, and representing in the South abont 400 oil mills.

Mr. HAUGEN. How mnch of this $\$ 65,000,000$ goes into the butterine? Mr. OLIVER. Of this $\$ 65,000,000$ ?

Mr. HAUGEN. I understand you to say that $\$ 65,000,000$ goes to the iuterests of the cotton raisers of the Sonth?

Mr. OLIVER. About $\$ 40,00,000$ was paid to the farmers for seed, about $\$ 15,000,000$ for the transportation of the seed in and products out; about $\$ 10,000,100$ for labor. In this country there is used probably 150,000 barrels of 50 gallons each of butter oil in mannfacturing oleomargarine-at least aboveboard. How much there is used secretly, I do not know.

Mr. HAUGEN. What part of it is cotton-seed oil?

Mr. OLIVER. About 150,000 barrels of cotton-seed oil of 50 gallons each goes into the oleomargarine throngh the large manufacturers that are now being taxed and living up to the regulations.

Mr. HAUGEN. About how much is this worth?

Mr. OLIVER. Abont 40 cents a gallon of $7 \frac{1}{2}$ pounds to the gallon.

Mr. Neville. Have you figured out the number of pounds so that you know?

Mr. OLIVER. No; it is only from what is pnblished and the amount of taxes paid on oleomargarine. Oleomarginine contains from 25 to 40 per cent of cotton-seed oil, depending upon the weather and the season of the year it is made.

Mr. AlLEN. Are you engaged in the manufacture of oleomargarine in any way?

Mr. Oliver. Not at all, sir.

Mr. ALLEN. Are you a cotton raiser?

Mr. OLIVER. Yes, sir; to a limited extent I am a cotton raiser. I am more of a wheat and oat raiser in the farming line.

Mr. ALLEN. Are you engaged in the manufacture of cotton-seed oil?

MIr. OLIVER. Yes, sir; in that I am very largely engaged. Our plant to day has more than $\$ 1,000,000$ right now invested in cotton-seed oil machinery and products.

Mr. Neville. One hundred and fifty thousand barrels, of 50 gallons each, or 375 pounds to the barrel. Do you mean that that amount you have given is for the oil sold, or is that including the cake sold for feeding cattle?

Mr. OLIVER. No, sir; only the cotton-seed oil used in bntter making.

Mr. Neville. I will ask you if you have figured the number of pounds of oil cake sold to feeders? 
Mr. OLIVER. There is about $\$ 3,000,000$ worth sold this rear and last, and $1,000,000$ tons of cake ground into meal, or sold as meal. kight there, why not tax cotton seed cake to prevent its being a competitor of oil cake, aud corn meal, and wheat bran. You have just as much right to do it, and it is exactly as just.

Mr. NEYILLE. Speaking of oleomargarine being made of the oil of cotton seed, I will ask you if it is not a fact that cotton-root tea and cotton-seed tea have not been used for the purpose of producing abortions?

Mr. OLIVER. Cotton seed or root tea has been used ever since it has been known for that purpose, but cotton-seed oil has no such effect.

Mr. Neville. Have yoll positive proof that it has no such effect?

Mr. OLIVER. We have chemists all over the world, who are constantly experimenting, and as they have experimented with oleomargarine, I think they would have discovered that fact if it had been a fact. I do not believe you can find a chemist who has given an adverse opinion against oleomargarine.

Mr. NEVILLE. Don't you know that it is a fact that chemists have given ample evidence on both sides of this question?

Mr. Oliver. I presume that that is true to some extent, and the evidence they have given has generally been according to the interests of those who employed them. There are dishonest chemists. But almost invariably the evidence has been favorable to the cotton seed produet.

Mr. Neville. Now, you have stated it as a fact that there was no one advocating this legislation excepting a few farmers, disreputable and dishonorable men, who wanted to palm off a fraud with their home manufactured oleomargarine; that they were the only ones urging this?

Mr. OLIVER. That was my statement, that it was being urged by that class.

1Ir. Nevilue. How do you acconnt for the fact that the legislatures of thirty-two States have already passed stringent laws prohibiting the sale of oleomargarine?

Mr. OLIVER. Simply because the political power of the parties in those States has been used in that way, and those in power are dictated to, or their leg pulled, or wire-pulling of some kind, which made them think it was necessary to advocate these laws.

Mr. NeviLLe. That would not apply to those who are represented by legislators who are not of their political faith?

Mr. Oliver. It applies to both parties, or all three parties, if you want to call it three parties.

Mr. Nevil.Le. Then it is simply that condition of corruption which you think has spread all over this eountry to which your remarks apply?

MIr. Oliver. Yes, sir; I do think so, in this line. But, when it comes to corruption and defrauling of the public, there is more defranding to-day in the clothing you are wearing and others are wearing in this room than iu any article you can mention.

Mr. Neville. Do you believe, becanse it has gotten to this corrupt state in all manufacturing matters with tho people of this country, that it is too late, and no use to try to do anything to make it better?

Mr. OLIVER. I believe the more laws you have the greater will be the corruption. You will kill, absolutely, the manufacture of oleomarganine on an honest, honorable basis; and you will put it into the bands of the secret manufacturers, farmers, and others, who are like money shavers, and the Goverument will not receive any tax to amount to anything. 
Mr. Neville. So you think that the plan was in the beginning that the big fish shonld eat the little fish, and the big arimals should ehew 11) the little ones, and therefore it ought to be allowed to go on as it was intended?

Mr. OLIVER. No, sir; I think it is simply the case of one elass in this comitry trying to benefit itself at the expense of another class. The South has no interest in the dairies, and they have a very large interest in the cotton-seed oil.

Mr. Neville. Is not it a fact that all the Southeru States have this law?

Mr. OLIVER. I do not know of a single Southern State that has a law against oleomargarine. And, while we use in this country 150,000 barrels of oil, they use on the Continent the much larger amount of 500,000 barrels in butter making. The passage of this law will be an incentive for every country to pass something of the same kind in order to put their farmers on the same level with ours.

Mr. WILson. I would like to know whether you have any reports as to the healthy qualities of oleomargarine?

Mr. (OLIVER. I have not here.

Mr. WILson. They are to be had, are they not?

Mr. OLIVER. I have read plenty of such reports from the United States Government cliemists passed on it.

Mr. Wrlson. The reports on that wonld be of more information to us than all the testimony on earth.

IIr. OLIVER. I think the last Congress appointed a eommittee which has alreadly reported favorably on oleomargarine as a food product; it was Senator Mason's eommittee.

MIr. Allen. Yes; Senator Masou's committee.

Mr. Wilson. If this bill is passed will it not luave the effect of an absolutely prohibitory tax?

Mr. OLIVER. It will, so far as aboveboard manufacturing goes.

Mr. WILson. That is what I mean.

Mr. OLrver. It will induce all sorts of people to go into the secret manufacture of oleomargarine.

Mr. WILSON. What is the cost of mannfacturing oleomargarine?

Mr. Oliver. It lias about 50 per cent of butter, cream, or milk, churued with the cotton-seed oil, nentral oil, oleo oil, etc.

Mr. WILsun. What will it cost?

Mr. Oliver. It will depend on what milk and cream is worth at any particular season of the year, and on the prices of the oils used. To day they are worth almost double what they were.

Mir. WiLsoN. I want to know what the cost is, and as to whether this tax will drive it out of the market?

Mr. ULIVER. As I say, you can not take any one date for the cost of oleomargarine. Right now, the cost of oleo, stearin, neutral oil, and cotton-seed oil are alunost double what they were a year. ago.

IIr. VEville. What does it amonnt to now approximately, per pound?

I1\%. ULrver. I suppose oleomargarine, the best grades, is selling at 15 cents, probably costing the manufacturers 10 cents, making "2 cents tax and 3 cents profit.

Mr. Neville. Then a tax of 10 cents per pound will put it above the price of butter?

Mr. OLIYEl. Abore the best grades of butter on the average.

Mr. Nerille. So that butter that would gu below that wonld simply undersell it and drive it ont of the manket?

MIr. OLIVEk. Ies, sir; butter will simply drive it out of the market. 
You will draw from oleomargarine $\$ 100,000,000$ in this case, and I think that you will find that the value of butter, genuine butter of the low grades male by the farmer, will be enlanced very much.

The Chalrvan. Do you mannfacture more than one grade of oil?

Mr. Oliver. Yes, sir; you cau manufacture a dozen grades.

The CHaIRMan. What grade do you sell to the manufacturers of oleo?

Mr. Oliver. They buy the highest grade made in the South.

Mr. Neville. That is called butter oil, and takes its special name from its use.

The CHAIRIAN. What, if anything, have the chemists said about the healthfulness of butter oil?

Mr. OLIVER. All chemists, withont exception, agree that cotton-seed oil is as healthfin as olive oil, and that it is one of the healthiest kinds of oil that can be used in food.

The Chairinan. What relation does it bear to olive oil?

Mr. OLIVER. It is almost identical in every respect.

Mr. Wilson. It goes to England as cotton seed oil and comes back here as olive oil.

Mr. Oliver. I suppose there is some of that done.

Mr. WiLson. Why would the prohibition of the color in oleomargarine stop the sale of it?

Mr. Oliver. Just because your palate is the same as your idea, and you would not buy natural white butter if you could buy natural yellow butter; and I claim that the coloring of oleomargarine is being copierl by the butter makers and not the coloring of butter by the oleo. margarine makers. Oleomargarine luas always been colored and butter lias not. It is only since the finely colored oleomargarine has been on the market that it has been fonnd necessary to color butter.

Mr. Neville. Do you know where oleomargarine was first manufactured?

Mr. Oliver. A French chemist discovered it in 1870.

Mr. Neville. Didn't it grow out of the necessities of the people during the Frauco-Prussian war?

A MeMber. It was during the siege of Paris.

A MeMiber. Jo you think the Government would have trouble in collecting the tax, if this bill was passed?

Mr. OLIVer. Ten times more than in South Carolina and in Kentucky collecting the internal revenue tax on whisky.

A Menber. IVould they liave any considerable difficulty in collecting the internal revenue tax?

Mi'. OLIVER. They have no trouble now with the large manufacturers of oleomargarine.

A MEMBER. But they would have.

Mr. OLIVER. They would have with everybody, beeause anybody could buy what is necessary to make oleomargarine and take it home with them. But there wonld not be a jound of oleomargarine made where there is $\mathbf{1 0}$ ponnds made now if it had to be placed on the market as oleomargarine and uncolored.

Mr. Neville. Is there auy competition of paraftin with cotton-seed oil for nse in making oleomargarine?

Mr. Oliver. None whatever. Paraffin is worth 14 cents a pound and cotton-seed oil 5 cents.

Mr. Neville. Parafinin is worth almost what it is worth to manufacture oleo. 
Mi. OLIVER. It is worth more to-day. It was, until two or three years ago, a drug on the market, and it was then discovered that paraftin was the best insulitor that comld be had for electric light wires and tubes, filling the tubes with paraffin, and its present value is two or three times what it was several years ago.

Mr. HAUGEN. You stated a while ago that this legislation grew out of politics, and that the politicians had been bulldozed and hoodwinked. I will state for your information that you are mistakeu. I happened to be a member of the legislature of Iowa when such legislation was passed, and I will state tibat it received the support of Populists and Republicans and Democrats by nearly a unanimous vote, and I clo not believe they were all representatives of the moonshiners. As I under. staud you, if this matter is left to Armour and the other large manu. facturers, there is no danger of their violating the law, but if it should pass into the hands of the farmers they would violate the law.

Mr. OLIVER. They are violating the law to day.

Mr. HAUGEN. You say they are violating the law now?

Mr. OLrver. I know persoually from seventeen years ago, when I knew a man at Paterson, N.J., who was mixing oleo oil in his churn on his farm, and churuing it into butter, and selling it as natural butter in the country back of there.

Mr. HAUGEN. There is at present of course a tax on it.

Mr. OLIVER. There is a tax of a dollar and ten cents a gallon on whisky, but, are you collecting it?

Mr. HAUGEN. I think so.

Mr. OLIVER. You are not collecting one tenth part of it.

Mr. HAUGEN. I want to know what the objection of the opposition is to this bill. As I understand it now, you say it is sater to leave this matter in the hands of the Armours and other large manufacturers than to leave it in the hands of the farmers because the farmers are all dishonest. That is the principal objection?

Mr. OlIVER. No, sir; it would throw it in the hands of the farmer.

Mr. Hadgen. That is your principal objection?

M. Oliver. No, sir; it would eurtail the use of cotton-seed oil, and finally, in the end, curtail the use of it in the comntries of the Continent.

Mr. NEviLLE. Is not it a fact that this law aims to do away with the infringement with a tax, and that it may be sold uncolored without $\operatorname{tax}$ ?

Mr. OLIVER. Yes, sir; provided you do not color it. But why should not gemuine butter pay a tax when it is colored? It is not genuine butter when it is colored. Oleomargarine has been colored firom the first, and butter has been colored, since the introduction of oleomargariue, universally. I say, wby should the butter have a monopoly of it?

Mr. HAUGEN. That question was asked and fully answered before the committee the other day.

A Member. Do I understand you to say that the oleomargarine that is made consists of from 25 to 40 per cent of cotton-seed oil, depend. ing upon the temperature and the reather at the time it is made and sold?

Mr. Oliver. Yes, sir.

Mr. H $\triangle$ UGEN. And 50 per cent of it is milk and cream?

Mr. OLIVER. Yes, sir: about 50 per cent:

Mr. Haugen. That leaves only 10 per cent

Mr. Olrver. No, sir: you can make it without any cotton-seed oil. It is made with neutral lard oil, exclusively, but I believe the wost of 
the manufacturers make a combination. They have to use stearin, or soine such substance, in orler to hold it properly.

Mr. DAHLE. Do you think a large percentage of butterine is made in this way?

Mr. OLIVER. In what way?

Mr. DAHLE. Do you think about all the butterine is made in the way you say?

Mr. OLIver. In what way?

Mr. DAHLE. Do you believe that 40 per cent of oil and 50 per cent of milk and cream-_

Mr. OLiver. Its basis is about 50 per cent of oil of some kind, not all eotton-seed oil, and not all oleo oil, and not all nentral oil, or peanut oil, if they are making it, which is used largely in the business, and about 50 per cent is from butter and milk.

Mr. DAIILE. Do you know this to be a fact?

Mr. Oliver. Yes, sir.

Mr. DAHLE. And there are more farmers, the small farmers that are making butter now-they are the ones that are asking for this law, rather than the larger farmers patronizing the creameries?

$\mathrm{Mr}$. OLIVER. It is my honest belief that a large part of the interest taken in this bill is for the sake of throwing it into the hands of the larger farmers to-day.

Mr. DAHLE. It is not the creamery men?

Mr. Otrver. No, sir; it is the small dairymen.

Mr. DAHLE. Do you know that?

Mr. OLIVER. I say that I kuow personally that seventeen years ago a man was doing that out there near Paterson, N. J., and from what I have learned and heard, I should say that can be done and is being done to day.

Mr. DAHLE. Suppose that we members get letters asking for this legislation. Do yon believe that these letters, judging from your experi. ence, come from this kind of people?

Mr. Oliver. Some do.

Mr. DAHLE. A large pe centage?

Mr. OLIVER. I believe that a large percentage of humanity are honest.

Mr. DAHLE. Do you believe a large percentage-

Mr. OLIVER. I do not know whom you have letters from, for or against.

Mr. DAHLE. No, I do not think you do, according to your statement.

Mr. ALLEN. I understand that you do not undertake to speak for the farmers of the United States generally, but so far as your knowledge extcuds in your locality. Is that it-the dairy farmers?

Mr. OLIVEL. No, sir; I do not think the dairy farmers of North Carolina and South Carolina are doing an illegal oleomargarine business any more than anyone else. It is only here aud there now that it is being done; but I think it would be done almost universally, or at least one fourth or one-half of the farmers would make oleomargarine and sell it for butter if this tax was placed upon it.

Mr. NevilLe. How would that affect the cotton-seed oil?

Mr. OLIVFR. I do not know that it would affect it, except that it would be sold to men that would carry it back into the comntry secretly. The chances are that they would try to get all the oil they could use from their home market.

Mr. STOKES. I think Mr. Oliver, as I understood his presentation, so far as related to the reasoms why certain leyislatures have passed such 
legislation, said that that was his opinion, that that was the tendency, and he stated that it applied to all parties; and then on the other question, as to why that should not be passel, was it not your state. ment, Mr. Oliver, that you undertook to say that that would be the tendency of this legislation, and not that it was already going on, except to a very limited clegree?

Mr. HAUGEN. But he stated this was bis opinion, and as the rejresentative of the cotton-seed industries of North and Sonth Uarolina. There will be other parties, as I understand, from other States that will ask for hearings before this committee.

Mr. BAILEY. I would like to ask what States he thinks this counter. feitiug of butter is carried on in?

Mr. OLIVER. Every one.

Mr. BaIley. In every State of the Union?

Mr. Oliver. Yes, sir; wherever there is a smart Aleck of a farmer that can make butterine. Any man can make it.

SATURDAY, March 31, 1900.

The subcommittee of the Bureau of Animal Industry of the Committee on Agriculture met at 10.30 o'clock a. m., Hon. William Lorimer in the chair.

\section{STATEMENT OF W. S. HANNAH, PRESIDENT OF THE KANSAS CITY LIVE STOCK EXCHANGE.}

The Chatruan. Mr. Hannah, will you state in your own way your views on this bill that is under consideration, commonly known as the oleomargarine bill?

Mr. HANNAH. Mr. Chairman and gentlemen of the committee, I am here in an official capacity representing the Kansas City Live Stock Exchange. Believing that the legislation proposed by the bill under consideration by your committee means a loss and damage to the livestock interests of the whole country and that we Western people are particularly affected, and while we disclaim any technical knowledge of the oleomargarine industry, we feel that our knowlerlge of it makes it appear to us that it means a loss and damage to the live stock trade, and that, as a consequence, we feel like protesting against the passage of this bill.

Now, the growth of the packing industry from the earliest tlays, from its inception to the present day, while I am not able to trace it in all its details, yet it is a well-known fact, and can be substantiated by my colleagues on our committee and doubtless by members of your committee, that there was a time in the history of the packing industry when a good deal of the product went to waste, when the hoofs and horns, and blood, and other parts of the animals slauglitered went to absolute waste, and as the packing business grew and developed, and they learned how to utilize the product, the time came when the discovery of the butterine or oleomargarine gave another use for beef fat, certain beef fat, and as a consequence there was a utilization of that product and, as well, another use of the leaf lard of the $\mathrm{hog}$, and in that way the matter has grown and developed, and has presented a good food for the liuman family, and we have found a natural demand for it, and we believe it to be a pure, wholesome food. We believe there is need for it, that the public demands it, and wants it, because S. Rep. $2043-43$ 
it is a food prodnct within the reach of all, and particnlarly of advantage to that elass of on prople who must ecommize ia their expenses, and must of necessity take pains about their expenditures, and in spite of the growth and development of the oleomargarine industry the butter interests have also grown, anl we feel that there is room enongh for both products in the markets of the wolld, that there is room enongh for both products in this eountry, and we ronsequently believe that any legislation that attempts to put down one industry at the expense of the other is not just legislation.

I am not here to present any particular argument in my capacity for the industry, as my committee has arranged for the presentation of a specially prepared paper by Mr. McCoy, and it is through him that we desire to present our main argument, but 1 r. Walden, a member of our committee, wonld like to be heard in a few words, and I shall be glad to give way to him and subsequently to Mr. MaCoy.

\section{STATEMENT OF G. M. WALDEN, DIRECTOR OF THE KANSAS CITY LIVE STOCK EXCHANGE.}

The Chamman. Just state to the committee in your own way, Mr. Walden, your views on this bill.

Mr. WALDEN. Mr. Chairman and Gentlemen: The president of our exchange has outlined, in a general way, something of the nature and purpose of oul visit. He has told you that $\mathrm{Mr}$. McCoy will follow with the argument.

As live stoek men we are busy. You understand the magnitude of that trade in the United States, and you understand, gentlemen, that we are here in the intelest of that body alone. I care nothing whatever about all the sille issues that may be brought into the question; I look upon it solely in its relation to us as cattle and hog men.

Much has been said and written of this industry of the mannfactnre of oleomargarine. Much that has been said and written, no doubt, has been born of prejudice in one direction or another-local interests, etc. Much has been said about its hurtfulness, its harmfulness as a food. I weigh 230 pounds and have not been sick a day in years. I eat it three times a day and it has never had any bad effect on me.

Much has been said about the eleanliness of food products generally. You gentlemen are all busy men. I take it that you are very murb interested in this problem before you. Would it not be wise for you, as business men, to unrlerstand the subject from personal observation. What I mean by personal observation is to go to the centers of this great industry and investigate its methools, its manufaeture, ete.

My purpose simply is to invite this eommittee as a whole, or any sub. committees that you may appoint, to go to these great centers of this manufacturing interest-Chicago, St. Lonis, Kansas City, and other points in your country-and go through the institutions and learn about the inanufacture of this product. It is simple. There is noth. ing that you can not understand about it from the time the bullock is taken out of the yard, sold, taken to the seales, inspecterl there by your Government inspectors, passed, if you please, and sent to the slanghterhouses. There is nothing that you can not see from the time he is knocked down until this great feature of the butterine or oleomargarine is taken from him, and sent right through the different processes until it comes ont butterine. And if you will come into that locality we gentlemen from Kansas ('ity will furnish you an escort from our exehange, take yon throngh the packing honses, and assist you in 
every way in our power. We will not wine and dine you; we will not go out and get drunk with you, or anything of the kind. I take it for granted that nowe of you gentlemen do such things: we do not in the West. We simply want you to come as business men and understand what the manufacture of this great food product means to the millions who are compelled to buy it, and who can not buy the higher priced butter.

I thank you, gentlemen.

\section{STATEMENT OF JOHN C. MCCOY.}

Mr. McCor. Gentlemen, I am a member of the Kansas City Live Stock Exchange, a commission merchant, a farmer, a stock raiser, and a feeder.

I am one of those persons who believe the Lord made everything for some purpose, and all men for special lines. While I have been trying for a good many years to find out just exactly what I was made for, I learned a good many years ago that it was not to make a speech. And if this committee will pardon me in what I have to say, I would like the privilege of realing.

There is a bill pending before the House of Representatives, viz, House bill No. 3717, known as the Gront bill, which has been referred to your honorable body, and it is for the purpose of discussing that measure we have asked for a bearing. This bill is aimed at the life of a great commercial industry, that of oleomargarine. We believe it will, if enacted into a law, seriously cripple one with which by comparison both oleomargarine and that of its opponent, butter, pale into insig. nificance. I refer to the live-stock industry. My associates and myself, representing as we do the second largest live-stuck market in the world, a market at which was received, during the year $1899,5,963,573$ head of live stock that had a valuation of $\$ 120,946,439$; a market which loans annually from $\$ 20,000,000$ to $\$ 30,000,000$ to the farmers, feeders, stock growers, and ranchmen to assist them in carrying on their industries: a market that had for its patrons during 1899 the stock raisers of thirty-two Statesand Territories, feel that our interests in these measures are of sufficient importance to be our apology for thus trespassing upon the time of the conmittee.

In discussing this bill it is not my purpose to go into the relative merits of oleomargarine and butter as an article of food, as I am willing to leave that to such eminent students of ecomomic questions as Professor Sill weitzer, professor of chemistry, Missomi State University; Prof. G. C. Cillwell, of Cornell University; Prof. W. (). Atwater, Direc.or of the United States A gricultural Experiment Stations; Prof. H. W. Wiley, chief chemist of the United States Department of A griculture, and scores of other's who have expressed themselves on the subject. Nor will $!$ discuss the purity or healthfulness of the two commorlities, as the subcommittee appointed by the United States Senate Committee on Manufactures, of whieh the Hon. W. E. Mason was cliairman, found "that the product known as oleomargarine is liealthful and mutri tious and no furtlıer legislation is necessary." But, even if that were not the case, the most scientific chemists of the National Laboratory are available to this committee for that purpose. Nor will I touch upon the question of coloring matter, whether each commolity has a different material or both the same, whether it be liamless or muliealthful, for that question comlil he settlen within trenty-four honrs to the entire satisfaction of this commiltee by the Goverument chemist just 
referred to. While to my mind the enactment into laws of such meas ures as those moler discuision-laws which pat a prohibitive tax mon one commercial industry for the benefit and upbuilding of another, that permits the introduction of one healthful and harmless ingredient into an article of food in order to make it more palatahle and prohibits the introduction of the same ingredient into an equally healthful and harmless article of food-smaeks of eliss legislation of the most objectionable eharacter, I admit my defieiency in legal knowledge and training and leave that to the eminent legal minds both on this committee and in the country at large. I do not believe there is any donbt in the minds of this committee that the proposed mensure is intended to place a prohibitive tax upon the manufacture of oleomargarine, thus legislating the industry ont of existence. Let us see what effect it wonld have upon the cattle industries of the comitry.

It is a well-known fact that the principal ingredients of oleomargarine are the caul fat of the beef steer, the leaf laril of the hog, pure cream, milk and butter, cotton seed oil, salt, and coloring mitter. In each beef steer there is an average of 50 pounds of caul fat from which the oleo oil is extracterl, and in each hog there is an average of 8 pounds of leaf lard which forms the neutral oil. The market price to day for caul fat for oleomargarine purposes is 10 cents per pound, while tallow is worth 6 cents; leaf fat is worth, for oleomargarine purposes, 81 cents per pound, and for lard 6 cents. There were slaughtered at Kansas City from Jannary 1, 1899, to Jannary 1, 1900, 991,78:3 head of eattle, produeing 49,589,150 pounds of oleo oil, worth to-day 10 cents per pound, a total value of $\$ 4,958,915$. W'e it not for the lemand the manufacture of oleomargarine has created for oleo oil this product would have been sold for tallow, which is worth 6 cents per pouncl, netting for the above production $\$ 2,975,349$, a difference of $\$ 1,983,566$, or $\$ 2$ less to the cattle raiser for each steer slanghtered. There were slanghtered at Kansas City during the period mentioned above $2,700,109$ hogs, produeing $21,(; 00,8$ i2 pounds of nentral lard worth to day $8 \frac{1}{2}$ cents per pound, a total value of $\$ 1,836,074$.

The demand for neutral lard as an oleomargarine ingredient removed, this product would have been solıl for lard at 6 cents per pound, a total value of $\$ 1,296,052$, a difference of $\$ 510,022$, or 20 cents less to the farmer for each hog slanghtered. Thus it can be readily seen from the above figures that had the oleomargarine factories been closed Jannary 1, 1899, it would have cost the eattle and hog raisers marketing their stock at Kansas City for the year 1899 the sum of $\$ 2,523,588$. And this amount does not by any means represent what the total loss would have been, for if all the oleo oil and leaf fat used in this comntry for oleomargarine purposes were to be used as common tallow and larrl, aidd for soap-making purposes, it wonld make an over supply of those commodities, thereby reilneing the market price from 1 to 2 cents per pound, but that is a matter upon which no reliable data ean be given. Have we not a right, therefore, to step in and file our protest against so unjust a measure? But some one may say, that presents a coudition entirely local. Then let us step up to higher ground and take a broader view.

The Govermment report shows that on January 1,1900 , there were in the United States $43,9(02,414$ heall of cattle, of which $16,292,360$ head were mileh cows; and of eattle other than mileh cows, 27,610,054. By the enactment of laws prohibiting the use of oleomargarine each head of those cattle other than milch cows would have a depreciation in value, as shown above, of $\$ 2$ per head, or a total of $\$ 55,220,108$. A gain, the Government report showed that on January 1, 1899-no estimate 
being made by the Govermment for the year 1899 , it having devided to a" ait the census enumeration in Jume, but it is safe to assume that the numbers were approximately the same January 1, 1899, and Jannary 1, 1900 -there were in the United States 38,651,631 hogs. If the leat lard of the hogs of the United States had to be used for lard by the death of oleomargarine, it would mean a depreciation in value of 20 cents per head, a total of $\$ 7,730,326$. Thus it will be seen if these measures become laws, at that instant $\$(92,950,4: 34$ will be taken directly fiom the farmers and stock raisers of the country. To that could be added the vast sums invested in manufacturing plants and the loss in wages to an army of laborers; but that is a field ontside of my domain.

And now, rentlemen, I wish to eall your attention to another phase of this question, and to illustrate it you will find below the number of cattle in the United States as given by the Government report, those States dividerl into three classes, viz, dairy States, cattle-growing States, and States that are agricultural, but having fewer milch cows than other cattle, which I will term Sonthern States:

CATTLE-GROWING STATES.

Arkansas.....................

Texas .....................

Kentucky ...................

Inwa......................

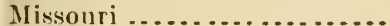

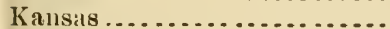

Nebraska ................

South Dakota ................

North Dakota..............

Montana

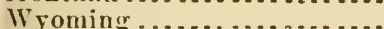

Colorarlo . . . . . . . . . . . . . . .

New Mexico...............

Arizona..................

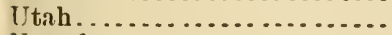

Nevirda ....................

Itlahı ....................

Washington......................

Oregon

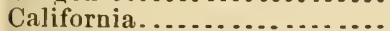

Oklahonia.

Total

$25,001,112$

DAIRY STATES.

Maine

New Hanpshire............

Vermont ..................

Misssichusetts. . . . . . . . . . .

Rhorle Island

419,422

5, 046, 335

539,449

$3,442,012$

$2,047,346$

$2,867,224$

$2,206,792$

879,200

431,371

959.808

747,826

$1,115,421$

679,359

381,861

336,076

238,081

397,928

390,444

637,433

913,753

323,971

\section{ב.}

316,537

214,678

401, 336

254,967

35,405
Connecticnt_.............

210,717

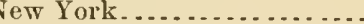

New Jersey .................

Pennsylvania ............

Delaware .................

Maryland .................

Ohio

Michigan .........................

Indiana..................

Illinois ......................

Minnesota .............. 1,237, 003

Total

$14,218,200$

SOUTIERN STATES (MORE CATTLE-GROWING THAN DAIRY).

Virginia ................ 567,488

North Carolina............. 518,141

South Caroliua.............. 260.223

Georgia ................. 666,147

Floridla .................. 412,820

Alabama ............... 511,080

Mississippi................ 517,809

Lonisiana .................. 294,961

Tennessee................ 526, 235

West Virginia............. 408, 198

Total

$4,683,102$

Grand tótal

$43,902,414$

By the above it is slown that seventeen States, all of them in the extreme East, except six which are in the middle West, have $14,218,200$, while thirty-one States in the West and South have $29,(38+, 214$; the six great cattle-growing States of the West, Missouri, Kansas, Iowi,

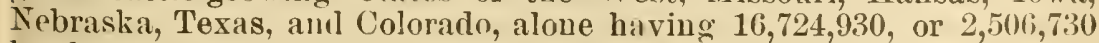
head more than the whole seventeen dairy States combined. Where then, gentlemen, will the burden of snch legislation fall? Nor is that all. Is it to be supmoserl that the stock raisers, farmers, and feerlers of the State of Illinois, with their 1,303,018 cattle, other than milch cows, will willingly consent to have their property depreciated $\$ 2,606,036$ for the benefit of their creamery neighbors? Is it right to tax the stock 
growers of the great State of Iowa-the seeond largest eattle growing State in the Union-with their $3.442,000$ head of "attle, $\$ 4,3.77,458$ to build up the creamery industry of their State? Or the Kansas stockmen contribute $\$ 4,319,095$ to the creamery industry when the total output of butter for the entire state was only \$.5,890,272? Shall the owners of the 1,387,615 head of beef and stock cattle in the State of Missouri consent to a depreciation of $\$ 2,775,230$ in their property when the situte contains only $659,731 \mathrm{mil} \cdot \mathrm{h}$ cows and not one third of those used for commercial purposes, their uses being entirely domestic? The same is true of many of the other States. New York has one-thicd as many other cattle as milelı cows, and P'ennsylvinia one-half as many.

By this bill yon are asked to do three things: Take from the fruits of lahor by depreciating the property of a large class of the American people over $\$ 62,0 m, 000$ that another and a far less numerons class might profit thereby; to 'ripple the industries and retard the growth of thirty-one States and 'Territories of this great Union that a favored few in the remaining seventeen States might be correspondingly benefited, thus helping to establish a commercial sectionalism, to close and destroy one vast hranch of our commercial industries in which are employed over $\$ 5,000,000$ and thonsands of laborers, that a lesser industry, which is unable to compete on fair and equal grounds, might assume to itself the monopoly in its line of trade. The enatment of such laws is a long step toward paternalism, antagonistic to the freerlom of our American institutions and contrary to the principles of our republican form of government. An able writer in a paper on the sulpject of "Food and legislation" before The National Pure Food and Diug Congress, held in Washington March 7 to 10 of this year, said:

The ain of all food legislation should be for the general weal and the pullic health. The tendency of State legislatures is to control by local interests, and the result of this domination is a breed of selfish local statutes whicl tend to block national distribution. The primary object of such provincialism is gain and not the public welfare. Interstate free tracle and free distribution has been thu hoast of our federal system of sovereign States. In spite of this boast Stato lenislatures, influenced by local intrests for the mere purpuse of adclitional profit, are erecting State-line birriers and manacling the internal eommerce of our free system. No wise economist can ask a State legislatnre to lestroy competition, and Congress should not do so. If a thing is an injury, kill it entirely. If loutterine is pure in its constitnent parts and is liealthful food, jt has a free and perfoct right to an unlıam!pererl market.

It is therefore to Congress that the live stock-growers of the country look for protection of their rights and their juterests, and tliey ask and expect absolute fainess and impartiality. The cattle and long growers of the West could with as much consistency ask Congress to put a prohibitive tax on mackerel from the coasts of Maine, the oysters along the Maryland shores, or the fish from the mortliern lakes, thereloy increasing the comsmuption of beef and pork, as well as the ereanery interests to ask the pasiage of this bill.

Bnt, gentlemen, flo the creamery and diriry interests need your fostering care in the shape of special legislation, or is it for the purpose of getting a monopoly on one of the chief necessities of life? Legislate out of existence their only competitor, oleomargarine, and might not the supply of hutter in this country be regulated by the Figin Dairy Excluange as the price of butter is now fixel hor the United States by that institution every Monday molning?

Representative ALLEN. You say that the price of butter "is fixed by that institution every Momblay morning"?

Mr. McCor. That is common lepurt. I suppose it is within the power of this committee to find ont alsolutely whether that statement 
is corrcet or not. It is the general report all throngh omr comtry.and is gencrally understood on the commercial exchinge, and by people generally, that the Elgin Dairy Exchange meets Monday morning and fixes the price at which butter shall be sold throughout the country.

liepresentative AlLwin. For that ensuing weel?

.17r. MaCor. Yes, sir. That is not from my personal knowledge.

Representative ALLEN. It is currently understood?

Mr. McCoY. It is currently understood-common report. I asked as to whether the creamery interests as dairy interests needed special legislation to foster their industry.

Un Jamuary 1, 1890, the number of milch cows in the United States, by (iovermment report, was $15,952,883$, and on January 1,1900 , the number by the same anthority was $16,292,360$. The butter exported finm the United States during 189t, as given by the Department of Agri. culture, was $11,812,092$ pounds, valued at $\$ 2,077,608$, and in $15 ! 15-$-I regiet I have not later statisties-was $25,690,025$ pounds, valued at $\$ 3,5 t 1,765$. Does that, gentlemen, seem to be a waning industry? Now let us look at the other side. On Jamary 1,1890, by the same authority quoted above, there were in the United States cattle other than milch cows 36,849,024, and on Jannary 1, 1900, only 27,610,05. In oflıer words, while the cattle growers were struggliug througb liard times and prices were at such a low ebb as to discourage the growing of lierls to such an extent as to slow a decrease of $9,238,970$, the dairy interests were enabled not only to remain in business, but to increase their lieris 33!, 447. The Orange Judd Farmer, published in the State of New York, an agricultural journal of exceptionally high standing, aud one that has enjoyed the conficlence of the agricultural community for a clecirde, in a recent issue say's:

Cows are worth 50 per cent more now than during the ten years preceding 1897 , and are fully as high as during the boom of 1884-85. Last smmmer cheese got hack to olil-time prices. Butter has of late sold much above the low quotations of funr or five years ago. Even nilk sold in market is stiffening in prices and may go up to the values of the early 80 's, and will go there with organized persistency by producers and reasonable cooperation from the trade.

If I understand the bill under discussion it provides for a tax of one. quartrer cent per pound for uncolored oleomargarine and teu cents per pound for colored, thereby iuferring that uncolorel oleomargarine is a harmless article of food and on the sime plane with nucolored butter, but should pay into the internal-revenue department of the Giovermment a tax of one-quarter cent per pound in orler that the public officials night see, for the benefit of the general health, that it was kept in the best of sanitary condition, but that colored oleomargarine is an mulicalthful aud daugerous substance that should be suppressed by means of a prohibitive tax. The ouly question, therefore, in this bill is, Do the oleo manufacturers use as harmless an ingredient for coloring purjuses as do the creameries; and if so, shall Congress say to one imlustry you sliall not and permit it to be nsed by the other? As this and similar bills liave hern introduced by the creamery interests, as is clearly shown by 1 heil allocacy of the same, we can say to them that it would be of iar graiter benefit to the public health were they to follow the teachings of the Gieat Mastel when he said: "Cast ont first the beam out of thine own eye, and then shalt thou see clearly to pull ont the mote that is in thy biother's eye." It is a well established fact that diseases may be transmitted of a most malignant type from animals to the human system through the medium of foor and drink, and the American people hare cause to congratulate themselves upon the great work that is being done 
and has been done during the past ten years by the Department of Agriculture, through its most excellently couducted Burean of Animal Industry, to reduce that danger to a minimum. While the Burean of Animal Industry, assisted by State sanitary boards, are endeavoring to stamp out and protect the public health from several diseases of miuor importance, there is only one disease among the cattle of the United States to-day that is of sufficient importance to menace the public health, and that is the great arehenemy of the human race, tuberculosis. And, again, we desire to commend the Bureau of Animal Indıstry for the scientific knowledge and successful experiments that enabled it to bring forth tuberculin, with which they are so nobly tighting that fell destroyer. The I) epartment of Agricul ure, appreciating the necessity for vigorous measures for its suppression, said in its "Year Book," published January 1, 1899 :

The bealth of animals and of men is very largely dependent upon the use of sanitary precautions and the enforcement of sanitary regulations. As tuberculosis in animals is reduced, so will the disease in man be proportionately decreased. There is every evirlence to prove conclusively that man may be infected with tuberculosis by drinking the milk from tuberenlous animals.

I call upon this committee to ascertain from the Department of Agriculture if it is not a fact that tuberenlosis exists to a very large extent among the dairy herds of this country, and is of very rare occurrence among the beef herds, and practically unknown among the vast herds of the great West. The State board of live stock com. missioners for the State of Illinois in its thirteenth annual report, issued October 31, 189!, said:

The experience gained throngh tubercnlin tests made in dairy herds by the board since the efficiency aud accuracy of tuberculin as a diagnostic agent has become established points very clearly to the fact that throughout the dairy districts of the State tnberculosis prevuils among the dairy cattle to a consiclerable extent. While in many herds ouly a few cases bave been disclosed, in a large number of herds a considerable percentage has been found affected.

\section{And in another place this board in the same report says:}

The persistency of tuberculosis in remaining in a herd when once introdnced, the certain ultimate destruction through the disease of each affected animal, and its certainty to spread to other animals through contagion, * * * and the dinger that exists of the disease being communicated to human beings throngh the milk or the meat of affected animals, makes the question of effectually dealing with this disease, an effort to eradicate it from among the breeding and dairy herds of the State, one of the first importance to every taxpayer and citizen.

This same board reports that in two years-1897 and 1898-ont of 929 dairy cattle tested, over 12 per cent were found, upon post-mortem examination, to be diseased.

About six years ago the Department of Agrienlture, through the Burean of Animal Industry, instituted the system of governmental inspection of live stock, and at all the principal live stock and packing centers have maintained an efficient and intelligent corps of inspectors. They have gradually improved the service, as experience demonstrated the requirements, until to day it is one of the most valuable branches of the Department. Graduates of veterinary colleges are placed at the head of the varions stations, and the inspectors, with a few exceptions, are under the civil service, and must pass examination for proficiency. Each animal, before being permitted to enter the premises of a slangli. tering establishment, must pass an antemortem examination, and if found to have tuberculosis, actinomycosis (or lumpy jaw), hog cholera, far advanced in pregnancy, or if it is diseased in any manner so as to render it unfit for food, it is condemned. 
At each killing establishment inspectors are stationed who mako post-mortem examination of each head of cattle killed, placing a Government certificate of inspection on each carcass, and in case of hog products for export microseopical examinations are made.

There are no diseases of a maliguant type amoug the beef herds of the United States, and all claims of impurity by foreign countries are like the f'eatures of this bill, mere subterfuges maile for the purpose of alvancing selfish interests, and even if there were the thorough inspection given by the Bureau of Animal Industry, assisted by State sanitary hoards, and such associations as I have the homor to represent, the health of the public would be amply protected. The past three years the cattle inclustry of the country has taken rapid strilles on the road to recovery from the extreme depression which reached its low est point in 1890. A reversal at this time would be of serious consequence to the country at large, especially all that territory west of the Mississippi River. The only two dark clouds that appear on the horizon to threaten the industry are bills before our own Congress, which, if passed, would surely cause an enormous decrease in values, and the bill now pending before tlie Reiclistag of Germany to prohibit the importation of American meat products into that empire.

They are equally uıjust and unwarranted. If the seal of official condemnation is thus placed by Congress upon two of the important prociucts from our cattle and hogs, with what grace or under what pretext can the people of this country demand retaliation on the part of our Government, should the German bill become a law?

The ChaIRMaN. Does any member of the committee want to question Mr. McCoy?

Representative BAILEY. Mr. McCoy, I notice that you make the claim of a certain loss to animal industry on account of the passage of this bill, which, if true, would of course be a very potent leasou why it should not become a law. The National Dairy Association has published a pamphlet in which they take issue with that proposition, and have compiled some tigures to prove that the number of cattle slaughtered in this country and the number of hogs slaughtered in this comntry, as compared with the amount of oleomargarine which is male, would only reduce the price about 20 cents a head. Can you tell us how this would be-why there is such a difference in figures between the Dairy Association and the Cattle Association?

Mr. MoCoy. In this day of close competition and great manufactur. ing interests, every commodity, as I understand it, is bought with a view to what can be brought out of the raw material. If, in these late days, when the killing establishments can use every part of an animal, and, through improved machinery and processes of manufacture, can nse parts that were unavailable before, you reduce the articles that can be manufactured from the raw material in the shape of the beef stcer, you naturally depreciate him in value. I have seen a statement somewhere, probably the one to which you refer, in which they claim that there would be a depreciation of only 20 cents per head, and claim that of the output of oleo product, leaf fat, amounting to in the neighborhond of $80,000,000$ to $83,000,000$ of pounds for the year, orly a very small percentage went into oleomargarine, It seems to me that the foreign demand for this prodnct, the immense amount of this prodinct that is sold outsicle of the United States, has not been taken into account in that estimate. Even if that were the case, I have offered an explanation on that point right at the very last of this paper-that if we ourselves claim that our product is unhealthy, with what grace can we ask another country to come in and accept it and use it? 
Representative BAIlEY. In other worls, then, I nnderstand that your argument is that this amomit of vleo oil is actually manntactured from the animals that are slaughtered, part of it being used in this country and part of it being sent abroad, and that this legislation will put the seal of condemmation upon its use by our comntry, the comitry that produces the great bulk of it for the world, and will only be the beginning of the destruction of the oleomargarine business of the world? You say that the agrarian people of other countries, if we put our seal of condemnation on it, saying that it is impure, will decline to accept it, and the result will be the absolute abolishment of the nse of oleo oil in the production of butterine as it enters into human food? 'l'hat would be the natural consequence, would it?

Mr. McCoy. It would be the natural consequence, I should think. I do not know what amount of oleo oil is produced in Germauy, for instance; bnt if the agrarian party in Germany are able to raise sufficient eattle to supply their own country with oleo oil, they certainly would not use ours if we claim that it is unhealthy and no good.

liepresentative STokes. Mr. MeCoy, I understoon you, in the early part of your argument, to present some figures based upon the operations of the slanghterhouses in Kansas City. Did I understand you, a little further on, to extend those operations or those figures to other exclianges?

Mr. MoCoy. No, sir.

Representative STOKES. I think your estimate was about $\$ 2$ a head of cattle?

Mr. MoCoy. Yes, sir.

Representative SToKes. Are we to understand that those same estimates would probably apply to the other sections or slauglitering houses?

Mr. McCoy. Unquestionably; yes, sir.

Representative STokEs. That is a fair estimate, you think, that would apply to any of the slaughter liouses?

Mr. McCoy. I think so. I think the same conditions wonld exist.

Representative STokEs. They buy practically at the same figures that you do?

Mr. McCor. Yes, sir.

Representative STOKFs. And the same prices prevail?

Mr. McCoy. Freights considered; yes, sir.

Representative ALLEN. Your spoke in your paper of condemning cattle by virtue of inspection if found diseased. What becomes of those cattle?

Mr. McCoy. The different markets have different methods of dealing with them. In the Chicago market that matter is under the direction of the Burean of Animal Industry, through its chief veterinarian, an insplector for the State of Illinois, an inspector for Chicago, Cook County, and the secretary of the Chicago Live Stock Exchange. The principle under which they operate there is this: A man is fined $\$ 50$ if lie undertakes to sell a diseased animal knowingly. If an animal is fonnd with actinomycosis, or "lumpy jaw," it is the cluty of the salesman to immediately cut that animal ont from the herd, and place a tag in his ear. Then the committee, whith consists of the persons I have named, representing the Government, the State, the city, and the exchange, meet and decicle from observation whether that animal is sufficiently diseased to render it untit for food. If it is, it is taken to a rendering establish. ment, and put into soap, so far as I know.

If it is a doubtful case, and they are cuable to tell without a post- 
mortem cxamination whether it is so discased or not, the committee rakes the animal to a slaughtering establishnent, and it is killel. A post-mortem examination is then made, and if the animal is diseased sufficiently to be consilered unhealthy, kerosene is ponded over the carcass. If it is the julgment of the committee that the animal is not cliseased sufficiently to render it unfit for food, it is sold in the open market.

In our eity the Government inspectors are all over the yards. They stal:d in the gates as the "attle go to the scales. There are two inspectors at each scale as the cattle run in the wate. Thry examine those cattle, maling what we term an ante-mortem examination; and if, from the appearance of any one of the cattle, they deem it diseased, it is rut ont. Then, after those cattle go to the slanghtering establishment, they are reinsperted under ante-mortem examination; and when they are slanghtered they are inspected post-mortem, as I have stated.

Now, in that post-mortem examination the Department of A gliculture, through its chief veterinarians, opes ating under the Burean of Animal Industry, has sole power to decisle as to whether that animal is or is not so discased as to render it untit for human food. If it is it goes into the rendering tank and is made into soal). If it is healthy it is put on the marliet and sold.

Representative ALLEN. You say that kerosene is poured over it?

Mr. McCoy. That is the Chicago system; yes, sir.

liepresentative ALLEN. If it is found to be diseased?

Mr. McCoy. Yes, sir.

liepresentative ALLEN. Then what is done?

Mr. McCoy. It goes into the rendring tanks for soap.

liepresentative BAlLsy. Mr. MeCoy, the object of putting the kerosene on it is to absolntely nutit it for luman food, so that it ean not be used. It is to prevent any fraud.

Mr. McCoy. Yes, sir.

liepresentative A I.LEN. You do not undertake to say that that would prevent the fat of the animal from being used for oleomargarine, do you?

Mr. McCoy. If you put roal oil all over it?

Representative ALLLN. Yes; can you not extract that by some process.

Mr. McCoy. I do not know, sir. I am not sufficiently posted to answer as to that, but I should not think you comld. Even if that were not the case, the United States Govermment has its official right there, and it is his duty to see that that animal is not used for food; aud the burden falls upon the Goverument.

The CHairuan. The coal-oil process is a local law, a local ordinance.

Mr. McCoy. Yes; in Chicago.

The CHairnaN. And it was enacted beeanse a large crowd of fellows got togethir and sold the carcases, and shipped them down to the Ful. ton street market, and sold them there. 'Tlue iden of pouring the oil over it was to prevent it frum going down to linlton strect.

Representative BAILEY. Mr. MeCoy, may I ask you a question? Do you consider it impossible to get diseased meat, or the produet of any part of the animal, unon the market for sale as food muder onr present inspection?

Mr. McCor. No, sir; I do not; nor do I believe that laws generally ahsolutely eradiuate crime. I believe that some men will steal in spite of the laws on the subject. 
Representative BAILFY. In a general way, then-in the general application of it?

Mr. McCor. In a general way, I think it has been a very broad step; and our live stock markets have assisted the Government, and worked hand and glove with it for the past seven or eiglit years to perfect the system; and while there may be some criticism npon it, I am here to say that it has done gool work.

Representative BAILEY. I will say that my experience (and it has been considerable general experience) is that $l$ have never been able to shove one through that had lumpy jaw, or anything that looked bad on it.

Representative ALLen. You do not mean to say that you have had the disposition

Representative BAlLEY. Well, I have turned them over to these Kan-as City fellows to sell them if they coull, but they eut them out, and I lost then. It has been claimed that these cattle go on the market. They do not. I do not believe it "an be done. They are sold for what they will bring. Five dollars a head is what they get out of them.

Representative STOKEs. Mr. McCoy, you referred to the communication of tuherculosis through milch eattle. That disease is communicated through germs, is it not?

Mr. MCCOY. I supuose so, sir. I am not an expert on that question, but that is my understanding.

liepresentative S'Tokes. It has heen impossible, as. I understand, to eliminate those germs from the milk, or to so sterilize the milk as to render it absolntely safe, if the cow from which the milk is taken is inferted with tubereulosis?

Mr. McCor. Yes, sir.

Representative SToKEs. On the other hand, are you sufficiently faniliar with the process of making oleomargarine to know whether, during that process, there is any step taken to eliminate a similar germ from the firt of the cattle?

Mr. MCCoY. Of conrse, not having any chemical knowledge or any knowledge of what degree of heat it would take to kill the germs or hacilli, I can not answer that question positively. I have been through fiacking establishments, however, in the course of my business, where this oleo, this caul fat and leaf lard, is put to a very high point of heat; and it is my impression that the heat is sufficient to kill the germs. Whether it does or not I could not say.

Representative Stores. I aprreliended that at some stage of the process these products were subjected to high temperatures, and I wanted to develop that fact-whether, so far as your information goes, it is a suthicient degree of heat to destroy those germs or not?

Mr. McCor. I should say, sir, that if an extremely high boiling point would kill the germs, they wonld be killed; because I have seen this product boiling at a very high temperature.

liepresentative DAHLE. Have you seen the stuff boiled that the oleomalgarine has come from?

Mr. McCor. I have seen it when it came out of the tanks.

Representative D $\Lambda$ HLE. In a boiling condition?

Mr. MCCoy. I do not know. I lave seen it where they had it in their furnaces, or rather their boilers, and after it is poured into their tanks. I do not know that I have ever seen exactly how high it was boiled or how hard it was boiled. It seems to me it was boiling at a pretty good boiling point as it came out of those furnaces. 
Representative STOKEs. You do not know what the boiling point of those oils is, do you?

Mr. MeCoy. No, sir; I do not.

Representative SToKES. It is ligher, I know, than that of waterhigher than $212^{\circ}$ - but I do not know just what it is.

The Chairman. What Mr. Dahle asked was if you saw it in a boiling condition. When it came from the tanks it was at a high temperature?

Mr. McCor. A high temperature; yes, sir; very hot; but I do not know that I have ever seen it at a high boiling temperature. When I come to think about it, it was up where I could not see that part of it.

Representative SToKES. It has to boil in order to extract the oil, does it not?

Mr. McCor. It had to boil in order to get it to the eonsisteney it was.

Representative AlLEN. What do you think will be the result of this bill, if passed, upon the manufacture of oleomargarine?

Mr. MCCoY. I believe that the first result, as a matter of course, will be the closing of the oleomargarine factories.

Representative ALLEN. You think it will prohibit the manufacture of oleomargarine?

Mr. McCor. I think it will, sir; that is, it would not absolutely prohibit it, probably, but it would destroy it.

Representative Allen. You mean the legitimate manufacture?

Mr. McCoy. The legitimate manulacture. It would, in my opinion, destroy that. If those factories are closed I think a great many laborers who have made that a special study, a special line of business, will be thrown ont of employment.

Representative Allwin. You live at Kansas City, I believe?

Mr. McCoy. Yes, sir.

Representative ALLFN. Have you ever heard any complaints on the part of the consumers of oleomargarine?

Mr. McCoy. None whatever.

Representative ALLEN. Of it as a food product?

Mr. McCoy. No, sir.

Representative ALLEN. Is there any complaint that eomes from your section of the country with reference to oleomargarine?

Mr. McCor. I do not recall that I have ever lieard of any complaint in regard to it. There might be individual cases where there might be, in the case of some man whose taste was prejudiced.

Representative STores. You are referring to the consumers?

Representative Allen. Yes; of course.

Mr. McCoy. There has been no organized complaint.

Representative ALLEN. Now, do you know anything about the retail sale of it in your city?

Mr. McCoy. No, sir; except that I know it is sold very largely.

Representative ALLEN. Have you ever bought any?

Mr. McCoY. Yes, sir.

Representative ALLEN. For consumption in your own family?

Mr. McCoy. Yes, sir.

Representative ALLEN. In what kind of packages?

Mr. McCoy. Square-brick packages, about that long and that wide [inclicating abont 3 or 4 inches].

Representative ALLEN. What weight?

Mr. McCor, I do not remember-probably pound packages. 
Representative Alten. Wrapped in paper?

Mr. MoCoY. Yes, sir.

Representative ALLEN. Did you notice any stamp upon that paper charaeterizing it as oleomargarine?

Mr. MaCoy. Yes, sir.

Representative ALLEN. What position did that stamp bear upon the paper? Was it where it could be seen, or was it eoncealed?

Mr. McCor. Yes, sir; it was generally wrapped $u p$ in the shape of a briek aud folded at the end, with the brand upon it. Some paekages bear one brand and some another.

Representative ALLEN. Was that plain to be seen by the purchasers? Mr. McCor. It was whenever I have bought it.

Representative ALLEN. As far as you have bouglit it, and as far as you have observed the sale, is that the custom that prevails in your country, in the sale of oleomargarine, in the way of exhibiting the stamp?

Mr. McCoy. Well, I am unable to say whether it is sold out of the tub or not. I never bought any out of the tub.

Representative ALLEN. I mean in the different places where you have bought it-the different stores-is that the way it is sold?

Mr. McCor. Yes, sir; but, as I say, whether those same stores use the tub, the bucket, or not, I do not know. I have only bought it in bricks.

Representative AlLen. What do you think of it yourself as a food article?

Mr. McCoy. I think it is a very good artiele of food.

Representative ALLEN. What is the retail price of it in your eity?

Mr. McCor. It varies at different times, aecording to quality, from 15 to 22 cents.

Representative AlLEN. From 15 to 22 cents a pound?

Mr. McCoy. Yes, sir.

Representative ALLEN. What is the price of ereamery butter there? Mr. McCoy. We very frequently buy it for alnost the same prieea little bit more.

Representative ALLEN. Have you had any occasion in your own family to compare the relative merits of the two products? If so, what has been the result?

Mr. McCoy. Well, no, sir; not as an experiment.

Representative ALLEN. Did I understand you to say that you were a cattle dealer-shipper-a seller of cattle and a seller of cattle in the market?

Mr. McCoy. Yes, sir; my prineipal business is that of a live-stoek commission merchant. My brother and I together rmn a farm where we feed cattle, raise cattle, feed hogs, and raise hogs.

Representative LAMB. Mr. Chairman, ean I ask a question?

The Chairinan, Yes.

Representative Lamb. Yon stated a while ago that the probable effeet of the passage of this bill would be to close the oleomargarine faetories. Now, what is the present tax npon that article? Is it not 2 cents?

Mr. McCoy. I think so, sir.

Representative LAMB. Does not this bill rednce it to one-quarter of a cent?

Representative Allen. That is the micolored oleomargarine, I would suggest.

Representative LAMB. That is what I am getting at. If the manu- 
facturers are able to live mosperomsly, as they seem to be doing, muler a tax of 2 cents per pombl, will they not prosper umder a tax of one. quarter of a ceut?

Mr. McCox. 'They should, if the article were as palatable in its light color. As we all know, it is uaturally white.

Representative LAџB. Does the fact of its being colored make it more palatible?

Mr. McCor. 1t would very much to me, sir; I suppose it would to other people.

Representative LAлв. Is it not a fact that when it is colored, it is a fraud apon butter, an initation of butter?

Mr. McCor. I do not know that it would be, if it is sold muder its name. Probably ten, twelve, or fifteen years ago the public might have been imposed on in that way; but I do not suppose in this day there is a person in the country of even ordinary intelligence who does not understand that it is male; and it is not sold as butter.

Representative $\mathrm{L}_{\mathrm{A}} \mathrm{MB}$. But is it not a fact that the same article, out of the same vessel, is being sold loth as oleomargarine and as butter, now, in all of the commercial centers of this country? Is not this identical article sold both as oleomargarine and as butter, accord. ing to the request made by the consumer of the merchant?

Mr. Mc(jor. I do not kuow, sir; I am not posted on that subject.

Representative LАлв. 'Tlose facts seem to have been brought out here, and I know from my personal knowledge that they do exist. I simply asked those questions to see how the current trend of thought upon that subject is. I am only an inquirer myself. That is all I wanted to ask.

The Uhalrman. You said, Mr. McCoy, that it is possible to place a diseased carcass on the market. Is it possible for a diseased carcass to pass into the bands of those who use the fat for oleo oil?

Mr. MCCoy. Not from a killiug establishment. Of comse, Mr. Chairman, some man in the comtry districts of Illinois, at some place, might kill his own stcer, and, umler cover of night, slip in and scll it to some oleomargariue firctory in the eity of Chicago; and it inight slip through in that way. Of course, it is possible for that to oicur.

The CHAIRMAN. Is it possible to work in a diseatsed earcass in the institutions where the great bulk of the slaughtering is done in this country?

Mr. MaCor. No, sir. If it is done, it would have to be done through the negligence and carele-sness or the corruption of a Government official.

Representative STokEs. But in case suclı a carcass sliould get into the jossession of the oleo maker.as I unilerstand the matter, the product is subjected to a very high temperature during mannficture?

Mr. McCor. That is my nuclestanding, sir. Frmm what I have seen of the factories, I think it is put to a very high boiling joint.

Representative DAHLE. Mr. McCloy, do you make any allowance for the amount of oleo nil that is exported, or may be exported, in calculating, as you do, the loss tu the firmer in ease this bill sliould bo passed? As I understand, (mly a smill part of the oleo oil which is made in this comntry is used hire, and the larger amonut is exported. I can not see where you make such an allowance. Do you?

Mr. Mlcloy. No, sir.

liepresentative DAILF. Wonld it not be fair to make sucl an allowance, linowing, as we do, that by far the larger part is exported? Is not that the case? 
Mr. McCor. That is my understanding, that the larger percentage of the maunfactured oleo product is exported.

Representative STOKES. Withont attempting to anticipate the gentle. man's answer at all, I would like to supplement the question by this inquiry: Is it not a fact which is generally recognized with regard to all export commodities that the price of the exported part is really the principal factor in lletermining the local price?

Mr. McCoy. As a general rule that is the case, yes, sir; because it is the only way of getting rid of our surplus.

Representative IAHLE. About how much is exported in proportion to what is used here, if you can tell?

Mr. McCoy. I can not tell, except from a statement I have seen. I may be wrong in my recollection of it, but I think I saw it stated that $132,000,000$ pounds were exported in 1898.

Representative DAHLE. And about what amount would be used here?

Mr. MCCor. And 83,000,000 pounds of oleomargarine were manufactured. Now, that is my recollection of it, and I may be mistaken.

Representative DAHLE. If $83,000,000$ pounds of oleomargarine were manufactured in that yeir, then only a small fraction of the total amount of oleo oil made was used here at home?

Mr. MoCor. Exactly.

The Chamrian. Your contention, then, is that if you put the stamp of disapproval on the article in this country it will drive it out of the export trade, and liave the effect of redncing the value of that steer fat to the value of tallow?

Mr. McCoy. That is the point which I made in the last part of my argument.

Representative DAHLE. Mr. McCoy, along those lines let me ask this question: In your opinion does the feeling igainst this bill come from people who are afraicl of oleomargarine, claiming that it is not health. ful, or does the feeling come fiom the manufacturers of butter? Do the remonstrances against this bill, in your opinion, come from the pro. ducers of butter or from health officers?

Representative SToKEs. And the people?

Representative DAHLE. And the people, along these lines; yes.

Mr. MCCoy. Yoll say there are remonstrances against this bill?

Representative DAHLE. Yes; or, rather, we get prayers asking for its passage.

Mr. McCor. And some against its passage.

Representative DAHLE. Now then, do those come from the farmers, do you suppose, who produce butter, or who produce the milk that is made into butter; or do they come from other sources?

Mr. MCCoy. You say you get petitious favoring its passage? I suppose they would naturally come from people in dlairy districts, who have milch cows, and sell their milk to creameries, and make their own butter. The protests from our country, however, come from the cattle raisers, the farmers, the feeders, the stockmen, and the manufacturers of oleomagarine.

Representative BAILEY. And the men who sell it?

Mr. MCCoY. I do not know that there lave been any official protests, so far as that is concerned.

Representative BAILEY. Well, there have. I have received them.

The Champin. Now, you are a consumer. Will you protest, as an individual consumer, on the ground that you onght to have the privilege of buying colored olemuargarine?

Mr. Mc Loy. Yes, sir. I think if it is a pure and healthful article of 
food-and it is within the province of this committee to determine that fact-and call be sold for a less price than a hicher valued product, I believe every man has got a right to buy it if he wants to.

Representative Lamb. Mr. McCoy, are there not three classes, so to speak, advocating the passage of this bill-first, the clairy; second, the small farmer throughout all the rural districts of this ('ountry; and third, the man who sells this article, the butter merchants in all the towns? From the hearings at which I have been present and the observations that I have made upon both sides, I have been convinced that those three factors enter into the application here for the passage of this bill-the dairyman, the small farmer (and the large farmer, so far as that is concerned, the butter maker), and the man who sells the butter in the town. I gather that from observations in my own rlistrict and from telegrams received this morning. I have received half a dozen or more telegrams this morning from men who sell this butter to the working men and the laboring people. Now, if any protests come from the consumer, it seems to me they would reach us through the man who sells the butter to the cousumer.

Representative ALLEN. I will ask the gentleman from Virginia, right there, if his district ships any beef cattle or sells any beef cattle on the market?

Representative LamB. A good many people in my district fatten beef cattle and sell them.

Representative ALLEN. And ship them to the market and sell them?

Representative LAMв. And ship them to the market.

Representative ALLEN. Do you know the amount of the exportation?

Representative LAIIB. No; but it is nothing in comparison with your district, for this reason: My district was a storm center of war, and it never has recovered from it, while along the rivers, the James River, etc., there are numbers of men engaged in the cattle industry. They not only raise them, but they buy a great many steers in the fall to fatten. They feed their corn and hay to them in the fall and winter, and turn them on the grass in the spring. Some of the best people in Richmond buy those cattle raised in my district.

The Champinan. Mr. Lamb, you say there are three elements. Now, after all, are not the man who milks the cow, who produces the nilk, the dairyman who makes the butter, and the agent who sells it for them in the city, all one interest, and not three interests?

Representative LАMB. I did not say they were separate. As I say, they are three factors.

The Chairman. Three factors of one interest?

Representative LAMB. Yes.

The Chairman. Just like the clerks and the teamsters

Representative LAMB. There is a community of interest, yes, sir.

The CHAIRMAN. It is one interest; without any element of it, any one element, there would be no interest.

Representative STOKES. I wonld like to ask the gentleman one question inyself, growing out of his remark.

1 epresentative LAMB. I do not know that I am on the stancl. I am getting information here. This is the first time I have not had an opportunity to hear the otlier sile. However, go oll.

liepresentative STOKEs. I thought the gentleman was giving us a little testimony a while ago, from his personal knomledge. 'That is the I alson I ask.

I mirsentative I.AMB. Yes: I will hear you on that point.

licpresentative STores. The question I wanted to ank you was this: S. Rep. $20 \pm 3-44$ 
The gentlemen seem to assume that the country merchant, the local merchant, the local groceryman, who sells this butter or butterine to the consumer, is the monthpiece of the consumer-that their interests are identical.

Representative LAMB. To a certain extent.

Representative SrokEs. It seems to me that in the general conception, they are considered to be diametrically opposed-that is, that the seller and buyer are usually on opposite sides of the proposition.

Representative Lamb. Yes. Well, I mean by that that the most natural thing in the world would be for the seller of that butter to respond quickly to the demands of his customer. If his customer preferred this manufactured article to genuine butter, he would say to him, "WVe prefer this oleomargarine, and we will buy it." The fact of the business is that it is not se.

Representative BAILEY. Let me give a little personal experience on that subject. I have spent parts of two days in this market here. I have made two trips down through it for the purpose of getting information on that very point. I went down there absolutely incognito; and I tried my best to buy oleomargarine for butter. I went to this place and to that, and did my best to do it, without their knowing a thing about-

Representative LAMB. What did you ask for?

Representative BAILEY. I asked for butter. I would say, "What do you sell your best creamery butter for?" "Thirty-five and 40 cents." "What have you got some other grade for?" They would say that they had a cheaper grade down to 28 cents; and I think the lowest butter I saw or had priced to me was 25 cents. When it got below that, it was oleomargarine or butterine every time.

Now, I was unable in that market to buy a single pound of it; and I could not get a single man to admit to me down there that it was sold-not a single man. Now, I want you to go down there, Mr. Lamb. I will tell you what I will do. I will bet you a \$5 bill that, if you choose to try it, you can not get one of those men to sell oleomargarine to you for butter.

Representative Lamb. Do you know the reason?

Representative BAILEY. I do not know; I suppose the reason is that it is a violation of law. That is the reason they gave me, that it is a violation of law, and that the law was enforced.

Representative LAMB. I understand that the law is not euforced.

Representative BAlLEY. Does not that settle the whole thing?

Representative ALLEN. Will not the enforcement of law remedy the whole thing?

Representative LAMB. Is not this law trying to supplement the State acts in doing that very thing? There is not a better law in the 32 States than Virginia has got on her statute books in regard to this matter, but it seems to be utterly impossible to enforce it for some reason or other.

Representative ALLEN. Because it is against public sentiment. The consumers do not want it enforced. That is the reason.

Representative LAмв. Well, I do not think it is against public sentiment in my State. I can not tell the public sentiment everywhere, of course.

Representative BAILEY. You know, personally, that that is the case in your section, do you?

Representative LaMB. Oh, yes.

Representative DAHLE. I notice that the gentleman had something to say regarding the value of milk made into butter, or of the value of 
butter, since the introduction of oleomargarine. I believe you quoted that up to 1890, and stopped there. Now, what bas been the tendency of the price of milk during the last ten years, especially during the winter months, since oleomargarine got to be more and more commonly used?

Mr. McCor. I am unable to say, Mr. Dahle, because I have never looked the question up. But, if you will remember, l dealt with it in a general way. I stated that while the dairy people had been able to hold their own and increase their dairy herds, the cattlemen had suffered a depreciation of over $\$ 9,000,000$ by reason of hard times, and there was not money in the business, and it drove them out of it, while the indications were that the dairy men had been prosperous, because they had increased their herds in the State of Nebraska-

Representative DAHLE. During what years?

Mr. McCor. From 1890 to 1900.

Representative DahLE. But now I know that the price is differentthat the value of milk has gone down.

The CHAIRMAN. How much?

Representative DAHLE. It is luarl to say how much.

The ChaIrman. How much was it prior to 1890 ?

Representative DAHLE. Well, it ranged differently, but anyone who has handled butter knows this, that butter has been Iower during the winters of the past two years than it was. There has been a deeline. This winter it is higher, but there has been a decline, nevertheless. Instead of the market going up, as you suggested there, the market, since 1890, has been going down.

The Chairman. The market for milk?

Representative DAHLs. The market for milk in the winter months.

The Chairiran. It costs just 1 cent a quart more to buy milk in Chicago now than it did two years ago.

Representative DAHLE. That is very likely; I know nothing about that; but it is milk made into butter in the country that I am speaking of. I happen to have dealt in milk for these many years, so that I know whereof I speak.

The CHAIRIAN. I have been feeding a family of about 15 for a good many years aud I know whereof I speak, too.

Representative DAHLE. I have handled 1,000 pounds, then, for every 1 your family has purchased.

The Chairman. But you have not paid for it as I lave.

After informal discussion among members of the committee, an adjourument was taken until Wednesday, April 4, 1900, at 10 o'clock a. $\mathbf{m}$.

WEDNEsday, April 11, 1900-10.30 a. $m$.

The committee met at 10.30 o'clock a. m., Hon. W. Lorimer in the ehair.

The Charrman. Mr. Aldredge, the committee will be glad to hear your views on the Grout bill.

\section{STATEMENT OF GEORGE N. ALDREDGE.}

Mr. Chairman and Gen'plemen of the Commitem: I have made some notes with reference to the discussion, and I am afraid that I will occupy too much of the committee's time. There are representatives 
here from Texas, Arkansas, Tennessee, and Mississippi, and I would be glad to hear from all of thein; and I hope the committee will cut me off in time to give these gentlemen ample opportunity to be heard.

I desire to be entirely candid with the committee. I have a little stock in a cotton seed oil mill, and was appointed by the Oil Mill Association of the State of Texas to come here as a delegate. But my interest as a farmer, raising the seed itself, is fifty times as great as my interest in the oil mill. In ordinarily good seasons I raise about a thousand bales of cotton a year, and this question affects me vitally.

Gentlemen, every section of this country within the last three years has become prosperous, except the cotton-raising South. The wave of prosperity has never struck that section. Its people are as poor to day as they ever have been. And why? They have heen making cotton at $4 \frac{1}{2}$ and 5 cents per pound. No man can do that and do more than barely live. It is a life and death struggle for his very existence. The manufacturing interests have prospered; the cattle interests have prospered; all interests have prospered, except the man that raises cotton and sells it at $4 \frac{1}{2}$ and 5 cents.

There has lately been a little spurt in the price of cotton, owing to an exceedingly short crop. But, gentlemen, the farmers of the South, the men wh" till the ground, did not get the benefit of that rise. 'They are poor people; they were in debt to the merchants. They had to sell their cotton early in the season for 6 cents; and the merchants and the bankers and the specnlators have reaped the benefit of the rise in cotton, and not the men that made it.

I desire to slow you briefly what a cotton farmer has to contend with. I mean a tenant farmer. The great bulk of them are negroes.

He can cultivate abont 40 acres of land. Say that he puts half of that in corn. The corn will only furnish bread for his family and feed his pair of mules or horses and raise the pigs for his family. Very few of them ever sell corn in the Sontl. Now, on the other 20 acres he raises 7 bales of cotton. That is a little over one-third of a bale to the aere, and that is a good average for the whole South. Those 7 bales of cotton, at 5 cents a pound, are worth $\$ 175$. From those 7 bales he gets 31 tons of seed, worth $\$ 10$ per ton. That is $\$ 35$. Then his whole crop nets him $\$ 210$. But he pays from $\$ 2.50$ to $\$ 3$, say $\$ 2.50$, an acre rent on the 40 acres. That takes out $\$ 100$, leaving him net for the services of himself, a pair of mules, a wagon, and all of his family of women and children working during the fall picking this cotton, 30 cents a day for the whole fanily.

Now, you are having strikes all over the North by men who earn from $\$ 2$ to $\$ 5$ a day. And yet here are a class of people who are striving to live and support a family npon 30 cents a day for the whole family. These are the people that I represent before you.

Last Christmas eve, a year ago, I received a telephone message from my plantation manager. My plantations are near Hern. I live at Dallas, 140 miles from there. I received a telephone message that the town was full of my negroes, and that they wauterl money to buy a bottle of whisky. They did not have it. Now, these negroes had worked faithfully. I had no complaint to make. In the winter storms and in the heat of summer they had bent to the plow and the hoe, and they had lived on cornbread and bacon and cheap molasses throughout the year. They had made 985 bales of cotton, and yet they could not buy a bottle of whisky to get drunk on at Christnias. Well, I telephoned ny manager to buy every one of them a bottle, on the ground 
that under the Constitution and laws of the United States and of the States, a mau had an inalienable right to get drunk on Christmas, and I furnished it to them. [Laughter.]

Now, gentlemen, I feel that we of the South have been stepchildren of this Government. For a hundred years we have been paying the indirect import tax on almost all that we used for the benefit of the factories Nortl. We have been paying the fiddler for a hundred years, and have never been allowed to dance in the set. But after a while we discovered that there was money in cotton-seed oil, and all over the South we built up cotton-oil factories. But as soon as we did, why, here comes the dairy interest, the curled darlings of the nation, and says, "You shall not produce a product that competes with ours." That is the proposition. Why, do you know that we are paying taxes to-day on olive oil from Italy, high taxes-why? Because there are a few olive orchards in California. TVe have more cotton interest in one county in Texas than they have olive interest in the whole State of California. See how anxious the Government is to protect every interest in the Government until it comes to the poor devil of a cotton man.

Yes, sir; we began manufacturing cotton seed oil. One of the products of cotton-seed oil is oleomargarine. Now they say, "Because, forsooth, oleomargarine competes with our product, we, the Imperial Cow-Milkers of the United States are to be protected by this Government against the poor cotton farmer."

Well, if our own Government is going to kick us, that teaches all of Europe to kick us. Any mother that kicks her own child licenses the whole world to kick and cuff' it. And they will quickly follow suit. We are in competition over there with the nlive interest, mainly of Spain and France; and they will kick. We thought it horrible that those Dutchmen over there objected to the importation of our meat against them; yet they are foreigners to us.

Now, it is not the best butter makers that are in this fight against oleomargarine at all. We do not compete with the Elgin people. They do notcomplain of us. There are rich people all over this country that are going to have butter, and pay for it; and we are not, in competition with the elass of butter they buy. But when you go down to the low grades, then we are; and they are the people that are complaining to day. I heard Bob Ingersoll make a speech at Forest Garden in 1596 , in the political campaign. IVhile I wanted to throw a rock at him all the time he was talking, some things he said have stuck to we. I remember a picture he drew of a horse race. He said: "Here is a fine race horse, with flashing eye and nostrils distended, and sinews of steel, reatly to outfly the wind." He said: "The owner of that horse does not object if someborly wants to put a mule in the race. But," he said, "every owner of a little scrub, who doesn't believe he ean beat a mule, and is contesting for second, third, or fourth money in the race, objects to competition with a mnle." And to day the best butter makers of this comntry, the clean butter makers, are not in this fight against oleomargarine; but it is these men that want to offend the nostrils and vitiate the taste and poison the stomachs of men with inferior butter that are elamoring here to Congress to shut out a perfectly pure, clean product, with which they find they can not compete. 'That is the sitnation.

What is oleomargarine, gentlemen? Now, I am going to read two certificates from gentlemen right here in the city. One is from Professor Atwater. It is ouly a few lines: "Butterine" (which is oleomarga- 
rine) "is perfectly wholesome." This is from Prof. W. O. Atwater, Director of the United States Government Agricultural Experiment Station, Washington, D. C.

Butterine is perfectly wholesome and healthy and has a high nutritive value. The same entirely favorable opinion I find expressed by the most prominent European anthorities, English, French, and German. It contains essentially the same ingredients as natural butter from cow's milk. It is perfectly wholesome and healthy, and has a high nntritive valne.

The other is from Prof. Harvey W. Wiley, Chief Chemist of the United States Department of Agriculture:

There can be no reasonable objection to the use of oleonargarine. It is clean, wholesome, and digestible. When it is to be kept for a long time before use, as on shipboard or in distant mining camps-

and he miglit have said, in the Army-

it is preferable to butter, because it has but little tendency to become rancid. For similar reasons, there can be no possible objection to the use of cotton-seerl oil as a substitute for lard, or when mixed with lard.

Now, here are certificates from the greatest chemists in America and Europe outside of the ones that I have read; but I will not take up your time with reading them.

Representative WILLIAMS. Just hand them, if you please, to the stenographer, so that they may be made a part of the record.

(The certificates above referred to by the wituess are as follows:)

Prof. G. C. Caldwell, of Cornell University, says:

The process for making butterine, when properly conducted, is cleanly throughont, free from animal tissne or other impurities, and consists of pure fat, made up of the fats commonly known as alaine and margarine. It possesses no qualities whatever that can wake it in the least degree un wholesome.

Prof. Panl Schweitzer, Ph. D., LL. D., professor of chemistry, Missouri State University, says:

As a result of my examination, made both with the microscope and the delicate chemical tests applicable to sucb cases, I pronomice butterine to be wholly and unequivocally free fiom any deleterions or in the least objectionable substinces. Carefully made phrsiological experiments reveal no difference. whatever in the palatability and digestibility between butterine and butter.

Dr. Adolph Jolles, of Vienna, from address before section 7 of the International Hygienic Congress at Budapest, says:

As regards nutritive valne, pure butterine or oleomargarine is as digestible and nutritious as pure butter.

\section{Prof. George F. Barker, of the University of Pennsylvania:}

Butterine is, in my opinion, quite as valuable as a nutritive agent as butter itself. It is perfectly wholesome and is desirable as au article of food. I can see no reason why bntterine should not be an entirely satisfaetory equivalent for ordinary butter, whether considered from the physiologieal or eomuercial standpoint.

Prof. S. W. Johnson, director of the Connecticut Agricultural Experiment Station, and professor of agrieultural chemistry at Yale College, New Haven, says:

It is a product that is entirely attractive and wholesome as food, and one that is for all ordinary and culinary purposes the full equivalent of grood butter made from cream. I regard the manufacture of oleomargarine as a legitimate and beneficent industry.

Dr. A. G. Stockwell, who needs no introduction, says in the Scientific American:

In everyday life butter is very essential. Its free nse lyy sufferers from wasting diseases is to be encouraged to the utmost. Comsirlering the foregoing, it seems 
strange that oleonalyarine has not been thought of as a palatalule aud suitable article of diet for thust: sutfiring firm wasting aliseases.

It is free from all objections. As a malter of lact, it is a hetor and purer butter than nine tentlis of the dairy prodnet that is marketed, mol me that is far more easily preserved. There are a large number who inatine oleomargarine is male from any old serilys of grease regardless of a lge or cleauliness. 'The reverse is the fact. Good oleo can only be had by employing the very best and freshest of fitt. 'This artificial butter is as purely wholesome (and perhaps even better ay food) as the best dairy or creamery product.

Jollies and Winkler, the official ehemists of the Austrian Government, after thorough investigation of butterine, reported:

The only germs fonnd in "oleo" are those cummon to air aud water. Althongh carefully searched for, tubercular bacilli and other obnoxions bacilli were conspicuons by their absence.

Mr. Aldredge. Now, when these inferior butter makers strike the ehemist they always dodge. I have seen a mule that was beaten over the head by a negro nutil every time a man raised his hand 50 yards away from him he would commence to dodge him. And you can't get one of them to talk abont a chemist. Whenever he gets in the neighborhood of a chemist he says, "Well, he don't know." Why, that is what they are liere for. The chemist is the highest product of science; and he is liere to tell us what is in every article about which we want to ask him. And yet they say, "He don't know." They dodge him every time.

Now, gentlemen, I will elevate this butter crowd. I will agree that their product is prerfectly pure. That is agreeing to a great deal. I was raised on a finm, and my business when I was a boy was to mind the ealf off and hold him oft" while the cow was being milked. It is clone in a little pen; and the cows drop a great deal of manure. That is all gromnd up. You can not milk them in a big pen. That manure is all ground up and in the air, and they are walking to and fro; and I ('an show you certificates here fiom a dairyman in Iowa where he found that vory stuff in his milk, and complained about it. But we will grant that they are making a pure prodnet. Then what? Here is a contest between two perfectly pure, wholesome articles of food. And one party says, "Stop the manufacture of the other!"

Now, why shonld the Government be called upon to interfere in such a contest as that? Why should the Government be called upon to take one man's business in its liand, aud lilt it up and put its hand upon the other and sink it? Gentlemen, government among men never was organized or contemplated for such a purpose as that-never.

There is lorlged in every man's breast an innate love of justice. You can take the vilest criminal, and eliminate his self-interest, and it blazes in his bosom. No man can erallieate the love of justice. lioloert E. Lee said: "The biggest word in the English language is duty." Well, he was close to the mark, but there is one bigger word than that, and that is justice aud fair dealing among men.

Now, sir, if I were to see a dog fight out in the street, and if I were to see one man go and take hold of the leg of one of those dogs and hold him while the other one chered him up, I would have a contempt for thit man as long as I lived. Suppose there was a boat race between Yale and Harvard on the Hndson liver, and they had been practicing for months. Suppose the river was lined with a vast multitude to see a fair contest. and just before they started here wonld arrive a brassbuttonerl officer, sent by C'ongress to tio a log to Yale's boat. Wery man, woman, and child on the bank of that river would curse this 
Government with curses loud and deep for such an act of ipfamy and injustice.

Yet, gentlemen, that is precisely what you are asked to do by the curled darlings of the dairy. They will admit to you, and they have done it before your committee, that this product of ours is pure, it is healthful, it is nutritious; and yet they say, "Because it competes with us, kill it!"

Now, I know that there are a lot of Congressmen going to vote for just such unjust and outrageous legislation as that. T'hey have got to do it. They live in a dairy district. They have got to put their conscience deep down in the seat of their pants, and sit on it while they vote, too. It is vote that way or lose their place. Well, maybe I would do the same thing; I don't know. I hope to God I never will be tempted that way.

Now, these dairymen are wealthy. They tell you how much they control. They appropriated $\$ 14,000$ lately for this campaign; and every little dairyman that milks a cow in the United States has run around and gotten all his neighbors to sign a petition; and yet, to day there are not 20 per cent of them who can remember ever signing a petition, or who know what was in it when they did sign it, and yet they have flooded your committee with these petitions.

Now, gentlemen, is there any reason why this unjust legislation should be accomplished? Why, butter is higher to day than it ever was. It is higher than it was forty, twenty, or ten years ago; and the can not supply the demand. I see that New York is short of butter all the time. They want a monopoly, so that they can put their prices out of sight; and when they do, they want the people that are not able to pay for it to be denied this wholesome article of food. These dairymen are already immunes from smallpox, and they ask of the Government to give them immunity against competition. That is their position. Now, who are on the other side? Why, the dairyman himself is halfway on the other side, because the value of every bull calf born on his farm is increased by the manufacture of oleomargarine. He does not knowit, but he is. In the first place, these cotton farmers that I have been telling you about are on the other side. The oil mills, the recent development all over the South, are on the other side. The butterine makers are on the other side. The mannfacturing establishments all over the North, that make the machinery for the oil mills, are on the other side. The mill in which I am interested bonght its machinery in Ohio, bought part of its apparatus in Chicago, bought another part in Massachusetts, and bought something from almost every portion of the North. Those people, those manufacturers, are on the other side. The cattlemen are on the other side. I do not know about it myself, as I am not a cattleman. But the southwest cattle convention that met at Fort Worth declared that the manufacture of oleonargarine added about $\$ 3$ to the value of every beef steer raised, and they protested, in the strongest terms, against this legislation. The hog men are on the other side, because butterine or oleomargarine is made from the very purest, best fat of the beef, the very purest, best fat of the hog, cotton seed oil, cream and butter, churned together. And the laboring men, all over this country, are on the other side.

Gentlemen, the tirst thing I did yesterday morning when 1 reached Washington City was to go over to the market. I found two stalls there, butterine stalls. There are quite a number of butter stalls, but I found two butterine stalls. One of them had in great gilt letters over it, "Only butterine sold here." The other had a great glass sign 
with "Butterine" on it that could be read almost a quarter of a mile away. I interrogated the first man. I said, "How is your business?" He said, "It is good. I think I sell more than any of these butter fellows." "Well," said I, "why do your people buy butterine instead of butter?" Said he, "I will tell you. Yon see, this bntterine is 15 cents a pound. They can't buy butter as good as this for less than 30 or 35 cents a pound." He said, "Poor people buy this; it suits their taste, and it suits their pocketbook."

I went to the other stall aud asked the dealer, "How is your business?" "Good." Said I, "Who bnys from you?" "Well," he said, "a great many poor people; but," he said, "don't you think they are only poor people." He said, "A great many people who are amply able to pay for butter patronize me." "Well," said I, "why do they do that?" "Well," he said, " our product is uniform the year round, and you can't get that in butter. Our product is inspected by the Government, and guaranteed as to its purity; and," he said, "a great many people who want a good article, and a uniform article, all the year round, patronize me."

Gentlemen, all the butter men in the United States can not answer the arguments of those two men.

You cut off the butterine indnstry and what are a great many labor. ing men who work for $\$ 1$ and $\$ 1.50$ a day and have a big family going to do? It seems that generally the less able a man is to take care of a family the more family surrounds him. Now, take a man with a big family of children, where is he going to get money to pay 30 or 35 cents a pound for butter? Yet these dairymen ask you absolutely to prohibit it from his table.

Now, they come before you and they say that thirty-two States have adopted this butterine law, and that it has not liad any effect. They can not stop it. Why is that? Can Congress do any more? Why is it they can not stop it? I will tell you. The world has never yet found anything that it wanted that it did not get in some way. No man can throttle a world's wauts. The world has tried oleomargarine; it has found out that it is nutritious; it is pure; it is just what they want; and all the legislation on earth can not prevent their getting it. You might as well stand on the seashore and bid the incoming waves recede.

Why, a great many of the States and a great many cities have tried prohibition, but the world likes red liquor, and the result is that prohibition has been a failure everywhere it has been trierl. Almost all the States of this Union have legislated against the social evil, but the social evil has its attractions, and they liave never been able to eradi. cate it. They have succeeded in scattering it, and that is precisely all that can be done.

Representative NEviLLE. Will you permit me a question right there?

Mr. ALDREDGE. Yes, sir.

Representative NEVILLE. With reference to the social evil, they do fix it so that a man who does not want it need not take it, do they not?

Mr. AldRedge. Yes, sir; I reck on they do. It is all Greek to me. I don't know anything about it. I will get to that directly, though.

Now, as Mr. Oliver, representing the North Carolina and Sonth Carolina oil mills said, we have taught the people how to make one of the finest foods in the world, and if you cut it off in its legitimate tax-paying shape, why, every little farmer in the country will commeuce making it. And, as he said, you will have oleomargarine moonshiners galore. You wou't have courts enough to try them; you haveu't got 
jails enough to hold them. It will be like the Quaker's prayer when the stars fell. He had not been very devont, and he fell on his knees and said: "O, Lold, this do be the judgment day, and Thou knowest that hell won't hold half of us." Thit is the way it would be. [Laughter.]

Now, they say that this butterine is a frumd. Gentlemen, I want to draw a distinction between fraud and innocent deception. There can be no frand without injury. If' a man connes to me and says, "Let me have a \$5 silver certiticate," and instead of that I give him a s.i national. bank note, I liave deceived him, but I have not defranded lim. Then, if butterine is as pure as butter (and the fact is, it is much purer) and a man's landlady fools him with it, all right; slie has not lıurt him. If a man's wife fools him, all right; she has not hurt him. And she would have to have as many lives as a eat in order to fool him in this innocent way as many times as he fools her in one other way.

Now, who is making this ery of frand? Who is making it? Why, when I was a boy I heard something to the effect that a man living in a glass lonse should not hurl briekbats. For eight months in the year every butter factory in the United States puts this coloring matter in. Many of them put it in the whole year round. Yon can't have yellow butter unless you liave rich, green grasses. I know abont that: I have churned it. 'That used to be my business, too, when I was a boy. I have churned it. I expect, nearly a thonsand times. Yol can't have yellow butter muless you have rich grasses, clover and alfalfa for the cow to run on. Why, there are hundreds of dairies whose cows are right in the cities, and never see a blade of grass. Thuse men, where they are making genuine butter, color it twelve montlis in the year. And any farmer colors it all during the eight months when the grass is not green.

Now, theic proposition is, "Let us fool the people: let us fool them for eight months in the year; but, for the Lord's sake, dlon't let these other fellows fool them at all." That is the proposition. It is a pious frand, if a franci at all, all around; nobody gets hurt.

Now, if the Government is going to stop deception, the Goverument is going to liave its hancls full. In the first place, if there is any mentber of Congress who dyes his whiskers or his hair, he is a flaud, and ought to be taken out and clipped. [Langliter.] Every time one of you gentlemen goes to a bar, they liand you out beantiful red whisliy, and every bit of it eame from the still as white as water. Maybe you don't know what I am talking abont: but if you don't, you 'an send out and have the information gathered for your benefit. Why, we smoked Havana eigars here the whole time, for three years, while the Cuban iusurrection and war was going on. "Ihy, theie was not a blade of tobacco raised over thore, and yet it har no appreciable effect upon the smpply of Havana tobacoos and eigars in the United States.

Nearly all of us carry alligator grips. There they are; and if every alligator that was ever killed was a mile wide, he couldn't furnish the hide for those grijus.

All of you wear kaugarno shoes. I lave a pair at home myself; and there are probibly a dozen poor liftl' kangaroos abont as big as a fire dog killed once a year, and yet they supply shoes for the whole world.

These are innocent deceptions. I want to show what the Government will have on hand.

We all eat canned goods. Dir you ever sit down at the table and have the good lady at the head tell you "These are canned pears," or "These are canned cherries"? Never once in the world. Why, if we 
believe that the cherries come right off' of the tree onto the table, they taste better and they look better to ns. We get onr inngination mixed in with it. That is all right; it is an innocent dereption. They never say anything about their coming out of a can; yet they are just about as good as when fresh. I have eaten gallons of sorghum molasses, and they never told me that that was not made from river' (ane.

We will have to regulate the ladies. Why, they use praint; they use powier. One of them steps ont of her home onto the strret. or to her jarlor, and she has these yellow ribbons on. That is the thing that makes these dairy people so awful hot. And her shape is perfeetion. Visions of "the Greek Slave," and all the lovely statuary, rise before you as she ambles down the street. Sho is perfection. And yet they are not all built that way. Some of them are fearfully and wonderfully made. [Laughter.] Now, the Government ouglit to take a liand in that, and stop that kind of deception which they practice on us men.

Why, sir, the very wearing of elothes is a deception, and disgnises a man's deformities. Congress must step in and make every fellow go naked, and grow hair like a logg. That's the way to be natural.

Now, gentlemen, the fact is that if the Government is going to regulate all the domestie aftairs, and poke its nose into lutter and everything else, then the Government has got to quit everything else. She gives up the Philippines and the management of cnba, and quits making treaties with the power's, and stays at home and attends to the lome duties. Why, sir, a lot of people would like to put this Government to grinding coffee and toting ont slops. That is their idea of government. That is their illea of what government is for. What business has the Government fooling around here in butter?

Now, I grant you that if it is a police regulation, and we were making: something that lunt the people, the Government onght to step forward. But here the truth is, disgnise it as they may, that they do not claim our article is not just as pure as theirs. The rnestion is, Shall the Government put its hand on one man's business and lift it up and sink the other down?

Gentlemen, the Constitution (I will not read the different sections; 1 had intended to do it) does not anywhere say in positive terms that "ommeree between the States shall be free; but, sir, there are a number of sections theie that go to show that that is the very spirit of the Constitution. And, gentlemen, if one State can lay an embargo against the products of another State, why, that other State onght to be turned loose to retaliate. And what do we have? Insteat of a great nation, cemented together by the band of conmerce, interchanging its eummodities freely one with another, we have a lot of little, jealons, petty republies, wor'se than South America.

I say that if Maine and Penusylvania and Illinois and other States ale going to legislate against a perfectly pure, healthy Texas product, tl:(+11. I say, turn Texas loose and letus retaliate. And whenerer we do, I am going to the legislatme. I would hate to be canght in that crowd, but I will go; and, let me tell you, I'll make it liot for every State that has lewislated acainst our prodnets. I'll make it a penitentiary ollense to setl Maine's fish down there. I will make it a penitentiary oflense to sell llinois buggies anıl Ohio buggies and other manufacturing interests up there. It a man wants to ship a lot of corn clown there to us cotton farmers, and a ealload of bacon, why, I will make it a penitentiary offense to do such a thing.and we will be just like two cats strung on a wire; we will all be wool pulling.

Now, that is the lind of a government they want. What right has 
any State to ostracize and taboo our products-if they are healthy, mark yon, all the time, if they are good, if they are pure? They talk about police regulations. This Grout bill says that in the exercise of police powers each State shall be permitted to deal with this thing as it pleases. Each State shall be permitted to lay an embargo on our produets when not a man in the State will stand np and tell yon that our prodnets are not pure, healthy, and good for them. Is that the exercise of a police power? Gentlemen, it is a flaring falsehood on its face.

Now, this [inclicating map] represents all the States in black that have passed this law; and it is very appropriate. It is a shady, dark business. I am glad they put it that way. And I see here Alabama, Georgia, and Sonth Carolina. God knows the inlea of a Sonthern state in legislating against its ehief prodnct at the behest of a dairy trust a thousand miles away! They need the prayers of the church. The fool killer has not got around there yet, evidently.

Now, gentlemen, I will not detain you mueh longer. I am about through. These men that are asking this legislation are but trying to impede the wheels of progress. That is all. The genius of this age is manifested in the cheapening of all articles worn or eaten or used by man. Nore has been aceomplisherl in the last fifty years in that direetion than has been accomplished since the time when Adam was a baby. It is the law of nature, gentlemen. What is it? 'The survival of the tittest-development-evolution. There is a great law of commerce. What is it? The survival of the cheapest and the best. And the man or set of men who gets in the way of that law is crusherl, inevitably. He is bound to be. The whole is greater than any part of it. The welfure of a whole people-what is cheapest and best for them-will prevail. You might as well attempt to roll the sun back as to deny the perple that right. They will have it.

Now, if the people prefer this article, which the dairy interest is fighting simply beeause their business is exploited by this manufactured article-because it is eheaper and just as good as theirs-who shall say them nay?

Why, gentlemen, why did not the shoemakers, the men that sit crosslegged and rew, when these people up here in Boston and New Yurk and all over the country began to make shoes by machinery, come here aud ask you to stop it? You ought to have done it? The tailors ought never to have allowed the making of hand-me-down elothes. They have just as much argument in their behalf as the dairies.

Now, the business of the man who makes tallow caudles (and I used to mold them myself when I w.Is a boy) was exploited by the discovery of petroleum. 'Then, petroleum was exploited by the discovery of gas; and, then, gas weut to the wall when electric lights Hawhed out; and yet, in each of these stages, the Government ought to have enjoined the proceeding and stopped it. We can't have that sort of development. And when the fellow that swung the cradle saw the MeCormick harvester, that went across the field, and mowed down the grain, and tied it up, and then threshed it, and all that-did everything, except eating the bisenit-he ought to have enjoined McCormick.

Gentlemen, these men have gotten in the way of public progress. They say, "But the people eat it as butter, and, therefore, it is a frand." "Well," I say, "the people eat your yellow winter stuff, as yellow as summer butter, and therefore you are a fraud." But he answers back, "Ours is butter, and that is just as good and just as rich as the yellow butter of summer." Well, I say the same. You ean't use auy argument that does not apply to us. I say that our stuff is just as good, just as 
nutritious, just as health giving as yours; consequently we are in the salle boat.

Why, one man who arldressed you said that the States ought to be allowed to prohibit this thing, just like they did whisky. Now, gentlemen, whisky demoralizes a man; it breaks mp and ruins his family, degrades them, and impoverishes them. Whisky does tlıat. But a man might gourmandize on oleomargarine for forty years, and he would be a better man and a stronger man every day. The algument does not hold. I thank you for your attention. [Applause.]

The Acting Chairman. Mr. Dadie, of Chicago, will next address the committee.

\section{STATEMENT OF JOHN DADIE, ESQ, OF CHICAGO, ILL.}

Mr. Chairman and Members of The Committee: My illeas on the oleomargarine question I have gotten up in manuseript form, and with your jermission I would like to read them to you, after which I will be glad to answer questions that you may care to ask, if I am able to do so.

I have been actively engaged in the manufacture and sale of oleomargarine for the past sixteen years, and this is the first time I have ever appeared before any legislative body in the interest of the business that I represent, although during this period there has scarcely been a time that some restrictive or prohibitive legislation has not been pendiug of a State or national character.

It is unnecessaly to call the attention of the older members of this committee to the fact that the Grout bill has been introduced here many times before, and we find it presented again for your consideration, but dlessed in sumewliat of a now garb. The Grout bill of to-day differs from the Gront bill of the past. The present measure in its first section embraces everything the original bill contained, but a new section has been added thereto, which further provirles for an additional tax, the object of which is to throttle and strike out the very life of the industry, so that the jobbers of butter may have no competition in their field of commerce.

The history of oleomargarine, since its introduction, has been one of continual strife for its existence. In its earlier days it was the object of ridicule in comic papers, wherein was described in print aud caricature methods and formulas for its manufacture that originated in the lively inagination of the writer or the artist. They were all ridieulous exaggerations, yet the dairy papers of the country would at once possess themselves of the idea and publish the same in all seriousuess, warning the public against the use of the article which they claimed could only result in harm to the consumer, even when used in the smallest quantities. These waruings, predictions, and misrepresenta. tions of the dairy people failed in their object, and they viewed with alarm the growing popularity and increasing demand for oleomargarine as an article of food and commerce. Relief was then sought from the different State legislatures, and by threatening the future political life of the legislator who failed to labor in the interest of their iniquitous measures, several were enacted into laws. A number of them, liowever, have since been declared uncoustitutional by State and Federal courts.

In 1886 a bill was framed and presented to Congress placing the manufacture and sale of oleomarwarine absolutely under the control and supervision of the Goverument. This measure placed an internal-reveune tax of 10 cents per pound on goods when nade. It further 
provided for special taxes as follows: Six hundred dollars per anmmm for a manufacturer, \$4s0 per anmm for a wholesaler, $\$ 45$ per anum for a retailer, and as a protection to prevent fiand in sales, the manufacturer is required to keepr a book, in which entries must be made in trip. licate of daily sales, giving name ant adlress in full of each purchaser and ummler of packinges and pounds solv. The original and duplicare of this report is presented monthly to the collector of internal revenue in the district in which the factory is located, with an affidavit certifying that it is an acenrate and complete reeord of all business doue during the time specified. 'The same method applies to sales made by wholesalers. Special tax stamps of required values are furnished to the manufacturer by the collector of internal revenne, which are aftixed to the ontside of each and every package, and thereon canceled as the law directs. There is also a caution notice attached to each package, warning the public against using the package again as a container for oleomaryarine. The law also provides for the manner in which a retailer shall make sales. That the goods shall be sold by him from the original package, in quantities not to exceed 10 pounds, and when so sold shall be packed by him in new wooden or paper packages, with his name amb address, the number of pounds in the package, and the word olcomalyine in onequarter inch letters, plainly stamped thereon, so that the purchaser may be advised of the contents of the package. Heavy pewalties are fixed for failure to comply with any of these provisions.

The Goverument is also anthorizen to contiscate any oleomargarine that in its judgment is impure, unwholesome, or in any way deleterious to health, and it is further provided that the Commissioner of Internal lievemue is authorized, with the approval of the Secretary of the Treasury, to make all neelful regulations for the carrying into effect of this act. This bill was given careful consideration; was finally amencled by striking ont the 10 cent per pound tax and substituting in lien thereot a tax of 2 cents per posud, atter which it became a law, and the lobby that was instrumental in securing its passage were correspondiugly jubilant. The prediction was freely made that oleomar. garine bad received its quietus. Bnt the manufacturers, lecognizing the merit in their prodnct, accepted the new condition of things and inaugurated a campaign of education. To educate the public as to the merits and use of an article is not an easy task. This is particularly true when the producers and agents of a rival product resort to questionable aud vicious means to prevent that end. To educate the public to the use of oleomargariue has required a vast amount of energy and the expenditure of large sums of money ammually. In Chicago alone, the center of the manufieturing industry in this line, thousands of dollars is spent monthly in displaying large artistic sign posters trom 20 to 60 feet long and 10 to 20 feet high, extolling the merits of oleomargarine.

Demonstrations of the product can be seen in the largest concerns in every market, and tons of it are given away yearly to bring about a true realization of its merits, and how well it has succeeded is demonstrated in the increase of siles since 1886 . The first tiscal year of operation under the then new Federal law, the total sales in the United States were about 21,000,000 pomnds, while this year the aggregate ontput will be in the neighborliood of $100,000,000$ pounds. Could any better object lesson be used to convince you, gentlemen, of the merits of oleomargarine, when it is borne in mind that every new convert to the ranks as a dealer in it immeliately becomes the target for persecution at the hands of the butter trust and its agents?

One of the old eharges against oleomargariue, in days goue by, was 
that it was unwholesome, and consequently its manuficture and sale should be prohibited. This argument, false in its inception, is now considered crude, and is never used by intelligent defamers of the article. Unfortunately, however, a misguided and overzealous orator is occasionally found who, in his anxiety to make a damaging statement, will so far forget himself as to reflect mpon its purity and wholesomeness. People of this class are grenerally opposed to advancol idlas along any liue, and continue their harangue auninst improvenents of all kinds until they are eanght and crushed beneath the wheels of progress, and their fomeral is usually small.

It is a well established fact that the methods employed in the manufacture of oleomargariue are of a scientific natmre; that the buildings and appurtenances are of modern kind and latest imporovenent, insuring perfect sanitation and ventilation, as well as absolute cleanliness in every department. Of the product itself; Jollies and Winckler, oflicial chemists of the Austrian (iovernment, after a searching investigation, report that the only germs ever present in oleomargarine are those common to air and water. Althongli carefully sought for, tubercular bacilli and other obmoxious bacilli were conspicuously absent, and to-kay there is no recognized sciontific authority in this country or any other that does not indorse oleomargarine as a healthiul food prodinct.

We have heretofore refrained from attacking butter and the methods of its manufacture, lut Mr. Edward Clıalwick, mana ger of a large cream. ery at Osgood, Iowa, in a letter to his patrons, which was published in the columus of the Chicago Dairy Produce, the official organ of the dairy people, says:

A good deal of milk is bronglit in dirty, because not strained at bome, and no effort marle to keel' straws or filth ont of it. Some of the cans are seldom or never properly washed, and a thick coating of sticks filth may be siraped off' them, both insicle and ont. I can strain the milk, run it throngh the separator, and remove a large part of the dirt, but no butter makir on earth can remove the tainted and filthy smell that wilk gets from staying in muelean cans in bad-smelling barus. Some of onr patrons wonld be horrified if they saw the dirt and filth I renove firm my sirainer and separator. Does anyboly think that a bar of soap, a chunk of stable namure, potatoes, parsuips, dish lags, or hairpins soaking in pour cans overnight or longer will improve the flavor of the milk? I have found all of the alove and ninre in the strainer of the weigh can. How ean good butter be made from such milk? When you send your jar to the creamery for lutter for your own nse, what would rou say if I shonil put some of the dirt I find in your milk on top of the butter in your jar? Yon would retnin that butter to the crimery, and be mad besides. If the butter maker would retnrn your dirty milk to your Lime he would be doing his duty, although it would nake you mad.

In addition to the above, recent experiments in Chicago have demonstrated the fact that a laige percentage of the dairy lierds of the Northwest are infected with tuberculosis. The deadly character of these germs is only too well known, and the introduction of them into the luman system throngh the use of contaminated milk or butter is cincerled by every recoguized authority.

This, gentlemen, is a fair comparison of the advantages and disadvautages under which the two products are maufactured. Now the contention is advancerl by the parties interested in the passage of this bill that they do not want oleomangarine colorel in imitation of natural butter, and I want to siy most emphatically to the members of this committee that oleomargarine is not colored to represent natural butter, and further, that, practically speaking, no such thing as matural butter is offererl for sale in any market. It is all artificially coloren. and further, that if not artificially colned six months out of the your it could not be sold other than at a sacrifice. Why are these people 
not honest in their statements, and why is it that they attempt to conceal the fact that butter is artificially colored and is not natural, as they falsely represent it to be? Why should the producers of butter, who are the framers of this bill, attempt to secure to themselves the exclusive use of color when the manufacturer of oleomargarine is responsible for its introduction as an artiele of eommerce? Their answer is: To prevent oleomargarine being sold as butter. Well, then, I say: Let the prodncers of butter discontinue the use of artificial color and sell their butter in its natural state and no one will be deceiverl in purchasing oleonar. garine. Is it not as fair a proposition to say that butter shonld be sold free from color as to deny its use in a rival product? Is this question not pertinent when it is remembered that the article of color is the property of the oleomargarine manufacturer by right of priority and eonstant use?

With the introdnction of oleomarganine, the very nature of the article made it necessary to introduce a snbstance that wonld make it pleasing to the eye, and the result was the use of a color. The producers of butter were quick to see the advantages derived from the use of this eolor, and it is now used in common by oleomargarine and butter makers alike. From this it wonld appear that if any rights are to be motected by legislative enactment, in so far as color is concerued, the makers of oleomargarine are entitled to such protection, and we empliatically protest against the passage of any law that gives to the dairy interest exclusive rights on color and denies that right to ourselves.

It has been stated to your committee, by speakers on the other side of this question, that they represent'd the great dairy interests of the comtry as well as the consmmers of butter, but, gentlemen, no evidence has been submitted liere in support of this remarkable statement, and I doult if the speaker had as many proxies as be desired to lead yon to brlieve he hatl.

1 also join issme with the statement that large quantities of oleomargarine are sold as butter. The records of the Internal Revenue Office show that ont of the $80,000,000$ pounds marketed in the United States last year only 1 per cent of it was sold in violation of law.

A significant fact that speaks volumes for the makers of oleomargarine, and the lonest and conscientions manner in which it is sold, is evidenced by the fact that no consumer has ever prosecuted a dealer for violating a State or Federal law, or for selling him oleomargarine when butter was called for, notwithstanding the fact that last year the agents of the butter trust in Chicago offered throngh the daily press a tenpting standing reward for any information against dealers who sold oleomargarine for' butter. 'They also tendered the services of their chemists to anvone for the purpose of analyzing samples of any butter bought by them that was suspected of heing oleomargarine, and in the event of the discovery that framl or deception was practiced by the dealer in making the sale they wonld assume the prosecution of the case and defray all expenses incideut thereto. Even this method failed to prodnce the evidence they were so anxious to secure, and not a single violition was reported to them. As a matter of fact the comparative price at which oleomargarine and butter are sold by the retailer precludes the possibility of deceiving the customer as to the identity of oleomargarine, the retail price of which varies during the year from 12 cents to 20 cents per pound.

In reply to the contention of Mr. Charles Y. Knight, who submits in his brief for your consideration a copy in part of some of the corre- 
spondence of the William J. Moxley Corporation, that was sent to its customers at various times, tourhing on the color quesrion and the liability of prosecutions that woulil naturally follow if the letters of the Illinois Dairy Union were to be taken seriously.

Now, as to color; it is a well.known fact that large dealers in butter or oleomargarine will display and sell goods of different colors, and they find it necessary to do so in order to snit the requirements of their different customers. 'Then, too, some particular district will use an article that conld not be sold in another market by reason of its being too high or too light in color to properly appeal to the consuner's taste. For example, the markets of the South, notably in St. Lonis and New Orleaus, order what is known to the trade as an oringe or brick color, and it is popular with certain people in those districts, while in other sections of the comntry it could not be sold at all, ats a different shade of color is demanded and the concern who issued the color card referred to, recognizing the importance of every detail of its business, did so for the purpose of avoiding confusion, by supplying its customers with goods that would suit in color the requirements of their trade. There is no deception practiced or intencled, nor conld there be, as the interualrevenue law and regulations apply to all our product, regardless of the amount of color used.

In July, 1899, an attorney in Chicago, Hngh V. Murray, claiming to represent the Illinois Dairy Union, an organization that had no legal existenee, as it had never applied for or been granted a charter to operate under, but was composed of a few jobbers in butter in South Water street, issued a letter over this assumed title, in whirlh he said that the Illinois Dairy Union had retained him to prosecute dealers who violated the State laws in selling oleomargarine, when he well knew that the State law had been declared nneonstitutional in every court in which a case had been bronght in Illinois. It was in reply to this letter, and a similar one issued by Mr. Knight, who claimed to be the seeretary of the same organization, that we agreed throngh our circular letter to defend our customer's against prosecutions brought by these people under the name of this assumed organization, and in doing so it was not our purposo to defend violations of a law or to eucourage any dealer to commit violations thereof, but we simply endeavored to protect our business against a law that had alrealy been declared unconstitutional, and nowe but legitimate methods were employel in defense of our customers; and I desire to be fully understood when I repeat that it is our purpose to continue the defense of cases brought against our customers by irresponsihle organizations and agents of renovated butter maunfacturers until the supreme Court passes upon the constitutionality of the laws in question, and we will then abide by their decision.

A vast amount of importance seems to attach itself to the correspondence received by members of Congress from country districts urging the passage of this bill as a protection to the dairy interests. It may be of interest to you gentlemen to know through what channels this eorre. spondenre passes before reaching members in Washington. These apleals for protection are compilen and printed by one man in South Water street, in Chicago, and mailed by him broidcast to the rural districts throughout the country, with a personal lut ter asking the party atdressed to sign and direct the letter furmished him to his liepresentative in Congress, and as a reward for his trouble extend to him the hope of a permanent increase in the price of his butter if they are successlul in destroying the oleomarganine industry. Would it not be as well to 
minimize the labor and expense, and at the same time insure the earlier receipt of these letters by the parties for whom they are intended, it they were mailed direct from Chicago, and withont any interference on the part of the farmer or dairyman who simply affixes lis siguature?

The people who are opposed to this measure include all classes of citizens, from the man who represents vast and diversified business interests to the lahorer, who is the consumer, and who demands it as his right that he be permitted to purchase his oleomargarine of a sightly color without adrlitional Congressional restrictions, and at minimm cost. They have sent their solemu protest to you against this pernicious piece of class legislation. They are the purehaser's and the consumers of this article, and their demands and their rights in this matter should certainly be respecterl. The toiler objects to drawing the line of demarcation between brawu and wealth in a manner to give ocular clemonstration of his poverty by compelling him to purchase his substitute for butter white, or clo withont it. The great central body at Chicago of the Federation of Labor have placed their stamp of disapproval on this bill, and other organizations throughout the country have followed their example, or are jreparing to do so, and a statement to the contrary in a brief submitted for your perusal is probably as truthful as the other statements therein contained. The same party makes a vicions, baseless, and unwarranted attack on the Govermment officials under whose jurisliction these goods are made and sold. These gentlemen need no defense before this committee, but in all fairness I am impelled to say that I never met one who was not active and conscientious in the discharge of his duty, and the statement reflecting on the integrity of these ofticials is cowardly, false, and mujust.

I an fully convinced if this question was honestly explained to, and thoronghly molerstood by, the farmers of this country, that they would join with the others and ourselves in protesting against the passige of this bill. There is not a single ingredient that enters into the composition of oleomarganine that is not the product of the farm, and whose market value is not increased by its introduction as a commercial prodnet throngh this channel.

Gentlemen, as an American citizen, I can not allow myself to believe that ('ongress will permit itself to be used as a bumper between rival industries. Congress was nuver intended to exercise its legislative powers in such a manner as to confer rights upon one industry that wonld canse the total destruction of a rival business, and this is what the framers of the Gront bill are asking you to do.

Gentlenen, I solemnly nrotest against unwise and vicious legislation of this kind, and l appeal to your business jud gment when you deliberate on this question among yonrselves. I protest against the passage of the Gront bill; it is an invasion of onr rights; it is practically a confiscation of our property interests, an injustice to the prodncer aud consumer alike.

Now, in adilition to this, gentlemen, I have bronght down some samples of oleomargarine in original packages that are put up as the present law directs, and with your permission, I would like to show you how it is done.

Representative Neville. Will you answer a question or two before yon do that?

Mr. DaDiE. Yes, sir.

Representative NEviLLE. When you state that only 1 per cent of the amount that is sold in the United states was suld fimdulently or for butter instead of butterine, do you mean that that amount was sold by 
the manufacturers, or do you mean that that 1 per cent is the total anount which has ever been sold by the retailers?

Mr. DADIE. That is the total amount.

Representative Nivince. All that has been sold by the retailers, with the manufacturers' sales, amounted to only 1 per cent of the total amount sold?

Mr. DADIE. Yes, sir.

Representative Nevilue. Now, in Nebraska we lıave a law which absolntely prohibits the sale of oleomargarine in the color of butter, or colored as butter. While last year, with $1,058,910$ population

The Chankun. Mr. Neville, I would suggest that we have quite a number of witnesses here, and I think you ought to confine your thonghts to questions.

Representative Neville. That is my intention.

The Chairman. You can take up the balance of the time of the committee with two or three questions in that way.

Representative NrviLLE. My intention is simply to ask questions; that is all. Now, in Neluraslia there was sold 1, (124,985 pounds, by 73 dealers, colored as butter; and I find that in all the States together which sold butter where tliere was an anticolor law, there was more butterine sold, or a total of $62,525,582$ pounds, as against $16,560,142$ pounds in the States where there were no such laws.

Mr. DADIE. I liave no doubt but what those things that you have mentioned were sold as oleomargarime, and not as butter.

liejuesentative NEviluE. What do you say as to the people who (niter the hotels and are getting butterine or oleomargarine every day? 1)o they believe that is butterine or do they think it is butter?

Mr. DADIE. My experience has been that in a botel, now, people imagine they are getting oleomargarine all the time.

Reprosentative Nrville. You think that is what they think they are getting. Now, I would like to ask you another question or two. You state that you are the originators of the process of coloring untter in oleomargarine, and that you used it prior to any color liaving been used in butter. Do you mean to assert that as a fact?

Mr. DADIE. I am talking about a commercial product. Everybody knows that on a farm, before oleonargarine was ever invented, the people used to grate carrots and use other things to color their butter. But it is a fact that butter has not been colored to any extent until after oleomargarine was manufactured and colored, and that the introduetion of color is the result of the introduction of oleomargarine as an article of commerce.

Representative NEVILLE. Is it not true that oleomargarine was discovered as a product and first manufactured at the time of the FrancoPrussian war as a necessity in France?

Mr. DADIE. I believe that is true.

Representative NEviLLE. Now, do you pretend to assert that butter was not colored in creameries in the United States prior to that time?

Mr. DADIE. I have no recollection of any color being used prior to that time. As a matter of fact creameries are an invention of about the same date.

Rejresentative NEviLcE. Well, I do not think so. I think I know creameries that existed before that time. Yon may assert that that is not true; but that is merely a diflerence of memory, perhaps.

Now, I rant to ask you this question. You state that butter is colored in the winter time in order to malie it look like June butter, or butter that was made from cattle fed upon green grass. I want to ask 
you if the coloring that is added to the butter adds anything to its nutritious quality as a food product?

Mr. DADIE. It simply adds to its appearance, I presume.

Tepresentative Neville. It simply adds to its appearance. Now, I desire to ask you if that is true witi reference to the color used in oleomargarine. Does that color add to its nutritious quality?

Mr. DADIE. The same rule would apply there. It is simply added

Representative NEville. It does not add anything, then, to its nutritious quality, but simply adds to its aplearance?

Mr. DADIE. Exactly.

Representative NevilLs. Now, you understand that if this bill becomes a law it will permit you to manufacture oleomargarine without coloring matter in it; and it would be just as nutritious without it, would it not?

Mr. DADIE. Yes; I understand that; but I also understand

Representative Nuville. Now, would not that be mannfatured and sold cheaper to the laboring people than it is sold when it is colored so as to appear to be butter?

The Cilairman. Now, Mr. Neville, he undertook to answer one question, and I think it is only fair that one question be asked and answered at a time.

Representative Neville. I did not intend to interrupt him.

The Chairman. I suggest that the gentleman he permitted to answer your first question before you ask him another.

Representative NEviLLE. Well, let the stenographer read that question to him.

The stenographer thereupon read the following question and answer:

Now, you understand that if this bill becomes a law it will permit you to manufacture oleomargarine without coloring natter in it; and it would bo just as nutritious witlout it, would it not?

Mr. DADIE: Yes; I understand that, but I aiso understand-

The WITnEss (continuing). But it is also a fact that uncolored butterine could not be sold any more than nncolored butter eonld, and that butterine is colored for the same purpose that you people color butterto make it more attractive to the eye, and consernently more palatable.

Representative Neville. You say "you people." İ am not a lairyman by any means. I am not engaged in the business.

Mr. DADIE. I am talking abont the dairy people.

Representative Neville. Now as a matter of fact, then, the coloring simply.adds to the appearance, you state; and you say you could not sell it if it was left uncolored?

Mr. DADIE. It would be practically prohibition.

Representative Neville. Now, let me call your attention to a letter written by your firm. You represent IV. J. Mioxley, do you not?

Mr. DADIE. Yes, sir.

Representative NEVILLE. This is a notice to the trade, dated April 5,1899 , from your firm. In that letter you say:

In nearly every section of the country there is a difierence in the color of butter, and even in certain seasons of the year there is a chauge, as you will have noticul. In winter butter is of a lighter color than in summer; in many sections this is the result of the difference in feed or pasture. We can give you just what you want at all seasous, if we linow your roruiremults.

Now, I ask if that was intended for the purpose of giving notice to yonr trade that they could sell your artinle as butter or as butterine? MI. DADIE. No, sir; it was inteuded for just exactly what it said. 
As I said in this manuseript, there are certain sections of the conntry that reguire rertain shades of "olor. It was for the purpose of meeting" the wints of those people in those parts of the country that we issued that cireular.

liepresentitive Nrvillw. Now, you say as an example, in the notice, "No. 1 has no coloring matter." Do you sell any of that?

Mr. DAD1k. (Becasiomally.

Representative NEviLLE. You conld sell it, then. if, as a matter of fact, it is just as nutritious and just as wholesomw, if the people really wanterl butterine or oleomargarine, could you not?

Mr. I)AlnIE. Oceasionally yon will fiud in a German settlement a party who will order a 50.pound ease of it.

liepresentative STOKks. Let me ask a question there.

Mr. 1)ADIE. Certaiuly.

Representative STokES. What proportion of your trade or of your orders would probably be for that kind of oleomargarine?

Mr. DADlE. Why, the percentage would be so small that it would be hard to compute it.

Representative ALLEN. I would like to ask if you know Mr. Cohen, the revenue man?

Mr. DADIE. Ies, sir.

liepresentative ALLEN. What do you know of him personally, as to his character or standing as a man?

Mr. DADIE. He is a man of high standing in Chicago.

Representative ALLEN. Has there ever been any reflection there against his honesty and integrity, so far as you know?

Mr. DADiE. Not so far as I know; no, sir. I never heard of any sueh thing.

Representative ALLEN. Is he a native resident of Chicago?

Mr. DADIE. Yes, sir.

Representative AlLEN. Now, I would like to ask you further if you know of William Y. Broadwell?

Mr. Dadie. Yes, sir; I do.

Representative AlLEN. There have been exhibited here some original paclisges of the wrappings of olenmargarine, and the stamp lias been impressed upon the eorner of the wrapper, and turned down in that manner [indicating] , so as not to be seen by the purchaser. What do you know about that?

Mr. DADIE. I understand that eharge has been made against him; but there are about 2.500 lieensed dealers in the first district of 11 inois, and it applars that this man Broadwell is about the only oue against whom thry have been able to get any eases of that kind.

liepresentative ALLEN. Yon say he is one out of about 2,500?

Mr. DADIE. One out of about 2,5$)$.

Representative ALI.EN. Of the retail dealers?

Mr. OADIE. lietail licensed dealers in that distriet.

liepresentative ALLEN. Are you a manufacturer or retail dealer?

Mr. DADIE. A manufacturer.

Representative ALLiN. Yon are a manufacturer?

Mr. DADIL. Yes, sil.

liepuesentative Neville. Excuse me, Mr. Allen. Would you mind telling this committee the ingledients and quantity of each ingredient in the manufacture of oleomaryarine?

Mr. DADIE. That yuestion I wonld rather not answer in the way it is put. The guantities of the difles (nit ingerlients are one of the secrets of the trade; but 1 will say that they vary with the grades made. 
Representative NEviLLE. Then, as a matter of fact, you, as the dealer and the manufacturer and the seller of this product for the ennsumption of the people of the Unitel States, want them to take your word absolutely for it that no ingredient is put into the manulacture of the article which would injure their stomachs?

Mr. DADIE. No, sir; that is not right. The present law regulates that. The ingredients used in the mannfacture of oleomargarine are reported to the Internal Revenue department, and when there is anything userl that in their judgment is deleterious to the public healti, they immediately can confiscate these goods. The chenist connected with the department is the party who is supposed to look after that matter, and his judgment in things of that kind is final.

lepresentative NEVILLE. Now, do you mean to be understood that your firm, in the manufacture of oleomargarine, manufactures it differently and from different ingredients from what other manufacturers in this country and in other countries do?

Mr. DADIE. I presume that we use the same ingredients. We possibly differ a little as to the amounts used, aud we may differ somewhat in the way we handle them.

The Acting Chamman. You do not object to telling what you do use, do you?

Mr. DADIE. Oh, no, no.

The Acting Cmairian. Suppose you tell the committee what the ingredients are.

Representative WiLLiAMs. It is just the proportions which you decline to tell?

Mr. DADIE. That is all. The ingredients used are oleo oil, what is known as neutral lard, cotton seed oil, milk and cream, color, and salt. Oceasionally a little butter is used.

The Chairman. Mr. Dadie has some samples. which he wishes to show us. We have only five minutes left, and I suggest that he bring them over and slow them to the committee.

liepresentative Williams. Mr. Chairman, before that is done permit me to make one suggestion. One of the objects of the meeting has failed by lack of time. There are various g(nt]lemen liere fiom Arkan. sas, Tennessee, and Mississippi, and I ask that the committee have another meetiug, and that the secretary be requested to give notice of it, say, to-morrow morning at half past 10, to hear these other gentlemen. It will be impossible to do it to day.

Representative ALLEN. Why not meet to night?

Representative Williams. Because the House takes up this Porto Rican question at 12 o'clock, and we have got to go there.

Representative ALLEN. I mean to-night.

Representative WiLlians. That would suit me if it would other members of the committee as well.

Representative ALLEN. Well, suppose we make it to morrow morning, then?

The Chamman. Then it will be understood that we will meet tomorrow morning at half "past 10 o'clock, or $100^{\circ}$ 'dock, if that wonld be more acceptable to the gentlemen. It wonld certainly wive more time.

Representative WRIGHT. I wonld like to ask just one question: Referring to that letter from the head of an industry in Iowa, showing the impurities in the cream and milk, l want to ask you how you treat the part of the cream and milk you use in making your product so as to take out those impurities?

Mr. DADIE. Well, we have a process of euring and ripening- 
Representative WRIGMT. But it takes them all out?

Mr. DADIE. We attempt to do so.

Representative WRIGHT, It makes it absolutely pure?

Mr. DADIs. That is one of the things that we attempt to do, aud we think we are quite suecessful in it, as the chemists are unable to fincl any of those germs or bacteria that are found in butter.

Now, here is the cover of what is called a solid-packer tub, on which you will see printed "Oleomargarine, factory No.5, First listrict of Illinois." This is the gross, tare, and net reight of the package. Every cover on an original package of oleomargarine as put up by the mamufacturer has that same brand on it. The tub itsedf then carries the intermal-revenue stamp, which is nailed on with five tacks and canceled with wavy lines as you see here, in addition to which we put on a caution notice, warning the public against the use of the package again as a container for oleo.

A Menber. Can the retail dealer take it out in ponnd packages?

Mr. DADis. Yes, sir; he is obliged to take it out in any quantity that the buyer may wish. The retail dealer is not allowed to sell the origiual package.

liepresentative Wullams. But when lie does talie it out lıe is compelled by the law to put it either in a wooden or laper wrapper containing the worls "oleonargarine" and the quantity.

Representative LАмB. Yes, and then he sells it as butter and as olemuargarine, both. Ile sells it as oleomargarine to one customer, and as butter to another.

Representative WiLlians. Tlıere are men who violate all laws, and that is a violation of law, it it is done.

Mr. DADIE. Here, gentlemen, is what is known as a case. You will find that is marked in the same way. Here is the manner in which the retailer is compelled to stamp every package that he sells. That is one of the regulations. That is the present law. You will notice that there is a blank space left, so that he can fill in the number of pounds he sells.

Now, there [producing another sample] is a print. Yon will notice the word "oleomargarine" stamped right in the wrip) wer. The present regulation compels every manufactmer who puts a printed wrapper on a print to adl the word "oleomargarine" to the other matter that he may put on it.

A MEMBER. Is that your first quality of goods?

Mr. DAdre: No, sir.

Representative Nevilue. Now, Mr. Dadie, 1 saw a little pamplilet the other day-I have it at my office-with regard to a package something similar to this, with a brand on top of it, "Best Jersey oleomargitine."

Mr. Dadre. Yes, sir.

liepresentative NevilLE. I think that was the exact wording. Now, floes that indioite that the oleo in that brand of oleomargarine comes from Jersey cattle? Is that the irlea?

Mr. DADIE: Oh, I could not say is to that. We do not manufacture that brand.

Now, here is a sample that is uncolored.

Tepresentative WILLIAMS. 'That is not colored at all?

Mr. DadiE. No, sir. There [prolucing sample] is a sample of pure butter, gentlemen. That is absulutely pure, and without color.

Representative WiLLIdus. Who marle this?

Mr. DADIE. I made that at the filctory in Chicago. Here is a sam- 
ple of uncolored oleomargarine, what they want us to put up. Now, in addition to that, I have different shades of color. I want to call your attention to these different shades of color that are required by different dealers. And I want to call your attention particularly to the manner in which the mannfacturer is obliged to put his oleo up.

(After informal discussion among members of the committee:)

The CIIARMan. Will you state, for the benefit of the committee, where these differ'?

Mr. DADIE. As I sairl in the paper that I read, there are certain customers throughont the country who require different eolors of butter. Yon will notice that these different shades here vary from absolutely no color to one that is very high.

Representative NEville. Mr. Darlie, I would like to ask you another question. If, as a matter of fict, ron think a majority of the people are looking for butterine when they go in to the hotels and restaurants, and expect to be served with butterine, amd that as a matter of fact it is an article that does sell on its own merits, and not by reason of its imitation of another product, to wit, butter, why in your letter did you use the word "butter" instearl of "bntterine" or "oleomargarine" when asking with reference to their trade and their demands"

Mr. DADIE. Well, I presume the word "oleomargarine" could have been used to just as good advantage.

Therenpon the committee adjourned until Thursday, April 12, 1900, at 10 o'clock a. m.

APRIL 12, 1900.

The suhcommittee on the Burean of Animal Industry of the Committee oll A griculture met at $10.300^{\prime}$ clock a. m., Hon. William Lorimer in the (Jiair.

The Chairman. Mr. Hobbs, the committee can hear you now, if you are ready.

\section{STATEMENT OF MR. JOHN S. HOBBS, EDITOR OF THE NATIONAL PROVISIONER, OF NEW YORK AND CHICAGO.}

Mr. Chairman and gentlemen of the committee, I will read the papel which I have prepared.

\section{BUTTER AND BUTTERINE AS FOODS.}

A great deal has been said lately about the public liealth and about pure and impure foods. Most of this has been said by laymen and those who ring their statements upon their pocket interests; mostly by the butter sellers and not by the milk farmers. Scientists have no pocket interest at stake. Accorting to Koenig, the noted European expert, nolmal salted butter contains:

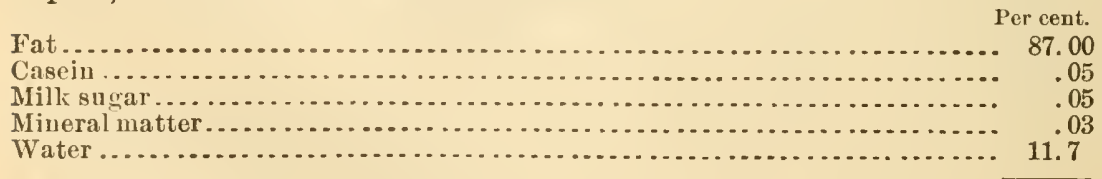

Total 


\section{Mirket butter contains :}

\begin{tabular}{|c|c|c|}
\hline & Minimum. & Maxinum. \\
\hline 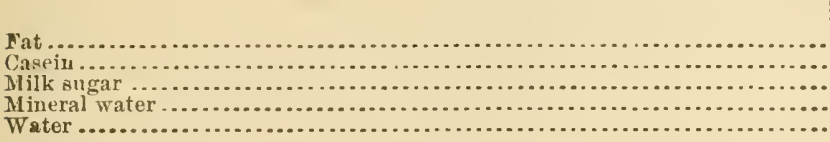 & $\begin{array}{r}\text { Per cent. } \\
76.37 \\
.19 \\
.85 \\
.06 \\
5.50\end{array}$ & $\begin{array}{r}\text { Per cent. } \\
83.27 \\
.71 \\
.58 \\
.95 \\
14.49\end{array}$ \\
\hline & 100.00 & 100.00 \\
\hline
\end{tabular}

Wing, the Ameriean authority, gives the following averages of an equal number of samples of salted butter and oleomargarine, the samples in each case being taken for the consmmptive stock in the ordinary way of trade:

\begin{tabular}{|c|c|c|}
\hline & $\begin{array}{c}\text { Nornal } \\
\text { 8alted } \\
\text { butter. }\end{array}$ & $\begin{array}{l}\text { Oleomar- } \\
\text { garine. }\end{array}$ \\
\hline 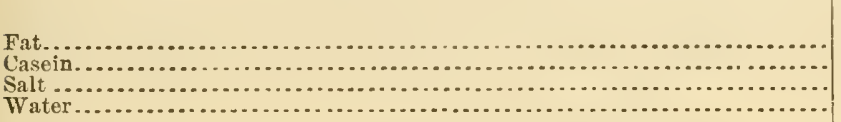 & $\begin{array}{r}\text { Percent. } \\
85.00 \\
1.00 \\
3.00 \\
11.00\end{array}$ & $\begin{array}{r}\text { Per cent. } \\
87.16 \\
.43 \\
2.08 \\
10.33\end{array}$ \\
\hline Total........................ & 100.00 & 100.00 \\
\hline
\end{tabular}

Casein is principally nitrogen. Its office in the human system is to form inuscle, tendons, tissues, blood, ete.

Fat in mutrition is the heat prorlucer. It supplies warmth to the body and prevents the body from eating up the nitrogenons foods for the production of the needed warmth.

The glycerides, or fugitive volatile acids of what is ealled ereamery butter, are merely Havor's without any food value whatever. In their rancid state they are, on the contrary, harmful to the system. 'They are in no seuse a nutrient.

\section{DIGESTIBILITY OF TIIE BUTTERS.}

I rofessor Atwater, of Wesleyan University, after exhaustive experiments finds that the digestibility of butter fat is 96 per cent and butterine abont the same. There was no practical difference in the digestibility of the fints of butter and of butterine.

H. Lnelrig, the eninent German scientist, fonnu, as a result of his recent investigations of commercial oleomargarine, which he bonght in the open malket, that its digestibility was 96.7 to 9.9.93 per cent, while Holstein clairy butter, puchased in the same manner and experimented with in the same way, digested 95.96 per cent, a practieal verification of Atwater. 'The experiments with these butter' substances were, the scientist tells us, "carriel out on a strong, liealthy man, 29 years old and possessed of sound normal digestion."

J. C. Duff, S. B., the chief chemist of the National Provisioner Lahoratory, official chemist of the New York Produce Exchange, after a long series of earefinl tests with butter and butterine reached the following conclusions:

The nutritice value of both lutter aul butterine consists almost entirely of fats. The quantities of fats are the same in both; the fats of butterine contain nothing 
that the fats of butter do not contain, hence there can be no difference in the food valnes of them, except that the thermal or heat-producing properties of the lontterine fits are superior to those of butter, and consequently more valuable to the buman system as a food.

'The digestibility of the respective fats are alike. Repeated experiments have shown this to be true. Numlerless analyses of butterine have shown it to be alusolutely free from any and all deleterious substances.

The melting points of all sumples of hutterive which I have examined have, with no single exception, been as high as the temperature of the human stomach, thus showing its free capability of thorough assinilation and of free digestion.

I desire to digress here to say that this chemist has experimented with samples from original packages which the laboratory laid received or had taken by its own agents from the commercial stocks in every Government-inspected butterine factory in the United States, with the exception of the factory in Washington-The National Dairy Company, I believe it is called-and with the exceptson of the Cloverdale Factory, at Camden, N. J.

\section{Mr. Duff continues:}

I unhesitatingly pronounce butterine, as manufactured to-day in Governmentinspested factories, to be equal in every respect-healthfuluess, assimilability, purity, digestibility, and hyienie valne-to ereamery bntter.

Butter itself has about 8 per cent of volatile acids. This constitutes the difference between the two substances. It is flavor. When these volatile acirls are imparted to butterine the difference between the two products both physically and chemicallly disappear.

HEAT-PRODUCING FATS.

The lieat-prodncing value of different fats is as follows:

Calories or umits.

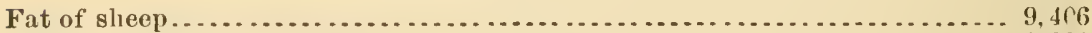

Fat of swine ........

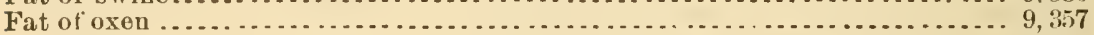

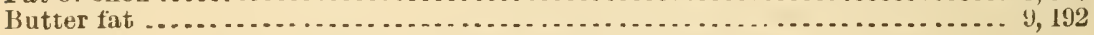

\section{THE BIR'TII OF BUT'JIINE.}

Mege-Monries, a French chemist of note, in response to the wish of Napoleon III for a cheaper bntter for the sailors and the poor, devised and patented the process for making oleomargarine. This cheaper nutritions butter was thus discovered and first made in 1869. It has been made and paten ever since then. Americans and Europeaus simply perfected the modern product and processes for cleaning and purifying its ingredients to a greater clegree.

The French colored oleomargarine, too, before the American dairymen found that this coloring evened up his rich and his poor butter to one selling standard. Then, finding the deception a good one, the dairyman desires the sole right, after stealing the hue of Napoleon's poor-man butter, to use coloring in butter.

Good butter fat, accorling to Dr. H. W. Wiley, chief of the division of ehemistry of the United States Dejartment of Agriculture, contains:

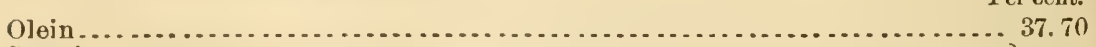

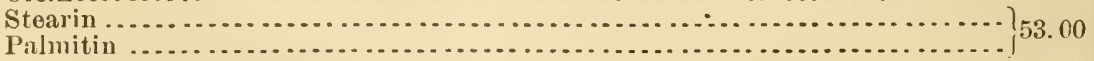

Total ..................................................... 90.70

Now, beef fat consists mainly of stearin, palmitin, and olein, just like butter does. 
Cotton-seed oil contains 25 to 30 per cent of stearin, some palmitin, and much olein.

The essential difference between these tats and butter fat is butyric flavor. But this Havor las no food value whatever. A bacteria or microscopic plant is now planted and developed in cream to enlance this butyric flavor or smell in butter. In loing so not a particle of nutritive value is arlled to the finislied produr.t.

These inmmerable bacteria plantsire called cultures-butter cultures. The dairymen of Europe, Denmark especially, plant these bacteria in cr(am and develop them there to raise the smell. Now, if the butterine maker begins to plant these crean stinks, which have no food value, in his product le will probably be jailed for fraululent initation of an artificial componeut of butter on the plea that butter used them first.

\section{A PAINTED VIRGin.}

The fact of the matter is that butter is a painted virgin of ill repute. Butter is far from being a faultlessly clean and harmless product of irmproachable ancestry and character. Cold water will draw off butter's fugitive volatile oil and heat will cause it to escape. 'Then the two proilucts of butter and butterine are physical and chemical eyuals, harring the matter of disease germs, which more often than not infest butter to the injury of the human species.

Our dairies will not, as a rule, pastemrize or sterilize their cream, beranse it kills that sacred flavor. Without being so treated cream is a lurking evil. It is positively dangerous in its original raw and tuber. culous state, coming, as it loes, from nnimspected cows that graze anywhere, drink any sort of water, sleep in filth and foul influences, and exist in unsanitary surromolings and uncouth barus.

As to the problematical healthfulness of butter, an answer might well be drawn fiom the condition of the milk which yields the crean from which it is made.

Ask the medical profession-the practicing plyysicians-of this commtry if they will recommend the use of cow's milk iu hospitals and among children and weak people withmut its being first sterilized or pastemrized. Yet the dairies do not so treat the milk or the crean from which is male the butter about which we hear so much virtuous talk. Physicians will not prescribe raw milk in their prartice. Mind yon. the cream of such milk is mot more healthful than tho original substances from which it was extr:irferl. Call more witmesses. Ask the dairy inspectors, dairy commissinners, and the boalds of health of the varions rities anl States of this comtry about impme milk. The answer is always the same. Call even some more testimony. Ask the reterinary surgeons what have they found as to the invasion of the nolder and to what extrut this invasion is a fact in the dairy lerd. The same lurid answer as to heally germs and disease is given. Ask the agricultural experiment stations of thiscountry, when they have examined milk and the cattle that give it, to what extront are the mileh cows infected with dangers to our system. Ask the question not only in our own land, but in all other combries. 'The answer, as I have lieard it, is simply aplalling. Yet the butter people stand up before Congress with their invalined product, proluced from the milk of minspected cows, and ask that the product malle from sterilized cream and the puritied oils of Govermment-inspecterl stock be driven from the market for the unclean thing which we eat, and whose assassiuation of us we. excuse simply because it smells ince. 
Some years ago I liad the honor, in part, of representing a government whose health officers made an extensive iuspection of the dairy herds of a famons butter and cheese district. As a result of this insprction this competent officer found that more than half of the cows then in scrvice were infected with tuberculosis in one stage or another of that dread disease. No government in the world exercises greater precuntions than did that one against cattle disease or paid greater attention to the condition of its dairy herds. I refer to an Australian goverument. Our owı milch cows have not shown a better character than the alove.

Mr. AlLEN. Do I understand you to use "oleomargarine" and "butterine" as syuonymons?

Mr. IlobBs. Yes, sir; they are the same. It is simply a variety of explessinn.

So well established is this fact of the existence of the disease in milk and in the cows which furmish it in Europe that the pasteurizing of cream intended for lıman consumption, whether in butter or otherwise, is insisted mpon and, in most quarters, enforced.

I feel that most well informed men must admit the above as facts. If so, then, logically, butter needs more getting after and legislating aguinst than does oleomargarine. That sort of legislation is needed in the interest of the public health. Butterine is harmless. There is not an umbealthy thing in oleomargariue, while butter from unpasteurized milk is a hygieuic problem, intested with tubercules and other fatal germs.

\section{THE BUTTER TRUST.}

Does Congress desire to form and weld together a butter trust? What are the market conditions? Cremmeries now get higher prices for conmercial butter than ever before in the history of the industry; this. too, in the fare of the fact that methods are clieaper to work out, machinery is cheaper, milk is no learer-butter however is dearel. The milk famer gets ahout $\$ 1.10$ per 100 pounds of 5 per cent cream milk. A bont 15 cents worth of milk makes 1 pound of butter, for which the gincers have paid as high as 30 cents per pound wholesale this year. It is lower now. 'The grocer sold it for 32 cents per pouml, jaying rent, hire, and other trade burdens to do so. The creamery foll: made 15 cents per pound, and the grocer ouly got 2 cents per jound "ven after a lot of the water, for which he paid 30 cents per pound also, had evaporated after the butter reached his store. No wonder the butter factory doesu't wish to let the grocer sell butterine! This retailer is what is vulgarly called a "cinch" for him. Will Congress step in on top of all this, put the requested 10 cents per pound additional tax on butterine, wipe the product from the market, and thus ('ement the structure of the butter combine? The good sense of Congress is not yet ready, I feel, to mark up prices to the consumer, to mark up still higher the steep profit of the butter factory and in doing so imperil millions upon millions in legitimate fields affected by oleomargarine and the manufacture of it.

\section{A FORTY PER CENT FRAUD.}

A butter legislator has been pleased to talk abont circulating connterfeit money. How about poor winter butter as a counterfeit and a fiaud mpon the consumer in the guise of rich smmmer butter and at the price of it? The winter butter of any cow is 30 to 40 per cent poorer in butter fats 
than is the product from her rich summer cream. Butter color is used instead of grass to cover up the difference in rich quality. By this simple dyeing process the low grade, whitish, winter-waxy stuff is marle to lowk like the superior summer substance and to sell for the sime price. Cold storage is utilized to distribute the product evenly in the produce mirket. So this 40 per cent counterfeit is painted up and shovol ont into the current of trade as the Simon pure virgin article. It is a flant. It is poorer than even "blind tiger" butterine, and no bette" tha" innch of the Western "real butter," which comes East fiom the diririosstuffed with common hog lard-not leaf lard-even in its untreater state.

\section{UNDER COLOR COVER.}

Housewives know that oleomargarine is colored. They do not know that butter is artificially colored. On the contrary, they believe that real rich creamery butter is sold in its natural color aud that the complexion of it as seen in the tub is that given to it by the cream of the cow. I ascertained the truth of this for myself in New York City. I interviewed more than 300 housewives in that eity on their reasons for purchasing butter of such and such color. All but $S$ of them purchased butter of certain colors because they thought that hne was given the substance by the natural richness of the cream; these generally purchased butter of lighter color because they feared that the others were artificially colored. 'Thus, in no instance, did a grocery shoppel' buy a butter which she thought was artificially colored. Iot all of these butters were artiticial in color. Was the woman in each cisse deccived? Butterine is the same quality, whether colored or not. That is not true of butter-when a 60 per cent tallowy white stuff' goes masıneradiug under the color of a 100 per cent pure article selling at the same price. If the light buff summer product-its natural color-were placed along side of the white winter wax on the same counter the lousewite wonld severely let the poor white stuff alone. Yet some people ask Congress to tax a pure and a wholesome product that the dairies might get higher prices for their deceptions.

The few noisy dairymen, and others that are not really dairymen, who go to form what is swung in under the high-sounding name of "The National Dairy Union," are a curious lot. They come together as a combine in convention and protest as a crowd; they go houle and protest again as separate concerns; then they stand out by themselves and protest as businesses; finally, they write individual protests to Congressmen. If you add them up, it is a big noise, but it is all clone by the same 3,000 who claim to rejresent the 50,000 dairymen in this country. The absence of the other 47,000 looks bad for the "aluse of these agitators. It may have been noticed in all of this noise that the public hise not yet asked to be protected against oleomargarine. The chemists refuse to condemn it, and the grocers desire to sell it.

Iou can notmake oleomargarine very inferior. The low-grade ingredients will not mix. Paraffin is unnecessary in it. It wonld be foolish (1) use this substance when stearin, the natural component of butter and butterine, is much cheaper than paraffin.

I will close with a statement of Chief Chemist Duff:

The constituents of which butterine is uade are each manufuctured with the purpose of obtaining pure and cleanly products. As the animal products are ohtained from Government-inspected cattle and logs, there is, first, no question as to the healthfuluess of the liard, aud oleo oil or mentral lard suitable for this julpose cinn be made successfully withont scrupulons cleanliness in the entiro course of its manufacture.

The cleanliness and healthfulness of cotton-seed oil is beyond question. 
Mr. Duff onght to know, as he is considered one of the most competent and best informed oil and lard experts in this comntry, having given years of labor and work to those products in the great parking houses of this conntry.

Now, Mr. Chaiman, I have a sliort statement of the working of a butterine finctory. If the committee has time I will read it.

The Cuamman. We have guite a number of gentlemen to be heard this morning, and I would suggest that you leave it with the eommittee to be inchuded with your statement.

Mr. Ilombs. Very well, then, I will just file it.

(The additional statement of Mr. Hobls referred to will be found at the encl of his statement.)

I will simply state that the oleomargarine is made up-I have gotten this from all the factories in this country-that the oleomargarine is made up of 15 to 20 per cent of cotton-seed oil, 25 to 35 per cent of nentral lard-the neutral lard is made from the leaf fat of the hog, the richest and eleanest fat in the animal-20 to 35 per cent of oleo oil, which is mate of the caul fitt of tine beeves, and fiom 20 to 35 per cent of butter.

Mr. AlLen. Will you explain what is meant by the "canl" fat?

Mr. HonBs. The fat aromul the caul or intestines. Then, last, is 20 to 3.5 per cent of butter oil, which is malle from cotton seed of a certain gralle at a certain season of the year, and it can not be made from any other kind. It is the prime oil, and I will state, also, that this extra prime oleo oil is about nine grades above eommon tallow.

Mr. BALEY. Yon make the statement that butter is higher this year. Is it higher this year than for some time?

Mr. IIoBns. 'This season it has bronght a miform price of 30 cents, and it has never been-

Mr. BAILEY. Are yon familiar with the prices for the last two years?

Mr. IIOBBs. I went over a scale compiled by the Produce Exchange giving the prices for a number of yeals past.

Mr. Balley. Can you furnish the committee that?

Mr. Hobis. I eal get it in New York.

Mr. BAILEY. I wish you would submit a statement, with data on that subject, showing the prices of butter in the open market.

Mr. HobBs. I will do so. This is the general price we are speaking of, becanse bntterine sells for 15 cents a pound to 18 cents a pound in other places. But I am speaking of New York, Boston, Washington, and Philadelphia.

(The statement of prices referred to will be found at the conclusion of the present statement of Mr. Hobbs.)

Mr. AlLen. What has been your observation of the manner in which retail dealers conduct the sale of the oleomargarine product?

Mr. Honis. I went into, I suppose, forty places in New York that are selling or are supposed to sell butterine. I wanted to get some myself. I will say to you, gentlemen. that after analyzing butterine so thoroughly in our laboratory, I use it on my table. I pay my grocer 20 cents a pound for it. The man does not know what my business is. He simply knows me as one of his customers.

Mr. ALLisn. Have you seen any disposition on the part of any of these retail dealers to coneeal the stamp placed on the wrappers?

Mr. HоBBs. I wilhums el that by telling you of a discovery that $I$ have macle in New York of what is known as a "blind tiger." The prodnce dealer, I will not give the name of either; it is a professional secret. 'The New York Department of Agriculture of New York City may hunt 
it up. It is a factory where butterine was made out of erude products, where butter was reworked, and other ingredients pul into it, and where the produce dealer had some duplicate tubs. I wave that statement to Semator Mason's committee. But that is a piece of villainy for which oleomargarine is not responsible, any more than butterine is responsible for the renovated butter, or the lard that is dumped into it.

Mr. Allen. Now, as to the retail merchants?

Mr. HoBBs. That was a retail merchant. I have found no disposition on the part of the retailers to do that. There are very few in New York that sell it, but in New Jersey - I went over there, and there may be mole there. There is very little disposition to dereive the public. There seems to be more of a disposition to educate the public into the idea of the value and qualities of butterine as a just as good produet, and to sell it as such. I made the discovery of this frandulent fellow by finding him selling Elgin creamery butter at 21 cents a pound, when I knew that it cost 27 cents, and I tracked him. I made him give me, under the promise of secrecy, the name of his produce dealer. The retailer, I believe now, was perfectly innocent.

Mr. Allkn. Do you know anything abont what has been said with regard to the Elgin butter jeople? Do you know whether they are making any objertion to the selling of oleomargarine, or making any particular fight agaiust it ?

Mr. HoвBs. We ouly examined butterine to see how it is sold. The produce papers would have more interest in the produce of the Elgin, butter people.

Mr. Allen. Do I understand you that there is no eomplaint from the consumers of butterine?

Mr. Новвs. I find nont where we have made investigation.

Mr. ALLEN. To what extent have you made that iuvestigation?

Mr. HoBBs. I told you that I interviewed three hundred women in New York City. I suppose they are alout the same as anywhere else, as most people are made up mostly of lıman nature and dirt.

Mr. Allen. Have you any interest in oleonararine?

Mr. HobBs. No, sir; not a dollar-I must qualify that, too. I believe I have inheriter an old plantati " in South Carolina, which I pay out money for every year. It has cost me ten thonsand dollars, and I haven't gotten anything out of it. It was all ruu llown by the war.

The CHAIRMAN. Do you know anything about this renovated butter business?

Mr. Hoввs. Do you mean the prices, or the business itself?

The Chairman. Prices first, and the business secondly. I wish you would give us a short statement about it.

Mr. HoBBs. I will hand you in a statement which I lave witten, and which appears in my paper. The butter is melted and the acids are freed, and it is worked over and packed, aud it lasts about five days and then goes bad.

The Charrman. I have introduced a bill for making the provisions of the oleomargarine legislation apply to renovatel butter. There is some complaint on the part of the dairies about maling that legislation apply to it, and about its being a good thing.

Mr. HoBBs. I will send you down a statement giving laboratory analyses of renovated butter.

The Chamman. Yes, we would be glad to have it. Just send it to the committee.

Mr. HoBBs. Very well. 


\section{THE WORKING OF A BUT'IERINE FAC'TORY.}

After a thorongh personal inspection of the Govel'mment-licensed and Groverument-inspected butterine factories, some of these inspections made in company with our chief food chemist and expert, and all of them made withont any kuowlenge of the oleomargarine people that I was coming, I find the following a summary of then all.

Of conrse, the formulas change, but only as to proportions of the same ingredients, and the temperatures vary a few degrees, according to the experience of the particular factory making the variation. There is no material difference. I quote from my memoranda:

The oleomargarine is made up of a mixture of-

Per cent.

Cotton-seed oil ............................................... 15 to 25

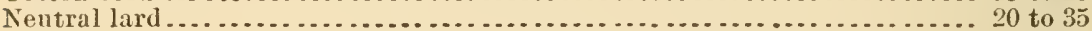

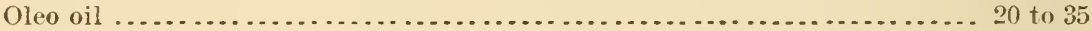

Butter ........................................................ 20 to 35

This formula changes in the same factory slightly with the varying temperatures of the seasons.

THE ORIGIN OF THE INGREDIENTS.

The healthfulness of the ingredients which go into butterine and the product itself is better understood when it is known whence and how these parts of the product come.

Neutral lard is a swine oil made from the leaf fit of Govelnmentinspected animals. It is the richest, cleanest, and finest fat of the long. lieing a log product, it might from religions scruples be objected to by the orthodox Jew, just as he would from scruples of conscience object, to the whole hog and all his connections.

Oleo oil is made from the caul fat of prime liaud fed Government. insprected beeves. It is the best oil which comes from the bovine species.

Butter oil, or that grade of cotton-seed oil which is so kuown because of its extra prime quality, is made from a certain grade of cotton seer, gathered and selected at a certain stage of the cotton crop. They must be well matured or butter oil will not result. It is the finest and dearest of the grades of cotton oil. 'The butterine maker might desire to use a cheaper oil, but no other quality can be used. To attempt it wonld be to ruin his prodnet. The above grades of the above ingredicnts must be employed; no other will mix perfectly. These ingredients are perfectly healthful and very nutritious. Nentral lard lias neither taste nor smell. The same may be said of butter and oleo oils; such is virtually true.

Butter, of course, comes from dairy cream. It is the other ingredient, and is pasteurized because not from Government insjected stock, and to kill the germs, which are well known to generally exist in milk from the dairy.

The neutral lard is melted at about $160^{\circ} \mathrm{F}$. ; the oleo oil $160^{\circ}$; the cream is sterilized at about $170^{\circ}$.

Most factories buy their neutral lard ready for mixing. When it is not so bonght it is malle as follows:

1. The fresh leaf fat is hasherl that is, cut up for cooking the oil out.

2. The pieces go into a rendering kettle, where the oil is cookerl out at a temperature of about $170^{\circ}$. This temperature destroys all germs, if any remain in a Goverument-inspected hog. 
3. The oil is then drawn off throngh fine hair-mesh sieves into receiving tanks, where it is cooled down to about $1100 \mathrm{~F}$. for churning.

4. From the tanks this neutral is talien in its proportion to the butterine churn, where it becomes one of the ingredients of the oleomargarine.

Most factories bny their oleo oil ready for mixing in the churn. Where this is not done, the oil is made as follows:

1. 'I'he caul fat of prime hand-fed beef purchased. No other grade of fat will do for this extra prime oleo oil.

2. The fat is then hashed for cooking. The oil is cooked out at a temperature of about $170^{\circ} \mathrm{F}$.

3. 'The oil is next drawn off throngh a thin, hair-mesh wire screen into tanks, where it is cooled down to a lower temperature.

4. Thence it goes into a room which is kept above $900 \mathrm{~F}$., where it remains about twenty-foul hours.

5. The oil is then pressed to separate the stearine from it.

6. The oleo oil then goes into the churn as the oleo ingredient of oleomargarine.

The butter oil joins these as the cotton-seed oil ingredient of the forming product.

The cream is obtained, of course, from milk bought of the dairy farmers. Very few butterine factories use less than 3.500 quarts per day, and some as high as 14,000 quarts daily. When the milk reaches the factory, it takes the following course to the margarine churn:

1. The milk is dumped from the dairy can into a factory receiving can, where it is tested for conditions of sweetress, etc.

2. It is then pumped into an open, zinc-lined vat.

3. From this vat it runs into a zinc-lined, copper cooling trough, where it is brought to a temperature of about $80^{\circ} \mathrm{F}$.

4. It then goes into a seluarator, which revolves at about 4,000 , and throws out the milk from it. The bulk of the eream filth is dropped into a trough.

5. The cream then goes to the pastemrizer to be sterilizea. The skim milk rums through elilling coils which cool it down to about $400 \mathrm{~F}$. by the time it reaches the cans that rereive and hold it for disposal to farmers and others. The cream is pastenized at about $1700 \mathrm{~F}$.

6. From the pasteurizer the cream goes to a can which is placed in ice water to leep it at a temperature of 340 to $35^{\circ} \mathrm{F}$.

7. From this ice-water tauk it is taken to the churn room on an upper floor,

8. Where it is ripened at a temperature slightly abore $700 \mathrm{~F}$. for the churn. This ripening process takes about 30 hours, more or less, according to the season.

9. When properly ripened, the cream also goes into the butterine churn as an ingredient of oleomargarine.

This completes the parts which go to make the product called oleomargarine or butterine. The "butter color" is also addled now, and the whole is churned into one homogeneous mass. This is completed in about eiglit minutes.

THE FINISHED PIRODUCT.

After leaving the churn, the mass is run into vats of water at the bottom of which are ancliored eakes of ice to keep the temperature down to abont $35^{\circ} \mathrm{F}$. The butterine is left in this ice bath about ten minutes to set it.

The butter is then thrown on incline tables with wooden shovels. S. Rep. $20+3-46$ 
There it drains. The temperature of this room is abont $70 \circ \mathrm{F}$. The butter mass drains on these slanting tables abont ten hours, one day's chnruing being worked off tle next day. The salt is put on the mass while it is on these draining tables. The butter is turned thren or four times while lying there. From the draining tables the butter goes to the butter workers, where it is packed for the tranle.

The factory and all of the vessels and tools used in it are washed, steamed, and scoured laily. Live steam is generally nsed in cleaning chnrus, vessels, etc. Not a smell nor an odor can be detected anywhere. The ventilation is perfect, and the surroundings are sweet everywhere.

Butter priees for sixteen years.

[In cents per pound.]

\begin{tabular}{|c|c|c|c|c|c|c|c|c|c|c|c|}
\hline Month. & \multicolumn{2}{|c|}{1885.} & \multicolumn{2}{|c|}{1886.} & \multicolumn{2}{|l|}{1887.} & \multicolumn{2}{|l|}{1888.} & \multicolumn{2}{|l|}{1889.} & 1890. \\
\hline 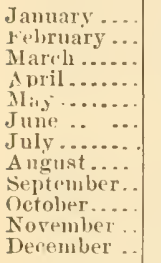 & \multicolumn{2}{|c|}{ 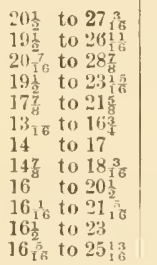 } & \multicolumn{2}{|c|}{ 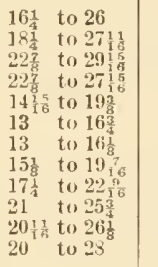 } & \multicolumn{2}{|c|}{ 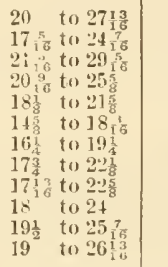 } & \multicolumn{2}{|c|}{ 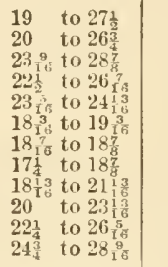 } & \multicolumn{2}{|c|}{ 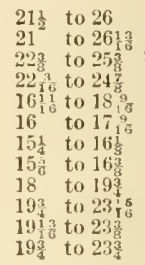 } & 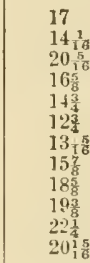 \\
\hline A verage.. & \multicolumn{2}{|c|}{$17 \frac{1}{8}$ to $22 \frac{9}{16}$} & \multicolumn{2}{|c|}{$17 \frac{15}{6}$ to $2: 3 \frac{13}{16}$} & \multicolumn{2}{|c|}{$18 \frac{8}{8}$ to $23 \frac{15}{16}$} & \multicolumn{2}{|c|}{$2 U_{1}^{\frac{1}{6}}$ to $24_{16}^{5}$} & \multicolumn{2}{|c|}{$18 \frac{15}{16}$ to 217} & $17 \frac{1}{4}$ \\
\hline Month. & 1891. & 1892. & 1893. & 1894. & 1895. & 1896. & 1897. & 1898. & 1899. & & 1900. \\
\hline 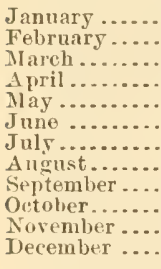 & $\begin{array}{l}23 \\
23 \frac{3}{4} \\
29 \\
25 \\
183 \\
17 \frac{1}{4} \\
16 \frac{1}{3} \\
17 \frac{3}{4} \\
20 \frac{1}{4} \\
21 \frac{3}{8} \\
23 \frac{1}{4} \\
22 \frac{1}{3}\end{array}$ & $\begin{array}{l}22 \frac{1}{8} \\
241 \\
23 \frac{1}{8} \\
20 \frac{1}{8} \\
18 \frac{9}{16} \\
17 \frac{1}{4} \\
18 \frac{3}{4} \\
20 \frac{3}{8} \\
20 \frac{1}{2} \\
21 \frac{13}{16} \\
2316 \\
23 \frac{1}{4}\end{array}$ & 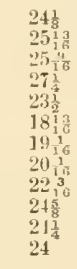 & 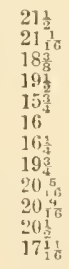 & 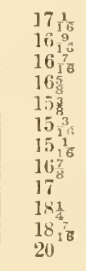 & $\begin{array}{l}17 \frac{13}{16} \\
16 \frac{3}{8} \\
17 \frac{1}{8} \\
14_{16}^{3} \\
13 \frac{7}{16} \\
13 \frac{1}{4} \\
13 \\
133_{16}^{3} \\
131 \frac{1}{16} \\
148 \\
18^{5} \\
15 \frac{3}{9}\end{array}$ & 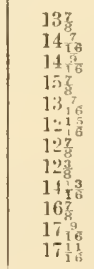 & 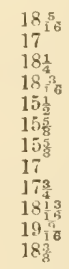 & 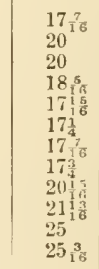 & & 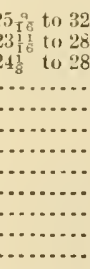 \\
\hline A rerage. & $21_{16}^{7}$ & $21_{16}^{\frac{5}{6}}$ & $23 \frac{1}{4}$ & $18 \frac{5}{16}$ & $16_{16}^{15}$ & $14 \frac{3}{6}$ & $14 \frac{7}{8}$ & $16_{16}^{1}$ & $18 \frac{1}{8}$ & & \\
\hline
\end{tabular}

PROCESS BUTTEL-HOW MADE.

Process, or what is usually kuown as renovatecl, butter is old, rancid butter reworked, fresliened up, and sold for the real article. The workings of this phase of the butter business, not being subject to municipal, State, or Government supervision, are involied nore or less in secrecy. The process by which renovated butter is produced is as follows:

The rancid, olt, unsalable butter is first melted and heated at a high temperature to drain off' as much of the accumulated gases as possible, after which cold water is passed into the oil. The oil rises to the top on settling. It is then removed. 'I his oil constitutes the base of the process butter. The water in which the oil has been waslied elininates the solid impurities, etc. After being removed, the oil is allowed to set in a cold temperature and then, when sufficiently cooled, is churned with fresh milk, sometimes with cream. 
Fresh milk has the property of absorbing very freely butyric acid, the rancid properties of butter. The butter is then worked in the usual way with fresh cold water, salt, etc., thus reproducing fresh butter of degenerate merit and short life. After a few dlays its old character begins to reappear. There are no records as to the effect of such butter upon the human bealth. A vile-smelling flavoring matter is used to give process butter the desired creamery odor. Coloring matter is also used to give it the trade color of butter substances. It is then marketed in tons as fresh creamery butter.

\section{STATEMENT OF MR. GEORGE B. ALEXANDER.}

Mr. ALEXANDER. I will state that I am engaged in the manufacture of cotton-seed oil. I am the manager of the mill at Greenville, Mo. I represent the Cotton Seed Crushers' Association, and am here to protest against this bill, because they believe it is injurions to their interests. This organization that I have mentioned extends not only to all of the States which raise cotton, but also to many other States'where machinery is made which is userl in oil mills and to States where cottonseed products are handled. The object of this association is to improve and promote the general welfare of the cotton-seed industry by seeking new channels for its consumption aud by finding improved methods of manufacture. We meet always once a year-a social meeting-and discuss these matters. There is invested in the oil-mill business of the Sonth about $\$ 100,000,000$. It is comparatively a new industry, having been built up in the last few years, and has converted what was formerly worthless stuff into a valuable product and adıled to the wealth of the conntry and to its export trade, and helped to make the balance of trade in onr faror. Our product enters largely into butterine-

Mr. Willianis. Before you go into that, about what proportion of the value of a bale of cotton is in the seed itself?

Mr. Alexander. Take a 500-pound bale of cotton and it yields on the average 1,000 pounds of seed.

Mr. WILliaMs. At present prices that would be what percentage of the total?

Mr. Alexander. The average price would be 8 cents; that would be $\$ 40$ for a bale of cotton. The last seed I purchased cost me $\$ 20$ a ton delivered at my mill.

Mr. Williams. Twenty dollars?

Mr. Alexander. Yes; $\$ 10$ for what comes out of a 500-pound bale of cotton.

Mr. WiLliais. That would make the seed worth abont one-quarter of the cotton, at present prices?

Mr. Alexander. Yes, sir.

I/r. WILliais. That is what I wanted to get before the committee.

Mr. Alexander. Gentlemen, I am not a speaker, and have prepared no speech. I say that this is a new industry, and that if any protection is to be given anyone we think we are entitled to protection, but we do not ask it. All we ask is a fair field and a free fight, and we will take care of ourselves. We have a product which has merits and needs no protection, and we object being taxed for the benefit of another industry, and we do not think it would be fair to tax one agricultural produet for the benefit of another. There are other gentlemen who will follow me and who will have something to say on the subject, and 
I thank you, gentlemen, for the privilege of allowing me to eome before your.

Mr. Allen. Just one question. What proportion of the oil produced from the eotton seed is used in the manuficture of oleomargarine?

Mr. Alexander. I am not prepared to answer that question fully, because I know nothing at all of the butterine industry. I only know that they use our oil in the manuficture of it. I understand it has 20 per cent, but there are gentlemen here who can answer those questions.

Mr. AlLEN. To whom do you sell or ship the most part of your produet; to whom does it go?

Mr. Alexander. To Chicago, Louisville, New Orleans, Cincinnati, and other places.

Mr. Allen. Do you export it?

Mr. Alexander. We sell to exporters, and we sell to Kansas City

Mr. AlLen. That is all.

Mr. Alexander. I manufacture only the ernde oil, and do not know anything about the butterine industry at all.

Mr. ALLEN. You do not mannfacture the refined oil?

Mr. Alexander. No, sir.

I would state that in giving the price of cotton seed I said that I had paid \$20 a ton for the last seed I bought. I want to say that is not the average. That is the last that I bought, and is the highest price I paid during the season. I do not want to convey a false impression. I will also state that that has not been the price of cotton all through the year.

\section{STATEMENT OF MR. J. W. ALLISON, PRESIDENT OF THE ENNIS COTTON OIL AND GINNING COMPANY, AT ENNIS, TEX., AND PRESIDENT OF THE TEXAS COTTON SEED CRUSHERS' ASSOCI- ATION.}

Mr. Altison. Mr. Chairman and gentlemen of the committee, after the addresses which you lave heard from the members of this delegation, there really remains but little to be said on this side of this ease. Appreciating that you have the faets, and all the facts in this case, wo are liere, with no pretense at speeebmaking, to take up and discuss this business with you as a business proposition. Nearly every single, or every, member of the delegation here present is either directly or indireetly, either as a producer of cotton seed or a mill owner or a dealer in the products of cotton scerl, directly interested in the question which is before you to day, and it is our object to give you our side of the case as it appears to us from onr several individual puints of view. For, after all, it is a selfish motive that brings us here. I am here as a mill owner and as a representative of the Cotton Seer Urushers' Assoeiation of Texas. The State contains about 132 enttorl-seed oil mills, one-third of the yearly product of entton, and has uearly one-third of the eotton-seed product that is made in the United States. We are not butterine people any further than that one component jortion of butterine is our product-cottm-seed oil. The butterine case has been very ably taken eare of by the gentlemen we had the pleasure of hearing yesterday, and we propose to defend only our portion of it.

I do not know that it is charged at all here, and certainly it is not proven, that butterine is an unlealth ful product. We who are engaged in the manufacture of cotton-seed oil know that it is not unhealthful. 
On the other hand, it is one of the purest and most delightful of the vegetable fats. The seed comes to our mills fresh from the cotton fields, and is never tonched by hand from that time until it is delivered to the refiners or the ultimate buyers. It is handled exclusively by machinery. The oil-that part of it which is now under discussion here to-day-is lrermetically sealed by nature in an airtight ease, which is the seed. It is carried to the expressing machinery by machinery itself, aud it is not tonched by human hand, lut is expressed by machinery. There is no possible opportunity for contamination. The process of expressing is extremely simple. Nothing is left after it but the pure oil itselfi. There conld not possibly be any purer fat. There could not come to any table anything cleaner. I am not a technical man, and do not propose to enter into any discussion upon butter or any of the dairy products, but we all kuow that they have a thousand processes of being handled in a small way, and that they are all subject to a great deal of contamination. None of these things apply to cotton seed.

We have in the United States virtually three buyers of cotton-seed oil. The oleomargarine people take our best product and pay us a little more money for it than anybody else. They demand an exceptioually good oil, made by special processes from seleeted seeds. Those mills which have the facilities for furnishing this oil enjoy that trade to the exclnsion of the mills who through any cause furnish an inferior article. Next comes the lard people, who are nearly as eritical in their demands. Next the soapmaker's, who will take anything we give them. It is becanse we do not want to lose a eustomer who buys from us $\$ 3.000,000$ worth of cotton-seed oil every year that we are opposing this bill. It is becaluse we do not want to lose a customer of that kind, and it is because they tell us that the imposition of a tax like this will put them out of business that we are here protesting against it. As I said, two of the gentlemen here are directly interested in this business. Some of them liave been interested in it from its infuncy. I believe there are five gentlemen in the room who have been interested in the business since possibly the mills in the United States conld have been eounted on the fingers of your hands. To day I think there are about three hundred and twenty-five of these mills. I believe there is present in the room the oldest man in the business-I mean in a business way, for he is yet a boy in some respects. I myself have been connected with the business during the whole of my business life. Unfortminately in this great development of the business, the demands for the product have not quite kept pace with the improver facilities. Unfortunately, too, the exact statistics in regard to our business are absolutely unattainable.

The inills are widely scattered. The large majority of them are small enterprises, and the owners are men who are not acenstomed to give out the details of their business, and absolutely refuse to do so. Secondily, exact statistics in regard to the business are unattainable, and any figures given with regard to the business must be taken as very wide approximations. But it is now estimated that there is crushed in the United States about two million tons of seed annually. In round figures, a bale of eotton means half a ton of cotton seed. Giving a crop of ten millions of bales, that would mean live million tons of seed. Not over one and one-half million tons of seed are required for the repletion of the crop each year. That would leave, on the face of the figures, a very large portion of the seed to be culushed. It must be remembered that a large portion of that seed is produced in ont-ofthe-way places, away from large centers, and away from freight facili- 
ties. It is a eheap product, and ean not stand very heavy freight charges; henee, I think the estimate of two million tons is a large one. I believe one-third of that is crushed in my own State.

The use of cotton-seed oil as a food is as old as history itself. Long before the oil was made in the United States by modern methods it was made in all oriental eountries and is to day a staple artiele of food in all the oriental comntries. Even in Bible countries it is spoken of. It is spoken of to day as one of the adulterants of olive oil in every single one of the olive-producing countries, and the statement has been made, I do not know how truly, that an absolutely pure olive oil was unattainable from the fact that the olive growers in the olive-producing conntries are in the habit of starting their oil with cotton seed oil. Even the farmer who makes only a small quantity of cotton oil in the hills of Spain starts his olive oil by pouring eotton-seed oil over it. How much of that eomes back to us as olive oil I have no means of knowing. The butterine people are amply able to take care of their side of the business of their products. We know that the introdnction of eotton oil itself as a cooking fat is one of the possibilities of the future. It is being done, and lias been done, in a small way, by nearly all mills, and is used by nearly all the people in their immediate localities.

The families of nearly all the mill operatives use cotton-seed oil at lome. It certainly can not ehange its natnre if put into butterine. Upon the estimate of the erop as just male the sale of cotton seed in the South must add on the average two to three dollars to every bale of cotton marketed in the South. There is a little more than that. It adds the two or three dollars not to the large planter, not to the dealer, but to the small prodneer. Those of us who are older in the business recollect the time when we were compelled to buy our seed from the small farmers and the negroes, and the large planter considered it as much beneath his dignity to worry about the sale of the cotton seed from his cotton as it was to trouble himself abont the selling of the eggs and chickens on his place.

Mr. WiLlians. And is not it a rule now with the larger planters that the cotton seed is left to the negroes to sell?

Mr. Allison. It is, to a great extent.

Mr. WiLliaus. In the mortgage regulations in the South cotton-seed oil was esprecially exempted from the mortgages in order that the tenant farmer miglit have the cotton seed with which to pay for his neeessities. In many cases it was his profit out of the crop.

Mr. Algison. Yes; it is a cash prodnct, for no such thing as a purchase of cotton seed on time is known. We do business almost always on eredit in the South and cotton seed is the exception to that rule. It is worth so much in cash, that is, between sump and sundown; because after sundown it is against the law to sell it. It nsed to be left to the negroes and the smaller farmers, but now it is used as a inedium for small purchases; a load of cotton seed is used as a eash payment for small purebases. 'They do that because there is no danger of interfering with crop mortgages. We, of course, are not going to pay the price for this cotton seed if we are deprived of those purchasers whom this bill would deprive us of. We will take it out of the price of the things we sell. It is the man with the hoe that pays for it, and the manufacturer, of eourse, would pay that much less for his raw material. While it may be true that we would replace the buyer of this $\$ 3,000,000$ worth of cotton-seed oil if the butter maker went out of existence, it has a wider significance. We have struggled for years to introduce our product into the European eountries, and the largest 
consumers there are the olive-oil producers. Those countries are talking of discriminating against cotton-seed oil, begimning a few years ago with a proposed tax in Italy, and followed 11) by a proposition male in France and one also in Germany, and an effort has been mane to crowl our probluct ont of those comtries, because of its competition with the other edible oils, odive oil aud, in Russia, linseed and other oils. Russia does crowd it out, because she arluits of no competition with linseed oil. Russia has in prospect the production of cotton-seed oil, and she produces now a small quantity of it.

Our fear is that if our friends, the pure-butter people, are suecessful in driving out the butter industry, or at any rate in putting upon it an additional tax, whether it kills the industry or not, that puts such a stigma upou our proiluct, which foreign countries are buying, that they will not continue to buy of us. The proposition has been made to exclucle American oil out of France in order that the Egyptian seed shall be crushed in France and cotton oil malle in France. It' it should be stated that the American oil was legalderl as such a harmful prodnct in America as to be taxed at home, the Frenclı deputies would not be slow to take it as a chance and erowd us out of France.

We are, then, confined to the home market, which cousists of lard com. petition. It is not a violent smpposition, that if the butter producers lave been alme to legislate us out of France, that the hog people would be, if those things conld come to pass, able to legislate us out of competition with them in this country, and the cotton-seed industry would be dead. It is hardly to be anticipated, but it is possible.

Mr. ALLEN. Wliat effect do you think the prohibition of the manufacture of oleomargarine would have upon the price of your oil, per gallon or pcund, in a general way?

Mi. Allison. I hardly know how to answer that question, sir, except to say that it deprives us of a market that is consmming between 5 and 10 per cent of our production-of our best production-and pays us more money for it than any other channel into which our product goes. We would then sell what we call butter oil at the same price that we sell some other oil, the yellow oil being butter oil.

Mr. AlLEN. What is the price of your butter oil; what do you sell it at to day in New York?

Mr. Allisun. Forty to 45 cents, depending entirely upon the quality and the production of the plant.

Mr. ALLEN. Forty to 45 cents a gallon?

Mr. Allison. Yes, sir; as against 37 cents for the other oil.

Mr. WILliams. And the 7 to 8 cents additional makes three to four dollars a barrel?

Mr. Alurson. One of the gentlemen here has a sample of white oil. I am sorry that we have not any sample of the butter oil, but we did not have any inlea that you would want it, and dirl not bring it. But I have a sample of the white oil here. (The witness here produced a bottle of the white oil spoken of and exhibited it to the committee.)

Mr. Cooney. What do you mean by butter oil; is that tho oil that goes into the butterine?

Mr. Aluison. 'That is the name for the highest grade of butter oil. It is a special oil and is a kind made from selected seerl, and is the kind of oil that goes into the butterine.

Mr. Neville. How do yon figure that this bill would drive the oleomargarine ont of the market?

Mr. Allison. I do not tigure that at all. I did not state that as a fact of my own knowledge. I asserted what the butterine people have 
told us, which is that the 10 cents a pound in ardition to the cost of its mannfacture would prohibit its manufacture in competition.

Mr. Neville. You do not contend that this would place 10 cents a pound on all butterine?

Mr. Allison. Colored?

Mr. Nisilue. Colored as butter.

Mr. Allison. Yes, sir.

Mr. Neville. But when it is not colored you do not understand it as imposing any tax?

Mr. Allison. No; I understand it.

The Umarrman. There are two questions in one there. You say colored as butter. The contention is that it is not colored as butter but that they simply use a color. Did you intend to answer the question in that way-colored as butter, or colored?

Mr. Allison. I do not understand the question.

Mr. Neville. The question I asked was-

Mr. Allison. I understand his guestion to be, if my understanding is correct, I understand this bill to impose a tax on oleomargarine colored as butter.

Mr. NeVILLE. That is right.

Mr. Allison. That is all; colored like the butter we know; whether that is the natural color of the butter or not, I am not a butter maker, and I do not know. I do know this, that the producers of natural butter in all of the butter-producing countries are themselves the largest producers of cotton-oil butter. 'They are themselves the prodicers of the butter containing very largely the very element that we furuish to the butterine manufacturer to put in his butterine, and in this way-of the $2,000,000$ tons of cotton seed annually crushed in the South, there is made three-quarters of a million ponwils of cotton-seed meal, which is recognized as the most nutritive and highly concentrated cattle food known. The butter producers are buyers of the cotton-seed meal.

Mr. Neville. To feed to their cows?

Mr. Allison. Yes, sir; the German and Holland people, who are the largest butter producers, buy it simply because the cattle fed upon it produce better butter and more butter. It prodnces it becanse of its nutritive qualities, and becanse of that certain small percentige of the cotton-seed oil left in the meal, which is of so nearly the same constituents of the material required to make the butter that it passes through the cow's stomach almost unchanged into the milk duet..

Mr. Neville. Does it bring about as mueh when sold to the dairy people as food for their cows as when it is sold to the butterine people?

Mr. Alcison. I think yon misapprehend me.

Mr. Neville. You mean cotton-seed oil?

Mr. Allison. Yes, sir.

Mr. Neville. Will the cotton seed produce as much when sold to the dairy people as feed for cows as when sold to the butteriue people?

Mr. Allison. I do not understand.

Mr. NeVILLE. Is the oil used in the production of oleomargarine higher priced, and does it hring more value to the producer of cotton seed than the cotton-seed meal when sold to the dairy poople?

Mr. Allison. Why, they are two entirely diflerent products. They are entirely different products. They are not to be compares at all-

Mr. Williams. What you want is to know which is the by-product and which is the main product?

Mr. BAILEY. What do you sell the eake at?

Mr. Allison. 'T'wenty-one lollars a ton, about.

Mr. BAILEY. Twenty-oue dollars a tou? 
Mr. Allison. Yes, sir.

Mr. BAILEY. Thit is what it will cost the dairyman. Now, you say your oil is worth how much a gallon?

Mr. Aluison. Fonty cents; that is, the butter oil.

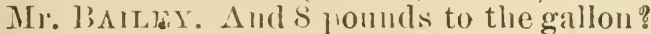

Mr. Allison. Seven and a half; yes, sir.

Mr. BAILFr. Five cents a pound?

Mr. Aluisun. It would bring $\$ 100$ a ton in oil, and $\$ 20$ a ton in these by-jurlucts.

Mr. BAILEY. Of comrse there is oil in this [indicating piece of oil cake in the hands of Mr. Neville].

Mr. AluISon. It is impossible to extract it, even if we thought it advisable. By solvents it would be possible to take all the oil out.

Mr. Neville. You simply leave some of the oil in there?

Mr. AlLison. Yes, abont 10 per cent, and for the very reason that it malies it more valuable as a feed for cuttle.

Mr. Williams. That oil, you say, eomes to $\$ 100$ a ton?

Mr. BAILET. Yes; and this calie to $\$ 20$ ?

Mr. Allison. Yes, about $\$ 20$ a ton.

Mr. BAlLEY. I liave bought carloads of it.

Mr. Neville. The point I lesiled to make was that even though the oil was not used in oleomargarine a large portion of it still remained in the eake, and would be sold to the eattle feeders.

Mr. Allison. It is left intentionally in the cake, in order to improve the quality of the cake as a feed for the eattle.

Mr. WiLlians. I am sure that Mr. Neville does not understand. 'This is aftel' the oil is pressed ont [indicating piece of eake in his hand].

Mr. NEVILLE. I understaud that that is oil cake-

Mr. WILLIAMS. The main product is the oil, and the by product is the "ake. Then, in addition to that, there is the hull, which is used for cattle feed.

Mr. BAILEY. Ronghers.

Mr. Neville. But the principal feed with us is oil cake, in Western Nebiaska, and it has oil in it. I do not know what the quantity it has in it is.

Mr. AliLison. It is a butter producer. If it is possible to kill the oil mills of the south the butter feerler would suffier. It would deprive lim not only of the best feed, but of the feed that enables him to use his home-grown feen-cotton.sued meal being a highly concentrated food which crables him to use roughers.

Mr. WILLIAMs. Suppose you were deprived of the sales for your oil, would it pay you to run your eotton-seed mills just for the cake?

Mr. Allison. No, sir.

Mr. Williais. That is the point.

Mr. Aluison. Mr. Alexander has said tluat he was buying cottonseed cake at $\$ 20$ a ton. It is worth a little over that. It takes three tous of cotton seed to make one ton of cake.

\section{STATEMENT OF MR. W. R. CANTRELL, SECRETARY OF THE WILLIAMS \& FLASH COMPANY, OF NEW YORK CITY, EXPORTERS AND COM- MISSION MERCHANTS OF COTTON-OIL PRODUCTS.}

Mrr. CANTRELL. Mr. Chairman and gentlemen of the committee, this subject has been so thoroughly gone over that there is very little I can ald to it, but I do desire to call your attention for a moment to a few figures going to show the extent to which the manufacture of cotton- 
seed oil and its by-products has grown, and the position it occupies in the foreign commerce of this conntry.

Your attention has been called to the injury the passage of the Grout bill would inflict on the southern farmers and laborers by depriving the manufacturers of cotton oil of one of their most important home outlets.

Not only, however, would the home consumption of cotton oil he enrtailed, if this proposed bill should become a law, but we should also sufier in our export demand, and, as evideneed by the following figures, the cotton-oil exports in the last three years have assumed a position of considerable importance in this conntry's foreign commerce.

In 1897 the exports were $27,198,883$ gallons, or 543,976 barrels.

In 1898 they were $40,230,78+$ gallons, or 804,615 barrels. In 1899 they were $50,6 \pm \overline{2}, 21 !$ gallons, or $1,0 \pm 1,514$ barrels, which latter amonnt, taken at the average price of that year, represents a value in dollars and cents of $\$ 13,163,076.94$. This sum simply represents the exports of oil alone, and does not include the exports of meal and cake, which would amount to as much more.

This foreign demand has been created after years of effort and at the expentiture of thousands of dollars, bnt at this juncture it is menaced by comntry after country endeavoring to stop its import by the imposi tion of prohibitive duties. France, to whom was shipped last year 339,187 barrels, and Germany, 70,428 barrels, are both laboring to enact legislation that wonld close their ports to this great American staple.

Now, if our own legislature should stigmatize this article, and by a prohibitive tax prevent its sale in this country in the form of oleomargarine, it would be putting a weapon in the hands of our foreign competitor's that they would not fail to use to enact legislation that would prohibit its sale, thus entailing a loss of millions of dollars to our foreign commerce and the effects of which would be felt by every railroad in this conntry and by every ocean steamer leaving our ports.

'The growth of the cotton oil industry has been rapid, and the demand, especially in this country, has failed to keep pace with the increasing production, therefore, if the article were deprived of any portion of its aheady inadequate home lemand it wonld mean that the surplus thus created would have to force an ontlet in Europe, and this conld only be accomplished at the expense of values.

If the outlet we now possess in oleomargarine is destroyed and a surplus thus created it wonld canse a decline in values of at least $\$ 2$ per harrel, which, taken on last year's prodnction of ' $2,000,000$ barrels, means a loss to the fitrning interests of the South and Sonthwest of $\$ 4,000,000$.

Mr. Nevilie. Is it not true that the proposed legislation in France is against oleomargarine and not against cotton-seed oil?

Mr. UANTRELL. No, sir; that is not true. France, a few years ago, and up to within the last four or five, took about ten or twenty thous. and barrels of cotton-seed oil. They used the arrish-seed oil, which is a wild peanut, as well as several other things of that sort, but the cotton-seed oil was so much cheaper and purer that the manufacturers of those comitries were forced to use it, and they were forced to go to the cotton-seed people. And they found themselves compelled in France to put a prohibitive duty upon it.

Mr. Neville. Is it not a fact that only a few weeks ago they did pass legislation against oleomargarine?

Mr. CANTRELL. Not that I am aware of.

Mr. Neville. The reason I asked you is because I read it only day before yesterday. 
Mr. Wirciams. Do you know any thing about the eomparative purity of fine cotton-seed oil and olive oil and vegetable products?

Mr. CaNTRELL. Yes, sir; bit I would very much prefer the cottonseed oil. In fact, salad oil which is made from cotton seed oil is not only purer, but more cleanly, and it is sold in all the large cities of the North now as cotton-seed oil. In fact, the bulk of the olive oil coming to this comntry is mostly the poorer grade, and it is prepared and made in rather an uncleanly manner. The olives are put in the press and the first pressure taken from them is a very tine grade of oil, and that retails in a city like New York in this country for four or five dollars a gallon. Then, having extraeted the better parts of the oil, the olives are put in a bath of hot witer, and sometimes salt, and are pressed again, and that is a very inferior product, and is the olive oil that is sold to the average person in the larger cities, and is absolutely unfit for consumption.

\section{STATEMENT OF MR. EDWARD S. READY, SECRETARY, TREASURER, AND MANAGER NEW SOUTH OIL COMPANY, OF HELENA, ARK.}

Mr. READY. I have never made a speech in my lite, Mr. Chairman, nor am I used to talking publicly. You gentlemen have listened very patiently to the other gentlemen, and consequently I will say nothing of the general conditions, and will sjeak only of local conditions, and that very briefly. We have in Helena four oil mills. The town is located on the Mississippi River. We have there four oil mills and the cost of the equipment of these four mills is about $\$ 350,000$. In addition to that we have capital invested to the extent of another $\$ 350,000$, making $\$ 700,000$ invested. We employ 200 people, all adults with a few exceptions; there may be eight or ten boys in the whole business. Sixty-six to 70 per-cent of those men are heads of families and I think I am safe in saying that ont of the population of 8,000 inhabitants those four mills support 750 to 800 people.

Thus, you see, it is a matter of very considerable moment to us. Of those employees about 85 per cent are colored and the remaining 15 pel cent are whites. We handled last season, I presume, as near as I can get at it-I can safely say that we expenderl $\$ 600,(100$ for the pur. chase of cotton seed. We ran about six months in the year and furnished employment, as I say, immerliately in the mill, for 200 men. The surrounding conntry depends very largely in addition to the town-700 or 800 of the population depend very largely upon our mills. The farmers come there, as has been stated to you, the negro small cropper, and the small white farmer, and we buy all of our sup)plies of seed from them. If this bntterine or oleomargarine law is enacted it would affect onr markets very considerably. It wonld result in the rednction of the price of seed, how much I can not say, but it would be largely felt, and I felt that I shonld come here and enter our protest against it, and request the committee not to deal too har,hly with the butterine industry, as it largely affects ourselves.

The CHAIRMAN. Are there any other questious?

Mr. CoONEY. Yon have four mills?

Mr. READY. Yes, sir.

Mr. CoONEY. You are secretary and treasurer of the society there? Of what is that society commosed?

Mr. REAnY. No, sir; I did not say that. I au secretary and treasurer of one of the four mills. 
Mr. CoONex. All these mills are acting independently?

Mr. READY. Eutirely so.

Mr. COONEY. Absolutely?

Mr. ReADy. Yes, sir.

Mr. COONEY. No connection?

Mr. READY. No, sir; none whatever.

Mr. Allen, No trust in them?

Mr. READY. No, sir. There is one of the mills that is under the socalled American Cotton Oil Trust.

Mr. WILLIAMrs. Is not it a fact that the cotton-seed crushing trust business is one of the few instances of a trust which is not a success?

Mr. READY. Yes, sir; I would say that I was comluected with the American Cotton Seed Oil Trust and left it in $18: 17$ and went into business on my own account, and I did not fear it, and I think the three independent mills there in my town are hitting it pretty hard.

IIr. WiLLIAMs. Independent mills are springing up everywhere?

Mr. READY. Yes, sir; everywhere. Two were built right elose there last year.

Mr. WiLlians. Yes, one was built right in my own town.

\section{STATEMENT OF MR. W. H. WRIGHT, PRESIDENT OF THE PINE BELT COTTON OIL COMPANY, OF LITTLE ROCK, ARK.}

Mr. WrigHT. I think, Mr. Chairman, that about everything has been said that ought to be said from the crushers' standpoint. There are other gentlemen here in lifferent lines of the business who have not been heard, and I had rather give up my time to them.

\section{STATEMENT OF MR. MARION SANSOM.}

Mr. SANsonr. Mr. Chairman, I have to go away to-morrow and I am here representing the eattle interests of 'l'exas, and I will only detain you for a minute-just long enough to cast my vote-and if you will allow me I would just like to do the voting act for you, as they sent me up here. As I come up here representing these people I wonld like to get before the committee, and I am obliged to leave to-morrow. I have here a letter from the live stock association and they just simply wanted me to appear here in opposition to this bill as representing them, and also I speak in the interest of the cotton-seed oil industry.

The Cindruan. We have made this arrangement for this day's nieeting for a cotton-seed oil meeting.

Mr. SANSOM. I will just read this letter so yon will understand what my credentials are.

(Mr. Sansom here read the letter referred to.)

W e come here to show you the interest we feel in this matter and we put forward our best people liere yesterday to take this matter up. We wish to show to yon, however, that 'Texas is interested in every single article that enters into the manufacture of oleomargarine except the coloring, so-called, and I do not know but we may mannfacture that; but I do not know what it is. But we do raise about one million head of cattle which are slaughtered annually and which you nnderstand, as has been gone over to you a unmber of times, enter very largely into the prolnct. We raise abont one-third of the cotton raised in the United states. We are third on the list of log raisers of the United States. So, you see we are very materially affected by this legislation. 
Now, it oecurs to me this way, that this thing has simmered down very largely to the matter of color. We are not a maunfacturing people there in 'lexas. We hope some day to get in line and are getting along a little. This is really the only manufacturing industry we have worth speaking of in the State, in which we have about 130 mills.

We are perhaps the largest buyers of imported goods in this Union. When I say imported, I mean from other States. We send our cotton up here to our Eastern neighbors and they make it into goods so beantiful and so tine we do not know whether it is silk or cotton; but we have never said that they have no right to lo that, bnt we have gone on and bouglit the cotton. They have put a coloring in it which makes it very beautiful and fine, and it suits us, and theu we want to buy it. And we can see no reason why things shonld not be colored. They put a color on all kinds of machinery we buy. I do not know whether coloring makes machinery any better; perlıaps it dloes. Whether it makes butter any better I do not know, but I suppose the people like it better for that reason. But we simply enter our protest, insomuch as we understand it, from the eattle raisers' standpoint, regarling this as a question of class legislation, one class against the other, and it anveurs to us we are not considered as we should be in this matter. All we ask is to be let alone. Of course if we are doing anytling that is going to really injure anybody, then we are willing to be called down; but we do not think it is proper and just to people that have been struggling as we have, sending away all of our raw material to be manufactured elsewhere, and this is the only manufacturing industry that we have. I will say that all of our cotton has been sent away to be manufactured to the Eastern cities and it has been mannfactured and we have sent all our hides and cattle. We are now engaged in the manufacture of this product, in the manufacture of cotton-seed oil, and it is a big thing to our people, and Texas, and from this we expect to get into other lines, and if we get stricken down and knocked out in this matter riglit on the start we do not think it is really fair.

Mr. NEVILLE. If you were to send your cotton up to the mannfacturing concerns up here and they should manufacture it into imitation silks and send it down to you and sell it to you for silk, would you care or not?

Mr. SANSOM. If they sold it to me at a proper price, I probably would not. If they sold it to me for a price that was unjust, I probably would not like it.

Mr. NEVILLE. The difference is that you manufacture this oleomargarine in suclı a shape that I can not tell it from butter, and they nut cotton-seed oil and other kinds of oil into it and deceive me, and yet you think it does not hurt me and you insist that you have a right to do that.

Mr. Sansom. I would like to auswer that question this way: If the silk producer and the wool producer, if you please, had as much right to come to Congress and ask for legislation against woul entering into the manufacture of cotton goods, or cotton into wool goods, which is usually the cheaper of the two, as you all know very well-as you klow woolen goods has always a percentage of cotton goods nixed in with it-now, the wool man would lave just as much right to come to us, he mannfacturing the most valuable part of it. We object to this. You and all of the balance of us have worn and are wearing every day what is supposed to be all wool and a yarl wide, aud yet we all know that there is a large percentage of cotton in all this gools. You are not particularly damaged and you have got your gools worth 
the money, and you have the same riglit the wool man does to come to Congress and ask to bave these people stopped from mixing this goods and foreed to make it all cotton or all wool.

Mr. Neville. Don't you believe that we would have the right to come to Congress and ask them to prohibit the manufacturing of cotton goods and the selling it as silk goods?

Mr. S $\Lambda$ Nsom. We believe in letting people who are enterprising and trying to moduce something for themselves go on and try to produce the best results. We do not think the position taken by the people who are urging this bill here, asking the Congress of the United States to come to their relief - we do not think the ground is well taken, and we think for yon to lend the assistance of this Government to the manufaeturer of one article, for the product of one article, above and to the discrimination of another which is equally pure, as we claim, from the standpoint of our conntry that furnishes the lard and tallow and the oil that goes into this product, is wrong and unjust. I do not understand that the purity of this food has really been questioned at all, and if we have done this we can not see why we should be discriminated against.

Mr. Cooney. What is your conneetion with the cattle business?

Mr. Sansom. I raise eattle and feed eattle pretty extensively. I am what we call a pretty large feeder in Texas.

$\mathrm{Mr}$. CoONEY. Is your business more largely involved with the cattle feeding and raising than with the oil production.

Mr. SANson. Yes, sir; my interest is much larger in that business. I am engaged in the oil mill business, but my business is much greater and $I$ levote much more time to raising and feeding eattle than to the oil business.

Mr. CoONEy. Raising them on the ranch or buying and selling them?

Mr. SANsour. Yes, sir; I own a ranch, and I buy a great many cattle which I mature at these oil mills-feed the product of two or three oil mills.

In this connection I would like to show further that there has been a disposition from the time we began to manufacture the cotton-seed products on the part of people we came in contact with-and that means the dairy people and the Western people who produce beef-to diserininate and to knock us out. They had even gone so far as to propose at one time that they would condemn the beef fed on cotton-seed meal. If the beef business had not been handled by such strong hands there is no donbt there would have been some such aetion taken. But when it came to condemning all the beef fed on cotton-seed meal, the dairy people found that was too strong for them.

Further, I wonld like to refer to the value of cotton-seed meal as a food stuff. I myself, as yon will see by referring to the Breeder's Gazette, furnished beef fed on cotton-seed meal to parties in Chicago, in Mareh, 1S99, and I have sold cattle in Chicago at 25 cents a hunlreil above any native steer on the market, for more than forty days aiter the sale was made, and ten or fifteen days before. In November, 18!!!, I sold cattle there as high as $\$ 6.75$ a hundred, which is much higher than the higliest price paid for natives at that time, and they were not quite so well finished as those I had sold before. I mention this to show yon the interest we have in this legislation; and whenever any legislation comes up onr interest is identical, except that onr interest in the cattle is large. Every time you take off 10 cents from cotton seed in 
the State of Texas you reach and touch the very poorest people we have in the State-the very poorest people who have contended liardest for a living.

Now, with reference to the price of the seed. When cotton was $4 \frac{1}{2}$ cents a pound, and they were selling it for that, we were at that time paying as mueh for seed as now. We were helping these poor people very greatly. If it hall not becin for the priee he was getting for his seed, it would have absolutely bankimpted the tenant.

Mr. WiLlians. At that time the value of the eotton seed was a little over a third of the value of the cotton itsell.

Mr. SANsom. Yes. as high as twelve and fourteen dollars a ton. It helped them out a great deal. Of eourse, when you speak of Texas, it is quite an extent of "ountry. The part of Texas 1 represent las no negrnes. We never see a negro there, except if we have got any he is in town shaving someborly or waiting on the table. They are white people there, and an industrious, hand-working people, male up) from every section of the conntry represented there, and they work and till their land. The section I am interested in is made up of small farmers owning from 200 acres of land and over. Whenever you touch the cotton crop you hurt them and hurt them bad. They will find another outlet for this oil, if this business is elosed to their product. The whole world is nsing it, not the United States alone, but I do not believe that "ven Congress ean tax it out of existence. You may hurt it for a time, bint you can not down it.

They first educated us abroall to nse this oil. Our product was used before we knew the value of it at all abroad-both the meal produet and the oil as well-when our own farmers at home, many of them, did not know the value of a sack of cottonl sexe meal. And they do not know it to-day, many of them. They donot know the valne of it as compared with the German farmer who never saw a stalk of eotton in his life. That being the "ase- lhese beople raising it and displaying it as a cheap) food-we are naturally jealous of any attempt to cut off our market for it. There is a principle of ownership involved there-one section against another. If cotton sfeel were raised all over this eountry, don't you think it would be a pretty hard matter to come in here with a bill like this? Thele are some people in this comntry who are opposed to cotton seed, and when you find a man like that he is a dairyman every time. And these propile come here and eall upon you to help them down the other fellow, and then they will be able to make all the money they want. They say "Hel]) me down him, and then I will make all the money I want after I get shut of him." It is a class legislation that we do not think is riglit.

Mr. Neville. Yoil mulerstand that this bill does not seek to do away with oleomargarine altogether, but simply to prevent its being made as a counterpart and in imitation of bntter?

Mr. SANsour. I stated in my talk a while ago that I understood the proposition came down to a question of coloring. I believe I answered that by saying this: Suppose you go to work and say that we conld not color our eotton goods when they are manufactured, if people like color and it does not make it harmful?

Mr. NeVILLE. I woull certainly say you would not have a right to color it in imitation,$i$ anything else and sell it in imitation and for that other goods.

Mr. Saxisom. We mulerstand the law protects you fully; that is, the license has to be praid ou it to be suld; but the law is violated 
occasionally. It is against the law down in our country to steal a horse, but they do steal one oceasionally. Still, I would take it that in the main the law was enforced.

Mr. NeVILLe. If, as a matter of fact, all the ingredients in olenmargarine are healthy and wholesome and it is cleanly made, is it not true that it would recommend itself without being in imitation of anything else?

Mr. Sansom. That is probably true, and you might edueate the people to eat white butterine. The same thing applies to other articles, and it might alply if you took the color out of your dairy butter. It is a matter of eustom, largely.

Mr. NeVille. You would not maintain for a moment that yon would have the right to build up a traffic in any kind of product aud palm it off on the people as something it was not?

Mr. Sansom. No, sir; we do not wish to do that, and are not here in the interest of any concern that we understand is cloing that. We are here simply for the purpose of keeping the color on butter the same as we color ot her kinds of goods. People do not like white or uncolored butter. You would not want to come in here with red clothes on, becanse it would be very unusual. We do not want to force perple to use things that are not fashionable. We do not want to do that.

\section{STATEMENT OF MR. A. D. ALLEN, REPRESENTING THE CONSUMERS COTTON OIL COMPANY, OF LITTLE ROCK, ARK.}

Mr. Allen. After so much has been said here, I think it would be merely thrashing over old straw to add to the discussion. In fact, I have nothing to add. In onr town of Little Rock we have four oil mills, representing a plaut investment of three quarters of a million if dollars, and we pay to the farmers perhaps as mnch more for seed during the season. We employ between four and five hundred men in the mills, and those men are mostly-well, you might say 80 per cent of them-unskilled laborers, negroes, that we employ in the mills, ranging from $\$ 1.15$ to $\$ 2$ a day. Those people are dependent upon our mannfactories there for a living, and we get our seed from the farmers around us. It is quite an industry. It is, I expect, the largest covered industry we have in the State of Arkansas, and we fiel that we ought not to be opripressed. I do not know that I can add anything to what has been said before, and I thank you, gentlemen.

\section{STATEMENT OF MR. F. W. BRADY, OF MEMPHIS, TENN.}

Mr. Brapy. I can scarcely add anything to the remarks given here. I have come here in the interest of the committee. The gromud has been gone over very fully here, and very ably by Mr. Aldrich and Mr. Allison; I merely wish to call your attention to one fact which may have been lost sight of, the general industry of the cotton seed product in the mills, the cotton seed of the whole Sonth. I mulerstancl the dairy interest is only in five States and I also wish to say here that the Sonth, I do not believe, ever has come to Congress and the Government for any legislation in any shape, manner, or form. I do not think they ever liave asked protection for anything. This is the only industry they can really call their own. I do not believe there is anything else of such magnitude, and therefore I want to eall attention to it.

In the fourteen States in the South, representing the whole South 
and one or two others, which represent the cotton-seed industry-fourteen States have 387 mills. There are 14 mills in Tennessee, 31 in Alabama, 2: in Arkansas, Florida has 2, Georgia 50, Louisiana 2, Missouri 2, Illinois 2, Mississippi 5, North Carolina 22, South Carolina 48, Oklahoma Territory 6 and tho Indian Territory 5, and the Great State of Texas 117. That certainly represents a large territory and also a great deal of money involved, as has already been stated here. They employ, I presume, I should say, about twenty to twenty-five thousand men. Of course, if that industry was interfored with the loss would not fall on the rich mill owner but on the farmer, and some of the small farmers are negroes who receive a portion of this for their seed. As has been already stated here the butter oil which is used in the manu. facture of butterine is a small portion of the general production. Still, that helps the general industry, and another point that is to be consid. ered is that the foreign countries will take advantage of anything that is passed to condemn the oil. In fact, it is a fact that the foreign countries first taught us what it was. We did not know.

Germany was a pioneer in this, and France followed, and then the New England States took it up and from them the South learned the value of the cotton-seed oil and cotton-seed meal, and then the value was enhanced by foreigu countries. New England and the foreign countries taught us what was the value of all these products of ours. Now, why should it be that these are the very people that are coming in and try. ing to take away from us that value? That is a question I have revolved in my mind from day to day, Why should these very States be against it? It seems absurd to me. It is a wholesome article of food, and if it is, and furthermore it is a cheap one, it is not alone the producers who are interested in this; far from it. The cousumer is also interested. By the manufacture of this cotton-seed industry we get cheaper lard, cheaper butter and better butter, and also cheaper and better olive oil-an article used in food from time immemorial-aud it is carried to every industry and I do not see why there shonld be any objection to it.

You have here the statement made by Mr. Aldrich as to the other articles nsed in the mannfacture of this product, and as to thoir purity and cleanliness, and $\mathrm{Mr}_{\mathrm{r}}$. Allison made a statement as to the purity and cleauliness of the olive oil. Those are facts and there is no question abont them at all. I passed one establishment in Chicago, a slaughtering establishment, where they used the cleanest water and the cleanest handling of this oleo fat. They put it in clean water, and I inade inquiries and found it was the purest water they conld obtain for that lurpose; and then they put it in cold storage. The butter men will make the same statement. I am satisfied that you must be satisfied of that, and another point is made. We do not say the other article is not good, but wo say onrs is good. The whole matter has been over. hauled so much, and wo speak for the Southern industry, and I do not think it is right and I do not think it will pass and I think people in general are against it.

Fourteen States are producing this, and there are only four or five States that are interested in the dairy interests at home. Here is a statement I have made up, showing the location of each individual mill of the cotton-seed industry. However, it is not complete. I lnerely saw it lying on my desk when I came out of my office and took it up without any idea of turning it in to the committee, and I would like to lnave the privilege of revising it and completing it before I do so.

S. Rep. $2043-47$ 
Mr. BAILEY. We would like to get it into the report of the committee and if you will send it to ns afterwards we will be much obliged.

Mr. BRADY. I will be pleased to do so. There might be some mills left off here.

\section{STATEMENT SUBMITTED BY MR. ROBERT GIBSON, OF DALLAS, TEX}

I have been associated in and with the cotton-seed oil industry for the past twenty-three years, moving from Tennessee to Texas in 1877 to huild and operate cotton-seed oil mills, and was actively employed in the management of oil mills for some fifteen years. Since that time I have been more or less interested in the industry. For the past five years I liave been filling the position of secretary of the Interstate and 'Texis Cotton seed Crushers' Associations.

My association with the mills and the two associations has given me a thorough insight into and knowledge of the cotton seed crushing industry, which has increased from some 5 or 6 mills in 1865 to over 300 mills in 1899. In the mills of recent years over 90 per cent of the labor used in these mills are negroes who are paid from $\$ 1$ per clay to as ligh as $\$ 3.50$ per day for their services. These mills, with the exception of some 4 or 5 , are located in the cotton-growing States of the Sum and the Indian 'Territory; in my State, Texas, and the Indian Territory there are some $135 \mathrm{mills}$, and more being built every year as the cotton growing is being developed. Iive years ago there was not a cotton-seed oil mill in the Indian Territory; to day there are 10 or 1', and every year as the cotton average is increased, more mills are built. The same conclition, too, exists as to the increase in mills in the old cottongrowing states. These facts I give you to show the great injury you would inflict on this growing industry by the passage of laws taxing one of our principal products-the oil, which is largely nsed in the manufacture of butterine, a pure and wholesome food-which tax, if placed as contemplated in pending bills, will cut off the use of this oil to a great extent, and, in consequence, unless other uses can be found for it, must materially affect its price, as well as the profits of the farmer who raises the cotton and seed used in its manufacture, particularly the latter, which now pays the farmer from $\$ 4$ to $\$ 5$ per bale for all seed sold. I beg further to show you that the injury to this industry not only affects the cotton growing States of the Sonth and Indian Territory, but as well a great many of the Midcle and Eastern States that mannfacture the machinery used in these oil mills, as well as the manufacture of the snpplies nsed in their manipulation.

The three largest companies building oil machinery, and furnishing over 75 per cent of it, are located in Dayton, Ohio, though there are some three others located in Thompsonvilie, Conn., Richmond, Va., and Chattanooga, Tenı. The largest and principal companies furnishing camel's-hair press cloth are loeated in New York and Massachusetts; besides, there are others located in Chicago and St. Louis. The mannfacturers of other parts of machinery nsed largely in the construction of oil mills-in fact, almost all of the machinery and supplies come from the Middle and Eastern States, and I am satisfienl that each and every concern engaged in said manufacture would join us in our protest against the inflietion of this unjust tax.

In conclusion, I beg to say that the members of our two cotton-seed crushing associations are not confined alone to the States operating oil mills, but are composed as well of members from Missouri, Kentucky, Ohio, Illinois, Pennsylvania, New York, Connecticut, Nebraska, Jowa, 
and Kansas, all of whom are represented here to day by the committee composed of E. H. Ferguson, of Lonisville, Ky.; W. R. Cantrell, New York; George B. Alexander, Greenville, Miss.; E. M. Durham, Vicksburg, Miss.; E. Steinhart, New Orleans, La.; E. S. Ready, Helena, Ark.; W. H. Wright, Pine Bluff, Ark.; A. D. Allen, Little Rock, Ark.; F. W. Brode, Memphis, Tenn.; L. W. Haskell, Savannal, Ga.; Jo. W. Allison, Ennis, Tex.; George M. Allridge, Dallas, Tex.; Marion Sansom, Alvarado, Tex.; A. P. McCord, Cameron, Tex., and Robert Gibson, Dallas, Tex., who respectfully petition that your homorable body do not pass this, to us, unjust measure.

Therenpon the subcommittee adjourned.

House of Representatives, April 17, 1900.

The subcommittee on the Burean of Animal Industry of the Committee on Agriculture met at 11.15 a. m., Hon. Henry D. Alleu in the chair.

The Chairman. Mr. Hake, I understand that you gentlemen desire to be heard this morning, and I would like to have you indicate which one of you wonld like to be heard first.

Mr. HAKE. I will make a short statement, Mr. Chairman.

\section{STATEMENT OF MR. J. A. HAKE.}

Mr. HaKe. I am in the live-stock commission business at South Omaha, Nebr.

The CHAIRMan. Have you any official position in any organization?

Mr. HАKE. I am president of that association that we have there called the Live Stock Exchange.

Doubtless this committee has been regaled with all the arguments that acute and quick minds could conceive of in the direction of argument on the question that we think interests us. We do not desire to be understood as being so conceited as to believe that we could change the minds of people who had already made their minds up, or convince a man against his will; but we in the West are engaged in stock growing and beef making, and we feel that these measures in relation to oleomargarine would affect the value of our products; and we have a little information in relation to our markets and our city which we would like to present for the consideration of the committee.

There being several bills now pending before the different committees in Congress seeking to impose a tax on oleomargarine, or manufactured butter, to such an extent as to absolutely prohibit its manufacture and sale, we wish to say that the result of the passage of such measures would appear to be in the interest of the dairy-producing and dletrimental to the meat-producing sections of this country.

Coming as we do from Nebraska, one of the largest meat-producing States among the sisterhood of States, and representing a commercial body-the Sonth Omaha Live Stock Exchange-whose members transact a daily busines; the aggregate of which is greater than any corporation, company, association, or individual in the State, and possibly greater than all these combined, we have asked this hearing for the purpose of offering some information as to the extent of the livestock industry in our State and the damages that would result thereto should these measures become a law. 
South Omaha is the third largest livestock market in the world.

For the year ending Decomber 31, 1S99, there were 540,502 cattle slanghtered and, for the same period, there were slanghtered $2,185,7$, 9 hogs. The makers of oleomargarine create a demand for oleo oil which is made from the choice fats of the beef and which is worth, for butter purposes, 10 cents per pound. If thesc choice fats were not utilized in the manufacture of butter, they would have to be sold as tallow, which is worth about 5 cents per pound. A steer will yield forty to fifty pounds of oleo oil; therefore, should the butterine industry be destroyed, each steer would depreciate in value at least $\$ 3$. Now, the same is true of hogs. Leaf lard, or nentral, being used in the manufacture of butterine, is worth 8 to 9 cents per pound; lard is worth about 6 cents; a $\log$ will yield abont $S$ pounds of nentral, and if there was no demand for neutral as a butterine ingredient, it would have uo greater value than ordinary lard; lience each hog would be worth about 20 cents per head less than present price. Upon this basis the loss to the producers of cattle and hogs during 1899 in South Omalua alone would be-

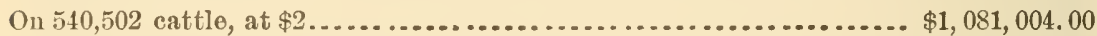
On $2,188,779$ hogs at, 20 cents.................................... $437,755.80$

Total ............................................ $\overline{1,518,759.80}$

The total number of beef cattle and hogs in the United States is a matter of stati-tics, which has lloubtless been presented for your consideràtiou, or, if not, can be easily obtained.

The probable loss to the beef producers of this country, should this measure become a law, has been estimated by different persons to be about $\$ 100,0(10,0) 0$, to say nothing of the confiscation of about $\$ 15,000,000$ iuvested in the manufacture of oleomargarine and butter. ine and the loss of employment to about 25,000 men.

The bntterine business of 1890 was 2.6 per cent of the totai amount of butter made in the United States. These figures are taken from the records of the Burean of Internal lievenue and the A gricultural Department. lior the year enting June 30,159 !), there were $83,000,000$ ponuds of butterine manufactured in the United States, and, according to the estimate of Mr. Wilson, editor of the Wlgin Dairy Report, Elgin, Ill., there were something over $3,000,000,000$ pounds of butter made in the Uniter States for that year. Figuring on this basis, the annonnt of butterine ununfactured as compared with the amount of butter made is '2. per cent, showing that the make of butterine has decreased, in comparison to the make of butter, in the past ten years to the extent of one-tenth of 1 per cent. The Government received, for the year ending June 30, 1899, about $\$ 2,000,000$ from tax and license on bntterine.

From experience it has been proven that uncolored butterine is unsalable; therefore, if the proposer legislation in Washiugton should become a law, it would practically kill the butterine business.

There are in the United States about 44,000,000 cattle, one-third of which are milch cows, the other two thirds being meat products. In legislating for the cattle industry, it would hardly be fair to protect and foster the small minority of one-third against the large majority of two thirds.

That is, being two-thirds of the whole number of cattle or beef products, while one-third are dairy-prolucing products.

While Nebraska is chiefly a meat.porlucing State, we also have more or less, dairy interests and we know of no conflict between the two 
industries, the dairymen finding a market for all the produce they can make without unfavorable legislation to the meat inclustry.

Oleomargarine, or butterine, is a wholesome and absolutely pure article of diet, manufactured and sold at about one-half the price of creamery or dairy butter, and is very desirable for and largely userl by laboring classes and, in fact, all of frugal habits and moderate means.

I desire to read in this connection, as a part of my remarks, the memorial to Congress that was passed by our exchange last winter. Possibly it is on file here with the committee already, but I would like to read it.

The Chatrman. If you would like to read it, do so. Mr. HAKE (reading):

We beg to represent that our organization has a membership of over $200 \mathrm{meu}$, all of whom are eugaged in handling live stock in some form, and are well acquainted with the subject and do enter a most earnest and emphatic protest against said legislation of this character because:

First. "The consumers at the table," in whose interest the enactment is proposed, are in no need of such protection. It is probable that many legislatures favor these bills under the belief that butterine, etc., are composed of impure materials, compounded in filthy establishments, and foisted upon an innocent and unsuspecting public through deceptive and fraudulent methods. A brief investigation will conviuce them of their mistake. 'The most eminent chemists of the world pronounce butterine and oleomargarine substantially the same as natural butter, differing from it only in the lack of butyric acid, which produces rancidity in the uatural article. England, the foremost among nations in the passing of stringent laws for the protection of her citizens against impure food products, indorsed butterine and oleomargarine, and encourages their production and sale because of their wholesomeness and cheapness. Our own Government, likewise, sanctions their production and use, and protects the consumer by having every pound made and sold under the strictest supervision of the department of internal revenue. The materials and processes are as well known as those which produce flour, lard, sugar, or any other necessary staple of life. Butterine factories are noted for the scrupulous care and cleanliness shown in every detail, and are always open for the inspection of visitors, thus effectually disproving the malicions falsehoods uttered regarding secret methods, impnre ingredients, harmful chemicals, ete. They court the closest and most thorough investigation, and challenge any advocate of these bills to prove that such laws are needed for or will benefit the health of a single citizen of the United States.

Second. Since the introduction of butterine and oleomargarine the prices of the leaf fats, from whicl they are chiefly made, have relatively increased $2 \frac{1}{2}$ to 3 cents per pound, thus adding millions of dollars annually to the value of the cattle and log products of the United States. If this prohibition scheme is carried out, stock raisers of the United States will lose each year this vast sum of money.

Third. If such legislation is enacted, it will decrease the worth of the live stock of the country by many millions of dollars. It will also deprive the National Governuent of a revenne now reaching $\$ 2,000,000$ annually and steadily increasing. This loss would bave to be replaced by taxation elsewhere, a portion of which would fall upon our own people.

Fourth. It is clear from the foregoing facts (eversone of which can be substantiated by undoubted testimony) that the proposed laws are not in the interests of the people generally, nor of the State, nor of the nation. They must therefore be intencled to benefit certain selfish and designing individuals who hope, by creating popular prejudices against butterine, to stop its manufacture and again open the way for those vile butter-mixing establishments which formerly abounded in every city and town, whose concoctions and compounds are as far inferior to butterine in purity, healthfulness, and cleanliness as a bucking broncho to a Nebraska thoroughbred. Butterine, with its nniformly good qualities, drove theso mixtures from tho field, and they havoever since been moving heaven and earth to regain their lost position and once more enjoy the enormous profits arising from their nefarions work. They have craftily enlisted on their side honest dairy farmers and creameries whom they have temporarily won by false statements and fallacious arguments. To these latter we beg to say there is no real coullict between the honest butter prodncers and the makers of butterine. A large portion of the people will buy natural at almost any price, if they can always procure it of first-class quality. By makiug nothing but the luest grades, the dairies will always have a realy market at fnil prices, thereby leaving butterine to supply those content with a wholesome, healthful, and cheap substitute. 
We hope these brief statements will couvince yon that the bill in question is purely "class legislation," which is always vicious in teudency and contrary to the principles of a repulblican form of goverument, which seeks "the greatest gool to the greatest number."

I have here a few letters which I have obtained very easily, and very quickly. I would like to read them. They come from the farmers and producers of stock throughout the State. Here is a letter sigued by S. S. Hadley, of Cedar Rapids, Nebr.:

To Nebraska Delegation in Congress:

Congress is now consideriug a measure contemplating the taxing of oleo oilsoleomargarine and butterine-10 cents per pound.

As these products are manufactured from the oils extracted from the fats of cattle, hogs, and sheep, the animal of right should be and is worth from $\$ 1$ to $\$ 3$ per head more, where the product cau be manufactured into a valuable article, than when used as ordinary tallow and lard.

I believe the passage of such a measure would be legislating in the interest of a very small minority and not in the interest of the masses.

Oleomargarine or bntterine, being absolutely pure and wholesome and furnished the consumer at about half price of creamery bntter, is a very desirable commouty for the laboring classes, and in fact all people of firngal habits and moderate means; and the tax practically prohibits its manufactnie.

I am engaged in producing, shipping, bngiug, and selling meat and fat producing animals and am iuterested as mnch and more than the dairymau can possibly be in the product of the dairy.

I therefore desire to enter my earnest protest against the passage of any such measure, and ask your earuest cooperation in defeating House bill No. 6.

\section{S. S. HADLEY,}

Cedar Rapids, Nebr.

Here is one signed by B. J. Tierney, of Ansley, Nebr., which reads as follows:

J. A. HAKE, Esq.,

South Omaha, Nebr.

DFar Sir: I mulerstand that a conmitteo from the South Omaha Exchange will visit Washingtou, D. C., in the near future for the pripose of discouraging the passage of Honse bill No. 6, regarding the maunfacturing of butterine and oleomar. garines, and 1 trust $\mathrm{j}$ ou may be successful, for in my opiuion the passage of such a bill would be against the interests and highly detrimental to farmers and all growers of stock, inasmuch as the effect would be to linit the use of all animal fats and oils.

This section is practically an agricultural and farming region, but I am shipping frou Ansley annually about 1,000 heal of eattle and from nine to ten thousaud head of hogs, :mel I estimate that if the proposed bill should become a law it would diminish the agrregate value of the stock shipped from this place aloue from $\$ 4,000$ to $\$ 6,000$, all of which must of necessity fall on the grower.

Siucerely believiug that the best interests of the sinall farmer and stock growers will be promoted by the defeat of the proposed measure, I am, Yours, truly,

B. J. Tierney.

Here is one, dated Lewellen, Nebr., April 10. That is in your district, Mr. Neville?

Mr. Neville. Yes, sir. That is from Mr. Delatour, isn't it?

Mr. HAKE. Yes, sir. Mr. Delatour's letter reads as follows:

J. A. HAKE, Esq.,

Lew Ellen, NeBr., April 10, 1900.

President South Omaha Live Stock Exchange.

DeAR Sik: I tiust the South Omaha Live Stock Exchange will take an active part in trying to defeat House bill No. 6, which contemplates a tax of 10 ceuts a pound on mannfactured butter, butterine, or oleomargarine. The increase of the tax will prohibit the maunfacturing and sale of said articles. The enactment of this law will reduce the value of our stock from $\$ 1$ to $\$ 2$ per head. The law as it now stauds seems to be liberal to the dairy interest aud it should not clamour for auy more legislation, and especially for legislation that will result in great damage aud loss to another legitimate industry.

Very respectfully, yours,

S. P. Delatour. 
The Chairman. Who is Mr. S. P. Delatour? What is his occupation?

Mr. HAKE. He is a grower of stock and is outside of the agricultural districts. They raise very little crops in his district-raise some corn and some altilfa, but he is practically a range man.

Mr. Neville. He is one of the brand commissioners of the State of Nebraska.

Mr. HAKE. This letter of Mr. Tieruey and those of the other's go to show who they are. Here is a letter from Mr. T. B. Hord:

Central City, Nebr., April 7, 1900.

The Representatives of the State of Nebraska,

The Senate and the House of Congress, Washington, D. C.

Genthemen: Being largely interested in the production and maturing of cattle, hogs, and sheep in the State of Nebraska, I feel it to be a great injustice to not only myself but to producers at large to have the present oleomargarine bill now pending in Congress; if passed, would positively prohibit the manufacture of oleomargarine or butterine, for which the butter fats of the cattle, hogs, and sheep is used.

Last year I matured and disposerl of 17,000 cattle, 12,000 hogs, and 12,000 sheep. It means $\$ 2$ a head on each head of cattle matured, 50 cents on each hog, and 25 cents on each sheep, amounting to $\$ 43,000$. IVe are practically feeding the same numbers this year.

Such a reduction last year would have shown a loss in our business and this year a much greater one, and we sincerely hope that you will use your best endeavor's to defeat said bill.

Very respectfully, yours,

T. B. HoRD.

T. B. Hord is a grower of eattle on the ranges and a feeder in the agricultural districts. He moves them down from the ranges and feeds them on corn and prepares them for the market.

Mr. DAHLw. Regarding the way he expresses it there, do you regard it as a fair statement as to the amount of difference it wonld make on the value of hogs, eattle, and sheep? That does not agree with your claim, as I understand it.

Mr. HAKE. Practically it does on cattle.

Mr. DAHLE. It does on cattle?

Mr. HAKE. 'That question

Mr. DAHLE. How about hogs?

Mr. Hake. Twenty cents; of course-

Mr. DAHLE. You figure about 20 cents?

Mr. Hake. Yes, sir. He has estimated 50 cents.

Mr. DAFLE. How about sheep?

Mr. HaKE. Sheep hitrdly enter into the business that he does. Of course he does not understand much abont that.

Mr. Dafile. He does not understand it?

Mr. HAKE. This letter is gotten up and written by himself, you understand.

MIr. DAHLE. Does it appear that he does understand it from tlat?

Mr. HaKE. He understands that the fat ont of a certain animal, and to a certain amount, and of a certain variety goes into these oleo oils, and he takes it that the sheep, knowing them to be tallow producers the same as the cattle, that the tallow of these sheep would enter into it the same.

Mr. DAHLE. But it does show that he does not know any thing about it?

Mr. HAKE. I do not think that he fully understands that.

Mr. DAHLE. He does not understand that fully?

Mr. HAKE. I think it shows a larger estimate than the absolute facts would warrant.

The Cmamuan. I would suggest that there are two or three of these gentlemen, and we had better let them be heard and then ask them questions. 
Mr. DAHLE. Very well.

Mr. HAKE. Here is a letter from the feeding station of the Standard Cattle Company. It is as follows:

\author{
Standard Cattle Company, \\ Office of the General MaNager, \\ Ames, Nebr., April 11, 1900.
}

Mr. J. A. HAKE,

Union Stock Yards, South Omaha, Nebr.

DEAR Sir: Answering yours of the 17th instant, we have fed about 65,000 cattle here the last fourteen years aud are largely interested in the cattle business, as you know. We do not attempt a very large business in hogs. We geverally have about 2,500 on hand; less than this now becanse of cholera last year.

1 certainly do not approve of the bill to tax oleomargarine products 10 cents per ponnd and think it to be an nujustifiable thing to do. I think they should be sold as oleomargarine products and a heavy penalty exacted for noucompliance of the law, and the only doubt I have in the natter is whether it is practicable or not to detect their being placed on sale as butter. Yours, truly,

R. M. Allen, General Manager.

Mr. Allen is the mauager of the Standard Cattle Company, and he has four or five thousand cattle a year. 'They used to feed 3,000, but have increased their feeding very much lately.

Here is another letter:

J. A. Hake, Esq.,

Grand Island, Nebr., April 10, 1900.

President South Onaha Live Stock Exchange, South Omaha, Nebr.

DEAR SiR: In answer to your letter regarding the IIouse roll No. $6 \mathrm{my}$ viows agreo with those of the Live Stock Exchange.

As long as the manufactured butter is a healthy product, and not being prohibited by our Government to be put in the market, it surely is a wrongful move of Congress to the stock men of United States to put a tax on this product, decreasing the value of their stock.

It looks to me that if Congress passed such a law they would be making a class legislation of it, favoring their citizens engaged in the creamery business and damaging their citizens engiged in the stock business. As we are all citizens of Unitel States, it surely is wrong to tax one to protect the other.

I therefore herewith express my sincere hope that your committee will be successful in defeating such law.

Very respectfully,

JOHN REMERS.

\title{
Here is a letter from Mr. N. L. Anderson, of Sacramento:
}

\section{Sacrauento, Nebr., April \%, 1900.}

Dear Sir: I desire to enter an earnest protest a gainst the passage of a bill now pending in Congress which seeks to tax the manuficture of oleomargarine so high as to prohibit its manufacture. As you know, I am a large feeder of cattle in Nebraska (running from 500 to 1,000 head every year). MIy beef cattle bring $\$ 2$ more per head than they wonld if the oleomargarine product in them could not be used for butter.

I am reliably informed that butter so manufactured is equal in every respect to dairy butter and sells for considerably less money in the market. I also think that the passage of such a law would be class legislation and against the best interests of the producers of beef cattle and the consumers of lutter. Yours, truly,

The Nebraska Representatives in Congress.

\section{N. L. Anderson.}

Mr. Anderson owns about a section and a half of land, on which he raises corn largely and feeds the products to cattle.

The letter I am about to real here-I presume you have something of this kind, but this is a little extravagant, gentlemen, I will admit, but I read it:

The Nebraska Delegation in Congress.

Sidney, Nebr., April 9, 1900.

GENTLEMEN : A resident of Nebraska for nearly thirty years, I have noted, as you have, its rapid development in wealth. My observation and experience has convinced me the greatest factor in creating its wealth has been its live-stock industry. 
Cattle raising was its first attempt; thon came feeding and fattening for market. Hog raising became a great factor at once, and sheep raising and sheep foelling rapidly followed. So that Nebraska is preominently a stock State. I am amazed that there should be anyone who may be interested in House roll No. 6 ind 11 ging the hope that a single member of the Nehraska delegation will support it. The loss to the Nebraska live-stock interest would be severe by its passage.

We had in 1898 in the State 716,017 cattle, 2,339,086 hogs, 1, 193,250 head of sheep. The loss on sheep and swine if this bill becomes a law will be $\$ 1$ per head, or a total loss in these two classes of stock of $\$ 3,532,336$. 'The loss on cattle will be from $\$ 3$ to $\$ 5$ per head; at a minimum of $\$ 3$ per head the loss to cattle in this State would orpual $\$ 2,148,051$, or a total loss on oattle, hogs, and sheop, in Nebraska of $\$ 5,680,387$. 'The loss on this same basis in the nation holis a ratio even greater than in Nebraska. In 1897 there were in the United States 15,941,727 head of milch cows, of other cat tle there were $30.508,408$, of shee] there were $36,818,643$, of swine there were $40,600,276$, which by the passage of this bill would represent a lost valne of the enormous sum of $\$ 168,944,141$ on these three classes of live stock. This great loss to be consummated by the passage of this bill for what purpose? Simply to enhance the price of butter, the product of $15,941,727$ milch cows.

We understand, of course, the plea for the bill is pure butter. A certain per cent of pure butter will be made, but a large per cent, as is the custom now with creameries, will be old refuse gathered up in the stores, reeking with filth, washed in the fresh buttermilk of the creamery, worked over and labeled second creamery, and of course will be sold as pure and at a price beyond the reach of thousands of poor people in our large cities who are glad to get pure, wholesome butterine at a price within their means. The passage of this bill means the poor eating no butter.

Gentlemen, for these reasons I urge you all as Nebraskans to oppose this bill.

Very truly, yours,

Matt. Daugherty.

Here is another one, signed by Col. F. M. Woods, and another by George Harvey, and another by A. M. Treat, of Chappell, Nebr. Some of these letters, the last two, for instance, are from Mr. Neville's district.

Mr. NevilLE. Matt. Dangherty is from my district.

Mr. HAKE. Yes; Chappell is in your district.

Mr. NEville. Yes; Delatour is from my district, and Tierney. Ho is at Ansley.

Mr. HaKE. Yes, sir.

The Chairman. Are there any gentlemen of the committee who desire to ask Mr. Hake any questions?

Mr. DAHLE. When you were saying or figuring that oleomargarine costs about half what butter costs-you advanced that idea?

Mr. НАкE. Yes, sir.

Mr. DAHLE. At what prices do you figure the two, respectively?

Mr. HAKE. Fifteen to thirty cents. Fifteen to thirty cents for creamery. It costs 25 to 30 cents with us, but that is in our conntry, you understand. I presume it might not cost as much in other places. It costs from 15 to $: 25$ cents, and we rarely buy it for less than 25 cents, and sometimes pay 30 .

Mr. CHewK. Creamery has been as high as 32 cents.

Mr. DaHLE. You figure cleamery from 22 to 35 cents 9

Mr. HAKE. Twenty-two to thirty cents.

Mr. DaHLE. And oleomargarine?

Mr. HAKE. It has been 13 to 15 cents.

Mr. DAHLE. I can ouly say that that is away too high.

Mr. HAKE. How?

Mr. DAHLE. Butter in the summer is worth with us 16 cents, that is creamery butter.

Mr. HAKE. I have never bought it tlat way.

Mr. DAHLE. Well, I have sold lots of it that way.

The CHairis N. That would be argument, Mr. Dahle.

Mr. DAHLE. Yes, I linow; but I am sorry that we get into our records things that look away off". I would like to correct them. 
Mr. Balley. These figures, you do not intend to say that they are technically true. The general impression and belief of the cattlemen in your country is that the killing of this industry must materially affect the cattle and stock interests of the Northwest, and the whole country.

Mr. HAKE. Yes, that is it.

Mr. BAILEY. As regards technical knowledge, you do not pretend to have absolute technical knowledge?

Mr. HAKE. No, sir, and it varies; it varies with the seasons-the price of the product of cattle and the price of hogs. Again, with hogs or sheep the product is not as high, and we could not make an arbitrary figure that wonld cover all this.

Mr. NeVILLE. There was about 4,000,000 pounds sold in Nebraska last year.

Mr. HAKE. Yes; sir.

Mr. Neville. As I understand the statistics, between three and four millions. And it was sold at as low as 15 cents a pound-oleomar. garine.

Mr. HaKe. I think so. I never bought any of it.

Mr. NEVILLE. Was it colored?

Mr. HAKE. I think it was, yes. I never saw any of it.

Mr. NEVILLE. In imitation of butter?

Mr. HAKE. I think it was colored. I know it is colored.

Mr. Neville. Now, is it not true that there is a law in Nebraska which prohibits this coloring of butter?

Mr. HAKE. There is a law which prohibits its sale, and permitting it to be manufactured and shipped to other States. Under the interstatecommerce regulations other States enjoy the same privileges and we simply deprive our citizens of the privilege of manufacturing it. But the other states manufacture it and ship it to us. That is the result.

Mr. DAHLE. Any State may send out what it manufactures

Mr. NeVille. Yes; sir.

Mr. DaIlLE (continuing). But under the law of Nebraska it is prohibited?

The CHAIRMaN. I would suggest that that matter of the law will speak for itself.

Mr. Neville. My question was intended to bring ont a fact with reference to it. He was simply quoting the prices and the difference in priees between butter and oleomargarine. I simply wanted to show that all of it sold there is in violation of the law, and the plea is that it must be continned to be sold in violation of law.

The CHarruan. We will go over that matter in the committee.

Mr. NEviLLE. These people who have written letters here, how were they notified as to the contents of this bill?

Mr. HAKE. It lias been a matter of consideration with our people, and has been agitated.

Mr. NEVILLE. You sent some communications?

Mr. HAKE. Yes; we have gotten the business up.

Mr. Neville. I notice that in each one of these letters-I liave received letters from one of these gentiemen you refer to, and also from John Bradt. You kuow him?

Mr. HAKE. Yes, sir.

Mr. NeVILLE (continuing). And I notice that in these letters I have received, and also those you have real here, they simply speak of this as a tax upon oleomargarine of 10 cents.

Mr. HaKE. Ten cents a pound? 
Mr. Neville. Yes, 10 cents a pound I mean. As a matter of fact, your organization simply knew that it was proposed to tax it when in imitation of butter?

Mr. HAKE. Yes, the framer of that bill knew that it was absolutely impossible to make lard and sell it for butter.

Mr. NevilleE. Did Mr. Delatour and Mr. Tierney know this?

Mr. HAKE. Yes, they knew it, and we have known that the committee only meant to tax oleomargarine the 10 cents a pound when it was colored in imitation of butter.

Mr. NEVILLE. They knew that?

Mr. HAKE. I should say they did. They are intelligent people, all of them, and no doubt knew it.

The letters of Mr. Woods, Mr. Harvey, and Mr. Treat, submitted by Mr. Hake, are as follows:

\section{South Omaha Live Stoci Exchange,} South Omaha, Nebr., April \%, 1900.

\section{The Nebraska Delegation in Congress:}

Our National Legislature is now considering a measure contemplating the taxing of oleo oils, oleomargarine, or butterine to the amount of 10 cents per pound. As these products are mannfactured from the oils extracted from the fats of cattle, hogs, and sheep, the animal of right should be, and is, worth from $\$ 1$ to $\$ 3$ per head more where the product can be manufactured into a valuable article than when used as ordinary tallow and lard. I believe the passage of such a measure would be legislating in the interest of a very small minority and not in the interest of the misses.

Oleomargarine or butterine, being absolutely pure and wholesome, and furnished the consumer at about half the price of creamery butter, is a very desirable commodity for the laboring masses, and, in fact, all people of moderate means. As this tax practically prohibits its manufacture, I desire to enter my earnest protest against the passage of any snch measure. Having been engaged in the live stock industry all of my life, selling somewhere near 10,000 head annually, I ask feur cooperation in defeating House bill No. 6 .

F. M. Woods, Auctioneer.

\section{To Nebraska Delegation in Congress:}

Congress is now considering a measure contemplating the taxing of oleo oils, oleomargarine, and butterine 10 cents per pound.

As these products are manufactured from the oils extracted from the fats of cattle, hogs, and sheep, the aninal of right should be, and is, worth from $\$ 1$ to $\$ 3$ per head more where the product can be manufactured into a valuable article than when used as ordinary tallow and lard.

I believe the passage of such a measure wonld be legislating in the iuterest of a very small minority and not in the interest of the masses.

Oleomargarine or butterine, being absolutely pure and wholesome, and furnished the consumer at about half price of ereamery butter, is a very desirable commodity for the laboring classes, and, in fict, all people of frugal habits and moderate means, and the tax practically prohibits its manufacture.

I am engaged in producing, shipping, buying, and selling meat and fat-proulucing animals, and am interested as much and more in their valne than the dairyman can possibly be in the product of the dairy.

I therefore desire to enter my earnest protest against the passage of any such measure, and ask your earnest cooperatiou in deteating House bill No. 6.

GEO. HARVEY,

APRIL 11, 1900.

Kearney, Buffalo County, Nebr.

\section{To Nebraska Delegation in Congress:}

Chappell, Nebr., April 10, 1900.

Our National Legislature is now considering a measure contemplating the taxing of oleo oils, oleomargarine, or butterine to tlie amount of 10 cents per pount. As these products are manufactured from the oils extracted from the fats of cattle, hous, and sheep, the animal of right shonld be, and is, worth from $\$ 1$ to $\$ 3$ per liead uore where the product can be manufactured into a valuable article than when used as 
ordinary tallow and lard. I believe the passage of such a measure would be legislating in the interest of a small minority and not in the interest of the masses. Oleomargarine or butterine, being absolutely pure and wholesome, and furnished the consumer at abont half the price of creamery butter, is a very clesirable commodity for the laboring masses, and in fact all people of molerate means.

As I have heen and am still engaged in raising, buying, and shipping live stock on foot, and as this measure would practically probibit the manufacturing of a part of the animal into a most valnable product, thereby reducing the price of killing stock, I desire to enter my earnest protest agaiust its passage, and would respectfully ask your cooperation in endeavoring to defeat this measure.

A. M. Treat.

\section{STATEMENT OF MR. W. B. CHEEK, OF SOUTH OMAHA, NEBR.}

The Chamrian. What is you occupation?

Mr. Chenk. I am vice-president of the Live Stock Exchange at South Omaha, Nebr.

The Chamritan. Do you desire to make any statement to the committee?

Mr. CHEeK. No; I have no argument on the subject aside from that which has been made by Mr. Hake.

The Chatrman. Do you know anything about the retail sale of oleo. margarine in your city?

Mr. Chenk. Yes, sir.

The Cramman. Will you tell us how it is sold? Is it sold openly as oleomargarine, or secretly?

Mr. CHEEK. It is sold openly in the grocery stores and butcher shops as oleomargarine. For instance, in my shop, where I buy my meat, is a tilble, and on that table is butterine in boxes and tubs, and stacked np outside of the boxes, and marked at all the way from $12 \frac{1}{2}$ cents to $18 \frac{1}{2}$ cents. I believe what they call prime butterine sells for from $18 \frac{1}{2}$ cents to 19 cents.

The ChatRMan. What does the creamery butter sell for?

Mr. CineK. I have wever been able to buy it for less than 18 cents.

The Chairman. Do you know of any complaint from the consumers of the oleomargarine in your district?

Mr. Cheer. No, sir; I never heard of any.

The Ciramman. What class of people is it that consumes that oleomargarine?

Mr. CInEEK. The laboring class-principally men working in the stock yards and packing houses, and general laborers.

The Chalrman. Have there been any claims of illegal sales?

Mr. OHEeK. No, sir; no complaint at all.

The Cmalrian. I will ask you this question: Has there been any decrease in the price of dairy cattle in your country?

Mr. CHEEK. No, sir.

The CmaIRMAn. Has there been any decrease in the price of the dairy product of butter?

Mr. CHEEK. No, sir.

The CHAIRMAN. Has there been any decrease in the value of your dairy farm land?

Mr. CheEk. I should say not. It has been on the increase.

The CHAIRMAN. It has increased?

Mr. CHEEk. Yes.

The ChaIRMan. Then do you know of any reason why, in that country, there should be any protection given to the dairy interests over the oleomargine interests?

Mr. Cheik. I see no reason at all. There has always been an excessive demand for dairy products. 
The Chatrman. The demand for dairy products has been greater than the supply?

Mr. UheEк. Yes, sir.

The Chatrman. How large a place is South Omaha?

Mr. Cheek. Twenty-five thousand.

The ChaIriran. What character of industries have yon there?

Mr. CHEек. Packing houses, stock yards, and miscellaneous manufacturing -a few foundries, and things like that-but the principal industries there are the stock yards and packing houses.

The Chatrman. How many people are employed there?

Mr. OHEEK. Eleven thonsand men, I think.

The Chairinan. Can you tell this committee which there is the most consumption of there, dairy butter or oleomargarine?

Mr. CHEEK. I should say the principal consumption was dairy bntter. A large amount of oleomargarine is consumed, but the principal consumption is dairy butter.

Mr. DAHLE. Do you have a dairy commissioner?

Mr. CHEeK. I never heard of any.

Mr. DAHLE. You do not have one in your State?

Mr. CHEEK. No, sir.

Mr. DAHLE. Do you have any State official to see that the law is enforced as refers to butterine?

Mr. CHeек. Our city has a health inspector, who looks after everything of that kind. He looks after the purity of the meat in the meat shops and the purity of the groceries. He is a health commissioner.

Mr. HAKE. I want to make an explanation. Mr. Cheek said that the butterine was a little higher than the butter. I presume that the committee understands that while oleomargarine is made out of the fat of the animal altogether, bntterine is supposed to be one-third pure bntter.

The Chairman. We draw no distinctions between them.

Mr. MAKE. It is a mixture; it is part butter and part oleo oil.

Mr. DAHLE. Is it butterine that is sold with you, or oleomargarine? Mr. HAKE. It is both.

Mr. DAHLE. Both? Then, when yon spoke of it being laalf the price of butter is tiat for butterine or for oleomargarine?

Mr. HAKE. It is for oleomargarine. Butterine comes a little higher.

Thereupon, at 12 o'clock m., the subcommittee adjourned.

Commitiee on Agriculture,

HOUSE OF REPRESENTATIVES,

Washington, D. C., Wednesday, MIay 16, 1900.

The committee met at 10 o'clock a. m., Hon. Hermau B. Dahle in the chair.

Present: Representatives Wadsworth, Henry, White, Bailey, Wright, Haugen, Dahle, Williams, Stokes, Lamb, Cooney, Allen, Neville, and Wilson.

\section{STATEMENT OF HON. GEORGE W. WILSON, COMMISSIONER OF INTERNAL REVENUE.}

Representative BAILEY. Mr. Wilson, the committee has asked you to come before it for the purpose of giving it such information as you have in your possession in regard to the internal revenue, and the enforcement of the laws in regard to the manufacture and sale of oleo- 
margarine. You understand that there is a bill pending before Congress to raise the tax on colored oleomargarine to 10 cents a pound, do you not?

Commissioner WiLson. Yes, sir.

Representative BAILEY. What would be the effect of that bill, in your opinion, Mr. Wilson, in regard to the collection of revenue?

Commissioner Wulson. It is pretty hard for me to foreshadow what wonld be the result of forcing the sale of white or uncolored oleomargarine. I should regard the tax of 10 cents a pound on colored oleomargarine as prohibitive. I do not think the manufacturers can do much with it with a tax of that amomt. I think the bill would defeat the end of deriving any revenue from the sale of colored oleomargarine. I think that would be largely the result of its passage.

Representative BAILEY. Do you consiler the present laws regarding the nıanufacture of oleomargarine sufficient to prevent its fraudulent use?

Commissioner WiLson. With a very slight change in the law, yes, sir-almost absolutely so.

Representative WILLIAMs. What change would you recommend?

Commissioner WiLson. I would recommend a change which would require the manufacturer to put up statutory packages in subpackages, to meet the lowest demand of the retail trade and the highest demand of the wholesale trade, npon each of which subpackages should be impressed, in such a way that it could not be obscured or obliterated without manifest effort and intention, the word "oleomargarine."

Representative ALLEN. I would like to ask you, Mr. Wilson, what is your knowledge of the efficiency of the service in executing the law with reference to dealers in colored oleomargarine, especially retail dealers? I have been told that your representative in the city of Chicago is either indifferent, negligent, or possibly particeps criminis to the evasion of the law.

Commissioner W1Lson. I think that is an unjust charge. I would prefer that Collector Cohen should come before the committee and defend limself. He is a good collector. There is this to be said generally upon the whole subject, gentlemen: The manufacture of oleomargarine in this country reaches $80,060,000$ of pounds annually, and the product is distributed to possibly lialf of the people of this country; and when you come down to handing it ont to those people in quantities of from half a pound to 5 poinds at a time, you necessarily have, in a year, a great many transactions; and it is utterly impossible, with the means placed in the hands of the Internal-Revenue Burean, to place such a close espionage upon these little transactions as to prevent any misrepresentations with reference to the sale of oleomargarine as butter. We give more attention and spend more money on that subject than we do upon anything else, although the ad valorem tax upon the product, as compared to other things, is very low.

The incentive which brings about this violation of the law is not limited, in my judgment, simply to the desire for gain upon the part of the retail dealer who is selling oleomargarine. There are other sides to the question. The private family, the boarding-house proprietor, the hotel proprietor, do not want to carry home oleomargarine marked as such. We encounter a great deal of that feeling. The dealer has paid his special tax; he has no object in evading the law, but he sells oleomargarine without any mark on it. Although the person who buys it understands that it is oleomargarine, the dealer has violated section 6 of the law by not putting any mark on it, or else by putting it on in such 
an obscure manner that it can not be seen. In some general stores we liave peculiar complications arising from this condition of things. For instance, I recall a case which came into the office the other day where the goods of a particular store, including coffee and a pair of small pants for a boy, were all marked "Oleomargarine," because the man said, "Now, I want this to be marked oleomargarine, and in order that there may be no mistake about it, just take down that lot of brown paper and mark every sheet of it "Oleomargarine." That is simply an illustration of the condition of things that prevails.

Ily julgment is that the amount of this material that is known as butter is not nearly so large as some people believe; and my judgment is that there is not nearly so much viciousuess as is commonly supposed in the sale of that which is not marker. I make a distinction, in other words, between that which is sold as butter and that which is handed out in a passive way, without its being indicated whether it is butter or oleomargarine. I clo not think there is as much of that which is actuated by gain as has been represented.

A large portion of this product is sold by various small dealers, impecunious, poor people. In handling that sort of cases we follow the same rule that we follow with reference to any other tax law. The Supreme Coult has said to the Internal-Revenue Burean, "This is a tax law, and you must enforce it as such." The judge in Philadelphia the other clay, in passing sentence on a man over there who has been rather notorious in some of his transactions, quoted from the Supreme Comrt upon that question, and sair that the law which provides incidentally for marking packages of oleomargarine must be treated as a tax law.

We have had considerable complaint from some of the dairy associations about the failure to euforce this law. In all cases where such complaints have come to the office, instructions have been given to the collectors that where dairy associations or other interests ontside of the internal-revenue force bring complaints to the collectors that the law has been violated with respect to evading the tax, or selling the product for what it is not, those cases ouglit to be accepter with the same solemnity and confidence that any other cases are accepted, and treated in the same way. The statute provicles that all such cases shall be reported by the collector to the district attorney, with his recommenda. tion that they be prosecuted or not prosecnted, giving his reasons therefor. I have said to collectors that in all such cases they should follow the same rule with respect to information received from the dairy associations as if their own deputies, or the internal-revenue agents, discovered the case; and I think that rule has been observed. When that is done, the matter is in the hands of the district attorney; and I have said also to the collectors that where the district attorney recommends a prosecution no proposition for compromise can be entertainerl.

Now, some of these cases have been compromised, and some complaint has been made of the Internal-Revenue Bureau with reference to that policy. We are not as liberal with respect to compromising oleomargarine cases, considering the amount of tax evaded, as we are with some vther lines of internal revenue violations. Under no circumstances is an oleomargarine case ever compromised unless it involves the favorable recommendation of the deputy or agent who discovered it, the collector of the district, and the district attorney. Unless all of those recommendations are made we do not do it. But when the local force which has made the discovery and investigated it, backed up by the rlistrict 
attorney, comes forward and says that a particular case onght not to be prosecuted for such and such reasons, then the Internal-Revenue Bureau, as a rule, accepts the arlvice.

Representative ALLEN. You stated a while ago that you thought the imposition of this tax would defeat the manufacture of oleomargarine. I understand you to mean its legitimate manufacture.

Commissioner Wilson. Yes.

Representative ALLEN. What do you say with regard to its illicit, "moonshine" manufacture?

Commissioner Wilson. We have not any.

Representative ALLEN. What would happen if this prohibitive tax is pliced upon the product, in your opinion?

Commissioner WILSON. If it operated in the same way that a high ad valorem tax does upon distilled spirits, it wonld result in the manufacture of "moonshine oleo." But I think it would drive it out.

Representative ALLEN. You think it would abolish the industry entirely?

Commissioner Wilson. Yes, sir; I do not think we can have"moonshine" oleo. There has never been any evasion of the law with respect to paying the tax on oleomargarine, except in a very incidental and limited way. Neither the special tax (although it is high) nor the 2 -cent pound tax have ever been evaded. We have no trouble in collecting them.

Representative ALLEN. Under the present law you have the right to inspect and investigate and have an analysis made of this product, I believe.

Commissioner WiLson. Yes, sir.

Representative ALLEN. What has been your experience, and what has been the resnlt of any work you have done along that line?

Commissioner. Wmson. There has been a very limited amount of what might be called a general investigation made. In a very brief way I will recite the history of that investigation; it will not take more than a minute or two. You will find it all pecorded in Senate Document No. 2346. There is one very short parigraph which I want to rearl from the testimony of Prolessor $\lambda$ lorton. I was here when this legislation was passed, and was present at a good many of these hearings. Congress never made such a research, so far as I liave any knowledge, with respect to the propriety of passing a law, as it did before the passage, in 1886, of this internal-revenue law. It was a most protracted and searching hearing, as will be found by any of you who examine this document, which Congress had in order to find a foundation upon which to place their feet if they did pass the law; and they found it. It is contained here in a dozen-line paragraph-the whole foundation on which the Internal-Revenue Bureau stands with respect to these investigations.

Representative ALLEN. What is the page of that document?

Commissioner WILsoN. This is page 47 of this hearing. I read from the testimony of Professor Morton:

In the first place, I have found, as a matter of observation, that fat which is to be used in the manufacture of oleomargarine, if it is in the slightest degree tainted before the manufacture begins, if it is not strictly fresh, if it is not taken almost directly from the slanglitered animal, if it is allowed to stand in a barrel for a few hours in ordinary weather or iu cold weather, if put in a barrel with any animal heat, in a few hours, theu an incipient change begins, which in the succeeding processes is exaggerated, so that an ntterly ofiensive material is produced which could not be used for any such purpose.

That doctrine is sustained by all the seientists who testified during the course of that hearing. Following right after the enactment of the 
law, in 1887 or 1858 , a general examination was made over the whole country with respect to that condition of things; and the report was universal that the statement which I have just read was found to be true for the whole sixty-three collection districts of the comntry. From that time until to-day no further general examination has been made. Desultory investigations have been marle of certain oil that has been brought in. Some manuficturer would wander off the track, and use a name which was a little strange; and that would excite some curiosity to know what it was; but it would turn ont to be the same flower with a different name. But in order to be reasonably certain about that matter, Congress has provided the Interual Revenue Bureau with a laboratory and a competent chemist, and with money with which to purchase the current literature of the day upon these questions. And I have asked our chemist if in this hiatus of time from 1887 or 18s8, when this last general investigation was made, up to date science has made any advance which would change the condition of things described by Professor Morton; and my advice is that if it has our scientist does not know it, and it has not been written in the books.

Representative ALLEN. Now, sir, have any complaints been made to your department of any deleterious or injurious effect caused by the consumption of this article?

Commissioner Wilson. No, sir; no, sir. The only complaint that has ever reached the office was a letter which Mr. Tawney published here, in the Star, I think-at least, it was the same letter that he read to me. I took a copy of it and sent it to the agent in charge of the territory where most of these oils are produced, and had a very complete and thorough investigation marle, and have here a copy of his report.

Representative ALLEN. That is a copy of the report?

Commissioner WILson. A copy of the report of the agent-yes, sir. He does not find any ground whatever for the charge made in that letter. He says it is false and ntterly unworthy of belief; and he slows pretty conclnsively, I think, that his statements are trme. And without his knowing anything about the doctrine laid down here, in this investigation to which I have referred, he brings out in this same report the fact that the same concition of things exists.

Representative ALLEN. Will you file that report with your evidence, as an exhibit?

Commissioner Wilson. Yes.

(The report referred to above is as follows:)

Internal-Revenue Service, Office of Agent,

Chicago, Mll., May 2, 1900.

Hon. G. W. WILson,

Commissioner Internal Revenue, Tashington, D.C.

Sik: In accordance with instructions contained in your letter of the 2 . th nltimo, in which you inclose copy of a pubiished letter describing the character of material nserl by some of the oleomargarine manufacturers in Chicago, directing me to make a most thorongh search and investigation of the charges contained in the published letter, being careful to eliminate every donbt that might be involved in the matter before making my report, I now have the honor to report as follows:

On the 30th ultimo I, in company with Rovenue Agent H. B. Burgh and Special Employees O. S. Martin and J. O. Anderson, proceeded to the Chicago Union Stock Yards, where we visited the following establishments, which are either engaged in the business of manufacturing oleomargarine or are producers of either oleo oil or neutral oil. Revenue Agent Bnrgh visited the place of business of Armonr \& Co., Thomas J. Lipton Company, and Boyd, Lunham \& Co.; Special Employees Martin and Anderson visited the place of bnsiness of Swift \& Co. and Nelson Morris \& Co., while I visited the place of business of Friednan \& Co., Anglo-American Provision Compans, and the International Packing Company.

It was understood by all of the visiting revenue officers that in pursuing their investigations at the several establishments particular attention should be given to the 
so-called renlering tanks that are complained of in the published letter, and that they should follow the different materials that go into the production of oleomargarine from the point where the animals are slaughtered, or where the fats are taken from the animals after being slaughtered, through all of their different processes aud manipulations, to the finished oils.

Revenue Agent Burgh rcports the following as being the result of his investigation at the establishment of Armour \& Co. He took up his investigation of the materials that enter into the production of oleomargarine at the point where the fats are taken from the carcasses; that he followed the fat products of the hog and of the beef from that point through their various channels until the process of the production of neutral oil and oleo oil was fully completed. In pursuing his investigations with reference to neutral oil, he found that the leaf of the hog, commonly known as the leaf lard, and back fat-that is to say, that portion of the fat of the hog that is taken from the back-are the only portions of the hog product that goes into the prodnction of neutral oil. These fats, after being taken from the hor, are placed for a time in a refigerating room for the purpose of extracting all animal heat, and are allowed to remain there nntil such time as they nay be needed for the production of nentral oil, when they are taken from the refrigerating room to a cutting machine, where they are reduced to smaller particles. From the cutting machines all particles are removed to a grinding machine, where the mass is reduced to a pulp about the consistency of ice cream. 'The ground mass or pulp is put into open heating tanks, where it is allowed to heat to about $160^{\circ}$ temperature, where the nentral oil is separated from the fiber or tissue.

Reventie Agent Burgh further reports that his investigation at Armour \& Co.'s establishment, like that at other packing establishments visited by him, disclosed the fact that these establishments do employ in their business rendering tanks, but these rendering tanks are in no wise employed in the production of nentral oils, and can not be so employed. (This will be commented upon later and the reasons fully set forth.)

The question of the production of oleo oil was next taken up by Revenue Agent Burgh, and made the subject of his investigation at the Armour plant. It was found, by following the fat from the point at which it was taken from the beef, that oleo oil is obtained in a similar manner to that by which nentral oil is obtained. 'The beef fats that go into the production of oleo oils are known as canl fat, ruffle fat, and kidney fat, the caul fat and ruffle fat being used in the production of the higher grades of oleo oil and the kidney fat being used in the lower grades of oleo oil.

Revenue Agent Burgh further reports that in his investigation at Armonr \& Co.'s he did not find any process employed by that conpany for processing and deodorizing $11 \mathrm{nwholesome}$ fats, such as is mentioned in the published letter, and upon this point he obtained a statement flom G. J. Brine, of Armour \& Co., which statement is herewith submitted, and is nale a part of this report, and marked Exhibit A.

Revenue Agent Burgh next visiterl the establishment of Thomas J. Lipton Company, packers of meats and producers of both neutral and oleo oils, where the same conditions were found as wele found at Armour \& Co.'s. These gentlemen informed Revenue Agent Burgh that, so far as they were concerned, they had received no demands from oleomargarine manufacturers for either neutral oil or oleo oil that is produced from any of the lower grades of fats. At this ostablishment there was an absence of the so-called rendering tanks for rendering the poorer grades of fat mentioned in the published letter.

Revenue Agent Burgh next visited the packing establishment of Boyd, Junham \& Co., packers of meats and prodncers of oleo and neutral oils. The same method of investigation was pursued at this establishment as that employed at the Armour \& Co. and Thomas J. Lipton Company plants. Boyd, Lunham \& Co., in a letter to Revenue Agent Burgh, which I inclose with this report, say, in answer to his inguiry relative to the nature of the materials that are used by them in the production of nentral and oleo oils: "We supply to the manufacturers of oleomargarine and butterine, and in no case have we delivered to them other than the straight goods, viz, leaf lard and back fat, nor has there been any solicitation on the part of such manufacturers to furnish any other than the two above-named products." (See Exhibit B.)

Special employees O. S. Martin and J. O. Anderson, having visited Swift \& Co. and Nelson Morris \& Co., report the result of their investigations with reference to the materials used in the manufacture of neutral oil and oleo oils by these establish. ments in the following manner. I quote from their report:

"On the 30th ultimo we visited the packing house of Swift \& Co. at the Union Stock Yards and began our investigations at the slanghtering pens at the hog department, and found that upon the opening of the slaughtered hog the leaf fat is taken therefrom and removed to the cooling room, where the animal heat is allowed to escape. This leaf fat we then followed to the top of the neutral department, where we spent some time in watching the product enter what is known as the 
chopping machines, into which nothing was put but the finest leaf fats. We then followerl this product next to the grinding machines, which pulverize or grind the leaf fat to a pulp closely resembling ice cream. The pulp is then conducted to open kettles, which aro heated to a certain low temperature by means of hot water circulating around the open kettle. 'The product from these kettles is then drawn off and is allowed to percolate through several thicknesses of struining eloth, and the resilue, after the neutral lard is strained off, is pumped across to the lard department, where it is subjected to a bigh lieat under pressuro for the prodnction of steam lard. We then followed the weutral oil through the numerons straining processes to the cooling room, where it is drawn off into new barrels and prepared for saleor pumped to the tanks in their oleomargarine department.

"()ur attention was then directed to the possibility of fats from diseased and clead hogs being used in the production of neutral oil, and we find two very substantial reasons why it would be impossible for anjthing of that kind to enter into its production:

"First. Because in the case of a hog that dies of disease, or is killed withont immediately losing its blood, each part of the borly becomes at once permeated with the hog or linrdy taste, which prevents the making of an odorless or tasteless product, snch as is required in the production of neutral oil.

"Second. Because the rules of the Stock Yards Company require the disposal of and inmediate removal of dead and diseased hogs from the yards, and the Stock Yards Company are now under contract with Jolnn Brannock, of Globe, lnd., for the immediate removal of all such hogs to his rendering plant at that point, where, we were informed, the extracted greases are disposed of to lubricating companies and eheap soap companies.

"Wo then took up the subject of oleo oil, following this product from the slaughtering rooms, where the caul fat and the ruffle fat of the beeves are taken after the animal has passed the inspection of the Government inspectors of the Department of Agriculture. The above-described fats, after' being removed from the animal, are immediately snbjected to ice-water baths, and pass from one tank of ice water to another until they reach the cutting room in the oleo-oil department. The fats then pass through grinding machines, and from the grinding machines into buge open kettles, where they are subjected to a low heat, after whieh they aredrawn off intovats to cool. After cooling the fats are placed in small cotton sacks and put under pressure, thus extracting the oleo oil, similar to methorls employed at a cider mill for extracting the cider from the apple. The residue, or tallow y substance remaining, commonly known as 'stearin,' being a commereial article, is much sought after by soap manufactnrers. We then followed the oleo oil to the cooling room, from which point it is either pumped to the vats in the oleomargarine department, to be used in the production of oleomargarine, or is drawn off into new barrels for local shipment or for export.'

With reference to the examination of the methods and materials emplored by Nelson Morris \& Co. for the prodnction of neutral and olen oils Special Employees Martin and Anderson report the result of their investigations as follows. I quote from their report:

"We visited the packing house of Nelson Morris \& Co., at the Union Stock Yards, who are mannfacturers of oleo oils and neutral oils, where our investigation was as thorough as the one made at Swift \& Co.

"We were conducted through this plant by Mr. Johnson, general superintendent, who informed us, in response to the query as to the possibility of oftal and diseased fats entering into the manufacture of oleo oils and nentral oils, that each beef and hog was regularly inspected by the Government inspectors after the animal harl been killed and bled, and that the anonnt of stock which had been rejected by these inspectors during the year 1899, and which by reason of that inspection had been pronounced to be unfit for consumption and had been sent to the soap-grease factory, covers an amount exceeding over $\$ 20,000$. Onr entire investigation at this plant resulted, substantially, the same as at the packing honse of Swift \& Co."

On the 2d instant Special Employees Martin and Anderson visited the eleomargarine factories of W. J. Moxley, 63 West Monroe street, and Braun \& Fitts, North Union street, Chicago, for the purpose of ascertaining the methoils employed and the materials used by them in the production of nentral oil. 'I'hesegentlemen report the result of their investigations at the above estal,lisluments as follows:

"We found that, in the manufacture of oleomargarine, they (W. J. Moxley and Brann \& Fitts) used neutral oil of their own manufacture. They buy leaf lard at the Union Stock Yards, usually from Armour \& Co. and Swift \& Co. and Nelson Morris \& Co., which leaf is taken to their fictories, where it is put throngli the various proeesses employed by other producers of nentral oil. Neitlier W. J. Mloxley nor Braun \& Fitts are prodncers of oleo oil. Oleo oils are purchaserl by these tirms from Armour \& Co., Swift \& Co., and Nelson Morris at the stock yarels. The materials found at these establishments, whiel enter into the production of nentral 
oils, were in no wise different from that found to be employed at other establishments that produced neutral oils, and there was nothing in the investigation that would go to show that any of the low grades of fats complained of in the published letter are used by these concerns."

As both W. J. Moxley and Braun \& Fitts manufacture leaf lard for commercial purposes, it is necessary for them to have in their establishments rendering tanks, but these rendering tanks are not used in the production of neutral oils.

The result of $\mathrm{my}$ own investigations at the establishments visited by me are as follows:

Friedmann \& Co. are not packers of meats. They are manufacturers of oleomargarine and proclucers of neutral oils, but do not produce oleo oil. The fats from which they produce their neutral oils are purchased from the Anglo-American Provision Company, packers of meats at the Chicago stock yards. At the time of my arrival at the establishment of Friedmann \& Co., several wagons of the Anglo-American Provision Company and Nelson Morris \& Co. were found unloading leat lard of the finest and best grade. No inferior or low grades of fats were found in any of the wagons. I followed the leaf lard that was being received from the time it left the wagons until it was placed in the refrigerating room, where it is allowed to remain until all of the animal heat has been removed. This process, I am informed, requires anywhere from two to four days. From the refrigerating room I followed the leaf lard to the cutting machines, where it is cut into smaller bits, and from there to the criuding machines, where it is reduced to a pulp, and then on to the lieating kettles, where it is heated to about the temperature of $155^{\circ}$ to $160^{\circ}$. These heating kettles are open kettles and are heated with hot water (not steam) by having the hot water circulate around the kettle in which the leaf lard is being heated. In other woris, the heating kettle is a kettle within a kettle, hot water circulating between the two, in a space of 3 or 4 inches all around the inver kettle. From the heating kettle the nentral fats are removed and the neutral oils are expressed by straiuing process and filtration from the fiber and tissue.

All of the fat that is not expressed from the leaf lard in the production of neutral oil, and that portion that remains in the tissue, together with other fats, is taken to a rendering tank, where it is subjected to a steam pressure of about 50 pounds to the sqnare inch, and at a teluperature anywhere from $260^{\circ}$ to $300^{\circ}$, the result being the production of what is known as steam lard.

Every packer of meats, whether he be also a manufacturer of oleomargarine or a prorlucer of nentral or oleo oils, has in his establishment rendering tanks, but nentral oil is not and can not be obtained by heating in these tanks. In the first place there nust be a total absence of any lardy smell in the neutral oil that is intended to go into the production of oleomargarine, and in order to obtain that result the leaf lard must le heated in open kettles, such as I have already deseribed, and with only sufficient heat to break the grain of the fats.

Any lard, whether leaf lard of the tinest quality or of the lower grades, that has been subjected to heat at a temperature of more than about $160^{\circ}$, would take on the lardy flavor (the very thing that overy oleomargarine manufacturer and prodncer of nentral oils desires to avoid), and would be wholly unfit for the manufacture of oleomargarine.

I then visited the Anglo-American Provision Conıpany, packers of pork at the Uniou Stock Yards. The Anglo-American Provision Company manufacture neither neutral oil nor oleo oil. 'They dispose of all their leaf lard to Friedmann \& Co., and the balance of the hog fats are rendered up by themselves into steam-rendered lard.

I next visited the plant of the Intermational Packing Company at the Chicago stock yarils. The International Packing Company are manufacturers of oleomargarine and producers of neutral oils. The oleo oil that is used by this company in the production of their oleomargarine is purchased by them from Swift \& Co. and is considered to be of the finest quality. (A sample of this oleo oil is mailed to you this day, together with a sample of the neutral oil produced by the International Packing Company, and is made the subject of a separate letter.)

The Interuational Packing Compan, , being manufacturers of oleomargarine, have set apart a portion of their plant to be used exclusively in the prodnction of that article. Into this building all of the fats that go into the production of nentral oil are brought and are heated in open kettles, such as I have already described, as are used by every producer of neutral oil. The only portion of hog fats that come into this building that go into the prodnction of neutral oil, which is used in the manufacture of oleomargarine, is the leaf lard, the lower grades of hog fats being rendered up in the rendering tanks that are kept in their other buildings.

On the 1st instant Revenne Agent H. B. Burgh and myself went to Hammond, Ind., where we thoroughly investigated the methods that are employed by the G. $H$. Hammond Company for producing neutral oil and oleo oil, and the materials that enter into their production. As in other establishments of this kind visited by us, we followed the fats that go into the production of neutral oil and those that go 
into the production of oleo oil from the time the fats are taken from the slaughtered animals to the finished oils, and from that on into where the oils are used in the production of oleomargarine. 'The production of neutral oil and oleo oil by the G.H. Hammond Company is in no wise different from that found in other similar establishments. The materials used in the production of these oils were closely examined by us, and were found to be of the highest grades. The much-mooted question of rendering tanks, which is referred to in the published letter, was carefully investigated by $11 \mathrm{~s}$, with the result that the conditions found did not bear out the charges contained in that letter. On the other hand, the materials used in the production of these oils are of the finest quality and are carefully handled from start to finish, extra care being used with reference to cleanliness.

The G. H. Hammond Company, at my request, furnished me with a sample of their neutral oil, a sample of their oleo oil, and a sample of their salad or cotton-seed oil. These samples I have this day forwarded to your office for your inspection with relerence to the purity of the materials used by the G. H. Hammond Company, in the production of their oleomargarine, and are made the subject of a separate report.

In pursuing our investigations with reference to the charges set forth in the published letter, we have the honor to advise jou that, instead of finding the conditions as charged in that letter, I think wo are absolutely safe in saying that we found the conditions to be exactly opposite. There is nothing in our investigations to show that producers of neutral oils and oleo oils have any knowlerge of the "deodorizing process," nor have they introduced any deodorizing process in their establishments whereby the lower grades of fats can be processed and turned into the products that go into the manufacture of oleomargarine and butterine, as is stated in the published letter.

The packers at the Chicago stock yards, who are also prodncers of neutral and oleo oils, have read published accounts in the Chicago papers, which are similar in tone to the clipping that you sent to me, aud are making every effort to learu who the employee is that wrote the letter, claiming to have had thirteen years' experieuce at the stock yards as an employee, but so far they have been unable to locate the writer. However, it is the general impression among nearly all of the packers, as well as the oleomargarine mannfacturers, that the anthor of the published letter is Charles Y. Kuight, manager Chicago Dairy Produce, a publication published in the interest of dairy products, 188 Sonth Water street, Chicago.

We have tried to make our investigations full and complete, and have endeavored to give the facts just as they presented themselves, with the view of supplying all of the information relative to the published charges that was obtainable, and hope we have covered the most important points. Our report may seem a little lengthy, but considering the ground that had to be gone over in order to make an intelligent report, we do not see how we could have conveyed the information otherwise.

We are very respectfully, yours,

Jaues W. MCGiNnIS, H. B. BURGH,

Revenue Agents.

\section{Exhibit A.}

Mr. H. B. BURGH, lievenue Agent, Chicago, Ill.

Dear Sir: We have looked over the letter sent to the honorable Commissioner of Internal Revenue under date of April 24, 1900, purporting to have been written by an employee of the stock yards, and we beg to state that most of the statements therein we believe to be entirely without foundation in fact.

The allegation that "the demand for so-called oleo oil or fat has so increased that the stock yards plant has introduced deodorizing processes, so that all kinds of inferior fats and ofial can be tnrned into products which go in to the mannfacture of oleomargarine and butterine." we answer by saying that as we ourselves abancloned the manufacture of oleomargarine immediately upon the passage of the Illinois law rendering it illegal to color this article, we have since then sold the oleo oil and other products entering into the mannfacture of oleomargarine to manufacturers of that article. The demand that we supply being both foreign and domestic, we are in position to state emplatically that we find no inquiry existing for the lower grades of fats and oils mentioned in the letter alluded to, lut on the contrary that oleomargarine manufacturers demand and have supplied to them invariably products made from material that is first class in every particular. 
The statement t'at "barrels are filled with anything that can be processed, deodorized, and turned into oleo oil and then delivered to the factories; when these barrels are empty they are returned to the grease producers and filled again. This is the principal ingredient in the much advertised grade of finely colored butterine on the market at the present time. It is carefully gotten up for the retail trade," we beg to say, so far as we know (and we believe we are fully informell) is made without the slightest warrant.

The further" statement in this leticer as follows: "No tallow is sold from the stock yards nowalays," is false. "The further statement that "Butterine demands it all," we know to be false.

It is further stated that "the horse killers and dead animal contractors and fertilizing prodncers furnish soap stocks, etc." which is false, and we are not surprised that "no name is furnished as to who the writer of the above letter may be."

Respecting the use to which many of the by-produets of the hogs and cattle killed at the Union Stock Yards are put, we beg to state that-

Leaf lard is exclusively used in the production of neutral oil.

Beef suet and kidney fat of beef cattle are exclusively used in the production of oleo oil.

Wo beg to state, in answer to your question respecting the employment of a rendering tank for rendering pooler grades of fat either from hogs or cattle for the production of neutral oil and oleo oils, that no such rendering tanks for this purpose is employed by us, and that therefore we are sure that these so-called poorer gratles of fat are not used in the manufacture of the cheaper grades of oils, oleomargarine, or butterine.

In answer to your question as to whether any of the oils manufactured by us and used by oleomargarine manufacturers in the production of their oleomargarine or butterine are in any manner deleterious to pnblic health, we beg to state that these oils are not only not deleterious to public health, but are wholesome, nutrient, palatable, and in all respects as desirable for human food as any other portion of the animals from which these oils are produced.

In conclusion, we beg to state that the anonymous letter to which our attention has been ealled is ntterly devoid of truth, and that tho charges made respecting the quality of the oleomargarine now upon the market (and of the products from which it is manufactured) are, to the best of our knowledge and in the light of our experience, entirely without foundation.

Yours, very truly,

ARMOUR \& Co., Geo. J. BRINE.

UNION STOCK YARDS, Chicago, April 30, 1900.

Mr. H. B. BURGR.

DEAR SIR: In answer to your inquiry relative to the nature of the product we supply to the manufacturers of oleomargarine and butterine, we have bnt to sav that in no case have we delivered them other than the straight goods, viz, leaf lard and back fat, nor bas there been any solicitation on the part of such mauufacturers for us to furnish any other than the two above-named products.

Yours, truly,

Boyd, Lunhan \& Co.,

Per WM. GroH, Superiutendent.

Commissioner WILSON. It must be understood that I am not talking to you as a scientific man. I am telling you these things from the records. When it comes to science it is getting a little out of my line.

Representative BAKER. Will you please give me again the page of that investigation from which you were reading?

Commissioner WILson. This is Senate Document 2346. I read from page 47.

Representative BAKER. When were those hearings had; during what Congress and session?

Commissioner WILSON. This is Senate Miscellaneous Document No. 2316 of the first session of the Forty-ninth Congress, 1885-86, volume 5 . Representative ALLEN. That was before what was known as the Mason Committee, I believe?

Commissioner WILson. No, no; that was the investigation made by

a joint committee of Congress with a view of determining whether or 
not they would enact this original legislation. It is the fomdation on which the whole thing is built.

Representative ALLEN. 'There is one other question I would like to ask, if you will permit me. I will ask you to state to the committee if you have any information as to the extent of the consumption of this article by the public and by what classes of people it is generally consumed, if you know firom your personal knowledge or from matters in connection with your department.

Commissioner WILSON. It is pretty hard for me to give any opinion which would be worth anything on that subject. I thinls everybody buys it. I think it is clenn and reputable.

Representative ALLEN. 1)o you regard its manufacture as a fixed industry in the comtry, which onght not to be abolished?

Commissioner WiLson. Yes, sir, I certainly do; and, if I may venture this statement (you will pardon me if I go beyoud what 1 should say), I will say to you, gentlemen, that any legislation which you may enact here with respect to stamping or identifying as an entity the quantity of oleomalgarine that goes into the hands of $\mathrm{A}, \mathrm{B}$, or $\mathrm{C}$ to be used on their tables will give it a barlge of ererlibility that it would not get anywhere else.

'The tobaceo manufacturers would pay for all the marks, brands, and stamps that are on their tobacco simply for the purpose of having it under Govermment iuspection.

Representative BAILEY. Do you believe that this amenrment you recommend would protect the public against the fraudulent sale of oleomargarine?

Commissioner WILson. Yes, sir.

Representative BAILEY. You think it would?

Commissioner Wilson. Now, I do not say it would completely protect it. Of course, we have very strict laws with respect to the tax on distilled spirits; the tax is very high and the law is drastic and harsh, and yet-

Representative WADSWor'TH. And there is a law against murder, is there not? But murler is committed.

Commissioner WVilson. Yes; and yet there are murder's. But I say to you that the percentage of fraud would be extremely small if that were done.

Representative BAlLEY. Mr. Wilson, a statement was male here by the friends of the dairy interests that 90 per cent of the oleomarginine marketed in this country was sold as butter. Do you believe that is true?

Commissioner WILson. I say it is nearer 10 per cent.

liepresentative WILLIAMS. What was that question?

liepresentative BAILEY. The question was that it had been stated to this committee that 90 per cent of the oleomargane sold in this country was sold as butter.

Commissioner WiLson. Of course I can not tell, but I do not think that is aecurate. I simply do not think so. That is my honest conviction about it.

liepresentative BAILEY. Do you think that this law is enforeed as well as any other intermal-revemue law?

Commissioner WILSON. With respect to collecting the tax, better; with respect to the incidental matters, so far as the prure food law is concerned, no.

Representative Williams. Mr. Commissioner, I would like to ask you a question a little off of this line; I do not know whetler you know 
anything about it or not. Do you know anything about "renovated butter?"

Commissioner Wilson. Yes, sir; I have been after those people lately, and taken every one of them ont of the oleo factories. They have tried to renovate butter at some of these factories, as well as other places, and I have stopped it.

Representative Willians. I wish you would tell us about that.

Commissioner WiLsoN. I do not know much about it, except that they appeared to have wagons over the cities, and, indeed, at various conntry places where they have this product, and it gets spoiled; and they gathered the stuff in and sent it to these renovating establish. ments. One or two of the oleomargarine factories had arranged an annex of that kind, and I cleaned them out.

Representative WILLIA IS. Talking about frands upon butter, or upon butter eaters, which do you regard as the greatest fraud being perpetrated now, and the most plansible one, the one most easy to mislead people-oleomargarine or renovated butter?

Commissioner WiLson. Well, I hardly think any idea which $I$ might have on that subject could be of much importance or weight. 'The oleomargarine factories are wonderfully cleanly conducted alliirs. If you gentlemen will send a committee in among them without their knowing it, and take hold of the matter yourselves, you will find that to be the truth. They are wonderfully cleanly conducted affairs.

Representative WiLlians. Now, I have understood-and I do not know but what you may have had occasion to find out something about it-that they send around and get the old rancid butter from restaurants and hotels and other places, and carry it up to a central place, and "renovate" it, as they call it.

Commissioner WrLson. Yes, they do. That is not denied. It is an industry.

Representative WILLIAMS. It is an industry.

Representative ALLEN. And that material is then sold for butter?

Commissioner WiLson. Yes; but so far as I know, the dairy people have nothing to do with that. That is a business as distinct from them, I presume, as it is from the oleomargarine business. I do not know that they have anything to do with it. I do not think so.

Representative HAUGEN. You stated a while ago that the 10-per-cent tax would practically drive oleomargarine out of the market. On what ground do you base this opinion?

Commissioner WiLson. I do not think they could produce it.

Represtative HAUGEN. What makes you think so?

Commissioner WILsON. I do not think a good class of oleomargarine can be produced and placed in the hands of the consumer with that tax. Now, I have not any data at hand-I liave some at the office, but none here-upon that question; so that I do not like to talk about it without being better informed.

Representative HAUGEN. But in order to express an opinion of that sort you would naturally have some knowledge of the cost of the production of oleomargarine, and also the present or average market price of butter?

Commissioner Wilson. Yes.

Representative HAUGEN. Have you any information as to the cost of oleomargarine, uncolored? I believe the evidence before this committee is that its cost is about 8 cents a pound.

Commissioner WILSON. I have it down at the office.

Representative HAUGEN. Can you not give us an estimate? 
Commissioner WiLson. I should not vary it much from what you huve stated.

Representative HAUGEN. Eight cents a pound?

Commissioner Wilson. Yes; I think so.

Representative HAUGEN. Now, then, what is creamery butter selling for in the markets, or what has been its average cost during the past year?

Commissioner WiLson. I do not know what the average cost of butter would be; possibly 25 cents.

Representative HAUGEN. The proposed tax is 10 cents, which, added to the 8 cents per pound, wonld be 18 cents?

Commissioner Wilson. Yes.

Representative BAUGEN. It is claimed that oleomargarine is as wholesome and as good an article as butter, and that it is worth as much, and sells for as much. Now, then, 10 and 8 are 18 , representing the cost price of oleomargarine, according to those figures, while the average price of butter is put at 25 cents. How do you arrive at the conclusion, from those figures, that this act would practically drive the oleomargarine manufacturers out of business?

Commissioner WiLsun. In the first place, you rob it of its pleasant aspect to the eye. You do not like to buy lardy-looking stuff for your table. It would be a worse badge upon it than to stamp the word "Oleomargarine" right on it, if it were colored.

Representative HAUGEN. Yes; but under this bill the paying of the 10-per-cent tax would permit the manufactnrers to color their product and make it an imitation of butter, and then it would cost only 18 cents per pound, while you place the cost price of butter at 25 cents. That leaves a difference of 7 cents per pound in the price of the two commodities.

Commissioner WiLson. Well, I do not know about the average cost of butter; I do not want to undertake to speak definitely on that point, becanse I am not acquainted, with it.

Representative WILLIAIIS. Mr. Commissioner, in the price of oleomargarine which you have given, have you iucluded the various taxes and licenses which may be paid along the line in order to comply with the laws governing its sale, or have you simply given the cost of manufacture?

Commissioner WILsON. It is simply the cost of manufacture which has been referred to, as I understand-the special taxes and the pound tax. The special taxes, together with the pound tax, I presume add about 50 per cent to the cost of production, I should say. There are 7,000 dealers in the United States at \$4 each.

Representative WILLIAıIs. Retail dealers?

Commissioner WILSON. Yes.

Representative WiLLIAis. Then there are the wholesale licenses?

Commissioner WILson. The wholesale license fee is $\$ 180$, and there are 300 or 400 wholesale dealers.

Representative WILLIAMS. And the various States have legislation on the point, too, have they not?

Commissioner WILson. And then there are the manufacturers, 25 or 30 of them, who pay $\$ 600$ each.

Representative HAUGEN. How many wholesale dealers are there?

Commissioner WILSON. I would not like to say; I have not the exact figures in my mind. There are a good many.

Representative Henry. Mr. Commissioner, the reduction of the tax proposed by the bill this committee has been considering, from 2 cents 
a pound to a quarter of a cent per pound, would of course reduce the cost of uncolored oleomargarine to the consumer by just that amount, would it not?

Commissioner Wilson. Oh, yes; yes sir.

Representative HENRY. And would it materially interfere with the consumption of oleomargarine as used for cooking purposes in hotels, saloons, etc.? Would it not be a positive benefit to the laboring man who uses oleomargarine to have the price reduced practically 2 cents a pound?

Commissioner Wilson. Well, indeed, I hardly think so. I think the laboring man has a right to have his eye tiekled about the color of his butter just as well as we have.

Representative HENRY. It is not a question of tickling his eye, but a question of whether he is to be deceived or not. Is the colored oleomargarine any the less palatable?

Commissioner Wilson. Oh, no; I presume it would be just as palatable, sir, uncolored as colored. It is simply a question of its appearance. I think the same result would follow prohibiting the eoloring of butter that would follow prohibiting the coloring of oleomargarine; it would hurt its sale in the same way. It would make it objectionable. The two products stand exactly on the same basis as far as that is concerued.

Representative Allen. Following that line, I understand you to say, Mr. Wilson, that you believe this tax on colored oleomargarine would entirely prohibit its manufacture. That being the ease, the demand being so decreased, there would not be enough demand to justify the mantucture of uncolored oleomargarine, would there?

Commissioner WiLson. Those are abstract questions about which I do not like to venture an opinion. You gentlemen who are farmers know more about it than I clo.

Representative HenRy. You do not for a moment suppose that the practical abolishment of the tax on mucolored oleomargarine, or its reduction from 2 cents a pound to one-quarter of a cent a pound would prevent the consumption of oleomargarine to a very great extent, do you?

Commissioner WILson. You would have to commence de rovo and educate the people. They started in with it eolored, in the first place. I presume everybody was afraid of it, even colored, in the first place; and now, if you take the coloring away, you will have to start again and get the people acquainted with it, and make them know that it tastes just as good, although it does not look so well.

Representative HENRY. But the party using it for cooking purposes would not pay the extra 2 cents a pound for uncolored oleomargine?

Commissioner WiLson. I do not know whether he would or not. My judgment is that sueh a law would be a serious blow at the industry. That is simply my opinion.

Representative WILLIAMs. I would like to ask you a question there, Mr. Commissioner. Have you read the Grout bill, which is now pending before the committee?

Commissioner Wilson. Yes, sir.

Representative WILLIAMS. Is there anything in that bill which would enable an internal-revenue officer to punish a man guilty of deception in selling oleomargarine as butter, any more than the existing law?

Commissioner WILSON. I think not. I think the difference would simply be in redueing the number of people who would do so, and possibly redueing the number of people who would invite it. It would change 
the condition of things from what exists now ; there is no question about that, because I think the sale of oleomargarine, not tor butter, but the sale of oleomargarme blank. is largely indnced by the purchaser.

Representative WiLlians. He simply does not want his neighbor to know that it is oleomargarine that he is buying, although he knows it very well?

Commissioner Wilson. That is it exactly.

The Acting Cirainuan. As to the coloring of butter and oleomargarine, you put the two on the same basis, as I mulerstand?

Commissioner WILSON. Oh, coloring accomplishes the same thing for eacli.

The acting Chairman. Do you think it as necessary for butter to be colored as for oleomargarine to be colored-and what difference would you find in that respect, as between seasons, in butter?

Commissioner WiLson. There are certain seasons of the year, you know, when butter is nearly white; and there are certain seasons of the year when, by reason of the food consumed by the animal, the butter is almost the color of the commercial product. Indeed, I think (though I do not want to say much about it, becanse I do not know much about it) the dairyman can feed his cows so as to color the butter. I may be wrong about it, but that is my impression.

Representative WILsON. As a matter of fact, are not butter and oleomargarine both colored for the same purpose?

Commissioner Wilson. Ol, yes; that is my understanding of it.

Representative HENRY. You would make this distinction, wonld you-that oue is a natural color, and the other is entirely artificial?

Representative WILSON. But one is a natural color for a very short while only, of course.

Commissioner WiLson. They can feed the cattle so as to get the desired color in the butter, I think, but not so miformly, and in a state so pleasing to the eye, as by using coloring matter in the butter.

Representative Henry. The demand for that unitorm and pleasiug appearance to the eye, to which you altude so pathetically, is largely an originated taste, an acquired taste, is it not? If people were accustomed to use white bntter or white oleomargarine, there would be no necessity for the use of coloring matter.

Commissioner WILson. I say, if you commence and educate again, yes, sir; most certainly. I do not think it would hurt me at all. I could eat white butter. I have eaten it many a time. I have churned many a churuing of it myself.

Representative HAUGEN. You stated a while ago that these special taxes added 50 per cent, I believe, to the cost of the oleomargarine. Did I understami you correctly?

Commissioner WILSON. Well, my recollection is that the special tax receipts would not be that much. Twice 8 is 16 . The pound tax from oleomargarine last year must have amounted to about sixteen or seventeen humclred thousand dollars, or somewhere along there.

Mr. KNIGHT. It was $\$ 1,660,000$.

Commissioner WILson. You see, there is between three and four hundred thousand dollars of special taxes. The number of special tax-payers has heen doubled in the last year. We had a little more money to use for that purpose, and we have done a good deal of work along that line. The result has been that we have cloubled the number of retail oleomargarine dealers in the comntry.

Representative HAÜGEN. That would not be much over 2 cents a pound, would it? According to those figures, the cost of manufacturing 
oleomargarine would be about 4 cents a pound, if your statements are correct, if the 2 cents a pound is 50 per cent of cost?

Representative WiLLIAMS. I understood him to say that that was the amount collected-that the tax was 2 cents a pound.

Commissioner Wilson. Yes, sir. With a tax of 2 cents a pound, the $\$ 1,000,000$ collecterl would represent about $80,000,000$ pounds.

Representative WiLliams. That does not include these licenses and other expenses, does it?

Commissioner Wilson. No. Between three and four hundred thou. sand dollars of the $\$ 1,600,000$ comes from the special taxes.

Representative HAUGEN. That would be about $2 \frac{1}{4}$ per cent, would it not?

Commissioner WiLson. Yes, sir; something like that.

Representative HaUgEN. Then, if that is 50 per cent of the cost, the cost of the oleomargarine to the manufacturer would be about $4 \frac{1}{2}$ cents a pound.

Commissioner WiLson. I do not know whether the 8 cents which has been referred to includes the pound tax and the special tax, or not. Of course if it does that would mean that the actual cost of manufacture was 5 and a fraction or 6 cents a pound. If it does not it means that the cost is 10 cents and a fraction. I do not know anything abont that subject; I have not gone into it.

Representative BAILEY. Have you seen the bill introduced recently by Mr. Wadsworth along this line?

Commissioner WILson. Yes, sir.

Representative BAILEY. Do you think that bill will meet the requirements of protecting the people as against fraud and the fraudulent sale of oleomargarine?

Commissioner Wilson. I do, in the fullest possible way, and still allow them to manufacture oleomargarine.

Representative WRIGHT. As I understand it, the figures which you have given of 8 cents a pound, cost of manufacture, and also in regard to the 50 per cent which you mentioned, are only given according to your opinion, without having the figures before you?

Commissioner WIIsoN. That is all.

The Chairman. If that is all, we thank you very much, Mr. Wilson, for your information.

Commissioner Wilson. I bave brought here Dr. Crampton, our chem. ist, to whom I refer all scientific matters, if the gentlemen wish to ask him anything on this subject.

STATEMENT OF DR. CHARLES A. CRAMPTON, CHEMIST, INTERNALREVENUE DUREAU. TREASURY DEPARTMENT.

Representative ALLEN. Doctor, what position do you occupy?

Dr. Crampton. I am the chemist of the Internal-Revenue Office.

Representative ALLEN. What have you under your immediate supervision or care in that line?

Dr. CRAMPTON. I have the investigation of products which are subject to an internal-revenue tax.

Representative ALLEN. Oleomargarine?

Dr. Crampton. Oleomargarine, and other products.

Representative ALLEN. If you have had any occasion to investigate or make an analysis of oleomargarine, I wish you would state to the 
committee to what extent your researches have gone, and what have been their results?

Dr. Crampton. The great bulk of my work on that product is in the direction of determining whether a suspected sample is oleomargarine or butter. 'That constitutes the greater part, niue-tenths or ninetynine one-hundredths, of my work in conneetion with the product. I have, however, occasionally mąle a special investigation of the article, as to the ingredients which are used in it, and so forth.

Representative ALLEN. Do you know from what manufacturer the oleomirgarine which you liave examined has come or of what factory it was the product?

Dr. Cramp'on. Not in all cases. I do, however, in the case of these samples which I have in my hand, which are, you might say, a supplement to the report of Revenue A gent MuGinnis.

Representative ALLEN. Just go ahead and make your statement in that regard in such way as you desire.

Dr. CRAMPTON. These samples were sent in by the revenne agent at the time he made his investigation of the fatories in Chicago, and are samples which he took of the materials which entered into the minufacture of oleomargarine at these factories at the time he made his investigation. These materials are probably quite well known to the committee as the ordinary ingredients of oleomargarine. Three of these samples came from one place and two from another.

Representative ALLEN. Designate the places.

Dr. Crampton. Do you want the name of the manufacturers from whom they came?

Representative ALLEN. Yes.

Dr. Crampton. The three samples came from Hammoud Company, Hammond, Ind., near Chicago. The tro samples came from the International Packing Company, of Chicago.

The three samples are, respectively, oleo oil, nentral lard, and cotton. seed oil. These I luave examined with a view simply of determining whether they are or are not what they are represented to be, and as to their general character as ingredients of oleomargarine, whether they are or are not fit materials to use for that purpose. This examination I made under the direction of the commissioner, simply as a sup. plement to the revenue agent's reports; and I may say that these samples speak for themselves, withont; any investigation. They seem to be wholesome and palatable, and proper materials for the production of this commodity, the manufacture of which is licensed by law, and with which we have to deal. If the committee cares to see these samples I will be very glad to exhibit them.

Representative ALLEN. Do you find anything in the composition of those samples which reucler them deleterious as food for the human stomach?

Dr. Crampton. No, I do not; no, sir. Of course. the investigation of them which I made was not a searching bacteriological investigation or a very extensive investigation; because they are articles which are pretty well known, and lıve been investigated a great deal.

liepresentative ALLEN. What is the relative proportion of bacteria found in oleomargarine and butter?

Dr. CRAmpton. I am not able to speak ou that subject as to my own investigations. I have not made investigations along that line.

Represontative Allen. But you give it to this committee as your opinion, as an officer of the Government in charge of that duty, and 
disinterested in the matter, that oleomargarine is a healthful article of food cousumption?

Dr. Crampton. Yes, sir; I have no hesitation in saying that. As the Commissioner said in his remarks, we base the aetion of the office largely upon the extensive investigation which was made in the year 1886 into the character of this moduct is a food material. At that time the opinion of the learling scientists of the country was, as the Commissioner has stated, in favor of the product-that it was not, in general, a material which shomld be conclemned as an article of foor. And while I have kept wateh of literature on sueh matters since that time, I have not been able to find any chemical literature or any patent bearing upon the subject which lias led me to suppose that the process of mannfacture has ehanged radically in any way from the time the original bill was passed.

liepresentative Cooner. I would like to ask you a question for my own information. I was not in here when the Commissioner commenced his remarks. When I came in he was spealing with reference to that Senate document, and stating that what he read was the sulustance of the fommdation npon which the internal serenue law was based-and that was in regard to these fats which are used in the production of oleomargarine. It was stated that if they were permitted to remain munsed in the product for a little while, or placed in ressels which were not absolutely untainted, they would becouse an obnuxions -

Representative WiLliaus. "Offensive" was the word lie used.

Representative Cooner. (Continuing.) An offensive product. 'That is your experience, likewise, is it?

Dr. Cramp'ton. Yes, sir.

Representative CoONEY. Now, what I womld like to know is what means the Government has of knowing that this fat is used at the proper time and in the proper way by the manufacturers of oleomargarine?

Dr. Cranpton. Well, I presume it has no means of aseertaining the condition of the materials, except that the factories are open at all times to the inspection and supervision of the in ternal-revenue officers.

Commissioner WILson. P'ardon me, but may I insert a few words right there? The fact that "the first law of nature is self-preservation" is the answer to that question. If the materials are not used before they become rancid, they have lost their substance and are forever ruined; so that the manufacturer's can not sell what they make of such materials.

Representative WADSWORTH. It is the same-as with eream, in butter making. If your cream is not used at the proper time, at the exact moment, your butter is of an inferior quality. The same law applies to oleomargarine. If you do not use the materials at the proper time the manufictured product is of poor puality.

Representative Cooney. 'The statement of the Commissioner, then, as I understand it, is that the prodnet, when the materials were not used at the proper time, would be offensive and obnoxions in itself.

Representative WILSON. In other words, it would tell its own tale?

Doctor Crampton. Yes; that is the gromnd upon which we lave always proceerled. That is just what is stated in that testimony.

Representative Cooner. And the process of manufacturing the oleomargarine out of these fats at improper times would not render the detection of that obnoxious quality any the less easy? Is that what I understand. 
Dr. Crampton. I think that is so.

Representative WILSON. In other words, it would not take the offensiveness away?

Dr. Crampton. No. Now, J do not know that such processes have not been perfected; I am not undertaking to say that. I lo not make inspections of factories myself, and that is a matter of which I ean not speak from my personal knowlerge. It may be that metlods and processes are used for renovating such fats. We know that they do renovate butter. But if such practices are carried on they have not come to my knowledge. No such knowlerge has come to me, or', so far as I know, to the Interual-Revenue Oftice. We have gone upon the supposition that this statement is trine-that these fats can not, after they have once become rancid, be snccessfully renovated and rensed. That is the ground which we have always taken. If things have changed, and if new methods have been perfected, or if something unusual has occurred in the industry whereby this can be accomplished, we do not know of it, sir; we have no knowledge of it.

liepresentative S'oKks. If such processes had been discovered, is it not likely that in the course of your reading upon the subject some information in regard to them would have come to you?

Dr. Urampton. I think so; yes, sir.

Representative WILLIAnIs. The dairymen would have reported it to him.

Representative BAILEY. Mr. Williams, I would suggest that the time is slipping by, and we have several men yet to hear, some of whom are expert butterine makers.

Representative Williams. Mr. Commissioner, I would like to ask you this question: Has there been reported to your office any attempt to do away with the offensiveness which would follow from the standing of these ingredients?

Commissioner WILson. No, sir.

Representative Williams. Nothing of the kind has been reported by the dairy interests or by anybody else?

Commissioner Wilson. No, sir.

Representative WrLurais. That is what I want to know.

Representative BAILEY. I will say to the committee that we have here the two expert butterine manufacturers from Armour and Swift's great factories at Kansas City, who are perfeetly familiar with the manufacture of the product. If Dr. Wiley will now come before the committee, we shonld be glad to hear him for just a moment, and then have him give way to these men who are actually engaged in the manufacture of butterine in two of the greatest manufacturing establishments of the world.

Representative WiLson. I would like to ask Dr. Crampton just one more question. I want to know, Doctor (if you know), what is the difference between butter and oleomargarine, so far as the chemical elements which enter into each are concerned?

Dr. Crampton. They are very much the same, with the exception of the small amount of what are called the volatile or soluble fatty acids, which enter in to butter and which do not enter into oleomargarine. The great bulk of the fat is of the same composition, ehemically speaking; they are both glycerides. Of course, these volatile, fatty acids are very important, however; they give butter its flavor and taste, the pleasant "bouquet," you might say; and that is very important. There is no question about that. 
Dr. Craupton also submitted, as part of his remarks, the following letter:

Treasury Department,

Office of Commissioner of Internal Revenue, Wrashington, May 16, 1900.

The Commissioner of Internal Revenue.

SIR: I have the honor to report that I have made an examination of five samples of materials nsed in the mannfacture of oleomargarine, sent in by Revenue Agent MeGinnis, and described by him in his two letters dated May 2.

Nos. 3972 , 3973, and 3974 were obtained from the G. H. Hammond Company, manufacturers of olcomargarine, Hammond, Ind.

Nos. 3975 and 3976 were obtained from the International Packing Company, manufacturers of oleomargarine, Chicago, Ill.

These samples are designated as follows:

No. 3972, oleo oil, from Hammond.

No. 3973 , neutral, from Hammond.

No. 3974 , cotton-seed oil, from Hammond.

No. 3975 , oleo oil, International Packing Company.

No. 3976 , neutral lard, same.

I have niade chemical and microscopical examination of these samples and find them to be as described on the labels and the reports of the agent. I find uothing objectionable abont them, and should consider them entirely fit for nse in the manufacture of oleomargariue.

Respectfully,

Charles a. Crampton, Chemist.

\section{STATEMENT OF DR. HARVEY W. WILEY, CHIEF CHEMIST UNITED STATES DEPARTMENT OF AGRICULTURE.}

Representative BAILEY. Dr. Wiley, please give your name to the stenographer.

Dr. WILEY. My name is H. W. Wiley.

Representative BAILEY. What position do you hold in the Goverument, Dr. Wiley?

Dr. WilEY. I am chief chemist of the Department of Agrieulture.

Representative BAILEY. Have you any knowledge of the component parts of oleomargarine?

Dr. Wiley. Yes, sir.

Representative BAILFY. Will you please tell the committee, in as brief a way as you can, whether or !ot, in your judgment, it is a wholesome article of food?

Representative WiLliams. Before you answer that, excuse me one moment while I ask you this question: Has not the Ohemical Division of the Department of A griculture become, in a measure, the chemical division of the entire Govermment? Are not things sent to you from the other Departments to be investigated?

Dr. WILEX. Yes, sir.

Representative WiLliams. From the Treasury Department and elsewhere?

Dr. WiLtiy. Yes, sir.

Representative WiLliams. I simply wanted to bring ont that fact.

Dr. WILEY. Throngh the Secretary of Agriculture, we collaborate with almost all the Departments of the Goverument, and especially the Treasury Department.

With relation to the question just asked Dr. Crampton, I have here a chart which will show you at a glance the difference between butter and some of the other products. Butter is a much more complex substance than oleomargarine.

At this point Dr. Wiley exhibited a chart, of which the following is a colpy:] 
Composition of butter fat

\begin{tabular}{|c|c|c|c|c|c|}
\hline & Acids. & $\begin{array}{l}\text { Glycer- } \\
\text { ides. }\end{array}$ & & Acids. & $\begin{array}{l}\text { Glycer- } \\
\text { ides. }\end{array}$ \\
\hline 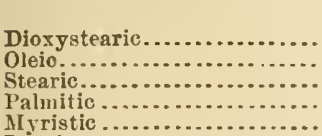 & $\begin{array}{r}\text { Per cent. } \\
1.00 \\
32.50 \\
1.83 \\
38.61 \\
9.89\end{array}$ & $\begin{array}{r}\text { Per cent. } \\
1.04 \\
33.95 \\
1.91 \\
40.51 \\
10.44\end{array}$ & 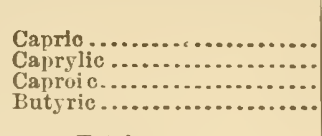 & $\begin{array}{r}\text { Per cent. } \\
.32 \\
.49 \\
2.09 \\
5.45\end{array}$ & $\begin{array}{r}\text { Per cent. } \\
.34 \\
.53 \\
2.32 \\
6.23\end{array}$ \\
\hline Lauric ...................... & $\quad 2.57$ & 2.73 & Total & 94.75 & 100.00 \\
\hline
\end{tabular}

Dr. WrLEY. This table shows the average composition of American butter, a substance alont which the committee has beard a great deal. There may be some terms there which are not strictly legal, and which some of you who are farmers may not thoronghly understand.

Representative WILLrais. The first item in the column is "dioxystearic acid." What kin is that to stearin?

Dr. Wiler. That is a very near relation.

Represeutative WrLliams. Theu it appears that butter has stearin in it?

Dr. WILEY. Oh, yes. Yes; it has quite a potable quantity of stearin in it. It not only has dioxystearic acid but it has stearic acid also. These acids which compose butter are, in butter, combined with glycerin; and it is the combination of glycerin, which is a base, with these and other acids, which makes the butter fat.

The acids are named in the left-hand column, the percentage of the acids in the average butter in the midclle colnmm, and the percentage of the glycerides (that is the name applied to the combination of the acids with the glycerin) in the right-hand column.

Now, dioxystearic glyceride or stearin-the proper name of that substance would be dioxystearin, when combined with glycerin-comcomposes 1.04 per cent of the average butter fat.

Representative WADsworTH. You state positively, then, that butter contains stearin, do you?

Dr. WILEY. Oh, yes; there is no doubt of that.

Representative WADSWORTH. That is positive, is it?

Dr. WrLEx. That is absolutely certain. It contains, altogether, 3 per cent of stearin.

Representative WADsw ORTH. Three per cent of stearin?

Dr. WILEY. Yes; that is, the two stearins together-stearin and dioxystearin-form 3 per cent of bntter. Olein folms a little over nnethird of the whole quantity of butter-that is, of course, butter which is free of water, free of curd, and free of salt. These are pure fats. In butter they are not. The butter, as it goes on the malket, contains about 12 per cent of water and 2 per cent of curds, and the amount of salt wlich it is desired to put in it. Some people want more and some less; but this table shows the composition of the pure fats which compose tlie butter.

Representative WADSWORTH. What relation does oleic acid bear to oleo oil, which is used in the manufucture of butterine?

Dr. WILEY. Oleo oil is largely pure olein; not altogether, but practically so. Cotton oil is largely olein and linoleine and the olein in butter is of exactly the same composition as the olein in cotton-seed oil. Olein, wherever it oceurs, whether in animal or veretable products, has the same composition; and palmitin has the same composition wherever it occurs. 
Representative WILLIAMs. Will you explain what is meant by the figures opposite "oleic," under the head of "glycerides?"

Dr. WrLEY. When you combine glycerin with oleic acid, it forms olein; and that is the form in which it exists in butter. Palmitin, you see, is the chief constituent of butter, making $40 \frac{1}{2}$ per cent, altogether, of the total.

[At this point Dr. Wiley submitted the following:]

\section{Characteristics of certain fats.}

The composition of butter fats, as shown by the latest analyses, is exhibited in the table.

lt should be mentioned in addition that butter fat has been found to contain minute quantities of coloring natter-lecithiu, cholesterol (cholesterin) and phytosterol (pliy tosterin).

Further, there is evidence to show that butter fat is not made up of the simple triglycerides, but that it contains mixed glycerides of butyrio, palmitic, and oleio acids. Such componnds are represented by the formula-

$$
\mathrm{C}_{3} \mathrm{H}_{5}\left(\mathrm{C}_{4} \mathrm{H}_{7} \mathrm{O}_{2}\right) \cdot\left(\mathrm{C}_{16} \mathrm{H}_{31} \mathrm{O}_{2}\right) \cdot\left(\mathrm{C}_{18} \mathrm{H}_{33} \mathrm{O}_{2}\right) \text {. }
$$

The evidence of the presence of these compounds is obtained in the following manner:

"If a mixtnre of tributyrin, tripalmitin, and triolein be prepared and treated with alcohol, it is possible to extract the tributyrin completely. With butter fat, on the other hand, such an experiment can not be made-a fact due, without doubt, to the butyric acid being combined with certain higher fat acils, and the same glycerol radicle."-(C. A. Browne's recent article.)

Beef fat and lard are composed of a mixture of the triglycerides of stearic, palnitic, and oleic acids.

Cotton seed oil differs from the two last-named by containing a large percentage of the linnitl glycerides, olein, and linolein. According to Hazura the ratio of oleic to inoleic acils in cotton-seed oil is $3: 4.5$.

Several investigators have found cotton-seed oil to contain from $1 \frac{1}{2}$ to 2 per cent of unsaponifiable matter. Blyth states that this unsaponifiable matter is phytos. terol (photosterin), which has the formula $\mathrm{C}_{26} \mathrm{H}_{44} \mathrm{O}$ ancl resembles in many ways a similar product found in animal fats and known as cholesterol (cliolesterin).

Representative WADsworTH. What is palnitin?

Dr. WrLEY. It is a componnd of palmitic acid with glycerin. These acids, althongh they have differcut names, are very closely relaterl. This is simply a series of what is known as the fatty acids, of which vinegar is the beginning. The substance we know as vinegar is the lowest of this series: and these fatty acids are formed by additions to that substance. These are the fatty acids:

[At this point Dr. Wiley exhibiter two tables, of which the following are copies:]

Acetic acid serics:

Fatty acids.

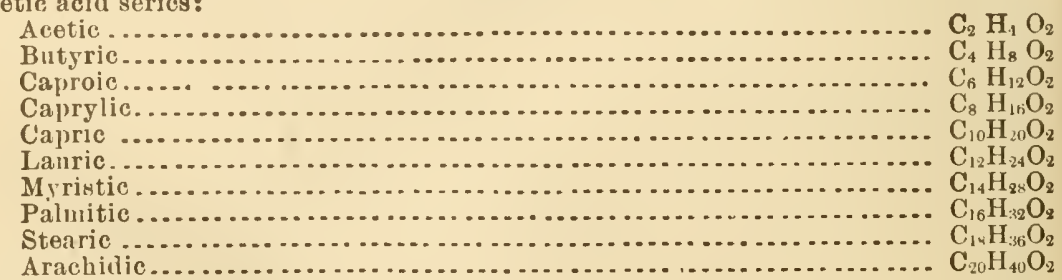

Oleic acid series:

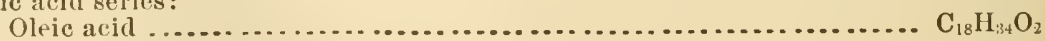

Linoleic acid series:

Linoleie acid ........................................... $\mathrm{C}_{18} \mathrm{H}_{22} \mathrm{O}_{3}$

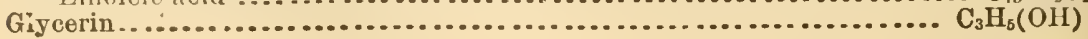


Glycerides :

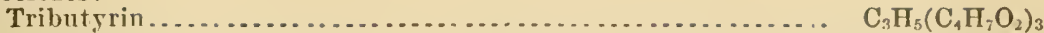

Tripaluitin . . . . . . . . . . . . . . . . . . . . . . . . . $\mathrm{C}_{3} \mathrm{H}_{6}\left(\mathrm{C}_{16} \mathrm{H}_{1} \mathrm{O}_{2}\right)_{3}$

Tristentin . . . . . . . . . . . . . . . . . . . . . . . . . . . . $\mathrm{C}_{3} \mathrm{H}_{5}\left(\mathrm{C}_{18} \mathrm{H}_{35} \mathrm{O}_{2}\right)_{3}$

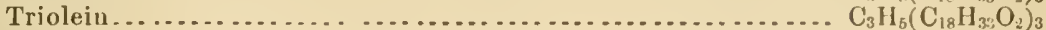

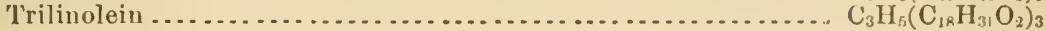

Mixed glyceride of butyric, palmitic, and oleic acids............. $\mathrm{C}_{3} \mathrm{H}_{5}\left\{\begin{array}{l}\mathrm{C}_{4} \mathrm{C}_{4} \mathrm{H}_{7} \mathrm{O}_{2} \\ \mathrm{C}_{16} \mathrm{H}_{31} \mathrm{O}_{2} \\ \mathrm{C}_{18} \mathrm{H}_{33} \mathrm{O}_{2}\end{array}\right.$

Dr. WrLer. The acid in vinegar is acetic acid, which is the first of these fatty acids, aud the others which you see there, of which acetic acin is the tyle, form the lowest members of this series. Then comes, after acetic acid, butyric acid, which is the chief volatile acid of butter, and gives it its peculiar flavor; while in goat milk the percentages of caproic, caprylic, and capric acids are qnite large, and give it that strong, goaty flavor which it lias. They are also present in butter, but in lesser quantities. Now, these are the other fatty acids: Lamric, myristic, palmitic, stearic, and arachidic (which is found in peanuts); while the oleic acid series (which is nearly related to them) and linoleic acid (which exists in flaxseed oil) form members of a separate series of acids.

Before leaving this table, I want to call your attention to the remarkable resemblance botween these acicls, simply increasing, as they do, in regular order by the ardition of a molecule composed of hydrogen and carbon to each one. In the table, "C" means carbon, "H" means hydrogen, and "O" means oxygen.

Look at acetic acid, which is the acid in vinegar. That los two atoms of carbon, four of hydrogeu, and two of oxygen in its molecule. Now, you see, all the acids of that series have absolutely the same amonnt of oxygen. They all liave two atoms of oxygen; but the increase in each case is made by adding two atoms of carbon and four atoms of hydrogen. In other words, if you add $\mathrm{C}_{2}$ and $\mathrm{H}_{4}$ to one acid, you get the rext. You will see that in every case it is a regular increase from the beginning to the end of the series. If you add $\mathrm{C}_{2} \mathrm{H}_{4}$ to acetic acid, for instance, you get butyric acid. Add $\mathrm{C}_{2} \mathrm{H}_{4}$ to butyric acisl and you get caproic acid, and so on down through the series. They are all related in that step-ladder way, one with another.

Representative BAILky. In regular numerical progression?

Dr. WILEY. In numerical progression. Now, there is no acetic acid in butter; but the next one to acetic acid (the vinegar arid) is butyric acid, which is the chief one of these volatile acisls in buttrer. You see, there is 6.23 per cent of butyric acicl in butter. Now, the goaty acirls, which are named from the Latin name for "goat," beranse they exist largely in goat fat, are the caproic, caprylic, and capric acids, the caproic acid being the largest in amount, and the others being present in small quantities. Next comes lauric acid and myristic acid in considerible percentage; but the most abundant of them are the oleic, stearic, and palmitic acids belonging to the mpper series. The rearic acid of the upper series is the smallest in qnantity and the palmitic acil the largest in quantity in butter fat.

Rejuresentative WILLIAis. Is palmitic acid named from palm oil?

Dr. Wrley. Yes; palmitic acid exists largely in palm oil; hence the name. Now, so far as wholesomeness is concernerl, these borlies bear practically the same relation to the digestive organism, with this exception. that the lower acids are more easily decomposed, and hence, under the intluence of the ferments which prouluce digestion the presumption is that they digest more rapidly. This is exactly what I said in my 
testimony before the Senate committee. They asked me if I thought oleomargarine was as digestible as butter. I do not think it is. I do not think it digests so well as butter, because it contains more of the higher series of acids, and practically none of the lower series, which are more easily decomposed under the influence of ferments. All cligestion is fermentation.

Some one has spoken about the bacteria. We have, unfortunately, a prejulice against bacteria in this country. As a matter of fact if it were not for bacteria we would all speedily die; we would have no agrienlture, no manufactures, and no human beings. The bacteria are essential to all kinds of life, and hence the fact that a food contains or does nut contain bacteria is not a measure of its wholesomeness. The most wholesome foods, such as milk and butter, often contain the largest number of bacteria.

Now, butter is perfectly full of bacteria, teeming with bacteria, while oleomargarine, properly magle, has practically only the bacteria which come from the milk or eream used in its mannfacture. It is, therefore, a substance which naturally keeps mnch longer than butter, because of the alsence of the ferments which decompose the latter, so that is rather against its digestibility, becanse the ferments are essential to all digestion.

Now, in oleomargarine you have practically tristearin, triolein, and tripalmitin. 'Those are the three chief' eonstituents of oleomargarine, because all the elements which enter into the composition of oleomargarine are rich in those three bodies. The oleo oil, the neutral lard, and the cotton seed oil all contain almost exclusively these high glyecrides, ancl very little, a mere trace, of the lower glycerides. I have never condneted any digestion experiments-I have digested oleomargarine myself oftell, $\dot{I}$ am sure, in the ordinary way, but without giving it any scientifie control-

liepresentative ALLEN. What is the result of your experiments as to digestion?

I)r. WILEY. Mly impression in regard to the digestibility of butter as compared to oleomargarine is formed from a purely theoretical standpoint, without having tried experiments on human beings and noted the time of digestion, becanse I do not know that that has been accomplished, and more than that the actual time of digestion is a matter of very little consequence, provided the food is digested. In fict it is a very good thing that we do not digest all our food instantaneously, because otherwise we would be hungry after one meal before we would get the next. The fact that a food is slow of digestion, like fruit, for instanee, is no reason that it is unwholesume. No one would say that meat is necessarily more wholesome than fruit because it is more easily digested. Fon can digest meat in much less time than you can digest frnit, and yet nobody elaims that fruits are unwholesome.

The AC'ing Chairman. You would say, then, that butter is more quickly digested than oleomargarine?

Dr. WILEY. I believe it is more easily digested; that it requires less effort.

The Chatrman. You think that is the reasonable inference?

Dr. WILEY. From a chemical study of the composition of butter, it is reasonable to infer that it requires less efiort on the part of the vital organs to ferment the butter, and that is the reason why I say that I believe butter is a more digestible substance, more easily digested, more quickly digested than oleomargarine.

Now, the value of a food is measured solely by two staudards. First, 
its palatability, and, second, its nutritive properties. You need not try to convince human beings that palatability is not an element in nutrition, because it is, and yet you get a great deal more out of a food if it is palatable in its taste and attractive in its appearance, because the attitude of the digestive organs changes absolutely with the appearance of the food. If you were to put butter up in the form of ink it might be just as digestible, and all that, and yet it would not be so useful as a food. The appearance of a food has a great deal to do with the attitude of the digestive organs towarl it.

A MEMBER. It is simply a reflex action from it?

Dr. WILEY (continning). Yes; because the mind, the mental attitude, influences the secretion of the ferments which produce the digestion, and hence we must have some regard to that appearance.

Representative Willians. That is so true, Professor, is it not, that sometimes when a person takes a prejudice against a particular artiele of food it will make him vomit if he attempts to eat it?

Dr. WILEY. That is very often the ease. That is due to his mental attitude. We all have our idiosyncrasie's.

I would like to say that we have studied in the Department of Agriculture for seventeen years, since I have been the chief chemist of that Department, the subject of food adulteration; and, among others, this substitution of oleomargarine for butter is one of the chief items of study which we have undertaken. My own personal attitude is perfectly well-known. I think that anyone who sells an article for what it is not is obtaining money under false pretenses. I believe it is a crime, a criminal offense; and I believe that the sale of oleomargarine as butter is a criminal offense, and should be prosecuted as such. 'The Commissioner of Internal Revenue says he gets the money out of it. That is very well from his point of view; he said he did not execute the latw from the pure-food point of view. But what we want is a law which will be executerl from the pure-food point of view, so that the man who offends not only has to pay the tax, but has to pay the penalty for offendling against the criminal cole.

Representative Williaurs. Have you read this Grout bill?

Dr. Wilex. Yes, sir.

Representative WILLIAMS. Is there anything in the Gront bill which executes the law, from the pure-food standpoint, auy better than any existing legislation?

Dr. Wiley. Of course, I am not lawyer enough to give an opinion in respect to that; but wliat $I$ want to call to your attention on this point is this matter of color.

Now, I am not a prohibitionist in regard to color. I think if people want to color their food with harmless materials it is perfectly proper that they shonld do so, provided the purchaser understands in buying a food that he is buying an artificially colored one, and let him be the judge. If he wants the artificially colorel article, all right.

I sent out just a fow weeks ago in to the markets of this town to buy some oleomargarine and butter. I also got a piece of white silk. I took the samples of oleomargarine and butter which I got, took about the amonnt which one would use in an ordinary meal, and I dyed this silk with the coloring matter which these samples contained. I could not find on the markets of this town a sample of uncolored butter, nor of uncolored olcomargarine; but I did find this-that instead of securing uniformity by coloring butter we get the greatest disparity in appearance.

One argument which has been advanced in support of coloring butter 
is that it is made uniform. But the point is not a good one, because the people who color butter do not color it uniformly. We find the most remarkable variations in color. Some of it is almost red and, ou the other hand, there [exhibiting a piece of silk] is a pale yellow, closely resembling the natural tint of butter.

Now, these colors are all coal-tar dyes, everyone of them. The vegetable dyes, like annotto, liave almost ceased to be used iu coloring butter. Youmay find them in some loealities. Some States require that butter be colored with annotto and not with coal tar dyes, but everyone of these is a coal tar dye, and yon will see by the variations in tint (they lo not show very well in artificial light) that the amount of color in the samples was very clifterent. The same amount of material was used in each case. Now, compare these two [exhibiting samples]. That [indicating] was a very light-colored sample; this [indicating] was a very heavily colored sample.

Dr. Wiley at this point submitted the following statement:

\section{COLORING MATTERS USED FOR COLORING BUTTER AND ITS IMITATIONS.}

Annotto, the principal vegetable dye used, is mainly composed of the pulp surromding the fruit Bixa orellaua growing in the East and West Indies and Sonth America. Allen states that two different kinds reach England, namely, the Spanish annotto, imported from Brazil, and the flag or French annotto, which comes from Cayenue.

Annotto contains two yellow coloring matters which have been given names derivel from the botanical wames of the plants.

Bixin, $\mathrm{C}_{28} \mathrm{H}_{34} \mathrm{O}_{5}$, is one of these, but its properties and chemical relationships have been imperfectly studied. When separated in the form of its soda salt it has a reddishe color.

Clellin is described as yellow and solnble in water and alcohol. These two coloring matter's combined, in annotto, give the sulsstance its characteristic orange-yellow color.

Coal-tar dyes. - When diazobenzene-sulphonic acid acts on amids, with an alkaline solutiou of phenols, a series of coloring matters is obtained ranging from sellow to deep orange or red. These dyes are cilled tropeolins, because the sharles of color they prodnce resemble those of the nasturtinm flower (Troperolum maguns). They nsually occur in commerce as soda salts and are distingnished according to their shades, tropeolin $Y$, being the most jellow, and the tropeolin 0,00 , and so on, as the shades become redder. The shade of the color becomes redder by the substitution of tolnene, xylene, or cumene for benzene.

Two of these dyes which have been used for coloring foods are the acid or fast yellow and the orange yellow or orange G.

The acid yellow, or the fast yellow, is the soda salt of amido-azobenzene sulphonic acid, represented by the formula:

$$
\mathrm{C}_{6} \mathrm{H}_{4}\left(\mathrm{SO}_{3} \mathrm{Na}\right) . \mathrm{N}: \mathrm{N} . \mathrm{C}_{6} \mathrm{H}_{4} \cdot \mathrm{NH}_{2} \text {. }
$$

Orange $G$ is sodium salt of benzene-azobetanaphtol-disulphonic acid, having the formula:

$$
\mathrm{C}_{6} \mathrm{H}_{5} \mathrm{~N}: \mathrm{N} . \mathrm{C}_{10} \mathrm{H}_{4}\left\{\begin{array}{l}
\left(\mathrm{SO}_{8} \mathrm{Na}\right)_{2} \\
\mathrm{OH}_{3}
\end{array}\right.
$$

This elass of dyes is also known as sulphonated-azo dyes.

Victoria yellow has also been reported as a coloring material for butter. This substance is a mixture of the sodium salts of the dinitro-ortho and dinitro-paracresol $\mathrm{C}_{6} \mathrm{H}_{2}\left(\mathrm{CH}_{3}\right) \cdot\left(\mathrm{NO}_{2}\right)_{2}$. ONa.

Representative Williams. Do you get the colors in these samples from butter?

Dr. WILEY. From butter and oleomargarine, indiseriminately.

Representative Henry. Are we to understand that aniline dyes are used in coloring oleomargarine and butter?

Dr. Wiley. Yes, sir; almost exclusively.

Representative HENRY. I supposed that annotto was the coloring matter used. 
Dr. Wiley. I doubt if you can find a sample of butter in this town colored with annotto.

Representative Henry. Annotto is used all through the creameries of the Nortl, so far as I know.

Representative WiLlianis. Perhaps the law in Connecticnt requires butter to be colored with amiotto.

Dr. Wiley. They use coal-tar dyes in the prolluct sold here.

Representative WiLlians. Do you regard the aniline dyes as equally wholesome?

Dr. WILEY. I do not say that coloring your intestines saffron injures your health. The amount of color used in these substances, however, is very small. I do not, myself, fancy eating artificial colors. I would rather have the good, old-fashioned butter, with its natural colır, whether deep or light; and I believe that we ought to educate the taste of our people in that way. I believe we are ruining the taste of our people by coloring our butter; and the farther South you go the rleeper the color gets.

lepresentative Hexry. Pardon me again-do you think these aniliue dyes affect the flavor of butter?

Dr. Wiley. No, sir; oh, no. These dyes are absolutely without flavor.

Representative HeNRY. Wherein are they unwholesome?

Dr. W'ILEY. I dill not say they were. I said I did not, myself, fancy eating them.

Representative Neville. Do you think the fact that people color butter is any excuse for people being permitted to color oleomargarine, if, as a matter of fact, it results in putting butter aud oleomargarine onto people who do not want to eat it in that shape?

Representative BAILEY. Then reverse the question.

Representative Neville. Yes, sir; answer it, and then reverse it?

Dr. WiLEY. I believe that every food product should have the same right before the law. I do not see why there should be a distinction.

lepresentative BAKER. You stated a minnte ago that the manuficturer of every food product lias the right to make it palatable to the cousumer.

Dr. Wiley. And to make it attractive in its taste, provicled he tells what is in it-provided he does not injure the health of the consumer.

Representative Neville. You just stated that you would prefer to have butter without coloring?

Dr. WiLEY. Yes, sir; I prefer it so, very much, for myself.

Representative Neville. So do I, and 1 apprehend there are a great many people in the same position.

Dr. WILEY. I prefer it very much; and having beeu bronglit np in the dairy industry, and being interested in the subject, I believe we are injuring our dairy industries by pernitting the coloring of butter.

Representative HeNR $Y$. That has been for years my coutention with butter makers-that the dairy interests were injuring their own products by artificial coloring.

Dr. Wrley. Yes; that is my idea, my conviction. Yon can get uncolored butter in New York; you can go and get it at Delmonico's, and some other high-priced restaurants; and the finct that the uncolored butter brings the highest price in the market ought to be an object lesson to our dairymen that they are standing in their own light when they color their butter. Now, if they would let the manufacturers color olcomargarine, and would keep butter at its natural color, there would be no difficulty in discriminating between the two. 
Representative NeviLle. Another question, Professor: Were any of these tests that you have deseribed made on butter furnislied by farmers from the country?

Dr. WILEY. Oh, I do not know. I simply bought my butter and oleonargarine in the open market. The samples which I bought are all here; but I do not know who made them.

Representative ALLEN. Professor, with regard to the he:Ithfulness of oleomargarine, have you found in it anything deleterious to the human system as a food product?

Dr. WILEY. I never have in the analysis of oleomargarine.

Representative ALLEN. You bave examiued it with that view and purpose, have you?

IOr. WILFY. Not especially with a view to finding deleterious substances; no, sir; but with simply a view to determining its composition. But I never have detected in tresh samples of oleomargarine any bad odor or bad taste, nor have I noticed in the analysis the presence of bodies foreign to those which I lave just mentioned, except that there are portions of butter in oleomargarine, if chmrned with cream or milk; and I believe that for many markets at the present time glueose is used in small quantities in oleomargarine as a preserving agent. It is demanderl by the markets of some portions of this country or of foreign comntries.

Representative ALLEN. What is the relative amount of stearin in butter and oleomargarine?

I)r. WILEY. There is very much more in oleomargarine.

Rejuresentative ALLEN. To what extent?

Dr. WILEY. I could not now state the exact quantity of stearin in olemarganine, but it must be 20 or 25 per cent, perliaps, while in butter it is only abont 4 per ceut.

lieprosentative BAkER. Twenty-five per cent of stearin, you say?

Dr. WILEY. I do not remember the exact fignres, but I know there is very much more in oleomargarine than in butter.

Representative BAKER. Let me call your attention to the fact that the report of the Treasury Department does not show any-

Dr. WiLEY. I have not looked into the question for years.

Representative WILLians. The report of the Secretary of the Treasury, Dr. Wiley, shows the amount of stearin in oleumargarine as 0.007 . That is almost inappreciable?

Dr. WILEY. Yes.

Representative Wrumrams. Now, then, I notice that, according to your statement, the amount of stearic acid, or whatever it is -

Dr. WILEY. Dioxystearin and stearin.

Representative WiLLIAMs. Yes; the amount of dioxystearin in but ter was 1.04 per cent, was it not, or just 1 per cent?

Dr. WileY. One per cent in round numbers.

Representative WILLIAMIS. Exactly 1 per cent.

Dr. WILEY. And of stearin about'2 per cent.

Representative WiLLIA IIS. So, according to that, if these two reports are correct, there is more stearin in butter than in oleomargarine?

Dr. WILEY. Now, I wish to state to the committee that I liave not looked at this point, in regard to the amount of stearin in oleomargarine, for many years; and 1 may be mistaken in my statement. If so, I wish to reserve the right to correct it after looking the matter up.

Representative WiLliams. I simply took the amount of stearin in butter from your statement.

Dr. WILEY. Yes; that is all right. 
Representative WiLliams. And the amount of stearin in oleomargarine, 0.007 , from the statement of the Secretary of the 'Treasury.

Dr. WILEY. I know about the amount in butter, because it is only lately that I have male up this table, and looked the matter up afresh. But in regard to the amount in olenmargarine I have not looked at it for many years. I wish to reserve the right to correct my statement in that respect after further investigation.

(A copy of the report of the Secretary of the Treasury was handed to Dr. Wiley.)

Dr. WILEY. He does not give the anount of stearin in the neutral lard and the oleo oil and cotton-seed oil. He does not give that at all. He only gives some that is used specially; but stearin is found in those other ingredients, which he does not mention there at all. I will give the committee the exact figures on that point. [Dr. W
letter:]

United States Departuent of Agriculture, DIVISION OF CIIEMISTRY, Washington, D. C., May 16, 1900.

Hon. Jas. W. WADSWORTH,

Chairman of Committee on Agriculture, House of Representatives.

Dear: SrR: I desire to submit the following additional statement in regard to the percentage of stearin in oleomalg.urine:

In the statement furnished by the Commissioner of Internal Revenue it is said that ouly 0.007 per cent of stearin are found in oleomargarine. On examining carefully these data I find that they refer to the amonnt of stearin which is added in the process of manufacture, but this statement does not refer to the stearin which is wormally found in the natural constituents used in the manufacture of oleomargarine.

Stearin is a natural glyceride found in the fats of all animals and in the oils of all vegetables. It has the highest melting point of any of the ordinary natural fats, and those bodies which contain the largest percentage of it have the li ghest melting point, such as tallow, while those bodies which have smaller quantities of stearin have low melting points, as, for instance, cotton-seed oil.

'The natural quantity of stearin found in lard, oleo oil, and cotton-seed oil varies largely with different samples. The average composition of nentral lard, from the data which $I$ am able to find on record, may be given as 62 parts of olein and 38 parts of stearin and palmitin combined, of which the greater amonnt is stearin. Tallow contains a very much larger proportion of stearin, but the oleo oil which is used in the maunfacture of oleomargarine has a large part of its stearin separited ly subjecting it to cold before it is used in the mannfacture. It is difficult, therefore, to state even approximately the quantity of stearin in oleo oil, but I should say that 20 per cent wonld be a very low estimate.

Cotton-seed oil has a still lower percentage of stearin, but I can not give definitely the quantity which the arerage oil employed would represent.

From the above it is seen that in ventral lard and oleo oil, which are the chief constituents of oleomargarine, there would be an average content of at least " 55 per cent of stearin. These two fats constitute about 60 jer cent of oleomargarine; bence the total anount of stearin in olcomargarine is approximately 15 per cent. This, you will see, is exactly in accordance with my statement before the committee, where I said I thonght that oleomargarine would contain 20 per cent of stearin.

Yon will understand that the above is an approximate estimate, but it will be found on further investigation, I an sure, to be very close to the truth. Fon will notice from the testimony which I gave before the committee this morning thit butter fat contains abont 4 per cent of stearin in varions forms. Oleomargarine contains, say, at least 16 per cent. Thus the quantity of stearin in olcomargarine is approximately four times as great as in butter.

I trust the above, given in harmony with your request, will prove satisfactory. Respectfully,

\section{H. IV. WILEY, Chemist.}

Representative WiLliams. Do you not think it would be a step forward, which wonld be advisable, to prohibit impartiality, in connection with all food products, artificial coloring of oue product in the semblance of other products, or of other articles of the same product, or 
selling one product in the name of other products or of other articles of the same product?

Dr. WILEY. Well, I have just said that I was not a prohibitionist in regard to coloring foods. I would not say that colors shonld not be used in the manufacture of food. I would even be willing to admit the use of eoplyer in preserving the color of peas and beans, which look so attractive in their green color, and which, if not preserved in this way, soon become yellow on standing, and lose their attractive appearance. But $I$ have always insisted, in my public addresses and in my communications to Congress, before eommittees and otherwise, that no coloring matter should be employed unless the faet is plainly indicated upon the package, so that the purchaser may know exactly what it is. And that is the attitude that I hold toward pure-food legislation-that it should be general and not special in its character. I believe that the dairy interests would be far better protected nnder the Brosins bill, which is pending before Congress, than under a special bill, because all the interests would be placed on the same footing. The Brosins bill absolutely prohibits the sale of any product as an imitation or under the name of another, and provides penalties for that specific purpose; so that it would be absolntely impossible muder the law, if that bill were passed, to sell oleomargarine for butter anywhere in this conntry.

Representative WrLLrans. That is, in interstate commeree?

Dr. WileY. Yes; as fiur as Congress can provide, under interstate commerce, of course, for prohibiting the transportation of these articles. At the present time, with perhaps the exception of - - rell, I do not know that I will make any exeeption-I believe that the frand in selling oleomargariue for butter (althongh I do not know the statistics) is perlaps the most pronounced of any food frand in this country and is deserving of the most rigid punishment.

Representative WilLians. In that connection, will you tell us something abont the fiaud of "renovated butter," if you know abont it?

Dr. Wiley. Yes; I know a good deal about that, not from a manufacturing point of view, but the other.

Representative WiLlians. I wish you wonld tell the committee about it.

Dr. WILEY. Two years ago I was addressing farmers' institutes in sonthern Indiana. and I saw, loading on the cars at North Vernon, ear after car of barrels. I said to my firiend, who was the agent, "What have you got in all these barrels?" "Why," he said, "butter, which we have bought all over this comtry." I said: "Are you sending it to New York?" "No, sending it to Elgin." "What for?" "Why," he said, "they take it there, aud it is renovated and sold as Elgin creamery butter all over this country." And there was earload after carload of country butter (and some of you know what country butter is, indiscriminately) which was hardly fit to go on to the market, but which was being sent there for the purpose of having it reduced to uniform grade in a town famous for its butter, so that, being seut from that town, it conld get an additional price in the world's markets. And that is a very common practice where creameries rlo not exist; and they are not found all over this comntry. The old-fashioned way of makiıg butter in the farm-house still obtains in such places; and sometimes, as Mr. Wadsworth has said, the butter is made of cream which is not taken at the right moment, and which is not entirely palatable. Now, I do not know the exact process of renovation, althongh I know something about it. I know that the butter is melted; I know that the curd is removed, and it has been stated that the ran- 
cidity is eorrected by the adılition of an alkali, presumably bicarbonate of socla, or something of that kind, but of this I lave no personal knowlenge. Then the material is rechurued with fresh milk, resalted and molded, and makes a very presentable appearance in the market. That is what is known as renovated butter.

Representative WrLLIAns. Do you know anything about their collecting and buying rancid butter from the hotels aud restaurants, and renovating that?

Dr. WILEY. No; I only know what I have seen, as described to you. I do not know anything, personally, about the collection of such butter; but I imagine that economica] lotel keepers and restaurateurs do not throw away their left-over butter.

\section{STATEMENT OF W. E. MILLER, ESQ., REPRESENTING ARMOUR \& C0., KANSAS CITY, KAN.}

Representative BAILEy. I will say to the committee that Mr. Miller is the expert who has control of the butterine factory of Armour \& Co., at Kansas City.

Mr. Miller. Mr. Chairman and members of this committee, no manufactured article has been so grossly misrepresented and abused as the product known as "butterine" or "oleomargarine," and the first point we wish to make is that butterine is not an imitation.

Butterine possesses merit, and it is not necessary to imitate another article in order to sell it. This prodnct has a separate and distinct value commercially, and is not confused with butter in the mind of the housewife.

The first butterine manufactured was of very high color, while butter at that time was almost universally sold in its natural state. The dairymen were quick to see that the high color pleased the public, and they immerliately com menced to eolor their product also. We have taken the aggressive at all times. The progressive butterine manu1:1: turers conceived the illea of new slape rolls, brick, and prints, and also attractive packages, which apliealed to the eye of the bu yer $\mathrm{We}$ have had many prominent dairymen acknowlec'ge that the bntterine manufactures discount them when it comes to attractive appearance of their product in packages.

Butterine has a great deal of merit. People know what they are buying, and eall for it. On pages 7 and 9 of the report of the committee appointed by the Senate to investigate pure food, we real the following:

I will not read all that I intended to read, on account of the lateness of the hour. This is a summary of their report:

In regard to butterine or oleomargarine, it is not elaimed by any of the witnesses before your committee that it is in any way deleterions to public health. On the contrary, all expert evidenco upon the point strongle confirms the testimony of the manuficturers of this article to the effect that it is it healthful food product.

As regards the much disenssed question of color, I would say that we use exactly the same as that sold to a majority of all the creameries in the West, and in about the same proportion. In order to sell our product we must color it now the same as wo did when we commenced its manufacture. If we had started out using no coloring whatever we would doubtless have had as large a business established on uncolored to day as we have on colored butterine. However, as the trade have become accustomed to colored goods, we could not at this late hour get them accustomed to the uncolored product. In fact, we have 
attempted to sell uneolored butterine in a number of prohibitive States, but it has proved a rank failure.

I will say just here that in ease this Grout bill is passed it will kill the industry. The uncolored product will not sell. We have tried it in a number of prohibitive States, and, as I say, it has proved a failure in each instance.

Why should color be prohibited from butterine and not from butter? The same color is used in similar quantities in both articles. If it is undesirable in one, why is it not undesirable in the other?

Taxing butterine is discrimination in favor of butter. Why would it not be just as reasonable to place a ban on cable and electric cars, because they displace the horse; or to say that gas and electricity must be restricted, because they decrease the protits of the oil kings; or that "nearsilk" shonld be heavily taxed, becanse it is an imitation of the real article and answers the same purpose as silk? This is a progressive age. Something valuable is given to the public each year in the way of invention; and while it may interfere with the interests of a few, yet it benefits thonsands. Butterine is an up-to-date product, and possesses sufficient merit to sell suceessfully throughout the world for just what it is.

It has been represented to this committee that a large per eent of the butterine manufactured is sold for butter. This is a mistake and can not be proven by facts. Mnch publieity has been given to the sale of a few packages of butterine for butter, the wrappers of which were branded "oleomargarine," but this is not conclusive evidence that all dealers in the United States are practieing the same deception. We acknowledge that a small per cent of butterine is sold frandulently, but this is no reason why its sale should be prohibited altogether, simply becanse one unscrupulous clealer in a hundred may give it to a purchiser when he calls for butter. It shonid be noted that no purchaser has ever been heard to complain of being deceived and not getting goorl valne for his money. The eomplaint comes from the National Dairy Association, who are posing as philanthropists, and esponsing the eanse of these purchasers without even first getting their permission.

Much of the literature with which Congress has bern flooded emanated from one source. Postal cards and petitions were sent individnals throughont the United States, with the request that they sign and mail them to members of Congress. It is easy to get the assistance of the ignorant by telling them in a long editorial that butterine is unwholesome, etc., but when these same individuals come before intelligent men, such as we bave before us to-day, they dare not say one word on this point.

Right here I will prodnce a copy of the Chicago Dairy Produce, edited by Mr. Knight, in the back of which I notice eopies of blank applications which he has asked his reader's to send into members of Congress. I also understand that they have a printing establishment in Chicalgo where most of this literature is printed; and here is a card which was sent a certain party, dated Mareh 15, 1900 .

[At this point Mr. Miller exhibited a printed postal card, which was left with the committee.]

I also see that here is a piece of literature which has been mailed indiscriminately over the United states under the frank of Congressman Gront.

Representative BALLEY. What is that?

Mr. MnLLER. It is an al'ticle on butterino. 
Representative BAILEY. Did you get one of them ?

Mr. Milleter. It is in the interest of the Grout bill.

Representative ALLEN. Did you get one of them under a frank?

Mr. MILlER. No; but this came to a party in our employ.

Representative Allex. Who was he?

Mr. MILIER. The one in our employ, you mean?

Representative ALLEN. Who was that man?

Mr. MrLler. One of our employees.

Representative ALLEN. What is his name?

Mr. Miller. James Hobson. He is an assistant in the butterine department.

Representative Allen. He got that under the frank of Mr. Grout?

Mr. Miller. Yes, sir; here is the document, right here.

Representative AlLEN. Leave it with the committee.

Representative NEVILLE. I would like to ask if that is not a public document?

Mr. Mrller. Why, yes; it is published, but it is published by Congressman Grout.

Representative BAILEI. No; he asked if it was not a public document?

Mr. Mrller. No; it is a reprint.

Representative BAILEY. A reprint of what?

Mr. MILLER. It is the reprint of an article by some Ph. D. It says: Reprinted from the Year Book of the United States Department of Agriculture for 1895.

Now, gentlemen, dealers do not sell butterine promiscuonsly for butter, as is claimed; and if the promoters of this crusade had taken the time and trouble to investigate in the various markets, they would have found such was the case. We furnish all dealers selling our butterine with signs. They do not find it necessary to practice deception. Our butterine sells on its own merits.

Just here I think it apropos to inform this committee that the seeretary of the National Dairy Association made the statement to Charles A. Sterne, a broker of Chicago, at the close of the senatorial pure food investigation there, that he had never been inside of a butterine faetory. Yet this gentleman leads the fight against butterine, and writes long editorials on a product he has never even seen manufacturer.

The internal-revenue regulations are strict and effective, and if the National Dairy Association will commence the frauduleut sale of butterine they will very soon find ont that this department is not only alive and active, but tliat justice is dealt out very swiftly. We urge our trale to sell butterine for just what it is, and never encourage or countenanee violation. All original packiges are branded "oleomargarine," and all of our regular brands which are sold under wrapper's are also branded "oleomargarine." In addition to this, the retail dealer must brand the word "oleomargarine" on the outside of the wrapper.

Butterine is wholesome, nutritious, and palatuble. There is no secret whatever abont the process of manuficture. Our factory is open to the public at all times. This product is composed of the tollowing ingredients: Oleo oil (made from choice fats of the beef). nentral lard (or the leaf lard of the hog), refined cotton-seed oil, milk, cream, silt, and butter.

We have never had a pound of paraffin in our factory, and we do not desire stearin.

The proportions of butterine vary according to the grades desired. Cleauliness is enforced in our factory with the rigidity of the laws of 
Columbia, Mo., and he is also professor of agricultural chemistry and chemist to the experiment station.

Representative Cooney. Chemist?

Mr. Miller. Yes, sir. Now I will read the opinions of a number of other well-known chemists.

Prof. S. W. Johnson, director of the Connecticut A gricultural Experiment Station and professor of agricultural chemistry at Yale College, New Haven, says:

It is a prodnct that is entirely attractive and wholesome as food, and one that is for all orlinary and culinary priposes the full eqnivalent of good butter made from crean. I regarl the manufacture of oleomargarine as a legitimate and beneficent inclustry.

\section{Dr. A. G. Stockwell, who needs no introduction, says, in the Scientific American:}

In every-day life bntter is very essential. Its free nse by sufferers from wasting diseases is to be enconraged to the utnost. Consilering the foregoing, it seems strange that oleomargarine has not been thought of as a palatable and suitable article of diet for those suffering from wasting diseases.

It is free from all objections. As a matter of fact, it is a better and purer butter than nine-teutlss of the dairy product that is marketed, and one that is far more easily preserved. There are a lavge unnber who imagine oleomargarine is made from any old scraps of grease regardless of age or cleanliness. The reverse is the fact. Good oleo can only be had by employing the very best and freshest of fat. This artificial butter is as purely wholesome (and perhaps oven better as food) as the best dairy or creamery product.

Jollies and Winkler, the official chemists of the Australian Government, after thorough investigation of butterine, reported:

The only germs found in "oleo" are those common to air and water. Although carefully searched for, tubercular bacilli and other obnoxious bacilli were conspicuous by their absence.

\section{Prof. G. C. Caldiell, of Cornell University, says:}

The process for making butterine, when properly coudncted, is cleanly throughont, free from animal tissue or other impuritios, and consists of pure fat, made up of the fats commonly known as alaine and margarine. It possesses no qualities whatever that can make it in the least degree nuwholesome.

Prof. W. O. Atwater, director of the United States Government Agricultural Experiment Station, Washington, D. C., says:

Butterine is perfectly wholesome and healthy, and has a higli and nutritions raluo. The same entirely favorable opinion I find expressed by the wost prominent Enropean anthorities-English, Irevel, and German.

It contains essentially the same ingredients as natmal hutter from cow's milk. It is perfectly wholesome aud healthy, and has a high untritive value.

Prof. Panl Sch weitzer, Ph. D., LL. D., professor of chemistry, Missouri State University, says:

As a result of my examination, made both with the microscope and the delicate chemical tests applicalıle to such cases, I promounce lutterine to be wholly and unequivocally free from any feleterions or in the least objectionable substances. Carefulls marle physiological experinents reveal no ditierence whatevor in the palatability and digestibility between butterine and butter.

Dr. Adolph Jolles, of Vienna, from address before scction 7 of the International Hygienic Congress at Budapest, said:

As regarls nutritire value, pure butterine or oleomargarine is as digestible and nutritive as pure buttel.

Prof. George F. Barker, of the University of Pennsylvania:

Butterine is, in my opinion, quite as valuable as a untritive agent as butter itself. It is perfectly wholesome, and is flesirable as an article of fook. I can see no reason why butterine should not be an entirely satisfactory eqnivalent for ordinary lutter, whether considered from the physiological or commercial standpoint. 
Gentlemen, the passage of a law such as the Grout bill would destroy an industry in which there are $\$ 15,000,000$ invested and 25,000 men employed. Butteriue in its natural state is unsalable, because it is not pleising to the sight. We conld not sell butterine with an additional tax of 3 cents per pound; therefore, should this bill become a law, a legitimate industry, which it has taken years to build up, would be wiped out of existence. The effects of such legislation are manifold. The butterine mannfacturers, wholesale and retail dealers, and consumers, are not the ouly injured parties. It would deprive the Government of over $\$ 2,000,000$ revenue annually, and practically destroy the cotton-seed oil industry of the South, in which there are millions of dollars invested and many thousand men employed. The injury to the cattle and hog industry is almost beyond estimate, although it has been conservatively stated that the depreciation would be $\$ 6 \%, 000,000$ anmually."

The present tax and regulations are sufficient to control the sale of this product, and the intent of the proposed legislation is not to further regulate but to destroy the inciustry altogether. This would establish a dangerous precedent of destroying one industry to the advantage of another, which is directly against our Constitution.

While butterine is consumed in large quantities by the better class of people, yet it is sold principally to a class of buyers who can not afford high priced butter. Kill the butterine industry and millions of poor laborers will be compelled to do without a palatable artich for their bread. Twenty cents per pound was the very lowest price at which the chèapest grade of butter could be purchased during the winter months in Kansas City, and the quality of the article was not even up to the cheapest grade of butterine. A good, sweet, and palatable grarle of butterine retailed during this time at 15 cents for a single pound, or 2 pounds for 25 cents. The laboring man has some rights, as well as the creamery man, and his rights shonld be taken into consideration by all legislative bodies.

It has been represented to this committee that the butterine industry was killing the butter busiuess-that, to use the language of the opposition-

National legislation such as is embraced in the Gront bill is absolutely essential to prevent the almost absolute destruction of an industry bringing to the agriculturists of this country fully $\$ 500,000,000$ per year.

We would call attention to the fact that figures do not show thint the butter business is going backwarl, but, on the contrary, actual figures show that it is stendily growing. From 1870 to 1890 the output of butter in the United states increased 134 per ('ent. From 1890 to 1900, the production of butterine in the United States increased 172 per cent. The total sales of butterine the last revenue year are only 21 per cent of the total inake of butter. In 1890 the total butterine sales were 2.6 per cent of the total amount of butter produced, or a decrease of oneteuth of one per cent in ten years. Yet without these figures you would be led to believe that butterine was an octopus, the arms of which were stubbornly fastened into the very vitals of the dairy industry, crushing out its life and energy. The average prices of butter for the year ending Jannary 1, 1900, was the highest since 1894. Does this look as if the industry needs protection to prevent its almost alsolute destruction? This crusade is purely a matter of sentiment rather than justice.

Now, it may be asked where I got my figures for the last year. I will say that I got them from Mr. Wilson, who is editor of the Elgin Dairy 
Report, and is supposed to be one of the leading men in the dairy interest; so 1 would judge that what he gave us was about correct.

Before closing, I would like to quote here from the New York Produce Review and American Creamery, but I will simply give you the snbstance of their artiele. In speaking of the output of butter for the last year and the prospect for the coming year, they say that the inerease would be from 10 to 20 per eent, and that the industry is flourishing and prosperous. Yet they come before Congress and would make you believe that the industry needs protection.

Representative Allew. Give that quotation to the reporter, in connection with your remarks.

Mr. MilLER. Very well; I will do so. I thank you, gentlemen.

Representative BAKER. How large a percentage of your produetion of oleomargarine or butterine is uncolored?

Mr. Miller. Uncolored? We make practieally no uneolored butterine at all. There is no demand for it.

Representative BAKER. It is sold to some extent?

Mr. Miller. Very little. I do not suppose we make 2,000 pounds of uncolored butterine a week. When the prohibitive laws went in to effect in Missouri and Iowa and a number of other States we tried to do some uncolored butterine business, but we could not sell the product at all.

Representative BAKER. I hold in my hand several bills-not from your firm, but from a Chicago firm-for uncolored butterine sold to the retailers.

Mr. Mrller. Weare doing practieally nothing in uncolored butterine.

Representative BAKER. Another question, if you please. You speak of cotton-seed oil as being how large a percentage of butterine? How much do you use in your establishment?

IIr. Miller. It varies at different seasons of the year. In the winter time we use a larger per cent than we do in the summer time.

Representative BAKER. I suppose so; but can you not tell us, roughly?

Mr. Miller. It will range, I suppose, from 18 to 25 per cent.

Representative BAKER. Oh, that is not in accord with the information we have.

Mr. MILLER. I am only speaking about our own faetory. I know nothing about what the others do. I know what we use.

Representative BAKER. How large an amount of milk and eream do you use?

Mr. MLller. That will vary. The volume of milk, eream, and salt will be somewhere about 20 per cent.

Representative BAKER. The reports made from the Internal-Revenue Bureau the other day established the fact that the percentage of milk and cream as reported, not from your establishment, but altogether, was very much larger than of cotton-seed oil. In fact, if I am not mistaken, the cotton-seed oil was only about 5 per cent, and the milk and cream some 16 or 17 of the entire composition.

Representative WiLlians. No; you made a mistake there. You were misled by the form of the report, to some extent. I understand that what they call butter oil

Representative BAKER. That makes about 10 or 11 per eent.

Representative WILLIAMIS. That inakes about 8 per cent and a fraetion-42 of cotton-seed oil, and 4 of what they eall butter oil.

Representative BAKER. In other words, it makes about one-half of the amount of milk and cream used-that is to say, it is a very small percentage of the aggregate.

Representative WILLIAMs. I was astonished, like you, to notice that S. Rep. $2043-50$ 
the proportion of cotton-seed oil was less than I had been told, and that the per cent of milk and butiter was greater than I had been told.

Representative BAKER. Yes; I was, too.

Representative Neville. Will you permit me, Mr. Miller? You stated a moment ago that you could not sell butterine in its uncolored state, did you not?

Mr. Milleir. Yes, sir.

Represeutative NevilLE. That you had tried it, and that it was a failure?

Mr. Miller. Yes, sir.

Representative NeviLLE. But that you did sell it in its colored state without any frandulent sales of it-that as a matter of fact, it was sold (you mean by that that it was sold by you as a wholesaler, or as a manufacturer) as butterine?

Mr. Miller. As butterine.

Representative NEVILLE. Not as butter?

Mr. Miller. No, sir.

Representative NEville. And that the dealers to whom you sold it, also sold it upon its merits? Is that what you mean to say?

Mr. MILJER. Yes, sir.

Representative Neville. Now, you sell it in Nebraska, do you not? Mr. Miller. Yes, sir; we sell some there.

Representative Neville. Do you not send a good deal of it from Kansas City into Nebraska?

Mr. Miller. Well, it could not be called a great deal, because it is not a very large market. We sell considerable; yes.

Representative Neville. Now, is it not true that every pound of colored oleomargarine that is sold in Nebraska is sold in violation of law?

Mr. Milleir. Well, that may be; yes.

Representative NEVILLE. Then, as a matter of fact, that which is sold in Nebraska is sold in violation of law?

Mr. Miller. Not necessarily. The law was tested in Omaha, and the lower courts declared the Nebraska law unconstitutional. The dealers feel that they are handling the goods on a strictly legitimate basis now.

Representative WiLLIAMs. It is sold in violation of the statute, then, but of a statute which has been declared unconstitutional?

Mr. Millere. Declared unconstitutional.

Representative HAUGEN. You stated a minute ago that this 10 per cent tax would destroy the cotton industry of the South. You meant the cotton seed industry, did you not?

Mr. Miller. Yes, sir.

Representative HAUGEN. What is the number of pounds or gallons of cotton-seed oil nsed in the oleomargarine ontput?

Mr. Mrller. How much do we use, do you mean?

Representative HAUGEN. What is the amount used in the aggregate, by all the factories?

Mr. MiLler. I think it is in the neighborhood of 10,000,000 pounds.

Representative HAUGen. Per annum?

Mr. Miller. Yes, sir.

Representative HAUGEN. What is the amount used each month?

Mr. Miller. Of butterine?

Representative HAUGEN. Of cottonseed oil?

Mr. MILLER. I could not give you those figures. 
Representative HAUGEN. You had some estimate in your mind when you made that assertion, did you not? You certainly would not make a statement of that kind unless you had.

Mr. MILLER. You mean the amount of cotton seed oil manufactured? Representative HaUGEN. Yes.

Mr. MILLER. I am not prepared to give you that statement, because I am not in that business.

Representative HAUGEN. On what ground do you base your statement that the passage of the Grout bill would destroy the cotton-sred industry in the South, unless you know something as to the proportion used in your industry?

Mr. Miller. For the reason that if they could not use these $10,000,000$ gallons of the refined oil in the manufacture of butterine, they would have to sell it in its crude state; and it would place a ban upon what little export business they had, and kill that. Therefore, it would practically ruin the industry.

Representative HAUGEN. It would be necessary to know what per. centage the $10,000,000$ gallons is of the whole production, would it not?

Mr. MILLER. I make the statement that it would destroy the industry for the cotton-seed oil people.

Representative HAUGEN. It would cut off the sale of the $10,000,000$ pounds anmually, would it not?

Mr. MiLler. Well, it would cut off the sale of more than that, because they export considerable. If the sale of the product was killed in this country, the exporters would not buy it.

Representative $H \Delta$ UGEN. The 10 per cent tax would not affect the expor't of cotton oil?

Mr. MILLER. It would kill the butterine industry. They would not liave any use for the butter oil here; and if they went to export it, the people on the other side would say, "That product is under a ban in the United States; why should we buy it?"

Representative HAUGEN. You state, then, that you have no knowledge of the number of gallons or the number of pounds of cotton-seed oil produced in this country?

Mir. Miller. No, sir.

Representative HAUGEN. And yet you make the statement that this bill would destroy the cotton-seed industry of the sonth?

Mr. MILlER. I make the statement as I get it from the cotton-seed oil people.

Representative NEviLLE. I wanted to ask one further question when I was interrupted a while ago. You state that you are now selling butterine in Nebraska because the lower courts have held that the law was uncoustitutional?

Mr. Milluer. Yes, sir.

Representative NuviLle. You know that that matter has been carried to the Supreme Court, do you not?

Mr. Miller. No, sir.

Representative Neville. And you also know that the case was only decirled a few months ago, do you not?

Mr. Miller. No, sir.

Representative NevilLe. When was it decided?

Mr. MILLER. The cases that were decided in the lower courts were only decided a few months ago, and have never been carried up. If they have, they have been carried up without ny knowledge; and they were our cases, and we handled them. 
Representative NEviLLE. I understand that they have been carried up, notwithstanding you have no knowledge of it, but that the deeision was only rendered a few months ago.

Mr. Miller. Yes, sir.

Representative Nevilite. Now, then, is it not true that you sold butter all last year and the year before in violation of the law?

Mr. Miller. No, sir; we did not. We sell our goods in Kansas. There is no law in Kansas.

Representative NEVILLE. But at the same time, you sell in Nebraska also, do you not?

Mr. Miller. We sell in Kansas. Our goods are sold in Kausas City, and uot in Nebraska.

Representative Neville. But you sold them to your Nebraska customers?

Mr. Miller. Yes, sir; we did.

Representative NEVILLE. And you knew that if they sold your produet there, culored, they either had to sell it as butter or colored oleomargarine, in violation of law, did you not?

Mir. MILLER. As soon as the law went into eflect the cases were bronght up to see whether the law was unconstitntional or not; and in the meantime the retailers went ahead and sold.

Representative Wilcians. Being advised by their counsel that the law was unconstitutional?

Mr. Miller. Yes, sir.

Representative WinTE. Has the law been finally adjudicated in the last court of the State of Nebraska?

Mr. Miller. No, sir; not in the last court.

Representative STOKES. Do we understand you to say that the passage of this law wonld destroy the cotton industry of the South?

Mr. Miller. Ies, sir; the cotton-seed oil industry.

Representative STokEs. That is the point I wanted to bring out.

Mr. Miller. Yes; the oil part of it.

Representative STOKES. Have there not been published statementsI do not know that you are aware of what was saicl before the committee here, but I thiuk the statements were made by the cotton-seed oil men here that that would be the eflect on their business.

Mr. Mrlletr. Yes, sir.

Represcutative CoONer. Now, Mr. Miller, I would like to ask a question for ny own special information, which I have not heard explained here, while I have been here, anyway. This eattle industry cuts a bigger figure in this matter with many of us than has been given attention. In iny comntry, the cattlenen, the cattle raisers and hog raisers, are mider the immression that they now receive from $\$ 2$ to $\$ 3$ per head more for their rattle, and from 20 to 30 per cent more for their hogs, than they will if this bill is passed; and $I$ believe they get the information from Kausas City. Now, I am very anxious to know if that is a fact, and I will be very glad if you can figure out aud show to me how these parties living in my country get that additional amount of money out of their eattle and hogs.

Mr. MILLEk. I will explain it in this way: We use only the ehoice fats of the beef in the manufacture of oleo oil.

Representative Cooney. Will you give the figures and facts, so that I can be satisied on that point?

Mr. MILler. 'The rich caul fat which we get out of the beef will average about 40 pounds to the steer, and in usiug it in the manufacture of butterine it has an enhanced value over ordinary tallow. Of course 
that value varies at different times of the year-sometimes there is a difference of 3 cents, sometimes more, and sometimes not so muehbut say to day oleo oil is worth 9 cents and common tallow is worth 5 cents, and if we could not use this caul fat in the mannfacture of butterine it would go into tallow and have no greater value tlian tallow. The same is true of the lard of the hog. We only use the leaf lard in the mannfacture of butterine. Now, if we conld not use it in butterine it would be sold as ordinary lard, and there a difference of about 2 cents a pound in the two articles.

liepresentative CoonEr. Have you any figures on that subject, in regard to cattle, which you conld leave here?

Mr. Mili.er. Yes, sir; I can do that.

Representative CooNer. Yon say the cattle raiser makes $\$ 2$ or $\$ 3$ a head which be would not make if this bill were passed?

Mr. Mrluer. I might supplement my remarks by saying that if there were no demanil for this nentral lard and oleo oil in the manutacture of butterine it wonld depreciate the value of his stock.

liepresentative Cooner. How much?

Mr. Miller. Well, it will vary at different times in the year. We figure about 20 cents per log and about $\$ 2$ per head of steer.

Representative COONEY. Now, who gets that $\$ 2$ per head 8

Mr. Miller. Who gets it now?

Representative CooNEr. Yes; who gets it now?

Mr. MILLER. The cattle raiser.

Representative Cooner. How do you make that out?

Mr. Miller. Why doesu't he get it?

Representative Cooner. Well, he sells his cattle to those who buy cattle ju the market, and it is when they are slanghtered that the fat is purchased by the oleomargarine men. Do they divide any of this profit amoug them?

Mr. Miller. It is just this way. If this law went into effect

Representative CoONEY. Does the farmer who raises the steer or sells the steer upon the market get all of this difference?

Mr. Muller. He is getting it now; yes, sir; and if thelaw went into effect he would not get it thereafter. He wonld accept $\$ 2$ a head less for each steer.

Representative Cooner. That is just what I would like to know, Mr. Miller. If you have any proof of that fact, that the farmer who raises the steer and sells it upon the market gets the two or three extra dol. lars himself, I would be very glad to have it. I can see how the value of the steer may he enhanced; but does he get all this enhanced value?

Mr. Miller. Le does.

Representacive CoONEY. That is what I wanted to know.

Representative WiLliams. That wonld be a mattel of bargaining and huckstering in the market, ronld it not?

Mr. Mlller. Yes, sir.

Representative Willians. Of course the farmer and the johber-the men who bought the stock to sell again-would each be trying to get the most they conld out of it?

Mr. Miller. That is right.

Representative WiLliairs. It would depend upon the individual sales as to who got it and who did not.

Representative BAKER. Mr. Miller, does the firm that yourepresentthe Armonr Packing Company-manufacture a substitute for lard commonly known as "cottolene?"

Mr. Miller. No, sir. 


\section{Representative BAKER. Nothing of that eharacter?}

Mr. Miller. No, sir; the Kansas City firm rloes not.

Representative HAUGEN. And rou claim that if the sale of this oil is cnt off entirely it will make a difference of $\$ 2$ for every steer killed iu this eountry?

Mr. MiLLEL. In the lard, it would make a difference of 20 cents per head in the log, and $\$ 2$ per liend in the steer.

Representative JAUGEN. I understand that there were about 4,600,000 cattle killed last year, and that about $24,000,000$ pounds of this lard was used, which would amount to abont $2 \frac{1}{4}$ poumls to every steer killed in this country, every head of cattle. Now, do you figure that this is worth \$1 a pound?

Mr. Miller. You understand that there is quite a good deal of this oil exporter?

Representative HAUGEN. Oh, well, that has nothing to do with this, you understand. 'This bill will not eut off' the export business.

Mr. Mllleir It will injure the export business, too.

Representative HAUGEN. It lias nothing whatever to do with that.

Representative NeviLLE. Mr. Chairman, I understand that there are other gentlemen here who desire to he heard, and it is now the, usual hour of going up to the session of the House. I move that we adjourn nutil to morrow morning.

[Mr. Miller also submitted the following as part of his remarks:]

[Extract from editorial in the New York Produce Review and American Creamery, issue of Weduesday, A pril 18, 1900.]

In the first place there is every prosnect of a larger make of bntter in this conntry. Some new ereameries have beeu inilt, finmers are inclued to give the dairs more attention, and more cows will be milked this year. To what extent this will inerease the ontpnt of bntter it is difficnlt to deternine, but if the weather eunditions are reasonably favorable the production for the eutire country may be 10 per cent greater than in 1×99. Reports that have already come to 11 from a given territory show alont this increase for the tirst half of April, aud the season is certainly no earlier than last year. It is quite probable that the New Lngland States, New York and 'ennsylvania may show a proportionately larger increase than the West, as all of these States suffered severely from an early dronght last year.

[Extract from eritorial in the Chicago Dairy Produce, issue of Saturday, April 7, 1900.]

\section{CHICAGO BUTTER RECEIPTS.}

A glance at the table printed elsewhere in this issue, showing arrivals of butter in this market for eleven months, beginuing May 1, 1899, compared to the correspouding eleven months of the precerling year, reveals for the past four uonths quite an increase. For last month this increase amounted to over 19,000 packages.

[Extract from the New Fork Produce Review and American Creamery, issue of Wedneslay, II ay 2,1900 .]

GOOD YEAR'S BUSINESS-REVIEW OF THE BUTTER MARKET HOR TIE PAST TWELVE MONTHS-VOLUME OF TRADE WAS LIGHTER-HIGHER PRICES RULE TROCGIIOUT, THE AVERAGE BEING ABOUT $2 \frac{1}{2}$ CENTS MORE THAN THE PIEVIOUS YEAR.

On Monday last the trade year for bntter closed, and while the varied expcriences of the season are too fresh in the minds of most operators to need extended comment, some features were of such special interest as to merit a hrief summary.

Ever since the senson of 1896 , when summer prices were so low, we have been working towarl a higher level of values, and the past season has male recurils that have not been equaled since 1893. It has been a year of large speenlation and large profits. The high cost of the summer prodnet did not seem to lessen the interest in the storage deal, aud nearly as much butter was pnt away in June and July as during the corresponding months of 1898 .

The storage butter of the country was worker ont at a handsome profit to holi!ers, and the better rates ruliug throughout for the fresh grouls gave satisfactory returns to the dairymeu. It is true that the higher prices ruling for butter have made a 
much larger sale for oleomargarine, but, on the other hand, the more profitable returns for the lairy jrodnct will greatly enconrage the business and filrmers, who have devoted so nuch attention to grain and stock raising, will now give attention to the dairy herds, believing that the restoring of remunerative prices is not for a single season only but for sone years to come.

The fluctuations in prices have been most markerl, showing a viriation from the lowest to the highest point of 12 cents a pound, and the avera'se for the year was $2 \frac{1}{5}$ cents higher than for the previons year. 'The shortage of supplies during the wiuter, after the storage goods were practically exhansterl, forcerl the market so high as to curtail consumption largely, but when the market was 25 cents or less the movement was geverally free and hualthy.

[Extracts from pages 659, 660, and 661 of No. 7. Vol. XI, of United States Experiment Station Record, edited by $\mathbf{E}$. W. Alien, $\mathrm{Ph}$. D.]

The relatire digestibility of several sorts of fat by man. I, Margarinand naturalbutter, H. Lühriy (Ztschr. [utersuch. Niehr. u. Genussmtl., 2 (1899), No. 6, pp. 484-506).-The author reviews the literature of the subject aud reports results of 4 experintents on the digestibility of margarin aud bntter made with a healthy man, 29 years old, weighing $74 \mathrm{~kg}$. Holstein butter and 3 sorts of inargarin were used, called according to their quality, No. 1, 2, and 3. The tests were quite similar, the fat in ench ease forming part of a mixed diet of meat, bread, regetables, etc. The composition of the margarin and butter was determined and the fat content of all the articles of diet.

The average results of the tests follow:

Average digestibility of margarin and butter.

Margarin No. 1, consumed with mixed diet 6 days.

Mararin No. 2 , consumed with mixed diet 4 days....

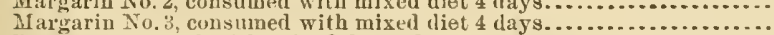

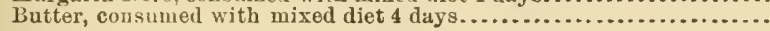

\begin{tabular}{|c|r|r}
\multicolumn{3}{|c}{ Fat. } \\
\hline $\begin{array}{c}\text { In daily } \\
\text { food. }\end{array}$ & $\begin{array}{r}\text { In daily } \\
\text { feces. }\end{array}$ & Digested. \\
\hline & & Grams. \\
Grams. & Per cent. \\
138.35 & 4.62 & 96.68 \\
118.64 & 3.91 & 96.70 \\
112.89 & 3.46 & 96.93 \\
111.79 & 4.82 & 95.69 \\
\hline
\end{tabular}

If corrections are made for the fat in the food supplied by other materials than margarin or butter, the average coefficients of digestibility in the 4 tests are 97.35 , 97.39, 97.10, and 96.53 ner cent, respectively. The anthor stullied the nndigested fat in the 4 experiments and detemined the amount of true fat in the nndigested ether extract. Takiner account of these values, the corrected digestibility of the margarin and butter fat in the tests reported above is $9831,98.25 .98 .46$, and 97.77 per cent, respectively. In the anthor's opinion the true undigested fat was not butter or margarin fat, and accordingly he believes that it is safe to conelnde that hutter and margarin are completely digesterl. ('The fat recovered in the feces is helieved to be derived from the digestive juices and metabolic prodnets produced in the body during the experiment.) If it is insisted upon that the $t w$ kinds of fat are not completely dipested, it must still be granted that as regarils digestibility they are practically alike, since the difference is very smalll.

From a study of the chemical characteristics of the undigesterl fat the anthor introdnces certain corrections in the above values and concludes that 97.86 per cent of the butter was actually digested and 97.55 per cent of the margarin. From a physiological standpoint the 2 fats are thought to be conpletely digestible and of equal value.

[Extract from pp. 375, 376, Experiment Station Record, Vol. XI, No. 4, Department of Agricrlture.]

The nutritire value of margarin compared with butter, E. Bertarelli (Riv. Iq. e. San. Pubb., 9 (1398), Nos. 14, pp. 538-545; 15, pp. 570-579).- Three experiments with healthy men are reported, in which the valne of margarin and hintter was tested when consumed as part of a simple mixed diet. In one experiment the value of a mixture of olive oil and colza oil, which is cummonly used in Itals, in the neighborhood of Turin, wis also tested. The anthor himselt was the snliject of one of the tests. He was 24 years old. The sulijects of the other tests were two laboritury servants; one 27 years old, the other 32 years old.

The principal conclusions follow: When properly preparesl, margarin differs but little from natnril butter in chemical and physical properties. On an average, 93.5 to 96 per cent of fat was assimilated when margarin was consumed, and 94 to 
96 per cent when butter formed part of the diet. The moderate nse of margarin did not cause any disturliance of the digestive tract. (Experiment Station Record, Vol. XI, No.4, Department of Agriculture, pp. 375, 376.)

(The committee thereupon, at $120^{\circ}$ clock $\mathrm{m}$, adjourued to meet Thursday, May 17, 1900, at 11 o'clock a.m.)

\section{Committee on A Griculture,}

HUUSE OF RePRESENTATIVES,

Washington, D. C., Thursday, May 17, 1900.

The committee met at 11 o'clock a. m., Hon. Herman B. Dahle in the chair.

Present: Representatives Wadsworth, Henry, Bailey, Wright, Hangen, Dable, Williams, Stokes, Lamb, Cooney, Allen, and Neville.

Present, also, Professor H. W. Wiley, chief chemist, United States Departiuent of A griculture; W. L. Miller, esq.. representing the Armour Packing Company, Kansas City, Kans.; C. N. Lavery, esq., representing Swift \& Co., Kansas City, Kans.; Charles Y. Kuight, esq., representing the National Dairy Association, and others.

\section{STATEMENT OF C. N. LAVERY, ESQ., REPRESENTING SWIFT \& C0.,} KANSAS CITY, KANS.

Representative BaILEy. Mr. Lavery, will you please state to the committee what your business is?

Mr. LAvery. I am manager of the butterine or oleomargarine department of Swift \& Co., Kansas City, Kans.

Mr. Chairman and gentlemen of the committee: We, as representatives of three of the largest manufacturers of oleomargarine in the United States, beg to enter our protests against the passage of House of Representatives bill 3717, known as the "Grout bill."

The Grout bill, if enacted by the voice of Congress, means the wiping out of one of the chief industries of our country (that of the manufacture of oleomargarine), a business which has been recognized by the laws of the United States as legitimate and a common necessity. It means the taking away from the millions of laboring men of the only opportunity they bave of procming a clean, pure, wholesome article of food at a reasonable cost-not as a luxury, but as a daily diet. It means the crushing of one industry and making a monopoly of another.

We, as manufacturers, wish to refute in the most emphatic terms rhe claim that oleomargarine is placed on the market and sold for butter. The internal-revenue laws provide that a manufacturer or wholesile dealer shall place on each package of oleomargarine sold a tax-paid stamp to the amonut of 2 cents for each pound contained. He must also stencil on it, in a conspicuous place, the word "oleomargarine," in letters not less than 1 inch square. He is compelled to keep a correct record of each package of oleomargarine sold, together with the buyer's full name and address, which information is furnished the honorable Commissioner of Internal Revenue, through his various collectors, at the end of each month.

The retail dealer is compelled to keep his stamp (which is a permit from the Government to sell oleomargarine, and for which he pays \$4 per month) conspicuously (lisplayed. He is required to sell from the original package in lots not to exceed 10 pounds, and to stamp ou the 
outside of each package sold the word "oleomargarine" in letters not less than one-fourth inch square, together with his name and address.

Thus it can realily be seen that there is absolutely no excuse for a consumer being sold oleomargarine for butter. We, as manufacturers, enconrage the handling of oleomargarine strictly in compliance with the revenue regulations, furnishing to the trade, free of charcre, all necessary stamps for marking packages, signs, notices, ote.

We desire that oleomargariue be placed before the consumer strietly on its merits.

Representative WiLliams. One word right there, if you please. Have you read this Grout bill?

Mir. Lavery. Yes, sir.

Representative WiLliams. Do you find any provision in it wlich would lead to the detection of lawbreakers or law violators any more than the provisions of the existing law?

Mr. LAVERY. No, sir; I do not.

Representative WiLLIAMs. Une other question. This bill inereases the tax upon oleomargarine, when colored, to 10 cents"

Mr. LA VERY. Yes, sir.

Representative IVILLIaus. Now, would or would not lawbreakers who have been violating the law with the present tax have additional temptation to violate the law under the new tax"?

Mr. LAVER S. I should say that they would.

Representative WiLlians. Let me ask you one other question. What would be the effect of the Grout bill upon honest nen, who have eomplied with the present law? Would it not mean simply an increased expense to them?

Mr. LAVERY. It would mean an inereased expeuse.

Representative WILLIAMs. Unless it drove them out of business, of course.

Mr. LAvery. And their business would be decreased to such an extent that they would probably go out of the business entirely?

Representative WiLLIAus. Now, the point I want to get at is this: You have read these laws, I presume. I understand you to say that your iclen, as a business man, is that the effect of the passage of the Grout bill would be to punish the homest dealers and furuish further temptation to the dishonest dealers to violate the law ?

Mr. Lavery. Yes, sir.

There is no need to go into the details of the manufacture of oleomar. garine, as it has become such a well-kuown alticle of commerce that everyone knows its general process.

That the people want oleomargarine is elearly demonstrater by the fact that the sales in the Uniter States increased firom 21,513,573 pounds in $188 S$ to $83,145,081$ pounds in 1899 . This increase is not due to the public being deceired and sold oleomargarine for butter, but to the faet that the consumirs have learned the value of oleomargarine and ask their dealer's for it.

We claim the same right to color oleomargarine yellow that a cream. ery elaims to color butter, and most respectfully ask this committee not to vote to prohibit the use of a harmless coloring in one in favor of the otlıer. We claim that oleomargarine is not an initation of butter, but that it is recognized "in the exact form it lias always been sold" by the United States Grovernment as a separate and distinct artiele of commerce, and that through public use it is acknowledged to be at the present time a staple artiele of food.

It is a well-knowu fact that the manufacturer of oleomargarine first 
conceived the idea of giving to his prodnct a uniform eolor, and thereby rendering it more pleasing to the eye by the use of a harmless coloring. The creameries throughout the country, taking advantage of the idea suggested, adopted the same color as their standard. They found it improved the appearance of butter as well as of oleomargarine. Now these same creameries come before Congress and ask to bave a law enacted to force the manufacturer of oleomargarine to abolish the use of coloring, claiming that they have the exclusive right to its use.

A prominent dairy authority writes:

The manuficture of oleomargarine is as legitimate as tlat of butter. It suppresses the lower grades of butter, and makes the finer butter more sought after. There is nothing for the dairyman to fear in it; his safoty can be insured by improving the quality of lis butter. The trade in oleomargarine might safely be left to itself. It is a blessiug to the community to supply it, at a low price, a clean, sweet substitute for costly bintter.

It will be seen that there are yet some people in the butter business who are willing to admit that the manufacture and sale of oleomargarine is legitimate, and a separate and clistinct business, and not maintained for the purpose of antagonizing the dairy interests of the conitiy.

We make oleomargarine because the people demand it. We color it yellow because it has always been sold that way.

Gentlemen, do you believe it wonld be right to say to the consumers of this country, "In future you will have to take your oleomargarine white, or buy butter?" Do you think, in justice to the oleomargarine manufacturers, that Congress should destroy their business (which has taken years of labor and thousands of dollars to establish) by foreing them to place their product on the market in an misightly and musalable form?

People who want butter should, by all means, have it. People who buy oleomargarine because they know it is good, should not be compelled to accept it in a distasteful form or go withont.

Butter and oleomargarine both occupy conspicuons places when considering the demands of the consumers of this country, and neither shouk be discriminater against for the sake of the other, but they should be placed on an equal basis and sold on their merits.

The creamery interests have no more right to say we shall not color oleomargarine than we have to say they shall not color butter.

It has been said that if Congress forbids the coloring of oleomargarine it should also forbid the coloring of butter. This is wrong. Congiess shonld not forbid the coloring of either, but shonld encourage the coloring of these products, in order to enhance the value and sightliness of both.

Again, it has been claimed that our packages are in imitation of those nsed for butter. Our packages consist of more than 20 different styles against two standard butter packages, viz, solid-packed tubs and 1-pound square prints or bricks. The latter style of package originated with the oleomargarine manufacturers, and has been adopted by the creameries.

Sixty per cent of our production goes on the market in packages known as rolls and prints, which are wrapped in printed parchment paper, as per samples, which we herewith respectfully submit to your honorable body for inspection.

(Mr. Lavery at this point exhibited to the committee samples of wrappers for packages of oleomargarine.)

Mr. Lavery. You will notice, gentlemen, that the word "oleomargarine" is plainly printed on each of those wrappers in letters the size 
of the largest letters in the brand, which is strictly in compliance with the internal revenue regulations.

hepresentative HENis. Allow me to ask where in the country those packages are retailed?

Mr. LAVERY. We sell them in the entire West. My house does business in the western territory, and these are our standard brands. Those wrappers have been approved by the honorable Commissioner of Interual Reventue.

Representative Allen. Do I understand you to say that each package has a wrapper of that kind around it?

Mr. LAVERY. Yes, sir. Now, I do not make the statement that all of our rolls and prints are put up in that wrapper; but the majority of them are.

Representative Allen. Why not all?

Mr. LAVERY. We can not print a cloth wrapper, for the reason that we have not been able to secure an ink which will not rnn, after the cloth becomes moist from the ramp and moisture in the oleomargarine. It runs throngh and discolors the goods mnderneath. But ink will stand on a parchment paper; and therefore we nse that wrapper as much as possible.

Representative Williams. How are these packages which are put up in cloth branded?

Ir. LAVERY. They are not branded at all. The cases containing them are branded in accordance with the regulations.

Representative Willians. Those you put in cloth, then, are contained in wooden cases, and the "ases are branded, are they?

Mr. LAVERY. Yes, sir; they are packed in wooden cases or tubs, and the outside of the package or tub is properly marked.

Representative Willians. The law requires, does it not, that they shall be put in packages either of wood or of paper, and that the packages are to be branded?

Mr. LAVERx. Yes, sir; the law requires that what is kuown as an original package (which is a package containing ten pounds or more) must be branded with the word "Oleomargarine," in letters not less than one inch square, and shall bear the mannfacturer's name.

Representative AlLEN. I do not suppose there is any question abont the law. That law speaks for itself, and I do not suppose there will be any dispute about it; so it will not be necessary to consume time on that point.

Represcutative Henry. Mr. Chairman, if I may be permitted, I would like to ask a question just for information. We had, some little time ago, an exhibit made of quite a large number of pound packages, bought of dealers in Chicago, a pound of oleomargarine in each. They were wrapped in ordinary brown japer, a sheet four times as large as that [indicating] - beavy brown paper. The four corners were turned down like that [indicating]. Under one corner there was printed the word "Oleomargarine."

Mr. LAVERY. Yes, sir.

Representative HENRY. The packages, in each case, were handed out by the retailer in response to an inquiry for butter. In order to determine that the law had been complied with, the purehaser wonld have had to turn down and examine critically each one of the four corners. I wish to ask if $y$ ' $u$ have any knowledge of that practice; and if so, how far it obtains in your part of the country?

Mr. LAVERY. I have heard of a few isolated cases of that kind. In the majority of cases the customer would ask for oleomargariue, but 
would require it not to be stamped; but the dealer, in orler to comply with the regulation, would stamp it and turu down the corners in the manner you have mentioned.

Representative Williajis. Let me ask you a question. Doing that was a violation of the law, was it not?

Mr. LAVERY. Well, strictly speaking, I should say it was; yes.

liepresentative WILLIAMS. Is there anything in the Grout bill that would prevent that violation of law?

Mr. LAVERY. No, sir.

Representative ALLEN. What is your purpose or reason for not wrapping all these packages with this loranded paper? Why do you wraly some with that and some without? Please explain that to the committee.

Mr. LAVERY. We have some trale which does not eare for the printed wrappers, for reasons of its own; of conrse we are in business to give the people what they want, as long as we can do so consistently; and we do not refuse to fill their orlers for plain-paper prints.

Representative AlLen. You sell to the jobbers, do you?

Mr. LAVERY. Yes, sir'; we scll to the jobbers and retail dealers.

Representative AlLen. And you sell to retail dealer's also?

Mr. LAVERY. Yes, sir.

Represcntative AlLEN. Alont what proportion of your ontput is put up in the wrappers of this kind, and what in the other packages?

Mr. LAVERY. I would say that about 60 per cent of our produet goes on the nuarket in rolls and prints, and of that 60 per cent I would say 50 per cent goes out in this style of package, wrapped in branded paper.

liepresentative Allen. And the other 10 per cent, say, goes out in the other shape"

Mr. LAVERY. In cloth wrappers, or oceasionally a plain paper wrapper.

Representative ALLEN. Now, you supply those wrappers yourselves, do you?

Mir. Lavery. Oh, yes; yes, sir.

Representative ALLEN. Do you use any ordinary brown wrapping paper for that purpose?

Mr. LAVERY. No, sir; we do not.

Representative Allen. You do not use any of that?

Mr. LAVERY. We do not.

Representative ALLEN. Do you stamp each one of those papers that your use?

Mr. LAVERY. Only in this mamer. [Bxhibiting wrappers.]

Representative BAILEY. As to these original packages, where you put them out without putting this brand on them, the law provides that the retail (lealer, when he sells the separate packages, shall rewrap) them, and stamp "Oleomargarine" on them; does it not?

Mr. LAVerY. Yes, sir: for which purpose we fiurnish to all retail trade, free of charge, a rubber stamp, made strictly in accorlance with the internal-revenue regulations.

Representative BAILEY. That is all.

Mr. Lavery. Permit us to ask, gentlemen, would it be possible to soll to a consumer who can read the luglish language, one of these packages for butter?

There have recently appeared, in certain newspapers, editorials and interviews regarding the purity of oleomargarine. Some people through ignorance, or with a desire to deceive, have made the statement that all kinds of fats, with no regard to their condition, are used in its man- 
ufacture. They have even goue so far as to say that fats from animals which have died of disease and scraps from retail meat markets and hotels-in fact, anything of a fatty nature that can be procmed at a low cost-enter into the manufacture of this prociuct.

I waut to say to this committee that all such stories emanate from people who know absolutely nothing of the subject they are discuss. ing, or are malicious falsehoods given out for the purpose of creating prejulice against oleomargarine. The ingrerlients of oleomargarine are of so delicate a nature that the greatest care is absolntely necessary in their preparation. We could not use an inferior oil if we wanted to, because the product made from it would not be salable. (Jleomargarine, to be acceptable to the consumer, must be pure, sweet, and wholesome; and in orler to have it so we must use the choicest of ingredients in its manufacture. Both oleo oil and neufral lard, as well as oleomargarine itself, are by nature very susceptible to foreign flavors of any kind. So much so, in fact, that were a whole carload of either shipped in a refrigerator car containing a single box of oranges, the flavor from the oranges wonld penetrate the other contents of the car to such an extent that they would be rendered useless for the purposes for which they were intended. It can, therefore, readily be seen that the newspaper stories above referred to are so utterly ridiculous and imposible that they deserve no consideration whatever.

To verify my statements in this regard, I take pleasure in referring to Prof. Henry Morton's statement before the Senate Committee on Agriculture and Forestry in the year 1856. In the course of that statement, in reply to Senator Jones, who asked about the "vile compounds" which are used in making oleomargarine, Professor Mortou said:

To anjone who knows about it these stories are simply alsurd. It is utterly impossible to do any such thing. As I have silil, if the anim:l has been dead a short time the fat cin not he used. For instance, you can not use fat from the meat which is hung up and exposed for sille in the nurket for the purpose of nuaking oleomargarine. Although such meat is not hurt for ordinary nse and can be cooked and eaten, the fat of it wonld be utterly ruined for the purpose of making oleomargarine.

Professor Chandler, testifying before the same committee, said, at the commencement of his remarks:

I would not, of course, wish to take up the time of the committen by repeating anrthing that Dr. Morton has said, but I will say at the outset that I agree with Dr. Morton in every statement that he has made.

\section{Professor Chandler also said:}

Some of yon remember, I presume, that before the discovery of the passage arnuml the Cape of Good Hope to India the only dyestuff cultivater to any extent in Euyland was woad, an inferior dye which our ancestors employed for dyeing their products. When the trade with Bengal sprang up indigo was brought to Eunlaud, and immediately there was a great hue and cry made against indigo. It was said that it was going to ruin the woad farmer of England, aud they called it devil's dirt-Teufelsdröckh was the name in German-and it was marle a capital crime in England, France, and Germany for anybody to be cauglit with indigo on his premises. It ras not snggested that it should be colored blue, because that was its natural color, and it was not necessary. Soon after low wood was discovered in Houduras. and when it was attempted to introduce it into Lingland as a dye laws were passed against it; and we have had that kind of legislation al wajs.

It is not many years since a petition was presented to Parliament, in Englaud, protesting against the nse of bops in beer, ou the gromul that it would ilestrog thu digestion of the English people. There was a similar attempt at legislation in regard to the burning of soft coal. Thoy had used only wood and cliarcoul in England, aud when it was proposed to take coal out of the ground and bring it to London they said it wonld ruin the industry of the people who cut wood in tho forests to make charcoal; that it was unhealthy, and would nake a smoke thit would get into the lungs of the kuights who came from the country to Parliament to sit and legislate for the people. 
The demand for oleomargarine is due to education. The pnblic has become acquainted with olcomargarine throngh a disposition on the part of the manufacturers to teach it. Our factory is always open to the inspection of the public. We are always at lome to visitors. Nothing gives us more pleasure than to see a party of visitors approach. ing our oleomargarine factory. We have no secrets. Every branch of our business, from churning to shipping, continues in the presence of visitors.

It is our pleasure to show the public every ingredient of oleomargarine going throngh its course of preparation. Onr churns, and every utensil used in connection with oleomargarine, are as sweet and clean as hot water and steam will make them. Our floors are cleaner thau the average dining table.

We claim that it is absolutely impossible for germ life to exist in our oleomargarine factory, and we want the public to come and see for themselves. These are the reasons the oleomargarine business is growing, and not that this product is palmed off on innocent purchasers for bntter.

In the face of an increasing production of butter in the United States, and advancing prices for this product-the Lilgin market ruling higher the past year than at any time since 1894 -we ask, gentlemen, do you think this article of food is really suffering for the want of such protection as the creamery interests are asking Congress to give it?

The passing of the Gront bill would be one of the most unjust pieces of class legislation ever enacted. It wonld mean that thonsands of families would actually be deprived of one of the necessities of life, as they could not pay the prices asked for butter, and would not buy oleomargarine in the form this measure asks us to make it.

Gentlemen, we ask you, in justice to the business to which the Grout bill means a death blow, and in justice to the thousands of consumers throughout the comntry, not to recommend the passage of the Grout bill by Congress, thins placing your stamp of approval upon a measure which, if enacted, will destroy a legitimate business, make a monopoly of another, and work one of the greatest of hardships on the laboring men and consumers of this country forever afterwards.

Permit us, gentlemen, to thank you for the privilege of being heard before your most honorable borly.

Repu'esentative AlLEN. I wonld like to ask you, sir, about what amount of capital your company has invested in this industry? I refer to this industry alone, the manufacture of oleomargarine.

Mr. LAvery. Swift \& Co. have two oleomargarine factories, one at Chicago, and one at Kansas City. At Kansas City we have, I should say, taking the cost of the plant and of wholesale licenses, etc., au investment of $\$ 500,000$.

Representative ALLEN. In the two plauts?

Mr. Lavery. Yes, sir.

Representative ALLEN. How many employees have you who are engaged exclusively in this industry?

Mr. LAVEry. At the factories alone we employ about 250 people, all told.

Representative ALLEN. In both factories?

Mr. Lavery. Yes, sir. Aside from that we have salaried representatives all over the country.

Representative ALLEN: Does your knowledge serve you as to whether these employees are mostly men of family-whether married men predominate among them or not? 
Mr. LAvery. As a rule, yes, sir. The majority of the men employed by our factory at Kansas City are married men.

Representative Allen. Can you tell this committee about the average pay which you give them per day?

Mr. LAVERY. The average for ordinary labor, I should say, is about $\$ 18$ to $\$ 20$ a week. Skilled laborers and foremen of departments will earn $\$ 25$ and $\$ 30$ per week.

Representative ALLEN. Will the abolition of this industry throw those men out of employment?

Mr. LAVERY. It eertainly will.

Representative AlLEN. Have you any knowledge, personally, as to whether or not the produetion of oleomargarine increases the price of beef cattle?

Mr. LAVERT. Yes, sir.

Representative ALLEN. Will you tell the committee about that?

Mr. Lavery. Each beef contains about 50 ponnds of fat, kuown as eaul fat, from which oleo oil is made. Should we not utilize this fat in the production of oleo oil, it would go on the market as a cheaper fat, on the basis of tallow, and at a difference in price to day of about 4 cents a pound.

Representative ALLEN. That is the difference between tallow and oleo oil?

Mr. LAvery. Yes, sir. In the tallow and oleo oil markets to day there is a difference of about 4 cents a pound. That would mean a difference in the price of the 50 pounds of eaul fat taken from each beef equal to $\$ 2$ a head.

Now, you might go further, and say that were the oleo-oil production of this country discontined, and that fat thrown into tallow, it wonld result in an increased production of tallow, and would naturally force the tallow market down far below what it is to-day. Of course you can not tell where it would go, but it would do away with the use of oleo oil, and that fat would have to be sold as a cheaper fat.

Representative Allen. Where do you get your fat? From the beef you kill yourselves?

Mr. LAVERY. Yes, sir; entirely.

Representative ALLEN. From what part of the country is your product generally derived? In what part of the country do you get your tallow prineipally.

Mr. LAvERY. From the entire West-Kansas, Nebraska, Colorado, New Ilexico, Arizona, Texis-in fact, you migit say, from every State west of the Mississipli River.

Representative ALLEN. Do you know the average number of eattle you slaughter per year?

Mr. LAVERY. There were slaughtered at Kansas City last year 1,912,019 head of cattle. Now, Swift \& Co. killed, I presime, onequarter of that number-I would say one-third of that number.

Representative Allew. It is elaimed by the adrocates of the Grout bill that the average increase in the price of each steer slanghtered is only about 40 cents, I believe, taking the whole number of cattle slaughtered in the United States, together with the value of the oil used in the manufacture of oleomargarine. Have you any information on that point?

Mr. LAVERY. Yon will understand that we use the entire canl fat from the beef in making oleo oil. We do not consume all of that oleo oil ourselves; we export a great deal of it. 
Representative WiLLiaus. Let me ask you, right there, whether or not you export it as oleo oil.

Mr. LAVERY. As oleo oil.

Representative WILLiAiss. As oleo oil, and not as olenmargarine?

Mr, LAVERY. Yes, sir.

Representative ALLEN. Now, about what proportion of that do you consume and what proportion do you export?

Mr. Lavery. We consume, ourselves, a fourth, I should say, of our entire produetion.

Representative ALLEN. Now, do you think that the prohibition of the use of oleo oil here, in the manufacture of oleomargarine, would have any effect upon that export production?

Mr. LAVERY. It most certainly would.

Representative ALLEN. In what way?

Mr. LAVERY. Foreign countries, and especially Germany, are wateh. ing for every opportunity to legislate against the entrance of American meats and by-products, and if our own Congress should pass a law which would practically kill the oleo industry in this country we have no reason to believe that Germany and other European countries would not take similar action and prohibit the entrance into their conntry of oleo oil and such materials as we have legislated against ourselves; and such action would therefore kill, or at least greatly injure, the export oleo-oil business.

Representative ALLEN. I will ask you another question with regard to the cotton-seed oil that you use in the production of this material. Do you use any of that?

Mr. LAVERY. Yes, sir.

Representative ALLEN. To what extent?

Mr. Lavery. The four principal ingredients used in the manufacture of oleomargarine are oleo oil, neutral lard, milk and cream, and cottonseed oil. Of those four ingredients eotton-seed oil comprises about 25 per cent. We are now using on an average, we will say, for the year, about a car of cotton-seed oil a week, or four cars a mouth.

Representative ALLEN. How much is a car?

Mr. Lavery. From 32,000 to 35,000 pounds.

Representative ALLEN. What grade of cotton-seed oil do you use?

Mr. LAVERY. The very best grade of cotton-seed oil, known as butter oil-highly refined cotton-seed oil.

Representative ALLEN. Of your personal knowledge what class of people generally consume oleomargarine in your eity, where you live?

Mr. LA VERY. All classes of people buy oleomargarine; but the mass of buyers, I should say, are among the laboring class of people.

liepresentative HenRy. Mr. Lavery, can you explain the discrepaney between your statement as regards the percentage of cotton-seed oil you use and the official statement male in reply to an inquiry of Congress by the Internal-Revenne Bureau?

Mr. LAVERY. Yes, sir; I stated that

Representative HENRY. The report, as I understand, shows the use of abont 10 per cent; you say you use about 25 . It may be that you use more than other manufacturers.

Mr. LAVERY. I stated that oleomargarine consists of four principal ingredients-oleo oil, nentral lard, willk and cream, and cotton-seed oil. Now, of those four ingredients cotton-seed oil comprises about 25 per cent. Of course, we add salt and coloring matter.

Representative HenRy. The Commissioner of Internal Revenue, in 
response to an inquiry from Congress, says that about 10 per cent of cotton-seed oil is used.

Mr. LAvEli. He says 10 per cent of all ingredients. He gives liere nentral lark, oleo oil, cotton-seed oil, sesame oil, coloring matter, sugir, glycerin, stearin, glucose, milk, salt, butter, oil, aud cream. I aun taking the four principal ingredients.

Representative HENRY. I simply wish you would explain the difference between the two statements.

Mr. LAvery. I am leaving ont a great many of the small items which are given in that statement, and taking the tom principal ingredients.

Representative HeNRI. Then allow me to ask you what percentage cottou-seed oil is of your gloss product?

Mr. LAVERY. I woull say, taking all the materials used, that this. statement is abont correct.

Representative HENRY. That is all.

Riepresentative Nevilite. Now, I want to ask yon a question or two. Of what is oleo oil composed-just the fat of which you speak, the caul fat?

Mr. Lavery. Ies, sir.

Representative NEVILLE. The caul fat alone?

Mx. LAVERx. The eaul fat alone.

Representative NeviluE. How much of that oleo oil did your firm produce last year? Have you not got those figures?

Mr. LAVERY. I have not got those figures at hand; no, sir.

Represutative Neville. You have them on your books at Kansas City?

Mr. LAtERY. We have. I can furnish them, but I can not give them offlimal.

Representative Nevilue. Now, you speak of being unable to sell this material unless it is colored?

Mr. LAvery. Yes, sir.

Representative NEviLLE. As a matter of fact, if it is wholesome, and the people want it, will ther not buy it when it is not colored?

Mr. LAvery. It it is placed on the same basis with butter, I should say that in the course of time we could educate the people to buy uncolored butterine the same as uncolored butter. But they have almays bought oleomargarine colored. It has always been colored since we first began to manufacture it in this country. The people are eclucated to the use of colored oleomargarine, and they do not want to buy it otherwise.

Representative NEVILLE. Now, as a matter of fact, the coloriug adds nothiug to its quality, except simply as far as its appearance is con. cerned?

Mr. LAVERY. Nothing except the appearance.

Representative NEviLLE. Now, you also stated that your trade was largely in the West.

Mr. LAVERY. Yes, sir.

Representative NeviLLE. You have been selling, and did sell last year, and year before last, in Nebraska very largely, did you not?

Mr. LAverY. Yes, sir.

Representative NEviLLE. Is it not true, when you say there are certain customers who, for their own reasons, desire to liave the oleomargarine go ont without the brand upon it, that that is for the puxpose of enablin coloring it ${ }^{\circ}$

S. Rep. $2043-51$ 
Mr. LAVERY. I do not think so.

Representative NEviLLE. Now, there was a lot of your manufactured proluct sold in Nebraska last year and the year before, was there not?

Mr. LAVERY. We do some business in Nebraska; yes, sir.

Representative NEviLLE. Now, is it not true that there is and has been right along a law upon the statute books there which prohibits the sale of oleomargarine colored in initation of butter.

Mr. LAVERY. Well, there has been a law there, but it has been in litigation.

Representative NEVILLE. But is it not true that this butterine of yours which was sold in Nebraska, colored, had to be sold as butter, or it could not have been sold?

Mr. LAVERY. No, sir: I do not think so.

Representative Neville. Have you traveled through Nebraska lately?

Mr. Lavery. I have been in Nebraska; yes, sir.

Representative NEviLLE. And have you seen establishments there selling colored oleomargarine branded as oleomargarine?

Mr. LA VERY. Yes, sir.

Representative NEVILLE. Tell me one place where you saw it.

Mr. Lavery. Omaha has a number of stores which bandle oleomargarine, pay the internal-revenue license, and sell it as oleomargarine.

Representative NeviluE. And have it branded as oleomargarine?

Mr. Lavery. Yes, sir.

Representative NEviLLE. Notwithstanding this law on the statute books?

Mr. Lavery. Yes, sir. We have oursolves sent in the last three months at least a dozen oleomargarine stamps to retail dealers in Omalıa.

Representative Neville. In the last three montbs?

Mr. LAVERY. Yes, sir.

Representative NEville. Now, that was since the lower court held that the law, for technical reasons with reference to its passage, was not constitutional, was it not?

Mr. LAVERY. We have always furnished the stamps necessary for the marking of packages in Omaha; and I believe the Omaha dealers, without exception, handle oleomargarine and sell it for exactly what it is.

Representative Nevilus. Do you not know that a firm there in Omaha was fined $\$ 800$ only a short time ago for selling oleomargarine as butter, and that they have now got an application before the Interual Revenue Department here, which was put in through me, to have that money returned to them?

Mr. Lavery. I do not know, sir.

Representative Neville. The application was put in throngh me, and I was called upon to assist in getting the money returned to them.

Mr. LAVERY. I do not know that, no, sir.

Representative NeviLle. Well, I say to you that that is true.

(After informal discussion among members of the committee)

Representative WiLliaus. Suppose there were a law of the United States taxing butter, when colored artificially in any manner, 10 cents a pound; do you think it wonld interfere with the sale of butter?

Mr. Lavery. I most certainly do. It would be a pretty good thing for butterine.

Representative WiLliais. Then a law taxing oleomargarine to that 
amount would interfere with the sale of oleomargarine for exactly the same reasons, would it not?

Mr. LaveliY. Yes, sir. A law of that kind would be a pretty good thing for the oleomargarine manufaeturers.

Representative NEviLLE. Now, is it not true that if oleomargarine were not put up in such shape that it could be sold apparently as butter, oleomargarine would sell to the poor people, who, you say, want it, for a much lower price than it does in its present form?

Mr. LAVERY. I do not think so. I think the vast majority of the oleomargarine sold in this conntry is sold for oleomargarine.

Representative Neville. Now, then, you know that a majority of the states in the Union lave laws prohibiting the coloring of oleomargarine in imitation of butter, do you not?

Mr. LAVERY. Yes, sir.

Representative Nevilie. In those States which have such laws will you explain to me how you sell oleomargarine as such, and yet colored as butter, without violating those laws?

Mr. Laverr. Well, l can only say that the people want oleomargarine even in the anticolor. States, and, regardless of the fact that there are laws on the statute bookis prohibiting the sale of the product colored yellow, there is such a demand for it that in a great many of the States there is very little attuntion paid to the enforeement of that law. Take the Sonthern States, for example.

liepresentitive Nevilde. Now, would not the same thing be true with reference to the pechllers of green goods, if there were such a demand for them?

Mr. LAVERY. I do not think that is a fair comparison.

Representative NEvrLLE. l'erhaps not; it may be extravagant.

Representative Williams. Iiy the way, Mr. Neville, do you contend that the law of the State of Nebraska forbidding a man to manufacture colored oleomargarine in Kansas and ship it into Nebraska in the original paekage is a constitutional and valid law?

Representative NEviLLE. Why, I confess that, like all other matter's of the kind, it comes under the police-regulation law; but I say that when the packages get into Nebraska and are broken, if their contents are then sold as colored oleomargarine they are sold in violation of law.

Representative Willians. Your opinion and mine, then, eoincide, of course?

liepresentative Nevili.e. There is no question about that. I think we both know what the law is. But you can not ship oleomargarine there, and break the packages and sell it, except in violation of law.

Representative WILLIAlis. No; that eomes under the local law. But these people who manufacture oleomargarine in other States are not amenable to any law of Nebraska.

Representative NEYiLLE. Mr. Lavery, let me ask you just another question. In what sized packages do you ship colored oleomargarine to the retailers in Nebraska?

Mr. Lavery. Our packages range from 30 to 60 pounds; that is, for the retail trade.

Representative Neville. In one caddy?

Mr. LA VERY. Y'es, sir.

Representative NEvilLe. When the retailer gets it in Nebraska, he is compelled, if he sells it pound by pound, to break the package, is the not?

Mr. TAAVERY. We sell-

Representative NeviluL. Auswer that question. 
Mr. LAVERY. What is your question?

Representative NEviLLE. The retailer who sells it in Nebraska, pound by pound, is compelled to break the package when he sells it there, is he not?

Mr. La very. Certainly.

Representative NEville. That is all.

Mr. Lavery. We ship any amount of oleomargarine to Nebraska, to the city of Omaha and other places.

Representative NevilLe. I know it; I live there and I know all about it.

Representative Cooney. Mr. Lavery, I would like to ask you a question. Have you any figures in your statement here with reference to the values placed upon cattle for slaughtering purposes, with reference to the oleo oil which is made from the fat?

Mr. LAVERY. I have not prepared any figures; no, sir.

Representative Cooney. Yon have none, then, in your statement here?

Mr. Lavery. No, sir. What information dil you want, Mr. Cooney?

Representative CoONEr. I wanted information in regard to the value which this oleomargarine business gives to cattle.

Mr. IAAVERY. I stated a while ago that there are about 50 pounds of caul fat taken from each beef.

Representative Cooney. Yes; you state that from memory, do you not?

Mr. LAVERY. That is an actual fact. There is an average of 50 pounds to a beef, and that is the fat fiom which oleo oil is made.

Representative CooneY. Tes; I understand that.

Mr. Lavery. There is to day a difference between the price of oleo oil and tallow

Representative COONEY. I understand that perfectly; you went all over that. Now, do you say that all of this fat is made into oleo oil?

Mr. LAVERY. Yes, sir.

Representative CooNEr. In a!l the beeves that are slanghtered?

Mr. LAVERY. Yes, sir.

Representative Cooner. That is the general method pursued by slanghtering institutions?

Mr. LAVERY. Yes, sir; I think so.

Representative CoONEY. To devote this part of the animal to the manufacture of oleo oil?

Mr. IAAVERY. Yes, sir; I think that is the method generally pursued.

Representative CoONEY. Now, this oleo oil is either mauufactured into oleomargarine here or is shipped abroad?

Mr. Lavery. Yes, sir.

Representative Conney. And you say that of the fat which your institution receives you utilize about one-fourth in the manufacture of oleomargarine?

Mr. LAVERY. Yes, sir; that is right.

Representative Cooney. And the balance you ship. Those answers were drawn from you by questions asked by Mr. Neville. Have you any figures at liand to show just what anount you use and what amount you ship?

Mr. LAVERY. No, sir. I stated a while ago that I could furnish those figures, but I have not them at hand now.

Representative Cooney. You did not really charge your mind with them when you left home, did you? You did not charge your mind with the figures on that particular subject? 
Mr. LAVERY. No, sir.

Representative CoONey. And what you state is simply from your best information on that subject, according to your recollection?

Mr. LAvery. And from experience.

Representative COONEY. Now, there is another question in connection with that matter which I want to ask, and that is, if, in making this statement, you meant to say that to the stock raisers of the country their beef cattle are worth \$z per head more than they would be if there was no manufacture of oleomargarine?

Mr. LAVERY. The figures certainly show that.

Representative Cooney. These $\$ 2$ go, then, to the cattle raiser, do they?

Mir. Lavery. Yes, sir.

Representative Cooner. None of that amount goes to the oleomargarine manufacturer?

Mr. LAVERY. Why should it? If it increases the value of a beef steer, the man who owns the beef steer certainly reaps the benefit of it.

Representative Coonex. Then the oleomargarine manufacturer and the man who buys and slaughters the steer make none of this extra profit; that is, they receive none of this extra profit of \$2.

Mr. LAVERY. I do not see how they could, except the profit through the manufacture and sale of oleomargarine.

Representative CoonEx. Well, do they receive part of that $\$ 2$ in that way; and if so, how much?

IIr. LAVERY. None whatever, that I can see.

Representative Cooney. Do they receive any profit on the balance of the beef, then?

Mr. LAVERY. How is that, sir?

Representative CoonEy. Do they receive any of the profit out of the balance of the beef, or is it all given to the cattleman?

Mr. LAVERY. According to the method of buying cattle to-day, the value of a steer is arriverl at by figuring what the beef contained in that steer is worth, together with the by-products.

Representative CoONEY. Yes.

Mr. LAVERY. If there is a by-product contained in the steer which is of value in bringing a high price on the market, it increases the price which the packer can pay for the steer just that much; but if you reduce the value of that by-product $\$ 1$ a head, it simply cuts off that much money from the price of your steer.

Representative Cooney. This is what I want to get at, Mr. Lavery. You state that a slanghtered steer will contain about 50 pounds of this fat, ont of which yon make oleo oil?

Mr. LAVERY. Ýes, sir.

Kepresentative CoONEx. And that that fat is worth 4 cents per pound more than it would be if it were made into lard?

Mr. LAVERY. I said tallow, not lard.

Represenfative CoONEy. Into tallow, I mean; and that 4 cents, you say, goes to the stockman?

Mir. LA VERY. Yes, sir.

Representative CoONwy. Now I will ask you if you treat the stock. man, and if the stockman is treated in the market, upon the same basis of the value of his steer on all other parts of the steer?

Mr. LAVERY. Yes, sir.

Representative Cooner. And if he is not, why is he not

Mr. LAvery. Well, he celtainly is. He is given credit for all the by-products in the purchase price of that steer. 
Representative CoonEY. He is given all of the value of all parts of his steer, then?

Mr. lavkRY. Yes, sir; in the purchase price.

Representative WiLliams. You mean that renders him able to offer that much more?

Mr. IAAVERY. That is exactly it.

Represmatitive WiLLIAis. As a matter of fact, however, the actual price arrived at in selling a steer, like anything else, is a matter of bartering and huckstering in the narket?

Mr. LAVERY. That is the idea; yes, sir.

Representative Cooney. That is a rery different thing. I want to know who gets this $\$ 2$ which Mr. Lavery is talking abont. He says it is the stockman who gets it. It conld not be a matter of huckstering and bartering, then, if the farmer gets it.

Representative HAUGEN. I would like to continue the questions which have been asked you. You claim that the manufacture of this prodnct makes $\$ 2$ of difference per head of eattle?

Mr. LAVEri. Yes, sir.

Representative BAUGEN. On what gromul do you base your claims? What is the number of cattle slanghtered, according to the Government reports or estimates which you have?

IIr. LAVERY. In the United States?

Representative HAUGEN. Tes, sir.

Mr. LaVERY. I have not those figmes at hand.

Representative IlAUGEN. I think it is about $5,000,000$ head, is it not? According to the A grienltural Department report, it is $4,6 \tilde{5} 4,000$.

Mr. LAVERY. I only have the figures for the Kansas City markets.

Representative HaUgwn. According to the reports, there were $24,491,769$ ponnds of this oleo oil consumed.

Mr. LaverY. Yes, sir' here in this comtry.

Representative HAlGis. Iu mannfacture?

Mr. LAVERY. Yes, sir.

Representative HAUGEN. That would amount to less than 5 pounds to each head of cattle, would it not?

Mr. LAYERY. Well, yon understand that, as I stated a while ago-

lepresentative HAUGEN. I an referring now to whatever this bill refers to. It has nothing to do with the oleomargarine shiplerl abroad. This bill does not affect the exports; it refers to what is consumed here at home, or what is eolored. Now, this would amount to less than 5 pounds to a head, would it not?

Mr. LAVERY. I have not figured that out.

Representative IIAUGEN. Well, it is necessary, in vinw of the statements and assertions that you have made, to figure it out in dollars and cents, and in pounds.

Mr. Lavery. Yes, sir.

Representative HAUGEN. Now, then, if there are $24,000,000$ pounds used or consumed, and 5,(100,000 head of cattle slanghtered, that is less than 5 ponnds to each head of eattle killed?

Mr. Lavery. Tes, sir.

Represeutative HAUGEN. You stated a while ago that there was a difference of 4 cents a pound between the prices paid for this fat for the purposes of tallow and oleo oil. Now, then, 5 pounds of fat at 4 cents per pound is 20 cents, or less than 20 cents lor each head of cattle killed, according to your own statement, is it not?

Mr. LAVERY. IVell, taking only the amonut of oleo oil consumed in this country, it would probably be that much less than $\$ 2$. I consider that this bill would affect more than our own country. 
Representative HAUGEN. We will come to that later, but I wish to make this point clear.

Mr. LAVERY. It would be much less than $\$ 2$ on that basis.

Representative HACGEN. Are my statements correct, then?

Mr. LAVERY. It is simply a question of figures. I lave not figured it out.

Representative HAUGEN. It is necessary to use figures to arrive at the result.

Mr. LAVERY. That is simply a question of figures.

liepresentative STokEs. Is it possible, Mr. Lavery, for you to have one set of prices for home consumptiou, and another set of export prices? Is that possible under any conditions in our commercial arrangements?

Mr. LAVERY. Do you refer to oleo oil?

Representative S'TOKEs. I refer to any commodity that is exported.

Mr. LAVERY. No, sir; the prices are usually the same.

Representative Stok ks. The same?

Mr. LAVERY. Yes; sir.

Representative STOKES. Undoubtedly.

Mr. Lavery. We base our market price of oleo oil, for both foreign and domestic use, on exactly the same conditions.

Representative HAUGEN. Now, you state that this bill will affect the price of the oil which yon export. Let me ask you this question: Did it affect the price of oleomargarine when the present law, providing for the 2-cent tax, was enacted? I believe you staterl a moment ago that the trade had increased.

Mr. LAVERY. Why, no, sir. While I think the 2-cents per pound tax is unjust, it is within reason; and we can pay that tax and still clo business.

Representative HAUGEN. You claim that the 10-cent tax would practically kill your industry?

Mr. LAVERY. I certainly do; yes, sir.

Representative HAUGEN. Wlat is oleomargarine worth to-day, uncolored? What is the average price for the year? sale.

Mr. Lavery. The average price to day is, say, 11 to 14 cents, whole-

Representative HAUGEN. The uncolored oleomargarine?

Mr. laVERY. The mucolored oleomargarine; yes, sir. There is no difference between the cost of the colored and the uncolored product.

Representative HAUGEN. What is the average price of butter the year round?

Mr. LAVERY. The Elgin market this week is, I think, 18 or 19 centspossibly 19 .

Representative Hatgen. You sell the uncolored oleomargarine now for how much, you say?

Mr. LAVERY. We make no difference in the price of colored and uncolored oleomargarine.

Representative IIAUGEN. It is about 11 cents, you say?

Mr. LAVERY. That is the wholesale price; yes, sir. The price ranges from 11 to 14 cents. You understand that we make two or three differ. ent grades of oleomargarine.

Representative HAUGEN. At this time of the year butter is much lower than at other seasons, is it not?

Mr. LAVERy. Yes, sir.

Representative HAUGEN. The price of butter, on an average, is 22 to 24 ceuts, is it not? 
Representative WiLLIAMs. Do you mean retail or wholesale? liepresentative HAUGEN. I mean wholesale.

Mr. LAVERY. I think that is a fair average. It averaged higher than that last year, howerer.

liepresentative HATGEN. Say that a fair average price for butter, at wholesale, is '24 cents a pound, and that of your prodnet is 11 cents. You claim that your profuct is worth just as much and will sell for just as muel as bintter, do you?

Mr. Lavery. You must understand that there are seasons when the Elgin market has been much lower than that. If this bill were passed, half of the time the cost of oleomargarine would be higher than the Elgin market price of butter. Based on the present figures oleomar. garine would cost more to produce than Elgin butter.

Representative HAUGEN. At the present market price yon could not pay the 10 cents per jound?

Mr. LAVERY. No, sir.

liepresentative HAIGEN. But on an average, if the average price of butter is 22 cents, then yon could pay the 10 cents. as I minlerstand oleomargarine can be manufactured for abont scuts per pound? I believe that is the testimony before this committee.

Mr. LAVERY. No, sir; it can not; that is too low.

Representative HATGEN. But it sells at 10 or 11 ceuts. Is it not a fact that it is sold for less than 10 cents?

Mr. LAVERY. No. sir; it is not.

Representative WhignT. I whuld like to ask one question in conneetion with $11 \mathrm{r}$. Inangun's questions. From your answers to his question, Mr. Lavery, I infer that the wholesale price of oleomargarine is about 11 cents. and the wholesale price of butter about '2y cents.

Mr. Lavery. The Wigin market to day is about 18 or 19 cents. I would not say jositively on that point. one way or the other.

liepuresentative WRIGHT. I wanter to ask, then, if it is true that people want olemmargarine. whether you could not still add the 10 cents to it and sell it onl the same basis as butter?

Mr. Lavery. No, sir; they wonld not buy it on the same basis as butter. They buy oleomargarine beanse it is a wholesome product, and can be bouglit slightly cheaper than butter.

The AcTiNg CHAIRMAN. When you sprak of the cost being 11 or 14 cents, does that include the :-cent tax, ol not?

Mr. LAVERY. That includes the tax; yes, sir. It includes the 2-cent tax only.

The ACTING GHAIRMAN. A re there any further questions?

Representative Neville. I would like to ask the gentleman one further question. If, as a mather of fact, this tax is established at 10 cents per pound, and the people actually want to consume oleomargarine, want to eat it, eould they not afford then to buy it direct themselves and color it, and still get it much chenuer than they get butter, and would they mot do it?

Mr. LAVERY. No, sir; becanse thry have not the facilities for color. ing it, for handling the coloring in the way it should be handled; and they would not go to that trouble.

Representative NEVILLE. Now, then, by coloring it, you add at least from 8 to 10 cents jer pound in value to it, do you?

Mr. Lavery. Well, I do not figure that way; no, sir.

Representative NEville. How much clo you figure that you add to its value by coloring it?

Mr. LAVERY. You might say the whole value of the product is taken away from it if you take the color ont. 
Representative NEVILLE. And then, by putting the coloring inatter in-

Mr. LAVERY. Our experience is that uncolored oleomargarine will not sell.

Representative NevilLE. Then, the putting of the color into it is what gives it its valne?

.Ir. LAVERY. Yes, sir. If people had been educated to nse uncolored oleomargarine, they would not ex]ect it any other way, but they have not; they have always bonght it colored.

Rejresentative Nevilus. Now, what does it cost to make it without the coloring in it?

Mr. LAVERY. The manufacture costs about a cent under the wholesale price.

Representative NEVILLE. It would then cost about 10 cents?

Mr. Lavery. Yes, sir.

Representative NEvilLE. That is the wholesale price?

Mr. Lavery. Tes, sir.

Representative NEVILLE. Now, the retail price, you say, is about 18 cents?

Mr. Lavery. No, sir; I said 11 to 14.

\section{ADDITIONAL STATEMENT OF DR. H. W. WILEY, CHIEF CHEMIST, UNITED STATES DEPARTMENT OF AGRICULTURE.}

Dr. WILEY. I simply wish to say that I have prepared here a little statement to place in my evidence of yesterday, in connection witl my statement in regard to stearin in oleomargarine. It appears in the report of the Commissioner of Internal Revenue that there is only 0.007 of one per cent in oleomargarine. On lonking the matter up I find that he means that that much stearin has been arded in the process of manufacture. He does not refer to the stearin which is present in the nentral lard, the oleo oil, and the cotton-seed oil. They all contain stearin. My statement which I made to the committee is strictly correct-that the total amount is from 15 to 20 per cent. I wonld like to submit this and have it incorporated in my evidence, as I proposed yesterday.

That is all I have to say.

Representative S'rokes. Dr. Wiley, I would like to ask you a question. Will you please state to the committee what dewree of heat will destroy the tuberculosis germ, in the opinion of chemists?

Dr. WILEY. It takes a temperature of from $1500^{\circ}$ to $160^{\circ} \mathrm{F}$. to surely destroy the pathogenic germ of consumption.

Representative STrokEs. Have you any information as to what degree of temprature is reached in the production of oleomargarine, or the preparation of its elements?

Dr. WILEY. I can state in regard to nentral lard, because I have often seen that made. I think the temperature there is probably high anough to kill the germ. I do not know what temperature is used in preparing oleo oil. I am not acquainted with that.

Representative STokis. One other question. Is it not a fact, pretty well demonstrated through the Burean of Aninal Industry, that the dairy herds of the comntry are largely impregnated with tuberculosis germis?

Dr. WiLEY. I think that is well recognizerl everywhere-that tuberculosis is very prevalent among our dairy cows. 
Representative STokES. Another question. Is it equally so among the beef herds?

Dr. WILEY. I could not say in regard to that. I do not think it is.

Representative STOKES. Is it not true that the beef herds, however, before slanghtering, are subjected to an inspection by the Government thronglı the Burean of Animal Inclustry?

Dr. WilEY. Not being connected with that Burean, I could not say positively.

Representative STokEs. That is a fact which has been developed liere.

Dr. WILEY. Yes, sir; I think they are all inspected.

Representative STOKES. Another questiou: Do you know whether or not they are inspected after slaughtering?

Dr. WILEY. I know that pork is inspected for trielina. I think beef cattle are inspected also after slaughtering.

Representative STOKES. They are inspected also?

Dr. WILEY. Yes; that is my impression.

Representative STokEs. Then in the event that an animal here and there should eseape these tests, and should still contain tuberculosis germs, is it not probable that that danger would be eliminated in the process of manufacturing oleomargarine, which is subjected to the high temperature you have mentioned?

Dr. WILEY. The temperature required in rendering the tat and preparing the oil would be high enongh to kill most of those germs, I should think.

Representative STOKEs. One other question: Is it possible, in the manufacture of butter from the cow, in the ereameries, to eliminate those germs if the germs exist in the herd?

Dr. WiLEY. Not by the application of heat, because that would ruin the physical properties of butter.

Representative S'rokEs. Is there any other process within your knowledge?

Dr. WILEY. Nothing exeept the addition of preservatives, which is equadly objectionable.

Representative CoONEY. I want to ask you this question, Dr. Wiley: If the answers given by you to Mr. Stokes's questions are correct, wonld it not follow that it is much safer and healthier for a person to confine himself strictly to eating oleomargarine and let creamel'y butter entirely alone; does that not necessarily follow from the questions and answers?

Dr. WILEY. If you are to avoid danger from infection of tubereulosis, I think that would be true.

Representative Neville. Professor, would not that apply to every other food product in just the same way?

Dr. Wiley. Yes, sir. There is no food product which does not at some time carry dangerous germs. If we applied that rule we would exelude all food.

Representative Cooner. As a matter of faet, then, it would be much better to direct the attention of this bill to creamery butter than to eleomargatine?

Dr. IVILEY. As far as tuberculosis is concerned, undoubtedly.

Representative BAILEY. Dr. Wiley, let me ask you this question: Do you consider oleomargarine a wholesome article of fool.

Dr. WILEY. I do.

The Acting Cinamian. I would like to ask Mr. Lavery to wliat temperature he heats the milk and cream used in the manufacture of his butterine? I believe you stated, Mr. Lavery, that you used milk and cream? 
Mr. Lavery. Tes, sir.

The Acring Chambinan. You sterilize it?

Mr. LAVERY. We to not sterilize it; no, sir. We handle our milk ancl eream exactly as a creamery would for making butter. In fact, we have a graduate of the Madison (Wis.) Dairy School looking after our milk rooms; and of conrse we set that milk at night to ripen for the next day's use. It all depends on the condition of the weather as to how warm that milk is when it is set-from $65^{\circ}$ to $75^{\circ} \mathrm{I}$ would say.

The Acting Chairman. Pint you eal not heat it up to $140^{\circ}$ or $150^{\circ}$, as Dr. Wiley says cream or milk must be heated in order to destroy these germs?

Mr. LAVERY. No, sir; we ean not. If we should do that we would cook it, and spoil it.

Mr. MILlER. I will say, just here, to settle this question of the temperature, that our oleo oil is heated up to $150^{\circ}$ or $1600^{\circ} \mathrm{F}$. In making oleo oil, we lieat it to $1500^{\circ}$.

I wonld like to ask Dr. Wiley a question just there. Dr. Wiley has male the statement here that butterine eontains 15 to 20 per cent stearin. I wonld like to have him state to the committee that that stearin in itself is perfectly wholesome and healthy, because all oils contain stearin. Stearin is simply the heavy borly in all oils. I think, perhaps, the commission liave a wrong impression of the article of stearin; and if $\mathrm{Dr}^{2}$. Wiley will kindly explain to them just what stearin is in oil, I think it will leave a better impression.

1)r. Wiley. It is fully explained in this doeument, which I will put in my evidence.

Mr. Millek. It is?

Dr. Wiley. Tes.

Mr. MILLkR. Then that is all right.

Mr. Lavery submitted the following peoition:

Mr. Chalriax and Gentlemen of the Commitee on Agriculture: We, the undersigned merchants of Kansas City, herewith wish to aftirm that we are provilled with a Felleral retail license for the sale of oleomargarine. We nuderstand finly all the laws regulating the sale of this product, and do comply with them in every particular.

At no time have we sold oleomargarine for butter or allowed packages of same to leave onr respective places of husiuess withont being stamped in accorlance with the internal-reienue regulations.

In our opiuion, the passage of House of Representatives bill No. 3717, known as the Gront bill, wonld be an iujustice to us, as it would take away our light to buy and sell a legitimate article of commerce, and one which the demands of our trade justify ns in handling.

It wonld work a bardship on hundreds of Kansas City laboring men and their f:unilies who are regnlar purchasers of oleomargarine.

IVe therefore respectfully request that you consider our protests when passing upon the proposel measure.

Reinharlt Bros., M. Quinn, M. Ross, A. Denebeim, A. L. Shauklin, C. S. IBrigham, A. R. IIoss, J. H. Duncau, E. Klein, Wm. Burnett, Elstein Bros., Rice \& Gibson, R., E. E. Shafer, H. F. Schaible, H. hoberts' Sons, C. E. Robiuson, M. Mrers, M. Klein, Jones Dry Gonds Co., Silveruan Bros., A. I. Chnrchtler, R. H. Williams, H. Stelling. Jos. Smart, Davidl smart, D. A. White, J. D. Quinn, W. Barrett, C. P. Jehn, Matthews ('ooperative Grocery Co., by M. W. Matthews, Manager., A. H. Kimpunir, Walt H. Mailand, E. H. Rorlekopf, L. T. Bush \& Co., 13lum's Parlor Market, Aaron P. Duncan, Theo. Tegren, Sammel Stewart, L. H. Heury, C. A. Pettit, N. Hoogland, Otto Anderson, J. L. .lones, B. M. White, L. G. likike, Geo. J, Clansen, Jimes Maymre, Hartford Bros. Frovery Co., N. R. Poler, F. F. Brandt \& Co., L. T. Franks, McHale of Co.. A. Ofner, A. H. Schuyler, W..J. Donst, II. A. Griswold, Jones \& Irvin, M. H. Brotherson; L. Benson, Tucker \& Company, Headley \& Moore, W. A. Yearnshaw, C.W. Green. S. D. Hustead, M. J. Marley, J. C.Tenuier, Lilles d C'lark, Frank Forsberg, L. H. Tennier, F. J. Koch, J. C. Fisher, Peter Goos

(The eommittee thereupon, at 12.15 o'eloek p. m., adjourued.) 
Oleomargarine

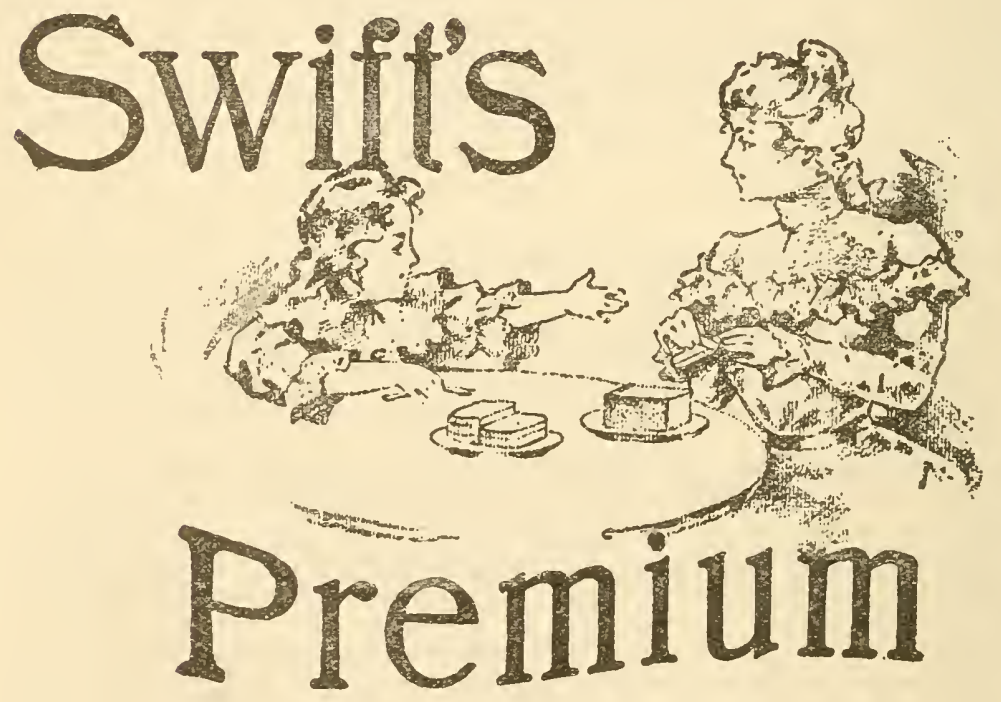




\section{OLEOMARGARINE

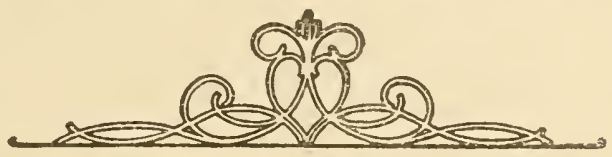 \\ Swift's Jersey}

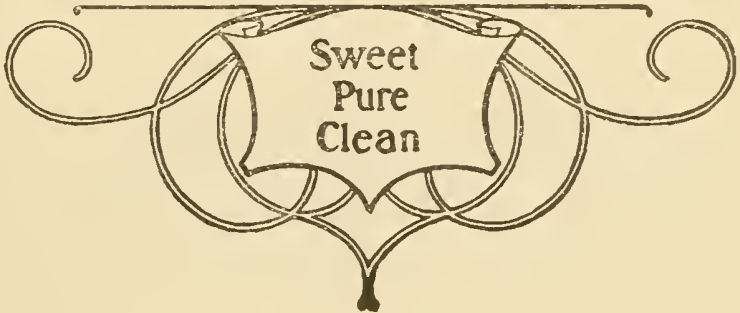

\section{OLEOMARGARINE}

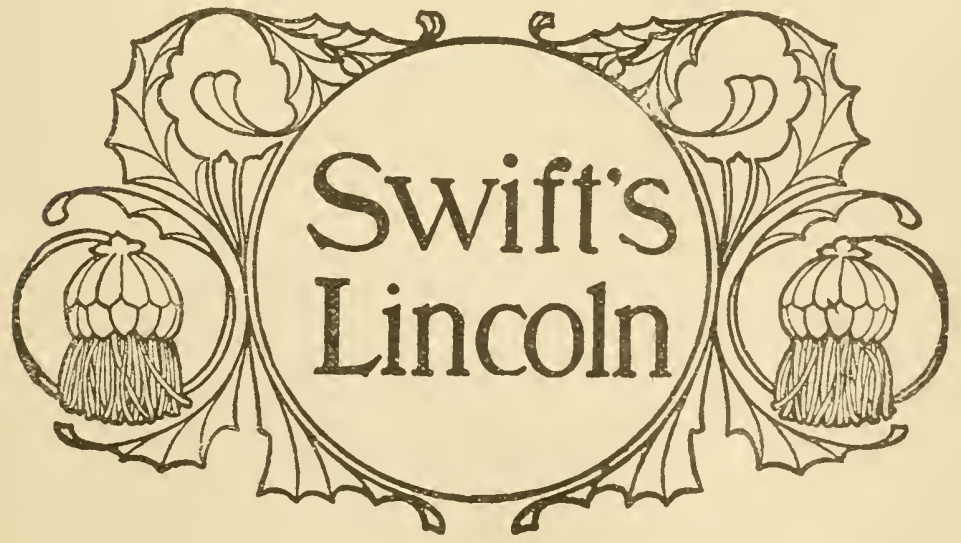



SUMMARY OF EVIDENCE INTRODUCED IN SUPPORT OF II. R. 3717 (THE GROU'T BILL) BEFORE THE SENATE COMMITTEE ON AGRICULTURE AND FORESTRY.

COMPILE1) BT

CHARLES Y. KNIGHT,

Secretary National Dairy Lnion,

AT THE REQUEST OF THE COMMITTEE. 


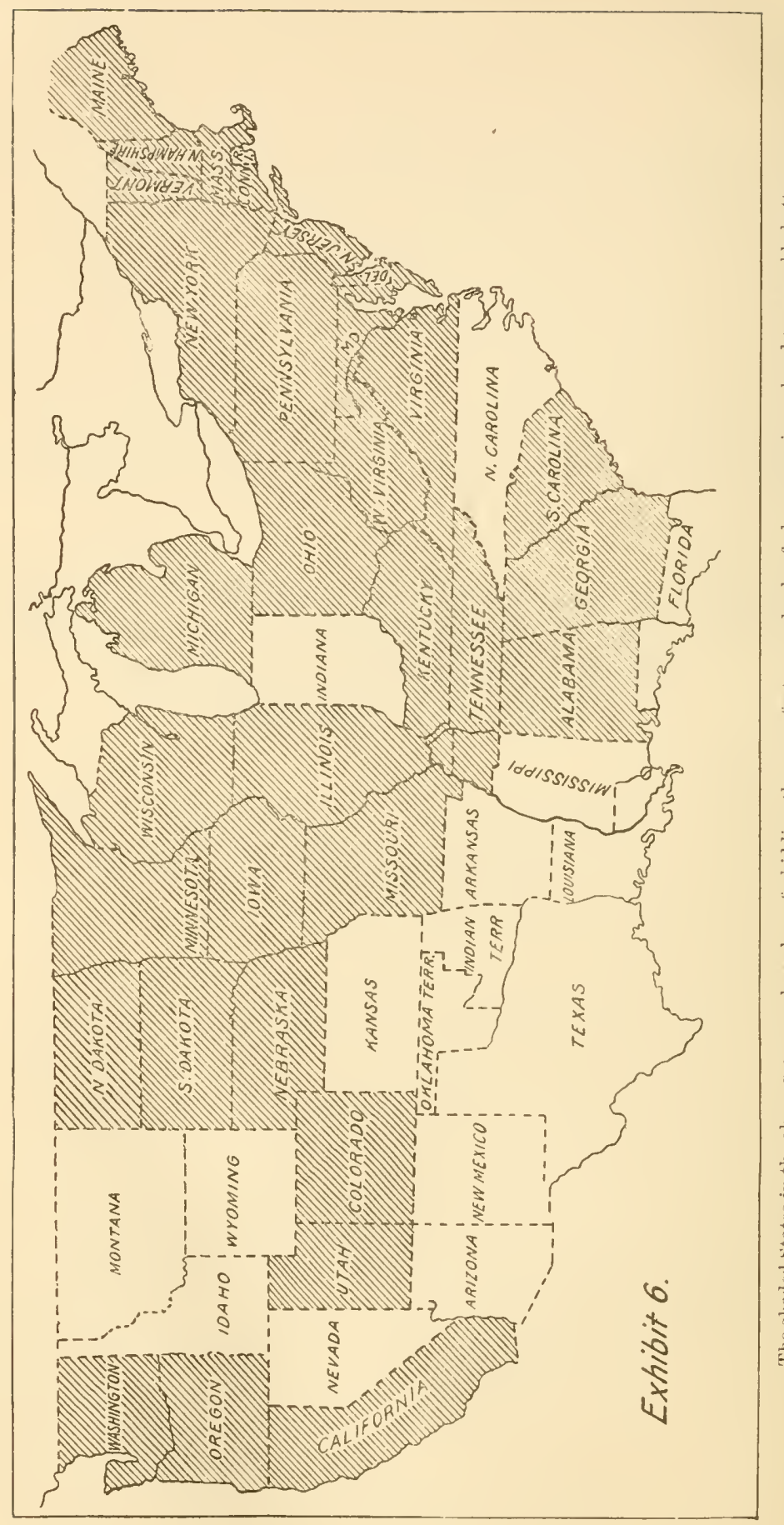




\section{SUMMARY AND REVIEW OF EVIDENCE.}

\section{Appearing in behalf of the Grout bill were:}

Hon. James Wilson, Secretary of Agriculture.

Hon. S. C. Bassett, president Nebraska State Board of Agriculture.

Hon. John Hamilton, secretary department of agriculture of Pennsylvania.

Hon. G. L. Flanders, assistant commissioner of agriculture, New York.

Hon. F. J. H. Kracke, assistant commissioner of agriculture of New York.

Hon. H. C. Adams, food commissioner of Wisconsin.

Hon. J. C. Blackburn, food commissioner of Ohio.

Hon. IV. WV. Grout, of Vermont.

Hon. W. D. Hoard, president National Dairy Union.

Hon. James A. Tawney, of Minnesota.

Chas. Y. Knight, secretary National Dairy Union.

Luther S. Kaufman, attorney for Pennsylvania Pure Butter Protective Association.

John H. Habacker, butter merchant, Philadelphia.

Isaac W. Cleaver, retail merchant, Philadelphia.

Joseph C. Sharpless, farmer, Westchester, Pa.

E. D. Edson, butter merchant, Philadelphia.

W. F. Drennen, butter merchant, Philadelphia.

Thomas Sharpless, farmer, Chester County, Pa.

Isaac W. Davis, president Produce Exchange, Philadelphia, Pa.

Samuel Jamison, wholesale butter dealer, Philadelphia, Pa.

C. H. Royce, from Norton's farm, New York.

J. J. Dillon, editor Rural New Yorker.

E. B. Norris, master of New York State Grange, and representing National Grange. W. A. Rogers, from Watertown, N. Y., Produce Exchange.

Summerfield B. Medairy, president Baltimore Pure Butter Protective Association. James Hewes, president Baltimore Produce Exchange.

Food commissioners not present, but filing letters of approval of the Grout bill wereHon. Elliott O. Grosvenor, food commissioner of Michigan.

Hon. B. P. Norton, food commissioner of Iowa.

Hon. J. B. Noble, food commissioner of Connecticut.

\section{LAWS OF THE STATES.}

The strongest evidence we offer Congress of our claim of protection against a counterfeit article is the fact that thirty-two States, with over $60,000,000$ of the $74,000,000$ population, have condemned the article we seek to tax 10 cents per pound through its absolute exclusion from commerce in their borders, so far as State laws can do so.

The map upon the opposite page appears on page 557 of the committee testimony, showing the States which have passed these laws absolutely forbidding the sale under any condition of oleomargarine colored in semblance of butter, and Montana has levied a tax of 10 cents per pound upon such article.

A synopsis of these laws, prepared by the Agricultural Department of the Government, will be found in the testimony before the House Committee on Agriculture, beginning at page 593.

$$
\text { S. Rep. } 2043-52
$$


The constitutionality of such laws, forbidding the manufacture and sale of oleomargarine made in semblance of butter, has been upheld in every supreme court the matter has ever been brought before, including Massachusetts, New York, New Jersey, Maryland, Ohio, Missouri, and the Supreme Court of the United States in the case of Plumley $v$. Commonwealth, handed down December 10, 1894, and reported in United States, 155. The State cases are: New York, People $v$. Arenburg, 105 N. Y., 123, 129, 130; supreme court of Maryland, McAllister $v$. State, 72 Maryland, 390; supreme court of Maryland, Pierce $v$. State, 63 Maryland, 596; supreme court of New Jersey, Waterbury $v$. Newton, 21 Vroom (50 N. J. Law), 534-537; supreme court of Missouri, decision handed down in 1897, and Ohio case in April, 1900.

Yet despite the strong support these laws receive in the upper courts, during the fiscal year ended. July 1, 1899, the Treasury Department figures show that $62,825,000$ of the $83,000,000$ pounds of colored oleomargarine made were sold in violation of the laws of these States (House evidence, p. 20), and that of the 9,068 retail dealers doing business in the United States for the year ending July 1 last, 7,073 were violating the various anticolor laws of the United States and only 1,995 were doing business as permitted by the laws. Of the $107,000,000$ pounds of oleomargarine produced in the United States for the year ending July $1,1900,66,820,196$ pounds were produced in States which prohibit the manufacture and sale of colored oleomargarine, and 40,240,859 pounds were produced in those States which permit such production. (Senate evidence, p. 463.)

\section{FRAUD AND LAWLESSNESS.}

The most important testimony in connection with the measure now before the committee, however, we believe to be that which goes to show that the same condition exists to-day that existed when the dairymen came before Congress in 1886 and asked for national legislation to stop the sale of oleomargarine as butter, securing what at the time was thought to be permanent relief.

The original basis of a demand for national legislation was that oleomargarine was being sold to the public as butter, to the prejudice of the public and the financial loss of those who produce and deal in the pure article of butter. We believe that the evidence which we have presented before this committee, although only an infinitesimal part of what could easily have been adduced, has proven that the same conditions exist to-day.

In reviewing this evidence, we shall begin with the city of Chicago, because it is at this point, as shown in the statement of the writer, on page $463,2,691$ of the 9,068 retail dealers in oleomargarine of this country were doing business at the end of the last fiscal year, June 30 , 1900 , and the Gorernment reports show that in that State was sold almost 25 per cent of all oleomargarine produced in the United States the year previous. It is in the city of Chicago that $46,500,000$ of the $107,000,000$ pounds of oleomargarine made in the United States were manufactured last year. It is here where two leading firms make from 25 to 33 per cent of all the oleomargarine produced in this country.

On page 461 will be found the following as the opening of my statement before your honorable body:

Mr. Chairman and gentlemen, I want to open this matter by reading a statement which is a copy of a letter which I received from a retail grocer's clerk in the city of 
Chicago some time last year. I am familiar with the gentleman's name, but I have not put it in here. I will vouch, however, for the condition, and prove it to you, but I merely read it as an introduction:

"During the past twenty-two years I think I have worked in nearly every firstclass grocery in Chicago, and I can truthfully say that eight out of every ten have been and are still selling butterine for pure butter. I recently was employed in one of the largest groceries and markets on one of the most prominent streets of the city. During the time I was employed there we never sold one pound of butter, for we never had it in the house to sell. We clerks would talk among ourselves about it, and would often compare notes with other clerks, and to satisfy myself I made quite a canvass of all the stores in the mile and found only one that did not impose on its trade."

Gentlemen, from experience I can vouch for the accuracy of that statement, and I want to give you a little experience and I propose to demonstrate it right here.

And on page 469 the following, in a letter written me by J. H. Monrad, assistant food commissioner of the State of Illinois, will further substantiate what this clerk says:

DEAR SrR: In reply to your inquiry, I beg to say that it is my impression that about 75 per cent of all the oleomargarine retailed in Chicago is sold as butter.

After having heard these statements before your committee, certain oleomargarine makers questioned their accuracy in the public prints of Chicago, whereas the matter was taken before the Chicago Butter and Egg Board, an organization of the wholesale butter and egg interests of Chicago, and the following conclusions mailed the writer, which appear in full on pages 554 and 555 of the printed report:

\section{Chicago Butter and Egg Board, Chicago, January 12, 1901.}

At the regular meeting of the Chicago Butter and Egg Board, held January 12 , 1901, the following statement was presented by George IV. Linn, president of the Illinois Dairy Union, and generally discussed by the members of the board, and by a unanimous vote it was declared to be the sentiment of the individual members, as nearly every member has been familiar with the unfair and unlawful methods pursued by the dealers in oleomargarine for years.

Jонм W. Low, President.

Charles E. MicNeill, Secretary.

The statement alluded to follows, and was signed by eighteen leading butter firms of Chicago:

Chicago, January 12, 1901.

Whereas we are informed by newspaper reports and other sources that the manufacturers of oleomargarine are inclined to deny the assertion of the officers of the National Dairy Union that the retail trade sell oleomargarine almost exclusively as butter; and

Whereas from our long experience in competition with this class of goods we have repeatedly and continually been brought face to face with the fact that fully 75 per cent, and possibly as high as 95 per cent, goes to the consumer as pure butter, we, as an organization and as individuals, desire to go on record as corroborating the statement made in that particular by the officers of the National Dairy Union.

The following will be found also on page 555, from the Daily Trade Bulletin, the ofticial price current of the Chicago market, for January 12, 1901:

It is generally admitted by dealers that the demoralized condition of the butter market at present is due to the use of butterine. Dealers estimated that at least 75 per cent of the retailers are selling butterine.

Such has been the condition in Chicago for years. State laws had proved wholly inadequate, but during the summer of 1899 your orator, as secretary of the Ulinois Ditiry Cnion, concluded to make an extreme effort to stop some of this fraud, and employed Mr. Hugh V. Murray 
as counsel. Under the instructions of the Illinois Dairy Union Mr. Murray sent the following letter to every licensed olemargarine dealer in the city of Chicago, which, with further details, appears on page 465 Senate testimony:

\section{[Office of H. V. Murray, attorney at law.]}

Chicago, Ill., July 29, 1899.

Dear Str: I have been employed by the Illinois Dairy Union to prosecute any cases of violation of the dairy laws of this State which may result from the arrest of any dealer selling oleomargarine when butter is called for. As you probably know, a commission, consisting of a food commissioner and eight assistants and inspectors, was provided for by the late legislature, whose duty it is to enforce these laws. The commissioner has been appointed, and until he has appointed his assistants and gotten to work the Illinois Dairy Union's inspectors will look after the protection of consumers of butter and see that those who sell them oleomargarine for butter are prosecuted under the State laws, and also reported to the Internal Revenue Department as violators of the internal-revenue laws. I herewith inclose extracts from three State laws. These laws are not tied up in the courts, and the oleomargarine manufacturers will not place themselves in the light of protecting those who sell oleomargarine for butter, although they may consistently fight the law forbidding coloring, which has not yet been passed upon by the supreme court.

If you sell oleomargarine this year rest assured that the State food commissioner and the Illinois Dairy Union will see that you are not permitted to sell it as butter. Respectfully, yours,

Hugh V. Murray, Attorney for Illinois Dairy Union.

This letter should be read carefully. It was the intention of the writer to convey clearly to the retailer two things:

First. That the prosecutions would be for the sale of oleomargarine as butter, and not for the sale of oleomargarine as oleomargarine colored in semblance of butter, as prohibited by a law passed two years previous, but at that time tied up in the courts.

Second. That the prosecutions would be begun under the laws which were not tied up in the courts, thereby giving the manufacturers no excuse for defending such prosecutions without coming out in the open light and defending fraud.

These letters created consternation in the ranks of the dealers. The sale of pure butter increased immensely, and the sale of oleomargarine decreased correspondingly. The manufacturers of oleomargarine were in desperate straits to save their business, and on August 2 the following letter, printed on page 465, the original of which was displayed before this committee, was mailed by William J. Moxley, claiming to be the largest maker of oleomargarine in the United States:

[William J. Moxley, manufacturer of fine butterine, 63 and 65 West Monroe street.]

City.

Chicago, August 2, 1899.

DeAr SrR: Our attention has been called to two circulars which have been mailed to you-one signed by Hugh V. Murray, an attorney, and the other by Charles Y. Knight, editor in chief of a periodical without subscribers named the Chicago Dairy Produce. The circular bearing Mr. Knight's name bas at its head an imposing lot of names, gentlemen whose aim it is to prevent the manufacture and sale of butterine, so that the butter trust might be enabled to get from 30 to 40 cents a pound for butter, depriving, as they would, a great many of the industrial classes from being able to use butter through its excessive price.

With the hired attorney, who is earning his fee, we have nothing to say, only to inform you that these gentlemen are trying to ring in a bluff. You will notice in their circulars that by insinuations they would have people believe they represent some official authority. The Internal Revenue Department looks after their own 
business and the State after theirs, and should this so-called Dairy Union interfero with your business in the way of prosecution as to the State laws, we hereby guarantee you protection to the extent of paying all fines, costs, etc., until the color law is decided unconstitutional in the supreme court of the State of Illinois, and will further, on receiving complaint, take such action for damages as will make it unpleasant for some of those who are attempting to interfere with your and our own legitimate business.

We were under the impression that the severe censure they received from the judges during their filibustering of last year would have been suflicient for all time, but have been informed that to be successful in obtaining money from farmers and butter men a few circulars with imposing headlines are required.

We strongly recommend you to pay no attention to those circulars. We have always been in a position to protect our customers from injustice aud blackmailers, and will be ever at your service should you require our aid.

Respectfully, yours,

WM. J. Moxlex.

Jn the following day the following circular was issued by Messrs. Braun \& Fitts, whose vice-president, Mr. Jelke, has been a constant attendant at these hearings, and is printed on page 466 :

Every licensed butterine dealer in Chicago has received circular letters from the secretary and attorney for the Illinois Dairy Union, promising all sorts of trouble to dealers in butterine (that honest and pure article of food). Well, now, don't you believe a word of it; there is a law against blackmailing, and we want now and here to go on record to the assertion, as an aftidavit, that we shall civilly and criminally prosecute any man or party of men interfering unlawfully with the butterine business in this or any other State. We know exactly where we stand; we are properly advised on the subject, and now we make you a "fair offer:" "Handle our goods as you always have; we in turn promise and guarantee full protection against the State law (which has been declared unconstitutional) to the extent of paying cost of prosecution, fines, and paying all costs pertaining thereto." In declaring the law unconstitutional one of the judges stated to the effect "that the butter ring were, in his opinion, liable to prosecution to recover damages done an honest industry." Fair enough, isn't it? Renew your efforts, and be assured that we will be prepared to fight any number of rounds in any kind of a legal fight to the finish. Handle our butterine and be safe.

True to its promise, the Illinois Dairy Union began prosecutions in earnest. The arrests were in every instance upon charge of selling oleomargarine for butter.

And as true to their promise these manufacturers sent their attorneys and representatives into court to defend these cases upon technical grounds.

The attorney who represented the oleomargarine makers was Roy O. West, with Worth E. Caylor as assistant or trial lawyer, the former appearing in court only once or twice. The connection of Mr. Caylor with the oleomargarine makers is clearly established on page 462 , in a reproduction of an extract from a pamphlet issued by Moxley, in which he speaks of Mr. Caylor as their attorney in these cases.

The special representatives of the oleomargarine makers at these trials were William Gleeson, for Moxley \& Co., and F. M. Lowry, for Braun \& Fitts, both occupying positions of confidence and trust with their respective concerns. These two representatives looked after the comforts and convenience of those under arrest and went their bonds. The prosecution made its appearance in court nine times, and each time the bonds of these defendants were renewed by the representatives of Moxley and Braun \& Fitts.

The printed record (page 467) will show that Mr. Jelke denied before the committee these charges, and stated emphatically that Mr. Lowry did not go on the bonds of any retailer charged with selling olcomargarine for butter. On page 552 will be found a record of the produc- 
tion before the committee by your orator of the original bonds signed by said Lowry for the appearance of some of the most notorions of these swindlers in the city of Chicago, as well as the production of bonds signed by Moxley's man, Gleeson, the charges against each defendant appearing upon the bonds, and reading, "Selling oleomargarine as butter."

In these cases the facts set forth were never denied. They were defended purely upon technical grounds, the claim being set up that the statutes under which they were bronght had been repealed by implication by a later general food act, and were unconstitutional. The Illinois Dairy Union expended more than $\$ 1,600$ in an effort to secure a conviction. A justice of the peace took it upon himself to adjudicate the question, and decided in favor of the defense upon this complicated point, and after that we could do nothing in the lower courts, although we carried the matter to the supreme court in mandamus proceedings in an effort to compel the issue of warrants under a law that would enable us to proceed. The jndgment of the supreme court was that the issuance of a warrant was a judicial act, and that a judge could not be compelled by mandamus to move judicially. These facts are all set forth in the testimony before the House committee.

Their very unique claim of unconstitutionality is set forth on page 467 , which goes to show that they make the same claim about every law that is attempted to be passed to regulate the sale of their product, i. e., that it will prove prohibitory. 'This is from their brief, filed in the cases alluded to in the foregoing:

It is very evident that a man who sells an article can not know the proportions that any adulterant enters into the butter, unless he mixes or manufactures it. Nere hearsay from the person from whom the seller purchases the article would not be evidence of the correct proportions or ingredients, so as to relieve the seller from any liability. The labeling by the manufacturer or the mixer of the article would not bind the seller with the true knowledge of the constituents of the article sold.

Manifestly it would be impossible for the retailer or seller to make a chemical analysis of every article of this kind that enters his place, because it would make such additional expense that it would prohibit the sale of the article. If it would prohibit the sale of the article the statute is unconstitutional.

In explanation of the above it might be stated that the law under which these prosecntions were brought also required the stamping upon each retail package the ingredients and proportions thereof which go to make up the mixture. What they claimed here was utterly impossible to do is being done in Ohio every day, samples of which stamps were exhibited before this committee by Mr. Schell.

If further evidence were needed of the backing up of dealers in the sale of oleomargarine as butter, a notorious case occurring right here in Washington a few years ago might be cited, inasmuch as it is a matter of record in the courts and with the Attorney-General.

Joseph Wilkins was of the firm of Wilkins \& Co., of Washington, whose brother, Walter E. Wilkins, comprised the company, the latter now being president of the new Standard Butterine Company of this city.

Joseph Wilkins and his clerk, Howard Butler, were, after months of surveillance, detected removing the marks of identification and revenue stamps from a carload of oleomargarine in Philadelphia, the practice being to remove the marks in that city in the railroad yards and send the goods here to be sold as pure butter.

Joseph Wilkins and Howard Butler were sentenced to jail, with fines. 
An attempt was made to pardon them. The matter was brought before President McKinley, who referred it to Attorney-General Grigg's. The latter wrote the President as follows, showing up the character of such violations, which letter appears between pages 612 and 615 in the House testimony:

The petitioners, Joseph Wilkins and Howard Butler, were convicted of fraudulently removing labels from packages containing oleomargarine in violation of the act of August 2, 1886, and were sentenced on March 17, 1898, as to Wilkins, to imprisonment for six months and to pay a fine of $\$ 1,500$ and costs, and, as to Butler, to imprisonment for four months and to pay a fine of $\$ 500$ and costs.

The judgment of the district court was subsequently affirmed in the circuit court of appeals, to which it was taken by the defendants, and an application subsequently made to the Supreme Court for a writ of certiorari was denied. Thereupon, in November last, the petitioners were committed to serve their sentences of imprisonment.

The grounds of the application for a pardon as to Joseph Wilkins are that he has a wife and child, and that each of the prisoners is of good reputation and standing, and has never been convicted of any other crime. They request, in view of the humiliation and disgrace already suffered by them, as well as of the heavy fines imposed, and in view of their good reputation and standing in the community, and of the fact that no revenue has been lost to the Government, that that portion of the sentence providing for imprisonment be remitted.

The records of the office of internal revenue show that Wilkins has been a persistent violator of the oleomargarine laws, and that prior to the present prosecution he has escaped punishment by means of money payments in compromise. The records show that on December 14, 1893, Wilkins filed a proposition to pay $\$ 2,100$ and costs in compromise of all liabilities, civil and criminal, incurred in the First district of Illinois, for selling oleomargarine as butter, and by violating various sections of the law relating to wholesale dealers in oleomargarine. This offer was accepted December 26, 1893.

A pril 4, 1895, less than a year and a half after the last settlement, Wilkins again filed an offer of compromise, agreeing to pay $\$ 2,000$ in settlement of his liabilities for alleged frauds under the oleomargarine law committed in connection with a firm in West Virginia. This offer was also accepted.

A year later, April 2, 1896, Wilkins was indicted with another in the District of Columbia for selling unstamped oleomargarine. On June 20, 1896, he offered to pay $\$ 1,000$ in compromise, but this being rejected the case went to trial and the accused was acquitted. There are three separate indictments against him pending now in the District of Columbia for selling oleomargarine in unstamped packages. These indictments were found January 4, 1897.

The offense of which the petitioners are now convicted was committed December 20,1896 , two days after the verdict of acquittal in the trial in the District of Columbia. The petitioners were discovered by a revenue agent in the act of scraping off the stamps, marks, and brands from packages of oleomargarine.

In connection with the present case an offer to pay $\$ 8,000$ and costs in compromise was made, but rejected February 23, 1898, and thereupon the case went to trial with the result above stated.

It is obvious that the business in which Wilkins was engaged must have been one of great profit, otherwise he could not have afforded to make the very large payments in compromise which he did make or offered to make.

That he was aware of the fraudulent and dishonorable nature of the business in which he was persistently engaged appears from his own statement, made in a letter addressed to the Commissioner of Internal Revenue October 31, 1893, from which I quote the following:

"Having a thorough knowledge of the butterine business, and knowing the possibilities of that business, if worked in certain directions and ways, I determined to try it, having the desire to make large gains quick. * * * After I found that some of my goods had been seized in Cincinnati, I settled up my business as quickly as possible, and did not ship any more. I came to you voluntarily, and I sincerely trust you will deal with me as leniently as the law will allow you, promising you faithfully that no such thing as this will ever occur again with me, and if I am allowed to make a request, I ask that I be allowed to settle without having the western houses know anything of my doings, because I know it was very dishonorable in me to do as I have done, and if I am allowed to go along in life without the public knowing of my misdeeds, then I feel sure that I can make a new start in some way that is entirely honorable. I realize full well that $I$ could have in some way kept away 
from the hands of the law, but to do this would mean the staying away from home and relatives, and, above all, the constant strain on my mind, and with the sense that $I$ had done a great wrong I could not stand it. Trusting that you will allow me to settle immediately, which will allow me to drift back into the channels of straight, legitimate business soon, I remain."

Notwithstanding that the authorities were induced to settle with him upon his promise of abstention in the future from similar violations of the law, it appears that he straightaway resumed his operations, undoubtedly taking courage from the success with which he had compromised the first offenses in which he had been discovered.

It is absolutely clear that for such a persistent violator of the law something more than a money penalty was essential. The sentence of imprisonment imposed in this case was peremptorily required by the circumstances. Nor can I say that the sentence was anything but moderate. It is less than the average sentence imposed upon persistent violators of the internal-revenue laws relating to the distillation of spirits, and much less than the ordinary sentences imposed for violation of the lawg against the use of the mails for fraudulent purposes.

Not only is the dignity of the law to be upheld against such persistent violations, but the public is entitled to be protected by the salutary influence of stern punishment against fraud and deception such as were practiced in this case, by means of which the petitioners were enabled to impose upon innocent persons as genuine butter a counterfeit article which, if sold for what it really was, would have brought very much less in the open market.

I do not think that the sentences should be interfered with.

Who is this man Wilkins?

As soon as detected in the act of removing oleomargarine marks at Philadelphia, so that his Washington business was no longer profitable, being indicted by the Federal grand jury, Wilkins was brought to Chicago by Messrs. Braun \& Fitts, the largest manufacturers of oleomargarine in the country, and given the responsible position of directing the salesmen, which class have for years coached retailers in the art of swindling the public.

Wilkins held this position as confidential man with Braun \& Fitts during the time his case was being fought in court and the effort being made to pardon him, and went directly from their employ to prison at Philadelphia.

During the time when Wilkins's pardon was being most actively sought by the influence of the oleomargarine manufacturers two other swindles of even as great magnitude, and of the same character, were unearthed. Not, however, by the Internal-Revenue Department, but by the agricultural department of New York.

These swindles were gigantic in their proportions. The details were excellently set forth in the Times-Herald of Chicago, in its issue of Sunday, February 11. The Times-Herald's account of this swindle follows:

Seek fraud in "oleo"-Suspicious of prime butter-Revenue agents claim to have unearthed a swindle on the Government-Shipment seized and arrests made-More to follow.

Government officials from three States are investigating what they believe to be the largest oleomargarine fraud in the history of the local internal-revenue department. The work of the officers has resulted in the arrest of John F. Rooney, who has had a preliminary hearing before Commissioner Mason and who is now on bonds of $\$ 2,500$.

Rooney is charged with selling oleomargarine as butter. The business was conducted in the names of the Aurora Produce Company and the Elgin Produce Company. Checks produced in evidence upon the preliminary hearing tend to show that Rooney and his associates bought as high as $\$ 1,000$ worth of the product daily and shipped it to customers in several States who had purchased it in the belief that it was high-grade butter. It is charged that in the three or four months that Rooney has been operating he has disposed of between $\$ 80,000$ and $\$ 124,000$ worth of oleomargarine, upon which he made at least 40 cents on the dollar. Rooney's 
arrest occurred nearly three weeks ago at the Ceylon and Japan Tea Company's place, 700 West Forty-seventh street.

REVENUE AGENT AT WORK.

Since Rooney's arrest several of the cleverest special agents in the employ of the Government have been further investigating in the belief that certain manufacturers of oleomarcarine were back of Rooney. It is also believed that had the scheme proved safe the fraudulent dealings would have been increased to a point limited only by the ability to get customers.

Last November the Agricultural Department learned that large quantities of suspicious butter were being reshipped into eastern New York, and IV. H. Butcher, of Troy, was detailed to look the matter up. On November 27 a consignment of 623 tubs was found in J. B. Wattles's store in Buffalo. Samples were taken and the consignment allowed to go. Agents followed it to Chicago, where the Wabash officials were told that the shipment here was a mistake, and that the stuff should have been sent to Liverpool. It was reshipped and the Government agents seized it in Detroit. This lot is said to have been sold by Edward Marhoffer, of the Elgin Produce Company, 6242 Halsted street. O.S. Martin, special agent of the internal-revenue department for Indiana, was sent to Chicago, and found that large quantities of oleomargarine had been shipped to John Schmitz, of Milwaukee. The latter told the agent that a man representing the Aurora Produce Company had called to see him and had said that his concern had a lot of high-grade butter which they could sell at less than prevailing market prices. Schmitz had at various times purchased several hundred dollars' worth from the concern in the belief that he was buying good creamery butter.

SCHMTTZ PAYS HIS LICENSE.

Schmitz was a witness before the commissioner and has since paid the Government $\$ 480$ which is required for a wholesale oleomargarine license. The fact that he did not know he was selling oleomargarine did not cut any figure with his being liable for the license money. The department here has a list of forty or fifty dealers who will have to pay $\$ 48$ for a retail license for having bought "prime butter" of the concern.

Agent Martin went to Aurora after seeing Schmitz and began looking for the Aurora Produce Company. He learned that a man named Rooney had rented a box at the post-office with instructions to have placed in it all his mail and that addressed to the Aurora Produce Company. Later he had given up the box and left instructions to have his mail forwarded to 196 LaSalle street. At this place Attorney Maurice Langhouse told the officer that Rooney had asked him to permit his mail to come there, and had paid him $\$ 10$. Every day a boy came in and, placing the mail in another envelope, forwarded it to Rooney, at 700 West Forty-seventh street.

The agent's next move was to rent a room opposite the tea company's store. He soon discovered that wagons from Braun \& Fitts, oleomargarine manufacturers, made almost daily deliveries of oleomargarine at the store. There the stamps would be removed and Expressman J. W. Foley would take the stuff to various freight offices for shipment.

BEIZURES AND ARRESTS.

When the evidence was conclusive seizures were made and a warrant sworn out for Rooney's arrest. It was learned that his brother, Elmer K. Rooney, was in the deal, and a telegram was sent to Joliet, where he happened to be selling "butter," to cause his arrest. Some one gave him timely warning and he fled. It is said that Edward Marhoffer, George E. Brannen, and a man named Casey have also disappeared.

In connection with Rooney, the officers arrested Patrick F. Butler, who worked at the Forty-seventh street place. His arrest was due to the fact that all checks in payment for the oleomargarine were made out to Walter F. Butler, and a bank clerk identified Patrick F. Butler as the man who drew the money on them. The evidence was insufficient to connect Butler with the fraud and he was discharged.

The carload of oleomargarine seized at Detroit is valued at $\$ 5,000$, and would indicate that the fraudulent dealings were even more extensive than appears from the evidence attained thus far. It is said that the local department is preparing to make other arrests in a few days, although the warrants have not been sworn out. W. J. Moxley, who sold Rooney small amounts of oleomargarine; John Dadie, and former Iayor John P. Hopizins went on Rooney's bond. Officers who have investigated 
the Rooneys' history before the time they came to Chicago claim that they were supplied with large capital before engaging in the sale of "prime butter." When an attempt was made to gain possession of the books of the Aurora Produce Company it was learned that Rooney and another man had burned them in the kitchen stove.

There were a number of very peculiar things about these cases, one of which was the ability of these adventurers, with no known financial responsibility, to obtain credit for such large amount. Another was the fact that the salesman who went into New York and sold the "butter" proved to be a traveling salesman for" one of these Chicago oleomargarine manufacturers, and still another peculiar thing was that representatives of the firms of Braun \& Fitts and W. J. Moxley, the Chicago oleomargarine manufacturers who sold this oleomargarine to these swindlers, appeared before Commissioner Mason, and John Dadie, of Moxley's concern, went bail for Rooney.

We desire to call the attention of your honorable body to the following in the statement of Mr. Schell, page 264:

I was talking with different members of the firm of French Brothers' Dairy Company, at Cincinnati, before I came here. I might say that Mr. Tilden R. French, one of the present brothers, has been our county treasurer. He stands high politically, socially, and financially. The family have been in the dairy business from a "time whence the mind of man runneth not to the contrary." * * * They have creameries in Hamilton County and creameries in the other southern counties of the State. Mr. Albert French told me very recently that they had over $\$ 100,000$ invested in creameries in Warren County, one of our adjoining counties.

I want to add here the statements of Tilden R. French and Mr. Albert French, of French Brothers, to the effect that they do not recognize olemargarine as a competitor in their business at all. On the contrary, they commend the manufacture and sale of oleomargarine, in that it supplies people who are not able to buy their product.

Thinking this rather a strange position for such a prominent firm to take, I telegraphed them the purport of the above statement. In reply I received the following telegram, printed on page 473:

Cincinnati, OHio, January 9, 1901.

Secretary National Dairy Union, National Hotel, Wushington, D. C.:

Large percentage oleo sold here as butter. Hurts legitimate butter business. We want Grout bill passed.

The French Bros. Dairy Co.

And French Bros. Dairy Company are supported in this statement by the testimony of ten leading wholesalers in butter at Cincinnati, whose letters are published on pages 474,475 , and 476 , nearly every one of which tell of a fund of one-half cent per pound laid aside to defend violators when prosecuted.

One of these Cincinnati merchants writes:

Of course the wholesaler, in selling to the retailer, sells oleomargarine for what it is; he could not do otherwise. The retailer sells 90 per cent of what he buys for butter, and gets butter prices for it. More than 100 retail grocery stores in Cincinnati are to-day advertising the best Elgin Creamery at retail for 25 cents, while it is worth $25 \frac{1}{2}$ cents in a jobbing way. The only opportunity in such transactions for profit is to substitute oleomargarine for butter, which is being done to a very great extent.

Another one says:

It is the retailers who offer it to the unsuspecting public as the genuine butter, and this without any interference. We know this to be a fact from transactions of this nature in Cincinnati.

A third substantiates the others, as follows:

DeAr SrR: We have just seen a telegram that a statement had been made to the committee that all oleomargarine was sold as such in Cincinnati. We wish to 
emphatically deny such statement. The wholesale dealers may, as the United States Government compels them to, but the retailers sell it any way just to sell it, becanse they are protected by the wholesale dealers, who pay their fines if caught. We know it is sold as butter from personal olsservation. We also know that the retail dealer is protected in selling it, as our customers tell us when they take out licenses that they have no fear, as the wholesale dealers pay their fines if arrested. If no check is put on this frand or imposition on the consumer, it is only a question of time when the dairy interests will be overwhelmed.

\section{A fourth has this to say:}

The wholesalers guarantee the retailers protection and pay their fines. If the Government does not pass the Grout bill, butter will soon be a thing of the past, as honest dealers in pure butter can not compete with fraud. Some of the retailers make no effort any more to sell for oleo, as the wholesalers pay the fines. There is nothing too mean or low for the oleo dealers to do.

\section{And another says:}

This butterine is sold here by retailers, grocers, market hucksters, and everybody else, and is palmed off to the trade for butter. The wholesalers here have told us that they charge one-half cent a pound advance, and lay that money aside to fight the food inspectors. Every time a man is arrested, and from 5 to 20 a week are arrested for palming off butterine for butter, these wholesale men protect them. They come up and pay the fine and the retailer sells it again.

\section{A sixth writes:}

If I am informed rightly, you want to know if oleo is being sold for butter. It is not sold for butter by the wholesale dealers, but the deception practiced by the retailers is where the mischief is done. Every now and then a raid is made on these dealers. They are arrested, fined $\$ 50$ and costs, which is paid by the wholesaler who furnishes, and in turn he charges one-half cent extra on the oleo for this protection.

\section{And a seventh:}

DEAR SIR: I learn from some of the members of the produce exchange of our city that a committee of oleomargarine men have reported in Washington that oleomargarine is sold as oleomargarine only in our city, which is false in its entirety. I know positively that there is sold daily thonsands of pounds of oleomargarine for pure butter, and that the food and dairy commissioners are either powerless or are inclisposed to antagonize.

While there are some arrests being made, it seems to be on account of local petty jealonsies among dealers, and not touching on the main offense. The oleomargarine dealers have a corruption fund with which they encourage the retail dealers to sell oleomargarine for butter.

The following extract from the testimony on page 163 gives the estimate of Hon. J. C. Blackburn, food commissioner of Ohio, of the proportion of oleomargarine which ultimately goes to the consumer as butter in his State:

Mr. ADAms. I would like to ask you what percentage of oleomargarine, in your judgment, in the State of Ohio is sold for butter at retail stores, or finally sold upon the tables of hotels, restaurants, and boarding houses, as well as to the ordinary consumer?

Mr. Blackburs. I would have to guess at that, Mr. Adams. My judgment would be 75 per cent of it.

In speaking of the condition which prevailed in Philadelphia a snort time ago, Mr. Luther H. Kauffman, attorney for the pure butter protective association of that city, said before your honorable committee, as shown on page 238:

We found again, in February of 1899, with this same United States law still in force, not a dealer in oleomargarine in the city of Philadelphia but who was selling oleomargarine as and for butter; and the detectives went out and paid butter prices for it, paying as high as 40 cents a pound for oleomargarine bought as butter.

I have the cases here. There [exhibiting paper] is the list of cases, with the date of purchase and the name and address of the party. These are purchases made dur- 
ing that time by this association. There they are, right straight along, page after page-more than 500 cases of purchases of oleomargarine in the city of Philadelphia. I am going to give you a summary of them. There are in this list more than 500 cases of purchases of oleomargarine in the city of Philadelphia. The detectives, in every single case, without exception, asked for butter; and they got oleomargarine at butter prices, without any indication from the seller that it was oleomargarine. There you have a fraud directly upon the purchaser.

Now, let me give you a summary of these cases. How many were marked? There are 508 cases here. I have the details there. I am not talking about supposititious cases. Every case is there, with the name and date and the result. These detectives went into these places, places kept by men who were supposed to be selling oleomargarine and who had paid revenue taxes. They asked for butter. Five hundred and eight purchases were made. Of those 508 purchases, 49 were butter and 459 were oleomargarine.

Gentlemen, I have heard a great many theories, but one ounce of fact is worth tons of theories. That is a fact. There was not a single case of oleomargarine sold as oleomargarine. Of this large number of purchases there were marked surreptitiously, marked on the packages inside, marked with the word "Oleomargarine" turned down, perhaps 50 cases. Oh, if I were to go on to tell you the trickery, the fraud, the schemes resorted to to deceive the purchaser, I could talk to you here for two hours. But I will not go into such detail. The simple statement of the matter is that every one of these purchases was made as butter, while out of 508 purchases only 49 were butter and the balance were oleomargarine.

* * * No law or regulation can be made to prevent the sale of colored oleomargarine as and for butter. I do not care what your penalties are. Therefore, because of the impossibility of selling colored oleomargarine under restrictions, we ask that if colored oleomargarine shall be sold at all the manufacturer shall pay 10 cents a pound tax upon it, so as to make the expense of the article so much more.

In relating his experience with oleomargarine, Mr. John J. Habacker, one of the delegation of buttermen from Philadelphia, who appeared before this committee, said, as shown on page 217 :

Now, I persollally went into the butter business in 1878. I stood behind the counter and retailed butter to the amount of $\$ 35,000$ a year, and I have yet the first person to come to me and ask me for oleomargarine-that is, a private individual. My experience in the business all through is that oleomargarine is a fraud from the beginning to the end; that it is made in the semblance of butter and is sold for butter.

And the statement which follows, printed on pages 224 and 226 , was made by Mr. W. F. Drennen, one of the most substantial of Philadelphia's wholesale buttermen, who also appeared here personally:

We used to handle oleomargarine many years ago. We handled it largely up to the time the first law was enacted, and we have handled it pending the decision on the constitutionality of our State law. After it became a settled fact that we could not handle it without violating the law, we quit it. *** * After being in the commission butter business over twenty years I can call to mind only one instance in which a consumer ever admitted that he bought it willingly or bought it for what it was. That may seem very strange to you, and yet it is true. I repeat that $I$ can recall but one instance in all my lifetime where any person admitted that he bought it knowingly for what it was because he wanted it on his table.

Now, then, I think the facts will bear me out in that. As chairman of the executive committee of the Pure Butter Association, we were compelled two years ago to enforce our State law through the medium of what money we could raise on the street and through appointing our own attorney and our own detectives. After having purchased about 161 samples and having them analyzed, and having those purchases recorded in a book where we could have access to them, the question came up: "How many purchases were made in which the vender gave them to the purchaser for oleomargarine?" Butter was asked for, of course. Out of 161 cases, one was sold for exactly what it was. The 160 were sold for butter and at practically butter prices.

* * * I have enough knowledge of the oleomargarine business to know that it is not sold for what it is; that there is no wholesaler who wants it sold for what it is, and that in fact there is no manufacturer who really wants it sold for what it is, for the reason that he can make a great deal more out of it and sell a great deal more of it through having it sold for butter. 
Now, then, I do not want to forget anything. I came near forgetting a point that I wished to make. We formerly sold to one man perhaps $\$ 50,000$ worth of highgrade oleomargarine every year. That man had a rule behind his stalls, where he had four cutters, that if one of them ever gave away the fact that oleomargarine was being sold in that stall he did it at the peril of his position, and he maintained that rule for years. I can think of three gentlemen in Camrlen who bought it and sold it, and they will tell you to-day that a pound never went out of their possession except for genuine butter, and they would not dare do it, and they would not do it. They sold it all for butter.

Now those are the facts. I would be glad to be permitted to sell oleomargarine if there were any demand for it as such. But 99 per cent of it is sold fraudulently. That is absolutely my candid conviction, and it is what I gather from facts that have come under myown knowledge. Every dealer to whom we sold oleomargarine would tell you that he never conld sell it, or would not sell it, except as butter, for the reason that he would not want his trade to know he was handling oleo. If he did, the customer would say, "Why don't you let me have it at a reasonable price?" The dealer would sell it at a price about a cent below that of fancy butter; bence the enormous profit.

Mr. Samuel Jamison, also of Philadelphia, appeared before the committee, and his evidence appears on page 232, senate testimony, from which we take the following:

We ask for additional legislation because we find that the goods can not be controlled except at the factory. The minute they leave the factory the deception begins. As reputable merchants, merchants of standing, with capital behind us, and with prominent locations in the center of a large city, we can not violate these laws. We are the first men to be arrested if we do violate them. But we have customers who sell these goods at retail. After they get possession of those goods, they remove all marks absolutely. They remove the revenue stamp; they scrape the word "oleomargarine" off the boxes. They receive the oleomargarine itself without any marks whatever on it. Then they proceed to sell it as butter. ***

I doubt very much whether any individual can go to any one of those retail dealers who has a Government license to sell oleomargarine and succeed in obtaining oleomargarine if he asks for it. I have repeatedly asked retail dealers who had a Government license (generally under some assumed name; instead of taking their own name, they call themselves some creamery company or other) for oleomargarine. I have said to these men, "Are you handling oleomargarine?" "No; I do not sell it." Still, we know that they pay for a Government license. We know that they receive the goods. We know that they sell to their regular trade, every day, oleomargarine for butter. A stranger who comes to one of their places of business and asks for butter will probably receive butter, because he is an unknown buyer; but to their regular trade we find that they sell oleomargarine to this day, in spite of what may be called the prohibitory law of the State of Pennsylvania and a national law which requires oleomargarine to be marked. We find it simply impossible to control the sale of oleomargarine as oleomargarine after the goods leave the factory.

From Baltimore, Mr. S. B. Medairy, of the firm of Bosce, Medairy \& Co., and president of the protective association of Baltimore, appeared, and made, among others, the following statement, as printed on pages 440 and 442 :

During that time (two years), as well as my memory serves me, out of nearly one hundred and forty-one cases-I think that was the exact number, although I may be mistaken in regard to one or two cases-there was not a single retail sale in the course of prosecution but what was sold as and for butter by the storekeeper or the restaurateur, and in many instances we found that the people who were being prosecuted were innocent of any intention of violating the law, but had been deceived by the vender, who in turn had bought his product from the manufacturer's agent, but had, subsequent to its purchase, taken the product from the original package and placed it in a basket or a box, a vessel of some kind, and sold it as and for butter. The uninitiated, not being able to distinguish one from the other by virtue of its semblance, bought the same for butter anil in turn sold it as such.

* * * We have yet to have an arrest of a dealer, other than a manufacturer's agent, and my statement can be rerified upon investigation, wherein anyone, without exception, man, woman, or child, sold colored oleomargarine as and for such. 
From Hon. G. L. Flanders, assistant commissioner of agriculture for the State of New York, we have the following statements, printed on pages 121, 135, and 125, respectively:

In 1878 it appeared in the State of New York that oleomargarine was being sold, and sold as butter. It was thought then that the State would try to regulate the matter. It passed a statute that the goods might be sold, but should be branded as such. That law proved ineffective, and in 1880 the State passed another act providing that when sold it should be branded as oleomagarine. That act, although more restrictive, proved ineffective; and in 1882 the State passed another law more restrictive, and that failed to produce a result, and, finally, in 1884 it passed an act providing oleomargarine should not be sold as a substitute for butter. That act was declared unconstitutional. ****

For sixteen years I have been watching this work, seeing it go on. There is a gentleman here representing a large firm in Chicago. They came down into our State two or three years ago and attempted to put in oleomargarine. I myself went into the city of Cohoes with two other men. We watched for two weeks. We finally found that it came in over the railroad in barrels of 10-pound tubs, with canvas over the heads of the barrels. We had it watched day and night. I went myself with men from house to house inhabited by French families who could not speak a word of English. I asked an old woman if she bought it for butter. ' She conld not speak any English. I got a little girl there to ask the old lady what she bought it for, and she said, "For butter." "For pure butter?" I asked. She said, "Yes." I said, "What did you pay?" She told me 22 cents, and that was the price of butter. It was sold to those people for butter. It has been our experience for sixteen years in the State of New York that that is what is done. ****

Now, I am not guessing or talking at random, for in 1884 and 1885, when we com menced to enforce these laws, you were selling, or those who were in the same business that you are in to-day were selling, in the State of New York 15,000,000 pounds, and they told the same story then as glibly as you tell it now-that they wanted to sell it for what it was. Our men went into the city of New York, and if they went into a store where they were known and called for butter they got butter; but just as soon as they put on the garments of 'longshoremen, which they did in a great many instances, to see what the facts were, and took a basket upon their arms and bought a quarter of a pound of tea and a loaf of bread, they got oleomargarine. This is no fanciful dream. It is a fact.

And from another assistant, Mr. Kracke, having charge of the enforcement of the law in Greater New York, we have the following statement, on pages 365 and 367 :

It is said here by some of the friends of the bill that 75 per cent of the oleomargarine sold is sold as and for butter. Now, I rather disagree with them. From my experience in New York, and I have had five years' experience there in enforcing the law, I rather disagree with that proposition and that statement. Every ounce of it that is sold in New York is sold as and for butter.

Now, from New Jersey these peddlers with wagons come over and deliver oleomargarine to private houses and boarding houses in this way:

An agent will come along, calling at the different houses, asking for the mistress of the house, and tell her a story about how he can deliver her some nice creamery butter for a certain price if she will contract with him for a year. Of course that price will always be from 5 to 10 cents below the creamery-butter price- 5 cents, as a rule. Then, after she has seen the cheapness of the thing, the saving in the price, believing this to be genuine butter, she will give the order. Then, a few days later, these wagons come over from New Jersey into New York to deliver these goods. They are bought for and as butter.

On page $367 \mathrm{Mr}$. Kracke tells of one ingenious method uncovered for the fraudulent sale of oleomargarine as butter.

The method is this: The man has a boy there in the store. Next time you go there you will see this boy walking in the place. As the men, about 10 or 11 o'clock in the morning, get their orders ready and they are put in the wagon for delivery, this boy will be walking up and down, watching the orders. He will have on a very large coat. This coat is very heavily lined, and it is interlined and intersewed so that it will permit a number of pound prints of oleomargarine to be placed in the Jining. The boy will go with the wagon, and when it gets to a certain house where he wants to deliver oleomargarine with the order, whereas butter has been ordered, 
he will take one print or two prints out of the lining of his coat pocket, put it in the order, and take it in the house.

That is an illustration of how they sell oleomargarine for butter, gentlemen.

Mr. Miller. What do they do on hot days?

Mr. Kracke. This was not a hot day. [Laughter.]

Mr. MILler. How many pounds did this boy carry at once?

Mr. KRACKE. He carried 28 pounds.

Mr. Tillinghast. Now, do you mean to tell the committee that the person to whom that oleomargarine was delivered was deceived in the purchase?

Mr. Kracke. Unquestionably.

Mr. Tillingmast. Do you know that, or is it simply a question of opinion?

Mr. KRAcke. I know it absolutely, because we went there and asked them, and after that they testified to it. Moreover, they paid 28 cents a pound for it.

Mr. Tillinghast. In how many instances did you find that to be true?

Mr. Kracke. In every instance.

Mr. Tillinghast. How many were there?

Mr. Kracke. What do you mean?

Mr. Tillinghast. Of how many cases of that kind have you any recollection?

Mr. KRACKE. One thousand. [Laughter.]

Mr. Tillinghast. Do you mean prosecutions?

Mr. Kracke. One thousand prosecutions.

Mr. TILLINGHAST. What was the prosecution for-selling oleomargarine for butter?

Mr. Kracke. Selling oleomargarine for butter.

Mr. Tillinghast. Or was it for selling oleomargarine colored?

Mr. KrAcke. Selling colored oleomargarine for butter.

Mr. Tillingmast. That was what the prosecution was for?

Mr. KRACKE. That was what the prosecution was for, and there were 1,000 convictions, too.

Mr. Trllinghast. In how long a time?

Mr. Kracke. In the last three or four years. Do you want me to go back further?

And on page 450 the following statement from the Hon. S. C. Basset, president state board of agriculture of Nebraska, who appeared before this committee:

In my own State very few measures before Congress have ever created the interest among our farmers that this one does.

We have been struggling for years to suppress the fraudulent sale of oleomargarine as and for butter. By a large majority in the house and with but two dissenting votes in the senate we passed in 1895 a law prohibiting the sale of imitation l sutter colored yellow.

This law is openly violated. Large quantities of oleomargarine of a yellow color are sold, and I fully believe 90 per cent of the same is sold to the consumer as and for butter.

It ought not to be forgotten, but should be kept constantly in mind, that the exceedingly large profits which dealers in oleomargarine receive is the reason why its sale is so strenuously pushed. Those who divide the profits of this most profitable business are comparatively few in number, and the retail dealers, whs are the principal violators of the law, receive the lion's share of the profit, considering the amount handled. With us a retail dealer makes not to exceed an average of 2 cents per pound on butter sold, while the retail dealer in oleomargarine makes a profit of 8 to 10 cents per pound.

By State legislation we seem well-nigh powerless to control this fraud, and this is why we come to the National Congress, believing that this is the only power which can compel the sale of this product on its own merits and for what it is.

When the Secretary of Agriculture, the Hon. James IVilson, appeared before this committee, he was asked and answered a question as follows:

Mr. Schell. I would like to ask further, if you know from your own experience or from the reports that have come to you of a single case where the consumer has ever been prosecuted because of being defrauded by the dealer.

Secretary WilsoN. I can find plenty of such cases in this very city. * * * There is no question about the everyday deception of us people who have to buy butter. 
And later, in reply to a question by Senator Money (p. 421), Mr. Wilson said:

Well, you have a perfect right to buy oleomargarine, but I do not want you to be deceived and pay 10 cents a pound too much. The poor people are being robbed by this deception to the extent of 10 cents a pound; and you and $I$, who have to take butter from second or third hands in this city, are deceived regularly. If you will send me samples of the butter you are eating between now and spring, I will tell you the percentage of it that is oleomargarine. I will have it analyzed. In fact. we nave been analyzing it for members of Congress who have sent samples to us.

Said President Cleveland, in his message approving the oleomargarine legislation of 1886 , as shown by evidence before House committee, page 3 :

"Not the least important incident related to this legislation is the defense afforded to the consumer against the fraudulent substitution and sale of an imitation for a genuine article of food of a very general household use. * * * I venture to say that hardly a pound ever entered a poor man's house under its real name and in its true character."

\section{THE COLOR QUESTION.}

The entire question now before Congress is, Shall the General Government aid, through the Gront bill, the enforcement of the laws of the various States which prohibit the manufacture and sale of oleomargarine colored in semblance of butter?

It is admitted and expected that colored oleomargarine with a tax of 10 cents per pound upon it will have to compete in price with butter. The intention of the framers of the law is to bring its cost of production up to such a figure that there will be no incentive of a large profit, which is now the sole cause of the great fraud being perpetrated upon the public at the expense of producers of pure butter.

It is admitted that the producers of butter do in many months of the year color their product. But they claim that they have done this from time "whence the mind of man runneth not back." To quote Senator Dolliver, "The poets speak of butter as yellow." Henry C. Pirrung, general manager of the Capital City Dairy Company, Columbus, Ohio, makers of oleomargarine, in his statement (see p. 188) said:

On the contrary, in my humble opinion the coloring of butter should be allowed, because even the school child who has passed the primary grade will define the color of butter as "yellow," and every adult expects at this advanced age to have the product served to him "yellow."

Mr. Rathbone Gardner, attorney for the Oakdale Manufacturing Company, oleomargarine makers, of Providence, R. I., said, as recorded on page 33 :

Even before the invention of the great creameries, and before the use of the substance which has now been adopted for coloring it, butter has always been artificially colored.

Hon. G. L. Flanders, assistant commissioner of agriculture of New York State, is reported, on page 125, as follows:

Now, how about the question of competition? In the first place, let us no back to the color of butter. The natural color of butter, when the cow is living on nature's food, is a rich yellow. Butter has been that color so long that the memory of man runneth not to the contrary. When these people, back in the seventies, started to make oleomargarine what did they do? They undertook to make it look like our commodity. Is that all? No. In taste and smell they attempted to make it like our commodity, so that every feature would deceive every sense that man could possibly apply to the commodity. Were they content with that? No, sir. They came into the market and sold it for butter.

It seems to be settled, therefore, that butter has always been known, spoken of, and looked upon as yellow. Therefore the only question 
is, has a new article the right to come in and usurp a characteristic absolutely foreign to its natural condition under any circumstance and the distinct property of another popular and more expensive article for centuries?

To settle this question, we must inquire, why should not the new article assume the cloak and color of the older and more popular and expensive?

The answer, as we claim is shown by the testimony, is that the yellow color in oleomargarine makes it look like butter and causes thousands to buy it at a butter price, thinking it is butter, or to consume it as butter when they would reject it if its real character were not concealed by the yellow color. The color in butter fools nobody into believing it is anything else.

How do we prove that the yellow color in oleomargarine is used to deceive?

First, by the common sense of every man who knows he has eaten oleomargarine hundreds of times at public houses, because a large proportion of them serve it, and not having recognized it. Had it not been disguised by the color, he would have known it at the time.

But to go to the testimony and prove our case by the record.

On April 5, 1899, William J. Moxley, of Chicago, sent his trade the following circular letter, as shown in the House testimony (page 606):

[William J. Moxley, manufacturer of fine butterine, 63 and 65 West Monroe street.]

Chicago, April 5, 1899.

NOTICE TO THE TRADE.

Inclosed find a color card, which is as near the color of our butterine as the printer's art can represent. Our aim in sending you this card is to aid you in selecting the proper color suitable to your trade. Miistakes are easily made, but hard to remedy.

In nearly every section of the country there is a difference in the color of butter, and even in certain seasons of the year there is a change, as you will have noticed. In winter butter is of a lighter color than in summer; in many sections this is the result of the difference in feed or pasture.

We can give you just what you want at all seasons if we know your requirements. As an example: No. 1 has no coloring matter; No. 2 a little coloring, and so on to No. 8, which is the highest-colored goods we turn out. Preserve this card, order the color you waut by number, and we will send you just what you want.

Yours, truly,

W. J. MOXLEY.

Now, if Mr. Moxley had not anticipated or intended to suggest that his customer should sell this olcomargarine as butter, why should he suggest the ordering by color card to correspond with the natural color of "butter?" He might have some claim to a desire to furnish a color suitable to a locality, but why suggest that "the color of butter is lighter in winter than in summer?" Are we to presume that the taste of the consumer" changes with the "season?"

Does not the above circular show that the object of coloring oleomargarine is to imitate butter even to the different scasons, when feed or pasture changes its natural color?

If the intention was not to imitate butter, why mention butter at all?

If tastes vary for oleomalgarine, why not say, "In nearly every section of the country there is a difference in the color of oleomargarine, and even at certain seasons of the year there is a change, as you rill have noticed. In winter oleomargarine is a lighter color than in summer. In many sections this is the result of the difference in feed or pasture."

But Mr. Gardner, representing the Oakdale Manufacturing ComS. Rep. $2043-53$ 
pany, oleomargarine makers, admits, we think, that oleomargarine must sail under butter's colors, no matter what they are, in the following (p. 44):

Mr. GARDNER. I say that as long as there is in the market something which people want and which they have been accustomed to use you can not sell them something which they do not want and which they are not accustomed to use. Do not misunderstand me, please. If all butter was left uncolored and if all oleomargarine was left uncolored, of course both oleomargarine and butter would sell, and they would sell npon the same plane. People would still have something to put on their bread, although they could not get what they wanted.

The following colloquy and statement from pages 204 and 205 will, we believe, throw considerable light upon the subject:

Senator Dolliver. Have you discussed the reason why the product is colored? Why do they not put it on the market in its natural condition?

MIr. Tillinghast. That has been discussed by others who preceded me, and very thoroughly, too.

Senator Dolliver. If it is in the record, that is all that is necessary.

Mr. Tillingirast. I will say that it is simply conformable to the law of custom and taste, one of the strongest laws to run up against.

Senator Dolliver. Do you think anybody would buy it if it was light or white colored?

Mr. Tillinghast. Yes, sir; I think it would be sold in very limited quantities.

Senator DoLliver. I understood from some of your people that they thought if they were compelled to color it white it would destroy the market. They have written to me to that effect.

Mr. Tillinghast. Yes, sir; there is no doubt about that. It would entirely destroy the industry as an industry. An industry putting out 107,000,000 pounds a year would be practically totally destroyed, because nobody would buy white oleomargarine to put upon their table.

Senator DoLLIVER. Is that mere prejudice and custom?

Mr. Tillinghast. Solely that and nothing more, sir.

Senator DoLLrver. It seems to me you might overcome that prejudice?

Mr. Tillinghast. You could not overcome it so long as butter is colored. So long as butter is put upon the table yellow, in my judgment, it would be impossible to sell white oleo as against colored butter. You can sell white oleo against white butter.

The Acting Chatrman. Would it destroy the butter business if butter were not colored?

Senator Dolliver. The great hotels, I notice, are serving white butter. Have you noticed that?

Mr. Tillinghast. Yes, sir.

Senator Dolliver. Without even salt in it?

Mr. Tillinghast. Yes, sir. I know that is true in some cases.

Senator Dolliver. I noticed that iu a hotel in New York the other day.

Mr. Tillingh Ast. Yes; that is true, I think, at the Waldorf.

Senator Dolliver. They do that, perhaps, in order to guarantee their good faith.

Mr. Tillinghast. In response to your question, Mr. Chairman, I am of the opinion that people would eat butter, that they could not get along without the use of butter, and that if all butter was white there would be the same quantity of butter used as is used to-day.

Senator HEITFELD. Then you think if all butter was uncolored you could let your oleo go uncolored?

Mr. Tillinghast. Why; certainly.

Senator HEITFELD. I would suggest a compromise with the dairyman-throw away all the color.

Mr. Tilitinghast. Yes, sir; if they will do that. I noticed the gentlemen on the other side laugh when I said that if all butter was white we could sell oleomargarine white.

Senator Heitfeld. Oh, well, you had your laugh yesterday.

Mr. Tillinghast. I am going to have it again. I said that if all butter was white we could sell oleo white; and that is true. I will tell you why it is true. I am here to confess and to state that oleomargarine, notwithstanding it is a distinct product known to science, is a product that is used by people who use it for butter knowing that it is oleomargarine, and using the substitute instead of the real article. They use it because it is a substitute. You may use the word "imitation" if you please, and I will agree with you. It is an imitation of butter; and being an imitation it is 
sold as the imitation, and people buy it because it is an imitation, and they would not want it if it was not an imitation. It is an imitation, precisely the same as cotton may imitate worsted. People buy it because it is an imitation, and they know what they are buying and they know what they are using. Would you pass a law here that would destroy the use of all imitations? Why, it is one of my delightful recollections to think that for 25 cents I can buy a painting that will imitate the finest paintings in the world by the finest masters, and I buy it because it is an imitation. It is gratifying to me to know that for 25 cents I can buy a volume of Shakespeare that will contain just as good reading matter as the most expensive edition that could possibly be put out. Imitations are not to be legislated against. They are proper; they are legitimate; they are right; and the people will have them just as long as people live.

So that if oleomargarine imitates butter, as it does, and people buy it because it imitates butter, and would not buy it if it did not imitate butter, then unless there is some reason other than has been given here, there should be no legislation against it. The only reason suggested is that in some instances it is sold for butter. I have already stated that that is of too small consequence to be considered by the Congress of the United States, because is amounts to so very, very little.

Here is an honest confession that oleomargarine is an imitation and a claim that it must imitate butter to be successfully sold.

And yet we contend that there is a field for a substitute that is not a counterfeit; that oleomargarine can be sold in its natural color if its makers will spend the time and money to build up a trade and reputation for it instead of endeavoring to push it into consumption upon the reputation of and demand for butter.

This, we believe, will be proven by the following statement by Hon. H. C. Adams, food commissioner of Wisconsin, on page 432:

I have here samples of butterine which may interest this committee, and the gentlemen upon the other side of the question are invited to inspect thein. These samples were obtained in obedience to my orders by N. J. Field, of Milwaukee. He was instructed by me a week ago last Thursday to go to the stores of Oshkosh, Milwaukee, and Racine, in our State, and purchase samples of uncolored butterine, and to write upon those samples the date of purchase; the name of the firm from whom they were purchased, and the cost. I now have the pleasure of submitting these samples to this committee for their inspection.

Senator HANSBROUGa. You say he was instructed to procure samples of uncolored butterine?

Mr. ADAMs. Yes, sir; of oleomargarine. I would like to say that one or two of these samples, possibly more, are slightly colored, but they were purchased for uncolored oleomargarine.

Mr. JeLke. If the chairman will permit me, I would like to make a suggestion that these samples be submitted to the Government chemist to find out whether or not they contain artificial coloring, and also to report on whether they contain any unwholesome ingredient. I do not know where they come from, or anything about it.

Senator Allen. I think that ought to be done.

Senator HANSBROUGH. I shall direct the clerk of the committee to take care of these samples after they have been exhibited, and send them to the chemist at the Agricultural Department for examination.

Mr. JELKE. May I suggest that the analysis be made for the purpose of ascertaining the percentage of butter fats in each one, as well as the color and what kind of color.

Senator HansBrodgh. Yes; he will be directed to make a thorough analysis.

Mr. ADAMs. I wish to say, gentlemen, that all these samples, with the possible exception of this one, weresold by the dealer in response to a call for uncolored butterine, they claiming that they had received it from the manufacturers as uncolored butterine.

Mr. Jelze. The test will show that.

Mr. ADaus. I now wish to present to the committee and have incorporated in the testimony the bill for this. It is as follows: William J. Motley,
Mayofacturer of Fine Butterine, 66 and $67 \mathrm{~W}$. Monroe Street, Chicago, January 25, 1900.

W. R. WRIGHT \& Co., 4845 N. Clark street, Rogers Park, Ill.

Uncolored oleomargarine: 2 / 56 D. 2 pts. 112 13, \$14.56. 
Senator Hansbrough. Did all this come under an order for uncolored goods?

Mr. ADAus. These all came under an order from my inspector, Mr. N. J. Field, to Jensen \& Beck, Racine; Hanley Brothers, Racine; D. C. Adams, Niilwaukee; J. Linehan, Milwaukee, and Hoenig \& Co., Oshkosh. He purchased samples of uncolored butterine for the purpose of demonstrating the fact that some of the grocers of our State think they are endeavoring to comply with the law, and some of them are endeavoring to comply with the law, and some of them sell oleomargarine uncolored.

*

*

*

*

The figures given to me or to my assistant by gentlemen connected with the firms which have been cited here as to their sales of what they call uncolored butterine, a portion of which is evidently uncolored butterine, and a portion of which is faintly colored, possibly, and possibly not-that is to be determined by a chemist-are: Jensen \& Beck, 3,000 pounds a year; Hanley Brothers, 3,000 pounds a year; D. C. Adams, Milwaukee, 19,000 pounds a year; L. Linehan, 5,000 pounds a year, and Hoenig \& Co., of Oshkosh, 6,000 pounds a year. These are approximate figures. Perhaps D. C. Adams, of Milwaukee, who said he sold 60 pounds a day, sells more or less than the figures I have given. Sixty pounds a day during six days of the week, calling 320 days to the year, would amount to about 19,000 pounds. 531:

The following, in this connection, is interesting, as printed on page

Mr. JeLke. Would you want to eat uncolored oleomargarine on your table?

Senator Dolliver. No; I have a constitutional prejudice against it, I must confess.

Mr. JELkE. Would you want to eat white butter?

Senator Dolliver. Oh, yes; I have eaten it the year round, and in youth I churned it. As Senator Allen says, everybody eats white butter on the farm.

Mr. JeLke. As soon as that butter is shipped to the city it is colored.

Senator DoLliver. I am talking about my own taste.

Mr. Schel. The wholesale dealers in Cincinnati have tried to put white oleomargarine on the market, but have reported to me that it was absolutely impossible to do it. Mr. Seither, who claims to be, and I believe is, the olclest man in that business in this country, tells me he has tried it from time to time, but it is utterly impossible; that the people will not take it. He has not told me the reason why, but I think one of the principal reasons is the fact that there is an unwarranted sentiment attached to it, an unwarranted prejudice against it, and people do not want to put it on their tables for the criticism of their neighbors. You know how a neighboring woman will say: "Nrs. Smith uses oleo," etc.

Senator Allen. Is not this the fact: That the man does not want to put oleomargarine on his table knowingly, because of his natural inclination for butter?

Mr. Schell: No; I think not. * * *

Now, as to the fairness of coloring butter and not coloring oleomargarine. There were a number of interesting discussions. The following is reported on page 127:

Mr. Mathenson. Would it be a fair proposition to ask the manufacturers of creamery butter to leave the color out of their butter?

Mr. Flanders. No, sir; and I will tell you why. In the first place, that is the natural color of the butter, if they color it as they ought to color it. Butter is yellow when the cows feed upon nature's succulent food. Color in butter is for the purpose of uniformity.

Mr. MAthewson. It brings a little more on the market.

Mr. Flanders. Not at all. I ate butter in New York City the other day with all the flavoring you could ask, and not one bit of coloring and not a bit of salt in it. I ate to-day down at the hotel cheese with not one bit of coloring matter in it, and I liked it just as well. The truth is that the people, if your commodity is good, can be educated to eat it without its coloring matter, and you will not deceive them as to the commodity.

\section{On page 421 Secretary Wilson says:}

There is no difficulty about having naturally colored butter. It is colored by the grass in summer. That is nature's way, and when you imitate nature you are probably not going very far wrong; but we do not know enough about milk, any of us yet, to be able to form a substitute that will stay on the stomach the same as butter. 


\section{And on page 11 Governor Hoard brings out a point, as follows :}

I had a distinguished member of the other House ask me if butter was not colored in winter to make the consumer believe that it was made last June. That gentleman was a student of maxims, not of markets. The cheapent and poorest butter in winter is that made last June. The highest-priced butter is that which is not over ten days old and faultless in character and flavor.

A very complete statement was made on page 525, the most interesting part of which follows:

Mr. KNIGHT. I will say in that connection that I have been in the butter trade for twelve years, and I have never heard that the color of butter was indicative of its quality, so far as its wholesomeness is concerned. Senator Dolliver has had experience in New York to the effect that at the Waldorf-Astoria they serve you with butter perfectly white. I was in England for the Agricultural Department investigating butter in that country, and they served me there with white butter all the time I was there, and I never heard anybody complain because it was white.

Mr. Tompkins. Why do they ever want to have the color in it?

Mr. KNIGIT. The average natural color of butter is two-thirds normal. You take our dairies throughout the United States, and one cold wave or storm will change the color of the butter. One cold wave that will drive the cows from feeding on the green pastures to feeding on hay or any kind of green food will make the butter white this week which last week was yellow. That is true of any place.

The tendency of all commerce is toward uniformity in everything. Butter is put up in packages or in tubs. Everybody puts up everything with this idea of uniformity in view. That is what the public demands. It does not make any difference in what shape the packages are, but all the packages must be uniform in order to be merchantable. So with butter. Butter must be uniform in packages, uniform in body, uniform in the amount of salt, uniform in flavor, uniform in color. The weather conditions may be such that one day will make white butter and another day will make yellow butter. I tell you that it is necessary that we do something to keep the color uniform. When I tell you that, I am telling you what I know. I say to-day that it would be better for the butter trade if butter could be made white uniformly and all the time, rather than yellow part of the time and white part of the time. The consumers would soon become used to that uniformity. But we can not accomplish that. In the winter time butter is white all the time if the color is kept out of it. If oleomargarine were white, where would our distinction be? In this bill we seek a distinction between the two articles.

If a bill could be passed that would cause the color to be kept out of butter and oleomargarine in the winter time, then the oleomargarine men would go to their retailers and tell them, "You know there was a law passed at the last Congress which practically forbids coloring butter." Where would the value of the law be that would bring the two articles down to the same basis as regards color? It is true that would be an advantage in the summer time, when butter is cheap, and they have no market for oleo to amount to anything then. But when it came to the winter time the color might be taken out, and the two articles standing side by side would show the same color, and then fraud would be practiced just the same. Every man who wanted to sell oleomargarine for butter would convince the consumer that it was natural butter, and would tell him that color had been forbidden by law, and that butter is white in winter.

And the following discussion between Senator Money and Secretary Wilson is instructive:

Senator Money. I never know that I have got the genuine article except when I go home.

Secretary Wrison. After living a winter in Washington and eating bogus butter our taste becomes vitiated. Some of the first-class hotels and first-class restaurants here do get first-class butter from reputable dealers, but the majority of them use oleomargarine.

Senator Money. If we are all eating bogus butter and we can not tell it by the taste, and we cau not tell it by the color, and we can not tell it by the effect, what harm has happened to anybody?

Secretary WILson. The bogus butter deceives you in your pocketbook. It costs you far more than it should. There is where the trouble comes. It costs you too much.

Senator Money. Would I get the fine-grade butter any cheaper if we abolish oleomargarine? 
Secretary Wrison. If you abolish the coloring proposition. I would not abolish oleomargarine. The manufacture of that is legitimate, but the moment you buy it you,are deceived by somebody. We are not the men who select the butter that we eat if we board at a hotel or boarding house, and the boarding-house man can deceive us, and he does.

\section{In Twelfth Missouri Appeals appears the following in relation to the coloring of oleomargarine to imitate butter:}

The mere fact that experts may pronounce an article intended for human food to be harmless does not render it incompetent for the legislature to prohibit the mannfacture and sale of the article. The test of the reasonableness of the police regulation prohibiting the making and vending of a particular article of food is not alone whether it is in part unwholesome and injurious. If an article of food is of such a character that few persons will eat it, knowing its real character, if at the time it is of such a nature that it can be imposed upon the public as an article of food which it is not, and yet to which and against which there is no protest, and if in addition to this there is probable ground for believing that the only way to prevent the public from being defrauded into the purchasing of the counterfeit article for the genuine is to prohibit altogether the manufacture and sale of the former, then we think that such a prohibition may stand as a reasonable police regulation, although the article prohibited is indeed innocuous, and although its production might be found beneficial to the public if in buying it they could distinguish it from the production of which it is an imitation.

The manufacturer may brand it with its real name. It may carry that brand with it into the hands of the broker and commission merchant and even into the hands of the retail grocer, but there it will be taken off and it will be sold to the consumer as real butter or it will not be sold at all. The fact that the present state of the public taste, the public judgment, or the public prejudice with regard to it is such that it can not be sold except by cheating the ultimate purchaser into the belief that it is the real butter stamps with fraud the entire business of making and vending it and furnishes a justification for the police regulation prohibiting the making and veuding of it altogether.

And when asked why color butter in winter and not oleomargarine, Secretary Wilson said (page 419):

I have had that question asked me before and have thought a great deal about it. The reply is simply this: The coloring of butter in the winter time deceives nobody. The coloring of the fats of commerce to make an imitation deceives everybody.

\section{THE LIVE-STOCK QUESTION.}

The most active, aggressive opponents of the Grout bill have been the live-stock organizations.

A little idea of the cause for their aggressiveness may be had from a review of the statements made before the committee by their representatives, or through them.

The basis of the opposition of the National Live Stock Association, represented by Judge Springer, before the committee, is shown in the resolution he presents from his association, which contains the following (page 78 printed testimony):

The "butter fat" of an average beef animal, for the purpose of making oleomargarine, is worth from $\$ 3$ to $\$ 4$ per head more than it was before the advent of oleomargarine, when the same had to be used for tallow; which increased value of the beef steer has been added to the market value of the animal, and consequently to the profit of the producer.

To legislate this article of commerce ont of existence, as the passage of this law would surely do, would compel slaughterers to use this fat for tallow, and depreciate the market value of the beef cattle of this country $\$ 3$ to $\$ 4$ per head, which would entail a loss on the producers of this country of millions of dollars. 
At the conclusion of Judge Springer's argument, as shown on pages 114 and 115, the following colloquy occurred:

Mr. SPRiNger. If any gentleman desires to ask questions, I will be rery glad to answer as I may be able.

Mr. KNIGHT. You have not stated what the objections of the live-stock growers are to the bill.

Mr. Springer. Those were stated-

Mr. KNIGHT. In the resolution?

Mr. SPRINGer. In the memorial which will be printed.

The Acting Chairman. It will be printed.

Mr. Springer. I read a portion of it. I have asked the committee to embody it at length, but I will briefly state the objections. They object to it because it deprives them of a market for one of their products. In other words, the product of beef known as caul fat, which amounts in the average beef to about 58 pounds per steer, is now or may be manufactured into oleo oil, and if the whole product were so manufactured there would be a large amount-in fact, nearly all of it-used for that purpose, thus increasing the value of the caul fat in the steer to the amount of the difference between oleo oil and tallow.

Mr. HoARD. Does that include kidney fat?

Mr. Springer. It includes all that is known as caul fat. I am not an expert as to the various fats.

Mr. Kлight. Your objection, then, is not so much to what it will do to the livestock industry as to what it will deprive the live-stock industry of some time in the future?
*
*
*
*
*
$*$

Mr. Grout. Are you able to state the number of pounds of oleo oil that was used in the production of oleomargarine last year?

Mr. SPRinger. Yes, sir.

Mr. Grout. Will you give it?

Mr. Flanders. He will publish that statement.

Mr. KNight. It is $24,400,000$ pounds.

Mr. Springer. The table gives the "quantities and kinds of ingredients used in the production of oleomargarine in the United States for the fiscal year ending June 30 , 1899 ; also the percentage each different ingredient bears to the whole quantity." Neutral lard, 31,000,000 pounds; oleo oil, 24,000,000 pounds; cotton-seed oil, 4,357,000 pounds.

Mr. Grout. What is the amount we exported?

Mr. Springer. We exported $142,000,000$ pounds of oleo oil, I think. That is not taken into consideration in the amount that was used in this country.

Mr. Krignt. But in the resolution of the live-stock associalion is it not stated that the passage of the Grout bill would mean a damage or loss in value of $\$ 3$ or $\$ 4$ a head per cattle?

Mr. Springer. Yes, sir; it is so stated, I think.

Mr. KNiGHт. How do you figure that, please?

Senator HeITYELD. Was it not $\$ 2$ in the statement made here?

Mr. KNIGHT. From $\$ 2$ to $\$ 4$ in some statements.

Mr. SPRINGER. They say in their memorial:

"In oleomargarine a very large proportion of the consumers of this country, especially the working classes, have a wholesome, nutritious, and sativfactory article of diet, which before its advent they were obliged, owing to the high price of butter and their limited means, to go without.

"The 'butter fat' of an average beef animal, for the purnose of making oleomargarine, is worth from $\$ 3$ to $\$ 4$ per head more than it was before the advent of oleomargarine, when the same had to be used for tallow, which increased value of the beef steer has been added to the market value of the animal, and consequently to the profit of the producer.

"To legislate this article of commerce out of existence, as the passage of this law would surely do, would compel slaughterers to use this fat for tallow, and depreciate the market value of the beef cattle of this country $\$ 3$ to $\$ 4$ per head, which would entail a loss on the producers of this country of millions of dollars."

Mr. KNight. The amount of oleo oil used was $24,000,000$ pounds?

Mr. Springer. Yes, sir.

Mr. KNIGHT. Valued last year at about $\$ 2,000,000$ ?

Mr. SPRING Er. Yes, sir.

Mr. KNIGHT. There were $5,000,000$ head of cattle slaughtered in this country last year. 
Senator Heitfeld. If you took that amount out of the use to which it was formerly put, would not that make a difference?

Mr. HoARD. The Treasury Department shows that there was used of oleo oil in oleomargarine produced in this country $24,000,000$ pounds. That is a fraction less than 5 pounds of fat from each animal.

Senator HerTFELD. It takes that 5 out of the gross product.

Mr. HOARD. It is 4.99 pounds to each animal. At their figures it would be worth about $\$ 1$ a pound.

Mr. Grout. What is the price of it?

Mr. HOARD. Nine cents.

Senator HeitFeld. In what way would it?

Mr. HOARD. Because there are 5,000,000 animals slaughtered and 24,000,000 pounds of oleo oil used. Divide one by the other, and it makes 4.99 pounds to each animal; 45 cents a pound.

Senator HEITFELD. I do not think that is a fair estimate.

Mr. Springer. I will make this explanation.

Mr. HOARD. I am taking the amount that would be used in oleomargarine.

Senator Heitfeld. But you are figuring the $24,000,000$ pounds as the entire output from the beef, and the only output that is bringing any money, throwing away the other 95 per cent.

Mr. HOARD. I am figuring as to relationship and the worth of the oleo oil, and it does not square with that live-stock statement.

Mr. SPRinger. I will answer that.

Mr. Hoard. It is overestimated.

Mr. SpRINGER. Mr. Knight, in his statement before the committee of the House (pp. 26 and 27 of the House hearing), endeavored to expose the figures used by Swift \& Co. in regard to this subject. I did not prepare those figures, and I do not know who did, but it appears to me from an examination of both of those statements that the gentlemen and those who prepared these estimates are both out of the way in their estimates upon this subject. In other words, they have, by a loose manner of expression, failed to state exactly what the truth is and what the difference would be. It seems to me that the proper statement is this: We must go for the amount of oleo oil that was consumed in the manufacture of oleomargarine to the Treasury, statistics in order to ascertain the exact truth. That does not embrace the amount of oleo oil exported, and a great deal more is used for export than is used in this country.

Mr. KNIGHT. What has this to do with the oleo oil that is exported?

Mr. SPRINGER. Nothing, except that the use of oleo throughout the world has created a demand for it, and a portion of that demand is in this country. Now, if all of the caul fat in the beeves that were slaughtered during the year had been used in the manufacture of oleomargarine in this country it would have amounted to the figures stated by Mr. Swift in his circular, which are practically the ones stated in the resolution and memorial of the cattle men.

Mr. KNIGHT. Is there anything in the Swift letter to Congress indicating that it was not?

Mr. SPRINGER. I say that I think he was mistaken in placing it upon that basis; but I wish to call the attention of the committee to the fact that it is beyond the power of man to tell what would be the loss to the cattle men of this country by reason of the destruction of oleomargarine as an article of commerce.

Mr. HOARD. It is beyond the power of man to tell what the destruction to the butter industry is by this business.

Mr. Springer. You can guess at it.

Mr. Knight. Now, Judge-

Mr. Springer. Let me finish. You can not tell. Why? There was already created, by the amount of oleo oil used in the actual production of oleomargarine in this country, a demand for $24,000,000$ pounds of their product which would not have existed if oleomargarine had not been manufactured in this country. To that much we will all agree.

Mr. Hoard. Tes.

Mr. SPRINGEr. There is that much increased demand for their stock.

Mr. HOARD. With a corresponding destruction on the other side.

Mr. Springer. Excuse me for one moment. There is that large increase. Now, gentlemen, how can you tell what effect that increased demand for the $24,000,000$ pounds had upon the price of all the other products of animal fats? Who can tell that? Nobody can tell. But it is my opinion that the pending bill and the restrictive laws in 32 States in this Union will injure the cattle and hog industry to the extent of many millions of dollars annually, and that injury will reach the extent stated in the memorial of the National Live Stock Association. 


\section{And on page 118 Judge Springer says:}

While I can not say, and no other man can say, just how much the price of cattle would be depreciated by destroying this industry, or how much it would be appreciated by repealing the restrictive State laws and letting oleomargarine go free, as other food products do, yet I know it would depreciate animal fats in the one case, and it would appreciate in the other very largely if this article should be left in the same condition that other food products are left.

Hon. James Wilson, Secretary of Agriculture, answered questions as follows, on page 418, upon the subject of damage to live-stock interests:

Senator Allen. Have you inquired into the effect the passage of this bill will have upon the value of animals raised for food purposes; not for dairy purposes?

Secretary Wilson. Very carefully.

Senator ALLen. What will be the effect of the passage of this bill on that class of animals?

Secretary Wilson. I tried to reason that in my short paper which I have read. There is a little oil furnished by cotton-seed people, and a little by the people who grow steers; but the old-fashioned steer that had lots of fat in him is not the steer that is used to-day. The young beef, under 2 years of age, put into the market and prepared for the shambles, is not an animal that produces much body or intestinal fat. That is the animal that is wanted to-day.

The old-fashioned steer that was $3 \frac{1}{2}$ years old before he got to market had a large amount of fat, running up in some cases to 150 and as high as 180 pounds.

Now, then, the tendency in the South, where they have destroyed the lands by perpetual cropping, and the tendency west of the Missouri, in the semidry belt, where they are destroying the grazing lands by injudicious overgrazing, is to take greater interest in the dairy cow than in the steer, and in the case of settlers who want to raise families out west of the one hundredth meridian the interest grows every day on behalf of the dairy cow, and with regard to the production of steers east of the Missouri River on the farms there is no comparison whatever. The small amount of fat from cattle that commerce calls for in making oleomargarine is infinitesimal in value compared with the injury that the growth of this bogus industry will inflict upon legitimate agriculture that requires a dairy cow.

\section{And the following is an excerpt from the printed testimony on page 425:}

Senator DoLliver. I received a telegram from a cattle dealer in Iowa stating that this bill was likely to very greatly damage the value of beef cattle.

Secretary Wilson. Yes; he does not know what he is talking about, that same cattle dealer.

\section{The following representations are made by the National Live Stock} Exchange, as shown on page 185:

The "butter fat" of an average beef animal for the purpose of making butterine is worth $\$ 3$ per head more than it was before the advent of butterine, when the same had to be used for tallow, which increased value of the beef steer has been added to the market value of the animal, and consequently to the profit of the producer.

\section{And by the Kansas City Live Stock Exchage (page 72):}

That the bill above referred to, if it become a law, will reduce the value, to the farmers and raisers of cattle, an average of $\$ \notin$ per head and a corresponding decrease in the value of hogs.

The basis of the Kansas City Commercial Club's opposition to the Grout bill is shown on page 62 to be the following:

This measure, if passed, will build up one industry at the expense of tearing down and ruining another industry, and will in effect amount to the giving of a monopoly to the industry sought to be benefited by such legislation; that the bill above referred to, if it becomes a law, will reduce the value to the farmers and raisers of cattle an average of $\$ 2$ per head and a corresponding decrease in the value of hogs. 


\section{The South St. Paul Live Stock Exchange objects to the measure} on the following grounds, as shown by resolutions printed on page 57:

The butter fat of an average beef animal for the purpose of manufacturing oleomargarine is worth from $\$ 3$ to $\$ 4$ per head more than before the advent of oleomargarine. This has increased the value of the beef steer, and consequently to the profit of the producer.

To legislate this article of commerce out of existence, as the passage of this law would surely do, would compel slaughterers to use this fat for tallow and depreciate the market value of beef cattle of this country $\$ 3$ to $\$ 4$ per head, which would entail a loss on the producer of this country of millions and millions of dollars.

And yet nobody has been able to successfully dispute the statement made by Hon. S. C. Bassett, president of the board of agriculture of Nebraska, given on page 451 , in which he gives facts and figures showing the fears of the live stock men and their opposition is without foundation. The statement follows:

The National Live Stock Association has adopted resolutions opposing the passage of this measure, and a representative of the association has appeared before this committee and attempted to show by statistics and otherwise that this proposed law would very materially lessen the value of all live stock marketed.

On December 17 last, by means of the Associated Press dispatches, there was broadcasted over the country the following statement, purporting to come from Mr. John W. Springer, president of the National Live Stock Association. It is dated at Denver, Colo., and is as follows:

"The stockmen of the West are all interested in this bill," said Mr. Springer to-day, "and so are all manufacturers. If such a measure as this can become law no industry in the country is safe. If it should become a law and take effect it means simply that the stockmen of the West will lose from $\$ 3$ to $\$ 4$ on everv : teer they market. We also claim that the only people directly interested in the passage of this law is the butter trust."

A neighbor of mine who annually feeds large numbers of cattle for market, after reading this statement, said to me: "If that statement be true I certainly am opposed to your Grout bill."

Gentlemen of the committee, as I understand this matter, this statement is not true, and neither by statistics nor otherwise can it be shown to be true. Statistics published by the United States Department of Agriculture for the fiscal year ending June 30,1899 , show that at 41 packing centers the number of cattle inspected before slaughter was $4,654,842$. Outside of those inspected by the Department it is estimated that enough more were slaughtered to make the aggregate number slaughtered for the year, 5,000,000 head.

The report of the Secretary of the Treasury of the United States to Congress in May last shows that in all the $83,000,000$ pounds of oleomargarine manufactured in this country last year there were but $24,491,769$ pounds of oleo oil used. This at 9 cents per pound has a value of $\$ 2,204,259$, which sum divided among the $5,000,000$ head of cattle who produced this oleo oil makes an average of 44 cents per head.

In some cases this product is priced at 10 cents per pound, but I think that is unjust from a producer's standpoint, for the reason that at 10 cents a pound oleo oil is a manufactured product into which labor, etc., goes, and on which profit is realized, but the man who markets the cattle does not receive 10 cents a pound for it, and I have used the figure 9 cents, which, in my judgment, is a proper estimate. No one believes or for a moment seriously contends that if this oleo product used in the manufacture of oleomargarine could not be so used it would be a total loss, and lessen by the sum of 44 cents the average amount received by the owners of cattle for each animal sold for slaughter. But suppose it needs be sold at the price of other fats -5 cents per pound-it would mean a mere nominal loss of 20 cents ou each animal sold for slaughter, which sum every owner of live stock well knows is hardly given a thought when his stock is being disposed of for slaughter at packing centers.

Mr. Bassett also showed (p. 452) that of the $43,891,814$ head of cattle owned in this country $28,825,933$ were owned in the States prohibiting the sale of yellow oleomargarine, while but $15,065,881$ were owned where its sale is permitted.

And in closing Mr. Bassett said (p. 453):

I do not wish to discredit the National Live Stock Association before this committee. but in its appearance here it does not represent either the wishes or sentiments of 
the very large majority of the farmers and stock raisers of my State. It undoubtedly does represent the sentiment of the packers, commisuion men, owners of live stock on the ranges, and like interests, but it does not represent the sentiment of our farmers and dairymen who are by far the largest raisers and owners of live stock.

When I say "owners of live stock on ranges," I have reference to that class of men who own large interests in live stock.

Senator ALLEN. Large herds?

Mr. Bassetr. Large herds, yes; and those men do not do much in a dairy way. I have reference to men who own comparatively small herds of cattle.

In view of the statement made by Judge Springer, on page 114, which would lead one to believe that 58 pounds of oleo oil came out of every steer, as there was that amount of caul fat therein, attention is called to the following discussion, which appears on page 559:

Mr. KNIGHT. Now, there is another matter that has been in question here. Mr. Miller made the statement to you that some 40 or 50 pounds of oleo oil came from the caul lat of a steer. I have here Iowa Agricultural Bulletin No. 20, showing the weight of 18 fatted steers fed at that station, and the amount of caul fat therein, as taken out by Swift \& Co., of Chicago, and reported to Director James Wilson, now Secretary of Agriculture. That bulletin shows that the average amount of caul fat in steers weighing on an average 1,508 pounds was 37.66 pounds. The statement made before the Agricultural Committee of the Senate-

Senator ALlEN. That is a pretty good steer.

Mr. Knight. The statement made before the Senate Committee on Agriculture in 1886 by Elmer E. Washburn, a live-stock dealer in Chicago, showed that from 148,S93 head of cattle slaughtered in that city by one of the largest packing concerns there was an average of 61.5 pounds of fat in those animals used in oleo oil, and that those 61.5 pounds made 28.1 pounds of oleo oil, which goes to prove that there is less than 1 pound of oleo oil to 2 pounds of fat.

The oleomargarine people, in all of their claims before this committee and in other places, have stated that the fat used from the steer or cattle was only the finest and choicest caul fat; and Mr. Miller made the statement to you that if they used any other it would be tallowy.

According to this report of Secretary Wilson, there are on an average but 37.66 pounds of caul fat to the steer of 1,508 pounds, and it is well known that cattle that are marketed will not average over 1,200 pounds. That would be a heavy average, would it not?

Senator Allen. I should think it would be a full average, at least.

Mr. KNight. Under those circumstances, I think you can go to the bottom of the thing and find that they can not make more than 15 pounds of oleo oil from the raul fat of the average animal. Counting 15 pounds to the average animal, and counting $5,000,000$ cattle slaughtered last year, they have recourse to caul fat for the making of but $75,000,000$ pounds of oleo oil. There were $142,000,000$ pounds of oleo oil exported, and $24,400,000$ pounds used in oleomargarine, a total, I think, of over $166,000,000$ pounds, with a capacity of but $75,000,000$ pounds of oleo oil from caul fat.

Senator Dolliver. I supposed they used all the fat.

Mr. KNignt. They must do it in order to get out everything, I should say. Now, those are simply statistics, gentlemen.

Senator Dolliver. Would that lift them out entirely?

Mr. KNight. Not at 28 pounds to the head; no, sir.

Senator Allen. Many of these animals, as I understand, are calves and other animals that have not much fat in them.

MIr. KNIGHT. On an average, according to Mr. Washburn's statement, they get 28.1 pounds of oleo oil from each animal.

Mr. Miller. That was one special lot?

Mr. KNIGHT. Oh, no. One hundred and forty-seven thousand head.

Senator Money. Whose report is that?

Mr. KNight. That is the report of Elmer E. Washburn, a live-stock dealer of Chicago, who appeared on behalf of the oleomargarine makers. It is in that record.

Which we claim disproves the theory that oleo oil is made wholly from the "caul fat" of the steer.

THE COTTON-SEED OIL OPPOSITION.

The protests of the cotton-seed-oil presser's against the Grout bill have been second only to the expressions of the cattlemen. The 
basis of their opposition may be best understood from the following, taken from page 667 of the House testimony, Mr. Fred Oliver representing a committee from about 400 oil mills in the South:

Mr. Oliver. About $\$ 40,000,000$ was paid to the farmers for seed; about $\$ 15,000,000$ for the transportation of the seed in and products out; about $\$ 10,000,000$ for labor. In this country there is used probably 150,000 barrels, of 50 gallons each, of butter oil in manufacturing oleomargarine-at least aboveboard. How much there is used secretly I do not know.

Mr. Haugen. What part of it is cotton-seed oil?

Mr. Oliver. About 150,000 barrels of cotton-seed oil, of 50 gallons each, goes into the oleomargarine through the large manufacturers that are now being taxed and living up to the regulations.

Mr. HAUGEN. About how much is this worth?

Mr. Orjver. About 40 cents a gallon, of $7 \frac{1}{2}$ pounds to the gallon.

Mr. Neville. Have you figured out the number of pounds so that you know?

Mr. Oliver. No; it is only from what is published and the amount of taxes paid on oleomargarine. Oleomargarine contains from 25 to 40 per cent of cotton-seed oil, depending upon the weather and the season of the year it is made.

It appears from the above that these cotton-seed-oil people were led to believe that $55,250,000$ pounds of their oil were used in the $83,000,000$ pounds of oleomargarine made the previous year, as that is the weight of 150,000 barrels, of 50 gallons each. He stated, as shown by the record, that oleomargarine contained from 25 to 40 per cent of cottonseed oil.

Secretary Gage's report, quoted a number of times before this committee, shows that, instead of there being $55,250,000$ pounds of cottonseed oil used in the $83,000,000$ pounds of oleomargarine, there were less than 9,000,000 pounds; that instead of the quantity used in oleomargarine being from 25 to 40 per cent, as represented to the pressers of cotton seed, it was only about 10 per cent.

Efforts to pin the representatives of the cotton-seed oil pressers down to some definite statement before this committee have been futile, as the record will show. The point has been evaded through one subterfuge or another, and the following discussion or colloquy is a good example of the futility of attempts to get any intelligent statement from those interested, and is found on pages 520 and 521:

Mr. Tompkins. With reference to communications from farmers, I want to say that I have not the slightest doubt that the farmers, who are very much interested in this subject, up to the present time do not know about it, and those who produce the cotton seed and are interested in the cotton seed that goes into the cotton-seed oil mills do not know abont it. If it is a question of getting communications from farmers, I have not the slightest doubt that at least 50 per cent of the farmers could be got to petition against the bill, which will depreciate their interest not less than $\$ 2$ a ton on $2,000,000$ tons of seed.

On the subject of the interests that are affected we have some testimony that was given before the House committee on the subject of the cattle interests, that since the fall of 1895 there has been a depression in the value of live stock to the extent of $\$ 62,000,000$. I have not the slightest doubt that the passage of the bill would affect the farmers' cotton-seed interests to the extent of at least $\$ 2$ a ton on all the seed that they sell.

Mr. Knight. Will you yield to a question?

Mr. Tompkins. Yes, sir.

Mr. KNight. How do you figure it out?

Mr. Tompkins. By taking the quantity of oil off the market where it is sold at present; it will depreciate the value of the whole amount of cotton-seed oil, because the surplus product is what controls prices, not the whole quantity.

Mr. KNight. What is the quantity of oil?

Mr. Tompkins. The quantity of oil is from $1,500,000$ to $2,000,000$ barrels. It is difficult to state the amount exactly.

Mr. KNight. What is that quantity?

Mr. Tomprins. It is from 1,500,000 to $2,000,000$ barrels of oil that is produced. 
Mr. KNight. You do not grasp my question. That is what I have been trying to get at in the cotton-seed business. What do you consider to be the relative value of the production of oleo in this country to cotton-seed oil?

Mr. Tompkins. I consider the finest pressed oil about 5 cents a gallon.

Mr. KNIGHT. That is not the question at all. What is your market for cotton-seed oil to these manufacturers? How mueh do you market?

Mr. Tomprins. IVe have their testimony for that. I think they can give you a more accurate estimate of it than I can, probably.

Mr. KNIGHT. Is it not true that the Internal-Revenue Commissioner shows that you sold to them last year less than $\$ 500,000$ worth of that oil?

Mr. Tompkins. I could not answer that question.

Mr. KNight. Well, it is a fact. I think the committee will accept my statement, because this is a matter of record.

Mr. Tompkins. But that may not be any measure at all of the quantity of oil that goes into the product, because it may have gone through several other channels. WVe know that they use cotton-seed oil to the extent of 10 to 30 per cent and that it furnishes a large market for it.

Mr. KNight. Do you not know how much they actually use?

Mr. Tompkins. According to their testimony, I say.

Mr. KNIGHT. Do you not know how much, exactly, they use according to their own testimony?

Mr. Tompkins. That testimony stands for itself.

Mr. KNight. What I want to get at is, what is the value of the product? According to the Secretary of the Treasury it was about $8,800,000$ pounds, as I understand.

Mr. Tompkins. It is not a question of the value of that. It is a question of what will be the cause of destroying that market and limiting the sale of cotton-seed oil in the markets that are left.

Mr. KNight. I want to ask you this question: You claim here, as I understand, that the loss of a market of a half million dollars' worth of cotton-seed oil would lower the value of your product to the extent of $\$ 2,000,000$.

Mr. ToMpkins. In a differential market it might easily.

Mr. KNight. Then, why would it not be a good investment to burn up a half million dollars' worth and thus advance the price $\$ 2,000,000$ ?

Mr. Tonipkiss. We are not in the business of burning up. Each man would have to burn his own oil, and you can not bring about a situation of that kind. It might bring about the same result if you did. No individual man is going to burn his own product, and I doubt if the law would permit a combination to do it. That is not the question at issue.

Failing to secure any satisfactory explanation the following statement was made at the suggestion of Senator Allen, as shown on page 487. The representatives of the oil mills were present, one of them having just concluded, and they made no objection or criticisms further than recorded, Mr. Miller being a representative of the Armour Packing Company, of Kansas City, Mo. The statement and discussion follows:

Mr. KNighт. It was stated by Senator Allen that probably I would want to answer something that the gentleman preceding me has said in regard to cotton-seed oil.

From his figures I gather that the value of the cotton production of this country is $\$ 475,000,000$. From figures presented by other people here I take it that the value of the cotton-seed-oil industry is $\$ 50,000,000$, making a total of $\$ 525,000,000$. Of those $\$ 525,000,000$ in value of the cotton and cotton-oil product, the oleomargarine people of this country use less than one-half of $\$ 1,000,000$ worth. The amount of cotton-seed oil used in the manufacture of oleomargarine in this country, in proportion to the product of oleomargarine, basing it upon the figures of the cotton-sced-oil people themselves, is about two-thirds of 1 per cent. So that we can not see, gentlemen, any great harm that can accrue to the manufacturers of cotton-seecl oil as a result of this legislation, even if it would (as they claim) crush out the industry entirely, which we deny.

Mr. Miller. I would like to call the attention of the committee to the statement marle by Mr. Culbertson, representing the Paris Cotton Oil Comprany, of Paris, Tex. That statement was to the effect that the amount of oil made for the manufacture of oleomargarine was 25 per cent of the total amount of oil made.

Mr. KNIGHT. I do not know what Mr. Culbertson said, but I do know that the Secretary of the Treasury has reported that in the $83,000,000$ pounds of oleomargaiske made in this country last year there were less than $9,000,000$ pounds of cotton-seed 
oil. I can not give you in pounds the amount of cotton-seed oil produced; I am only giving it in dollars, as shown by this report, which does not give it in pounds. So that that statement will hardly stand the test of reason, when it is seen that the value of all of the cotton-seed oil is $\$ 50,000,000$ yearly and there is only $\$ 500,000$ worth used in the oleomargarine made in this country, as 25 per cent of the $\$ 50,000,000$ would be $\$ 12,500,000$.

Mr. MiLLer. You are not taking into consideration the amount exported?

Mr. KNIGHT. Do we make into oleomargarine in this country the cotton-seed oil that is exported?

Mr. Miller. What would be the effect upon the export trade if you should place a ban on the oil used in this country?

Mr. KNIGHT. I want to speak in connection with this matter of "placing a ban" on the oil in this country. When this bill was up for consideration in 1886, the cry was, "If you place a 2-cent stamp of disapproval on oleomargarine, you will place a ban on the article, so that nobody in the United States will use it." But the minute the tax was placed on oleomargarine its manufacturers began to call it an indorsement by the Government of oleomargarine; and the matter has been carried into the courts, and it has been claimed that this taxation gave the Government's stamp of approval to oleomargarine.

Now, if 2 cents a pound tax will give you the Government's stamp of approval, a tax of 10 cents a pound will give you five times that much approval. [Laughter.]

Upon the question of policy of the South opposing the Grout bill and thereby crippling the dairy interests, Secretary Wilson discussed the matter as follows (p. 427):

Secretary WILson. There is no possible direction in which the South can renovate its worn-out lands so fast as to feed that cotton seed to stock. It is the finest feed on earth.

Senator MONEY. I know that. I am a farmer. I raise cotton.

Secretary Wilson. And you can not do it without the dairy cow.

Senator Money. I raise cows, too.

Secretary WiLson. The dairy cow is the only instrumentality. You can not do it by commercial fertilizers, because it will not put the humus in the soil.

Senator Money. You are right about that.

* * * *

A 10,000,000-bale crop of cotton gives 5,000,000 tons of seed. Two hundred and twenty-five million gallons of oil from this seed may be sold without injury to the soil upon which the plant grows, but the residue should not be exported. The sale from the land of this nitrogenous by-product results in shorter crops and ultimate sterility, which, however, may be arrested by encouraging dairying and feeding for meats.

A great deal having been said by the makers of oleomargarine about the use of strong acids in the so-called renovation of old butter, it will be interesting to note that practically all oleomargarine contains an oil that has been refined by one of the most powerful chemicals in use. The following is from page 348 :

Mr. KNight. Will you pardon a question?

Mr. Culberson. Yes, sir.

Mr. KNight. Are you a refiner of cotton-seed oil?

Mr. Culberson. We have refineries at our plants; yes, sir.

Mr. KNIGHT. Do you use any chemicals in refining cotton-seed oil?

Mr. Culberson. There is no way to refine it other than by chemicals

Mr. KNIGHT. What chemical is used?

Mr. Culberson. Various.

Mr. KNight. What is the principal one?

Mr. Culberson. The same chemicals that have been used ever since cotton-seed oil was refined.

Mr. KNIGHT. I am not a cotton-oil man, so I do not know what those are, and I do not think the committee does.

Mr. Culberson. We use caustic soda in diluted form. We furthermore have our own processes by which when the oil is finished it is perfectly neutral. There is absolutely no sign of chemical or of coloring matter.

Mr. KNIGHT. You can refine cotton-seed oil and make it absolutely white-make what they call a winter oil? 
Mr. Culberson. Yes; tnat can be done.

Mr. KNight. Do you think it is possible that any of that caustic soda will be left in the oil after the refining?

Mr. Culberson. It is possible, but not for butter-oil purposes.

Mr. KNight. Then in all of the oleomargarine that we eat we eat an oil that has been through a process of refinement by caustic soda or with caustic soda?

Mr. Culberson. Not necessarily.

Mr. Knight. Well, some other chemical equally strong.

Mr. Culberson. Not necessarily. There are other processes. I tell you what we use.

\section{HEALTHFULNESS OF OLEOIIARGARINE.}

This is a subject upon which "doctors disagree," and which, while we have always and do now claim is absolutely immaterial when the evil we seek to remedy is fraud, yet we do not shrink from the discussion of the proposition.

\section{Dr. Wiley said before the House Committee on Agriculture, as printed on page 772 of the House report:}

From a chemical study of the composition of butter, it is reasonable to infer that it requires less effort on the part of the vital organs to ferment the butter, and that is the reason why I say that I believe butter is a more digestible substance, more easily digested, more quickly digested than oleomargarine.

\section{Speaking from a practical standpoint, Secretary Wilson said, as} printed on page 417 :

There is an impression abroad that the oleomargarine industry is as legitimate and praiseworthy as making butter from the cow. As far as the making of oleo oil, to be sold as such, is concerned there is no controversy, but that the mixture of ingredients that compose oleomargarine is as healthy as the butter from milk of the cow nobody who has inquired into both can believe. The flavor of butter, a prime element in palatability and digestibility, comes from bacteria universally present whenever milk is exposed to the atmosphere. Fine butter has a fine flaror, one of its principal characteristics. Bacteria feed upon casein, an element not found in vegetable fats nor in the tallow of animals. The imitation of butter known as oleomargarine is washed in milk in order that some of the casein may be present as the basis of the flavor. The imitation, in as far as it varies from genuine butter, lacks both the flavor that comes from a full complement of casein and the digestibility natural to the cow's product. It is well known that the scalding of milk kills the bacterial growth, after which it will keep longer, but its digestibility is greatly.impaired. Butter for immediate consumption is but slightly worked, so that the leaving within it of a considerable amount of casein will grow bacteria and develop flavor. If it is to be consumed in a week it is worked over more, and if within two weeks still more. If it is to be kept for months the buttermilk with the casein is thoroughly worked out, unless it is to be put in cold storage and kept at a temperature at which bacteria will not multiply.

Milk contains a ferment that changes casein into a digestible nutrient. The imitation of butter made by the chemist is a mixture of fats that should be sold for what it is. It is not as palatable nor as digestible nor as grateful to the human system. The digestible juices flow freely. When palatable food is caten, the mouth waters. Oils and fats as such have their uses, but the coloring of them deceives the people and induces a consumption as liberal as with butter, which, while not so injurious to people in full vigor as to children and invalids, is nevertheless undoubtedly harmful. The yellow coloring of butter in winter, when it has a light shade, if green cured hay or roots are not used, deceives nobody. The yellow coloring of a mixture of fats is with intent to deceive.

The present law is not well enforced; it is evidently difficult of enforcement. The effacement of marks and brands is easily done. The greatest sufferers are the poorer classes and consumers who have not the opportunity to select their food. If there were no coloring there would be no fraud. The most intelligent are deceived, however, with good imitations, and from careful inquiry I am satisfied that most of $11 \mathrm{~s}$ are using the bogus product at greatly increased expense over the price of the oils of commerce, and with danger to health from the less digestible and less palatable imitation. 
And on page 585 of the House report will be found the following, submitted by Hon. W. D. Hoord:

Is oleomargarine a healthful food? There is no way to determine this question except by actual trial; not for a day, a week, or a month, but for several successive months, and not with strong, robust men with plenty of outdoor exercise.

Chemistry can not answer. For example, the chemist will tell you that he finds the same elements in swamp peat that are found in the grasses and hays that are fed to our cows, and in approximately the same proportion. And the chemist is at a loss to determine from the standpoint of his science why cattle should not feed on swamp peat. Chemistry can not determine whether any particular substance is poisonous or not. It must take a stomach to do that.

There is no credible evidence to show that oleomargarine is innocuous; no evidence to show that when eaten continuously in place of butter it is not harmful. But there are reports in great abundance to the effect that oleomargarine is harmful.

Mr. Edmund Hill, a member of the Somerset County council, England, reports that the great bulk of oleomargarine, or "margarin," as it is called there, is eaten in public institutions, convents, schools, etc. At the Wells Asylum, with which he is connected, the inmates receive oleomargarine. In the asylums of Dorset, Wells, and Hants-the adjoining counties-butter is furnished, and the death rate at Wells is 30 per cent higher. At the Taunton Hospital there were 11 deaths in thirteen months. Oleomargarine was substituted, and in nine months the deaths rose to 22 .

This accords with the experience in France, where its use in hospitals is forbidden. In the United States, in institutions for the blind and for girls, it has been noticed that the use of oleomargarine lowered the vitality of the inmates very perceptibly.

Hon. G. L. Flanders, assistant commissioner of agriculture of New York, throws some light upon this question on page 129:

I now turn to the report made by Dr. R. D. Clark upon the healintuiness of oleomargarine. He is a chemist and medical man of twenty years' standing, and I want to say here and now that our opinion in the State of New York, after having given this subject a great deal of study and thought and after having obtained the very hest advice we could get, is that a chemist is not, by virtue of his chemical knowledge, a competent man to tell about the healthfulness of food products. A chemist's province is to take a commodity and take it apart, and tell what is in it. It is no part of his work to tell what effect that article produces upon the human system. That is a physiological question. Dr. Clark, a physician, says, relative to the healthfulness of oleomargarine:

"We now come to the all-important aspect of the subject, Is artificial butter a wholesome article of food? We answer it in the negative, on the following grounds:

"First. On account of its indigestibility.

"Second. On account of its insolubility when made from animal fats.

"Third. On account of its liability to carry germs of disease into the human system.

"Fourth. On account of the probability of its containing, when made under certain patents, unhealthy ingredients."

A full report of Dr. Clark's statement is contained on pages 129, 130, 131, and 132 of the Senate testimony.

But this is a question the discussion of which would occupy volumes, with no possibility, apparently, of an agreement of authorities, except that the chemist appears to be on the side of oleomargarine and the physician on the side of pure butter.

\section{AS TO GOVERNMENT INSPECTION.}

As producers bearing a large share of the burdens of taxation for the support of the Government, we feel it no more than just that the impression which the makers of oleomargarine seek to convey, that their product has the stamp of approval of the Government and that its purity is certified to by the Internal-Revenue Department, should be dispelled.

We desire to call your attention to the statements of various witnesses upon this subject, which statements convey a wrong impression, 
as also shown by the records. Rathbone Gardner, representing the Oakdale Manufacturing Company, of Providence, R. I., said on pages 18 and 19:

As I have said, I believe it is the one substance which is, as no other substance possibly can be under existing laws, certified by the Government of the United States to be absolutely pure. * * * It seems unnecessary to argue this point. I presume the members of this committee know the conditions under which oleomargarine is produced-that there has to be a regular formula; that there is a chemist maintained at the expense of the Government who examines samples; that representatives of the Internal-Revenue Department stand in the doorway of every oleo manufactory; that they know exactly what comes into the building and what goes out of the building.

And on page 37 entered into the following discussion:

Mr. Gardner. To see what ingredients go into oleomargarine. The manufacturer is required to make a monthly statement, under oath, of every pound of ingredient he uses in the manufacture. It is the duty of the inspector or the deputy inspector, as I understand it, to verify that report and under oath to say that the manufacturer's statement is correct or incorrect.

Mr. HoAnd. Do you believe that the manufacturer always states the truth concerning the ingredients of olemargarine?

Mr. Gardner. Yes, sir; the manufacturers of which I know allything. That is my belief; it is not worth much one way or the other.

In his testimony on page 111 Judge Springer, representing the National Live Stock Association, said:

Let me call your attention to several statements made by gentlemen at that time. You will hardly believe that such things could have been. There were several bills pending, and the Hatch bill was finally passed. It provides for placing a tax of 2 cents a pound upon oleomargarine, and for a general inspection, through the Departments of the Government, of every part of the article manufactured, so that when you see oleomargarine manufactured in this country you see an article that the officers of the Govermment have inspected from its inception to the time it passes away from the factory in the original packages. They certify to its condition.

Mr. HoArd. You mean that the law provides for the inspection?

Mr. Springer. Yes, I do.

Mr. Flanders. That it may be done.

Mr. SPRINGER. It provides for it.

Mr. HOARD. It may be done.

Mr. SPRINGER. It provides for it.

Mr. Hoard. You do not assert that it is done?

Mr. SPRINGER. No, sir; I do not assert as to whether or not anybody performs his duty, but the law presumes that every officer of the Government does his duty, and until the contrary is shown I assume that they have done their duty. The law assumes that everybody is honest, and especially does the law assume that the officers of the Government and of the States do their duty. I hope they do. If they do not, they ought to be taught to do it.

On page 262 the following will be found in the remarks of $\mathrm{Mr}$. Charles E. Schell, representing the Cincinnati Butterine Company, et al.:

Again, the factories must be ready at all times for Government inspection. The local people, it will perhaps be claimed, could be provided against. They would know them, and perhaps would know of their coming. Fellow-citizens of the same town are not apt to take undue arlvantages, possibly; but the Government, the revenue officers, have their secret agents who go about from time to time, and the manufacturers know not the day nor the hour when they are going to appear. They must be ready at all times.

And on page 149 the following discussion, Mr. Pirrung being the manager of a butterine concer'u at Columbus, Ohio:

Mr. KNight. Another thing. In speaking of the inspection of the Government in the oleo factories, do you mean to infer that the Government does inspect the oleo factories?

Mr. Pirrung. Most decidedly.

S. Rep. $2043-54$ 
Mr. KNIGHT. Do they make chemical analyses of the oleomargarine right along?

Mr. PinRung. Yes, sir; the Bureau of Chemistry of the Agricultural Department does that for them.

Mr. KNiGHT. How many factories are there in the United States?

Mr. Pirrung. I think about twenty-five or thirty.

Mr. KNight. And about how many inspections do they make of the products you turn out?

Mr. Pirrung. I can not state for other manufacturers, but perhaps they come to us five or six times a year. They do not only require samples from the factories for the inspection; they go all over the United States, or States where our product or any other manufactured product is sold, and take up samples unknown to us.

Mr. KNight. Do they analyze them?

Mr. Pirrung. Yes.

Mr. KNIGHT. That is done among the retailers?

Mr. Pirrung. Yes; I presume so, and among wholesalers as well.

Mr. KNIGHT. There are about 10,000 retailers in the country, according to the last report.

Mr. Pirruna. I do not know. You are better posted on that than I am.

Mr. KNIGHT. What is the penalty if anything is found in your product that is not wholesome?

Mr. Pirrung. I have always understood the Government would be compelled to close up our factory.

Mr. Knight. You are not acquainted with the law very well, then, are you?

Mr. Pirrung. I thought I was.

Mr. Clark. They would not only close it up, but would confiscate it.

Mr. KNIGHT. They would confiscate the goods that they find.

Mr. Pirrung. They will close up our factory. If you will read the law, you will post yourself.

\section{On page 493 will be found the following statement made before the} committee by your orator:

Now let me show you another case. These people have said a good deal to your committee down here about the inspection of the Internal-Revenue Department, and about how they are compelled to report every ingredient, and that they are compelled to do this that, and the other.

As a matter of fact, the present oleomargarine law can not compel them to do anything that they do not want to do. All that they need to do is to hide behind their constitutional right and claim that the evidence called for will incriminate them.

Here is a case which is entitled "In re Kinney, collector of internal revenue." The heading is "Examination of books."

"W. F. Kinney, collector of internal revenue, district of Connecticut, issued a summons, under section 3173, Revised Statutes, against the Oakdale Manufacturing Company, a corporation engaged in the manufacture of oleomargarine. The parties refused to comply with the summons, and the collector petitioned the United States district judge for an attachment against F. M. Mathewson, president of the company, directed to the United States marshal of the district, commanding him to arrest said Frank M. Mathewson and bring him before the judge to show cause why he should not be adjudged in contempt and punished according to law, as provided by section 3175, Revised Statutes."

In this connection it may be said that this talk about these people being compelled to make a return of the materials and products is all bosh. They can not be made to do it if they do not want to. They make the return if they wish, and if they do not wish they will not do it, and they do not have to, according to this decision.

The decision of the judge was adverse to the collector. He held that-

"The provisions of Revised Statutes, section 3173, authorizing a collector of internal revenue to summon before him for examination any person charged by the law with the duty of making returns of objects subject to tax, do not apply to persons required under the oleomargarine law to make returns of materials and products. Such provisions relate only to objects of taxation upon which the tax is collected by the method of return and assessment, and not to those upon which the tax is required to be paid by a stamp; and a collector has no power under section 3173 to compel a person to appear and testify to the correctness of the returns made under the oleomargarine law." (102 Fed. Rep., 468.)

It will be noted that the above is the concern represented by $\mathrm{Mr}$. Gardner.

Your committee can hardly believe men engaged in a business in 
which they have thousands of dollars invested can be so ignorant of the law as to unintentionally make such statements.

But in order to fully settle this matter we refer to the testimony of the honorable Secretary of the Treasury, upon pages 564 and 565:

The Acting Chairman. Your revenue agents, Mr. Secretary, are expected to visit these factories and to take observations with respect to the quality of the ingredients constituting oleomargarine, are they not?

Secretary GAGE. Yes, sir.

The Acting Chairman. What are their opportunities for observation in that direction?

Secretary GAGE. Oh, they are ample in these large establishments. They are all open to our agents.

Senator BATE. Have you scientific inspectors to investigate what the component parts of this product are?

Secretary GaGE. No; I do not think we have. We put it to the test frequently, however. We get samples and have analyses made of the product. That is to say, we have done so in the past; I do not know what we are doing just at this moment.

Senator Allen. Your agents, however, are not all experts in the examination of oleomargarine, are they?

Secretary GAGE. Oh, no-no.

Senator AlLEN. So that they might be imposed upon, as well as the ordinary intelligent citizen?

Secretary GAGE. Very easily.

Senator ALLEN. They might walk into a place and call for butter, and oleomargarine might be handed to them as butter; and unless they took it to some person competent to make an analysis of it, they might not know the difference?

Secretary GAGE. That is quite true.

Senator BATE. Do you keep agents at any of these large establishments?

Secretary GAGE. I do not think we do keep any regular watch on them.
* *
*
*
*
*

Senator Allen. Then you do not keep such agents in these large establishments which manufacture oleomargarine?

Secretary GaGE. No.

* * * * * * * * *

Senator Aluen. The only thing with which you are concerned is the tax?

Secretary GAGE. That is the main thing, of course.

Senator MoNey. The remark you have just made, Mr. Secretary, suggests this question: You say the greater the tax the greater the incentive to fraud. The same rule would apply here, would it not?

Secretary GAGE. Undoubtedly.

The Acting ChairmaN. Do the instructions of your Department, Mr. Secretary, require the agents who visit these manufactories to report to you with respect to the purity of the ingredients used?

Secretary GAGE. No; I do not think so.

And to show the utter absurdity of this claim of inspection your attention is called to the following statement of your orator on page 499:

There are in the United States over 9,500 dealers, I believe, and 30 manufacturers of oleomargarine. The report of the Commissioner of Internal Revenue for the year 1900, which I hold here, shows that during the year 1900 the chemical department of that bureau made 177 analyses of oleomargarine. You can figure the proportion 177 bears to nearly 10,000. That will show you how many times a year they get around to these retailers and inspect their goods, and inspect the wholesalers, and inspect the factories.

\section{AS TO POLICY.}

The dairymen are not asking paternal protection for the sole purpose of fostering their great and important industry. They only ask the Government to use its strong arm to protect them against an illegitimate fraud which has proven itself to be beyond the reach of State laws.

But in the evidence a number of points have been brought out which are worthy of consideration by your committee. 


\section{Along this line Secretary Wilson says, on page 415:}

The dairy cow is the most valuable agent of the producer, and her milk is one of nature's perfect rations. She gives profitable employment to all who care for her or her products. She gathers her food from the tields withont intervening help in summer, and turns cheap forage into high selling products in winter. The grasses that grow for her in her pasture return humus to worn-out lands, enabling them to retain moisture and resist droughts, in addition to inviting nitrogen from the atmosphere through the agency of the legumes upon which she grazes. She is the mother of the steer that manufactures beef from grasses, grains, and the by-products of the mills.

* *

*

*

*

*

*

The farmer who keeps a herd of dairy cows returns through the herd to the soil all the crops he gathers from it, except the products of skill that take little plant food from the soil. The lint of cotton and the fine flour of wheat are among our leading exports, and take little from the soil; the fats of the cow and the plants take nothing whatever. The cow and her calf are prime necessities in reclaiming wornout land. The cotton-growing States that have reduced fertility by too much cropping can bring back the strength of the soil by growing the grazing plants and feeding the meal of cotton-seed to the dairy cow and her calf, but the farmers of no part of our conntry can afford to keep cows for the sole purpose of raising calves, except free commoners on the public domains, whose privileges are being contracted to such an extent by injudicious grazing that every year fewer cattle are found on the ranges of the semiarid States.

The meats to feed our people in future must come, in large measure, from the highpricer farms east of the one hundredth meridian of west longitude. The feeding steers will be bred on those farms from the dairy cows that are now and will become more and more a necessity.

Hon. John Hamilton, secretary of agriculture for Pennsylvania, is reported as follows, on pages 157 and 158 :

Careful examination should be made in to the effect which this will have upon the dairy industry of the Commonwealth, which has now become one of the leading and most profitable branches of our agriculture. If, upon examination, it is found that oleomargarine will to any considerable degree drive ont the dairy interests from the markets of the Commonwealth, it would seem to be only wise public policy to first make sure that the industry that is to replace this branch of our agriculture shall do more for the Commonwealth in the way of substantial and permanent support than the important occupation that it proposes to supplant.

The admitting of oleomargarine in competition with the dairy products of the State endangers a great industry that is now a part of our system of agriculture more widely distributed than any other. We have now abont 1,100,000 cows in Pennsylvania. Their product is about $90,000,000$ to $100,000,000$ pounds of butter per year, and according to the census of 1890 the milk product was $437,525,349$ gallons. These cows are distributed among 211,412 farmers' families, consisting of over 1,000,000 persons, or about one-fifth of our entire population. The income of the farming people of Penusylvania last year from butter alone amounted to between eighteen and twenty millions of dollars; and the milk protuct, at 8 cents per gallon, amounted to $\$ 35,000,000$ more. This vast sum is a new product each year, adding this much to the actual wealth of the State, and is distributed all through the Commonwealth, going to the support of over $1,000,000$ people, enabling them to maintain themselves in comparative comfort. The loss of such a sum as this by the agricultural people of the State would be a calamity, particularly becanse much of the material that is used in the feeding of these dairy cows would, if the industry were destroyed, be left on the farmers' hands valueless.

And on page 134 will be found the following from Hon. G. L. Flanders, assistant commissioner of agriculture of New York State:

Do you know that in the great State of New York there are 1,600,000 cows? Do you know we liave 250,000 persons engaged in farm work? And yet you seek to come into our market and drive us out and ruin that industry. Is there anything fair about that? We ask you to stand up like men and sell your commodity for what it is. Then if you can compete with us we will stand it like men. Not many years ago we were in the meat market. We raised cattle in New York and sold them for meat. We sold cereals. The Geneseeand Rochester valleys were great wheat fields. Then the wheat 
fields of the Mississippi Valley were opener up, cultivated by machinery. Then South America opened up her wheat fields and produced grain at 37 cents a bushel on shipboard, Australia opened up her wheat fields, and now Russia is opening up Silueria to the production of the cereals. We are driven entirely out of the cereals market. We have been driven ont of the meat market, and there has not been one word of complaint. It was clone among men in open competition; but we rlo complain when you take all that is left and seek to do it by frand. I can not conceive how any man who has had any experience anywhere that gives him a knowlerge of ethies can sustain the man who has placed upon the market a commodity looking, smelling, and tasting like another, as that other, and then say when we ask him to stop it that we are trying to down a healthy competition. It is not competition. It is downright robbery.

And from Hon. IV. D. Hoard, president of the National Dairy Union, the following on page 413 :

This law is demanded in the interest of a broad public policy, for the protection of legitimate industry against illegitimate counterfeiting and fraud. Compare the policy pursued by the United States with that of Canada. The Dominion government guards the purity and honesty of her dairy products to the extent of absolute prohibition of any adulteration or counterfeiting of the same. As a result her export of cheese to England alone has grown in twenty years from $\$ 3,000,000$ to $\$ 20,000,000$, while ours has declined nearly the same amount, because we did not place the strong hand of the law on the adulterated product, filled cheese, until we had lost the confidence of the foreign consumer.

The fears of the dairymen from the encroachment of the oleomargarine frand find good roice in the following extract from Judge Springer's statement on page 91:

The total production of oleomargarine in the United States for the year ending June 30,1900 , was $107,045,028$ pounds. This was a consumption of only 1.4 pounds per capita. Without repressive laws in any of the States the consumption might have been as great per capita as in Rhode Island. This would have increased the demand for oleomargarine for consumption in the United States per annum to over $600,000,000$ pounds. It is not surprising, in view of these facts, that the friends of the pending bill desire the enactment of the first section, which will place oleomargarine under the repressive laws of 32 States in the Union, with a fair prospect of securing equally oppressive legislation in the remaining 13 States.

As the dairymen's market for butter in this country only amounts to about $800,000,000$ pounds outside of the producer, who consumes $700,000,000$ pounds of the $1,500,000,000$ pounds of butter produced, it would seem that conditions do warrant their present alarm.

\section{EVIDENCE INTRODUCED UNDER FALSE PRETENSES.}

We deem it our duty to call the attention of the committce to the evidence of Francis W. Lestrade, of New York City, who appeared before this committee in the interests of oleomargarine.

The record (p. 16t) shows that he introduced himself as follows:

Mr. Lestrade. Mr. Chairman and gentlemen of the committee, I wish to state on the outstart that it is seldom I am called upon to speak in public:.

The ChaIrMaN. You are interested in the manufacture, are you, or are you acting as counsel?

Mr. Lestrade. No; I was about to say that I am nothing more than a practical everyday butterman. I have been in business for twenty years, and what I say before you is entirely from a practical standpoint, not a theoretical stanilpoint, and not from any scientific point of view, but from what has come under my observation as a butterman ever since I was a boy.

I am a member of the firm of Lestrade Brothers, New York City. I am an owner of and interested in dairy farms, loth in the West and in the East. I am also interested in cows. I am also interested in three different creameries. I am also, and this is our chief business in the city, an exporter, a packer of butter and cheese to the hot countries as well as to the Continent, but mostly to the hot countries. Our 
business extends over all the hot countries -that is, the tropical climates, consisting of the West Indies, the East Indies, South Africa, China, South America, and even now into the Philippine Islands.

So what I have to say is entirely in my own interest, and more particularly as an exporter of the genuine butter that goes out of this country to foreign climates.

And to further impress upon the committee the cause of his interest in the bill he stated on page 177, as shown by the discussion in the record:

The question may arise in your minds, gentlemen, why am I opposed to this bill, as all my interests-my money, what little I have, or the greater part of it-are in butter. It is merely this: That, as I have stated, oleomargarine has been a friend to butter; has made us dairymen, farmers, creamery men, make better butter. The second reason is that the dairymen throughout the United States are getting a good profit on their butter. We are making money. My creameries are making money. I do not know of any creameries that are not making money. We are making from 10 to 50 per cent. Legitimately we are making from 10 to 20 per cent; speculatively we are making a great deal more.

I do not want the sale of oleomargarine prohibited. I want it for a balance, so to speak, to keep wild speculation down. I can not afford as a creamery man-a man interested in butter-to put myself in the position, if I can help it, of allowing speculators to come iu and manipulate butter. It is bad enough now as it is; but wipe out oleo, which you will if you put this 10-cent prohibitory tax on, and there is not a man in the country could do anything in regard to steady prices. They can no more sell oleomargarine white than you could sell butter white. I have made white butter up in small quantities, and the only people who take white butter are our friends the Israelites, and they only take it in small quantities.

On page 369 appears the following from Assistant Commissioner of Agriculture Kracke, of the Metropolitan district of New York:

Mr. KRACKE. There is one other point to which I want briefly to call attention, and that is the fact that there appeared before this committee last week a man from New York who stated that he was a commission merchant and a dealer in butter. In making his statement he took up an interview of mine in a New York paper and attempted to distort it so as to have me say something that I did not say. I refer to Mr. Lestrade, who came here and made a statement before the committee. I wish now to ask the committee if Mr. Lestrade told the committee that he was an oleomargarine manufacturer?

The record will here show that an attempt was made to ascertain what representations Mr. Lestrade made as to his interest in the matter, but the notes not having been transcribed it was not possible to review the proceedings. Because of this lack of facility at the time, we believe we are warranted by the condition to state that investigation shows that Mr. Lestrade is one of the proprietors of the Goshen Manufacturing Company, makers of oleomargarine, Providence, R. I. The following appears on page 369 of the record, however:

Mr. KniGHT. Have you ever had any trouble, Mr. Kracke, with any Providence concern shipping stuff in through Jersey City?

Mr. KRACKE. Well, there was trouble with this particular one-Lestrade Brothers.

The difficulty referred to was the fining of Mr. Lestrade's concern $\$ 600$ for violations of the New York oleomargarine law.

Before bringing the matter to the attention of your committee, we have carefully searched the record and in no place find the admission of Mr. Lestrade that he is a manufacturer of oleomargarine.

\section{LABOR'S OPPOSITION.}

Members of the committee present at the hearings when representatives of labor organizations appeared are well prepared to judge of the force of the opposition they represent. 
Your orator will briefly call attention to his statement on pages 471 and 472, wherein it is shown that organized labor in Chicago, in 1897, severely condemned the yellow oleomargarine fraud. The following is a portion of that statement:

In 1897 we had before the legislature of the State of Illinois a law which sought to prohibit the coloring of oleomargarine in the semblance of butter, known as the Fuller bill, which I was looking after at the time, and which passed the legislature finally. I went to the Federation of Labor of the city of Chicago and called on its legislative committee. I called those gentlemen together and I told them the condition of things in Chicago. I showed them what we were attempting to accomplish, and asked their cooperation in the matter. I asked them if they could not give the indorsement of the Federation of Labor. They said they did not think there was any doubt but what they could. I now want to read you from the Chicago Federationist, a labor paper, of the date of April 9, 1897:

WORKINGMEN INDORSE IT—ANTICOLOR BILL APPROVED BY THE CHICAGO FEDERATION OF LABOR-COLORED OLEOMARGARINE CONDEMNED AS A FRAUD-A RESOLUTION PASSED AT LAST SUNDAY'S MEETING INDORSING THE FULLER BILL IS UNANIMOUS-LABOR IS AGAINST THE FRAUD.

The defenders of the colored oleomargarine fraud have had their last prop knocked from under arguments.

For years they have pleaded for protection of oleomargarine "in behalf of the workingman.". Oleomargarine was christened "the poor man's butter" by those who were aiding manufacturers in making millions off the same "poor man."

The anticolor bill was brought before the Chicago Federation of Labor by the legislative committee of that body Sunday, April 4, by Chairman Williams, who has claimed that large quantities of oleomargarine were being dealt out in the city by retailers to those who called for butter and paid for butter. This fraud was made possible, he stated, because of the fact that the substitute was made in perfect semblance of butter, and the workingman was the chief victim. He explained that the only remedy for this fraud was the enactment of a law which would make it possible for buyer and consumer to distinguish the compound whenever he saw it.

Only one delegate in the entire body objected to the indorsement of the measure, and after he thoroughly understood the question he moved to make the vote for its adoption unanimous, which was done.

The sentiment expressed by the different delegates to the Federation at the close of the meeting was that, should a petition be circulated among the army of workingmen of Chicago calling for the passage of the Fuller anticolor law, it would meet with no opposition.

Then the resolution which was passed at that time, and which I have in my possession, in the city of Chicago reads as follows:

Charles Y. Knight, Secretary Dairy Union.

Dear Sir: At a meeting of the Chicago Federation, held on the 4 th instant, that body unanimously indorsed the Fuller bill, and requested all subordinate bodies to use their utmost to secure its passage.

Very truly,

Chicago, April 4, $189 \%$.

Chairman Legislative Committee, Chicago liederation of Labor.

The fact that not a single delegate in that meeting cared enough about the color in oleomargarine or oleomargarine itself to oppose the passage of the resolution we consider pretty good evidence that few workingmen know when they are buying oleomargarine if they consume it, and do not care for the color if they do buy it.

That there is no great demand for oleomargarine, and as evidence that it is forced upon the public instead of being demanded by the people, we submit the following from the evidence of Isaac IV. Cleaver, 
of Philadelphia (p. 221), manager of the 63 stores of the Acme Tea Company, of that city. Mr. Cleaver said:

We are in no way interested in the manufacture of butter; only in the sale of it. If we could sell oleomargarine legally and there were a demand for it, we would just as lief sell it as we would butter.

With reference to whether or not there is a demand for it, I have only this to say: We have a printed slip, with questions on the slip which must be answered every week by every manager in each of our stores. One of those questions is this: "Has there been anything asked for during the week that we do not keep? If so, what?" We have yet, from all those 63 stores, to have an inquiry for oleomargarine or butterime. Consequently, we are convinced that the masses of the people in Philadelphia do not want oleomargarine or they would ask for it.

And Mr. Cleaver further testified that they sold to the masses, their stores being what are known as "cut-rate" or cheap stores.

\section{CONSTITUTIONALITY AND AIM OF THE 10-CENT TAX.}

There is of course a prejudice against the use of the internal-revenue tax for protective purposes, particularly when it is argued that the purpose is to entirely prohibit the manufacture and sale of the article taxed. In this case we claim that the tax is being employed only for the purpose of turning into the United States 'Treasury that portion of the profits upon a counterfeit article which may furnish an incentive for the vender thereof to practice fraud upon the public.

We contend and believe that we have established the fact through the testimony of food commissioners and other's who are in best position to judge that at least 75 per cent, if not more, of the oleomargarine produced goes to the consumer as butter and at practically butter prices. The evidence (p. 470) shows one case of where the manufacturer advised the dealer that a brand of oleomargarine quoted at 18 cents per pound should retail at 25 to 30 cents. General experience is that when oleomargaine is sold as butter it is sold just a trifle under butter prices as a bait to draw custom, and in twenty-five such cases reported by the Massachusetts food commissioner in a statement filed with this committee it was shown that the average price of such oleomargarine sold as butter during the year was $22 \frac{1}{2}$ cents per pound. A prospectus of the Standard Butterine Company, of Washington, filed with this committee shows that the average finished product minus the present 2 -cent tax costs the producer 6.92 cents per pound. Add 10 cents to this as the tax under the Grout bill and the cost is brought up to 16.92 cents per pound. At an average price of $22 \frac{1}{2}$ cents the retailer and manufacturer would have left between them a profit of 5.58 cents, and could still sell the product at the same price to the consumer he is now paying for it. 'This is about the profit made by the manufacturer and retailer of butter.

Under these circumstances, can it be said the 10-cent tax is a tax that will destroy? If so, how?

Only in this way: These goods, now sold at $22 \frac{1}{2}$ cents, are sold as butter. This is forbidden by the State laws. The State laws of 32 leading States also forbid the sale of oleomargarine colored in semblance of butter. The present profit of 13.58 cents per pound on oleomargarine (costing, with the 2-cent tax, 8.92 cents per pound) when sold as butter at $22 \frac{1}{2}$ cents is what causes its sale as such. The additional 8 cents will stop that fraudulent sale, of course, by taking away 8 cents of the profit in the transaction and bringing the business down to a basis where the dealer will, because of the normal profit 
only, be as willing to sell butter to those who call for it as he will oleomargarine. He will not take the chance of prosecutions under the State laws unless there is some incentive.

Therefore the 10-cent tax will act merely as an agent to destroy that fraudulent incentive. A very small proportion of the people who really know what they are buying will be put to any greater expense in their purchases, because they are few who knowingly buy the article, compared with those who are defrauded.

And in the case of hotels and restaurants, the public gets absolutely no benefit from the economy of their proprietors in foisting a counterfeit upon their guests. Whatever saving there is in the matter goes absolutely into the pockets of the proprietors, while the guest pays the same price he always did for his entertainment, and the dairyman loses the market for that trade, which in the aggregate is enormous throughout the United States.

In this way we believe that the 10-cent tax will not destroy any legitimate business, but only that part of the traffic which is fraudulent. On the other hand, the reduction of the tax from 2 cents to one-fourth eent upon the uncolored article will give the makers an opportunity to furnish those who really desire the artiele for nourishment and economy's sake oleomargarine at a much lower price.

But, even should it be considered that the tax wonld destroy to a large extent the production and sale of colored oleomargarine, what do the authorities say of the use of the taxing power in such cases?

Chief Justice Marshall, in the case of McCulloch $v$. Maryland, said:

That the power to tax involves the power to destroy; that the power to destroy may defeat and render useless the power to create; that there is a plain repugnance in conferring on one Government a power to control the constitutional measures of another, which other, with respect to those very measures, is declared to be supreme over that which exerts the control, are propositions not to be denied.

Tustice Story, in his work on the Constitution (Book 1, pp. 677, $678)$, says:

Nothing is more clear from the history of nations than the fact that the taxing power is very often applied for other purposes than revenue. It is often applied as a virtual probibition; sometimes to banish a noxious article of consumption, sometimes as a suppression of particular employments.

Justice Woodbury, in the case of Pierce et al. v. New Hampshire (5 Wheat., 608), said:

But I go further on this point than some of the courts and wish to meet the case in front and in its worst bearings. If, as in the view of some, these license laws are in the nature of partial or entire prohibitions to sell certain articles as being dangerous to public health and morals, it does not seem to me that their conflict with the Constitution would by any means be clear. Taking for granted that the real design in passing them is the avowed one (prohibition), they would appear entirely defensible as a matter of right though,prohibiting sales.

In Walker's Science of Wealth this mle of taxation is also general:

The heaviest taxes should be imposed upon those commodities the consumption of which is especially prejudicial to the interests of the people.

Desty, in his work on Taxation, says:

One purpose of taxation sometimes is to discourage a business, and perhaps put it out of existence, and it is taxed without any idea of protection attending the burden.

The authorities are very clear on all these points, and particularly on the right of Congress to use its discretion in the amount of tax levied upon any article. 


\section{Cooley on Taxation (p. 5) says:}

Everything to which the legislative power extends may be the subject of taxation, whether it be person or property, or possession, franchise or privilege, or occupation or right. Nothing but express constitutional limitation upon legislative authority can exclude anything to which the authority extends from the grasp of the taxing power if the legislature in its discretion shall at any time select it for revenue purposes.

And not only is the power unlimited in its reach as to subjects, but in its very nature it acknowledges no limit, and may be carried to any extent which the Government may find expedient. It may, therefore, be employed again and again upon the same subjects, even to the extent of exhaustion and destruction, and may thus become in its exercise a power to destroy. If the power be threatened with abuse, security must be found in the responsibility of the legislature which imposes the tax to the constituency who are to pay it. The judiciary can not afford redress against oppressive taxation, so long as the legislature in imposing it shall keep within the limits of legislative authority and violates no express provision of the Constitution. The necessity for imposing it addresses itself to the legislative discretion, and it is or may be an urgent necessity which will admit of no property or other conflicting right in the citizen while it remains unsatisfied.

\section{The Supreme Court, in McCulloch v. Maryland (4 Wheat., 428), says:}

It is admitted that the power of taxing the people and their property is essential to the very existence of the Government and may be legitimately exercised to the utmost extent to which the Government may choose to carry it. The people give to their Government the right of taxing themselves and their property; and as the exigencies of the Government can not be limited, they prescribe no limits to the exercise of this right, resting confidently on the interest of the legislator and on the influence of the constituents over their representatives to guard them against its abuse.

In 8 Wall., 548, is reported the opinion in the Veazie bank case wherein the court was appealed to in an effort to have the 10 per cent tax on State bank circulation set aside. In this case the court's reasoning was:

It is insisted, however, that the tax in the case before us is excessive, and so excessive as to indicate a purpose to destroy the franchise of the bank, and it is therefore beyond the constitutional power of Congress.

The first answer to this is that the judiciary can not prescribe to the legislative departments of the Government limitations upon its acknowledged powers. The power to tax may be exercised oppressively upon persons, but the responsibility of the legislature is not to the courts, but to the people by whom its members are elected. So if a particular tax bears heavily upon a corporation, or a class of corporations, it can not ior that reason only be pronounced contrary to the Constitution.

\section{In 3 Gill., 28, is quoted the following:}

* * * We are not driven to the perplexing inquiry so unfit for the judicial department, What degree of taxation is the legitimate use and what degree may amount to abuse of power?

\section{And further along, on page 28:}

On the contrary, when the Supreme Court has been required to speak upon this subject they have discountenanced the notion of implied restriction.

\section{And from 9 Wall., 41 to 45 :}

It is true that the power of Congress to tax is a very extensive power. It is given in the Constitution with only one exception and with only two qualifications. Congress can not tax exports and it must impose direct taxes by rule of uniformity. Thus limited, and thus only, it reaches every subject, and may be exercised at discretion.

We reiterate, the 10 -cent tax is only directed at fraud and that quality of an article already condemned by the people, who, through their State legislatures, have made every possible effort to suppress it. And it seems to us that if there ever was an excuse for the use of the 
taxing power to promote the welfare of the people through the turning into the Treasury profits which are now an incentive to defraud, we have it here, particularly when the very use of the taxing power in the original law of 1886 is and has for years been used as a basis for the defeat of the enforcement of the laws of the various States, through the standing such taxation has given oleomargarine as an article of interstate commerce.

\section{A BRIEF ARGUMENT IN FAVOR OF H. R. 3717, KNOWN AS THE GROUT} BILL.

Mr. Chairman and gentlemen of the Senate Committee on Agriculture: If one will read the reports of decisions from the United States Supreme Court, which constitute the controlling law of our country upon the subjects therein reviewed, he will notice that the question most frequently discussed, and up to this time never settled, is, What constitutes a valid exercise of the police power by the several States? And the necessity for the legislation contained in this bill, familiarly called the Grout bill, lies in the fact that notwithstanding the police features contained in nineteen sections of the act of 1886 , known also as the national oleomargarine law, policing by the several States, the District of Columbia, and the Territories must continue so long as oleomargarine is manufactured as at present and transported from State to State, if the welfare of the dairy is to be considered and the people protected from fraud, actual or potential.

What can the States, Territories, and District of Columbia do, however, in this regard and in this direction but strike down the retailers, unless Congress limits the effect of the commerce clause of the Constitution, as provided for in section 1 of this bill, in view of the diversity of opinion of the several justices of the Supreme Court? It is rather the rule now than the exception, when a case involving interstate commerce and police power is before the Supreme Court, to see the justices disagree and a dissenting opinion filed. Examine Liesy v. Hardin, 135 U. S., 107 and 125; Plumley v. Mass., 155 U. S., 462 and 480; Geer v. Conn., 161 U. S., 521, 535, and 542; Schollenberger v. Penna., 171 U. S., 6 and 25 , and you will no longer marvel that judges of the United States district courts entertain varying opinions, nor that the appellate courts of the States are not in harmony on such questions. (In re Scheitlin (Missouri), Jan. 8, 1900; in re Brundage (Minn.), Jan. 12, 1896, Fed. Rep., 963.)

Therefore, in order that there may be a uniform system of laws regulating traffic in oleomargarine, and that force and effect may be given to the enactments of thirty-two States, as well as others that may pass such laws later on, and to carry out the views of Justice Harlan, as expressed on pages 467 and 468, 155 U. S. - the Plumley case-your favorable report is requested.

\section{I quote from Justice Harlan's opinion in the Plumley case:}

It will be observed that the statute of Massachusetts, which is alleged to be repugnant to the commerce clause of the Constitution, does not prohibit the manufacture or sale of all oleomargarine, but only such as is colored in imitation of yellow butter produced from pure, unadulterated milk or cream of such milk. If free from coloration or ingredient that "causes it to look like butter," the right to sell it "in a separate and distinct form, and in such manner as will advise the consumer of its real character," is neither restricted nor prohibited. * * * The statute seeks to suppress false pretenses and to promote fair dealing in the sale of an article of food. It compels the sale of oleomargarine for what it really is, by preventing its sale for what 
it is not. * * * Does the freedom of commerce among the States demand a recognition of the right to practice a deception upon the public in the sale of any articles, even those that may have become the subject of trade in different parts of the country?

The Grout bill in its proviso affords the same privilege to dealers in oleomargarine that the statute of Massachusetts afforded, and only gives vitality and power to laws of the same liberality of construction.

The substitute bill, known as the Wadsworth or the minority bill, is the old attempt at regulating presented in a different form; all of the safeguards against deception and fraud can be broken down with the same ease that other regulating laws have been violated; protection can only come by taking away the color, or if the manufacturer sees fit to pay the 10-cent tax for the privilege of imitating yellow butter, then the difference in price being greatly reduced the inducement to defraud is considerably lessened. The true delight from eating butter comes to the palate, not the eye, and pure butter by any other color than yellow would taste as sweet. Why does this not hold true of oleomargarine?

JAMES Hewes, President Produce Exchange, Vice-President National Dairy Union. 


\section{BRIEF OF TESTINONY IN OPPOSITION TO THE GROUT BILL (H. R. 3717).}

\section{[By Mr. Springer.]}

[The figures refer to pages of the Hearings of the House Committee on Agriculture and the Senate Committee on Agriculture and Forestry. H. H. will stand for House Hearings and S. H. for Senate Hearings.]

Oleomargarine as a food product is wholesome, palatable, and nutritious: S. H., 17, $18,19,25,48,49,65,70,72,96,97,205,206,207,208,209,261,262,337-338,351,397$, 514. H. H., 694, 703, 713, 716 .

Expert opinions of oleomargarines: S. H., 85, 86. H. H., 694, 712, 713, 714, 717, 720, $721,765,766,767,768,769,770,771,772,773,774,775,776,777,778,782,783,791$, $797,809,810,811$.

Ingredients of oleomargarine are farm products, and no unwholesome articles are used: S. H., 41, 54, 55, 56, 88, 202. H. H., 753-758 (Commissioner W'ilson's Investigation), $706,713,714,716,720,721,800,801$.

The bill would destroy oleomargarine industry: S. H., 14, 37, 38, 39, 65, 174, 271, 274, $303,352,353,358,382,391,509$. H. H., 750, 784, 792,793 .

Grout bill is unconstitutional: S. H., 93-107 (Mr. Springer's argument). S. H., 392411 (argument of Mr. Henry E. Davis, of Washington, D. C., attorney for the Standard Butterine Company).

Consumption of oleomargarine in the States: S. H., 90-91, 415 (Secretary Wilson's remarks).

Oleomargarine is a proper subject of interstate and foreign commerce, and its manufacture is a lawful pursuit: S. H., 95, 96, 97, 98, 396.

Grout bill not a revenue measure: S. H., 16, 17, 43, 106, 561 (Secretary Gage's statement).

Coloring matter is used both in making butter and in manufacturing oleomargarine for the purpose of catering to the tastes of consumers: S. H., 22, 33, 39, $40,44,69$, $262,263,272,309,310,316,335,336,347,355$. H. H., 704, 705, 708, 709, 714, 763, $779,793,794$.

Live-stock interests injuriously affected: S. H., 60, 61, 62, 63, 66-67, 68, 71, 72, 77-78, $79,80-116,117,118,119,120,121,182,183$. H. H., $653,654,655-660,661,673,674$, $675,676,677,678,679,680,681,682,683,732,733,734,735,739,740,741,742,743$, $744,745,747,748,749,788,789,790,799$.

Cotton-seed oil industry injured: S. H., 314, 315, 316, 318, 320, 321, 322, 323, 324, 325 , $326,327,343,344,345,346,347,483,484,485,486,487$. Н. H., $663,664,665,666$, $692,693,694,695,723,724,725,726,727,728,729,730,731,732,736,737,738$.

Labor organizations opposed to bill: S. H., 307, 308, 309, 310, 311, 312, 314, 319, 320, $350,351,352,353,354,357,359,360,361,362,504,505,506,507,508,509,510$. H. H., 706.

Alleged frauds in selling oleomargarine for butter: S. H., 19, 20, 27, 28, 29, 32, 33, 34, 35, $40,201,202,270,274,275,292,297,301,302,383,387,562,563,564,565 . \quad$ H. H., 704 , $705,717,750,751,752,753,754,755,756,757,758,759,761$.

Process butter: S. H., 22, 29, 30, 31, 39, 108, 109, 266, 267, 338 (Professor Alvord's views), 339, 387, 385, 389, 390, 518. H. H., 719, 722, 723 .

Butter interests not injured by competition with oleomargarine: S. H., 114, 171, 172, $173,174,175,176,177,179,180,202,203,215,216,264,268,304,308,337,523$. H. H., 716, 784, 785, 790, 791 .

Substitute bill: S. H., 305, 398, 366, 568, 569 (statement of Mr. Wadsworth, chairman of House Committce on Agriculture). II. H., 750, $75 \%$.

Substitute bill would reduce fraudulent sales of oleomargarine for butter to an infinitesimal amount. (Testimony of Secretary Gage): S. H., 565, 566, 567. H. H., 274.

Argument of Hon. John S. Williams, of Mississippi. Reference is made to the able argument of Hon. John S. Willians, .II. C., from Mississippi, in opposition to the Grout bill before the House Committee on Agriculture, May 26, 1900. 
PETITIONS AgAINST PASSAGE OF THE GROUT BILL.

National Live Stock Association: S. H., 78, 79, 80. H. H., 657.

South St.Paul Live Stock Exchange: S. H., 56, 57.

Texas Cotton-Seed Crushers' Association: S. H., 58, 59.

Sioux City Live Stock Exchange: S. H., 60.

Cotton oil superintendents from South and North Carolina: S. H., 60.

Kansas City (Kans.) Mercantile Club: S. H., 61, 62.

Kansas City (Mo.) Commercial Club: S. H., 62, 63.

Kansas City Live Stock Exchange: S. H., 71, 72.

National Live Stock Exchange, Chicago: S. H., 185, 186.

Holland Butterine Company, of Pittsburg, Pa.: S. H., 199.

Cattle Raisers' Association of Texas: H. H., 653, 654.

The South St. Joseph Live Stock Exchange, South St. Joseph, Mo.: H. H., 654, 655.

The South Omaha Live Stock Exchange: H. H., 739, 741, 742.

Merchants of Kansas City, Mo.: H. H., 502. 


\section{REVIEW OF THE EVIDENCE PRESENTED BEFORE THE HOUSE}

AND SENATE AGRICULTURAL COMMITILEES ON H. R. $371 \%$.

[Prepared by Charles E. Schell, at the requeat of the Senate committee.]

\section{The Committee on Agriculture and Forestry, United States Senate, Washington, D. C.}

Gentlemen: In response to a request by members of your body that I furnish a brief résumé of the evidence presented by the friends and the opponents of the Grout bill I will endeavor so to do, speaking, however, only for my own clients. In the beginning, allow me to state that in my opinion the full enormity and infamy of the bill in question can not be comprehended properly by any member of this committee without carefully reading everything that has been offered on both sides, and I would earnestly urge that this be done. There has been but little repetition, and the principal part of that has been in the memorials from live stock and cotton growers associations whose interests are sufficiently large that a little repetition as a means of more fully impressing the importance of their claims would not be amiss.

In calling attention to the estimates of probable loss to the live stock and cotton-seed oil interests should this bill become a law, I wish to remind the committee of what appeared during the hearings to the effect that some of the estimates of losses took into consideration only the actual net loss by reason of the destruction of the local oleomargarine industry; others computed the loss by taking into consideration the total output for the purpose of manufacture of oleomargarine, both at home and abroad; while others, and perhaps the most accurate computations, were based upon the loss that would accrue from lack of a home market and by reason of the effect upon the general market and the export trade by reason of the official condemnation which would be placed upon the various products and would necessarily affect, if not entirely destroy, the export trade. As was fully shown before the committee the actual loss can not be estimated by merely taking the difference between the price of the materials for the purpose of manufacturing oleomargarine and the price of the same materials still retained in their original uses. Their return to former uses would necessarily reduce the existing price of the materials still so used, and the effect of a total destruction of one market for a product, however small that market might be, compared with the eutire output, would be more vast than the most expert board of trade manipulator could estimate. However, the estimates from the various sections as a result of different experiences and different evidences sufficiently coincide that a fairly accurate idea can be established as to the minimum loss even if no one can estimate the total loss that this legislation would bring about.

In the interests of cotton-seed oil we first hare Fred Oliver, beginning at page 81 of the hearing before the House committee, and I carn- 
estly recommend the reading of the entire statement, especially that part in which he estimates an annual loss of $\$ 65,000,000$ to his people and to the elemental wealth of the country should this bill become a law. His statements and estimates are sustained by numerous others who appeared before this committee and the House committee for the cotton industry, and all of whom produce additional interesting points showing their individual reasons why their indnstry should not be legislated against. Especially was a strong point made by Mr. Ready, of Arkansas, who states, at page 149 of the House Hearings, that in Helena they have four oil mills, with an investment of about $\$ 700,000$, and which four mills support 800 people. I would especially ask the committee to read in full the argument of Judge Aldredge, at page 109 of the House hearings, in which he presents plain facts and dry statistics in a very interesting manner; and also the statements of Mr. Conley, at page 322 of the Senate hearings.

'The first presentation of the cattle growers' interests was by $\mathrm{Mr}$. Cowan, of Fort Worth, Tex. (House Hearings, p. 70, et seq.), whose particular client, The Texas Cattle Raisers' Association, showed a membership of 1,200 cattlemen and a property interest of $\$ 100,000,000$, but who also represented other identical interests, all of whom figured a probable loss in the value of their cattle of from $\$ 3$ to $\$ 4$ per head. He was followed by Mr. Tomlinson, representing the Chicago Live Stock Exchange, who agreed with him as to the loss of from $\$ 3$ to $\$ t$ per head on cattle. There were others before both committees who shared these views. However, the statement most in detail on this branch of the subject was by Mr. John McCoy (House Hearings, p. 93), who figures the result of the passage of this bill as a net ammual loss to the farmers and stock raisers of the country of $\$ 62,950,434$. Mr. MeCoy's estimates are very conservative and were to a limited degree explained before this committee at pages 64 to 72 of the Senate committee hearings. At page 68, Senate Hearings, he read from an agricultural paper to show the increase in the value of milch cows, of milk, of butter, and of cheese.

Mr. J. A. Hake, of South Omaha, Nebr. (House Hearings, p. 157), makes a computation slightly varying, but substantially the same as the others, and setting out the local conditions; also showing, from statisties taken from the Bureau of Internal Revenue and the Agricultural Department, that for the ten years ending June 30, 1899, the butter industry had increased more rapidly than had the butterine industry. Mr. Thompson, president of the Live Stock Exchange of Chicago (Senate Hearings, p. 182), figured the loss on each head of cattle as the result of the passage of this bill at $\$ 3.42$, and sustains the statements and computations of his predecessors before both committees. Judge Springer presented to your committee (Senate Hearings, p. 78) the memorial of the National Live Stock Association, which estimates a loss of from $\$ 3$ to $\$ t$ per head on the cattle of the country as a result of the proposed class legislation. He has compiled numerous statistics and has very ably treated all the legal phases of the question. The argument of Henry E. Davis, at page 392, is also a very able presentation from a legal standpoint.

The statement of Col. John S. Hobbs, editor of the National Provisioner, of New York and Chicago (House Hearings, p. 130), is full of information on this subject, and especially his detailed statement of the workings of a butterine factory, at page 138. 
The statement of Professor Wiley (House Hearings, p. 186) will be read with interest by any member wishing to fully inform himself as to the chemistry of the article, and the statements of Internal Revenue Commissioner Wilson (House Hearings, p. 167 et seq.) should have great weight in deciding this question. At page 168 he specifically recommends a regulation similar to that incorporated in the Wadsworth substitute bill, and at page 182 considers it will meet the requirements of preventing fraud "in the fullest possible way." $\mathrm{He}$ commends the article as at present manufactured and the dealers generally as giving his department no particular trouble. At page 168 he pronounces the 10-cent tax prohibitive and thinks it would defeat the end of deriving any revenue from it.

The most important of the oleomargarine manufacturers have been before you, either per'sonally or by counsel, and tell the same story in a slightly different manner. They unite in claiming cleanliness and wholesomeness in their product, in obeying the laws, in inviting a full investigation of their every act, and in offering their assistance in passing and enforcing any law which will reduce the fraud to a minimum, in denying the charges that they connive at the alleged fraud of the retailer or that they defend him for selling oleomargarine for butter, and in insisting that it is utterly impossible to market uncolored oleomargarine, and that to be compelled to abandon the use of color would mean the total destruction of the industry and an abandonment of their plants. A strong presentation of the case, from both a practical and legal standpoint, was made by Mr. Gardner early in the hearing before this committee, and I would earnestly recommend that his article be given a second reading before taking the committee vote on this subject.

\section{MERITS AND DEMERITS OF THE BML ACCORDING TO THE TESTIMONX.}

Now, as to the merits of the respective sides from the evidence produced.

Bliefly stated, the friends of the bill base their claim on-

Alleged public sentiment in its favor.

Alleged fraud in competition and on consumers.

Threatened absolute destruction of the dairy industry.

Failure of state legislation.

Nonenforcement of existing revenue laws governing retailers.

The opponents of the bill deny all this, and claim that the bill is1. Dishonest in name and in purpose.

2. Class legislation.

3. An exer'cise of police power.

4. Destruction by taxation.

5. Confiscation of property without due process of law.

6. Delegation of control of interstate comnerce.

And the bill is dishonest in that it is not what it purports to be nor what its friends claim for it. 'They admit that under the guise of a revenue measure it is an excrcise of police power for the alleged purpose of preventing fraud and regulating competition. But the testimony shows that it is for the actual purpose of destroying one industry in the interest of another.

It is class legislation of the most vicious kind. That it is unconstitutional is not disputed, but they depend lipon the unwillingness of

S. Rep. $2043-55$ 
the courts to inquire into the motive of an exercise of the taxing power.

First, regarding their claim of a united public sentiment, I will request the committee to exervise those means of knowledge which Senator Dolliver says the member's possess to a larger degree than anyone else and ascertain to what extent the various communications with which the Senators have been favored have been actually good-faith representations of the senders, and to what extent they have been the results of requests emanating from lobbyists or from dairy and creamery journals, whose means of support consist largely in selling gold bricks to their subseribers and who create discontent among the farmers and then get employed to correct the evils at whatever contribution they can levy, from 50 cents up. (House Hearings, p. 62.)

I will also call attention to the analysis of the authorized representation of record of the gentlemen standing most prominently before the committee as favoring this measure, as shown at pages $279,282,283$, and 304 of the hearings before the Senate committee. Also, to some of the means by which these various letters hare been brought about, as shown in the statements at page 198 of the House hearings. Also, to the statement of Mr. Knight, on pages $4 t$ and 45 of the House Hearings and pages 472,473 , and 519 of the Senate Hearings, in which he told how he obtained indorsements from Cincinnati butter men, and how he had aimed to get the labor organizations arrayed on his side of the question, and after having promises from some of the members of a certain labor union his first notification of the results of his efforts was a resolution in which the said union had opposed the passage of the bill. This ball set rolling by himself, so far as there is any record, without any other incentive than the fact that the subject Wis before Congress, has been the means of the protest of hundreds of thousands of laboring men all over the conntry, the representatives of some of whom appeared personally (Senate Hearings, pp. 307, 310, 350 , and 50S) and in other instances your committee has been memorialized, and in numerous instances of which I know no steps have been taken other than to merely pass condemnatory resolutions. The workingmen as a class, as well as every consumer of whom there is any evidence in the record, are unanimous against the passage of this bill. I asked repeatedly during the hearings if any case had ever been brought on complaint of a consumer, but no case was cited nor was a single protest from a consumer presented.

The allegations of fraud in the sale of the product have been sweeping. According to Governor Hoard, "The business is based from manufacture to sale on wrong and illegitimate methods." The dealer' is accused of selling practically all of the oleomargariue he handles for butter to a long-suffering public; the manufacturer and wholesaler are accused of furnishing to him all sorts of encouragement and financial backing in carrying out his fraudulent undertaking; but the only testimony that is worth a moment's consideration that has been offered in connection with this wholesale claim of fraud was the evidence from Philadelphia, which would probably have stood the test of investigation, but which was brought about by the peculiar condition of the Pennsylvania laws and the Philadelphia situation. The few eases from Chicago wherein retailers did not comply as closely as they should with the revenue provisions were no evidence of the true condition of things in Chicago. 'The charges were confined to one section and 
largely to one Broadwell. Nobody disputes but what there are some wicked people in the retail oleomargarine business the same as in anything else, but they are the exceptions to prove the rule that the majority of the retailer's are conducting the business as it ought to be conducted.

The only attempt to specify any manufacturers or wholesalers who are said to be aiding the retailers in any fraudnlent sales of oleomargarine are allegations wherein Mr. Kinight claimed that some employee of Braun \& Fitts and of Moxley \& Co. gave bond and aided in the defense of certain alleged violations of the liaw. It was promptly denied by Mr. Jelke on behalf of Braun \& Fitts that this man had any anthority from his firm to do other than protect their customer's when they were prosecuted for violations of what were deemed to be, or of what were in some instances judicially held to be, unconstitutional laws; that it was a part of the business of this emploree to keep in tonch with everything connected with the trade, including prosecutions, and doubtless he was present, but if said employee exerted himself in behalf of a dealer guilty of selling oleomargarine for butter, that it was against express instructions of the firm of Braun \& Fitts, and that he was further of the opinion that Mr. Moxley did not countenanee such proceedings. Mr. Knight also produced some correspondence of the two firms which he claimed amounted to an agreement to furnish assistance in violating the laws, but which the representatives of the firms insist were merely an assurance that they would defend against any unwarranted interference under invalid laws by the officers and the attorneys of the National Dairy Union. (Senate Hearings, p. 465; House Hearings, p. 3S.) And it seems the factories were right, since, according to Mr. Knight's own statement, the suits failed. (House Hearings, p. 40.) And it seems that his nameless clerk, who had worked in nearly all the stores and was ready to betray his employers, was not able to furnish a case that would stand a legal test (p. 461$)$.

The Ohio commissioner impliedly accused the Columbus company of a wholesale defense of retail dealers, but in reply to a question from Senator Foster as to whether or not they defended cases where the retailers were selling oleomargarine for butter be stated that his impression was that they did, but he could not recall one particular instance of that kind. (Serrate Hearings, p. 163.) Except general accusations, there is nothing in the record charging any of the other 24 manufacturers of oleomargarine or any of the 400 wholesalers of defending any retailer for selling oleomargatrine for butter. Mr. Flanders, who was very free in most of his accusations, was careful not to even make these accusations against the manufacturers. He started at the top of page 126 of the Senate Hearings to make a wholesale accusation as to what the manufacturers did all over the conntry; then he modified the statement and confined it to New York; then he called attention to that statement, saying: "Nind you how $\mathrm{I}$ put it-that we are told by parties who have heen approached that they offered to indemnify them." They failed to produce a single man who has ever been indemnified or who has been offered to be indemnified by either a factory or wholesaler of oleomargarine.

Gentlemen, they have failed in their proof of any fraud at all on the part of inanufacturer or wholesaler and have shown an amount of fraud on the part of the retailer's as small as could be expected to exist, 
considering the immense number and the fact that these same dealers have been assailed regardless of their business integrity or otherwise, while, on the contrary, it appears from the records (House Hearings, pp. 108, 169, 199, 211, and 229, and Senate Hearings, pp. 2S0, 292, 298 , etc.) that oleomargarine is sold for exactly what it is in almost every instance. Nor have they produced a single consumer who complains of having been swindled in purchasing oleomargarine for butter. On the contrary (Senate Hearings, p. 20), it was stated that threefourths of the entire product of one factory went direct to the consumer, and at page 381 I presented a list of 1,083 names of consumers who buy direct from one factory and who wish to continue so to do and protest most vigorously against the passage of this bill. Secretary Gage (Senate Hearings, p. 563) also told you in part of their experience with a cheese plant whose owner purchased the milk from the farmers in his vicinity and who in turn, as the agent of these farmers, purchased from an oleomargarine factory the butter substitute which these same farmers use on their tables. The workingmen (as consumers) appeal to you to leave the colored production within their reach. (Senate Hearings, pp. 307, 310, 350, 508, and 568.)

On the subject of threatened absolute destruction of the dairy industry I wish to call your attention to the fact that they have not introduced any evidence to show that the industry is in any danger, but that the evidence throughout the record is to the effect that the growth of the dairy industry has been even more rapid in the last ten years than the growth of the oleomargarine industry. (House Hearings, p. 158; Senate Hearings, pp.439-440). I call attention to the statement of Mr. Lestrade before the Senate committee at pages 166 and 171 as to the growth in quality and quantity of the butter industry, and his further statement, at page 216 , that the butter men were making better profits than ever before. Also to the statement of Mr. Kimball, at page 55 of the House Hearings, to the effect that butter was then 2 cents per pound higher than formerly; to the statement of Mr. Thomas Sharpless (Senate Hearings, p. 228) that he still received 35 cents per pound for his entire output, and that his neighbors received from 25 cents up; and to the statement of C. H. Royce (p. 379), who gets 50 cents per pound for his butter; and particularly to the statement of Govelnor Hoard, quoted by Representative Bailey, at page $6 \pm$ of the House Hearings, to the effect that the dairy industry has made more rapid strides than any other industry in the country; and to page 439 , where Mr. Jelke asks Mr. Adams, "Is not your industry more prosperous now than it ever was before?" Mr. Adams. "Yes, sir."

Regarding their claim that State legislation is a failure, we must say again that they have not proven their claim. On the contrary, as appears from the evidence, the "oleomargarine or butter" laws are capable of enforcement and are enforced in every State, so far as is shown by the record. It is also shown that the color laws are strictly enforced in New York, in Iowa, in Wisconsin, and also in Pennsylvania, in so far as any effort has been made to enforce them. It also appcars of record that the color laws are much more difficult to enforce than the other provisions of the law; that they are utterly unfair and consequently unpopular. And it stands to reason that so long as a man accused of a crime has the right of trial by jury and that crime is merely selling other men what they want, for what it is, and colored as they want it, and those other men sit in judgment, it will be 
extremely difficult to enforce any such laws as these. And, gentlemen, the Grout bill can't deprive a man of the right to trial by jury.

Their charges against the revenue agents have been pronounced false by the agents themselves and their superiors in office. They claim that the revenue department will not enforce a law unless the collection of revenue be the incentive. While that cowardly charge against the revenue department is not to be considered, yet the Wadsworth substitute bill offers this additional incentive to the revenue collector to enforce retail regulations.

This, gentlemen, we take to be a fair analysis of the alleged strong points of the case attempted to be made in favol of the Grout bill. Now, we beg to call your attention briefly to what we term the weak points of the bill, or some of the reasons why not only the bill, but its friends, should hear the voice of condemnation, and that in no uncertain terms, from the members of the committee. I refer to the ntter and absolute dishonesty of the measure itself, to the dishonest attitude that has been taken before this committee regarding the bill and its true purport, and to the fact that although attempting to conceal the full iniquity of their purpose they have yet had the audacity and unparalleled insolence to ask this committee to be a party to an act of dishonesty so base that it would make a black stain on the darkest walls of perdition.

Gentlemen, they have not been fair and open with you in this matter. They come here under the alleged authority of millions of producers and consumers, and with the false battle cry of "fraud." On demand they fail to produce even a forged power of attorney from more than 30,000 people. Their alleged constituency wilted away like a blighted flower, but they still strained their utmost efforts to keep the alleged fraud in the foreground, and directly and persistently evaded the questions asked by members of this and the House committee in an effort to get at their real motives and purposes. (See an example in Senator Money's efforts, pp. 488, et seq.)

At the bottom of page 2 of the House hearings Governor Hoard says:

That with the tax of 10 cents per pound on the counterfeit substitute we believe the temptation for unjust profits, deceptive sale, dishonorable and dangerous conspiring against law, and fraudulent competition with an honest industry will be greatly modified.

\section{At page 10 of the House Hearings $\mathrm{Mr}$. Knight says:}

All we ask is that the people be protected in the right to choose between the two articles.

In the Senate hearings, at page 6, Senator Allen asks Mr. Grout: "Suppose that it is apparent on the face of this bill that the motive for imposing this tax is to destroy the thing taxed?" Mr. Grout: "We deny this. We say that is not the motive." And at the bottom of the page General Grout sars further:

But let me say it is not the purpose here to tax it out of existence. The object of this second section is to prevent the sale of oleomargarine as butter, to prevent a fraud. * * * No; instead of destroying, it encourages the manufacture of the honest article. All that it seeks to destroy is the fraud that is perpetrated when it is colored like butter.

At page 179 of the House hearings Representative Haugen, a friend of the bill, says to Commissioner WVilson:

Yes; but under the bill the paying of the 10-cent tax would permit the manufacturers to color their product and make it an imitation of butter, and then it would cost only 18 cents per pound. 
At page 81 of the Senate hearings Mr. Adams feels called upon to deny the only record of his statement before the House committee, to the effect thit he wanted to drive the oleomargarine manufacturer out of the business. And Mr. Knight at the same time disputed the authenticity of the letter purporting to have been written by him to the Virginia dairymen, and which was to the same general effect. Your committee will recall-and it is in evidence at pages 220,234, 235, $248,252,253$, and 25t-the efforts to get the Philadelphia delegation on record as to whether they wanted a total destruction of the industry or merely wanted oleomargarine kept on its own side of the fence. 'The delegrates all evidently had views of their own, but their attorney insisted on talking for them, and in the end Mr. Grout insisted on telling him what to say, and he said it. There is nothing more true in the Bible, however, than that "from the fullness of the heart the mouth spcaketh." And because of this failing of the human mind, rather than from any intention on the part of the friends of this bill, we have the gentlemen on record.

At page 4 of the House Hearings Governor Hoard says: "The whole proposition is in a nutshell-force out the color or semblance to butter and you put a stop to its being imposed upon the consumer for butter." He does not say raise the price of the colored article, but "force out the color." At page 62 of the House Hearings Mr. Knight says: "I do not believe that there is any necessity for" the colored oleomargarine being sold:" At page 69 of the House Hearings Mr. Hewes, whom the committee will remember, says: "The 10-cent tax is with the view of prohibiting all manufacture of oleomargarine yellow unless they want to pay the penalty. It is to tax that yellow color." And Mr. Adams, in his correction of the minority report (Senate Hearings, p. 81), says:

He simply stated *** that we had no purpose to stop the manufacture and sale of oleomargarine, but simply of the colored imitation-counterfeit product.

Mr. Grout keeps himself well in reserve on the subject of crowding out any recognized product, but at the top of page 9 of the Senate Hearings he becomes warmed up to his subject and says: "But if you will put this 10-cent tax on it and stop all coloring like butter, the game will then be up." "This same expression, which seems to be an outlet for his pent-up feelings, was again delivered with great oratorical effect before your honorable committee on the last day of your regular hearings on this subject, and at which hearing, as appears (Senate Hearings, pp. 579, 580) of record, Mr. Grout was asked directly, and failed to answer, how, under his bill, the factories could supply their export trade or their orders from consumers who wanted the colored oleomargarine and were willing to pay the extra 10 cents per pound, when their return to the Government would be a sworn plea of guilty to the violation of a State law and would put them immediately in the grasp of the State officers in thirty-two States of the Union. A letter from Mr. Blackburn, quoted at page 354, says: "We should stand together in a fight to a finish against oleomargarine."

Mr. Hamilton, of Pennsylvania, on page 152 of the Senate hearings, quotes with approval from the governor's message, which says:

I am much gratified at the prospects of the early passage in Congress of the Grout bill; for if this bill becomes a law, it will greatly aid in the suppression of the oleomargarine traffic. 
Notillegal traffic, but "oleomargarine traffic." Gentlemen, throughout the record, from the various expressions of those who have been heard in favor of the passage of this bill, creeps to the surface the sentiment that it is not the suppression of fraud. It is not the protection of the consumer. It is not a question of mere regulation of competition between rival industries. It is not a question of insufficiency of State legislation. It is not a question of nonenforcement of existing revenue laws. It is not a question of threatened absolute destruction of the dairy industry. But it is a question of systematic organized effort to legislate out of existence the manufacture of oleomargarine. Not, as some of the friends of the bill reluctantly or unguardedly admit, the driving ont of the manufacture of the colored product, because they all know, and the manufacturers all know and have testified, either personally or by counsel, before your committee that the uncolored article. is absolutely unmarketable. (Senate hearings, pp. 37, 39, 47, 204, 531, 568, etc.) And the same thing is admittedly true with regard to butter. In vain we ask: "Why should one product have a monopoly on color?" The answers would apply equally as well in defending a law regulating the color of a man's clothes or a maiden's cheeks according to their respective stations in life.

These men have laid their lines well by working on the credulity of the farmer, by taking advantage of the lack of any resistance, organized or otherwise, on the part of the oleomargarine industry, and they have passed prohibitory laws in thirty-two different States, laws necessarily umpopular, and, as to their unfair features, hard to enforce. And now they come before Congress asking that a bill be passed by which the manufacturer of oleomargarine is crushed, not by the conflict of laws, but by the coming together of the State and national laws.

'They come before you reeking' with dishonesty of purpose and with every claim supported by glaring falsehoods. And, attempting to conceal what they can of theil duplicity, they still say: "Gentlemen, we want this law. We concede that we can not gret it under its proper classification, but if you will impose upon the people and on the Supreme Court by giving us this law under the guise of a revenue measure, the future butter trust and the dairy publications will rise up and call you blest." And they do not hesitate to make you parties of record to this fraud which they want perpetrated.

At page 2 of the House hearings Gorernol Hoard says: "In plain words this is repressive taxation." At page 11 of the hearings before this committee he says: "The Federal Government is limited in its constitutional power. It has no right to enact prohibition. It has no police power. These things you are as well aware of as I am." At page 7 of the Senate hearing's General Grout says: "I do not think it [the one-fourth-cent revenue] ought to be less, for it ought to be large enough to cover the cost of policing the business." And, in reply to the question as to whether or not the subject is one of police regulation in the State: "Yes, but we have got a regulution here in this second section which transcends police regulations; and if the Senator will allow me a moment, I will make it plain to him." Senator Allen: "Can you do that?" General Gront: "Oh, yes, sir; in the way we propose to do it here, as I believe." He does not proceed to tell the way, but the way is to cover up the motive by giving the act a rerenue cloak. 


\section{At page 65 of the House hearings Mr. Hewes says:}

And so it went on until the year 1886, when we appeared here for the purpose of having Congress exercise its police regulations, and of course we could only get to Congress and ask for a revenue measure, and, as the late lamented Mr. Dingley said to me only a year or two ago: "Mr. Hewes, you know well enough that that was a ruse of yours to get this thing into Congress under the head of a police measure by drawing the revenue to the Government;" but we knew what we were talking about.

And at page 69 he says: "We [the butter men] said [to the Government] * * * we will give you a million and a half dollars of revenue, and we ask you simply to act as policemen." At page 109 of the Senate hearings, referring to a fraud mentioned by Judge Springer, Mr. Flanders says: "It is not a proper subject of the police power. We are invoking the Police power." At page 6 of the House Hearings Mr. Knight says:

The matter of legislating against the counterfeit article, however, was found to be a complex proposition for Congress because of the constitutional restriction, which prevents the Congress of the United States exercising police powers except for the protection of its revenue receipts, interstate commerce, and other matters absolutely within the limits of the Constitution.

The markings of the "wolf" appear very much in evidence regardless of his "sheep's clothing."

On the Wadsworth substitute bill, allow me to say, from the standpoint of an attorney who for years has been aiding the manufacturers and wholesalers in keeping oleomargarine on the market for what it is, what $X$ have already said at your hearing, that $I$ agree with Commissioner Wilson and others who have testified that it will reduce the possibility of fraud to a minimum.

And as to the Grout bill, I repeat what I have heretofore said, that it places a premium on fraud. It does not prevent the sale of oleomargarine for butter. Every rogue in the business can greatly increase his profits and be safer than at present. And I believe the law was drawn partly for that purpose. The coloring by the retailer is one way and an easy one, and there is no law to prevent, but it is crude. 'There are other and better ways and they will be used. But, gentlemen, prevent it by preventing this useless and iniquitous law from becoming a blot on the statute books of this great country.

This is a history-making age, and as you value justice and your records as legislators do not allow an otherwise fairly clean chapter to be marred by the actual taking of the worst backward step with which this country has been threatened since it first placed a premium on freedom in all the word implies.

I had intended to submit a brief on the law applying to this subject, but to do it justice it would be necessary to begin with the constitutional debates and review all decisions on delegation of power, enlarging of power, police power, taxing power, and interstate commerce, and how far a supreme court will allow a dishonest or a misguided Congress to impose on the people (under proper headings) improper laws.

And again, this committee needs no enlightenment on whether or not this is a lawful measure. Every member knows it is not, every Congressman knows it is not, every advocate of the bill knows it is not, and friend and foe alike concede that only as a revenue measure would it stand a constitutional test for a minute.

I can not leave this question without mentioning the methods of intimidation that have pervaded the pressing of this bill, from the 
inciting of telegrams and letters, so strongly denounced by Senator Allen (p. 24), to more open threats of punishment at the polls.

Governor' Hoard's main effort was in parading his alleged millions of dairymen, and, at page 414 , he boldly says:

The Government has the power in this way to discourage wrongdoing and encourage honest industry, and the people will hold it responsible for the exercise of that power when the opportunity comes, as in the present case.

And the gentlemen of the committee who were present will recall how Mr. Knight and Mr. Flanders showed their harmless fangs in an imitation gloat over an alleged falling off of the majority of Congressman Wadsworth when Judge Springer read an attack made by Mr. Knight on him because he had the moral courage to "face floods of petitions" and do as his conscience dictated. Judge Springer read a letter from Mr. Knight to a Mr. Hubbard, of Mr. Wadsworth's district. I quote from the letter as appears at page 83 of the Senate hearings:

Well, if you have ever been in court and observed a lawyer defending a criminal, you can understand how he fought for the oleomargarine makers. He was the most active opponent we had in Congress. He spent more time lobbying against our bill than even the acknowledged agent of the oleomargarine makers-Lorimer, of Chicago-to whose tender mercies Wadsworth consigned the Grout bill when it was referred to his committee, that it might be smothered.

*

*

$\ddot{*}$

*

*

While no oleomargarine is made in his State, he has conceived a great affection for the kind of oleomargarine that is an exact counterfeit of butter, forbidden by New York, and which defrauds the public everywhere, and the only kind we are seeking to suppress.

Wadsworth's friends in Congress were amazed at his attitude in this matter. His conduct was unprecedented. No Congressman representing a Northern agricultural district has ever been known to take such an aggressive stand against the farmers of his district in face of such floods of petitions, and no support whatever from his own people in his position.

Wadsworth, with his bill, is the most dangerons enemy the dairymen bave in the world. As chairman of the agricultural committee he has certain prestige. If he is returned to Congress by the votes of the farmers of his district, thereby winning their approval of his course, it will be bad for us. His reelection, unless with a greatly reduced majority, will be a victory for the stock yards and oleomargarine fraud of Chicago and a death knell to the farmers' influence in Congress.

You who were present will recall the menacing manner of $\mathrm{Mr}$. Knight and Mr. Flanders during the conversation which followed and in which Mr. Knight interrupted with the question, "Judge Springer, do you know how far he ran behind his ticket?" Judge Springer"I do not." Mr. Knight-"I do." Mr. Springer-" "He got votes enough, however, to give him a majority of about 9,000 in his district." Mr. Flanders-"The official returns of the State of New York have not been printed, but the returns in the agricultural papers in the State of New York show that he ran 2,000 behind."

Gentlemen, when Mr. Wadsworth came before you (p. 159) to state that he did not run behind his ticket, but had an increased majority, and that the farmers of his district at least approved of the Wadsworth substitute bill the representatives of those same prevaricating agricultural papers had nothing to say.

Gentlemen, it is not the oleomargarine industry alone that is here on trial. You are arraigned before the bar of the people. A few men, well organized and backed only by a manufactured public sentiment, are saying to you, "Violate your oaths, trample your consciences and the Constitution under foot, give us what we ask and in the language 
we ask it, change not one word, or we, the dairymen, will hold rou responsible. Some dishonest dealer in a doubtfiul district of Chicino has sold oleomargarine for butter, and you must even up the seore by giving the nation a discriminating law under the guise of a revenue measure."

On the other side-on the side of right and justice and your consciences-is a larger number of all classes and conditions, making no threats, asking no favors, but simply, quietly, and unostentatiously asking to be left to the enjoyment of the rights given them by God and guaranteed by the Constitution. 'These people are not organized, their protests have been made politely by letter and by resolution and sent to this committee; and some have found their way into the record and some have not.

Gentlemen, we have of record one instance of the extent of the power of this "united dairy sentiment." The constitueney of Congressman Wadsworth approved of his attitude and his bill; and so does every fair-minded man of whaterer walk in life. But the Grout bill can not bid for the stamp of publie approval. It is dishonest on its face, and its viciousuess is apparent to all. It is so plain "that he who runs may read," and "a wayfaring man, though a fool, need not err therein." The people, including the dairymen, know it for what it is, and they know the actual sentiment on the subject, and their judgment is suspended awaiting your action, and to see whether or not you can be foreed into line by the searecrow of alleged public sentiment, wielded by a few dairy publishers and lobbyists.

Gentlemen, I have spoken plainly, but truly, and the importance of the subject and the truth of my assertions are my only excuses, if excuses are necessary. 


\section{OUTLINE OF STATEMENTS AND INDEX.}

Explanatron.-Owing to the great volume of the testimony taken at these hearings the committee felt that the salient points were likely to be buried beyond the reach of the average investigator in the mass of evidence presented.

At the suggestion of those interested condensed summaries and indexes were requested of each side in order that the important points might be brought out.

The Outline of Testimony and Index which follow were prepared by Charles $Y$. Knight, secretary of the National Dairy Union, representing the dairymen before the committee, and while they are conceded by the opposition to be fairly compiled, presenting the strong points adduced on each side, it was requested by the opposition that the authorship be stated herein in order that the investigator might fully understand the matter, the claim being that no matter how fair-minded he might be the compiler of an index could not fully put his interest in the case in the background. It was thought necessary to have the index compiled by some one thoroughly familiar with the importance of each point, in order that the reference might reveal the entire strength of both sides.

ADAms, Hon. H. C., food commissioner of Wisconsin-For bill-Grout bill aims at fraud-Denmark eats white oleo, 431-Proof that oleomargarine can be sold uncolored, 433-Why State laws were passed, 435-Legal view of right to color oleomargarine, 436-Protection against State laws guaranteed, 439-Profits in manufacture of oleomargarine, 442-How State laws are evaded in Wisconsin, 443-All food commissioners for Grout bill, 445-Extent of cattlemen's interest, 445-Ashamed to buy oleomargarine in its own name, 446-Resolutions of Commission Merchants' League, 447-Question of healthfulness not germane, 448Use of the taxing power, 448.

Bassext, Hon. S. C., president State board agriculture of Nebraska-For bill-Few measures created so much interest among farmers-State laws openly violated in Nebraska-Fraud induced by large profits, 450-Facts misrepresented to cattle growers-Facts about value of oleomargarine to growers of cattle, 451-Majority of cattle owned in States with anticolor laws-Grout bill only measure that can protect consumers, 453 .

Blackburn, Hon. Joseph E., food commissioner of Ohio-For bill-Why State laws are not enforced-Honey spent in prosecutions, 161-Difficulty in jury trialsBanqueting jurors-Manufacturers' guarantee of protection to retailers, $162-$ How justice is defeated-Seventy-five per cent of oleomargarine sold as butter in OhioWill require national legislation to stamp out fraud, 163.

Bond, Henry, manufacturer cotton-seed oil, Cliattanooga, Tenn.-Against billNumber cotton-seed-oil mills in Tennessee-Amount cotton-seed-oil used in oleomargarine in this country, 324-Estimated damage to cotton-seed-oil interests by passage of Grout bill-Manufacture of cotton-seed oil, 325-Amount used in compound lard, 326-Amount made from ton of seed, 327-State laws in Sonth, 328Violations in Tennessee, 329.

Cleaver, IsaAC W., manager Acme Tea Company, Philadelphia-For the billBeaten by our competitors who resort to fraud, $220-$ No demand for oleomargarine at our 63 stores, 221 .

Conley, J. B., Greenville, Miss., representing Cotton-Seed Crushers' AssociationAgainst the bill-Effect of passage of bill on cotton-seed oil-Number of cottonseed-oil mills, 322-Estimated loss per gallon-An entering wedge-Unfair that oleomargarine makers should not be permitted to color, 323 .

Culbertson, J. J., Dallas, Tex., treasurer Continental Cotton Oil Company, of New York-Against the bill-Government stamp of approval on oleomargarine-Right of use of color in, 346-Color of cotton-seed oil, 347-Use of caustic soda in refining cotton-seed oil, $3 \pm 8$.

Davis, Henry E., attorney for Standard Butterine Company, Washington-Against the bill-Right of States to tax, 392-Right of Congress to delegate power to States, 393-Healthfulness of oleomargarine recognized by Supreme Court, 396- 
Why Grout bill is unwise and unjust, 399-Oleomargarine not an imitation of butter-The one purpose of the Grout bill, 401-Color made by cotton-seed oil, 402-Testimony of chemist as to natural color, 403-Oleomargarine colored for same reasons as butter, 405-Artificial color invented by oleomargarine makers, 406-Why State laws are not repealed, 406-Curious story of labor federations, 407-Can not stop traffic in colored oleomargarine, 407-Collection of the tax, 408-The color question, 409.

Davis, IsaAC W., president Philadelphia Produce Exchange-For the bill-Grout bill most effective method of stopping the fraud, 230-Wadsworth bill no good for hotels or restaurants, 231.

Dillon, J. J., editor Rural New Yorker-For the bill-How bill is looked upon by farmers, 373-The color question, 374-Why color is reprehensible in oleomargarine, 374-Attempt to compel sale of colored oleomargarine as such in New York State, 376-Wadsworth bill able work of makers of oleomargarine, 376Fraud admitted at the boarding houses, 377-Fraud in Paterson, N. J., 377Object of coloring is to sell as butter and at butter prices, 377-Facilities for making all butter country can consume, 379 .

Dolan, PATrick, president United Mineworkers Association-Against the bill-Is white oleomargarine good enough for the workingman, 307-Supply and prices of butter, 307-National law unjust, 308-People know what they are buying, 308-Pride of the poor, 309-Why disreputable to purchase oleomargarine, 309Butter is never white, 310 .

Drennen, W. F., Philadelphia butter merchant-For the bill-Why I favor Grout bill, 221 -Oleomargarine largely sold as butter-Amount sold as butter, 224No wholesaler wants it sold for what it is, 225-Average buyer doesn't want oleomargarine, 225-Work of irresponsible dealers, 225-Wadsworth bill the worst thing we could have, 226-Sale of $\$ 50,000$ per year as butter by one retailer, 226-Sellers' guarantee of protection, 226-What renovated butter is made of, 226.

Edson, E. D., Philadelphia butter merchant-For the bill-Dealers admit they must sell oleomargarine as butter, 222-How it is disposed of, 223.

Flanders, Hon. G. L., assistant commissioner of agriculture of New York-For the bill-Oleomargarine thrives upon fraud-Consumer a big element in this fightOleomargarine sold as butter-History of laws of New York State, 121-Fraud on large scale-Testing of laws, 122-Question of interstate commerce, 123-Why right was given Congress to regulate interstate commerce, 124-Police powers under State laws-The Plumley decision, 124-Butter imitated-Fraudulent sale of oleomargarine in New York, 125-Ten-cent tax would stop fraud-IVhy color butter?-Healthfulness of oleomargarine, 127-Paraffin in oleomargarine, 128Dr. Clark's statement as to healthfnlness, 129-136-Comparative digestibility of oleomargarine and butter, 144-Patents for making oleomargarine, 129-Hore oil used in oleomargarine-New York's dairy interest, 131 - Sold as butter, 135.

Gage, Hon. Lyman J., Secretary of Treasury-Called upon by committee for information-Objection to Grout bill, 561-Revenue on oleomargarine well collected, 562 -Percentage of loss of reveuue, 562-Offenses against national laws, 562 Where information of violations comes from, 563-Visit of inspectors to factories, 564 - No scientific inspectors to investigate-No revenue agents in factories, 564 Government agents do not report on purity of ingredients used, 564-Force inadequate for enforcement in places, 565-Opinion of Wadsworth bill, 566Difference between offenses under present law and Wadsworth bill, 566.

Gardner, Rationone, attorney for Oakdale Manufacturing Company, Providence, R. I.-Against the bill-Believe bill will destroy oleomargarine industry-Measure not honest, 15-Constitutionality not questioned, 15-Congress no right to prevent fraud through taxation-Oppressive State laws would be made effective, 16-Rhode Island permits sale of colored oleomargarine, 16-Imitates butter with every ingredient, 17 -Color given oleomargarine by ingredients-Inspection by Government, 18-Healthfulness of oleomargarine-Fraudulent sales of oleomargarine-Evidence of Commissioner of Internal Revenue, 19-Oleomargarine as butter-Oleomargarine sold to consumers, 20-Price of oleomargarine, $21-$ Natural color of oleomargarine-Renovated butter, 22-Food effects on butter, 22-Inspection by Government, 25-Purity of oleomargarine, 26-Fraudulent sales, 27-Condition in Massachusetts, 28-More of renovated or process butter, 29--Repeal State laws, 33-Color not butter's trade-mark, 33-Butter always colored, 34-Present kind of color originated by oleomargarine makers, 35Doesn't compete with butter of higher grade, 35-Quality of butter made, 36Use of paraffin-Intended to destroy industry, 37-Purpose of State laws shown, 38-Oleomargarine can't pay 10-cent tax, 38-Cost of renovated butter-Uncol- 
ored oleomargarine can not be sold, 39-Color not to resemble butter-Attention called to renovated-butter bill, 40-Interest of cattlemen in oleomargarine, 41What is nentral lard? 41-Precise wording of Grout bill, 42.

Grosvenor, Hon. E. O., food commissioner of Michigan-For bill-Letter filed, 447. Grout, Hon. W. W., For bill-Explanation of bill, 3-Discussion of Wilson interstatecommerce law-Original-package decision, 4-Explanation of 10-cent tax-Manufacturers of oleomargarine and fraud-Constitutionality of tax, 5-Profits in sale of oleomargarine, 7-Difference between coloring oleomargarine and butter, 8Wadsworth-bill scheme of Wm. Lorimer-Does not protect consumer at table, 570-Butter at Delmonico's white, 573-Cost of oleonargarine, 574.

Habecker, John J., Philadelphia butter merchant-For the bill-Few people buy oleomargarine knowingly-History of oleomargarine's imitations of the various grades of butter, 217-Oleomargarine business is fraud all through, 218-Why oleomargarine is not sold honestly, 219.

Hamilton, Hon. JoHn, secretary of agriculture of Pennsylvania-For the billIndorsements of Grout bill-Pennsylvania is pledged to it-Difficulties of enforcement of State laws, 152 -The constitutional question-Do the States know what they want? 153-Bill is constitutional, 154-Healthfulness of oleomargarine, 155-Digestibility, 156-How dairy interests would be affected with oleomargarine, 157-Evidence of fraud corroborated by every food commissioner-Grout bill will overcome all difficulties, 160 .

Hewes, James, president Produce Exchange of Baltimore-For the bill-Serving oleomargarine at hotel or restaurant a legal sale, 457.

HosRD, Hon. W. D., president National Dairy Union-For the bill-Purpose of bill-Difference between coloring oleomargarine and butter-Coloring winter butter, 11-Canada forbids manufacture and sale of oleomargarine in any formGrout bill needed for promotion of honesty, 113.

Janison, SAMUEL, Philadelphia butter merchant-For the bill-Difficulty of enforcing State laws, 231-We are not the police power, 232-Oleomargarine is not sold as such, 232-Grout bill will relieve great expense, 233-Wholesale dealers asked to enter fictitious names, 234 - Highest prices butter white, 235-No law will stop fraud while oleomargarine is colored, 235.

Jelke, JoHn F., of Braun \& Fitts, manufacturers of oleomargarine, Chicago-Against the bill-No objection to legislation for identification-What 10-cent tax would make it cost-Importance of color to palatableness, 382-Butter prices kept down by oleó, 382-Consumption of oleomargarine in England-Retail dealers the principal violators-Oleomargarine will stand on its own merits, 383-Advertising oleomargarine, 381-Branding of oleomargarine, 386-Amount of oleomargarine fraudulently sold, 387-Processes for renovating butter, 387-Advertisement of butter color, 388-Internal-Revenue Department should investigate renovated butter-Advocate Wadsworth bill, 390-Extract from Cleveland's message-Don't rob oleomargarine of one of its first qualities, 391.

Kaufmann, Luther F., attorney for Pennsylvania Pure Butter Protective Association-For the bill-History of laws of Pennsylvania, 236-Attempts to secure enforcement of national law-Fraud rampant in Philadelphia, 237-Every dealer selling oleomargarine as butter-Incentive for frand, 238-Concealing of original packages, 239-Wadsworth bill vastly more damaging than any legislation Congress could enact, 240 - Dairymen not interfering with oleo, but vice versa, $240-$ Healthfulness question in doubt-Transmission of tuberculosis through oleo oil, 241 -Germs not killed in raw materials-Opinions of chemists $v$. physicians, 242-Temptation to sell for butter when colored, 243-Should laws be violated while in dispute, 244-No law ever passed that oleo people did not claim unconstitutional-Viciousness of Wadsworth bill, 245-Where oleomargarine is sold-Fraud in name of seller of oleomargarine, 246-Tricks to evade law, 247Why Grout bill should be passed, 248-Why not sell butter white, 248-Cost of oleomargarine, $249-$ Who represents the farmers, 250 -Have live-stock men ever heard other side? 250-Prices of butter, 252.

KNight, Chas. Y., secretary National Dairy Union-For the bill-Grocer's clerk's statement of fraud in Chicago-Oleomargarine sold as butter in eight out of ten places-Production and exhibition of swindling sign, 461-Manufacturers' connection with fraud-Production of photograph of store front where butter is advertised and oleomargarine sold exclusively, 462-How the Illinois food department was beaten-Amount of olcomargarine produced in Chicago-Number of retail dealers in the United States-Number of retail dealers in ChicagoAmount illegally sold-Fraud shown in concealed marks-Fraudulent use of brand of butter, 463 -Using colored wrapper to conceal marks, $46+-A$ ttempt to enforce State laws in Illinois-Fraud defended by manufacturers, 565-Guar- 
anty of protection by William J. Moxley and Braun \& Fitts in case of prose cution for fraud, 466-Defending sellers of oleomargarine for butter, 467IV. J. Moxley's defense of seller of illicitly made oleomargarine-Cost of attempts to enforce State laws-Oleomargarine makers still defending violators who sell oleomargarine for butter, 468-Profit in sale of oleonargarine-Seventyfive per cent of oleomargarine sold as butter in Chicago-Difficulty of enforcement of State laws, 469-Revocation of charter of Capital City Dairy Company in Ohio for violations of State laws, 469-Oleomargarine at 30 cents a pound, 470 -Offer of $\$ 7,500$ in settlement of cases prosecuted by Government for fraud, 471-Indictments against president of Standard Butterine Company, of Washington, for fraud-Source of labor resolutions, 471-Colored oleomargarine condemned by Chicago Federation of Labor by unanimous vote, 472-Fraud in Cincinnati, 473-Large percentage sold as butter, 473-Protection of retailers at Cincinnati, 474-Letters from Cincinnati telling of frauds, 474 and 475-" "Push sale of oleomargarine and build up reputation for good butter," 477-Amount of color in 1,000,000 pounds of oleomargarine-Amount in $1,000,000$ pounds of butter, 479 - Color of butter 75 per cent natural, 480 Prices of butter-Receipts of butter, 481-Receipts of butter in New York since 1890, 481-Cause of advance in 1899, 482-Value of cotton crop-Value of products or cotton-seed oil in the United States-Proportion used in oleomargarine made in this country, 487-Why tax uncolored oleomargarine?-What renovated butter is marle from, 489-No objection to red color in oleomargarine, 490-Makers sympathize with fraudulent dealers- "Covering-up dealers"The Aurora Produce Company swindle, 491-Refusal of manufacturers to show books-Refusal of manufacturers to make returus-Makers of oleomargarine swear inspection of books would furnish evidence that would incriminate them, 493-Fraud shown Collector Coyne by Chicago Record, 495- Why all butter men don't sell oleomargarine, 497-Difficulty of securing evidence against illicit venders, 498 - Scheme by which oleomargarine is sold as butter with little chance of detection, 498-Why Grout bill will protect, 499-About Government "inspection" of oleomargarine-Number of analyses made by Govermment last year, 499- What is renovated butter made of, 534-No acids used in renovated butter, 534-Process of manufacture, 534-Qnantity made compared with whole volume of butter produced in United States, 536-Why anticolor laws are not applicable to process lutter-Where process butter is made, 537-How sale of butter is damaged by oleomargarine, 530 - Chemists can't distinguish renovated butterBacteria in butter, 538-Original bonds produced showing connection of Braun \& Fitts and William J. Moxley with defense of sellers of oleomargarine as butter, 552 Amount of oleomargarine made by two concerns openly defending fraud, 553-Letter from Cincinnati relating to resolutions, 554-Butter board's estimate of amount of fraud in Chicago, 555-Oleomargarine the cause of demoralized butter market, 555-Map showing States which have prohibited sale of oleomargarine colored in imitation of butter, 557-Agricultural Department chart showing values of butter for ten years, 558-Evidence of amount of caul fat and oleo oil therefrom in steer, 559 .

Kracke, F. J. H., assistant commissioner of agriculture of New York-For the billHow oleomargarine is sold by peddlers in New York City, 365-How handicapped, 366-State law regarding boarding houses-Scheme for defranding, 367One thousand convictions for selling oleomargarine as butter, 368-Amount of oleomargarine sold in New York State, 369-Sales of oleomargarine outside the State just as damaging to the producer, 372-Cost of enforcing State laws, 370.

Liestrade, Francis IV., butter dealer and manufacturer of oleomargarine-Against the bill-How farm butter is made and shipped-What labels comprise-Imitation creamery-Creamery butter-Process butter, 165-Oleomargarine no detriment to butter, 166-Quality of butter compared with years ago, 167-Quick production of butter, 168-Prices of butter, 172-Corner in butter, 174-Trade of 1900,175 -Exports of, 176-Not 30,000 pounds uncolored oleomargarine sold in United States, 178-Australian industry, 179-More about butter prices, 215Butter trust, 216.

McCoy, John C., representing Kansas City Live Stock Exchange-Against the billHealthfulness of oleo, 6t-Grout bill aims at life of industry-Cost of butter to the people, 65-Organization of the creamery interests-Amount of caul fatLive- ock statisties for Kansas City, 66-Loss to live-stock interest if bill should pass-How price of cows would be affected by Grout bill, 67-Valne of cowsValue of hogs and loss on, 68-Tax paid by oleomargarine-Cattle interests only asked protection once, 70-Resolutions of Kansas City Live Stock Exchange, 71.

McNAMEE, J. F., vice-president and chairman of legislative committee Columbus Trades and Labor Assemby, Columbus, Ohio-Against the bill-Labor dis- 
cussed-Want to perpetuate employment of men making oleomargarine, 351If oleomargarine is suppressed butter will be high, 352-Grout bill means destruction of industry-Establishes a precedent, 353-Use of oleomargarine prosecutions for political purposes, 35t-Always accustomed to eating butter yellow, 355-Oleomargarine's keeping qualities, 357-Thy not eat all oleomargarine white, 358-Eating oleomargarine no disgrace, 359-Resolutions of Chicago Federation of Labor against, 360-Resolutions Horseshoers' Union, 361Resolutions of decorators of Cleveland, 362-Credentials from organization, 504 -Reprisal against labor threatened, 505-Would make butter 55 or 60 cents, 507-Resolutions Cleveland Building Trades Council, 508-Senator Allen's experience, 509-Fooling the old lady, 510-Amount caul fat-Temperature raw materials of oleomargarine heated to-Method of making oleo oil-Stearin in all oils-Paraffin from petroleum, 510-Number cattle slaughtered in United States-Amount lard used in oleomargarine--Amount cotton-seed oil-Percentage ingredients in oleomargarine-Cotton-seed oil not a necessary ingredient, 511Distinguishing oleomargarine from butter-Melting point of oleomargarine and butter, 512-Clarifying point of oleomargarine, 513.

Mediry, Summerfield B., president Baltimore Pure Butter Protective AssociationFor the bill-Fraud in Baltimore-All oleomargarine was sold as butter, 410Why Grout bill is wanted, 441 .

Miller, W. E., representing Armour \& Co., Kansas City-Against the bill-Investment in oleomargarine business-Color of oleomargarine-Can't pay 10-cent tax, 47-Digestive experiments, 48-New York butter receipts, 50-Butter market conditions, 51-Senator Warner IIller's remarks, 52-Political methods of National Dairy Union, 52-Percentage of butter-Coloring used-Fats userl, 5t-Paraffin in oleomargarine, 55-Oleo oil, how made, 56-Petition of South St. Paul stockmen, 57-Resolution of Cotton Oil Crushers' Association, 5s-Oleomargarine, exports of, 59-Resolutions of Sioux City Live Stock Excliange, 60Resolutions, Kansas City Commercial Club, 61-Resolutions, Kansas City Mercantile Club, 62-Attempt to defeat Hon. James A. Tawney, 63-How packers elected Congressman Cowherd, 64 .

Noble, T. B., food commissioner of Connecticut-Letter indorsing Grout bill, 447.

Nonton, B. P., food commissioner of Iowa-Letter indorsing Grout bill, 447.

Norris, E. B., president New York State Grange, and representing National GrangeFor the bill-Statement filed, 412-National Grange wants Grout bill-New York State Grange wants the Grout bill-People are being forced to use oleomargarine against their inclinations and desires.

Paul, George E., oleomargarine dealer, Philadelphia-A gainst the bill-Difference in color of butter-Quality of butter, 540-When oleomargarine was introduced, 541-Laws of Pennsylvania, 542-History of prosecutions in Pennsylvania, 542"Persecution" under State laws, 544-If oleomargarine were driven out creamery system would suffer, 546-If nonsensical State laws were repealed-Proportion of uncolored oleo-Consumer won't buy uncolored butter any more, 547Prices of butter, 548-Oleomargarine never quoted in open market, 548-Proportion of labor idle in rural districts, 550-Oleomargarine sells best when butter is high-IVhat is a good price for butter, 551.

Person, William, of Ammon \& Person, Jersey City, N. J., dealers in oleomargarineAgainst the bill-Legal machinery of New Jersey-Labels used on oleomargarine in New Jersey-Price of butter, 331-Decrease in number of cattle, 332-Price of cows, 333-A Aility of cows in this country to produce milk, 331-How is yellow oleomargarine sold in New Jersey, 33t - Color of butter, 335-Decisions of New Jersey courts-Oleomargarine without any color would look like lard, 336-1Ianufacture of oleomargarime in Holland-Benefit of oleomargarine to the farmer, 337-Major Alvord's letter on renorated butter, 338-Receipts of butter in New York-Agreement on distinct color proposed, 339-Color made in oleomargarine by mixture of fats, 340 -Color in oleomargarine can't be made in oleomargarine by mixture of fats, 340-Color of cotton-seed oil a little green, 341-How State laws are evaded by oleomargarine dealers, 343.

Pierce, JoHn, representing the Amalgamated Steel Workers' Association-Against the bill-Price of oleomargarine-Pride in the homes of workingmen, 311-Don't want oleomargarine uncolored because it doesn't look like butter-Oleomargarine sold as butter, 312 - "I never eat any oleomargarine; I don't have to," 313.

Peters, E. S., president Cotton Growers' Association, Calvert, 'Tex.-Against the bill-Acreage of cotton-Value per bale, 483-Value of cotton seed, 484-Put renovated butter in oval packages, 486-Letter from Cotton Growers' Protective Association of Georgia, 487.

Pirrung, Henry C., manager Capital City Dairy Company, Columbus, Ohio-Maker of oleomargarine-Against the bill-Natural butter, 186-How oleomargarine is 
made-Composition of, 187-Coloring of butter twenty-five years ago-Color deceives in butter, 188-The pink laws-Forbidding of coloring in oleomargarine, 189-Decision in pink-law case, 190-Justice Peckham quoted on color, 190Healthfulness as referred to in Plumley $v$. Commonwealth, 191-Prices of butter, colored and uncolored, 192-Why not prohibit oleomargarine altogether if not healthful, 193-Definition of adulteration-Who asks this protection, 193-Palatability should be encouraged, 194-Inspection of oleomargarine by Government, 194-How sold in District of Columbia, 195-How oleomargarine is marked under new rulings, 196-Experience of Congressmen in District, 196.

Rogers, W. A., representing board of trade of Watertown, N. Y.-For the bill-Statement filed, 412-Why the Grout bill is favored.

Royce, C. H., manager Morton farm, New York-For the bill-Dairymen have the right to the use of the yellow color, 379 .

Scheld, Charles E., representing the Ohio Butterine Company, of Cincinnati, Jacob Dold Butterine Cumpany, Kansas City, Mo., and Union Dairy Company, Cleveland, Ohio-Against the bill-Discrimination condemned, 255-Oleomargarine and butter almost identical, 257-Natural color of oleomargarine and butter, 259-Nutritive qualities of oleomargarine, 260-Used in majority of Soldiers' Homes, 261-Oleomargarine is butter-Opposes adulterations, 261-Factories must be ready for Government inspection-Both oleomargarine and butter are colored, 262-Amount of color in butter-Color requirements of various markets-Creamery butter, 263-Tilden R. and Albert French, of French Brothers Dairy Company, quoted, 264-How some butter is made, 265-Oleomargarine doesn't imitate butter, 266-Milk and cream used in oleomargarine-Use of acids in renovated butter, 267-Packing stock-Talk of a trust-Oleomargarine advertised by retailers, 269-What makes difference in price of various grades of oleo, 269-Retailer must be fair, 270-Best way of making butter, 271-Opponents of Grout bill-Destruction of industry-Can't taste be cultivated for oleomargarine without color, 271-Effect of color upon the palate, 272-All farm products enhanced in value-Pride of poor man, 273-Commissioner Wilson quoted, 274Dr. Wiley's statements, 277- "United dairy sentiment" questioned-Consumers buy direct-Conspiracy denied, 280-Where State laws are enforced, 281-Legal side, 282-Officers of National Dairy Union, 282-IVhy not select another color, 284-Why oleomargarine makers acquiesced in State legislation, 286-Supreme court decisions, 287-Attitude of General Grout, 289-Enforcement in Ohio, 290-The bill's avowed purpose and its real purpose, 291-Have they really proven any amount of fraud, 291-How oleomargarine is sold, 292Federal regulations, 293-Ohio pure-food law, 294-Present law sufficient, Grout bill prohibitive, 295 - Number of retail oleomargarine dealers in Ohio-Instructions to dealers, 296-Notifying hotel and restaurant guests, 297-Oleomargarine not sold for butter, 301-Manufacturers do not defend fraud, 302-Effect of Grout bill-Evasions of friends of bill, 303-Difference between Wadsworth substitute and present law, 305-Grout bill only reduces tax-Fails as a revenue measure-Summing up, 306-List consumers offered, 381-Telegrams offered, 568.

Sharpless, Joseph C., Chester County, Pa., farmer-For the bill-From standpoint of farmer-Use of his brand by oleomargarine maker, 220.

Sharpless, Thomas, Chester County, Pa., farmer-For the lill-Healthfulness not the question-We color butter-Depreciation of lands in valne--Butter sold at 35 cents, 228-Experience with fraud in Pittsburg-What milk bings for butter making, 229.

Springer, Hon. W. M., representing National Live Stock Association--Against the bill-List of live-stock associations-Values of live stock-Resolutions of Fort Worth convention, 77-Speech of J. S. Hobbs, 79-Prices of butter-Vote on resolution, 80 - Statement denounced as false, 81-Claim letter to be forgeryOleomargarine combine, 82-Bribery of merchants denied and aftirmed, 83-Election of Wadsworth, 84-Report of committee of manufacturers-Healthfulness of oleomargarine-Legality of color, 85-Production of oleomargarine, 87-Ingredients, 88- Where colored article is prohibited, 89-Amount of oleomargarine consumed in each State, 90-Per capita consumption of, 91-That will become of cow, 92-Legal aspects of color, 93-Interstate-commerce question from legal standpoint, 97-Police powers of States, 103-Legality of taxation, 104-Discussion of Wilson Act, 105, 106, 107-Constitutional restrictions, 106-State la ws will have force, 108-Attempt to tax compound lard, 108-Renovated butter, 109Why not protect woolgrowers from shoddy, 110-Inspection of oleomargarine factories-Discussion of Hatch bill, 111-Amount caul fat used, 114-Value of fat to cattle industry-Ingredients of oleomargarine, 115-Value of fat per steer, 116. 
Trompson, William H., presirlent National Live Stock Exchange-Against the bil] Number of cattle in United States-Damage by pasiage of Grout bill-Healthfulness and inspection of olenmargarine, 182-Whom olcomargarine benefitsWhy not color one if the other-Attempt to tax one industry at the expense of another, 183-Price of oleonargarine, 181-Resolutions of National Live Stock Association, 185 .

Tompkiss, A. D., Charlotte, N. C., representing cotton-seed oil mills-Against the bill-Loss of $\$ 2$ per ton on eatton seer-Price of cotton seed, 315-Right of people for color, 316-Why no petitions from the South- IVill hear from constituents-Anything the matter with the coloring, 317-Cotton-seed oil has color in it, 318-Once prejudice against cutton-seed oil-Workingmen do not question what process butter is made by, 319-Some who help pass (irout bill will stay home and run dairies, 320-Estimate of proportion of total product of cottonseed oil used in oleomargarine in this country-Interest in oleomargarine, 121Healthfulness of oleomargarine-Bacteria in butter, 514-Butter made of swillfecl cows, 515-Use of cotton-seed oil in Holland and Germany-Nixed flour law-Sold as butter, 516-Charge renovated butter makers back of bill-Farmers' interest-Resolutions condemning Grout bill defeated, 518-Resolutions from Cincinnati-Denial that oleomargarine is sold as butter in Cincinnati, 520Cotton-seed oil's interest in oleomaryarine-Proportions of crop, 521-Effect of sales of oleomargarine on butter- Why not oleomargarine occupy whole field, 522-Where oleomargarine took prize as butter, 522-Bacteria in butter-Deception in coloring butter, 524- Why butter is colored, 525-Color of butter at different seasons, 527-Standard of Philadelphia market, 528-Evidence of dodging national law-White butter in England, 529-JIost butter consumed by farmers uneolored, 530-Failure of attempts to sell white oleomargarine in Cincinnati, 531-How much has duplicity brought oleomargarine business into disreputeClaim 90 per cent oleomargarine sold as butter in Chicago-Why not remove stamp as easily as fail to affix - Why increase of penalty would be unwise, 532No interest in enforcement of branding clause of national law, 532-Coloring uneolored oleomargarine, 533-Tax will be collected, 534.

Tillinghast, Frank W., president Vermont Mianufacturing Company, makers of oleomargarine, Providence, R. I.-Against the bill-Communication from Holland Butterine Company, 199-Grout bill-will not raise revenue-State laws are sufficient-Rhode Island satisfied, 200-1Iore fraud where colored oleomargarine is prohibited-How oleomargarine is sold in Rhode Island-Three-fourths sold in Iassachusetts in original packages-Not more than 25 per cent sold as butterEvery ingredient from tarm, 202-Frand could be stopped by Wadsworth substitute, 203-Effect if not colored-Is an imitation of butter, 20t-Healthfulness of, 205-Dr. Wiley's statement, 206-Difference in grades of oleomargarine, 206-Average digestibility of oleomargarine and butter, 208-Eastern dealers try to market goods honestly, 210-The present law, 212-Hotels and restaurants, 212-Senator Mason's report-Change in Grout bill suggested, 213.

W ADsworTh, Hon. J. W.-Explanation of statement regarding letters in House $\mathrm{Agri}$ cultural Committee minority report, 159-A ppears for JIr. Lorimer-How substitute will prevent frand-Grout bill too drastic-Ocular demonstration of workings of Wadsworth substitute, 568 .

WaLden, G. MI., president Kansas City Live Stock Exchange-Against the bill-Cattle killed at Kansas City, 119-Loss on cattle, 120.

Wilson, Hon. JAmes, Secretary of Agrieulture-Invited by the committee to present views-Grout bill has my full sympathy-Law of 1886 not adequate, 414Increase in sale of oleomargarine-Mostly consumed as butter-If sold in compliance with State laws-Miay diminish sales of colored oleomargarine-Cow most valuable agent for producer, 415 - Value of cow to the soil-Population increasing faster than cattle-Best interest of cotton-seed belt lies in dairy cow, 416Oleomargarine not as healthy as butter-National law not well enforced-1lost oleomargarine sold as butter, 417 - Fat steers not desirable to-day -Small anmunt of loss on fat used in oleomargarine amounts to little, 418-Color in butter deceives nobody; color in oleomargarine dercives everybody, 419-Renovated butter, 422-Reply to dealer who says hill will injure cattle industry, 420-The future growers of cattle, 426 .

$$
\text { S. Rep. } 20 \pm 3-56
$$





\section{INDEX T0 SENATE HEARINGS.}

Adulteration: Page.

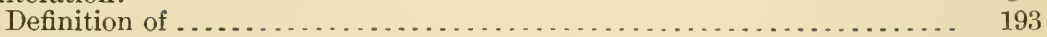

Butter:

Chart showing values for ten years . . . . . . . . . . . . . . . . . . . . 558

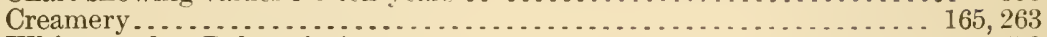

White, used at Delmonico's . . . . . . . . . . . . . . . . . . . . . . . 573

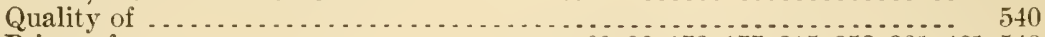

Prices of $\ldots \ldots \ldots \ldots \ldots \ldots \ldots \ldots \ldots \ldots \ldots 68,80,172,177,215,252,331,481,548$

Imitation creamery ........................................ 165

Oleo's competition with higher grades of . . . . . . . . . . . . . . . 35

Quality compared with twelve years agn .................... 167

Ladles, what they comprise . . . . . . . . . . . . . . . . . . . . . . . . 165

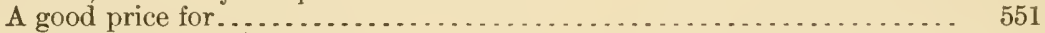

Accustomed to eating yellow . . . . . . . . . . . .

Receipts in New York............................. 50, 339, 481

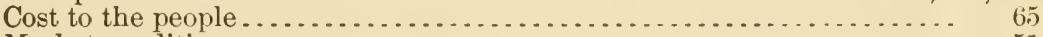

Market conditions . . . . . . . . . .

Green color of ........................................... 513

Demoralized market for, and cause ........................... 555

Uncolored, not salable any more.............................. 457

Sale, how damaged by oleomargarire ........................... 538

Quantity made ................................................ 36

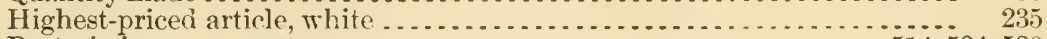

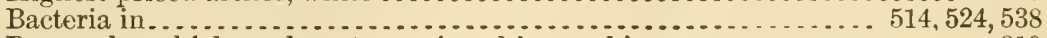

Process by which made not questioned by workingmen . . . . . . . . . . 319

Standard of Philadelphia market............................ 528

Made from swill-fed cows ................................... 515

Effect of sale of oleomargarine on ........................ 522

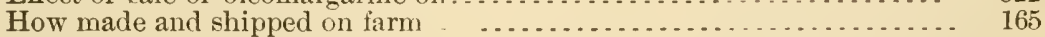

Facilities in country for making . . . . . . . . . . . . . . . . . . . . . . .

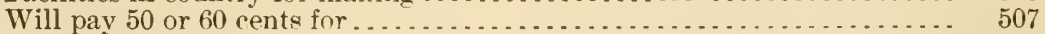

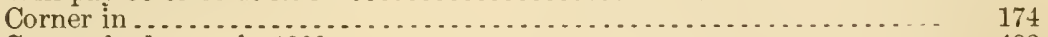

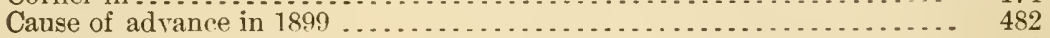

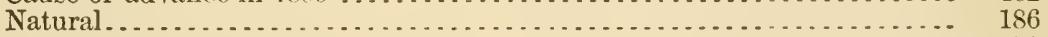

Australia's industry . . . . . . . . . . . . . . . . . . . . . . . . . . . . . 179

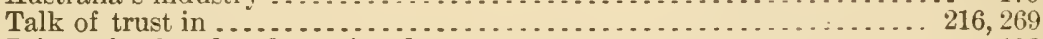

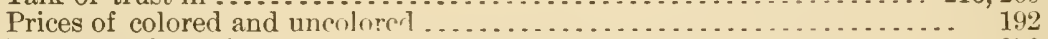

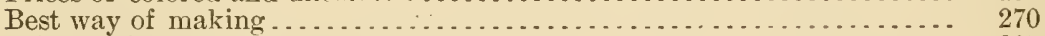

Prices and supply of ....................................... 307

What milk brings for manufacturin . . . . . . . . . . . . . . . . . . 229

How some is made . . . . . . . . . . . . . . . . . . . . . . . . . . . . . 265

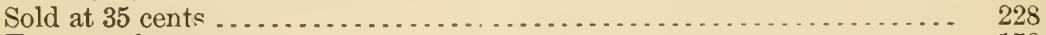

Exports of ....

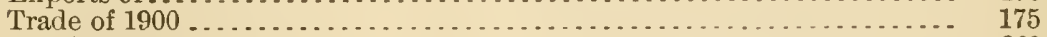

Packing stock ........................................................ 269

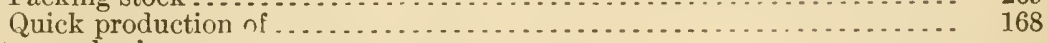

Butter-color in:

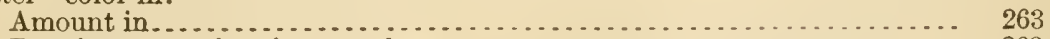

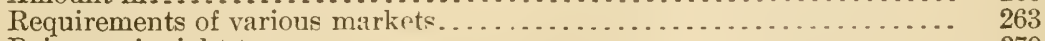

Dairymen's right to use . . . . . . . . . . . . . . . . . . . . . . . . . . . . . 379

In December butter .............................................. 188

Twenty-five years ago . . . . . . . . . . . . . . . . . . . . . . . . . . . 188

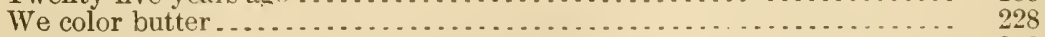

Butter never white ...................................... 310

Butter naturally two-thirds normal color ...................... 525

Why butter is colored ........................................ 525 
Butter-color in-Continued.

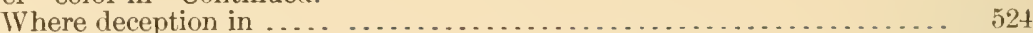

At different seasons. . . . . . . . . . . . . . . . . . . . . . . . . . . . . 527

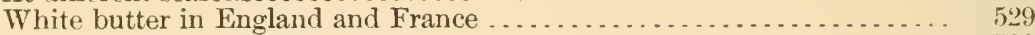

Little in that consumed on farms. . . . . . . . . . . . . . . . . . . . . . . 530

Deceives nobody .... . . . . . . . . . . . . . . . . . . . . . . . . . . 419

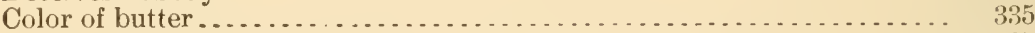

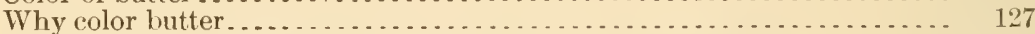

Food effects on butter . . . . . . . . . . . . . . . . . . . . . . . . . . . . 22

Always was colored. . . . . . . . . . . . . . . . . . . . . . . . . . . . 34

Butter's trade-mark . . . . . . . . . . . . . . . . . . . . . . . . . . . . . . . . 33

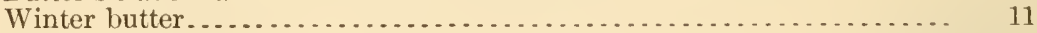

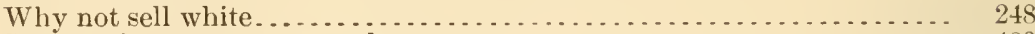

Seventy-five per cent natural . . . . . . . . . . . . . . . . . . . . . . . . . 480

Amount in 1,000,000 pounds butter . . . . . . . . . . . . . . . . . . . . 479

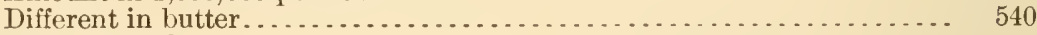

Butter, relovated:

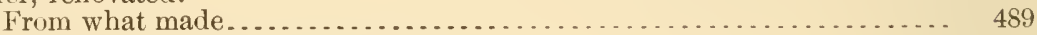

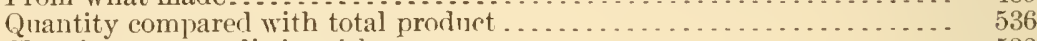

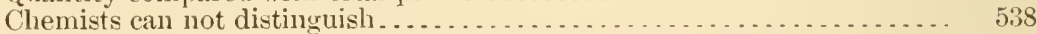

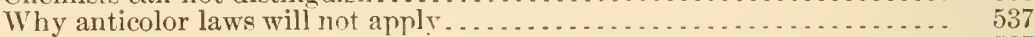

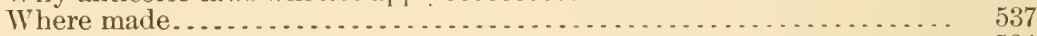

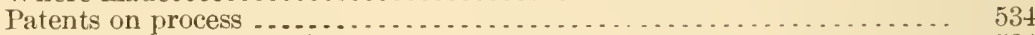

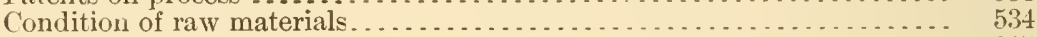

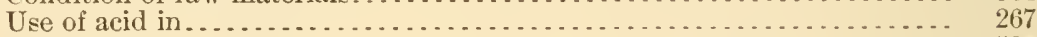

No acids used by makers . . . . . . . . . . . . . . . . . . . . . . . . . 534

Process of manufacture . . . . . . . . . . . . . . . . . . . . . . . . . . . . . . 534

Internal Revenue Department should investigate . . . . . . . . . . . . . 390

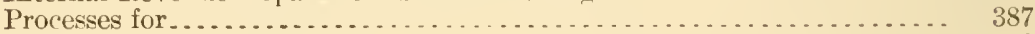

House bill ralled attention to ........................... 40

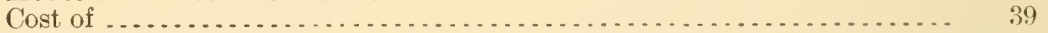

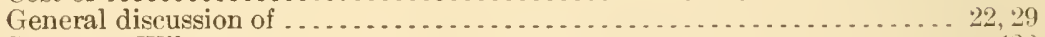

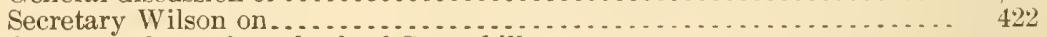

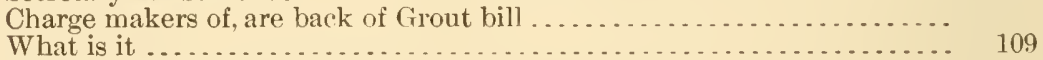

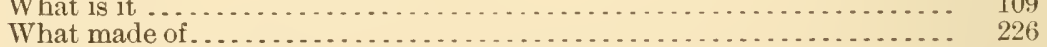

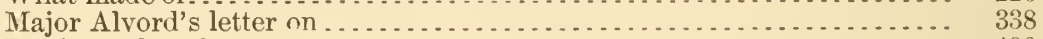

Put in oval package . . . . . . . . . . . . . . . . . . . . . . . . . . . . . 486

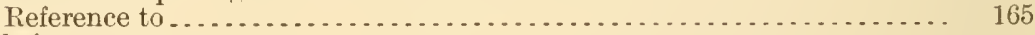

Cattle interests:

Number slaughtered . . . . . . . . . . . . . . . . . . . . . . . . . . . . . . 511

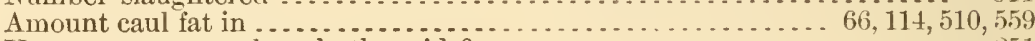

Have growers ever heard other sidn? . . . . . . . . . . . . . . . . . . 251

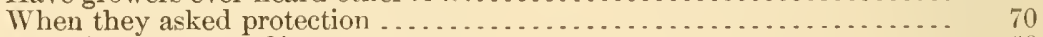

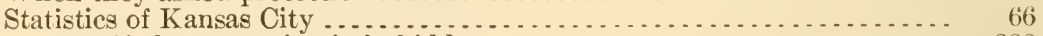

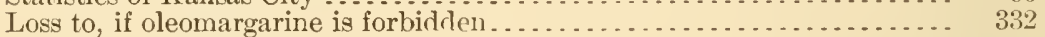

Decrease in number of . . . . . . . . . . . . . . . . . . . . . . . . . . . . $3: 42$

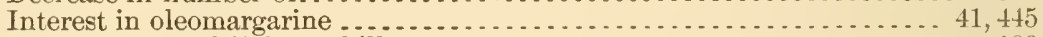

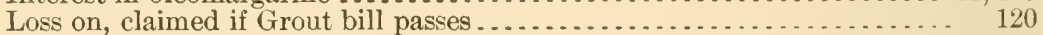

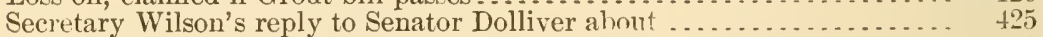

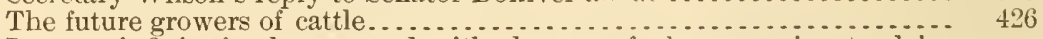

Loss to, infinitesimal compared with damage of oleomargarine to dairy interests

Excessive fat steers a thing of the past

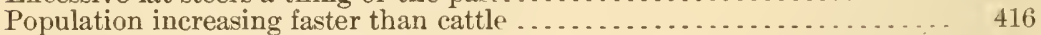

Number cattle killed at Kansas City . . . . . . . . . . . . . . . . . . . . . . . 119

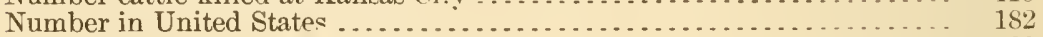

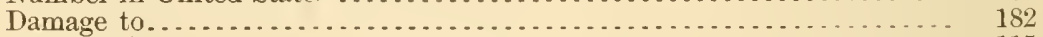

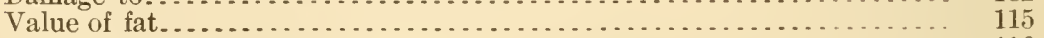

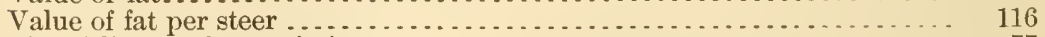

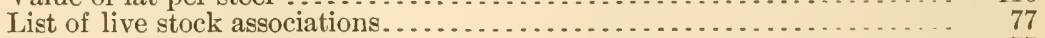

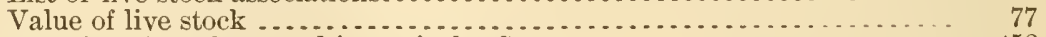

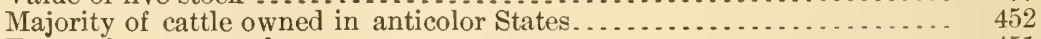

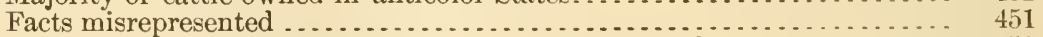

The facts in the case, showing amount of loss per head... . . . . . . . . 451

Cleveland:

Extract from message ... . . . . . . . . . . . . . . . . . . . . . . . . . . . 391 
Constituents:

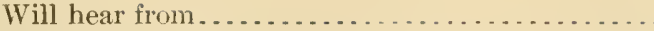

Cotton-seed oil interest:

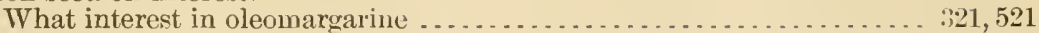

Use in Holland and Germany . . . . . . . . . . . . . . . . . . . . . . . . . . 516

Estimated proportion used in oleomargarine in United States.... . . . . 321, 487

Prejudice against once... . . . . . . . . . . . . . . . . . . . . . . . . . . . 319

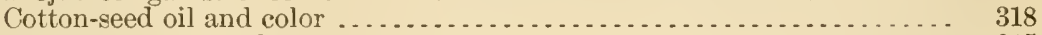

Loss per ton on seed. . . . . . . . . . . . . . . . . . . . . . . . . . . . 315

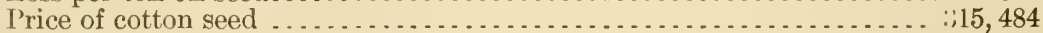

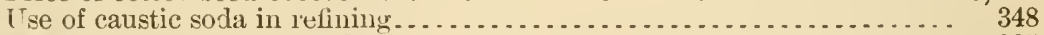

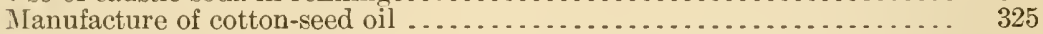

Color of cotton-seed oil .................................... 347

liffect of passage of Grout biil vil . . . . . . . . . . . . . . . . . . . $; 22,325$

Number of mills............... . . . . . . . . . . . . . . . . . . . . . . . 322

Fistimated loss per gallon by passage of bill .................... 323

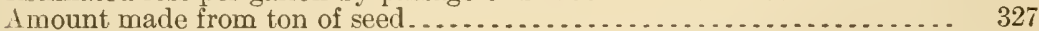

A mount used in compound lard . . . . . . . . . . . . . . . . . . . . . . 326

Number mills in Tennessee ..... . . . . . . . . . . . . . . . . . . . . . . . . . . . 324

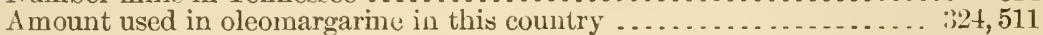

A creage of cotton. ......................................... 483

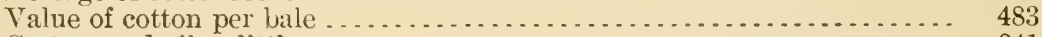

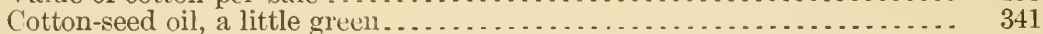

Proportions of crop....................................... 521

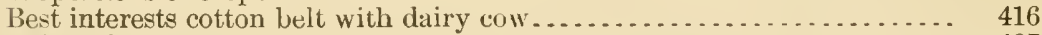

Value of crop ........................................... 487

Cotton-seed oil nut a necessary ingredient in oleomargarine . . . . . . . . . 511 Cow:

Value of product of cotton-seed oil of United States................ . 487

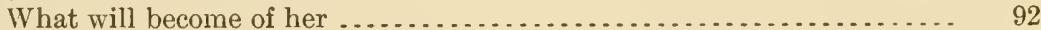

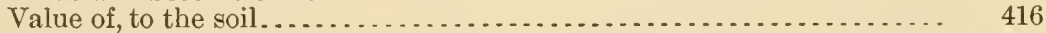

Most valuable agent for the proulucer . . . . . . . . . . . . . . . . . . . 415

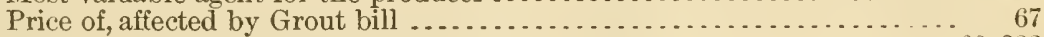

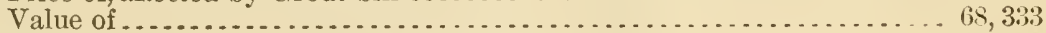

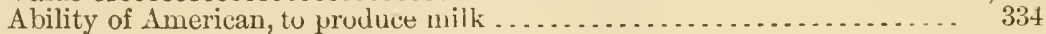

Cowherd:

How packers elected........................................ 64

Creamery interests:

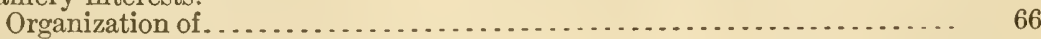

Farmers:

By whom represented .................................... 250

Grout bill:

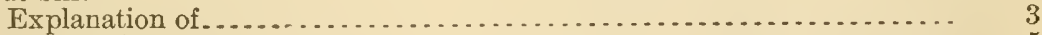

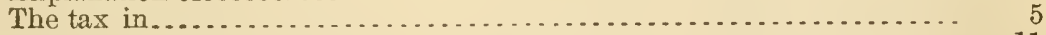

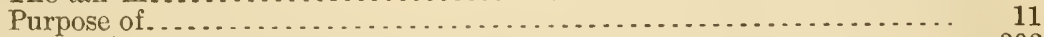

Effect of . . . . . . . . . . . . . . . . . . .

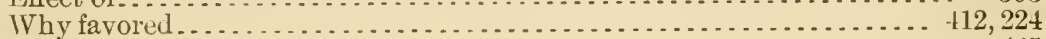

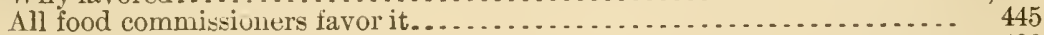

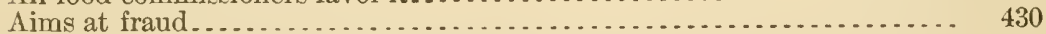

Few measures created su much interest . . . . . . . . . . . . . . . . . . 450

Iost effectual means of stopping fraud . . . . . . . . . . . . . . . . . . . . 230

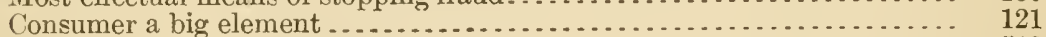

Farmers' interest in . . . . . . . . . . . . .

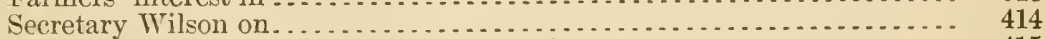

May diminish sales of culored oleomargarine. . . . . . . . . . . . . . . . 415

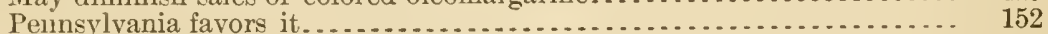

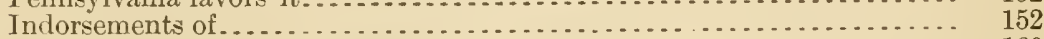

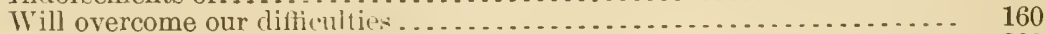

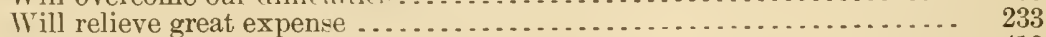

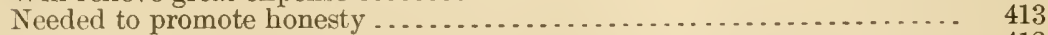

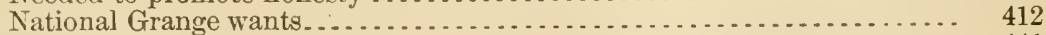

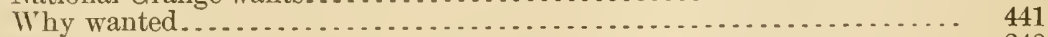

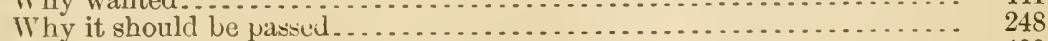

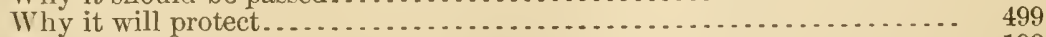

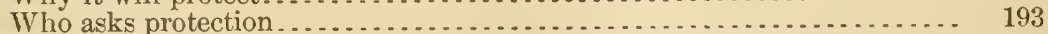

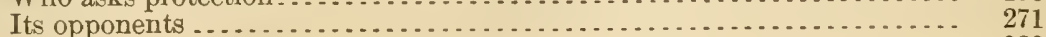

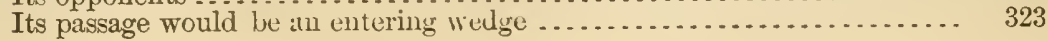


Grout bill-Continued.

Its one purpose .......................................... 401

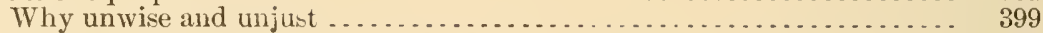

Its avowed purpose and its real purpose. . . . . . . . . . . . . . . . . . . . 291

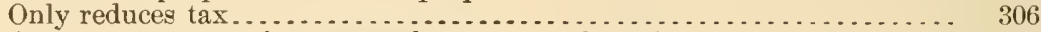

Attempt to tax one interest at the expense of another............. 183

Some who help pass it will stay at home............ . . . . . . . . . 320

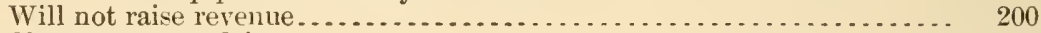

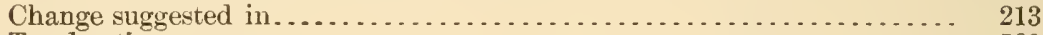

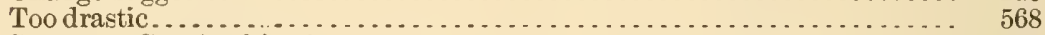

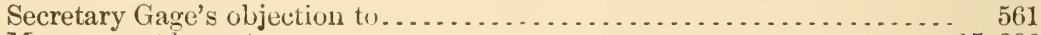

Measure not honest.................................. 15,306

Believe bill will destroy industry . . . . . . . . . . . . . . . . . . . . . . . 37

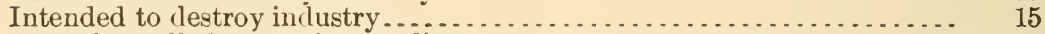

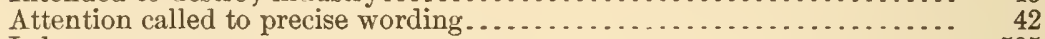

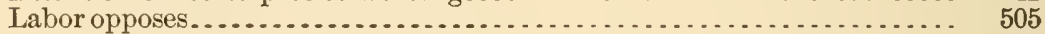

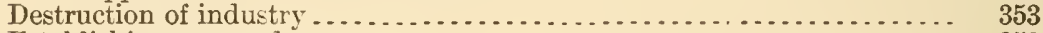

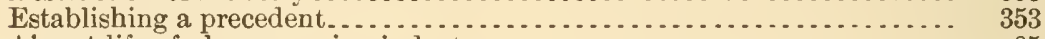

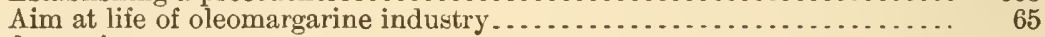

Legal questions:

Constitutional questions ................................ 153

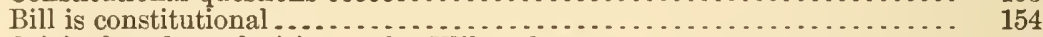

Original-package decision under Wilson law ................ . . . . 4

Constitutionality of tax ..................................... 5

Constitutionality not questioned . . . . . . . . . . . . . . . . . . . . 15

Congress no right to prevent fraud through taxation . . . . . . . . . . . . . . 16

Plumley v. Commonwealth ................................ 124

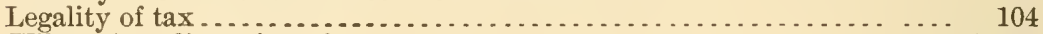

Wilson Act, discussion of . . . . . . . . . . . . . . . . . . . . . . 16j, 106, 107

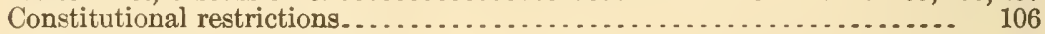

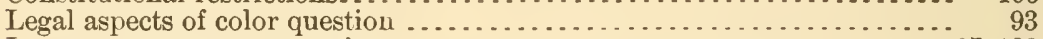

Interstate-commerce question . . . . . . . . . . . . . . . . . . . . . . . 97, 123

Why right was given Congress to regulate interstate comwerce . . . . . . . 124 Hogs:

Congress can not delegate power to State ........................ . 393, 400 Lard:

Value of, and loss on, by passage of bill.......................... 68

Amount neutral, used in oleomargarine . . . . . . . . . . . . . . . . . . . . 511

Compound, attempt to tax .................................. 108 Labor:

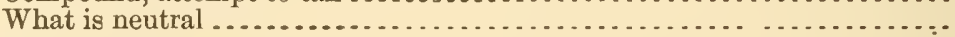

Proportion idle in rural districts......................... 550

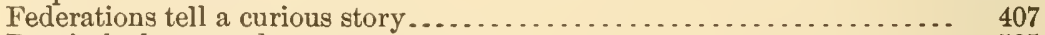

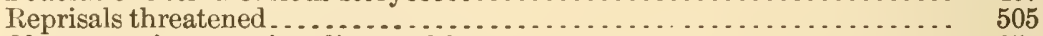

Oleomargarine question discussed by ............................ 351 Lands:

Want to gerpetuate employment of men making oleowargarine......... 351

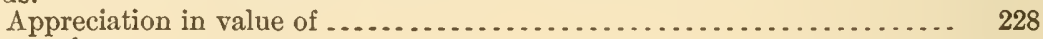

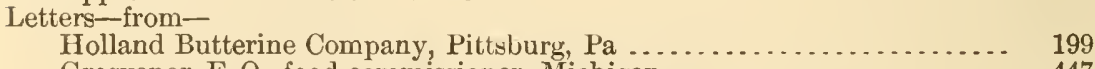

Grosvenor, E. O., food commissioner, Michigan . . . . . . . . . . . . . . . . . . . 447

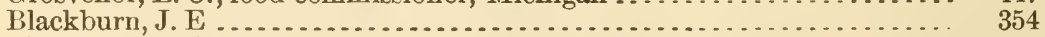

Cincinnati, telling of sale of oleomargarine as butter . . . . . . . . . . . $174-476$

Braun \& Fitts, guaranteeing protection against State laws . . . . . . . . . 466

Wm. J. Moxley, guaranteeing protection in case of prosecution ........ 465

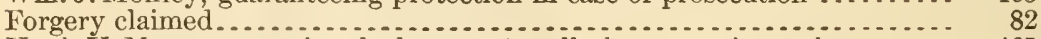

Hugh V. Murray, waming dealers not to sell olcomargarine as butter ... 465

Cotton Growers Protective Association of Georgia.... . . . . . . . . . . . . . 487

Oleomargarine-

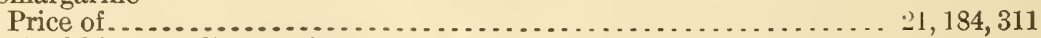

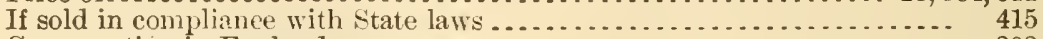

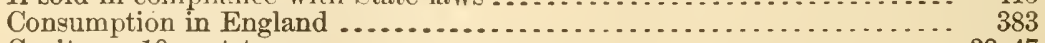

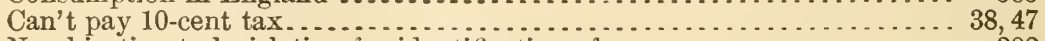

No objection to legislation for identifieation of . . . . . . . . . . . . . . . . 382

Branding of . . . . . . . . . . . .

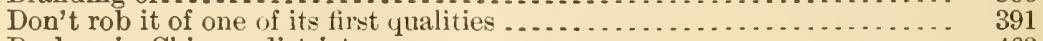

Dealers in Chicago district. ............. . . . . . . . . . . . . . . . . . 463 
Oleomargarine-Continuel.

30 cents a pound

Retail dealers in United states

Proportion of uncolored. ... . . . . . . . . . . . . . . . . . . . . . . . . .

Labels used on, in New Jersey . . . . . . . . . . . . . . . . . . . . . . . 331

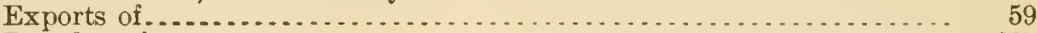

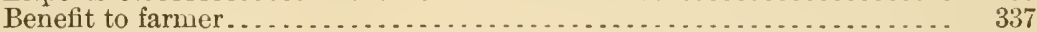

When first introduced........................................ 541

Imitates butter with every ingredient. . . . . . . . . . . . . . . . . . . 17

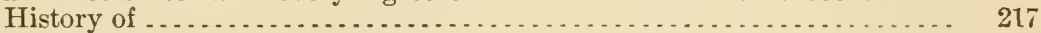

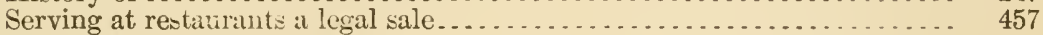

Tax it now pays. . . . . . . . . . . . . . . . . . . . . . . . . . . . . . . 70

Amount produced in Chicugu . . . . . . . . . . . . . . . . . . . . . . . . . 463

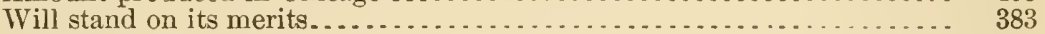

Profits in sale of . . . . . . . . . . . . . . . . . . . . . . . . . . . . . . 469

Sells best when butter is high. . . . . . . . . . . . . . . . . . . . . . 551

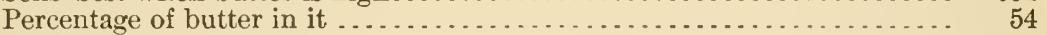

Without color would look like lard... . . . . . . . . . . . . . . . . . . . 336

If driven out, creamery system would suffer ... . . . . . . . . . . . . . . . . 546

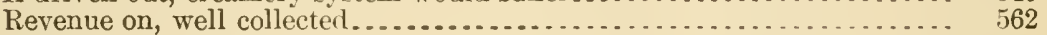

Can not be sold uncolored... . . . . . . . . . . . . . . . . . . . . . . . . . . 39

Distinguishing from butter. . . . . . . . .

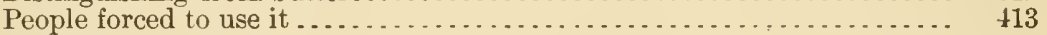

If suppressed, butter will be high . . . . . . . . . . . . . . . . . . . . . . . . . 352

Difficulty of securing evidence against illicit veudors. . . . . . . . . . . . . 498

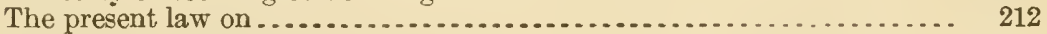

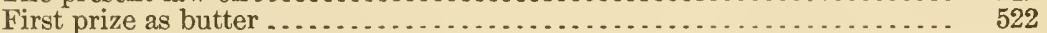

Attempt to sell it white in Cincinmati . . . . . . . . . . . . . . . . . . 531

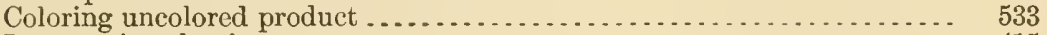

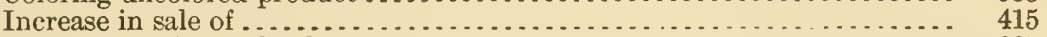

Manufacture in Holland . . . . . . . . . . . . . . . . . . . . . . . . . . . 337

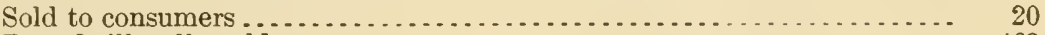

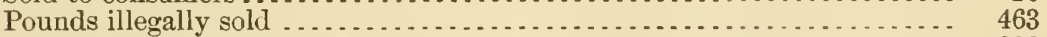

What 10-cent tax would make it cust . . . . . . . . . . . . . . . . . . . . 382

Makers of, swear their books would incriminate them.............. 493

Sales outside New York just as damaging ... . . . . . . . . . . . . . . . . . . 372

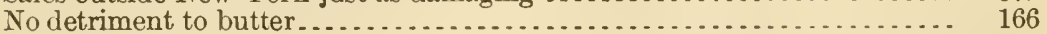

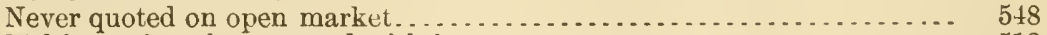

Melting point of, compared with butter ........................ 512

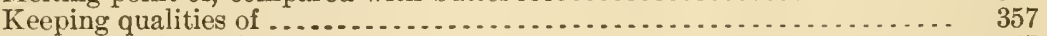

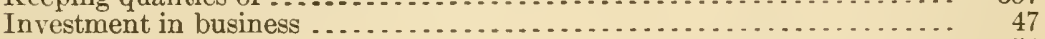

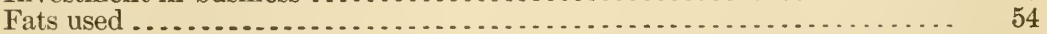

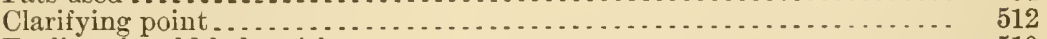

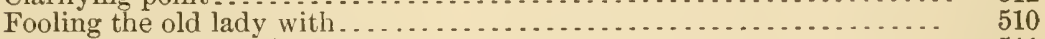

Percentage of ingredients of . . . . . . . .

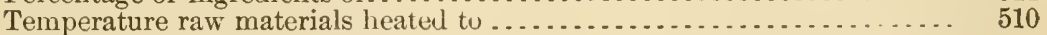

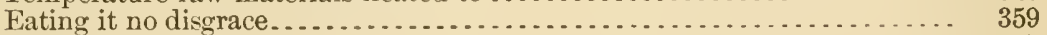

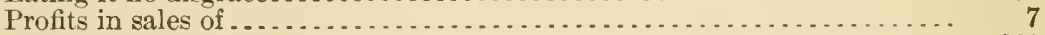

Amount sold in New York State. . . . . . . . . . . . . . . . . . . . . . . 369

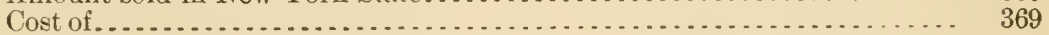

Prohibited ausulutely in Canalla........................... 413

Don't want it uncolored because it don't luok like butter. . . . . . . . . . . . 312

"I never ate any; I don't have to" ................................ 313

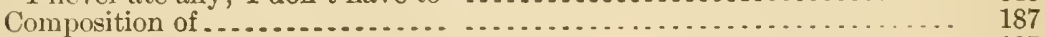

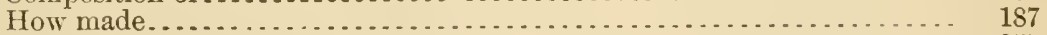

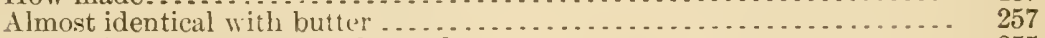

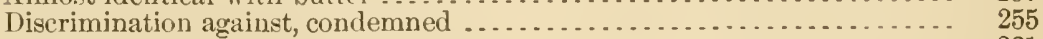

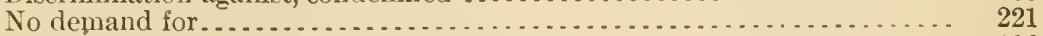

Experience of Congressman in District . . . . . . . . . . . . . . . . . . . 196

About branding under new rulings........................... 196

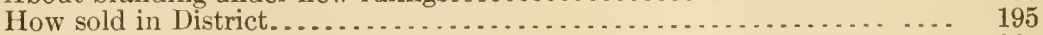

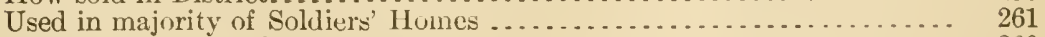

Nutritive qualities of. . . . . . . . . . . . . . . . . . . . . . . . . . . . . . . 260

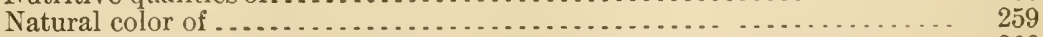

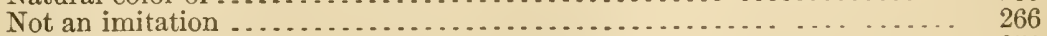

Can't taste be cultivated fur it without color? . . . . . . . . . . . . . . . $\quad 271$

What makes difference in price.... . . . . . . . . . . . . . . . . . . . . . 269 
Ueomargarine-Continued.

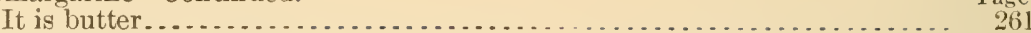

Ashamed to buy it under its own name . . . . . . . . . . . . . . . . . . 446

Profits in manufacture of . . . . . . . . . . . . . . . . . . . . . . . . . . . . . 442

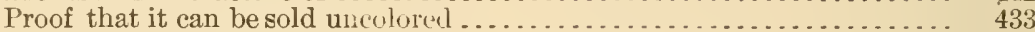

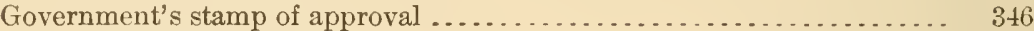

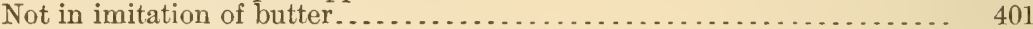

Can't stop traffic in colored . . . . . . . . . . . . . . . . . . . . . . . . . . . . 407

Is white oleo good enough for the workingman? . . . . . . . . . . . . . . . 307

Why disreputable to buy it . . . . . . . . . . . . . . . . . . . . . . . . . . . 309

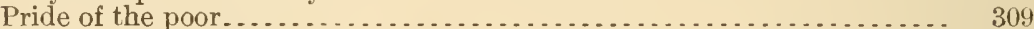

Average buyer of butter duesn't want vleo ........................ 225

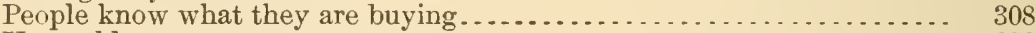

How sold . . . . . . . . . . . . . . . . . . . . . . . . . . . . . . . . . . . . . . . . . . . 292

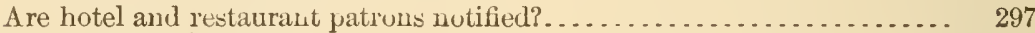

Retail dealers in Ohio ......................................... 297

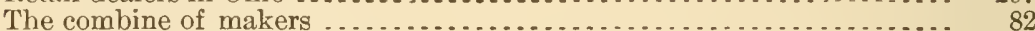

Amount consumed in each State. . . . . . . . . . . . . . . . . . . . . 90

Where colored article is prohibited........................... 89

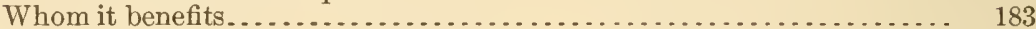

Per capita consumption in Uuited States ............................ 91

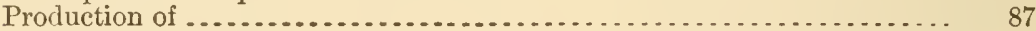

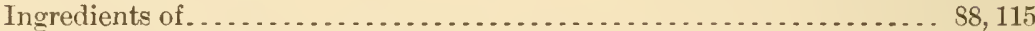

Why not occupy whule butter field .............................. 522

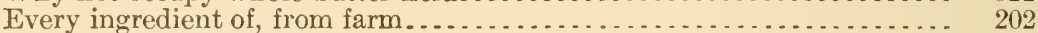

How sold in Rhode Island ... . . . . . . . . . . . . . . . . . . . . . . . . . . 201

Three-fourths sold in Massachusetts suld in vijginal package .......... 202

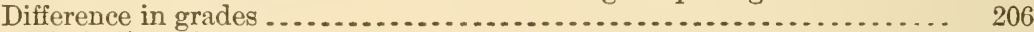

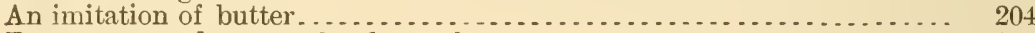

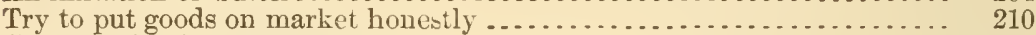

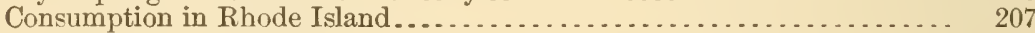

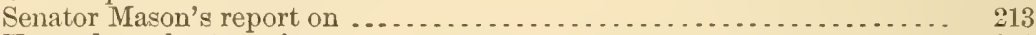

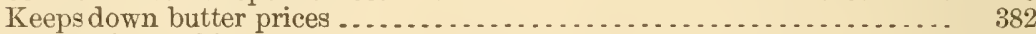

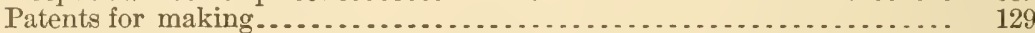

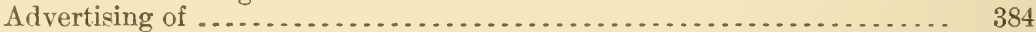

Why all butter men do not sell it ................................ 497

Butter men not interfering with................................. 240

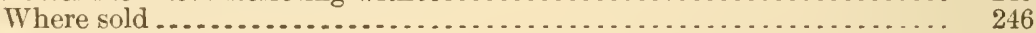

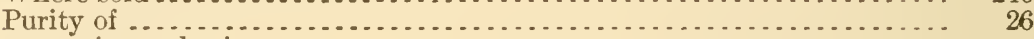

Oleomargarine, color in-

Right of people for ................................... 316

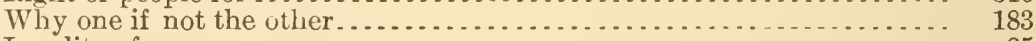

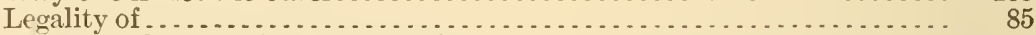

Why reprehensible in oleomartrarine ... . . . . . . . . . . . . . . . . . 374

Artificial coloring invented by oleomaryaine maker's . . . . . . . . . . . . : :5, 406

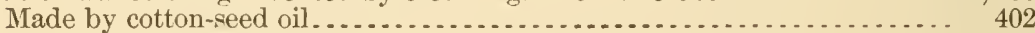

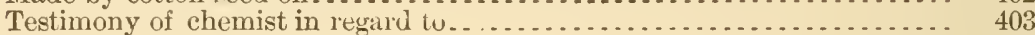

For same reasons as in butter. . . . . . . . . . . . . . . . . . . . . . . . . 405

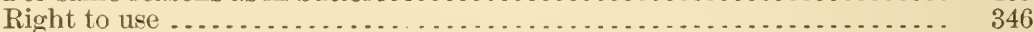

Unfair that oleomargarine maket should not use................. 323

Demmark eats without color . . . . . . . . . . . . . . . . . . . . . . . . . . 431

Legal view of right to use. . . . . . . . . . . . . . . . . . . . . . . . . . . . . . 436

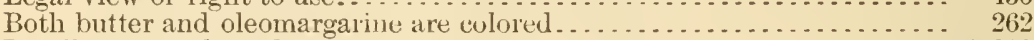

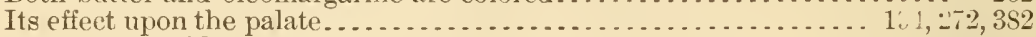

Poor man's pride. . . . . . . . . . . . . . . . . . . . . . . . . . . . . . . 273, 311

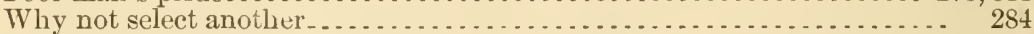

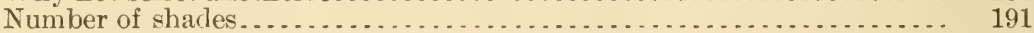

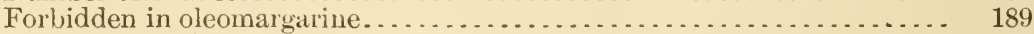

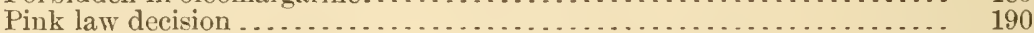

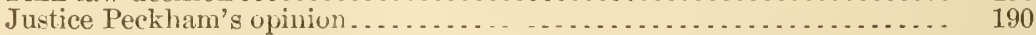

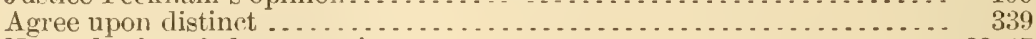

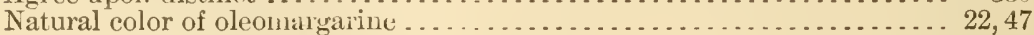

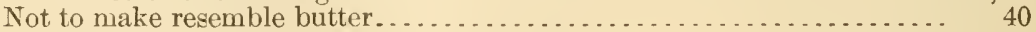

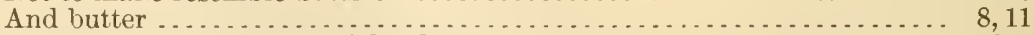

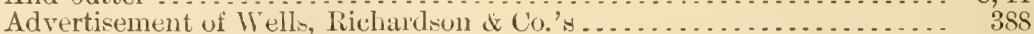

Makes temptation to sell as butter. . . . . . . . . . . . . . . . . . . . . . . . 243

Not 30,000 pounds uncolored oleomalgarine sold in United states . . . . . 178 
Oleomargarine, color in-Continued.

Amount in $1,060,000$ pounds olermargarine . . . . . . . . . . . . . . . . . . . 479

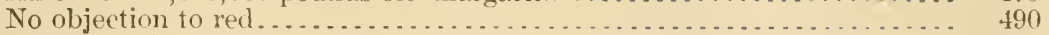

Can be made by mixture of fats . ........................ 340

Denial that mixture of fats will color oleomargarine . . . . . . . . . . . . 340

Given by ingredients ...................................... 18

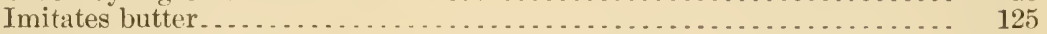

Effect if not colored .......................................... 204

Anything the matter with ................................... 317

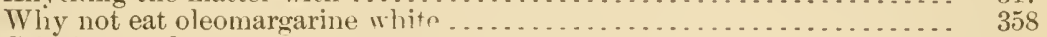

Coloring used .................................................. 54

Oleomargarine, fraud in sale of-

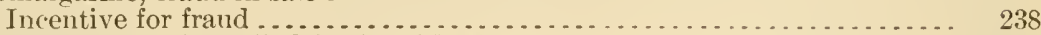

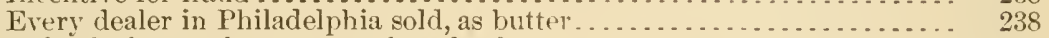

Refusal of manufacturers to show books........................ 493

Aurora Produce Company swindle . . . . . . . . . . . . . . . . . . . . . . 491

"Covering up" dealers.................................... 491

Fraud shown to collector by Chicago Record ................... 495

Scheme to sell as butter and evarle law . . . . . . . . . . . . . . . . . . . . 498

Fraud in Baltimore.......................................... 440

Chicago Butter and Egg Board's estimate of fraud in Chicago ....... . 555

Documentary evidence connecting manufacturers with frand ......... 553

One thousand convictions for selling as butter................. 368

Tricks to evade law ....................................... 247

Fraud in name of seller ................................... 246

Production of swindling sign ................................... 461

Sold as butter in eight out of ten places ...................... 461

Grocer clerk's statement ...................................... 461

Photograph of store front exhibited......................... 462

Mannfacturers' defense of fraud shown ...................... 462

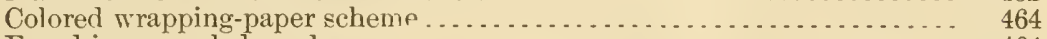

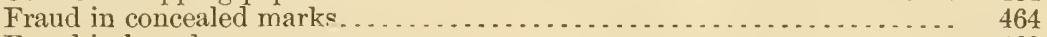

Fraud in brand................................................. 463

How sold by peddlers in New York . . . . . . .................... 365

Will require national legislation to stamp out frand ............... 163

Seventy-five per cent sold as butter.......................... 163

How enables competitors to beat honest dealers ................ 220

As seen by farmers ........................................ 373

Fraud admitted at boarding houses ............................. 377

For seven years endeavored to enforce honest sale ................ 370

Object is to sell as butter at butter prices ....................... 377

Fraud in Paterson, N. J ...................................... 377

Not largely sold as oleomargarine ............................... 224

Amount sold as butter.......................................... 224

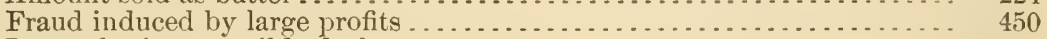

Its use by irresponsible dealers. . . . . . . . . . . . . . . . . . .

No wholesaler wants it sold for what it is . . . . . . . . . . . . . . . . . . 224

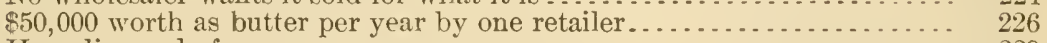

How disposed of .............................................. 223

Dealers admit must sell for butter ................................ ${ }_{22}$

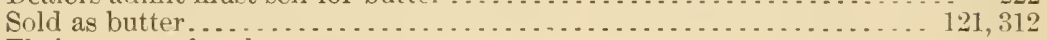

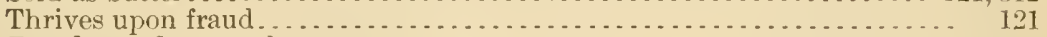

Fraud on a large scale ........................................ 122

Have they really proven any amount of fraud? ................. 291

Claim manufacturers do not lefend fraud . . . . . . . . . . . . . . . . . 302

Sharpless brand of butter counterfeiter . . . . . . . . . . . . . . . . . . . 220

Experience with fraud at Pittsburg ............................ 229

Report of Senate Committee on Manufactures..................... 85

Sold as butter.................................. $19.20,27,28,135,516$

Denial of fraud in Cincinnati........................................ ${ }_{520}$

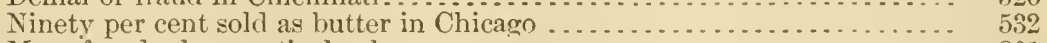

More fraud where anticolor laws ........................... 201

Could be stopped by original-package law . . . . . . . . . . . . . .

Twenty-five per cent sold as butter . . . . . . . . . . . . . . . . . . . . 20.2

Mostly consumed as butter............................. 415

Most oleomargarine sold as butter ............................ 417

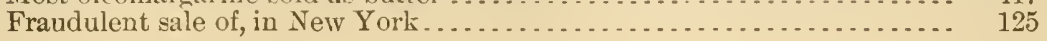


Oleomargarine, fraud in sale of- $\quad$ Page.

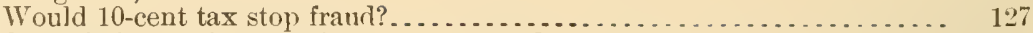

Commissioner of Internal Revenue quited . . . . . . . . . . . . . . . . . . . 19

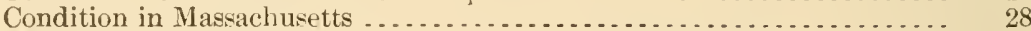

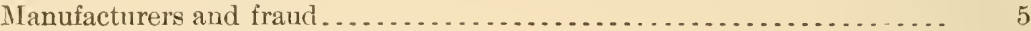

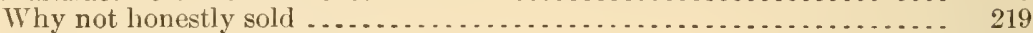

Business is fraud all through . . . . . . . . . . . . . . . . . . . . . . . 218

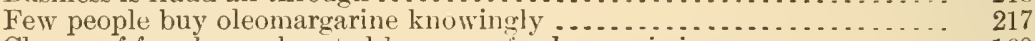

Charge of fraud corroborated ly every food commissionfr......... $\quad 160$

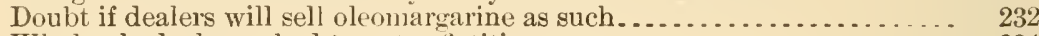

Wholesale dealers asked to enter fictitious names . . . . . . . . . . . . . . . . 234

No law can stop fraud while oleomargarine is colored . . . . . . . . . . . . 235

Retailers principal violators of law . . . . . . . . . . . . . . . . . . . . . 383

Amount fraudulently sold. . . . . . . . . . . . . . . . . . . . . . . . . . . . . . 387

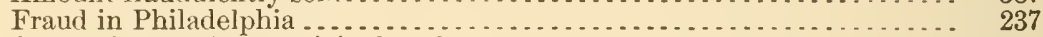

Concealing marks on original jackages . . . . . . . . . . . . . . . . . . 239

Fraud in marking package . . . . . . . . . . . . . . . . . . . . . . . . 463

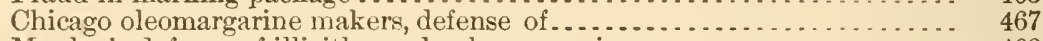

Moxley's defense of illicitly made oleomargarine ...................... . 468

Seven thousand five hundred dollars offerel in settlement . . . . . . . . . 471

Indictments for fraud against Washington man . . . . . . . . . . . . . . . . 471

Fraud in Cincinnati .... . . . . . . . . . . . . . . . . . . . . . . . . . 473

Sympathy of makers with fraud. .....

Seventy-five per cent sold as butter in Chicago . . . . . . . . . . . . . . . . . 469

Large percentage sold as butter. . . . . . . . . . . . . . . . . . . . . . . . . . 473

Senator Allen's experience.................................. 509

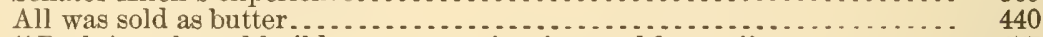

"Push its sale and build up a reputation for gond butter" $\ldots . . . . . . .4477$

Scheme for defrauding..... . . . . . . . . . . . . . . . . . . . . . . . . 367

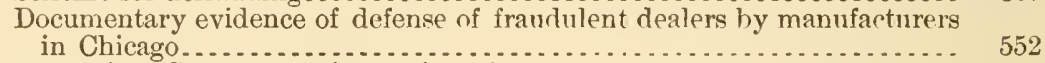

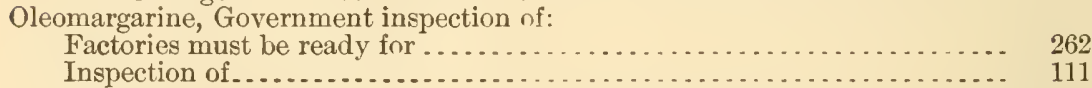

Inspection by Government . . . . . . . . . . . . . . . . . . . . . . . . . 18, 25,499

Government does inspect . ... . . . . . . . . . . . . . . . . . . . . . . . . 194

No revenue agents in factories. . . . . . . . . . . . . . . . . . . . . . . . . 564

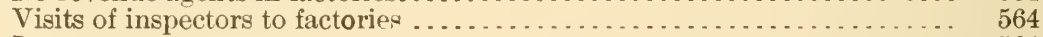

Inspectors not experts. . . . . . . . . . . . . . . . . . . . . . . . . 564

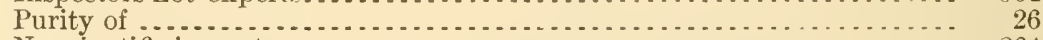

No scientific inspectors. . . . . . . . . . . .

Government agents do not report on purity of ingredients. . . . . . . . . . 564

Refusal to make returns .................................... 493

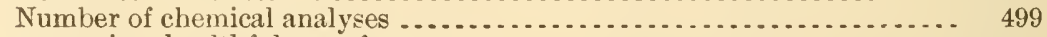

Oleomargarine, healthfulness of:
Healthfulness of oleomargarine $\ldots \ldots \ldots \ldots \ldots \ldots . \ldots 19,64.85,127,136,182,205,514$

Reference in Plumley $v$. Commonwealth . . . . . . . . . . . . . . . . . 191

As healthful as butter . . . . . . . . . . . . . . . . . . . . . . . . . . . . . 417

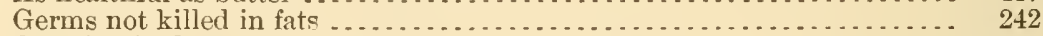

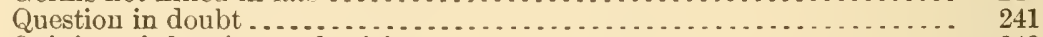

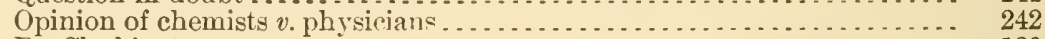

Dr. Clark's statement . . . . . . . . . . . . . . . . . . . . . . . . . . . . . 129

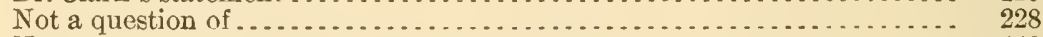

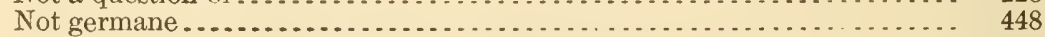

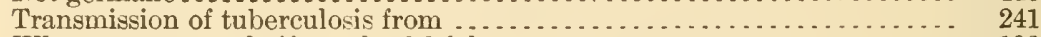

Why encourage sale if not healthfu] . . . . . . . . . . . . . . . . . . . . 193

Dr. Wiley's statement . . . . . . . . . . . . . . . . . . . . . . . . . . 206, 277

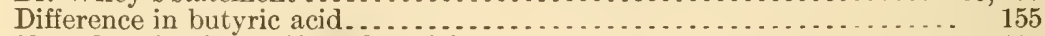

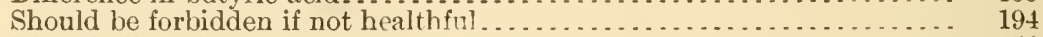

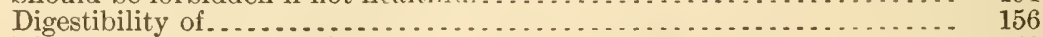

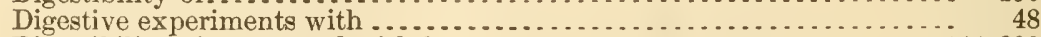

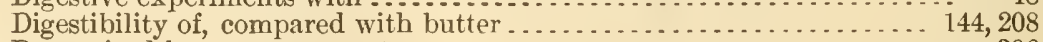

Oleo oil:

Recognized by supreme court . . . . . . . . . . . . . . . . . . . . . . 396

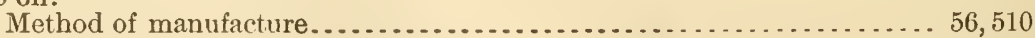

Amount possible from caul fat of average animal ................ 559 
Oleomaryarine-State laws: Page

Ilap showing number of antimlnr . . . . . . . . . . . . . . . . . . . 557

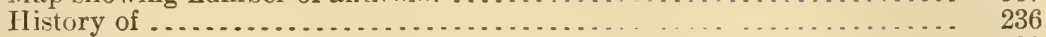

We are not the police power ................................ 232

Difficult for individuals to enforce.......................... 231

Do States know what they want .................................. 153

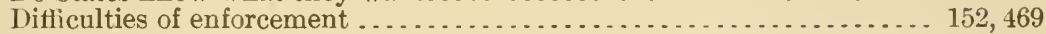

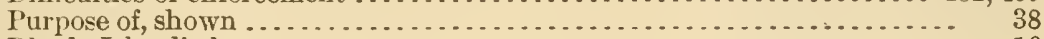

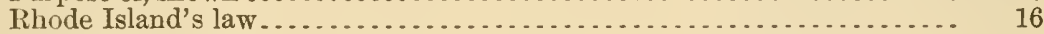

Would be made effective................................... 16

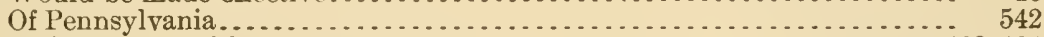

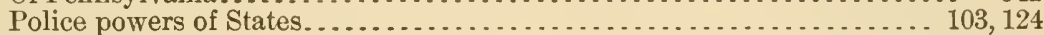

Regarding hotels and restaurants ............................. ${ }_{2} 212$

Are sufficient .............................................. 200

Rhode Island satisfied .................................... 200

Has not evasion of, brought oleomargarine into disrepute ............. 532

Will have force .......................................... 108

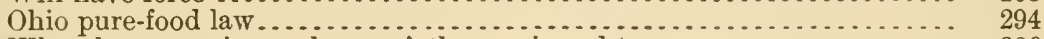

Why oleomargarine makers quietly acquiesced to ................ 286

Supreme Court decisions on ............................. 287

Enforcement of, in Ohin . . . . . . . . . . . . . . . . . . . . . . . . . . 290

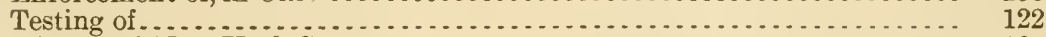

History of, New York State ................................ 121

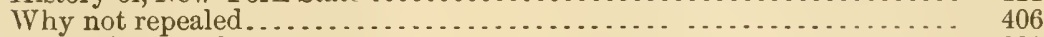

Right of tax under .................................... 392

Violations in Tennessee................................... 329

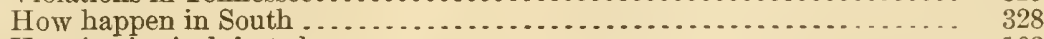

How justice is defeated .................................. 163

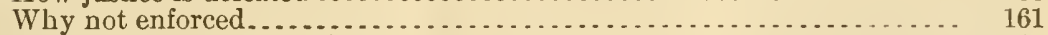

Money spent in prosecutions .............................. 161

Difficulty of jury trials .................................. 162

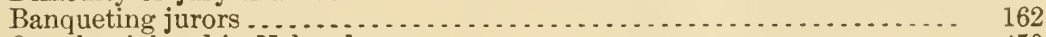

Openly violated in Nebraska............................. $\quad 450$

How handicapped in New York............................... 366

Regarding boarding houses in New York ....................... 367

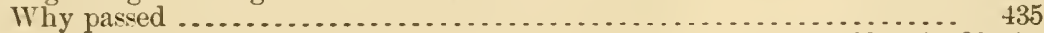

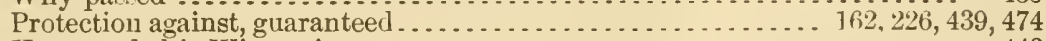

How evaded in Wisconsin . . . . . . . . . . . . . . . . . . . . . . . . . . 443

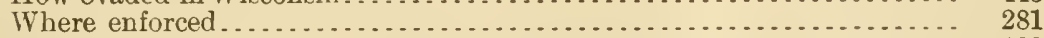

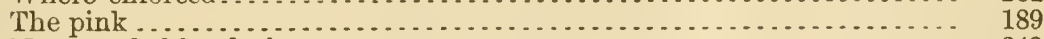

How evaded by dealers........................................ 343

History of Pennsylvania prosecutions under....................... 542

"Persecution" under........................................... 544

Attempt to enforce in Illinois ................................... 465

Cost of effort to enforce...................................... 468

Decision of New Jersey courts................................ 336

Should they be violated when disputed ?......................... 244

All claimed to be unconstitutional .............................. 245

Cost of enforcing in New York . . . . . . . . . . . . . . . . . . . . . . . . . . $\quad 370$

How Illinois food department was beaten ....................... 468

('harter of oleomargarine concern revoked for violations of ........... 469

How is yellow oleomargarine sold in New Jersey?............... 334

Legal machinery of New Jersey ............................ 331

If nonsensical were repealed ..................................... 547

Anti-color only can protect consumer . . . . . . . . . . . . . . 453

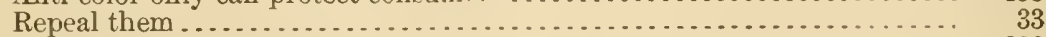

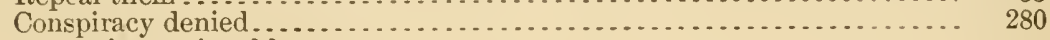

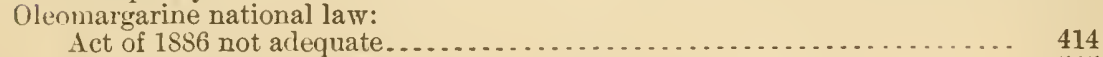

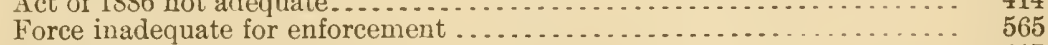

Not well enforced ....................................... 417

Attempts to get enforcement ............................... 237

No interest in enforcement of branding clause.................... 532

Offenses against ......................................... 562

Where information of violations come from .................. 533

Why increase of penalty would be unwise.................... 532 
Oleomargarine national law-Continuerl.

Page.

Evidence of dodging . . . . . . . . . . . . . . . . . . . . . . . . . . . . . . . . 529

Regulations of . . . . . . . . . . . . . . . . . . . . . . . . . . . . . 293

Is unjust. . . . . . . . . . . . . . . . . . . . . . . . . . . . . . . . . . 308

Miller, Senator Warner, remarks. . . . . . . . . . . . . . . . . . . . . . 52

Analyses made under last ye:ir . . . . . . . . . . . . . . . . . . . . . . . . 499

Collection of tax under . . . . . . . . . . . . . . . . . . . . . . . . . . . . . 408

Hatch bill discussed.................................... 111

Paraffin:

Use of, in oleomargarine . . . . . . . . . . . . . . . . . . . . . . 39,128

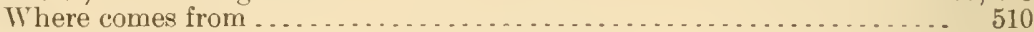

Petitions:

Use of, denied . . . . . . . . . . . . . . . . . . . . . . . . . . . . 55

Why none from the South ................................ 317

Resolutions:

360,505

Chicago Federation of Labor condemns colored oleomargarin ${ }^{2} . . . . . . . . .4472$

South St. Paul Live Stock Exchange......................... 57

Commission Merchants' League of the United Statrs. . . . . . . . . . . . . . 447

National Live Stnck Assnciation . . . . . . . . . . . . . . . . . . . . . . . . . . 77

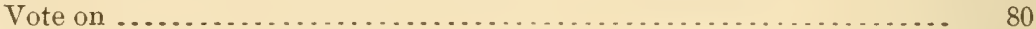

National Live Stock Exchange ... . . . . . . . . . . . . . . . . . . . . 185

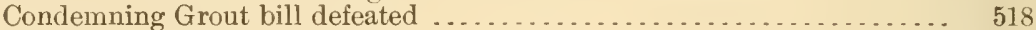

From Cincinnati explainer ............................. 554

From Cincinnati ....................................... 520

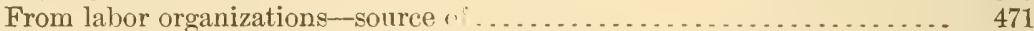

Kansas City Live Stock Exchange . . . . . . . . . . . . . . . . . . . . . . . . 71

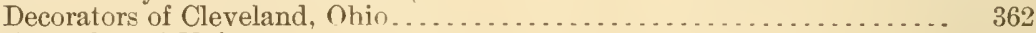

Horseshoers' Union ... . . . . . . . . . . . . . . . . . . . . . . . . . . . . . . 361

Building Trades' Council of Clevelanc?........................... 508

Sioux City Live Stock Exchange . . . . . . . . . . . . . . . . . . . . . . . . . . . 60

Cotton-seed crushers. . . . . . . . . . . . . . . . . . . . . . . . . . . . . . . 58

Kansas City Mercantile Cluh................................ 61

Stearin:

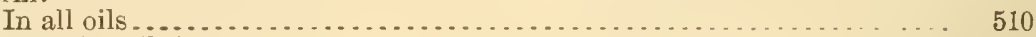

Tawney, Hon. J. A.:

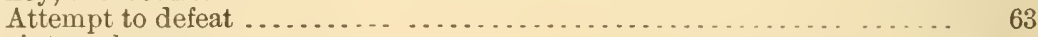

Tax, internal-revenue:

On mixed flour ............................................ 516

Percentage of loss in collecting, on oleomargarine ................. 562

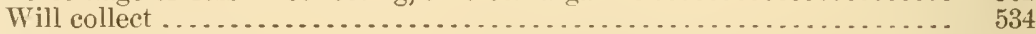

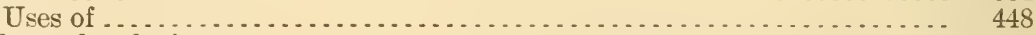

Wadsworth substitute:

The worst thing Congress could pas. . . . . . . . . . . . . . . . . . . . . 226

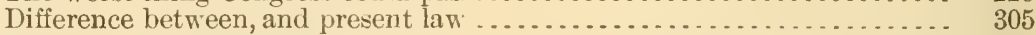

Able work of oleomargarine makers . . . . . . . . . . . . . . . . . . . 376

Ocular demonstration of . . . . . . . . . . . . . . . . . . . . . . . . . . 568

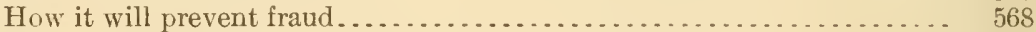

Why not remove stamp as easily as to fail to put oll . . . . . . . . . . . 532

Difference between offeuses under, and present law . . . . . . . . . . . . . . 566

Secretary Gage's opinion . . . . . . . . . . . . . . . . . . . . . . . . . . . . . . . 566

Does not protect restaurant or hotel patron . . . . . . . . . . . . . . . . . 571

Passage advocated. . . . . . . . . . . . . . . . . . . . . . . . . . . . . . 390

Vastly more damaging than any other legislation Congress could enart... 240

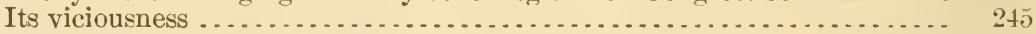

Wool growers:

Why not protect? . . . . . . . . . . . . . . . . . . . . . . . . . . . . . . . 110

\section{D $-22^{9}$}







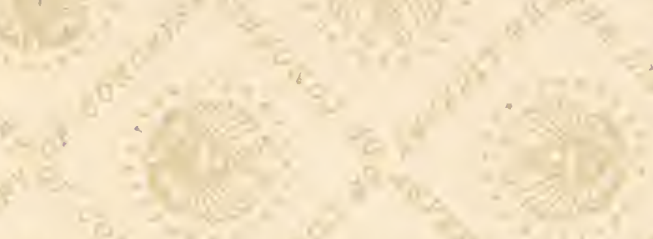
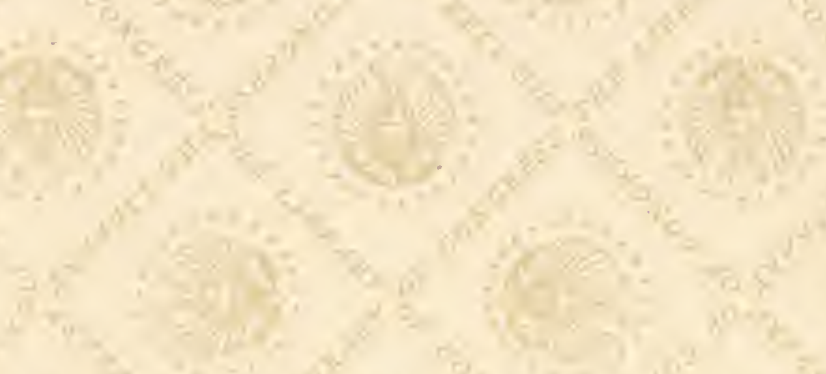

$x^{2}+x^{2}=$

\section{$-3 y^{2}+4 y$}

15. 6

38
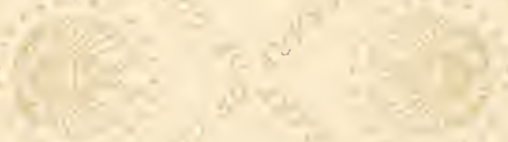

tris $(40)=\frac{6}{6}$

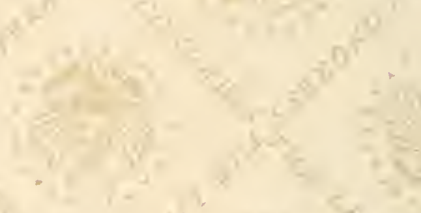

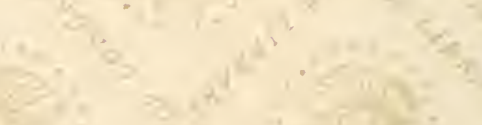





\section{LIBRARY OF CONGRESS}

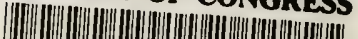

I... … …

(1)

00008913420 